\title{
PESQUISAS E ABORDAGENS EDUCATIVAS EM CIÊNCIAS DA SAÚDE
}

\section{VOLUME II}

\section{ORGANIZAÇÃo JOÃO VITOR ANDRADE JULIANA CRISTINA MARTINS DE SOUZA JOSÉ GILBERTO PRATES}




\section{PESQUISAS E ABORDAGENS EDUCATIVAS EM CIÊNCIAS DA SAÚDE}

\section{VOLUME II}

\section{ORGANIZAÇÃO JOÃO VITOR ANDRADE JULIANA CRISTINA MARTINS DE SOUZA JOSÉ GILBERTO PRATES}




\section{AMPLLA}

2022 - Editora Amplla

Copyright $\odot$ Editora Amplla

Editor Chefe: Leonardo Pereira Tavares

Design da Capa: Editora Amplla

Diagramação: Higor Costa de Brito

Pesquisas e abordagens educativas em ciências da saúde - Volume II está licenciado sob CC BY 4.0.

(c) (i) Esta licença exige que as reutilizações deem crédito ao criador. Ele permite que os ou formato, mesmo para fins comerciais.

O conteúdo da obra e seus dados em sua forma, correção e confiabilidade são de responsabilidade exclusiva dos autores, não representando a posição oficial da Editora Amplla. É permitido o download da obra e o compartilhamento desde que sejam atribuídos créditos aos autores. Todos os direitos para esta edição foram cedidos à Editora Amplla.

ISBN: 978-65-88332-99-3

DOI: 10.51859/amplla.pae1993-0

Editora Amplla

Campina Grande - PB - Brasil contato@ampllaeditora.com.br www.ampllaeditora.com.br

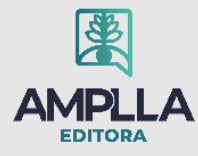




\section{CONSELHO EDITORIAL}

Andréa Cátia Leal Badaró - Universidade Tecnológica Federal do Paraná Andréia Monique Lermen - Universidade Federal do Rio Grande do Sul Antoniele Silvana de Melo Souza - Universidade Estadual do Ceará Bergson Rodrigo Siqueira de Melo - Universidade Estadual do Ceará Bruna Beatriz da Rocha - Instituto Federal do Sudeste de Minas Gerais Caio César Costa Santos - Universidade Federal de Sergipe Carina Alexandra Rondini - Universidade Estadual Paulista Carla Caroline Alves Carvalho - Universidade Federal de Campina Grande Carlos Augusto Trojaner - Prefeitura de Venâncio Aires Carolina Carbonell Demori - Universidade Federal de Pelotas

Cícero Batista do Nascimento Filho - Universidade Federal do Ceará Clécio Danilo Dias da Silva - Universidade Federal do Rio Grande do Norte Daniela de Freitas Lima - Universidade Federal de Campina Grande Denise Barguil Nepomuceno - Universidade Federal de Minas Gerais Dylan Ávila Alves - Instituto Federal Goiano

Edson Lourenço da Silva - Instituto Federal de Educação, Ciência e Tecnologia do Piauí Elane da Silva Barbosa - Universidade Estadual do Ceará

Érica Rios de Carvalho - Universidade Católica do Salvador

Gilberto de Melo Junior - Instituto Federal do Pará

Higor Costa de Brito - Universidade Federal de Campina Grande

Italan Carneiro Bezerra - Instituto Federal da Paraíba

Ivo Batista Conde - Universidade Estadual do Ceará

Jaqueline Rocha Borges dos Santos - Universidade Federal Rural do Rio de Janeiro Jessica Wanderley Souza do Nascimento - Instituto de Especialização do Amazonas João Henriques de Sousa Júnior - Universidade Federal de Santa Catarina João Manoel Da Silva - Universidade Federal de Alagoas

João Vitor Andrade - Universidade de São Paulo

Joilson Silva de Sousa - Instituto Federal do Rio Grande do Norte José Cândido Rodrigues Neto - Universidade Estadual da Paraíba Jose Henrique de Lacerda Furtado - Instituto Federal do Rio de Janeiro Josenita Luiz da Silva - Faculdade Frassinetti do Recife Josiney Farias de Araújo - Universidade Federal do Pará Karina de Araújo Dias - SME/Prefeitura Municipal de Florianópolis Laíze Lantyer Luz - Universidade Católica do Salvador Lindon Johnson Pontes Portela - Universidade Federal do Oeste do Pará Lucas Capita Quarto - Universidade Federal do Oeste do Pará Lúcia Magnólia Albuquerque Soares de Camargo - Unifacisa Centro Universitário Luciana de Jesus Botelho Sodré dos Santos - Universidade Estadual do Maranhão Luís Paulo Souza e Souza - Universidade Federal do Amazonas Luiza Catarina Sobreira de Souza - Faculdade de Ciências Humanas do Sertão Central Manoel Mariano Neto da Silva - Universidade Federal de Campina Grande Marcelo Alves Pereira Eufrasio - Centro Universitário Unifacisa Marcelo Williams Oliveira de Souza - Universidade Federal do Pará Marcos Pereira dos Santos - Faculdade Rachel de Queiroz Marcus Vinicius Peralva Santos - Universidade Federal da Bahia Marina Magalhães de Morais - Universidade Federal de Campina Grande Nadja Maria Mourão - Universidade do Estado de Minas Gerais Natan Galves Santana - Universidade Paranaense Nathalia Bezerra da Silva Ferreira - Universidade do Estado do Rio Grande do Norte Neide Kazue Sakugawa Shinohara - Universidade Federal Rural de Pernambuco Neudson Johnson Martinho - Faculdade de Medicina da Universidade Federal de Mato Grosso Patrícia Appelt - Universidade Tecnológica Federal do Paraná Paulo Henrique Matos de Jesus - Universidade Federal do Maranhão 


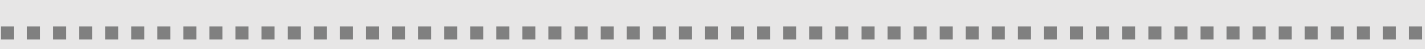

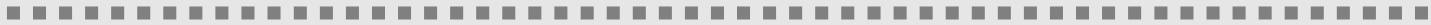

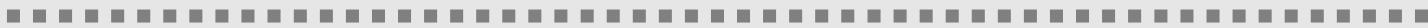
G

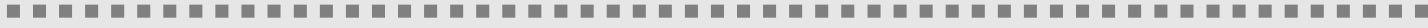

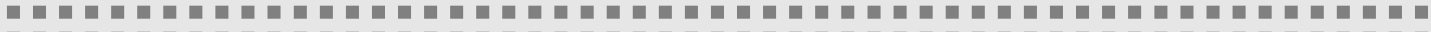

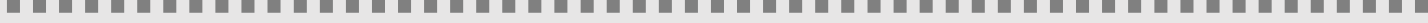

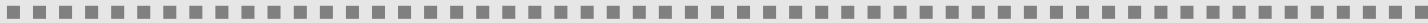

Rafael Rodrigues Gomides - Faculdade de Quatro Marcos

Reângela Cíntia Rodrigues de Oliveira Lima - Universidade Federal do Ceará

Rebeca Freitas Ivanicska - Universidade Federal de Lavras

Renan Monteiro do Nascimento - Universidade de Brasília

Ricardo Leoni Gonçalves Bastos - Universidade Federal do Ceará

Rodrigo da Rosa Pereira - Universidade Federal do Rio Grande

Sabrynna Brito Oliveira - Universidade Federal de Minas Gerais

Samuel Miranda Mattos - Universidade Estadual do Ceará

Shirley Santos Nascimento - Universidade Estadual Do Sudoeste Da Bahia

Silvana Carloto Andres - Universidade Federal de Santa Maria

Silvio de Almeida Junior - Universidade de Franca

Tatiana Paschoalette Rodrigues Bachur - Universidade Estadual do Ceará

Telma Regina Stroparo - Universidade Estadual do Centro-Oeste

Thayla Amorim Santino - Universidade Federal do Rio Grande do Norte

Virgínia Maia de Araújo Oliveira - Instituto Federal da Paraíba

Virginia Tomaz Machado - Faculdade Santa Maria de Cajazeiras

Walmir Fernandes Pereira - Miami University of Science and Technology

Wanessa Dunga de Assis - Universidade Federal de Campina Grande

Wellington Alves Silva - Universidade Estadual de Roraima

Yáscara Maia Araújo de Brito - Universidade Federal de Campina Grande

Yasmin da Silva Santos - Fundação Oswaldo Cruz

Yuciara Barbosa Costa Ferreira - Universidade Federal de Campina Grande 


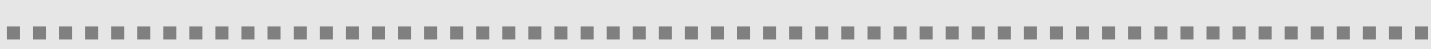

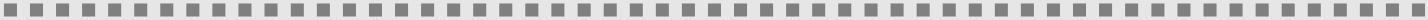

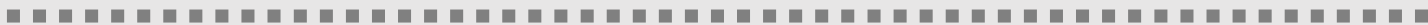
G

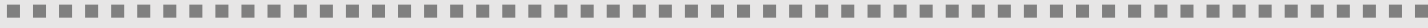

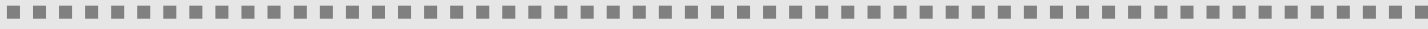

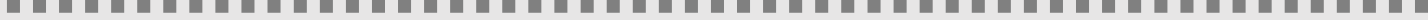

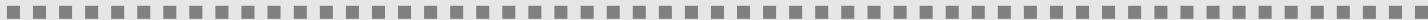

\section{AMPLLA}

2022 - Editora Amplla

Copyright @ Editora Amplla

Editor Chefe: Leonardo Pereira Tavares

Design da Capa: Editora Amplla

Diagramação: Higor Costa de Brito

Dados Internacionais de Catalogação na Publicação (CIP)

Pesquisas e abordagens educativas em ciências da saúde [livro eletrônico] / organização João Vitor Andrade, Juliana Cristina Martins de Souza, José Gilberto Prates. -Campina Grande : Editora Amplla, 2022.

$2 \mathrm{~V}$.

Formato: $\mathrm{PDF}$

ISBN : 978-65-88332-98-6 (Volume 1)

ISBN : 978-65-88332-99-3 (Volume 2)

1. Enfermagem. 2. Medicina. 3. Odontologia. 4. Saúde coletiva. I. Andrade, João Vitor. II. Souza, Juliana Cristina Martins de. III. Prates, José Gilberto. IV. Título.

$\mathrm{CDD}-610$

Sueli Costa - Bibliotecária - CRB-8/5213

(SC Assessoria Editorial, SP, Brasil)

\section{Índices para catálogo sistemático:}

1. Ciências médicas 610

\section{Editora Amplla}

Campina Grande - PB - Brasil contato@ampllaeditora.com.br www.ampllaeditora.com.br

\section{AMPLLA}

2022 


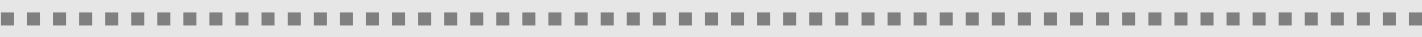 (50

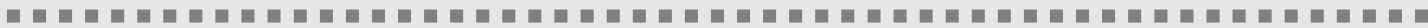 G

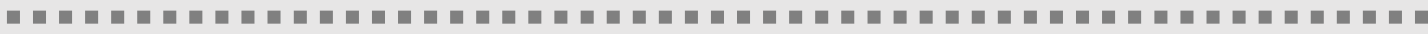

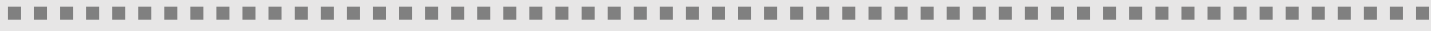

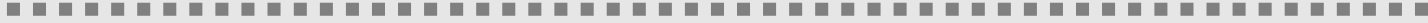

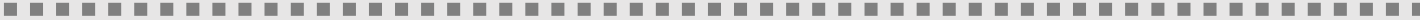 \\ PREFÁCIO}

A coleção "Pesquisas e abordagens educativas em ciências da saúde" apresenta, em dois volumes, a produção científica sobre as abordagens educativas em Ciências da Saúde nos mais variados contextos. Tem-se na obra desde estudos originais (construídos com métodos quantitativos e qualitativos) até estudos de revisão (narrativa, integrativa ou sistemática).

As Ciências da Saúde são uma das oito áreas do conhecimento classificadas pelo Conselho Nacional de Desenvolvimento Científico e Tecnológico (CNPq) e, indiscutivelmente, possuem importância imensurável para a sociedade. Destaca-se que no intento de desvelar fenômenos complexos, explorando novas fronteiras do conhecimento e do trabalho humano, a presente obra se constitui da união das Ciências da Saúde com as Ciências Humanas, conforme preceitos da Ciência Moderna, que estimula o cruzamento e a interação de áreas de saberes diferentes.

Além disso, estrutura-se em uma perspectiva multidisciplinar, contendo estudos oriundos das cinco regiões brasileiras, cujos autores possuem variadas formações. Com tal robustez, indubitavelmente esse material servirá como suporte para muitas pessoas, desde acadêmicos e profissionais, até a população em geral. Tendo em vista a relevância da temática, objetivou-se elencar de forma categorizada, nos dois volumes, os estudos de acordo com grandes áreas das Ciências da Saúde.

O volume 1 apresenta estudos relacionados aos fundamentos das profissões das Ciências da Saúde; a saúde da mulher, saúde da criança e do adolescente, saúde do adulto e do idoso, destacando as abordagens e técnicas educacionais, questões epidemiológicas, bem estar e saúde integral.

No volume 2 estão agrupadas as publicações com foco físico, biológico e bioquímico; aspectos legislativos e históricos e saúde coletiva. Chama-se atenção para as práticas integrativas e complementares, doenças crônicas e cuidado em saúde, temáticas predominantes neste segundo volume.

Os variados temas nessa coleção, divulgada pela plataforma confiável e consolidada da Editora Amplla, garantirão aos leitores uma leitura profícua e sobremodo proveitosa. Explorem e compartilhem o material. Ademais, desejamos uma excelente 


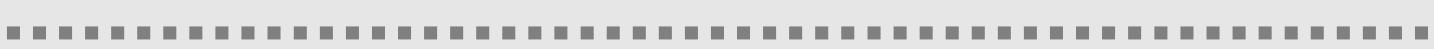

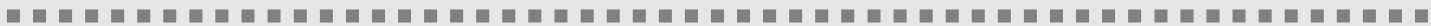

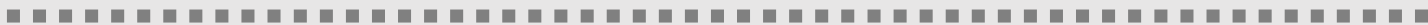

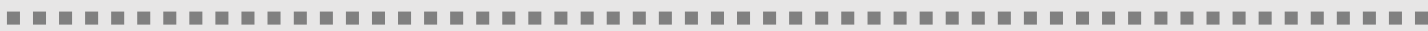

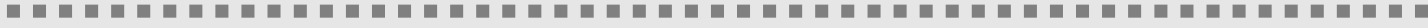

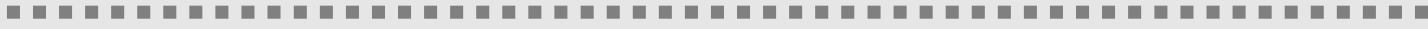

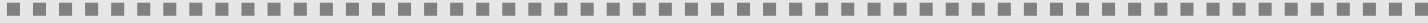

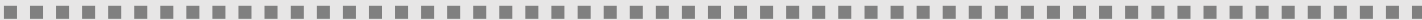

leitura, na certeza que a presente obra contribuirá para o fortalecimento da literatura

científica no tocante às abordagens educativas em ciências da saúde.

João Vitor Andrade

Enfermeiro, Especialista em Docência em Ciências da Saúde. Residente em Enfermagem em Saúde Mental e Psiquiátrica na Faculdade de Medicina da Universidade de São Paulo.

Juliana Cristina Martins de Souza

Enfermeira, Especialista em Enfermagem em Geriatria e Gerontologia e em Enfermagem em Saúde Mental e Psiquiátrica pela Faculdade de Medicina da Universidade de São Paulo.

José Gilberto Prates

Enfermeiro, Especialista em Saúde Mental e Psiquiátrica, em Terapia Comportamental Cognitiva e em Educação Profissional. Mestre e Doutor em Ciências da Saúde pela Escola de Enfermagem da

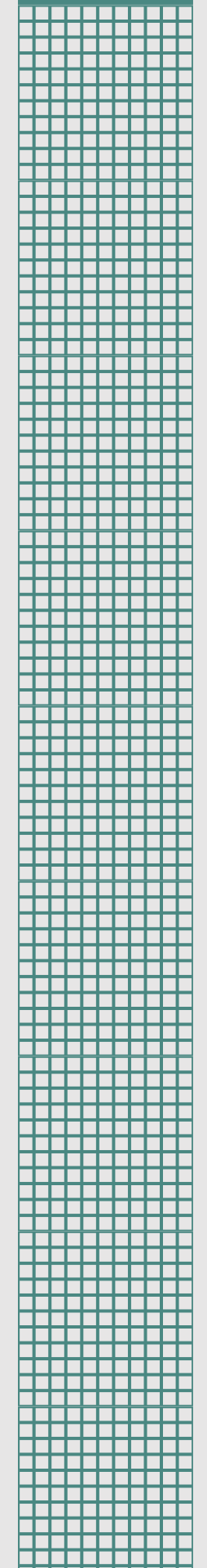

\author{
Universidade de São Paulo
}


G

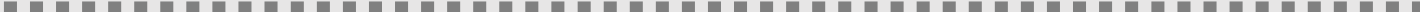

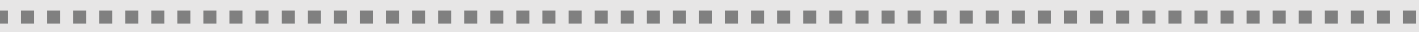

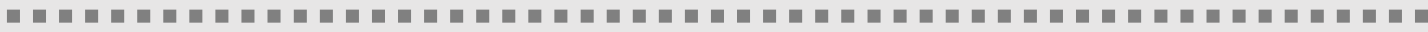

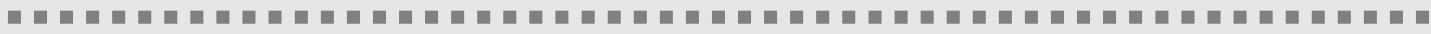

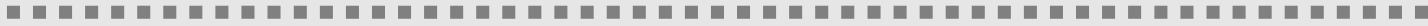

0.

\section{SUMÁRIO}

CAPÍTULO I - ANÁLISE DO POTENCIAL ANTIBIOFILME DO EXTRATO DE ROSMARINUS OFFICINALISL. (ALECRIM) CONTRA CANDIDASPP.

CAPÍTULO II - ANÁLISE FARMACOLÓGICA E TOXICOLOGICA DO MONOTERPENO SABINENO: UM ESTUDO IN SILICO .................31

CAPÍTULO III - ASPECTOS ETNOBOTÂNICOS DE CATINGA-DE-PORCO (CAESALPINIA PYRAMIDALISTULL). 42

CAPÍTULO IV - ATIVIDADE ANTIMICROBIANA E ANTIBIOFILME DO EXTRATO GLICÓLICO DE PUNICA GRANATUM (ROMÃ) SOBRE PREVOTELLA INTERMEDIAE PARVIMONAS MICRA.

CAPíTULO V- AVALIAÇÃO DA ATIVIDADE ANTIADERENTE DO GEOPRÓPOLIS DE UMA ABELHA SEM FERRÃO FRENTE AS CEPAS DE ESCHERICHIA COLI E ENTEROCOCCUS FAECALIS

CAPÍTULO VI- AYAHUASCA: FITOCOMPOSTOS, ETNOFARMACOLOGIA E POTENCIAL TERAPÊUTICO. 79

CAPÍTULO VII - CARACTERIZAÇÃO FISICO-QUíMICA DO CHÁ DE HORTELÃ (MENTHA PIPERITA L.) INDUSTRIALIZADO E IN NATURA..

CAPITULLO VIII - DIFERENTES TÉCNICAS DE REPARO DAS RESTAURAÇÕES DE AMÁLGAMA ..........................................104

CAPÍTULO IX - DOR, INFLAMAÇÃO E CICATRIZAÇÃO COM ÊNFASE EM TECIDO CUTÂNEO E REPARAÇÃO TECIDUAL ................119

CAPÍTULO X - LASER DE BAIXA INTENSIDADE NA PROLIFERAÇ̃̃O DE CÉLULAS-TRONCO DE ORIGEM DENTAL......................150

CAPITULO XI - O VÍRUS LINFOTRÓPICO-T HUMANO DO TIPO 1 (HTLV-1) ASSOCIADO À LEUCEMIA DE CÉLULAS T ADULTAS (ATL) E À PARAPARESIA ESPÁSTICA TROPICAL (HAM/TSP)

CAPÍTULO XII - NANOMATERIAIS: APLICAÇÕES DO GRAFENO E DO NIÓBIO NA MEDICINA. .178

CAPÍTULO XIII - O OIL PULLING NO TRATAMENTO DA GENGIVITE . .187

CAPITULL XIV - ÓLEOS ESSENCIAIS COM POTENCIAL ANTI-INFLAMATÓRIO NO TRATAMENTO DE DORES ARTICULARES.........196

CAPITULO XV - POTENCIAL ANTIOXIDANTE ATRIBUIDO ÀS PLANTAS MEDICINAIS E FITOTERÁPICOS

CAPÍTULO XVI - POTENCIAL FITOTERÁPICO DA AROEIRA-DO-SERTÃO (MYRACRODRUON URUNDEUVA ALLEMÃO: UM ESTUDO DE REVISÃO.

CAPITULO XVII - PREVALÊNCIA DAS DOENÇAS GENÉTICAS QUE AFETAM A ESTRUTURA OU A PRODUÇ̃̃O DAS MOLÉCULAS DE HEMOGLOBINA EM UM BANCO DE SANGUE NO NORDESTE DO BRASIL.

CAPÍTULO XVIIII - PRINCÍPIOS E GENERALIDADES SOBRE A AÇ̃̃O DOS FÁRMACOS

CAPÍTULO XIX - REVISÃO DA LITERATURA SOBRE O CORANTE AMARELO DE TARTRAZINA E SEUS EFEITOS À SAÚDE .267

CAPÍTULO XX - CONSTRUÇÃO DA IDENTIDADE DA PESSOA COM DEFICIÊNCIA: COMO 0 TERMO DE REFERÊNCIA PODE SER CAPACITISTA 
G

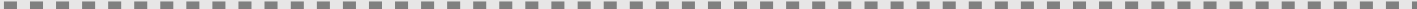

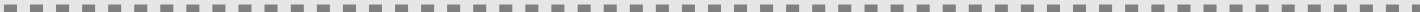

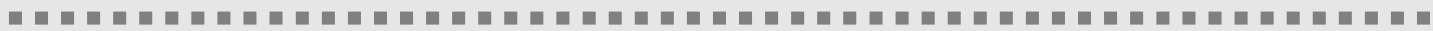

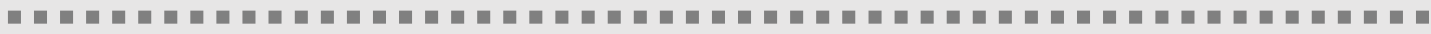

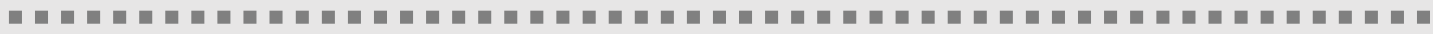

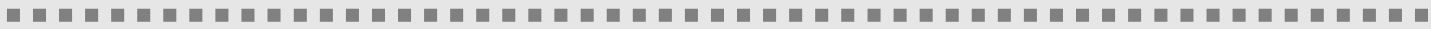

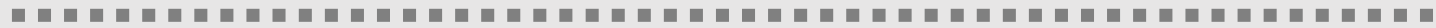

CAPÍTULO XXII - REFLETINDO SOBRE POLÍTICAS PÚBLICAS DE SAÚDE PELA ÓTICA CINEMATOGRÁFICA: UMA ANÁLISE DO DOCUMENTÁRIO ‘SICKO: SOS SAÚDE’

CAPITULLO XXIII - A PROTEÇ̃̃O DA PESSOA IDOSA: UMA ANÁLISE DA POLÍTICA PÚBLICA NO MUNICÍPIO DE PALMAS/TO ......323

CAPÍTULO XXIV - AÇ̃̃ES DA ATENÇÃO PRIMÁRIA À SAÚDE NO COMBATE À TUBERCULOSE: REVISÃO INTEGRATIVA ..............340

CAPÍTULO XXV - ESTEATOSE HEPÁTICA: UM RELATO DE CASO.

CAPÍTULO XXVI - AÇÕES INVESTIGATIVAS E EXTENSIONISTAS EM SAÚDE MENTAL PARA INCLUSÃO DE MULHERES, NEGROS

E IDOSOS FRENTE AO ESTIGMA SOCIAL VIVENCIADO . 365

CAPÍTULO XXVII - SIMULAÇ̃̃O REALÍSTICA EM SAÚDE MENTAL: RELATO DE EXPERIÊNCIA.

CAPITULO XXVIII - ALTERAÇÕES MORFOFISIOLÓGICAS CARDIOVASCULARES DECORRENTES DO PROCESSO DE SENESCÊNCIA

CAPITULO XXIX - ANÁLISE EPIDEMIOLÓGICA DA HANSENÍASE NO ESTADO DO PIAUÍ ENTRE OS ANOS DE 2015 A 2020 ........ 404

CAPÍTULO XXX - VITAMINA D EM INFECÇ̃̃O VIRAL POR SARS-COV-2: PERSPECTIVA TERAPÊUTICA NA COVID-19...............413

CAPITULO XXXI - AS CONTRIBUIÇ̃̃ES DO MANEJO RACIONAL DE CORTICOSTEROIDES SOB A COVID-19

CAPÍTULO XXXII - AS MÍDIAS SOCIAIS NA PROMOÇÃO DE SAÚDE E PREVENÇÃO DAS VIOLÊNCIAS CONTRA IDOSOS DURANTE A PANDEMIA DA COVID-19: RELATO DA EXPERIÊNCIA.

CAPÍTULO XXXIII - ASSISTÊNCIA DE ENFERMAGEM NO DOMICÍLIO A HIPERTENSOS E DIABÉTICOS ACOMPANHADOS PELA ESTRATÉGIA SAÚDE DA FAMÍLIA .

CAPITULO XXXIV - AVALIAÇÃO DAS PRESCRICÕES E DISPENSAÇ̃̃ES DE ANTIBIÓTICOS NA FARMÁCIA COMUNITÁRIA NO BAIRRO DA CIDADE OPERÁRIA EM SÃO LUÍS - MA..

CAPITULO XXXV - CARACTERIZAÇÃO EPIDEMIOLÓGICA DOS CASOS DE DENGUE NO ESTADO DO MARANHÃO ENTRE OS ANOS DE 2015 A 2020.

CAPÍTULO XXXVI - COVID-19 E OS IMPACTOS NA SAÚDE MENTAL DA POPULAÇÃO

CAPÍTULO XXXVII - ENTRE DESAFIOS E POTENCIALIDADES: O COTIDIANO DE TRABALHO NA VIGILÂNCIA DE ÓBITOS ............ 489

CAPÍTULO XXXVIII - EXERCÍCIOS FÍSICOS REGULARES COMO PROMOÇ̃̃O DE SAÚDE PARA INDIVÍDUOS IDOSOS................... 499

CAPÍTULO XXXIX - LISTA DE ESPERA PARA RESIDIR EM INSTITUIÇÃO DE LONGA PERMANÊNCIA PARA IDOSOS.....................511

CAPÍTULO XL - IMPORTÂNCIA DA EDUCAÇ̃̃O NA PREVENÇÃO E CONTROLE DA ESQUISTOSSOMOSE MANSÔNICA .................520

CAPITULO XLI - 0 LÚDICO COMO FERRAMENTA EDUCATIVA PARA O ENSINO DE UMA PARASITOSE INTESTINAL ....................533

CAPÍTULO XLII - O PAPEL DO ENFERMEIRO NA PREVENÇÃO DO CÂNCER DE PELE NA ATENÇ̃̃O PRIMÁRIA EM SAÚDE ..........547

CAPÍTULO XLIII - PANDEMIA DA COVID-19: IMPACTOS NO COMBATE E TRATAMENTO DA MALÁRIA.................................5 564

CAPÍTULO XLIV - RASTREIO DA DOENÇA RENAL CRÔNICA EM FUNCIONÁRIOS HIPERTENSOS E DIABÉTICOS DE UMA ESCOLA PÚBLICA . 


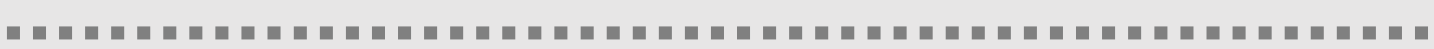

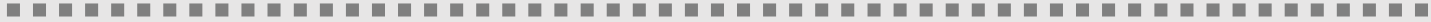

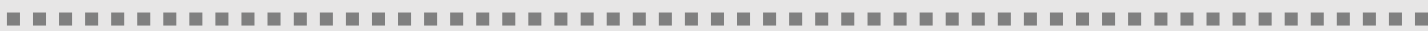

G

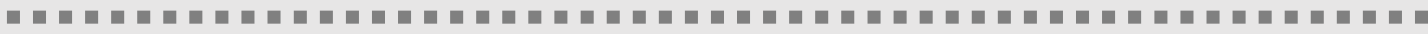

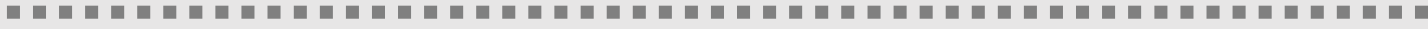

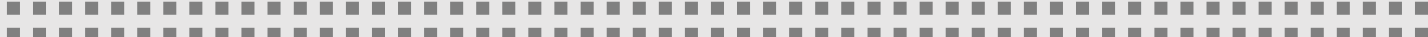

CAPÍTULO XLV - REVISÃO INTEGRATIVA DA LITERATURA SOBRE O TRATAMENTO E CONTROLE DE DIABETES MELLITUS COM

PLANTAS MEDICINAIS

CAPÍTULO XLVI - SÍNDROME DE BURNOUT EM PROFISSIONAIS DA SAÚDE: IMPORTÂNCIA DO CONHECER PARA PREVENIR.. 609

CAPÍTULO XLVII - SÍNDROME DE WOLFF-PARKINSON-WHITE COM VIA ANÔMALA PARA-HISSIANA: UM RELATO DE CASO .... 620

CAPÍTULO XLVIII - USO INDISCRIMINADO DE ANTI-INFLAMATÓRIOS NÃO ESTEROIDAIS (AINES) OBSERVADOS EM UMA

DROGARIA DE SÃO LUIS - MA.

CAPÍTULO XLIX - VIGILÂNCIA EM SAÚDE NO CONTEXTO BRASILEIRO: UMA REVISÃO INTEGRATIVA

.641

CAPITULO L - VIOLÊNCIA SEXUAL INFANTIL: ATUAÇÃO DOS CIRURGIÕES DENTISTAS NA IDENTIFICAÇÃO

CAPITULO LI - ARTEFATOS PRODUZIDOS POR MATERIAIS ODONTOLÓGICOS METÁLICOS RESTAURADORES EM IMAGENS DE RESSONÂNCIA MAGNÉTICA: UMA REVISÃO SISTEMÁTICA

CAPÍTULO LII - TEORIA DO ELO ENTRE VIOLÊNCIA DOMÉSTICA E MAUS-TRATOS CONTRA ANIMAIS: ABORDAGEM E PERSPECTIVA MULTIDISCIPLINAR 698 


\title{
CAPITULO I
}

\section{ANÁLISE DO POTENCIAL ANTIBIOFILIEE DO EXTRATO DE ROSMARINUS OFFICINALISL. (ALECRIM) CONTRA CANDIDASPP.}

DOI: 10.51859/AMPLLA.PAE1993-1

\author{
Vanessa Marques Meccatti ${ }^{1}$ \\ Jonatas Rafael de Oliveira ${ }^{2}$ \\ Leandro Wagner Figueira ${ }^{3}$ \\ Maria Cristina Marcucci 4 \\ Cláudio Antonio Talge Carvalho ${ }^{5}$ \\ Luciane Dias de Oliveira ${ }^{6}$
}

\begin{abstract}
${ }^{1}$ Doutoranda em Microbiologia e Imunologia. Universidade Estadual Paulista - ICT Unesp
${ }^{2}$ Docente na Universidade Anhembi Morumbi, campus de São José dos Campos/SP

${ }^{3}$ Doutorando em Microbiologia e Imunologia. Universidade Estadual Paulista - ICT Unesp

${ }^{4}$ Professora Colaboradora Universidade Estadual Paulista - ICT Unesp

${ }^{5}$ Professor Associado do Departamento de Odontologia Restauradora. Universidade Estadual Paulista ICT Unesp

${ }^{6}$ Professora Associada do Departamento de Biociências e Diagnóstico Bucal. Universidade Estadual Paulista - ICT Unesp
\end{abstract}

\section{RESUMO}

Objetivo: No presente estudo foi analisado o potencial antibiofilme do extrato de $R$. officinalis L. sobre C. albicans, C. dubliniensis, C. glabrata, C. krusei e C. tropicalis. Para tanto, biofilmes formados in vitro por $48 \mathrm{~h}$ foram expostos a diferentes concentrações do extrato vegetal $(50,100$ e $200 \mathrm{mg} / \mathrm{mL}$ ) por $5 \mathrm{~min}$ ou $24 \mathrm{~h}$. O efeito do extrato natural foi comparado ao antifúngico comercial nistatina. Métodos: Os biofilmes sofreram com a exposição ao extrato em ambos os tempos de avaliação e em seguida, foram desagregados, a suspensão gerada foi diluída e $20 \mu \mathrm{L}$ de cada diluição foram adicionados sobre ágar sabouraud dextrose para contagem de UFC/mL. Os dados foram apresentados em valores médios ( \pm desviopadrão) e analisados por ANOVA e Teste de Tukey, considerando diferença estatística significativa quando $\mathrm{P} \leq 0.05$ Resultados: Os percentuais de redução proporcionados pelo extrato vegetal foram significativamente semelhantes à nistatina. Conclusão: Desta forma, pode ser concluído que o extrato de $R$. officinalis $L$. apresentou efeito antibiofilme para cepas de Candida spp. de forma semelhante ao antifúngico comercial nistatina.

Palavras-chave: Candida spp. Rosmarinus officinalis L. Fitoterapia. Biofilme. Candidíase bucal. 


\section{INTRODUÇÃO}

Biofilmes são microecossistemas constituídos por micro-organismos de diferentes espécies envolvidos por uma matriz extracelular, de produção própria, estando aderidos a uma superfície (AMMONS et al., 2014; HARRIOTT; NOVERR, 2009).

Candida spp. são capazes de formar biofilme, tubos germinativos, apresentam proteínas de adesão, fosfolipases, proteases e outras enzimas extracelulares que contribuem para sua difusão pelo tecido do hospedeiro, devido estas enzimas estarem localizadas na extremidade de hifas (GANGULY; MITCHELL, 2011). Estes microorganismos possuem caráter oportunista por poder provocar doenças conhecidas por candidíases, por meio de fatores que propiciam sua penetração, difusão, instalação e desenvolvimento no hospedeiro (SOLL, 2002). Algumas situações como síndrome da imunodeficiência adquirida (AIDS), diabetes, antibioticoterapia, corticoterapia, quimioterapia, radioterapia, cirurgias, presença de sondas e cateteres podem favorecer o aparecimento da candidíase. Cerca de $80 \%$ das infecções fúngicas hospitalares são provocadas por espécies do gênero Candida. Além disso, casos de resistência à terapia antifúngica e às defesas do hospedeiro tem sido relatados (RAMAGE; LÓPEZ-RIBOT, 2005).

Na mucosa oral, a presença de infecção por Candida spp. é frequente e está relacionada com a capacidade de aderência da levedura às células epiteliais, um importante fator de virulência que propiciará a formação do biofilme após adesão microbiana (THEIN; SAMARANAYAKE; SAMARANAYAKE, 2006). Biofilmes orais são polimicrobianos, isto é, constituídos por espécies diferentes de micro-organismos, bem como, por várias espécies de Candida, como C. parapsilosis, C. tropicalis, C. krusei, C. glabrata e C. guillermondii (VIDOTTO et al., 2003).

C. albicans é a principal espécie responsável por causar candidíase oral. A capacidade de adesão às células epiteliais e a possibilidade de transformação de levedura em hifa constituem importantes fatores de virulência desta espécie (SHAPIRO et al., 2009; SILVA et al., 2011). Esta levedura pode invadir o sulco gengival e crescer em anaerobiose, podendo agravar os sintomas de doença periodontal existente. Além disso, é capaz de formar uma complexa comunidade microbiana com Streptococcus mutans facilitando a adesão da bactéria ao biofilme polimicrobiano (GREGOIRE et al., 
2011; TEN CATE et al., 2009). Em adição, o potencial cariogênico de Candida spp. tem sido relatado (NIKAWA et al., 2003). A levedura também pode inibir a ação de neutrófilos polimorfonucleares (MACCARINELLI et al., 2001) e produzir enzimas que degradam imunoglobulinas (HÄGEWALD et al., 2002).

C. dubliniensis pode ser mais prevalente em pacientes infectados pelo vírus da imunodeficiência humana (HIV) (LORETO et al., 2010). Trata-se de é um patógeno emergente que compartilha muitas características fenotípicas com C. albicans, pode produzir tubos germinativos e enzimas lipolíticas que são considerados importantes fatores de virulência desta espécie. A instalação da infecção por esta levedura é desencadeada pela liberação de enzimas lipolíticas utilizadas para difusão pelos tecidos do hosdeiro, acompanhada por adesão, interação sinérgica com outras enzimas hidrolíticas, ativação inespecífica de reação inflamatória e autodefesa, mediada pela eliminação da microbiota competidora (PARK; DO; JUNG, 2013; SARDI et al., 2013; TROFA; GÁCSER; NOSANCHUK, 2008).

C. glabrata é uma espécie encontrada com frequência em casos de candidemia (OREN; PAUL, 2014). Esta espécie não apresenta polimorfismo, com isso, é encontrada somente na forma de levedura na cavidade oral. Em infecções mistas, C. glabrata pode penetrar o epitélio oral com o auxílio de C. albicans (SILVA et al., 2011). Exposição prolongada a antifúngicos pode provocar aumento na probabilidade de infecções por $C$. glabrata e C. krusei. Além disso, casos de infecções por estas duas espécies tem aumentado em pacientes com condições debilitantes (OREN; PAUL, 2014; SAMPAIO; PAIS, 2014). Ambas as espécies têm apresentado resistência ao fluconazol e à anfotericina B (SHIRANI et al., 2017).

C. tropicalis geralmente está associada à infecções. Pacientes com câncer, infecções disseminadas ou neutropenia são os mais acometidos por esta espécie. Esta levedura apresenta algumas características que demonstram seu potencial virulento, como alta capacidade de adesão e formação de biofilme (NEGRI et al., 2010). Pacientes tratados por radioterapia podem ser mais susceptíveis a esta espécie, favorecendo a colonização pela levedura. A radiação gama utilizada no tratamento de cânceres pode provocar aumento da virulência de $C$. tropicalis por alterações morfológicas e fisiológicas (DA SILVA et al., 2017). 
Devido à incidência de doenças transmitidas por via oral, ao aumento de resistência de micro-organismos aos antimicrobianos disponíveis, à condições financeiras e aos efeitos danosos de alguns medicamentos, é notável a necessidade de métodos alternativos, como a fitoterapia, para prevenção e tratamento de doenças infecciosas, levando em consideração sua biocompatibilidade, eficácia e economia (PALOMBO, 2011). Constantemente tem surgido estudos relacionados à terapias alternativas com produtos vegetais. Substâncias isoladas de plantas medicinais, como extratos, tem despertado o interesse da área médica, visto que, podem apresentar efeitos menos agressivos ao organismo.

$R$. officinalis L. é uma das espécies vegetais que tem apresentando significativos efeitos biológicos (DE OLIVEIRA et al., 2017). Popularmente chamado de alecrim, está amplamente distribuído pelo globo. Esta planta medicinal é utilizada na indústria de cosméticos e na culinária, principalmente por sua essência aromática (MACHADO et al., 2009). Seus principais constituintes, como 1,8- cineol $(52.2 \%)$, cânfora $(15,2 \%)$ e $\alpha$ pineno $(12,4 \%)$ são responsáveis por diversas atividades biológicas (DE OLIVEIRA E SILVA et al., 2015). Dentre suas propriedades terapêuticas há destaque para a ação antibacteriana, antioxidante, antifúngica, antibiofilme e anti-inflamatória (BOZIN et al., 2007; CHIFIRIUC et al., 2012; DE OLIVEIRA E SILVA et al., 2015; KSOURI et al., 2017; LIAKOS et al., 2017; POZZATTI et al., 2010).

Com isso, no presente estudo foi avaliado o efeito antifúngico do extrato de $R$. officinalis L. sobre C. albicans, C. dubliniensis, C. glabrata, C. krusei e C. tropicalis em culturas planctônicas e biofilmes, por meio de exposição ao extrato vegetal em diferentes concentrações e tempos.

\section{METODOLOGIA}

\subsection{EXTRATO VEGETAL}

O extrato de $R$. officinalis L. foi adquirido comercialmente na concentração de $200 \mathrm{mg} / \mathrm{mL}$ em propilenoglicol (Seiva Brazilis, São Paulo, Brasil). O extrato foi obtido a partir de folhas e flores do vegetal, sendo quimicamente composto por acid saponin, borneol acetate, camphene, camphor, cineol, free borneol, glucosidic compounds, little tannin, oleanolic acid and pinene, according to the manufacturer. 


\subsection{CEPAS DE LEVEDURAS}

Cepas de referência (ATCC - American Type Culture Collection) de C. albicans (ATCC 18804), C. dubliniensis (ATCC MYA646), C. glabrata (ATCC 9030), C. krusei (ATCC 6258) e C. tropicalis (ATCC 13803), provenientes do Laboratório de Microbiologia e Imunologia (ICT/UNESP), foram utilizadas no presente estudo. As cepas foram armazenadas a $-80^{\circ} \mathrm{C}$ em Yeast Extract Peptone Dextrose broth (YPD - Himedia, Mumbai, Índia) com 16\% de glicerol.

\subsection{EFEITO ANTIFÚNGICO DETERMINADO SOBRE CULTURAS PLANCTÔNICAS}

Concentração inibitória mínima (CIM) e concentração fungicida mínima (CFM) do extrato vegetal foram determinadas por método de microdiluição em caldo, segundo Clinical and Laboratory Standards Institute (CLSI, 2002; 2012). Inicialmente, as cepas foram cultivadas em ágar Sabouraud dextrose (SD - Himedia) por $24 \mathrm{~h}$ a $37^{\circ} \mathrm{C}$. Suspensões fúngicas foram preparados em solução salina estéril $(\mathrm{NaCl} 0,9 \%)$, cuja turbidez foi ajustada em espectrofotômetro (Micronal, São Paulo, Brazil) com os parâmetros de $530 \mathrm{~nm}$ e densidade óptica (DO) de $0.284 \pm 0.02$, para obtenção de $10^{6}$ unidades formadoras de colônia por mililitro (UFC/mL). Está solução foi diluída e a concentração do inóculo utilizada esteve entre $5 \times 10^{2}$ e $2.5 \times 10^{3} \mathrm{UFC} / \mathrm{mL}$. Dez diluições seriadas do extrato foram realizadas em microplacas (TPP, Trasadingen, Suíça). Para tanto, caldo RPMI 1640 com glutamina, sem bicarbonato e com indicador vermelho de fenol (Himedia) tamponado a pH $7 \pm 0,1$ com ácido 3-( $\mathrm{N}$-morfolino) propanosulfônico (MOPS - Sigma-Aldrich, St. Louis, EUA) foi adicionado (100 $\mu \mathrm{L} /$ poço). A microdiluição foi iniciada acrescentando $100 \mu \mathrm{L}$ do extrato vegetal apenas no primeiro poço. Por meio de transferências sucessivas de $100 \mu \mathrm{L} /$ poço, dez diluições foram obtidas após adição do inóculo padronizado em todas as concentrações avaliadas (50 a 0,09 mg/mL). Wells for growth control ( $\mathrm{C}_{-}$, medium plus inoculum) and medium ( $\mathrm{C}_{+}$, medium alone) were added. Após incubação $\left(37^{\circ} \mathrm{C} / 24 \mathrm{~h}\right)$, a $\mathrm{CIM}$ foi determinada no primeiro poço sem turvação, seguinte ao poço com aparente crescimento microbiano. Para determinação da CFM, conteúdo de poços (CIM e concentração acima dela) foram adicionados em ágar SD. Após incubação $\left(37^{\circ} \mathrm{C} / 48 \mathrm{~h}\right)$, a CFM foi determinada em placa com ausência de crescimento de colônias, contendo a menor concentração do extrato. A ação do propilenoglicol também foi checada sobre as leveduras. 


\subsection{EFEITO ANTIFÚNGICO DETERMINADO SOBRE BIOFILMES}

As leveduras foram cultivadas em ágar SD e posteriormente em caldo Yeast Nitrogen Base (YNB - Sigma-Aldrich), por $24 \mathrm{~h}$ a $37^{\circ} \mathrm{C}$, cada cultivo. A suspensão fúngica foi centrifugada a $2000 \mathrm{rpm} / 10 \mathrm{~min}$ (MPW-350, Warsaw, Poland) e o sobrenadante foi substituído por solução salina $(\mathrm{NaCl} 0,9 \%)$ e outra centrifugação foi realizada, este procedimento foi realizado por duas vezes. A turbidez da suspensão fúngica foi ajustada em espectrofotômetro $(\lambda=530 \mathrm{~nm}$; DO $=0.381 \pm 0.02)$ para obtenção de $10^{7} \mathrm{UFC} / \mathrm{mL}$. Esta suspensão padronizada foi adicionada em microplaca (200 $\mu \mathrm{L} /$ poço) e incubação (37 ${ }^{\circ} \mathrm{C} / 90 \mathrm{~min}$ ) sob agitação (75 rpm - Quimis, Diadema, Brazil) foi realizada. Após préaderência das células fúngicas, o sobrenadante foi substituído por caldo YNB e o biofilme foi formado por $48 \mathrm{~h}$, ocorrendo troca do meio de cultura após $24 \mathrm{~h}$ de incubação $\left(37^{\circ} \mathrm{C}\right.$; $75 \mathrm{rpm}$ ) (OLIVEIRA et al., 2017).

Os poços da microplaca foram lavados com solução salina ( $200 \mu \mathrm{L} /$ poço) para retirada de células não aderidas ao biofilme. Em seguida, os biofilmes foram expostos às concentrações efetivas do extrato de $R$. officinalis L. (200 $\mu \mathrm{L} /$ poço), previamente determinadas sobre culturas planctônicas. Nistatina (100.000 IU/mL) e solução salina foram utilizadas como controles. Dez replicatas foram realizadas em cada grupo experimental. Os tempos de exposição ao extrato ou à nistatina foram de 5 min ou 24 h. Após exposição, os poços foram novamente lavados com solução salina ( $200 \mu \mathrm{L} /$ poço) para retirar células afetadas pelo extrato. Os biofilmes foram desagregados por homogeneizador ultrassônico (Sonopuls HD 2200 - Bandelin Eletronic, Berlin, Alemanha) por 30 s e $25 \%$ de potência. A suspensão gerada foi diluída e $20 \mu \mathrm{L}$ de cada diluição foram adicionados em triplicada sobre ágar SD. Após secagem das gotas ( 5 $\min )$, a placa foi invertida e incubada $\left(37^{\circ} \mathrm{C} / 24 \mathrm{~h}\right)$. As colônias foram contadas em cada gota e os valores médios foram apresentados em UFC/mL.

\subsection{ANÁLISE ESTATÍSTICA}

Os dados foram apresentados em valores médios ( \pm desvio-padrão) e analisados por ANOVA e Teste de Tukey, considerando diferença estatística significativa quando $P$ $\leq 0.05$. O programa GraphPad Prism 5.0 foi utilizado para este fim. 


\section{RESULTADOS}

\subsection{EFEITO ANTIFÚNGICO SOBRE CULTURAS PLANCTÔNICAS}

O extrato de $R$. officinalis $\mathrm{L}$. apresentou CIM de $50 \mathrm{mg} / \mathrm{mL}$ sobre $C$. albicans, $C$. dubliniensis, C. glabrata, C. krusei e C. tropicalis. Deste modo, CIM (50 mg/mL), 2X CIM (100 mg/mL) e 4X CIM $(200 \mathrm{mg} / \mathrm{mL})$ foram avaliadas sobre os biofilmes. $\mathrm{O}$ propilenoglicol não apresentou efeito antifúngico, uma vez que, crescimento microbiano foi observado em todas as concentrações avaliadas. Com isso, ausência de interferência deste veículo sobre as leveduras foi comprovada.

\subsection{EFEITO ANTIBIOFILME APÓS EXPOSIÇÃO DE 5 MIN}

O extrato de $R$. officinalis L. proporcionou reduções significativas do biofilme de C. albicans (UFC/mL) em relação ao grupo controle $\left(4 \times 10^{4} \pm 2.03 \times 10^{4}\right)$, após exposição a $50 \mathrm{mg} / \mathrm{mL}\left(2.11 \times 10^{4} \pm 1.2 \times 10^{4}\right)$ e $100 \mathrm{mg} / \mathrm{mL}\left(7.3 \times 10^{2} \pm 6.12 \times 10^{2}\right)$. A $200 \mathrm{mg} / \mathrm{mL}$ foi observada eliminação total do biofilme. As concentrações avaliadas do extrato apresentaram efeito antifúngico semelhante à nistatina $\left(1.67 \times 10^{3} \pm 0\right.$ ) (Figura 1 a). Com isso, as concentrações de 100 e $200 \mathrm{mg} / \mathrm{mL}$ apresentaram os maiores percentuais de redução, $99 \pm 0$ e $100 \pm 0$, respectivamente, em comparação com a concentração de 50 $\mathrm{mg} / \mathrm{mL}(50 \pm 8 \%)$. Estes percentuais foram similares ao apresentado pela nistatina (90 \pm 1\%) (Figura 1 b).

Biofilme de $C$. dubliniensis foi significativamente afetado pelo extrato vegetal a $100\left(5.38 \times 10^{6} \pm 1.56 \times 10^{6}\right)$ e $200 \mathrm{mg} / \mathrm{mL}\left(2.25 \times 10^{6} \pm 2.33 \times 10^{6}\right)$, em comparação ao grupo controle $\left(9.38 \times 10^{6} \pm 1.69 \times 10^{6}\right)$. No entanto, a $50 \mathrm{mg} / \mathrm{mL}\left(6.56 \times 10^{6} \pm 2.08 \times\right.$ $10^{6}$ ), a redução não diferiu estatisticamente do grupo controle. Por outro lado, as concentrações avaliadas do extrato apresentaram efeito semelhante à nistatina (4.36 $\mathrm{x}$ $10^{6} \pm 1.53 \times 10^{6}$ ) (Figura $1 \mathrm{c}$ ). Desta forma, a maior taxa de redução do biofilme foi encontrada após exposição a $200 \mathrm{mg} / \mathrm{mL}$ (76 $\pm 25 \%)$. Índices semelhantes foram observados a 50 ( $30 \pm 22 \%$ ) e $100 \mathrm{mg} / \mathrm{mL}$ ( $43 \pm 17 \%$ ). Os percentuais dos grupos expostos ao extrato não diferiam significativamente do grupo tratado com nistatina (54 $\pm 16 \%$ ) (Figura $1 \mathrm{~d}$ ).

O extrato vegetal atuou efetivamente sobre o biofilme de C. glabrata após exposição a $50\left(1.36 \times 10^{3} \pm 0.31 \times 10^{3}\right), 100\left(6.33 \times 10^{2} \pm 3.98 \times 10^{2}\right)$ e $200 \mathrm{mg} / \mathrm{mL}(6.67$ 
x $\left.10^{2} \pm 2.36 \times 10^{2}\right)$, em relação ao grupo controle $\left(2.5 \times 10^{3} \pm 0.97 \times 10^{3}\right)$. A ação antifúngica destas concentrações foi semelhante à nistatina $\left(1.67 \times 10^{3} \pm 0\right)$ (Figura 1 e). Diante disso, semelhanças nos índices de redução foram observados entre os grupos expostos ao extrato a 50 (46 $\pm 12 \%), 100$ (75 $\pm 16 \%$ ) e $200 \mathrm{mg} / \mathrm{mL}(73 \pm 9 \%)$, bem como, à nistatina (33 $\pm 0 \%)$ (Figura $1 \mathrm{f})$.

Redução do biofilme de C. krusei foram observadas após exposição ao extrato vegetal a $50\left(1.5 \times 10^{3} \pm 0.24 \times 10^{3}\right), 100\left(1.56 \times 10^{3} \pm 0.1 \times 10^{3}\right)$ e $200 \mathrm{mg} / \mathrm{mL}\left(1.67 \times 10^{3}\right.$ $\pm 0)$, em relação ao grupo controle $\left(2.78 \times 10^{3} \pm 0.48 \times 10^{3}\right)$. Os valores encontrados entre os grupos tratados foram semelhantes entre si e à nistatina $\left(1.67 \times 10^{3} \pm 0\right)$ (Figura $1 \mathrm{~g}$ ). Portanto, semelhantes índices de redução foram verificados nos grupos expostos ao extrato vegetal a 50 (46 $\pm 7 \%), 100$ (44 $\pm 3 \%$ ) e $200 \mathrm{mg} / \mathrm{mL}(46 \pm 0 \%)$ e ao antifúngico (40 $\pm 0 \%)$ (Figura $1 \mathrm{~h}$ ).

Biofilme de $C$. tropicalis foi prejudicado após tratamento com extrato vegetal. No grupo tratado com $200 \mathrm{mg} / \mathrm{mL}$ ocorreu total eliminação do biofilme, bem como, no grupo exposto à nistatina. Além disso, reduções do biofilme foram observadas nos grupos tratados com extrato a $50\left(2.37 \times 10^{3} \pm 0.9 \times 10^{3}\right)$ e $100 \mathrm{mg} / \mathrm{mL}\left(6.67 \times 10^{2} \pm 4.71\right.$ x $\left.10^{2}\right)$, em relação ao grupo controle $\left(1.87 \times 10^{4} \pm 0.84 \times 10^{4}\right)$. Grupos tratados com extrato a 100 e $200 \mathrm{mg} / \mathrm{mL}$ e nistatina demonstraram semelhante efeito antibiofilme (Figura i). Desta forma, as taxas de redução do biofilme foram similares entre os grupos tratados com extrato a 100 (96 $\pm 2 \%)$ e $200 \mathrm{mg} / \mathrm{mL}(100 \pm 0 \%)$ e nistatina (100 $\pm 0 \%)$, diferindo do tratamento com extrato a $50 \mathrm{mg} / \mathrm{mL}$ ( $87 \pm 5 \%$ ) (Figura j). 
Figura 1 - Redução do biofilme de Candida spp. com tempo de exposição de 5 min ao extrato de alecrim.
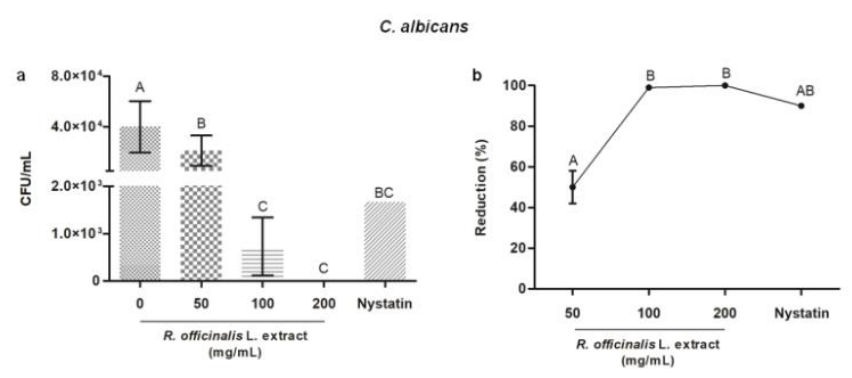

C. dubliniensis
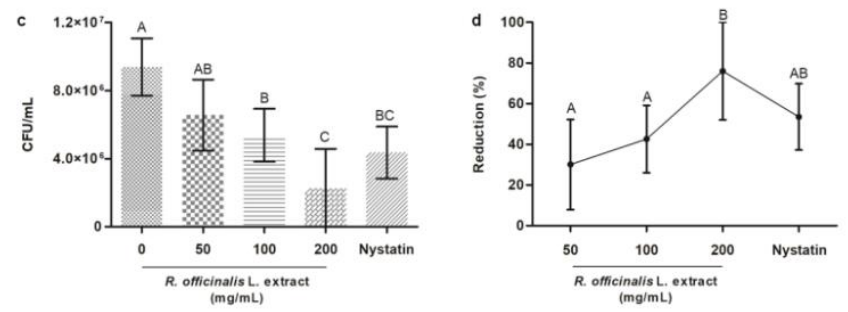

c. glabrata
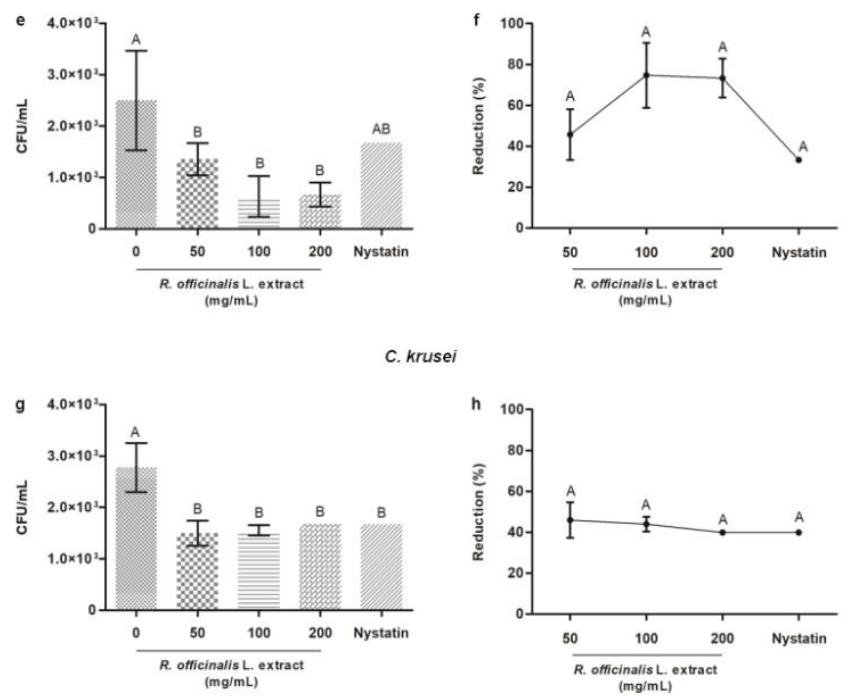

C. tropicalis
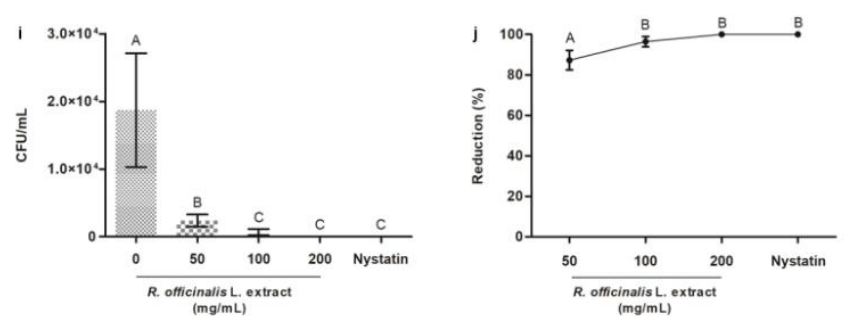

Valores médios ( \pm desvio-padrão) de $\mathrm{UFC} / \mathrm{mL}$ e percentuais de redução dos biofilmes de $C$. albicans (a, b), C. dubliniensis (c, d), C. glabrata (e, f), C. krusei $(\mathrm{g}, \mathrm{h})$ e $C$. tropicalis $(\mathrm{i}, \mathrm{j})$ obtidos após exposição por $5 \mathrm{~min}$ ao extrato de $R$. officinalis L. (50, 100 e $200 \mathrm{mg} / \mathrm{mL})$ e a à nistatina, em comparação ao grupo controle $(0 \mathrm{mg} / \mathrm{mL})$ composto por solução salina $(\mathrm{NaCl} 0,9 \%)$. Letras diferentes indicam diferença estatística significativa. $(n=10$; ANOVA e Tukey's Test; $P \leq 0.05)$. 


\subsection{EFEITO ANTIBIOFILME APÓS EXPOSIÇÃO DE 24H}

O extrato de $R$. officianlis L. reduziu significativamente o biofilme de C. albicans, após tratamento com concentrações de $50\left(7.65 \times 10^{6} \pm 1.52 \times 10^{6}\right), 100\left(3.87 \times 10^{4} \pm\right.$ $\left.0.46 \times 10^{4}\right)$ e $200 \mathrm{mg} / \mathrm{mL}\left(1.87 \times 10^{4} \pm 0.56 \times 10^{4}\right)$, em relação ao grupo controle $(1.94 \times$ $\left.10^{7} \pm 0.55 \times 10^{7}\right)$. Concentrações de 100 e $200 \mathrm{mg} / \mathrm{mL}$ apresentaram efeito semelhante a nistatina $\left(1.71 \times 10^{5} \pm 0.92 \times 10^{5}\right)$ (Figura 2 a). Sendo assim, o menor índice de redução do biofilme foi observado após exposição ao extrato vegetal a $50 \mathrm{mg} / \mathrm{mL}$ (62 $\pm 8 \%$ ). No entanto, concentrações de 100 (100 $\pm 0.02 \%$ ) e 200 mg/mL (100 $\pm 0.03 \%$ ) apresentaram índices semelhantes a nistatina ( $99 \pm 0.5 \%$ ) (Figura 2 b).

Biofilme de $C$. dubliniensis foi diminuído após exposição ao extrato vegetal nas concentrações de $50\left(7.43 \times 10^{6} \pm 1.51 \times 10^{6}\right)$ e $100\left(8.33 \times 10^{5} \pm 0\right)$ e total eliminação do biofilme foi observada a $200 \mathrm{mg} / \mathrm{mL}$, em comparação ao grupo controle $\left(2.98 \times 10^{7} \pm\right.$ $0.73 \times 10^{7}$ ). As concentrações de 100 e $200 \mathrm{mg} / \mathrm{mL}$ demonstraram efeito antibiofilme similar a nistatina $\left(1.11 \times 10^{4} \pm 0.82 \times 10^{4}\right)$ (Figura $2 \mathrm{c}$ ). Com isso, os maiores percentuais de redução foram observados nos tratamentos com concentrações de 100 (97 \pm 0\%) e $200 \mathrm{mg} / \mathrm{mL}(100 \pm 0 \%)$, que foram semelhantes a nistatina (100 $\pm 0.03 \%)$. O menor índice foi obtido na concentração de $50 \mathrm{mg} / \mathrm{mL}$ (75 $\pm 5 \%$ ) (Figura $2 \mathrm{~d}$ ).

O extrato vegetal apresentou ação antibiofilme sobre $C$. glabrata após contato com as concentrações de $50\left(6.4 \times 10^{5} \pm 4.93 \times 10^{5}\right), 100\left(8.33 \times 10^{5} \pm 0\right)$ e $200 \mathrm{mg} / \mathrm{mL}$ $\left(1.67 \times 10^{2} \pm 0\right)$, demonstrando efeito semelhante à nistatina $\left(1.58 \times 10^{4} \pm 0.12 \times 10^{4}\right)$. Uma vez que, no grupo controle foram obtidas $6.97 \times 10^{6} \pm 3.97 \times 10^{6} \mathrm{UFC} / \mathrm{mL}$ (Figura 2 e). Logo, os percentuais de redução foram semelhantes entre os grupos tratados com o extrato vegetal a 50 (91 $\pm 7 \%), 100(88 \pm 0 \%)$ e $200 \mathrm{mg} / \mathrm{mL}(100 \pm 0 \%)$ e grupo tratado com nistatina (100 $\pm 0.02 \%$ ) (Figura $2 \mathrm{f}$ ).

Biofilme de C. krusei foi afetado pelo extrato vegetal a $50\left(8.33 \times 10^{3} \pm 3.85 \mathrm{x}\right.$ $\left.10^{3}\right), 100\left(3.33 \times 10^{2} \pm 1.67 \times 10^{2}\right)$ e $200 \mathrm{mg} / \mathrm{mL}\left(2.08 \times 10^{2} \pm 0.83 \times 10^{2}\right)$, em comparação ao grupo controle $\left(1.78 \times 10^{5} \pm 0.51 \times 10^{5}\right)$. O efeito antibiofilme das concentrações do extrato foi semelhante ao efeito apresentado pela nistatina $\left(7.78 \times 10^{2} \pm 0.96 \times 10^{2}\right)$ (Figura $2 \mathrm{~g}$ ). Desta forma, os índices de redução observados nos grupos expostos ao extrato a 50 (95 $\pm 2 \%), 100(100 \pm 0.1 \%)$ e $200 \mathrm{mg} / \mathrm{mL}(100 \pm 0.05 \%)$ não diferiram dos índices apresentados pela nistatina (100 $\pm 0.05 \%)$ (Figura $2 \mathrm{~h}$ ). 
O extrato vegetal contribuiu efetivamente para a eliminação do biofilme de $C$. tropicalis, após exposição às concentrações de $50\left(1 \times 10^{5} \pm 0\right), 100\left(1.67 \times 10^{2} \pm 0\right)$ e 200 $\mathrm{mg} / \mathrm{mL}\left(1.67 \times 10^{4} \pm 0\right)$, em relação ao grupo controle $\left(4.56 \times 10^{5} \pm 1.62 \times 10^{5}\right)$. O efeito antibiofilme apresentado pelas concentrações de 100 e $200 \mathrm{mg} / \mathrm{mL}$ foi similar ao apresentado pela nistatina, que eliminou totalmente o biofilme (Figura 2 i). Com isso, os percentuais de redução do biofilme foram semelhantes entre os grupos expostos ao extrato a 100 (100 $\pm 0 \%$ ) e $200 \mathrm{mg} / \mathrm{mL}$ (96 $\pm 0 \%$ ) e a nistatina (100 $\pm 0 \%)$. O menor índice de redução foi observado na concentração de $50 \mathrm{mg} / \mathrm{mL}$ (78 \pm 0\%) (Figura 2 j).

Figura 2 - Redução do biofilme de Candida spp. com tempo de exposição de $24 \mathrm{~h}$ ao extrato de alecrim.
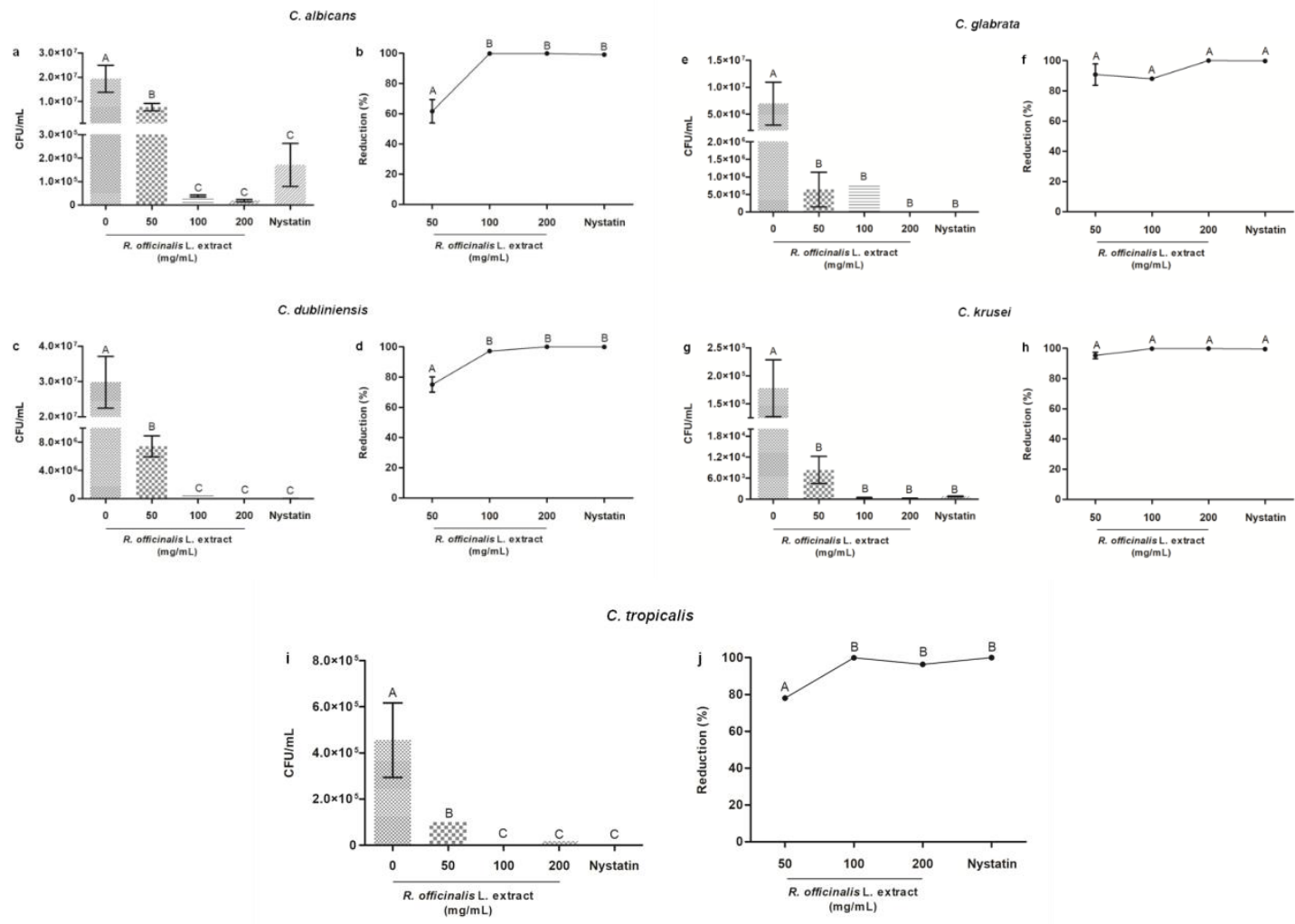

Valores médios ( \pm desvio-padrão) de UFC/mL e percentuais de redução dos biofilmes de $C$. albicans (a, b), C. dubliniensis (c, d), C. glabrata (e, f), C. krusei $(g, h)$ e C. tropicalis (i, j) obtidos após exposição por $24 \mathrm{~h}$ ao extrato de $R$. officinalis L. $(50,100$ e $200 \mathrm{mg} / \mathrm{mL})$ e a à nistatina, em comparação ao grupo controle $(0 \mathrm{mg} / \mathrm{mL}$ ) composto por solução salina ( $\mathrm{NaCl} 0,9 \%)$. Letras diferentes indicam diferença estatística significativa. $(n=10$; ANOVA e Tukey's Test; $P \leq 0.05)$.

\subsection{COMPARAÇÃO 5 MIN X 24 H}

Uma comparação entre os percentuais de redução obtidos dos grupos experimentais nos tempos de exposição de 5 min e $24 \mathrm{~h}$ foi apresentada na Figura 3 - 
Maior percentual de redução do biofilme de C. albicans foi observado após $24 \mathrm{~h}$ de exposição ao extrato a $50 \mathrm{mg} / \mathrm{mL}$ e a nistatina, em comparação à exposição de 5 min. Semelhantes percentuais de redução foram observados apões exposições às concentrações de 100 e $200 \mathrm{mg} / \mathrm{mL}$ do extrato de $R$. officinalis L.

A exposição por $24 \mathrm{~h}$ às concentrações de 50 e $100 \mathrm{mg} / \mathrm{mL}$ do extrato e à nistatina proporcionou maiores percentuais de redução do biofilme de $C$. dubliniensis, em comparação à exposição por 5 min. No entanto, percentuais semelhantes foram observados após tratamento com a concentração de $200 \mathrm{mg} / \mathrm{mL}$ do extrato.

Biofilme de C. glabrata apresentou os maiores percentuais de redução após exposição por $24 \mathrm{~h}$ ao extrato vegetal a 50 e $200 \mathrm{mg} / \mathrm{mL}$ e à nistatina, que na exposição por $5 \mathrm{~min}$. Semelhanças foram encontradas no tratamento com extrato a $100 \mathrm{mg} / \mathrm{mL}$.

Todos os grupos experimentais analisados demonstraram maior percentual de redução do biofilme de $C$. krusei após exposição de 24 h, em comparação à exposição por $5 \mathrm{~min}$.

As concentrações do extrato de 50 e $200 \mathrm{mg} / \mathrm{mL}$ apresentaram maiores percentuais de redução do biofilme de $C$. tropicalis após 5 min de exposição. No grupo exposto por $24 \mathrm{~h}$ à concentração de $100 \mathrm{mg} / \mathrm{mL}$ do extrato foi constatado o maior percentual de redução. A exposição à nistatina proporcionou percentual de redução semelhante entre ambos os tempos de exposição. 
Figura 3 - Comparação da ação antibiofilme do extrato de alecrim 5 min x 24h

C. albicans

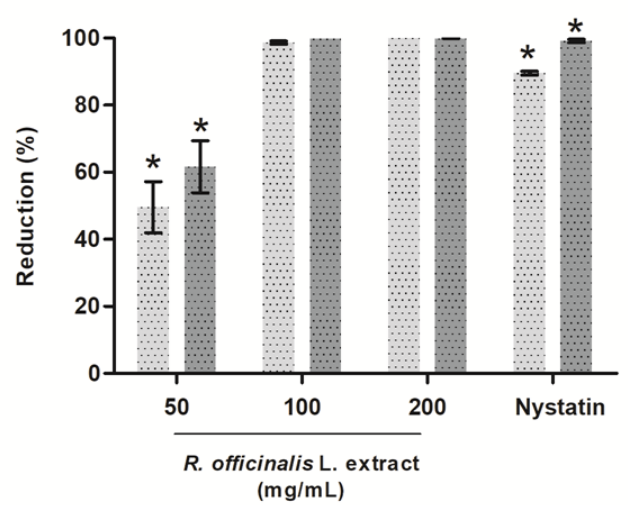

C. glabrata

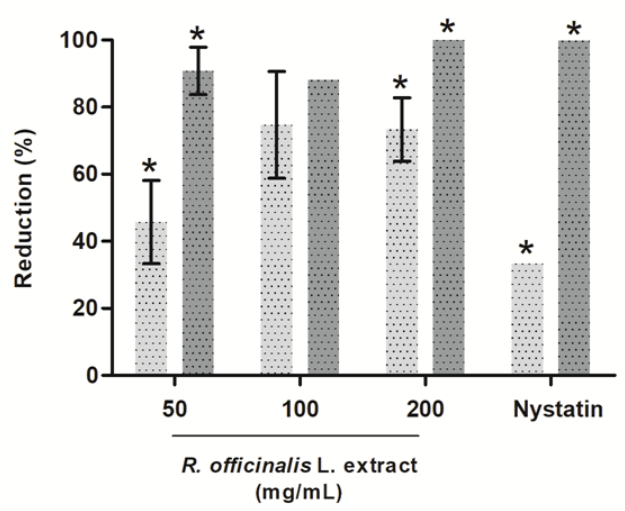

C. dubliniensis

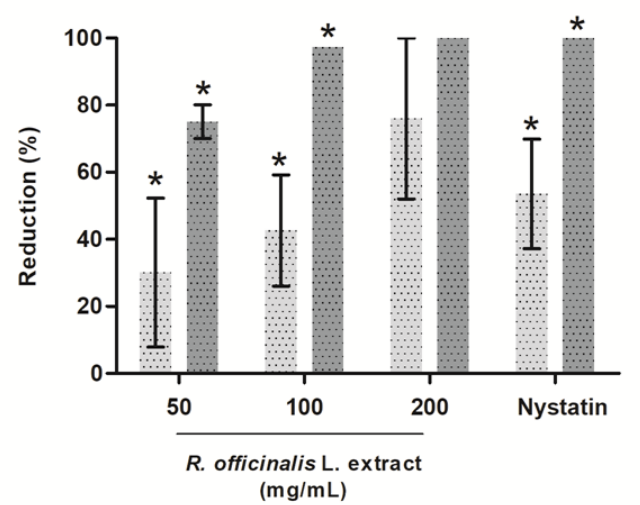

C. krusei

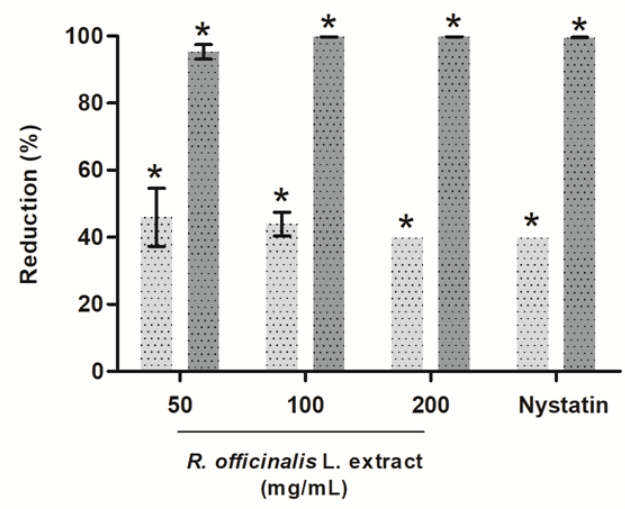

c. tropicalis

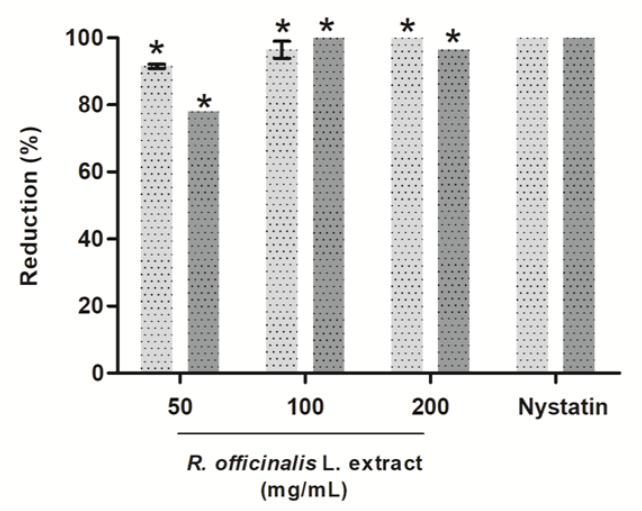

Comparação de valores médios ( \pm desvio-padrão) de percentuais de redução dos biofilmes de C. albicans, $C$. dubliniensis, C. glabrata, C. krusei e $C$. tropicalis entre os tempos de exposição de $5 \mathrm{~min}$ e $24 \mathrm{~h}$ ao extrato de $R$. officinalis L. (50, 100 e $200 \mathrm{mg} / \mathrm{mL}$ ) e à nistatina. Asteriscos indicam diferença estatística significativa obtida entre os tempos experimentais em cada concentração avaliada. ( $n=10$; T-Test; $P \leq 0.05$ ). 


\section{DISCUSSÃO}

No presente estudo, a concentração de $50 \mathrm{mg} / \mathrm{mL}$ do extrato de $R$. officinalis L., determinada como $\mathrm{CIM}$, foi capaz de inibir o crescimento de C. albicans, $C$. dubliniensis, C. glabrata, C. krusei e C. tropicalis na forma planctônica. Diante disso, CIM (50 mg/mL), 2X CIM (100 mg/mL) e 4X CIM (200 mg/mL) foram avaliadas sobre biofilmes de cada espécie, uma vez que, o uso de concentrações mais elevadas que a CIM é necessário para afetar significativamente biofilmes, em comparação com culturas planctônicas (LEWIS, 2001).

No biofilme de C. albicans, concentrações de 50, 100 e $200 \mathrm{mg} / \mathrm{mL}$ do extrato de R. officinalis L. apresentaram efeito semelhante à nistatina, apenas com 5 min de exposição (Figura 1 a, b). Concentrações de 100 e 200 mg/mL tiveram maior índice de redução que a concentração de $50 \mathrm{mg} / \mathrm{mL}$. Além disso, à $200 \mathrm{mg} / \mathrm{mL}$ foi observada eliminação total deste biofilme. Na exposição por 24h, concentrações de 100 e 200 $\mathrm{mg} / \mathrm{mL}$ apresentaram índices semelhantes à nistatina. Entretanto, a $50 \mathrm{mg} / \mathrm{mL}$ também foi observada redução significativa do biofilme, em relação com o grupo controle. Analisando os resultados de ambos os tempos de exposição, o percentual de redução deste biofilme com a concentração de $50 \mathrm{mg} / \mathrm{mL}$ foi maior, após exposição de $24 \mathrm{~h}$, como também foi ocorrido com a nistatina. Em demais concentrações o efeito foi semelhante. Outros estudos tem relatado que o óleo essencial de $R$. officinalis L. foi capaz de atuar sobre isolados clínicos de C. albicans, afetando a formação de tubos germinativos (GAUCH et al., 2014; KSOURI et al., 2017; POZZATTI et al., 2010). Adicionalmente, o efeito antibiofilme deste óleo essencial contra $C$. albicans também foi relatado. No entanto, o produto vegetal foi incorporado à nanofibras de acetato de celulose por se tratar de excelente carreador que não possuiu nenhuma atividade biológica. Este estudo comprovou que a união destes produtos resultou em uma estrutura uniforme, além de verificar que quanto maior a concentração do óleo essencial melhor foi a atividade antifúngica exercida contra as cepas de $C$. albicans (LIAKOS et al., 2017). Extratos etanólico e aquoso de folhas de $R$. officinalis L. e Echinophora platyloba foram avaliados e comparados. O extrato etanólico de $R$. officinalis L. demonstrou efetiva atividade antifúngica contra C. albicans, com efeito 
superior ao extrato etanólico de E. platyloba. Por outro lado, os extratos aquosos não apresentaram efeito significativo contra C. albicans (SEPEHRI et al., 2016).

O biofilme de $C$. dubliniensis sofreu reduções significativas quando tratado com extrato de $R$. officinalis L. A $200 \mathrm{mg} / \mathrm{mL}$ foi observado maior percentual de redução que a 50 e $100 \mathrm{mg} / \mathrm{mL}$. No entanto, as três concentrações do extrato aturam de forma semelhante à nistatina, após 5 min de exposição (Figura 1 c, d). Por outro lado, a 100 e $200 \mathrm{mg} / \mathrm{mL}$ também foi constatada ação similar ao antifúngico após $24 \mathrm{~h}$ de exposição. Em adição, a $200 \mathrm{mg} / \mathrm{mL}$ foi observada eliminação total do biofilme (Figura 2 c, d). Na comparação entre os tempos de exposição, foi verificado que no tempo de $24 \mathrm{~h}$ houve maior índice de redução do biofilme de $C$. dubliniensis nos grupos tratados com extrato vegetal a 50 e $100 \mathrm{mg} / \mathrm{mL}$ e com nistatina. O extrato a $200 \mathrm{mg} / \mathrm{mL}$ apresentou percentuais de redução semelhantes (Figura 3). Ainda não foram relatados estudos que avaliaram o efeito do extrato de $R$. officinalis L. sobre biofilmes de $C$. dubliniensis. Entretanto, sobre culturas planctônicas foi demonstrada a susceptibilidade desta levedura ao fitoterápico (HÖFLING et al., 2010).

$\mathrm{Na}$ avaliação por 5 min, o biofilme de $C$. glabrata foi afetado pelas concentrações avaliadas do extrato de $R$. officinalis L., ocorrendo atuação semelhante à nistatina (Figura 1 e,f). Na avaliação por 24h, todas as concentrações analisadas também apresentaram efeito semelhante à nistatina (Figura 2 e, f). Comparando-se os percentuais de redução obtidos entre os dois tempos de exposição, foi verificado que o contato por $24 \mathrm{~h}$ ao extrato vegetal a 50 e $200 \mathrm{mg} / \mathrm{mL}$, bem como, à nistatina, proporcionou percentuais de redução superiores ao contato por 5 min (Figura 3).

Biofilme de $C$. krusei sofreu significativa redução após exposição ao extrato de $R$. officinalis L. a 50, 100 e $200 \mathrm{mg} / \mathrm{mL}$ por $5 \mathrm{~min}$, apresentando percentuais semelhantes entre as concentrações avaliadas, bem como, à nistatina (Figura $1 \mathrm{~g}, \mathrm{~h}$ ). A exposição por $24 \mathrm{~h}$ também demonstrou efetiva ação antifúngica, uma vez que, o extrato vegetal, nas concentrações estudadas, apresentou efeito semelhante à nistatina (Figura $2 \mathrm{~g}, \mathrm{~h}$ ). Com isso, a exposição por $24 \mathrm{~h}$ demonstrou efeito antibiofilme superior, em relação ao contato por $5 \mathrm{~min}$, em todos os grupos experimentais (Figura 3). Este fato sugere que o tempo de exposição a um agente antifúngico pode afetar biofilmes de Candida spp. de forma diferente. A ação do extrato de R. officinalis L. sobre biofilmes de C. glabrata e $C$. krusei ainda não foi relatada, no entanto, sobre culturas planctônicas destas espécies foi 
verificada resistência ou efeito pouco satisfatório em relação ao extrato vegetal (HÖFLING et al., 2010; SOARES et al., 2015), porém no presente estudo CIM de $50 \mathrm{mg} / \mathrm{mL}$ foi encontrada para todas as espécies avaliadas, além de significativa ação antibiofilme.

Na exposição por 5 min ao extrato de $R$. officinalis L., o biofilme de $C$. tropicalis foi reduzido significativamente a 50, 100 e $200 \mathrm{mg} / \mathrm{mL}$. As duas maiores concentrações apresentaram percentuais de redução semelhantes à nistatina (Figura 1 i, j), com total eliminação do biofilme após uso da concentração de $200 \mathrm{mg} / \mathrm{mL}$ e nistatina. $\mathrm{Na}$ exposição por $24 \mathrm{~h}$ ocorreu eliminação total do biofilme nos grupos tratados com 0 extrato vegetal a 100 e $200 \mathrm{mg} / \mathrm{mL}$ e nistatina (Figura 2 i, j). Desta forma, a exposição por $5 \mathrm{~min}$ ao extrato vegetal a 50 e $200 \mathrm{mg} / \mathrm{mL}$ demonstrou maior índice de redução do biofilme que na exposição por $24 \mathrm{~h}$. Contudo, o contato por $24 \mathrm{~h}$ proporcionou maior percentual de redução a $100 \mathrm{mg} / \mathrm{mL}$ (Figura 3). O efeito antifúngico do extrato de $R$. officinalis L. também foi relatado sobre culturas planctônicas de C. tropicalis, sendo verificada sua susceptibilidade ao produto vegetal (HÖFLING et al., 2010). Sobre biofilmes, foi demonstrada a capacidade do óleo essencial de $R$. officinalis $L$. conjugado com nanopartículas em inibir a aderência e formação de biofilme polimicrobiano de $C$. albicans e C. tropicalis (CHIFIRIUC et al., 2012).

\section{CONSIDERAÇÕES FINAIS}

Na literatura, tem sido amplamente comprovada a eficácia de compostos naturais, como extratos e óleos essenciais de plantas medicinais. Estes produtos tem apresentado resultados significativos comparados aos agentes antimicrobianos disponíveis, como ocorrido no presente estudo, que foi demonstrado que o extrato de $R$. officinalis L. atuou de forma semelhante à nistatina, além de apresentar reduções significativas de biofilmes de C. albicans, C. dubliniensis, C. glabrata, C. krusei e C. tropicalis, em diferentes concentrações e tempos de exposição.

\section{AGRADECIMENTOS}

À Fundação de Amparo à Pesquisa do Estado de São Paulo (FAPESP) pela bolsa de Iniciação Científica (Processo 15/25338-0) e Auxílio Regular à Pesquisa (Processo 15/08776-3). 
Este artigo foi originalmente publicado nos Anais da Academia Brasileira de Ciências:

“Meccatti VM, Oliveira JR, Figueira LW, Lagareiro Netto AA, Zamarioli LS, Marcucci MC, Camargo SEA, Carvalho CAT, Oliveira LD. Rosmarinus officinalis L. (rosemary) extract has antibiofilm effect similar to the antifungal nystatin on Candida samples. An Acad Bras Cienc. 2021 Apr 30;93(2):e20190366. doi: 10.1590/0001-3765202120190366. PMID: 33950151."

\section{REFERÊNCIAS}

AMMONS, M. C. B. et al. Quantitative NMR metabolite profiling of methicillin-resistant and methicillin-susceptible Staphylococcus aureus discriminates between biofilm and planktonic phenotypes. Journal of proteome research, v. 13, n. 6, p. 2973-2985, 6 jun. 2014.

BOZIN, B. et al. Antimicrobial and antioxidant properties of Rosemary and Sage (Rosmarinus officinalis L. and Salvia officinalis L., Lamiaceae) essential oils. Journal of Agricultural and Food Chemistry, v. 55, n. 19, p. 7879-7885, 19 set. 2007.

CHIFIRIUC, C. et al. Hybrid magnetite nanoparticles/rosmarinus officinalis essential oil nanobiosystem with antibiofilm activity. Nanoscale Research Letters, v. 7, n. 1, p. 209, 2012.

DA SILVA, E. M. et al. Radiation used for head and neck cancer increases virulence in Candida tropicalis isolated from a cancer patient. BMC Infectious Diseases, v. 17, p. 1-9, 2017.

DE OLIVEIRA E SILVA, A. M. et al. Aqueous extract of Rosmarinus officinalis L. inhibits neutrophil influx and cytokine secretion. Phytotherapy Research, v. 29, n. 1, p. 125-133, 2015.

DE OLIVEIRA, J. R. et al. Biological activities of Rosmarinus officinalis L. (rosemary) extract as analyzed in microorganisms and cells. Experimental Biology and Medicine, v. 242, n. 6, p. 625-634, 2017.

GANGULY, S.; MITCHELL, A. P. Mucosal biofilms of Candida albicans. Current opinion in microbiology, v. 14, n. 4, p. 380-385, ago. 2011.

GAUCH, L. M. R. et al. Effects of Rosmarinus officinalis essential oil on germ tube formation by Candida albicans isolated from denture wearers. Revista da Sociedade Brasileira de Medicina Tropical, v. 47, n. 3, p. 389-391, 2014.

GREGOIRE, S. et al. Role of ghlucosyltransferase B in interactions of Candida albicans with Streptococcus mutans and with an experimental pellicle on hydroxyapatite 
surfaces. Applied and Environmental Microbiology, v. 77, n. 18, p. 6357-6367, set. 2011.

HÄGEWALD, S. et al. Salivary IgA subclasses and bacteria-reactive IgA in patients with aggressive periodontitis. Journal of Periodontal Research, v. 37, n. 5, p. 333-339, 2002.

HARRIOTT, M. M.; NOVERR, M. C. Candida albicans and Staphylococcus aureus form polymicrobial biofilms: Effects on antimicrobial resistance. Antimicrobial Agents and Chemotherapy, v. 53, n. 9, p. 3914-3922, 2009.

HÖFLING, J. F. et al. Potencial antimicrobiano de extratos de plantas na inibição de leveduras do gênero Candida. Brazilian Journal of Biology, v. 70, n. 4, p. 1065$1068,2010$.

KSOURI, S. et al. Antifungal activity of essential oils extract from Origanum floribundum Munby, Rosmarinus officinalis L. and Thymus ciliatus Desf. against Candida albicans isolated from bovine clinical mastitis. Journal de Mycologie Medicale, v. 27, n. 2, p. 245-249, 2017.

LEWIS, K. Riddle of biofilm resistance. Antimicrobial Agents and Chemotherapy Antimicrob Agents Chemother, 2001.

LIAKOS, I. L. et al. Electrospun fiber pads of cellulose acetate and essential oils with antimicrobial activity. Nanomaterials, v. 7, n. 4, 12 abr. 2017.

LORETO, É. S. et al. Candida dubliniensis: Epidemiology and phenotypic methods for identification. Mycopathologia Springer Netherlands, , 21 fev. 2010.

MACCARINELLI G, BELOTTI R, SAVOLDI E, GERVASONI M, C. D. Phagocytosis and killing of Candida albicans of polymorphonuclear cells in patients with organ transplant of periodontal disease. Minerva Stomatol, v. 50, n. (11-12), p. 345-9, 2001.

MACHADO, D. G. et al. Antidepressant-like effect of the extract of Rosmarinus officinalis in mice: Involvement of the monoaminergic system. Progress in NeuroPsychopharmacology and Biological Psychiatry, v. 33, n. 4, p. 642-650, 15 jun. 2009.

NEGRI, M. et al. Examination of potential virulence factors of Candida tropicalis clinical isolates from hospitalized patients. Mycopathologia, v. 169, n. 3, p. 175-182, 2010.

NIKAWA, H. et al. In vitro cariogenic potential of Candida albicans. Mycoses, v. 46, $n$. 11-12, p. 471-478, 2003.

OLIVEIRA, J. R. DE et al. Thymus vulgaris L. extract has antimicrobial and antiinflammatory effects in the absence of cytotoxicity and genotoxicity. Archives of Oral Biology, v. 82, p. 271-279, 1 out. 2017. 
OREN, I.; PAUL, M. Up to date epidemiology, diagnosis and management of invasive fungal infections. Clinical Microbiology and Infection, 2014.

PALOMBO, E. A. Traditional medicinal plant extracts and natural products with activity against oral bacteria: Potential application in the prevention and treatment of oral diseases. Evidence-based Complementary and Alternative Medicine, 2011.

PARK, M.; DO, E.; JUNG, W. H. Lipolytic enzymes involved in the virulence of human pathogenic. fungi Mycobiology, 2013.

POZZATTI, P. et al. Inhibition de la formation de tube germinatif de Candida albicans et de Candida dubliniensis par diverses huiles essentielles. Journal de Mycologie Medicale, v. 20, n. 3, p. 185-189, 1 set. 2010.

RAMAGE, G.; LÓPEZ-RIBOT, J. L. Techniques for antifungal susceptibility testing of Candida albicans biofilms. Methods in molecular medicine, v. 118, p. 71-79, 2005.

SAMPAIO, P.; PAIS, C. Epidemiology of Invasive Candidiasis and Challenges for the Mycology Laboratory: Specificities of Candida glabrata. Current Clinical Microbiology Reports Springer, 1 set. 2014.

SARDI, J. C. O. et al. Candida species: Current epidemiology, pathogenicity, biofilm formation, natural antifungal products and new therapeutic options. Journal of Medical Microbiology, jan. 2013.

SEPEHRI, Z. et al. Antifungal effects of the aqueous and ethanolic leaf extracts of Echinophora platyloba and Rosmarinus officinalis. Current Medical Mycology, v. 2, n. 1, p. 30-35, 1 mar. 2016.

SHAPIRO, R. S. et al. Hsp90 orchestrates temperature-dependent Candida albicans morphogenesis via Ras1-PKA signaling. Current biology : CB, v. 19, n. 8, p. 621629, 2009.

SHIRANI, M. et al. Chemical composition and antifungal effect of hydroalcoholic extract of Allium tripedale (Tvautv.) against Candida species. Current Medical Mycology, v. 3, n. 1, p. 6-12, 1 mar. 2017.

SILVA, S. et al. Candida glabrata and Candida albicans co-infection of an in vitro oral epithelium. Journal of Oral Pathology and Medicine, v. 40, n. 5, p. 421-427, maio 2011.

SOARES, I. H. et al. In vitro activity of essential oils extracted from condiments against fluconazole-resistant and -sensitive Candida glabrata. Journal de Mycologie Medicale, v. 25, n. 3, p. 213-217, 1 set. 2015.

SOLL, D. R. Candida commensalism and virulence: The evolution of phenotypic plasticity. Acta Tropica. Anais Acta Trop, 2002 
TEN CATE, J. M. et al. Molecular and cellular mechanisms that lead to Candida biofilm formation. Journal of Dental Research, 2009.

THEIN, Z. M.; SAMARANAYAKE, Y. H.; SAMARANAYAKE, L. P. Effect of oral bacteria on growth and survival of Candida albicans biofilms. Archives of Oral Biology, v. 51, n. 8, p. 672-680, ago. 2006.

TROFA, D.; GÁCSER, A.; NOSANCHUK, J. D. Candida parapsilosis, an emerging fungal pathogen. Clinical Microbiology Reviews, out. 2008.

VIDOTTO, V. et al. Adherence of Candida albicans and Candida dubliniensis to buccal and vaginal cells. Revista Iberoamericana de Micologia, v. 20, n. 2, p. 52-54, 2003. 


\section{CAPITULO II}

\section{ANÁLISE FARMACOLÓGICA E TOXICOLOGICA DO MONOTERPENO SABINENO: UM ESTUDO IN SILICO}

DOI: 10.51859/AMPLLA.PAE1993-2

Haycha Lopes de Lucena ${ }^{1}$

Thamires Olimpio Marinho ${ }^{1}$

Maria Alice Araújo de Medeiros ${ }^{2}$

Millena de Souza Alves ${ }^{2}$

Aleson Pereira de Sousa ${ }^{3}$

Abrahão Alves de Oliveira Filho ${ }^{4}$

\footnotetext{
' Graduada do curso de Ciências Biológicas. Universidade Federal de Campina Grande - UFCG

${ }^{2}$ Mestrandas em Ciência e Saúde Animal. Programa de Pós-Graduação em Ciência e Saúde Animal - UCFG

${ }^{3}$ Doutorando. Programa de pós-graduação em Desenvolvimento e Inovação Tecnológica em Medicamentos-UFPB

${ }^{4}$ Professor dos cursos de Ciências Biológicas e Odontologia. Universidade Federal de Campina Grande - UFCG
}

\section{RESUMO}

O presente trabalho teve como objetivo avaliar o potencial farmacológico e toxicológico do monoterpeno sabineno, utilizando o método in silico. Inicialmente, utilizou-se o software $P u b c h e m^{\circledR}$ para a obtenção das informações químicas da molécula, em seguida a análise da probabilidade das atividades biológicas da molécula foi realizada com o software Pass Online ${ }^{\circledast}$. Na análise dos parâmetros farmacológicos, foi avaliado a biodisponibilidade oral teórica do sabineno, pela "Regrados Cinco" de Lipinski com o software Molinspiration ${ }^{\circledR}$. Finalmente, os parâmetros toxicológicos bem como o estudo teórico sobre o efeito carcinogênico, o teste de AMES e a toxicidade oral aguda foi efetuada no programa admetSAR ${ }^{\circledR}$. No PassOnline ${ }^{\circledR}$ a molécula do sabineno apresentou 25 possíveis atividades farmacológicas, dentre elas: potencial antibacteriano, antifúngico, anti-inflamatório, antiparasitário e anti-helmíntico. No Molinspiration ${ }^{\circledR}$ a molécula demonstrou estar de acordo com as cinco regras propostas por Lipinski, logo, apresentando boa biodisponibilidade oral teórica e, pelo teste de toxicidade do admetSAR ${ }^{\circledR}$, revelou ter baixa toxicidade e potencial carcinogênico ao organismo. Com base em análises de softwares, pode-se concluir que o composto estudado oriundo de matéria prima vegetal apresenta atividades promissoras para estudos farmacológicos e toxicológicos pelo método in silico.

Palavras-chave: Farmacologia. Fitoterapia. Toxicidade. 


\section{INTRODUÇÃO}

A extração de recursos naturais oriundo de plantas é utilizada com fins medicinais desde as primeiras civilizações. De acordo com Teske (1994), pesquisas arqueológicas mostram que há mais de três mil anos o homem faz uso daservas para alimentação, fabricação de cosméticos e medicamentos. Ao longo dos anos, pesquisadores têm contribuindo para o desenvolvimento de novos compostos explorando suas propriedades que possuem diferentes aplicações sejam biológicas e/ou farmacológicas.

Através de estudos utilizando produtos naturais surgiu a fitoterapia, segundo Bastos e Lopes (2010) é um meio terapêutico simples e natural onde seus derivados atuam como tratamento e prevenção contra doenças por meio de preparos vegetais. A fitoterapia visa assistência utilizando diversos métodos, porém isso vai depender da capacitação profissional, o tipo da doença e a estrutura do serviço de saúde (PARAÍBA, 2002).

Os fitoterápicos são produzidos por matéria prima vegetal e possuem compostos conhecidos quimicamente como terpenos que são um dos fatores atribuídos ao efeito terapêutico desempenhado pelas plantas medicinais. Essas moléculas bastante estudadas são encontradas em $90 \%$ dos óleos essenciais de vários órgãos de plantas tais como caules, folhas, raízes, sementes e flores (BAKKALI et al., 2008).

De acordo com dados analisados no site Chebi (2016), o sabineno é um monoterpeno bicíclico natural, com fórmula molecular composta por dez átomos de carbono e 16 átomos de hidrogênio. Pode ser isolado do óleo essencial de várias espécies de plantas, incluindo suas partes estruturais folhas, flores e frutos deconíferas e outras gimnospermas, incluindo noz-moscada, semente de cenoura, manjerona, pimenta preta, velame, entre outros.

O processo pelo qual um fitoterápico passa para chegar ao consumidor leva muitas etapas e devem ser responsavelmente cumpridas. As três etapas principais se dividem em estudo in silico, in vitro e in vivo. Dentro de todas as vertentes que estão contidas em cada uma, todas seguidas em sequência, garantem exponencial sucessoe confiabilidade no uso potencial de um fármaco (VALERIO, 2009). 
De acordo com Moda (2011), análises com estudos in silico estão sendo empregadas de forma crescente na pesquisa para o planejamento de um possível fármaco. A utilização desse método computacional vai desde a identificação até a seleção e otimização de possíveis atividades terapêuticas.

$\mathrm{Na}$ inserção das plantas medicinais e fitoterápicos com finalidade biotecnológica deve-se aumentar o conhecimento sobre suas atividades farmacológicas e a toxicidade das plantas. Partindo desse conceito vê-se que para asciências biológicas, tais estudos contribuem para conhecimentos botânicos e sua preservação, ramos da ciência como microbiologia, imunologia, parasitologia, genética molecular, bioquímica, etnobotânica, entre outros, interligando tudo isso ainda à educação ambiental e saúde pública (VEIGA JUNIOR, 2008).

Maciel et al. (2002) afirmam que, as áreas multidisciplinares, como por exemplo, botânica, farmacologia e fitoquímica, enriquecem os conhecimentos sobre as fontes medicinais alternativas e despertam o interesse de pesquisadores.

Com base nisso, é importante que seja realizado testes in silico de vários metabólitos secundários de plantas com possíveis propriedades terapêuticas, como os terpenos. Diante do contexto exposto, este trabalho buscou avaliar as atividades farmacológicas e toxicológicas in silico, do monoterpeno sabineno, para verificar, se suas propriedades terapêuticas se aplicam com eficiência ao meio da cavidade oral.

\section{METODOLOGIA}

\subsection{ENSAIOS IN SILICO}

Substância-teste

Inicialmente, todas as informações químicas do composto foram obtidas no site gratuito Pubchem ${ }^{\circledR}$ (https://pubchem.ncbi.nlm.nih.gov).

\subsection{TESTES FARMACOLÓGICOS IN SILICO}

Para a análise das propriedades farmacológicas do sabineno foi utilizado o software gratuito PASS online ${ }^{\circledR}$. A previsão do espectro de atividade para substâncias PASS online ${ }^{\circledR}$ é um software gratuito que objetiva avaliar o potencial biológico de uma molécula orgânica quando em contato com o organismo humano. Por meio deste, é possível ter previsões simultâneas de múltiplos tipos de atividades biológicas com base 
na estrutura dos compostos orgânicos, além de permitir estimar o potencial de atividade de uma substância, podendo esta ser classificada como índices Pa (probabilidade "de ser ativo") e Pi (probabilidade "de ser inativo"), podendo ser acessado pelo endereço: (http://www.pharmaexpert.ru/passonline/).

\subsection{AVALIAÇÃO DA BIODISPONIBILIDADE ORAL IN SILICO}

Para a análise da biodisponibilidade oral teórica do produto foi utilizada a "Regra dos Cinco" de Lipinski, que estabelece que pelo menos quatro de cinco requisitos devam ser apresentados para que o composto possua uma boa biodisponibilidade. Assim, para que compostos sejam absorvidos, devem possuir miLogP menor ou igual a 5,00; MM menor ou igual a 500 g.mol-1; Área de superfície polar (TPSA) menor ou igual a $140 \AA^{2}$ ou a soma do número de aceptores e doadoresde ligação de hidrogênio menor que 12; Máximo de 10 grupos aceptores de ligação de hidrogênio (nALH), que é expresso pela soma de átomos de $\mathrm{N}$ e $\mathrm{O}$; Máximo de 5 grupos doadores de ligação de hidrogênio (nDLH), expresso pela soma de $\mathrm{OH}$ e $\mathrm{NH}$ na molécula.

Para esta predição, foi empregado o programa Molinspiration Cheinformatics, um software gratuito encontrado no endereço: (http://www.molinspiration.com/cgibin/properties).

\subsection{TESTE TOXICOLÓGICO IN SILICO}

Para a análise da toxicidade teórica foi utilizado um software gratuito admetSAR para verificar a partir de predições o potencial Toxicidade AMES, Agentes Cancerígenos, Toxicidade Oral Aguda e Carcinogenicidade, que foi submetida ao estudo in silico dos parâmetros ADMET (absorção, distribuição, metabolismo, excreção e toxicidade) usando o endereço: (http://Immd.ecust.edu.cn:8000/).

\section{RESULTADOS}

\subsection{TESTES FARMACOLÓGICOS IN SILICO}

No estudo do potencial farmacológico do sabineno o software Pass online mostrou que pode ocorrer 25 atividades e tem a possibilidade de apresentar efeitos biológicos: antifúngica (Pa: 0,340 e Pi: 0,066), anti-inflamatório (Pa: 0,853 e Pi: 0,005), anti-helmíntico (Pa: 0,430 e Pi: 0,013) e antiparasitário (Pa: 0,440 e Pi: 0,023), em que 
$\mathrm{Pa}$ e Pi variam em uma escala de 0 a 1 , quanto mais aproximado de 1 for o valor de $\mathrm{Pa}$ ou Pi indica a probabilidade de ser ativo ou inativo e exercer ou não seu efeito, conforme representado na tabela 1.

Tabela 1 - Farmacológica oral in silico do sabineno

\begin{tabular}{lcc}
\hline Atividade & $\mathbf{P a}$ & $\mathbf{P i}$ \\
Antibacteriano & 0,201 & 0,117 \\
Antibiótico & 0,110 & 0,073 \\
Anticarcingênico & 0,265 & 0,075 \\
Antidoto & 0,233 & 0,073 \\
Antifúngico & 0,340 & 0,066 \\
Anti-helmíntico & 0,430 & 0,013 \\
Anti-helmíntico (fascíola) & 0,137 & 0,125 \\
Anti-helmíntico (nematoides) & 0,287 & 0,122 \\
Anti-inflamatório & 0,853 & 0,005 \\
Anti-inflamatório (intestinal) & 0,232 & 0,142 \\
Anti-inflamatório (ocular) & 0,283 & 0,106 \\
Antimetastático & 0,587 & 0,006 \\
Antineoplástico & 0,891 & 0,005 \\
Antiparasitário & 0,440 & 0,023 \\
Antiprotozoário (amoeba) & 0,369 & 0,034 \\
Antiprotozoário (leishmania) & 0,398 & 0,049 \\
Antiprotozoário (trichomonas) & 0,227 & 0,089 \\
Antiprotozoário (trypanosoma) & 0,253 & 0,146 \\
Anti-espiroqueta & 0,135 & 0,044 \\
Antiviral (adenovírus) & 0,282 & 0,105 \\
Antiviral (CMV) & 0,237 & 0,097 \\
Antiviral (herpes) & 0,241 & 0,137 \\
Antiviral (influenza) & 0,254 & 0,128 \\
Antiviral (picornavírus) & 0,342 & 0,167 \\
Antiviral (rinovírus) & 0,339 & 0,178 \\
\hline Pa:probabildade de ser ativo. Pro
\end{tabular}

Pa: probabilidade de ser ativo. Pi: probabilidade de ser inativo.

Fonte: Elaboração própria.

\subsection{AVALIAÇÃO DA BIODISPONIBILIDADE ORAL IN SILICO}

A determinação das propriedades moleculares e biodisponibilidade oral se deu através da ferramenta computacional molinspiration, sendo que esta proporciona um conjunto de contribuições baseadas na estrutura molecular do composto. Este método é muito amplo e capaz de processar todas as moléculas orgânicas e organometálicas. Os resultados devem seguir de acordo com a "Regra dos Cinco" de Lipinski et al. (1997), na qual para que haja a análise da biodisponibilidade oral teórica, pelo menos quatro de cinco requisitos devem ser apresentados, identificando o composto com boa biodisponibilidade farmacológica. Os resultados de predição para o sabineno podem ser observados na tabela 2. 
Tabela 2 - Biodisponibilidade oral in silico do sabineno

\begin{tabular}{lcccccccccc}
\hline Composto & \multicolumn{7}{c}{ Propriedades moleculares } \\
Sabineno & milogP & TPS & natom & MW & nON & nOHNH & nV & nrotb & Vol \\
& & A & $\mathrm{s}$ & & & & & & \\
& 3.10 & 0.00 & 10 & 136,24 & 0 & 0 & 0 & 1 & 152,37
\end{tabular}

miLogP: coeficiente de partição octanol-água; TPSA: área de superfície polar total; natoms: número de área de superfície polar de átomos de não hidrogênio; MW: peso molecular; nON: Número de grupos aceptores de ligação de hidrogênio; nOHNH Número de grupos doadores de ligação de hidrogênio; nV: número de violações; nROTB: número de rotações; Vol: volume.

Fonte: Elaboração própria.

Após análise pelo software, pode-se observar que o sabineno não vai contra nenhuma das "Regras dos Cinco" de Lipinski, ou seja, a molécula apresenta boa biodisponibilidade oral teórica.

\subsection{ANÁLISE TOXICOLÓGICA ORAL IN SILICO}

Ao testar a toxicidade pela previsão do software admetSAR, o sabineno revelou não possuir toxicidade quanto a ADMET (Toxicidade AMES), com valor de 0.88 (88\%); quanto à Agentes Cancerígenos (Carcinogens), o teste mostrou que a molécula não apresentou efeitos carcinogênicos de modo sistêmico, com valor de 0.77 (77\%).

Para Toxicidade Oral aguda (Acute Oral Toxicity), a análise mostrou ser classificado como categoria III, 0,76 (76\%), o que inclui compostos com valores de DL50 (dose letal mediana) superiores a $500 \mathrm{mg} / \mathrm{kg}$ mas inferiores a $5000 \mathrm{mg} / \mathrm{kg}$. Isto significa que, sendo classificado como categoria III, é necessária uma dose elevada para que traga resultados tóxicos ao organismo.

A toxicidade oral aguda foi classificada com base nas quatro categorias da Agência de Proteção Ambiental dos Estados Unidos (USEPA), que divide os compostos de acordo com seu valor de DL50. A categoria I contém os compostos comvalores de DL50 inferior ou igual a $50 \mathrm{mg} / \mathrm{kg}$, a categoria II contém compostos com DL50 valores superiores a $50 \mathrm{mg} / \mathrm{kg}$ e inferior a $500 \mathrm{mg} / \mathrm{kg}$, a categoria III inclui compostos com DL50 valores superiores a $500 \mathrm{mg} / \mathrm{kg}$ e inferior a $5000 \mathrm{mg} / \mathrm{kg}$ e a categoria IV consiste de compostos com DL50 valores superiores a $5000 \mathrm{mg} / \mathrm{kg}$ (USEPA, 2018).

Ao analisar a Carcinogenicidade (Carcinogenicity [Three-class]), o valor foi de $0.47(47 \%)$, não apresentando risco. Quanto a dose para a Carcinogenicidade (Threeclass) se for igual ou inferior a $10 \mathrm{mg} / \mathrm{kg}$ de peso corporal/dia será designado como 
"perigoso" ao organismo, de outra forma, se a dose for superior a $50 \mathrm{mg} / \mathrm{kg}$ de peso corporal/dia será designado apenas como "alerta" de produto químico nãocarcinogênico, e que neste caso obteve-se um resultado de "não-carcinogênico" logo, doses baixas podem ser prejudiciais à saúde, como não ter feito, mas doses acima de $50 \mathrm{mg} / \mathrm{kg}$ de peso corporal/dia não representa efeito carcinogênico (USEPA, 2018).

As informações sobre a análise do sabineno pelo software de admetSAR acima discutidos estão representados na tabela 3.

Tabela 3 - Dados da análise do sabineno

\begin{tabular}{lcc}
\hline Sabineno & Toxicidade & \multicolumn{1}{c}{$\begin{array}{l}\text { Valor } \\
\text { (\%) }\end{array}$} \\
\hline ADMET (Toxicidade AMES) & Não tóxico & 0.8854 \\
Agentes Cancerígenos & Não cancerígeno & 0.7732 \\
Toxicidade Oral Aguda & Categoria III & 0,7601 \\
Carcinogenicidade (Three-Class) & Não carcinogênico & 0.4756 \\
\hline
\end{tabular}

ADMET: Absorção, Distribuição, Metabolização, Excreção, Toxicidade.

Fonte: Elaboração própria.

\section{DISCUSSÃO}

Ao passar dos anos, as pesquisas com produtos naturais têm crescido com o aumento do conhecimento botânico, a busca por novos produtos com uma melhor biocompatibilidade, maior atividade terapêutica e menor toxicidade, além de ser uma alternativa barata e de fácil obtenção. Dessa forma, o uso da fitoterapia e das plantas medicinais, vem com o intuito de expandir os recursos terapêuticos, resgatar saberes populares e preservar a biodiversidade (ANTÔNIO; TESSER; MORETTTI-PIRES, 2014).

O sabineno é um monoterpeno bicíclico, possuindo peso molecular de 136,26 $\mathrm{g} / \mathrm{mol}$. É um importante composto isolado dos óleos essenciais de várias espécies de plantas e tem demostrado um grande potencial farmacológico como agente antiinflamatório, antifúngico, antibacteriano entre outras coisas mais. Conforme Khani e Asghari (2012), vários óleos essenciais são bioativos a artrópodes e pragas, conforme seu desempenho e a resposta acerca de cada espécie alvo.

Este estudo evidencia o uso de modelos in silico, que tem crescido notoriamente nas áreas de simplificação, automatização, predição, correlação, dentreoutros aspectos 
importantes. Os ensaios experimentais tradicionais possuem baixa aplicabilidade em relação ao modelo farmacológico ADMET (Absorção, Distribuição, Metabolismo, Excreção e Toxicidade), pois são necessários maiores recursos para atender a alta demanda na triagem de moléculas novas (LIMA, 2007).

Os softwares se tornam um grande aliado para os ensaios in silico, pois eles armazenam através de banco de dados informações sobre compostos já conhecidos, manipulam e mostram estruturas químicas e avaliam através de algoritmos suas características. Dessa forma, essas informações se tornam uma ferramenta de uso crescente na pesquisa. Diante disso, novas possíveis funções biológicas de uma molécula podem ser elucidadas através da análise da estrutura química (CHAND, 2011).

Segundo Nigsch et al. (2011), o Pass Online ${ }^{\circledR}$ (Previsão de Espectros de Atividade para Substâncias) é uma ferramenta válida e bastante recomendada para avaliar o potencial biológico de uma molécula orgânica. Com base na estrutura de seus compostos, esse programa fornece vários tipos de atividades biológicas, obtendo os índices de Pa (probabilidade de ser ativo) e Pi (probabilidade de ser inativo) avaliando a categorização de um composto potencial em ser pertencente à subclassede compostos ativos ou inativos, respectivamente.

Logo, o sabineno possui potencial biotecnológico a ser explorado, adicionando ao seu valor bioativo como produto natural característica de aplicações na indústria farmacêutica. Estudos in vitro e in vivo utilizando principalmente plantas da família verbenácea revelam atividades biológicas como: antimicrobiana, antiparasitária, antiinflamatório, analgésica, anestésica e antitumoral, tendo em sua composição de forma majoritária o monoterpeno sabineno (SOARES, 2013).

Os óleos essenciais demonstram uma imensa variedade de ações farmacológicas, tornando-os potenciais fontes para o desenvolvimento de novas drogas. Dentre estas ações estão à antiparasitária, antimicrobiana, analgésica, diurético, antimalárico, antihemorroidário, miorelaxante, antiespasmótico, anti- inflamatório, anti-convulsivanlte e gastroprotetora (OLIVEIRA, 2005).

Lipinsk et al. (1997) estabelece que de cinco pontos importantes para que haja biodisponibilidade do fármaco pelo organismo é necessário que se tenha pelo menos quatro deles na molécula analisada. De acordo com essa regra o composto deve apresentar os seguintes resultados: miLogP menor ou igual a 5,00; MM menor ou iguala 
500 g.mol-1; Área de superfície polar (TPSA) menor ou igual a $140 \AA 2$ ou a soma do número de aceptores e doadores de ligação de hidrogênio menor que 12; Máximode 10 grupos aceptores de ligação de hidrogênio ( $\mathrm{nALH})$, que é expresso pela soma de átomos de N e O; Máximo de 5 grupos doadores de ligação de hidrogênio (nDLH),expresso pela soma de $\mathrm{OH}$ e $\mathrm{NH}$ na molécula.

Pode-se observar que o composto em estudo não foi contra nenhuma regra, apresentando uma boa biodisponibilidade oral teórica. Portanto, torna-se um promissor alvo para pesquisa científica no desenvolvimento de terapias utilizando produtos de origem natural. Dados assim, também foram encontrados no estudo do monoterpeno borneol (ALVES et al., 2019).

Os produtos naturais não estão isentos de riscos e possíveis efeitos tóxicos, segundo Smet (2004), plantas medicinais além da capacidade terapêutica podem conter substâncias tóxicas, alergênicas, contaminação por metais pesados ou por agrotóxicos e pode interagir com drogas sintéticas, causando danos à saúde. Além disso, todo princípio ativo quando usado em excesso se torna tóxico. Logo, há necessidade de realizar estudos toxicológicos para determinação de parâmetros de segurança.

$\mathrm{Na}$ análise da toxicidade oral, o processo de predição de efeitos biológicos executado pelo software gratuito admetSAR baseia-se em um conjunto de fragmentos moleculares pré-computadorizados que originam os alertas de toxicidade, no caso de sendo encontrado na estrutura molecular atualmente projetada. De acordo com Lipinski et al. (2004), o estudo por ADMET tem o objetivo de limitar gastos em ensaios biológicos economizando tempo e investimento.

Diante disso, o presente estudo do monoterpeno sabineno revelou não ser tóxico ao organismo nem apresentar toxicidade oral aguda, também não possui potencial carcinogênico/cancerígeno. Os dados corroboram com o estudo realizado por Alves et al. (2019) utilizando o monoterpeno borneol, onde o composto apresentou boa disponibilidade oral e baixa citotoxidade, tendo um perfil promissor para se tornar um fármaco, assim como o sabineno.

\section{CONSIDERACÕES FINAIS}

O estudo revelou através da análise in sílico que o monoterpeno sabineno, apresentou vários possíveis efeitos farmacológicos como: antii-flamatório, 
antiparasitário e antifúngico, revelou boa biodisponibilidade e baixo potencial de toxicidade. O sabineno torna-se uma molécula alvo para futuros estudos que irão contribuir para melhor elucidação do seu mecanismo de ação farmacológica e perfil de toxicidade.

\section{REFERÊNCIAS}

ALVES, M. F. V. et al. Análise da atividade farmacológica e toxicológica do monoterpeno borneol com finalidade odontológica: um estudo in silico. Journal of Medicine and Health Promotion, v. 27, n. 3, p. 12-17, 2019.

ANTONIO, G. D; TESSER, C. D; MORETTTI-PIRES, R. O. Fitoterapia na Atenção Primária à Saúde. Rer. Saúde Pública, v. 48, n. 3, p. 541-553, 2014.

BAKKALI, F. et al. Biological effects of essential oils-a review. Food and chemical toxicology, v. 46, n. 2, p. 446-475, 2008.

BASTOS, R. A; LOPES, A. M. C. A fitoterapia na rede básica de saúde: o olhar da enfermagem. Revista brasileira de ciências da saúde, v. 14, n. 2, p. 21-28, 2010.

CHAND B. Structure-Bioactivity-Relationship and Crystallographic analysis of Secondary Interactions in Pregnane-Based Steroids. Journal Chemical Crystallography, v.662, n.1-3, p, 22 - 30, 2011.

CHEBI, Chemical entities of biological interest, Sabineno, 2016. Disponível em: <https://www.ebi.ac.uk/chebi/searchld.do?chebild=CHEBI:50027>. Acesso em: 13 fev. 2020.

CHENG, F. et al. admetSAR: a comprehensive source and free tool for assessment of chemical ADMET properties, 2012.

KHANI, A; ASGHARI, J. Insecticide activity of essential oils of Mentha longifolia,Pulicaria gnaphalodes and Achillea wilhelmsii against two stored product pests, the flour beetle, Tribolium castaneum, and the cowpea weevil, Callosobruchus maculatus. Journal of Insect Science (Online), v. 12, n. 1, p. 73, 2012.

LIMA, L. M. Química medicinal moderna: desafios e contribuições brasileiras. Quimica Nova, v. 30, n. 6, p. 1456 - 1468, 2007.

LIPINSKI, Christopher A. et al. Experimental and computational approaches to estimate solubility and permeability in drug discovery and development settings. Advanced drug delivery reviews, v. 23, n. 1-3, p. 3-25, 1997.

LIPINSKI, C. A. et al. Lead and drug-like compounds: the rule-of-five revolution. Drug Discovery Today: Technologies. v. 1, n. 4, p. 337 - 341, 2004. 
MACIEL, M. A. M. et al. Plantas medicinais: a necessidade de estudos multidisciplinares. Química Nova, v. 25, n. 3, p. 429 - 438, 2002.

MODA, T. L. Modelagem In silico de propriedades farmacocinéticas para a avaliação de candidatos a novos fármacos. 2011. Tese de Doutorado. Universidade de São Paulo.

NIGSH, F. et al. Computational methods for early predictive safety assessment from biological and chemical data. Expert Opinion on Drug Metabolism \& Toxicology, v.7, n. 12, p. 1497 - 1511, 2011.

OLIVEIRA, M. F. S. Fitoterapia e Biodiversidade no Brasil: saúde, cultura e sustentabilidade. Revista Ideas Ambientales [online], 2005. Disponível em: <https://files.cercomp.ufg.br/weby/up/160/o/iaedicion2.pdf\#page=110>. Acesso em: 13 fev. 2020.

PARAÍBA, Secretaria de Saúde do Estado. Fitoterápicos: Guia do profissional de Saúde. Coordenação de Saúde. Núcleo de Assistência Farmacêutica, João Pessoa,2002.

SOARES, B.V; TAVARES-DIAS, M. Espécies de Lippia (Verbenaceae), seu potencial bioativo e importância na medicina veterinária e aquicultura. Embrapa AmapáArtigo em periódico indexado (ALICE), 2013.

SMET, P. A. G. M. Health risks of herbal remedies: an update. Clinical Pharmacology \& Therapeutcs, v. 76, n. 1, p. 1 - 17, 2004.

SOUZA, J. P. A. Estudo de ancoragem molecular de derivados de ácido cinâmico frente à enzimas do ciclo replicativo do HIV-1. 2015. Trabalho de Conclusão de Curso. Universidade Tecnológica Federal do Paraná.

TESKE, M. Herbarium: compêndio de fitoterapia. In: Herbarium: compêndio de fitoterapia, p. 268-268, 1994.

USEPA, United States Environmental Protection Agency. Computational Toxicology Research Program, 2018. Disponível em: < https://archive.epa.gov/nheerl/archive-comptox/web/html/index.html>. Acesso em: 13 fev. 2020.

VALERIO, L. G. In silico toxicology for the pharmaceutical sciences. Toxicology and Applied Pharmacology, v. 241, n.3, p. 356 - 370, 2009.

VEIGA JUNIOR, V. F. Estudo do consumo de plantas medicinais na Região Centro-Norte do Estado do Rio de Janeiro: aceitação pelos profissionais de saúde e modo de uso pela população. Revista Brasileira Farmacognosia, v. 18, n. 2, p. 308-13, 2008. 


\title{
CAPITULO III
}

\section{ASPECTOS ETNOBOTÂNICOS DE CATINGA-DE-PORCO (CAESALPINIA PYRAMIDALISTULL)}

DOI: 10.51859/AMPLLA.PAE1993-3

\author{
Adrielly de Sousa Costa ${ }^{1}$ \\ Perisvaldo Soares ${ }^{1}$ \\ Sabrina Silva de Souza ${ }^{1}$ \\ Vera Lúcia Neves Dias Nunes ${ }^{2}$ \\ Raquel Maria Trindade Fernandes ${ }^{2}$
}

${ }^{1}$ Graduando do curso de Química licenciatura. Universidade Estadual do Maranhão - UEMA
${ }^{2}$ Professora Adjunta do Departamento de Química. Universidade Estadual do Maranhão - UEMA

\section{RESUMO}

A catinga-de-porco é uma planta sertaneja, característica das caatingas, portanto, tem a necessidade de controlar o seu consumo de água. Restringe sua transpiração tanto no período de fim de chuva como de fim de seca. Para fins medicinais é utilizada para o tratamento de febres, doenças estomacais, diuréticos e infeções catarrais. Perante a importância da catinga-de-porco, vários estudos foram realizados com essa espécie, os quais relatam a identificação de metabólicos secundários e isolamento de compostos ativos como flavonoides e chalconas, assim como também foi determinada as atividades antifúngica, antioxidante, anticonceptiva e anti-inflamatória das diversas partes da planta. Destaca-se ainda que estudos adicionais se fazem necessários, incluindo etapas de isolamento, caracterização dos compostos responsáveis pela atividade antioxidante e, finalmente, para elucidação do mecanismo de ação e possível sinergismo entre os compostos identificados.

Palavras-chave: Catinga-de-porco. Medicinais. Metabólicos. Compostos. Tratamento. 


\section{INTRODUÇÃO}

A Caesalpinia pyramidalis é uma Leguminosae (Fabaceae), subfamília Caesalpinioideae e gênero Caesalpinia L. distribuídas nas regiões tropicais e subtropicais. Árvore endêmica do sertão nordestino que habita em lugares pedregosos, conhecida popularmente como: "catingueira" "pau-de-porco", "catinga de porco", "pau-de-rato", "mussitaiba" e "catingueira-das-folhas-largas" (MENDONÇA, et al., 2016).

A catinga-de-porco (Figura 1) é uma planta sertaneja, característica das caatingas, portanto, tem a necessidade de controlar o seu consumo de água. Restringe sua transpiração tanto no período de fim de chuva como de fim de seca. Seus gomos brotam às primeiras manifestações de umidade anunciadora do período chuvoso. Árvore com cerca de 4 a $8 \mathrm{~m}$ de altura, podendo chegar a $10 \mathrm{~m}$ e um diâmetro de até 50 $\mathrm{cm}$ quando vegeta nas várzeas úmidas. No Seridó semi-árido, se reduz a arbustos de menos de 2 m e poucos centímetros de diâmetro na base (NEIVA, 2020).

Figura 1 - Arvore florida de Caesalpinia pyramidalis Tull (Catinga-de-porco).

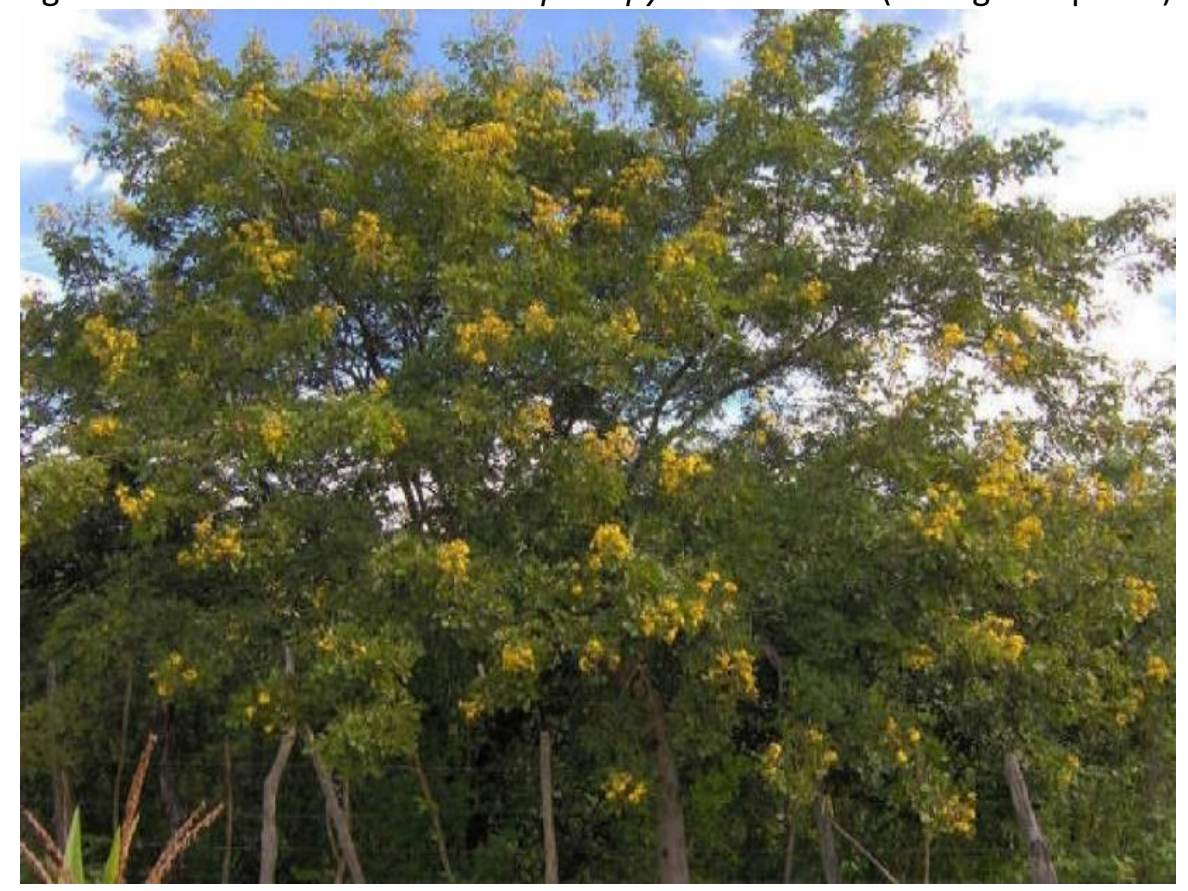

Fonte: SARAIVA, 2007.

Apresenta casca viva de espessura delgada, cinza-claro, internamente begeclaro, às vezes levemente castanha. A casca morta de tronco idoso possui espessura 
delgada $(<2,0 \mathrm{~mm})$, rígida, com partes lisas e ásperas, cinza-claro, e apresenta numerosas lenticelas pequenas, dispostas irregularmente. Com o fendilhamento destas, são limitadas porções laminares irregulares, que ao desprender-se, deixam depressões superficiais. Por incisão, apresenta exsudato transparente aquoso de sabor levemente amargo e odor indistinto (NEIVA, 2020).

\section{METODOLOGIA}

O presente trabalho tratou-se de uma pesquisa qualitativa e de uma investigação bibliográfica fundamentada em estudos e pesquisas que abordaram estudos botânicos, estudos químicos e atividade farmacológica de Caesalpinia pyramidalis Tull (catinga-deporco).

\section{RESULTADOS E DISCUSSÃO}

\subsection{ESTUDOS BOTÂNICOS}

A catinga-de-porco é uma arvore que atinge até 4 a 8 metros de altura com folhas bipinadas, 5-11 folíolos, sésseis, alternos, obtusos e oblongos. As flores são amarelas (Figura 2), dispostas em racemos pouco maiores ou tão longos quanto às folhas e sua vagem é achatada de cor escura (BRAGA, 1960) A catinga-de-porco é uma das plantas sertanejas cujos gomos brotam às primeiras manifestações de umidade, pelo qual é dita como anunciadora de períodos chuvosos (SILVA et al, 1998).

Figura 2 - Flores de Caesalpinia pyramidalis Tull (Catinga-de-porco).

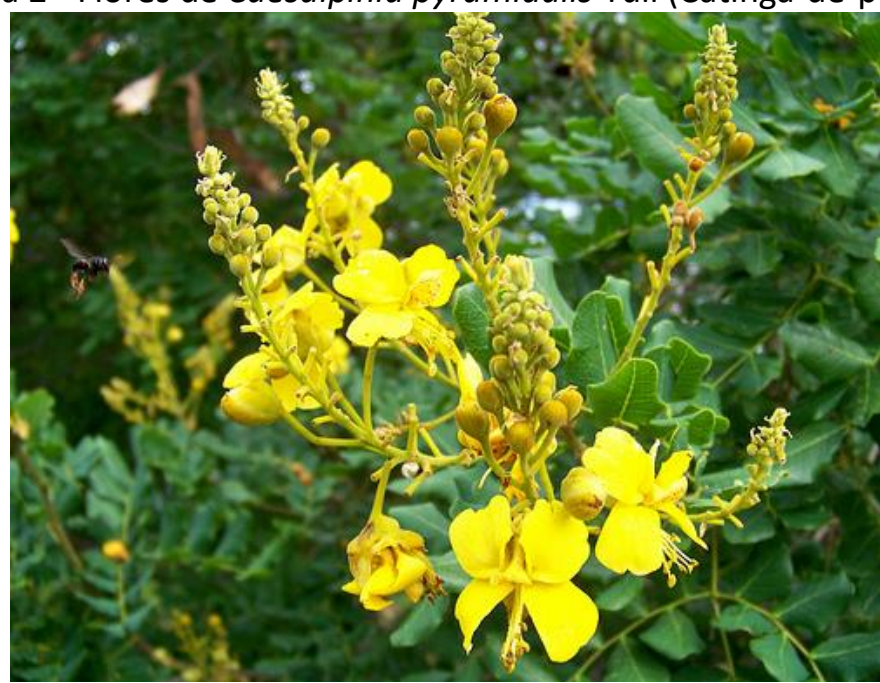

Fonte: COSTA, 2011. 
Sua madeira é empregada nas construções, produção de lenhas e carvão, além de possuir um potencial para reflorestamento, pois é uma espécie que se adequa aos mais variados tipos de solos que permite a recuperação de áreas degradadas (SANTANA et al., 2012). Também pode ser utilizada para produção de álcool combustível e coque metalúrgico. A cinza da madeira tem elevado teor de potássio e é usada para fabricação de sabão (MAIA, 2004).

Referentes ao uso, a madeira é recomendada para lenha, carvão e estaca, enquanto que as folhas fendadas constituem boa forragem, sendo considerado como excelente alimento animal, por conter alto valor proteico e menor de fibras (ZANINE et al., 2005).

\subsection{ESTUDOS QUÍMICOS}

Para fins medicinais é utilizada no tratamento de febres, doenças estomacais, diuréticos e infeções catarrais. Suas propriedades medicinais estão associadas à presença de compostos químicos como biflavonóides, flavonóides, triterpenos e fenilpropanóides,

- Os fenilpropanóides são metabólitos secundários das plantas, largamente encontrados nas partes aéreas e são constituintes importantes dos óleos essenciais. Possuem marcada atividade anti-inflamatória, antioxidante, cicatrizante e antitumoral.

- Os flavonóides são espécies não-nutritivas presentes em alimentos do reino vegetal, como chás, maçã, cebola, uva, brócolis, chicória, aipo e vinho. Tem sua atividade antioxidante atribuída aos radicais fenólicos de sua estrutura. Possuem estrutura básica formada por $\mathrm{C}_{6}-\mathrm{C}_{3}-\mathrm{C}_{6}$.

- Os terpenoides ou terpenos, por vezes designados por isoprenoídes, são compostos que integram uma diversificada classe de substâncias naturais, ou metabólitos secundários de origem vegetal, especialmente das coníferas, de fórmula química geral $\left(\mathrm{C}_{5} \mathrm{H}_{8}\right)_{n}$.

E nas folhas (Figura 3) da catinga-de-Porco dentre outras substâncias também contém o Luperol em sua composição, que consistem em substâncias que estimulam a ação das enzimas que, como consequência, inibem o crescimento de tumores. 
Figura 3 - Folhas de Caesalpinia pyramidalis Tull (Catinga-de-porco).

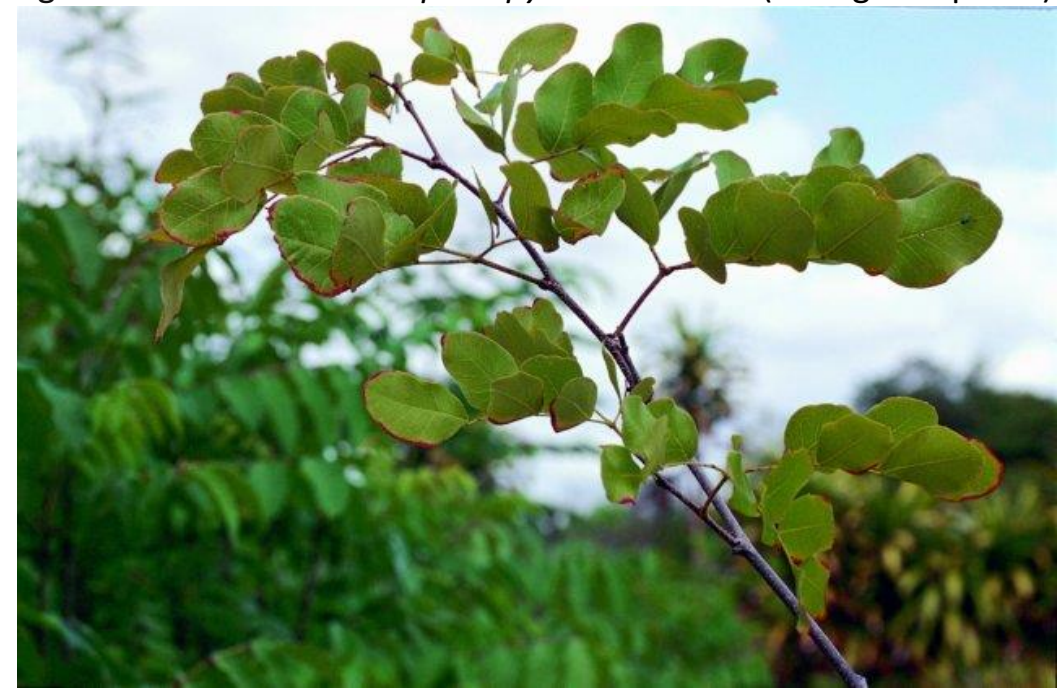

Fonte: COSTA, 2011.

No levantamento bibliográfico da espécie foi assinalado o isolamento de vários metabólitos secundários, principalmente nas folhas, destacando-se polifenóis e terpenóides. A Tabela 1 apresenta as principais substâncias isoladas e caracterizadas.

Tabela 1 - Substâncias isoladas e respectiva localização em Caesalpinia pyramidalis Tull (Catinga-de-porco)

\begin{tabular}{|l|l|}
\hline SUBSTÂNCIAS ISOLADAS & PARTE DA PLANTA \\
\hline
\end{tabular}




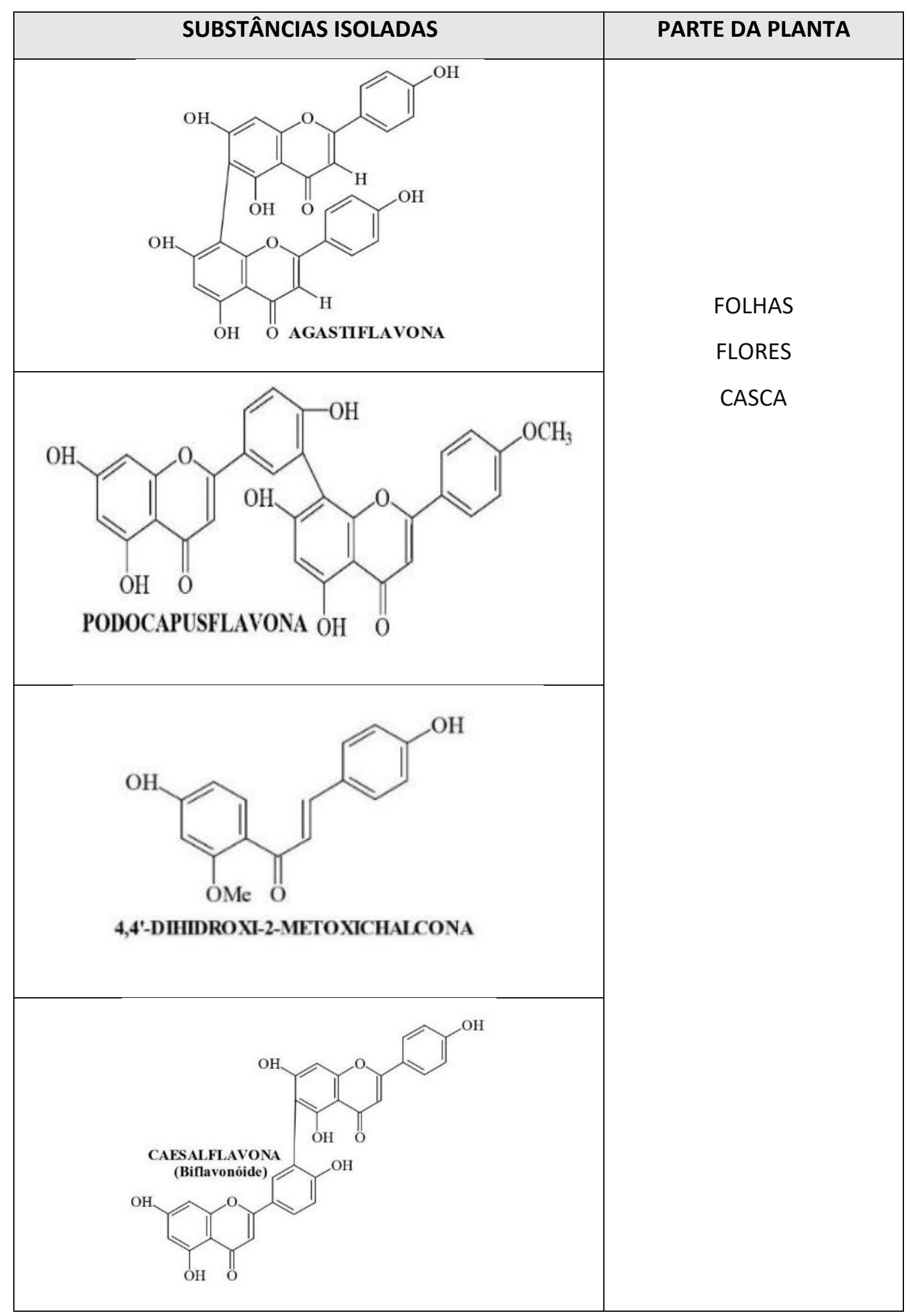




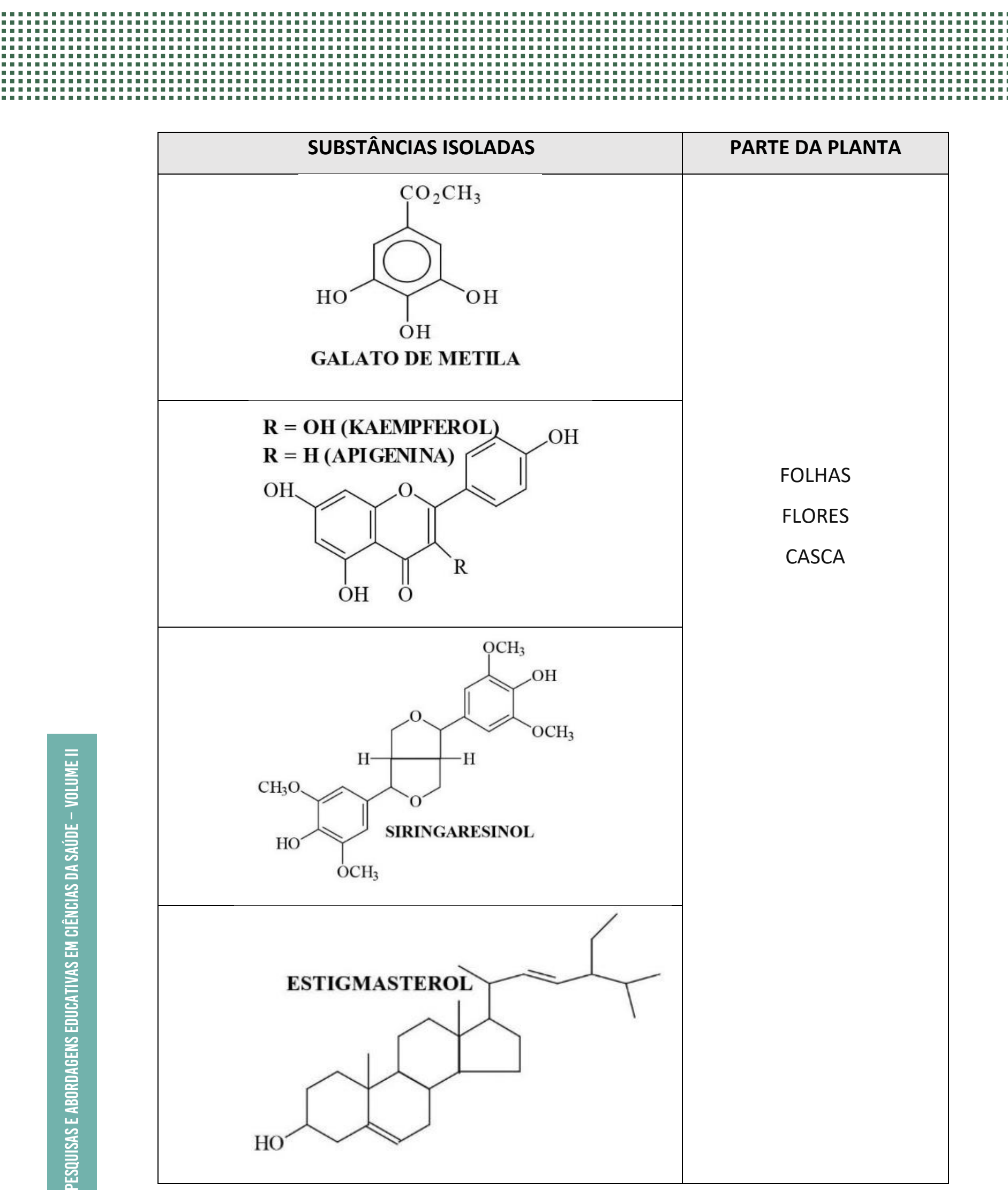




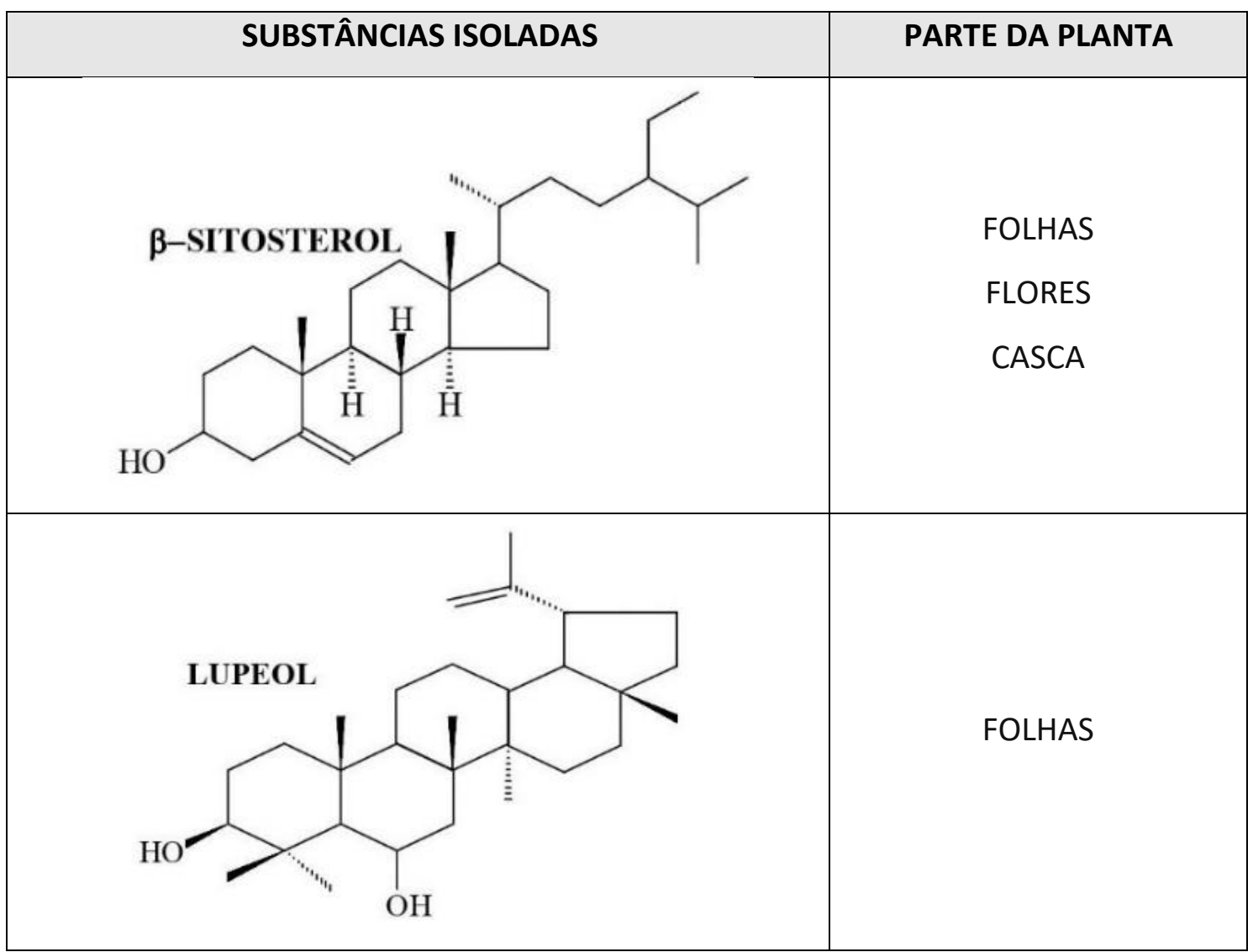

Fonte: Autoria própria

\subsection{ESTUDOS FARMACOLÓGICOS}

Perante a importância da catinga-de-porco, vários estudos foram realizados com essa espécie, os quais relatam a identificação de metabólicos secundários e isolamento de compostos ativos como flavonoides e chalconas, assim como também foi determinada as atividades antifúngica, antioxidante, anticonceptiva e antinflamatória das diversas partes da planta. Segundo Lima et al., a catinga-de-porco possui ação antibacteriana, cujo extrato etanólico tem sido usado contra linhagens resistentes de Escherichia coli e Staphylococcus aureus (LIMA et al., 2006). Na medicina popular, as flores, folhas e cascas são usadas no tratamento das infecções catarrais, nas diarreias e disenterias (BRAGA, 1960), ainda apresenta ação antipirética e como diurética (MENDES et al., 2000). A populações locais geralmente fazem uso de suas cascas depositando em um recipiente com água por algumas horas e ingerindo a solução e utilizam as folhas e flores como chás.

Atividade Antimicrobiana: Estudos realizados com extratos em acetato de etila, das folhas e caule de Caesalpinia pyramidalis frente a cepas de Escherichia coli $e$ Staphylococcus aureus pelo o método de difusão em disco, obtendo halos da ordem de 
$10 \mathrm{~mm}$ apenas para a cepa de S. aureus (NOVAIS et al., 2003). Assim mesmo, no Instituto de Antibiótico - UFPE num "Screening" de plantas superiores, a Caesalpinia pyramidalis foi estudada frente as sete cepas seguintes: Staphylococcus aureus, Bacillus subtilis, Mycobacterium smegmatis, Escherichia coli, Escherichia faecalis, Candida albicans e Neurospora crassa, constatando atividade somente sobre as três primeiras (SARAIVA, et al., 2012).

\section{CONSIDERAÇÕES FINAIS}

Através da literatura consultada, observou-se um grande potencial para a Caesalpinia pyramidalis Tull (catinga-de-porco) em seus vários aspectos e ainda se considera que os extratos de diferentes partes da planta podem ser considerados boa fonte de antioxidantes, pois demonstra resultados significativos de estudos de atividades antioxidantes. É importante salientar que a planta avaliada neste estudo geralmente é utilizada pela população local desde os antepassados, passando de geração em geração seus benefícios principalmente com finalidades medicamentosas e que apresentam pouco valor comercial. Destaca-se ainda que estudos adicionais se fazem necessários, incluindo etapas de isolamento, caracterização dos compostos responsáveis pela atividade antioxidante e, finalmente, para elucidação do mecanismo de ação e possível sinergismo entre os compostos identificados.

\section{REFERÊNCIAS}

BRAGA, R. Plantas do Nordeste - Especialmente do Ceará. Editora Universitária da UFRN, 4ạedição, Natal - RN, 1960.

COSTA, A. Catingiera - Caesalpinia pyramidalis Tul. Natureza Bela, 10, agosto, 2011. Disponível em: https://www.naturezabela.com.br/2011/08/catingueiracaesalpinia-pyramidalis-tul.html. Acesso em: 24/08/2021.

LIMA, M. R. F., LUNA, J. S., SANTOS, A. F., ANDRADE, M. C. C., SANT'ANA, A. E. G., GENET, J-P., MARQUEZ, B., NEUVILLE, L., \& MOREAU, N. Anti-bacterial activity of some Brazilian medicinal plants. Journal of Ethnopharmacology, 105 (1), 137-147, 2006.

MAIA, G. N. Caatinga. Árvores e arbustos e suas utilidades. 1a edição São Paulo; D \& Z Computação gráfica e editora, 2004. 
MENDES, C.C; BAHIA, M.V.; DAVID, J.M.; DAVID, J.P. Constituints of Caesalpinia pyramidalis. Fitoterapia, 71:205-207, 2000.

MENDONÇA, A., FREITAS, T., SOUZA, L., FONSECA, M., \& SOUZA, J.. Morfologia de frutos e sementes e germinação de Poincianella pyramidalis (Tul.) L. P. Queiroz, comb. Nov. Ciência Florestal, 26(2), 375-387. - 2016.

NEIVA, M. S. M. Estrutura dos tegumentos, germinação e aspectos boquímicos das sementes de quatro espécies de leguminosae (caesalpinoideae), ocorrentes numa área de caatinga. Biologia vegetal. Recife, UFPE - Universidade Federal de Pernambuco: 89. 2020.

NOVAIS. T.S.; COSTA, J.F.D.; DAVID, J.P.L; DAVID, J.M.; QUEIROZ, L.P.; FRANÇA, F.; GIULIETTI, A.M.; SOARES, M.B.P; SANTOS, R.R. Atividade antibacteriana em alguns extratos de vegetais do semi-árido brasileiro. Rev. Bras. Farmacogn., 13 (supl. 2): 5-8, 2003.

SANTANA, D. G., SANTOS, C. A., SANTOS, A. D.C., NOGUEIRA, P. C. L., THOMAZZI, S. M., ESTEVAM, C. S., ANTONIOLLI, A. R., \& CAMARGO, E. A. Beneficial effects of the ethanol extract of Caesalpinia pyramidalis on the inflammatory response in abdominal hyperalgesia in rats with acute pancreatitis. Journal of Ethnopharmacology, 142 (2), 445-455, 2012.

SARAIVA A.M. Estudo Farmacognóstico e Determinação da Atividade Biológica de Caesalpinia pyramidalis Tull. e Schinopsis brasiliensis Engl. frente a cepas de Staphylococcus aureus MRSA Multirresistentes. Dissertação (Mestrado - Área de Concentração em Farmácia) - Departamento de Ciências Farmacêuticas, Universidade Federal de Pernambuco, Recife. 2007.

SARAIVA, A. M. GONÇALVES, A. M., SENA FILHO, J. G., XAVIER, H. S. \& PISCIOTTANO, M. N. C. Avaliação da atividade antimicrobiana e perfil fitoquímico de Caesalpinia pyramidalis Tull. (Fabaceae). Biofar: Revista de Biologia e Farmácia, 12(7), 5259, 2012.

SILVA, L.M.M. \& MATOS, V.P. Morfologia de frutos, sementes e plântulas de catingueira (Caesalpinia pyramidalis Tul. - caesalpinaceae) e de Juazeiro (Zizyphus joazeiro Mart. - rhamnanaceae). Rev. Brasileira de Sementes, v.20 (2), p. 25-31, 1998.

ZANINE, A DE M.; SANTOS, E.M.; FERREIRA, D.J.; ALMEIDA, J.C.C.; MACEDO JÚNIOR, G.L.; OLIVEIRA, J.S. Composição bromatológica de leguminosas do semi-árido brasileiro. Livestock Research for Rural Development, v. 17 (8), 2005. 


\title{
CAPITULO IV
}

\section{ATIVIDADE ANTIMICROBIANA E ANTIBIOFILME DO EXTRATO GLICÓLICO DE PUNICA GRANATUM (ROMÃ) SOBRE PREVOTELLA INTERMEDIA E PARVIMONAS MICRA}

DOI: 10.51859/AMPLLA.PAE1993-4

\author{
Vanessa Marques Meccatti ${ }^{1}$ \\ Lavinia Barbosa Senna ${ }^{2}$ \\ Thais Cristine Pereira ${ }^{3}$ \\ Lucas de Paula Ramos ${ }^{3}$ \\ Claudio Antonio Talge Carvalho ${ }^{4}$ \\ Luciane Dias de Oliveira ${ }^{5}$
}

\begin{abstract}
'Doutoranda em Microbiologia e Imunologia. Universidade Estadual Paulista - ICT Unesp
${ }^{2}$ Cirurgiã-Dentista. Universidade Estadual Paulista - ICT Unesp

${ }^{3}$ Doutoranda em Microbiologia e Imunologia. Universidade Estadual Paulista - ICT Unesp

${ }^{4}$ Doutor em Microbiologia e Imunologia. Universidade Estadual Paulista - ICT Unesp

${ }^{5}$ Professor Associado do Departamento de Odontologia Restauradora. Universidade Estadual Paulista - ICT Unesp

${ }^{6}$ Professora Associada do Departamento de Biociências e Diagnóstico Bucal. Universidade Estadual Paulista - ICT Unesp
\end{abstract}

\section{RESUMO}

Objetivo: O presente estudo se propôs a avaliar in vitro a atividade antimicrobiana e antibiofilme do extrato glicólico de Punica granatum (romã) sobre culturas planctônicas e sobre biofilmes monomicrobianos de Parvimonas micra e Prevotella intermedia com diferentes tempos de contato. Métodos: Para verificação de atividade antimicrobiana do extrato, foi aplicado teste de microdiluição em caldo, segundo Clinical and Laboratory Standards Institute (CLSI), norma M11A7, sobre os microrganismos anaeróbios. A concentração mais efetiva foi analisada sobre biofilmes por $5 \mathrm{~min}$ e $24 \mathrm{~h}$. Os resultados foram analisados estatisticamente por ANOVA e Tukey Test ou Kruskal-Wallis suplementado pelo teste de Dunns $(p \leq 0,05)$. Resultados: Não foi possível obter a CIM do extrato devido a turbidez do meio de cultura. 0 extrato de romã apresentou 74 $\%$ de redução da viabilidade celular de Parvimonas micra no tempo de $24 \mathrm{~h}$, diferindo estatisticamente quando comparado ao controle $(p \leq 0,05)$. Conclusão: $O$ extrato de romã possui ação antibiofilme contra Parvimonas micra.

Palavras-chave: Parvimonas micra. Prevotella intermedia. Romã. Punica granatum. Fitoterapia. 


\section{INTRODUÇÃO}

Com o avanço das pesquisas, os cientistas têm identificado cada vez mais a relação entre a saúde bucal e a saúde sistêmica do indivíduo. O biofilme dental é um fator predisponente para o desenvolvimento de diversas infecções bucais como lesões cariosas e doenças periodontais pois, com o amadurecimento do biofilme, o meio tornase propício para instalação da microbiota patogênica (LEVINE, 1992; MARK STEVEN; CHARLIE, 2009). Os microrganismos tornam-se menos suscetíveis aos antimicrobianos e podem viver em ambientes hostis quando estão organizados em biofilme (DEL POZO, 2018). Em biofilmes maduros é possível encontrar patógenos como o Parvimonas micra e Prevotella intermedia que são bactérias anaeróbias.

Cronologicamente, pode-se verficar uma mudança nos achados científicos com relação a $P$. micra. Em meados de 2005 a 2007, alguns estudos afirmaram que esse microrganismo é "raramente encontrado em infecções em outras partes do corpo" (BARTZ et al., 2005; ÖZOK et al., 2007). Contudo, nos últimos anos, houve uma alta considerável no número de estudos encontrados na literatura sobre infecções sistêmicas correlacionadas a P. micra como por exemplo a espondilodiscite (infecção na coluna vertebral). Em uma série de seis casos publicada em 2020, em cinco desses relatos $P$. micra foi o único patógeno isolado da infecção na coluna (DUROVIC et al., 2020). Estudos atuais (PIÑON-ESTEBAN et al., 2020; TANNEERU; MAHENDRA; SHAIK, 2020; ZHANG et al., 2020) sugerem que a doença periodontal pode estar relacionada ao aumento do risco de infarto, do câncer bucal e ser um fator de risco para pré-eclâmpsia. $P$. intermedia foi o microrganismo comum entre todos os estudos, no qual o DNA desse patógeno foi isolado do material trombótico de pacientes com intervenção coronariana, foi uma das espécies que apresentou aumento quantitativo em sítios tumorais e foi a espécie mais expressa em mulheres com pré-eclâmpsia e periodontite.

Métodos mecânicos são a principal forma de remoção do biofilme (SABA CHUJFI et al., 1992), mas métodos químicos são coadjuvantes para maior eficiência no tratamento. Porém, bactérias resistentes as substâncias antimicrobianas empregadas no tratamento das infecções bucais têm surgido e consequentemente a necessidade pela busca de antimicrobianos alternativos, seguros e eficazes é evidente. Com isso, os 
fitoterápicos se mostram uma alternativa promissora por apresentar baixo custo, menor toxicidade e biocompatibilidade (MACHADO; OLIVEIRA, 2014).

Punica granatum conhecido no Brasil como romã é um fruto oriundo da árvore romanzeira e cultivada em maior escala em regiões tropicais e subtropicais (GARCIA, 1992). O extrato de romã tem apresentado forte potencial antimicrobiano e antibiofilme (PEREIRA et al., 2006; XU et al., 2017), antifúngico (LAVAEE et al., 2018), anticâncer (TURRINI; FERRUZZI; FIMOGNARI, 2015), antioxidante, anti-inflamatório e neuroprotetivo (FOROUZANFAR et al., 2013). Um enxaguante bucal à base de romã apresentou efeito antibiofilme com resultados comparáveis a clorexidina quanto a redução dos índices de placa e ainda apresentou efeito inibitório in vitro contra Aggregatibacter actinomycetemcomitans, Porphyromonas gingivalis e P. intermedia (BHADBHADE; ACHARYA; RODRIGUES, 2011). Outro estudo que avaliou a ação antimicrobiana in vitro de vários extratos naturais concluiu que o extrato de romã foi o único que promoveu inibição no teste de difusão em disco de todos os microrganismos estudados, dentre eles $P$. intermedia e $P$. micra (VELOSO et al., 2020). Algumas revisões de literatura demonstram que devido as propriedades do extrato, este pode ser uma boa alternativa para tratamento coadjuvante em terapia periodontal não cirúrgica (DANTAS MACEDO; NOCA DE SOUZA; GUIMARÃES, 2020) pois demonstrou reduzir o sangramento assim como a progressão da doença periodontal (THANGAVELU et al., 2017). Diante disso, o objetivo do presente estudo foi avaliar a atividade antimicrobiana e antibiofilme de extrato glicólico de romã (Punica granatum) sobre cepas padrão de microrganismos anaeróbios de interesse odontológico (Prevotella intermedia e Parvimonas micra).

\section{METODOLOGIA}

\subsection{EXTRATO VEGETAL}

O extrato glicólico de Punica granatum foi adquirido na concentração de $20 \%$ em propilenoglicol (MAPRIC, SP), com os devidos laudos e especificações do produtor.

\subsection{MICRORGANISMOS}

A atividade antimicrobiana e antibiofilme do extrato foi avaliada sobre cepas de referência (ATCC - American Type Culture Collection) de Prevotella intermedia (ATCC 
33563) e Parvimonas micra (ATCC 33270) provenientes do Laboratório de Microbiologia e Imunologia do Curso de Odontologia do ICT - UNESP.

\subsection{ATIVIDADE ANTIMICROBIANA SOBRE PLANCTÔNICOS}

A avaliação sobre planctônicos foi baseada no Clinical and Laboratory Standards Institute (CLSI), norma M11-A7. Em placas de 96 poços foram adicionados $100 \mu \mathrm{L} /$ poço de caldo Brucella suplementado e no primeiro poço de cada coluna $100 \mu \mathrm{L}$ do extrato, iniciando diluições seriadas (concentrações de 100 a 0,78 mg/mL). Foram adicionados $10 \mu \mathrm{L} /$ poço de suspensão bacteriana preparada em solução fisiológica estéril $(0,9 \%$ de $\mathrm{NaCl}$ ) e padronizada na escala 0,5 de McFarland e em seguida, o conjunto foi levado para incubação em anaerobiose (37ํC/48 h). Como controle, foi utilizado $100 \mu \mathrm{L}$ de caldo Brucella enriquecido e $10 \mu \mathrm{L}$ de suspensão bacteriana. A Concentração Inibitória Mínima (CIM) foi determinada no primeiro poço visualmente límpido e a Concentração Bactericida Mínima (CBM) foi determinada como a menor concentração do extrato capaz de inibir o crescimento bacteriano. Para isso, alíquotas de $20 \mu \mathrm{L}$ de cada poço foram inoculadas em ágar Brucella enriquecido por meio da técnica da gota e incubadas (37ำ / 7 dias) em anaerobiose. Após período de incubação, em placas que não foram observados crescimento de colônias, foi determinada a CBM do extrato para cada cepa bacteriana. Com base nos resultados deste teste em cultura planctônica, foi realizada a atividade antibiofilme do extrato vegetal, com as concentrações determinadas previamente.

\subsection{ATIVIDADE ANTIMICROBIANA SOBRE BIOFILMES}

As bactérias foram cultivadas em meio sólido (ágar Brucella) e incubadas em anaerobiose (37으 $/ 48 \mathrm{~h})$. Em seguida, foram preparadas suspensões microbianas em solução fisiológica estéril e padronizadas na escala 0,5 de McFarland. Alíquotas da suspenção foram adicionadas (100 $\mu \mathrm{L} /$ poço) em placas de 96 poços acrescido de $100 \mu \mathrm{L}$ de caldo Brucella enriquecido. A placa foi levada para incubação (37으) 7 dias em anaerobiose) com troca do meio de cultura a cada $48 \mathrm{~h}$. Depois o biofilme foi lavado (0,9\% de $\mathrm{NaCl})$ e exposto a diferentes concentrações do extrato previamente selecionadas no teste de microdiluição em caldo com diferentes tempos de contato (5 min e $24 \mathrm{~h}$ ). Como controles negativos, foram utilizados solução salina (5 min) e 
salina/meio de cultura ( $24 \mathrm{~h}$ ) e como controle positivo, clorexidina $0,12 \%(n=12)$. Após os tratamentos com extrato e duas lavagens com solução salina, foi realizado o teste de viabilidade celular da bactéria em que foram adicionados $100 \mu \mathrm{L}$ da solução de MTT (3(4,5-Dimethylthiazol-2-yl)-2,5-Diphenyltetrazolium Bromide) em cada poço e a placa foi incubada ao abrigo da luz a $37^{\circ} \mathrm{C}$ durante 1 hora. A solução de MTT foi removida e foram adicionados $100 \mu \mathrm{L}$ de álcool absoluto. Uma nova incubação foi feita ao abrigo da luz por 10 minutos em Shaker e 10 minutos em estufa a $37^{\circ} \mathrm{C}$. A leitura foi realizada em espectrofotômetro com $570 \mathrm{~nm}$ e as densidades ópticas (DO) foram convertidas em redução de viabilidade celular por meio da fórmula:

\% Redução de Viabilidade = 100 - (DO Poço Tratado x 100 / Média de DO Controle Negativo)

\subsection{ANÁLISE ESTATISTICA}

Os resultados que apresentaram distribuição normal foram analisados por ANOVA e complementados pelo teste de Tukey e os resultados que não apresentaram, pelo teste de Kruskal-Wallis suplementado pelo teste de Dunns ambos com nível de significância de $5 \%(p \leq 0,05)$.

\section{RESULTADOS}

\subsection{ATIVIDADE ANTIMICROBIANA SOBRE BACTÉRIAS PLANCTÔNICAS}

Não foi possível obter a CIM do extrato devido a turbidez do meio de cultura, impossibilitando a leitura visual dos resultados. Com relação a CBM, as concentrações mais altas do extrato glicólico de $P$. granatum não apresentaram ação microbicida uma vez que houve crescimento de colônias em todas as concentrações avaliadas.

Figura 1 - Concentração inibitória mínima e concentração bactericida mínima do extrato de romã avaliado sobre $P$. intermedia e $P$. micra.

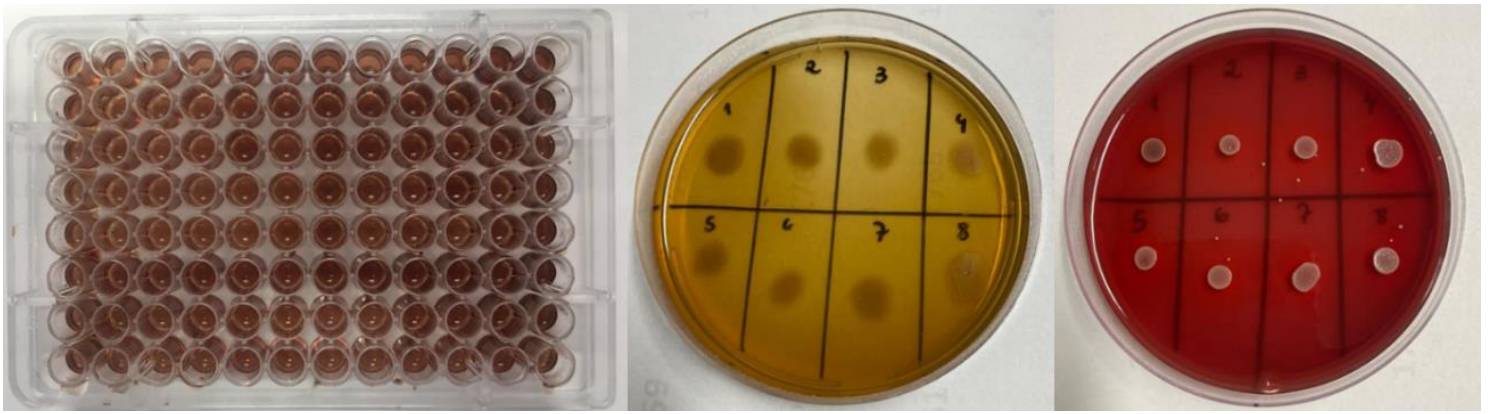

Fonte: autores. 


\subsection{ATIVIDADE ANTIMICROBIANA SOBRE BIOFILMES MONOTÍPICOS}

Foram utilizadas as concentrações de 200 (extrato puro), 100 e $50 \mathrm{mg} / \mathrm{mL}$ para os tratamentos de 5 minutos e de 100, 50 e $25 \mathrm{mg} / \mathrm{mL}$ para 24 horas, visto que a CBM não foi definida para nenhuma cepa. As concentrações utilizadas para o tratamento de 24 horas foram menores pois, por conta da incubação de longo período, seria necessário fornecer nutrientes (meio de cultura) aos microrganismos de forma a evitar interferência nos testes, impossibilitando a utilização de extrato puro $(200 \mathrm{mg} / \mathrm{mL})$.

\subsubsection{TEMPO DE TRATAMENTO - 5 MINUTOS}

Sobre biofilme de $P$. intermedia, as concentrações de 100 e $50 \mathrm{mg} / \mathrm{mL}$ promoveram uma redução da viabilidade celular, porém sem diferença estatística ( $p$ > $0,05)$ quando comparados ao controle. Sobre biofilme de $P$. micra, nenhum dos grupos tratados diferiram estatisticamente do controle negativo $(p>0,05)$ (dados não mostrados).

\subsubsection{TEMPO DE TRATAMENTO - 24 HORAS}

Sobre $P$. intermedia, todas as concentrações do extrato de romã atuaram de maneira similar a clorexidina $0,12 \%$ com semelhança estatística quando comparado entre eles $(p>0,05)$. Quando tais grupos foram comparados ao controle negativo, houve um ligeiro aumento da viabilidade celular.

Figura 2 - Atividade antibiofilme do extrato de romã sobre P. intermedia após 24 horas.

Prevotella intermedia - $24 \mathrm{~h}$

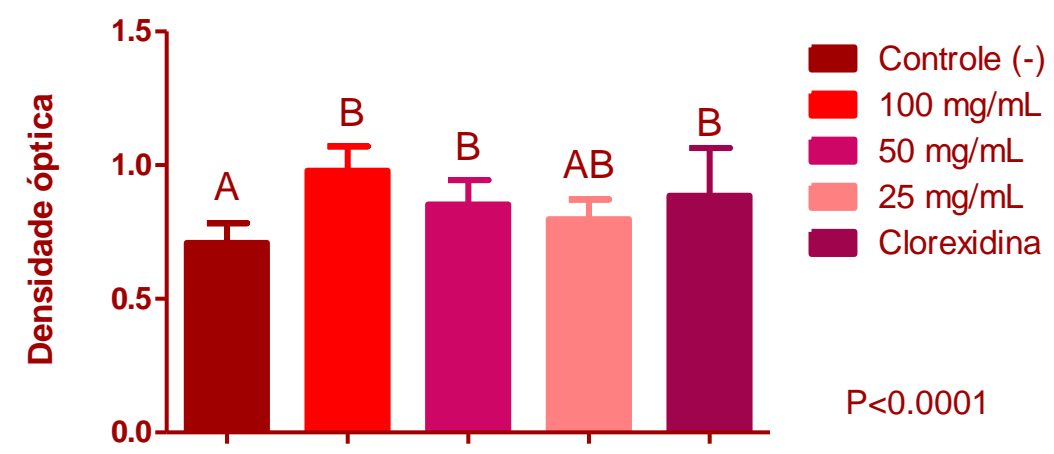

Redução da viabilidade celular

Letras diferentes indicam diferença estatisticamente significativa. ANOVA e teste de Tukey ou Kruskall-Wallis e Dunn com significância de 5\%.

Fonte: autores. 
Sobre biofilme de $P$. micra, todas as concentrações promoveram uma redução significativa do biofilme. As concentrações de 25 e $50 \mathrm{mg} / \mathrm{mL}$ promoveram reduções de $33 \%$ e $29 \%$ respectivamente. Já o grupo tratado com $100 \mathrm{mg} / \mathrm{mL}$ do extrato de romã sofreu uma redução de $74 \%$ do biofilme, atuando de forma semelhante a clorexidina a qual promoveu uma redução de $87 \%$. Tais grupos diferiram estatisticamente do controle negativo $(p<0,05)$.

Figura 3 - Atividade antibiofilme do extrato de romã sobre P. micra após 24 horas.

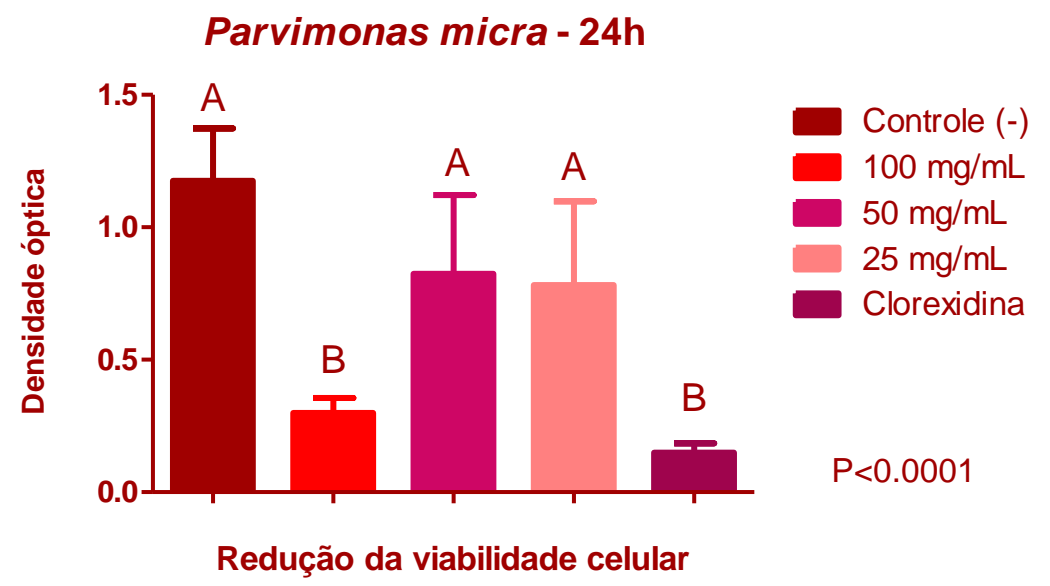

Letras diferentes indicam diferença estatisticamente significativa. ANOVA e teste de Tukey ou Kruskall-Wallis e Dunn com significância de 5\%.

Fonte: autores.

\section{DISCUSSÃO}

Na análise da ação antimicrobiana do extrato sobre culturas planctônicas, não foi possível obter os dados da CIM devido a turbidez do meio de cultura. O extrato não apresentou uma concentração bactericida mínima, uma vez que a maior concentração disponível não promoveu tal efeito. Tal resultado está de acordo com o estudo de Veloso et al. (2020) que testaram a CIM e CBM de diversos extratos vegetais sobre diversos microrganismos, entre eles a P. micra e P. intermedia. De todos os extratos avaliados, 0 único que não apresentou ação inibitória e microbicida nos testes de CIM e CBM sobre $P$. micra foi o extrato de romã e na concentração de $160 \mu \mathrm{g} / \mathrm{mL}$, o extrato não foi eficaz em $P$. intermedia. Sobre outros microrganismos como Staphylococcus aureus, Staphylococcus epidermidis, Streptococcus mutans, Candida albicans, Candida tropicalis e Candida glabrata o extrato glicólico de romã apresentou uma concentração inibitória 
mínima de $50 \mathrm{mg} / \mathrm{mL}$ para todas os microrganismos analisados (DE OLIVEIRA et al., 2013).

Quanto a atividade antibiofilme do extrato sobre $P$. intermedia no tempo de 5 minutos, pode-se verificar ligeira redução do biofilme nas concentrações de 100 e 50 $\mathrm{mg} / \mathrm{mL}$ respectivamente. Tais concentrações atuaram de forma semelhante a clorexidina 0,12\% que é considerado "padrão ouro" na eliminação do biofilme de bactérias orais. Tais resultados vem de encontro ao estudo de Bhadbhade et al. (2011) no qual verificaram que o enxaguante bucal à base de romã apresentou efeito antibiofilme e efeito inibitório in vitro contra A. actinomycetemcomitans, $P$. gingivalis e P. intermedia. Sobre P. micra, não foram encontradas reduções significativas do biofilme com apenas 5 minutos de contato ao extrato vegetal.

No tempo de 24 horas sobre $P$. micra, pode-se verificar reduções significativas do biofilme em todas as concentrações avaliadas. As concentrações de 25 e $50 \mathrm{mg} / \mathrm{mL}$ promoveram reduções de $33 \%$ e $29 \%$ respectivamente. A concentração de $100 \mathrm{mg} / \mathrm{mL}$ promoveu uma redução de $74 \%$ do biofilme quando comparadas ao grupo controle, apresentando semelhança estatística com a clorexidina. Pode-se afirmar que nesta concentração o extrato atuou de forma semelhante a clorexidina. No tempo de contato de 24 horas sobre $P$. intermedia, não houve reduções significativas em qualquer grupo, sejam os tratados com extrato vegetal ou clorexidina. Não foram encontrados estudos na literatura consultada sobre a ação antibiofilme do extrato de romã contra $P$. micra.

São escassos na literatura estudos sobre a atuação do extrato glicólico de Punica granatum contra biofilmes de $P$. micra e $P$. intermedia. Com isso percebe-se a importância do presente estudo. O extrato polifenólico da casca do fruto da romã foi capaz de inibir a formação de biofilme e destruir biofilmes pré-formados de Streptococcus mutans, Streptococcus oralis, Streptococcus mitis e Rothia dentocariosa (SATERIALE et al., 2020). Outros extratos como o Zingiber officinale, popular gengibre, apresentou atividade antimicrobiana em biofilmes monotípicos de $P$. intermedia, no tempo de contato de 5 minutos e 24 horas (ÁVILA, 2019). Outro estudo semelhante verificou que os extratos aquoso e glicólico de própolis verde apresentaram atividade antimicrobiana para $P$. micra, $P$. intermedia, $F$. nucleatum, $P$. gingivalis e $P$. endodontalis (ASSIS, 2018). 
Os autores acreditam que a continuação dos estudos é necessária para esclarecer algumas variáveis. Neste estudo foram testados dois tempos de contato do extrato vegetal com biofilmes monotípicos de bactérias anaeróbias a fim de observar os efeitos do extrato em um primeiro contato e em um contato a longo prazo. Pode-se verificar que o extrato vegetal apresentou diferentes atuações nos diferentes tempos de contato com os biofilmes.

\section{CONSIDERAÇÕES FINAIS}

De acordo com o exposto, pode-se observar que a romã possui um potencial ainda inexplorado, principalmente na área odontológica. No presente estudo, o extrato glicólico de Punica granatum apresentou efeito antibiofilme semelhante a clorexidina 0,12\% contra $P$. micra no tempo de contato de 24 horas. Não foram encontrados estudos na literatura consultada sobre a ação antibiofilme do extrato de romã contra $P$. micra, o que torna o presente estudo pioneiro. Os autores acreditam que os próximos passos são avançar nas investigações para em um futuro próximo, introduzir o produto vegetal nas clínicas odontológicas.

\section{AGRADECIMENTOS}

Ao Programa Institucional de Bolsas de Iniciação Cientifica (PIBIC) pela concessão da Bolsa de Iniciação Científica.

\section{REFERÊNCIAS}

ÁVILA, D. S. Ação citotóxica e antimicrobiana do extrato glicólico de zingiber officinale sobre micro- organismos de interesse para odontologia. 2019. Dissertação (Mestrado) Universidade Estadual Paulista (UNESP) - Instituto de ciência e tecnologia (ICT). São José dos Campos - SP, 2019.

ASSIS, M.A. Ação antimicrobiana e citotoxicidade de extratos aquoso e glicólico de própolis sobre bactérias anaeróbias de importância odontológica. 2018. Dissertação (Mestrado) Universidade Estadual Paulista (UNESP) - Instituto de ciência e tecnologia (ICT). São José dos Campos - SP, 2018.

BARTZ, H. et al. Micromonas (Peptostreptococcus) micros: Unusual case of prosthetic joint infection associated with dental procedures. International Journal of Medical Microbiology, v. 294, n. 7, p. 465-470, 26 jan. 2005. 
DANTAS MACEDO, D. R. R. B.; NOCA DE SOUZA, H. T.; GUIMARÃES, M. V. AÇÃO ANTIMICROBIANA E ANTI-INFLAMATÓRIA DA Punica granatum L. (ROMÃ) NO TRATAMENTO DA DOENÇA PERIODONTAL: UMA REVISÃO DE LITERATURA. Revista Saúde - UNG-Ser, v. 14, n. 1/2, p. 52, 10 jul. 2020.

DE OLIVEIRA, J. R. et al. Cytotoxicity of Brazilian plant extracts against oral microorganisms of interest to dentistry. BMC Complementary and Alternative Medicine, v. 13, n. 1, p. 1-7, 15 ago. 2013.

DEL POZO, J. L. Biofilm-related disease. Expert Review of Anti-Infective Therapy Taylor \& Francis, , 2 jan. 2018.

DUROVIC, A. et al. Parvimonas micra as a rare cause of spondylodiscitis - Case series from a single centre. Swiss Medical Weekly, v. 150, n. 25-26, p. 1-5, 2020.

FOROUZANFAR, F. et al. Protective effect of Punica granatum L. against serum/glucose deprivation-induced PC12 cells injury. Evidence-based Complementary and Alternative Medicine, v. 2013, 2013.

GARCIA. La terapeutica com plantas medicinales: fitoterapia - vademecum de prescripcion. [s.l: s.n.].

LAVAEE, F. et al. Antifungal effect of the bark and root extracts of Punica granatum on oral Candida isolates. Current Medical Mycology, v. 4, n. 4, p. 20-24, 1 dez. 2018.

LEVINE. Bases científicas da educação para saúde dental. In: Lindhe J. Tratado de periodontia clínica. [s.l: s.n.].

MACHADO, A. C.; OLIVEIRA, R. C. Medicamentos Fitoterápicos na odontologia: Evidências e perspectivas sobre o uso da aroeira-do-sertão (Myracrodruon urundeuva Allemão)Revista Brasileira de Plantas Medicinais, 2014.

MARK STEVEN, W.; CHARLIE, L. The cariogenic dental biofilm: Good, bad or just something to control? Brazilian Oral Research, v. 23, n. SUPPLE. 1, p. 31-38, 2009.

ÖZOK, A. R. et al. Comparison of Growth and Susceptibility to Sodium Hypochlorite of Mono- and Dual-Species Biofilms of Fusobacterium nucleatum and Peptostreptococcus (micromonas) micros. Journal of Endodontics, v. 33, n. 7, p. 819-822, jul. 2007.

PEREIRA, J. V. et al. Efeito antibacteriano e antiaderente in vitro do extrato da Punica granatum Linn. sobre microrganismos do biofilme dental. Revista Brasileira de Farmacognosia, v. 16, n. 1, p. 88-93, mar. 2006. 
PIÑON-ESTEBAN, P. et al. Presence of bacterial DNA in thrombotic material of patients with myocardial infarction. Scientific Reports, v. 10, n. 1, 1 dez. 2020.

SABA CHUJFI, E. et al. Avaliação dos métodos de motivação/educação em higiene bucal aplicados em adolescentes de 12 a 16 anos de idade TT - Evaluation of motivation/education methods on oral hygiene applied on adolescents from 12 to 16 years old. RGO (Porto Alegre), v. 40, n. 2, p. 87-90, 1992.

SATERIALE, D. et al. Phytocompounds vs. Dental Plaque Bacteria: In vitro Effects of Myrtle and Pomegranate Polyphenolic Extracts Against Single-Species and Multispecies Oral Biofilms. Frontiers in Microbiology, v. 11, p. 2742, 5 nov. 2020.

SMRUTI J BHADBHADE, ANIRUDH B ACHARYA, SILVIA V RODRIGUES, S. L. T. The antiplaque efficacy of pomegranate mouthrinse. Quintessence Int, v. 42, n. 1, p. 29-36, 2011.

TANNEERU, S.; MAHENDRA, J.; SHAIK, M. V. Evaluation of microflora (viral and bacterial) in subgingival and placental samples of pregnant women with preeclampsia with and without periodontal disease: A cross-sectional study. Journal of International Society of Preventive and Community Dentistry, v. 10, n. 2, p. 171-176, 2020.

THANGAVELU, A. et al. Ancient seed for modern cure - Pomegranate review of therapeutic applications in periodontics. Journal of Pharmacy and Bioallied Sciences J Pharm Bioallied Sci, , 1 nov. 2017.

TURRINI, E.; FERRUZZI, L.; FIMOGNARI, C. Potential effects of pomegranate polyphenols in cancer prevention and therapy. Oxidative Medicine and Cellular Longevity Oxid Med Cell Longev, , 2015.

VELOSO, D. J. et al. Potential antibacterial and anti-halitosis activity of medicinal plants against oral bacteria. Archives of Oral Biology, v. 110, 1 fev. 2020.

$\mathrm{XU}$, Y. et al. Antimicrobial Activity of Punicalagin Against Staphylococcus aureus and Its Effect on Biofilm Formation. Foodborne Pathogens and Disease, v. 14, n. 5, p. 282-287, 1 maio 2017.

ZHANG, L. et al. The Oral Microbiota May Have Influence on Oral Cancer. Frontiers in cellular and infection microbiology, v. 9, 15 jan. 2020. 


\title{
CAPITULO $V$
}

\section{AVALIAÇÃO DA ATIVIDADE ANTIADERENTE DO GEOPRÓPOLIS DE UMA ABELHA SEM FERRÃO FRENTE AS CEPAS DE ESCHERICHIA COLI E ENTEROCOCCUS FAECALIS}

\author{
DOI: 10.51859/AMPLLA.PAE1993-5
}

\author{
Laís Sousa Maia ${ }^{1}$ \\ Filipe de Oliveira Lima ${ }^{1}$ \\ Natália Oliveira Matos ${ }^{1}$ \\ Rafaella Bandeira de Melo Souza Cavalcanti ${ }^{1}$ \\ Renata Valéria Regis de Sousa ${ }^{2}$ \\ Abrahão Alves de Oliveira Filho ${ }^{3}$
}

\begin{abstract}
${ }^{1}$ Graduando do curso de Odontologia. Universidade Federal de Campina Grande - UFCG
${ }^{2}$ Professora do curso de Ciências Biológicas. Universidade Federal Rural de Pernambuco - UFRPE

${ }^{3}$ Professor do curso de Odontologia. Universidade Federal de Campina Grande - UFCG
\end{abstract}

\section{RESUMO}

As pesquisas com produtos naturais têm avançado bastante nos últimos anos dentro do ramo da Odontologia. Desta forma, no contexto atual, os produtos obtidos da Apicultura são destacados por possuírem compostos bioativos que apresentam potente atividade antimicrobiana e farmacológica. Nessa perspectiva, o geoprópolis produzido pelas abelhas sem ferrão, é reconhecido como um produto natural que possui diversas finalidades terapêuticas, despertando o interesse na indústria. O objetivo deste estudo foi avaliar a atividade antiaderente do geoprópolis, produzido pela abelha sem ferrão da espécie Melipona scutellaris, sobre as cepas patogênicas das bactérias Enterococcus faecalis e Escherichia coli. No experimento, foi realizada a técnica da Concentração Inibitória Mínima de Aderência (CIMA). As amostras foram coletadas de meliponários na cidade de Bonito/PE. Para a realização da técnica utilizou-se uma amostra de extrato etanólico de geoprópolis, sendo os ensaios laboratoriais realizados utilizando a técnica de tubos inclinados, na presença de $5 \%$ de sacarose e a leitura da CIMA foi executada por meio da análise observacional na superfície do vidro comparando-a com a do controle positivo (clorexidina $0,12 \%$ ), seguindo os métodos de referência. Os resultados da avaliação demonstraram que esse produto natural não foi capaz de inibir a formação do biofilme das bactérias em estudo, diferentemente do controle positivo que apresentou CIMA de 1:1 e 1:8, para E. faecalis e E. coli, respectivamente. Tendo em vista tais resultados, tornase necessário a realização de mais pesquisas avaliando outras propriedades dessa substância e frente a outras espécies de microorganismos.

Palavras-chave: Abelhas. Geoprópolis. Microbiologia. Odontologia. 


\section{INTRODUÇÃO}

O biofilme é caracterizado como uma comunidade de microrganismos associados entre si, protegidos por uma matriz polimérica extracelular, e aderidos à superfícies biológicas ou sintéticas (BEIKLER; FLEMMIG, 2011; FLEMMING et al. 2016). O processo de formação do biofilme começa com a deposição dos microrganismos e em sequência a adsorção reversível à superfície de adesão (MONROE, 2007). Nesse contexto, é importante salientar que a manutenção de bactérias patogênicas que compõem o biofilme na cavidade oral é determinada por aderência individual e propriedades de crescimento; considerando que a sequência de infecção determina a composição do mesmo (JACOB, 2006). Além disso, também irá depender de fatores de virulência como: a presença ou ausência de fímbrias, formação de adesinas, existência ou não da cápsula exopolimérica e de condições físico-químicas da superfície a qual se encontra aderido (RECH et al. 2016).

Uma das estratégias para a prevenção ou controle de doenças biofilmedependentes, seria a inibição, por agentes químicos, dos fatores de virulência dos microrganismos envolvidos que podem reduzir os polissacarídeos responsáveis pela aderência de microrganismos ao biofilme dental ou interferir na produção de ácidos dos microrganismos, resultando em uma menor atividade da afecção (DUARTE et al. 2006).

Nessa perspectiva, é fundamental associar aos procedimentos mecânicos de controle de microrganismos do biofilme dentário, os métodos químicos, tendo em vista as dificuldades quanto à manutenção da motivação dos indivíduos para realizar uma adequada limpeza da cavidade bucal (WOLFF; LARSON, 2009). Agentes químicos antimicrobianos têm sido propostos com a finalidade de inibir o crescimento e a proliferação de microrganismos no ambiente bucal, reduzir a adesão bacteriana às superfícies, modificar a atividade bioquímica desses microrganismos e alterar a ecologia do biofilme dentário para uma microbiota menos patogênica (MARSH, 2010).

O digluconato de clorexidina $0,12 \%$, em função do seu amplo espectro de ação, baixa toxicidade e elevada substantividade, é o agente antimicrobiano mais utilizado, atualmente, no controle químico do biofilme dental. Entretanto, seu uso por períodos prolongados altera a microbiota natural e produz efeitos adversos, como manchas acastanhadas nos dentes, em alguns materiais de restauração e no dorso da língua; 
alteração no paladar e mais raramente erosões na mucosa oral e tumefação unilateral ou bilateral na parótida (LINDHE et al. 2005). Assim, diante dos efeitos colaterais demonstrados pelo digluconato de clorexidina $0,12 \%$ e da sua possibilidade de causar resistência bacteriana, torna-se necessário investigar as propriedades antimicrobianas de novas substâncias (MOTA; TURRINI; POVEDA, 2015).

Considerando as substâncias químicas introduzidas no mundo entre os anos de 1981 e 2010 , sabe-se que 74\%, ou seja, mais da metade são provenientes de produtos naturais, compostos sintéticos embasados em produtos naturais ou semissintéticos análogos a produtos naturais (NEWMAN; CRAGG, 2012). No entanto, os produtos naturais ainda são pouco estudados, levando em consideração a biodiversidade mundial e a presença de compostos bioativos com atividade antimicrobiana que poderiam ser utilizadas como alternativas terapêuticas em doenças orais (JEON et al. 2011).

\section{METODOLOGIA}

Este estudo foi realizado por meio da observação direta, experimental e de laboratório, avaliando o geoprópolis de Melipona scutellaris e sua atividade antiaderente "in vitro", frente aos microrganismos Enterococcus faecalis e Escherichia coli.

\subsection{SUBSTÂNCIA-TESTE}

As amostras de geoprópolis da abelha sem ferrão Melipona scutellaris foram obtidas de um meliponário localizado em Bonito, Pernambuco, Brasil. As amostras de geoprópolis foram coletadas por meliponicultores diretamente de diferentes caixas com o auxílio de uma espátula e acondicionadas em depósito plástico. Realizou-se a identificação dos produtos e o período de coleta, que compreendeu dezembro de 2020. Posteriormente, as amostras foram levadas ao Laboratório de Bioquímica e Microbiologia da Universidade Federal de Campina Grande (UFCG), e ficaram armazenadas em temperatura ambiente até a realização do experimento.

\subsection{ESPÉCIES BACTERIANA E MEIO DE CULTURA}

Foram utilizadas cepas bacterianas das espécies: Enterococcus faecalis (EF 110) e Escherichia coli (EC 110). Todas as cepas foram mantidas em meio Ágar Muller Hinton 
(AMH) a uma temperatura de $4^{\circ} \mathrm{C}$, sendo utilizados para os ensaios repiques de 24 horas em $\mathrm{AMH}$ incubados a $35^{\circ} \mathrm{C}$. Nesse estudo da atividade antiaderente, foi utilizado um inóculo bacteriano de aproximadamente 1,5 x $108 \mathrm{UFC} / \mathrm{mL}$, padronizado de acordo com a turbidez do tubo 0,5 da escala de McFarland.

\subsection{PREPARAÇÃO DAS AMOSTRAS DE GEOPRÓPOLIS PARA ANÁLISE MICROBIOLÓGICA}

As amostras de geoprópolis foram maceradas manualmente com um cadinho de porcelana e posteriormente o Extrato Etanólico de Geoprópolis (EEGP) foi preparado, utilizando álcool etílico $70 \%$ (100 mL) com uma proporção de $30 \mathrm{~g}$ de amostra. 0 extrato foi armazenado em um balão volumétrico, mantido em temperatura ambiente e agitado diariamente durante 30 dias. Em seguida, filtrado com filtro de papel e distribuído em seis béqueres na quantidade de $10 \mathrm{~mL}$ para a secagem na estufa em uma temperatura de $40^{\circ} \mathrm{C}$. Após a secagem preparou-se a solução-mãe utilizando uma proporção préestabelecida de $10 \mathrm{mg} / \mathrm{ml}$. Seguindo essa logística, foram pesados 0,1 g e acrescentouse $1 \mathrm{ml}$ de DMSO (Dimetil Sulfóxido) para ajudar na solubilização com água destilada (9 $\mathrm{ml}$ ) e foram acrescentadas também 10 gotas de tween, que é o agente dispersante. Para a realização da técnica utilizou-se uma amostra do extrato etanólico de geoprópolis, sendo os ensaios laboratoriais realizados utilizando a técnica de tubos inclinados, na presença de $5 \%$ de sacarose e a leitura da CIMA foi executada por meio da análise observacional na superfície do vidro comparando-a com a do controle positivo (clorexidina 0,12\%), seguindo os métodos de referência de acordo com Albuquerque et al. (2010).

\section{RESULTADOS}

O método da CIMA foi utilizado na presente pesquisa por permitir avaliar o potencial antiaderente dos produtos naturais utilizados no estudo de forma rápida e eficaz. Além disso, outra vantagem desse método se caracteriza pela análise experimental de forma observacional direta, possibilitando a seleção de produtos com potencial antiaderente (RAMALHO et al. 2020).

Nas tabelas 1 e 2, estão representadas as Concentrações Inibitórias Mínimas de Aderência (CIMA) do extrato etanólico de geoprópolis da abelha sem ferrão Melipona 
scutellaris contra as cepas de Enterococcus faecalis (EF 110) e Escherichia coli (EC 110), respectivamente, em comparação com o digluconato de clorexidina $0,12 \%$.

Tabela 1 - Concentração Inibitória Mínima de Aderência em $\mu \mathrm{g} / \mathrm{mL}$ do Extrato etanólico de geoprópolis da Melipona scutellaris e do digluconato de Clorexidina 0,12\% contra a cepa de Enterococcus faecalis (EF 110)

\begin{tabular}{|c|c|c|c|c|c|c|c|c|}
\hline \multicolumn{9}{|c|}{ Geoprópolis } \\
\hline \multirow{2}{*}{$\begin{array}{c}\text { Concentração } \\
\text { em } \mu \mathrm{g} / \mathrm{ml}\end{array}$} & $1: 1$ & $1: 2$ & $1: 4$ & $1: 8$ & $1: 16$ & $1: 32$ & $1: 64$ & $1: 128$ \\
\hline & + & + & + & + & + & + & + & + \\
\hline \multicolumn{9}{|c|}{ Digluconato de Clorexidina $0,12 \%$} \\
\hline \multirow{2}{*}{$\begin{array}{c}\text { Concentração } \\
\text { em } \mu \mathrm{g} / \mathrm{ml}\end{array}$} & $1: 1$ & $1: 2$ & $1: 4$ & $1: 8$ & $1: 16$ & $1: 32$ & $1: 64$ & $1: 128$ \\
\hline & - & + & + & + & + & + & + & + \\
\hline
\end{tabular}

Fonte: Autoria própria.

Legenda: (-) sem adesão a parede do tubo (+) com adesão a parede do tubo

Tabela 2 - Concentração Inibitória Mínima de Aderência em $\mu \mathrm{g} / \mathrm{mL}$ do Extrato etanólico de geoprópolis da Melipona scutellaris e do digluconato de clorexidina 0,12\% contra a cepa de Escherichia coli (EC 110)

\begin{tabular}{|c|c|c|c|c|c|c|c|c|}
\hline \multicolumn{9}{|c|}{ Geoprópolis } \\
\hline \multirow{2}{*}{$\begin{array}{c}\text { Concentração } \\
\text { em } \mu \mathrm{g} / \mathrm{ml}\end{array}$} & $1: 1$ & $1: 2$ & $1: 4$ & $1: 8$ & $1: 16$ & $1: 32$ & 1:64 & $1: 128$ \\
\hline & + & + & + & + & + & + & + & + \\
\hline \multicolumn{9}{|c|}{ Digluconato de Clorexidina $0,12 \%$} \\
\hline \multirow{2}{*}{$\begin{array}{c}\text { Concentração } \\
\text { em } \mu \mathrm{g} / \mathrm{ml}\end{array}$} & $1: 1$ & $1: 2$ & $1: 4$ & $1: 8$ & $1: 16$ & $1: 32$ & 1:64 & $1: 128$ \\
\hline & - & - & - & - & + & + & + & + \\
\hline
\end{tabular}

Fonte: Autoria própria.

Legenda: (-) sem adesão a parede do tubo (+) com adesão a parede do tubo

De acordo com a tabela 1 e 2, o extrato etanólico de geoprópolis não apresentou atividade de inibição do biofilme produzido pelas cepas de $E$. faecalis e $E$. coli, pois o biofilme formado ficou aderido na parede de todos os tubos de ensaio.

\section{REVISÃO BIBLIOGRÁFICA E DISCUSSÃO}

\subsection{AS ABELHAS SEM FERRÃO}

De acordo com Barbosa et al. (2017), acredita-se que existão mais de 20 mil espécies de abelhas no mundo. No Brasil, as espécies sociais compreendem as abelhas 
sem ferrão, pertencentes ao grupo meliponini, e também as abelhas domésticas (Apis melifera) (BENDINI et al. 2020). Um grande diferencial que existe entre essas espécies refere-se ao aspecto morfológico relacionado a sua picada, pois as fêmeas de meliponíneos não apresentam ferrão ou quando esse existe ocorre uma atrofia do mesmo. Essas abelhas possuem outra forma de defesa, que se caracteriza pela produção de ácido fórmico por suas glândulas mandibulares, que provoca um aumento da dor durante picada (MICHENER, 2013). Ainda, de acordo com Bankova (2005), quanto a alimentação das abelhas, suas principais fontes de nutrição vem do néctar das plantas e do pólen. Dessa maneira, ao mesmo tempo em que satisfazem suas demandas nutricionais, as abelhas também apanham metabólitos especializados das plantas, que possuem compostos químicos com propriedades significativas biológicas frente a patógenos.

O Brasil possui a maior diversidade de meliponíneos do planeta (VENTURIERI, 2012), com mais de 200 espécies e 29 gêneros que estão distribuídos pelo país inteiro (LAVINAS et al. 2019). De acordo com Pedro et al. (2014), cerca de 89 espécies são endêmicas no Brasil, o que corresponde a cerca de $20 \%$ do total de abelhas neotropicais sem ferrão. Quanto à produção da geoprópolis advindo de abelhas sem ferrão, segundo Souza et al. (2011) a sazonalidade influencia na atividade de produção independentemente do método de coleta utilizado. $O$ autor relatou também que a estimulação de abelhas rainhas por programas de melhoramento genético pode aumentar a produção desse produto natural.

Dentre as muitas espécies de abelhas nativas, a que apresenta maior destaque na região Nordeste do Brasil é a Melipona scutellaris, que se encontra nas áreas de transição entre a Mata Atlântica e a Caatinga, nos estados da Bahia e Rio Grande do Norte (VIANA et al. 2013). Essa espécie, também é conhecida regionalmente como uruçu e caracteriza-se pela produção da geoprópolis (BARTH, 2006), que despertou a atenção de pesquisadores em todo o mundo em função do seu potencial e propriedades farmacológicas (ARAÚJO et al. 2016). 


\subsection{GEOPRÓPOLIS DE ABELHAS SEM FERRÃO: CARACTERÍSTICAS E PROPRIEDADES}

Existem diversos tipos de própolis produzidos por diferentes espécies de abelhas, na qual a composição química e atividade biológica de cada tipo podem apresentar características específicas (BANKOVA; POPOVA; TRUSHEVA, 2018). Tendo em vista fatores ambientais, sazonais e ecológicos, a constituição química da própolis pode ser influenciada quali e quantitativamente, sendo referida como responsável por uma diferente eficácia terapêutica e atividade biológica (CASTRO et al. 2007).

A abelha Melipona scuttellaris produz uma variação da própolis, que é chamada de geoprópolis, um produto apícola, viscoso (ARAÚJO et al. 2016), o qual é constituído pela união de resina, cera e terra, sendo este último elemento o promotor do prefixo desta própolis (BARTH, 2006). Este tipo, produzido pelas abelhas sem ferrão, difere das amostras de própolis por caracterizar-se como um material resinoso menos maleável e também por seu conteúdo mineral e do solo (BARTH; LUZ, 2003). A geoprópolis é utilizada pelas abelhas para a construção e proteção da colmeia (OLIVEIRA et al. 2013), além de demonstrar ação antimicrobiana que confere uma defesa química para as abelhas e para o mel contra microrganismos (CAMPOS et al. 2015).

Cunha et al. (2015) relataram que estudos com a própolis da abelha Apis melífera têm sido predominante na literatura internacional, enquanto outros tipos de própolis coletados por diferentes espécies de abelhas são pouco pesquisados. De acordo com Sousa et al. (2019) e Sanches (2012), pouco se investiga sobre as propriedades biológicas e a composição química da geoprópolis.

A composição da geoprópolis é variável e depende das fontes vegetais utilizadas pelas abelhas e época do ano. Dessa forma, apresentam variações principalmente nos seus constituintes químicos e atividades farmacológicas (LIMA, 2016). Segundo Matos et al. (2019) a resina vegetal, coletada pelas abelhas, é a principal matéria-prima presente na composição do produto. De acordo com Salatino et al. (2011), essa resina vegetal, coletada pelas abelhas, de diferentes origens vegetais, não apresenta toxicidade e é fundamental para a proteção da colmeia. Ademais, quanto as características, de modo geral as amostras da geoprópolis contêm grânulos inodoros, de consistência heterogênea e coloração marrom escura (CUNHA et al. 2009). 
Nessa perspectiva, a geoprópolis é reconhecida como um produto natural com diferentes finalidades terapêuticas, destacando-se atividades biológicas que têm sido estudadas, como a ação antioxidante (FERREIRA et al. 2018), antinflamatória (FRANCHIN et al. 2013; GUZMÁN-GUTIÉRREZ et al. 2018), antimicrobiana (MOLNÁR et al. 2017; CUNHA et al. 2013), antiaderente (CUNHA et al. 2019), anticâncer (BARTOLOMEU et al. 2016) e antiproliferativa (CUNHA et al. 2015). Além ter sido usada, em alguns países, empiricamente pela população para a cicatrização de feridas, agente antibacteriano e tratamentos de gastrites (QUEZADA-EUAN et al. 2001). Na odontologia, a própolis vem sendo empregada em experimentos nas áreas de endodontia, cariologia, cirurgia oral, patologia oral e periodontia, entre outras (LUSTOSA et al. 2008).

A literatura evidencia grande potencial antimicrobiano para a geoprópolis de diversas espécies de meliponíneos, e entre as principais classes de substâncias encontradas estão: terpenoides, ácidos terpênicos, álcoois, ácidos alifáticos e seus ésteres, flavonoides, saponinas e ácidos aromáticos. (SANCHES; PEREIRA; SERRÃO, 2017). Libério et al. (2011), relataram que o extrato com maior concentração de flavonoides demonstrou um maior potencial antimicrobiano. De acordo com Oliveira et al. (2013), os flavonoides e ácidos fenólicos têm sido destacados e atribuídos como os principais compostos responsáveis pelos efeitos terapêuticos tanto do mel como da geoprópolis coletados por essas abelhas. Cunha et al. (2013), propõem que a geoprópolis apresenta como composto principal benzofenomas poliprenilados. Dualibe, Gonçalves e Ahid (2007) evidenciaram que bochechos com extratos de geoprópolis podem diminuir a contagem de estreptococos orais. No estudo de Libério et al. (2011) as amostras de geoprópolis de Melipona fasciculate, do Nordeste brasileiro, apresentaram potencial antibacteriano contra o S. mutans e não evidenciaram toxicidade em

pesquisa "in vivo", demonstrando também efeito antinflamatório.

A ação antibacteriana da própolis tem sido relatada principalmente contra estreptococos do grupo mutans (CUNHA, et al. 2013; DUALIBE, GONÇALVES, AHID, 2007; KOO et al. 2005), atuando de diversas formas, como na inibição das enzimas glucosiltransferases (GTF), um dos principais fatores de virulência relacionado a aderência do microrganismo ao biofilme (KOO et al. 2002). Ademais, considerando um estudo mais recente utilizando a geoprópolis da Melipona scutellaris coletada da região entre rios no estado da Bahia, Cunha et al. (2013), identificaram uma fração ativa contra 
vários microrganismos gram-positivos, incluindo o S. mutans organizado em biofilme. Além disso, a utilização da propólis tem sido sugerida como adjuvante para controle ou profilaxia de doenças infecciosas da cavidade oral (SAWAYA et al. 2004).

Nesse contexto, segundo o estudo "in vitro" realizado Gebara, Zardetto e Mayer (1996), que analisaram a Concentração Inibitória Mínima de Aderência de produtos naturais, incluindo a própolis, constatou que esse produto apresenta a capacidade de inibir a aderência dos microrganismos S. mutans e S. sobrinus. Liberio et al. (2011), avaliaram em seu estudo a atividade antimicrobiana de extratos de geoprópolis de Melipona fasciculata frente a patógenos orais e também investigaram a ação no biofilme de S. mutans. Em seus resultados observaram efeito contra o biofilme e também o potencial antimicrobiano. Velikova et al. (2000), investigaram a atividade antimicrobiana de amostras de geoprópolis brasileiras contra Staphylococcus aureus e Escherichia coli. No estudo, analisaram amostras de doze espécies de meliponíneos e constataram a presença de compostos, sendo eles o di e triterpenos, além de ácido gálico. Nos resultados constataram significativa atividade contra o Staphylococcus aureus e baixa atividade citotóxica. Gonçalves et al. (2005), realizaram uma pesquisa "in vitro" por meio da difusão em ágar, a qual verificou a atividade antibiótica do mel da Nannotrigona testaceicornis (abelhas indígenas sem ferrão) frente aos microrganismos Escherichia coli, Pseudomonas aeruginosa, Streptococcus pyogenes e Staphylococcus sp. O resultado do estudo demonstrou sensibilidade desses microrganismos ao mel testado.

\subsection{OUTROS ESTUDOS E PESQUISAS ENVOLVENDO A GEOPRÓPOLIS}

Dualibe, Gonçalves e Ahid (2007), avaliaram o potencial antibacteriano do extrato de geoprópolis produzido pela abelha Melipona compressipes fasciculata frente a Streptococcus mutans por meio de bochechos realizados por jovens voluntários. A partir desse estudo, constatou-se a atividade antimicrobiana "in vivo" da geoprópolis contra S. mutans presentes na cavidade oral. No estudo de Eduardo (2014), que teve como objetivo isolar e identificar compostos ativos da geoprópolis de Melipona scutellaris frente ao biofilme oral de Streptococcus mutans, realizou testes em um biofilme de S. mutans organizado em discos de hidroxiapatita e avaliou os efeitos sobre a integridade bacteriana, biomassa, adesão, proteínas da matriz e polissacarídeos, 
utilizando como controle positivo a clorexidina $(0,12 \%)$. Em seus resultados constatouse que a substância bioativa encontrada tem a capacidade de reduzir polissacarídeos e proteínas da matriz, afetando a viabilidade celular, se apresentando como um agente promissor para controle de biofilmes orais patogênicos. Entretanto, os resultados não demonstraram diferença significativa quando comparado ao grupo tratado com a clorexidina $(0,12 \%)$.

Cunha et al. (2013), investigaram a influência da fração hexânica do extrato etanólico de geoprópolis no biofilme de S. mutans a partir de análises "in vitro" e evidenciaram que o extrato etanólico de geoprópolis de Melipona scutellaris interferiu na formação do biofilme de $S$. mutans, reduzindo a biomassa, os polissacarídeos e o teor de proteínas da matriz do biofilme, concluindo que essas substâncias bioativas da geoprópolis são promissoras para controlar a formação do biofilme de S. mutans. Rochele et al. (2016), avaliaram o potencial antibiofilme do extrato hidroalcoólico de diversos resíduos agroindustriais (o que sobrou após o uso e seria descartado), incluindo o da geoprópolis de Melipona scutellaris. Com isso, foi possívelobservar que a adesão de microrganismos como S. epidermides, $S$. aureus meticilina resistente, $S$. aureus e $S$. mutans foi inibida, destacando a atividade antibiofilme frente a patógenos da área médica e odontológica.

De forma semelhante, um estudo mais recente realizado por Cunha et al. (2019), no qual avaliou-se as propriedades antimicrobianas e de antiaderência de um composto isolado da geoprópolis da abelha sem ferrão Melipona scutellaris contra as cepas de Staphylococcus aureus (sensível e resistente a meticilina) e ao biofilme em formação e maduro desses microrganismos, obteve em seus resultados a confirmação da atividade antimicrobiana contra ambas as cepas e verificaram que esse composto diminuiu significativamente a formação e viabilidade do biofilme desses microrganismos. Demonstrando outra perspectiva, no presente estudo, testou-se a atividade farmacológica do extrato etanólico de geoprópolis, para a análise do potencial antiaderente deste produto natural, produzida pela mesma espécie de abelha dos estudos supracitados. Entretanto, os ensaios "in vitro" foram realizados utilizando cepas de $E$. faecalis e $E$. coli, quepor sua vez, apresentaram aderência a superfície do tubo de vidro nos testes com a substância em análise. 
Kayaoglu et al. (2011), analisaram a atividade antibacteriana de duas amostras de extrato etanólico de própolis obtidas em diferentes locais, em comparação com a clorexidina eo hidróxido de cálcio contra Enterococcus faecalis. Para o experimento utilizaram blocos de dentina padronizados, infectados com E. faecalis e preencheram o espaço do canal radicular com as substâncias. Em seus resultados, demonstraram que todos os agentes reduziram significativamente o número de bactérias cultiváveis. As duas amostras de própolis foram estatisticamente semelhantes e ambas se mostraram eficazes, entretanto, a clorexidina foi o agente mais potente.

Semelhantemente, no estudo de Maia Filho et al. (2008) investigaram a atividade antibacteriana "in vitro" da própolis produzida pela abelha sem ferrão Scaptotrigona sp, e de outras soluções usadas no tratamento endodôntico frente a Enterococcus faecalis. As substâncias foram separadas para o teste em quadro grupos: Grupo I: hidróxido de cálcio (Calen $\left.{ }^{\circledR}\right)$; Grupo II: gel clorexidina 2\%; Grupo III: NaOCl 5\% e Grupo IV: extrato de própolis. Em seus resultados as substâncias apresentaram efetividade na seguinte ordem decrescente: Clorexidina > Hidróxido de Cálcio > Extrato de Própolis > Hipoclorito de sódio $5 \%$. Assim, concluiu-se que o extrato de própolis demonstrou mais eficiência do que o Hipoclorito de sódio 5\%, entretanto a clorexidina foi a substância mais potente frente a $E$. faecalis. O presente estudo não engloba a análise do potencial antibacteriano "in vitro" da geoprópolis como nos estudos citados. No entanto, na avaliação comparativa da CIMA, que investigou a atividade farmacológica a partir da análise do potencial antiaderente, a clorexidina (controle postivo) inibiu o biofilme tanto de $E$. faecalis, como de E. Coli.

\section{CONSIDERAÇÕES FINAIS}

Foi verificado na presente pesquisa que a geoprópolis não apresentou atividade antiaderente frente as bactérias $E$. coli e $E$. faecalis. Sendo assim, e tendo em vista esses resultados, tornam- se necessários a realização de mais estudos que investiguem o potencial antibiofilme desse produto natural com a finalidade promissora na Odontologia e possíveis indicações terapêuticas. É relevante salientar ainda que se identificou poucos trabalhos referentes à atividade antiaderente da geoprópolis de abelhas nativas sem ferrão, sendo predominante na literatura pesquisas que contemplavam o potencial antibacteriano, utilizando como metodologia a 
Concentração Inibitória Mínima (CIM) da geoprópolis frente a microrganismos patogênicos orais. Com isso, reforça-se ainda mais a necessidade de aprofundar as investigações sobre o potencial antibiofilme desse tipo de produto natural.

\section{REFERÊNCIAS}

ALBUQUERQUE, A. C. L. et al. Efeito antiaderente do extrato da Matricaria recutita Linn. sobre microorganismos do biofilme dental. Rev. Odontol. UNESP, v. 39, n. 1, p. 21-25, 2010.

ARAÚJO, K. S. S. et al. Physicochemical properties and antioxidant capacity of propolis of stingless bees (Meliponinae) and Apis from two regions of Tocantins Brazil. Acta Amaz, v. 46, p. 61-68, 2016.

BANKOVA, V. Recent trends and important developments in propolis research. Evid Based Comp Alt Med, v. 2, n. 1, p.29-32, 2005.

BANKOVA, V.; POPOVA, M.; TRUSHEVA, B. The phytochemistry of the honeybee. Phyto, v. 155, p. 1-11, 2018.

BARBOSA, D. B. et al. As abelhas e seu serviço ecossistêmico de polinização. Rev e Cient da UERGS, v. 3, n. 4, p. 694-703, 2017.

BARTH, O. M. Análise palinológica de amostras de geoprópolis obtidas de seis espécies de Meliponinae no Campus da Universidade de Ribeirão Preto, USP, Brasil. Apiacta, v. 41, n. 1, p. 1-14, 2006.

BARTH, O. M.; LUZ, C.F.P.D.; Palynological analysis of Brazilian geopropolis sediments. Grana, v. 42, n. 2, p.121-127, 2003.

BARTOLOMEU, A. R. et al. Combinatorial effects of geopropolis produced by Melipona fasciculata Smith with anticancer drugs against human laryngeal epidermoid carcinoma (HEp-2) cells. Biomedi \& Pharmacoth, v. 81, p. 48-55, 2016.

BEIKLER, T.; FLEMMIG, T. F. Oral biofilm-associated diseases: trends and implications for quality of life, systemic health and expenditures. Periodont 2000 , v. 55 , p. $87-$ 103, 2011.

BENDINI, J. N. et al. Meliponário didático: a extensão universitária como uma estratégia para a conservação das abelhas sem ferrão no semiárido piauiense. Rev Bras de Ext Uni, v. 11, n. 3, p. 277-288, 2020.

CAMPOS, J.F. et al. Antimicrobial, antioxidant, anti-inflammatory, and cytotoxic activities of propolis from the stingless bee Tetragonisca fiebrigi (Jataí) Evid. EvidBased Comp and Alt Med. v. 2015, p. 1-11, 2015. 
CASTRO, M. L. et al. Própolis do sudeste e nordeste do Brasil: influência da sazonalidade na atividade antibacteriana e composição fenólica. Quim Nova, v. 30, n. 7, p. 1512-1516, 2007.

CUNHA, M. G. et al. Antiproliferative constituents of geopropolis from the bee Melipona scutellaris. Plant Med, v. 82, n. 3, p. 190, 2015.

CUNHA, M. S. et al. Padronização de extrativos de geoprópolis de Melípona fasciculata Smith (tíuba). Cad de Pesq UFMA, v. 16, p. 31-38, 2009.

CUNHA, M.G. et al. Antimicrobial and antiproliferative activities of stingless bee Melipona scutellaris geopropolis. BMC Comp and Alt Med, v. 13, n.23, 2013.

CUNHA, M.G. et al. Antimicrobial, anti-adherence and antibiofilm activity against Staphylococcus aureus of a 4-phenyl coumarin derivative isolated from Brazilian geopropolis. Microbial Patogh, v. 139, 2019.

CUNHA, M.G. et al. Apolar bioactive fraction of Melipona scutellaris geopropolis on Streptococcus mutans biofilm. Evid-based Comp and Alt Med, v. 2013, 2013.

DUALIBE, S. A. C.; GONÇALVES, A. G, AHID, F. J. M. Effect of a própolis extract on Streptococcus mutans in vivo. J Appl Oral Sci, v.15, n.5, p. 420-423, 2007.

DUARTE, S. et al. The influence of a novel propolis on mutans streptococci biofilms and caries development in rats. Arch of Oral Biol, v. 51, n. 1, p. 15-22, 2006.

EDUARDO, P. L. F. Isolation and identification of bioactive compounds of geopropolis (Melipona scutellaris) bioguided by the antimicrobial effect. Dissertação (Mestrado em Odontologia, área de farmacologia, anestesiologia e terapêutica) - Faculdade de Odontologia de Piracicaba, Universidade Estadual de Campinas. Piracicaba-SP, 36f. 2014.

FERREIRA, J.M. et al. Antioxidant activity of a geopropolis from Northeast Brazil: chemical characterization and likely botanical origin. Evid Based Compl Alt Med, v. 2017, 2018.

FLEMMING, H.C. et al. Biofilms: na emergent formo $f$ bacterial life. Nat Rev: Microbiol, v.11, p. 563-575, 2016.

FRANCHIN, M. et al. Bioactive fraction of Melipona scutellaris geopropolis decreases neutrophils migration in inflammatory process: involvement of nitric oxide pathway, Evid- Based Comp and Alt Med, v. 2012, p. 1-9, 2013.

GEBARA, E. C. E.; ZARDETT, C. G. C.; MAYER, M. P. A. Estudo in vitro da ação antimicrobiana de substâncias naturais sobre $S$. mutans e S. sobrinus. Rev Odontol Univ São Paulo, v. 10, n. 4, p. 251-256, 1996. 
GONÇALVES, A.L.; ALVES FILHO, A.; MENEZES, H. Atividade antimicrobiana do mel da abelha nativa sem ferrão Nannotrigona testaceicornis (Hymenoptera: apidae, meliponini). Arq Inst Biol, v. 72, n.4, p.455-459, 2005.

GUZMÁN-GUTIÉRREZ, S.L. et al. 2018. Mexican propolis: a source of antioxidants and anti-inflammatory compounds, and isolation of a novel chalcone and caprolactone derivative. Molecules, v.23, n.2, p.334, 2018.

JACOB, M. Biofilms, a new approach to the microbiology of dental plaque. Odontology, v. 94, n. 1, p. 1-9, 2006.

JEON, J.G. et al. Natural products in caries research: current (limited) knowledge, challenges and future perspective. Caries Res, v.45, n.3, p. 243-63, 2011.

KAYAOGLU, G. et al. Antibacterial activity of Propolis versus conventional endodontic disinfectants against Enterococcus faecalis in infected dentinal tubules. J Of Endod, v. 37, n. 3, p. 376-381, 2011.

KOO, M.H. et al. Apegenin and tt-farnesol with fluoride on S. mutans biofilm and dental caries. J Dent Res, v.84, n.11, p. 1016-1020, 2005.

KOO, M.H. et al. Effect of a mouthrinse containing selected própolis on 3-day dental plaque accumulation and polysaccharide formation. Caries Res, v.6. n.6, p. 445448, 2002.

LAVINAS, F. C. et al. Própolis de abelha sem ferrão brasileira e geoprópolis: fontes promissoras de compostos biologicamente ativos. Rev Bras Farmacogn, v.29, p. $389-399,2019$.

LIBERIO, S. A. et al. Antimicrobial activity against oral pathogens and immunomodulatory effects and toxicity of geopropolis produced by the stingless bee Melipona fasciculata Smith. BMC Comp and Alt Med, v. 11, n.108. 2011.

LIMA, R. Características biológicas da geoprópolis da abelha social sem ferrão uruçu (Melipona scutellaris Latreille, 1811) proveniente da Baía do Iguape-Ba. Dissertação (Mestrado em Ciências Agrárias - Área de Fitotecnia) - Universidade Federal do Recôncavo da Bahia. Cruz das Almas - Bahia, 80f. 2016.

LINDHE, J.; KARRING, T.; LANG, N. P. Tratado de Periodontia Clínica e Implantologia Oral. 4ed. Rio de Janeiro: Guanabara Koogan, p. 450-477, 2005.

LUSTOSA S.R, et al. Própolis: atualizações sobre a química e a farmacologia. Rev Bras Farmacogn, v.18, n.3, p. 447- 454, 2008.

MAIA FILHO, E. M. et al. Efeito antimicrobiano in vitro de diferentes medicações endodônticas e própolis sobre Enterococcus faecalis. RGO, v.56, n.1, p. 21-25, 2008. 
MARSH, P.D. Controlling the oral biofilm with antimicrobials. J of Dent, v.38, p. 11-15, 2010.

MATOS, V. R.; SANTOS, F. A. R.; Diagnóstico polínico da geoprópolis de Melipona scutellaris L. (Meliponini, Apidae, Hymenoptera) coletada em uma área de Mata Atlântica no Nordeste do Brasil. Paubr, v. 2, n. 1, p. 6-16, 2019.

MICHENER, C. D. The Meliponini. In: Vit, P. et al. (Eds.), Pot-honey a legacy of stingless bees. Springer: New York, p. 3-17, 2013.

MOLNÁR, S. et al. Comparative studies on polyphenolic profile and antimicrobial activity of propolis samples selected from distinctive geographical areas of Hungary. $\mathbf{F}$ Sci Technol Int, v. 23, p. 349-357, 2017.

MONROE, D. Looking for chinks in the armor of bacterial biofilms. PLOS Biol, v.5, p. 2458$2461,2007$.

MOTA, V.S.; TURRINI, R. N. T.; POVEDA, V.B. Antimicrobial activity of Eucalyptus globulus oil, xylitol and papain: a pilot study. Rev da Esc de Enf da USP, v. 49, p. 216-220, 2015.

NEWMAN, D. J.; CRAGG, G. M. Natural products as sources of new drugs over the 30 years from 1981 to 2010. J of Nat Prod, v. 75, n. 3, p. 311-335, 2012.

OLIVEIRA, F. F. et al. Guia ilustrado das abelhas" sem ferrão" das Reservas Amanã e Mamirauá, Amazonas, Brasil (Hymenoptera, Apidae, Meliponini). Tefé: IDSM, p. 267, 2013.

PEDRO, S. R. The stingless bee fauna in Brazil (Hymenoptera: Apidae). Sociobiol, v.61, p. 348-354, 2014.

QUEZADA-EUAN, J. J. G.; JESUS, M.W.; GONZALEZ-ACERETO, J. A. Meliponicultura no México: problemas e perspectivas para o desenvolvimento. Bee World. v. 82, p. 160-167, 2001.

RAMALHO, M. A. et al. Atividade antiaderente dos óleos essenciais de Eucalyptus globulus e Eucalyptus citriodora contra cepas de Klebsiella pneumoniae. Res Soc and Develop, v.9, n.7, p.3-7, 2020.

RECH, C. R. et al. Adesão e formação do biofilme de Escherichia coli em poli (tereftalato de etileno) e resistência a sanificantes. Evidência, v. 16, n. 2, p. 113-130, 2016.

ROCHELLE, S. L. et al. The anti-biofilm potential of commonly discarded agro-industrial residues against opportunistic pathogens. Industrial Crops and Products, v. 87, p. 150-160, 2016. 
SALATINO, A. et al. Propolis research and the chemistry of plant products. Nat Prod Repor, v.28, p. 925-936, 2011.

SANCHES, M. A.; PEREIRA, A. M. S.; SERRÃO, J. E. Pharmacological actions of extracts of propolis of stingless bees (Meliponini). J of Apicult Res, v. 56, n. 1, p. 50-57, 2017.

SANCHES, M.A. A própolis de abelhas sem ferrão e suas propriedades terapêuticas. Pesqu Tecnol. v. 9, n.1, p. 1-6, 2012.

SAWAYA, A.C.H.F. et al. Análise da composição de extratos de própolis brasileira por cromatografia e avaliação de sua atividade in vitro contra bactérias grampositivas. Braz J Microbiol. v.35, p.1-2, 2004.

SOUSA, J. P. L. Estudo Químico e Potencial Antimicrobiano da Própolis Brasileira Produzida por Diferentes Espécies de Abelhas. Rev Virt de Quím, v. 11, n. 5, 2019.

SOUZA, L. S. et al. Produção de geoprópolis sob diferentes métodos de coletas em colônias de Melipona scutellaris Latreille (Hymenoptera: Apidae). Magist. v. 23, 2011.

VELIKOVA, M. et al. Chemical composition and biological activity of propolis from Brazilian meliponinae. Zeitsch für Natur C, v. 55, n. 9-10, p. 785-789, 2000.

VENTURIERI, G. C. et al. Meliponicultura no Brasil: situação atual e perspectivas futuras para o uso na polinização agrícola. Contribuição e perspectivas para a biodiversidade, uso sustentável, conservação e serviços ambientais, p. 213236, 2012.

VIANA, J. L. et al. Genetic variability in Melipona scutellaris from Recôncavo, Bahia, Brazil. Gen and Mol Res, v. 12, n. 3, p. 3444-3454, 2013.

WOLFF, M. S.; LARSON, C. The cariogenic dental biofilm: good, bad or just something to control? Braz oral research, v. 23, p. 31-38, 2009. 


\section{CAPITULO VI}

\section{AYAHUASCA: FITOCOMPOSTOS, ETNOFARMACOLOGIA E POTENCIAL TERAPÉUTICO}

DOI: 10.51859/AMPLLA.PAE1993-6

Kátia Thaís Fernandes Gurgel ${ }^{1}$ Ítalo Diego Rebouças de Araújo ${ }^{2}$

Geovan Figueirêdo de Sá-Filho 3 Luanne Eugênia Nunes ${ }^{4}$

\footnotetext{
'Graduanda do curso de Farmácia. Faculdade Nova Esperança de Mossoró - FACENE/RN.

${ }^{2}$ Biomédico. Mestre em Biologia Parasitária (UFRN. Professor do Curso de Farmácia. Faculdade Nova Esperança de Mossoró - FACENE/RN.

${ }^{3}$ Ecólogo. Mestre em Ecologia e Conservação (UFERSA). Professor do Curso de Farmácia. Faculdade Nova Esperança de Mossoró - FACENE/RN.

${ }^{4}$ Farmacêutica. Doutora em Ciências Farmacêuticas. Professora do Curso de Farmácia. Faculdade Nova Esperança de Mossoró - FACENE/RN.
}

\section{RESUMO}

A ayahuasca é o nome dado a uma bebida psicoativa endógena sacramental, utilizada em rituais indígenas e religiosos obtida através da decocção de duas plantas a Banisteriopsis caapi (Malpighiaceae), conhecido como cipó de mariri, nativo da Amazônia e dos Andes Peruanos, e das folhas do arbusto Psychotria viridis (Rubiaceae) conhecido como chacrona. A bebida psicoativa conhecida, entre vários nomes, como ayahuasca, vem sendo usada a décadas nos rituais indígenas e que se espalhou por diversas regiões do Brasil e do mundo e se diversificou. Atualmente, a bebida está sendo cada vez mais estudada no tratamento da dependência a substâncias psicoativas, como o álcool, e para o tratamento da depressão. Portanto, o presente trabalho objetivou, por meio de uma revisão narrativa, descrever os principais fitocompostos, a etnofarmacologia e o potencial terapêutico da ayahuasca, bem como as propriedades psicoativas da bebida.

Palavras-chave: N, N dimetiltriptamina. Banisteriopsis caapi. Psychotria viridis. $\beta$ carbonilas. Substâncias psicoativas. 


\section{INTRODUÇÃO}

Estudos recentes têm revelado que o uso de plantas desempenha o mesmo potencial farmacológico que medicamentos de grandes indústrias farmacêuticas, e que podem ser utilizados no tratamento da depressão. Diante disso, podemos destacar o uso da ayahuasca, que vem se apresentando como um possível tratamento utilizado na depressão sendo seus componentes capazes de possibilitar novos estudos sobre sua eficácia terapêutica (WINKELMAN, 2014).

O uso de plantas para o tratamento de doenças é tão antigo quanto a civilização e com a ayahuasca não é diferente. Ayahuasca é o nome dado a uma bebida psicoativa endógena sacramental, utilizada em rituais indígenas e religiosos obtida através da decocção de duas plantas a Banisteriopsis caapi (Malpighiaceae), conhecido como cipó de mariri, nativo da Amazônia e dos Andes Peruanos, e das folhas do arbusto Psychotria viridis (Rubiaceae) conhecido como chacrona (GROISMAN, 2000).

A bebida psicoativa conhecida, entre vários nomes, como ayahuasca, vem sendo usada a décadas nos rituais indígenas e que se espalhou por diversas regiões do Brasil e do mundo e se diversificou. Nas primeiras décadas do século XX a ayahuasca passou a ser utilizada como sacramento principal de três sistemas religiosos brasileiros, a Barquinha, o Santo Daime, e a União do Vegetal (THEVENIN; PIROLI, 2017).

O uso da ayahuasca tem sido perpetuado na América do Sul por milênios, no início era utilizada por xamãs de diversas etnias da Amazônia sul-americana, e depois se propagou na pós-modernidade na forma de religiões sincréticas e recriações do mito da ayahuasca. Essa planta ayahuasca tem seus efeitos tidos como positivos por aqueles adeptos de preceitos religiosos e cosmovisões de religiosidade, que utilizam a bebida em seus sistemas de crenças (ESCOBAR, 2012).

Ainda de acordo com Escobar (2012), a ayahuasca é considerada pelos diversos grupos religiosos, como capaz de permitir que seu usuário entre em contato com o Divino ou dimensão divina, permitindo a evolução material e espiritual, e atuando ainda como modo de orientação da conduta diária das pessoas que fazem o uso. Neste sentido, a ayahuasca emerge em um contexto mundial, tornando-se uma das mais importantes e mais conhecidas substâncias psicodélicas utilizada ritualisticamente (ESCOBAR, 2012). 
Desse modo, o objetivo do estudo foi elaborar uma revisão narrativa sobre a ayahuasca, com ênfase no uso ritualístico, nos compostos fitoquímicos com ação psicoativa e sobre os efeitos terapêuticos descritos sobre a bebida.

\section{METODOLOGIA}

O estudo trata-se de uma revisão narrativa, de caráter descritivo, com análise qualitativa de estudos já publicados em bases de dados como: PubMed, Scientific Electronic Library Online (Scielo), Scholar Google e Biblioteca Virtual em Saúde (BVS), bem como a utilização de legislações vigentes.

As palavras-chaves utilizadas na pesquisa estão listadas nos Descritos em Ciências da Saúde (DeCS), sendo elas: "Ayahuasca", "N,N-dimetiltriptamina", " $\beta$ carbonilas", "Banisteriopsis caapi" e "Psychotria viridis".

\section{REVISÃO}

\subsection{HISTÓRICO DA AYAHUASCA NO BRASIL}

Desde as antigas civilizações, têm-se utilizado as plantas com finalidades terapêuticas para prevenção, tratamento e cura de doenças. E o uso de substâncias denominadas psicodélicas, enteógenas ou alucinógenas que são derivadas de espécies vegetais é uma prática que acompanha a humanidade há milhares de anos (WINKELMAN, 2014).

A ayahuasca trata-se de uma infusão vegetal psicoativa utilizada a milênios por diversas tribos indígenas da região amazônica, incluindo os Kaxinawá, Yaminawá, Sharanawa, Asshaninka, Airo-pai e Baranara (MORAIS, 2014).

No Brasil seu uso é empregado em contexto religiosos como uma bebida capaz de permitir ao usuário o contato com o Divino ou dimensão divina (ESCOBAR, 2012). O uso ritual da ayahuasca difundiu-se por quase toda a Amazônia, chegando às fronteiras do Brasil e disseminando-se pelos centros urbanos (LIMA, 2009). Com a globalização mundial e a aproximação de outros povos a expansão da utilização do chá difundiu-se, das práticas indígenas e ocidentais, levando o uso religioso e terapêutico (VILLAR, 2017). 
As religiões ayahuasqueiras no Brasil surgiram no século $X X$, influenciadas por outros tipos de religiões, como o espiritismo, catolicismo popular, cultos e magias, que introduziram a bebida em seus rituais. As religiões ayahuasqueiras mais antigas são o Santo Daime, a Barquinha e a União do Vegetal (MORAIS, 2014).

O termo ayahuasca é de origem quéchua, língua indígena dos Andes Peruanos, falada pelos Incas (aya - pessoa, alma, espírito morto; waska - corda, cipó, liana), então a palavra ayahuasca pode ser traduzida por "trepadeira das almas" ou "corda dos mortos" (MORAIS, 2014). A infusão também é conhecida por outros nomes, como daime, caapi, yajé, natema, vegetal e hoasca (MORAIS, 2014).

Recentemente o uso da ayahuasca passou a ser utilizado por religiões brasileiras, como o Santo Daime, a Barquinha e a União do Vegetal (UDV) (VILLAR, 2017). O Santo Daime, foi fundada em 1930 por Raimundo Irineu Serra, é a religião mais velha, nela a ayahuasca é chamada de "Daime", que significar "dar", representando um pedido que deve ser feito ao espírito da bebida na hora de ingerir o chá (ALBUQUERQUE, 2015).

Em 1945 a Barquinha foi fundada por Daniel Pereira de Mattos, é considerada a menor entre as três religiões ayahuasqueiras, formada através da influência de vários elementos como o cristianismo, umbanda com os símbolos de pretos velhos, caboclos e, ainda o xamanismo. Para essa religião a bebida não é classificada como uma "droga", e sim como um sacramento, um ser divino (OLIVEIRA, 2016).

E por fim, a União do Vegetal (UDV), última a ser fundada em 1960 por José Gabriel da Costa, diferente das outras religiões a UDV apresenta um perfil mais sóbrio, sem práticas de cantos ou instrumentos, cujos ensinamentos são baseados na doutrina espírita kardecista e de outras manifestações urbanas religiosas (VILLAR, 2017).

\subsection{USO POPULAR E RITUALÍSTICO}

Nos rituais religiosos não há uma padronização do uso ou preparo da ayahuasca, mas geralmente são realizadas quinzenalmente no período da noite, com orações, cantos e danças. A duração do culto é de aproximadamente 4 horas, os líderes servem aos membros um copo com a bebida psicoativa e eles começam a vivenciar os efeitos alucinógenos do chá (MORAIS, 2014).

Após ingestão da bebida os membros começam a sentir a purga, onde o indivíduo sente náuseas, vômito e diarreia, considerada como uma purificação física, moral e 
espiritual (MORAIS, 2014). Além da purga a ayahuasca pode proporcionar ainda visões, que podem ser abstratas, geométricas, coloridas, antropomórficas, visões gerais em relação a humanidade, ao universo, a própria pessoa (vida, relacionamentos), demoníacas, celestiais ou místicas (GOMES, 2016).

\subsection{CARACTERÍSTICAS ETNOBOTÂNICAS DA AYAHUASCA}

\subsubsection{PSYCHOTRIA VIRIDIS}

Pertencente à família Rubiaceae, a Psychotria viridis é comumente encontrada em toda a Floresta Amazônica (Brasil, Colômbia, Peru, Bolívia e Equador). A P. viridis é conhecida popularmente como chacrona ou folha-da-rainha (VILLAR, 2017).

A P. viridis, trata-se de uma planta arbustiva, de caule escuro, de pequeno porte de clima tropical e úmido, tendo, em média, $2 \mathrm{~m}$ a $3 \mathrm{~m}$ de altura, $12 \mathrm{~cm}$ a $15 \mathrm{~cm}$ de comprimento por $4 \mathrm{~cm}$ a $5 \mathrm{~cm}$ de largura (VILLAR, 2017). Apresentando folhas lanceoladas com distribuição oposta e nervação peninérvea. Suas flores são brancas esverdeadas e frutos com forma de bagas vermelhas, podendo ser confundida facilmente por outras espécies do mesmo gênero (RÄTSCH, 2005).

Suas inflorescências são cimosas, apresentam flores pouco vistosas, bissexuadas, diclamídeas, monoclinas, de simetria actinomorfa, cálice pentâmero dialissépalo, gamopétala e com ovário ínfero. O seu fruto é do tipo drupa com o epicarpo, quando maduro é de coloração avermelhada, suas sementes são convexas em sua parte dorsal e aplanadas em sua parte ventral. Suas folhas apresentam disposição cruzadas e opostas, com inervação peninérvea, bainha semi amplexicaule e pecíolo curto, seu limbo é simples e inteiro, liso na parte superior e com presença de domácias na parte inferior, e apresenta folhas completas e lanceoladas que variam de tons de verde-claro ao verde escuro PIANURA; MARTINEZ; SILVA, 2009).

O gênero Psychotria é conhecido popularmente por suas características medicinais (TEIXEIRA et al., 2012), e com grandes propriedades de ação no sistema nervoso, daí seu uso no preparo da ayahuasca (RIBA et al., 2012). As espécies de Psychotria, a partir do seu metabolismo secundário, metabolizam inúmeras moléculas bioativas, que incluem principalmente as seguintes classes de metabólitos: naftoquinonas, peptídeos, benzoquinona, pigmentos e alcaloides. Dentre os alcaloides, a espécie $P$. viridis é conhecida por a partir de suas folhas, realizar a biossíntese do 
alcalóide N, N-dimetiltriptamina (DMT), o seu principal bioativo, um potente alucinógeno de curta ação, que pode ser encontrado em fungos e outras espécies vegetais (VILLAR, 2017).

\subsubsection{BANISTERIOPSIS CAAPI}

Popularmente conhecida como Jagube, Mariri, Cabi, Caupurí e Uni, a Banisteriopsis caapi é pertencente à família Malphigiaceae, oriunda das regiões amazônicas e das Antilhas (COSTA; FIGUEIREDO; CAZENAVE, 2005).

No Brasil, a família Malphigiaceae é composta por 38 gêneros e, aproximadamente, 300 espécies. A morfologia caulinar é uma das principais características dessa planta, que apresenta duas variedades em seu caule, a caupurí apresenta nos mais evidentes em seus troncos, no entanto a tucunacá seus nós são menos evidenciados (SÉRPICO; CAMURÇA, 2006).

Com relação as características botânicas das folhas de $B$. caapi, é descrito que estão em disposição oposta cruzada, medindo cerca de $15 \mathrm{~cm}$ a $20 \mathrm{~cm}$ de comprimento por $7 \mathrm{~cm}$ a $11 \mathrm{~cm}$ de largura; seu limbo simples e inteiro de forma oval, afinando nas pontas, liso na parte superior, piloso na parte inferior, inervações peninérvea, pecíolo e ausência de bainha e ainda apresentam nectários foliares no pecíolo ou na face abaxial (PIANURA; MARTINEZ; SILVA, 2009).

Exclusiva de climas úmidos, a floração de B. caapi é rara, apresenta ainda inflorescências paniculadas em suas axilas superiores ou terminais, com pedicelos pilosos e flores rosadas, diclamídeas, monoclinas, de simetria actinomorfa, cálice pentâmero e dialissépalo, dialipétala apresentando cinco pétalas longas, diplostêmone apresentando dez estames heterodínamos, anteras arredondadas, com três estiletes, estigmas capitados e com ovário súpero. Possui frutículos samaroídeos com sementes aladas, localizadas na parte da sâmara (PIANURA; MARTINEZ; SILVA, 2009). As sementes de B. caapi possuem características morfologia que facilitam sua dispersão pelo vento, por serem leves, permitindo que sejam sopradas de um local para outro (RAVEN et al., 2001).

Os cipós de B. caapi são ricos em $\beta$-carbolinas: harmina (HRM), também conhecida como telepatina, harmalina (HRL) e tetrahidroarmina (THH). Essas moléculas agem como inibidoras da Monoaminoxidase (MAO), preferencialmente a MAO-A, 
responsável pelo controle dos neurotransmissores serotonina, dopamina e norepinefrina. A inibição da MAO possibilita a ação da DMT ingerida no chá de ayahuasca, pois permite sua chegada ao cérebro, elevando os níveis de serotonina, noradrenalina e dopamina por isso são capazes de aumentar os níveis de serotonina na fenda sináptica (TELES, 2016).

\subsection{FARMACOLOGIA DA AYAHUASCA}

A bebida Ayahuasca é preparada pela associação de duas plantas, as cascas e caules da B. caapi juntamente com as folhas da $P$. viridis. A combinação dessas duas plantas forma uma associação sinérgica, onde as $\beta$-carbonilas presentes no caule da B. caapi tem ação inibitória reversíveis da enzima monoaminoxidase (MAO). E a dimetiltriptamina (DMT), presente nas folhas da $P$. viridis, é um potente alucinógeno (VILLAR, 2017). As principais substâncias bioativas dessa preparação são os alcalóides como as $\beta$-carbolinas harmina (HRM), tetrahidroharmina ( $T H H)$ e harmalina ( $H R L)$, além do N,N-dimetiltriptamina (DMT) (SANTOS, 2007).

O alucinógeno DMT quando ingerido isoladamente é inativado por via oral, independentemente da quantidade de dose tomada, isso acontece porque o DMT é degradado pela enzima MAO, presente no nosso organismo, no sistema gastrointestinal, tornando-a assim inativa. Estudos recentes mostram que as $\beta$-carbonilas presentes no chá são suficientes para inibir temporariamente a MAO, principal alvo farmacológico ativo dos antidepressivos. Com sua inibição, a DMT não será degradada, permitindo-lhe exercer suas propriedades psicotrópicas quando ingerida de forma oral (VILLAR, 2017).

A $\beta$-carbonila harmina (HRM) está presente em maior concentração no chá, ela apresenta alta afinidade pela MAO, tem efeito antidepressivo por sua afinidade pelo receptor 5-HT2A, e consequentemente nos níveis de BDNF (Fator Neurotrófico Derivado do Cérebro) nas áreas pré-frontais. Por inibir a MAO no intestino e no fígado, esta ação impede a degradação da DMT, facilitando assim os efeitos psicoativos da ayahuasca (VILLAR, 2017; ITO e SAKAMOTO, 2020).

A segunda $\beta$-carbonila mais abundante na bebida é a tetraidroharmina (THH), ela vai atuar como um fraco inibidor da recaptação de serotonina e inibir a MAO, prolongando assim a meia vida da DMT, em razão de um bloqueio intraneural e pelo bloqueio da recaptação de serotonina no neurônio, o resultara em níveis elevados de 
5HT na fenda sináptica, aumentando os efeitos da DMT quando ingerida de forma oral (VILLAR, 2017).

Em síntese, a atividade inibidora da MAO (IMAO) exercida pela ayahuasca devese à abundante presença da $\beta$-carbonila harmina, que tem potencial inibitório equivalente ao da harmalina, a qual possui maior atividade IMAO, porém é encontrada apenas em traços no chá. A tetrahidroharmina (THH) possui a menor atividade dentre as três $\beta$-carbolinas e é a segunda mais abundante. Portanto, a combinação harmina/THH praticamente produz a atividade IMAO da ayahuasca (PIANURA; MARTINEZ; SILVA, 2009).

Assim, o alcaloide DMT é metabolizado pelas isoenzimas MAO hepáticas e intestinais, em decorrência a sua semelhança estrutural com a serotonina (5-HT), já que ambos compartilham o aminoácido triptofano como origem da rota de biossintese. A capacidade de inibição da MAO, devido a presença dos alcalóides da B. caapi, resulta em uma maior disponibilidade da DMT no sistema nervoso central, e desse modo permite a sua atuação como agonista parcial dos receptores serotoninérgicos póssinápticos (SILVA et al., 2021).

\subsection{LEGISLAÇÃO E LEGALIDADE}

Com a expansão do uso da ayahuasca nas últimas décadas, veio com ela a sua repressão, por sistemas sociais legais que propiciaram manifestações contra o seu uso visto que, a bebida psicoativa possuía em sua composição uma substância de uso proibido (ARAUJO, 2010).

Em 1970, o DMT foi classificado como uma droga de Classe I de acordo com a Lei de Substâncias Controladas dos EUA (ARAÚJO et al., 2015). Em 1971, na Convenção sobre Substâncias Psicotrópicas, da Organização das Nações Unidas (ONU), foi publicada a Lista I das substâncias que são consideradas pôr a ONU sem valor medicinal, dentre elas estão incluídas a MDMA (3,4-metilenodioximetanfetamina), psicodélicos e canabinóides (BLAINEY, 2015). Essas classificações quase interromperam as pesquisas sobre muitos tratamentos valiosos em potencial para uma ampla gama de doenças (HAMILL et al., 2019).

Por meio da Divisão de Medicamentos do Ministério da Saúde (DIMED) em 1985 surgiu no Brasil a primeira política que classificava as plantas que compõem a ayahuasca 
como substâncias proibidas. No entanto, somente em 1987, o uso da ayahuasca em um contexto religioso foi protegido pela legislação brasileira. Porém, mais adiante as plantas foram listadas pela portaria № 344/98 da Agência Nacional de Vigilância Sanitária (ANVISA). Após um longo período, o uso da bebida foi aprovado em 2010, pelo Conselho Nacional de Políticas sobre Drogas (CONAD) (VILLAR, 2017).

\section{CONSIDERAÇÕES FINAIS}

Ayahuasca é uma preparação obtida das cascas e caules da espécie B. caapi juntamente com as folhas da P. viridis. É considerada uma bebida psicoativa e alucinógena que é rica em substâncias bioativas que são os componentes do metabolismo secundário como o DMT, um alcaloide, e em $\beta$-carbolinas, potentes inibidores da enzima MAO. Ação dessas substâncias no organismo, em especial no SNC, desencadeia diversas reações bioquímicas e fisiológicas com diferentes intensidades.

Neste sentido, é necessário o desenvolvimento de novos estudos com metodologias capazes de avaliar o potencial terapêutico e tóxico da bebida, pois, as bases farmacológicas da ayahuasca ainda são pouco elucidadas, o que leva à das espécies utilizadas na preparação da bebida.

\section{REFERÊNCIAS}

ALBUQUERQUE, M. B. B. Religião e educação: os saberes da ayahuasca no santo daime. Revista Brasileira de História das Religiões, v. 4, n. 10, 2015.

ARAUJO, F. S. Os usos lícitos da ayahuasca no contexto internacional de políticas sobre drogas. II Seminário de Estudos Culturais, Identidades e Relações Interétnicas. Universidade Federal de Sergipe, Campus Itabaiana, 2010.

ARAÚJO AM, CARVALHO F., BASTOS M.L., GUEDES DE PINHO P., CARVALHO M. O mundo alucinógeno das triptaminas: uma revisão atualizada. Arco. Toxicol. 89 (8): 1151-1173, 2015. [http://dx.doi.org/ 10.1007 / s00204-015-1513-x]. [PMID: 25877327].

BLAINEY, M.G. Terapias proibidas: Santo Daime, ayahuasca e a proibição de enteógenos na sociedade ocidental. J. Relig. Saúde. 2015; 54 (1): 287-302. [http://dx.doi.org/10.1007/s10943-014-9826-2]. [PMID: 24477460].

BRASIL. Portaria n. 344, de 12 de maio de 1998 a. Aprova o Regulamento Técnico sobre substâncias e medicamentos sujeitos a controle especial. Agência Nacional de 
Vigilância Sanitária. Disponível em: http://www.anvisa.gov.br/ legis/ portarias/344_98.htm.

COSTA, M.C.M., FIGUEREIDO, M.C., CAZENAVE, S.O.S. Ayahuasca: a toxicological approach of the ritualistic use. Rev. Psiquiatria Clínica. 32(6): 310-318, 2005.

ESCOBAR, J. A. C. Ayahuasca e saúde: efeitos de uma bebida sacramental psicoativa na saúde mental de religiosos ayahuasqueiros. 260 f. Tese (Doutorado) - PósGraduação emPsicologia Cognitiva, Universidade Federal de Pernambuco, Recife, 2012

GOMES, B.R. O uso ritual da Ayahuasca na atenção à população em situação de rua. EDUFBA, 2016.

GROISMAN, A. Santo Daime in the Netherlands: an anthropological study of a new world religion in a European setting. Doutorado em Antropologia, Universidade de Londres, 2000.

HAMILL, J., HALLAK, J., DURSUN, S.M., BAKER, G. Ayahuasca: psychological and physiologic effects, pharmacology and potential uses in addiction and mental illness. Current neuropharmacology, 17(2), 108-128, 2019. DOI: 10.2174 / 1570159x16666180125095902. PMID: 29366418; PMCID: PMC6343205.

ITO, G.C.; SAKAMOTO, G.A. Tratamento atípico da depressão grave com uso de psicodélicos como ayahuasca, ketamina e psilocibina: revisão sistemática. Universidade Municipal de São Caetano do Sul - USCS, São Paulo, 2020.

LIMA, E.G.C. O uso ritual da Ayahuasca: da Floresta Amazônica aos centros urbanos. Monografia em Geografia Cultural, Universidade de Brasília, Brasília, 2009.

MORAIS, J.A. de. Toxicidade aguda e crônica do chá ayahuasca (Banisteriopsis caapi e Psychotria viridis), por análise histológica em ratas wistar. Master's Thesis, University of Brasilia, Brasilia, Brazil, 2014.

OLIVEIRA, R.B.S. Os Saberes da Ayahuasca na Barquinha. Revista Científica Multidisciplinar Núcleo do Conhecimento. Ano 1. Vol. 11. pp 246-259, 2016.

PIANURA, A.S.; MARTINEZ, G.B.; SILVA, C.P. Ayahuasca - Aspectos botânicos e farmacológicos. Revista de Atenção à Saúde (ISSN 2359-4330), v. 7, n. 22, 2009.

RAVEN, P.H., EVERT, R.E., EICHHORN, S.E. Biologia Vegetal. 6 ed. Rio deJaneiro: Guanabara Koogan, 906 p., 2001.

RÄTSCH C. The encyclopedia of psychoactive plants: ethnopharmacology and its applications. USth ed. Rochester: Park Street Press; 2005. 
RIBA, J., MCILHENNY, E.H., VALLE, M., BOUSO, J.C., BARKER, S.A. Metabolism and disposition of $\mathrm{N}, \mathrm{N}$-dimethyltryptamine and harmala alkaloids after oral administration of ayahuasca. Drug Testing Analysis, v. 4, n. 7-8, p. 610-616, 2012.

SANTOS, Rafael Guimarães dos. AYAHUASCA: neuroquímica y farmacología. SMAD. Revista eletrônica saúde mental álcool e drogas, v. 3, n. 1, p. 00-00, 2007.

SÉRPICO, R. L.; CAMURÇA, D. M. Ayahuasca: revisão teórica e considerações botânicas sobre as espécies. Monografia. Universidade Guarulhos, 2006.

SILVA, B.S; LIMA, G.P.; SANTOS, I.R.A.; SILVA, J.C.; GARCIA, D.G; ANTUNES, A. A. O Uso da Ayahuasca como terapia alternativa na depressão: efeitos farmacológicos e adversos. Brazilian Journal of Natural Sciences, [S. I.], v. 4, n. 2, p. e1432021, 16, 2021. DOI: 10.31415/bjns.v4i2.143. Disponível em: https://www.bjns.com.br/index.php/BJNS/article/view/143.

TEIXEIRA, V. A.; COELHO, M. F. B.; MING, L. C. Ipecac [Psychotria ipecacuanha (Brot.) Stoves]: aspects of cultural memory of" poaieiros" in Cáceres-Mato Grosso, Brazil. Revista Brasileira de Plantas Medicinais, v. 14, n. 2, p. 335-343, 2012.

TELES, T.B. O potencial terapêutico da Ayahuasca na doença mental. Núcleo do Conhecimento, v. 12, n. 01, pp. 41-58, 2016.

THEVENIN, J.M.Reis; PIROLI, E.L. O uso ritual da Ayahuasca e práticas de conservação florestal em paisagens fragmentadas de Rondônia: um reconhecimento com classificação GEOBIA. Periódico Eletrônico Fórum Ambiental da Alta Paulista, v. 13, n. 3, 2017.

VILLAR, Thaís Coelho. Ayahuasca: uso terapêutico do chá no tratamento da dependência e depressão. Revisão bibliográfica. UFRJ, 2017.

WINKELMAN, Michael. Psychedelics as medicines for substance abuse rehabilitation: evaluating treatments with LSD, peyote, ibogaine and ayahuasca. Current drug abuse reviews, v. 7, n. 2, p. 101-116, 2014. 


\title{
CAPITULO VII
}

\section{CARACTERIZAÇÃO FISICO-QUÍmICA DO CHÁ DE HORTELÃ (MENTHA PIPERITA L.) INDUSTRIALIZADO E IN NATURA}

\author{
DOI: 10.51859/AMPLLA.PAE1993-7
}

\author{
Layane de Sousa Santana ${ }^{1}$ \\ Valdiléia Teixeira Uchôa ${ }^{2}$ \\ Maciel Lima Barbosa ${ }^{3}$ \\ Herbert Gonzaga de Sousa 4 \\ Eduarda Alves de Oliveira ${ }^{5}$ \\ Larisse Oliveira Quadros ${ }^{6}$
}

\author{
1 Graduada do curso de Química. Universidade Estadual do Piauí - UESPI \\ 2 Professora Adjunto do Departamento de Química. Universidade Estadual do Piauí - UESPI \\ ${ }^{3}$ Mestrando em Química na Universidade Estadual do Piauí - UESPI \\ ${ }^{4}$ Doutorando em Química na Universidade Federal do Piauí - UFPI \\ ${ }^{5}$ Graduada do curso de Química. Universidade Estadual do Piauí - UESPI \\ ${ }^{6}$ Graduada do curso de Química. Universidade Estadual do Piauí - UESPI
}

\section{RESUMO}

O chá é uma bebida bastante apreciada em diversas culturas e que vem conquistando vários adeptos, seja pela sensação revigorante ou pelas suas propriedades medicinais. A hortelã (Mentha piperita L.) é uma planta aromática e refrescante, considerada uma das ervas mais consumidas do mundo, muito utilizada no preparo de comidas e bebidas, também apresenta propriedades terapêuticas capazes de trazer benefícios à saúde. A hortelã tem uma ampla aplicabilidade na indústria, como na indústria de fármacos, cosméticos, produtos de higiene e limpeza, entre outros. O objetivo deste trabalho foi avaliar as características físico-químicas e os metabólitos secundários nos chás de hortelã natural e industrializados. O material para obtenção dos extratos aquosos foi obtido nos supermercados da cidade de Teresina-PI e na horta comunitária da Zona Leste da cidade. Os extratos foram obtidos pelo método de decocção e a identificação das classes de metabólitos secundários se deu através de reações químicas que resultaram em mudanças de coloração e precipitação, características de cada classe. Os resultados físico-químicos dos chás apresentaram características esperadas, $\mathrm{pH}$ variando de 4 a 6 e Acidez total titulável com variações de $0,0064 \%$ a 0,0358\% ácido cítrico/100mL. Nas análises fitoquímicas foram identificadas cinco classes de metabólitos secundários (taninos, flavonoides, esteroides, triterpenoides e saponinas), a presença desses bioativos na hortelã apontam um potencial alvo de estudos devido à crescente popularidade dos medicamentos fitoterápicos.

Palavras-chave: Mentha piperita L. Hortelã. Chá. Metabólitos secundários. 


\section{INTRODUÇ̃̃o}

Consumir chá todos os dias se tornou um hábito, costume a muitas culturas e tem atraído a atenção na dieta de muitas pessoas no mundo devido à sua capacidade antioxidante, seu uso é um dos métodos medicinais mais antigos da humanidade. As plantas medicinais apresentam uma variedade de características químicas que estão associadas a prática de tratamentos alternativos para problemas de saúde, utilizando extratos de plantas e seus princípios ativos. Por esses motivos, o chá é considerado um alimento funcional e, se consumido no dia a dia, pode trazer muitos benefícios à saúde. (BRAIBANTE et al., 2014); (MORAIS et al., 2009); (LIMA et al., 2009).

A origem do chá é repleta de histórias e a maioria delas inclui alguns mistérios e fábulas. A mais conhecida surgiu em 2737 a.C. quando o imperador chinês Shen Nong descobriu acidentalmente o chá. Por motivos de higiene o imperador só bebia água fervida e durante uma caminhada ele decidiu descansar perto de uma árvore, quando algumas folhas caíram em um recipiente com água fervida. Em vez de tirar as folhas, ele percebeu que a cor da água estava diferente, e decidiu prova-la e descobriu que a bebida era deliciosa e revitalizante. Não há registro que comprove essa história, mas existem vários relatos e se tem o conhecimento que os chineses foram um dos pioneiros no consumo do chá (TREVISANATO; KIM, 2000).

O chá consiste de partes de vegetais destinadas a preparações aquosas pelos seguintes métodos: imersão, que consiste em colocar água fervente em partes coletada da planta, abafar e deixá-la repousar por alguns minutos, isso é indicado para flores, pétalas e folhas de plantas que geralmente liberam compostos biologicamente ativos em baixas temperaturas; decocção, consiste na fervura da água com partes coletada da planta por determinado período de tempo, adequado para casca, raízes e caules que liberam compostos ativos em altas temperaturas; maceração, método de amassar ou picar a planta e adicionar água para manter suas propriedades terapêuticas. (BARACUHY et al., 2016); (ROSA et al., 2016).

A qualidade do chá é influenciada pelos componentes orgânicos e inorgânicos que atuam como precursores que determinam a eficiência das plantas medicinais e podem acelerar ou retardar a absorção dos princípios ativos pelo corpo. Alguns compostos específicos têm certas características que atuam direta ou indiretamente, 
como por exemplo, o sabor doce, adstringente e amargo, que são características associadas a presença de alcaloides, cafeína e catequinas (LIMA et al., 2009); (BALDUINO, 2012). A concentração uniforme de compostos ativos durante o ciclo de vida pode variar de acordo com o desenvolvimento, a sazonalidade, temperatura e preparação (GOBBO-NETO; LOPES, 2007).

A hortelã (Mentha piperita L.) pertence à família Lamiaceae, é uma erva herbácea, com odor forte e aromática, com coloração verde escuro, folhas ovais e pode chegar até $30 \mathrm{~cm}$ de altura. Rica em sais minerais e antioxidantes, que ajudam a proteger e reparar as células dos danos causados pelos radicais livres, além disso, diferentes substâncias químicas podem ser produzidas durante toda a vida do vegetal, em determinadas épocas e instantes. Apresentam compostos orgânicos que sintetizam e armazenam substâncias durante o processo de crescimento, chamados de princípios ativos. (BRAIBANTE et al., 2014). Esses ativos tem se destacado no comércio por apresentar ações nos tratamentos terapêuticos pelas propriedades analgésicas, antiespasmódica, anti-inflamatória, descongestionante, expectorante e antimicrobiana (GASPARIN et al., 2014). Apresenta ampla aplicabilidade na indústria, como na de produtos de limpeza, cosméticos, higiene, farmacêuticos, bebidas e também muito utilizada como tempero na culinária por apresentar característica marcante como o frescor e aroma (PAULUS et al., 2007; GARLET et al., 2007).

Essas características tornaram o chá uma bebida muito apreciada, sendo consumida tanto na sua forma seca, industrializada quanto in natura (SCHMITZ et al., 2005). Seu consumo foi se estabelecendo e hoje apresenta grande importância socioeconômica, existindo no mercado vários produtos industrializados (garrafinha, lata, sachê), embora no processo de fabricação do chá industrializado alguns compostos podem ser perdidos, como aroma, sabor, polifenóis e nutrientes, e em geral, são adicionados conservantes ou corantes artificiais para compensar essas perdas (KHAN; MUKHTAR, 2007); (OLIVEIRA et al., 2016).

Entre os chás mais consumidos no Brasil estão o de camomila, hortelã, boldo, erva-cidreira e erva-doce. Além de promover e reconhecer a prática popular do uso de plantas medicinais, a legislação brasileira garante a segurança, eficácia e a qualidade do acesso à essas plantas. Nesse ponto de vista, o Inmetro (Instituto Nacional de Metrologia, Qualidade e Tecnologia) considera necessária a avaliação da qualidade do 
chá industrializado disponíveis para o consumo, no que diz respeito ao atendimento aos critérios estabelecidos na legislação e assegurando uma composição de dieta saudável, que não cause risco à saúde para as pessoas que os utilizam (INMETRO, 2018); (AZEVEDO et al., 2009).

Considerando a ampla popularidade do consumo de chá e suas propriedades terapêuticas, o objetivo deste projeto visa avaliar os parâmetros físico-químicos e os metabólitos secundários presentes no chá industrializado e natural da hortelã.

\section{METODOLOGIA}

As análises dos chás foram realizadas no Laboratório de Pesquisa Núcleo Interinstitucional de Estudo e Geração de Novas Tecnologias (GERATEC) e no Centro de Tecnologia Mineral (CETEM - PI) da Universidade Estadual do Piauí - UESPI, Campus Poeta Torquato Neto, na cidade de Teresina - PI.

\subsection{OBTENÇÃO DOS EXTRATOS AQUOSOS}

As amostras foram adquiridas nos supermercados da cidade de Teresina - PI e na horta comunitária localizada na zona leste da cidade. O preparo do extrato aquoso industrializado foi realizado de acordo com os fabricantes (acrescentado 1 sachê do chá em $200 \mathrm{~mL}$ de água fervida e deixado em infusão por 3 minutos). E para o extrato natural, as folhas de hortelã foram submetidas ao método de decocção por 3 minutos, com massa de $10 \mathrm{~g}$.

\subsection{CARACTERÍSTICAS ORGANOLÉPTICAS}

Essa análise foi realizada através dos sentidos humanos, observando a coloração, odor, sabor e textura dos chás de hortelã industrializados e natural.

\subsection{ANÁLISES FÍSICO-QUIIMICAS}

\subsubsection{PH SÓLIDOS E SOLÚVEIS TOTAIS (SST)}

As análises do $\mathrm{pH}$ dos extratos foram realizadas utilizando fitas de $\mathrm{pH}$ (indicadores universais), para determinar a escala de acidez e/ou basicidade dos chás. Para a verificação da quantidade de sólidos solúveis usou-se um refratômetro manual 
portátil de escala ${ }^{\circ}$ Brix, gotejando sobre o prisma 2 gotas da amostra do chá de hortelã industrializado, em seguida o mesmo foi feito no chá in natura.

\subsubsection{ACIDEZ TOTAL TITULÁVEL (ATT)}

Para determinar à porcentagem (\%) de ácido cítrico contido no chá a análise foi realizada de acordo com as técnicas descritas pelo Instituto Adolfo Lutz (2008). Uma amostra de $10 \mathrm{~mL}$ foi colocada no erlenmeyer com $50 \mathrm{~mL}$ de água e 5 gotas de fenolftaleína (indicador), e então titulada com $\mathrm{NaOH}(0,1 \mathrm{~N})$ em triplicata. Posteriormente, a porcentagem de ácido cítrico foi determinada a partir das titulações, pela equação 1, onde o valor final foi expressado em porcentagem de ácido presente no chá de hortelã.

Onde:

$$
A T T=\frac{n \times N \times E q .}{10 \times V}
$$

$\mathrm{n}=$ volume de $\mathrm{NaOH}$ titulado

$\mathrm{N}=$ normalidade da solução de $\mathrm{NaOH}(0,1 \mathrm{~N})$

Eq. = equivalente-grama do ácido cítrico

$\mathrm{V}=$ volume da amostra em $\mathrm{mL}$

\subsection{PROSPECÇ̃̃O FITOQUÍMICA}

Foram verificados os seguintes metabólitos secundários: taninos, flavonoides, esteroides, triterpenoides, saponinas e alcaloides. Os extratos aquosos obtidos foram submetidos à triagem fitoquímica por meio de reações químicas, realizadas em triplicata, que resultaram em mudança de cor e precipitação seguindo a metodologia de Matos (1997).

\subsubsection{TESTE TANINOS}

Em tubos de ensaio contendo $2 \mathrm{~mL}$ do extrato, adicionou-se três gotas de solução alcoólica de cloreto férrico $\left(\mathrm{FeCl}_{3}\right)$ a $5 \%$ agitou-se a fortemente e observou-se se houve qualquer variação de cor. Precipitado de tonalidade azul indica a presença de taninos condensados (Figura 1a), e verde, a presença de taninos hidrolisáveis (Figura 1b). 
Figura 1 - (a) Tanino condensado, (b) Tanino hidrolisável
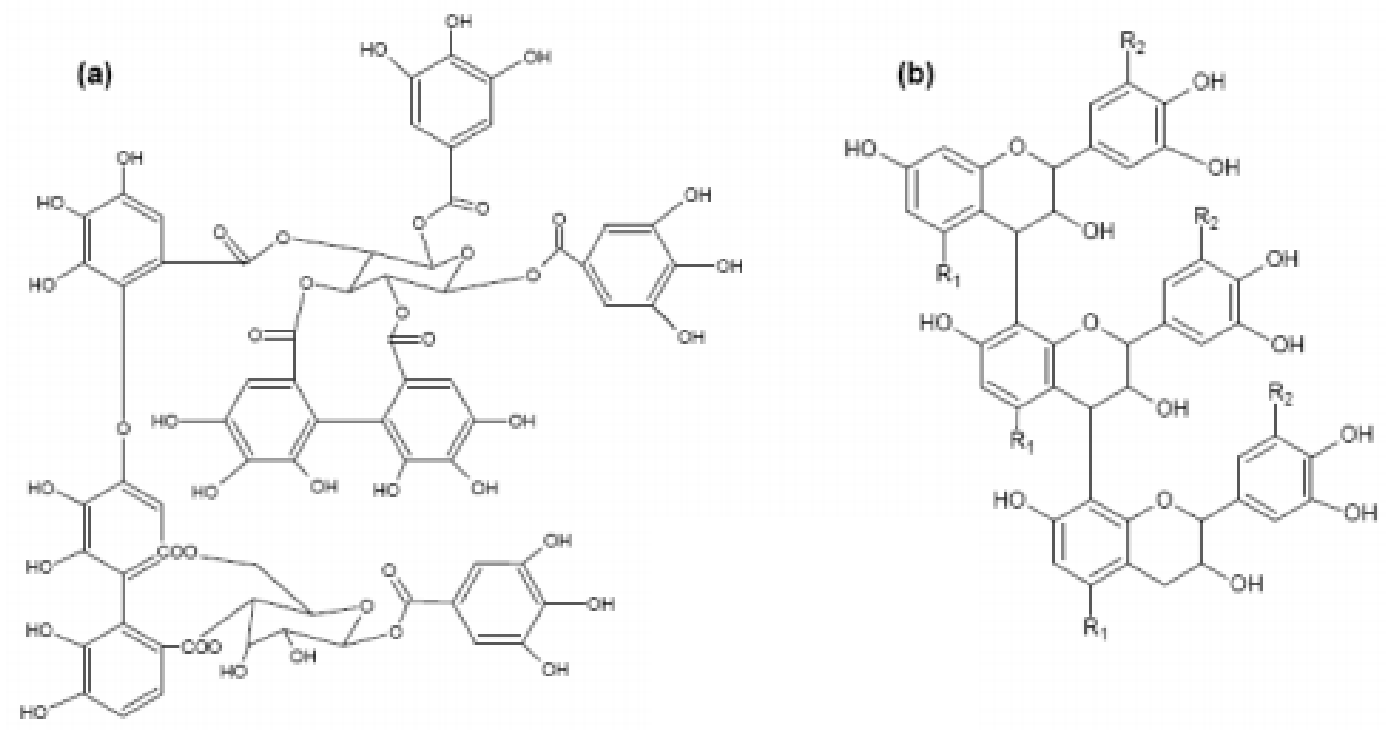

Fonte: MANGRICH, et al., 2014.

\subsubsection{TESTE FLAVONOIDES}

Em um tubo de ensaio contendo $2 \mathrm{~mL}$ do extrato, adicionaram-se $2 \mathrm{~mL}$ de ácido clorídrico concentrado $(\mathrm{HCl})$ e aproximadamente $1 \mathrm{~cm}$ de fita de magnésio, feito através do teste de Shinoda, o término da reação é indicada pelo fim da efervescência. A coloração que variou de parda a vermelha, indica a presença de flavanoides.

Figura 2 - Estrutura química de um flavanoide após a reação com Mg e $\mathrm{HCl}$<smiles>O=C1c2c(O)cc(O)cc2OC(c2ccc(O)c(O)c2)C1O</smiles><smiles></smiles>

Fonte: Autoria própria (ChemDraw).

\subsubsection{TESTE ESTEROIDES E TRITERPENOIDES}

Os testes foram feitos através da reação de Lieberman-Burchard (anidrido acético + ácido sulfúrico concentrado). Em um tubo de ensaio contendo $2 \mathrm{~mL}$ do extrato aquoso, foi adicionado $3 \mathrm{~mL}$ de clorofórmio, com $2 \mathrm{~mL}$ de anidrido acético, este foi suavemente agitado e acrescentado de forma cuidadosa 3 gotas de $\mathrm{H}_{2} \mathrm{SO}_{4}$ concentrado, onde agitou-se repetidamente observando se ocorreu aparecimento de coloração. A coloração azul evanescente seguida de verde permanente indica a presença de 
esteroides/triterpenoides, respectivamente. A coloração parda até vermelha indica a presença de triterpenoides pentacíclicos livre.

Figura 3 - Estrutura química para reação de identificação de esteroides e triterpenoides pela reação de Liebermann-Burchard

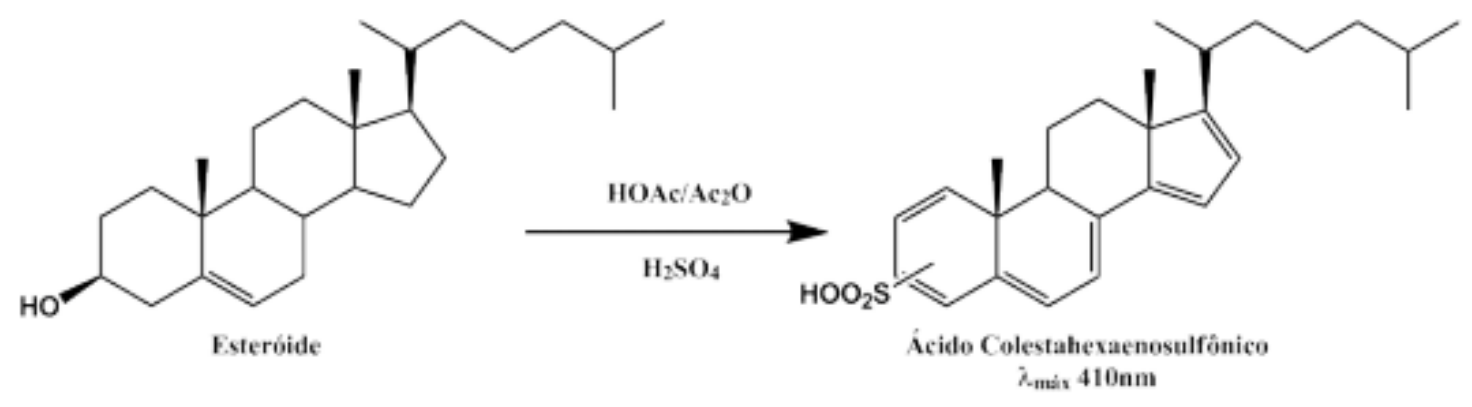

Fonte: Queiroz, 2009.

\subsubsection{TESTE SAPONINAS}

Em um tubo de ensaio contendo $2 \mathrm{~mL}$ do extrato, adicionaram-se $2 \mathrm{~mL}$ de clorofórmio e $5 \mathrm{~mL}$ de água destilada, filtrando-se logo após para outro tubo de ensaio. A solução foi agitada permanentemente por 3 minutos até obtenção do resultado após reação. A formação de uma camada de espuma por aproximadamente 30 minutos indica a presença de saponinas.

Figura 4 - Estrutura básica de saponina

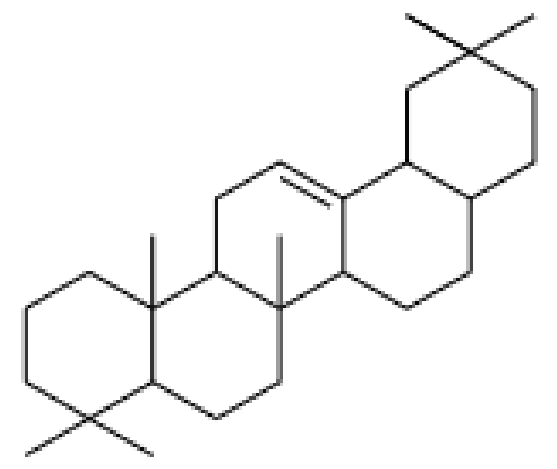

Fonte: Autoria própria (ChemDraw).

\subsubsection{TESTE ALCALOIDES}

Em $2 \mathrm{~mL}$ do extrato, foram alcalinizados com quinze gotas de hidróxido de sódio $\left(\mathrm{NH}_{4} \mathrm{OH}\right)$ a $1 \%$, acrescentaram-se $2 \mathrm{~mL}$ de água e adicionou-se $2 \mathrm{~mL}$ de clorofórmio. Foi desprezada a fração aquosa e acrescida na fração clorofórmica quinze gotas de ácido clorídrico a $1 \%$, em seguida, foi extraída $2 \mathrm{~mL}$ de água. A fração clorofórmica foi desprezada e os testes foram realizados com a fração aquosa ácida, onde foi 
acrescentado três gotas do reagente de Mayer (Cloreto de mercúrio + lodeto de potássio). A presença de alcaloides é indicada pela formação de precipitados insolúveis e floculosos de coloração laranja avermelhada.

Figura 5 - Estruturas de alguns alcalóides

\begin{tabular}{|l|l|l|l|}
\hline Piperidina & Piridina & Quinolina & Pirrolidina \\
\hline
\end{tabular}

Fonte: Autoria própria (ChemDraw).

\section{RESULTADOS E DISCUSSÃO}

As análises organolépticas foram realizadas principalmente para avaliar o estado de conservação dos extratos aquosos, a Figura 6 traz as colorações dos chás industrializados onde apresentaram a mesma tonalidade de cor nas 4 amostras e o chá natural apresentou uma coloração mais escura Figura 7, isso é possível pelo fato do chá industrializado sofrer a perda de algumas propriedades durante o processo de fabricação, o que pode levar a menor eficiência para os métodos fitoterápicos, em seguida, foram percebidos o odor/sabor aromático e refrescante em todas as amostras.

Figura 6 - Colorações dos chás industrializados de hortelã, marcas a, b, c e d

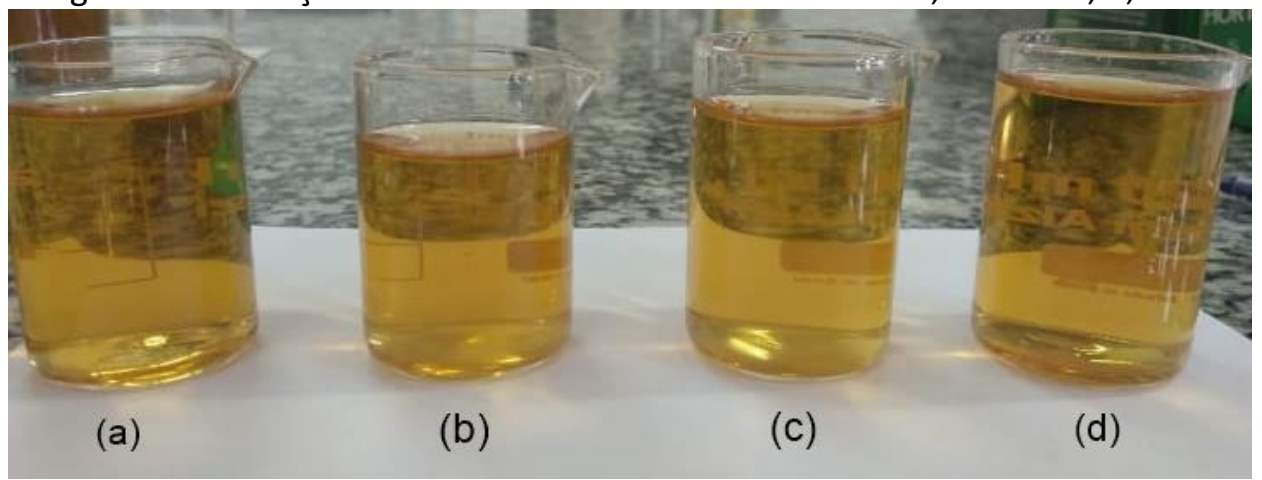

Fonte: Autoria própria. 


\section{Figura 7 - Coloração do chá natural de hortelã}

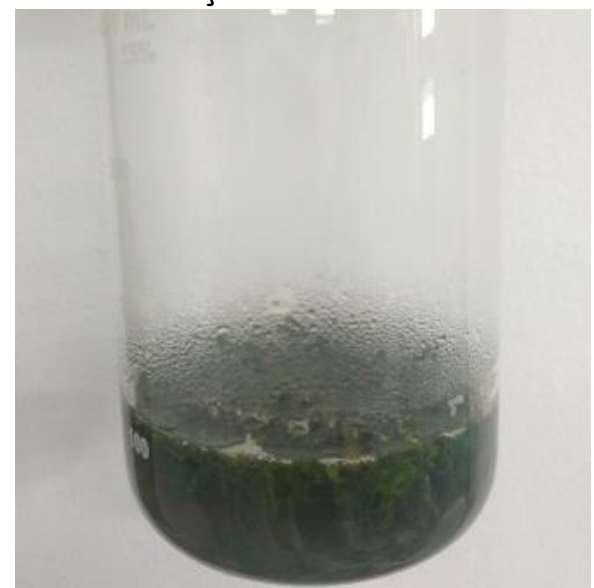

Fonte: Autoria própria.

A Tabela 1 mostra a variação do pH dos chás natural e industrializado, que são 6 e 4, respectivamente. Segundo Hoffmann (2001), o pH > 4,5 é pouco ácido, o que proporciona maiores condições para o crescimento de patógenos e fungos (bolores e leveduras), favorecendo a multiplicação dos patógenos e cria vantagens para seu desenvolvimento. Os microrganismos são mais restritos em alimentos ácidos $(\mathrm{pH} \mathrm{4,0} \mathrm{a}$ 4,5), o que corresponde às bactérias lácticas e algumas bactérias esporuladas, onde a maioria dos patógenos não se multiplica. Quanto a quantidade de Sólidos Solúveis Totais, todas as amostras apresentam 0 Brix, o que significa que não contém açúcar.

Tabela 1 - Resultados da caracterização físico-química dos chás de hortelã

\begin{tabular}{cccc}
\hline Chá de hortelã & pH & $\begin{array}{c}\text { Sólidos Solúveis } \\
\text { Totais (-Brix) }\end{array}$ & $\begin{array}{c}\text { Acidez Total } \\
\text { Titulável (ATT) }\end{array}$ \\
\hline Natural & 6 & 0 & $0,0358 \%$ \\
Marca A & 4 & 0 & $0,0083 \%$ \\
Marca B & 4 & 0 & $0,0102 \%$ \\
Marca C & 4 & 0 & $0,0064 \%$ \\
Marca D & 4 & 0 & $0,0083 \%$ \\
\hline
\end{tabular}

Fonte: Autoria própria.

A presença de ácidos orgânicos, constituintes dos alimentos, pode alterar as suas características organolépticas, estabilidade e qualidade. Quanto a ATT, os chás apresentaram variações de 0,0064\% a 0,0358\% de ácido cítrico/100mL (Tabela 1). Segundo Batista et al. (2014) essa variação do teor de ácido cítrico pode ser explicada pelo tempo de maturação da planta. Portanto, é importante enfatizar que essas diferenças nos resultados podem estar relacionadas a fatores ambientais que apresentam aspectos específicos de suas características. 
As plantas produzem uma ampla gama de componentes orgânicos, que são divididos em metabólitos primários e secundários. Os metabólitos primários apresentam funções de estrutura, armazenamento de energia e fazem parte da síntese de compostos essenciais para a sobrevivência das espécies vegetais. Os metabólitos secundários são em geral compostos sintetizados pelas plantas de acordo com as suas necessidades específicas, que incluem as condições ambientais, as interações com outras plantas e a proteção contra predadores (ALMEIDA, 2017; VIZZOTO et al., 2010). A avaliação fitoquímica realizada nos extratos aquosos da hortelã mostraram a presença importantes metabólitos secundários e os resultados basearam-se nas reações de precipitações e coloração.

Tabela 2 - Triagem fitoquímica preliminar de compostos secundários de Mentha piperita $L$

\begin{tabular}{cccccc}
\hline $\begin{array}{l}\text { Metabólitos } \\
\text { secundários }\end{array}$ & Natural & Marca A & Marca B & Marca C & Marca D \\
\hline Taninos & + & + & + & + & + \\
Flavanoides & - & + & + & + & + \\
Esteroides & + & + & + & + & + \\
Triterpenoides & + & - & - & - & - \\
Saponinas & + & + & + & + & + \\
Alcaloides & - & - & - & - & - \\
\hline
\end{tabular}

(+) Resultado positivo; (-) Resultado negativo.

Fonte: Autoria própria.

Os taninos foram identificados em todas as amostras analisadas, caracterizados como moléculas mais resistentes à fragmentação, que precipitam proteínas e estão relacionados com compostos fenólicos, regulação enzimática e protéica e ativos nos processos de cura de feridas, queimaduras e inflamações (MONTEIRO; ALBUQUERQUE; ARAÚJO, 2005); (ROCHA et al, 2011).

A presença de flavonoides foi identificada somente nos extratos industrializados, é bastante conhecido pelo seu efeito antioxidante e anti-inflamatório, muitos pesquisadores têm mostrado interesse nesse composto, por apresentar uma ampla ação biológica, dentre elas prevenção de doenças cardiovasculares, doença pulmonar, entre outras (MACHADO et al., 2008).

Os esteroides livres foram identificados em todas as amostras dos extratos, estão envolvidos no desenvolvimento humano na forma natural e podem ser produzidos sinteticamente com várias finalidades, como ingredientes ativos para anticoncepcionais 
orais. A presença de triterpenoides foi identificado somente no chá natural, as propriedades desse metabólito têm mostrado uma ampla gama de atividades biológicas, tais como: anti-inflamatória, proteção hepática, antioxidante, antialérgica e antimicrobiana (SILVA et al., 2020).

Foram identificadas a presença de saponinas em todas as amostras. Este metabolito nas plantas desempenha um papel importante na defesa contra insetos e microrganismos. Elas possuem atividade antibacteriana e antimicrobiana, sendo bastante usada na indústria alimentícia como agente espumante e na indústria de cosméticos para diversos produtos de beleza (CHEEKE, 2001). De acordo com as análises de Félix-Silva et al. (2012) utilizando extrato natural da hortelã, foram identificados triterpenoides e alcaloides, metabólitos secundários que não foram possíveis ser identificados nas análises do presente trabalho.

\section{CONSIDERAÇÕES FINAIS}

As análises físico-químicas apresentaram resultados satisfatórios de $\mathrm{pH}$ e acidez titulável. As características organolépticas do chá natural foram mais intensas em relação ao industrializado, essas características podem estar associadas ao desenvolvimento, sazonalidade, índice pluviométrico, temperatura e solo. Os resultados fitoquímicos apresentaram importantes metabólitos secundários, como taninos, flavonoides, esteroides, triterpenoides e saponinas, estes compostos podem ser utilizados como medicamentos (princípios ativos ou excipientes), aromatizantes ou corantes. Diante desses resultados, a hortelã apresenta uma fonte promissora de pesquisa voltada para a identificação de atividades terapêuticas interessante.

\section{REFERÊNCIAS}

AZEVEDO J.; AZEVEDO, R. M. M. C.; OLIVEIRA, J. T. G. S. B.; MONTEIRO, L. C.; CARVALHO JÚNIOR, P. R. C. INMETRO - Instituto Nacional de Metrologia, Qualidade e Tecnologia. Programa de análise de produtos: relatório sobre análise em chás. Rio de Janeiro: Inmetro, 2009.

BALDUINO, M. A. Aplicação da metodologia de engenharia Kansei na análise de consumo de chás. Dissertação (Mestrado em Ciências do Consumo e Nutrição) Faculdade de Ciências, Universidade do Porto, 2012. 
ALMEIDA, D. F. L. S. Estudo das vias metabólicas das plantas na síntese de pigmentos naturais. Dissertação (Mestrado em Ciências Farmacêuticas) - Universidade Fernando Pessoa, Faculdade de Ciências da Saúde. Porto, 2017.

BARACUHY, J. G. V.; FURTADO, D. A.; FRASCISCO, P. T. M.; LIMA, J. L. S.; PEREIRA, J. P. G. Plantas Medicinais de uso comum no Nordeste do Brasil. 2 ed. Campina Grande: EDUFCG, 2016.

BATISTA, A. D.; FONSECA, A. A. O.; COSTA, M. A. P. C.; BITTENCOURT, N. S. Caracterização física, físico-química e química de frutos de pitangueiras oriundas de cinco municípios baianos. Magistra, Cruz das Almas - BA, v. 26, n.3, p.393-402, 2014.

BRAIBANTE, M. E. F.; SILVA, D.; BRAIBANTE, H. T. S.; PAZINATO, M. S. A Química dos Chás. Química Nova na Escola, v.36, n.3, p.168-175, 2014.

CHEEKE, P. R. Actual and potential applications of Yucca schidifera and Quillaja saponaria saponins in human and animal nutrition. Advences in animal nutrition in Australia, v.13, p.115-126, 2001.

FÉLIX-SILVA, J.; TOMAZ, I.M.; SILVA, M.G.; SANTOS, K.S.C.R.; SILVA-JÚNIOR, A.A.; CARVALHO, M.C.R.D.; SOARES, L.A.L.; FERNANDES-PEDROSA, M.F. Identificação botânica e química de espécies vegetais de uso popular no Rio Grande do Norte, Brasil. Revista Brasileira de Plantas Medicinais, v.14, n.3, p.548-555, 2012.

GARLET, T. M. B., SANTOS, O. S., MEDEIROS, S. L. P., MANFRON, P. A., GARCIA, D. C., BORCIONI, E., \& FLEIG, V. Produção e qualidade do óleo essencial de menta em hidroponia com doses de potássio. Ciência Rural, v.37, n.4, p.956-962. 2007.

GASPARIN, P.P.; ALVES, N.C.C.; CHRIST, D.; COELHO, S.R.M. Qualidade de folhas e rendimento de óleo essencial em hortelã pimenta (Mentha x Piperita L.) submetida ao processo de secagem em secador de leito fixo. Revista Brasileira de Plantas Medicinais, v.16, n.2, p.337-344, 2014.

GOBBO-NETO, L.; LOPES, N. P. Plantas Medicinais: Fatores de influência no conteúdo de metabólitos secundários. Química Nova, v.30, n.2, p.374-381, 2007.

HOFFMANN, F. L. Fatores limitantes à proliferação de microorganismos em alimentos. Brasil Alimentos, v.9, n.1, p.23-30, 2001.

INMETRO. Informação ao Consumidor - Chá. Disponível em: http://www.inmetro.gov.br/consumidor/produtos/cha.asp. Acesso em: 14 julho, 2018.

INSTITUTO ADOLFO LUTZ. Métodos físico-químicos para análise de alimentos. 4 ed. São Paulo: Instituto Adolfo Lutz, p. 1020, 2008.

KHAN, N.; MUKHTAR, H. Tea polyphenols for health promotion. Life Sciences, v.81, n.7, p.519-533, 2007. 
LIMA, J. D.; MAZZAFERA, P.; MORAES, W. S.; SILVA, R. B. Chá: aspectos relacionados à qualidade e perspectivas. Ciência Rural, v.39, n.4, p.12701278, 2009.

MATOS, F. J. A. Introdução a Fitoquímica Experimental. 2. ed. EUFC. Fortaleza: Edições UFC, 1997.

MACHADO, H.; NAGEM, T. J.; PETERS, V. M.; FONSECA, C. S.; OLIVEIRA, T. T. Flavanoides e seu potencial terapêutico. Boletim do Centro de Biologia da Reprodução. Juiz de Fora, v. 27, n.1/2, p.33-39, 2008.

MANGRICH, A. S.; DOUMER, M. E.; MALLMANN, A. S.; WOLF, C. R. Química Verde no Tratamento de Águas: Uso de Coagulante Derivado de Tanino de Acacia mearnsii. Revista Virtual de Química, v. 6, n.1, p.2-15, 2014.

MONTEIRO, J. M.; ALBUQUeRQUE, U. P.; ARAÚJO, E. L. Taninos: Uma abordagem da química à ecologia. Química Nova, v.28, n.5, p.892-89, 2005.

MORAIS, S. M., CAVALCANTE, E. S. B., COSTA, S. M. O. \& AGUIAR, L.A. Ação antioxidante de chás e condimentos de grande consumo no Brasil. Revista Brasileira de Farmacognosia Brazilian Journal of Pharmacognosy, v.19, n.1B, p.315-320, 2009.

OLIVEIRA, V. B.; ZUCHETTO, M.; OLIVEIRA, C.F.; PAULA, C.S.; DUARTE, A.F.S.; MIGUEL, M.D.; MIGUEL, O.G. Efeito de diferentes técnicas extrativas no rendimento, atividade antioxidades, doseamentos totais e no perfil por clae-dad de dicksonia sellowiana (presl.). Hook dicksoniaceae. Revista Brasileira de Plantas Medicinais, v.18, n.1, p.230-239, 2016.

PAULUS, D.; MEDEIROS, S.L.P.; SANTOS, O.S.; MANFRON P.A.; PAULUS, E.; FABBRIN, E. Teor e qualidade do óleo essencial de menta (Mentha arvensis $L$.) produzida sob cultivo hidropônico e em solo. Revista Brasileira de Plantas Medicinais, v.9, n.2, p.80-87, 2007.

QUEIROZ, G. S. Análise de esteróides em extratos vegetais e estudo fitoquímico e biológico preliminar de Brunfelsia uniflora. Dissertação - Universidade Federal de Santa Catarina. Santa Catarina, 2009.

ROCHA, W. S.; LOPES, R. M.; SILVA D. B.; VIEIRA, R. F.; SILVA, J. P.; AGOSTINI-COSTA, T. S. Compostos fenólicos totais e taninos condensados em frutas nativas do cerrado. Revista Brasileira de Fruticultura, v.33, n.4, p.1215-1221, 2011.

ROSA, R. C. A.; RIBEIRO, L. R.; SOUZA, A. M. G.; FONSECA, T. A. Triagem Fitoquímica dos Extratos Aquosos de Bauhinia candicans, Foeniculum vulgare, Mentha puleguim e Morus nigra. Revista Conexão Ciência, v. 11, n.1, p.44-51, 2016. 
SCHMITZ, W.; SAITO, A. Y., ESTEVÃO, D.; SARIDAKIS, H. O. O chá verde e suas ações como quimioprotetor. Semina: Ciências Biológicas e da Saúde, Londrina, v.26, n.2, p.119-130, 2005.

SILVA, F. C. O.; FERREIRA, M. K. A.; SILVA, A. W.; MATOS, M. G. C.; MAGALHÃES, F. E. A.; SILVA, P. T.; BANDEIRA, P. N.; de MENEZES, J. E. S. A; SANTOS, H. S. Bioatividades de Triterpenos isolados de plantas: Uma breve revisão. Revista Virtual de Química, v.12, n.1, p.1-14, 2020.

TREVISANATO, S. I.; KIM, Y. I. Tea and health. Nutrition Reviews, v.58, n.1, p.1-10, 2000.

VIZZOTO, M.; KROLOW, A. C.; WEBER, G. B. Metabólitos secundários encontrados em plantas e sua importância. Pelotas: Embrapa Clima Temperado, 2010. Doc. 3016. $16 \mathrm{p}$. 


\title{
CAPITULO VIII
}

\section{DIFERENTES TÉCNICAS DE REPARO DAS RESTAURAÇÕES DE AMÁLGAMA}

\author{
DOI: 10.51859/AMPLLA.PAE1993-8
}

\begin{abstract}
Paulina Renata da Silva Paiva ${ }^{1}$ Jefferson Lucas Mendes ${ }^{1}$ Edjardi de Pontes Viana ${ }^{1}$ Anna Clara Gomes de Araújo ${ }^{1}$ Marcelo Gadelha Vasconcelos ${ }^{2}$ Rodrigo Gadelha Vasconcelos ${ }^{2}$
\end{abstract}

'Graduando (a) do curso de Odontologia pela Universidade Estadual da Paraíba - UEPB, Araruna-PB, Brasil.

2 Professor Doutor efetivo da Universidade Estadual da Paraíba - UEPB, Araruna-PB, Brasil.

\section{RESUMO}

Em restaurações de amálgama com defeitos localizados, o reparo constitui uma alternativa de tratamento a ser indicado, por ser um procedimento minimamente invasivo que demonstra eficácia semelhante às restaurações substituídas. Para sua realização, diversas técnicas podem ser utilizadas, como reparo com o próprio amálgama ou com materiais resinosos. Diante disso, este trabalho teve por objetivo revisar a literatura a fim de elucidar quais técnicas podem ser realizadas e enfatizar que o reparo é tão eficaz quanto a substituição. Foi feito um levantamento bibliográfico nas bases de dados eletrônicos: PubMed, ScienceDirect, LILACS e SciELO, considerando relevantes as publicações pertencentes ao período de 2015-2020. Os estudos demonstraram que o reparo é uma alternativa de tratamento conservadora, com ótimas vantagens, que pode ser utilizada mediante restaurações de amálgama com defeitos localizados, estando na classificação Bravo ou Charlie dos critérios USPHS (United States Public Health Service) e USPHS modificados, apresentando resultados clínicos e de sobrevida semelhantes às substituições. Para a realização do reparo, pode-se lançar mão das técnicas que utilizam o próprio amálgama ou os materiais resinosos, como resina composta, resina composta fluida, cimento autoadesivo, selantes resinosos e ionoméricos. Com base na literatura, as técnicas com materiais resinosos são mais indicadas que o reparo com o próprio amálgama, devido suas vantagens de baixa viscosidade, possibilitando melhor adaptação à cavidade e baixo modulo de elasticidade, que reduz a microinfiltração marginal.

Palavras-chave: Amálgama. Reparo de restaurações. Técnicas. Reparo de Amálgama 


\section{INTRODUÇ̃̃o}

O amálgama é um material restaurador bastante consolidado na prática clínica odontológica, sua popularidade é baseada em suas boas propriedades mecânicas e físicas, que lhe permite ter resistência ao desgaste, como também às forças mastigatórias. Soma-se a isso outras vantagens, tais como: baixo custo, boa durabilidade, fácil manuseio, bom desempenho clínico a longo prazo, baixa sensibilidade técnica e, se necessário, as restaurações de amálgama são passíveis de serem reparadas. Embora tais restaurações tenham sua longevidade comprovada por mais de 100 anos, clinicamente, essa durabilidade pode ser comprometida devido a presença de falhas, tais como: cáries secundárias, deficiências marginais, degradação, desgaste, fratura de uma das faces do dente ou de parte da restauração, perda da conformação anatômica, falta de contorno ou contato proximal e excesso proximal (PHILLIPS, 1984; ORSTAVIK, 1985; MONCADA, et al. 2015; GUMUSTAS; SISMANOGLU, 2018; MOTA, et al. 2019).

Diante de uma restauração defeituosa que apresentem falhas localizadas, o reparo tem sido uma alternativa de tratamento eficaz e, segundo os estudos, com resultados clínicos e sobrevida semelhantes a uma restauração substituída (MONCADA, et al. 2015; ESTAY, et al. 2018). O reparo envolve a remoção da parte da restauração que está com alguma falha, do tecido cariado ao redor da área defeituosa e do restante da restauração do local que foi preparado (MONCADA, et al. 2015).

O principal fator a ser considerado para a realização do reparo é a preservação da estrutura dentária, por se tratar de uma alternativa minimamente invasiva para restaurações que estejam com defeitos localizados, divergindo da substituição (ÖZCAN; VOLPATO, 2016; MOTA, et al. 2019). Outros fatores a serem considerados são a redução dos danos pulpares; o aumento da longevidade da restauração, por ser mais conservador, postergando a indicação de tratamentos mais invasivos; a questão econômica no que diz respeito aos custos do paciente e ao tempo de tratamento (ESTAY, et al. 2018; MOTA, et al. 2019).

Para a confecção do reparo de amálgama, pode-se lançar mão de várias técnicas, tais como: reparo com o próprio material, amálgama, através da técnica imediata ou mediata. Uso da resina composta, selantes resinosos ou ionoméricos, resinas de baixa 
viscosidade do tipo flow, adesivos e cimento autoadesivo. Embora não sejam muito esclarecidas na literatura (GUMUSTAS; SISMANOGLU, 2018; MOTA, et al. 2019).

Dessa maneira, o estudo objetiva revisar a literatura, ainda que escassa, a fim de elucidar a respeito do reparo de restaurações de amálgama e expor as técnicas pelo qual pode ser realizado, enfatizando ser uma alternativa de tratamento tão eficaz quanto a substituição das restaurações.

\section{METODOLOGIA}

O presente artigo corresponde a uma revisão de literatura acerca das diferentes técnicas que podem ser realizadas para o reparo de restaurações de amálgama. Para a fundamentação de tal estudo, foi feito um levantamento bibliográfico nas seguintes bases de dados eletrônicos: PubMed, ScienceDirect, LILACS e SciELO; com a utilização dos subsequentes descritores em português e inglês: amálgama dental/dental amalgam; reparo de restauração/restoration repair; técnicas/techniques; reparo de restaurações de amálgama/repairs of amalgam restorations. Juntamente aos descritores, foi utilizado o sistema de formulário avançado "AND" para filtragem dos artigos relacionados ao tema. Dessa maneira, foram consideradas relevantes as publicações pertencentes ao período entre 2015-2020, e após a análise dos resumos, foram excluídos os artigos que não se enquadravam na temática a ser abordada. Além disso, realizou-se também uma busca manual nas referências dos artigos que foram selecionados para complementação da literatura.

\section{REVISÃO BIBLIOGRÁFICA}

\subsection{DECISÃO DE TRATAMENTO}

Mediante uma restauração que apresente falhas, o cirurgião-dentista se depara com uma decisão a ser tomada sobre qual procedimento deve-se realizar; seja o reparo, a substituição, ou apenas uma manutenção daquela restauração através de um selamento, polimento, ou ainda, apenas proservar aquela estrutura (CENA, et al., 2016).

Clinicamente, a decisão de substituir a restauração continua se mantendo soberana, porém sabe-se que a medida em que um dente é restaurado ele passa a fazer parte de um ciclo restaurador que se repete, conhecido popularmente como "espiral da 
morte do dente", que, como o próprio nome sugere, pode levar à perda do órgão dental (CENA, et al., 2016).

Dentre as desvantagens da substituição total da restauração, estão: maior perda de estrutura dentária; pois quando uma restauração é substituída, uma quantidade significante de estrutura hígida é perdida, levando ao aumento da cavidade e, consequentemente, à menor longevidade do dente. Somado a isso, possui maior custo financeiro; é um procedimento que demanda mais tempo operatório; existe o risco de transformar a restauração direta em indireta, ou até mesmo de gerar uma lesão no tecido pulpar, necessitando de tratamentos mais invasivos como o endodôntico (MONCADA, et al. 2015; CENA, et al., 2016; ESTAY, et al. 2018).

Segundo Moncada, et al. (2015), a odontologia reconheceu o problema envolvido na substituição das restaurações em cerca de mais de quatrocentos artigos publicados nos últimos anos. Haveriam estudos clínicos e laboratoriais relacionados ao reparo das restaurações que demonstram que o reparo de amálgama seria possível e bem-sucedido, com qualidade semelhante às restaurações substituídas.

Esses resultados concordam com os autores Estay, et al. (2018), que realizaram uma pesquisa com o objetivo de avaliar o reparo de restaurações de amálgama e resina com defeitos marginais oclusais, observar se as condições clínicas seriam melhoradas e se o desempenho seria semelhante à substituição após 12 anos. Concluindo que, após esse período de tempo, todos os grupos se comportaram de forma semelhante quanto à adaptação marginal, manchamento, sensibilidade e forma anatômica. Assim, o reparo das restaurações em amálgama foi considerado uma boa opção clínica, tendo em vista sua característica de ser minimamente invasivo e poder aumentar a longevidade das restaurações.

Não existe evidência científica que indique claramente quando uma restauração com falha deve ser reparada ou substituída, porém há uma aceitação do uso dos critérios propostos por Cvar e Ryge, em 1971. Tais critérios são denominados como critérios USPHS (United States Public Health Service) e são constituídos por parâmetros que norteiam a avaliação clínica das restaurações e, consequentemente, a decisão do tratamento mediante as falhas (CENA, et al., 2016; MOTA, et al. 2019).

Os parâmetros de avaliação propostos inicialmente foram: cor da restauração, alteração da cor do ângulo cavo-superficial, forma anatômica, adaptação marginal e 
diagnóstico de cárie; associando fatores estéticos e funcionais. Em 2005, os pesquisadores aumentaram a quantidade de parâmetros, adicionando as seguintes características: avaliação da oclusão, sensibilidade pós-operatória, fraturas, retenção das restaurações e relação com o periodonto; configurando os critérios USPHS modificados (CENA, et al., 2016; MOTA, et al. 2019).

Esses critérios classificam as restaurações em aceitáveis ou inaceitáveis, a fim de decidir se o tratamento ideal será a manutenção, reparo ou substituição. Os critérios possuem seus respectivos escores, Alfa, Bravo e Charlie. Em que Alfa refere-se a uma restauração totalmente satisfatória; Bravo, algo parcialmente satisfatório e clinicamente aceitável; e Charlie, algo insatisfatório, clinicamente inaceitável (MOTA, et al. 2019).

Na tabela 1 e 2, os critérios USPHS e USPHS modificados, respectivamente, de acordo com o escore Bravo e Charlie.

Tabela 1 - Critérios USPHS

\begin{tabular}{|c|c|c|c|c|c|}
\hline Escore & $\begin{array}{c}\text { Cor da } \\
\text { restauração }\end{array}$ & $\begin{array}{l}\text { Pigmentação } \\
\text { marginal }\end{array}$ & $\begin{array}{c}\text { Forma } \\
\text { anatômica }\end{array}$ & $\begin{array}{c}\text { Adaptação } \\
\text { marginal }\end{array}$ & $\begin{array}{c}\text { Cárie } \\
\text { secundária }\end{array}$ \\
\hline Bravo & $\begin{array}{l}\text { Pequena } \\
\text { alteração de } \\
\text { cor entre a } \\
\text { restauração } \\
\text { e o dente } \\
\text { adjacente. }\end{array}$ & $\begin{array}{l}\text { Pequena } \\
\text { pigmentação ao } \\
\text { longo da } \\
\text { margem. }\end{array}$ & $\begin{array}{l}\text { Restauração em } \\
\text { descontinuidade } \\
\text { com a forma } \\
\text { anatômica do } \\
\text { dente, mas sem } \\
\text { exposição da } \\
\text { dentina ou da } \\
\text { base da } \\
\text { restauração. }\end{array}$ & $\begin{array}{l}\text { Fenda } \\
\text { detectada pela } \\
\text { sonda } \\
\text { exploradora, } \\
\text { mas sem expor } \\
\text { dentina ou base } \\
\text { da restauração. }\end{array}$ & Ausente. \\
\hline Charlie & $\begin{array}{l}\text { Nítida } \\
\text { alteração de } \\
\text { cor. }\end{array}$ & $\begin{array}{l}\text { Presente ao } \\
\text { longo da } \\
\text { margem. }\end{array}$ & $\begin{array}{l}\text { Perda de } \\
\text { material, } \\
\text { expondo } \\
\text { dentina ou a } \\
\text { base da } \\
\text { restauração. }\end{array}$ & $\begin{array}{l}\text { Restauração } \\
\text { com mobilidade } \\
\text { ou fratura. }\end{array}$ & $\begin{array}{l}\text { Presença de } \\
\text { cárie na } \\
\text { margem. }\end{array}$ \\
\hline
\end{tabular}

Fonte: Adaptado de Mota et al., 2019. 
Tabela 2- Critérios USPHS modificados

\begin{tabular}{|c|c|c|c|c|c|c|}
\hline Escore & $\begin{array}{c}\text { Contato } \\
\text { oclusal }\end{array}$ & $\begin{array}{c}\text { Contato } \\
\text { proximal }\end{array}$ & $\begin{array}{c}\text { Textura } \\
\text { superficial }\end{array}$ & Fratura & $\begin{array}{c}\text { Sangramento } \\
\text { da papila }\end{array}$ & $\begin{array}{c}\text { Sensibilidade } \\
\text { Pós-operatória }\end{array}$ \\
\hline Bravo & Aceitável. & $\begin{array}{l}\text { Restauração } \\
\text { descontínua } \\
\text { em relação ao } \\
\text { dente, mas } \\
\text { sem } \\
\text { exposição. } \\
\text { Perda de } \\
\text { contato } \\
\text { proximal. }\end{array}$ & $\begin{array}{l}\text { Superfície } \\
\text { mais } \\
\text { irregular } \\
\text { que o } \\
\text { esmalte } \\
\text { adjacente. }\end{array}$ & Ausente. & Ausente. & $\begin{array}{l}\text { Presente, mas } \\
\text { diminuindo de } \\
\text { intensidade. }\end{array}$ \\
\hline Charlie & Ausente. & $\begin{array}{l}\text { Restauração } \\
\text { descontínua e } \\
\text { a } \\
\text { perda de } \\
\text { material } \\
\text { expõe a } \\
\text { dentina } \\
\text { ou base da } \\
\text { restauração. }\end{array}$ & $\begin{array}{l}\text { Existência } \\
\text { de } \\
\text { sulco e } \\
\text { fratura. }\end{array}$ & $\begin{array}{l}\text { Com } \\
\text { mobilidade } \\
\text { ou } \\
\text { fraturada. }\end{array}$ & Presente. & $\begin{array}{l}\text { Sensibilidade } \\
\text { Espontânea. }\end{array}$ \\
\hline
\end{tabular}

Fonte: Adaptado de Mota et al., 2019.

\section{REPARO}

Nas situações de defeito localizado, o reparo seria o tratamento mais simples a se fazer, constituindo uma alternativa minimamente invasiva e econômica, em detrimento da substituição total da restauração, principalmente em tempos de uma odontologia que visa ser mais conservadora possível (CENA, et al., 2016; ÖZCAN; VOLPATO, 2016; ESTAY, et al. 2018).

O ato de reparar consiste na remoção das partes defeituosas da restauração e de qualquer tecido cariado que esteja adjacente e subjacente. Neste caso, os preparos são menores, menos invasivos, e após a remoção das áreas citadas, ocorre a inserção de um novo material restaurador (MONCADA, et al. 2015; SILVA; LUND, 2016).

Dentre as vantagens da escolha do reparo, estão: a preservação do tecido dentário, removendo o mínimo possível de estrutura dental hígida; redução do risco de algum dano à polpa, ou aos dentes adjacentes, de forma iatrogênica; possui menor custo; é um procedimento simples que necessita de menos tempo clínico; confere maior longevidade à restauração e ao dente, culminando na desaceleração do ciclo restaurador repetitivo (MONCADA, et al. 2015; CENA, et al., 2016). 


\subsection{TÉCNICAS DE REPARO DAS RESTAURAÇÕES DE AMÁLGAMA}

De acordo com Silva \& Lund (2016), existem algumas modalidades do reparo que podem ser aplicados na prática clínica, tais como: o recontorno da restauração através do simples acabamento e polimento; o resselamento das margens da restauração, ou ainda o reparo propriamente dito.

O recontorno ou repolimento pode ser atribuído a uma situação de excesso marginal, e costuma ser indicado nas fases iniciais, de controle. Já o selamento da margem defeituosa pode ser feito através da utilização de um material resinoso, como os selantes, ou os selantes ionoméricos, além das resinas de baixa viscosidade, do tipo flow, ou ainda dos sistemas adesivos. O material a ser utilizado vai depender da profundidade e extensão do defeito. Geralmente o selamento marginal é realizado quando a degradação da margem não é extensa, visando evitar o desgaste adicional da estrutura hígida (MOTA, et al. 2019).

O reparo propriamente dito, que seria a remoção da parte defeituosa e a consequente inserção de um novo material restaurador na área, pode ser feito através de várias técnicas, seja utilizando o próprio amálgama ou os materiais resinosos (MOTA, et al. 2019).

\subsubsection{REPARO COM AMÁLGAMA}

A técnica do reparo das restaurações de amálgama com o próprio amálgama pode ser subdividida em duas técnicas: imediata e mediata. A técnica imediata, que pode ser realizada após o período de tempo de 10 a 15minutos depois de já ter inserido o amálgama na cavidade, seria atribuída a casos em que o reparo a ser realizado constitui o acréscimo de material que está em falta, sem necessidade de um preparo prévio da cavidade. Para realizá-la, é necessário a utilização do isolamento absoluto, em seguida insere-se o material na porção defeituosa, e efetua-se a condensação, brunidura e posteriormente o acabamento e polimento (SILVA; LUND, 2016).

Já a técnica mediata requer um preparo prévio para a remoção da área defeituosa, buscando sempre preservar a estrutura dental sadia, desgastando apenas a restauração antiga defeituosa, seguindo os princípios de resistência e retenção preconizados para o amálgama. Deve ser realizada com o auxílio de uma broca troncocônica de numeração 330, 331 ou 245. Após o preparo, insere-se o material na cavidade, 
condensa, realiza a brunidura, escultura e, posteriormente, após o tempo adequado, deverá ser feito o acabamento e polimento (SILVA; LUND, 2016). Em alguns casos, podese lançar mão de retenção mecânica dentro da restauração antiga de amálgama (MONCADA, et al. 2015).

\subsubsection{REPARO COM RESINA COMPOSTA}

Os reparos de amálgama com resina composta geralmente estão indicados em casos de pequenas falhas ou quando há pouca retenção para o material restaurador a ser utilizado. Inicialmente, deve-se fazer a profilaxia, em seguida a seleção de cor, isolamento absoluto, realização de microrretenções, ou seja, deve-se fazer um preparo na área defeituosa de amálgama a fim de criar retenção micromecânica, que pode ser obtida a partir das brocas, pontas diamantadas ou através do jateamento com óxido de alumínio, com o auxílio de um microjateador. Após isso, condiciona a superfície com o ácido fosfórico 37\%, aplica o sistema adesivo, posiciona a matriz e a cunha, se for necessário, e insere-se a resina composta por meio da técnica incremental. Posteriormente, após o período determinado, deve-se realizar o acabamento e polimento para garantir as boas propriedades do material restaurador (SILVA; LUND, 2016).

\subsubsection{REPARO COM RESINA COMPOSTA FLUIDA}

As resinas fluidas, conhecidas como do tipo flow, também, são indicadas para reparo de restaurações de amálgama principalmente devido suas características favoráveis, como: baixa viscosidade, facilitando a sua inserção na cavidade e desempenhando também uma melhor adaptação às paredes cavitárias; e por possuir baixo módulo de elasticidade, que reduz a microinfiltração marginal (GUMUSTAS; SISMANOGLU, 2018).

Para sua aplicação, após a remoção da área marginal defeituosa, deve-se realizar o condicionamento da área com ácido fosfórico a 37\%, lavar, secar, mantendo a dentina úmida. Após a aplicação do sistema adesivo (primer; adesivo) espera-se a volatilização do solvente para a etapa de fotopolimerização. Após esses passos, a resina fluida pode ser aplicada (GUMUSTAS; SISMANOGLU, 2018). 


\subsubsection{REPARO COM COMPÓSITO DE RESINA FLUIDA AUTO-ADERENTE}

\section{(VERTISE FLOW@ - KERR, ORANGE, CA, EUA)}

O Vertise Flow $^{\circledR}$ (figura 1), é o primeiro compósito autoadesivo desenvolvido com a tecnologia de adesão OptiBond ${ }^{\mathrm{TM}}$ da Kerr, constituindo um material inovador composto por resina fluida auto-aderente, que associa os componentes essenciais de um condicionador, um primer e adesivo e os reúne em um só material, eliminando tais etapas adicionais. Assim, possui a vantagem de simplificar os procedimentos restauradores, possibilitando menor tempo de aplicação, menor sensibilidade técnica e reduz a chance de sensibilidade pós-operatória. Além disso, o composto dispõe de alta aderência, alta resistência mecânica e outros atributos físicos comparáveis aos tradicionais compostos fluidos (GUMUSTAS; SISMANOGLU, 2018; KERR, 2021).

Figura 1 - Compósito de resina fluida autoadesivo - Vertise ${ }^{\mathrm{TM}} \mathrm{Flow}^{\circledR}$. Na imagem, kit composto por seringa, pincel e ponta dispensadora.

Figura 1 - Compósito de resina fluida autoadesivo - Vertise ${ }^{\text {тM }}$ Flow $^{\circledR}$. Na imagem, kit composto por seringa, pincel e ponta dispensadora.

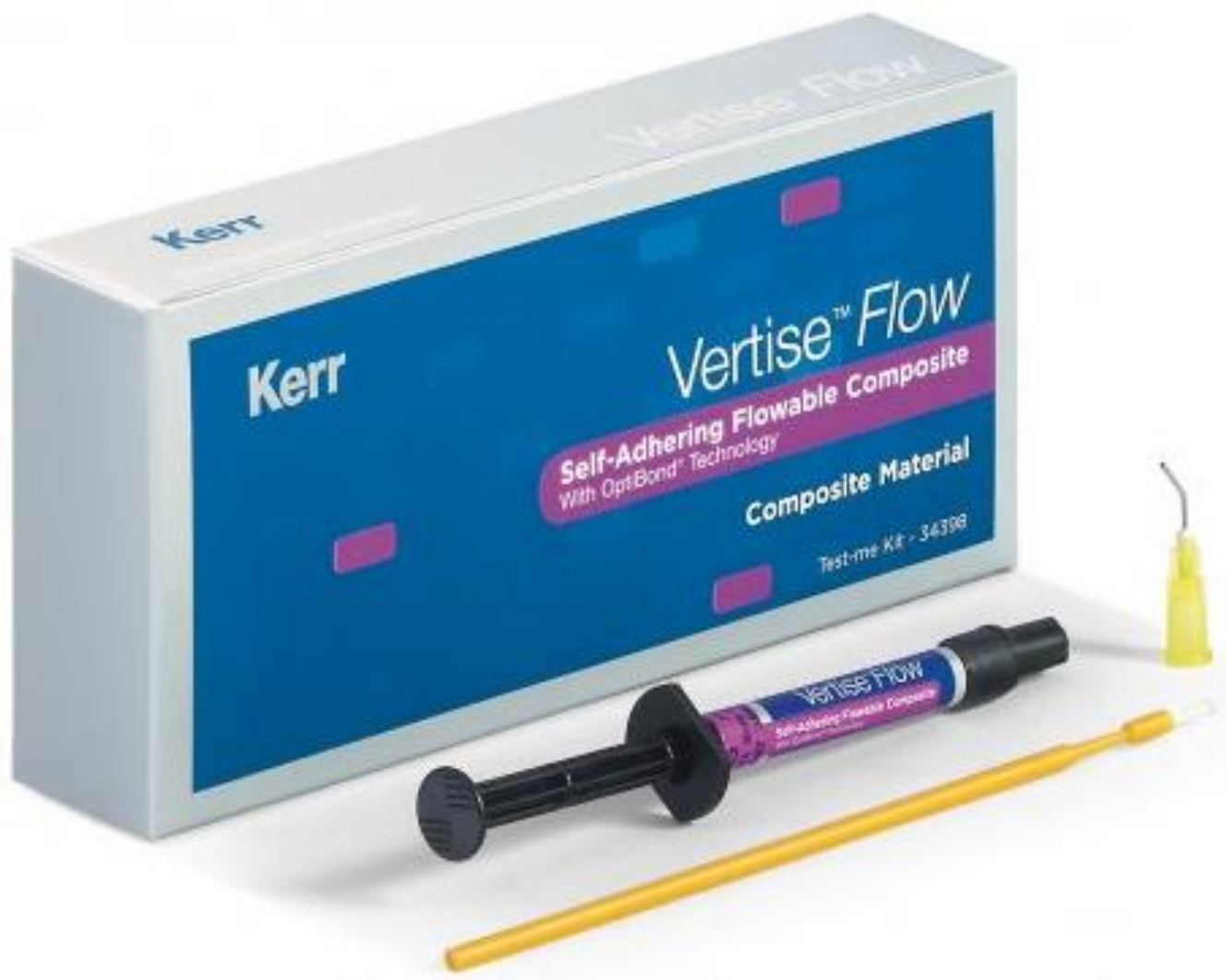

Fonte: Site da Kerr Dental Corporation, 2021. 
Para aplicação do material, a área marginal defeituosa deve ser lavada e secada com suaves jatos de ar por 5 segundos. $O$ material é injetado na área por meio da ponta dispensadora fornecida pelo fabricante. Seguindo as instruções determinadas, deve-se utilizar o pincel fornecido para aplicar o Vertise Flow $^{\circledR}$ em toda a área a ser restaurada, com pressão moderada friccionar por 15-20 segundos a fim de obter uma fina camada e acomodar o material. Se necessário, pode-se remover o excesso de material com o pincel. Após isso a restauração será fotopolimerizada por 20 segundos (GUMUSTAS; SISMANOGLU, 2018; KERR, 2021).

\subsubsection{REPARO COM RESINA COMPOSTA BULK FILL SONICFILL 2@ ATIVADA}

\section{POR SONICFILL@}

A resina composta bulk fill nanohíbrida SonicFill $2^{\circledR}$ (figura 2 ) é um material aplicado através da peça de mão SonicFill ${ }^{\circledR}$ (figura 2). O sistema de ativação sônica através do SonicFill ${ }^{\circledR}$ permite realizar restaurações de até $5 \mathrm{~mm}$ em passo único (KERR, 2021). Tal ativação também reduz a viscosidade do material em até $87 \%$, permitindo uma fácil adaptação (GUMUSTAS; SISMANOGLU, 2018).

Figura 2 - Sistema SonicFill ${ }^{\circledR}$ composto por ponteira, peça de mão, e resina composta bulk fill SonicFill $2^{\circledR}$, contida em cápsulas unidoses.

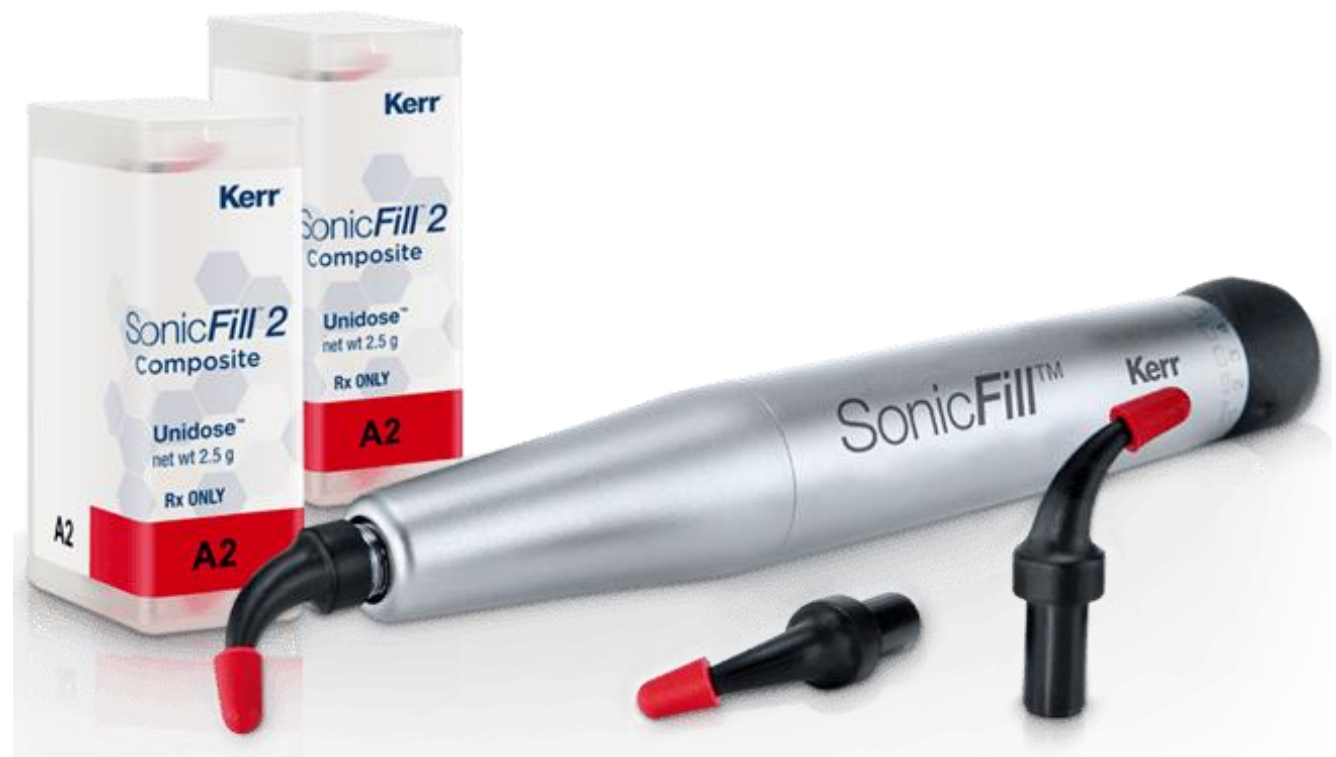

Fonte: Site da Kerr Dental Corporation, 2021.

Para utilização do material, realiza-se o condicionamento ácido e aplica-se o sistema adesivo na área marginal defeituosa a ser restaurada. Posteriormente, uma cápsula unidose da resina SonicFill $2^{\circledR}$ deve ser inserida na peça de mão SonicFill ${ }^{\circledR}$ (Kerr, 
Orange, CA, EUA) e a ponteira aplicadora é inserida na cavidade para a aplicação do produto. A energia sônica é produzida pela peça de mão e transferida para a ponteira, possibilitando o aumento da fluidez da resina. Após a ativação da peça de mão, a resina é dispensada na cavidade buscando aplicá-la apenas na área do defeito marginal, às margens do amálgama e ao esmalte adjacente. A resina, em seguida, será fotopolimerizada por 20 segundos (GUMUSTAS; SISMANOGLU, 2018; KERR, 2021).

\subsubsection{REPARO COM CIMENTO AUTOADESIVO}

Os cimentos resinosos autoadesivos também são um material de escolha para realização do reparo em restaurações de amálgama (GUMUSTAS; SISMANOGLU, 2018). Podendo ser utilizados, por exemplo, os cimentos: RelyX Unicem ${ }^{\circledR}$ (3M/ ESPE), Maxcem Elite $^{\circledR}$ (Kerr), SmartCem $2^{\circledR}$ (Dentsply) - (figura 3), AllCem ${ }^{\circledR}(F G M)$, entre outros.

Figura 3 - Cimento autoadesivo SmartCem $2^{\circledR}$, composto por seringa AutoMix e ponta de mistura

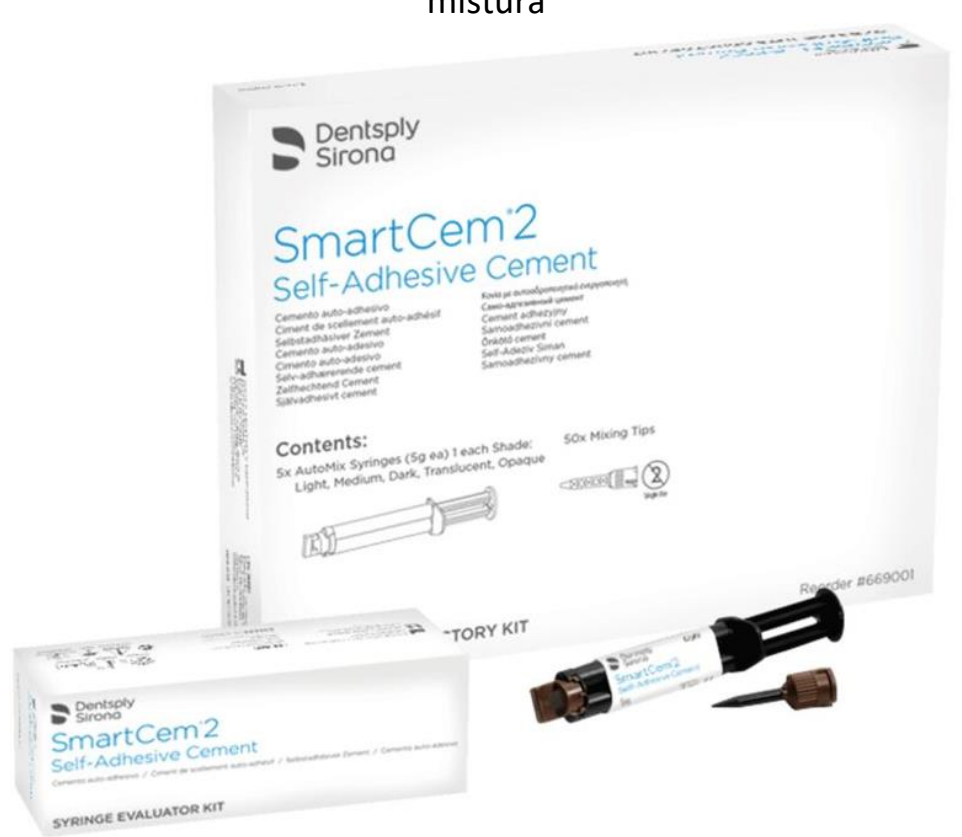

Fonte: Site da Dentsplay Sirona Brasil, 2021.

O SmartCem $2{ }^{\circledR}$ é um agente de cimentação autoadesivo dual, de alta resistência, que possui pequenas partículas de enchimento. Tem como vantagens sua baixa viscosidade e a fácil e rápida aplicabilidade (GUMUSTAS; SISMANOGLU, 2018; DENTSPLAY SIRONA, 2021). Para aplicação, inicialmente, deverá ser dispensado uma parte do material e depois adaptada a ponta de mistura. Em seguida, o cimento será aplicado suavemente em toda superfície interna do defeito marginal e sua polimerização dura em torno de três minutos (GUMUSTAS; SISMANOGLU, 2018). 


\section{DISCUSSÃO}

Mediante uma restauração de amálgama com falhas, o cirurgião-dentista é confrontado com a decisão de qual procedimento deve ser escolhido para a resolução do problema. Dentre as opções de tratamento, estão o reparo e a substituição das restaurações.

Estudos anteriores abordaram que as restaurações reparadas e substituídas apresentaram resultados semelhantes em uma situação de defeitos marginais e cárie secundária em pacientes com risco de cárie baixo e médio, sendo a maioria das restaurações clinicamente aceitáveis após cinco, sete e dez anos; demonstrando novamente que o reparo seria tão eficaz quanto a substituição (ESTAY, et al. 2018). Concordando com a opinião dos autores Gumustas e Sismanoglu (2018), também ratificam que o reparo seria uma alternativa de tratamento eficaz para restaurações de amálgama defeituosas.

Além disso, os resultados demonstrados por Moncada, et al. (2015), a partir de suas pesquisas, expõem que o reparo das restaurações pode aumentar a longevidade por pelo menos mais dez anos. Durante esse período de tempo, o estudo não evidenciou fratura dentária, de amálgama ou lesão pulpar; em consenso também com outros relatórios anteriores que abordavam que a resistência da restauração reparada era aceitável, sem evidência de fratura na interface reparada.

Não há um consenso científico que indique claramente quando uma restauração defeituosa deve ser reparada ou substituída, todavia, os critérios USPHS e USPHS modificados classificam a condição da restauração e norteiam a decisão de tratamento (CENA, et al., 2016).

Segundo os autores Hickel, et al. (2010), o reparo seria indicado em casos de defeitos localizados que sejam clinicamente insatisfatórios ou não aceitáveis, inserindose na categoria Charlie. Contudo, Silva \& Lund (2016) abordam que atualmente, o reparo seria indicado em casos de restaurações clinicamente aceitáveis com defeitos localizados, como: presença de cárie secundária, alteração de cor, desgaste acentuado, fraturas de parte da restauração ou do dente, e outros. Concordando com os estudos de Gordan et al. (2006) que enfatizam que o reparo seria a opção mais conservadora indicada para restaurações defeituosas com classificação Bravo. 
Tendo optado por reparar uma restauração de amálgama, surge também a decisão de qual técnica e qual material restaurador escolher para tal procedimento. No estudo de Gumustas \& Sismanoglu (2018), os autores utilizaram quatro materiais restauradores à base de resina composta (Grupo 1: sem tratamento - controle; Grupo 2: Compósito de resina fluida autoadesiva; Grupo 3: Resina composta fluida; Grupo 4: Resina composta bulk fill SonicFill $2^{\circledR}$ aplicada pelo dispositivo SonicFill ${ }^{\circledR}$; Grupo 5: Cimento autoadesivo) a fim de avaliar a eficácia de tais materiais no reparo de defeitos de margem de amálgama não cariados. Esses materiais restauradores possuem em comum características como: baixa viscosidade, alta molhabilidade da superfície dentária, penetrando em todas as irregularidades, e também possuem como vantagem a possibilidade de formação de finas camadas quando aplicados, melhorando ou eliminando o aprisionamento do ar. Porém, apesar da baixa viscosidade do SonicFill ${ }^{\circledR}$ (Grupo 4), a liquefação não atinge uma consistência fluida e o material não consegue melhorar de forma mensurável o grau de proteção contra microinfiltrações. Assim, segundo os resultados do estudo, todos os materiais desempenharam menor microinfiltração que o grupo controle, exceto o SonicFill ${ }^{\circledR}$, que não apresentou diferença estatística significativa quando comparado com tal grupo sem tratamento. Não foram encontradas diferenças significativas nos valores de microinfiltração entre os grupos 2Vertise Flow ${ }^{\circledR}$; 3-Resina composta fluida e 5-SmartCem2, porém o grupo 5 apresentou o menor valor médio de microinfiltração. Dessa maneira, os autores concluíram que, em relação à fácil e rápida aplicabilidade, o Vertise Flow $^{\circledR}$ e o SmartCem $2^{\circledR}$ oferecem um grande benefício para a prática clínica e podem aderir bem a vários substratos diferentes, como esmalte, dentina, porcelana, metais e compósitos.

Além disso, de acordo com Özcan \& Volpato (2016), o reparo de restaurações de amálgama defeituosas com o próprio amálgama não seria confiável, assim, ratificam que a abordagem de reparo com materiais adesivos deve ser considerada.

\section{CONSIDERAÇÕES FINAIS}

As restaurações de amálgama ainda são uma realidade, e como qualquer material restaurador, está susceptível às falhas. Diante desse fato, um reparo pode ser uma alternativa plausível e bastante favorável no reestabelecimento do sucesso clínico. 
Neste contexto, diante de restaurações de amálgama com defeitos localizados, o reparo constitui uma alternativa de tratamento a ser indicada, tendo em vista suas vantagens de ser um procedimento minimamente invasivo, conservando a estrutura dental hígida, além de possibilitar um aumento da longevidade das restaurações, e apresentar resultados clínicos semelhantes às substituições.

Mediante a escolha do reparo, o profissional pode optar pelas diversas técnicas, tais como: reparo com o próprio amálgama, com resina composta, resina composta fluida, cimento resinoso autoadesivo, ou apenas realizar o selamento marginal com selantes resinosos, ionoméricos ou com os adesivos, dependendo do grau do defeito. Todavia, o reparo com os materiais adesivos torna-se mais indicado do que com o próprio amálgama, tendo em vista que os materiais com baixa viscosidade e baixo módulo de elasticidade tendem a reduzir a microinflitração marginal.

Portanto, restaurações defeituosas nem sempre requerem substituição. Tornase necessário a realização de uma avaliação criteriosa a fim de verificar a possibilidade de um tratamento mais conservador, como os procedimentos de reparo ou até mesmo a realização de um acabamento e polimento.

\section{REFERÊNCIAS}

DE CENA, Jéssica Alves et al. Manutenção, reparo ou substituição de restaurações: uma reflexão necessária. Oral Sciences, v. 8, n. 1, p. 28-32, 2019.

Dentsply Sirona. Site da Dentsply Sirona Brasil, 2021. Empresa focada no empoderamento de profissionais da odontologia para trazer um tratamento melhor, mais seguro e mais rápido. Disponível em: https://www.dentsplysirona.com/ . Acesso em 28/06/2021.

ESTAY, J. et al. 12 Years of Repair of Amalgam and Composite Resins: A Clinical Study. Operative Dentistry, v. 43, n. 1, p. 12-21, jan/feb2018.

GORDAN V. V; Riley J. L 3rd; BLASER P. K; MJÖR I. A. Avaliação clínica de 2 anos de tratamentos alternativos à substituição de restaurações de amálgama defeituosas. Operative Dentistry, v. 31, n. 4, 418-425, 2006.

GUMUSTAS, B; SISMANOGLU, S. Effectiveness of different resin composite materials for repairing noncarious amalgam margin defects. Journal of Conservative Dentistry, v. 21, n. 6, p. 627-631, nov. 2018. 
HICKEL R, et al. FDI World Dental Federation: clinical criteria for the evaluation of direct and indirect restorations - update and clinical examples. Clinical Oral Investigations, v. 14, n. 4, p. 349-366, ago-2010.

Kerr Dental Corporation. Site da Kerr Dental, 2021. Fabricante de consumíveis dentais de primeira linha presente em todo mundo. Disponível em: https://www.kerrdental.com.br/ . Acesso em 28/06/2021.

MONCADA; G. et al. Longitudinal results of a 10-year clinical trial of repair of amalgam restorations. Operative Dentistry, v. 40, n. 1, p. 34-43, jan-feb. 2015.

MOTA M. S, et al. Reparos e substituições de restaurações: como avaliar as restaurações, quando e como reparar ou substituí-las. Odontologia Clínico-Científica, Recife, v. 18, n. 4, p. 265-271, out-dez. 2019.

ORSTAVIK D. Antibacterial properties of and element release from some dental amalgams. Acta odontologica Scandinavica, v. 43, n. 4, p. 231-9, 1985.

ÖZCAN, M; VOLPATO, C. Â. M. Repair Protocol for Amalgam Fillings with and Without Cusp Fracture: How and Why? Journal of Adhesive Dentistry, v. 18, n. 4, p. 3645, 2016.

PHILLIPS, R. Amalgam. Phillip Journal fur restaurative Zahnmedizin, v.1, n. 2, p. 103-4, 106-9, 1984.

SILVA, A. F; LUND. RF. Dentistica restauradora do planejamento a execução. Rio de Janeiro. Editora Guanabara Koogan Ltda. 2016. 


\title{
CAPITULO IX
}

\section{DOR, INFLAMAÇÃO E CICATRIZAÇÃO COM ÊNFASE EM TECIDO CUTÂNEO E REPARAÇÃO TECIDUAL}

DOI: 10.51859/AMPLLA.PAE1993-9

\author{
Magnaldo Inácio Tavares Medeiros ${ }^{1}$ \\ Lariane Thays Albuquerque Ribeiro ${ }^{2}$ \\ Melyssa Lima de Medeiros ${ }^{3}$ \\ Maria Aparecida de Medeiros Maciel 4,5
}

\begin{abstract}
Doutorando em Biotecnologia em Saúde (RENORBIO). Universidade Federal do Rio Grande do Norte - UFRN.
${ }^{2}$ Mestre titulada em Biotecnologia (PPGB-UnP). Enfermeira do Hospital Deoclécio Marques Lucena. Natal/RN.

${ }^{3}$ Doutora Titulada em Biotecnologia (Rede Renorbio-UFRN). Coordenadora Nacional de Processos de Avaliação da Medicina da Rede Ânima. Universidade Potiguar (UnP).

4 Professor/Pesquisador do Programa de Pós-Graduação em Biotecnologia da Rede Renorbio. Universidade Federal do Rio Grande do Norte - UFRN.

5 Professor/Pesquisador do Programa de Pós-Graduação em Biotecnologia. Universidade Potiguar (UnP), Campus Natal.
\end{abstract}

\section{RESUMO}

A dor é o mecanismo utilizado pelo organismo como alerta sobre a presença de um estímulo agressor, e representa um dos sintomas mais comuns relacionadas a inflamação. Nos quadros em que há lesão tecidual, o processo inflamatório se instala a partir da liberação de mediadores químicos pró-inflamatórios que modificam a vascularização local e atraem as células de defesa para a área da lesão/invasão. Nesta perspectiva, feridas crônicas são um problema de saúde pública e acometem aproximadamente $3 \%$ da população brasileira. Os sinais e sintomas associados a esta injúria tecidual impactam negativamente na qualidade de vida dos pacientes, culminando em internações prolongadas, reclusão social, baixa autoestima, ansiedade e até mesmo quadros de depressão. No mundo inteiro, os efeitos desta infecção são tratados satisfatoriamente, utilizando-se um grande aparato tecnológico. No entanto, o conhecimento dos profissionais da saúde a respeito dos processos biológicos envolvidos no reparo tecidual, se torna um grande obstáculo para o êxito do tratamento. Portanto, uma intervenção efetiva no processo cicatricial, depende do diagnóstico preciso do tipo de lesão e seu estágio cicatricial, bem como de critérios clínicos e técnicos. Neste cenário, a presente revisão teve como objetivo levantar as principais informações fisiológicas acerca do processo de reparo tecidual cutâneo, e ainda, fatores associados. A pesquisa bibliográfica foi realizada em acervos científicos, com base nos descritores da dor, inflamação, cicatrização, reparo tecidual e suas fisiologias, e recursos que auxiliam o processo de cicatrização. Os artigos contemplados foram escolhidos em função das abordagens voltadas para o tema proposto.

Palavras-chave: Dor. Inflamação. Feridas crônicas. Reparo tecidual. Recursos que auxiliam o processo de cicatrização. 


\section{INTRODUÇÃO}

O envelhecimento populacional representa um imenso desafio para a saúde pública contemporânea em função do surgimento ou agravamento de doenças crônicas, gerando alterações negativas na qualidade de vida humana. Dentre as patologias prevalecentes têm destaque as feridas crônicas, caracterizadas por uma ruptura na pele que culmina em alterações morfofuncionais associadas ao processo de reparo tecidual prolongado, acometendo indivíduos de maior vulnerabilidade física, social e econômica (FEARNS et al., 2017; GUPTA et al., 2017).

A fase inflamatória do processo de reparo tecidual é caracterizada por uma séria de alterações vasculares e celulares na tentativa de neutralizar antígenos e expelir qualquer elemento que possa dificultar a fase proliferativa, que consiste em uma das etapas do processo de cicatrização. Especificamente, a cascata inflamatória consiste na migração de neutrófilos e macrófagos para a área lesada, com síntese e liberação de diversas citocinas e interleucinas mediadoras deste processo, responsáveis também, pelos sinais e sintomas clínicos manifestados pelo paciente (RODRIGUES et al., 2019). Dentre os sintomas a dor é o agravo mais incapacitante, podendo ser intensificada pela por tempo prolongado, em função da resposta inflamatória, influenciando consequentemente, nas atividades diárias do indivíduo, gerando instabilidade emocional, baixa capacidade funcional, e sofrimento que pode desencadear baixa estima e até mesmo depressão (RENNER; ERFURT-BERGE, 2017; KAPP et al., 2017).

$\mathrm{Na}$ tentativa de acelerar o processo de reparo tecidual e reduzir esses sinais e sintomas, diversos produtos comerciais são empregados. Produtos com alta tecnologia que permite alcançar os objetivos do tratamento de forma mais segura e eficaz, em menor tempo, de forma seletiva, agindo em cada etapa do processo cicatricial. No entanto, a falta de conhecimento sobre os processos fisiológicos envolvidos no reparo tecidual pode prejudicar a assertividade das prescrições dos profissionais da saúde, repercutindo no agravamento das lesões, encarecimento dos gastos e ainda, maior exposição do paciente a outros agentes patogênicos (PROBST et al., 2020; MELO; FERNANDES, 2011).

Neste cenário, o presente trabalho tem por objetivo produzir um material informativo atualizado, destacando os principais pontos referente ao processo de 
reparo tecidual, inflamação e dor possibilitando contribuir com a compreensão acerca das bases biológicas da cicatrização, fornecendo paralelamente, um auxílio adicional que promova melhores condições de vida para os pacientes.

\section{METODOLOGIA}

A pesquisa bibliográfica foi realizada nas bases de dados do Google acadêmico, Science Direct, Medline, PubMed e Scielo, extensivo ao acervo do INPI (Instituto Nacional da Propriedade Industrial) com enfoque nos seguintes descritores: dor, inflamação, cicatrização, reparo tecidual e suas fisiologias, e recursos que auxiliam o processo de cicatrização, com filtros preferenciais para o período 2000 a 2021, porém, não limitantes. Um total de 130 publicações foram avaliadas, das quais 108 foram escolhidas em função das abordagens voltadas para o tema proposto.

\section{RESULTADOS}

\subsection{ASPECTOS TEÓRICOS DE INFLAMAÇÃO E DOR}

A inflamação é uma resposta inespecífica do sistema imunológico, caracterizada como resultado passivo de uma injúria tecidual, a qual as sucessivas produções de mediadores inflamatórios provocam alterações bioquímicas, celulares e vasculares a fim de restaurar a homeostase. Porém, quando mantido a longo prazo o processo inflamatório traz injúrias teciduais severas, promovendo incapacidade funcional e comprometimento da qualidade de vida dos pacientes, como observado em pacientes que sofrem de feridas crônicas, osteoartrite, artrite reumatoide, asma, enteropatia imunomediada (doença celíaca), alergias, infecções, dentre muitas outras doenças

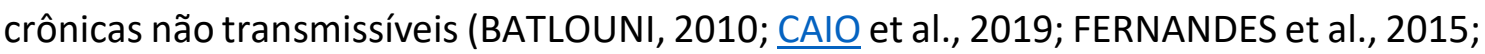
MELO et al., 2020; STAUDACHER; STEVENS, 2019).

De forma abrangente, a inflamação é um evento multifacetado que envolve a resposta fisiológica do organismo após sofrer uma lesão celular causado por agentes biológicos (vírus, bactérias, protozoários), agentes físicos (radiação, trauma, queimaduras), químicos (toxinas, substâncias cáusticas), necrose tecidual e/ou reações imunológicas e agentes imunes causados pela exposição aos antígenos para a ativação 
da resposta imunológica do hospedeiro (ABBAS; JANEWAY, 2000; GILROY et al., 2004; MELI et al., 2018).

A reação inflamatória é desencadeada pela mudança no ambiente químico que se caracteriza pelos sinais clássicos da inflamação, tais como: calor, rubor, edema, dor e perda de função vital, provocados pela ação dos mediadores nos tecidos locais. Especificamente, a vasodilatação e o aumento da permeabilidade vascular provocam o surgimento do calor e rubor, e as proteínas plasmáticas induzem a evasão de água para os tecidos, ocasionando a formação de edema. A dor, por sua vez, é decorrente da ativação dos nociceptores (IWALEWA et al., 2007; SPOCUA, et al., 2019).

A resposta inflamatória pode ser classificada em aguda ou crônica de acordo com a duração do processo. A forma aguda apresenta início rápido, porém com uma curta duração, sendo evidenciado pela presença de exsudação de líquido e proteínas plasmáticas, bem como pela migração de leucócitos, em especial, neutrófilos para a área da lesão. Portanto, manifesta-se histologicamente pela presença de linfócitos e macrófagos, ocasionando fibrose e necrose tecidua. Desta forma, a imflamação pode ser biomonitorada pela vasodilatação, quimiotaxia de leucócitos, seguido do influxo de macrófagos e células do sistema imune no foco inflamatório, que regride com resolução completa, após a remoção do estímulo que a desencadeou. Tais respostas são consideradas protetoras do organismo, que se destinam a combater bactérias, vírus e parasitas facilitando o reparo tecidual. No entanto, em casos extremos, a inflamação aguda pode evoluir para inflamação crônica, que por sua vez, apresenta duração prolongada, contudo, em ambos os processos, possuem respostas bioquímicas e celulares que acarretam uma série de alterações locais ou sistêmicas (COLEMAN, 2002; GILROY et al., 2004; IWALEWA et al., 2007; SERHAN; CHIANG, 2008;).

As inflamações associadas a doenças autoimunes, alergias, infecções, feridas crônicas, dentre outras, podem persistir por meses, anos ou se tornarem permanentes, e podem ser detectas pela presença de células mononucleares, remodelamento tecidual, angiogênese e fibrose. A inflamação crônica é considerada um fator de risco principalmente para alguns tipos de neoplasias gastrintestinais, como esofágica, gástrica, hepática ou colorretal. Isto acontece porque os mediadores liberados continuamente geram um ambiente favorável à progressão tumoral (AIOKY; NARUMIYA, 2012; FERNANDES et al., 2015; WANG; DUBOIS, 2015). 
De acordo com Rang et al. (2016) para que ocorra o processo inflamatório, as células envolvidas (macrófagos, mastócitos, eosinófilos, neutrófilos e leucócitos polimorfonucleares) liberam mediadores químicos como as histaminas, serotoninas, leucotrienos, citocinas e prostaglandinas. Portanto, se faz necessário observar os mecanismos e os mediadores subjacentes envolvidos no início da inflamação, iniciandose pela alteração da homeostase celular e tecidual, que é um importante papel desempenhado pelas membranas que contribuem para manter o equilíbrio no microambiente.

Especificamente, a composição da membrana celular é basicamente formada por fosfolipídeos, e quando ocorre o trauma, fragmentos destes fosfolipídeos são liberados e experimentam a ação da enzima fosfolipase $A_{2}$ (enzima presente em leucócitos e plaquetas na sua forma não ativada). A consequência dessa reação é a liberação do ácido araquidônico que embora não apresente diretamente ação inflamatória, os produtos que se originam em decorrência da sua degradação, provocam a inflamação. A degradação do ácido araquidônico, atua como substrato para duas enzimas, a lipoxigenase que é responsável pela síntese de leucotrienos, lipoxinas e outros compostos, e a cicloxigenase que desencadeia a biossíntese das prostaglandinas e dos tromboxanos (CARVALHO; LEMÔNICA, 1998; MELI et al., 2018).

Após a lesão, a sequência de eventos desencadeada contribui para a ativação do sistema de cininas que são pequenos polipeptídeos oriundos dos líquidos orgânicos, que ao serem acionados induzem a gênese final da bradicinina que uma vez formada, provoca intensa dilatação arteriolar e aumento da permeabilidade capilar, contribuindo para a disseminação da reação inflamatória. Entretanto, além da bradicinina, a histamina também produz vasodilatação, assim como outros mediadores como óxido nítrico (NO), prostaglandina E2 (PGE2) e prostaciclinas (PGI2), que são formados por meio da interação do agente agressor com o tecido. É importante destacar ainda, que a permeabilidade vascular também sofre alteração por ação da histamina e da bradicinina, devido a participação dos leucotrienos, fator de agregação plaquetária (FAP) e substância P (MEDZHITOV, 2008; ROCHA et al., 2007).

As citocinas constituem mediadores indispensáveis para dirigir a resposta inflamatória ao foco da lesão. São produzidas por sistema imunológico (linfócitos e macrófagos), células do endotélio, epitélio e tecido conjuntivo e exercem influência na 
atividade, diferenciação, proliferação e na sobrevida da célula imunológica, e auxiliam também, na regulação da síntese e na atividade de outras citocinas, que podem aumentar (pró-inflamatórias) ou diminuir (anti-inflamatórias) a resposta inflamatória. Estes mediadores podem ser classificados em interleucinas (IL), quimiocinas, interferons (INF), fatores do crescimento e fatores de necrose tumoral (TNF) (STARR et al., 1997; ZHANG; AN, 2007).

Neste contexto, destacam-se ainda, as endotelinas, que são mediadores peptídeos vasoconstritores, e possuem um importante papel na formação da dor inflamatória atuando no tecido lesionado por intermédio dos seus receptores do tipo A (ETA) e o receptor do tipo B (ETB), que por sua vez, pertencem a superfamília dos receptores da proteína G da membrana plasmática (ABDEL-SAYED et al., 2003; LEUNG, 2005).

Na inflamação aguda, logo após a injúria tecidual, as primeiras modificações se dão pelas alterações vasculares diante da liberação dos diversos mediadores inflamatórios, principalmente histamina, bradicinina, prostaglandinas, leucotrienos, substância P e óxido nítrico, levando ao aumento da permeabilidade vascular, que por sua vez, favorece a perda de líquido intravascular para o interstício (edema) gerando um acúmulo de hemácias no vaso e consequentemente limitando o fluxo sanguíneo (ABBOTT, 2000). Além disso, alterações endoteliais são desencadeadas pela liberação de fator de ativação plaquetária (PAF), histamina, trombina, fator de necrose tumoral $\alpha$ (TNF- $\alpha$ ) e interleucina 1 (IL-1) que levam a expressão de selectinas (ex. P-selectina, Eselectina), integrinas (ex. VCAM-1, ICAM-1) entre outras moléculas que favorecem o processo de rolamento, adesão e transmigração de leucócitos para o sítio inflamatório onde são de fundamental importância para o controle e resolução do processo inflamatório (LEUNG, 2005).

Quando a resposta inflamatória aguda é insatisfatória e incapaz de exercer a função reparadora e/ou eliminar os agentes etiopatogênicos o infiltrado de leucócitos se modifica, com predomínio de macrófagos e linfócitos T. Diante da presença persistente de corpos estranhos e/ou microrganismos o processo fagocitário realizado pelos macrófagos passa a ser constante levando o surgimento de granulomas e, ainda, necrose tecidual. Ainda se tratando de persistência do processo inflamatórios, várias patologias poderão surgir, principalmente as autoimunes onde os autos anticorpos 
evolvidos na inflamação passam a participar ativamente na patogênese de dor inflamatória crônica, como no caso dos lúpus eritematoso sistêmico, contribuindo para a ocorrência de lesão tecidual e inflamação excessiva. Os autoanticorpos mudam o estado funcional de neurônios, levando a uma excitabilidade dos mesmos, gerando sensação dolorosa constante (MCMAHON et al., 2015; MEDZHITOV, 2008).

Os anti-inflamatórios, na grande maioria, atuam na inibição da biossíntese dos mediadores inflamatórios derivados do ácido araquidônico. Os não-esteroidais (AINEs) possuem a função de inibir as ciclooxigenases (COX), enzimas responsáveis pela deterioração do ácido araquidônico e formação de prostaglandinas, prostaciclinas e tromboxanos, desempenhando ação analgésica, antipirética, anti-inflamatória e antitrombótica. Estes agentes, são utilizados principalmente no tratamento da osteoartrites, artrite reumatoide e distúrbios músculo-esqueléticos (BATLOUNI, 2010; KUMMER; COELHO, 2002; WANNMACHER; BREDEMEIER, 2004).

A enzima ciclooxigenase, apresenta duas isoformas a COX-1, que é expressa constitutivamente na maior parte dos tecidos, sendo responsável por funções fisiológicas, e a COX-2 ou indutiva, que é detectável na maioria dos tecidos normais, mas é induzida por estímulos inflamatórios. Nesse sentido, os anti-inflamatórios AINEs são capazes de inibir a COX-1 e COX-2 de maneira variável e, portanto, limitar a prostaglandina em todo o corpo (KUMMER et al., 2002; LUPEPSA et al., 2015; NEILL et al., 2013). No entanto, tem sido questionada a segurança do uso prolongado dos AINEs não seletivos da COX na prática clínica, já que inibem a produção de prostaglandinas na mucosa gastrointestinal, podendo causar gastroduodenite, úlcera gástrica e sangramento digestivo (BATLOUNI, 2010).

Segundo Alves Neto et al. (2008) com a resolução do processo inflamatório, a sensibilidade aumentada do tecido inflamado também tende a desaparecer. No entanto, em algumas situações mesmo não sendo observado lesão aparente, a dor pode continuar ou mesmo reaparecer após algum tempo. A dor se manifesta de diversas formas, podendo ser de maneira contínua, descontinua, difusa e até perfurante, estando classificada em aguda ou crônica (ALVES NETO et al., 2008; CALIL; PIMENTA, 2005).

Em relação a sua origem, a dor química está relacionada com as alterações metabólicas e eletroquímicas locais ocasionadas diante de um processo inflamatório 
agudo, oriundo de uma perda tecidual, rupturas vasculares, e outros estímulos. Já a dor neurogênica está associada com estímulos diretos as terminações nervosas ou a alterações genéticas, resultando em manifestação dolorosa irradiada aguda ou crônica. Na dor mecânica associa-se a compressão e distensão prolongadas do tecido (NIELSEN et al., 2012; STERIN; GALLEGO, 2005).

Existem quatro tipos principais de dor: dor nociceptiva, inflamatória, neuropática e funcional (RUSCHEWEYH et al, 2011). A dor nociceptiva é definida como uma dor finita e localizada, que resulta da ativação direta de nociceptores da pele e outros tecidos em resposta a uma lesão tecidual. Os tumores, por exemplo, podem contribuir para a dor nociceptiva ao esticar ou comprimir as vísceras e os tecidos circundantes (KLAUMANN et al., 2008; RUSCHEWEYH et al, 2011).

Especificamente, a dor nociceptiva se origina a partir da estimulação direta das terminações nervosas (nociceptores), podendo ser somática quando estas terminações forem de topografia de pele, ossos e músculos, ou visceral quando estas terminações forem das vísceras. Já a neuropática surge a partir de lesões ou compressões do sistema nervoso central (SNC) ou periférico (SNP), com dano nervoso determinado por diversos fatores, tais como: trauma, infecção, injúria química, isquemia, comumente percebidas pela sensação de queimação ou formigamento, sendo de difícil controle com analgésicos usuais. A dor inflamatória (complexa ou mista) envolve múltiplas características e requer a associação de fármacos para o seu controle. A dor funcional surge de alterações no processamento central dos sinais de dor recebidos (ALMEIDA et al., 2006; BABOS et al, 2013; FILLON, 2020; GARCIA, 2010; KLAUMANN et al., 2008; LIN KING et al., 2019; YADAV; SUROLIA, 2019).

Do ponto de vista clínico a dor fisiológica está relacionada com a sensibilidade (nociceptiva), caracterizada por ser uma alerta contra agentes nocivos como o calor, frio e objetos afiados. Já a dor inflamatória resulta do aumento da sensibilidade sensorial após um dano tecidual mais grave, que também possui função protetora, porém, mais inconveniente e duradora, gerando restrição de contato (perda funcional). Esta hipersensibilidade auxilia na redução de danos teciduais, buscando impedir a perpetuação do dano, o que teoricamente, favorece o reparo (GRUNDY et al., 2019; WOOLF, 2011). 
O fechamento das feridas em humanos por exemplo, acontece por reepitelização, por se tratarem de lesões superficiais que envolvem apenas a epiderme e parte da derme, devolvendo as características estruturais e funcionais do tecido. No entanto, nos casos de feridas de espessura total, com destruição total da epiderme e derme, o processo de reparo do tecido tem início com a formação do tecido de granulação e posteriormente, acontecerá a re-epitelização da lesão (SORG et al., 2017). Neste e em outros quadros, a manifestação de dor inflamatória varia de acordo com a percepção e limiar de dor de cada indivíduo, cedendo também aos estímulos nocivos (químicos, físicos ou mecânicos), constituindo um desequilíbrio na homeostase, que perturba a integridade do tecido e dispara uma resposta mediada por células efetoras que por sua vez, liberam mediadores químicos e sensibilizam a via periférica. Esta sensibilização ocorre quando nociceptores são expostos aos produtos do dano tecidual e da inflamação (cascata inflamatória), como histamina, bradicinina, citocinas, TNF- $\alpha$ e interleucinas (BASBAUM, 2009; HARGREAVES; RUPAREL, 2016)

As diferentes percepções da dor também estão relacionadas com à adversidade estrutural e funcional das vias condutoras dos sinais dolorosos. Estas vias, distintas em fibras do tipo $A \delta$ e $C$, estão envolvidas diretamente na diferenciação da dor aguda ou

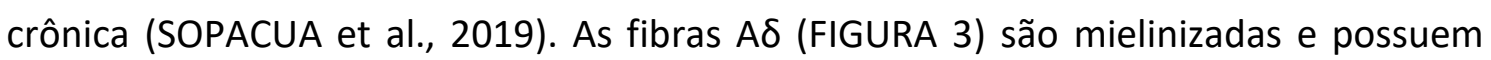
calibre e velocidade de condução intermediários (2 a $6 \mu \mathrm{m}$ de diâmetro e 12-30 m/s), estando envolvidas especificamente com a dor aguda (JI, CHAMESSIAN; ZHANG, 2016), o que se diferencia das fibras do tipo $C$, mais delgadas (0,4 - $2 \mu \mathrm{m}$ de diâmetro), amielinizadas e com baixa velocidade de condução $(0,65$ a $2 \mathrm{~m} / \mathrm{s})$, onde muitas destas fibras são chamadas de nociceptores polimodais, pois respondem a estímulos químicos, térmicos e mecânicos, estando associadas com a dor de origem inflamatória (crônica) (Jl et al., 2016).

Neste cenário, tem destaque um terceiro grupo denominadas de fibras $A \beta$, que são fibras espessas (> $10 \mu \mathrm{m})$, mielinizadas, e apresentam rápida velocidade de condução (30 - 100m/s), porém, não estão envolvidas com transmissão de estímulos nociceptivos, sua finalidade é detectar estímulos inócuos como o toque e a vibração, e inclusive, estão relacionadas à atenuação da dor, provavelmente atuando em interneurônios inibitórios (através de movimentos de friç̧ão/pressão no local da lesão) (JULIUS; BASBAUM, 2001). 
Além das diferentes formas de condução dos impulsos dolorosos, as fibras $A \delta$ e C também fazem a transdução dos estímulos nociceptivos externos em atividades elétricas, a partir disto iniciasse a liberação de mediadores inflamatórios como histamina, bradicinina, prostaglandinas, leucotrienos, entre outros, que desempenham um papel importantes no início da resposta inflamatória e na sensibilização de novos nociceptores. Após a sensibilização, o potencial de ação resultante é conduzido até o corno dorsal da medula espinhal onde convergem, havendo o processamento sináptico por neurônios de segunda ordem, através das vias espinotalâmica e espinoparabraquiais para os centros superiores (Bulbo, ponte, mesencéfalo, tálamo e hipotálamo). Estas atividades no trato espinotalâmico atravessam o tálamo até o córtex somatorensorial e áreas associativas. O núcleo parabraquial do tronco cerebral tem conexões com neurônios de terceira ordem no núcleo medial ventral do hipocampo e o núcleo central da amígdala, as regiões do cérebro envolvidas na resposta emocional da dor encerrando a via ascendente do processo doloroso (JI et al., 2016; EDVINSSON, 2011).

Alguns neurotransmissores como noradrenalina (NA), serotonina (5-HT), acetilcolina (Ach), ácido gama amino butírico (GABA), dopamina (DA), encefalinas, endomorfinas, entre outros, liberados durante o circuito nociceptivo, poderão modular a transmissão dos impulsos dolorosos nas vias superiores, principalmente os impulsos dos centros supraespinhais, que estão integrados na substância cinzenta periaquedutal do mesencéfalo, fundamental na modulação dos sinais nociceptivos (BANNISTER; DICKENSON, 2016).

Estas substâncias moduladoras atuam facilitando ou inibindo (efeito pró ou antinociceptivo) a resposta nociceptiva dependendo da intensidade do estímulo, a região do SNC envolvida, os receptores envolvidos no processo de transdução entre outros fatores. Esta diversidade de transmissores e de respostas geradas pela interação destes com os neurônios que compõem as vias do controle descendente da dor tornase um desafio. O melhor entendimento do processo doloroso pode ser considerado um elemento de alto impacto para os efeitos colaterais encontrados nas classes terapêuticas disponíveis (BANNISTER; DICKENSON, 2016).

Clinicamente a dor é um dos cinco sinais cardinais do processo inflamatório, geralmente associada a estímulos térmicos, mecânicos e/ou biológicos que ofereçam riscos a integridade tissular. Quando associada ao acúmulo de mediadores endógenos, 
liberados de neurônios aferentes, se caracteriza como uma inflamação neurogênica, ou de células não-neuronais que residem ou, principalmente, que infiltram a área lesionada, como macrófagos e neutrófilos. Esta sensibilização periférica é comumente resultante de alterações associadas ao processo inflamatório, como mudança no padrão de mediadores químicos que podem atuar nas fibras nociceptivas (SPOCUA et al., 2019).

Os nociceptores estão presentes na pele, nos músculos, nas articulações e nas vísceras com diferentes graus de densidades, o que possibilita uma capacidade sensorial diferencial em cada componente. Estão localizados nas terminações de fibras aferentes primárias do tipo $A \beta, A \delta$ e $C$, porém, cada um possui uma função específica, a fibra $A \beta$ por exemplo, é responsável por detectar estímulos inócuos aplicados a algum sistema, possui alto calibre e é mielinizada, e não está diretamente relacionada a transmissão dolorosa. Já as fibras aferentes primárias (A $\delta$ e C), quando sofrem ativação, passam por alterações em sua membrana, permitindo a deflagração de potenciais excitatórios que são propagados até o SNC, distinguindo-se na velocidade de disseminação dos estímulos. As fibras $C$ não são mielinizadas, e as $A \delta$ são pouco mielinizadas, o que contribui para uma maior velocidade de condução do impulso nervoso (LEMA; VOSCOPOULOS, 2010; JULIUS; BASBAUM, 2001).

Segundo Alves Neto et al. (2008) as fibras Aठ são responsáveis por propagar estímulos mecânicos e térmicos, originando a primeira fase da dor, e as fibras $\mathrm{C}$, ficam encarregadas da segunda fase que geralmente é mais duradoura e menos localizada, recebendo também estímulos químicos.

Dentre os estímulos que ativam os receptores da dor destacam-se componentes químicas que atuam como excitatórios, tais como: bradicinina, serotonina, histamina, íons potássio, acetilcolina, ácidos e enzimas proteolíticas. Comparativamente, a bradicinina em doses baixas, induz dor de forma mais acentuada, atuando na sensibilização direta dos nociceptores. Em doses mais altas, liberam mediadores que ativam nociceptores e causam dor, sendo um dos agentes principais responsável pela dor, após a lesão tecidual. Os íons potássio e as enzimas proteolíticas estão inteiramente associados com a intensidade da dor, sendo que as enzimas agem diretamente nos terminais, causando aumentando de permeabilidade. Já as prostaglandinas e a substância P atuam aumentando a sensibilidade das terminações nervosas (GUYTON; HALL, 2011; PATERSON et al., 2013; ROCHA et al., 2007). 
Na ocasião em que o estímulo ocasiona lesão tecidual se estabelece o processo inflamatório, e as células danificadas desprendem enzimas do seu interior, que no ambiente externo degradam ácidos graxos de cadeia longa e atuam sobre os cininogênios, dando gênese as cininas que contribuem para formação da bradicinina, que por sua vez, acarreta aumento da permeabilidade vascular auxiliando na propagação do estímulo. As interleucinas, o fator do crescimento, a bradicinina e a prostaglandina E2 desempenham papel fundamental na nocicepção periférica, por causar alteração nos receptores específicos, potencial receptor transiente (TRP) que são conectados aos canais iônicos ligante-dependente via ativação do AMPc e das proteínas cinases $A(P K A)$ e $C$ (PKC), minimizando o tempo pós-hiperpolarização da membrana neural, reduzindo o limiar para disparo da fibra nervosa (O'BANION, 1999; ROCHA et al., 2007).

A dor aguda é muito intensa ou repetitiva, os impulsos nociceptivos e a resposta de stress a ela associados, podem induzir nas redes neuronais estados de hiperexcitabilidade persistentes, que culminam para dor crônica, mesmo que a lesão aguda já tenha desaparecido. Este tipo de dor inicia-se com um agravo que contribui para que substâncias algogênicas sejam liberadas, estimulando as terminações nervosas (nociceptores) de fibras mielinizadas finas ou amielínicas. Na sequência, o impulso é conduzido das fibras aferentes para o corno posterior da medula ou para os núcleos sensitivos, como os nervos cranianos, onde ocorre a modulação, amplificação ou cancelamento do sinal, antes de ser projetado para as áreas específicas do tronco cerebral, tálamo, hipotálamo e córtex cerebral, onde é interpretado (DWORKIN et al., 2010; CALIL; PIMENTA, 2005).

De acordo com Klaumann et al. (2008) a dor crônica pode se manifestar de forma espontânea ou em decorrência a vários estímulos externos, apresenta resposta tipicamente exagerada em duração e amplitude sendo persistente além do período comumente esperado de uma doença ou injúria, e tem sido definida como aquela com duração maior que 3 a 6 meses. A dor crônica além de manifestar-se por um longo período, possui um significante impacto sobre a qualidade de vida do paciente e caracteriza-se por uma resposta pobre às terapias analgésicas convencionais. 


\subsection{FERIDA E REPARO TECIDUAL}

A pele é o maior órgão do corpo humano e representa aproximadamente $16 \%$ do peso corporal total. Este órgão atua como uma barreira de proteção contra agentes estressores ambientais, controla a perda de água e eletrólitos, dentre outros, com a finalidade de manter a homeostase orgânica. Porém, estas funções podem ser comprometidas diante de fatores que prejudicam a sua integralidade, como o aumento da pressão local, traumas mecânicos, químicos, físicos e intencionais (cirúrgicos), dando início ao desenvolvimento das lesões cutânea ou feridas, como são mais conhecidas (ALMEIDA et al., 2018).

Estas injúrias teciduais constituem um sério problema de saúde pública mundial, com aumento significativo no número de casos nos últimos dez anos. Segundo Vos et al. (2016), no período 2005 a 2015 houve um aumento significativo na prevalência de casos de lesões cutâneas, com base em dados globais, regionais e nacionais de mais de 195 países, resultando em 112.153 .000 casos. No Brasil, estes dados são preocupantes, já que aproximadamente 3\% da população, que equivale a 6,3 milhões de pessoas, têm algum tipo de ferida, o que gera altos custos para os serviços de saúde, uma vez que envolvem tratamentos complexos, internações prolongadas, uso de terapias adjuvantes, e cuidados domiciliares, além de estarem associadas a altos índices de recorrência (CAVASSAN; CAMARGO et al, 2018; OLIVEIRA et al., 2019; REICHENBERG; DAVIS, 2005).

Feridas são definidas como a perda da continuidade do tegumento, representadas não apenas pela ruptura da pele e do tecido celular subcutâneo, mas também, em alguns casos, músculos, tendões e ossos (SMANIOTTO, 2010). Estas lesões cutâneas podem ser classificadas quanto a sua etiologia, tempo de tratamento, morfologia e grau de contaminação, o que torna o tratamento destas lesões complexo exigindo curativos assertivos e profissionais qualificados para promover uma cura eficaz e livre de danos (COSTA; RODRIGUES, 2018).

Segundo o Guia Básico de Prevenção e Tratamento de feridas (LINS et al., 2016), podemos classificar as feridas quanto a sua etiologia em incisas ou cortantes, contusas, lacerada, perfurante, penetrante, escoriações, queimaduras, patológicas, iatrogênicas e amputação. De acordo com o grau de contaminação, as feridas podem ser classificadas 
em 4 subtipos, as feridas limpas, feridas potencialmente contaminadas, feridas contaminadas ou infectadas (COSTA et al., 2019).

As feridas limpas são caracterizadas por se manterem em condições assépticas e não apresentarem sinais de infecção. Já às feridas potencialmente contaminadas ou limpa-contaminadas são caracterizadas por possuírem menos de 6 horas de existência, sem contaminação significativa ou pouco contaminadas, porém, de maneira controlada ou premeditada. As feridas contaminadas são descritas como lesões existentes a mais de 6 horas ou técnica asséptica não foi realizada de maneira adequada, porém, ainda sem sinais de infecção. Por fim, as feridas infectadas são aquelas que apresentam sinais claros de infecção, com a presença dos sinais cardinais da inflamatória (edema, calor, rubor e dor) (RODRIGUES et al., 2019).

Levando em consideração as características morfológicas, as lesões ulcerativas são as mais prevalentes, seguidas de contusas e incisivas. As úlceras são lesões com características escavadas, circunscritas na pele, com profundidade variável, podendo atingir camadas superficiais ou profundas, evolvendo desde a epiderme, derme, tecido subcutâneo, músculos e osso (COSTA, et al., 2019).

De acordo com o tempo de tratamento, as feridas podem ser classificadas como agudas ou crônicas. As Feridas agudas são caracterizadas pela perda da integridade do tecido ou de partes moles circundante de qualquer parte do corpo, ocasionada, na maioria das vezes, por uma intervenção cirúrgica ou trauma. O processo de reparo tecidual não apresenta dificuldades e persiste até 14 dias, no entanto, algumas são sujeitas a fatores que impedem a evolução do processo cicatricial, como fluxo sanguíneo local, fornecimento de oxigênio deficiente, infecção ou danos ao sistema vascular (ANDRADE; SANTOS, 2016).

As feridas crônicas possuem um tempo de cicatrização maior que o esperado, havendo um retardo no processo de cicatrização devido a fatores extrínsecos e/ou intrínsecos. Para esta categoria de ferida a cura não ocorre antes de três meses, o que torna o seu tratamento um grande desafio para as autoridades de saúde pública, ainda mais quando associada as doenças de base como diabetes, obesidade e doenças vasculares, que tendem a dificultar ainda mais o processo de cicatrização (ALAMEIDA et al., 2018; COSTA; RODRIGUES, 2018). 
A classificação assertiva da ferida torna-se relevante para o entendimento de como ocorrerá a cicatrização tecidual, ponto esse decisivo para a escolha do melhor tratamento e, consequentemente, o melhor resultado. Segundo Costa et al. (2019), o processo de cicatrização pode ocorrer por cinco tipos, tais como:

i) cicatrização por primeira intenção, comum em lesão por incisão cirúrgica (feridas cirúrgicas) quando é possível realizar a junção das bordas da lesão por meio de suturas ou qualquer tipo de aproximação, facilitando e diminuindo o tempo de cicatrização;

ii) cicatrização por segunda intenção, prevalentes em feridas com perda acentuada de tecido, bordas afastadas, na maioria dos casos infectadas fazendo com que o risco de complicações aumente e o tempo de cicatrização se estenda quando em comparação com a cicatrização por primeira intenção;

iii) cicatrização por terceira intenção ocorre quando há fatores que retardam a cicatrização de uma lesão inicialmente submetida a um fechamento por primeira intenção, ou quando a ferida é deixada, intencionalmente, aberta para que diminuam os sinais de infecção ou para permitir uma drenagem de substância contida na ferida.

iv) cicatrização no diabetes mellitus é caracterizada pelo endurecimento e estreitamento de vasos sanguíneos, que tem como consequência uma redução do fluxo causadas pela hiperglicemia. Podem estar associadas ou não a neuropatia diabética resultando na diminuição ou perda da sensibilidade térmica, tátil e dolorosa.

v) cicatrização em coagulopatias é descrita como um processo lento, a depender da etiologia, que podem ser primárias ou secundárias que diante da ausência de algum dos fatores de coagulação retarda a cicatrização, pela dificuldade da hemostasia gerando atraso no início a reparação tecidual.

A cicatrização consiste em um processo organizado e estruturado em forma de cascata onde uma sequência de eventos celulares e bioquímicos passam a interagir culminando em regeneração do tecido lesionado (CAMPOS et al., 2007). Este processo é complexo e dinâmico, e pode ser dividido em quatro fases: hemostasia, inflamatória, proliferativa, e remodelamento, e se estendem em torno de duas ou três semanas (RODRIGUES et al., 2018; SINNO et al., 2013).

Neste sentido, é importante ressaltar que a resposta de reparação do paciente também pode interferir no controle e regulação de processos multicelulares e 
moleculares da cicatrização de feridas, comprometendo (ou otimizando) a inflamação, angiogênese, deposição de matriz extracelular e recrutamento celular. Desta forma, os mecanismos regulatórios do processo de reparo tecidual podem estar vinculados a enfermidades associadas como o diabetes, câncer, desnutrição, imunossupressão, quadros infecciosos e outras doenças crônicas e vasculares, que juntos ou isoladamente, podem estender o período de cura da ferida por semanas, meses e anos. $O$ atraso no processo de reparo tecidual poderá acontecer em qualquer lesão, porém, é mais frequente nos casos de insuficiência vascular, diabetes, exposição à radiação, ou ao prolongado tempo de imobilismo no leito (EMING et al., 2014; GURTNER et al., 2008; SEN et al., 2009).

A fase da hemostasia ocorre logo após o dano tecidual e é caracterizada por hemostasia e inflamação, tendo como objetivo limitar a hemorragia e a perda de fluidos, a remoção de tecidos desvitalizados e a prevenção de infecções. A exposição do colágeno ativa a cascata de coagulação sanguínea e ainda nesta fase, haverá vasoconstrição e adesão e agregação plaquetária, formando o coágulo ou trombo sanguíneo. Em seguida haverá a infiltração da fibrina, formando o arcabouço fibroso para sustentação das células que irão iniciar o processo de reparo tecidual. A degranulação das plaquetas ativa a cascata de complemento (C5), libera mediadores vasoativos e quimiocinas, que desempenham um papel fundamental na quimiotaxia para neutrófilos. Concluída a fase de hemostasia, há liberação de histamina pelos mastócitos, que irá favorecer a vasodilatação, aumentando o fluxo sanguíneo e a permeabilidade vascular e, consequentemente, a migração de células inflamatórias. Os neutrófilos são as primeiras células de defesa a migrarem para o local da lesão e logo em seguida chegam os monócitos, que se diferenciam em macrófagos, continuam o processo de desbridamento da ferida iniciado pelos neutrófilos e liberam citocinas, colagenases e fatores de crescimento que estimulam os fibroblastos a iniciarem a angiogênese (EMING et al., 2014; GONZALEZ et al., 2016; GURTNER et al., 2008; REINKE; SORG; 2012; SORG et al., 2017; TAKEO et al., 2015; WOO, et al., 2004).

A fase inflamatória é caracteriza pela migração de neutrófilos e macrófagos para a área lesada, com síntese e liberação de citocinas pró-inflamatória, com destaques para TGF- $\beta$, IL-1, IL-8, TNF- $\alpha$ e IFN- $\gamma$ que agem auxiliando na quimiotaxia celular e na diferenciação de monócitos em macrófagos. Além disso, receptores estimulam a 
ativação de vias de sinalização intracelulares, incluindo o fator nuclear Kappa-beta (NFkB) e vias de proteínas quinase ativas por mitogênio (MAPK) que levam à expressão de genes envolvidos com a perpetuação da inflamação, mantendo a produção e liberação de citocinas, quimiocinas e peptídios antimicrobianos (KAISHO; AKIRA, 2006; DABIRI et al., 2016; RODRIGUES et al., 2019; TAKEUCHI; AKIRA, 2010).

A fase proliferativa se caracteriza pela formação do tecido de granulação, epitelização, angiogênese e deposição de colágeno. Nesta etapa haverá a substituição da matriz extracelular por um tecido conjuntivo mais resistente e elástico, produzido pelos fibroblastos, formando um novo substrato para migração subsequente de queratinócitos. Os macrófagos e as células endoteliais continuam liberando fatores de crescimento, tais como: Fator de Crescimento de Fibroblasto (FGF), Fator de Crescimento do Endotélio Vascular (VEGF) e o Fator de Necrose Tumoral Alfa (TNF- $\alpha$ ), promovendo, desta forma, a fibroplasia, colagênese e angiogênese. A partir da formação de novos vasos e reparação dos capilares lesionados, estarão garantidos a nutrição celular e a manutenção do tecido de granulação. Ainda nesta fase, ocorre a reepitelização, quando os queratinócitos basais proliferam para assegurar o número de células para re-estruturação do tecido e consequentemente, migram das bordas da ferida para o leito da lesão, restabelecendo a função de barreira do epitélio. Além disso, como células contráteis, os miofibroblastos depositados nas bordas da lesão irão contribuir para a contração da ferida (DRISKELL et al., 2013; GONZALEZ et al., 2016; GURTNER et al., 2008; LI et al., 2007; SINNO; PRAKASH, 2013).

Portanto, na fase proliferativa os queratinócitos existentes na camada basal das bordas da ferida e as células-tronco dos epitélios dos folículos capilares ou glândulas sudoríparas próximas começam a proliferar (LAU, et al., 2009). Este processo é desencadeado pela perda de inibição de contato e tensão física nas estruturas de adesão celular, ou seja, desmossomos e hemidesmossomos, que ativam as cinases associadas à membrana, levando a um aumento da permeabilidade da membrana ao cálcio. Este é um sinal para a reorganização da migração do citoesqueleto (DABIRI et al., 2001; 2016; RODRIGUES et al., 2019).

A re-epitelização é estimulada a partir de liberação de vários fatores de crescimento, dentre os principais está o EGF - fator de crescimento epidérmico, NGF fator de crescimento nervoso, VEGF - fator de crescimento endotelial vascular e bFGF - 
fator básico de crescimento de fibroblastos. Com a liberação destes fatores de crescimento ocorre a fibroplasia, processo de deposição de fibras de colágeno, e a angiogênese (gênese de novos vasos) aumentado a vascularização tecidual dando o aspecto vermelho brilhante, clinicamente chamado de "tecido de granulação", culminando na repitelização, caracterizada pela migração de queratinócitos não danificados das margens da ferida para o centro, que com o apoio dos miofibroblastos, retrai a lesão até o seu fechamento (DABIRI et al., 2016; LI et al., 2003; RODRIGUES et al., 2019).

Na última fase, o remodelamento começa no final do desenvolvimento do tecido de granulação, que a partir da liberação de citocinas, como o TGF- $\beta$, os fibroblastos se diferenciam em miofibroblastos que passam a expressar a actina do músculo liso (SMA) e contrai a ferida (HINZ, 2007).

O colágeno produzido inicialmente é mais fino do que o colágeno presente na pele normal, e tem orientação paralela à pele. Com o tempo, o colágeno inicial (colágeno tipo III) é reabsorvido e um colágeno mais espesso é produzido e organizado ao longo das linhas de tensão. Estas mudanças se refletem em aumento da força tênsil da ferida. A reorganização da nova matriz é um processo importante da cicatrização. Mesmo após um ano a ferida apresentará um colágeno menos organizado do que o da pele sã, e a força tênsil jamais retornará a $100 \%$, atingindo em torno de $80 \%$ após três meses (DABIRI et al., 2016; GREENHALGH, 1998; RODRIGUES et al., 2019).

\subsection{RECURSOS QUE AUXILIAM O PROCESSO DE CICATRIZACÃO}

Os produtos para tratamentos de feridas podem ser reunidos em dois grandes grupos: agentes tópicos e curativos. Segundo Ayello (2003) o sucesso no tratamento de feridas depende da avaliação assertiva e do uso de técnicas e recursos. Portanto, uma intervenção efetiva no processo cicatricial, depende do diagnóstico preciso do tipo de lesão e seu estágio cicatricial, e critérios clínicos e técnicos. No entanto, a diversidade de opções pode tornar extremamente desafiadora a decisão, já que estão disponíveis mais de 2.500 produtos que se destinam ao tratamento de feridas agudas e crônicas, e vão desde os materiais mais simples (soluções para higienização e antisepsia) até os mais complexos tipos de curativos, que interferem de forma ativa nas diversas fases do 
processo cicatricial, dos vários tipos de feridas (CUZZELL; KRASNER, 2003; MARQUEZ, 2003).

Pesquisas relacionadas a compreensão dos efeitos fotobiológicos do método LLLT (Low-Level Laser Therapy) nos tecidos lesionados, mostram que os resultados de cicatrização vinculados a este método, dependem diretamente do comprimento de onda do laser e da absorção da energia pelos cromóforos, via absorção dos fótons pela enzima citocromo-c-oxidase (DE FREITAS; HAMBLIN, 2016). As pesquisas relacionadas a compreensão dos efeitos fotobiológicos da LLLT mostram que inicialmente ocorre a fotoativação da molécula fotorreceptora, principalmente a Citocromo C Oxidase da cadeia respiratória, em seguida a absorção da luz, o que leva a tradução e amplificação do sinal, e por fim, o desencadeamento das respostas bioativas. Após a absorção dos fótons ocorre a ativação de diferentes vias de sinalização envolvendo espécies reativas de oxigênio (ROS), AMP cíclico, oxido nítrico e cálcio $\left(\mathrm{Ca}^{2+}\right)$, culminando com a ativação de fatores de transcrição e posteriormente, com o aumento da expressão de genes envolvidos na síntese de proteínas, migração e proliferação celular, sinalização da resposta anti-inflamatória, ativação de enzimas antioxidantes e proteínas antiapoptóticas (DE FREITAS; HAMBLIN, 2016; KARU, 2008; MÁRQUEZ-MARTíNEZ et al., 2008).

Apesar da amplitude de estudos que avaliam os efeitos da LLLT em tecidos biológicos, de acordo com alguns autores, foram observadas imprecisões nas descrições de parâmetros de irradiação, como comprimento de onda, potência, tempo de irradiação, área do feixe, parâmetros de pulso, intervalo entre tratamentos, número de sessões, dentre outros aspectos. Portanto, ainda não há consenso e diretrizes claras para a determinação da dosimetria ideal bem como definição dos mecanismos de ação envolvidos nos efeitos biológicos (DA SILVA et al., 2010; HADIS et al., 2016; MUSSTTAF et al.; 2019; POSTEN et al., 2005; RODRIGUES et al., 2015; WHINFIELD; AITKENHEAD, 2009).

Apesar das propriedades farmacológicas eficazes de muitos biomateriais, evidenciam-se muitas limitações para bioativos lipofílicos, que não apresentam solubilidade em água e ainda, apresentam baixa solubilidade em solventes orgânicos biologicamente compatíveis. A busca por novos recursos terapêuticos eficazes que possibilitem redução de toxicidade reforça o interesse e a importância do 
desenvolvimento de novos medicamentos. Nesta perspectiva, dentre os importantes veículos de liberação controlada de fármacos no seu sítio de ação, tem destaque os sistemas coloidais (nano- e microemulsões) pela possibilidade de biodisponibilizar o fármaco (componentes lipossolúveis ou hidrossolúveis) na sua forma solubilizada, via liberação controlada, mantendo os efeitos terapêuticos mediante redução da dose bioativa, e consequentemente, diminuição de efeitos adversos (EMERENCIANO et al., 2019; KASSEM et al., 2016; UPPAL et al., 2018; XAVIER-JUNIOR et al., 2016). Neste contexto, evidencia-se o progresso biotecnológico de fármacos com ações analgésica, anti-inflamatória e cicatrizante, como exemplificados a seguir.

Sistemas coloidais nano- e microemulsionados, resistentes a diluições em água, carreadores de óleo de copaíba $(O C)$ veiculado em baixa concentração $(0,5$ a $2 \%)$ em sistema isento de co-tensoativo, contendo o tensoativo Tween ${ }^{\circledR} 80$, para uso oral e tópico. Possibilitaram a solubilização e doseamento de OC com ação terapêutica eficaz, isenta de efeitos adversos, para tratamento específico de lesões cutâneas. O bioativo OC nano- ou microestruturado, acelerou o processo de cicatrização com favorecimento de neovascularização e ação fibrinogênica (MACIEL et al., 2014a, 2014b; DE MEDEIROS et al., 2017)

De Medeiros et al. (2019) desenvolveram nanoemulsões com característica SNEDDS (self-nanoemulsifying drug delivery system) à base de óleo de copaíba (OCP) para uso tópico e oral na terapêutica de cicatrização, associada com laser, com aplicação tópica em lesões cutâneas. Para tanto, amostras de óleo de copaíba (OCP) das espécies Copaifera reticulata Ducke e Copaifera multijuga Hayne), foram veiculadas (0,5\% a 3,0\%) em sistema coloidal SNEDDS para uso tópico associado com laser (Laser vermelho $660 \mathrm{~nm}, 4 \mathrm{j} / \mathrm{cm}^{2}$, contínuo, potência $40 \mathrm{~mW}$, pontual, mantendo a distância de um centímetro do bordo da lesão e entre os pontos). Os ensaios in vivo para cicatrização de feridas (não infectada) foram realizados com ratos Wistar (Rattus novergicus albinus). Os animais foram divididos em grupos de 5 animais $(n=5)$, submetidos a cirurgia para retirada de retalho cutâneo na região dorsal e receberam tratamento tópico diário, com os sistemas SNEDDS-OCP, durante o período pós-operatório. Análises histopatológicas e imunohistoquímicas foram realizadas após 7 e 14 dias de tratamento para ambos os grupos. Análises histomorfométricas revelaram um menor número de neutrófilos e linfócitos nos grupos tratados ( 7 dias), bem como aumento da colagênese, proliferação 
de fibroblastos e maior espessamento epitelial, que por comparação, foram mais evidentes nos grupos tratados (14 dias). Nos grupos controle, o atraso no reparo tecidual foi relacionado à presença de queratinócitos em função do aumento da imunorreatividade para IL-1 $\beta$. O maior número de células imunocoradas com FGF-2 foi associado à melhora da colagênese e do processo de reparo tecidual cutâneo. Além disso, foi realizada uma abordagem comparativa in vivo dos processos terapêuticos, em modelo experimental de lesões cutâneas, na qual foi avaliado o efeito da terapia com laser de baixa intensidade (LLLT) na angiogênese e imunoexpressão da metaloproteinase-2 de matriz, na ausência e/ou presença do sistema SNEDDS-OCP. Os nanoformulados SNEDDS-OCP também foram avaliados via protocolos experimentais in vivo pelo método de analgesia via inibições das contorções abdominais induzidas pelo ácido acético. Os resultados mostraram resposta anti-inflamatória, cicatrizante e antiséptica, via uso tópico, bem como efeito antinociceptivo, via administração oral.

Ribeiro et al. (2018) viabilizaram veiculações e avaliações terapêuticas de bioformulados do tipo SNEDDS preparados a base de Morinda citrifolia Linn. (noni). 0 sistema SNEDDS carreador foi eficaz na solubilização e veiculação do extrato hidroalcoólico (1,0 mg a 10,0 mg) obtido do fruto desidratado de noni, para uso oral, no combate a processos inflamatórios. Os dados farmacológicos obtidos comprovaram a eficácia anti-inflamatória e analgésica dos formulados SNEDDS-noni, que poderá contribuir com o uso terapêutico de M. citrifolia no tratamento de patologias inflamatórias, tais como: artrite, artrose, fibromialgias e colites ulcerativas. Estes formulados também foram avaliados no tratamento de cicatrização de feridas cutâneas com resultados significativos, com aumento da colagênese, proliferação de fibroblastos e maior espessamento epitelial (SAMPAIO et al., 2015).

Veiculações de extratos, frações e compostos bioativos obtidos de Croton cajucara Benth, incorporadas em sistemas coloidais SMEDDS (self-microemulsion drug delivery system), foram eficazes na terapêutica da dor e inflamação. As atividades analgésica e anti-inflamatória dos bioprodutos (25 a $5 \mathrm{mg} / \mathrm{kg}$ ), foram avaliadas via protocolos experimentais in vivo (v.o.) com resultados significativos, com possibilidade de novas avaliações em diversas patologias inflamatórias, tais como: artrite, artrose, fibromialgias, colites ulcerativas, dentre outras (MEDEIROS et al., 2016a; 2016b). 
Martins et al. (2018) desenvolveram um biofilme cicatrizante a base de quitosana e extrato hidroalcoólico de Croton cajucara Benth veiculado em baixas concentrações (5 mg - $30 \mathrm{mg}$ ) em nanoemulsão SNEDDS (self-nanoemulsion drug delivery system). Após avaliação do biofilme cicatrizante em modelo experimental in vivo, observou-se evolução do processo cicatricial via estudos histopatológicos, com indução satisfatória de neovascularização e formação de fibras de colágeno.

Por uma questão de conscientização ambiental associada ao progresso de novos produtos biotecnológicos, Maciel et al. (2016) desenvolveram formulações nanoemulsionadas (NE) contendo fitocomponentes extraídos dos extratos hidroalcoólicos preparados a partir da biomassa FC (farinha obtida do rejeito orgânico "bagaço de caju") em mistura $(1 ; 1)$ com o pó das cascas do caule do cajueiro (AO). As biomassas FC/AO e AO foram veiculadas na forma de extratos $\left(\mathrm{EtOH} / \mathrm{H}_{2} \mathrm{O}\right)$ em um sistema NE carreador, preparado com mistura de Tweens e óleo vegetal, em baixas concentrações, produzindo nanoformulações (NE-FC/AO e NE/AO) que agme com liberação assistida (gradual e prolongada). As nanoemulsões foram avaliadas em experimento in vivo, e apresentaram ação antinociceptiva significativa, contribuindo com a produção de medicamentos naturais advindos da biodiversidade botânica brasileira. Portanto, expandem as opções de fabricação biossustentável de produtos medicinais produzidos no Brasil.

\section{REFERÊNCIAS}

ABBAS, A. K.; JANEWAY, C. A. J. Immunology: improving on nature in the twenty-first century. Cell, v. 100, n. 1, p. 129-138, 2000.

ABBOTT, N. J. Inflammatory mediators and modulation of blood-brain barrier permeability. Cellular and Molecular Neurobiology, v. 20, n. 2, p. 131-47, 2000.

ABDEL-SAYED, S.; NUSSBERGER, J.; AUBERT, J. F.; GOHLKE, P.; BRUNNER, H. R.; BRAKCH, $N$. Measurement of plasma endothelin-1 in experimental hypertension and in healthy subjects. American Journal of Hypertension, v. 16, n. 7, p. 515-521, 2003.

AIOKI, T.; NARUMIYA, S. Prostaglandins and chronic inflammation. Trends in Pharmacological Sciences, v. 33, n. 6, p. 304-311, 2012. 
ALMEIDA, T. P.; MAIA, J. Z.; FISCHER, C. D. B. Classificação dos processos dolorosos em medicina veterinária - revisão de literatura. Veterinária em Foco, v. 3, n. 2, p. 107-118, 2006.

ALMEIDA, W. A.; FERREIRA, A. M.; IVO, M. L.; RIGOTTI, M. A.; BARCELOS, L. S.; SILVA, A. L. N. V. Factors associated with quality of life of people with chronic complex wounds. Journal of Research: Fundamental Care Online, v. 10, n. 1, p. 9-16, 2018

ALVES NETO, O.; COSTA, C. M. C.; SIQUEIRA, J. T.T.; TEIXEIRA, M. J. Dor: princípios e prática. Porto Alegre: Artmed, 2008, p.1-15.

ANDRADE, S. M.; SANTOS, I. C. R. V. Oxigenoterapia hiperbárica para tratamento de feridas. Revista Gaúcha de Enfermagem, v. 37, n. 2, 2016.

AYELLO E, FRANZ R. Pressure ulcer prevent and treatment: competency-based nursing curricula. Dermatology Nursing, v. 15, n. 1, p. 44-65, 2003.

BABOS, M. B. Pathophysiology of pain. Disease-a-Month, n. 59, p. 330-358, 2013.

BANNISTER, K.; DICKENSON, A. H. What do monoamines do in pain modulation? Current Opinion in Supportive and Palliative Care, v. 10, n. 2, p. 143-8, 2016.

BASBAUM, A. I.; BAUTISTA, D. M.; SCHERRER, G.; JULIUS, D. Cellular and molecular mechanisms of pain. Cell, v. 139, p. 267-284, 2009.

BATLOUNI, M. Anti-inflamatórios não esteroides: efeitos cardiovasculares, cérebrovasculares e renais. Arquivo Brasileiro de Cardiologia, v. 94, n. 4, p. 556-563, 2010.

CALIL, A. M.; PIMENTA, C. A. M. Intensidade da dor e adequação de analgesia. Revista Latino Américana de Enfermagem, v. 13, n. 5, p. 692-699, 2005.

COLEMAN, J. W. Nitric oxide: a regulator of mast cell activation and mastcell-mediated inflammation. Clinical and Experimental Immunology, v. 129, n. 1, p.4-10, 2002.

CAMPOS, A. C. L.; BORGES-BRANCO, A.; GROTH, A. K. Cicatrização de feridas. Arquivos Brasileiros de Cirurgia Digestiva, v. 20, n. 1, p. 51-58, 2007.

CARVALHO, W. A.; LEMÔNICA, L. Mecanismos celulares e moleculares da dor inflamatória, modulação periférica e avanços terapêuticos. Revista Brasileira de Anestesiologia, v. 48, n. 2, p. 137-158, 1998.

CAVASSAN, N. R. V.; CAMARGO, C. C.; PONTES, L. G.; BENEDITO BARRAVIERA, B. FERREIRA, R. S.; MIOT, H. A.; ABBADE, L. P. F.; DOS SANTOS, L. D. Correlation between chronic venous ulcer exudate proteins and clinical profile: a cross sectional study. Journal of Proteomics, v. 192, p. 280-290, 2018. 
COSTA, A.P.; CAMPOS, E.R.; PERONDI, E.M.; VIEIRA, E.L.B.; ARAÚJO, J.M.A.; CHAVES, L.G.S.; OLIVEIRA, M.M.R. Protocolo de reconhecimento e tratamento de feridas na atenção primária. Porto Velho: Ed. UniSL, 2019.

COSTA, J. S.; RODRIGUES, L. D. C. V. Importância da assistência de enfermagem no tratamento de feridas complexas: uma revisão integrativa. In: II Congresso Norte-Nordeste de Feridas e Coberturas, 2., 2018, Maceió/AL. Anais de Congresso, Maceió: Hotel Best Western Premier, 2018.

COSTA SILVA, M. A antinocicepção induzida pela ingestão de óleo - resina de copaíba (Copaifera langsdorffii) nanoencapsulado recruta receptores opioides $\mu 1 \mathrm{e} \mathrm{k} d a$ substância cinzenta periaquedutal ventrolateral. Dissertação de Mestrado, Programa de Pós-Graduação em Ciências em Saúde da Universidade Federal de Mato Grosso. 2020. p. 66

CUZZEL J, KRASNER D. CURATIVOS. In: Gogia P. Feridas - tratamento e cicatrização. Rio de Janeiro: Livraria Editora Revinter Ltda., Cap. 9, p. 103-114, 2003.

DABIRI, G.; DAMSTETTER, E.; CHANG, Y.; EBOT, E. B.; POWERS, J. G.; PHILLIPS, T. Coagulation disorders and their cutaneous presentations: diagnostic work-up and treatment. Journal of the American Academy of Dermatology, v. 74, p. 795804, 2016.

DE MEDEIROS, M. L.; ARAÚJO FILHO, I.; RÊGO, A. C. M.; PEREIRA, J. D. S.; BARACHO, B. B. D.; LIMA, M. C. F.; VEIGA JÚNIOR, V. F.; MEDEIROS, M. I. T.; MACIEL, M. A. M. Formulados a base de óleo de copaíba biodisponibilizados para uso oral e tópico associado com aplicações terapêuticas na analgesia, inflamação e cicatrização. BR102017014800-9, INPI - Instituto Nacional da Propriedade Industrial. 2017.

DE MEDEIROS; PEREIRA, J. D. S.; BARACHO, B. B. D.; MEDEIROS, M. I. T.; ARAÚJO-FILHO, I.; VEIGA-JÚNIOR, V. F.; DE LIMA, M. C. F.; ALBUQUERQUE-JÚNIOR, R. L. C.; TAVARES, L. A.; GONÇALVES-JÚNIOR, W. D.; DO NASCIMENTO, J. H. O.; MACIEL, M. A. M. Nanoformulação desenvolvida à base de óleo de copaíba para uso tópico em processo de cicatrização associado com laser. BR102019015537-0, INPI - Instituto Nacional da Propriedade Industrial. 2019.

DOVI, J. V.; HE, L. K.; DIPIETRO, L. A. Accelerated wound closure in neutrophil-depleted mice. Journal of Leukocyte Biology, v. 73, p. 448-55, 2003.

DRISKELL, R. R.; LICHTENBERGER, B. M.; HOSTE, E.; KRETZSCHMAR, K.; SIMONS, B. D.; CHARALAMBOUS, M.; FERRON, S. R.; HERAULT, Y.; PAVLOVIC, G.; FERGUSONSMITH, A. C.; WATT, F. M. Distinct fibroblast lineages determine dermal architecture in skin development and repair. Nature, v. 504, n. 7479, p. 277-281, 2013.

DWORKIN, R. H.; O'CONNOR, A. B.; AUDETTE, J.; BARON, R.; GOURLAY, G. K.; HAANPAA, M. L.; KENT, J. L.; KRANE, E. J.; LEBEL, A. A.; LEVY, R. M.; MACKEY, S. C.; MAYER, 
J.; MIASKOWSKI, C.; RAJA, S. N.; RICE, A. S. C.; EMERENCIANO, D. P.; BARACHO, B. B. D.; MEDEIROS, M. L.; ROCHA, H. A. O.; XAVIER-JÚNIOR, F. H.; VEIGA-JÚNIOR, V. F.; MACIEL, M. A. M. Physicochemical characterizations and antioxidant property of copaiba oil loaded into SNEDDS systems. Journal of the Brazilian Chemical Society, v. 30, n. 2, p. 234-246, 2019.

EDVINSSON, L. Tracing neural connections to pain pathways with relevance to primary headaches. Cephalalgia, v. 31, n. 6, p. 737-47, 2011.

EMING, S. A.; MARTIN, P.; TOMIC-CANIC, M. Wound repair and regeneration: mechanisms, signaling, and translation. Science Translational Medicine, v. 6, n. 265, p. 16, 2014.

FEARNS, N.; HELLER-MURPHY, S.; KELLY, J.; HARBOUR, J.; Placing the patient at the centre of chronic wound care: a qualitative evidence synthesis. Journal of Tissue Viability, v. 26, n. 4, p. 254-259, 2017.

FERNANDES, J. V.; COBUCCI, R. N. O.; JATOBÁ, C. A. N; FERNANDES, T. A. M.; AZEVEDO, J. W. V.; ARAÚJO, J. M. G. The role of the mediators of inflammation in cancer development. Pathology \& Oncology Research, v. 21, n. 3, p. 527-534, 2015.

FILLON, M. Exploring the causes of chronic cancer pain and possible remedies CA. CA: A Cancer Journal for Clinicians, v. 70, p. 75-76, 2020.

GARCIA, J. B. S. Dor neuropática. Sociedade Brasileira para Estudos da Dor, f. 2, p. 1-7, 2010.

GILROY, D. W.; LAWRENCE, T.; PERRETTI, M.; ROSSI, A. G. Inflammatory resolution: new opportunities for drug Discovery. Nature Reviews Drug Discovery, v. 3, p. 401416, 2004.

GONZALEZ, A. C.; COSTA, T. F.; ANDRADE, Z. A.; MEDRADO, A. R. Wound healing - A literature review. Anais Brasileiros de Dermatologia, v. 91, n. 5, p. 614-620, 2016.

GREENHALGH, D. G. The role of apoptosis in wound healing. The International Journal of Biochemistry \& Cell Biology, v. 30, n. 9, p. 1019-1030. 1998.

GRUNDY, L.; ERICKSON, A.; BRIERLEY, S. M.; Dor visceral. Annual Review of Physiology, v. 81, p. 261-284, 2019.

GUPTA, S.; ANDERSEN, C.; BLACK, J.; LEON, J.; FIFE, C.; LANTIS, J.C.L.; NIEZGODA, J.; SUMPIO, B.; TREADWELL, T.; SNYDER, R.J.; TETTELBACH, W.; WEIR, D.; SILVERMAN, R.P. Management of chronic wounds: diagnosis, preparation, treatment, and follow-up. Wounds, v. 29, n. 9, p. 19-36, 2017. 
GURTNER, G. C.; WERNER, S.; BARRANDON, Y.; LONGAKER, M. T. Wound repair and regeneration. Nature, v. 453, n. 7193, p. 314-321, 2008.

GUYTON, A. C.; HALL, J. E. Tratado de fisiologia médica. 12a ed. Rio de Janeiro: Editora Elsevier, 2011, pp. 617- 621.

HARGREAVES, K. M.; RUPAREL, S. Role of oxidized lipids and TRP channels in orofacial pain and inflammation. Journal of Dental Research, 2016.

HINZ, B. Formation and function of the myofibroblast during tissue repair. Journal of Investigative Dermatology, v. 127, n. 3, p. 526-537, 2007.

IWALEWA, E. O.; MCGAW, L. J.; NAIDOO, V.; ELOFF, J. N. Inflammation: the foundation of diseases and disorders. A review of phytomedicines of South African origin used to treat pain and inflammatory conditions. Journal of Biotechnology, v. 6 , n. 25, p. 2868-2885, 2007.

JACINTO, A.; MARTINEZ-ARIAS, A.; MARTIN, P. Mechanisms of epithelial fusion and repair. Nature Cell Biology, v. 3, n. 5, p. 117-123, 2001.

JI, R. R.; CHAMESSIAN, A.; ZHANG, Y. Q. Pain regulation by non-neuronal cells and inflammation. Science, v. 354, n. 6312, p. 572-577, 2016.

JULIUS, D.; BASBAUM, A.I.; Molecular mechanisms of nociception. Nature, v. 413, n. 6852, p.203-10, 2001.

KAISHO, T.; AKIRA, S. Função e sinalização do receptor de pedágio. Journal of Allergy and Clinical Immunology, v. 117, n. 5, p. 979-987, 2006.

KAPP, S.; MILLER, C.; SANTAMARIA, N. The quality of life of people who have chronic wounds and who self-treat. Journal of Clinical Nursing, v. 27, n. 1-2, p. 182-192, 2018.

KASSEM, A. A.; MOHSEN, A. M.; AHMED, R. S.; ESSAM, T. M. Self-nanoemulsifying drug delivery system (SNEDDS) with enhanced solubilization of nystatin for treatment of oral candidiasis: Design, optimization, in vitro and in vivo evaluation. Journal of Molecular Liquids, v. 218, p. 219-232, 2016.

KLAUMANN, P. R.; WOUK, A. F. P. F.; SILLAS, T. Patofisiologia da dor. Archives of Veterinary Science, v. 13, n.1, p.1-12, 2008.

KUMMER, C. L.; COELHO, T. C. R. B. Anti-inflamatórios não-esteróides inibidores da ciclooxigenase-2 (COX-2): aspectos atuais. Revista Brasileira de Anestesiologia, v. 54, n. 4, p. 498-512, 2002. 
LAU, K.; PAUS, R.; TIEDE, S.; DAY, P.; BAYAT, A. Exploring the role of stem cells in cutaneous wound healing. Experimental Dermatology, v. 18, n. 11, p. 921-933, 2009.

LEMA, M.; VOSCOPOULOS, C. When does acute pain become chronic? British Journal of Anaesthesia, v. 105, n. 1, p.69-85, 2010.

LEUNG, K. 99m - Tc-fucoidan, a polysaccharidic ligand of P-selectin. Molecular Biology, v. 19, p. 619-624, 2005.

LI, J.; CHEN, J.; KIRSNER, R. Pathophysiology of acute wound healing. Clinics in Dermatology, v. 25, n. 1, p. 9-18, 2007.

LI, J.; ZHANG, Y. P.; KIRSNER, R. S. Angiogenesis in wound repair: angiogenic growth factors and the extracellular matrix. Microscopy Research and Technique, v. 60, n. 1, p. 107-114, 2003.

LIN KING, J. V.; EMRICK, J. J.; KELLY, M. J. S.; HERZIG, V.; KING, G. F.; MEDZIHRADSZKY, K. F.; JULIUS, D. Uma toxina de escorpião que penetra nas células permite a modulação específica do modo de TRPA1 e a dor. Cell, v. 178, p. 1362-1374, 2019.

LINS, M. L. B. C; OLIVEIRA, A. P.; VASCONCELOS, C. C. C. S.; NUNES, J. P.; ALENCAR, L. M.; RODRIGUES, M. S.; ALMEIDA, M. S; SANTOS, S. C. Guia básico de prevenção e tratamento de feridas. Natal: Ed. UFRN, 2016.

LUPEPSA, A. C.; SANCHEZ, P. K. V.; BALLER, E. M.; MORO, M. G.; TOSTES, A. F.; GEVERT, M. V.; BAGLIE, S.; SILVA, M. C.; FRANCO, G. C. N. Importância biológica da ciclooxigenase (cox) e o efeito de anti-inflamatórios na osseointegração. Brazilian Society of Periodontology, v. 24, n. 4, p. 39-43, 2014.

MACIEL, M. A. M.; DE MEDEIROS, M. L.; ARAÚJO FILHO, I.; SALGUEIRO, C. C. M.; ROSSI, C. G. F. T.; VEIGA JUNIOR, V. F. Nanoformulação contendo bioativos naturais para cicatrização de lesões cutâneas. BR102014033133-6, INPI - Instituto Nacional da Propriedade Industrial. 2014a.

MACIEL, M. A. M.; DE MEDEIROS, M. L.; ARAÚJO FILHO, I.; RÊGO, A. C. M; EMERENCIANO, D. P.; VEIGA JUNIOR, V. F. Preparo e avaliação de bioformulação contendo óleo de copaíba para tratamento de enfermidades cutâneas. BR102014033132-8, INPI - Instituto Nacional da Propriedade Industrial. 2014b.

MACIEL, M. A. M., MACIEL, A. S. S., MedeIROS, M. I. T., DE ARAUJO, L. B. A., DE MEDEIROS, D. L., XAVIER JÚNIOR, F. H., VANDERLINDE, F. A. Desenvolvimento de formulados analgésicos nanoestruturados a base de Anacardium occidentale LINN. BR102016006687-5, INPI - Instituto Nacional de Propriedade Intelectual. 2016. 
MANDELBAUM, S. H.; PAMPADO, E.; SANTIS, D.; MANDELBAUM, M. H. S. Cicatrização: conceitos atuais e recursos auxiliares - Parte I. Anais Brasileiros de Dermatologia, v. 78, n. 4, p. 393-408, 2003.

MARQUEZ, R. R. Avaliação da ferida. In: Gogia P. Feridas - tratamento e cicatrização, Rio de Janeiro: Livraria e Editora Revinter Ltda, Cap. 2, p. 11-23; 2003.

MARTINS, I. F. B.; AZEVEDO, E. P.; ARAÚJO-FILHO, I.; SAMPAIO, T. B. M.; ROCHA, K. B. F.; MEDEIROS, M. I. T.; MACIEL, M.A.M. Biofilme cicatrizante desenvolvido a base de quitosana e extrato hidroalcoólico de Croton cajucara Benth solubilizado em nanoemulsão. BR102018068447-7. INPI - Instituto Nacional de Propriedade Intelectual. 2018.

MCMAHON, S. B.; LA RUSSA, F.; BENNETT, D. L. H. Crosstalk between the nociceptive and immune systems in host defence and disease. Nature Reviews Neuroscience, v. 16, p. 389-402, 2015.

MEDEIROS, M. I. T.; DE MEDEIROS, D. L.; PEREIRA, J. D. S.; VANDERLINDE, F. A.; MACIEL, M. A. M. Desenvolvimento biotecnológico de formulação a base de alcalóides de Croton Cajucara BENTH para tratamento da dor e inflamação. BR1020160142377, INPI - Instituto Nacional da Propriedade Industrial. 2016a.

MEDEIROS, M. I. T.; DE MEDEIROS, D. L.; PEREIRA, J. D. S.; VANDERLINDE, F. A.; MACIEL, M. A. M. Preparo de formulações coloidais a base de componentes bioativos de Croton Cajucara BENTH para tratamento da dor e inflamação. BR1020160244692, INPI - Instituto Nacional da Propriedade Industrial. 2016b.

MEDZHITOV, R. Origin and physiological roles of inflammation. Nature, v. 454, p. 428435, 2008.

MELI, R.; PIROZZI, C.; PELAGALLI, A. New perspectives on the potential role of aquaporins (AQPs) in the physiology of inflammation. Frontiers in Physiology, $v$. 9, n. 101, p.1-11, 2018.

MELO, E. M.; FERNANDES, V.S. Avaliação do conhecimento do enfermeiro acerca das coberturas de última geração. Revista Estima, v. 9, n. 4, p. 12-20, 2011.

MELO, E. R.; FIGUEIREDO, S. A.; OLIVEIRA, R. T.; AGRIPINO, E. C. B.; DA SILVA, M. H. S. N.; DOMINGUES, H. C. A.; BARBOSA, J. M. A. X.; DE ANDRADE, L. L. S. P. Anemia da doença crônica: uma revisão da fisiopatologia, do diagnóstico e do tratamento / anemia of chronic disease: a review of pathophysiology, diagnosis and treatment. Brazilian Journal of Development, v. 6, n. 12, p. 98941-98947, 2020.

NEILL, A. S.; NAGLE, C. M.; PROTANI, M. M.; OBERMAIR, A.; SPURDLE, A. B.; WEBB, P. M. Aspirin, nonsteroidal anti-inflammatory drugs, paracetamol and risk of endometrial cancer: a case-control study, systematic review and meta-analysis. International Journal of Cancer, v. 132, p. 1146-1155, 2013. 
NIELSEN, C. S.; KNUDSEN, G. P.; STEINGRÍMSDÓTTIR O. A. Twin studies of pain. Clinical Genetics, v. 82, n. 4, p. 331-340, 2012.

OLIVEIRA, A.C.; ROCHA, D.M.; BEZERRA, S.M.; ANDRADE, E.M.; SANTOS, A.M.; NOGUEIRA, L.T. Qualidade de vida de pessoas com feridas crônicas. Acta Paulista de Enfermagem, v. 32, n. 2, p. 194-201, 2019.

O'BANION, M. K.; Cyclooxygenase-2: Molecular biology, pharmacology, and neurobiology. Critical Review in Neurobiology, v. 13, n. 1, p. 45-82, 1999.

PATERSON, K. J.; ZAMBREANU, L.; BENNETT, D. L. H.; MCMAHON, S. B. Characterisation and mechanisms of bradykinin-evoked pain in man using iontophoresis. Official journal of the International Association for the Study of Pain, v. 153, p. 782-792, 2013.

PROBST, S.; SÉCHAUD, L.; BOBBINK, P.; SKINNER, M. B.; WELLER, C. D. The lived experience of recurrence prevention in patients with venous leg ulcers: an interpretative phenomenological study. Journal of Tissue Viability, v. 29, n. 3, p. 176-179, 2020.

RANG, H. P.; RITTER, J. M.; FLOWER, R. J; HENDERSON, G. Farmacologia. 8. ed. Rio de Janeiro: Editora Elsevier, 2016, p.22-24.

REICHENBERG, J.; DAVIS, M. Venous ulcers. Seminars in Cutaneous Medicine and Surgery, v. 24, n. 4, p. 216-26, 2005.

REINKE, J. M.; SORG, H. Wound repair and regeneration. European Surgical Research, v. 49, n. 1, p. 35-43, 2012.

RENNER R, ERFURT-BERGE C. Depression and quality of life in patients with chronic wounds: ways to measure their influence and their effect on daily life. Chronic Wound Care Management and Research, v. 4, p. 143-51, 2017.

RIBEIRO, L. T. A.; MEDEIROS, M. I. T.; SAMPAIO, T. B. M.; RÊGO, A. C. M.; MACIEL, M. A. M. Bioformulado preparado a base do extrato hidroalcoólico do fruto de noni (Morinda citrifolia LINN.) com indicação terapêutica para patologias inflamatórias. BR102018006616-1, INPI - Instituto Nacional da Propriedade Industrial. 2018.

RODRIGUES, M.; KOSARIC, N.; BONHAM, C. A.; GURTNER, G. C. Wound Healing: A Cellular Perspective Physiological Reviews, v. 99, n. 1, p. 665-706, 2019.

ROCHA, A. P. C.; KRAYCHETE, D. C.; LEMÔNICA, L.; CARVALHO, L. R.; BARROS, G. A. M.; GARCIA, J. B. S.; SAKATA, R. K.; Dor: Aspectos atuais da sensibilização periférica e central. Revista Brasileira de Anestesiologia, v. 57, n. 1, p. 94-105, 2007. 
RODRIGUES, I. A.; RAMOS, A. S.; FALCÃO, D. Q.; FERREIRA, J. L. P.; BASSO, S. L.; SILVA, J. R. A.; AMARAL, A. C. F. Development of nanoemulsions to enhance the antileishmanial activity of Copaifera paupera oleoresins. BioMed Research International, 9781724, 2018.

SCHMADER, K. E.; STACEY, B.; STANOS, S.; TREEDE, R. D.; TURK, D. C.; WALCO, G. A.; WELLS, C. D. Recommendations for the pharmacological management of neuropathic pain: an overview and literature update. Mayo Clinic Proceedings: Innovations, Quality and Outcomes, v. 85, n. 3, p. 3-14, 2010.

SEN, C. K.; GORDILLO, G. M.; ROY, S.; KIRSNER, R.; LAMBERT, L.; HUNT, T. K.; GOTTRUP, F.; GURTNER, G. C.; LONGAKER, M. T. Human skin wounds: a major and snowballing threat to public health and the economy. Wound Repair and Regeneration, v. 17, n. 6, p. 763-771, 2009.

SMANIOTTO, P. H. S.; GALLI, R.; CARVALHO, V. F.; FERREIRA, M. C. Tratamento clínico das feridas-curativos, Revista Médica, v. 89, n.3/4, p. 137-141, 2010.

SINNO, H.; PRAKASH, S. Complements and the wound healing cascade: an updated review. Plast Surg Int, v. 2013, ID 146764, p. 1-7, 2013.

SPOCUA, M.; HOEIJMAKERS, J. G. J.; MERKIES, I. S. J.; LAURIA, G.; WAXMAN, S. G. Smallfiber neuropathy: expanding the clinical pain universe. Journal of the Peripheral Nervous System, v. 24, n.1, p. 19-33, 2019.

STARR, R.; WILLSON, T. A.; VINEY, E. M.; MURRAY, L. J. L.; RAYNER, J. R.; JENKINS, B. J.; GONDA, T. J.; ALEXANDER, W. S.; METCALF, D.; NICOLA, N. A.; HILTON, D. J. A family of cytokine-inducible inhibitors of signaling. Nature, v. 387, p. 917-921, 1997.

STAUDACHER, A. G.; STEVENS, W. W. Sinus infections, inflammation and asthma. Immunology and Allergy Clinics of North America, v. 39, n. 3, p. 403-415, 2019.

STERIN, G. M.; GALLEGO, F. C. Fundamentos da fisioterapia na terapêutica da dor. In: OTERO, P. E. Avaliação e tratamento em pequenos animais. São Paulo: Interbook, 2005. pp. 212-225.

SORG, H.; TILKORN, D. J.; HAGER, S.; HAUSER, J.; MIRASTSCHIJSKI, U. Skin wound healing: an update on the on the Current Knowledge and Concepts. European Surgical Research, v. 58, n. 1-2, p. 81-94, 2017.

TAKEO, M.; LEE, W.; ITO, M. Wound healing and skin regeneration. Cold Spring Harbor Perspectives in Medicine, v. 5, n. 1, p. 1-13, 2015.

TAKEUCHI, O.; AKIRA, S. Receptores de reconhecimento de padrões e inflamação. Cell, v. 140, n. 6, p. $805-820,2010$. 
TORRES, R. C.; INSUELA, D. B. R.; CARVALHO, V. F. Mecanismos celulares e moleculares da ação anti-inflamatória dos glicocorticoides. Corpus et Sciencia, v. 8, n. 2, p. 36-51, 2012.

UPPAL, S.; ITALIYA, K.S.; CHITKARA, D.; MITTAL, A. Nanoparticulate-based drug delivery systems for small molecule anti-diabetic drugs: an emerging paradigm for effective therapy. Acta Biomaterialia, v. 81, p. 20-42, 2018.

VOS, T.; ALLEN, C.; ARORA, M.; BARBER, R.M.; BHUTTA, Z.A.; BROWN, A.; CARTER, A.; CASEY, D.C.; CHEN, F.J.C.; COGGESHALL, M.; CORNABY, L.; DANDONA, A.; DICKER, D.J.; DILEGGE, T. Global, regional, and national incidence, prevalence, and years lived with disability for 310 diseases and injuries, 1990-2015: a systematic analysis for the Global Burden of Disease Study 2015. Lancet, v. 388, n. 10053, p. 1545-1602, 2016.

WANG, D.; DUBOIS, R.N. Immunosuppression associated with chronic inflammation in the tumor microenvironment. Carcinogenesis, v. 36, n. 10, p. 1085-1093, 2015.

WANNMACHER, L.; BREDEMEIER, M. Anti-inflamatórios não-esteróides: uso indiscriminado de inibidores seletivos de cicloxigenase-2. Uso racional de medicamentos. Brasília: Ministério da Saúde, 2004.

WOO, Y. C.; PARK, S. S.; SUBIETA, A. R.; BRENNAN, T. J. Alterações no pH e na temperatura do tecido após a incisão indicam que a acidose pode contribuir para a dor pós-operatória. Anesthesiology, v. 101, n. 2, p. 468-475, 2004.

WOOLF, C.J. Central sensitization: implications for the diagnosis and treatment o pain. Pain, v. 152, n. 3, p. 2-15, 2011.

YADAV, S.; SUROLIA, A. A lisozima provoca dor durante a lesão do nervo pela ativação do receptor 4 Toll-like neuronal e tem potencial terapêutico na dor neuropática. Science Translational Medicine, v. 11, n. 504, 2019.

XAVIER-JUNIOR, F. H.; VAUTHIER, C.; MORAIS, A. R. V.; ALENCAR, E. N.; EGITO, E. S. T. Microemulsion systems containing bioactive natural oils: an overview on the state of the art. Drug Development and Industrial Pharmacy, v. 43, n. 5, p.1-5, 2016.

ZHANG, J. M.; AN, J. Cytokines, inflammation and pain. International Anesthesiology Clinics, v. 45, n. 2, p. 27-37, 2007. 


\title{
CAPITULO $X$
}

\section{LASER DE BAIXA INTENSIDADE NA PROLIFERAÇÃO DE CÉLULAS-TRONCO DE ORIGEM DENTAL}

DOI: 10.51859/AMPLLA.PAE1993-10

\author{
Diego Moura Soares ${ }^{1}$ \\ Jéssica Gomes Alcoforado de Melo ${ }^{2}$ \\ Renato de Souza Melo ${ }^{3}$
}

\footnotetext{
1 Doutor em Odontologia pela Universidade Federal de Pernambuco - UFPE.

${ }^{2}$ Mestre em Odontologia pela Universidade Estadual da Paraíba - UEPB.

${ }^{3}$ Doutor em Saúde da Criança e do Adolescente pela Universidade Federal de Pernambuco - UFPE.
}

\section{RESUMO}

O uso de células-tronco mesenquimais de origem dental na engenharia de tecidos tem sido extensivamente investigado. Quanto maior for à proliferação deste tipo celular, maior será a capacidade regenerativa e cicatrizante dos tecidos. Para isso, o laser de baixa intensidade tem sido utilizado como um método adjuvante no aumento da proliferação, e consequentemente do rendimento, de células-tronco. Dessa forma, objetiva-se relatar características básicas acerca das células-tronco e da laserterapia, bem como discutir sobre a ação no laser de baixa intensidade na proliferação de célulastronco de origem dental. Verificou-se que a laserterapia de baixa intensidade estimulou a proliferação de células-tronco do ligamento periodontal, da polpa de dentes decíduos e permanentes e da papila apical. Os estudos relataram que além do maior rendimento a viabilidade celular foi mantida, assim a irradiação de culturas de células-tronco de origem dental com laser de baixa intensidade pode ser um método que contribuía com a proliferação e aplicação clínica dessas células em menos tempo.

Palavras-chave: Células-tronco. Laser. Proliferação celular. Cultura de células. 


\section{INTRODUÇÃO}

A utilização dos lasers vem sendo cada vez mais presentes na clínica odontológica, tanto como método auxiliar no diagnóstico, como em procedimentos que envolvam tecidos moles e duros, além de ser bastante utilizado como terapia complementar de diversas doenças e lesões que acometem a cavidade bucal (KARA et al., 2020). Diversas aplicações da laser terapia de baixa intensidade na odontologia apresentam respaldo científico, como alívio da dor, auxílio na cicatrização de feridas e efeito positivo em processos inflamatórios. O laser de baixa intensidade também vem sendo avaliado como um método que possa estimular a proliferação de células em cultura, dentre elas as células-tronco de origem dental aumentando assim o seu rendimento (GINANI et al., 2015; MUSTAFF et al., 2018).

A fotobiomodulação da atividade celular estimulada pelo laser de baixa intensidade provocada uma variedade de mecanismos que resultam em melhora no reparo do tecido, resolução mais rápida do processo inflamatório e uma redução na dor. Estudos anteriores têm mostraram que vários tipos de células respondem de maneira diferente ao laser, dependendo de parâmetros como, comprimentos de onda, potência, energia, potência densidade e densidade de energia, utilizados (PEPLOW et al., 2010). Além disso, a capacidade de acelerar o processo de cura está provavelmente relacionado ao fato de que o laser de baixa intensidade consegue promover a proliferação celular (GINANI et al., 2015).

Diversos estudos tem mostrado que, quando aplicado em células-tronco, o laser de baixa intensidade promoveu aumento da sua proliferação e estimulou diferenciação celular. Esses resultados podem ser observados em células-tronco adultas derivadas de diversas fontes de origem dentais como ligamento periodontal (SOARES et al., 2015), polpa de dentes decíduos (BRIDAR et al., 2021) e não dentais como medula óssea (HOU et al., 2008) e tecido adiposo (VILLIERS et al., 2011). Considerando que a discussão sobre a bioestimulação de células-tronco em cultura ainda está em andamento. $E$ que a ausência de um relatório uniforme sobre as variáveis físicas e biológicas, como o tipo de laser, potência de saída, frequência do comprimento de onda do disparo, tempo e modo de aplicação e características de absorção, dificultam a padronização dos resultados. Este trabalho tem como objetivo relatar características básicas acerca das 
células-tronco e da laserterapia, bem como discutir sobre a ação no laser de baixa intensidade na proliferação de células-tronco de origem dental.

\section{REVISÃO BIBLIOGRÁFICA}

\subsection{CÉLULAS-TRONCO}

As células-tronco são comumente definidas como células indiferenciadas que, quando induzidas corretamente, apresentam grande capacidade de auto-renovação e de diferenciação em tipos celulares especializados (FRESHNEY, STACEY e AUREBACH, 2007). Baseado em sua capacidade de originar um ou mais tipos celulares especializados, são classificadas em diferentes níveis de potencialidade, incluindo a totipotência do zigoto, a pluripotência de uma célula-tronco embrionária, a multipotência de uma célula-tronco do tecido adulto e a unipotência de tipos celulares específicos (SERAKINCI e KEITH, 2006).

As células-tronco (CT) embriononárias pluripotentes, procedentes do embrioblasto durante a fase de blástula do embrião, são capazes de dar origem a todas as linhagens celulares do corpo, sendo esta a sua maior vantagem (SOUZA et al., 2003). Contudo, a sua instabilidade genética, a obrigatoriedade de sua transplantação para hospedeiros imunocomprometidos e o risco de formação de teratocarcinomas, além da questão ética, são algumas desvantagens da sua utilização (SOARES et al., 2007).

Por outro lado, as CT adultas multipotentes são capazes de originar tipos celulares específicos (SOUZA et al., 2003), mas apresenta como vantagem o fato de serem autogênicas, não incorrendo em limitações responsivas aos fatores de crescimento inerentes ao hospedeiro ou mesmo questões ético-legais. No entanto o fato de não serem pluripotentes, a dificuldade de obtê-las, purificá-las e cultivá-las in vitro, além de sua presença em menor quantidade nos tecidos, têm sido relatadas como desvantagens da utilização de células-tronco adultas (RISBUD e SHAPIRO, 2005).

Diversos tecidos e órgãos são considerados como fontes de células-tronco adultas, tais como: medula óssea (BIANCO et al., 2001), tecido adiposo (MVULA et al., 2008), cordão umbilical (KERN et al., 2006), sangue, córnea, retina e pâncreas (SLACK, 2000). Há alguns anos, inúmeros estudos têm isolado células-tronco derivadas dos tecidos orais, dentre os quais podemos citar a polpa de dentes permanentes 
(GRONTHOS et al., 2000), a polpa de dentes decíduos (MIURA et al., 2003) e o ligamento periodontal (CHEN et al., 2006).

\subsection{LASER E LASERTERAPIA}

O laser é uma forma de radiação não ionizante, não invasiva, sendo altamente concentrada, que em contato com os diferentes tecidos resulta em efeitos térmicos, fotoquímicos ou não lineares, dependendo do seu tipo. A palavra LASER é um acrônimo de Light Amplification by Stimulated Emission of Radiation, que significa amplificação da luz por emissão estimulada de radiação (SULEWSKI, 2000), esse significado expressa bem a forma pela qual essa luz é produzida.

Os lasers de baixa intensidade são absorvidos pelos tecidos e estimulam um efeito biomodulador, enquanto que os de alta potência atuam por meio do aumento da temperatura e produção de calor (JORGE, CASSONI e RODRIGUES, 2010). O laser é um dispositivo composto por substâncias denominadas de meio ativo, sendo estas essenciais para sua produção. O meio ativo pode ser um gás, um sólido, um líquido ou ainda uma associação, que quando excitados por uma fonte de energia externa, geram luz. Dessa forma a luz do laser pode ser definida como sendo um conjunto de fótons que seguem uma trajetória ondulatória apresentando características especiais de unidirecionalidade, coerência e monocromaticidade (CATÃO, 2004).

Miserendino e Pick (1995) citam esses fatores como sendo propriedades únicas e que diferem a luz do laser da luz comum. Almeida-Lopes et al. (2001) definem unidirecionalidade como a trajetória paralela que os feixes luminosos seguem entre si, não havendo divergência de seus feixes; coerência como sendo a propagação na mesma direção dos feixes luminosos, possuindo picos e vales da sua trajetória coincidente no tempo, espaço e freqüência e monocromaticidade como sendo a característica de que todas as ondas da luz possuir uma mesma cor, ou seja, um mesmo comprimento de onda.

Os lasers são nomeados de acordo com o meio ativo pelo qual são estimulados. Atualmente, diferentes meios ativos estão disponíveis e cada meio resulta em um tipo diferente de radiação ou comprimento de onda. O laser de baixa intensidade pode ser composto de um meio sólido, utilizado com uma combinação de Gálio (Ga), Arsênio (Ar), 
Alumínio (Al) e Indio (In), ou de um meio gasoso, através de uma combinação de Hélio (He) e Neônio (Ne) (PROCKT, TAKAHASHI e PAGNONCELLI, 2008).

A laserterapia pode ser realizada em dois diferentes espectros, estes são estabelecidos a partir do comprimento de onda utilizado. O espectro de ação vermelho ou visível apresenta comprimento de onda na faixa aproximada de 630 a 700 nm, já o infravermelho ou invisível comprimentos de onda próximo ao 700 a $904 \mathrm{~nm}$. Esses dois espectros apresentam mecanismos de ação diferentes. Os lasers com comprimento de onda na faixa do visível atuam primeiramente nas mitocôndrias e lisossomos, induzindo diretamente à síntese de enzimas. Os que possuem luz infravermelha agem nas membranas celulares através de alterações no potencial das mesmas, desencadeando efeitos fotofísicos e fotoelétricos, responsáveis pela excitação de elétrons, vibração e rotação de moléculas, que se traduzem no aumento da síntese intracelular de ATP (LIZARELLI, 2005).

O meio ativo que compõe o laser influência diretamente com comprimento de onda (espectro) que o mesmo consegue atingir. O espectro de luz visível é representado pelo Hélio-Neônio (HeNe), salientado por Tunér e Hode (1999) como um tipo de laser altamente colimado. Ainda no que se refere a radiação visível, Guirro e Guirro (2002) relatam a disponibilidade no mercado nacional o laser de Alumínio-Gálio-Índio-Fósforo (AlGalnP), com comprimento de onda de 630 e 685 nm na forma de onda contínua. Já os lasers infravermelhos são constituídos fundamentalmente pelo Arseneto de Gálio (AsGa), com comprimento de onda de $904 \mathrm{~nm}$ na forma de onda pulsada e o Arseneto de Gálio-Alumínio (AsGaAl), com comprimento de onda de 780 e 870 nm na forma de onda contínua.

Para que o efeito sobre o tecido irradiado seja efetivo, diversos parâmetros devem ser avaliados, como: comprimento de onda, densidade de energia ou dose (quantidade de energia por unidade de área transferida ao tecido), potência (valor dado pelo fabricante em watts), densidade de potência (potência de saída da luz por unidade de área medida em watts dividido por centímetros quadrados) e intervalo de aplicação (MOORE et al., 2005).

Outra característica relevante que os lasers apresentam, refere-se ao seu modo de funcionamento. Dessa forma existem os lasers de ondas contínuas, que quando acionados permanecem ligados continuamente até serem desligados e os lasers de 
ondas pulsada, que mesmo após serem acionados permanecem parte do tempo ligados e outra parte desligados, fracionando a liberação da luz durante o intervalo de aplicação (ALMEIDA-LOPES, 2003).

A LBI geralmente utiliza baixas densidades de energias e comprimentos de onda, porém suficientemente alta para desencadear na célula alvo o processo de biomodulação, ou seja, a energia é capaz de penetrar facilmente nos tecidos, resultando em aumento da atividade, proliferação e regeneração celular, síntese de fatores de crescimento, produção de colágeno, angiogênese, além de analgesia e efeito antiinflamatório (LI, CHEN e WANG, 2006). Tem sido relatado que a magnitude do efeito de bioestimulação do laser depende do comprimento de onda utilizado, bem como do estado fisiológico da célula no momento da irradiação (PINHEIRO et al., 2002).

A ação dos diferentes comprimentos de onda no metabolismo celular varia segundo a posição que ocupam no espectro de radiações eletromagnéticas, e que sua ação sobre as células é diferente para os comprimentos de onda vermelhos e para os infravermelhos (KARU, 1998).

\subsection{MECANISMO MOLECULAR DO LBI NA PROLIFERAÇ̃̃O CELULAR}

O mecanismo de ação do LBI no sistema biológico envolve, inicialmente, a fotoativação de uma molécula fotorreceptora da célula seguida de absorção da luz e o desencadeamento de dois mecanismos básicos (primários e secundários). Os mecanismos primários ainda não se encontram bem esclarecidos na literatura, porém as hipóteses prováveis incluem a formação de oxigênio singlete (espécie eletronicamente excitada da molécula de oxigênio), modificações das propriedades do estado redox, presença de óxido nítrico, aumento da temperatura local por tempo determinado ou superprodução de ânions superóxidos. Já os mecanismos secundários, compreendem a conexão entre a fotorresposta dos receptores localizados nas mitocôndrias e a síntese de DNA e RNA no núcleo celular (KARU, 2008). Para Xu et al., (2008) as alterações na função dos fotorreceptores são as reações primárias, e as alterações subseqüentes na sinalização e função celulares são reações secundárias.

Tentando explicar o efeito da bioestimulatorio do LBI em nível molecular, Karu (1998) propôs uma cadeia de eventos moleculares a partir da absorção de luz por um fotorreceptor levando à fotoativação de enzimas na mitocôndria, incluindo a transdução 
de sinal e eventos de amplificação, terminando com a foto-resposta. Segundo o mesmo autor, a luz é absorvida pelos componentes da cadeia respiratória, levando a mudanças nas mitocôndrias e no citoplasma. Em baixas doses de laser, $\mathrm{Ca}^{2+}$ adicional é transportado para o citoplasma por um processo que estimula síntese de DNA e RNA, mitose e proliferação celular. Em altas doses, muito $\mathrm{Ca}^{2+}$ é liberado, resultando em hiperatividade da ATPase, bombas de cálcio e consequentemente degradação do ATP presente na célula e inibição do metabolismo celular (SCHINDL et al., 2000). Segundo Friedmann et al., (1991) a liberação de $\mathrm{Ca}^{2+}$ ocorre a partir da força motriz protónica e que além da liberação de $\mathrm{Ca}^{2+}$ verifica-se também um aumento de curto prazo no pH intracelular.

O efeito bioestimulante do LBI resulta em um aumento na microcirculação, altas taxas de produção para a síntese de ATP, RNA e DNA, melhorando assim a oxigenação, nutrição e regeneração celular. Há também um aprimoramento no sistema mitocondrial de transporte de elétrons (YU et al., 1997) Fótons entram na célula e são facilmente absorvidos pelos cromóforos localizados na mitocôndria e na membrana celular. Estes cromóforos interagem fortemente com a irradiação laser. A energia fotônica é convertida em energia química dentro da célula, na forma de ATP, o que melhora as funções celulares e a taxa de proliferação. A permeabilidade da membrana celular é alterada, seguida por alterações fisiológicas nas células-alvo (PINHEIRO et al., 2002). O incremento na síntese de ATP observado após a irradiação com o laser de baixa intensidade tem importância salutar para o metabolismo celular, especialmente quando a célula está em situação de estresse ou diante de uma lesão tecidual (LIZARELLI, 2005).

Em se tratando da ação do laser nos diferentes espectros de luz, seu efeito molecular parece ocorrer de forma distinta quando se compara a luz vermelha com a infravermelha. A luz visível (vermelha) induz uma reação foto-química, ocasionando em uma direta ativação da síntese de enzimas, tendo como principal alvo os lisossomos e as mitocôndrias. As organelas não absorvem luz infravermelha (espectro invisível), apenas as membranas celulares apresentam respostas a esse estímulo, logo a luz infravermelha causa alterações no potencial de membrana induzindo efeitos foto-físicos e foto-elétricos, levando à excitação dos elétrons e a um aumento na síntese de ATP (ALMEIDA-LOPES et al., 2001). 


\subsection{AÇÃO DO LASER DE BAIXA INTENSIDADE NAS CÉLULAS EM CULTURA}

A LBI tem sido utilizada tanto no espectro de luz vermelho quanto infravermelho, mas os resultados mais eficazes vêm do espectro visível, variando de 600 a $700 \mathrm{~nm}$ (WILDEN e KARTHEIN, 1998). Em vários estudos in vitro observou-se que comprimento de onda de $860 \mathrm{~nm}$ estimulou a proliferação celular (BOLTEN, YOUNG e DYSON, 1995), de $812 \mathrm{~nm}$ aumentou a síntese de DNA (LOEVSHALL e RENHOLT-BINDSLEV, 1994), de $660 \mathrm{~nm}$ aumentou a produção de fator de crescimento fibroblástico (YU, NAIM e LANZAFAME, 1994), e de 632,8 nm induziu transformação de fibroblastos em miofibroblastos (POURREAU-SCHNEIDER et al., 1990). Também foi observado que uma luz laser de 632,8 nm, quando aplicada em culturas de queratinócitos, aumenta a proliferação celular (STEINLECHNER e DYSONM, 1993), estimula a liberação de IL-1 e IL8 (YU et al., 1997) e aumenta a taxa de motilidade (HAAS et al., 1990).

A fim de avaliar o efeito do laser com diferentes comprimentos de onda (625, 635, 645, 655, 665, 675 e $810 \mathrm{~nm}$ ) em dois tipos celulares (fibroblastos e células endoteliais), Moore et al. (2005) avaliaram a taxa de proliferação celular após um período de $72 \mathrm{~h}$ de cultivo. Eles verificaram um aumento no crescimento das células endoteliais em todos os comprimentos de onda estudados; os fibroblastos também responderam de forma positiva para todos os comprimentos de onda, exceto para o de $810 \mathrm{~nm}$, sugerindo que tipos celulares distintos podem responder de maneira diferente quando submetidos aos mesmos parâmetros de irradiação.

Hawkins-Evans e Abrahamse (2008) obtiveram resultados semelhantes aos verificado por Moore et al (2005) no que se refere a proliferação de fibroblastos. Eles avaliaram comprimentos de onda de 632,8 e $830 \mathrm{~nm}$ e verificaram um efeito estimulatório na proliferação desse tipo celular mais efetivo quando tratados com laser de $632,8 \mathrm{~nm}$, sugerindo que o comprimento de onda interfere potencialmente na resposta celular.

Além do comprimento de onda, a bioestimulação in vitro é dependente de outros fatores, tais como a potência (ALMEIDA-LOPES et al., 2001), a densidade de energia (PEREIRA et al., 2002; KREISLER et al., 2003) e o tipo de célula que está sendo irradiada (MOORE et al., 2005). Estes parâmetros são úteis para aumentar a taxa de proliferação, porém eventualmente promovem efeitos adversos sobre a síntese de proteínas 
(PEREIRA et al., 2002). Portanto, é crucial identificar a combinação correta desses fatores para atingir a taxa máxima de proliferação célular.

O efeito positivo LBI na proliferação e diferenciação das células em cultura vem sendo observado em diversos tipos, como ceratinócitos, fibroblastos, células endoteliais, mioblastos e osteoblasto, exibindo efeitos biomodulatórios positivos (KREISLER et al., 2003; EDUARDO et al., 2007; TUBY, MALTZ e ORON, 2007). No entanto, pouco se sabe sobre a ação da laserterapia sobre as células-tronco mesenquimais (TUBY, MALTZ e ORON, 2007; EDUARDO et al., 2008; AIGHAMDI et al., 2012).

Tuby, Maltz e Oron (2007) demonstraram que a laserterapia promove a proliferação de células-tronco mesenquimais e cardíacas in vitro. Foi utilizado um laser diodo (AsGa) com comprimento de onda de $804 \mathrm{~nm}$ e doses de 1,0-3,0 J/ $\mathrm{cm}^{2}$. A proliferação de ambos os tipos celulares aumentou significativamente após a aplicação do laser quando comparado ao grupo controle não irradiado sem causar efeito adverso sobre essas células.

Hou et al (2008) usaram o LBI para aumentar a taxa de proliferação de célulastronco mesenquimais da medula óssea a partir da utilização do laser com comprimento de onda de $635 \mathrm{~nm}$ e doses de 0,5;1,0;2,0 e 5,0 J/ $\mathrm{cm}^{2}$. Não foram encontradas diferenças significativas entre os grupos não irradiados e irradiados no que se refere à citotoxicidade. Por outro lado, a taxa de proliferação das células-tronco mesenquimais da medula óssea foi significativamente maior no grupo irradiado quando comparado com o grupo controle, sendo a dose de $0,5 \mathrm{~J} / \mathrm{cm}^{2}$ a mais efetiva.

Stein et al (2008) verificaram que o LBI com $670 \mathrm{~nm}$ e doses de $1,0 \mathrm{~J} / \mathrm{cm}^{2}$ e 2,0 $\mathrm{J} / \mathrm{cm}^{2}$ teve um efeito bioestimulatório positivo no crescimento e diferenciação de osteoblastos humanos durante as primeiras 72 horas após irradiação, obtendo melhores resultados quando irradiados com dose de $1,0 \mathrm{~J} / \mathrm{cm}^{2}$.

Em relação às doses utilizadas na $L B I$, sabe-se que doses menores $\left(2,0 \mathrm{~J} / \mathrm{cm}^{2}\right)$ estimulam a proliferação, enquanto que doses elevadas $\left(16 \mathrm{~J} / \mathrm{cm}^{2}\right)$ inibem este processo, indicando que a laserterapia apresenta um efeito dose dependente nas respostas biológicas (HUANG et al., 2009). Vale resaltar que cada tipo celular responde de maneira mais efetiva a parâmetros específicos (dose) que devem ser avaliados a fim de se conseguir melhores resultados. 
Villiers, Houreld e Abrahamse (2011) avaliaram a ação do laser diodo, com 636 $\mathrm{nm}$ e $5,0 \mathrm{~J} / \mathrm{cm}^{2}$ na proliferação de células-tronco mesenquimais de tecido adiposo humano, sendo uma linhagem extraída a partir de procedimento cirúrgico e uma outra comercial, as quais mostraram resultados completamente distintos. Na linhagem comercial não houve diferença significativa em nenhum dos tempos avaliados (24, 48 e $72 \mathrm{~h}$ ), por sua vez, as células oriundas de procedimento cirúrgico mostraram diferenças estatisticamente significativas na proliferação celular nos tempos de 24 e 72 h pósirradiação quando comparadas com o controle não irradiado. Esses resultados sugerem que cada linhagem responde de modo diferente ao efeito do laser.

Quando se trata da LBI em células de origem dental, um estudo realizado com células-tronco da polpa de dentes decíduos demonstrou que a irradiação dessas células com deficiência nutricional (10 e 5\% de FBS), utilizando comprimento de onda de 660 $\mathrm{nm}$ e $3,0 \mathrm{~J} / \mathrm{cm}^{2}$, promoveu aumento na proliferação celular. Porém quando se avaliou esse mesmo tipo celular em condições nutricionais normais (15\% de FBS), não houve diferença estatística entre os grupos (EDUARDO et al., 2008).

Com o objetivo de avaliar a ação do LBI na liberação de fatores de crescimento, fibroblastos gengivais humanos foram irradiados com dois comprimentos de ondas (780 e $660 \mathrm{~nm}$ ) e duas doses ( 3 e $5 \mathrm{~J} / \mathrm{cm}^{2}$ ). Dessa forma verificou-se que a libertação de fator de crescimento de queratinócitos foi semelhante em todos os grupos, enquanto que a de fator de crescimento de fibroblastos básico foi significativamente maior nos grupos tratados com laser infravermelho. Concluiu-se que aumento da produção de fator de crescimento de fibroblastos básico pode ser um dos mecanismos pelos quais o laser infravermelho estimula a proliferação celular (DAMANTE et al., 2004).

A proliferação de fibroblastos gengivais humanos induzidas pelo LBI também foi investigada a partir da irradiação (diodo, $664 \mathrm{~nm}, 56 \mathrm{~mW}$ ) com doses de 2, 5, 10 e 15 $\mathrm{J} / \mathrm{cm}^{2}$. Após seis dias verificou-se que as células irradiadas com diferentes doses apresentavam uma taxa de proliferação semelhante, sem diferença estatística, sendo que os melhores resultados foram conseguidos com a dose de $2 \mathrm{~J} / \mathrm{cm}^{2}$ (ALMEIDA-LOPES et al., 2001). 


\section{CONSIDERAÇ̃ES FINAIS}

Devido ao baixo rendimento das células-tronco de origem dental em cultura, o laser de baixa intensidade pode ser um método auxiliar importante para aumentar 0 rendimento das células em cultura. Dessa forma, uma aplicação clínica mais ágil desse tipo celular pode ser conseguida exigindo um menor tempo de procedimentos laboratoriais.

\section{REFERÊNCIAS}

AIGHAMDI, K. M.; KUMAR, A.; MOUSSA, N. A. Low-level laser therapy: a useful technique for enhancing the proliferation of various cultured cells. Lasers Med Sci, v. 27, p. 237-49, 2012.

ALMEIDA-LOPES, L.; RIGAU, J.; ZÂNGARO, R. A.; GUIDULI-NETO, J.; JAEGER, M. M. M. Comparison of the low-level therapy effects on cultured human gingival fibroblasts proliferation using different irradiance and same fluence. Lasers Surg Med, v. 29, p. 179-184, 2001.

ALMEIDA LOPES, L. Análise in vitro da proliferação celular de fibroblastos de gengiva humana tratados com laser de baixa intensidade utilizando diferentes parâmetros de irradiação. Tese (Doutorado em Ciências e Engenharia dos Materiais) - Universidade de São Paulo, São Paulo, 2003.

BIANCO, P.; RIMINUCCI, M.; GRONTHOS, S.; ROBEY, P. G. Bone marrow stromal stem cells: nature, biology, and potential applications. Stem Cells, v. 19, n. 3, p. 180192, 2001.

BIDAR, M.; BAHLAKEH, A.; MAHMOUDI, M.; AHRARI, F.; SHAHMOHAMMADI, R.; JAFARZADEH, $\mathrm{H}$. Does the application of GaAIAs laser and platelet-rich plasma induce cell proliferation and increase alcaline phosphatase activity in human dental pulp stem cells? Lasers Med Sci, v. 36, n. 6, p. 1289-1295, 2021.

BOLTEN, P.; YOUNG, S.; DYSON, M. The direct effect of $860 \mathrm{~nm}$ light on cell proliferation and on succinic dehydrogenase activity of human fibroblasts in vitro. Laser Ther, v. 7, p. 55-60, 1995.

CATÃO, M. H. C. V. Os benefícios do laser de baixa intensidade na clínica odontológica na estomatologia. Revista Brasileira de Patologia Oral, v. 3, n. 4, p. 214-218, 2004.

CHEN, S. C.; MARINO, V.; GRONTHOS, S.; BARTOLD, P. M. Location of putative stem cells in human periodontal ligament. J Periodontal Res, v. 41, n. 6, p. 547-553, 2006. 
DAMANTE CA, GREGHI SLA, SANT'ANA ACP, PASSANEZI E. Clinical evaluation of the effects of low-intensity laser (GaAlAs) on wound healing after gingivoplasty in humans. J Appl Oral Sci, v. 12, n. 2, p. 133-136, 2004.

EDUARDO, F. P.; BUENO, D. F.; DE FREITAS, P. M.; MARQUES, M. M.; PASSOS-BUENO, M. R.; EDUARDO, C. P.; ZATZ, M. Stem cell proliferation under low-intensity laser irradiation: a preliminary study. Lasers Surg Med, v. 40, n. 6, p. 433-438, 2008.

EDUARDO, F. P.; MEHNERT, D. U.; MONEZI, T. A.; ZEZELL, D. M.; SCHUBERT, M. M.; EDUARDO, C. P.; MARQUES, M. M. Cultured epithelial cells response to phototherapy with low-intensity laser. Lasers Surg Med, v. 39, p. 365-372, 2007.

FRESHNEY, I. R.; STACEY, G. N.; AUREBACH, J. M. Culture of human stem cells: culture of specialized cells. New York: Wisley-Liss; 2007.

FRIEDMANN, H.; LUBART, R.; LAULICHT, I.; ROCHKIND, S. A possible explanation of laserinduced stimulation and damage of cell cultures. J Photochem Photobiol B, v. 11, p. 87-91, 1991.

GINANI, F.; SOARES, D. M.; BARRETO, M. P. V.; BARBOZA, C. A. G. Effect of low-level laser therapy on mesenchymal stem cell proliferation: a systematic review. Lasers Med Sci, v. 30, n. 8, p. 2189-94, 2015.

GRONTHOS S, MANKANI M, BRAHIM J, ROBEY PG, SHI S. Postnatal human dental pulp stem cells (DPSCs) in vitro and in vivo. Proc Natl Acad Sci U S A, v. 97, n. 25, p. 13625-13630, 2000.

GUIRRO, E. C.; GUIRRO, R. R. J. Fisioterapia dermato-funcional: fundamentos, recursos e patoloigias, 3 ed. Barueri, SP: Manole Ltda, p. 209-222, 2002.

HAAS, A. F.; ISSEROFF, R. R.; WHEELAND, R. G.; ROOD, P. A.; GRAVES, P. J. Low-energy helium-neon laser irradiation increases the motility of cultured human keratinocytes. J Invest Dermatol, v. 94, n. 6, p. 822-826, 1990.

HAWKINS-EVANS, D.; ABRAHAMSE, H. Efficacy of three laser wavelengths for in vitro wound healing. Photodermatol Photoimunol Photomed, v. 24, p. 199-110, 2008.

HOU, J. F.; ZHANG, H.; YUAN, X.; LI, J.; WEI, Y. J.; HU, S. S. In vitro effects of low-level laser irradiation for bone marrow mesenchymal stem cells: proliferation, growth factors secretion and myogenic differentiation. Lasers Surg Med, v. 40, n. 10, p. 726-733, 2008.

HUANG, Y. Y.; CHEN, A. C. H.; CARROLL, J. D.; HAMBLIN, M. R. Biphasic dose response in low-level light therapy. Dose Response, v. 7, p. 358-383, 2009.

JORGE, A. C. T.; CASSONI, A.; RODRIGUES, J. A. Aplicações dos lasers de alta potência em odontologia. Rev Saúde. v. 4, n. 3, p. 25-33, 2010. 
KARA, N.; SELAMET, H.; BENKLI, Y. A.; BELDÜZ, M.; GÖKMENOGLU,C.; KARA C. Laser therapy induces increased viability and proliferation in isolated fibroblast cells. Wounds, v. 32, n. 3, p. 69-73, 2020.

KARU, T. I. Mitochondrial signaling in mammalian cells activated by red and near-IR radiation. Photochem Photobiol, v. 84, p. 1091-1099, 2008.

KARU, T. I. Primary and secondary mechanisms of the action of monochromatic visible and near infrared radiation on cells. In: The science of low-power laser therapy. Gordon and Breach Science, Amsterdam 1998.

KERN, S.; EICHLER, H.; STOEVE, J.; KLÜTER, H.; BIEBACK, K. Comparative analysis of mesenchymal stem cells from bone marrow, umbilical cord blood, or adipose tissue. Stem Cells, v. 24, n. 5, p. 1294-1301, 2006.

KREISLER, M.; CHRISTOFFERS, A. B.; AL-HAJ, H.; WILLERSHAUSEN, B.; D'HOEDT, B. LOWlevel 809-nm diode laser-induced in vitro stimulation of the proliferation of human gingival fibroblasts. Lasers Surg Med, v. 30, p. 365-369, 2003.

LI, W. T.; CHEN, H. L.; WANG, C. T. Effect of Light Emitting Diode Irradiation on Proliferation of Human Bone Marrow Mesenchymal Stem Cells. J Med Biol Eng, v. 26, n. 1, p. 35-42, 2006.

LIZARELLI, R. F. Z. Uso do laser de baixa intensidade: protocolos clínicos e odontológicos. 2a ed. São Carlos - SP, 2005.

LOEVSHALL, H.; RENHOLT-BINDSLEV, D. Effect of low-level diode laser irradiation of human oral mucosa fibroblasts in vitro. Lasers Surg Med, v. 14, p. 347-354, 1994.

MISERENDINO, L. J.; PICK, R. Laser in Dentistry. Carol Stream. Quintessence Publishing, p. 341, 1995.

MIURA, M.; GRONTHOS, S.; ZHAO, M.; LU, B.; FISHER, LW.; ROBEY, PG.; SHI, S. SHED: stem cells from human exfoliated deciduous teeth. Proc Natl Acad Sci U S A, v. 100, n. 10, p. 5807-5812, 2003.

MOORE, P.; RIDGWAY, T. D.; HIGBEE, R. G.; HOWARD, E. W.; LUCROY, M. D. Effect of wavelength on low-intensity laser irradiationstimulated cell proliferation in vitro. Lasers Surg Med, v. 36, p. 8-12, 2005.

MUSSTTAF, R. A.; JENKINS, D. F. L.; JHA, A. N. Assessing the inpact of low level laser therapy (LLLT) on biological systems: a review. Int J Radiat Biol, v. 95, n. 2, p. 120143, 2019.

MVULA B, MATHOPE T, MOORE T, ABRAHAMSE $H$. The effect of low-level laser irradiation on adult human adipose-derived stem cells. Lasers Med Sci, v. 23, n. 3, p. 277-282, 2008. 
PEPLOW, P. V.; CHUNG, T. Y.; BAXTER, G. D. Laser photobiomodulation of proliferation of cells in culture: a review of human and animal studies. Photomed Laser Surg, v. 28, Suppl 1, p. 3-40, 2010.

PINHEIRO, A .L.; CARNEIRO, N. S.; VIEIRA, A. L.; BRUGNERA, A.; ZANIN, F. A.; BARROS, R. A.; SILVA, P. S. Effects of lowlevel laser therapy on malignant cells: in vitro study. J Clin Laser Med Surg, v. 20, p. 23-26, 2002.

POURREAU-SCHNEIDER, N.; AHMED, A.; SOUDRY, M.; JACQUEMIER, J.; KOPP, F.; FRANQUIN, J. C.; MARTIN, P. M. Heliumneon laser treatment transforms fibroblasts into myofibroblasts. Am J Pathol, v. 137, n. 1, p. 171-178, 1990.

PROCKT, A. P.; TAKAHASHI, A.; PAGNONCELLI, R. M. Uso de terapia com laser de baixa intensidade na cirurgia bucomaxilofacial. Rev Port Estomatol Cir Maxilofac, v. 49, n. 4, p. 247-255, 2008.

RISBUD, M. V.; SHAPIRO, I. M. Stem cells in craniofacial and dental tissue engineering. Orthod Craniofacial Res, v. 8, n. 2, p. 54-59, 2005.

SCHINDL, A.; SCHINDL, M.; PERNERSTORFER-SCHON, H.; SCHINDL, L. Low-intensity laser therapy: a review. J Invest Med, v. 48, p. 312-326, 2000.

SERAKINCI, N.; KEITH, W. N. Therapeutic potential of adult stem cells. Eur J Cancer, v. 42, n. 9, p. 1243-1246, 2006.

SLACK, J. M. Stem cell in epithelial tissue. Science, v. 287, p. 1431-1433, 2000.

SOARES, A. P.; KNOP, L. A. H.; JESUS, A. A.; ARAÚJO, T. M. Células-tronco em odontologia. R Dental Press Ortodon Ortop Facial, v. 12, n. 1, p. 33-40, 2007.

SOARES, D. M.; GINANI, F.; HENRIQUES, A. G.; BARBOZA, C. A. G. Effects of laser therapy on the proliferation of human periodontal ligament stem cells. Lasers Med Sci, v. 30, n. 3, p. 1171-4, 2015.

SOUZA, V. F.; LIMA, L. M. C.; REIS, S. R. A.; RAMALHO, L. M. P.; SANTOS, J. N. Célulastronco: uma breve revisão. R Ci Méd Biol, v. 2, n. 2, p. 251-256, 2003.

STEIN, E.; KOEHN, J.; SUTTER, W.; WENDTLANDT, G.; WANSCHITZ, F.; THURNHER, D.; BAGHESTANIAN, M.; TURHANI, D. Initial effects of low-level laser therapy on growth and differentiation of human osteoblast-like cells. Wien Klin Wochenschr, v. 120, p. 112-117, 2008.

STEINLECHNER, C.; DYSONM, M. The effects of low-level laser therapy on the proliferation of keratinocytes. Laser Ther, v. 5, p. 65-73, 1993.

SULEWSKI, J. G. Historical survey of laser dentistry. Dent Clin Nortth Am, v. 44, n. 4, p. 717-752, 2000. 
TUBY, H.; MALTZ, L.; ORON, U. Low-level laser irradiation promotes proliferation of mesenchymal and cardiac stem cells in culture. Lasers Surg Med, v. 39, p. 373378, 2007.

TUNÉR, J.; HODE, L. Low level laser therapy. Clinical practice and scientific background. Spjutvagen, Suécia: Prima Books, p. 393, 1999.

VILLIERS, J. A.; HOURELD, N. N.; ABRAHAMSE, H. Influence of low intensity laser irradiation on isolated human adipose derived stem cells over 72 hours and their differentiation potential into smooth muscle cells using retinoic acid. Stem Cell Rev and Rep, v. 7, p. 869-882, 2011.

WILDEN, L.; KARTHEIN, R. Import of radiation phenomena of electrons and therapeutic low-level laser in regard to mitochondrial energy transfer. J Clin Laser Med Surg, v. 16, p. 159-165, 1998.

XU, X.; ZHAO, X.; LIU, T. C. Y.; PAN, H. Low-intensity laser irradiation improves the mitochondrial dysfunction of $\mathrm{C} 2 \mathrm{C} 12$ induced by electrical stimulation. Photomed Laser Surg, v. 26, p. 197-202, 2008.

YU, W.; NAIM, J. O.; LANZAFAME, R. J. The effect of laser irradiation on the release of bFGF from 3 T3 fibroblasts. Photochem Photobiol, v. 59, n. 2, p. 167-170, 1994.

YU, W.; NAIM, J. O.; MCGOWAN, M.; IPPOLITO, K.; LANZAFAME, R. J. Photomodulation of oxidative metabolism and electron chain enzymes in rat liver mitochondria. Photochem Photobiol, v. 66, p. 866-871, 1997. 


\section{CAPITULO XI}

\section{O VÍRUS LINFOTRÓPICO-T HUMANO DO TIPO 1 (HTLV-1) ASSOCIADO À LEUCEMIA DE CÉLULAS T ADULTAS (ATL) E À PARAPARESIA ESPÁSTICA TROPICAL (HAM/TSP)}

DOI: 10.51859/AMPLLA.PAE1993-11

Hellian Nice Bertalha Alves ${ }^{1}$

Akim Felipe Santos Nobre ${ }^{2}$

Biomédica. Escola Superior Madre Celeste - ESMAC, Ananindeua, Pará

2 Biomédico. Mestre e Doutor em Doenças Tropicais, Universidade Federal do Pará - UFPA. Belém, Pará.

\section{RESUMO}

Introdução: O vírus linfotrópico-T humano do tipo 1 (HTLV-1) foi o primeiro retrovírus humano descoberto, em 1980, pelo grupo de Robert Gallo, e desde então tem sido associado a diversas doenças. É um vírus negligenciado e pouco conhecido, ainda que tenha poder cancerígeno e inflamatório bem descrito. Objetivo: Este estudo de revisão tem como objetivo principal relatar as evidências sobre a associação do HTLV-1 com duas doenças de maior gravidade que ocorrem em decorrência da infecção, a Leucemia de Células T Adultas (ATL) e a Paraparesia Espástica Tropical (HAM/TSP). Metodologia: Foram selecionados artigos publicados no período de janeiro de 2009 a fevereiro de 2020 que relatavam essa associação. Entre as pesquisas selecionadas o grupo populacional de estudo foi variado, sendo doadores de sangue, gestantes, demanda espontânea e transeuntes. Resultados: Foi constatado que a associação do HTLV-1 com o desenvolvimento de doenças é relatada em todos os estudos, sendo a ATL a de maior gravidade seguida pela HAM/TSP, que se apresenta com maior prevalência, a qual variou entre $0,84 \%$ e 1,80\%. Conclusão: $O$ estudo indica que, mesmo após 40 anos da descoberta do HTLV-1, do notado poder oncogênico e dos importantes e graves achados patogênicos em humanos, o vírus ainda é pouco difundido, sobretudo em se tratando de um vírus endêmico, o que evidencia a necessidade de mais pesquisas e incentivo a informação com ênfase na prevenção, visando a possibilidade de vacinas no futuro.

Palavras-chave: HTLV-1, Epidemiologia, Virologia, Amazônia, Biologia Molecular. 


\section{ABSTRACT}

Introduction: The human T-lymphotropic virus type 1 (HTLV-1) was the first human retrovirus discovered in 1980 by Robert Gallo group, and has since been associated with various diseases. It is a neglected and little-known virus, although it has a well-described carcinogenic and inflammatory power. Objective: This review study has as main objective to report the evidence on the association of HTLV-1 with two more serious diseases that occur as a result of the infection, Adult T Cell Leukemia (ATL) and Tropical Spastic Paraparesis (HAM/TSP). Methods: Articles published in the period from January 2009 to February 2020 that reported this association were selected. Among the research group selected populacional study was varied, and blood donors, pregnant women, spontaneous demand and passers-by. Results: It was found that the association of HTLV-1 with the development of diseases is reported in all studies, with ATL being the most severe, followed by HAM/TSP, that is more prevalent, which varied between $0,84 \%$ and $1,80 \%$. Conclusion: The study indicates that, even after 40 years of the discovery of HTLV-1, the noticed power oncogenic and the important and serious pathogenic findings in humans, the virus is still not widespread, especially in the case of an endemic virus, which highlights the need for more research and encouragement of information with an emphasis on prevention, aiming at the possibility of vaccines in the future.

Keywords: HTLV-1, Epidemiology, Virology, Amazon, Molecular Biology.

\section{INTRODUÇÃO}

O vírus linfotrópico-T humano do tipo 1 (HTLV-1) pertence à família Retroviridae, mesma família do HIV, e a subfamília Orthoretrovirinae. Ele foi o primeiro retrovírus humano descoberto, em 1980, pelo grupo de Robert Gallo, e desde então tem sido associado a diversas doenças (TAGAYA; GALLO, 2017).

De formato arredondado e com aproximadamente 100nm de diâmetro, o HTLV possui um core esférico central, envolto por um envelope lipoproteico. O envelope é composto por proteínas virais transmembrana (TM) e de superfície (SU), que se projetam através de sua dimensão. O material genético é envolvido por um capsídeo com formato icosaédrico, que envolve também as proteínas enzimáticas importantes no ciclo celular do vírus: a protease viral, a transcriptase reversa e a integrasse (SANTOS, 2013).

O HTLV tem um genoma de RNA de fita simples com uma organização similar aos outros retrovírus (CARNEIRO-PROIETTI, 2015) e infecta principalmente células T CD4+ in vivo (MARTINEZ, 2019). No entanto, outras células vêm sendo descritas como alvo da infecção pelo HTLV, como as dendríticas e as mieloides. Modelos de patogênese atuais 
consideram que a via de penetração do HTLV possa ser um evento importante na determinação do desfecho da infecção viral, por causa da população alvo na infecção primária e consequente tipo de resposta imune que seria desencadeada (CARNEIROPROIETTI, 2015).

Como os demais retrovírus, seu ciclo é dependente da enzima transcriptase reversa. O RNA é liberado no citoplasma onde é reversamente transcrito. O DNA linear de dupla fita produzido migra para o núcleo da célula e se integra ao DNA cromossômico da célula hospedeira pela ação da integrase viral. Em seguida, o DNA viral integrado ao genoma hospedeiro, agora chamado de provírus, estabelece uma infecção prolongada e pode ficar latente por muito tempo (SANTOS, 2013).

A infecção pelo HTLV-1 é altamente dependente da propagação celular. Nesse sentido, a transmissão humana requer a transferência de células infectadas por vírus através da amamentação, relações sexuais, transfusão de sangue e partilha de agulha (CHOU-ZEN; SEMMES, 2016). A amamentação é a via mais comum de transmissão, com fatores de risco incluindo alta carga proviral do leite materno (MARTINEZ et al, 2019). Além disso, sabe-se que a infecção perinatal é responsável por cerca de 20 a $25 \%$ de todas as infecções pelo HTLV-1 (TAGAYA; MATSUOKA; GALLO, 2019).

$\mathrm{O}$ vírus é etiologicamente ligado à Leucemia de células $\mathrm{T}$ adultas (ATL) e à mielopatia associada ao HTLV-1/paraparesia espástica tropical (HAM / TSP), doenças causadas pelo vírus com prognóstico mais grave. Contudo, muitas outras doenças foram associadas ao HTLV-1, como a dermatite infecciosa, a uveíte, a polimiosite, a pneumonia alveolar brônquica, as bronquiectasias e a Síndrome de Sögren (RATHSAM-PINHEIRO et al., 2019).

Estima-se que 20 milhões de pessoas estejam infectadas pelo HTLV-1 no mundo. No entanto, a prevalência varia de acordo com a região geográfica, os padrões sociocomportamentais e étnicos das populações (ZIHLMANN; MAZZAIA; ALVARENGA, 2017). O HTLV-1 é frequente entre pessoas de ascendência africana, mas também em populações indígenas. Isso pode ter relação com a origem do HTLV-1 nas Américas, que é atualmente explicado por meio de duas hipóteses: o HTLV-1 foi trazido da África através do tráfico de escravos entre os séculos XVI e XIX ou foi introduzido cerca de 11000 a 13000 anos atrás, durante o período pré-histórico em migrações de populações infectadas (EUSEBIO-PONCE; CANDEL; ANGUITA, 2019). 
O Brasil é considerado uma área endêmica para o HTLV-1, estima-se que cerca de 2,5 milhões de indivíduos carregam o vírus (CASTRO et al., 2009), porém ainda não existe um estudo epidemiológico, com metodologia adequada, que tenha determinado a prevalência na população geral do Brasil. Contudo, baseando-se nos dados de prevalência em doadores de sangue, é possível estimar que no Brasil existam 2,5 milhões de portadores de HTLV-1 (CASTRO et al., 2009).

A maioria dos indivíduos infectados, cerca de $90 \%$, permanecem assintomáticos ao longo da vida, porém infecciosos; perpetuando, assim, a transmissão do HTLV-1, e em $5 \%$ dos portadores o HTLV-1 causa doenças (ROSADAS et al., 2018). Dos portadores, 2,5\% desenvolverão HAM, ATL e distúrbios inflamatórios relacionados com infecção por HTLV-1 (PILLAT et al., 2011), sendo o HTLV-1 o primeiro retrovírus com efeito oncogênico e também com maior potencial carcinogênico (TAGAYA; MATSUOKA; GALLO, 2019).

A infecção pode ser detectada por meio de testes de triagem, como reação imunoenzimática (ELISA), contudo é necessário testes confirmatórios de Western blot e PCR para concluir o diagnóstico (ROSADAS et al., 2018).

Não há consenso na literatura acerca de tratamento específico e eficaz para a infecção por HTLV-1. Desse modo, a terapêutica atualmente baseia-se em antirretrovirais, quimioterapia e transplante de medula óssea, que tem melhorado taxas de sobrevida, mas ainda com resultados limitados (MEHTA-SHAH; RATNER; HORWITZ, 2017). O trióxido de arsênio, que tem sido usado para tratamento de Leucemia Mieloide Aguda (LMA), também mostrou efeitos anti-ATL e efeitos em casos crônicos de ATL; ademais, há evidências sugestivas de que esse tratamento pode erradicar células precursoras de leucemia (TAGAYA; MATSUOKA; GALLO, 2019).

A infecção pelo HTLV-1 no Brasil estabelece um problema de saúde pública - que não possui uma política pública eficiente -, pois se trata de agente etiológico que causa doença negligenciada, incapacitante, progressiva e degenerativa, reconhecida pelo Ministério da Saúde, porém sem muita visibilidade quando comparada as demais doenças infectocontagiosas (RIVEMALES, 2013; ZIHLMANN; MAZZAIA; ALVARENGA, 2017). 
A infecção pelo HTLV-1 e pelo HTLV-2 encontra-se presente em todas as regiões brasileiras, mas as prevalências variam de um estado para o outro, sendo mais elevadas na Bahia, em Pernambuco e no Pará (SANTOS et al., 2009).

Apesar de a região Norte do país apresentar elevada prevalência para o HTLV-1, estudos envolvendo o perfil epidemiológico em Belém, no estado do Pará, ainda são escassos. Nesse contexto, o desconhecimento do vírus e as doenças causadas por ele dificulta o rastreio populacional (GLORIA et al., 2015).

O objetivo deste trabalho foi evidenciar e correlacionar o HTLV-1 como agente infeccioso diretamente ligado ao desenvolvimento de ATL e HAM/TSP.

\section{METODOLOGIA}

Trata-se de uma revisão da literatura realizada por meio de estudo transversal retrospectivo, com base em artigos científicos publicados nas bases de dados SciELO, MEDLINE e Pubmed, nas línguas portuguesa e inglesa, no período de 2009 a fevereiro de 2020.

Adotou-se os seguintes critérios de inclusão: artigos publicados em periódicos nacionais e internacionais que possuam relação com o tema de interesse, publicados dentro do intervalo de estudo nos idiomas estabelecidos, utilizando os descritores: HTLV-1, ATL, mielopatia. E como critério de exclusão, artigos publicados fora do intervalo do estudo e que não possuam relação de interesse como tema.

\section{RESULTADOS}

Os estudos selecionados foram publicados entre 2009 e 2019. O quadro 1 mostra a distribuição dos 15 artigos incluídos na revisão, dos quais 9 foram realizados no Brasil (Bahia, Pará e Maranhão) e 8 fornecem dados estatísticos de prevalência e grupo populacional acometido. Estudos realizados no estado do Pará e Bahia foram a maioria, seguidos pelo estado do Maranhão. 
Quadro 1 - Artigos incluídos na revisão

\begin{tabular}{|c|c|c|c|c|}
\hline $\begin{array}{l}\text { AR } \\
\text { TIG } \\
0\end{array}$ & AUTOR & $\begin{array}{l}\text { DELINEA } \\
\text { MENTO }\end{array}$ & TíTULO & $\stackrel{D}{n}$ \\
\hline 1 & $\begin{array}{l}\text { Castro et al., } \\
2009\end{array}$ & revisão & $\begin{array}{c}\text { Epidemiologia e origem do HTLV-1 em Salvador estado da } \\
\text { Bahia: a cidade com a mais elevada prevalência desta infecção } \\
\text { no Brasil }\end{array}$ & $\begin{array}{c}\mathrm{Br} \\
\text { asil }\end{array}$ \\
\hline 2 & $\begin{array}{l}\text { Sodré et al., } \\
2010\end{array}$ & $\begin{array}{c}\text { transvers } \\
\text { al }\end{array}$ & $\begin{array}{l}\text { Soroepidemiologia da infecção por HTLV-I/II em população } \\
\text { assistida pelo Programa Saúde da Família em Salvador, Bahia }\end{array}$ & $\begin{array}{c}\mathrm{Br} \\
\text { asil }\end{array}$ \\
\hline 3 & $\begin{array}{l}\text { Viana et al., } \\
2013\end{array}$ & $\begin{array}{c}\text { transvers } \\
\text { al }\end{array}$ & $\begin{array}{l}\text { Seroprevalence of HTLV-1/2 among blood donors in the state } \\
\text { of Maranhão, Brazil }\end{array}$ & $\begin{array}{l}\mathrm{Br} \\
\text { asil }\end{array}$ \\
\hline 4 & $\begin{array}{l}\text { Vallinoto et al., } \\
2015\end{array}$ & $\begin{array}{c}\text { transvers } \\
\text { al }\end{array}$ & $\begin{array}{l}\text { HTLV-1-Associated Myelopathy/Tropical Spastic Paraparesis Is } \\
\text { Not Associated with SNP rs12979860 of the IL-28B Gene }\end{array}$ & $\begin{array}{c}\mathrm{Br} \\
\text { asil }\end{array}$ \\
\hline 5 & $\begin{array}{c}\text { Chou-Zen e } \\
\text { Semmes, } 2016\end{array}$ & revisão & $\begin{array}{l}\text { HTLV-1 Infection and Adult T-Cell Leukemia/Lymphoma-A Tale } \\
\text { of Two Proteins: Tax and HBZ }\end{array}$ & $\begin{array}{c}\mathrm{EU} \\
\mathrm{A}\end{array}$ \\
\hline 6 & $\begin{array}{c}\text { Kogure e } \\
\text { Kataoka, } 2017\end{array}$ & revisão & Genetic alterations in adult T-cell leukemia/ lymphoma & $\begin{array}{l}\text { Jap } \\
\text { ão }\end{array}$ \\
\hline 7 & $\begin{array}{c}\text { Tagaya e Gallo, } \\
2017 \\
\end{array}$ & revisão & The Exceptional Oncogenicity of HTLV-1 & $\begin{array}{l}\text { Jap } \\
\text { ão }\end{array}$ \\
\hline 8 & $\begin{array}{l}\text { Aguiar et al., } \\
2015\end{array}$ & $\begin{array}{c}\text { transvers } \\
\text { al }\end{array}$ & $\begin{array}{c}\text { Human T-lymphotropic virus } 1 \mathrm{AA} \text { circulation and risk factors for } \\
\text { sexually transmitted infections in an Amazon geographic area } \\
\text { with lowest human development index (Marajó Island, } \\
\text { Northern Brazil) }\end{array}$ & $\begin{array}{c}\mathrm{Br} \\
\text { asil }\end{array}$ \\
\hline 9 & $\begin{array}{c}\text { Futsch; } \\
\text { Mahieux; } \\
\text { Dutarte, } 2017 \\
\end{array}$ & revisão & $\begin{array}{c}\text { HTLV-1, the Other Pathogenic Yet Neglected Human Retrovirus: } \\
\text { From Transmission to Therapeutic Treatment }\end{array}$ & $\begin{array}{c}\text { Fra } \\
\mathrm{nç} \\
\mathrm{a}\end{array}$ \\
\hline 10 & $\begin{array}{l}\text { Silva et al., } \\
\quad 2018\end{array}$ & $\begin{array}{c}\text { transvers } \\
\text { al }\end{array}$ & $\begin{array}{l}\text { Moderada endemicidade da infecção pelo vírus linfotrópico-T } \\
\text { humano na região metropolitana de Belém, Pará, Brasil }\end{array}$ & $\begin{array}{c}\mathrm{Br} \\
\text { asil }\end{array}$ \\
\hline 11 & $\begin{array}{l}\text { Nobre et al., } \\
2018\end{array}$ & $\begin{array}{c}\text { transvers } \\
\text { al }\end{array}$ & $\begin{array}{l}\text { Low genetic diversity of the Human T-cell Lymphotropic Virus } \\
\text { (HTLV-1) in na endemic area of the Brazilian Amazon basin }\end{array}$ & $\begin{array}{c}\mathrm{Br} \\
\text { asil }\end{array}$ \\
\hline 12 & $\begin{array}{l}\text { Rosadas et al., } \\
\qquad 2018\end{array}$ & $\begin{array}{c}\text { revisão } \\
\text { sistemáti } \\
\text { ca }\end{array}$ & $\begin{array}{l}\text { Estimation of HTLV-1 vertical transmission cases in Brazil per } \\
\text { annum }\end{array}$ & $\begin{array}{c}\mathrm{Br} \\
\text { asil }\end{array}$ \\
\hline 13 & $\begin{array}{l}\text { Pereira et al., } \\
2019\end{array}$ & $\begin{array}{c}\text { transvers } \\
\text { al }\end{array}$ & $\begin{array}{l}\text { Evidence of New Endemic Clusters of Human T-Cell Leukemia } \\
\text { Virus (HTLV) Infection in Bahia, Brazil }\end{array}$ & $\begin{array}{c}\mathrm{Br} \\
\text { asil }\end{array}$ \\
\hline 14 & $\begin{array}{l}\text { Tagaya; } \\
\text { Matsuoka; } \\
\text { Gallo, } 2019\end{array}$ & revisão & $\begin{array}{l}40 \text { years of the human T-cell leukemia virus: past, present, and } \\
\text { future }\end{array}$ & $\begin{array}{c}\text { EU } \\
\text { A }\end{array}$ \\
\hline 15 & $\begin{array}{l}\text { Araujo et al., } \\
2018\end{array}$ & $\begin{array}{c}\text { transvers } \\
\text { al }\end{array}$ & $\begin{array}{l}\text { Clinical and laboratory features of Adult T-cell } \\
\text { Leukemia/lymphoma (ATL): a study of } 37 \text { cases }\end{array}$ & $\begin{array}{c}\mathrm{Br} \\
\text { asil }\end{array}$ \\
\hline
\end{tabular}

Fonte: Autoria própria (2020).

Em todos os artigos pesquisados, a estimativa é de que o número de infectados por HTLV-1 esteja em torno de 20 milhões de pessoas em todo o mundo, sendo que a incidência de indivíduos sintomáticos está entre 2,5\% e 5\%.

Os trabalhos de pesquisa selecionados foram realizados com grupos populacionais variados, sendo doadores de sangue, gestantes, demanda espontânea e transeuntes. Além disso, não houve delimitação de idade. 
O grupo populacional mais acometido pelo HTLV-1, de acordo com a faixa etária, foi entre os indivíduos com mais de 50 anos (gráfico 1). A idade média identificada foi 48,4. De acordo com o gênero, nas mulheres a incidência foi maior, de $70 \%$, e nos homens, menor, de $30 \%$ (gráfico 2).

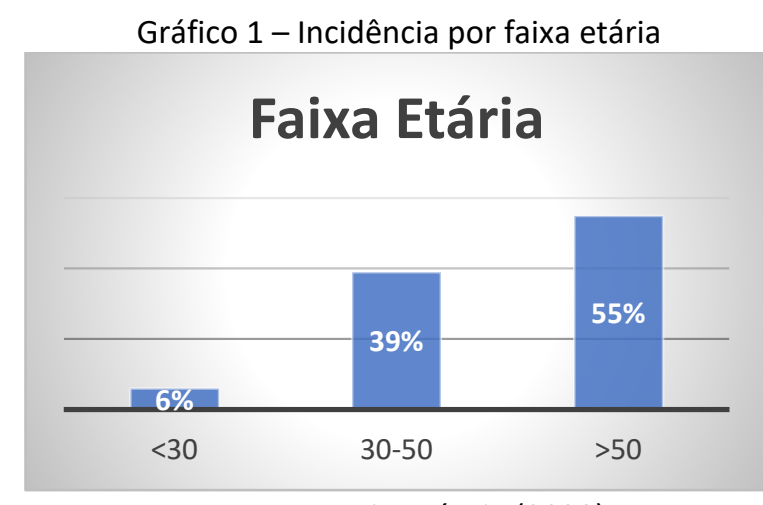

Fonte: Autoria própria (2020)

Gráfico 2 - Incidência por gênero

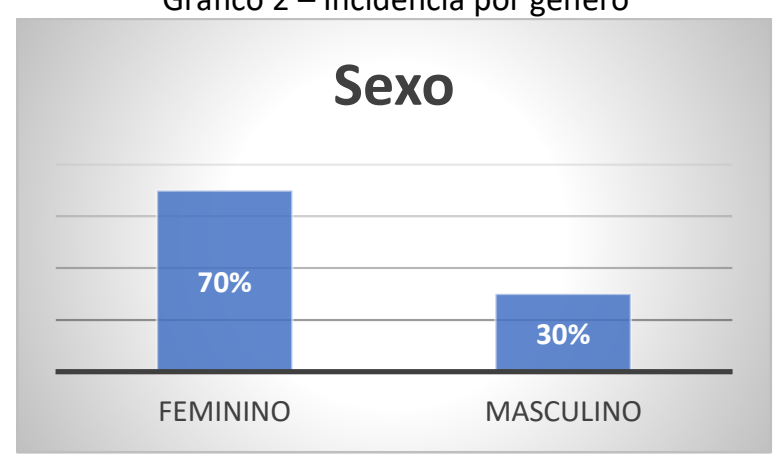

Fonte: Autoria própria (2020)

Nos artigos de pesquisa, a incidência mediana de prevalência de infecção pelo HTLV-1 foi de 1,04\%, (quadro 2). Em dois estudos, foi realizado o sequenciamento e análise filogenética e encontrado o subtipo 1aA cosmopolita transcontinental.

Quadro 2 - Prevalência de HTLV-1

\begin{tabular}{|c|c|c|c|}
\hline ARTIGO & AUTOR PRINCIPAL & PAíS & PREVALÊNCIA \\
\hline $\mathbf{8}$ & Vallinoto et. al, 2015 & Brasil & $0,11 \%$ \\
\hline $\mathbf{3}$ & Viana et. al, 2013 & Brasil & $0,15 \%$ \\
\hline $\mathbf{1 3}$ & Grassi et. al, 2019 & Brasil & $0,84 \%$ \\
\hline $\mathbf{1 2}$ & Rosadas et. al, 2018 & Brasil & $1,05 \%$ \\
\hline $\mathbf{1 0}$ & Silva et. al, 2018 & Brasil & $1,40 \%$ \\
\hline $\mathbf{1}$ & Castro et. al, 2009 & Brasil & $1,80 \%$ \\
\hline $\mathbf{2}$ & Sodré et. al, 2010 & Brasil & $1,96 \%$ \\
\hline
\end{tabular}

Fonte: Autoria própria (2020). 
Em relação à associação do HTLV-1 com o desenvolvimento de doenças, foi constatado que em todos os estudos é abordada essa possibilidade, sendo as doenças de maior gravidade a ATL, seguida pela HAM/TSP, que se apresenta como a de maior prevalência. Tagaya, Matsuoka e Gallo (2019) publicaram que a ATL ocorre em 3-5\% dos infectados e 0,3-5\% desenvolvem HAM/TSP; além disso, segundo os autores, o HTLV-1 está presente também em outros indivíduos com desordens inflamatórias e imunodeficiências.

Em estudo de Araújo et al. (2018), para o qual foram selecionados 46 doadores de sangue com teste HTLV-1 positivo, 37 foram confirmados com ATL, 80,43\%. Ademais, estudo desenvolvido por Nobre et al. (2018) detectou que 32\% dos pacientes HTLV-1 positivo eram sintomáticos sugestivo de HAM/TSP.

Quadro 3 - Principais achados dos autores

\begin{tabular}{|c|c|c|}
\hline ARTIGO & AUTOR & PRINCIPAIS ACHADOS \\
\hline 1 & Castro et al., 2009 & $\begin{array}{l}\text { Identificou prevalência maior em mulheres, e aumentando com } \\
\text { a idade consideravelmente nos indivíduos com mais de } 51 \text { anos. } \\
\text { A análise filogenética confirmou que as sequências estudadas } \\
\text { eram do subtipo Cosmopolita (a), subgrupo Transcontimental } \\
\text { (A) }\end{array}$ \\
\hline 3 & Viana et al., 2013 & $\begin{array}{l}\text { Em relação ao desenvolvimento clínico dos casos de HTLV-1, o } \\
\text { estudo incluiu o caso de paraparesia espástica tropical } \\
\text { associado à síndrome de Arnould-Chiari e siringomielia. }\end{array}$ \\
\hline 8 & $\begin{array}{l}\text { Vallinoto et al., } \\
2015\end{array}$ & $\begin{array}{l}\text { Confirmou a presença do HTLV-1 cosmopolita transcontinental } \\
\text { no arquipélago de Marajó, região amazônica. }\end{array}$ \\
\hline 10 & Silva et al., 2018 & $\begin{array}{l}\text { A infeç̧ão por HTLV demonstrou moderada prevalência na } \\
\text { população estudada, com predomínio do HTLV-1. Essa mostrou- } \\
\text { se associada à baixa renda e ao aumento da idade das mulheres. } \\
\text { Também apresentou disseminação intrafamiliar e negligência } \\
\text { no diagnóstico das doenças associadas. }\end{array}$ \\
\hline 11 & Nobre et al., 2018 & $\begin{array}{l}\text { Estudou } 78 \text { pacientes com resultado positivo para HTLV-1, } \\
\text { destes, } 50 \text { foram monitorados no ambulatório do Núcleo de } \\
\text { Medicina Tropical da UFPA, onde } 32 \% \text { apresentaram sintomas } \\
\text { de HAM/TSP, enquanto os outros } 68 \% \text { eram assintomáticos }\end{array}$ \\
\hline 12 & $\begin{array}{l}\text { Rosadas et al., } \\
2018\end{array}$ & $\begin{array}{l}\text { De acordo com o padrão de amamentação e a prevalência de } \\
\text { HTLV-1 em cada região, estima-se } 3.024 \text { novos casos de } \\
\text { infecção por HTLV-1 devido à transmissão de mãe para filho } \\
\text { anualmente. Essas } 3.024 \text { transmissões resultarão em 120-604 } \\
\text { casos de ATL e 8-272 de HAM / TSP. }\end{array}$ \\
\hline 15 & Araújo et al., 2018 & $\begin{array}{l}\text { Estudou } 46 \text { pacientes positivos para HTLV-1 e com doença nos } \\
\text { linfócitos T. Destes apenas } 37 \text { confirmados com ATL, } \\
\text { confirmado haver algumas dificuldades no diagnóstico dessa } \\
\text { doença no Brasil, devido às semelhanças com outros distúrbios } \\
\text { linfoproliferativos T. Foi encontrado } 1 \text { caso de ATL } \\
\text { concomitantemente com HAM / TSP. }\end{array}$ \\
\hline
\end{tabular}

Fonte: Autoria própria (2020). 


\section{DISCUSSÃO}

Ainda que o Brasil esteja entre os países com maior número de pessoas infectadas pelo HTLV-1, este vírus é desconhecido por grande parte da população e, também, por profissionais de saúde, ainda que tenha potencial para desenvolver ATL e HAM/TSP, doenças graves e crônicas, além de outras desordens relatadas por Tagaya (2019), como uveíte, artropatia, dermatite, exocrinopatia, miosite e bronquiectasia.

A negligência patogênica do HTLV-1 pode ser entendida pelo baixo risco de adoecimento, visto que entre os infectados até $5 \%$ desenvolvem doenças. Zihlmann, Mazzaria e Alvarenga afirmam, em estudo de 2017, que há uma invisibilidade do HTLV no Brasil e no mundo; devido a isso, muitos entendem o baixo risco de adoecer como justificativa para a negligência dessa endemia.

Não obstante, ainda não existe um estudo epidemiológico, com metodologia adequada, que tenha determinado a prevalência na população geral, principalmente no Brasil. Sabe-se da diversidade de prevalência em triagens sorológicas de doadores de sangue no país, onde se observa grande prevalência na Bahia, que é também uma região com grande número de estudos em HTLV.

Embora nos artigos selecionados para esta revisão não exista uma proporção justa dos investigados em relação ao sexo e idade, foi identificado que o grupo populacional mais acometido por HTLV-1 contempla as pessoas, predominantemente, do sexo feminino e acima de 50 anos. Tal cenário corrobora a pesquisa publicada por Champs e colaboradores em 2010, que estudou pacientes em hospital de reabilitação com diagnósticos de HAM/TSP e soropositivos para HTLV-1 durante 10 anos, dos quais 67\% eram mulheres, com 53 anos de média de idade.

Como o período de latência do HTLV-1 é longo, podendo durar entre 10 e 60 anos, ficou clara a prevalência do vírus em maiores de 50 anos, e o risco maior de infectados durante a infância, na amamentação, desenvolverem doenças. Com relação ao sexo, sabe-se que as mulheres são mais susceptíveis a contrair o vírus por via sexual

Quanto ao subtipo mais descrito, observou-se a prevalência do subtipo Cosmopolita (HTLV-1a), subgrupo Transcontinental (A) nos artigos que realizam análise filogenética, o que é validado por Carneiro-Proietti em estudo de 2006. Neste estudo, a autora afirma que na América do Sul, inclusive no Brasil, o subgrupo Transcontinental é 
predominante e afirma, também, que esta distribuição é resultado da migração de africanos durante o comércio de escravizados no século 16.

A ATL ficou bem reconhecida como doença associada ao HTLV-1. Em todos os estudos da revisão, é abordada essa associação etiológica do vírus, assim como a HAM/TSP. Isso é validado por estudos soroepidemiológicos de Catalan-Soares, que demonstraram ainda uma correspondência geográfica da incidência da malignidade de células T maduras e uma maior prevalência do vírus e de sorologias positivas para o vírus tipo 1 em $80 \%$ a $90 \%$ de casos de ATL, além de ainda demonstrarem a capacidade oncogênica do HTLV em modelos animais.

Em publicação de 2018, Araújo identifica 37 pacientes confirmados com ATL, dentre 46 HTLV-1 positivos, e relata a dificuldade no diagnóstico dessa doença, devido à semelhança com manifestações de outras doenças linfoproliferativas.

Percebe-se alguns obstáculos para esta revisão, ainda que se tenha encontrado resultados que se assemelham aos achados da literatura, quanto a prevalência do vírus, grupo acometido e subtipo predominante, são escassos os trabalhos que oferecem dados de diagnóstico de HTLV-1 concomitantemente com o diagnóstico de ATL ou de HAM/TSP. Do mesmo modo, estudos epidemiológicos de base populacional, de abrangência nacional com bases bem definidas para prevalência do HTLV-1, são limitados e desatualizados.

\section{CONCLUSÃO}

Apesar de causar grande impacto na saúde pública, o HTLV-1 permanece negligenciado, sendo desconhecido por grande parte da população e de muitos profissionais da área da saúde. O HTLV-1 é um vírus silencioso e endêmico em várias regiões do mundo. No Brasil, um dos países onde há um número expressivo de pessoas infectadas, trata-se de um problema de saúde pública.

Como não há tratamento para eliminar o vírus, é imprescindível conter a transmissão da infecção, evitando, assim, que ele se espalhe cada vez mais. Para tanto, é considerada como meio eficaz de prevenção a realização de triagem em gestantes e recomendável suspensão do aleitamento materno em mães soropositivas, como prevenção da transmissão vertical. Ademais, é fundamental que sejam desenvolvidas campanhas informativas sobre modos de transmissão e prevenção. 
A realização de maiores estudos de prevalência para HTLV-1 é de grande importância para conhecer o perfil clínico e epidemiológico da população, o que pode ajudar o profissional de saúde a suspeitar do diagnóstico, estimular a investigação dos sintomas associados e solicitar exames necessários.

\section{REFERÊNCIAS}

AGUIAR, S. A. et al. Human T-lymphotropic virus 1aA circulation and risk factors for sexually transmitted infections in an Amazon geographic area with lowest human development index (Marajó Island, Northern Brazil). BMC Infection Diseases, v. 17, n. 1, p. 1-11, dez. 2017. Disponível em: https://www.ncbi.nlm.nih.gov/pubmed/29216835. Acesso em: 20 fev. 2020

ARAúJO, C. S. R. et al. Clinical and laboratory features of Adult T-cell Leukemia/lymphoma (ATL): a study of 37 cases. Acta Haematologica Polonica, v. 49 , n. 2, p. 75-84, jun. 2018. Disponível em: https://content.sciendo.com/view/journals/ahp/49/2/article-p75.xml. Acesso em: 12 mar. 2020

BRASIL. Ministério da Saúde. Secretaria de Vigilância em Saúde Departamento de DST, Aids e Hepatites Virais. Manual técnico para o diagnóstico de hepatites virais. Brasília: Ministério da Saúde, 2014. Disponível em: http://www.aids.gov.br/pt$\mathrm{br} /$ noticias/manual-tecnico-para-o-diagnostico-das-hepatites-virais-eatualizado. Acesso em: 12 jan. 2020

CARNEIRO-PROIETTI, A. B. de F. (org.). HTLV. 6. ed. atual. e aum. Belo Horizonte: Fundação Hemominas, 2015. 615 p. v. 16. E-book. Disponível em: https://www.google.com/url?sa=t\&rct=j\&q=\&esrc=s\&source=web\&cd=2\&cad= rja\&uact=8\&ved=2ahUKEwiiwdbi64vpAhVMGbkGHQOBA4AQFjABegQIBBAB\&u $\mathrm{rl}=\mathrm{http} \% 3 \mathrm{~A} \% 2 \mathrm{~F} \% 2 \mathrm{Fwww}$.hemominas.mg.gov.br\%2Fpublicacoes\%3Fdownload\% 3D349\%3Acadernos-hemominas-htlv\&usg=AOvVaw0zVCD_Nfft7f3KKy_pDzna.

Acesso em: 12 jan. 2020

CASSEB, J. Is Human $T$ Cell Lymphotropic Type 1 (HTLV-1) Associated Myelopathy/Tropical Spastic Paraparesis (HAM/TSP) Syndrome a Neglected Disease? Plos. Negl. Trop. Dis., v. 24, n. 3, nov. 2009. Disponível em: https://www.ncbi.nlm.nih.gov/pubmed/19936247. Acesso em: 15 fev. 2020

CASTRO, B. G. et al. Epidemiologia e origem do htlv-i em Salvador estado da Bahia: a cidade com a mais elevada prevalência desta infecção no brasil. Gazeta Médica da Bahia, Salvador, v. 79, n. 1, p. 3-10, jan./dez. 2009. Disponível em: https://www.arca.fiocruz.br/handle/icict/7968. Acesso em: 01 fev. 2020

CATALAN-SOARES, B. et al. Heterogeneous geographic distribution of human T-cell lymphotropic viruses I and II (HTLV-I/II): serological screening prevalence rates in 
blood donors from large urban areas in Brazil. Cad. Saúde Pública, Rio de Janeiro, v. 21, n. 3, p. 926-993, maio/jun. 2005. Disponível em: http://www.scielo.br/scielo.php?script=sci_arttext\&pid=S0102$311 \times 2005000300027$. Acesso em: 12 jan. 2020

FUTSCH, N. et al. HTLV-1, the Other Pathogenic Yet Neglected Human Retrovirus: From Transmission to Therapeutic Treatment. Viruses, v. 21, n. 1, dez. 2017. Disponível em: https://www.ncbi.nlm.nih.gov/pubmed/29267225. Acesso em: 15 fev. 2020

GESSAIN, A. et al. Epidemiological aspects and world distribution of HTLV-1 infection. Frontiers in microbiology. Front. Microbiol., v. 3, p. 1-23, nov. 2012. Disponível em: https://www.frontiersin.org/articles/10.3389/fmicb.2012.00388/full. Acesso em: 12 jan. 2020

MEHTA-SHAH, N.; RATNER, L.; HORWITZ, S. M. Adult T-Cell Leukemia/Lymphoma.

NOBRE, A. F. S. et al. Low genetic diversity of the Human T-cell Lymphotropic Virus (HTLV-1) in an endemic area of the Brazilian Amazon basin. Plos One, v. 13, n. 3, mar. 2018. Disponível em: https://www.ncbi.nlm.nih.gov/pubmed/29558516. Acesso em: 05 fev. 2020

NOBRE, A. F. S. Modelagem comparativa tridimensional, dinâmica e caracterização molecular da glicoproteína gp46 do vírus linfotrópico-t humano do tipo 1 (htlv1). 2019. Tese (Doutorado) - Núcleo de Medicina Tropical, Programa de PósGraduação em Doenças Tropicais, Universidade Federal do Pará, Belém, 2019. Acesso em: 27 abr. 2020

POIESZ, B. J. et al. Detection and isolation of type $C$ retrovirus particles from fresh and cultured lymphocytes of a patient with cutaneous T-cell lymphoma. Proc. Natl. Acad. Sci. USA, v. 77, n. 12, p. 7415-7419, dez. 1980. Disponível em: https://www.ncbi.nlm.nih.gov/pubmed/6261256\#. Acesso em: 20 mar.2020

PROIETTI, F. A. et al. Global epidemiology of HTLV-I infection and associated diseases. Oncogene, v. 24, 2005, p. 6058-6068. Disponível em: https://www.nature.com/articles/1208968.pdf. Acesso em: 12 jan. 2020

RATHSAM-PINHEIRO, R. H. et al. Revisiting Keratoconjunctivitis Sicca associated with Human T-Cell Lymphotropic Virus Type 1: prevalence, clinical aspects and proviral load. The Brazilian Journal of infectious diseases, Salvador, v. 23, n. 2, mar./abr. $2019 . \quad$ Disponível em: http://www.scielo.br/scielo.php?script=sci_arttext\&pid=S141386702019000200095. Acesso em: 15 fev. 2020

SANTOS, E. C.; RODRIGUES, A. S. N. Perfil epidemiológico de pacientes portadores de desordens neurológicas funcionais não traumáticas infectados pelo Vírus HTLV. Biota Amazônia, Macapá, v. 1, n. 2, p. 79-85, 2011. Disponível em: https://periodicos.unifap.br/index.php/biota/article/view/335/v1n2p79-85.pdf. Acesso em:27 mar. 2020 
SANTOS, R. F. S. Prevalência do Vírus Linfotrófico de Células T Humanas Tipo 1 (HTLV1) nos pacientes em hemodiálise de manutenção em Salvador. 2013. Dissertação (Mestrado) - Programa de Pós-Graduação em Ciência da Saúde, Universidade Federal da Bahia, Salvador, 2013. Disponível em: https://possaude.ufba.br/pt-br/prevalencia-do-virus-linfotrofico-de-celulas-thumanas-tipo-1-htlv-1-nos-pacientes-em-hemodialise-de. Acesso em: 27 mar. 2020

SILVA, I. C. Moderate endemicity of the human T-lymphotropic virus infection in the metropolitan region of Belém, Pará, Brazil. Rev. Bras. Epidemiol., São Paulo, v. 21, 2018. Disponível em: https://www.scielo.br/scielo.php?script=sci_arttext\&pid=S1415790X2018000100417\&lng=pt\&nrm=iso\&tlng=en. Acesso em: 15 mar. 2020

SODRÉ, H. R. S. et al. Soroepidemiologia da infecção por HTLV-I/Il em população assistida pelo Programa Saúde da Família em Salvador, Bahia. Jornal Brasileiro de Patologia e Medicina Laboratorial, Rio de Janeiro, v. 46, n. 5, p. 369-374, out. 2010.

Disponível

em:

https://www.scielo.br/scielo.php?script=sci_arttext\&pid=S1676-

24442010000500005. Acesso em: 27 mar. 2020

TAGAYA, Y. et al. The Exceptional Oncogenicity of HTLV-1. Front. Microbiol., v. 8, p. 1-4, ago. $2017 . \quad$ Disponível em: https://www.ncbi.nlm.nih.gov/pmc/articles/PMC5539117/pdf/fmicb-0801425.pdf. Acesso em: 12 jan. 2020

TAGAYA, Y.; MATSUOKA, M.; GALLO, R. 40 years of the human T-cell leukemia virus: past, present, and future. F1000 Faculty Rev., v. 228, fev. 2019. Disponível em: https://www.ncbi.nlm.nih.gov/pmc/articles/PMC6396841/pdf/f1000research8-19114.pdf. Acesso em: 18 jan. 2020

VALLINOTO, A. C. et al. HTLV-1-Associated Myelopathy/Tropical Spastic Paraparesis Is Not Associated with SNP rs12979860 of the IL-28B Gene. Mediators Inflamm., v. 2015, p. 1-7, 2015. Disponível em: https://www.ncbi.nlm.nih.gov/pmc/articles/PMC4644563/pdf/MI2015804167.pdf. Acesso em: 27 mar. 2020

VIANA, G. M. C. et al. Seroprevalence of HTLV-1/2 among blood donors in the state. Journal of Oncology Practice, v. 13, n. 8, ago. 2017. Disponível em: https://www.ncbi.nlm.nih.gov/pmc/articles/PMC6366298/. Acesso em: 27 mar. 2020 


\title{
CAPITULO XII
}

\section{NANOMATERIAIS: APLICAÇÕES DO GRAFENO E DO NIÓBIO NA MEDICINA}

\author{
DOI: 10.51859/AMPLLA.PAE1993-12
}

\author{
Bárbara Queiroz de Figueiredo ${ }^{1}$ \\ Bruno Rodrigues Cancela ${ }^{2}$ \\ Leomar dos Santos Silva ${ }^{1}$ \\ Luanna Oliveira Gonçalves ${ }^{3}$
}

\footnotetext{
${ }^{1}$ Graduandos do curso de Medicina. Centro Universitário de Patos de Minas (UNIPAM).

${ }^{2}$ Mestre em Ciência e Tecnologia de Polímeros. Universidade Federal do Rio de Janeiro (UFRJ).

${ }^{3}$ Graduanda do curso de Medicina. Instituto Master de Ensino Presidente Antônio Carlos (IMEPAC).
}

\section{RESUMO}

Os chamados nanomateriais são considerados por muitos, materiais que possuem sua estrutura restrita a dimensões de 1 a $100 \mathrm{~nm}$. Os nanomateriais apresentam uma extensa faixa de aplicações como na biomedicina, na área de alimentos e agricultura, drogas e vacinas e principalmente na catálise. O óxido de grafeno reduzido tem se mostrado um excelente agente fototérmico, permitindo a eliminação eficiente de tumores em experimentos in vivo, bem como, devido a excelente condutividade elétrica do grafeno promete melhorar a conversão das sinapses em movimento. Além disso, 0 uso de nióbio cresce no campo da medicina como elemento de liga para aumento de resistência mecânica para implantes ortopédicos biocompatíveis. Assim, é possível afirmar que são muitos os benefícios que o grafeno e o nióbio, interligados com as nanotecnologias, gerarão à humanidade, e, principalmente aos avanços da medicina.

Palavras-chave: Nanomateriais; Aplicações; Medicina; Nióbio; Grafeno. 


\section{INTRODUÇÃO}

Os chamados nanomateriais são considerados por muitos, materiais que possuem sua estrutura restrita a dimensões de 1 a $100 \mathrm{~nm}$. Porém, essa definição é pouco importante, uma vez que as propriedades evoluem e não há argumento físico para essa classificação. De uma forma geral, são as propriedades dos materiais que regem esse conceito e não necessariamente as dimensões das partículas. O estudo de tais materiais ganhou importância considerável no final do século XX, o que levou ao aparecimento de um grande ramo da ciência conhecido como "Nanociência e Nanotecnologia". Assim, os nanomateriais apresentam uma extensa faixa de aplicações como na biomedicina, na área de alimentos e agricultura, drogas e vacinas e principalmente na catálise (ALVES, 2013).

O grafeno é uma folha plana de átomos de carbono compactados em uma grade de duas dimensões com espessura de apenas um átomo, reunidos em uma estrutura cristalina hexagonal. A folha de grafeno pode formar uma esfera (fulereno) ou um tubo (nanotubo). Se muitas dessas folhas forem empilhadas, resultará num grafite tridimensional. O uso do termo "camada de grafeno" é também considerado para a terminologia geral dos carbonos. O grafeno, que tem a espessura de um átomo de carbono, é um dos materiais mais revolucionários que se acredita ter desenvolvido, devido as suas excelentes propriedades mecânicas, elétricas, térmicas, ópticas, entre outras. Estas propriedades sugerem que o grafeno substituirá muitos materiais em diversas aplicações (JAIN et al., 2018).

Já o nióbio está presente na natureza na forma de pirocloro natural $[(\mathrm{Na}, \mathrm{Ca}) 2 \mathrm{Nb} 2 \mathrm{O} 6(\mathrm{OH}, \mathrm{F})]$ e columbita-tantalita $[(\mathrm{Ta}, \mathrm{Nb}) 2 \mathrm{O6})]$, que estão associadas às rochas pegmatitas. Suas diversas formas estruturais e fases cristalinas relatadas na literatura são consideradas complexas e possuem formas polimórficas: pseudohexagonal, ortorrômbico e monoclínico, conferindo a esses materiais diferentes atividades catalíticas. Também contém propriedades promissoras para aplicações ambientais como caráter hipoalergênico, citotoxidade e alta estabilidade termodinâmica e, por isso, pode ser utilizado não apenas na química, como na biologia, na genética e na medicina (TOMA, 2016). Sob essa perspectiva, o objetivo deste estudo 
foi de evidenciar as aplicações dos nanomateriais grafeno e nióbio na medicina, ressaltando seus resultados promissores nesse campo.

\section{METODOLOGIA}

Trata-se de uma pesquisa descritiva do tipo revisão narrativa da literatura, que buscou evidenciar as aplicações dos nanomateriais grafeno e nióbio na medicina, ressaltando seus resultados promissores nesse campo. A pesquisa foi realizada através do acesso online nas bases de dados National Library of Medicine (PubMed MEDLINE), Scientific Electronic Library Online (Scielo), Cochrane Database of Systematic Reviews (CDSR), Google Scholar, Biblioteca Virtual em Saúde (BVS) e EBSCO Information Services, no mês de novembro de 2021. Para a busca das obras foram utilizadas as palavraschaves presentes nos descritores em Ciências da Saúde (DeCS): em inglês: "nanomaterials", "medicine", "niobium", "graphene", "nantubes", "applications" e em português: "nanomateriais", "medicina", "nióbio", "grafeno", "nanotubos", "aplicações".

Como critérios de inclusão, foram considerados artigos originais, que abordassem o tema pesquisado e permitissem acesso integral ao conteúdo do estudo, publicados no período de 2007 a 2021, em inglês e português. O critério de exclusão foi imposto naqueles trabalhos que não estavam em inglês ou português, que não tinham passado por processo de Peer-View e que não abordassem o tema da pesquisa. A estratégia de seleção dos artigos seguiu as seguintes etapas: busca nas bases de dados selecionadas; leitura dos títulos de todos os artigos encontrados e exclusão daqueles que não abordavam o assunto; leitura crítica dos resumos dos artigos e leitura na íntegra dos artigos selecionados nas etapas anteriores. Assim, totalizaram-se 23 artigos científicos para a revisão narrativa da literatura, com os descritores apresentados acima.

\section{REVISÃO BIBLIOGRÁFICA}

\subsection{GRAFENO}

Nanomateriais de carbono com ligações $\mathrm{sp}^{2}$ possuem propriedades mecânicas, eletrônicas, óticas e químicas únicas e têm se mostrado interessantes para muitas aplicações. Entre eles, os nanotubos de carbono (nanoestruturas 1D de carbono na 
forma de um tubo) e os grafenos (folhas de carbono 2D) são os que mais têm chamado atenção e estudos recentes têm mostrado o elevado potencial destes materiais para aplicações em medicina. Eles têm sido amplamente investigados para aplicações em biossensores, engenharia de tecidos, drug-delivery, imageamento molecular, entre outros. Além disso, nanotubos de carbono e grafenos possuem forte absorção ótica na região do infravermelho próximo, tornando-os materiais promissores para utilização em fototermia (GEIM et al., 2007).

Com isso, os nanotubos de carbono têm sido amplamente utilizados como plataformas na fabricação de biossensores para detectar biomoléculas. Além disso, estudos têm mostrado que a funcionalização deste material permite sua atuação como moléculas carreadoras de medicamentos para aplicações em drug delivery e tem sido empregado com sucesso no tratamento de câncer, por exemplo, nanotubos de carbono funcionalizados com polietileno glicol e conjugados com o quimioterápico paclitaxel proporcionaram maior eficácia na supressão do crescimento do câncer de mama. Isto se deve, principalmente, ao maior acumulo do quimioterápico na região do câncer quando conjugado com os nanotubos (GEIM, 2009).

Recentemente, um número crescente de trabalhos tem explorado o potencial do grafeno para aplicações biomédicas. Por possuir uma estrutura similar as dos nanotubos de carbono, grafenos também podem ser utilizados como carreadores de medicamentos e no tratamento contra o câncer. Por exemplo, óxido de grafeno reduzido tem se mostrado um excelente agente fototérmico, permitindo a eliminação eficiente de tumores em experimentos in vivo. Em outro estudo, óxido de grafeno funcionalizado com polietilenoimina (PEI) foi conjugado com RNA de interferência e com o antitumoral doxorrucibina. Esta entrega simultânea permitiu um aumento significativo da eficiência na quimioterapia (NOVOSELOV et al., 2012). Além disso, o grafeno também tem sido conjugado com componentes de imageamento e terapêuticos, formando materiais teranósticos. Um estudo recente mostra a funcionalização de óxido de grafeno com nanopartículas de óxido de ferro e o polímero polietileno glicol (PEG) para adicionar propriedades magnéticas e melhorar a biocompatibilidade, respectivamente (PRADO et al., 2017).

Ademais, grupos de pesquisa estão desenvolvendo preservativos à base de grafeno, o que poderia conduzir mais calor que o látex, bem como pretende reduzir a 
espessura de 0,07 $\mathrm{mm}$ atuais para 0,04 $\mathrm{mm}$. Além disso, pesquisadores criaram uma lente de contato capaz de captar todo o espectro de raios vermelhos e, com isso, o usuário seria capaz de enxergar no escuro e devolver a visão a pacientes por meio de implantes de retina de grafeno (HU et al., 2017). Em testes realizados com animais, Jain et al. (2018) alcançaram resultados surpreendentes no combate ao glioma, um tipo de tumor cerebral. Ao isolar a célula cancerosa com uma película de grafeno, os pesquisadores conseguiram interromper o fornecimento de oxigênio e nutrientes e, assim, matar de fome a massa cancerosa. Também, a excelente condutividade elétrica do grafeno promete melhorar a conversão das sinapses em movimento (TANG et al., 2020).

\subsection{NIÓBIO}

Na última década as aplicações de nióbio aumentaram constantemente em vários segmentos, aproveitando suas características: aços microligados, super ligas, implantes médicos, supercondutores e condensadores (VASCONCELOS et al., 2019). A procura de novos materiais metálicos, aplicados em implantes ortopédicos, tais como os aços inoxidáveis austeníticos, tem se intensificado nestes últimos anos. Este fato deve-se às diferentes falhas que os mesmos ainda apresentam e que são de natureza fisiológica (biocompatibilidade), mecânica (resistência) e química (corrosão) (LOPES et al., 2015). Com isso, o uso de nióbio cresce no campo da medicina como elemento de liga para aumento de resistência mecânica para implantes ortopédicos biocompatíveis (Ll et al., 2011).

Em pesquisa de Shapira et al. (2020), que teve como objetivo investigar o comportamento de células humanas semelhantes a osteoblastos cultivadas, em todos os grupos as células proliferaram rapidamente entre os dias 1 e 3 e, em seguida, estabilizaram. A maioria dos implantes de titânio e ligas de titânio atualmente disponíveis em aplicações clínicas são densos. Embora alguns métodos, como o tratamento de superfície, possam ser aplicados para aumentar a área de contato, esses métodos produzem certos efeitos na integração óssea entre os implantes e o osso. Ademais, pesquisa de Wang et al. (2010) já havia descoberto que a taxa de osseointegração da liga de revestimento de titânio e nióbio ( $\mathrm{TiNb}$ ) era melhor do que a 
liga de revestimento de titânio (Ti), o que indiretamente provou a importância do nióbio misturado com titânio.

No entanto, o tecido ósseo só pode se estender ao campo da superfície do implante e não ao interior dos implantes. A fixação biológica não é alcançada quando a estabilidade a longo prazo não é garantida. Sob essa perspectiva, os ensaios in vivo e in vitro demonstraram que a presença do óxido de nióbio potencializou as propriedades osteoestimuladora do biovidro (CAVALCANTI et al., 2013). Assim, além de biocompatível, ele passou a ser também bioativo, favorecendo a regeneração do tecido ósseo. Ou seja, no caso do uso do material por parte da medicina regenerativa, os ganhos poderão ser significativos (MUNROE et al., 2009).

Dada a diferença nas propriedades mecânicas, a liga do tipo denso provoca proteção contra estresse após a implantação no corpo, o que acaba levando à reabsorção óssea (PYTLICEK et al., 2019). Muitos estudos mostraram que o excesso de perda óssea influencia o efeito de longo prazo dos implantes e leva ao deslocamento do implante, afrouxamento asséptico, fratura ao redor da prótese e aumento da dificuldade de cirurgia de revisão (SANTOS et al., 2019). Assim, o nióbio pode reduzir a temperatura de transição para a fase beta, aumentar a zona de duas fases alfa e beta e melhorar a usinabilidade e a resistência à corrosão da liga de titânio. Ademais, notou-se que todas as ligas porosas de titânio-nióbio mostraram boa biocompatibilidade, independentemente da porcentagem de porosidade (SHAREENA et al., 2018).

Ademais, recentemente, pesquisadores da Universidade Federal de Minas Gerais (UFMG) criaram uma solução à base de nióbio capaz de proteger diferentes tipos de superfície do SARS-CoV-2, por até 24 horas. Aplicada na forma de gel ou líquido spray, a solução tem ação prolongada para limpeza e desinfecção das mãos e não causa reações adversas, como sensação de ressecamento da pele. $O$ produto também se mostrou ativo na proteção de superfícies em ambiente doméstico e equipamentos e utensílios nos ambientes médico e odontológico (MAROLI, 2021).

\subsection{PRINCIPAIS PREOCUPAÇÕES DA APLICAÇÃO DE NANOMATERIAIS EM MEDICINA}

Para uma aplicação com alta sensibilidade e seletividade em sistemas diagnósticos e terapêuticos, os nanomateriais devem estar combinados com 
biomoléculas ainda mais específicas, por exemplo, sistemas antígeno/anticorpo, enzima/substrato, receptores ou proteínas de membrana, sequências de DNA, RNA ou aptâmeros, cofatores, enfim, uma variedade de biomoléculas como descrito anteriormente. Além desses fatores, um importante parâmetro que deve ser levado em consideração quando um sistema diagnóstico e/ou terapêutico é desenvolvido é a biodisponibilidade no meio biológico (FERREIRA et al., 2009).

Apesar da funcionalização de nanomateriais com moléculas específicas, a biodispersidade e disponibilidade de nanomateriais em sistemas biológicos ainda são reduzidas. Com isso, um novo termo foi estabelecido para se referir a esses materiais, os chamados nano-objetos e seus agregados e aglomerados, do inglês, nano-objects their agglomerates and aggregates (NOAA) sem alterar totalmente suas dimensões na nanoescala, podendo ou não possuir as mesmas características de um nanomaterial totalmente disperso (TOMA, 2016).

Além disso, devido às suas dimensões reduzidas, as nanopartículas podem penetrar em diversas regiões do organismo de um indivíduo que participa da fabricação, manipulação ou mesmo do uso destas como diagnósticas ou terapia em nanomedicina, isto é, por meio da absorção/adsorção desses nanomateriais no uso como creme para pele, via oral, ou por inalação. Porém, essa entrada no sistema biológico depende de diversos fatores como composição química da superfície, propriedades físico-químicas, tamanho e forma, capacidade de agregação ou aglomeração, ou mesmo a funcionalização com biomoléculas específicas (MAKVANDI et al., 2020).

Outro fator importante são as doses, e o questionamento de até que ponto as doses administradas não demonstram efeitos tóxicos, ou quanto tempo esse nanomaterial fica disponível dentro do organismo até ser completamente eliminado, e como será essa eliminação entram em xeque (TANG et al., 2020). Como os nanomateriais possuem diferentes tamanhos e funcionalizações, cada um poderá apresentar um mecanismo diferente de entrada na célula (ALVES, 2013).

Um estudo realizado com nanopartículas esféricas de poliestireno com dimensões de $20 \mathrm{~nm}$ sugere que essas entram nas células através da membrana em uma passagem direta sem a necessidade de mecanismos de transporte específicos, seguido da distribuição por todo o citoplasma e ligando-se a várias bioestruturas do citoesqueleto (STRÓZ et al., 2018). Ou seja, compreender os mecanismos de entrada e 
saída das células, assim como assegurar a estabilidade das nanopartículas, principalmente as propriedades de superfície, será fundamental para garantir a segurança e melhor aproveitamento de suas funções.

\section{CONSIDERAÇÕES FINAIS}

É possível afirmar que são muitos os benefícios que o grafeno e o nióbio, interligados com as nanotecnologias, gerarão à humanidade, e, principalmente aos avanços da medicina, que vão desde a formação de profissionais, desenvolvimento de novos produtos e processos, melhoria na qualidade de vida, materiais com novas propriedades, até o desenvolvimento científico, tecnológico, econômico e social.

\section{REFERÊNCIAS}

ALVES, O.L. Nanotecnologias: Elas Já Estão Entre Nós. Revista Ciência e Cultura, v. 65, n. 3, p. 22-23, 2013.

CAVALCANTI, R. M. et al. Characterization of ZSM-5 modified with niobium pentoxide: The study of thiophene adsorption. Journal of the Brazilian Chemical Society, $v$. 24, n. 1, p. 40-50, 2013.

FERREIRA, H. S., et al. Nanotecnologia: Aspectos gerais e potencial de aplicação em catálise. Química Nova, v. 32, n. 7, p. 1860-1870, 2009.

GEIM, A. K., et al. The rise of graphene. Nature Mater. v. 6, n. 5, p. 183-191, 2007.

GEIM, A.K. Graphene: status and prospects. Science. v. 324, n. 33, p.1530 -1543, 2009.

HU, M., et al. Graphene-Based Nanomaterials for Catalysis. Industrial and Engineering Chemistry Research, v. 56, n. 13, p. 3477-3502, 2017.

JAIN, A. et al. Nanomaterials in food and agriculture: An overview on their safety concerns and regulatory issues. Critical Reviews in Food Science and Nutrition, v. 58, n. 2 , p. 297-317, 2018.

$\mathrm{LI}, \mathrm{H}$., et al. Remarkable biocompatibility enhancement of porous NiTi alloys by a new surface modification approach: in-situ nitriding and in vitro and in vivo evaluation. J Biomed Mater Res., v. 99, n. 4, p.544-553, 2011.

LOPES, O. F. et al. Óxidos de nióbio: Uma visão sobre a síntese do Nb205 e sua aplicação em fotocatálise heterogênea. Química Nova, v. 38, n. 1, p. 106-117, 2015. 
MAKVANDI, P. et al. Metal-Based Nanomaterials in Biomedical Applications: Antimicrobial Activity and Cytotoxicity Aspects. Advanced Functional Materials, v. 30, n. 22, 2020.

MAROLI, C. Caracterização de nanoestruturas de óxido de nióbio para aplicação em fotocatálise heterogênea. TCC (graduação) - Universidade Federal de Santa Catarina. Centro de Ciências Físicas e Matemáticas. Curso de Química, 2021.

MUNROE, N., et al. Enhanced Biocompatibility of Porous Nitinol. J Mater Eng Perform., v.18, n. 6, p. 765-767, 2009.

NOVOSELOV, K.S. et al. A roadmap for graphene. Nature, v. 190, n. 5, p.192-200, 2012.

PRADO, N. T., et al. Nanostructured niobium oxide synthetized by a new route using hydrothermal treatment: High efficiency in oxidation reactions. Applied Catalysis B: Environmental, v. 205, n. 5, p. 481-488, 2017.

PYTLICEK, Z. et al. On-chip sensor solution for hydrogen gas detection with the anodic niobium-oxide nanorod arrays. Sensors and Actuators, v. 284, n. 12, p. 723-735, 2019.

SANTOS, A. J. et al. Niobium oxide catalysts as emerging material for textile wastewater reuse: Photocatalytic decolorization of azo dyes. Catalysts, v. 9, n. 12, p. 56-70, 2019.

SHAPIRA, L., et al. Efeito de uma liga de titânio contendo nióbio no comportamento de osteoblastos em cultura. Pesquisa Clínica de Implantes Orais, v. 20, n. 6, p. 578582, 2020.

SHAREENA, T. P. D et al. A Review on Graphene-Based Nanomaterials in Biomedical Applications and Risks in Environment and Health. Nano-Micro Letters, v. 10, n. 3, p. 1-34, 2018.

STRÓZ, A., et al. Electrochemical Formation of Self Organized Nanotubular Oxide Layers on Niobium (Review). Current Nanoscience, v. 15, n. 1, p. 42-48, 2018.

TANG, Z. et al. Phosphorus Science-Oriented Design and Synthesis of Multifunctional Nanomaterials for Biomedical Applications. Matter, v. 2, n. 2, p. 297- 322, 2020.

TOMA, H. Nanotecnologia Molecular - Materiais e Dispositivos. Edgard Blü ed. São Paulo: 2016.

VASCONCELOS, Y., et al. O polêmico nióbio. Revista Pesquisa FAPESP, v. 20, n. 277, p. 63-69, 2019.

WANG, X., et al. Biomimetic modification of porous TiNbZr alloy scaffold for bone tissue engineering. Tissue Eng Part., v. 56, n. 6, p. 309-316, 2010. 


\title{
CAPITULO XIII
}

\section{O OIL PULLING NO TRATAMENTO DA GENGIVITE}

DOI: 10.51859/AMPLLA.PAE1993-13

\author{
Álvaro Valgueiro da Silva Ferraz ${ }^{1}$ \\ Virnna Mariana Ferreira Silva ${ }^{1}$ \\ Diego Moura Soares ${ }^{2}$ \\ Renato de Souza Melo ${ }^{3}$ \\ Jéssica Gomes Alcoforado de Melo ${ }^{4}$
}

\footnotetext{
${ }^{1}$ Cirurgião-Dentista Graduado pela Faculdade de Integração do Sertão - FIS.

${ }^{2}$ Doutor em Odontologia pela Universidade Federal de Pernambuco - UFPE.

${ }^{3}$ Doutor em Saúde da Criança e do Adolescente pela Universidade Federal de Pernambuco - UFPE.

${ }^{4}$ Mestre em Odontologia pela Universidade Estadual da Paraíba - UEPB.
}

\section{RESUMO}

A gengivite induzida por placa é uma resposta inflamatória dos tecidos gengivais resultante do acúmulo de placa bacteriana localizada na margem gengival e abaixo dela. Por isso a placa bacteriana precisa ser removida ou desorganizada com métodos efetivos de controle mecânico da placa caseiro e profissional, podendo se adicionar o controle químico da placa, feito com enxaguantes bucais. Os métodos alternativos vêm sendo estudados, entre eles o oil pulling, tentando mostrar a eficácia na redução da inflamação gengival. Estudos recentes sobre a técnica do "oil pulling" usando óleo de gergelim, óleo de girassol e óleo de coco foram realizados para avaliar redução da gengivite induzida por placa. Maioria dos estudos utilizam os óleos de coco e de gergelim para a redução da gengivite, os mecanismos de ação deles pode ser explicado pela saponificação da hidrolise alcalina da gordura, viscosidade do óleo desorganiza a placa, a presença de antioxidantes previnem a peroxidação lipídica ajudando na destruição de microorganismos. Esses óleos são os mais utilizados porque o de gergelim é rico em antioxidantes (sesamina, sesamolina e sesaminol) e o óleo de coco por ser composto de 92\% de ácidos saturados, sendo o mais rico em ácido láurico (50\%) que tem efeito antiinflamatório e antimicrobiano, sendo assim, eficaz sua utilização para o controle da gengivite por meio da técnica do oil pulling.

Palavras-chave: Óleo de Gergelim. Óleo de Coco. Oil pulling. Biofilme Dentário. 


\section{INTRODUÇÃO}

A gengivite induzida por placa é uma resposta inflamatória dos tecidos gengivais resultante do acúmulo de placa bacteriana localizada na margem gengival e abaixo dela (LÖE, THEILADE, JENSEN; 1965). A placa bacteriana é formada por bactérias da microbiota normal da boca organizadas e agrupadas na superfície dos dentes, a sua desorganização deve ser feita para manutenção da saúde bucal por meio do controle mecânico e químico da placa caseiro e profissional, o primeiro é feito no contato das cerdas da escova com a superfície dos dentes e o segundo com dentifrícios e enxaguantes bucais, que também exercem efeitos positivos na desorganização da placa bacteriana, garantindo um controle da população bacteriana, prevenindo doenças nos tecidos periodontais e dentários (RIPARI et al., 2020; JAMES et al., 2017; METO et al., 2019).

O controle químico da placa é, comumente, feito com enxaguantes bucais como o gluconato de clorexidina, que é o agente antimicrobiano mais utilizado. No entanto, o uso a longo prazo é limitado pelos seus efeitos adversos, alguns como manchamento nos dentes e língua, alteração temporária na percepção do paladar, aumento nos depósitos de cálculo, sensação de queimação e citotoxicidade nas células epiteliais bucais (DURBAKULA, 2018; FARDAL, TURNBULL, 1986).

Por isso, alternativas naturais e com menos efeitos adversos se mostraram necessárias, como a técnica do "oil pulling", estudos recentes usando óleo de coco, óleo de girassol e óleo de gergelim foram realizados para avaliar redução da gengivite induzida por placa (NASEEM et al., 2017; SEZGIN; MEMIS; ALPTEKIN, 2019). Essa técnica vem ganhando destaque como alternativa natural de otimização da higiene oral, por conferir vários benefícios, como a redução da inflamação e sangramento gengival, alívio dos sintomas da xerostomia, ação em bactérias causadoras da halitose e da cárie, além da otimização da higiene bucal e fortalecimento dos músculos da face e cavidade oral (SHANBHAG, 2017). Desta forma, o objetivo deste trabalho é fazer uma revisão narrativa da literatura avaliar sobre o uso da técnica do oil pulling no tratamento da gengivite. 


\section{REVISÃO BIBLIOGRÁFICA}

\subsection{GENGIVITE}

A saúde da cavidade oral está associada à presença de inúmeros microrganismos que quando em desequilíbrio podem aumentar a chance de desenvolvimento de gengivite e periodontite, em casos agravados (FIORILLO et al., 2019). Segundo Kumar (2019), a gengivite é uma doença inflamatória reversível de muitas etiologias que afeta os tecidos moles de suporte e tende a resultar em sangramento espontâneo e/ou induzido, principalmente ao escovar os dentes, usar fio dental ou morder alimentos duros, hipertrofia gengival, edema, podendo agravar-se para periodontite quando ocorre a formação de bolsas periodontais. É uma de etiologia multifatorial caracterizada por placa bacteriana e a interação de cofatores, os três principais são: ambientais, comportamentais e susceptibilidade do hospedeiro (BAYANI; SEGURA; ALVARADOM, 2017).

Conforme Ripari et al. (2020), a presença da placa bacteriana e a ação dos fatores moduladores do estado da inflamação gengival classificam as patologias gengivais. A gengivite induzida por placa é uma inflamação gengival que acontece pela não desorganização da placa bacteriana na margem gengival, essas bactérias em excesso passam a induzir o processo inflamatório agudo em que as alterações prematuras do estado de saúde gengival podem não ser clinicamente avaliáveis, entretanto, quando a causa patogênica não é removida e/ou as defesas do organismo não são capazes de remover rapidamente o agente etiológico ou os danos gerados, a gengivite progride para uma cronicidade ou periodontite e os sinais e sintomas clínicos tornam-se mais evidentes (RIPARI et al., 2020)

\subsection{TRATAMENTO DA GENGIVITE}

A primeira causa da doença periodontal é a placa (RIPARI et al., 2020) que se manifesta inicialmente como a gengivite, para isso, o tratamento de primeira escolha é a realização de uma higiene bucal profissional eficiente com a finalidade de remover 0 principal fator etiológico, a placa bacteriana. Ao mesmo tempo, conscientiza-se e instruise a higienização bucal doméstica, pois ela é fundamental para que as bactérias não 
voltem a colonizar os tecidos gengivais e a inflamação não volte a aparecer (KAMATH et al., 2020).

Segundo Meto et al. (2019), a higiene bucal profissional é realizada por meio de instrumentos manuais, ultrassônicos e sônicos, que desorganizam a placa bacteriana e tártaro. Além disso, a higiene bucal doméstica, por meio da escovação é suficiente para reduzir o acúmulo de placa bacteriana nas superfícies dentais, com o uso correto de escovas dentais juntas à limpeza interdental mecânica realizada pelo fio dental. Para mais, no tratamento da gengivite pode-se agregar o controle químico de placa, feito pelo uso de dentifrícios e enxaguantes bucais, como a clorexidina. Porém, o uso prolongado dessa substância pode trazer efeitos adversos como: discromia dentária, alteração do paladar e depósito de placa, efeitos na mucosa oral dor, irritação, descamação leve e ulceração da mucosa e uma sensação geral de queimação ou uma língua ardente ou ambos (JAMES et al, 2017; METO et al., 2019). Por isso, nas últimas décadas, pesquisadores buscaram uma alternativa a essa molécula, para que a gengivite pudesse ser curada sem nenhuma limitação ou complicação, devido ao uso do medicamento ao longo do tempo (KAMATH et al, 2020).

\subsection{OIL PULLING}

A intervenção profissional, remoção de fatores etiológicos, instruções adequadas de higiene doméstica devem ser executados para manter um ambiente bucal saudável que dificulte a formação da placa bacteriana (AHMAD et al., 2019). Mas, em alguns casos o controle mecânico da placa não é suficiente e precisa-se de um coadjuvante para realizar o controle químico da placa no tratamento da gengivite (RIPARI et al., 2020). A clorexidina é o padrão como substância adjunta aos procedimentos mecânicos, pois apresenta alta qualidade de redução da placa, mas o uso prolongado apresenta malefícios (JAMES et al., 2017). Segundo Ripari et al. (2020), a medicina alternativa provou ser mais popular nas ultimas décadas. Os métodos alternativos vêm sendo estudados, entre eles o oil pulling, tentando mostrar a eficácia na redução da formação e agregação da placa bacteriana.

Estudos recentes sobre a técnica do "oil pulling" usando óleo de gergelim, óleo de girassol e óleo de coco foram realizados para avaliar redução da gengivite induzida por placa (NASEEM et al., 2017; VADHANA, 2019; SEZGIN; MEMIS; ALPTEKIN, 2019). De 
acordo com Ripari et al. (2020), “Oil pulling" é um termo que define um remédio ayurvédico tradicional na Índia que é explicado como o ato de enxaguar a boca com óleo. Esta prática é mencionada no texto "Charak Samhita e Sushruta Samhita" como "Kavala Graha" ou "Kavala Gandoosha". Mas, foi Dr. F. Karach que tornou essa técnica conhecida, afirmando que muitas patologias orais podiam ser curadas graças a este método, mas suas afirmações não se sustentavam em provas cientificas (SHANBHAG, 2017).

Acredita-se que essa técnica é capaz de curar mais de trinta doenças sistêmicas associadas a boca, além de conferir vários benefícios à saúde bucal, como a redução da inflamação e sangramento gengival, alívio dos sintomas da xerostomia, garganta seca, ação em bactérias causadoras da halitose e da cárie, além da otimização da higiene bucal e fortalecimento dos músculos da face e cavidade oral (SHANBHAG, 2017). A escolha do óleo vegetal para realização da técnica é importante que sua composição seja predominante de ácidos graxos de cadeia média como o óleo de coco ou de gergelim, em vez de ácidos graxos de cadeia longa, que podem influenciar as propriedades físicas e químicas (SHINO et al., 2016). Os mecanismos de ação dos óleos não são claros, mas existem algumas teorias como: (1) a saponificação ou processo de "fabricação de sabão" que ocorre como resultado da hidrólise alcalina da gordura, (2) a desorganização da placa bacteriana pela viscosidade do óleo, (3) a presença de antioxidantes nos óleos previnem a peroxidação lipídica ajudando na destruição de microorganismos (NASEEM et al., 2017).

Conforme Ripari et al. (2020) e Shanbhag (2017) a técnica do "oil pulling" consiste em colocar uma colher de sopa (ou colher de chá para crianças entre 5 e 15 anos de idade) de óleo de vegetal na boca e é sorvido, sugado e puxado entre os dentes e superfícies da boca durante 20 minutos, de preferência de manhã ainda em jejum. Ao final deste procedimento, se realizado corretamente, o aspecto do óleo deve ser fino, viscoso e leitoso. Em seguida, cuspir e enxaguar a boca. O óleo não deve ser engolido, pois contém bactérias e toxinas. A técnica deve ser seguida pela escovação dos dentes e é feita de preferência com o estômago vazio pela manhã (SHANBHAG, 2017).

Os óleos mais comumente usados para o oil pulling são óleo de gergelim e óleo de côco. Os componentes do óleo de gergelim (sesamina, sesamolina e sesaminol) possuem propriedades antioxidantes. O óleo de coco é composto por $92 \%$ de ácidos 
saturados, e aproximadamente $50 \%$ dos quais é ácido láurico que tem efeito antiinflamatório e também antimicrobiano (NASEEM et al., 2017).

\section{4. ÓLEO DE COCO}

O óleo de coco é um óleo vegetal comestível comum extraído mediante prensagem da polpa dos cocos. A principal composição desse óleo é de ácidos saturados (92\%), dos quais aproximadamente 50\% é ácido láurico um ácido graxo saturado de cadeia média que são eficazes na destruição de uma ampla gama de bactérias destruído sua membrana lipídica além de propriedades antivirais e antimicóticas (GBINIGIE et al., 2016; NASEEM et al., 2017). Segundo Shanbhag (2017), os mecanismos de ação do óleo de coco durante essa prática não são claros, mas as hipóteses são: (1) a manolaurina e outros ácidos graxos de cadeia média podem interferir na parede celular bacteriana, destruindo-as; (2) o filme oleoso gerado pela emulsificação recobre os dentes e gengivas reduzindo a adesão da placa e coesão; (3) o ácido láurico, rico nesse óleo, em conjunto com íons e minerais da saliva criam uma substância que reduz a adesão e acumulo da placa, tendo ação higienizadora. Apesar da incerteza sobre o mecanismo de ação desse óleo, alguns estudos têm mostrado efeito anti-inflamatório na gengivite induzida por placa (NASEEM et al., 2017; SEZGIN; MEMIS; ALPTEKIN, 2019).

\section{5. ÓLEO DE GERGELIM}

O óleo de gergelim é tradicionalmente documentado como o preferido para a prática do oil pulling (FAISAL; RAMYA, 2016). A raiz de gergelim (Sesamum indicum) contém clorosesamona, que tem atividade antifúngica. Também os ácidos graxos poliinsaturados presentes no óleo de gergelim reduzem a lesão de radicais livres que ocorre na cavidade oral, podendo ser essa o principal mecanismo de ação desse óleo no controle das bactérias que formam a placa (SOOD et al, 2014). O Sesamol-1 é um componente químico muito presente no óleo de gergelim (Sesamum indicum L) e é amplamente estudado como agente terapêutico (AKHILA; BEEVY, 2015). Segundo Jnaneshwari et al. (2014), esse componente tem propriedades antioxidantes capazes de suprimir a carcinogênese, além da sua atuação como regulador metabólico e sua capacidade antioxidante é apontada como agente anti-envelhecimento, antimutagênico, antihepatotóxico, antifúngico, agindo especificamente no tratamento 
de infecções por cândida. Também os ácidos graxos poliinsaturados presentes no óleo de gergelim podem reduzir o estresse oxidativo diminuindo lesões de radicais livres que ocorrem na cavidade oral (VADHANA et al., 2019)

Considerando os benefícios do sesamol e seus derivados que podem suprimir a resposta da imunidade celular e também modular as funções pró-inflamatórias dos macrófagos e das células dendríticas (GBINIGIE et al., 2016). O óleo das sementes de gergelim contém proteínas, vitaminas do complexo $B$, vitamina $E$, ácido fólico, magnésio, cálcio, fenóis bioativos e ácidos graxos. Os ácidos graxos são, basicamente, 0 ácido linoleico, ácido oleico e lignanos, como sesamol-1 e sesaminol-2, essas classes de fenóis são importantes. O sesamol, em especifico, tem estrutura aromática com uma ponte metilona que têm a reputação de maior potência antioxidante e quantidade amena de efeitos colaterais (ELSOHLY et al., 2019; JAYARAJ et al., 2020). Por isso, esses óleos vêm fazendo parte da medicina complementar pelas propriedades antimicrobianas, antifúngicas, antibacterianas e ações psicotrópicas (DAR et al., 2019; JAYARAJ et al., 2020).

\section{CONSIDERAÇÕES FINAIS}

A utilização dos óleos vegetais promove uma melhora nos sinais clínicos de inflamação e o sangramento gengival, promovendo melhoras na saúde bucal e sistêmica quando incorporados na rotina diária de higiene bucal. Atualmente, as práticas sugerem a utilização desses óleos como auxiliar na escovação dos dentes, para manter os cuidados de saúde bucal padrão. Essa técnica do uso do oil pulling como auxiliar no tratamento de inflamação gengival precisa ser estudada mais a fundo, apesar de que quando realizada conforme recomendado, pode ser usada com segurança como um complemento para manter uma boa higiene oral e saúde sistêmica, apresentando resultados positivos promissores.

\section{REFERÊNCIAS}

AINAMO, J; BAY, I. Problems and proposals for recording gingivitis and plaque. Int Dent J, London. v. 25, n. 4, p. 229-35, Dec 1975. 
AHMAD, F. A. et al. The Effect Of Oral Health Knowledge, Attitude, and Practice on Periodontal Status among Dental Students. Eur J Dent, Ankara. v. 13, n. 3, p. 437443, Jul 2019.

AKHILA, H; BEEVY, S. Quantification of seed oil and evaluation of antioxidant properties in the wild and cultivated species of Sesamum L. (Pedaliaceae). Int. J. Pharm. Pharm. Sci, Kolhapur. v. 7, p. 136-142, 2015.

BAYANI, M; SEGURA, A; ALVARADOM, Y, L. Based Library Automation and Monitoring system: Developing an Implementation framework of Implementation. e-Ciencias de la Información. v. 8, n. 1, p.1-18, 2017.

BLICHER, B; JOSHIPURA, K; EKE, P. Validation of self-reported periodontal disease: a systematic review. J Dent Res. v. 84, n. 10, p. 881-90, Oct 2005.

DAR, A. A. et al. Assessment of variability in lignan and fatty acid content in the germplasm of L. J of Food Sci and Technol, India. v. 56, p. 976-986, 2019.

DURBAKULA, K; PRABHU, V; JOSE, M. Genotoxicity of non-alcoholic mouth rinses: A micronucleus and nuclear abnormalities study with fluorescent microscopy. J. investig. clin. dent. (Online). v. 9, e. 1, May 2018.

ELSOHLY, A. M. et al. Methoxyphenols as Convenient Oxidative Bioconjugation Reagents with Application to Site-Selective Heterobifunctional Cross-Linkers. J. Am. Chem. Soc. v. 139, n. 10, p. 3767-3773, Feb 2017.

FAISAL, S. S; RAMYA, R. I. The effect of oil pulling with rice bran oil, sesame oil, and chlorhexidine mouth rinsing on halitosis among pregnant women: A comparative interventional study. Indian J Dent Res. v. 27, n.5, p.508-512, Sep-Oct 2016.

FIORILLO, L et al. Crevicular interferon fluid profile and correlation with periodontal disease and wound healing: a systemic review of recent data. Int J Mol Sci, v. 19, n.7, p. 1908, 2018.

FARDAL, O; TURNBULL, RS. A review of the literature on use of chlorhexidine in dentistry. J Am Dent Assoc. v. 112, p. 863-9, Oct 1986.

GBINIGIE, O. et al. Effect of oil pulling in promoting oro dental hygiene: A systematic review of randomized clinical trials. Complement Ther Med, v. 26, p. 47-54, Jun 2016.

JAMES; P. et al. Chlorhexidine mouthrinse as an adjunctive treatment for gingival health. Cochrane Database Syst Rev, v. 31, n. 3, p. CD008676, Mar 2017.

JAYARAJ, P. et al. Sesamol: a powerful functional food ingredient from sesame oil for cardioprotection. Food Funct. v. 26, n. 11, p. 1198-1210, Feb 2020.

KAMATH, N. P. et al. The effect of mouthwashes with aloe vera and tea tree oil on the oral health of schoolchildren. Eur Arch Paediatr Dent, v. 21, n. 1, p. 61-66, Feb 2020. 
KUMAR, S. Evidence-Based Update on Diagnosis and Management of Gingivitis and Periodontitis. Dent Clin North Am, v. 63, n. 1, p. 69-81, Jan 2019.

LANG, N; BARTOLD, P. Periodontal health. J Periodontol, v. 89, e. 1, p.S9-S16, Jun 2018.

LOE, H. The Gingival Index, the Plaque Index and the Retention Index Systems. J Periodontol, v. 38, n. 6, p. 610-617, Nov 1967.

LÖE, H; THEILADE, E; JENSEN, SB. Experimental gingivitis in man. J Periodontol. v. 36, p. 177187, Jan 1965.

METO, A. et al. Efficacy of a Copper-Calcium-Hydroxide Solution in Reducing Microbial Plaque on Orthodontic Clear Aligners: A Case Report. Eur J Dent. v. 13, n. 3, p.478484, Jul 2019.

NASSEM, M. et al. Oil pulling and importance of traditional medicine in oral health maintenance. Int. J. Health Sci, v. 11, n. 4, p.65-70, Sep-Oct 2017.

RIPARI, F. et al. Tea Tree Oil versus Chlorhexidine Mouthwash in Treatment of Gingivitis: A Pilot Randomized, Double Blinded Clinical Trial. Eur J Dent, v. 14, n.1, p.55-62, Feb 2020.

SEZGIN, Y; OZGUL, B. M; ALPTEKIN, N. O. Efficacy of oil pulling therapy with coconut oil on four-day supragingival plaque growth: A randomized crossover clinical trial. Complement Ther Med, v. 47, n. 102193, Dec 2019.

SHANBHAG, V. K. L. Oil pulling for maintaining oral hygiene - A review. J Tradit Complement Med, v. 6, n. 7, p. 106-109, Jun 2016.

SHINO, B. et al. Comparison of Antimicrobial Activity of Chlorhexidine, Coconut Oil, Probiotics, and Ketoconazole on Candida albicans Isolated in Children with Early Childhood Caries: An In Vitro Study. Scientifica, v. 2016, n.7061587, Mar 2016.

SILNESS, J; LÖE, H. Periodontal disease in pregnancy. II. Correlation between oral hygiene and periodontal condition. Acta Odontol Scandinavica. v. 22, p. 121-35, Feb 1964.

SOOD, P. et al. Comparative Efficacy of Oil Pulling and Chlorhexidine on Oral Malodor: A Randomized Controlled Trial. J Clin Diagn Res, v. 8, n. 11, p. ZC18-ZC21, Nov 2014.

VADHANA, V. C. et al. Effect of sesame oil, ozonated sesame oil, and chlorhexidine mouthwash on oral health status of adolescents: A randomized controlled pilot trial.. J Indian Soc Pedod Prev Dent, v. 37, n. 4, p. 365-371, Oct-Dec 2019. 


\title{
CAPITULO XIV
}

\section{ÓLEOS ESSENCIAIS COM POTENCIAL ANTI-INFLAMATÓRIO NO TRATAMENTO DE DORES ARTICULARES}

DOI: 10.51859/AMPLLA.PAE1993-14

\author{
Marilza Rossato ${ }^{1}$ \\ Kesley Yan Silva Rodrigues ${ }^{1}$ \\ Vívian Angélica dos Santos Malva ${ }^{2}$ \\ João Vitor Andrade ${ }^{3}$ \\ Silvia Helena Fabbri Sabbag 4 \\ Gabriela Massako Melo Dias ${ }^{5}$
}

\begin{abstract}
Discente de Naturologia. Universidade Anhembi Morumbi (UAM)
2 Naturóloga. Mestre em Saúde Ambiental. Universidade Anhembi Morumbi (UAM).

${ }^{3}$ Enfermeiro. Especialista em Enfermagem em Saúde Mental e Psiquiátrica. Universidade de São Paulo (USP).

${ }^{4}$ Naturóloga. Especialista em Yoga. Universidade Anhembi Morumbi (UAM).

${ }^{5}$ Naturóloga. Especialista em Acupuntura. Universidade Anhembi Morumbi (UAM).
\end{abstract}

\section{RESUMO}

Objetivo: analisar os benefícios dos óleos essenciais no tratamento de dores articulares em seres humanos. Método: trata-se de uma revisão integrativa da literatura, realizada nas bases de dados, BVS, PubMed, Science.gov, Scopus, BVSMTCl e Web of Science. No período correspondente aos últimos cinco anos, os descritores foram: "Essential Oils", "Joint Pain", "Oils, Volatile". "Anti-Inflammatory Agents", "Pain", "Arthralgia”, cruzados com o operador booleano "AND". Resultados: foram selecionados 9 artigos, e após análise, foram criadas três categorias, que sintetizam os achados na literatura, Uso de óleos essenciais em casos de artrite, óleos essenciais em casos de osteoartrite e Benefícios dos óleos essenciais para saúde. Conclusão: apesar de fazer parte das práticas integrativas do SUS, a aromaterapia, tem sido pouco difundida nos serviços de saúde, e sua aplicação para o cuidado em saúde é restrito. Portanto, sinaliza-se a necessidade de ampliação das práticas e de divulgação, bem como de mais pesquisas sobre o assunto, visto que existem benefícios na literatura sobre o uso de óleos essenciais.

Palavras-chave: Óleos essenciais. Dor nas articulações. Agente anti-inflamatórios. Dor. Artralgia. 


\section{INTRODUÇÃO}

Ao longo da história, nossos ancestrais, desenvolveram um vasto conhecimento sobre os recursos disponíveis na natureza. Há cerca de 40 mil anos, as tribos aborígenes da Austrália já tinham um certo conhecimento sobre o uso de plantas aromáticas, seja pela queima de eucaliptos e tea tree para tratar afecções respiratória ao aspirar as fumaças, ou a preparação de unguentos e pastas a base de argila e de folhas esmagadas de tea tree para tratar feridas (BAUDOUX, 2019).

A Índia se caracteriza por uma rica biodiversidade vegetal aromática, muito importante, possibilitando em tempos remotos o desenvolvimento do comercio entre os continentes, com a chamada "rota das especiarias" (BAUDOUX, 2019). Na China, há mais de 3,5 mil anos, surgiu o mais antigo tratado de fitoterapia com as plantas aromáticas e a composição de preparações aromáticas para a massagem (BAUDOUX, 2019). Assim o uso de ervas aromáticas foi passado de geração em geração, fornecendo conhecimento básico para o desenvolvimento da ciência moderna, desde então, várias pesquisas no campo da fitoterapia vêm sendo notadas pela comunidade científica (TISSERAND, 2017).

Foi no Egito, entre 3 mil e 2 mil anos atrás, que o uso das ervas aromáticas atingiu um desenvolvimento importante. Naquela época os médicos que também eram sacerdotes utilizavam-se de ervas, não só no tratamento das doenças, mas também para praticar rituais mágicos por sua ação espiritual. Por volta de 1,5 mil a.C., os escritos de Imhotep indicavam receitas que pareciam com a aromaterapia atual (BAUDOUX, 2019).

A aromaterapia pode ter começado no Egito, mas foram os gregos que a fizeram se desenvolver consideravelmente. Hipócrates, médico grego, considerado o pai da Medicina, indicava na obra Aforismos, a utilidade de banhos aromáticos (BAUDOUX, 2019). No 10 século d. C., Dioscórides médico e farmacêutico grego romano escreveu um tratado sobre medicina herbal, que incluem tanto substâncias aromáticas simples como compostas, e muitos de seus remédios, ainda hoje são empregados na aromaterapia (TISSERAND, 2017).

O grande avanço nesta área foi a "invenção da destilação" de plantas aromáticas, que foi atribuída aos Persas, a particular a Abu ibn Sina, (980-1037 d.C), o Avicena, 
médico e alquimista, que aperfeiçoou o método de extração, tornando-o mais sofisticado e refinado possibilitando a extração de um óleo essencial (OE) puro.

Há relatos que suas primeiras destilações bem-sucedidas foram feitas com a Rosa centifólia (TISSERAND, 2017). A França sempre teve forte influência na história moderna da aromaterapia cientifica. O termo aromaterapia foi criado pelo químico francês René Maurice Gatefossé em 1928; para ele a palavra Aromaterapia significava uma terapia através dos aromas dos OE (LAVABRE, 2019; AMARAL; BARROS, 2004).

Gatefossé falava da aromaterapia como sendo "uma terapia que emprega substâncias aromáticas em um campo de pesquisa que abre enormes perspectivas àqueles que começam a explorá-la" (TISSERAND, 2017). Ele tinha muito interesse na aplicação da aromaterapia, tanto cosméticos quanto médicos.

Durante a 2a Guerra Mundial, o médico cirurgião do exército Dr.Jean Valnet, influenciado pela obra de Gatefossé, utilizou os OE como antissépticos para tratar lesões de batalha dos soldados. Após a guerra, continuou a usar os óleos como médico, escreveu livros sobre o assunto, e ensinou outros médicos sobre os benefícios dos $\mathrm{OE}$ (TISSERAND, 2017).

Marguerite Maury (1895-1968), uma enfermeira austríaca, praticou e lecionou aromaterapia até o final de sua vida, inspirada por Gatefossé, escreveu dois livros sobre o assunto, em seu $2 \stackrel{2}{\circ}$ livro "Alquimia dos aromas para a juventude", reflete com precisão sua preocupação com o rejuvenescimento (TISSERAND, 2017). Ela estava em busca de um método alternativo a aplicação oral que não a satisfazia. Maury foi responsável pelo que se chama de "prescrição individual" e pela massagem com OE diluídos em óleo vegetal (TISSERAND, 2017).

No Brasil, a aromaterapia é reconhecida como uma prática integrativa e complementar com amplo uso individual e/ou coletivo, podendo ser associada a outras práticas. Como prática multiprofissional, foi adotada por diversos profissionais de saúde e empregada nos diferentes setores da área para auxiliar de modo complementar a estabelecer o reequilíbrio físico e/ou emocional do indivíduo. Além de agregar benefícios ao paciente, e colaborar com a economia de gastos da instituição pública por utilizar matéria-prima de custo baixo, contribuindo com o Sistema Único de Saúde (SUS) (BRASIL, 2018). 
OE são extratos de plantas aromáticas, compostos apenas de moléculas voláteis não adulteradas das plantas, obtidos por "destilação a vapor ou expressão a frio", extraídos praticamente de todas as partes de uma planta, como raiz, caule, folhas, flores, frutos e sementes (BRITO et al., 2013).

Segundo Therkleson (2014), a aromaterapia é uma prática natural não invasiva, aplicada não para atuar apenas no sintoma, ou na doença, mas também para manter o equilíbrio natural do organismo como um todo, pelo correto uso dos OE. E de fato seus benefícios estão no controle do estresse, insônia, ansiedade, entre outros estados de desconforto a saúde devido as suas propriedades terapêuticas.

A Naturologia como profissão na área da saúde, reúne conhecimento científico acerca de práticas integrativas milenares e complementares, voltadas ao uso de tratamentos naturais, baseado em uma visão integrativa do ser, que através de um processo de interagência, utiliza-se de várias técnicas, entre elas o uso de ervas e óleos vegetais e essenciais com propriedades terapêuticas, a fim de promover a saúde, a harmonia, o bem-estar e consequentemente a homeostase.

Com o surgimento da civilização industrial, a sociedade moderna se distanciou da natureza, com o desenvolvimento de novas tecnologias que deram destaque aos tratamentos farmacológicos, no entanto, após um século de progresso, a química terapêutica atingiu seu limite, ao passo que os recursos terapêuticos presentes nas plantas, ressurgem como em primeiro plano, devido a uma consciência coletiva em busca do que é natural (BAUDOUX, 2019).

Neste novo contexto social, milhões de pessoas são acometidas por doenças degenerativas das articulações, gerando impacto profissional, social e principalmente na qualidade de vida destes indivíduos. O termo "artrite" deriva das palavras gregas "artrão" e "ites", que significam inflamação da articulação. A artrite é um dos problemas crônicos de saúde mais comuns e uma das principais causas de incapacidade. Pode-se definir como uma doença autoimune crônica, inflamatória e sistêmica. Os sintomas incluem dor, edema e rigidez das articulações sinoviais (MARRELLI et al., 2020).

A artrite inclui mais de 100 doenças diferentes, sendo a osteoartrite (OA), a artrite reumatóide (AR), a artrite psoriática, a gota e a fibromialgia os tipos mais comuns. Os fatores genéticos, meio ambiente e autoimunidade, desempenham papéis na patogênese da $A R$, todos esses fatores induzem a ativação do sistema imunológico, que 
causa apresentação de autoantígenos com ativação de células T e B antígeno-específicas e produção de citocinas inflamatórias aberrantes, levando à sinovite e destruição da cartilagem e do osso subcondral. Órgãos extra-articulares, como a pele e o sistema cardiovascular, também podem estar envolvidos (MARRELLI et al., 2020).

A OA é uma doença degenerativa caracterizada por danos à cartilagem articular do joelho, quadril e outras articulações dos membros inferiores. Os sintomas incluem dor nas articulações, inchaço, sensibilidade, rigidez e até travamento articular, o que pode levar à incapacidade e afetar gravemente a qualidade de vida dos pacientes. Só nos EUA, $10 \%$ dos homens e $13 \%$ das mulheres com 60 anos ou mais foram diagnosticados com OA de joelho (ZHANG et al., 2016).

A Associação Internacional para o Estudo da Dor (IASP) conceitua a dor como "uma experiência sensitiva e emocional desagradável associada, ou semelhante àquela associada, a uma lesão tecidual real ou potencial" (SANTANA et al., 2020). As terapias farmacológicas, utilizadas para tratamento da OA são eficazes na redução da dor e da inflamação, mas insuficientes para resolver ou estabilizar o dano articular causado pela doença, além de causar efeitos adversos indesejáveis associados ao uso contínuo e progressão do quadro clínico (ZHANG et al., 2016).

Assim a aromaterapia é reconhecida e empregada em muitos países industrializados, como um método extremamente eficaz de terapêutica. A Inglaterra e a França são os países que mais se destacam, com trabalhos sérios e de qualidade. Cabe ressaltar que na Inglaterra existe um Conselho de Aromaterapia e na França existem faculdades que possuem a disciplina "Aromaterapia" nos seus cursos de medicina (BRITO et al., 2013).

Estudos demonstram que os $\mathrm{OE}$ atuam diretamente em nosso sistema límbico quando inalados e em contato com a pele seus princípios ativos são absorvidos pelo organismo através da corrente sanguínea. A sua utilização acontece através de várias vias: cutânea, oral, bucal e sublingual, retal, vaginal, otológica ou auricular, nasal e olfativa, via respiratória e olfativa por difusão, através de suas propriedades terapêuticas relaxantes, analgésicas, anti-inflamatórias, antivirais e antimicrobianas, atuam em nosso organismo, proporcionando bem-estar físico, mental e emocional (BAUDOUX, 2019). 
Baseado nesta reflexão justifica-se este estudo, com o objetivo de ampliar o conhecimento sobre o uso dos $\mathrm{OE}$, de forma correta, para tratar os agravos relacionados à saúde de indivíduos com dores crônicas, proporcionando um cuidado integral e reduzindo os efeitos colaterais indesejados. Então com base neste pensamento levantase as seguintes indagações: Quais os benefícios dos OE para controle ou diminuição da dor articular com o uso tópico, em seres humanos? Como os OE auxiliam nas dores articulares?

\section{MÉTODO}

Trata-se de um estudo de revisão integrativa da literatura. O método de revisão integrativa é um método que permite a síntese de conhecimento por meio de processo sistemático e rigoroso, partindo de estudos primários, a busca em banco de dados permite a inclusão de múltiplos estudos com diferentes delineamentos de pesquisa. A definição da pergunta norteadora, é essencial na construção do estudo, permite a determinação do problema a ser investigado. Para construção desta revisão integrativa, foram percorridas as 6 etapas do método: 1) elaboração da pergunta da revisão; 2) busca e seleção dos estudos primários; 3) extração de dados dos estudos; 4) avaliação crítica dos estudos primários incluídos na revisão; 5) síntese dos resultados da revisão e 6) apresentação do método (MENDES; SILVEIRA; GALVÃO, 2019).

A questão norteadora deste estudo foi: "Quais os benefício dos OE para controle ou diminuição da dor articular com o uso tópico, em seres humanos?" O levantamento bibliográfico foi realizado online nos meses de setembro e outubro de 2021, por meio das bases de dados BVS (Biblioteca Virtual em Saúde), PubMed (U.S. National Library of Medicine National Institute of Health), Science.gov (Government Science Portal), Scopus (Science Research), BVSMTCI (Biblioteca Virtual em Saúde em Medicinas Tradicionais, Complementares e Integrativas) e Web of Science.

Utilizou-se a estratégia PICOT para delimitar a revisão integrativa (MENDES; SILVEIRA; GALVÃO, 2019). Sendo a mesma um acrônimo, representando no presente estudo: P) População (seres humanos); I) Intervenção (uso de OE na mitigação e eliminação de dores articulares); C) Comparação (trazem benefícios?); O) Desfecho ou resultados (existe consenso ou descrição do uso?) e T) Tempo (estudos publicados no quinquênio 2016/2021). 
A busca foi realizada de maneira interdependente por dois pesquisadores, por meio dos descritores controlados disponíveis nos Descritores em Ciência da Saúde (DeCS) e seus correspondentes em espanhol e português da Biblioteca Virtual em Saúde: "Essential Oils", "Joint Pain", “Oils, Volatile". "Anti-Inflammatory Agents", "Pain", "Arthralgia", utilizou-se para o cruzamento dos descritores o operador booleano "AND".

Os estudos foram selecionados pela leitura criteriosa dos títulos, resumos e posteriormente dos artigos na íntegra. Os critérios de inclusão definidos foram artigos científicos similares com a temática deste estudo, produções disponíveis na íntegra, nos idiomas português, inglês e espanhol e que detalhassem e versassem o assunto: benefício dos OE no controle ou diminuição da dor articular com o uso tópico, estudos primários, e secundários (desde que fossem revisões sistemáticas de qualquer espectro), publicado no quinquênio 2016/2021. Artigos que se encontravam repetidos nas bases de dados e não abarcavam a temática principal não foram incluídos na análise.

Para a caracterização dos estudos selecionados utilizou-se um instrumento de fichamento de dados adaptado [incluindo-se os itens autor, ano, título do artigo, país de realização da pesquisa, método, nível de evidência, objetivos do estudo, amostra e conclusão], visando a sistematização e organização, os artigos selecionados foram avaliados quanto ao nível de evidência (GALVÃO, 2006). A análise dos dados deu-se através da leitura dos artigos, sendo as informações utilizadas para elaborar um quadro no Microsoft Word ${ }^{\circledR}$ 2016. Assim, a amostra da revisão integrativa foi composta de 9 estudos, conforme Figura 1. 
Figura 1 - Fluxograma da estratégia realizada para busca dos artigos, segundo modelo PRISMA (MOHER et al., 2009).

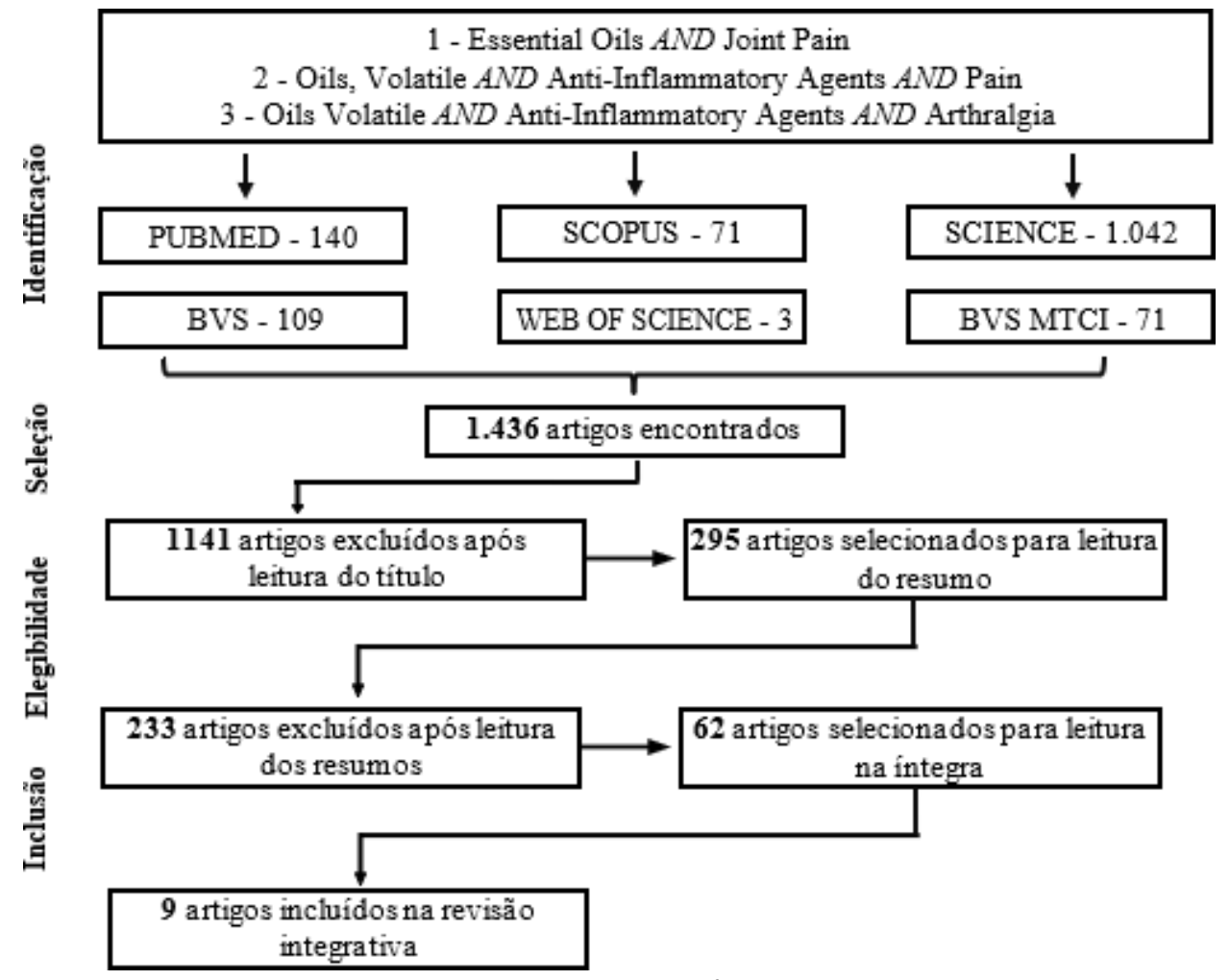

Fonte: Autoria própria.

\section{RESULTADOS}

Dos 9 (100\%) estudos incluídos na presente revisão, cinco (55,55\%) são originários da BVS, dois (22,22\%) da PubMed, e um (11,11\%) da Science e da Scopus.

Em relação aos anos de publicação dos estudos, dois (22,22\%) artigos foram publicados nos anos de 2016, 2018 e 2020 . E um artigo (11,11\%) para os anos de 2017, 2019, 2021.

Quanto aos tipos de estudos, foram incluídos cinco (55,55\%\%) revisões, dois estudos (22,22\%) randomizados, um estudo (11,11\%) opinião de especialista e um estudo $(11,11 \%)$ experimental. No que tange ao nível de evidência observou-se que cinco estudos $(55,55 \%)$ são nível V, dois estudos (22,22\%) são nível II, um estudo (11,11\%) nível III e um estudo nível VII.

Em referência ao país em que a pesquisa foi realizada, um artigo (11,11\%) proveniente dos EUA, e dois (22,22\%) do Brasil, Irã, China e Itália. 
Foram criadas três categorias, que sintetizam os achados na literatura, Uso de óleos essenciais em casos de artrite, Óleos essenciais em casos de osteoartrite e Benefícios dos óleos essenciais para saúde.

O Quadro 1 que segue, apresenta a descrição dos 9 artigos selecionados para análise.

Quadro 1: Síntese dos artigos selecionados para a análise, 2021.

\begin{tabular}{|c|c|c|c|c|}
\hline Autores [Ano] & $\begin{array}{l}\text { Título } \\
\text { [País] }\end{array}$ & $\begin{array}{c}\text { Tipo de } \\
\text { estudo } \\
\text { [Nível de } \\
\text { evidência] }\end{array}$ & $\begin{array}{l}\text { Objetivo } \\
\text { [Amostra] }\end{array}$ & Síntese das Conclusões \\
\hline BAHR et al. & $\begin{array}{l}\text { Effects of a } \\
\text { massage-like } \\
\text { essential oil } \\
\text { application } \\
\text { procedure using } \\
\text { Copaiba and Deep } \\
\text { Blue oils in } \\
\text { individuals with } \\
\text { hand arthritis } \\
\text { [USA] }\end{array}$ & $\begin{array}{l}\text { Randomizado, } \\
\text { duplo-cego e } \\
\text { controlado } \\
\text { [Nível II] }\end{array}$ & \begin{tabular}{|l} 
Investigar os benefícios do \\
AromaTouch r Hand \\
Technique ${ }^{\circledR}$ (ATHT), um \\
procedimento r que \\
combina um toque de \\
pressão moderada com a \\
aplicação de óleos \\
essenciais na mão, em \\
indivíduos com artrite de \\
mão. \\
[36 participantes]
\end{tabular} & $\begin{array}{l}\text { A ATHT com Copaiba e Deep } \\
\text { Blue pode ter efeitos } \\
\text { benéficos na artrite das mãos } \\
\text { Os participantes tratados com } \\
\text { a preparação de óleo } \\
\text { essencial mostraram redução } \\
\text { de cerca de } 50 \% \text { nos escores } \\
\text { de dor, aumento da força dos } \\
\text { dedos e ângulo de flexão } \\
\text { máxima. }\end{array}$ \\
\hline MAHBOUBI & $\begin{array}{c}\text { Mentha spicata as } \\
\text { natural analgesia } \\
\text { for treatment of } \\
\text { pain in } \\
\text { osteoarthritis } \\
\text { patients }\end{array}$ & [Nível VII] & $\begin{array}{c}\text { Confirmar os efeitos } \\
\text { analgésicos do óleo } \\
\text { essencial de } \\
\text { M. despicata }\end{array}$ & $\begin{array}{l}\text { Os efeitosanalgésicos de M. } \\
\text { spicata poderia estar } \\
\text { relacionada com os } \\
\text { componentes principais de M. } \\
\text { óleo de spicata como carvona, } \\
\text { limoneno e mentol, e } \\
\text { parecem estar relacionados a } \\
\text { neurônios periféricos de dor. } \\
\text { Contudo estudos clínicos mais } \\
\text { amplos são necessários para a } \\
\text { demonstração de M. eficácia } \\
\text { e segurança de spicata em } \\
\text { outras doenças com dor. }\end{array}$ \\
\hline $\begin{array}{l}\text { NASIRI; } \\
\text { MAHMODI; } \\
\text { NOBAKHT }\end{array}$ & $\begin{array}{c}\text { Effect of } \\
\text { aromatherapy } \\
\text { massage with } \\
\text { lavender essential } \\
\text { oil on pain in } \\
\text { patients with } \\
\text { osteoarthritis of } \\
\text { the knee: A } \\
\text { randomized } \\
\text { controlled clinical } \\
\text { trial } \\
\text { [Irã] }\end{array}$ & $\begin{array}{l}\text { Randomizado, } \\
\text { duplo-cego e } \\
\text { controlado } \\
\text { [Nível II] }\end{array}$ & $\begin{array}{l}\text { Investigar o efeito da } \\
\text { massagem de } \\
\text { aromaterapia com óleo } \\
\text { essencial de lavanda na dor } \\
\text { em pacientes com } \\
\text { osteoartrite do joelho. } \\
\text { [90 participantes] }\end{array}$ & $\begin{array}{l}\text { A massagem de aromaterapia } \\
\text { com óleo essencial de lavanda } \\
\text { foi considerada eficaz no } \\
\text { alívio da dor em pacientes } \\
\text { com osteoartrite de joelho . } \\
\text { No entanto, mais estudos são } \\
\text { necessários para confirmar os } \\
\text { achados deste estudo. }\end{array}$ \\
\hline LIMA et al & $\begin{array}{l}\text { Technological } \\
\text { development of } \\
\text { microemulsions } \\
\text { with perspectives } \\
\text { for pain treatment: } \\
\text { a patent review } \\
\text { [Brasil] }\end{array}$ & $\begin{array}{l}\text { Revisão } \\
\text { [Nível V] }\end{array}$ & $\begin{array}{l}\text { Investigar o potencial } \\
\text { toxicológico } \\
\text { antioniceptivo de sistemas } \\
\text { microemulsionados } \\
\text { contendo } \text { y-terpineno, por } \\
\text { via transdérmica, em } \\
\text { modelo animal de dor } \\
\text { neuropática. } \\
\text { [16 patentes] }\end{array}$ & $\begin{array}{l}\text { Esse estudo permite concluir } \\
\text { que formulações } \\
\text { microemulsionadas contendo } \\
\text { p-terpineno apresentam } \\
\text { pronunciada atividade } \\
\text { antinociceptiva, sugerindo } \\
\text { efeito terapêutico com } \\
\text { administrações agudas e sub- } \\
\text { agudas. }\end{array}$ \\
\hline
\end{tabular}




\begin{tabular}{|c|c|c|c|c|}
\hline Autores [Ano] & $\begin{array}{l}\text { Título } \\
\text { [País] }\end{array}$ & $\begin{array}{c}\text { Tipo de } \\
\text { estudo } \\
\text { [Nível de } \\
\text { evidência] }\end{array}$ & $\begin{array}{l}\text { Objetivo } \\
\text { [Amostra] }\end{array}$ & Síntese das Conclusões \\
\hline $\begin{array}{c}\text { MARTIM; } \\
\text { MARANHO; } \\
\text { CASAGRANDE }\end{array}$ & $\begin{array}{l}\text { Role of the } \\
\text { chemical } \\
\text { compounds } \\
\text { present in the } \\
\text { essential oil and in } \\
\text { the extract of } \\
\text { Cordia verbenacea } \\
\text { DC as an anti- } \\
\text { inflammatory, } \\
\text { antimicrobial and } \\
\text { healing product }\end{array}$ & Revisão & $\begin{array}{l}\text { Apresentar o papel dos } \\
\text { compostos químicos } \\
\text { presentes no extrato e no } \\
\text { óleo essencial de Cordia } \\
\text { verbenacea por suas } \\
\text { propriedades e } \\
\text { antiinflamatórias, } \\
\text { antimicrobianas } \\
\text { cicatrizantes. } \\
\text { [52 artigos] }\end{array}$ & $\begin{array}{l}\text { Os efeitos descritos dos } \\
\text { compostos químicos } \\
\text { encontrados no extrato são } \\
\text { aplicados em hematomas } \\
\text { musculares e dores } \\
\text { miofasciais, redução de } \\
\text { edema e tendinite crônica, } \\
\text { quando usados topicamente e } \\
\text { a processos reumáticos, } \\
\text { nevrálgicos e artríticos, } \\
\text { quando usados por via oral } \\
\text { como agente anti-ulcerativo; } \\
\text { bem como por suas } \\
\text { propriedades cicatrizantes e } \\
\text { analgésicas quando usado } \\
\text { topicamente ou em infusão. } \\
\text { Além de seu uso em dor } \\
\text { crônica e aplicação tópica. }\end{array}$ \\
\hline XU et al. & $\begin{array}{l}\alpha \text {-Bisabolol } \\
\text { suppresses the } \\
\text { inflammatory } \\
\text { response and ECM } \\
\text { catabolism in } \\
\text { advanced glycation } \\
\text { end products- } \\
\text { treated } \\
\text { chondrocytes and } \\
\text { attenuates murine } \\
\text { osteoarthritis } \\
\text { [China] }\end{array}$ & Experimental & $\begin{array}{l}\text { Avaliar o efeito } \\
\text { antiinflamatório } \\
\text { condroprotetor do BISA na } \\
\text { progressão da osteoartrite } \\
\text { e explorar seu mecanismo } \\
\text { subjacente. }\end{array}$ & $\begin{array}{l}\text { Os resultados deste estudo } \\
\text { indicam o potencial do BISA } \\
\text { na terapia da osteoartrite. A } \\
\text { administração de BISA } \\
\text { atenuou as alterações } \\
\text { radiológicas e } \\
\text { histopatológicas induzidas por } \\
\text { DMM em relação ao grupo de } \\
\text { DMM e resultou em } \\
\text { pontuações OARSI mais } \\
\text { baixas. Tomados em } \\
\text { conjunto, os resultados deste } \\
\text { estudo indicam o potencial de } \\
\text { BISA na terapia de } \\
\text { osteoartrite. }\end{array}$ \\
\hline SALEHI et al. & $\begin{array}{l}\text { Lamium Plants-A } \\
\text { Comprehensive } \\
\text { Review on Health } \\
\text { Benefits and } \\
\text { Biological Activities }\end{array}$ & 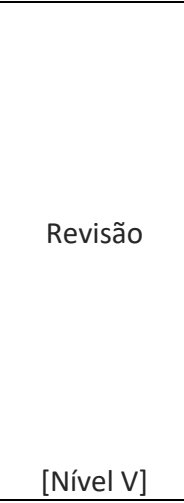 & $\begin{array}{l}\text { Trazer informações } \\
\text { encontradas na literatura, } \\
\text { dados sobre diferentes } \\
\text { aspectos } \\
\text { do Lamium.gênero sua } \\
\text { demonstrar química, } \\
\text { importância nas atividades } \\
\text { tradicionais, medicinais, de } \\
\text { composição químical } \\
\text { biológica e farmacológica, } \\
\text { bem como no potencial } \\
\text { industrial e uso econômico } \\
\text { [151 artigos] } \\
\end{array}$ & $\begin{array}{l}\text { Ao lado de aspectos } \\
\text { específicos da bioquímica } \\
\text { vegetal, esta revisão destacou } \\
\text { o uso de plantas Lamiun } \\
\text { (algumas espécies) na } \\
\text { formulação de remédios } \\
\text { naturais para uso tópico, } \\
\text { preparo de alimentos } \\
\text { funcionais, possível ação } \\
\text { como inibidores da tirosinase, } \\
\text { entre outros. }\end{array}$ \\
\hline $\begin{array}{l}\text { MARRELLI et } \\
\text { al. [2020] }\end{array}$ & $\begin{array}{l}\text { Essential Oils and } \\
\text { Bioactive } \\
\text { Components } \\
\text { against Arthritis: A } \\
\text { Novel Perspective } \\
\text { on Their } \\
\text { Therapeutic } \\
\text { Potential }\end{array}$ & Revisão & $\begin{array}{l}\text { Examinar o conhecimento } \\
\text { atual sobre os efeitos } \\
\text { benéficos dos óleos } \\
\text { essenciais no tratamento } \\
\text { de doenças artríticas, } \\
\text { fornecendo uma visão } \\
\text { geral dos relatórios sobre } \\
\text { os efeitos in vivo e in vitro } \\
\text { dos OE. }\end{array}$ & $\begin{array}{l}\text { A aplicação de OE e seus } \\
\text { constituintes no tratamento } \\
\text { da artrite parece ser uma } \\
\text { nova perspectiva interessante } \\
\text { sobre seus potenciais } \\
\text { benefícios à saúde. Contudo, } \\
\text { seus componentes químicos } \\
\text { estão sujeitos a danos } \\
\text { oxidativos, transformações } \\
\text { químicas e reações de } \\
\text { polimerização que }\end{array}$ \\
\hline
\end{tabular}




\begin{tabular}{|c|c|c|c|c|}
\hline Autores [Ano] & $\begin{array}{l}\text { Título } \\
\text { [País] }\end{array}$ & $\begin{array}{c}\text { Tipo de } \\
\text { estudo } \\
\text { [Nível de } \\
\text { evidência] }\end{array}$ & $\begin{array}{l}\text { Objetivo } \\
\text { [Amostra] }\end{array}$ & Síntese das Conclusões \\
\hline & [Itália] & [Nível V] & [100 artigos] & $\begin{array}{l}\text { geralmente levam à perda de } \\
\text { propriedades sensoriais e } \\
\text { farmacológicas. A análise da } \\
\text { literatura científica existente } \\
\text { com foco no potencial } \\
\text { antiartrítico dos OE revela } \\
\text { que as informações obtidas } \\
\text { por estudos in vitro e in vivo } \\
\text { ainda precisam ser } \\
\text { confirmadas por meio de } \\
\text { investigações clínicas. }\end{array}$ \\
\hline [2016] & $\begin{array}{l}\text { Current research } \\
\text { on pharmacologic } \\
\text { and regenerative } \\
\text { therapies for } \\
\text { osteoarthritis } \\
\text { [China] }\end{array}$ & $\begin{array}{l}\text { Revisão } \\
\text { [Nível V] }\end{array}$ & $\begin{array}{l}\text { Explanar sobre progresso } \\
\text { da pesquisa atual sobre } \\
\text { terapias farmacológicas e } \\
\text { regenerativas para } \\
\text { osteoartrite, incluindo } \\
\text { avanços importantes e } \\
\text { limitações potenciais. } \\
\text { [146 artigos] }\end{array}$ & $\begin{array}{l}\text { Os medicamentos tradicionais } \\
\text { de osteoartrite são eficazes } \\
\text { na redução da dor e da } \\
\text { inflamação, mas insuficientes } \\
\text { para retardar, interromper ou } \\
\text { reverter o dano articular e } \\
\text { estão frequentemente } \\
\text { associados a efeitos adversos. } \\
\text { Embora a terapia } \\
\text { farmacológica e regenerativa } \\
\text { atual mostre grandes } \\
\text { promessas, ainda existem } \\
\text { limitações. As terapias } \\
\text { potenciais podem ser } \\
\text { desenvolvidas explorando } \\
\text { mais alvos e métodos } \\
\text { terapêuticos. }\end{array}$ \\
\hline
\end{tabular}

Fonte: Autoria própria.

\section{DISCUSSÃO}

\subsection{USO DE ÓLEOS ESSENCIAIS EM CASOS DE ARTRITE}

Esta categoria visa correlacionar o uso dos OE na mitigação da artrite. Em umdos estudos avaliados Bahr et al. (2018), buscou evidências para controle da dor, em portadores de AR, OA ou inflamação crônica das mãos e dedos, utilizando a aplicaçãode OE de Copaíba (Copaifera langsdorffii) e OE Deep Blue ${ }^{1}$ (azul profundo-Blend) junto com a massagem de pressão moderada "Técnica de mão AromaTouch Hand Technique (ATHT) ". Dividiu 36 individuos em dois grupos, 20 indivíduos receberam OE Copaíba e Deep Blue (50/50) e 16 indivíduos do grupo controle usaram óleo de coco fracionado, duas vezes por 5 dias seguidos. Os participantes tratados com a preparação de óleo essencial

\footnotetext{
${ }^{1}$ Nota: Deep Blue. Mix de Óleos essenciais de Wintergreen, Camphor, Peppermint, Ylang Ylang, Helichrysum, Blue Tansy, Blue Chamomile e Osmanthus (DOTERRA, 2021).
} 
exigiram significativamente menos tempo para completar as tarefas de destreza com redução de $50 \%$ nos escores de dor, aumento da força dos dedos e ângulo de flexão máxima significativamente maior em relação ao grupo que usou apenas o óleo de coco.

Corroborando Marrelli et al.(2020), realizaram uma revisão para investigar os benefícios dos OE para o tratamento de doenças artríticas, analisando os efeitos dos constituintes fitoquímicosdos $\mathrm{OE}$, encontrou 31 diferentes espécies de plantas relatadas em literatura como tendo eficácia in vivo e in vitro.

Ainda neste aspecto, OE das famílias de plantas investigados por Marrelli et al., (2020), provaram ter potencial antiartrítico, foram principalmente as Lamiaceae (6 espécies) e as Zingiberaceae (5), seguida por Cupressaceae, Cyperaceae, Ericaceae, Myrtaceae e Pinaceae (2), sendo que a família da Laminaceae e Zingiberaceae mostraram maior eficácia em comparação com as outras plantas. Dentre as plantas analisadas, há muitas outras com grande potencial para o tratamento da dor, e que não fizeram parte das pesquisas dos últimos cinco anos, algumas bastante conhecidas como a sucupira (Pterodon pubescens) e a canela-de-velho (Miconia albicans) (MARRELLI et al., 2020).

Therkleson (2014), avaliou aplicação tópica com gengibre em 20 adultos com OA. Foram divididos em dois grupos: O grupo 1 recebeu uma compressa de gengibre preparada manualmente e o Grupo 2 um patch de gengibre ${ }^{1}$ (Zingiber officinale) padronizado. Após 7 diasde tratamento, foi relatado que aplicação tópica de gengibre produziu efeitos significativos e favoráveis na dor em comparação com patch de gengibre, tais achados vão do encontro aos estudos de Marguerite Maury, precursora da aromaterapia na Inglaterra, que percebeu e relacionou a biocompatibilidade dos OE e a pele, comprovando através de pesquisase práticas, que a aplicação de OE tem ação extremamente benéfica, quando aplicadosatravés de massagem (BAUDOUX, 2019).

Em comparação com os estudos, Bahr et al. (2018) mostraram que o betacariofileno (BCP) um constituinte químico do $O E$ da copaíba é um agonista do receptor2 de canabinóide (CB2). A ativação de $C B 2$ por um agonista experimental de CB 2 suprimiu significativamente a produção de autoanticorpos e citocinas pró-inflamatórias

\footnotetext{
${ }^{1}$ Nota: Patch de gengibre, compressa preparada com adesivo para auto-colagem, proveniente da industria farmacêutica.
} 
IL-6 e TNF- $\alpha$. Os achados acima são confirmados por Marrelli et al. (2020) que ao realizar um teste do potencial antiartrítico de uma pomada contendo OE de 16 espécies, o tratamento foi capaz de reduzir significativamente os níveis de TNF- $\alpha$ e IL-1 $\beta$.

Como observado anteriormente no estudo Bahr et al. (2018), o BCP, mentol e salicilato de metila têm função analgésica, BCP por meio da ativação de $C B 2$ e mentol/salicilato de metila por meio de ação antinociceptiva. Isso foi comprovado com aplicação da ATHT com OE de copaíba e deep blue nos participantes, que relataram $50 \%$ de redução em seus escores de dor. Os estudos mostram que analgésicos tópicos têm um efeito pronunciado sobre a dor artrítica quando combinados com massagem, especialmente na comparação direta de ambos individualmente, o que está em acordo com os resultados do presente estudo

\section{2. ÓLEOS ESSENCIAIS EM CASOS DE OSTEOARTRITE}

A segunda categoria visa explicitar o uso dos OE nos casos de OA. Nesta perspectiva, Zhang et al., (2016) analisaram diversos tipos de tratamentos farmacológicos e terapias regenerativas para tratar pessoas com OA. Aos autores concluíram que a terapia farmacológica traz benefícios no controle da dor, mas os medicamentos ainda são incapazes de reverter os danos nas articulações e apresentam efeitos indesejáveis, quanto as terapias regeneradoras, mostram-se promissoras, mas ainda não atendem as necessidades clinica, uma vez que poucas pessoas tem acesso a estes tratamentos, este é um campo ainda novo, que está em desenvolvimento, requer mais pesquisas e possui alto custo (ZHANG et al., 2016).

Destaca-se que há na literatura a descrição dos benefícios dos OE na OA. O estudo de Nasiri, Mahmodi e Nobakht (2016), ensaio clínico randomizado e cego, para determinar o efeito da massagem de aromaterapia na dor de pacientes com OA de joelho. O tratamento foi aplicado com OE de lavanda 3\% (Lavandula angustifolia) em um grupo e o outro grupo placebo recebeu óleo de amêndoa doce, todos os participantes foram treinados para realizar a massagem. O resultado mostrou que a intensidade da dor diminuiu significativamente após a intervenção imediata da massagem com OE de lavanda, em comparação com a massagem placebo com óleo de amêndoa doce e os grupos de controle. E 4 semanas após a intervenção nos três grupos, revelou que a média de intensidade da dor, não apresentava diferença 
significativa entre os grupos antes da intervenção. (NASIRI; MAHMODI; NOBAKHT, 2016).

Pontua-se que um ensaio clínico randomizado, cego, realizado no Irã, investigou o benefício da massagem de aromaterapia com OE de lavanda (Lavandula angustifolia) em pacientes com OA no joelho para prevenção as atividades de vida diária (AVD). Onde foram recrutados 90 pacientes, divididos em três grupos: grupo intervenção (massagem de aromaterapia com OE de lavanda), grupo placebo (massagem com óleo de amêndoa) e grupo controle (sem massagem). As AVD dos pacientes com OA melhoraram significativamente após 1 semana intervenção no grupo de intervenção em comparação com seu estado inicial $(p<0,001)$ e do grupo controle ( $p<0,001$ ep $=0,03$ respectivamente) (NASIRI; MAHMODI, 2017), tais achados fortalecem a presente revisão de literatura.

Em comparação com os estudos, Zhang, et al. (2016), citaram tratamentos para manutenção da saúde das articulações, como tratamento profilático e conservador na OA, como exercícios físicos moderados, redução de peso, massagem e outras técnicas integrativas, ajudam no fortalecimento dos músculos e podem retardar a progressão da doença, mas faltam evidencias científicas suficientes para apoiar sua eficácia. Assim sugere-se como uma alternativa complementar no tratamento de $\mathrm{OA}$ a massagem com $\mathrm{OE}$ de lavanda, visto que diminuiu significativamente a dor após a intervenção (NASIRI; MAHMODI; NOBAKHT,2016).

Enfatiza-se ainda que Arslan, Kutlutürkan e Korkmaz (2019), mostrou em seu estudo que massagem de aromaterapia aplicada em pacientes com OA reduziu os escores de dor no joelho, redução da rigidez matinal e melhora do estado de funcionamento físico.

O estudo de Pehlivan, Karadakovan (2019), investigaram os efeitos da massagem com aromaterapia na dor. Ao recrutar 90 idosos com OA de joelhos, divididos em grupos de aromaterapia, massagem e controle. Os grupos de aromaterapia e massagem receberam um total de 15-20 min de massagem clássica nas pernas, duas vezes por semana, durante 3 semanas. No grupo da aromaterapia, dois OE gengibre (Zingiber officinale) e alecrim (Rosmarinus officinalis L.) foram adicionados ao oleo de óleo de semente preta (Nigella Sativa). Os resultados obtidos demostraram que a massagem com aromaterapia reduziu a dor e melhorou a 
qualidade de vidas dos idosos com OA de joelhos (PEHLIVAN; KARADAKOVAN, 2019). Estando tais achados em conformidade com a presente revisão.

Em seu ensaio clinico Perlman et al. (2019), examinaram os efeitos da massagem sueca ou toque leve para OA do joelho, selecionando 3 grupos de indivíduos, para avaliar os efeitos iniciais e de longo prazo de 8 até 52 semanas por 60 minutos, e a utilidade da dosagem de manutenção quinzenal para continuar com massagem ou toque leve (mas quinzenal), ou nenhum tratamento (cuidado usual). Os autores concluíram que a massagem sueca reduziu os escores de dor, rigidez e função física em comparação com o toque leve, sendo significativa nas 8 primeiras semanas, o que valida o uso da massagem na terapêutica da dor (PERLMAN et al., 2019).

No estudo de Xu et al. (2020), onde realizou-se uma avaliação para comprovar o efeito do $\alpha$-Bisabolol (BISA) no tratamento da OA com resposta antiinflamatória e catabolismo da matriz extracelular (ECM) em condrócitos humanos tratados com produtos finais da glicação avançada (AGEs). O BISA é um álcool sesquiterpênico encontrado nos OE de camomila (Matricaria recutita), na sálvia (Salvia officinalis) e na madeira de candeia (Eremanthus erythropappus) e possui potencial efeito antiinflamatório (XU et al., 2020). Sendo imprescindível o uso e indicação dos OE de maneira mais comum no cotidiano no cuidar em saúde.

O estudo de Kamatou e Viljoen (2010), investigou aplicação e propriedades farmacológicos do $\alpha$-Bisabolol (BISA) e dos OE ricos em BISA. Os resultados mostraram que o BISA possui várias propriedades farmacológicas que variam de atividades antiinflamatórias e antioxidante, achados semelhantes ao estudo de SOUZA et al., (2020). Mas, demarca-se que estudos futuros são necessários para solidificar a temática em questão.

O estudo de Mahboubi (2017), buscou confirmar os efeitos analgésicos de M. OE de spicata, a partir de um estudo duplo-cego randomizado, analisou a eficácia de 600 $\mathrm{mL}$ de chá rico em ácido rosmarínico (rosA) (280 mg de $\operatorname{ros} \mathrm{A}$ ), comparada com o $\mathrm{M}$ comercial Spicata chá ( $26 \mathrm{mg}$ rosA), em 62 pacientes com OA. O resultado obtido foi que apenas o chá com alto teor de rosA melhorou significativamente a dor nos pacientes (MAHBOUBI, 2017).

Embora, M. spicata é padronizado à base de carvona, limoneno e outros componentes como o mentol ( $\mathrm{C} 10$ H20 O) também são encontrados em menor 
quantidade em seu óleo (MAHBOUBI, 2017). Um trabalho de investigação realizado por Yousuf et al., (2013), mostrou que o extrato metanólico de Mentha Spicata (MEMS) obteve resultados antipirético, analgésico e efeitos anti-inflamatórios com um perfil de segurança razoável.

\subsection{BENEFÍCIOS DOS ÓLEOS ESSENCIAIS PARA SAÚDE}

A presente categoria visa descrever os benefícios dos OE para saúde humana. Nesta perspectiva uma revisão de patentes mostrou que entre as patentes analisadas, três enfocam o uso de $\mathrm{OE}$ no desenvolvimento de microemulsão ${ }^{1}$ para o tratamento da dor, citando uma patente brasileira que enfatiza o uso do óleo de copaíba (Copaifera langsdorffii) para otimizar a ação terapêutica deste óleo em administração oral e tópica, em razão de suas propriedades analgésicas, inflamatórias e cicatrizantes, já estudas (LIMA et al., 2018).

Araújo et al. (2015), ao avaliar patentes biotecnológicas, mostrou benefícios dos OE com microemulsão no processo anti-inflamatório. Os resultados obtidos demostraram que a microemulsão é uma inovação tecnológica, dada as vantagens comparadas as formulações tradicionais, alta estabilidade e biodisponibilidade, facilidade de preparo, baixo custo. Ratifica-se a importância de tal análise, mas que estudos maiores e mais robustos são necessários sobre esse assunto.

Em comparação dos estudos, a aplicação das microemulsões como forma de tratamento em pacientes com AR e OA, mostrou ser uma alternativa complementar para o tratamento da dor, junto com o uso de óleo de copaíba e terapias farmacológicas. Contudo, o interesse das microemulsões partem de vantagens potenciais em relação as formulações tradicionais, tendo como benefícios a maior capacidade de absorção e biodisponibilidade dos princípios ativos, com liberação controlada da droga, e redução de efeitos indesejados (ZHANG et al., 2016; LIMA et al., 2018; BAHR et al.,2018).

1 Nota:Microemulsões (MEs) sao sistemas termodinamicamente estáveis, opticamente transparentes, isotrópicos e de baixa viscosidade, constituídos por gotículas de tamanho nanométrico dispersas em uma fase contínua de um solvente imiscível com a fase dispersa. sao constituídas de água, óleo, surfactante e, frequentemente, de um co-surfactante. Além de água, soluçoes salinas diversas também podem ser empregadas em seu preparo, como fase aquosa (Silva, et al., 2015). 
O estudo Salehi et al. (2019) relatam as propriedades das plantas Lamium, que pertence à família das limiaceaes, também conhecida como família das hortelãs. Com uma ampla variedade de gêneros descritos, o gênero Lamium tem potencial antiinflamatório, antinociceptiva, antimicrobiano, antiviral, citotóxica e citoprotetora estudados in vitro e poucos estudos in vivo. Mas no que se refere ao gênero Lamium as evidências de que algumas espécies podem trazer benefícios no tratamento da AR são consideradas fracas e especulativas por se basearem nas propriedades antioxidantes e anti-inflamatórias dos extratos de Lamium álbum.

Apesar do Lamium pertencer a mesma espécie botânica da M. spicata os resultados apresentados no estudo Salehi et al. (2019), diferem dos apresentados por Mahboubi (2017), que destacou o potencial analgésico e anti-inflamatório da Menta capaz de tratar tanto dores articulares, quanto dores viscerais e neuropáticas, sendo considerado um excelente analgésico.

O estudo de Martim, Maranho e Casagrande (2021), sobre o OE de Cordia verbenácea $D C$, planta comum nas áreas costeiras do Brasil, popularmente conhecida com erva baleeira estudou-se sua composição química. Os compostos químicos dos $\mathrm{OE}$, como o a-humuleno, como o principal elemento de propriedade anti-inflamatória, propriedades como o trans-cariofileno, artemetina, flavonóides, taninos e terpenos, rosA entre outros. Destaca-se que de semelhante modo ao resultado anterior, o estudo de Mahboubi (2017), destacou que o chá spicata com alto teor de rosA, melhorou significativamente a dor nos pacientes.

Fernandes et al. (2007), analisou em seu estudo as propriedades antiinflamatórias de dois sesquiterpenos isolados do OE de Cordia verbenácea, alfahumuleno e (-) - trans-cariofileno. Os resultados obtidos revelaram que o tratamento oral com ambos os compostos exibiu efeitos inibitórios marcados em diferentes modelos experimentais inflamatórios. Reforçando os achados da presente revisão. Ainda nesse aspecto, Passos et al. (2007), avaliou em seu estudo que o OE de Cordia verbenácea, diminuiu significativamente o TNF $\alpha$, sem afetar a produção de IL- $1 \beta$. E o edema, foi marcadamente inibido por ambos os compostos sesquiterpênicos obtidos do OE: alfa-humuleno e trans-cariofileno $(50 \mathrm{mg} / \mathrm{kg}$, po). Por fim, sinaliza-se a escassez na literatura em relação a estudos sobre $\mathrm{OE}$ aplicados a saúde, bem como a baixa robustez metodológica dos estudos encontrados. 
No tocante ao formulário fitoterápico nacional da farmacopeia brasileira, demarca-se que este precisa ser revisto e fortalecido. Assim a presente revisão além de descrever o uso de OE como possibilidade segura, eficaz e sem riscos para saúde Martim, Maranho e Casagrande (2021), problematiza-se a necessidade de se investir em mais pesquisas na área da Naturologia, sobretudo no tocante ao uso dos OE aplicados à saúde.

\section{CONCLUSÃO}

Entre as familias botânicas enfatiza-se as Lamiaceae, que pertencem ao gênero do hortelã (Mentha spicata), da lavanda (Lavandula angustifolia) e do alecrim (Rosmarinus officinalis L.), e a Zingiberaceae como o gengibre (Zingiber officinale), como espécies de potencial antiartritico, atuando no controle da dor e da inflamação, com ação importante na melhora na qualidade de vida a portadores de dores cronicas, como as doenças articulares.

Considerando os estudos das 3 categorias, destacam-se pelo potencial antiinflamatório os constituintes quimicos do OE de copaíba (Copaifera langsdorffii) como o beta- cariofileno (BCP), agonista do receptor 2 de canabinóide (CB2), e a erva baleeira (Cordia verbenácea), pela ação do a-humuleno e trans-cariofileno. E Ainda $\alpha$-Bisabolol (BISA) um álcool sesquiterpênico encontrado nos OE de camomila (Matricaria recutita), na sálvia (Salvia officinalis) e na madeira de Candeia (Eremanthus erythropappus) com potencial efeito anti- inflamatório.

Na presente literatura observou-se que os $O E$ são usados de forma restrita no cuidado com a saúde. Apesar de fazer parte das práticas integrativas do SUS, a aromaterapia, tem sido pouco difundida nos serviços de saúde, e sua aplicação no controle da dor é restrita a algumas categorias de profissionais da saúde.

Muitos agravos a saúde podem ser evitados, com o uso de terapêuticas naturais e de baixo impacto econômico, vale ressaltar que a sociedade atual, busca por práticas de saúde menos invasivas. Portanto, novos estudos sobre os OE e sua aplicação tópica, devem ser estimulados e desenvolvidos sob a visão naturológica do cuidado em saúde. 


\section{REFERÊNCIAS}

AMARAL F; BARROS MB. Aromaterapia. São Paulo: Caras S.A, 2004. 48p.

ARAÚJO, S. S et al. Prospecção de patentes biotecnológicas com óleo essencial em microemulsão como agente anti-inflamatório. Rev do cuidadoista GeintecGestao Inovacao e Tecnologias, v. 5, n. 2, p. 2058-2065, 2015.

ARSLAN, D. E.; KUTLUTÜRKAN, S.; KORKMAZ, M. The effect of aromatherapy massage on knee pain and functional status in participants with osteoarthritis. Pain Management Nursing, v. 20, n. 1, p. 62-69, 2019.

BAHR, T. et al. Effects of a massage-like essential oil application procedure using Copaiba and Deep Blue oils in individuals with hand arthritis. Complementary therapies in clinical practice, v. 33, p. 170-176, 2018.

BAUDOUX, Dominique. 0 grande manual da aromaterapia de Dominique Baudoux. Belo Horizonte: Editora Laszlo, 2019, 674p.

BRASIL. Ministério da Saúde. Portaria n 702, de 21 de março de 2018.

BRASIL. Ministério da Saúde. Protocolo Clínico e Diretrizes Terapêuticas Artrite Reumatóide. Brasília: Ministério da Saúde, 2019.

BRITO, A. M. G. et al. Aromaterapia: da gênese a atualidade. Revista Brasileira de plantas medicinais, v. 15, p. 789-793, 2013.

DOTERRA. Deep Blue ${ }^{\circledR}$ Mix de Óleos Essenciais. Disponível em: https://www.doterra.com/BR /pt_BR/p/doterra-deep-blue-oil. Acesso em:6 de Dez. de 2021

FERNANDES, E. S. et al. Anti-inflammatory effects of compounds alpha-humulene and (-)-trans-caryophyllene isolated from the essential oil of Cordia verbenacea. European journal of pharmacology, v. 569, n. 3, p. 228-236, 2007.

GALVAO, C. M. Níveis de evidência. Acta Paulista de Enfermagem, v. 19, n. 2, p. 5, 2006.

KAMATOU, G. P. P.; VILJOEN, A. M. A review of the application and pharmacological properties of $\alpha$-Bisabolol and $\alpha$-Bisabolol-rich oils. Journal of the American oil chemists' society, v. 87, n. 1, p. 1-7, 2010.

LAVABRE, M. Aromaterapia: a cura pelos óleos essenciais. Belo Horizonte: Editora Laszlo, 2019, 370p.

LIMA, M. P. D. et al. Technological development of microemulsions with perspectives for pain treatment: a patent review. Expert opinion on therapeutic patents, v. 28, n. 9, p. 691-702, 2018. 
MAHBOUBI, M. Mentha spicata as natural analgesia for treatment of pain in osteoarthritis patients. Complementary Therapies in Clinical Practice, v. 26, p. 1-4, 2017.

MARRELLI, M. et al. Essential Oils and Bioactive Components against Arthritis: A Novel Perspective on Their Therapeutic Potential. Plants, v. 9, n. 10, p. 1252, 2020.

MARTIM, J. K. P.; MARANHO, L. T.; CASAGRANDE, T. A. C. Role of the Chemical compounds present in the essential oil and in the extract of Cordia verbenacea DC as an anti-inflammatory, antimicrobial and healing product. Journal of Ethnopharmacology, v. 265, p. 113300, 2021.

MENDES, K. D. S.; SILVEIRA, R. C. C. P.; GALVÃO, C. M. Uso de gerenciador de referências bibliográficas na seleção dos estudos primários em revisão integrativa. Rev.Texto \& Contexto-Enfermagem, v. 28, 2019.

MOHER, D. et al. Preferred reporting items for systematic reviews and meta- analyses: the PRISMA statement. PLoS Medicine, v. 6, n. 7, p. e1000097, 2009.

NASIRI, A.; MAHMODI, M. A. Aromatherapy massage with lavender essential oil and the prevention of disability in ADL in patients with osteoarthritis of the knee: a randomized controlled clinical trial. Complementary therapies in clinical practice, v. 30, p. 116-121, 2018.

NASIRI, A.; MAHMODI, M. A.; NOBAKHT, Z. Effect of aromatherapy massage with lavender essential oil on pain in patients with osteoarthritis of the knee: $A$ randomized controlled clinical trial. Complementary therapies in clinical practice, v. 25, p. 75- 80, 2016.

PASSOS, G. F. et al. Anti-inflammatory and anti-allergic properties of the essential oil and active compounds from Cordia verbenacea. Journal of ethnopharmacology, v. 110, n. 2, p. 323-333, 2007.

PEHLIVAN, S.; KARADAKOVAN, A. Effects of aromatherapy massage on pain, functional state, and quality of life in an elderly individual with knee osteoarthritis. Japan Journal of Nursing Science, v. 16, n. 4, p. 450-458, 2019.

PERLMAN, A. et al. Efficacy and safety of massage for osteoarthritis of the knee: a randomized clinical trial. Journal of general internal medicine, v. 34, n. 3, p. 379386, 2019.

SANTANA, J. M. et al. Tradução para a língua portuguesa da definição revisada de dor pela Sociedade Brasileira para o Estudo da Dor. Brazilian Journal of Pain, v. 3, p. 1-8, 2020. 
SALEHI, B.et al. Lamium plants - A comprehensive review on health benefits and biological activities. Molecules, v. 24, n. 10, p. 1913, 2019.

SILVA, J.D.F. et al. Microemulsões: componentes, características, potencialidades em química de alimentos e outras aplicações. Quim. Nova, v. 38, n. 9, p. 1196-1206, 2015.

SOUZA, E. R. L. de; GOMES, N. M. L.; CRUZ, J. H. de A.; SANTOS, J. F. D. dos; OLIVEIRA FILHO, A. A. de. Propriedades farmacológicas do Sesquiterpeno $\alpha$ - Bisabolol: uma breve revisão. ARCHIVES OF HEALTH INVESTIGATION, v. 10, n. 1, p. 18-23, 2020.

THERKLESON, T. Topical ginger treatment with a compress or patch for osteoarthritis symptoms. Journal of holistic nursing, v. 32, n. 3, p. 173-182, 2014.

TISSERAND, R. Aromaterapia para todos. Belo Horizonte: Editora Laszlo, p.117-146, 48$52,2017$.

$X U, C$. et al. $\alpha$-Bisabolol suppresses the inflammatory response and ECM catabolism in advanced glycation end products-treated chondrocytes and attenuates murine osteoarthritis. International immunopharmacology, v. 84, p. 106530, 2020.

YOUSUF, P. M. Et al. Efeito analgésico, antiinflamatório e antipirético de Mentha spicata (hortelã). Journal of Pharmaceutical Research International, v. 3, n. 4, pág. 854864, 18 de julho. 2013.

ZHANG, W. et al. Current research on pharmacologic and regenerative therapies for osteoarthritis. Bone research, v. 4, n. 1, p. 1-14, 2016. 


\section{CAPITULO XV}

\section{POTENCIAL ANTIOXIDANTE ATRIBUIDO ÀS PLANTAS MEDICINAIS E FITOTERÁPICOS}

DOI: 10.51859/AMPLLA.PAE1993-15

Ádria Henrique Fernandes ${ }^{1}$

Luanne Eugênia Nunes ${ }^{2}$

${ }^{1}$ Graduanda do curso de Farmácia. Faculdade Nova Esperança de Mossoró - FACENE/RN

${ }^{2}$ Farmacêutica. Doutora em Ciências Farmacêuticas. Professora Adjunta do Curso de Farmácia. Faculdade Nova Esperança de Mossoró - FACENE/RN

\section{RESUMO}

Os fitoterápicos, medicamentos obtidos de matéria-prima de origem vegetal, estão em constante evolução na indústria farmacêutica. Em 2016, o mercado global desses produtos foi projetado para cerca de $2,7 \%$ do mercado global de medicamentos, correspondendo a, aproximadamente, 1,061 trilhão de dólares. Esses medicamentos são capazes de exercer diversas funções biológicas e farmacológicas, devido os produtos do metabolismo vegetal secundário, os metabolitos secundários. Dentre as funções estão a anti-inflamatória, antimicrobiana, cicatrizante, anticancerígena, surfactante e antioxidante. A atividade antioxidante é responsável pela inibição ou retardo da oxidação, processo fisiológico que ocorre nas células produzindo os radicais livres, que em excesso, podem causar danos teciduais, através da doação de hidrogênio ou elétrons ou por atuar como quelante de metais de transição. Assim, o estudo objetivou descrever, por meio de uma revisão narrativa da literatura, sobre a atividade antioxidante exercida, principalmente, pelas plantas.

Palavras-chave: Fitoterápicos. Antioxidante. Medicina popular. Radicais livres. Flavonoides. 


\section{INTRODUÇÃO}

Os fitoterápicos são medicamentos obtidos matéria-prima de origem exclusivamente vegetal com utilização em diversos contextos clínicos, incluindo o uso de cosméticos, estudados na fitocosmetologia (BRASIL, 2014). O conjunto de ativos naturais presentes nos fitoterápicos, fitocomplexo, são provenientes do metabolismo vegetal secundário e atribui às plantas defesa contra micro-organismos, proteção contra raios ultravioleta, adaptação ao meio e atração dos polinizadores (SANTOS, 2015).

A indústria de produtos de origem vegetal, em seus diversos usos, está em constante crescimento. Em 2016, o mercado global desses produtos foi projetado para cerca de $2,7 \%$ do mercado global de medicamentos, correspondendo a, aproximadamente, 1,061 trilhão de dólares. No Brasil, no mesmo ano, estimou-se que a participação desses produtos era de 0,73 bilhão de dólares em relação ao mercado geral de medicamentos, representando cerca de $2,9 \%$ do mercado mundial dos produtos obtidos de plantas (MARQUES, 2019).

A oxidação, metabolismo do oxigênio, produz energia para as atividades essenciais das células. Esse processo leva à formação de compostos reativos, os radicais livres (RLS), que em excesso, podem causar danos às estruturas celulares, ao DNA e membranas lipídicas (ROESLER et al., 2007). O controle da produção dos radicais livres, objetiva reduzir o stress oxidativo, a partir da estabilização ou inativação dessas substâncias, conhecidas como antioxidantes (SOUSA et al., 2007). Visto isso, o estudo objetiva descrever, por meio de uma revisão narrativa da literatura, sobre a atividade antioxidante exercida, principalmente, pelas plantas.

\section{METODOLOGIA}

O estudo trata-se de uma revisão narrativa, de caráter descritivo, e analise qualitativa de estudos já publicados em bases de dados como: PubMed, Scientific Electronic Library Online (Scielo), Scholar Google e Biblioteca Virtual em Saúde (BVS), bem como a utilização de legislações vigentes publicadas através do Ministério da Saúde, órgão regulamentador sobre as ações voltadas as plantas medicinais. 
As palavras-chaves utilizadas na pesquisa estão listadas nos Descritos em Ciências da Saúde (DeCS), sendo elas: "metabolismo secundário", "antioxidante", "fitoterapia", "radicais livres".

\subsection{USO DE PLANTAS MEDICINAIS NA FITOTERAPIA}

As plantas medicinais são aquelas capazes de curar ou aliviar doenças e sintomas. O uso delas é descrito, de forma empírica, desde as antigas civilizações, por meio da ingestão de ervas e folhas para alívio e cura de doenças. Esse conhecimento foi aperfeiçoado, de empírico para científico, a partir da implantação das políticas públicas, sendo elas a Política Nacional de Práticas Integrativas e Complementares (PNPIC) e a Política Nacional de Plantas Medicinais e Fitoterápicos, que visa garantir, à população brasileira, o acesso e o uso seguro de plantas medicinais e fitoterápicos (BRASIL, 2006; HOFFMANN; ANJOS, 2018).

Os fitoterápicos podem ser classificados como medicamento fitoterápico ou produto tradicional fitoterápico, ambos obtidos de matéria-prima vegetal, não estando de forma isolada, e com função profilática, curativa ou paliativa. Em 1996, estimou-se que, no Brasil, $25 \%$ do faturamento da indústria farmacêutica eram originados de medicamentos derivados de plantas (BRASIL, 2006). Esses produtos possuem atividade em diversos âmbitos, incluindo a área cosmética, caracterizando os fitocosméticos, produtos que contêm ativos de origem vegetal, sendo eles os extratos, óleos ou óleos essenciais (SIMÃO et al., 2019).

As atividades atribuídas às plantas são resultado do metabolismo vegetal secundário, que origina substâncias com diversas atividades biológicas e farmacológicas, como defesa das plantas, regulação do crescimento, ação anti-inflamatória, antioxidante e cicatrizante (CARDOSO, PEREIRA, 2012).

\subsection{METABOLISMO SECUNDÁRIO VEGETAL}

O metabolismo vegetal pode ser dividido em primário e secundário. O primário é comum a todos os vegetais e tem, como principais funções, a síntese dos metabólitos primários, componentes essenciais para os processos primários realizados pela planta, como fotossíntese, respiração e formação do protoplasma, e a produção de energia, sendo eles os carboidratos, lipídios, proteínas e ácidos nucleicos (REZENE et al., 2016). 
Já o metabolismo secundário, que não está relacionado aos primeiros processos da planta, não está presente em todas elas, caracterizando grupos ou espécies específicas. Eles apresentam diversas funções, como a defesa contra herbívoros e patógenos, proteção contra raios UV e poluição e atração de polinizadores. Os produtos desse metabolismo, os metabólitos secundários, são sintetizados por quatro principais vias, via do ácido chiquímico, do acetato malonato, do acetato mevalonato e do metileritritol fosfato, dando origem a três grandes grupos: terpenos, compostos fenólicos e compostos nitrogenados (MEYER et al., 2013).

\subsubsection{TERPENOS}

Os terpenos, derivados do isopreno (figura 1), formam a maior classe de produtos naturais e possuem como funções, a defesa das plantas, atribuição de aromas característicos, antimicrobiana, anticancerígena, surfactante e inseticida. Essas atividades são distribuídas entre os tipos de terpenos que são classificados de acordo com a quantidade de isopreno presente em cada molécula, sendo eles, diterpenos, triterpenos, tetraterpenos, hemiterpenos, politerpenos, monoterpenos e sesquiterpenos (MEYER et al., 2013).

Figura 1 - Estrutura química do isopreno.

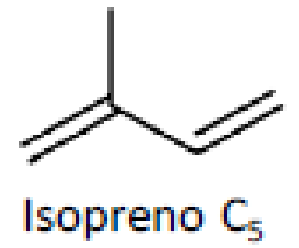

Fonte: Meyer et al. (2012).

Dentre os terpenos, destacam-se os monoterpenos e sesquiterpenos, que compõem os óleos essenciais. Eles atribuem aroma característico às plantas, defendendo-as de patógenos, atraindo polinizadores, e ainda, podem apresentar atividade antimicrobiana (SIMÕES et al., 2017).

\subsubsection{COMPOSTOS NITROGENADOS}

Os compostos nitrogenados apresentam um ou mais átomos de nitrogênio nos anéis heterocíclicos ou cadeias alifáticas e funcionam como defensores anti-herbivoria e como atrativos de polinizadores. Seus principais componentes são os alcaloides (figura 2), que estão presentes, principalmente, nos tecidos mais externos dos vegetais, 
defendendo a planta contra os predadores e protegendo contra os raios ultravioletas (UV) (MEYER et al., 2013).

Figura 2 - Exemplos de fitofármacos classificados como alcaloides.<smiles>Cn1c(=O)c2c(ncn2C)n(C)c1=O</smiles>

CAFEÍNA llex paraguariensis Coffea sp.<smiles>COc1cc2c(c(OC)c1OC)-c1ccc(OC)c(=O)cc1C(NC(C)=O)CC2</smiles>

COLCHICINA

Colchicum autumnale L.

Fonte: Juliana Pires (2010).

\subsubsection{COMPOSTOS FENÓLICOS}

Os compostos que fazem parte desse grupo possuem em sua estrutura um anel aromático com uma hidroxila, formando o grupo fenol (figura 3). A eles são atribuídos vários efeitos fisiológicos como: anti-inflamatório, antimicrobiano, antitrombótico, cardioprotetor, vasodilatador, e ainda, antioxidante (REZENDE et al., 2016).

Figura 3 - Estrutura molecular do fenol.

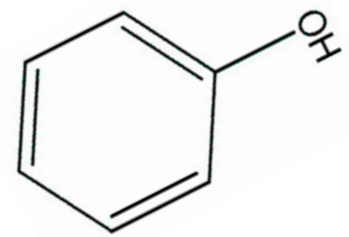

Fonte: Saad et al. (2018).

\subsubsection{FLAVONOIDES}

Nas plantas, os flavonoides exercem, como principais funções, a proteção contra radiações (UV), antioxidante e proteção contra micro-organismos. E, como atividades biológicas, estão a antioxidante, anti-inflamatória e inibição do ciclo celular. Essas 
atividades dependem da sua estrutura química, que caracteriza os diferentes tipos de flavonoides (figura 4), derivados da flavona (MACHADO et al., 2008).

Figura 4 - Estruturas químicas dos tipos de flavonoides identificados em vegetais.
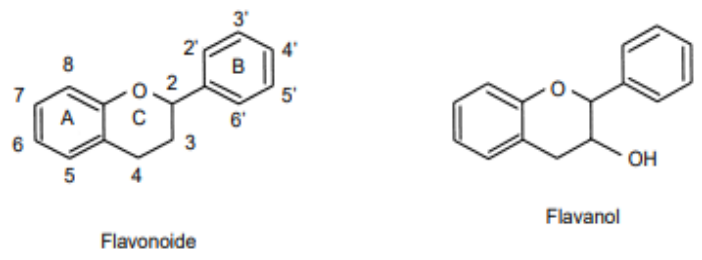

Flavanol<smiles>O=c1cc(-c2ccccc2)oc2ccccc12</smiles>

Flavona<smiles>O=c1c(O)c(-c2ccccc2)oc2ccccc12</smiles>

Flavonol<smiles></smiles>

Antocianidina

Fonte: Flórez et al. (2002).

\subsubsection{TANINOS}

Esse metabólito secundário possui a capacidade de se complexar com íons metálicos, atividade antioxidante e capacidade de se complexar com macromoléculas, atividades essenciais para a utilização dos taninos no tratamento de diversas doenças, tais como, diarreia, hipertensão arterial, hemorragias, feridas, queimaduras, problemas renais e urinários e processos inflamatórios em geral (BARBOSA, 2014). Os taninos podem ainda, exercer efeito bactericida e fungicida, dependendo da dose ingerida (CASTEJON, 2011).

\subsubsection{CUMARINAS}

Na rota do ácido chiquímico, a fenilalanina, aminoácido essencial, sofre dissociação da molécula de amônia através da ação da enzima fenilalanina amônia lipase (PAL), originando o ácido cinâmico, que é hidroxilado, formando o ácido cumárico, que sofre glicosilação, isomerização e lactonização, sintetizando as cumarinas (figura 5). As cumarinas apresentam atividade citotóxica, antifúngica e anticoagulante (CZELUSNIAK, K. E., 2012). 
Figura 5 - Estrutura química geral das cumarinas.

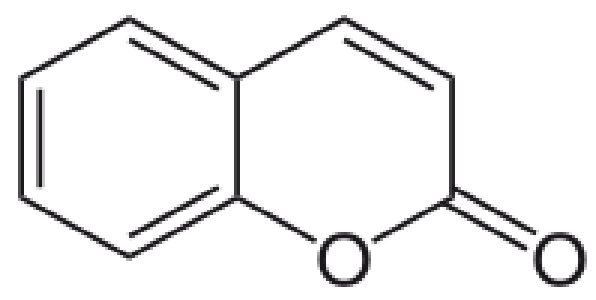

Fonte: SAAD et al. (2018)

\subsubsection{LIGNINAS E LIGNANAS}

As ligninas e lignanas formam um complexo polimérico que fornece rigidez e resistência mecânica à parte aérea das plantas. Elas são sintetizadas a partir do ácido cinâmico (figura 6), derivado da via do ácido chiquímico (REZENDE et al., 2016). Diversas atividades biológicas são atribuídas a esse complexo, destacando a anti-inflamatória, antioxidante, antifúngica, antiviral, antitumoral e imunossupressora (SIMÕES et al., 2017).

Figura 6 - Estrutura química geral das ligninas e lignanas.

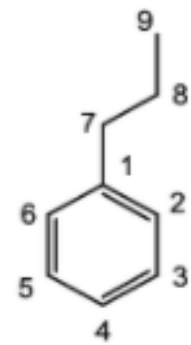

Fonte: Simões et al. (2017).

\subsection{ATIVIDADE ANTIOXIDANTE}

A oxidação é um processo fisiológico que ocorre nas mitocôndrias, membranas celulares e citoplasmas e produz os radicais livres (RLs), substâncias necessárias para a produção de energia, fagocitose, regulação do crescimento celular, imunidade, defesa celular e síntese de substâncias biológicas. Esses radicais livres são moléculas que possuem elétrons desemparelhados em sua última camada eletrônica, tornando-os instáveis e de alta reatividade (DUDA, 2013).

As espécies reativas de oxigênio (EROs) e espécies reativas de nitrogênio (ERNs) são exemplos de radicais livres, que quando em excesso no organismo, causam o estresse oxidativo (EO) que apresenta alguns efeitos prejudiciais, como a peroxidação 
dos lipídios de membrana e agressão às proteínas dos tecidos e das membranas, às enzimas, aos carboidratos e ao DNA (PEREIRA, CARDOSO, 2012).

A produção dessas substâncias também pode acontecer por influência de fatores exógenos, como estresses, raio-X, radiação ultravioleta (UV), poluição ambiental e resíduos de pesticidas em alimentos (VITAL, 2014).

O estresse oxidativo, além de causar danos aos tecidos, pode causar algumas doenças, como doenças autoimunes, câncer, envelhecimento, enfisema, cardiopatias e disfunção cerebral (PEREIRA, CARDOSO, 2012). Os antioxidantes têm a função de inibir ou retardar a oxidação, diminuindo a produção das moléculas reativas e, consequentemente, seus efeitos prejudiciais. (TIVERON, 2010).

Quimicamente, os antioxidantes são compostos aromáticos que contém, no mínimo, uma hidroxila, podendo ser sintéticos, como o butilhidroxianisol (BHA) e o butilhidroxitolueno (BHT), ilustrados nas figuras 7A e 7B, que são comumente utilizados na indústria alimentícia e farmacêutica, ou naturais (Figura 7C), substâncias bioativas, como organosulfurados, fenólicos e terpenos, que constituem diversos alimentos. Eles são classificados em primários ou secundários, de acordo com seu mecanismo de ação. Os primários, os aminoácidos e os tocoferóis, atuam por inativação dos radicais através da doação de átomos de hidrogênio ou de elétrons, estabilizando-os. Os secundários, antioxidantes naturais (figura 7C), compostos fenólicos, vitaminas A, C e E, podem atuar como quelantes de metais pró-oxidantes, como o ferro e o cobre; inativar EROs; converter hidroperóxidos em espécies não-radicalares ou absorver a radiação UV (TIVERON, 2010; VITAL, 2014).

Figura 7 - Estrutura química dos antioxidantes sintéticos (A e B) e naturais (C).

A

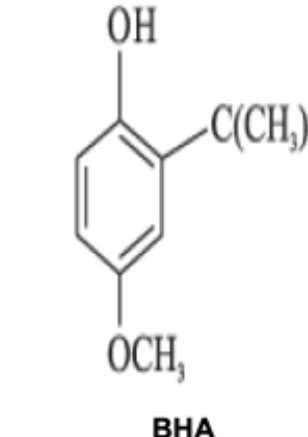

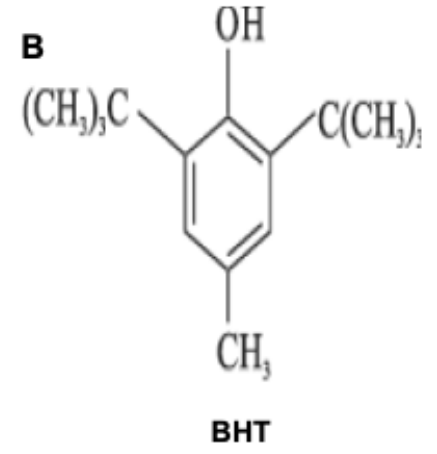

BHT

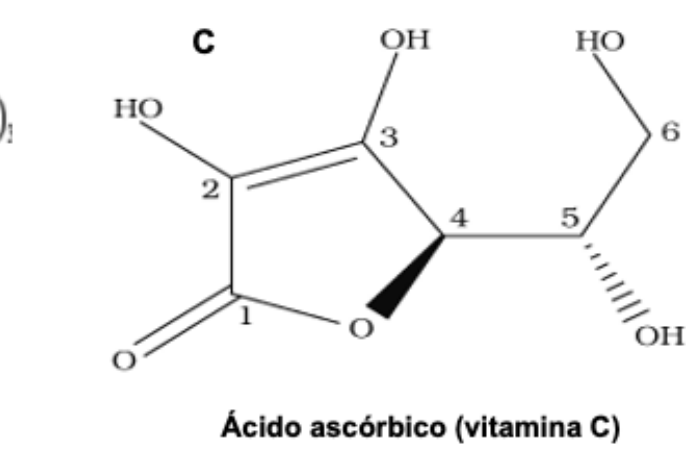

Ácido ascórbico (vitamina C)

Fonte: Vital (2014), Rosa et a.I (2007). 
Dentre os efeitos desencadeados pelo excesso dos radicais livres (RLs), observase o envelhecimento cutâneo, visto que a radiação solar absorvida pela pele aumenta a produção desses compostos reativos. Dessa forma, antioxidantes tópicos, principalmente vitamina $\mathrm{C}$ e $\mathrm{E}$, são adicionados a produtos cosméticos estáveis, de $\mathrm{pH}$ e veículo adequados para diminuir e prevenir o fotoenvelhecimento (WHITE, 2013).

O sistema de defesa antioxidante é classificado em enzimático e não enzimático, que em conjunto têm o objetivo de detoxicar os efeitos nocivos dos radicais livres. 0 enzimático ou endógeno é formado pelas enzimas glutationa-peroxidase e catalase, que são produzidas pelo próprio organismo, e possuem a função de prevenir a formação de radicais livres. Já o não enzimático ou exógeno, é composto por substâncias adquiridas pela dieta ou suplementação, sendo elas os minerais (cobre, manganês, zinco, selênio e ferro), vitaminas (ácido ascórbico, vitamina $E$, vitamina $A$, ), carotenóides (betacaroteno, licopeno e luteína), bioflavonóides (genisteína, quercetina) e taninos (catequinas) (VITAL, 2014).

\subsubsection{ATIVIDADE ANTIOXIDANTE DAS PLANTAS}

Dentre os antioxidantes exógenos, citam-se os compostos fenólicos (flavonoides, taninos, ligninas e cumarinas), um grande grupo com mais de 8.000 variedades distribuídas em vegetais, frutas e produtos industrializados. Eles podem ser encontrados em plantas não comestíveis ou comestíveis, despertando o interesse da indústria alimentícia (ARAÚJO, 2012; VITAL, 2014).

A ação antioxidante exercida por eles é caracterizada pela doação de hidrogênio ou elétrons ou por atuar como quelante de metais de transição, originando radicais intermediários e estáveis, que impedem a oxidação de algumas substâncias, principalmente, dos lipídeos, prevenindo a oxidação lipídica. Os taninos, além destas funções, agem por sua capacidade de ligar-se a proteínas suprimindo sua atividade enzimática (ARAÚJO, 2012).

\subsubsection{MÉTODOS PARA AVALIACÃO DA ATIVIDADE ANTIOXIDANTE}

O potencial antioxidante de um composto é determinado pela reatividade dele como um doador de elétrons ou hidrogênio, capacidade de deslocar ou estabilizar um elétron desemparelhado, reatividade com outro antioxidante e reatividade com 
oxigênio molecular. Essas características são analisadas nos ensaios de transferência de átomos de hidrogênio e de transferência de elétrons (NASCIMENTO, 2016).

Nas reações de transferência de átomos de hidrogênio (TAH), o antioxidante e o substrato competem por um radical gerado termicamente. Esse ensaio engloba o método de capacidade de absorção radical do oxigênio (ORAC) e o potencial relativo antioxidante total (TRAP). Já os ensaios baseados na transferência de elétrons (TE) avaliam a capacidade de um antioxidante na presença de um oxidante, o qual muda de cor quando reduzido. Nesse ensaio estão incluídos o método do reagente FolinCiocalteu (FCR), a capacidade antioxidante equivalente ao trolox (TEAC), o poder antioxidante redutor do ferro (FRAP) e o sequestro do radical 2,2-difenil-1-picrilhidrazil (DPPH) (NASCIMENTO, 2016).

Dentre os métodos utilizados, ABTS, FRAP, DPPH e Folin-Ciocalteu são os mais utilizados na literatura para a avaliação da capacidade antioxidante (NASCIMENTO, 2016).

Quadro 4 - Métodos para avaliação da capacidade antioxidante

\begin{tabular}{|c|c|c|c|c|}
\hline Método & Reagente & Procedimento & Reação & $\begin{array}{l}\text { Unidade de } \\
\text { medida }\end{array}$ \\
\hline DPPH & $\begin{array}{l}\text { Solução alcoólica } \\
\text { de DPPH + } \\
\text { substância } \\
\text { antioxidante. }\end{array}$ & $\begin{array}{l}\text { Eliminação do } \\
\text { radical livre estável } \\
\text { - DPPH. }\end{array}$ & $\begin{array}{l}\text { Mudança de } \\
\text { coloração violeta a } \\
\text { amarelo pardo. }\end{array}$ & $\mathrm{mg} \cdot \mathrm{mL}-1$ \\
\hline ABTS & $\begin{array}{l}\text { Oxidante para } \\
\text { geração de do } \\
\text { radical ABTS } \\
\text { persulfato de } \\
\text { potássio, dióxido } \\
\text { de manganês ou } \\
\text { enzimas. }\end{array}$ & $\begin{array}{l}\text { Captura do radical } \\
\text { ABTS }^{+} \text {por } \\
\text { substância } \\
\text { antioxidante. }\end{array}$ & $\begin{array}{lr}\text { Descoloração } & \text { da } \\
\text { solução } & \text { e } \\
\text { diminuição } & \text { da } \\
\text { absorbância. } & \end{array}$ & $\begin{array}{l}\mu \mathrm{M} \text { trolox. g- } \\
1\end{array}$ \\
\hline FRAP & $\begin{array}{l}\text { Ferricianeto de } \\
\text { potássio ou o } \\
\text { hexacianoferrato } \\
\text { (III) de potássio. }\end{array}$ & $\begin{array}{l}\text { Redução de } \mathrm{Fe}^{+3} \text { a } \\
\mathrm{Fe}^{+2} \text {, em meio } \\
\text { ácido, por uma } \\
\text { substância } \\
\text { antioxidante. }\end{array}$ & $\begin{array}{l}\text { Aparecimento de } \\
\text { intensa coloração } \\
\text { azul. }\end{array}$ & $\begin{array}{l}\mu \mathrm{mol} \mathrm{Fe}(\mathrm{II}) . \mathrm{g}- \\
1\end{array}$ \\
\hline $\begin{array}{l}\text { Folin- } \\
\text { Ciocalteu }\end{array}$ & Folin-Ciocalteu & $\begin{array}{l}\text { Redução do } \\
\text { reagente por } \\
\text { compostos } \\
\text { fenólicos, em meio } \\
\text { básico. }\end{array}$ & $\begin{array}{ll}\text { Emissão } & \text { de } \\
\text { coloração azul. }\end{array}$ & $\begin{array}{l}\text { mg de ácido } \\
\text { gálico }(A G) / g \\
\text { de extrato }\end{array}$ \\
\hline
\end{tabular}

Fonte: adaptado de Reis, E. C. (2016). 
Os resultados expressados por esses métodos precisam ser interpretados. 0 método DPPH apresenta os valores como $\mathrm{EC}_{50}$ ou $\mathrm{IC}_{50}$, que indicam a quantidade de antioxidante necessária para eliminar $50 \%$ do radical, assim, quanto menor for o valor de $\mathrm{IC}_{50}$ maior será a atividade antioxidante. No $\mathrm{ABTS}$, os resultados são expressos em equivalente Trolox, um análogo da vitamina $\mathrm{E}$, mostrando quantos de $\mu \mathrm{M}$ Trolox tem capacidade antioxidante equivalente àquela encontrada para $1 \mathrm{~g}$ da amostra. Portanto, quanto maior a quantidade de Trolox, maior será a capacidade antioxidante. E, a determinação da capacidade antioxidante pelo método FRAP acontece de forma direta, ou seja, quanto maior a intensidade da coloração azul, maior será a absorbância, maior será a redução e, maior será o potencial antioxidante (SILVA, 2017).

\section{CONSIDERAÇÕES FINAIS}

A atividade antioxidante é um efeito biológico importante para a prevenção de doenças e danos causados ao metabolismo corporal ocasionados principa. Ela também é bastante utilizada no âmbito da cosmetologia, que está em constante crescimento e inovação.

Além disso, percebe-se o aumento do consumo dos fitoterápicos, inclusive no Brasil, que em 2016, estimou-se que a participação desses produtos era de 0,73 bilhão de dólares em relação ao mercado geral de medicamentos, representando cerca de 2,9\% do mercado mundial dos produtos obtidos de plantas (MARQUES, 2019). Assim, há subsidio para estudos como este, sobre as propriedades farmacológicas das plantas.

\section{REFERÊNCIAS}

ARAÚJO, T. A. S. Atividade antioxidante de plantas medicinais da caatinga e mata atlântica: aspectos etnobotânicos e ecológicos. 2012. Tese (Doutorado em Ciências Farmacêuticas) - Universidade Federal de Pernambuco. Recife, 2012. Disponível em: https://repositorio.ufpe.br/bitstream/123456789/10367/1/tese\%20THIAGO\%2 OARA\%C3\%9AJO\%20eletronica.pdf. Acesso em 25 mar. 2021.

BARBOSA, N. C. Uma revisão bibliográfica dos fatores antinutricionais: taninos, inibidores de proteases e lectinas. 2014. TCC (Licenciatura em química) Instituto Federal de Educação, Ciência e Tecnologia de Goiás. Anápolis, 2014. Disponível em: http://www.ifgoias.edu.br/attachments/article/1704/TCC\%20\%20Natanael\%20Cardoso\%20Barbosa.pdf. Acesso em 15 mar. 2021. 
BRASIL. Ministério da Saúde. Secretaria de Ciência, Tecnologia e Insumos Estratégicos. Departamento de Assistência Farmacêutica. Política nacional de plantas medicinais e fitoterápicos. Brasília: Ministério da Saúde, 2006.

CASTEJON, F. V. Taninos e Saponinas. 2011. Seminário (Mestrado em Ciência Animal) Universidade Federal de Goiás. Goiânia, 2011. Disponível em: https://files.cercomp.ufg.br/weby/up/67/o/semi2011_Fernanda_Castejon_1c. pdf. Acesso em 15 mar. 2021.

CZELUSNIAK, K.E. Farmacobotânica, fitoquímica e farmacologia do Guaco: revisão considerando Mikania glomerata Sprengel e Mikania laevigata Schulyz Bip. ex Baker. Rev. bras. plantas med., v.14, n.2, Botucatu, 2012.

DUDA, N. C. B. Estresse oxidativo. 2013. Seminário (Pós-graduação em Ciências veterinárias) - Universidade Federal do Rio Grande do Sul. Rio Grande do Sul.

EMBRAPA. Manejo de Plantas Daninhas em Pastagens na Amazônia: Goiabeira. 2015.

FLÓREZ, S. M. et al. Los flavonoides: propiedades y acciones antioxidantes. Nutrición Hospitalaria, Espanha, v. 17, n. 6, p. 271 - 278, 2002. Disponível em: https://www.researchgate.net/profile/Javier-Gonzalez-Gallego-

2/publication/10961859_Flavonoids_Properties_and_antioxidizing_action/links /0deec52a6b0057f327000000/Flavonoids-Properties-and-antioxidizingaction.pdf. Acesso em 15 mar. 2021.

HOFFMANN, R.; ANJOS, M. C. R. Construção histórica do uso de plantas medicinais e sua interferência na socialização do saber popular. Guaju, Mantinhos, v.4, n.2, p. 142-163, jul./dez. 2018.

KAMATH, J. V, et. al. Psidium guajava L: A review. International Journal of Green Pharmacy (IJGP), v. 2, n. 1, 2018.

LIMA, R. S. Extração e caracterização de carotenoides e compostos fenólicos da polpa e do resíduo do processamento da goiaba (Psidium Guajava I.). 2019. Dissertação (Mestrado em Ciência de Alimentos) - Universidade Federal de Santa Catarina, Florianópolis, 2019. Disponível em: https://repositorio.ufsc.br/handle/123456789/214756. Acesso em 20 fev. 2021.

MACHADO, H. et al. Flavonóides e seu potencial terapêutico. Boletim do Centro de Biologia da Reprodução, Juiz de Fora, v. 27, n. 1/2, p. 33-39, 2008.

MEYER, J. $\mathrm{M}$ et al. Metabolismo secundário. In: FURLAN, C. M. (org.). Botânica no inverno. São Paulo: Instituto de Biociências da Universidade de São Paulo, 2013. P. 34-40. Disponível em: https://www.researchgate.net/profile/DiogoGaldeano/publication/297301899_Microrganismos_x_Planta_guerra_ou_parce ria/links/56deb86c08aeb8b66f95f6f7/Microrganismos-x-Planta-guerra-ouparceria.pdf\#page=42 Acesso em 10 mar. 2021. 
NASCIMENTO, K. S. Compostos fenólicos, capacidade antioxidante e propriedades físico-químicas de méis de Apis melífera do estado do Rio Grande do Sul. 2016. Dissertação (Mestrado) - Universidade de São Paulo. São Paulo, 2016. Disponível em: $\quad$ https://www.teses.usp.br/teses/disponiveis/9/9131/tde-08112016122334/publico/Kelly_Souza_do_Nascimento_ME_Corrigida.pdf. Acesso em 25 mar. 2021.

OLIVEIRA, I. P. et al. Cultivo da goiabeira: do cultivo ao manejo. Revista Faculdade Montes Belos, v. 5, n. 4, Montes Belos, 2012.

REZENDE, F. M. et al. Vias de síntese de metabólitos secundários em plnatas. In: FURLAN, C. M. (org.). VI Botânica no Inverno. São Paulo: Instituto de Biociências da Universidade de São Paulo, 2016. P. 93-104. Disponível em: https://www.researchgate.net/profile/Antonio-Azeredo-CoutinhoNeto/publication/318826409_Especies_reativas_de_oxigenio_em_plantas/links /59807f9fa6fdcc324bbe5ba4/Especies-reativas-de-oxigenio-emplantas.pdf\#page=93 Acesso em 10 mar. 2021.

RODRIGUES, F. Cosmetics. Polyphenols: Properties, Recovery, and Applications, [S.L.], p. 393-427, 2018.

ROESLER, R. et al. Atividade antioxidante de frutas do cerrado. Ciênc. Tecnol. Aliment., Campinas, v. 27, n.1, p.53-60, jan.-mar. 2007. Disponível em: https://www.scielo.br/pdf/cta/v27n1/09.pdf. Acesso em 15 mar. 2021.

ROSA, J. E et. al. Desenvolvimento de um método de análise de vitamina $\mathrm{C}$ em alimentos por cromatografa líquida de alta eficiência e exclusão iônica. Ciênc. Tecnol. Aliment. V.27, n.4, Campinas, Out./Dec. $2007 . \quad$ Disponível em: https://www.scielo.br/scielo.php?script=sci_arttext\&pid=S010120612007000400025. Acesso em 15 abr. 2021.

SAAD, G. A et al. Fitoterapia contemporânea: tradição e ciência na pratica. Ed. 2. Rio de Janeiro: Guanabara Koogan, 2018.

SANTOS, D. Y. C. Botânica aplicada: metabólitos secundários na interação plantaambiente. 2015. Tese (Título de livre-docente) - Universidade de São Paulo. São Paulo, $2015 . \quad$ Disponível em: https://www.teses.usp.br/teses/disponiveis/livredocencia/41/tde-29092015103721/publico//LD_DEBORAH.pdf. Acesso em 01 mar. 2021

SIGRIST, S. Goiabeira. PPMAC, $2013 . \quad$ Disponível em: http://ppmac.org/content/goiabeira. Acesso em 22 mar. 2021.

SIMÃO, D. et. Al. Cosmetologia Aplicada I. Porto Alegre: SAGAH, 2019.

SIMÕES, C. M. O et al. Farmacognosia: do produto natural ao medicamento. Porto Alegre: Artmed, 2017. 
SOUSA, C. M. M et al. Fenóis totais e atividade antioxidante de cinco plantas medicinais. Química nova, São Paulo, v.30, n.2, Mar./Apr. 2007. Disponível em: https://www.scielo.br/scielo.php?pid=S0100-

40422007000200021\&script=sci_arttext\&tlng=pt. Acesso em 15 mar. 2021.

TIVERON, A. P. Atividade antioxidante e composição fenólica de legumes e verduras consumidos no Brasil. 2010. Dissertação (Mestrado em Ciências e Tecnologia de Alimentos) - Universidade de São Paulo. Piracicaba, 2010.

VITAL, K. L. Extração e quantificação dos compostos fenólicos da romã. 2014. TCC (Graduação em química industrial) - Instituto de Ensino Municipal Superior de Assis. Assis, 2014. 


\title{
CAPITULO XVI
}

\section{POTENCIAL FITOTERÁPICO DA AROEIRA-DO-SERTÃO \\ (MYRACRODRUON URUNDEUVA ALLEMÃO): UM ESTUDO DE REVISÃO}

DOI: 10.51859/AMPLLA.PAE1993-16

\author{
Itamar de Miranda Pereira ${ }^{1}$ \\ Darlei Gutierrez Dantas Bernardo Oliveira ${ }^{2}$ \\ Damião Alves dos Santos Silva ${ }^{3}$ \\ Marcelo Bento da Silva ${ }^{4}$ \\ Winício de Abreu Alves ${ }^{5}$ \\ Yara Natane Lira Duarte ${ }^{6}$
}

\begin{abstract}
'Graduado do curso de Química. Universidade Federal de Campina Grande - UFCG
${ }^{2}$ Mestrando em Química. Programa de Pós-Graduação em Química - UEPB

${ }^{3}$ Mestrando em Química. Programa de Pós-Graduação em Química - UFPB

4 Graduado do curso de Química. Universidade Federal de Campina Grande - UFCG

5 Graduado do curso de Química. Universidade Federal de Campina Grande - UFCG

6 Graduada do curso de Química. Universidade Federal de Campina Grande - UFCG
\end{abstract}

\section{RESUMO}

A Aroeira-do-Sertão (Myracrodruon urundeuva Allemão) é uma arvore bastante utilizada na medicina popular brasileira, principalmente na forma de chás, infusões e decocções. As suas aplicações estão relacionadas com a presença de metabólitos secundários em sua composição química capazes de desempenhar diversas atividades biológicas, podendo ser utilizadas em ações farmacológicas e terapêuticas. Sendo assim, objetivou-se no presente trabalho realizar um levantamento bibliográfico sobre o perfil fítoquímico e o potencial farmacológico da espécie. Para isso, buscou-se artigos científicos publicados nos últimos cinco (5) anos em diferentes bancos de dados, tais como Google Acadêmico, Scielo e PubMed. Foram encontrados estudos etnobotânicos que avaliaram sua atividade anti-antiinflamatória, antibacteriana, antifúngica, antiviral, antioxidante e larvicida, a partir de extratos e óleos essenciais de diversas partes da planta. Com isso, é possível observar a versatilidade e o potencial da Aroeira em ser uma promissora alternativa para a confecção de medicamentos fitoterápicos. Nesse contexto, se faz necessário o aperfeiçoamento nas pesquisas e a busca por novos conhecimentos que contribuam diretamente para um melhor aproveitamento e valorização da espécie.

Palavras-chave: Compostos bioativos. Atividade biológica. Plantas medicinais da Caatinga. 


\section{INTRODUÇ̃̃̃O}

A utilização de plantas como recurso para prevenção e tratamento de doenças acontece desde a antiguidade. Essa prática está relacionada ao fato de algumas espécies possuírem em suas composições químicas, compostos bioativos com propriedades medicinais. Fato este, que despertou o interesse de pesquisadores e da indústria farmacêutica em estudar e analisar o potencial terapêutico de muitos vegetais ao longo dos últimos anos (MORAIS et al., 2016).

A comprovação cientifica tem fortalecido e valorizado muitas dessas espécies, colocando-as como fontes de medicamentos alternativos. Tanto que, no Brasil existem duas políticas nacionais que incentivam a implementação desta terapia no Sistema Único de Saúde (SUS). Criadas em 2006, a Política Nacional de Plantas Medicinais e Fitoterápicos (PNPMF) e a Política Nacional de Práticas Integrativas e Complementares (PNPIC), tem como objetivo facilitar a ascensão de medicamentos mais baratos, acessíveis e naturais para a população (BRASIL, 2015).

Nesse contexto, o incentivo das políticas nacionais para utilização da fitoterapia é potencializado pela grande biodiversidade na flora brasileira que garante uma ampla variedade de vegetais utilizados como fitoterápicos. A região Nordeste que possui um bioma único no mundo, a Caatinga, é constituído de espécies bastante resistentes por estarem adaptadas fisiologicamente a condições de deficiência hídrica e temperaturas elevadas (BRAND, 2017). Isso ocorre devido algumas delas em seus processos metabólicos serem capazes de sintetizar compostos bioativos, responsáveis pela característica de resistir e sobressair naquele ambiente (VINALE et al., 2014).

Dentre muitas espécies contidas na Caatinga, a Aroeira-do-Sertão (Myracrodruon urundeuva Allemão) ou simplesmente Aroeira, destaca-se por ser uma planta que, além de utilizada na medicina popular, também possui uma madeira muito comercializada e isso otimiza os riscos de entrar para a lista de espécies ameaçadas de extinção (RODRIGUES et al., 2017).

Em definição, a Aroeira-do-Sertão é uma arvore pertencente à família Anacardiaceae que se faz presente principalmente, na Caatinga e no Cerrado brasileiros, sendo também encontrada em regiões da Argentina e Paraguai (PEREIRA et al., 2014). Tem como característica importante ser uma espécie pioneira, e por conta disso, é 
recomendada e utilizada na recuperação de ecossistemas degradados e reflorestamento (CANUTO et al., 2016).

Uma variedade de metabólitos secundários faz parte da composição química da M. urundeuva, como bem aponta o estudo feito por Bessa et al. (2013). Dentre esses compostos estão: chalconas diméricas, saponinas, taninos, esteróides, catequinas, triterpenos, alcalóides e flavonóides. Sendo essas mesmas substancias, responsáveis por atividades anti-inflamatórias, cicatrizantes, antimicrobianas, antifúngicas, antioxidantes, entre outras (BUENO et al., 2018; FREITAS et al., 2018; OLIVEIRA et al., 2017; BONIFÁCIO et al., 2019).

Sendo assim, objetivou-se no presente trabalho realizar um levantamento bibliográfico sobre o perfil fitoquímico e o potencial farmacológico e terapêutico da Myracrodruon urundeuva, focando principalmente, nos estudos publicados acerca dos conhecimentos existentes que validem ou não a espécie como fonte de medicamento.

\section{METODOLOGIA}

O presente trabalho trata-se de uma revisão bibliográfica descritiva, qualitativa e exploratória. De acordo com Pizzani et al. (2012), trata-se de um método de investigação científica, que visa proporcionar o aprendizado sobre uma determinada área de estudo, facilitar a identificação e seleção dos métodos e técnicas a serem utilizados pelo pesquisador e oferecer fundamentos teórico/científicos para inovação do conhecimento. As buscas foram realizadas nas bases de dados Google acadêmico, Scielo e PubMed, no período correspondente entre maio e junho de 2021. Os critérios de inclusão adotados na revisão foram artigos publicados nos últimos cinco (5) anos acerca do potencial e aplicação da Aroeira como fitoterápico independentemente do idioma.

Para realização das buscas bibliográficas apropriou-se dos seguintes termos: "Myracrodruon urundeuva Allemão", "Aroeira-do-sertão", "atividade biológica", "atividade antinflamatoria", "atividade antimicrobiana", "atividade antifúngica", "plantas medicinais do Nordeste" e "plantas medicinais da Caatinga". 


\section{REVISÃO BIBLIOGRÁFICA}

A literatura em relação ao potencial farmacológico e terapêutico da Aroeira-doSertão é bastante ampla e difundida no meio acadêmico. Dentre as várias temáticas de estudo, uma das principais é a sua atividade antibacteriana. Essa constatação é observada no trabalho de Araújo (2017) e colaboradores, eles analisaram o efeito inibitório do óleo essencial das folhas da planta, e comprovaram atividade positiva contra todas as cepas analisadas: Staphylococcus aureus, Staphylococcus epidermidis, Escherichia coli, Pseudomonas aeruginosa e Salmonella Enteritidis, tendo concentrações mínimas de inibição para essas bactérias de 0,22, 0,11, 0,88, 7 e 0,44 mg/mL, respectivamente.

Tendo em vista o potencial antibacteriano da Aroeira, pesquisas relacionadas a odontologia também tem sido uma prática bastante corriqueira. Pires et al. (2019), por exemplo, observaram uma redução no número de microrganismos no biofilme dental. Fazendo uso de extrato das folhas de $M$. urundeuva em uma concentração de $10 \mu \mathrm{g} / \mathrm{mL}$, os autores constataram uma inibição frente a Streptococcus mutans de 74,59\%, mostrando o potencial do extrato em atuar positivamente contra a placa bacteriana sobre os dentes.

Em estudo semelhante, Machado et al. (2016) observaram que o extrato metanólico das folhas da Aroeira reduziu em 50 e 100\% a viabilidade de fibroblastos gengivais humanos nas concentrações de 100 e $1000 \mu \mathrm{g} / \mathrm{mL}$ respectivamente. Portanto, indicando que o extrato pode vir a se tornar um importante agente natural no combate a Fibromatose gengival.

A Aroeira também foi motivo de investigação a respeito de sua possível capacidade anti-incrustante. Agostini et al. (2020) evidenciaram uma diminuição na densidade bacteriana do biofilme marinho de cerca de $80 \%$ em tratamento feito com extrato aquoso das folhas da planta em uma concentração de $0,8 \mathrm{mg} / \mathrm{mL}$. Além disso, também é eficiente na inibição das espécies Chaetoceros calcitrans, Nitokra sp e Artemia salina. Com isso, o extrato se mostra ser uma alternativa ecológica e promissora para a composição de tintas anti-bioincrustante de embarcações.

Em relação a atividade antifúngica, Silva et al. (2020) analisou a ação inibitória do extrato hidroalcoólico da casca da M. urundeuva sobre as espécies Candida albicans, 
Cryptococcus neoformans e Cryptococcus gattii, e verificou como concentrações mínimas de inibição para as espécies fúngicas, os valores de 0,156, 0,0024 e 0,019 $\mu \mathrm{g} / \mu \mathrm{L}$ respectivamente. Com essa constatação, nota-se que o uso popular da planta no trato de doenças causadas por fungos tem realmente indícios de eficácia.

Em estudo semelhante, Oliveira et al. (2017) reafirma e assinala para a utilização da Aroeira no tratamento da candidíase vaginal. No trabalho, foi possível observar a ação inibitória total do extrato etanólico $(512 \mu \mathrm{g} / \mathrm{mL})$ da casca da arvore para com a Cândida albicans, Cândida krusei e Cândida tropicalis. Com a inibição desses fungos responsáveis pela doença infecciosa que acomete muitas mulheres, a Aroeira demonstra seu potencial antifúngico e abre caminho para que novas pesquisas venham a ter conhecimento de sua ação sobre outras espécies fúngicas.

Ainda falando sobre fungos, o Pseudofusicoccum stromaticum, é uma espécie endofítica capaz de sintetizar metabólitos secundários de sua planta hospedeira ( $M$. urundeuva). A espécie é responsável por biosintetizar a tefrosina, um composto com atividade antiproliferativa contra uma linha celular de câncer colorretal. Sobreira et al. (2018) em análise cromatográfica em coluna de vidro, caracterizando e isolando a molécula responsável por essa atividade antitumoral constataram uma redução na viabilidade das células cancerosas de 50\% em uma concentração 1,2 $\mu \mathrm{M}$ da substância. Com isso, fica evidente a versatilidade e os benefícios que podem ser gerados direta ou indiretamente pela arvore.

Outra atividade importante apresentada pela Aroeira-do-Sertão é a antiviral. Pois em estudo realizado por Cecílio et al. (2016), foi evidenciado uma inibição de 75\% do extrato etanólico das folhas da planta $(50 \mu \mathrm{g} / \mathrm{ml})$ frente ao rotavírus símio SA-11, corroborando assim o fato de ser uma espécie utilizada na medicina popular no tratamento da diarreia.

Já o extrato da casca da Aroeira pode ser uma alternativa ecológica e eficiente contra o Aedes aegypti. Alves et al. (2019), por exemplo, constataram a deformação e degeneração na superfície dos ovos do inseto após o tratamento com o extrato aquoso de Aroeira em uma concentração de $0,80 \mathrm{mg} / \mathrm{mL}$. Consequentemente, impedindo que os ovos viessem a eclodir, o que sugere ser um agente larvicida no combate ao mosquito transmissor da dengue. 
O óleo essencial das folhas da M. urundeuva por sua vez, é apontado como uma fonte natural e esperançosa contra o Leishmania amazonenses. Pois, Carvalho et al. (2017) observaram uma inibir total do protozoário com uma concentração de $400 \mu \mathrm{g} / \mathrm{mL}$ do óleo. Configurando assim, uma boa atuação diante desse parasita de mosquitos hematófagos e causador da leishmaniose.

Estudos também apontam que a Aroeira pode desempenhar atividade antioxidante. E Paulino et al. (2020) por meio do método DPPH, alcançaram uma redução de $50 \%$ de radicais livres da amostra usando extrato etanólico da casca de $M$. urundeuva em concentração de $11,153 \mathrm{mg} / \mathrm{mL}$. Tal resultado deu-se pela espécie ser rica em compostos fenólicos, como foi registrado pelos próprios autores (719,59 mg equivalente de ácido gálico/g de amostra). Corroborando com isso, Menezes Filho et al. (2018) atribuiram a relação direta entre esses compostos com as propriedades de óxidoredução, adsorção e neutralização de radicais livres.

Na mesma linha de pesquisa, Penido et al. (2017) obtiveram apenas 61,28 $\pm 0,44$ mg de equivalente de ácido gálico/g de amostra em compostos fenólicos, precisando assim de uma concentração maior $(48,01 \pm 0,35 \mu \mathrm{g} / \mathrm{mL})$ do extrato da casca da Aroeira para conseguir a redução de $50 \%$ de radicais livres utilizando o método in vitro DPPH. Também foi possível observar que o extrato inibiu a acetilcolinesterase em uma taxa de $50 \%$ com uma concentração de 10,75 $\pm 0,15 \mu \mathrm{g} / \mathrm{mL}$. A inibição dessa enzima no corpo humano aumenta os níveis de acetilcolina no cérebro, já que a deficiência desse neuro transmissor é o problema enfrentado por pessoas com Alzheimer. Portanto, indicando ser um produto natural promissor como agente farmacológico no tratamento dessa doença degenerativa.

Conforme observado nas duas últimas referencias citadas, a mesma planta apresentou concentrações diferentes de compostos bioativos. Ficou claro que o teor de compostos fenólicos obtidos em ambos os casos foi determinante para o sucesso dos extratos na atividade antioxidante. Segundo Costa et al. (2016), as diferenças observadas nos valores de bioativos podem ser o resultado de fatores ambientais como por exemplo: a composição química do solo, qualidade da planta, época da colheita, entre outros.

Em estudo com neutrófilos humanos, células que fazem parte do sistema imune, Aquino et al. (2019) inicialmente às estimularam com um agente inflamatório. Em 
seguida, notou que ao aplicar o extrato etanólico das folhas de $M$. urundeuva $(50 \mu \mathrm{g} / \mathrm{mL})$ obteve um efeito positivo, conseguindo uma inibição da ciclooxigenase de $82 \% \mathrm{em}$ relação à indometacina (fármaco de referência). Essa inibição por parte do extrato sobre uma enzima responsável pela via metabólica do processo de inflamação, comprova o sucesso de sua atividade anti-inflamatória.

As atividades biológicas da Aroeira-do-Sertão foram evidenciadas também por Galvão et al. (2018). Em estudo com camundongos, observaram que os estômagos dos animais tratados com extratos hidroalcolicos da casca $(1000 \mathrm{mg} / \mathrm{kg})$, caule (1000 mg/kg) e folhas $(700 \mathrm{mg} / \mathrm{kg}$ ) da planta, demonstraram ausência de edema, congestão, infiltrado inflamatório e necrose, sendo possível observar ação gastroprotetora pela preservação das células do epitélio glandular. Os autores ainda atribuem essas atividades à presença de flavonoides e taninos na composição química da planta.

Apesar de tantas evidencias de que a Aroeira pode ser utilizada como fitoterápico, é preciso estar atento a sua toxicidade. Nesse sentido, Higa et al. (2019) em teste com macrófagos de camundongo, constataram uma redução na viabilidade celular superior a $50 \%$ em todas as concentrações de um extrato glicólico das folhas da planta. Inclusive, na maior concentração testada $(200 \mathrm{mg} / \mathrm{mL}$ ), o resultado foi de $57 \%$ sob um tempo de exposição de 24 horas, o que representa uma baixa toxicicidade.

Em contrapartida, Matos et al. (2019) procurando determinar os efeitos osteogênicos in vitro de um extrato hidroalcóolico $(10 \mu \mathrm{g} / \mathrm{mL})$ de folhas de $M$. urundeuva em osteoblastos humanos primários, verificaram diminuição na viabilidade celular, regulação negativa da metaloproteinase da matriz óssea e também redução na atividade da fosfatase alcalina e mineralização. Revelando assim, toxicidade considerável perante a matriz óssea nesse ensaio.

\section{CONSIDERAÇÕES FINAIS}

De acordo com o exposto no presente trabalho, constata-se que a Myracrodruon urundeuva Allemão é uma espécie bastante estudada e com evidencias fortes de um potencial farmacológico e terapêutico como: efeitos anti-inflamatório, antioxidante, antibacteriano, antifúngico, inseticida, antitumoral, neuroprotetor, entre outros. E que essas atividades estão provavelmente relacionadas aos compostos bioativos presentes em sua composição, principalmente fenólicos e taninos. 
Apesar de despontar como uma espécie rica em metabólitos secundários, a $M$. urundeuva também apresenta toxicidade considerável nas células testadas a depender da concentração. Isso reforça a ampliação das análises, afim de que possíveis fármacos gerados a partir de seus derivados sejam confeccionados em concentrações não toxicas, gerando um produto que seja eficaz e principalmente seguro.

Vale ressaltar também que os estudos etnobotânicos acerca da planta se mostram muito relevantes e úteis. Pois possibilita um direcionamento paras as pesquisas no desenvolvimento de medicamentos de origem natural e mais acessíveis, além de ser artifício de valorização e preservação da espécie.

\section{REFERÊNCIAS}

AGOSTINI, V. O.; MACEDO, A. J.; MUXAGATA, E.; SILVA, M. V. \& PINHO, G. L. L. Non-toxic antifouling potential of Caatinga plant extracts: effective inhibition of marine initial biofouling. Hydrobiologia, 2020, (847), 45-60. https://doi.org/10.1007/s10750-01904071-6

AQUINO, V. C.; QUEIROZ, E. F.; MARCOUT, L.; FREITAS, L. B. N.; ARAÚJO, E. V. O.; LEAL, L. K. A. M.; BEZERRA, A. M. E.; BOCCARD, J.; WOLFENDER, J-L. \& SILVEIRA, E. R. Chemical Composition and Anti-Inflammatory Activity of the Decoction from Leaves of a Cultivated Specimen of Myracrodruon urundeuva. Journal of the Brazilian Chemical Society, 2019, v. 30, n. 8, p.1616-1623. http://dx.doi.org/10.21577/01035053.20190060.

ALVES, R. R.; SOARES, T.; BENTO, E. F. L.; ROLDAN-FILHO, R. S.; SOUZA, B. S. S.; LIMA, K. V. M.; NASCIMENTO, J. S.; COELHO, L. C. B. B.; SÁ, R. A.; LIMA, T. A., GONÇALVES, G. G. A., BRAYNER, F. A., ALVES, L. C., NAVARRO, D. M. A. F.; NAPOLEÃO, T. H. \& PAIVA, V. M. G. Ovicidal lectins from Moringa oleifera and Myracrodruon urundeuva cause alterations in chorionic surface and penetrate the embryos of Aedes aegypti eggs. Pest Managemet Science, 2019, (76), 730736. https://doi.org/10.1002/ps.5572

ARAÚJO, Í. D. R.; AQUINO, N. C.; GUERRA, A. C. V. A.; ALMEIDA JÚNIOR R. F.; ARAÚJO, R. M.; JÚNIOR, R. F. A.; FARIAS K. J. S.; FERNANDES, J. V. \& ANDRADE, V. S. Composição química e avaliação do antibacteriano e Atividades citotóxicas do óleo essencial das folhas de Myracrodruon urundeuva. BMC Complement Altern Med. 22 de agosto de 2017; 17 (1): 419. https://doi.org/10.1186/s12906-017-1918-6.

BESSA, N. G. F.; BORGES, J.C.M.; BEZERRA, F.P.; CARVALHO, R.H.A.; PEREIRA, M.A.B.; FAGUNDES, R.; CAMPOS, S.L.; RIBEIRO, L.U.; QUIRINO, M.S.; CHAGAS JUNIOR, A. F. \& ALVES, A. Prospecção fitoquímica preliminar de plantas nativas do cerrado de uso popular medicinal pela comunidade rural do assentamento vale verde - Tocantins. Revista Brasileira de Plantas Medicinais, v. 15, n. SUPPL. 1, p. 16, 2013. https://doi.org/10.1590/S1516-05722013000500010 
BONIFÁCIO, B.; VILA, T. M.; MASIERO, I. F.; SILVA, V. B.; SILVA, I. C. \& LOPES, E. O. Antifungal activity of a hydroethanolic extract from Astronium urundeuva leaves against Candida albicans and Candida glabrata. Frontiers in Microbiology, 2019, v. 10, p. 112. https://doi.org/10.3389/fmicb.2019.02642

BRAND, M. A. Potencial de uso da biomassa florestal da caatinga, sob manejo sustentável, para geração de energia. Ciência Florestal, 2017, 27(1), 117-127. https://doi.org/10.5902/1980509826452.

BRASIL. Ministério da Saúde. Secretaria de Assistência à Saúde. Departamento de Atenção Básica. Política Nacional de Práticas Integrativas e Complementares no SUS: PNPICSUS. Brasília: Ministério da Saúde, 2015. Disponível em: http://bvsms.saude.gov.br/bvs/publicacoes/politica_nacional_praticas_integrativa s_complementares_2ed.pdf. Acessado em: 08 de junho de 2021.

BUENO, C. R. E.; VALENTIM, D.; JARDIM JÚNIOR, E. G.; MANCUSO, D. V.; SIVIERI-ARAUJO, G.; JACINTO, R. C.; CINTRA, L. T. A. \& DEZAN-JUNIOR, E. Tissue reaction to Aroeira (Myracrodruon urundeuva) extracts associated with microorganisms: an in vivo study. Brazilian Oral Research, 2018, 32(42). https://doi.org/10.1590/18073107bor-2018.vol32.0042.

CANUTO, D. S. O.; SILVA, A. M.; MORAES, M. L. T. \& RESENDE, M. D. Estabilidade e adaptabilidade em testes de progênies de Myracrodruon urundeuva sob quatro sistemas de plantio. Cerne, 2016, 22(2), 171-180. http://dx.doi.org/10.1590/01047760201622021978

CARVALHO, C. E. S.; SOBRINHO-JUNIOR, E. P. C.; BRITO, L. M.; NICOLAU, L. A. D.; CARVALHO, T. P.; MOURA, A. K. S.; RODRIGUES, K. A. F.; CARNEIRO, S. M. P.; ARCANJO, D. D. R.; CITÓ, A. M. G. L. \& CARVALHO, F. A. A. Anti-Leishmania activity of essential oil of Myracrodruon urundeuva (Engl.) Fr. All.: Composition, cytotoxity and possible mechanisms of action. Experimental Parasitology, 2017, (175), 59-67. https://doi.org/10.1016/j.exppara.2017.02.012

CECÍLIO, A. B.; OLIVEIRA, V. C.; CALDAS, S.; CAMPANHA, V. R.; FRANCISCO, F. L.; DUARTE, M. G. R.; MENDONÇA, L. A. M. \& ALMEIDA, L. Antiviral activity of Myracrodruon urundeuva against rotavirus. Revista Brasileira de Farmacognosia, 2016, (26), 197202. http://dx.doi.org/10.1016/j.bjp.2015.10.005

COSTA, G. et al. (2016). - "Influence of harvest date and material quality on polyphenoliccontent and antioxidant activity of Cymbopogon citratus infusion". Industrial Crops and Products, 83 (2016) 738-745. Disponível em: https://www.sciencedirect.com/science/article/abs/pii/S0926669015305987. Acesso em: 09. ago. 2021.

FREITAS, R. F.; LIMA, P. R.A.; PIMENTEL, M. A. \& QUEIROZ, P. R. Perfil

fitoquímico, ensaio microbiológico e toxicidade frente a Artemia salina do extrato da entrecasca da Myracrodruon urundeuva A. Biota Amazônia, 2018, v. 8, n. 3, p. 2427. 
GALVÃO, W. R. A.; BRAZ FILHO, R.; CANUTO, K. M.; RIBEIRO, V. R.; CAMPOS, A. R.; MOREIRA, A. C. O. M.; SILVA, S. O.; MESQUITA FILHO, F. A.; SANTOS, S. A. A. R., MELO JÚNIOR, J. M. A., GONÇALVES, V. G. G., FONSECA, S. G. C. \& BANDEIRA, M. A. M. Gastroprotective and anti-inflammatory activities integrated to chemical composition of Myracrodruon urundeuva Allemão - A conservationist proposal for the species. Journal of Ethnopharmacology, 2018, (222), 177-189. https://doi.org/10.1016/j.jep.2018.04.024

HIGA, K. C.; JORJÃO, A. L.; OLIVEIRA, F. E.; OLIVEIRA, J. R.; BRITO, G. V. B.; JORGE, A. O. C. \& OLIVEIRA, L. D. (2019). Citotoxicidade dos extratos glicólicos de Cynara scolymus (alcachofra), Myracrodruon urundeuva (aroeira-do-sertão) e Camellia sinensis (chá verde). Revista Univap, 2019, 25(48). https://doi.org/10.18066/revistaunivap.v25i48.2198.

MACHADO, A. C.; SARTORI, V. F.; DAMANTE, C. A.; DOKKEDAL, A. L. \& OlIVEIRA, R. C. Viability of human gingival fibroblast (FGH) treated with ethanolic "Aroeira" extract (Myracrodruon urundeuva Allemão). Brazilian Archives of Biology and Technology, 2016 (59), 17. https://doi.org/10.1590/1678-4324-2016150335.

MATOS, A. A.; OLIVEIRA, F. A.; MACHADO, A. C.; SALDANHA, L. L.; TOKUHARA, C. K.; SOUZA, L. P.; VILEGAS, W.; DIONISIO, T. J.; SANTOS, C. F.; PERES-BUZALAF, C. P.; DOKKEDAL, A. L. \& OLIVEIRA, R. C. An extract from Myracrodruon urundeuva inhibits matrix mineralization in human osteoblastos. Journal of Ethnopharmacology, 2019, (237), 192-201. https://doi.org/10.1016/j.jep.2019.03.052

MENEZES FILHO, A. C. P.; OLIVEIRA FILHO, J. G.; CHRISTOFOLI, M. \& SOUZA, C. F. Atividade antioxidante, conteúdo de fenólicos totais, carotenóides e provitamina $\mathrm{A}$ em extratos vegetais do cerrado goiano. Revista Uniciências, v.22, n.1, p.28-32, 2018. Disponível

em: https://revista.pgsskroton.com/index.php/uniciencias/article/view/6065. Acessado em: 08 de junho de 2021.

MORAIS, N. R. L.; OLIVEIRA NETO, F. B.; MELO, A. R.; BERTINI, L. M.; SILVA, F. F. M. \& ALVES, L. A. Prospeç̧ão fitoquímica e avaliação do potencial antioxidante de Cnidoscolus phyllacanthus (müll. Arg.) Pax \& k. hoffm. Oriundo de apodi-RN. Revista Brasileira de plantas medicinais, 2016, 18(1), 180-185. https://doi.org/10.1590/1983084X/15_058

OLIVEIRA, F.A.; RORATO, C.; ALMEIDA-APOLÔNIO, A. A.; RODRIGUES, A. B.; BARROS, A. L.; SANGALLI, A.; ARENA, A. C.; MOTA, J. S.; GRISOLIA, A. B. \& OLIVEIRA, K. M. P. In vitro antifungal activity of Myracrodruon urundeuva Allemão against human vaginal Candida species. Anais da Academia Brasileira de Ciências, v. 89, n. 3, p. 2423-2432, 2017. https://doi.org/10.1590/0001-3765201720170254

PAULINO, M. L.; SILVA, A. P.; MARTINS, J. DOS S.; SILVA, J. A. \& SANTOS, A. F. Antiradical activity of the species Myracrodruon urundeuva Allemao. Revista Ambientale, 2020, 12(3), 59-66. https://doi.org/10.48180/ambientale.v12i3.225 
PENIDO, A. B.; MORAIS, S. M.; RIBEIRO, A. B.; ALVES, D. R.; RODRIGUES, A, L. M.; SANTOS, L. H. \& MENEZES, J. E. S. A. Medicinal Plants from Northeastern Brazil against Alzheimer's Disease. Evidence-Based Complementary and Alternative Medicine, 2017, 1-7. https://doi.org/10.1155/2017/1753673

PEREIRA, P. S.; BARROS, L. M.; BRITO, A. M.; DUARTE, A. \& E. MAIA, A. J. Uso da Myracroduon urundeuva Allemão aroeira do sertão pelos agricultores no tratamento de doenças. Revista Cubana de Plantas Medicinales, 19(1), 51-60, 2014. Disponível em: http://scielo.sld.cu/scielo.php?script=sci_arttext\&pid=S1028$47962014000100007 \&$ Ing=es\&nrm=iso. Acessado em 08 de junho de 2021.

PIRES JG, J. G.; BRAGA, A. S.; ANDRADE, F. B.; SALDANHA, L. L.; DOKKEDAL, A. L. OLIVEIRA, R C. \& MAGALHÃES, A. C. Effect of hydroalcoholic extract of Myracrodruon urundeuva All. And Qualea grandi flora Mart. Leaveson the viability and activity of microcosmo biofilm and on enamel demineralization. J Appl Oral Sci, 2019; 27: e20180514. https://doi.org/10.1590/1678-7757-2018-0514

PIZZANI, Luciana et al. A arte da pesquisa bibliográfica na busca do conhecimento. RDBCI: Revista Digital de Biblioteconomia e Ciência da Informação, Campinas, SP, v. 10, n. 2, p. 53-66, jul. 2012. https://doi.org/10.20396/rdbci.v10i1.1896

RODRIGUEZ, S.C.; ALVARADO, J.C.; ESPÍRITO-SANTO, M.M. \& NUNES, U.R.F. Myracrodruon urundeuva Fr. Allemão (Aroeira tree) populations dynamics, diameter growth rate and its potential for sustainable manegement in sucessional tropical dry forests of Brazil. Revista Árvore, 2017, v.41, n.3. https://doi.org/10.1590/180690882017000300010

SILVA, F. S.; LANDELL, M. F.; PAULINO, G. V. B.; COUTINHO, H. D. M. \& ALBUQUERQUE, U. P. Antifungal activity of selected plant extracts based on an ethnodirected study. Acta Botanica Brasilica [online]. 2020, v. 34, n. 2, pp. 442-448. ISSN 1677-941X. https://doi.org/10.1590/0102-33062020abb0003.

SOBREIRA, A. C. M.; PINTO, F. C. L.; FLORÊNCIO, K. G. D.; WILKE, D.; STAAS, C. C.; STREIT, R. A. S.; FREIRE, F. C. O.; PESSOA, O. D. L.; TRINDADE-SILVA, A. E. \& CANUTO, K. M. Endophytic fungus Pseudofusicoccum stromaticum produces cyclopeptides and plantrelated bioactive rotenoids. Royal Society of Chemistry Advances, 2018. https://doi.org/10.1039/C8RA06824K

VINALE, F.; SIVASITHAMPARAM, K.; GHISALBERTI, E. L, WOO, S. L.; NIGRO, M; MARRA, M.; LOMBARDI, N.; PASCALE, P.; RUOCCO, M.; LANZUISE, S.; MANGANIELLO, G. \& LORITO, M. Trichoderma Secondary Metabolites Active on Plants and Fungal Pathogens. The Open Mycology Journal, v. 8, n. 1, p. 127-139, 2014. Disponível em: https://benthamopen.com/contents/pdf/TOMYCJ/TOMYCJ-8-127.pdf. Acessado em 08 de junho de 2021. 


\title{
CAPITULO XVII
}

\section{PREVALÊNCIA DAS DOENÇAS GENÉTICAS QUE AFETAM A ESTRUTURA OU A PRODUÇÃO DAS MOLÉCULAS DE HEMOGLOBINA EM UM BANCO DE SANGUE NO NORDESTE DO BRASIL}

\author{
DOI: 10.51859/AMPLLA.PAE1993-17
}

\author{
Weber de Santana Teles ${ }^{1}$ \\ Paulo Vinícius dos Santos Nascimento ${ }^{2}$ \\ Bruno de França Santos ${ }^{3}$ \\ Max Cruz da Silva ${ }^{4}$ \\ Ângela Maria Melo Sá Barros ${ }^{5}$ \\ Ruth Cristini Torres ${ }^{6}$ \\ Marcel Vinícius Cunha Azevedo ${ }^{7}$ \\ Paulo Celso Curvelo Santos Júnior ${ }^{8}$
}

\author{
Doutor em Saúde e Ambiente. Centro de Hemoterapia de Sergipe - HEMOSE \\ 2 Biomédico. Universidade Tiradentes - UNIT \\ ${ }^{3}$ Biomédico. Universidade Tiradentes -UNIT \\ ${ }^{4}$ Graduando do curso de enfermagem. Faculdade Pio Décimo - FAPIDE \\ 5 Mestre/doutoranda em enfermagem. Universidade Federal do Rio de Janeiro - UFRJ \\ ${ }^{6}$ Doutora em saúde e ambiente. Instituto de Hematologia e Hemoterapia de Sergipe - IHHS \\ Mestre em saúde família. Centro Universitário Estácio de Sergipe \\ ${ }^{8}$ Mestre em saúde e ambiente. Universidade Tirandes - UNIT
}

\section{RESUMO}

As hemoglobinopatias são doenças hereditárias de alto impacto epidemiológico e clínico, acarretam em mudanças genéticas que apresentam formas clinicas diferentes, variando entre leves, incapacitantes ou alta taxa de mortalidade. A anemia ocorre pela diminuição de hemoglobina devido ao aumento de hemólise no baço, sendo importante a prática transfusional como terapia para pacientes portadores dessas enfermidades. O presente trabalho teve como objetivo avaliar o perfil epidemiológico, fenotipagem $A B O R h$, da medicação Hydrea portadores de hemoglobinopatias acompanhados no em um banco de sangue no nordeste do Brasil no período de 2017 a 2019. Trata-se de um estudo descritivo, documental com abordagem quantitativa. Foram analisados 165 prontuários dos portadores de hemoglobinopatias acompanhados no ambulatório de um banco de sangue no nordeste brasileiro, utilizando o programa IBM StatisticalPackage for the Social Sciences, 22.0, aplicando o teste estatístico Qui-quadrado de Pearson, com um intervalo de confiança de $95 \%$. Os resultados revelaram que as de maiores predomínios foram: de anemia falciforme, representando 143 (86,7\%), o sexo feminino 95 $(66,4 \%)$, procedentes da Zona Rural 47 (42,5\%). Porém, já em relação aos pacientes que fizeram uso da transfusão, notou-se que $88(61,5 \%)$ realizaram tal procedimento, sendo a maioria com o tipo sanguíneo O+ (44,9\% - 40). Em relação a terapia medicamentosa com Hydrea, 55,8\% (63) não fizeram o uso da medicação. Foi possível perceber que a anemia falciforme continua sendo um problema de saúde pública, havendo a necessidade de implementação de políticas que contemplem ações preventivas e consequentemente melhoria da qualidade de vida das pessoas acometidas pela patologia.

Palavras-Chave: Hemoglobinopatias. Transfusão. Hydrea. 


\section{INTRODUÇÃO}

As hemoglobinopatias são doenças hereditárias de alto impacto epidemiológico e clínico, que tem como característica mudanças genéticas que apresenta formas clinicas diferentes, variando de formas leves, formas incapacitantes ou com alta taxa de mortalidade. (SILVA; BALDIM; ESTEVÃO 2015).

A Organização Mundial de Saúde (2008), estima que no mundo 5\% dos habitantes possui o gene que causa a hemoglobinopatias, e que a cada ano aproximadamente mais de 300.000 recém-nascidos apresentam maior índice de anemia falciforme (AF) seguido de talassemias. (OMS, 2008).

As mutações genéticas que acontecem na hemoglobina $(\mathrm{Hb})$ são passadas através de herança familiar, e podem ser resultantes de modificações que atingem o gene que regulam o equilíbrio das cadeias polipeptídicas. (MINISTÉRIO DA SAÙDE, 2016).

Pesquisas realizadas indicaram que o gene dominante dessa doença surgiu no ocidente da África precisamente na parte centro-africano e que as populações ancestrais que migraram o espalharam por todo o continente chegando até a região mediterrânea (MINISTERIO DE SAÚDE ,2015). No território brasileiro estima-se que aproximadamente 15 milhões de indivíduos são portadores de algum tipo hemoglobinopatia, e esses dados se deve a migração e a misturas das raças.. (ALMEIDA et al., 2011).

Pesquisa realizada por Jesus (2010) demostra que em relação a incidência de nascidos vivos com AF, o estado da Bahia, em uma proporção de 1: 650, Rio de Janeiro (1: 1200) e Estados de Pernambuco, Maranhão, Minas Gerais e Goiás (1: 1400 cada). Quanto a prevalência dos nascidos com TF, os estados que mais se destacaram foram o estado da Bahia, Rio de Janeiro e Minas Gerais.

Leal et al., (2016), informa que alterações na estrutura globínica, formará hemoglobinas anormais ( $\mathrm{Hb} \mathrm{S}, \mathrm{Hb} \mathrm{C}, \mathrm{Hb} \mathrm{D}, \mathrm{Hb} E)$, sendo a que mais se destaca é $\mathrm{Hb} \mathrm{S}$, sendo que esse gene que causa a mutação em homozogiose são responsáveis pela formação da AF.

De acordo com a Portaria conjunta no 05, de 19 de fevereiro do Ministério da Saúde (2018), os sintomas, os indivíduos portadores da DF apresentam pode haver dor 
intensa, lesões isquêmicas teciduais e danos em todos os órgãos e sistemas (cérebro, coração, fígado, rins, pele, olhos, esqueleto e pulmões). A maioria dos desfechos fatais é precedida por episódios agudos, como a síndrome torácica aguda ou o sequestro esplênico.

Os testes para a confirmação da AF são: falcização ou teste de solubilidade, testes que positivam a presença de $\mathrm{Hb} \mathrm{S}$ nos eritrócitos, testes confirmatórios de genótipos (AS, SS, SC, etc.): eletroforeses de hemoglobinas em meios alcalino e ácido, isoeletrofocalização, dosagem de $\mathrm{Hb}$ Fetal, e cromatografia líquida de alta pressão (HPLC), testes que indicam os haplótipos por meio de técnicas de biologia molecular e testes de monitoramento: hemograma, contagem de reticulócitos, morfologia eritrocitária, dosagens de: ferritina, bilirrubina, ácido úrico, fosfatase alcalina, desidrogenase láctica (LDH) e metaemoglobina, e pesquisas intracelulares de corpos de Heinz, Hb H e Hb Fetal. (MINISTÉRIO DA SAÚDE, 2018).

O tratamento da DF é realizado com a hidroxiureia (HU), que atua na inibição da enzima ribonucleotídeo redutase. Leva a aumento da produção de $\mathrm{HbF}$, da hidratação do glóbulo vermelho e da taxa hemoglobínica, além de diminuição da hemólise, maior produção de óxido nítrico e diminuição da expressão de moléculas de adesão. Até o momento, a HU é considerada a terapia medicamentosa mais eficaz da DF. (MINISTÉRIO DA SAÚDE, 2018).

Baseando-se nestas premissas, este trabalho teve como objetivo analisar a frequência de casos de (AF) forme, perfil epidemiológico, e clínico dos pacientes atendidos em um banco de sangue no nordeste do Brasil, no período de 2017 a 2019.

\section{METODOLOGIA}

A pesquisa foi realizada no setor ambulatorial em um banco de sangue no nordeste do Brasil, no período de 2017 a 2019.Trata-se de uma análise retrospectiva de dados de 143 pacientes portadores de DF que foram atendidos pela equipe multidisciplinar do ambulatório em banco de sangue no nordeste do Brasil, no período de 2017 a 2019. os dados foram extraídos dos prontuários armazenados no ambulatório e organizados e classificados no programa Excel 365. Após a organização, a análise estatística deu-se pelo software IBM Statistical Package for the Social Sciences, 22.0, utilizando um intervalo de confiança de $95 \%(p<0.05)$ para significância estatística. 
Utilizou-se o teste estatístico Qui-quadrado de Pearson (X2) para comparação da distribuição dos valores a partir de duas variáveis (Hemoglobinopatias X Gênero; Hemoglobinopatias X Naturalidade; Hemoglobinopatias X Fez Transfusão ou não; Hemoglobinopatias X Uso da Hydrea). A partir dos resultados obtidos, foram confeccionados as tabelas e os gráficos.

\section{RESULTADOS}

Dos 165 pacientes portadores de hemoglobinopatias atendidos em banco de sangue no nordeste do Brasil, no período de 2017 a 2019, 86,7\% (143) eram portadores de (AF), 9,1\% (15) eram portadores de outras hemoglobinopatias e 4,2\% (7) portadores de talassemia (Figura 1).

Figura 1 - Frequência das hemoglobinopatias atendidos em banco de sangue no nordeste do Brasil, no período de 2017 a 2019.

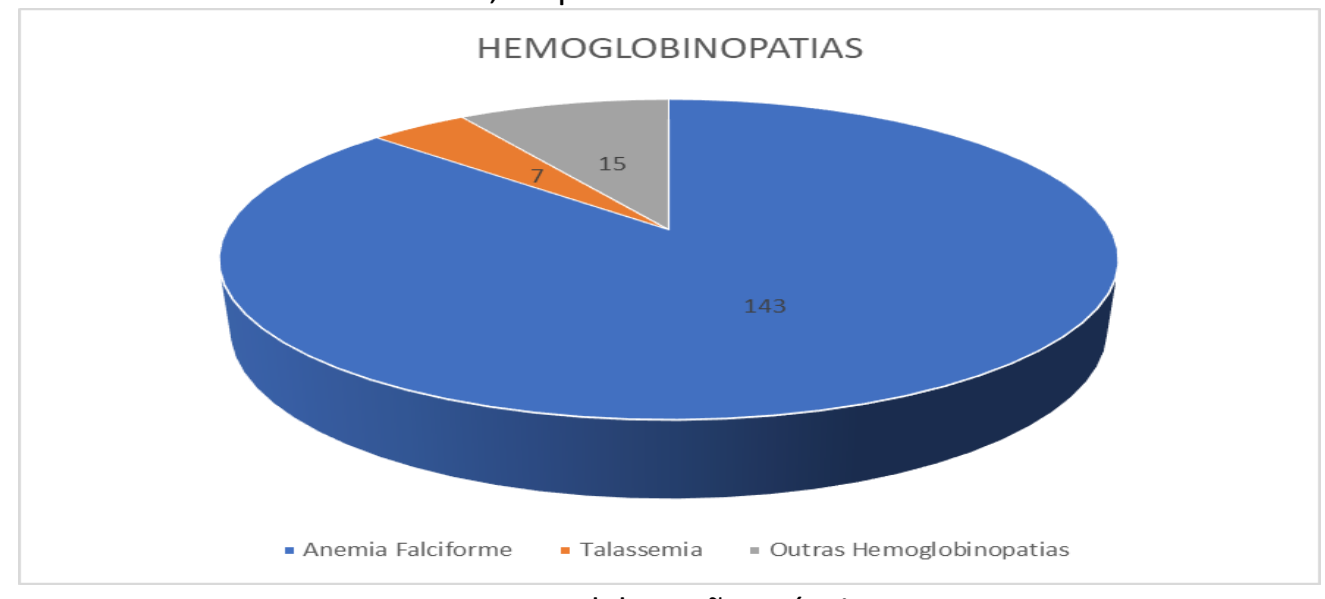

Fonte: Elaboração própria.

Na figura 2, nota-se que 33,6\% (48) dos pacientes que apresentam (AF) são do sexo masculino, enquanto 66,4\% (95) feminino. Já em relação aos indivíduos portadores de talassemia beta, 57,1\% (7) são homens, enquanto, nos indivíduos portadores de outras hemoglobinopatias $80 \%$ (15) são do sexo feminino, não apresentando diferença estatística. 
Figura 2 - Frequência de hemoglobinopatias em banco de sangue no nordeste do Brasil, no período de 2017 a 2019, organizada por gênero.

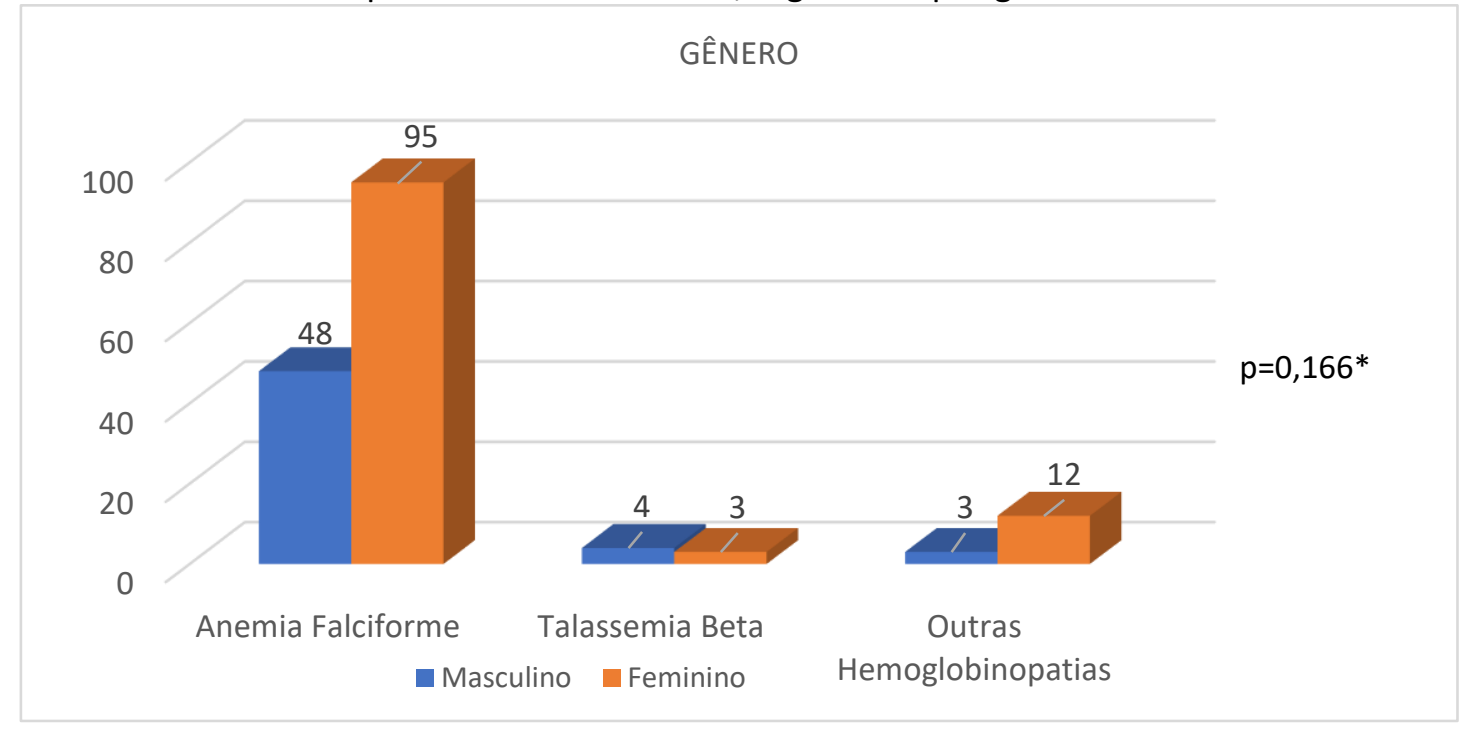

Fonte: Elaboração própria.

Na Figura 3 - Indica que 42,5\% (47) dos indivíduos portadores de DF são moradores da zona urbana, 38,9\% (44) são residentes na zona rural, 19,5\% (22) são provenientes de outros estados. Com relação a talassemia indicaram que $14,3 \%$ (1) dos indivíduos são moradores da zona rural e 85,7\% (6) são pessoas de outros estados, já os outros tipos de hemoglobinopatias $60 \%$ (9) residem na capital, 33,3\% (5) são moradores do interior, 6,7\% (1) são indivíduos provenientes de outros estados, apresentando diferença estatística $(p<0,05)$.

Figura 3 - Prevalência das hemoglobinopatias em banco de sangue no nordeste do Brasil, no período de 2017 a 2019, divididas por regiões.

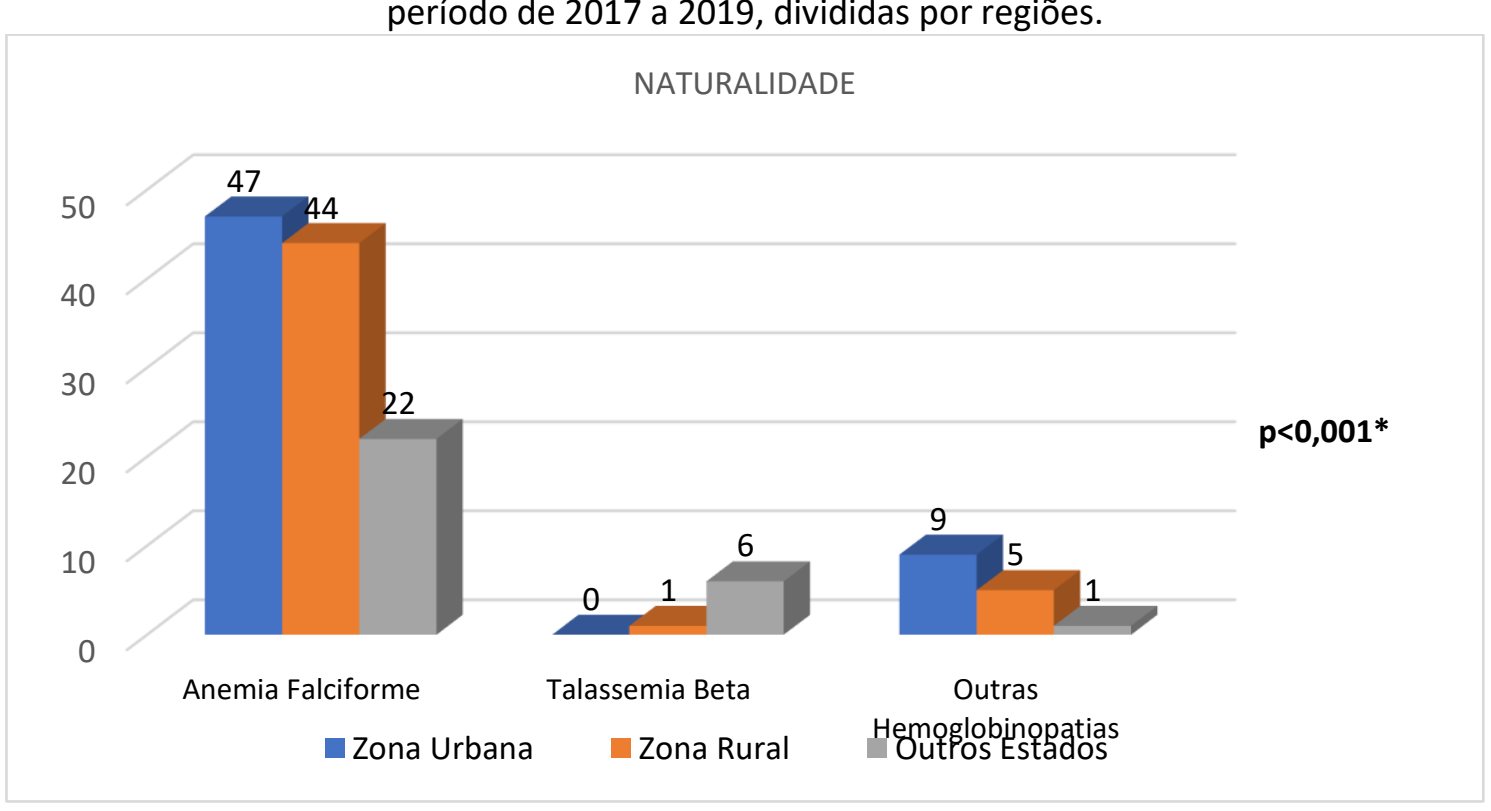

Fonte: Elaboração própria 
Na figura 4, observa-se que 61,5\% (88) dos indivíduos com (AF), foram infundidos com concentrado de hemácias $(\mathrm{CH})$, enquanto $71,4 \%$ (5) dos indivíduos com talassemia não fizeram uso, apresentando diferença estatística quando relacionado patologia com realização de transfusão $(p<0,05)$.

Figura 4 - Frequência de transfusões em banco de sangue no nordeste do Brasil, no período de 2017 a 2019.

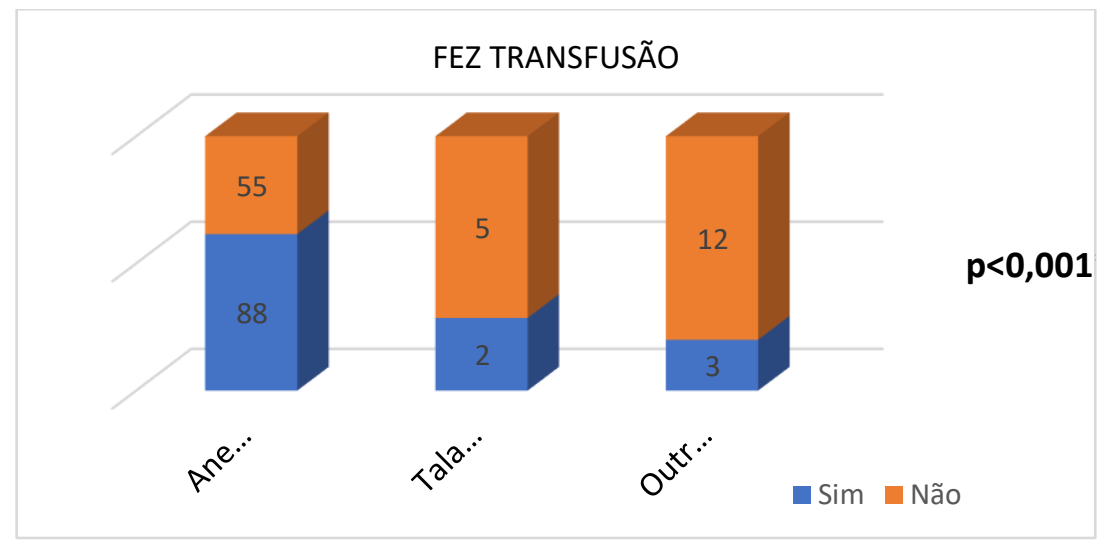

Fonte: Elaboração própria.

Na tabela 1 com relação a (AF) pode se observar que o fenótipo com maior prevalência foi $\mathrm{O}+(44,9 \%)$ e o com menor índice foi $\mathrm{AB}$-/B- $(0,0 \%)$ que não tiveram nenhum caso relatado, quanto à talassemia todos os dois casos pertencem ao fenótipo A+ $(100 \%)$, e com relação a outras hemoglobinopatias os dados tiveram total semelhança por com os dados da (AF).

Tabela 1 - Prevalência de fenótipo em banco de sangue no nordeste do Brasil, no período de 2017 a 2019.

\begin{tabular}{ccccc}
\hline \multirow{2}{*}{ FENÓTIPO } & $\begin{array}{c}\text { Anemia } \\
\text { Falciforme }\end{array}$ & Talassemia & $\begin{array}{c}\text { Outras } \\
\text { Hemoglobinopatias }\end{array}$ & TOTAL \\
\hline A+ & $21(23.6 \%)$ & $2(100 \%)$ & $0(0 \%)$ & $23(24.5 \%)$ \\
A- & $6(6.7 \%)$ & $0(0 \%)$ & $1(33.3 \%)$ & $7(7.4 \%)$ \\
B+ & $17(19.1 \%)$ & $0(0 \%)$ & $1(33.3 \%)$ & $18(19.1 \%)$ \\
B- & $0(0 \%)$ & $0(0 \%)$ & $0(0 \%)$ & $0(0 \%)$ \\
O+ & $40(44.9 \%)$ & $0(0 \%)$ & $1(33.3 \%)$ & $41(43.6 \%)$ \\
O- & $1(1.1 \%)$ & $0(0 \%)$ & $0(0 \%)$ & $1(1.1 \%)$ \\
AB+ & $4(4.5 \%)$ & $0(0 \%)$ & $0(0 \%)$ & $4(4.3 \%)$ \\
AB- & $0(0 \%)$ & $0(0 \%)$ & $0(0 \%)$ & $0(0 \%)$ \\
\hline
\end{tabular}

Fonte: Elaboração própria.

Com relação a AF na tabela 2 podemos observar um maior predomínio do fenótipo RH “c"(89.9\%) e "e"(91\%), e com menor prevalência kell (1.1\%) , talassemia e outras hemoglobinopatias compartilham os mesmos indicies, talassemia com 
"c"(100\%),"e"(100\%) e kell (0\%), outras hemoglobinopatias com "c"(66.6\%), "e"(66.6\%) e kell (0\%).

Tabela 2 - Prevalência de fenótipo fenótipo RH, Keel, talassemia e outras hemoglobinopatias em banco de sangue no nordeste do Brasil, no período de 2017 a 2019.

\begin{tabular}{ccccc}
\hline \multirow{2}{*}{ FENÓtIPO } & $\begin{array}{c}\text { Anemia } \\
\text { Falciforme }\end{array}$ & Talassemia & $\begin{array}{c}\text { Outras } \\
\text { Hemoglobinopatias }\end{array}$ & TOTAL \\
& & RH & & \\
\hline C & $39(43.8 \%)$ & $0(0 \%)$ & $1(33.3 \%)$ & $40(42.5 \%)$ \\
c & $80(89.9 \%)$ & $2(100 \%)$ & $2(66.6 \%)$ & $84(89.4 \%)$ \\
E & $21(23.6 \%)$ & $0(0 \%)$ & $0(0 \%)$ & $21(22.3 \%)$ \\
e & $81(91 \%)$ & $2(100 \%)$ & $2(66.6 \%)$ & $85(90.4 \%)$ \\
Kell & $1(1.1 \%)$ & $0(0 \%)$ & $0(0 \%)$ & $1(1.1 \%)$ \\
\hline
\end{tabular}

Fonte: Elaboração própria.

A tabela 3 indica o fenótipo do perfil 3, podemos observar uma maior prevalência na AF do "s" (95.5\%), e com menor prevalência " $\mathrm{S}$ " (37.1\%), já na talassemia se destacam "M", "S", "s". e com relação a outras hemoglobinopatias o com maior destaque é "s" (94.7\%).

Tabela 3 - Prevalência de fenótipo " $s$ ", "S" RH, na talassemia "M", "S", "s".e outras hemoglobinopatias em banco de sangue no nordeste do Brasil, no período de 2017 a 2019.

\begin{tabular}{ccccc}
\hline \multirow{2}{*}{ FENÓTIPO } & $\begin{array}{c}\text { Anemia } \\
\text { Falciforme }\end{array}$ & Talassemia & $\begin{array}{c}\text { Outras } \\
\text { Hemoglobinopatias }\end{array}$ & TOTAL \\
\hline & & PERFIL 3 & $1(33.3 \%)$ & $66(70.2 \%)$ \\
M & $63(70.1 \%)$ & $2(100 \%)$ & $2(66.6 \%)$ & $65(69.1 \%)$ \\
N & $62(70 \%)$ & $1(50 \%)$ & $0(0 \%)$ & $35(37.2 \%)$ \\
S & $33(37.1 \%)$ & $2(100 \%)$ & $2(66.6 \%)$ & $89(94.7 \%)$ \\
S & $85(95.5 \%)$ & $2(100 \%)$ & $0(0 \%)$ & $47(50 \%)$ \\
$\mathrm{Fy}^{\mathrm{a}}$ & $46(51.7 \%)$ & $1(50 \%)$ & $1(33.3 \%)$ & $50(53.2 \%)$ \\
$\mathrm{Fy}^{\mathrm{b}}$ & $48(53.4 \%)$ & $1(50 \%)$ & & \\
\hline
\end{tabular}

Fonte: Elaboração própria.

Observa-se na tabela 4 em relação ao fenótipo do perfil 2 na AF um

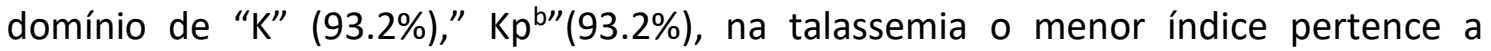

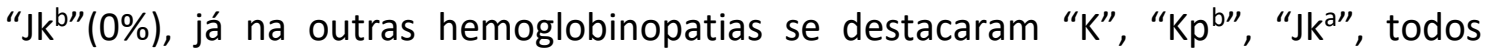
possuindo um índice de $66.6 \%$. 
Tabela 4 - Prevalência de fenótipo "K", $\mathrm{Kp}^{\mathrm{b}}$ "S" RH, na talassemia "Jk"

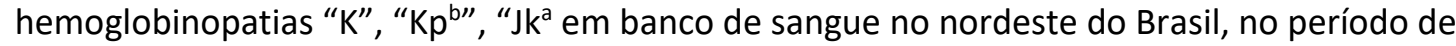
2017 a 2019.

\begin{tabular}{ccccc}
\hline FENÓTIPO & $\begin{array}{c}\text { Anemia } \\
\text { Falciforme }\end{array}$ & Talassemia & $\begin{array}{c}\text { Outras } \\
\text { Hemoglobinopatias }\end{array}$ & TOTAL \\
\hline $\mathrm{K}$ & $83(93.2 \%)$ & $2(100 \%)$ & $2(66.6 \%)$ & $87(92.5 \%)$ \\
$\mathrm{Kp}^{\mathrm{a}}$ & $2(2.2 \%)$ & $2(100 \%)$ & $1(33.3 \%)$ & $5(5.3 \%)$ \\
$\mathrm{Kp}^{\mathrm{b}}$ & $83(93.2 \%)$ & $2(100 \%)$ & $2(66.6 \%)$ & $87(92.5 \%)$ \\
$\mathrm{Jk}^{\mathrm{a}}$ & $71(80 \%)$ & $2(100 \%)$ & $2(66.6 \%)$ & $75(79.8 \%)$ \\
$\mathrm{Jk}^{\mathrm{b}}$ & $60(67.4 \%)$ & $0(0 \%)$ & $1(33.3 \%)$ & $61(64.9 \%)$ \\
\hline
\end{tabular}

Fonte: Elaboração própria.

Observando a tabela 5 tratando do fenótipo do perfil 1 da AF se destacou " Lu" (89.9\%), na talassemia observa-se um destaque para " $P$ ", "Le " “, " Lu" (100\%), já em outras hemoglobinopatias o destaque vai para "Lu" " (89.4\%).

Tabela 4 - Prevalência de fenótipo " $L u^{b}$, na talassemia " $P$ ", "Le ", " $L u^{b}$ " outras hemoglobinopatias "Lu " em banco de sangue no nordeste do Brasil, no período de 2017 a 2019.

\begin{tabular}{ccccc}
\hline \multirow{2}{*}{ FENÓTIPO } & $\begin{array}{c}\text { Anemia } \\
\text { Falciforme }\end{array}$ & Talassemia & $\begin{array}{c}\text { Outras } \\
\text { Hemoglobinopatias }\end{array}$ & TOTAL \\
\hline & & PERFIL 1 & \\
\hline P & $75(84.3 \%)$ & $2(100 \%)$ & $2(66.6 \%)$ & $79(84 \%)$ \\
$L^{a}$ & $14(15.7 \%)$ & $0(0 \%)$ & $0(0 \%)$ & $14(14.9 \%)$ \\
$L^{\mathrm{b}}$ & $53(59.5 \%)$ & $2(100 \%)$ & $2(66.6 \%)$ & $57(60.6 \%)$ \\
$\mathrm{Lu}^{\mathrm{a}}$ & $14(15.7 \%)$ & $0(0 \%)$ & $2(66.6 \%)$ & $16(17 \%)$ \\
$\mathrm{Lu}^{\mathrm{b}}$ & $80(89.9 \%)$ & $2(100 \%)$ & $2(66.6 \%)$ & $84(89.4 \%)$ \\
\hline
\end{tabular}

Fonte: Elaboração própria.

Em relação aos indivíduos portadores de (AF), nota-se que 44,2\% (50) fazem o uso de hydrea, enquanto nas outras hemoglobinopatias, apenas $26,7 \%$ (4) fazem uso. Em relação a talassemia, nenhum indivíduo faz uso da medicação. Dessa forma, nota-se diferença estatística quando comparado o tipo de hemoglobinopatias com o uso de hydrea $(p<0,05)$ (Figura 5) 
Figura 5 - Assiduidade do uso de hidroxiuréia em em banco de sangue no nordeste do Brasil, no período de 2017 a 2019.

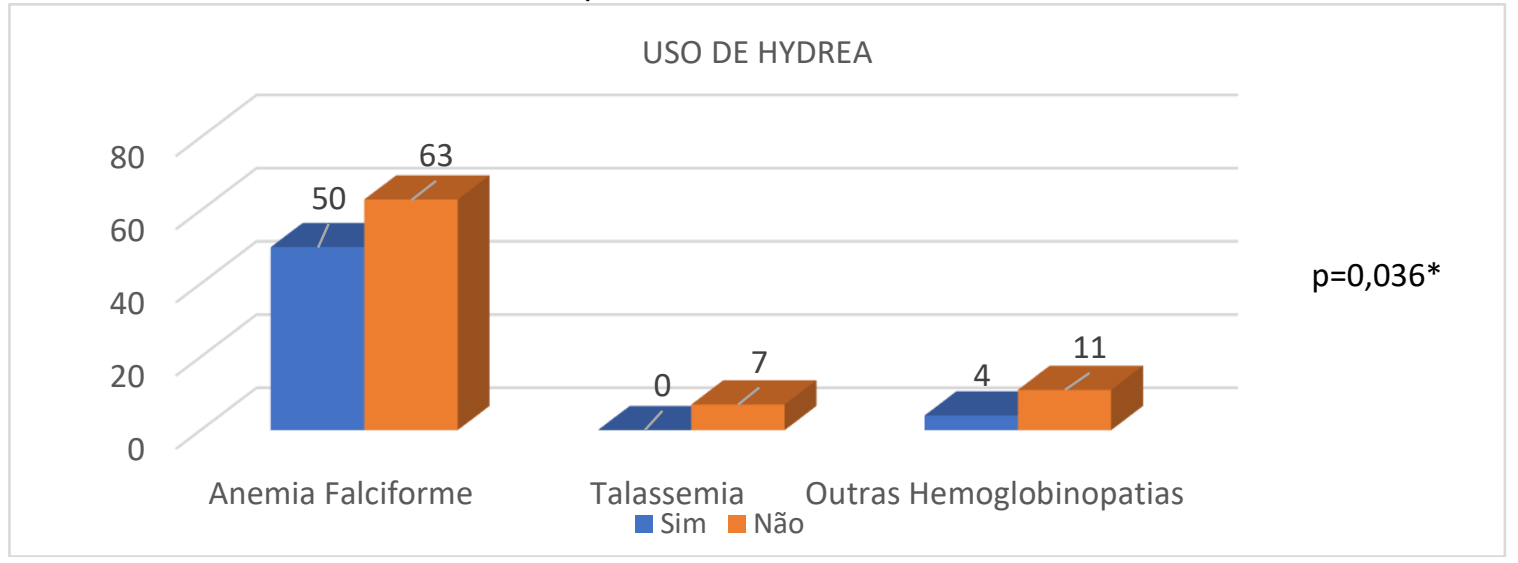

Fonte: Elaboração própria.

\section{DICUSSÃO}

Os dados obtidos nesta pesquisa demonstram que a AF apresenta maior índice dos pacientes atendidos no banco de sangue no nordeste do Brasil, um total de $86 \%$. Analise realizada em 26.976 prontuários de doadores de sangue do Distrito Federal em uma instituição particular no período de janeiro de 2013 a dezembro de 2015, mostrou que à presença da HbS foi de 26.354 (97,6\%), resultados semelhantes à da atual pesquisa.

Segundo Felix et al, (2010) é nos estados da Bahia, Rio de Janeiro, Pernambuco, Minas Gerais e Maranhão, que se encontra a maior prevalência. Entretanto diagnostico laboratorial de triagem neonatal demostra que a incidência do traço falciforme entre os nascidos vivos na Bahia é de 1 a cada 17 e, para a doença falciforme, de 1 a cada 650 nascidos vivos.

Existe uma escassez na literatura que aborde o gênero na doença falciforme, exatamente por se tratar de uma doença genética não relacionada ao sexo (FELIX et al, 2010). De acordo com a Fundação Instituto Brasileiro de Geografia e Estatística (2010), a dominância dos indivíduos com (AF) do sexo feminino sobre o masculino, demonstra o perfil população do território brasileiro, com discreta prevalência de mulheres $(51,7 \%)$.

Estudos realizados em 293 casos e controles realizados no Hospital de Clínicas de Porto Alegre demostraram que $176(60,1 \%)$ eram do sexo feminino e $117(39,9 \%)$ eram do sexo masculino, Pinheiro em (2006), mostra que a AF apresenta maior frequência em 
pacientes do sexo feminino, quanto à talassemia o sexo masculino tem uma maior prevalência. Em outro estudo Pinheiro (2006) avaliou 389 amostras do cordão umbilical e observou que crianças do sexo masculino tinha maior prevalência de $\mathrm{HbS}$ do que as do sexo feminino.

Quando comparado com um estudo realizado por Gonçalves (2015) no banco de sangue no nordeste do Brasil, no ano de 2017 verificou-se diferença significativa, pois o predomínio de pacientes é decorrente da zona rural 50\%, seguida da zona urbana com $34 \%$ e por últimos pacientes provenientes de outros estados $16 \% \%$.

Pesquisa realizada por Pinto et al (2011), demonstra que aproximadamente mais da metade dos indivíduos portadores de AF, no decorrer da vida recebem tratamento através da transfusão sanguínea e aproximadamente de $5 \%$ á $10 \%$ dos portadores da doença necessitam de transfusão constante.

No MT-Hemocentro no período de 2005 á 2010 foram realizados estudos e pesquisas por Silva et al. (2012), comprovando que a maior taxa de portadores de AF tinham como fenotipagem o tipo O+ como maior prevalência.

Pesquisas realizadas por Zanette, (2011) demonstra que a ocorrência nos indivíduos estudados referentes à anti-K, anti-E e anti-C foram menor que $10 \%$. No presente estudos o anti-K foi maior que $90 \%$, o anti-E maior que $20 \%$ e anti $\mathrm{C}$ maior que 40\%. De acordo com a literatura, diminuições na frequência dos aloanticorpos tanto de maneira combinada ou isolada ocorreram de maneiras iguais, entretanto um caso foi identificado 6 aloanticorpos (anti-C, anti-Jkb, anti-Fya, anti-S, anti-VS e anti-K). Na pesquisa supracitada prevaleceram o anti-Lub, anti-e, anti-c, anti-M, anti-s e o anti-K.

O processo de aloimunização apresentou nos indivíduos que tinham recebido pelo menos 3 bolsa de concentrado de hemácias $(\mathrm{CH})$ sendo que o maior indicie de anticorpos eritrocitários foi o anti-E. Quanto a fenotipagem Duffy para os antígenos Fya e Fyb foi prevalente o fenótipo Fy $(a-b+)$, seguido do Fy(a-b-) em 33,3\%, Fy(a+b-) em $21,6 \%$ e $F y(a+b+)$ em 10,8. Quanto ao referido estudo Fya e/ou Fyb obteve-se frequência maior que $50 \%$.

Darbonne et al. (1991), realizando estudo sobre osteonecrose, encontrou o fenótipo eritrocitário Duffy negativo e hemoglobina maior que $8 \mathrm{~g} / \mathrm{dl}$, entretanto o antígeno Duffy/DARC, tem sido considerado no processo de inflamação devido a 
funcionalidade dos receptores de quimiocinas que atuam como depurador dessas substancias dos locais onde haja produção excessiva, como os sítios de inflamação.

$\mathrm{Na} A \mathrm{~F}$ a inexistência eritrocitraria do antígeno Duffy/DARC tem associação com a patologia da doença especialmente a renal sendo assim um potencial marcador da lesão orgânica desta doença (Afenyi-Annan et al. 2008). Outros estudos demonstram que a expressão do antígeno Duffy/DARC e biomarcadores de inflamação em pacientes portadores de AF demonstra uma ligação da expressão eritrocitária desse antígeno e como consequência a morte do tecido ósseo, comprometimento renal, ulcera em regiões inferiores e ereção prolongada (Nebor et al. 2010).

Outra associação encontrada Mecabo et al. (2010), foi realizando uma análise de 87 pacientes de AF Duffy-negativos, demonstraram ligação com o fenótipo hemolítico nesses indivíduos havendo, um maior indicie de hipertensão pulmonar, priapismo e aumento da Desidrogenase Lática (DHL).O Departamento de Atenção Hospitalar e de Urgência da AF informa que no tratamento da doença supracitada os medicamentos básicos utilizados são: ácido fólico, antibióticos, analgésicos e anti-inflamatórios (nas intercorrências e hidroxiureia

\section{CONSIDERAÇÕES FINAIS}

Por meio do estudo realizado, verificou-se que a $(\mathrm{AF})$ trata-se de uma doença crônica, genética e hereditária com graves crises de vaso-oclusão responsáveis pelas principais manifestações clínicas da doença.

O diagnostico precoce da AF se mostrou extremamente importante com o intuito de dar uma melhor qualidade de vida e longenvidade aos portadores da doença, espera-se que os resultados desta pesquisa levem a um desenvolvimento de novos estudos, contribuindo cada vez mais com o desenvolvimento de todo surporte dado aos pacientes pelas instituições que realizam transfusões e acrescentar novos conhecimentos aos profissionais de saude que atuam nessa área.

Espera-se, portanto, que os resultados deste estudo possam subsidiar o desenvolvimento de novas pesquisas, colaborando, assim, para a melhoria contínua da assistência prestada por hemocentros e qualidade de vida dos pacientes. Ademais, os resultados podem servir como instrumentos propulsores de políticas públicas que 
amplifiquem o acesso dos pacientes ao tratamento e o conhecimento popular de que se trata de uma patologia tratável e passível de manejo clínico pelo sistema de saúde atual.

Os resultados obtidos nesse trabalho são concordantes com os encontrados nas literaturas consultadas, no entanto observou-se uma dificuldade em comparar este estudo com pesquisas realizadas sobre o uso da medicação, visto que a literatura é bastante escassa nesse sentido.

\section{REFERÊNCIAS}

ABBAS, A. K. ; LICHTMAN, A. H. \& POBER, J.S. Imunologia celular e molecular. 5 a ed., Rio de Janeiro, Elsevier, 2005. 580 p.

Afenyi-Annan A, Kail M, Combs MR, Orringer EP, Ashley-Koch A, Telen MJ. Lack of Duffy antigen expression is associated with organ damage in patients with sickle cell disease. Transfusion 2008;48(5):917-924.

ALMEIDA L. P. et al. O laboratório clínico na investigação de hemoglobinopatias,

Jornal Brasileiro de Patologia Médica Laboratorial, São Paulo, v. 47, n. 3, p. 271-278, jun. 2011.

Brasil. Ministério da Saúde. Secretaria de Atenção à Saúde. Departamento de Atenção Hospitalar e de Urgência. Doença falciforme: Hidroxiureia: uso e acesso / Ministério da Saúde, Secretaria de Atenção à Saúde, Departamento de Atenção Hospitalar e de Urgência - 1. ed., 1. reimpr. - Brasília: Ministério da Saúde, 2014.56. p114.

Brasil. Ministério da Saúde. Secretaria de Atenção à Saúde. Departamento de Atenção Hospitalar e de Urgência. Doença falciforme: diretrizes básicas da linha de cuidado / Ministério da Saúde, Secretaria de Atenção à Saúde, Departamento de Atenção Especializada e Temática. - Brasília: Ministério da Saúde, 2015.

Brasil. Ministério da Saúde. Secretaria de Atenção a Saúde. Departamento de Atenção Especializada e Temática. Triagem neonatal biológica: manual técnico / Ministério da Saúde, Secretaria de Atenção a Saúde, Departamento de Atenção Especializada e Temática. - Brasília: Ministério da Saúde, 2016.

CASTILHO, L. Aplicações da biologia molecular em imuno hematologia eritrocitária, 2007.Disponívelem:<http://www.imunohematologia.com.br/ello_plugins/cont ent/images/file/19_apostila_genotipagem.pdf>. Acesso em 09 maio de 2015.

DARBONNE, W.C., et al. Red blood cells are a sink for interleukin 8, a leukocyte chemotaxin. J Clin Invest 1991;88(4):1362-1369. 
DINIZ, D.; et al.. Prevalência do traço e da anemia falciforme em recém-nascidos do Distrito Federal, Brasil, 2004 a 2006. Cadernos de Saúde Pública. Rio de Janeiro,n.1, v. 25, p.188-194. Jan. 2009.

FELIZ, A.A, et al. Aspectos epidemiológicos e sociais da doença falciforme. Rev. Bras. Hematol. Hemoter. 2010; 32(3):203-8. 3

BELISÁRIO, A., et al. Genótipos da talassemia alfa e haplótipos do grupamento de genes da globina beta como moduladores da gravidade na doença falciforme em crianças do Programa Estadual de Triagem Neonatal de Minas Gerais, matriculadas no Hemocentro de Belo Horizonte da Fundação Hemominas. Belo Horizonte: Faculdade de Medicina, Universidade Federal de Minas Gerais; 2010.

GONÇALVES. P., et al. Anemia falciforme :um estudo de prevalência no centro de hemoterapia de Sergipe (HEMOSE), 2015.

GUIMARÃES, A.; MILTON, R. Prevalência do traço falciforme em doadores de sangue do Distrito Federal,2016.

JESUS, J.A. "Doença falciforme no Brasil." Gazeta Médica da Bahia 3 (2010).

LEAL, A. S. et al. Haplótipos da Bs-globina e sua co-relação clínica-hematológica em portadores de anemia falciforme, Jornal Brasileiro de Patologia e Medicina Laboratorial, Minas Gerais, v. 52, n. 3, p. 5-10, fev. 2016.

MARTINS, M. L.; CRUZ, K. V. D.; SILVA, M. C. F. ; VIEIRA, Z. M. Uso da genotipagem de grupos sanguíneos na elucidação de casos inconclusivos na fenotipagem eritrocitária de pacientes atendidos na Fundação Hemominas. Rev. Bras. Hematol. Hemoter.,v. 31, n. 4, p. 252-259, ago. 2009.

MECABO, G., et al. Duffy-negative is associated with hemolytic phenotype of sickle cell anemia. Clinical Immunology 2010 Sep;136(3):458-459.

MINISTÉRIO DA SAÚDE: Manual de Diagnóstico e Tratamento de Doenças Falciformes. Brasília: Agencia Nacional de Vigilância Sanitária - ANVISA. 2001.

Ministério da Saúde, Portaria № 822, de 06 de junho de 2001. Gabinete do Ministro, 2001.

NEBOR, D., et al. Association between Duffy antigen receptor for chemokines expression and levels of inflammation markers in sickle cell anemia patients. Clinical Immunology 2010;136:116-122.

BORDIN, J.O. Hemoterapia: fundamentos e prática. São Paulo: Atheneu; 2007. p 18689.

OLIVEIRA, J.F., et al. Vitamina D em crianças e adolescents com doença

Falciforme - Revista Paulista de Pediatria, São Paulo, v. 33, n 3, p. 349-355, jan. 2015. 
PINHEIRO, L. S., et al.. Prevalência de hemoglobina S em recém-nascidos de Fortaleza: importância da investigação neonatal. Revista Brasileira de Ginecologia e Obstetrícia. Rio de Janeiro, v. 28, n.2, p.122-125. Fev. 2006.

PINTO, P. C. A.; BRAGA, J. A. P.; SANTOS, A. M. N. Fatores de risco para aloimunização em pacientes com anemia falciforme. Revista da Associação Médica Brasileira. 57(6):668-673. 2011.

PORTARIA CONJUNTA № 05, DE 19 DE FEVEREIRO DE 2018. Aprova o Protocolo Clínico e Diretrizes Terapêuticas da Doença Falciforme (2018).

REIS, W. Anemia Falciforme: análises clínicas, 2010.

SILVA, A.M.B. Pesquisa de hemoglobinopatias em uma amostra de estudantes universitários da cidade de Belém (Pará). 2011.

SILVA, R. A.; SOUZA, A. V. V.; MENDES, S. O.; LUZ, P. R. G.; MEDEIROS, M. O. Estudo genético-populacional da doença falciforme a partir de doadores de sangue em Primavera do Leste - MT. Biodiversidade - V.11, N1, pág.108. 2012.

SILVA, Camila A., et al. Triagem neonatal de hemoglobinopatias - Revista Paulista de Pediatria, São Paulo, v.33, n. 1, p. 192-197, jan.2015.

SONATI, M. F. The genetic of blood disorders: hereditary hemoglobinopathies. Jornal de Pediatria, São Paulo, v.84, n. 4, p. 78-86, mar. 2008.

World Health Organization, Sickle Cell disease and other haemoglobin desorders

- Disponível em: http://www.who.int/mediacentre/factsheets/fs308/en/. Acesso em 15 de maio de 2016.

Zanette. A,M,D. Perfil clínico da Doença Falciforme: definição de subfenótipos clínicos e a influência do diagnóstico tardio, da aloimunização e do antígeno Duffy. Escola Bahiana de Medicina e Saúde Pública. 2011. 


\section{CAPITULO XVIII}

\section{PRINCÍPIOS E GENERALIDADES SOBRE A AÇÃO DOS FÁRMACOS}

DOI: 10.51859/AMPLLA.PAE1993-18

José Nyedson Moura de Gois ${ }^{1}$ Luanne Eugênia Nunes ${ }^{2}$

\footnotetext{
${ }^{1}$ Farmacêutico. Pós-graduando em Farmácia clínica e prescrição farmacêutica. Faculdade Vale do Jaguaribe - FVJ

${ }^{2}$ Farmacêutica. Doutora em Ciências Farmacêuticas. Professora Adjunta do Curso de Farmácia. Faculdade Nova Esperança de Mossoró - Facene/RN
}

\section{RESUMO}

Farmacologia é a área das ciências farmacêuticas que trata de estudar as substâncias dotadas de propriedades químicas, as quais conferem à molécula a capacidade de alterar as funções biológicas do alvo em questão. Entretanto, para que o fármaco possa chegar íntegro na região do receptor na qual ocorrerá a interação, ligar-se ao alvo e estimular uma resposta biológica específica, deve passar por algumas etapas, didática e funcionalmente divididas em: fase farmacêutica, farmacocinética e farmacodinâmica. Nesse sentido, este estudo objetiva condensar e descrever, de forma direta e objetiva, a partir de uma revisão narrativa da literatura, o conhecimento basilar para o entendimento da farmacologia, com ênfase na farmacocinética e farmacodinâmica.

Palavras-chave: Farmacocinética. Farmacodinâmica. Farmacologia. Fármacos. 


\section{INTRODUÇÃO}

A etimologia da palavra farmacologia é descrita a partir da tradução literal do termo grego composto pela associação de phármakon, que significa fármaco, droga, e lógos, estudo. Assim, a farmacologia representa a área da ciência que trata de estudar substâncias capazes de interagir com o sistema biológico, seja ativando ou inibindo funções fisiológicas, por meio de ligações moleculares entre o sítio-alvo e a molécula, desencadeando uma resposta benéfica (terapêutica) ou maléfica (tóxica) (KATZUNG; TREVOR, 2017).

Nas ciências farmacêuticas, entende-se por fármaco como uma substância capaz modificar sua função biológica por intermédio das suas propriedades químicas (KATZUNG; TREVOR, 2017). Por outro lado, apesar de ser indevido e constantemente confundido como sinônimo de fármaco, o conceito de medicamento é mais abrangente, sendo produto farmacêutico o qual apresenta-se em forma farmacêutica definida, contendo um ou mais princípios ativos (fármacos) associados a excipientes farmacêuticos (KOROLKOVAS; BURCKHALTER, 2017).

Logo, infere-se que o campo de pesquisa da farmacologia abrange as propriedades terapêuticas e tóxicas, bem como os efeitos adversos relacionados ao uso dos fármacos (KATZUNG; TREVOR, 2017). Nesse sentido, este estudo objetiva condensar e descrever, de forma direta e objetiva, a partir de uma revisão narrativa da literatura, o conhecimento basilar para o entendimento da farmacologia, com ênfase na farmacocinética e farmacodinâmica.

\section{METODOLOGIA}

Trata-se de um estudo analítico exploratório, com caráter descritivo e abordagem qualitativa, sendo, portanto, uma revisão narrativa da literatura, para a qual utilizou-se de dados secundários levantados nos bancos eletrônicos como: PubMed, Medical Literature Analysis and Retrieval Sistem Online (MedLine), Scientific Electronic Library Online (Scielo) e Scholar Google.

A busca procedeu-se mediante aplicação de palavras-chave listadas nos Descritores em Ciências da Saúde (DeCS), tais como: "farmacologia", "farmacocinética" e "farmacodinâmica". Deu-se preferência para utilização de artigos de pesquisa 
científica; no entanto, também houve inclusão livros e outros materiais de interesse pedagógico, como as figuras.

\section{REVISÃO BIBLIOGRÁFICA}

Como mencionado, Katzung e Trevor (2017) consideram fármaco uma substância capaz de interagir com o organismo e, através dessa ligação, modificar suas funções. Contudo, para uma farmacoterapia eficaz, é necessário haver concentrações ótimas do fármaco no local de ação. Para que o fármaco possa chegar íntegro na região do receptor na qual ocorrerá a interação, ligar-se ao alvo e estimular uma resposta biológica, deve passar por algumas etapas: fase farmacêutica, fase farmacocinética e fase farmacodinâmica (FREDERICO et al., 2017; KOROLKOVAS; BURCKHALTER, 2017), conforme figura 1:

Figura 1 - Fases da ação dos fármacos.

FASE FARMACÊUTICA

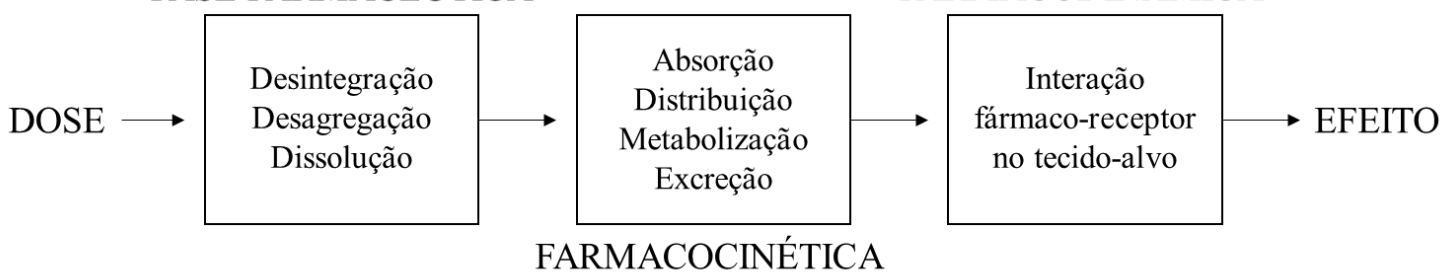

Fonte: Adaptado de KOROLKOVAS; BURCKHALTER (2017).

Na primeira fase, também denominada de fase de exposição, o medicamento administrado é submetido a etapas de desintegração, desagregação e dissolução, dependendo da forma farmacêutica, a fim de tornar o fármaco disponível para as etapas posteriores. A fase de farmacocinética remete aos processos de absorção, distribuição, metabolização e eliminação do fármaco no organismo. Por fim, a farmacodinâmica está relacionada a interação molecular do fármaco ao seu local de ação no sistema biológico, assim como a magnitude dos seus efeitos (FREDERICO et al., 2017; KATZUNG; TREVOR, 2017; KOROLKOVAS; BURCKHALTER, 2017).

\subsection{FARMACOCINÉTICA}

A farmacocinética é o ramo da farmacologia que analisa o trajeto percorrido pelo fármaco, desde a absorção até a eliminação, envolvendo ainda o transporte da molécula ao seu sítio-alvo por proteínas carreadoras e os processos que facilitam a excreção. Tais 
etapas ocorrem de forma sequenciada e simultânea, como mostra a figura 2 , permitindo uma concentração de fármaco no plasma, a qual é denominada de biodisponibilidade (FREDERICO et al., 2017).

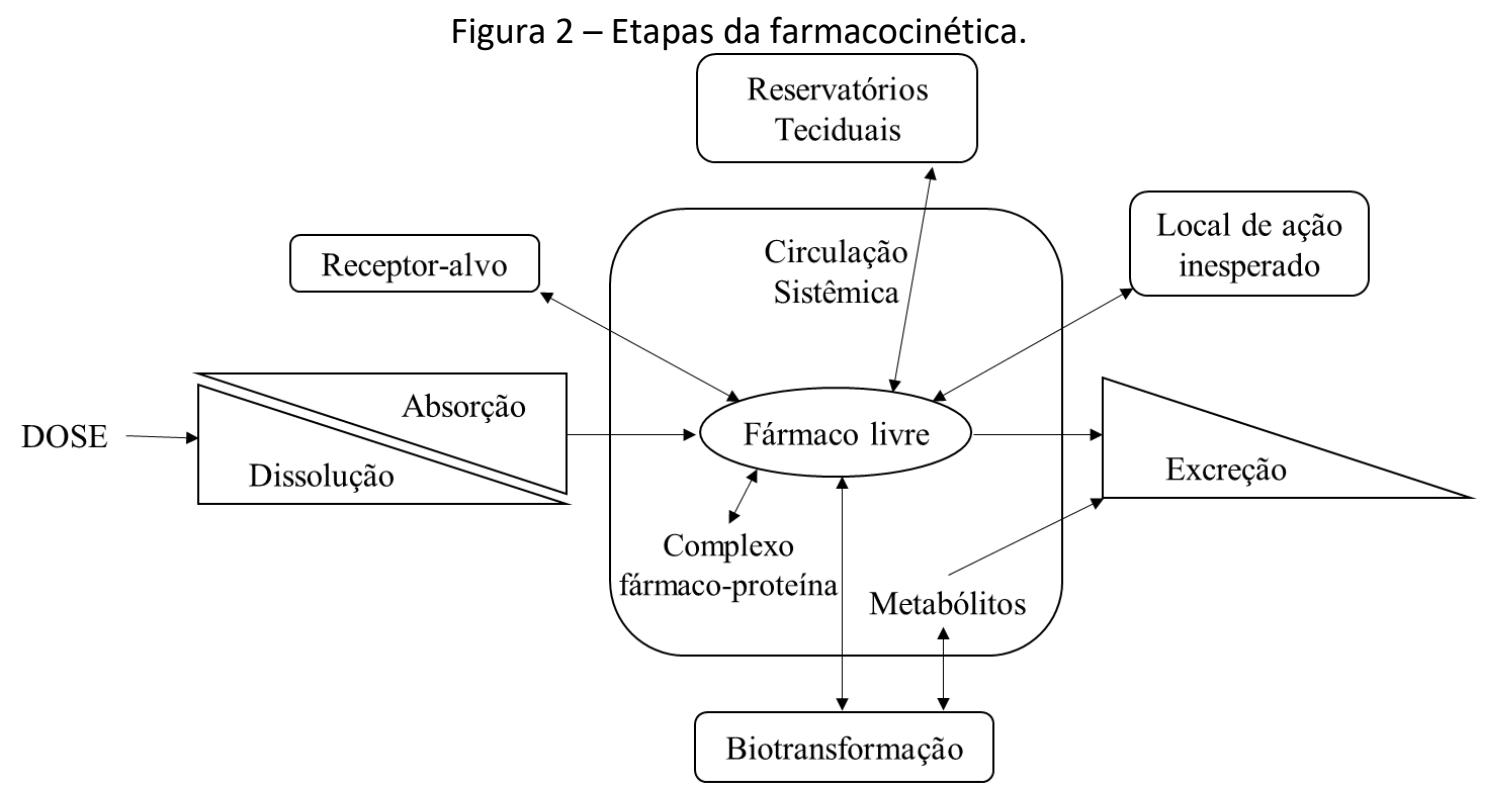

Fonte: Adaptado de GRANARA (2013).

Para que o fármaco exiba biodisponibilidade para desempenhar suas funções, alguns parâmetros farmacocinéticos são imprescindíveis no delineamento e na avaliação dos medicamentos, também conhecidas como etapas do estudo pré-clínico e clínico (KATZUNG; TREVOR, 2017). Para Frederico et al. (2017), os principais são: picoplasmático, tempo de meia-vida, área sob curva, ligação proteica, volume de distribuição e clearance.

Sabe-se que o estado fisiopatológico do indivíduo que utilizará o medicamento influencia diretamente nesses parâmetros, afetando o resultado clínico. Não obstante, as propriedades físico-químicas da molécula também interferem em todas as etapas da farmacocinética, nas quais cada uma possui peculiaridades para que o ligante possa chegar ao tecido-alvo. Sendo assim, compreende-se que um fármaco deve possuir propriedades que o beneficie nas diferentes barreiras impostas pelo organismo (FREDERICO et al., 2017).

A absorção consiste na transferência do fármaco desde seu local de administração até a corrente sanguínea, perpassando por membranas biológicas altamente lipofílicas devido a constituição de fosfolipídeos. Para atravessá-las, os fármacos devem possuir características que facilitam o tipo de transporte empregado, 
seja por difusão passiva (a favor do gradiente de concentração), difusão facilitada (transportador que não requer gasto energético) ou transporte ativo (mediado por um transportador que requer gasto energético) (KATZUNG; TREVOR, 2017).

Os fármacos ainda sofrem influência dos fatores relacionados ao local da administração $(\mathrm{pH}$, vascularização, integridade e espessura das barreiras, carreadores etc.) e das suas propriedades físico-químicas (peso molecular, solubilidade, grau de ionização, coeficiente de partição e constante de dissociação (pKa). Quando os fármacos são aplicados diretamente na circulação sistêmica (via intravenosa), não ocorre absorção (FREDERICO et al., 2017).

Para a distribuição, processo em que ocorre a translocação dos fármacos por meio do sangue para os tecidos-alvo, as propriedades físico-químicas dos fármacos também são fatores determinantes. Para circularem no organismo, as moléculas são transportadas por proteínas plasmáticas, sobretudo pela albumina, existindo em duas frações: a primeira ligada às proteínas por uma interação química, que pode ser permanente (ligação covalente) ou temporária (interação eletrostática, por exemplo), e outra livre, dispersa no plasma sanguíneo. Esta é responsável pela atividade farmacológica e/ou tóxica, como também sofre processos de metabolização e excreção facilmente (BARREIRO; FRAGA, 2014; FREDERICO et al., 2017).

Em síntese, a parte do fármaco que atinge a circulação sistêmica representa a fração que desempenhará o efeito e será a primeira a ser biotransformada e eliminada, devendo estar na sua forma ionizada para facilitar os três processos, incluindo a distribuição. Nota-se ainda que os principais índices farmacocinéticos e propriedades que condizem com a distribuição dos fármacos são: volume de distribuição, ligação às proteínas (abarcando a afinidade entre fármaco-complexo), tropismo pelos tecidos e grau de ionização (CAVALHEIRO; COMARELLA, 2016; FREDERICO et al., 2017).

Por fim, cita-se a biotransformação e eliminação dos fármacos. Esses processos são estudados em conjunto pois ambos se integram para facilitar a excreção dos xenobióticos. A biotransformação ou metabolização é feita especialmente através de reações dos complexos enzimáticos hepáticos, caracterizando o fígado como o principal órgão de metabolização, enquanto a excreção ocorre majoritariamente pelos rins, através da urina (CAVALHEIRO; COMARELLA, 2016; FREDERICO et al., 2017). 
As reações de metabolização podem ser categorizadas em fases. Na fase I ocorrem reações de redução, oxidação, hidrólise e desmetilação, ao passo que na fase II acontecem processos de síntese ou conjugação. Ambas objetivam a inativação dos fármacos, completa ou parcial, aumentando a solubilidade em água, possibilitando a filtração pelos glomérulos. Entretanto, algumas moléculas tornam-se ativas ao sofrerem biotransformação, sendo conhecidas como pró-fármacos (CAVALHEIRO; COMARELLA, 2016; KATZUNG; TREVOR, 2017).

Desse modo, denota-se que a excreção é imprescindível para a remoção dos fármacos do organismo. Alguns dos fatores determinantes para a biotransformação e eliminação são: funcionamento hepático, taxa de filtração glomerular, secreção tubular ativa e reabsorção tubular passiva, além das propriedades físico-químicas da molécula (CAVALHEIRO; COMARELLA, 2016).

\subsection{FARMACODINÂMICA}

O objetivo dessa fase é mensurar os mecanismos pelos quais as moléculas ligantes, ou fármacos, interagem com os sítios de ação no sistema biológico para resultar em efeitos bioquímicos e fisiológicos. Destina-se ainda ao entendimento do modo de ação a nível molecular, isto é, a relação entre estrutura química-atividade biológica e dose-resposta (BARREIRO; FRAGA, 2014; FREDERICO et al., 2017).

Os ligantes podem ser classificados em dois grandes grupos: agonistas e antagonistas. Considera-se agonista os fármacos que possuem atividade intrínseca, pois, ao acoplar-se com o receptor, gera alteração na conformação proteica, ativando-o. Fármacos antagonistas, por outro lado, não possuem atividade intrínseca. Seu efeito consiste basicamente em bloquear o sítio de ligação do receptor, impedindo que um agonista, por exemplo, o reconheça. Em síntese, têm-se o antagonista como barreira para a ligação fármaco agonista-receptor, sem desenvolver atividade biológica (BARREIRO; FRAGA, 2014).

Além desses, alguns outros conceitos são imprescindíveis para o entendimento das interações a nível molecular, como: (a) regiões de interação são partes dos receptores aptas para efetuar ligação com as moléculas; (b) grupos de interagem são partes da molécula que interagem com as regiões de interação; e (c) biofase é a região onde ocorre as interações intermoleculares (BARREIRO; FRAGA, 2014). 


\subsubsection{MECANISMO DE LIGAÇÃO FÁRMACO-RECEPTOR}

A atividade biológica proveniente de um estímulo dado por um fármaco é denominada de atividade ou ação farmacológica, sendo processada pela ligação dessa molécula ao substrato biológico, o qual é comumente chamado de receptor (AVER; KREUTZ; SUYENAGA, 2015; KATZUNG; TREVOR, 2017). As possibilidades de interação molecular com a biofase é dada mediante a estrutura tanto do fármaco quanto do receptor, determinando os grupos de interação que participam das ligações ou interações químicas, como: forças eletrostáticas e de dispersão, interações hidrofóbicas, ligações covalente e de hidrogênio (BARREIRO; FRAGA, 2014).

Os principais alvos de ação dos fármacos são sobre enzimas, receptores intracelulares ou transmembranas, podendo ser ionotrópicos (acoplados a canais iônicos) ou metabotrópicos (acoplados a proteína G), ácidos nucléicos e a própria membrana plasmática celular. Dependendo dessa classificação, busca-se aproximar as propriedades físico-químicas do fármaco das condições necessárias para interação, principalmente no que diz respeito à lipofilicidade e afinidade com a biofase (BARREIRO, FRAGA, 2014; KATZUNG; TREVOR, 2017).

Assim, entende-se que a efetividade terapêutica é determinada pelas propriedades físico-químicas dos fármacos, as quais dependem diretamente da estrutura molecular do composto, uma vez que modificações nesse parâmetro poderá resultar em alterações na forma como interage com a biofase, gerando mudanças na atividade biológica e, também, nos parâmetros farmacocinéticos, como na biodisponibilidade (BARREIRO; FRAGA, 2014).

Segundo Barreiro e Fraga (2014), a interação entre fármaco-receptor pode ser dividida em duas categorias: inespecíficos e específicos, de acordo com o modo pelo qual se relacionam com o organismo. No modo inespecífico, o efeito depende de doses elevadas do fármaco, por não existir uma acentuada afinidade. Assim, quanto maior a biodisponibilidade, mais chance terá de ligar-se ao receptor desejado. Em contrapartida, no modo específico o efeito biológico se dá pela interação seletiva com o sítio-alvo (KATZUNG; TREVOR, 2017).

Além disso, Barreiro e Fraga (2014) complementam que as características dos grupos funcionais da molécula, bem como suas propriedades estruturais, influenciam 
diretamente no reconhecimento molecular do fármaco pelo receptor, devendo haver uma complementariedade entre as regiões de interação e os grupos de interagem que é dependente da disposição espacial.

Em suma, para uma interação de modo específico, considera-se o arranjo tridimensional do fármaco e sua afinidade pelo receptor, reconhecendo, quase que unicamente, o sítio-alvo destinado, corroborando para a diminuição das RAM (BARREIRO; FRAGA, 2014; KATZUNG; TREVOR, 2017).

Contudo, algumas moléculas podem apresentar similaridades em suas estruturas, grau de toxicidade e efeito farmacológico. Isso se deve ao grupamento farmacofórico, ou seja, a parte da molécula responsável pelo estímulo da atividade terapêutica, sendo, assim, de grande relevância para o estudo da farmacodinâmica. Já as cadeias laterais, nomeadas de ramificações, dão as características farmacocinéticas da molécula (AVER; KREUTZ; SUYENAGA, 2015; KOROLKOVAS; BURCKHALTER, 2017).

O processo de reconhecimento molecular entre o fármaco-receptor é comumente representado pelo modelo proposto por Emil Fischer, denominado chavefechadura, na qual o fármaco apresenta-se complementar ao seu sítio receptor, assim como uma chave é para uma fechadura. Contudo, em condições biológicas, o acoplamento não é rígido, havendo uma flexibilidade e acomodamento conformacional recíproca, tanto da molécula quanto do seu sítio-alvo, facilitando o encaixe. Tal hipótese recebe o nome de teoria do encaixe induzido (BARREIRO; FRAGA, 2014), representada pela figura 3:

Figura 3 - Representação da teoria do encaixa induzido e do modelo chave-fechadura.

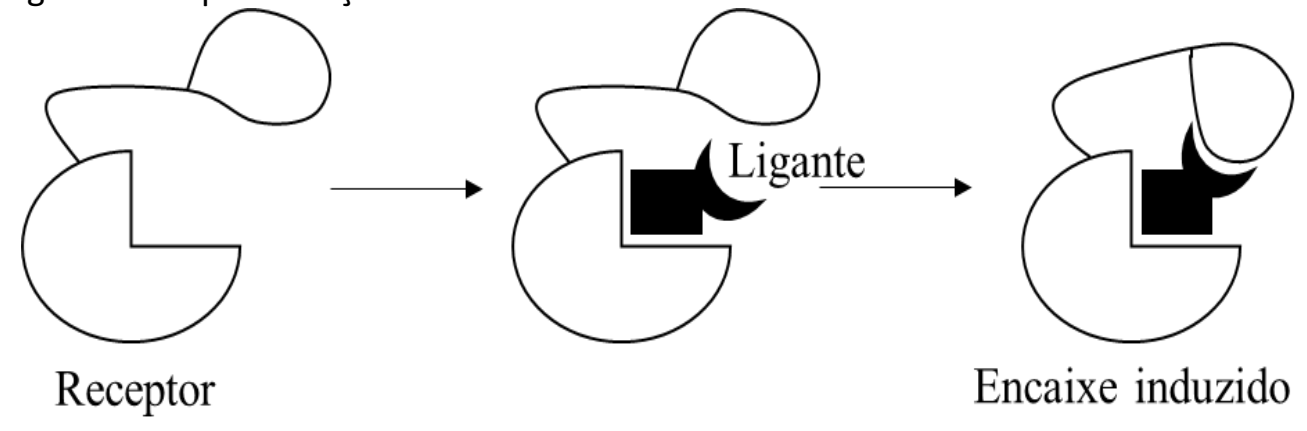

Fonte: Adaptado de KOSHLAND; NEMÉTHY; FILMER (1966).

A maneira pela qual as moléculas interagem nos receptores biológicos determinam a diferenciação em seu reconhecimento, individualizando-as. Assim, a 
flexibilidade e o acomodamento conformacional recíproco supra descrito exprime-se nas diferentes atividades farmacológicas dos diversos ligantes, sobretudo nos compostos que apresentam variação no arranjo tridimensional, posto que essa propriedade influencia na disposição da molécula na biofase; logo, não apresentarão a mesma quantidade de interações (SANTOS, 2012).

No entanto, as alterações estruturais moleculares não ocorrem apenas nos fármacos, atingindo, inclusive, os receptores biológicos. Como prova de que o estereoisomerismo está presente nos organismos vivos tem-se que, dos 20 aminoácidos identificados na natureza, apenas a glicina não possui um centro de quiralidade. Isso confere às macroestruturas formadas por essas unidades estruturais, como as proteínas, a propriedade da estereosseletividade (SIMONETTI; BATISTA; FERREIRA, 1998; SANTOS, 2012; MITRA; CHOPRA, 2011).

Devido a conformação organizacional espacial das moléculas que constituem os sistemas biológicos, vários receptores, enzimas, canais, transportadores, carreadores, dentre outras componentes envolvidos direta ou indiretamente nos mecanismos de ação ou nas etapas da farmacocinética podem possuir divergências de afinidade e interação com as demais moléculas, sejam elas endógenas ou exógenas. Portanto, o efeito biológico a ser alcanço varia de acordo com a estrutura tridimensional, tanto do receptor como do seu ligante (SIMONETTI; BATISTA; FERREIRA, 1998).

A interferência do estereoisomerismo nas estruturas biológicas não afetam somente a diferenciação entre os fármacos enantioméricos, uma vez que haverá variação no posicionamento dos grupos dos fármacos que interagem com as zonas de interação da macromolécula, resultando no não acoplamento, total ou parcial, da molécula, mas também nas suas funções orgânicas, divergindo os substratos (SIMONETTI; BATISTA; FERREIRA, 1998; SANTOS, 2012).

Corroborando com esses dados, Simonetti, Batista e Ferreira (1998) trazem que o reconhecimento entre a molécula opticamente ativa e o receptor que também apresenta quiralidade é procedido de acordo com as posições tridimensionais das regiões responsáveis pela afinidade química. Assim, depreende-se que todas as interações envolvidas no reconhecimento do ligante pelo receptor anteriormente descritas são afetadas pela disposição molecular espacial, justificando as diferentes formas de interagir com o sistema biológico (SANTOS, 2012). 


\section{CONSIDERAÇÕES FINAIS}

A farmacologia é uma área abrangente, sendo constantemente empregada por profissionais da área da saúde e de pesquisadores de modo geral em sua rotina de trabalho. Assim, mostra-se que conhecimento de farmacologia é imprescindível para garantir aos pacientes uma racionalização terapêutica. Contudo, a complexidade e densidade da matéria em questão nos faz esquecer alguns dos conceitos primordiais.

Além disso, é fundamental ressaltar que a elaboração de um material como este cumpre um papel essencial na formação acadêmica e profissional, pois auxilia na preparação e na estruturação de conhecimentos científicos acerca da temática, como também contribui com a correta disseminação de definições e informações técnicas, como também na facilidade de acesso.

Por outro lado, a síntese pode, às vezes, prejudicar a percepção da importância do aprofundamento no assunto pelos estudantes e profissionais. Dessa forma, não podemos esquecer que entender e conhecer este assunto é de suma relevância para assegurar o bem-estar relacionado ao uso de medicamentos pelo usuário e pela sociedade.

\section{REFERÊNCIAS}

AVER, G. M.; KREUTZ, O. C.; SUYENAGA, E. S. Métodos de obtenção de fármacos sob a óptica da química medicinal. Revista Conhecimento Online, v. 2, n. 7, p. 63-73, 2015.

BARREIRO, E. J.; FRAGA, C. A. M. Química Medicinal: As bases moleculares da ação dos fármacos. Porto Alegre: Artmed Editora, 2014.

CAVALHEIRO, A. H.; COMARELLA, L. Farmacocinética: modelos e conceitos: uma revisão de literatura. Revista Saúde e Desenvolvimento, v. 10, n. 5, p. 73-84, 2016.

FEDERICO, M. P. et al. Noções sobre parâmetros farmacocinéticos/farmacodinâmicos e sua utilização na prática médica. Revista da Sociedade Brasileira de Clínica Médica, v. 15, n. 3, p. 201-205, 2017

KATZUNG, B. G.; TREVOR, A. J. Farmacologia Básica e Clínica. Artmed, 13 ed. Porto Alegre, 2017.

KOROLKOVAS, A.; BURCKHALTER, J. H. Química Farmacêutica. Guanabara Koogan. Rio de Janeiro, 2017. 
MITRA, S.; CHOPRA, P. Quiralidade e medicamentos anestésicos: Uma revisão e uma atualização. Revista indiana de anestesia, v. 55, n. 6, p. 556, 2011.

SANTOS, M. B. Revisão sobre fármacos quirais e a sua importância na medicina atual. 2012. Trabalho de Conclusão de Curso (Licenciatura em Química) - Faculdade de Ciências, Universidade Estadual Paulista, São Paulo, 2012.

SIMONETTI, M. P. B.; BATISTA, R. A.; FERREIRA, F. M. C. Estereoisomeria: a interface da tecnologia industrial de medicamentos e da racionalização terapêutica. Rev Bras Anestesiol, v. 48, n. 5, p. 390-399, 1998. 


\title{
CAPITULO XIX
}

\section{REVISÃO DA LITERATURA SOBRE O CORANTE AMARELO DE TARTRAZINA E SEUS EFEITOS À SAÚDE}

DOI: 10.51859/AMPLLA.PAE1993-19

Heyder Pamplona da Silva ${ }^{1}$

Gustavo Júlio Santos Fróes ${ }^{1}$

Marlia Barbosa Pires ${ }^{2}$

Gleicy Kelly China Quemel ${ }^{3}$

\begin{abstract}
'Graduados do Curso de Bacharelado em Farmácia da Escola Superior da Amazônia (ESAMAZ), Belém-PA, Brasil
2 Doutora em Ciências e Tecnologia de Alimentos e Docente da Escola Superior da Amazônia (ESAMAZ), Curso de Nutrição, Belém PA, Brasil.

${ }^{3}$ Mestre em Ciências Ambientais e Docente da Escola Superior da Amazônia (ESAMAZ), Curso de Farmácia, Belém PA, Brasil.
\end{abstract}

\section{RESUMO}

Ao longo de décadas o ser humano tem passado por inúmeras mudanças em seus costumes dentre elas, a alimentação uma vez que passaram a optar por alimentos mais práticos, rápidos, industrializados e com a presença de aditivos. Entretanto, o potencial aumento do uso de aditivos químicos nas indústrias tem sido motivo de estudos científicos devidos os possíveis efeitos adversos à saúde incluindo algumas doenças, como o câncer. O presente trabalho tem por objetivo analisar, com base na literatura, os possíveis efeitos do corante tartrazina à saúde. Foi realizada uma revisão integrativa com apoio da análise documental de Bardin, a busca pelas literaturas foram na biblioteca do SCIELO, na base de dados MEDLINE e LILACS, e repositórios de instituição de ensino superior, utilizando os seguintes descritores, contidos nos DECs: [Aditivos alimentares/Food Additives/Aditivos alimentarios], [Corantes de alimentos/Food Coloring Agentes/Tintes alimentarios], [legislação/legislation/legislación], [tartrazina/tartrazine]. Os critérios utilizados foram: literaturas completas disponíveis no idioma inglês e português, e publicados no período de 2011 a 2021; e exclusas literaturas pagas e duplicadas. Foram selecionadas 26 literaturas, que destacaram o uso desse corante nas indústrias alimentícia e farmacêutica, que apresenta efeitos adversos, quando ingerido em grandes quantidades e potencial genototóxico. Portanto, os efeitos causados por esse corante são preocupantes e são necessários estudos cada vez mais aprofundados para obtenção de informações, para que possam ser compartilhadas e tomadas as medidas de intervenção pelos órgãos competentes na área da saúde.

Palavras-chave: Aditivos; Corante; Legislação; Tartrazina. 


\section{INTRODUÇÃO}

As cores seduzem os seres humanos há milhares de anos, na pré-história, os pigmentos foram utilizados, por exemplo, nas pinturas rupestres. Nos tempos antigos, vários tecidos achados em múmias eram coloridos. Na Idade Moderna, no ápice das monarquias e no período do descobrimento do Brasil, houve a era do pau-brasil, árvore da qual se retirava um pigmento com a capacidade de tingir tecidos com cores fortes e atualmente são utilizados os aditivos corantes (FERREIRA et al., 2018).

Os corantes alimentícios são aditivos com características de prover ou destacar a coloração de alimentos e bebidas. Esses corantes são usados pela indústria alimentícia com a função de restaurar a coloração dos alimentos, que pode ser perdida por meio do seu processamento ou armazenamento e na diminuição na mudança de cor entre lotes. Logo, adicionar cores aos alimentos tornando-os mais atrativos para os consumidores (DURIGON, 2020).

Essencialmente os corantes de fonte natural descendem de plantas ou animais/insetos, ou então são produzidos durante o processamento, de maneira que as plantas são fontes primordiais. Os principais grupos de corantes naturais são compostos pelas antocianinas, carotenóides e clorofilas, além das betaninas e das curcuminas possuem uma contribuição mais modesta (BENINCÁ, 2012), e artificial, obtida pelo processo de síntese, como exemplo: Amaranto (E123), Negro Brilhante (E-151), Verde Rápido (E143), Amarelo de Tartrazina (E102), entre outros (HAMERSKI; REZENDE; SILVA, 2013; DALPONTE, 2015).

O corante amarelo de tartrazina, denominado também como FD\&C tartrazine yellow № 5 é um aditivo alimentar que estabelece a cor amarelo-limão em alimentos (FLORIANO et al., 2020). Sintetizado a partir da tinta de alcatrão possui utilização diversificada, devido suas características físico-químicas como: boa estabilidade à luz, temperatura e $\mathrm{pH}$, superior a dos demais corantes, incluindo excelente custo benefício, boa solubilidade em água, tendo consumo máximo diário permitido de 7,5 mg.kg-1 (OLIVEIRA, 2019; MONTEIRO, 2020).

Entretanto, os corantes sintéticos podem ser rotulados como poluentes emergentes, esta classificação abrange as substâncias que são achadas no meio ambiente, porém ainda não estão incluídas em programas de monitoramentos ou 
legislação relevante a qualidade ambiental (BARBOZA et al., 2019). Segundo Pazzoti (2013), os corantes são substâncias prejudiciais à saúde escondidas dentro dos alimentos, pois podem provocar hiperatividade em crianças, crises asmáticas e eczemas.

Portanto, o objetivo do trabalho foi identificar nas literaturas disponíveis a utilização do corante alimentício amarelo de tartrazina e seus prováveis efeitos à saúde, bem como descrever os principais alimentos e medicamentos que contém o corante amarelo de tartrazina e analisar a contribuição do Farmacêutico no contexto corante alimentício.

\section{METODOLOGIA}

A metodologia utilizada para a realização da pesquisa foi a Revisão Integrativa da literatura (RIL), que propicia a síntese do estado do conhecimento de um tema, possibilitando a verificação de eventuais falhas e suas correções por meio de outros estudos (MENDES, SILVEIRA, GALVÃO 2008), cuja pergunta escolhida foi: “Quais os efeitos do corante amarelo de tartrazina à saúde?"

A seleção das literaturas foi conduzida na Biblioteca do SCIELO (Scientific Eletronic Library Online), MEDLINE (Medical Literature Analysis and Retrieval System Online), LILACS (Literatura Latino-americana e do Caribe em Ciências da Saúde) e repositório de ensino superior. Os descritores, contidos nos Descritores em Ciências da Saúde (DECs), utilizados na pesquisa foram: [Aditivos alimentares/ Food Additives/ Aditivos alimentarios], [Corantes de alimentos/ Food Coloring Agentes/ Tintes alimentarios], [legislação/legislation/ legislación], [tartrazina/tartrazine], combinados ou não com o operador booleano "And".

Os critérios de inclusão utilizados foram: literaturas completas, disponíveis nos idiomas portugueses, Inglês e/ou Espanhol, e publicado no período de 2012 e 2021, sendo excluídas literaturas duplicadas, não integralmente disponíveis e pagas.

A análise crítica dos estudos selecionados foi realizada segundo Bardin (2011), que é um tipo de análise interpretativa de documentos de diferentes aspectos, abrangendo técnicas de organização e sistematização de unidades textuais para a evidenciação de núcleos e sentido, por exemplo: temas, conceitos e significados. Esta análise apresenta três passos: pré-análise, exploração do material e tratamento e interpretação dos resultados. 
Na pré-análise foram utilizados cinco filtros para a coleta das literaturas, sendo que estes filtros estão relacionados com os critérios de inclusão e exclusão. Na exploração do material foram criadas as categorias de discussão: 1 - principais alimentos e medicamentos que contém a de tartrazina; 2 - toxicidade desse corante; 3 - efeitos adversos; e 4 - papel do farmacêutico no contexto dos aditivos alimentares, em especial ao corante amarelo de tartrazina. E no tratamento dos resultados foram apresentados os estudos selecionados e a explanação das categorias de discussão.

\section{RESULTADOS E DISCUSSÃO}

Foram selecionados 26 estudos para a pesquisa dos quais os Repositórios em instituição de ensino superior com quantitativo correspondendo a $38 \%$ (10), seguido da biblioteca virtual do SCIELO com 31\% (08), a base de dados MEDLINE com 19\% (05) e a base de dados LILACSapresentando $12 \%$ (03 artigos).

Do total de artigos analisados 61\% (16 artigos) correspondem ao idioma português, $31 \%$ (08) em inglês e $8 \%$ (02) em espanhol. Quanto às abordagens metodológicas 54\% (14) são pesquisas bibliográficas e 46\% (12) de análise experimental. Dos 26 artigos selecionados, 16\% (04) informam sobre a tartrazina, 19\% (05) abordam sobre a Tartrazina nos medicamentos, $8 \%$ (02) discorrem sobre a tartrazina nos alimentos, 23\% (06 artigos) discutem a toxicidade da tartrazina,19\% (05) falam sobre a genotoxicidade da tartrazina e $15 \%$ (04) relatam a contribuição farmacêutica.

As literaturas selecionadas para essa revisão estão dispostas no Quadro 1, que apresenta Título/Autor/Ano, Objetivo, Metodologia e Conclusão das literaturas selecionadas

Quadro 1 - Distribuição das referências incluídas na revisão integrativa

\begin{tabular}{|c|c|c|c|c|}
\hline $\mathbf{N}^{\circ}$ & Título/ Autor/Ano & Objetivo & Metodologia & Conclusão \\
\hline 01 & $\begin{array}{l}\text { Avaliação da } \\
\text { mutagenicidade do } \\
\text { corante tartrazina em } \\
\text { cultura de leucócitos } \\
\text { Humanos. } \\
\text { FLORIANO et al. (2020) }\end{array}$ & $\begin{array}{lr}\text { Avaliação } & \text { da } \\
\text { mutagenicidade } & \\
\text { do corante } & \\
\text { tartrazina } \quad \text { em } \\
\text { cultura } \quad \text { de } \\
\text { leucócitos } \\
\text { Humanos. }\end{array}$ & $\begin{array}{lr}\text { Análise } & \text { de } \\
\text { mutagenicidade por } & \text { meio de testes de } \\
\text { micronúcleo } & \text { em } \\
\text { leucócitos humanos. }\end{array}$ & $\begin{array}{l}\text { Há necessidade de } \\
\text { verificar a } \\
\text { concentração que } \\
\text { possa iniciar o } \\
\text { processo de lesão, } \\
\text { como o mutagênico. } \\
\text { Adicionalmente, há } \\
\text { necessidade de } \\
\text { confirmação dos } \\
\text { resultados obtidos } \\
\text { com outros testes de } \\
\text { avaliação de } \\
\text { mutagenicidade. }\end{array}$ \\
\hline
\end{tabular}




\begin{tabular}{|c|c|c|c|c|}
\hline $\mathbf{N}^{\circ}$ & Título/ Autor/Ano & Objetivo & Metodologia & Conclusão \\
\hline 02 & $\begin{array}{l}\text { Estudo comparativo } \\
\text { entre } \mathrm{BiFeO}_{3} \text { e } \mathrm{Bi}_{2} \mathrm{Fe}_{4} \mathrm{O}_{9} \\
\text { no processo de } \\
\text { fotocatálise } \\
\text { heterogênea. } \\
\text { MONTEIRO (2020) }\end{array}$ & 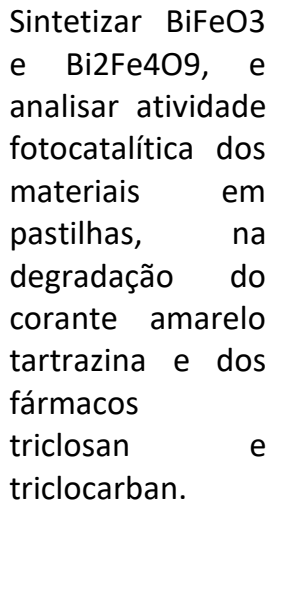 & $\begin{array}{lr}\text { Os testes } & \text { de } \\
\text { caracterização, } & \\
\text { degradação, } & \text { de } \\
\text { fitotoxicidade } & \text { e } \\
\text { ecotoxicidade } & \text { nas } \\
\text { soluções antes e } & \text { após } \\
\text { tratamentos } & \\
\text { fotoquímicos } & \\
\text { relacionados } & \text { de } \\
\text { materiais BiFeO3 } & \text { e } \\
\text { Bi2Fe4O9. } & \end{array}$ & $\begin{array}{l}\text { Com os dados } \\
\text { obtidos, foi possível } \\
\text { conseguir tal fato, } \\
\text { logo se conclui então, } \\
\text { que o material } \\
\text { Bi2Fe4O9 sintetizado } \\
\text { pelo método de } \\
\text { Pechini foi o melhor } \\
\text { fotocatalisador } \\
\text { dentre os materiais, } \\
\text { se mostrando } \\
\text { eficiente para uma } \\
\text { futura aplicação } \\
\text { industrial. }\end{array}$ \\
\hline 03 & $\begin{array}{l}\text { Atenção farmacêutica } \\
\text { nas intoxicações por } \\
\text { agrotóxicos: revisão } \\
\text { SILVA (2020) }\end{array}$ & 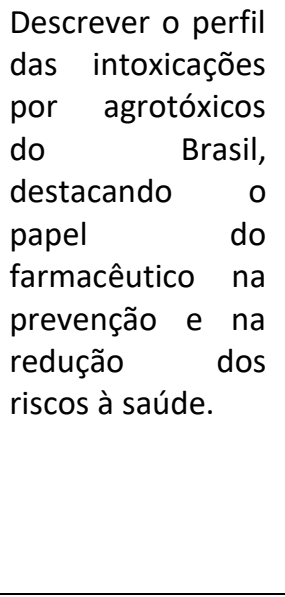 & $\begin{array}{l}\text { Pesquisa bibliográfica } \\
\text { descritiva sobre o perfil } \\
\text { das intoxicações por } \\
\text { agrotóxicos do Brasil. }\end{array}$ & $\begin{array}{l}\text { Necessidade de } \\
\text { intensificar estudos } \\
\text { dessa natureza, a fim } \\
\text { de aprofundar o } \\
\text { conhecimento dessa } \\
\text { temática e subsidiar } \\
\text { as ações preventivas } \\
\text { educativas e de } \\
\text { tratamento, com o } \\
\text { intuito de reduzir esse } \\
\text { quadro agravou no } \\
\text { Brasil, e garantir } \\
\text { maior qualidade de } \\
\text { vida à população. }\end{array}$ \\
\hline 04 & $\begin{array}{l}\text { High-Dose } \\
\text { Reverses Tartrazine- } \\
\text { Induced Cell Growth } \\
\text { Dysregulation } \\
\text { Independent of p53 } \\
\text { Signaling } \\
\text { Antioxidant } \\
\text { Mechanisms in Rat } \\
\text { Brain. } \\
\text { ALSALMAN et al.(2019) }\end{array}$ & $\begin{array}{lr}\text { Investigar } & \text { a } \\
\text { toxicidade } & \text { da } \\
\text { tartrazina } & \text { em } \\
\text { cérebro de } & \text { rato } \\
\text { com aspirina } & \text { em } \\
\text { altas doses. } & \end{array}$ & $\begin{array}{l}\text { Pesquisa Experimental } \\
\text { sobre a toxicidade da } \\
\text { tartrazina associada à } \\
\text { aspirina em cérebro de } \\
\text { ratos. }\end{array}$ & $\begin{array}{l}\text { Esses resultados } \\
\text { indicam que a } \\
\text { aspirina protege o } \\
\text { cérebro da toxicidade } \\
\text { induzida pela } \\
\text { tartrazina, } \\
\text { independentemente } \\
\text { da sinalização de p53 } \\
\text { e dos mecanismos } \\
\text { antioxidantes. }\end{array}$ \\
\hline 05 & $\begin{array}{l}\text { Embryotoxic and } \\
\text { Teratogenic Effects of } \\
\text { Tartrazine in Rats. } \\
\text { HASHEM et al.(2019) }\end{array}$ & 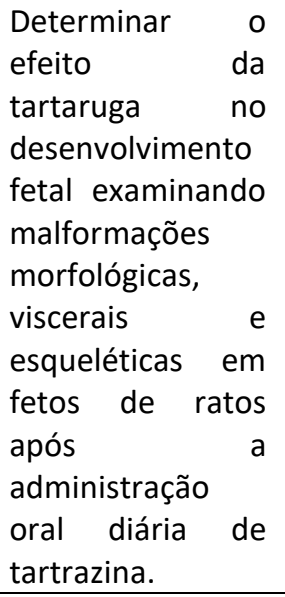 & $\begin{array}{l}\text { Análise dos efeitos na } \\
\text { formação do feto de } \\
\text { ratos ao consumo diário } \\
\text { da tartrazina. }\end{array}$ & $\begin{array}{lr}\text { Concluímos } & \text { que a } \\
\text { Tartrazina } & \text { tem } \\
\text { potencial } & \\
\text { embriotóxico } & \text { e } \\
\text { teratogênico } & \text { em } \\
\text { ratos. } & \end{array}$ \\
\hline 06 & $\begin{array}{lr}\text { Quantificação } & \text { do } \\
\text { corante } & \text { amarelo } \\
\text { tartrazina em } & \end{array}$ & $\begin{array}{l}\text { Verificar quais } \\
\text { produtos voltados } \\
\text { para o público } \\
\text { infantil contém na }\end{array}$ & $\begin{array}{l}\text { Pesquisa bibliográfica } \\
\text { sobre alimentos infantis } \\
\text { que contém o corante } \\
\text { tartrazina. }\end{array}$ & $\begin{array}{l}\text { Os aditivos assumem } \\
\text { papel importante na } \\
\text { produção de } \\
\text { alimentos. Entretanto }\end{array}$ \\
\hline
\end{tabular}




\begin{tabular}{|c|c|c|c|c|}
\hline $\mathbf{N}^{\circ}$ & Título/ Autor/Ano & Objetivo & Metodologia & Conclusão \\
\hline & $\begin{array}{l}\text { Alimentos destinados ao } \\
\text { público infantil. } \\
\text { OLIVEIRA (2019) }\end{array}$ & $\begin{array}{l}\text { sua formulação o } \\
\text { corante amarelo } \\
\text { tartrazina. }\end{array}$ & & 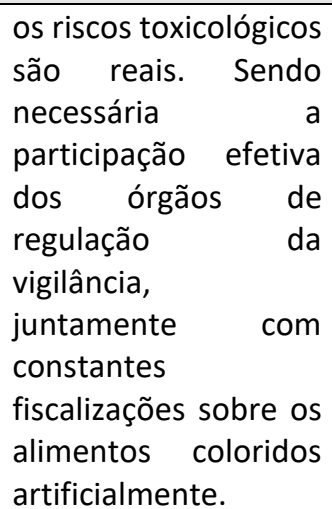 \\
\hline 07 & $\begin{array}{l}\text { Reacciones de } \\
\text { hipersensibilidad a } \\
\text { aditivos alimentarios. } \\
\text { SÁMANO et al.(2019) }\end{array}$ & $\begin{array}{l}\text { Avaliar as reações } \\
\text { de } \\
\text { hipersensibilidade } \\
\text { a aditivos } \\
\text { alimentares }\end{array}$ & $\begin{array}{l}\text { Pesquisa bibliográfica } \\
\text { sobre Análise das } \\
\text { reações de } \\
\text { hipersensibilidade dos } \\
\text { corantes alimentares. }\end{array}$ & $\begin{array}{l}\text { O diagnóstico é } \\
\text { baseado na suspeita } \\
\text { clínica adequada e na } \\
\text { correlação de um } \\
\text { fenômeno causal com } \\
\text { o aditivo alimentar, } \\
\text { sendo o desafio } \\
\text { alimentar o padrão- } \\
\text { ouro do } \\
\text { diagnóstico. O } \\
\text { tratamento } \\
\text { baseado na exclusão } \\
\text { completa do aditivo } \\
\text { alimentar e na correta } \\
\text { educação do paciente } \\
\text { para identificar os } \\
\text { sintomas de uma } \\
\text { reação de } \\
\text { hipersensibilidade e } \\
\text { as possíveis fontes do } \\
\text { aditivo em questão. }\end{array}$ \\
\hline 08 & $\begin{array}{l}\text { Protective effect of } \\
\text { crocin on food azo dye } \\
\text { tartrazine-induced } \\
\text { hepatic damage by } \\
\text { improving biochemical } \\
\text { parameters and } \\
\text { oxidative stress } \\
\text { biomarkers in rats. } \\
\text { VELIOGLU et al.(2019) }\end{array}$ & $\begin{array}{l}\text { Demonstrar o } \\
\text { efeito protetor da } \\
\text { crocina sobre os } \\
\text { efeitos adversos } \\
\text { da tartrazina no } \\
\text { fígado. }\end{array}$ & $\begin{array}{l}\text { Pesquisa bibliográfica } \\
\text { sobre o efeito da } \\
\text { crocina no combate aos } \\
\text { efeitos da tartrazina. }\end{array}$ & $\begin{array}{l}\text { O estudo demonstrou } \\
\text { que o dano hepático } \\
\text { de rato induzido por } \\
\text { tartrazina foi devido a } \\
\text { estresse oxidativo, e } \\
\text { esse dano foi } \\
\text { eliminado pelo } \\
\text { tratamento com } \\
\text { crocina com base nos } \\
\text { achados bioquímicos } \\
\text { e histológicos. Assim, } \\
\text { é necessário } \\
\text { conscientizar or o } \\
\text { consumidor sobre os } \\
\text { aspectos adversos } \\
\text { efeitos desses } \\
\text { corantes azo. }\end{array}$ \\
\hline 09 & $\begin{array}{l}\text { Is tartrazine really safe? } \\
\text { In silico and ex vivo } \\
\text { toxicological studies in } \\
\text { human leukocytes: a } \\
\text { question of dose. }\end{array}$ & $\begin{array}{ll}\text { Avaliar } & \text { a } \\
\text { citotoxicidade e } & \text { e } \\
\text { genotoxicidade } \\
\text { do corante TRZ } \\
\text { em culturas de } \\
\text { leucócitos } \\
\end{array}$ & $\begin{array}{lr}\text { Pesquisa bibliográfica } \\
\text { para avaliar a } \\
\text { citotoxicidade } & \text { e } \\
\text { genotoxicidade } & \text { do } \\
\text { corante tartrazina em }\end{array}$ & 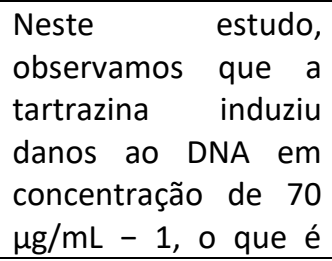 \\
\hline
\end{tabular}




\begin{tabular}{|c|c|c|c|c|}
\hline $\mathbf{N}^{\circ}$ & Título/ Autor/Ano & Objetivo & Metodologia & Conclusão \\
\hline & FLORIANO et al. (2018) & $\begin{array}{lr}\text { humanos } & \text { e } \\
\text { realizar estudos } \\
\text { teóricos para } \\
\text { predizer rua } \\
\text { toxicidade in } \\
\text { silico. }\end{array}$ & $\begin{array}{l}\text { culturas de leucócitos } \\
\text { humanos. }\end{array}$ & $\begin{array}{l}\text { perfeitamente } \\
\text { plausível de ser } \\
\text { alcançado na } \\
\text { corrente sanguínea } \\
\text { pelo consumo de } \\
\text { diferentes produtos } \\
\text { que o contêm. Além } \\
\text { disso, o teste in silico } \\
\text { corrobora com o teste } \\
\text { ex vivo em relação ao } \\
\text { potencial } \\
\text { capacidade } \\
\text { genotóxica } \\
\text { corante. do }\end{array}$ \\
\hline 10 & $\begin{array}{l}\text { Regulamentação de } \\
\text { bulas: cenário atual dos } \\
\text { medicamentos } \\
\text { antirretrovirais } \\
\text { Brasil. } \\
\text { NASCIMENTO (2018) }\end{array}$ & $\begin{array}{l}\text { Avaliar a } \\
\text { adequação das } \\
\text { bulas da classe de } \\
\text { medicamentos } \\
\text { antirretrovirais à } \\
\text { legislação vigente } \\
\text { e a inteligibilidade } \\
\text { das mesmas pelos } \\
\text { usuários. }\end{array}$ & $\begin{array}{l}\text { Pesquisa bibliográfica } \\
\text { analisou a adequação } \\
\text { das bulas da classe de } \\
\text { medicamentos } \\
\text { antirretrovirais à } \\
\text { legislação vigente e a } \\
\text { inteligibilidade das } \\
\text { mesmas pelos usuários. }\end{array}$ & $\begin{array}{l}\text { É necessário que o } \\
\text { Brasil tenha uma } \\
\text { regulamentação mais } \\
\text { robusta para que as } \\
\text { empresas } \\
\text { farmacêuticas } \\
\text { elaborem bulas de } \\
\text { medicamentos com } \\
\text { mais qualidade e que } \\
\text { a ANVISA fiscalize } \\
\text { com mais rigor as } \\
\text { bulas dos } \\
\text { medicamentos } \\
\text { criadas pela indústria } \\
\text { farmacêutica }\end{array}$ \\
\hline 11 & $\begin{array}{l}\text { Corantes Azos: } \\
\text { características gerais, } \\
\text { aplicações e toxicidade. } \\
\text { CÂMARA (2017) }\end{array}$ & $\begin{array}{lr}\text { Apresentar } & \text { as } \\
\text { características } & \\
\text { gerais, } & \\
\text { propriedades } & \\
\text { químicas, } & \\
\text { aplicações } & \text { e } \\
\text { toxicologia } & \text { dos } \\
\text { corantes } & \\
\text { alimentícios } & \text { da } \\
\text { classe } & \text { azo } \\
\text { permitidos } & \text { no } \\
\text { Brasil. } & \end{array}$ & $\begin{array}{l}\text { Pesquisa bibliográfica } \\
\text { sobre as características } \\
\text { gerais, propriedades } \\
\text { químicas, aplicações e } \\
\text { toxicologia dos corantes } \\
\text { alimentícios da classe } \\
\text { azo permitidos no } \\
\text { Brasil. }\end{array}$ & $\begin{array}{lr}\text { Estudo de efeitos } \\
\text { fisiológicos negativos } \\
\text { provenientes do } \\
\text { consumo dessas } \\
\text { substâncias, assim } \\
\text { fica clara } \\
\text { necessidade a } \\
\text { investimento de } \\
\text { estudos toxicológicos } \\
\text { e de uma } \\
\text { regulamentação mais } \\
\text { rigorosa, além de uma } \\
\text { reavaliação ro da } \\
\text { permissividade do } \\
\text { uso de algumas } \\
\text { dessas substâncias, } \\
\text { seguindo o exemplo } \\
\text { de outros países. }\end{array}$ \\
\hline
\end{tabular}




\begin{tabular}{|c|c|c|c|c|}
\hline $\mathbf{N}^{\circ}$ & Título/ Autor/Ano & Objetivo & Metodologia & Conclusão \\
\hline 12 & $\begin{array}{l}\text { Síntese e caracterização } \\
\text { de polímero } \\
\text { molecularmente } \\
\text { impresso para } \\
\text { determinação do } \\
\text { corante tartrazina } \\
\text { visando } \\
\text { desenvolvimento e } \\
\text { aplicação de novos } \\
\text { sensores biomiméticos } \\
\text { com transdução óptica. } \\
\text { CHIMELLO (2017) }\end{array}$ & $\begin{array}{lr}\text { Este } & \text { trabalho } \\
\text { visou } & \text { o } \\
\text { desenvolvimento } \\
\text { de um sensor } \\
\text { óptico para } \\
\text { determinação do } \\
\text { corante } \\
\text { Tartrazina } \\
\text { amostras } & \text { em } \\
\text { alimentos. } & \text { de }\end{array}$ & $\begin{array}{l}\text { Pesquisa Experimental } \\
\text { para explorar duas } \\
\text { diferentes sínteses de } \\
\text { polímeros impressos } \\
\text { para o corante } \\
\text { alimentício Tartrazina: } \\
\text { pelo método em bulk e } \\
\text { por precipitação. }\end{array}$ & 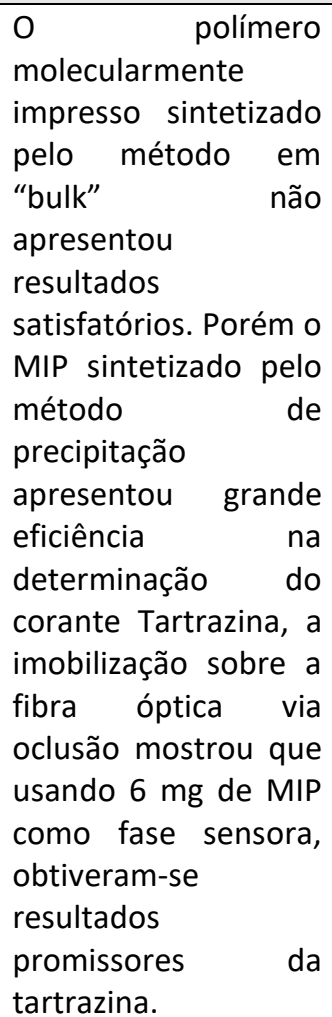 \\
\hline 1 & $\begin{array}{l}\begin{array}{l}\text { Curcumin } \\
\text { against } \\
\text { mediated } \\
\text { stress } \\
\text { tartrazine- } \\
\text { oxidative }\end{array} \\
\begin{array}{l}\text { and } \\
\text { rats. }\end{array} \\
\text { EL-DESOKY et al.(2017) }\end{array}$ & 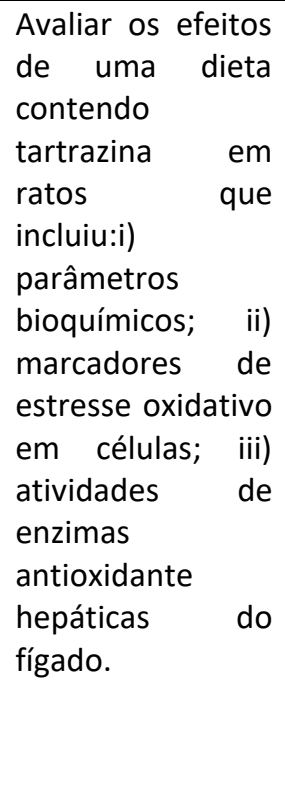 & $\begin{array}{l}\text { Pesquisa Experimental } \\
\text { para analisar os efeitos } \\
\text { da dieta contendo } \\
\text { tartrazina em ratos. }\end{array}$ & $\begin{array}{l}\text { A mistura de alguns } \\
\text { aditivos alimentares } \\
\text { naturais, como CUR } \\
\text { com dietas contendo } \\
\text { corantes sintéticos, } \\
\text { pode moderar os } \\
\text { efeitos potenciais } \\
\text { desses corantes } \\
\text { artificiais. Diminuir ou } \\
\text { remover toxinas nos } \\
\text { alimentos é uma } \\
\text { etapa essencial para a } \\
\text { melhoria do estado } \\
\text { de saúde humana e } \\
\text { diminuição do risco } \\
\text { de aparecimento ou } \\
\text { progressão } \\
\text { doenças de } \\
\text { degenerativas }\end{array}$ \\
\hline 14 & $\begin{array}{l}\text { Tartrazine induces } \\
\text { structural and functional } \\
\text { aberrations and } \\
\text { genotoxic effects in vivo. } \\
\text { KHAYYAT et al.(2017) }\end{array}$ & $\begin{array}{lr}\text { Analisar o } & \text { efeito } \\
\text { adverso } & \text { nas } \\
\text { estruturas } & \text { e } \\
\text { funções renais } & \text { e } \\
\text { hepáticas. E } & \text { o } \\
\text { potencial } & \\
\text { genotóxicos da } \\
\text { tartrazina em } \\
\text { células brancas do } \\
\text { sangue. }\end{array}$ & $\begin{array}{l}\text { Pesquisa bibliográfica } \\
\text { para avaliar o possível } \\
\text { efeito da tartrazina nas } \\
\text { estruturas e funções } \\
\text { renais e hepáticas. }\end{array}$ & $\begin{array}{l}\text { Conclui-se que a } \\
\text { tartrazina é capaz de } \\
\text { gerar ROS, } \\
\text { acelerando o estresse } \\
\text { oxidativo, alterando a } \\
\text { estrutura e os perfis } \\
\text { bioquímicos nos } \\
\text { tecidos hepático e } \\
\text { renal. }\end{array}$ \\
\hline 15 & $\begin{array}{l}\text { Corantes Alimentícios } \\
\text { Amaranto, Eritrosina B e } \\
\text { Tartrazina, e seus }\end{array}$ & $\begin{array}{l}\text { Avaliar } \\
\text { potencial } \\
\text { toxicológico, }\end{array}$ & $\begin{array}{l}\text { Pesquisa bibliográfica } \\
\text { analisou o potencial } \\
\text { toxicológico, }\end{array}$ & $\begin{array}{lrr}\text { Corante } & \text { amaranto, } \\
\text { eritrosina } & \mathrm{B} & \mathrm{e} \\
\text { tartrazina } & & \text { tem }\end{array}$ \\
\hline
\end{tabular}




\begin{tabular}{|c|c|c|c|c|}
\hline $\mathbf{N}^{\circ}$ & Título/ Autor/Ano & Objetivo & Metodologia & Conclusão \\
\hline & $\begin{array}{l}\begin{array}{l}\text { possíveis } \\
\text { Maléficos à } \\
\text { Humana. } \\
\text { Saúde }\end{array} \\
\text { ANASTÁCIO et al.(2016) }\end{array}$ & 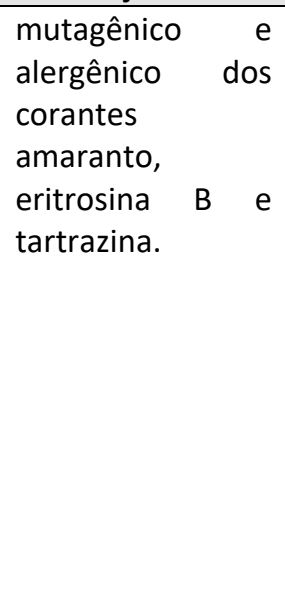 & $\begin{array}{l}\text { mutagênico e } \\
\text { alergênico dos corantes } \\
\text { amaranto, eritrosina B e } \\
\text { tartrazina }\end{array}$ & $\begin{array}{l}\text { potencial toxicológico } \\
\text { e mutagênico em } \\
\text { vários estudos. É } \\
\text { imprescindível que a } \\
\text { liberação e a } \\
\text { regulamentação do } \\
\text { uso destas } \\
\text { substâncias sejam } \\
\text { reavaliadas, em uma } \\
\text { tentativa } \\
\text { minimizar a exposição } \\
\text { disseminada } \\
\text { população a estes } \\
\text { aditivos alimentares. }\end{array}$ \\
\hline 16 & $\begin{array}{l}\text { Alergias a alimentos ou a } \\
\text { derivados usados como } \\
\text { excipientes em } \\
\text { medicamentos. } \\
\text { GONÇALVES (2016) }\end{array}$ & $\begin{array}{lr}\text { Descrever } & \text { as } \\
\text { características e } & \text { reações adversas } \\
\text { a alguns dos } \\
\text { excipientes mais } \\
\text { usados } \quad \text { em } \\
\text { formulações } \\
\text { farmacêuticas. }\end{array}$ & $\begin{array}{l}\text { Pesquisa bibliográfica } \\
\text { sobre os excipientes } \\
\text { naturais e sintéticos } \\
\text { mais usados na } \\
\text { indústria farmacêutica, } \\
\text { agrupando-os mediante } \\
\text { a sua função específica. }\end{array}$ & $\begin{array}{l}\text { Os profissionais de } \\
\text { saúde começam a } \\
\text { considerar não só o } \\
\text { princípio ativo, mas } \\
\text { também os } \\
\text { excipientes como } \\
\text { potenciais causadores } \\
\text { de reações adversas } \\
\text { dos medicamentos, } \\
\text { nomeadamente } \\
\text { reações alérgicas. }\end{array}$ \\
\hline 17 & $\begin{array}{l}\text { A automedicação no } \\
\text { Brasil e a importância do } \\
\text { farmacêutico na } \\
\text { orientação do uso } \\
\text { racional de } \\
\text { medicamentos de venda } \\
\text { livre: uma revisão. } \\
\text { SOTERIO e SANTOS } \\
\text { (2016) }\end{array}$ & $\begin{array}{l}\text { Avaliação de } \\
\text { índices de } \\
\text { automedicação } \\
\text { em diferentes } \\
\text { regiões do Brasil, } \\
\text { medicamentos } \\
\text { mais utilizados e o } \\
\text { papel } \\
\text { farmacêutico na } \\
\text { orientação do uso } \\
\text { de } \\
\text { medicamentos. }\end{array}$ & 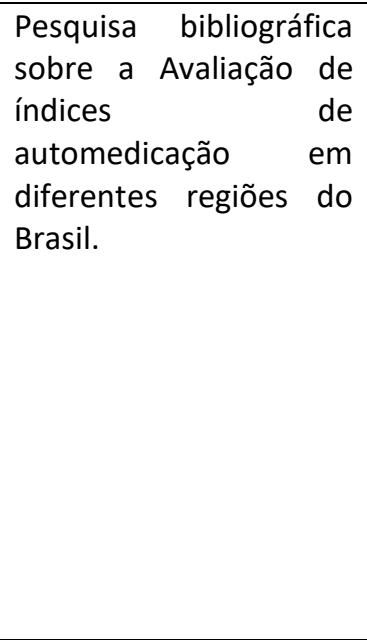 & $\begin{array}{l}\text { O presente estudo } \\
\text { mostrou que mesmo } \\
\text { com diferenças } \\
\text { percentuais entre os } \\
\text { estados, que a } \\
\text { automedicação no } \\
\text { Brasil é um problema } \\
\text { de saúde pública, e } \\
\text { essa situação só } \\
\text { tende a aumentar } \\
\text { com da } \\
\text { envelhecimento da } \\
\text { população e acesso } \\
\text { dificuldade de àde. } \\
\text { à saúde. }\end{array}$ \\
\hline 18 & $\begin{array}{l}\text { II-139 - Degradação do } \\
\text { corante tartrazina por } \\
\text { fotocatálise. } \\
\text { SOUSA et al (2016) }\end{array}$ & $\begin{array}{l}\text { Investigar o } \\
\text { processo de } \\
\text { degradação do } \\
\text { corante tartrazina } \\
\text { por fotocatálise, } \\
\text { utilizando-se } \\
\text { peróxido de } \\
\text { hidrogênio ou } \\
\text { dióxido de titânio. } \\
\text { O reator, operado } \\
\text { em bateladas, por } \\
\text { duas horas. }\end{array}$ & $\begin{array}{l}\text { Pesquisa Experimental } \\
\text { para investigar o } \\
\text { processo de degradação } \\
\text { do corante tartrazina } \\
\text { por fotocatálise, } \\
\text { utilizando-se peróxido } \\
\text { de hidrogênio ou } \\
\text { dióxido de titânio. }\end{array}$ & $\begin{array}{l}\text { O resultado se } \\
\text { mostrou eficiente } \\
\text { para a remoção da cor } \\
\text { e degradação dos } \\
\text { corantes, ambos os } \\
\text { processos de } \\
\text { fotocatálise, com } \\
\text { peróxido de } \\
\text { hidrogênio ou dióxido } \\
\text { de titânio, foram } \\
\text { determinados como } \\
\text { reações de pseudo- } \\
\text { primeira ordem. Já o } \\
\text { teste de adsorção, } \\
\text { mostrou não haver } \\
\text { forte competição }\end{array}$ \\
\hline
\end{tabular}




\begin{tabular}{|c|c|c|c|c|}
\hline $\mathbf{N}^{\circ}$ & Título/ Autor/Ano & Objetivo & Metodologia & Conclusão \\
\hline & & & & $\begin{array}{lr}\text { entre o solvente, } \\
\text { água, e o corante pelo } \\
\text { semicondutor, } \\
\text { podendo rer } \\
\text { interferido r no } \\
\text { resultado apenas em } \\
\text { até } 0,3 \% .\end{array}$ \\
\hline 19 & $\begin{array}{l}\text { Exposición de seres } \\
\text { humanos a alimentos y } \\
\text { cosméticos que } \\
\text { contienen colorantes: } \\
\text { un estudio de encuestas. } \\
\text { FONOVICH et al.(2015) }\end{array}$ & $\begin{array}{l}\text { Avaliar o consumo } \\
\text { dos produtos por } \\
\text { diferentes } \\
\text { amostras } \\
\text { Populacionais. } \\
\text { Corantes } \\
\text { declarados nos } \\
\text { rótulos dos } \\
\text { alimentos desses } \\
\text { produtos também } \\
\text { foram investigados. }\end{array}$ & $\begin{array}{l}\text { Pesquisa bibliográfica } \\
\text { para avaliar o consumo } \\
\text { dos produtos que } \\
\text { contêm corantes em } \\
\text { seus ingredientes. Além } \\
\text { de investigações sobre } \\
\text { os rótulos dos } \\
\text { alimentos. }\end{array}$ & 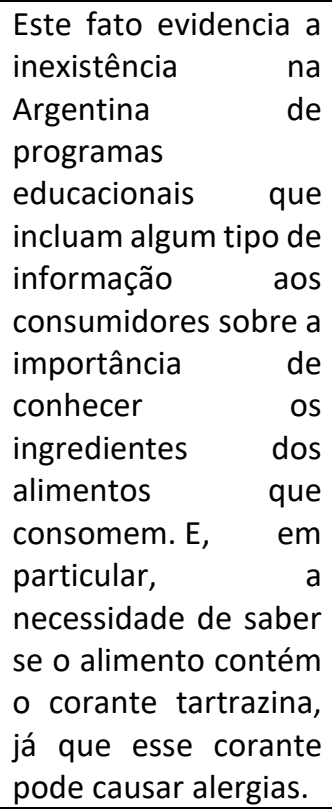 \\
\hline 20 & $\begin{array}{l}\text { Effects on DNA Repair in } \\
\text { Human Lymphocytes } \\
\text { Exposed to the Food Dye } \\
\text { Tartrazine Yellow. } \\
\text { SOARES et al.(2015) }\end{array}$ & $\begin{array}{lr}\text { Avaliou } & \text { o } \\
\text { potencial de } & \text { de } \\
\text { citotoxicidade in } \\
\text { vitro, } \\
\text { genotoxicidade e } \\
\text { efeitos no reparo } \\
\text { do DNA de } \\
\text { linfócitos } \\
\text { humanos } \\
\text { expostos } \\
\text { corante. }\end{array}$ & $\begin{array}{l}\text { Pesquisa bibliográfica } \\
\text { para analisar o } \\
\text { potencial de } \\
\text { citotoxicidade in vitro, } \\
\text { genotoxicidade e } \\
\text { efeitos no reparo do } \\
\text { DNA de linfócitos } \\
\text { humanos expostos ao } \\
\text { corante. }\end{array}$ & 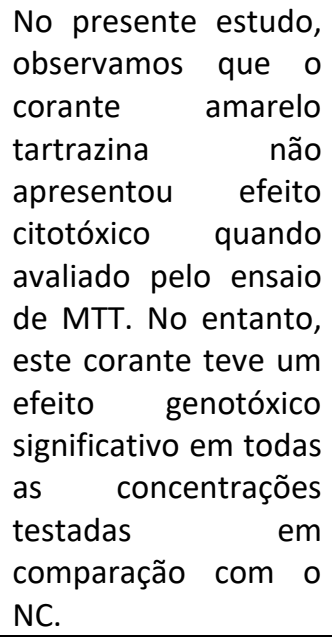 \\
\hline 21 & $\begin{array}{l}\text { Mutagenicidade do } \\
\text { corante alimentício } \\
\text { tartrazina no ensaio } \\
\text { salmonella/microssoma. } \\
\text { RESENDE (2015) }\end{array}$ & 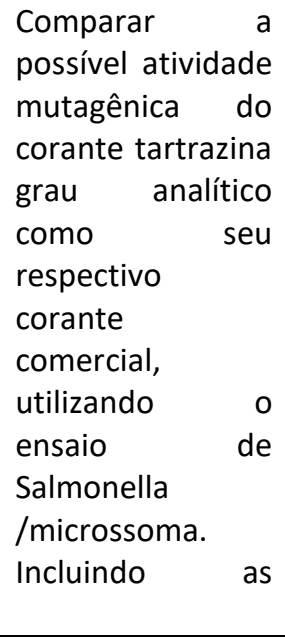 & $\begin{array}{l}\text { Pesquisa bibliográfica } \\
\text { analisou a atividade } \\
\text { mutagênica do corante } \\
\text { tartrazina, utilizando o } \\
\text { ensaio } \\
\text { Salmonella/microssoma } \\
\text { a partir das linhagens } \\
\text { recomendadas pela } \\
\text { OECD 471. }\end{array}$ & \begin{tabular}{l}
\multicolumn{3}{l}{ Diante dos resultados } \\
encontrados no \\
presente estudo, os \\
dois corantes não \\
apresentaram \\
atividade mutagênica \\
para nenhuma das \\
linhagens utilizadas \\
conforme \\
recomendações da \\
OECD 471. Contudo é \\
importante levar em \\
consideração os \\
processos \\
fabricação, de
\end{tabular} \\
\hline
\end{tabular}




\begin{tabular}{|c|c|c|c|c|}
\hline $\mathbf{N}^{\circ}$ & Título/ Autor/Ano & Objetivo & Metodologia & Conclusão \\
\hline & & $\begin{array}{l}\text { linhagens } \\
\text { OECD } 471 .\end{array}$ & & $\begin{array}{l}\text { contaminações e a } \\
\text { atividade } \\
\text { mutagênica. }\end{array}$ \\
\hline 22 & $\begin{array}{l}\text { Aditivos alimentares e } \\
\text { hipersensibilidades. } \\
\text { MOREIRA et al. (2014) }\end{array}$ & $\begin{array}{l}\text { Associar o uso de } \\
\text { aditivos } \\
\text { alimentares com a } \\
\text { possibilidade de } \\
\text { desenvolvimento } \\
\text { de reações } \\
\text { alérgicas. }\end{array}$ & 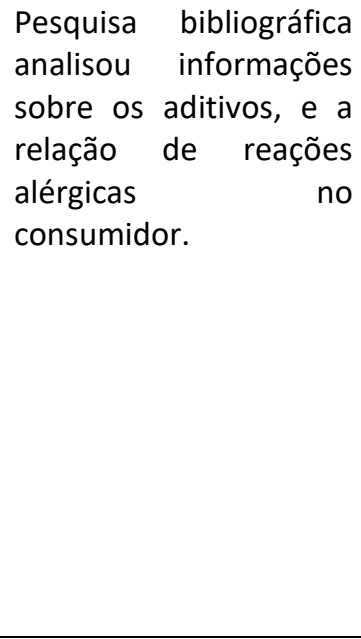 & $\begin{array}{l}\text { Segundo } \\
\text { nutricionistas é } \\
\text { primordial se fazer a } \\
\text { leitura da rotulagem } \\
\text { dos alimentos, pois } \\
\text { não existem testes } \\
\text { eficazes para } \\
\text { diagnósticos de } \\
\text { alergia aos corantes. } \\
\text { Por esse motivo as } \\
\text { dietas devem ser } \\
\text { feitas com a indicação } \\
\text { de nutricionistas e } \\
\text { médicos } \\
\text { alergologistas. }\end{array}$ \\
\hline 23 & $\begin{array}{l}\text { A análise da } \\
\text { concentração de } \\
\text { tartrazina em Alimentos } \\
\text { consumidos por crianças } \\
\text { e Adolescentes. } \\
\text { PIASINI et al. (2014) }\end{array}$ & $\begin{array}{l}\text { Analisar se a } \\
\text { concentração do } \\
\text { corante tartrazina } \\
\text { se enquadra nas } \\
\text { recomendações } \\
\text { previstas pela } \\
\text { Agência Nacional } \\
\text { de Vigilância } \\
\text { Sanitária } \\
\text { (ANVISA) }\end{array}$ & $\begin{array}{l}\text { Pesquisa Experimental } \\
\text { para analisar a } \\
\text { concentração de } \\
\text { tartrazina nos alimentos } \\
\text { consumidos por } \\
\text { crianças e adolescentes. }\end{array}$ & 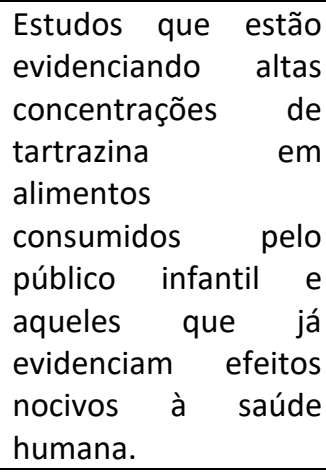 \\
\hline 24 & $\begin{array}{l}\text { Citotoxicity of food dyes } \\
\text { sunset yellow (E-110), } \\
\text { bordeaux red (E-123), } \\
\text { and tatrazine yellow (E- } \\
\text { 102) on Allium cepa L. } \\
\text { root meristematic cells. } \\
\text { GOMES et al.(2013) }\end{array}$ & $\begin{array}{l}\text { Avaliar o efeito } \\
\text { citotóxico dos } \\
\text { corantes sunset } \\
\text { yellow, bordeaux } \\
\text { red e tartrazine } \\
\text { yellow sobre o } \\
\text { ciclo celular } \\
\text { de Allium cepa L. } \\
\text { Cada corante nas } \\
\text { doses de } 0,4 \text { e } 4,0 \\
\text { mL, nos tempos } \\
\text { de exposição de } \\
24 \text { e } 48 \text { horas, em } \\
\text { células de pontas } \\
\text { de raízes de } \\
\text { Allium cepa L. }\end{array}$ & 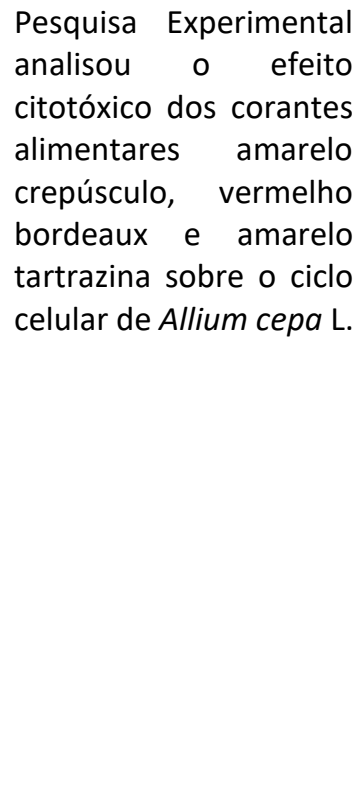 & $\begin{array}{l}\text { Os resultados obtidos } \\
\text { no presente estudo } \\
\text { indicaram atividade } \\
\text { citotóxica dos } \\
\text { corantes amarelo-sol, } \\
\text { vermelho-bordô e } \\
\text { amarelo-tartrazina } \\
\text { sobre as células } \\
\text { meristemáticas das } \\
\text { raízes de Allium } \\
\text { cepa. Esses achados } \\
\text { estão de acordo com } \\
\text { outros relatados na } \\
\text { literatura científica } \\
\text { que indicam que o } \\
\text { uso desses três } \\
\text { aditivos alimentares } \\
\text { pela população exige } \\
\text { um maior escrutínio. }\end{array}$ \\
\hline 25 & $\begin{array}{l}\text { Aditivos alimentares: } \\
\text { aplicações e toxicologia. }\end{array}$ & $\begin{array}{l}\text { Abordar o tema } \\
\text { sobre os aditivos } \\
\text { alimentares, suas } \\
\text { aplicações } \\
\text { toxicologia. }\end{array}$ & $\begin{array}{l}\text { Exploratório descritivo } \\
\text { para analisar os aditivos } \\
\text { alimentares, suas } \\
\text { aplicações e toxicologia. }\end{array}$ & $\begin{array}{l}\text { É necessário que } \\
\text { sejam feitos mais } \\
\text { ensaios para se } \\
\text { determinar os efeitos } \\
\text { nocivos desses } \\
\text { ingredientes } \\
\text { adicionados }\end{array}$ \\
\hline
\end{tabular}




\begin{tabular}{|c|c|c|c|c|}
\hline $\mathbf{N}^{\circ}$ & Título/ Autor/Ano & Objetivo & Metodologia & Conclusão \\
\hline & & & & $\begin{array}{l}\text { intencionalmente aos } \\
\text { alimentos. }\end{array}$ \\
\hline 26 & $\begin{array}{l}\text { Influência de excipientes } \\
\text { farmacêuticos em } \\
\text { reações adversas a } \\
\text { medicamentos. } \\
\text { ARAUJO et al. (2012) }\end{array}$ & $\begin{array}{lr}\text { Abordar } & \text { algumas } \\
\text { das } & \text { reações } \\
\text { adversas } & \text { já } \\
\text { descritas } & \text { para } \\
\text { excipientes } & \\
\text { comumente } & \\
\text { utilizados } & \text { na } \\
\text { indústria } & \\
\text { farmacêutica. }\end{array}$ & $\begin{array}{l}\text { Pesquisa Experimental } \\
\text { analisou as influências } \\
\text { dos excipientes } \\
\text { farmacêuticos e reações } \\
\text { adversas. } \\
\text {. }\end{array}$ & 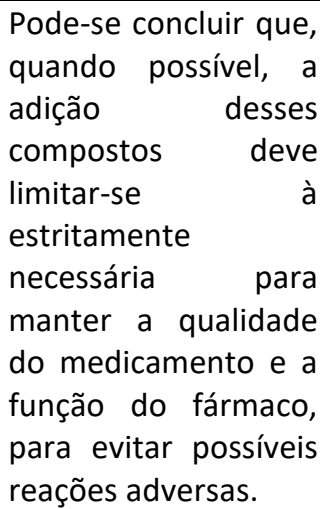 \\
\hline
\end{tabular}

Fonte: Autores (2021).

A utilização da Tartrazina também abrange produtos farmacêuticos, nos medicamentos, pode ser usada como excipientes, que são substâncias quimicamente heterogêneas, que podem ser moléculas bem simples ou misturas de complexos naturais, sintéticos ou semissintéticos. Esses excipientes apresentam uma ótima relação com os fármacos, são capazes de alterar a solubilidade de um medicamento podendo agregar doses adequadas ao mesmo ou promover doses tóxicas para o organismo (ARAUJO et al., 2012).

Atualmente os fármacos consumidos pelas pessoas possuem grandes variações de aditivos que combinado com princípio ativo tende a proporcionar maior eficácia, funcionalidade e biodisponibilidade do medicamento no organismo, além de garantir boas estabilidade quanto ao seu armazenamento (GONÇALVES, 2016).

Um exemplo da aplicabilidade desse corante foi observado nos estudos de Sousa et al. (2016), em que foram analisadas 2.204 formulações dentre as quais 124 destas apresentaram o corante em sua fórmula: como por exemplo a dipirona 500mg, paracetamol gotas, amoxilicina associada ao clavulanato, cefalexina e a claritoromicina. E a conclusão obtida foi que um dos corantes mais identificados foi o tartrazina presente em 124 medicamentos. Cabe ressaltar, que na indústria cosmética está presente em produtos para o cabelo, hidratantes e sabonetes (CHIMELLO, 2017).

Sob a obrigatoriedade da legislação (RDC 137/2003), as indústrias fabricantes dos medicamentos que contém o corante amarelo tartrazina em suas formulações, 
estão forçadas a enfatizar de maneira clara e visível, a advertência nas bulas e embalagens destes medicamentos: "Este produto contém o corante amarelo de TARTRAZINA que pode causar reações de natureza alérgica, entre as quais asma brônquica, especialmente em pessoas alérgicas ao ácido acetilsalicílico" (NASCIMENTO, 2018).

Resende (2015) descreve que o Ministério da Saúde por meio da ANVISA é quem regulamenta, fiscaliza e controla sobre o uso adequado dos corantes alimentícios e determina os padrões de limites máximos aceitáveis para o corante tartrazina.

Segundo Câmara (2017), em meados do século XX, os corantes azos começaram a ser usados como aditivos alimentares, por isso seus impactos tóxicos têm provocado atenção e porventura a obrigação de contínua regulamentação. Os corantes azos causam lesões nocivas em animais entre elas inflamação do revestimento do estômago, por ser catalisado na microflora intestinal pode ocasionar ações cancerígenas e mutagênicas. Além de causar patologias hepáticas e renais, mais agravantes em predisposto geneticamente (EL-DESOKY et al., 2017)

A tartrazina, pertencente à classe dos azos, pode induzir danos ao DNA relacionados com a dose glandular no estômago, cólon e bexiga, mesmo próximo à ingestão diária aceitável. Esse corante é metabolizado pela microflora gastrointestinal, e pode provocar reações alérgicas, como asma e urticária. Percebe-se que o corante tartrazina está amplamente interligado a danos à saúde, visto que em relação a outros aditivos sem dúvidas este é largamente mais utilizado na indústria alimentícia (HONORATO et al., 2013; MOREIRA et al., 2014; VELÁZQUEZ-SÁMANO et al., 2019).

Anastácio et al. (2016) informam em seus estudos que o corante tartrazina tem potencial para causar distúrbios de hipersensibilidade, acometendo $0,6 \%$ a $2,9 \%$ da população em geral, principalmente em pessoas intolerantes aos salicilatos ou nos indivíduos atópicos.

Além disso, Velioglu et al. (2019) apontaram que a tartrazina pode causar mudanças nos perfis bioquímicos dos rins e tecidos do fígado de ratos, altas doses resultam em estresse oxidativo em tecidos via formação radical e os metabólitos podem causar formação de ROS (Espécies que reagem ao oxigênio) no tecido, que pode contribuir para o estresse oxidativo no fígado. 
Em estudos, ainda em ratos, foi possível avaliar os efeitos do corante na expressão de genes reguladores do ciclo celular, estresse oxidativo e alterações histopatológicas no cérebro de ratos foram testados se a aspirina em fortes doses teria eficácia contra esses efeitos. Um desses genes (p53) que foram desregulados pelo corante demonstraram que a aspirina em altas doses pode reverter danos causados. As conclusões deste estudo demonstram que este aditivo alimentar é genotóxica e potencialmente tumorigênica no cérebro. Estes resultados oferecem outro olhar sobre o mecanismo de ação da tartrazina (ALSALMAN et al., 2019).

Cabe ressaltar que aditivos mais genotóxicos utilizados na indústria alimentícia são os corantes, e foi observado que a tartrazina também pode estar associada ao câncer intestinal, pois a degradação ocorre no intestino provocando reações carcinogenicidade e/ou toxicidade. A conexão de corantes e hipercinesia têm preocupado a comunidade científica devido alguns estudos terem mostrado anormalidade na aprendizagem de crianças, conforme (PIASINI et al., 2014).

Em estudos com camundongos, a tartrazina induziu danos ao DNA no cólon, além do potencial de promover dano no DNA dos linfócitos humanos, em que está associada ao surgimento de doenças, como o câncer (SOARES et al. 2015).

Floriano et al. (2018), também afirma que o corante tartrazina provocou danos ao DNA humano em concentração de $70 \mu \mathrm{g} / \mathrm{mL}$, valor fácil de ser inserido no corpo devido ao uso de vários produtos que tem esta substância, testes in silico afirmam em conjunto com o teste ex vivo em relação ao potencial pela capacidade genotóxicas.

Para Khayyat et al. (2017), esse corante tem ação na biotransformação ocasionando a construção de dois metabólitos, ácido sulfanílico e aminopirazolona e também pode formar espécies reativas de oxigênio (ROS), promovendo o estresse oxidativo e no abalo das arquiteturas hepática, renal e nos perfis bioquímicos, tal efeito genotóxicos se deu possivelmente pela reação do corante com o DNA nuclear.

Conforme Fonovich et al. (2015), a maior parte da população vive nas cidades e por esse motivo são grandes consumidoras de alimentos industrializados, dos quais vários destes podem conter aditivos alimentares. Pesquisas realizadas relatam que a maioria da população não apresenta interesse em saber ou ler de quais componentes foram feitos tais alimentos. Há certos descasos dos órgãos responsáveis em relação a campanhas educacionais para informar aos cidadãos a importância sobre os compostos 
e substâncias contidas nos alimentos. Especialmente verificar se o corante tartrazina está presente no alimento que vai consumir, devido ao mesmo ser potencial causador de alergias.

Gomes et al. (2013) relatam que aproximadamente 10 anos o corante tartrazina está em constante investigação pelos possíveis efeitos colaterais, inclusive foi proibido nos Estados Unidos e Japão, devido análises de bioensaios em mamíferos que causaram possíveis alterações genéticas. Entretanto, análises toxicológicas em demais países como Inglaterra e Brasil, não originaram citotoxicidade relevante em teste com roedores, portanto continuam sendo utilizados até os dias atuais. Em estimativa apontase que a cada dez mil pessoas uma pessoa sofre sequelas danosas pela ingestão deste corante.

Este quadro pode ser modificado por meio da contribuição de profissionais da área da saúde de maneira conjunta, ou isoladas, como a contribuição do farmacêutico. Esse profissional possui conhecimentos diversificados e pode atuar na toxicologia dos corantes, ajudando a esclarecer os efeitos fisiológicos e bioquímicos provocados pela interação de substâncias químicas e organismo; possíveis reações adversas; no diagnóstico, prevenção e tratamento nos quadros de intoxicação para promover o bem estar da população (SOTERIO; SANTOS, 2016; SILVA, 2020).

Quanto às suas atribuições voltadas a responsabilidade exercida em estabelecimentos industriais e de importação de produtos para a saúde, respeitando as atividades afins com outras profissões, esse profissional tem amparo legal na resolução no 448 de 24 de outubro de 2006 (BRASIL, 2006), cujas atividades vão desde o desenvolvimento do produto, produção, controle de qualidade e garantia da qualidade em escala industrial.

Cabe ressaltar também a importância das boas práticas de fabricação de medicamentos, disposta na resolução no 301, de 21 de agosto de 2019, que possui o objetivo de garantir qualidade na fabricação de medicamentos do Esquema de Cooperação em Inspeção Farmacêutica, visto que os corantes podem ser utilizados como excipientes em medicamentos (BRASIL, 2019). 


\section{CONCLUSÃO}

Com base nos estudos, o corante amarelo de tartrazina é um aditivo utilizado em alimentos, medicamentos e cosméticos. Além disso, pode desencadear quadros patológicos como: distúrbios de hipersensibilidade, ações cancerígenas e mutagênicas até mesmo alterações mais complexas, como danos ao DNA.

Portanto, faz-se necessário a atuação mais efetiva dos órgãos de vigilância e mais estudos sobre a toxicidade. Por isso, propõe-se que o farmacêutico, pode ser um potencial aliado aos meios de campanhas educativas contribuindo para informação e esclarecimentos sobre os cuidados toxicológicos, além de atuar no controle de qualidade das indústrias alimentícias e farmacêuticas monitorando o uso das quantidades adequadas permitidas para o consumo humano.

\section{REFERÊNCIAS}

ALSALMAN, N. et al. High-Dose Aspirin Reverses Tartrazine-Induced Cell Growth Dysregulation Independent of p53 Signaling and Antioxidant Mechanisms in Rat Brain. Hindawi BioMed Research International, v. 2019, 9096404, 2019.

ANASTÁCIO, L. B. et al. Corantes Alimentícios Amaranto, Eritrosina B e Tartrazina, e seus possíveis Efeitos Maléficos à Saúde Humana. Journal of Applied Pharmaceutical Sciences, v. 2, n. 3, p. 16-30, 2016.

ARAUJO, A. C. F.; BORIN, M. F. Influência de excipientes farmacêuticos em reações adversas a medicamentos. Revista Brasília Médica, v. 49, n. 4, p. 267-278, 2012.

BARBOZA, E. N. et al. Potencialidade da biodegradação de corantes têxteis. Revista Brasileira de Gestão Ambiental, v. 13, n. 04, p. 14-19, 2019.

BENINCÁ, C. Degradação do corante alimentício Ponceau 4R e tratamento de efluente de uma indústria de alimentos utilizando processos oxidativo avançados. 2012. 100f. Tese (Doutorado em Engenharia de Alimentos) - Programa de PósGraduação em Engenharia de Alimentos, Universidade Federal do Paraná, Curitiba, 2012.

BRASIL. Resolução no. 448 de outubro de 2006. Regula as atribuições do farmacêutico na indústria e importação de produtos para a saúde, 2006.

BRASIL. Resolução no. 301 de 21 de agosto de 2019. Dispõe sobre as diretrizes gerais de Boas Práticas de Fabricação de Medicamentos. Possui o objetivo de garantir qualidade na fabricação de medicamentos do Esquema de Cooperação em Inspeção Farmacêutica, 2019. 
CÂMARA, A. M. Corantes azo: características gerais, aplicações e toxicidade. 2017. 60f. Trabalho de Conclusão de Curso (Graduação em Nutrição) - Universidade Federal do Rio Grande do Norte, Natal, 2017.

CHIMELLO, P. H. P. Síntese e caracterização de polímero molecularmente impresso para determinação do corante tartrazina visando desenvolvimento e aplicação de novos sensores biomiméticos com transdução óptica. 2017. 81f. Dissertação (Mestrado em Biotecnologia) Instituto de Química - Universidade Estadual Paulista Instituto de Química, Araraquara, 2017.

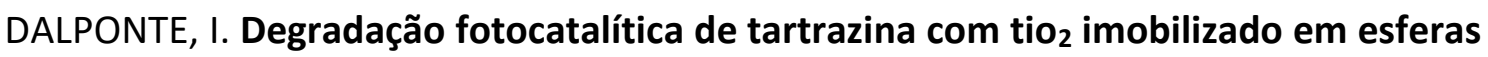
de alginato. 2015. 97f. Dissertação (Mestrado em Meio Ambiente Urbano e Industrial) - Universidade Federal do Paraná, Curitiba, 2015.

DURIGON, A. M. M. Screening e comportamento eletroquímico de corantes alimentícios em estado sólido. 2020. 106f. Dissertação (Mestrado em Química) - Universidade Federal do Rio Grande do Sul, Rio Grande do Sul, 2020.

EL-DESOKY, G. E. et al. Curcumin protects against tartrazine-mediated oxidative stress and hepatotoxicity in male rats. European Review for Medical and Pharmacological Sciences, v. 21, n. 3, p. 635-645, 2017.

FERREIRA, W. M. et al. Corantes: Uma Abordagem com Enfoque Ciência, Tecnologia e Sociedade (CTS) Usando Processos Oxidativos Avançados. Química Nova na Escola, v. 40, n. 4, p. 249-257, 2018.

FLORIANO, J. M. et al. Avaliação da mutagenicidade do corante tartrazina em cultura de leucócitos Humanos. Anais do 9o salão internacional de ensino, pesquisa e extensão - v. 9, n. 2, 3 SIEPE, 2020.

FLORIANO, J. M. et al. Is tartrazine really safe? In silico and ex vivo toxicological studies in human leukocytes: a question of dose. Toxicology Research, v. 7, n. 6, p. 11281134, 2018.

FONOVICH, T. M. et al. Exposición de seres humanos a alimentos y cosméticos que contienen colorantes: un estudio de encuestas. Acta Bioquímica Clínica Latinoamericana, v. 49, n. 3, p. 353-367, 2015.

GONÇALVES, L. A. A. Alergias a alimentos ou a derivados usados como excipientes em medicamentos. 2016, 64f. Dissertação (Mestrado em Ciências Farmacêuticas) Universidade Fernando Pessoa, Porto, 2016.

GOMES, K. M. S. et al. Citotoxicidade de corantes alimentares amarelo-sol (E-110), vermelho bordeaux (E-123) e amarelo tatrazina (E-102) em células meristemáticas de raiz de Allium cepa L. Food Science and Technology, v. 33, n. 1, p. 218-223, 2013. 
HAMERSKI, L.; REZENDE, M. J. C.; SILVA, B. V. Usando as Cores da Natureza para Atender aos Desejos do Consumidor: Substâncias Naturais como Corantes na Indústria Alimentícia. Revista Virtual de Química, v. 5, n. 3, p. 394-420, 2013.

HASHEM, M. M. et al. Embryotoxic and Teratogenic Effects of Tartrazine in Rats. Toxicological Research, v. 35, n. 1, p. 75-81, 2019.

HONORATO, T. C. et al. Aditivos alimentares: aplicações e toxicologia. Revista Verde (Mossoró - RN - BRASIL), v. 8, n. 5, p. 01 - 11, 2013.

KHAYYAT L. et al. Tartrazine induces structural and functional aberrations and genotoxic effects in vivo. PeerJ. v23, n. 5, p. e3041, 2015.

MENDES, K. D. S.; SILVEIRA, R. C. C. P.; GALVÃO, C. M. Revisão integrativa: método de pesquisa para a incorporação de evidências na saúde e na enfermagem. Texto Contexto Enferm, v.17, n.4, p.758-764,2008.

MONTEIRO, F. C. Estudo comparativo entre BiFeO3 e Bi2Fe4O9 no processo de fotocatálise heterogênea. 2020, 127f. Tese (Doutorado em Química)Universidade Estadual de Ponta Grossa, Ponta Grossa, 2020.

MOREIRA, G. B. et al. Aditivos alimentares e hipersensibilidades. Revista de trabalhos acadêmicos - universo recife, v.1, n.1 2014.

NASCIMENTO, A. L. S. Regulamentação de bulas: cenário atual dos medicamentos antirretrovirais no Brasil. 144 f. Dissertação (Mestrado Profissional em Gestão, Pesquisa e Desenvolvimento na Indústria Farmacêutica) - Instituto de Tecnologia em Fármacos, Fundação Oswaldo Cruz, Rio de Janeiro, 2018

OLIVEIRA; F. S. Quantificação do corante amarelo tartrazina em alimentos destinados ao público infantil. 2019, 38f. Trabalho de Conclusão de Curso (Graduação), Centro universitário UNIFACVEST, Lages, SC. 2019.

PAZZOTI, G. S. O. Utilização de corantes na indústria que processa balas, pirulitos e Chicletes. Revista científica unilago, p. 263-270 2013.

PIASINI, A. et al. Análise da concentração de tartrazina em Alimentos consumidos por crianças e Adolescentes. Revista UNINGÁ Review v.19, n.1,p.14-18, 2014

RESENDE, M. R. Mutagenicidade do corante alimentício tartrazina no ensaio de Salmonella/microssoma. 2015. 144f Dissertação (Mestrado em Tecnologia e Inovação) - Faculdade de Tecnologia , Universidade estadual de campinas Faculdade de tecnologia. Limeira, 2015. 
SILVA, V. B. Atenção farmacêutica nas intoxicações por agrotóxicos: revisão. 2020, 38f. Trabalho de Conclusão de Curso (Graduação em Farmácia) - Faculdade de educação e meio ambiente, Ariquemes-RO, 2020.

SOARES, B. M. et al. Effects on DNA Repair in Human Lymphocytes Exposed to the Food Dye Tartrazine Yellow. Anticancer research, v.35, n.33, p.1465-1474, 2015.

SOUZA, P.S.; TERAN, F.J.C.; CARVALHO,R.V. II-139 - Degradação do corante tartrazina por fotocatálise. IN: Congresso Interamericano de Engenharia sanitária e Ambiental, XXVII, 2016. Disponível em: https://abesnacional.com.br/XP/XPEasyArtigos/Site/Uploads/Evento32/TrabalhosCompletosPDF/II-139.pdf. Acesso em 13 de janeiro de 2021.

SOTERIO, K. A, \& SANTOS, M. A. A automedicação no Brasil e a importância do farmacêutico na orientação do uso racional de medicamentos de venda livre: uma revisão. Revista Da Graduação, v.9, n.2, 2016.

VELÁZQUEZ-SÁMANO, G. et al. Reações de hipersensibilidade a aditivos alimentares. Allergy Magazine México. v.66, n.3, p. 329-339, 2019.

VELIOGLU, C. et al. Protective effect of crocin on food azo dye tartrazine-induced hepatic damage by improving biochemical parameters and oxidative stress biomarkers in rats. Gen. Physiol. Biophys. Vol. 38 p.73-82, 2019. 


\title{
CAPITULO $x x$
}

\section{CONSTRUÇÃO DA IDENTIDADE DA PESSOA COM DEFICIÊNCIA: COMO O TERMO DE REFERÊNCIA PODE SER CAPACITISTA}

DOI: 10.51859/AMPLLA.PAE1993-20

\author{
Antonio Janiel lenerich da Silva ${ }^{1}$ \\ Henrique Alexander Grazzi Keske ${ }^{2}$
}

${ }^{1}$ Pessoa com deficiência e jornalista com formação pela Universidade Feevale.

${ }^{2}$ Advogado. Doutor em Filosofia. Membro do Grupo de Estudos de Direitos Humanos da Universidade Ritter dos Reis.

\section{RESUMO}

A forma como nos comunicamos diz muito sobre como pensamos, e também, como incluímos. Por isso, refletir sobre a forma que nos referimos a grupos identitários, é fundamental para que possamos entender seu lugar de representatividade. Discutir a terminologia de referência à pessoa com deficiência, é o que se propõe o presente artigo, com o objetivo de informar e alertar sobre o fato de que os termos antigos carregam consigo conceitos excludentes e que permanecendo na esfera social e somados a outras formas de preconceito acabam potencializando outras formas de exclusão. Diante disso, conclui-se que é necessário conhecer as terminologias antigas, pensar sobre a vigente, e repensar a nossa forma de comunicação para não carregarmos nela elementos discursivos discriminatórios.

Palavras-chave: Pessoa com deficiência. Terminologia. Capacitismo. Comunicação. Inclusão 


\section{INTRODUÇÃO}

Ao se tratar das formas de exclusão da pessoa com deficiência, logo pensamos nas barreiras urbanísticas presentes em ambientes públicos e privados, que nos ${ }^{1}$ impedem o acesso, bem como nas barreiras arquitetônicas quando não há rampas, corrimões ou direcionadores em Braille, por exemplo. E ainda, nas barreiras nos meios de transporte, como a falta de um elevador no ônibus, ou o desrepeito ao banco preferencial.

Ainda podemos pensar em barreiras nas comunicações como a ausência de intérprete de Libras, legendas e audiodescrição, que garantam o acesso pleno à informação que está sendo transmitida. Também temos as barreiras atitudinais, que são aquelas representadas por atos e ações que nos impeçam ou prejudiquem a participação social e que, juntamente com as barreiras tecnológicas, ainda atrapalham a inclusão da pessoa com deficiência no meio da tecnologia, seja para usufruir dela ou para trabalhar com ela.

São tantas barreiras, mas ainda caberia apontar mais uma, especificamente, ou seja, a que se refere à barreira terminológica que, apesar de se encaixar nas citadas anteriormente, devido à complexidade e aos reflexos causados pelo mau uso do emprego de uma terminologia adequada, poderia muito bem ter um tópico próporio. Esse mau uso dos têrmos se evidencia na circunstância de que, desde 2010, a Portaria $n^{\circ} 2.344$ de 03 de novembro, determina a substituição das expressões antes usadas, para se chegar, então, à terminologia atual, de Pessoa com Deficiência (PCD). Porém, essa não é a realidade, pois ainda convivemos com expressões como aleijado, manco, portador, pessoa com necessidades especiais, bem como deficiente.

Em um primeiro momento de análise, essas terminologias não parecem trazer grandes problemas às pessoas com deficiência, porém, ao se observar seus significados, eis que se percebe que elas dão voz e suporte a muitos preconceitos que estamos sofrendo, há muito tempo, a partir de um enfoque histórico, focado no uso de diversas expressões. Por conta disso, então, ao se aprofundar a análise, se pode evidenciar que

\footnotetext{
${ }^{1} \mathrm{O}$ uso dos tempos verbais na primeira pessoa do plural tem, assim, como motivação, o fato de que um dos autores é pessoa com deficiência, o que implica, também, em emprego de uma linguagem inclusiva, pois se refere a alguém que vivencia os problemas de que se trata nesses escritos.
} 
o uso de tais expressões remetem, principalmente, à exclusão da figura humana ali presente, focando, ao invés disso, apenas na deficiência e numa busca errônea de tentar curá-la, como se fosse uma doença.

A essas práticas podemos nominar de capacitismo, que, resumidamente, definimos como o nome dado às formas de preconceito relacionadas à pessoa com deficiência, no sentido de apresentarem suas capacidades reduzidas e, ao mesmo tempo, implicando em procedidmentos de superação, ou seja, na condição de que tais incapacidades podem ser superadas, apesar das condições adversas. Mas, além do viés capacitista, é preciso compreender o ambiente em que essas pessoas estão inseridas, tanto no âmbito social, educacional e/ou financeiro, entre outros, para se poder compreender que são as referidas barreiras, antes referidas, que devem ser suprimidas para uma inserção social de tais pessoas.

Entretanto, ao mesmo tempo em que esses termos excludentes sobrevivem, é possível, notar um avanço no sentido de mudança desse cenário, pois se identifica a necessidade de construir uma sociedade verdadeiramente inclusiva e capaz de vencer tais esteriótipos. Nesse sentido, se evidencia que o caminho para isso é a educação, mas também, que essa educação seja questionadora e libertadora e não apenas o acúmulo de conhecimento sobre um tema. É preciso despertar o senso crítico a ponto de que referir-se a pessoa com deficiência da forma certa seja tão importante quanto uma rampa, Libras ou outro tipo de adaptação.

E só chegaremos lá se vencermos esse capacitismo terminológico que nos causa inúmeros estigmas, há tanto tempo.

\section{A QUESTÃO TERMINOLÓGICA}

Quando pensamos numa forma de referência a um grupo, logo vem à nossa mente o nome, a profissão e em alguns casos a condição. No caso das pessoas com deficiência, a condição física, psíquica e social sempre pautou a representatividade desse grupo. No entanto, por várias razões, a representação da pessoa com deficiência, pelo uso de determinadas expressões, se constituiu de termos que carregavam mais do que caracterísiticas que pudessem representar sua condição. As construções terminológicas ao longo da história, de certo modo, sempre nos levaram a um afastamento da sociedade de forma geral. 
Seja por meio de preceitos religiosos, que tratavam a deficiência como uma representação maligna, ou mesmo de um suposto castigo divino àqueles (as) que, de alguma maneira haviam como que ousado desafiar a autoridade divina, sendo, então, por isso, punidos dessa forma. Nesse sentido,

Estudiosos dos usos e costumes dos povos afirmavam que a medicina contida nos evangelhos e mesmo nos atos dos apóstolos aceitavam três tipos de causas para doenças e para muitas limitações e deficiências que afligiam os homens: o castigo pelos pecados, a interferência dos maus espíritos e as forças más da natureza, contra os quais o poder divino era o único remédio. Está em pauta, agora, a identificação dos possíveis caminhos da cura de deficientes $^{1}$ : os milagres de Jesus. (FIGUEIRA, 2015 p.12)

Porém, não somente a religião cumpriu um papel excludente relativo à pessoa com deficiência, mas a sociedade também, pois além de assimilar essa concepção de castigo divino, eis que, de forma geral sempre nos "empurou", depois, para uma classficação médica, que passou, então, a nos considerar doentes, ou mesmo incapazes de uma convivência em sociedade.

Desta forma, surgem as casas de assistência, clínicas e manicômios, que ficavam encarregados de curar, amenizar ou esconder essas pessoas da sociedade; e, ao mesmo tempo, classificando-as como incapazes de gerir a própria vida e de proverem os meios adequados ao seu próprio sustento. Sendo assim, a consequência direta se revestiu, historicamente, do caráter de um verdadeiro processo de apagamento social deste grupo, que passou por esse longo sistema de invizibilização:

\begin{abstract}
Durante os séculos XVII e XVIII, a medicina em terras brasileiras viu-se de frente com casos de doenças mais sérias, pacientes com fraturas expostas ou complicadas, deslocamentos de membros e ossos. Não há números exatos, mas seguindo citações de cronistas da época, sabemos que houve muitos casos que provocaram lesões permanentes e de natureza incapacitante. (FIGUEIRA, 2008 p.56)
\end{abstract}

Depois desse período, surgem os primeiros cursos de medicina no Brasil com a criação das Escolas de Cirurgia e Academia, em 1808, na Bahia e no Rio de Janeiro, sendo que a Faculdade de Medicina da Bahia (1832) foi a primeira do país, seguida pela do Rio de Janeiro. Porém, nesse mesmo período, surgem os manicômios, que ficam encarregados de cuidar de pessoas com doenças mentais:

Havia uma preocupação de estabelecer uma catalogação de anormalidade. Pessoas com dificuldades pedagógicas seriam os dotados de inteligência e

\footnotetext{
${ }^{1}$ Para manter fidedigno o relato do autor, optou-se em deixar a palavra "deficientes", porém, cabe ressaltar que desde 2015, o termo correto é pessoa com deficiência (PCD).
} 
instrução de grau inferior à sua idade. $E$, visando completar os exames precários das chamadas "crianças com defeitos pedagógicos". (FIGUEIRA, 2008 p.81)

A ausência de bibliografia e, principalmente, o medo do desconhecido associado às crenças de que a deficiência era algo maligno, construiram uma densa estrutura de discriminação, levando ao que Bauman expressa, da seguinte forma: "Medo é o nome que damos a nossa incerteza, nossa ignorância da ameaça e do que deve ser feito - do que pode e do que não pode - para fazê-la parar ou enfrentá-la, se cessá-la estiver além do nosso alcance". (BAUMAN, 2008 p.09)

Somente nos anos de 1968, com o surgimento de um movimento chamado Disability Studies, que visavam chamar a atenção sobre uma necessidade de repensar a deficiência sob outras perspectivas opostas às pré-estabelecidas, é que tais enfoques começam a sofrer uma determinada alteração. Sendo assim:

Os Disability Studies objetivam realizar o mesmo movimento, embora sob
outras proporções, ao implodir os fundamentos do modelo individual da
deficiência e ressaltar a mesma como um produto histórico gestado pela
opressão secular alavancada nos ditames capitalistas. Que tamanha mudança
em termos políticos e práticos não representa o processo de deixar de
entender a deficiência como providência divina ou falha biológica, e passar a
configurá-la como um produto de uma sociedade altamente excludente?
(PICCOLO, 2015 p.25)

A construção terminológica, a seu turno, é vasta e representa muito do regionalismo de cada lugar, por isso, neste artigo vamos considerar apenas as nomenclaturas em documentos oficiais, tais como as Constituições Federais, bem como das leis relacionadas à pessoa com deficiência. Nesse sentido, se pode expressar, com clareza, a historicidade dos têrmos empregados como referência, para conceituar e enquadrar a pessoa com deficiência.

Assim, a Constituição de 1934 apresenta termos como aleijado, inválido, incapacitado, defeituoso e desvalido; e, a partir da Constituição de 1937, esses termos são substituidos por excepcional. Tal enfoque perdurou até 1978, através de uma Emenda Constitucional, quando foi usado, pela primeira vez, o termo "pessoa deficiente", que permaneceu por 10 anos, uma vez que, na Constituição Federal/88, foi adotado o termo "portadores de deficiência"; e assim permaneceu até 1993. Já em 1994, surgiu o termo "pessoa com necessidades especiais" e, logo, a sigla (PNE). Entretanto, só em 2009 é que tivemos a mudança para o termo vigente e orientado pela ONU, ou seja, "pessoa com deficiência". Portanto, foi a Constuição de 1988, que trouxe 
a expressão portadores de deficiência, que apesar de ter passado por algumas transformações, se manteve como a oficial até 2009, quando o Decreto $n^{\circ} 6949 / 2009$, obrigou, no ordenamento brasileiro, seguindo os padrões da Convenção da ONU, a se adotar, a partir de então, o termo pessoa com deficiência. (RIBEIRO, 2016). Nesse sentido, se pode apresentar o quadro a seguir, em que se apresentam as transformações da referida nomenclatura:

Figura 1 - Percurso histórico da terminologia: Fonte Autores da pesquisa

\begin{tabular}{|c|c|c|c|}
\hline 1934 & 1937 & 1978 & 1988-93 \\
\hline $\begin{array}{l}\text { Inválido, aleijado, } \\
\text { incapacitado, } \\
\text { defeituoso ou } \\
\text { desvalido }\end{array}$ & $\begin{array}{l}\text { Os termos anteriores } \\
\text { são substituidos por } \\
\text { excepcional }\end{array}$ & $\begin{array}{c}\text { Surge o termo } \\
\text { deficiente e pela } \\
\text { primeira vez ele é } \\
\text { associado a pessoa }\end{array}$ & $\begin{array}{l}\text { Surge o termo } \\
\text { portador de } \\
\text { deficiência }\end{array}$ \\
\hline & $\begin{array}{c}1994 \\
\text { Surge o termo } \\
\text { Pessoa com } \\
\text { Necessidades } \\
\text { Especiais }\end{array}$ & $\begin{array}{l}\text { Chegamos ao atual } \\
\text { Pessoa com } \\
\text { Deficiência }\end{array}$ & \\
\hline
\end{tabular}

Da mesma forma, se devem destacar algumas considerações acerca dos sentidos e significados do uso de expressões ainda em voga, tais como, por exemplo, portador de necessidades especiais, de maneira que:

\begin{abstract}
A deficiência não pode ser vista como um objeto que você tem opção de portar ou não. Por isso, tornam-se claramente inadequadas terminologias que contenham a palavra "portador". Eu não tenho a opção de deixar minha tetraplegia em casa por exemplo. Por outro lado, usar a expressão "pessoa com deficiência", demostra que a deficiência, é antes de tudo, ser pessoa humana. (RIBEIRO, 2016, online)
\end{abstract}

Seguindo o racíocinio do autor, o mesmo vale para o termo excepcional, pois se pode perguntar: o que é ser excepcional? Pode ser o homem mais rápido do mundo, o mais rico, o mais pobre ou o mais pesado? Pode! Portanto, porque usá-lo para referirse a uma deficiência? A princípio, por excepcional se compreende o que é fora do comum, que ocorre além dos limites do estabelecido ou do que é normal, frequente ou corriqueiro, mas, por outro lado, implica em algo ou alguém que está muito acima do padrão ou da qualidade normal como excelente e brilhante inteligência; o que leva ao ocultamento e invisibilidade da própria deficiência.

Cabe ressaltar que foi a prevalência da visão médica sobre a deficiência que, ao longo de muito tempo, determinou o olhar sobre essa circunstância, desde o momento do surgimento desse enfoque terapêutico-clínico, como o fora, no passado, o uso das expressões e das percepções sociais a partir das definições religiosas, anteriormente 
referidas. Nesse sentido, a expressão deficiente também carrega os significados inadequados, pois essa palavra é oriunda de déficit, ou seja, aquilo que vale menos, que está abaixo do aceitável. Logo, se usamos esse termo para referir-se a uma pessoa com deficiência estamos dizendo e aceitando que ela é menos que as outras por conta da deficiência.

A seu turno, o têrmo necessidade especial segue o mesmo caminho, pois uma necessidade especial recebe muitas interpretações, já que, para quem tem sede, a necessidade especial é a forma de saciar essa condição, como o fato de ter que ingerir água, mas, por exemplo, para quem tem fome, é a comida; e já para quem tem dívidas, é o dinheiro. De qualquer forma, essa generalização acaba por encobrir e, da mesma forma, ocultar as condições específicas enfrentadas pela pessoa com deficiência. Então, se pode perguntar: porque uma deficiência deve gerar uma necessidade especial? Talvez, somente para justificar a ausência de ambientes acessíveis, que lhe permitam níveis satisfatórios de inclusão.

$\mathrm{Na}$ sequência da busca por diversos protocolos capazes de realizar uma adequada classificação das hoje conceituadas pessoas com deficiências, se cunhou outra expressão, incluída como "Classificação Internacional de Incapacidade Funcional e Saúde", que busccava por uma classificação dos componentes de saúde de funcionalidade e incapacidade. Assim, ICF, na sigla em inglês, recebeu aprovação de todos os 191 estados membros da Organização Mundial da Saúde, em 22 de maio de 2001, durante a 54a Assembléia Mundial da Saúde. Entretanto, se pode, ainda, apresentar para tal enquadramento, as seguintes considerações:

A CIF ${ }^{1}$ também busca se tornar uma classificação universal com o intuito do desenvolvimento de uma política comum para pessoas com deficiências, iniciativa de inegáveis proveitos, contudo, a mesma continua a ampliar não a diferença com a alteridade constituinte do gênero humano, e sim a curva da normalidade, ou seja, tornar diferenças antes negadas como norma, o que efetivamente não satisfaz os teóricos do modelo social. (PICCOLO, 2015 p.93)

Com o avanço do olhar social sobre a pessoa com deficiência e, a partir da Convenção da ONU, em 2008 e da aprovação da Lei Brasileira de Inclusão, popularmente conhecida como Estatuto da Pessoa com Deficiência (Lei $n^{\circ} 13.146 / 2015$ ), se pode, então, chegar aos paradigmas atualmente aceitos, para se cunhar a expressão vigente,

${ }^{1}$ International Classification Of Functioning Disability and Health (ICF). No Brasil a sigla foi adotada como CIF. 
de forma que a expressão pessoa com deficiência se vê estabelecida pelos seguintes parâmetros:

\begin{abstract}
Esta Lei tem como base a Convenção sobre os direitos da pessoa com deficiência e seu protocolo Facultativo, ratificados pelo Congresso Nacional por meio do Decreto Legislativo $\mathrm{n}^{\circ} 186$, de 9 de julho de 2008, em conformidade com o procedimento previsto no § 30 do art. 50 da Constituição da República Federativa do Brasil, em vigor para o Brasil, no plano jurídico externo, desde 31 de agosto de 2008, e promulgados pelo Decreto $n^{\circ} 6.949$ de agosto de 2009 , data de início de sua vigência no plano interno. (Lei Brasileira de Inclusão, 2015 p.8).
\end{abstract}

$\mathrm{Na}$ análise desse dispositivo legal, se evidencia, na sequência no art. $2^{\circ}$, que a Lei Brasileira de Inclusão apresenta uma definição sobre o conceito de deficiência e a necessidade de que a avaliação seja biopsicossocial, ou seja, que se avaliem os enfoques de ordem biológica, psicológica e social, em tal conceituação; e não apenas como era feito no modelo biomédico, que não levava em conta o impacto social da deficiência. Nesse sentido, então:

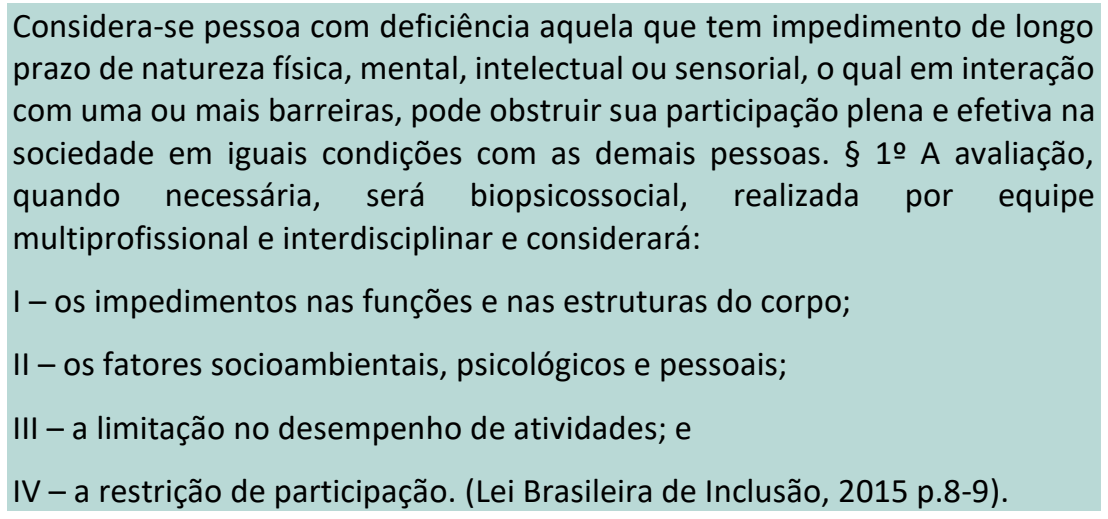

Mesmo, porém, diante dos esforços de modificação de paradigmas, levados a efeito pela ONU, em 2008; bem como das iniciativas legais instituídos no ordenamento brasileiro, como as da Lei Brasileira de Inclusão, em 2015, na tentativa de ampliar a participação e, principalmente, a fixação da ideia de que a pessoa com deficiência deve ser referida, sempre, como um ser social com possibilidade de participação em todos os níveis sociais, ainda persistem as denominações antigas e suas sérias implicações a gerar formas de exclusões. Por conta disso, a questão terminológica demonstra-se como um entrave nesse processo, visto que muitos dos termos usados carregam significados pejorativos, ou ideias que diminuem a pessoa perante a sociedade, como é o caso de deficiente, pessoa com necessidades especiais (PNE), portadores de deficiência; e os demais exemplos antes referidos. 
Essas condutas configuram, em verdade, ações capacitistas, pois segregam e classificam pessoas diante de suas características, a partir da afirmação de um caráter que fundamenta um tipo de corpo humano considerado normal e obrigatório para o desempenho de determinadas ações, nas quais as pessoas com deficiência não estariam incluídas. Portanto, nesse passo, se deve retornar às considerações acerca dos sentidos de capacitismo, antes referidas, de forma que, com Mello, se pode apresentar uma definição de capacitismo que explica perfeitamente esse ponto, uma vez que esse termo:

Tem uma conotação assumidamente agressiva, pejorativa e subversiva, a fim de marcar o compromisso em desenvolver uma analítica normalização do corpo contra todos aqueles que fogem dos padrões corporais/funcionais e cognitivos. (MELLO, Online. 2016).

Diante disso, precisamos analisar o contexto discursivo, com a finalidade de se compreender a realidade e entender a sutileza da ação capacitista, visto que ela está presente, desde a questão terminológica, até a falta de acessibilidade, inclusão, garantia de direitos, liberdades coletivas e individuais. Sendo assim, não há como definir o quanto um capacitismo pode ser mais danoso que outro, tendo em vista que toda a forma de discriminação e exclusão deve ser combatida. Mas só podemos combater aquilo que conhecemos e para temos clareza quanto a elucidar os conceitos empregados e, depois, apresentar um diagnóstico mais adequado dos problemas a serem enfrentados, se pode, igualmente, evidenciar outras perspectivas para essas circunstâncias, ainda que se careça de uma definição conclusiva para os sentidos implicados em tais usos, de forma que:

O capacitismo pode até ser uma categoria insuficiente na língua portuguesa,
mas é a capacidade de ser e que é reiteradamente negada às pessoas com
deficiências em diversas esferas da vida social. Por isso, para efeitos práticos,
proponho a sua adoção nos movimentos, nas produções acadêmicas e em
documentos oficiais de políticas públicas. (MELLO, Online, 2016).

Por conta da complexidade e da necessidade do tema, faz-se, então, importante uma reflexão e uma mudança de postura diante dos termos de representação da pessoa com deficiência, para que haja uma inclusão de fato e sem estereótipos. Nesse sentido, se deve destacar a importância dessa barreira terminológica, pois é por meio de tais expressões que se estabelecem os paradigmas a nortear as atitudes sociais diante do problema em comento, ou seja, de uma adequada inserção social e de adequado 
tratamento da pessoa com deficiência, inclusive, pela percepção de sua identidade própria, ou seja, de como essa pessoa passa a ver a si mesma, nesse contexto.

\section{ANÁLISE SINTÁTICA DOS TERMOS}

A construção de um termo carrega em si signficantes e significados que buscam representar a sociedade vigente, valores, crenças e o que naquele momento era o mais aceitável para representar aquele objeto. Tais construções semânticas mostram-se, também, em sua trajetória, como impactantes, tanto para a forma como a sociedade vê a pessoa com deficiência, como, da mesma maneira, a forma como a pessoa com deficiência acaba assimilando tais conceitos e passa a ver a si mesma.

Assim, no que tange ao conceito da pessoa com deficiência, como também já vimos, passamos por conceitos como "inválido", "aleijado", "incapacitado", "defeituoso", "desvalido", "excepcional", "pessoa deficiente", "portadores de deficiência", "pessoas com necessidades especiais" e, por fim, "pessoas com deficiência". Mas, em função dos objetivos perseguidos no presente artigo, vale destacar a seguinte questão: o que, realmente, essas palavras significam e quais os significantes que elas carregam? Pois bem, muitas vezes na busca por uma ideia de representação acabamos construíndo uma terminologia excludente. É o que explica Patrick Charaudeau:

Os dados variam, a fim de fazer com que surjam, dessas confrontações
sucessivas, conjuntos significantes, testemunhos da relação do ato de
linguagem com suas condições de produção-interpretação. Vemos que não
se trata de retomar o lugar da explicação, mas sim de um jogo de
deslocamentos de um lado para o outro, gerador de intertextualidade aberta,
lugar de conflito entre sujeito coletivo e um sujeito individual.
(CHARAUDEUAU, 2014 p.18)

A partir dessa reflexão, apresenta-se, então, nesse passo, uma breve demonstração da construção semântica, por meio da etimologia dos termos usados para representar as pessoas com deficiência. A palavra inválido, por exemplo, tem como significado simples, algo que não tem valor, fraco, sem figor nem energia. Já aleijado traz como significado alguém que tem deformidade, mutilação e que não funciona perfeitamente. A seu turno, incapacitado se traduz como o sem capacitação tanto para aptidões profissionais como para pessoais; da mesma forma que defeituoso em significado livre é aquele que apresenta defeito, imperfeito e que não consegue 
funcionar de maneira correta, como desvalido é aquele que se vê sem apoio, sem forças ou recursos.

Na construção do conceito excepcional se está diante de algo que é diferente, que não se encontra dentro dos padrões e limites e que precisa de atendimento especializado. Já pessoa deficiente, tem como positivo a inclusão da palavra pessoa, ou seja, começa, então, a se valer da ideia que permite ver que se está diante de uma pessoa, um ser social. No entanto, a palavra deficiente vem de déficit, incompleto ou que possui atributos diferentes dos que são exigidos pelos padrões definidos como de normalidade.

Na sequência vem o termo "portadores de deficiência", porém, semanticamente é um dos termos mais problemáticos já que sugere que podemos escolher ou não levar a deficiência conosco, já que portar signfica escolher carregar ou não. O mesmo racicínio cabe para "pessoas com necessidades especiais", visto que a amplitude de significados da expressão "necessidades especiais", pode abranger, por exemplo, um depósito financeiro na conta, ou mesmo o carinho da pessoa amada, ou ainda uma risada em um dia ruim. Necessidade especial não traduz o que uma pessoa com deficiência necessita, pois todos, de alguma forma, temos necessidades especiais; daí, como anteriormente referido, se evidencia o encobrimento e/ou invizibilização social das características específicas da pessoa com deficiência.

O conceito considerado mais apropriado, atualmente, é "pessoa com deficiência", que traz o conceito social (pessoa) e de saúde (deficiência), dando origem ao pensamento biopsicossocial. Apesar de ser o modelo socialmente mais correto, a supressão desse termo pela sigla PCD está trazendo uma nova problemática, que é a objetificação, ou seja, tornar a pessoa objeto, pelo uso somente da sigla, que passa a defini-lo como algo a ser assim representado. Ao transformar pessoas com deficiência em PCD, a pessoa desaparece e, novamente, regredimos. Para ver o uso em demasia dessa sigla basta observar anúncios de vagas de emprego (vagas $P C D$ ) e anúncios de veículos (carro PCD) entre outros. Dessa forma:

O campo semiolinguístico integra essas antinomias. O ato da linguagem não pode ser concebido de outra forma a não ser como um conjunto de atos significadores que falam o mundo através das condições e da própria instância de sua transmissão. De onde se conclui que o Objeto de Conhecimento é o do que fala a linguagem através do como fala a linguagem, 
um constituído do outro (e não um após o outro). (CHARAUDEUAU, 2014 p.20)

Cabe ressaltar, aqui, que essas são reflexões contemporâneas a respeito dos termos; e que tais considerações se constituem como resultado de uma análise sobre o assunto, mas que não invalidam a importância histórica do momento em que cada uma dessas expressões foi utilizada. Entretanto, alguns pontos são importantes para observarmos como esses termos nos levaram a uma visão excludente, paternalista e incapacitante da pessoa com deficiência.

Nesse sentido, pode-se perceber que a expressão "aleijado" remete diretamente ao corpo físico, ou seja, sem um físico "perfeito", de maneira que, por conta disso, a pessoa com deficiência passa a ser considerado incapaz de se integrar socialmente, enquanto que o termo "inválido" reforça essa ideia e define a pessoa com deficiência como fraca e, novamente, remente ao físico como característica predominante. "Incapacitado" e "desabilitado" seguem a mesma linha e dão a entender que, pelo fato de precisar de alguma forma de apoio, a pessoa com deficiência não dispõe de nenhuma autonomia. Por conta disso, com tais concepções enraizadas, se naturalizou a ideia de que todos deveriam ter cuidadores, vivendo sob tutela ou coratela e, até mesmo, em casas de reabilitação. Aqui fica vísivel a necessidade de uma nomenclatura inclusiva que quebre esses paradigmas e que crie condições de possibilidade de se considerar que a pessoa com deficiência é detentora, sim, de autonomia, nas mais diversas formas em que possa manifestar-se.

\section{CONSTRUÇÃO DA IDENTIDADE BRASILEIRA}

Além da questão terminológica, as pessoas com deficiência, no Brasil, apesar dos avanços legislativos antes mencionados, também enfrentam outra dificuldade social, que se traduz pela representação dos corpos, pois, mesmo com uma terminologia correta e inclusiva, do ponto de vista normativo-legal, ainda temos que lidar com a aparência, visto que muitas deficiências causam inconformidades físicas com os padrões socialmente para o de um corpo "normal", ou que dificultam essas pessoas para uma inserção social adequada. Nesse ponto, evidencia-se que, socialmente, se carregam consigo muitos estigmas e atitudes excludentes ao se exigir um corpo "perfeito" ou dentro dos padrões determinantes: 


\begin{abstract}
Há uma construção cultural do corpo, com uma valorização de certos atributos e comportamento em detrimento de outros, fazendo com que haja um corpo típico para cada sociedade. Esse corpo, que pode variar de acordo com o contexto histórico e cultural, é adquirido pelos membros da sociedade por meio da "imitação prestigiosa". Os indivíduos imitam atos, comportamentos e corpos que obtiveram êxito e que têm prestígios em sua cultura. É importante destacar que este processo de imitação não é, necessariamente, um ato consciente dos membros. (GOLDENBERG, p. 543, Online. 2011)
\end{abstract}

Diante deste cenário, uma nomenclatura verdadeiramente inclusiva e que não carregue ou represente estigmas, quer sejam biológicos ou sociais, é de grande importância para as pessoas com deficiência. Além disso, é preciso considerar o papel do corpo físico nessa construção, visto que ele faz parte das análises sociais de classe e cultura, já que é ele que define o status do indivíduo no grupo em que está inserido. Sendo assim:

A comunicação corporal ocupa posição fundamental na sua argumentação e
construção teórica, que coloca o consumo alimentar, cultural e a forma de
apresentação (incluindo o consumo de vestuário, artigos de beleza, higiene e
de cuidados e manutenção do corpo em geral) como as três mais importantes
maneiras de distinguir-se, pois são niveladoras das estruturas mais profundas
determinadas e determinantes do hábito. (CASTRO e PINTO, Online. 2014)

Vale lembrar que a identidade é uma tradição inventada, ou seja, é possível transforma-la, mas para isso seria preciso recriar um imaginário capaz de integrar diferentes corpos; e, a partir daí, construir nomenclaturas e termos de referência mais abrangentes e inclusivos. Assim, acerca dos sentidos de imaginário social, Silva diz que:

\begin{abstract}
Num sentido mais convencional, o imaginário opõe-se ao real, na medida em que, pela imaginação, representa esse real, distorcendo-o, idealizando-o, formatando-o simbolicamente. Numa acepção mais antropológica, o imaginário é uma introjeção social, a aceitação inconsciente, ou quase, de um modo de ser compartilhado pelos outros, como um antes, um durante e um depois (no qual se pode interferir em maior ou menor grau). O imaginário é uma língua. $O$ indivíduo entra pela compreensão e aceitação de suas regras; participa dele pelos atos de fala imaginal (vivências) e altera-o por ser também uma agente imaginal (ator social) em situação. (SILVA, Juremir Machado, 2003, p.09).
\end{abstract}

Para superar essa barreira tanto terminológica quanto identitária, seria, pois, preciso, então, rever os conceitos imaginais dos quais nos alimentamos, senão continuaremos criando e recriando fórmulas de representação incompletas. A seu turno, tais concepções afetam, diretamente, os processos de exclusão das pessoas com deficiência, que não se enquadram nas variáveis dessa equação, afirmadas por esse 
imaginário e, mesmo, aceitas, enquanto tal, para aqueles/aquelas que passam a se identificar com suas definições.

\section{METODOLOGIA APLICADA E PESQUISA DE OPINIÃO}

Assim, para dar conta de tais objetivos, se apresenta, agora, a análise da pesquisa de opinião veiculada em grupos de pessoas com deficiência nas redes sociais, com a finalidade de se identificar aspectos relevantes da identidade que a própria pessoa com deficiência reconhece em si própria, a partir, inclusive, dos impactos do uso da expressão capacitismo, como recorrente na mídia.

Quanto à sua metodologia, este trabalho é desenvolvido por meio de uma pesquisa exploratória, quanto ao tema do trabalho e também quanto aos conteúdos oferecidos no objeto inicial de estudo. Vale-se desse instrumento, uma vez que a pesquisa exploratória possibilita a apropriação sobre o objeto investigado, a fim de facilitar a delimitação do tema de pesquisa, fixação de objetivos e formulação de hipóteses. (PRODANOV E FREITAS, 2009). Também são utilizados dados secundários da pesquisa bibliográfica em si, que são documentos que, de alguma forma, já foram analisados, como obras literárias, publicações e obras relacionadas ao tema do trabalho. (PRODANOV E FREITAS, 2009).

\subsection{PESQUISA DE OPINIÃO}

A pesquisa apresentada abaixo não foi desenvolvida exclusivamente para esse artigo, porém, mostra-se como uma importante ferramenta para demostrar a visão das pessoas com deficiência sobre capacitismo, corpo e deficiência. A coleta de dados é facilitada pelo fato de que o autor da pesquisa interage diariamente com pessoas com deficiência na página Deficiência em Foco, onde produz conteúdos relacionados às pessoas com deficiência. 

Figura 4 - Qual a importância da terminologia "pessoa com deficiência (PCD) para você? 123 respostas

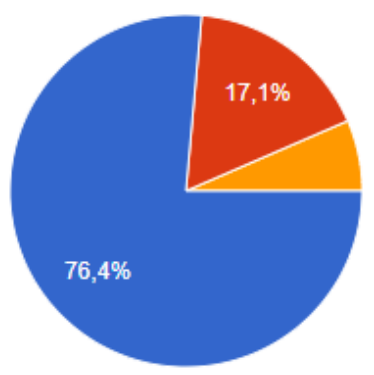

Muita, pois combate os termos antigos e que não nos representam

Pouca, não muda muito, pois as pessoas nem usam

Irrelevante

Fonte: autores da pesquisa.

No entanto, mesmo com a presença dos termos antigos, as pessoas consideram muito importante a nova nomenclatura, pois ajuda a combater estigmas e reforça o ser social presente ali.

Figura 5 - Em relação ao aspecto físico e a deficiência. Você está feliz com seu corpo? 123 respostas

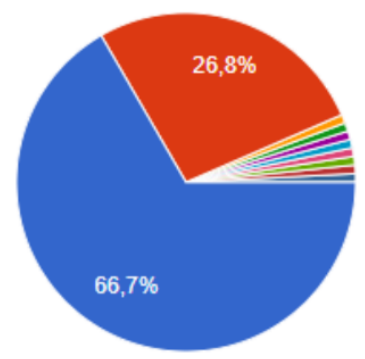

Sim

Não

Tem dias que sim, tem dias que não!

- Eu estou em processo de aceitação, $n$.

- Não sou portador de deficiência

- Acho que ninguém é feliz com a condi.

- ANTES AVC

Na maior parte do tempo sim. Mas ne.

$1 / 2 \nabla$

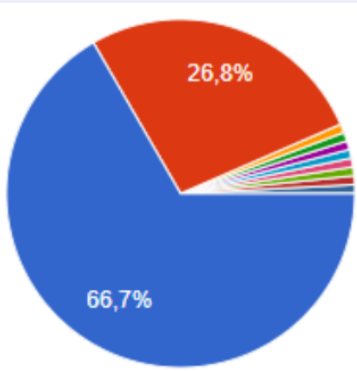

Não tem entendimento

Em processo de emagrecimento

Fonte: Autores da pesquisa.

A importância do corpo, na nossa sociedade, é determinante para a inclusão do indivíduo; e, quanto a isto, basta pensar, por exemplo, na representação dos corpos feitos pela mídia em novelas, filmes e anúncios. E como existem bem poucos corpos com deficiência nesses segmentos e quando aparecem, eis que não são apresentados grande destaque, o objetivo da pergunta foi identificar como a pessoa se sente em relação ao próprio corpo, tendo em vista que a exclusão pela aparência física também é uma forma 
de capacitismo. Provavelmente, essa questão se reveste do caráter de uma das mais problemáticas a serem consideradas, haja vista os processos de idealização estética dos corpos que se veem representados em todas essas produções midiáticas, criando esses paradigmas de exclusão da pessoa com deficiência, que não apresenta tais padrões socialmente determinados.

\section{CONSIDERAÇÕES FINAIS}

Diante do exposto acima, o capacitismo terminológico, que parece não ser tão importante, acaba sendo uma agente de exclusão dos mais significativos, visto que carrega valores históricos e culturais, que segregam a pessoa com deficiência e delimitam a sua participação social. Assim como a falta de acessibilidade, um erro terminológico pode causar a desvalorização da figura humana e consequentemente a exclusão da mesma. Conforme explica Goldenberg (2011), pois a valorização de atributos é fundamental para a representação, portanto, ao se definir alguém como deficiente, por exemplo, já se está dizendo que essa pessoa é menos que a outra, visto que deficiente tem origem em déficit, ou seja, negativo, menor ou ausente em certos atributos. Vale destacar, ainda, que sobre esse sentido das palavras, Charaudeau (2014) explica que todas as palavras carregam significantes e significados. Dessa forma, a maneira com que as empregamos faz com que elas adquiram características que irão compor a representação da própria pessoa, tornando-a inclusiva ou excludente. A seu turno, esse processo implica, diretamente, no olhar que a sociedade, como um todo, lança sobre a pessoa com deficiência, definindo, a partir disso, o lugar social a ser ocupado por essa pessoa, bem como acaba por constranger o enfoque que a própria pessoa com deficiência vem a adotar acerca de si mesma, por um processo de assimilação, por parte do indivíduo, da representação social em que se encontra inserido.

Quando falamos de representação de corpos, também é possível perceber que as pessoas se sentem mais ou menos felizes com o seu, sempre que se comparam com os padrões estéticos socialmente instituídos. No entanto, Costa e Pinto (2011) nos alertam que a comunicação corporal tem um papel importante nesse contexto, de tal forma que as pessoas podem se sentir felizes com seus corpos, mas, ao mesmo tempo, 
não se sentirem ou perceberem incluídas no contexto social onde vivem, em função desses padrões definidos.

Portanto, nessa questão terminológica, é interessante observar que há uma dicotomia, pois, ao mesmo tempo em que as pessoas acham importante a nova nomenclatura, eis que elas ainda convivem e replicam algumas das classificações antigas, seja por força do hábito, ou por estarem incluídas em um ambiente onde aquele termo seja parte do cotidiano do grupo. Para explicar isso, Silva (2003) diz que esse fenômeno faz parte do imaginário social daquele ambiente, fazendo da prática uma representação do real.

Assim, a transformação dessa realidade e a eliminação desse capacitismo só pode acontecer através da educação e da informação. Por conta disso, as instituições de ensino, por exemplo, devem cumprir seu papel discutindo e incluindo temas relacionados à inclusão em seus currículos. Mas além delas, a comunidade deve estar disposta a aprender e abandonar velhos hábitos, principalmente, buscando construir uma sociedade mais inclusiva e com menos estereótipos. Da mesma forma, as mídias, quaisquer que sejam, devem se especializar, para não acabarem difundindo tais estereótipos, geradores de exclusão social, pois acabam por desempenhar o papel de formadores de opinião pública que, assim, se vê exposta e formatada por essas visões que estimulam tal exclusão, mesmo que por meio dos mecanismos sutis abordados anteriormente.

\section{REFERÊNCIAS}

BAUMAN, Zygmunt. Medo Líquido. São Paulo: Zahar, 2008.

BRASIL. Lei Brasileira de Inclusão. Lei n 13.146/2015 de 06 de Julho de 2015. Online. Disponível em: <http://www.planalto.gov.br/ccivil_03/_ato20152018/2015/lei/l13146.htm> Acessado em mar.2020.

CASTRO, Ana Lúcia; PINTO, Renata Pires. Corporalidade brasileira na fabricação da identidade nacional. Online. 2014. Disponível em: <http://revistas.unisinos.br/index.php/ciencias_sociais/article/view/csu.2014.5 0.1.04> Acessado em mar.2020

Convenção sobre os Direitos das Pessoas com Deficiência: Protocolo Facultativo à Convenção sobre os Direitos das Pessoas com Deficiência: Decreto Legislativo no 186, de 09 de julho de 2008: Decreto no 6.949, de 25 de agosto de 2009: 
Declaração Universal dos Direitos Humanos. Disponível em: < http://www.planalto.gov.br/ccivil_03/_ato2007-

2010/2009/decreto/d6949.htm> Acessado em set.2020

CHARAUDEUAU, Patrick. Linguagem e discurso modos de aprendizagem. São Paulo: Editora Contexto, 2014.

FIGUEIRA, Emílio. Caminhando em Silêncio: Uma introdução à Trajetória das Pessoas com Deficiência na História do Brasil. São Paulo: Giz Editora, 2008.

Teologia da Inclusão: A trajetória das pessoas com deficiência na história do Cristianismo. São Paulo: Figueira Digital, 2015.

GOLDENBERG, Mirian. Gênero, "o Corpo" e a "Imitação Prestigiosa" na Cultura Brasileira. Online. 2011. Disponível em: <https://www.scielosp.org/article/sausoc/2011.v20n3/543-553/> Acessado em: mar.2020

MELLO, Anahi Guedes de. Deficiência, incapacidade e vulnerabilidade: do capacitismo ou a preeminência capacitista e biomédica do Comitê de Ética em Pesquisa da UFSC. Online. $2016 . \quad$ Disponível em: < http://www.scielo.br/scielo.php?script=sci_abstract\&pid=S1413$81232016001003265 \&$ Ing=en\&nrm=iso\&tlng=pt>. Acessado em 05 ago. 2019

PICCOLO, Gustavo Martins. Por um pensar sociológico sobre a deficiência. Curitiba: Editora Appris, 2015.

PRODANOV, Cleber Cristiano; FREITAS, Ernani Cesar de. Metodologia do Trabalho Científico: métodos e técnicas da pesquisa do trabalho científico acadêmico. Novo Hamburgo: Feevale, 2009.

RIBEIRO, Thiago Helton Miranda. Termos adequados: Primeiro a pessoa e depois a deficiência. Online. 2016. Disponível em: $<$ https://thiagohelton.jusbrasil.com.br/artigos/437759554/termos-adequadosprimeiro-a-pessoa-e-depois-a-deficiencia> Acessado em ago.2020

SILVA, Juremir Machado da. As Tecnologias do Imaginário. Rio Grande do Sul: Editora Sulinas, 2003. 


\title{
CAPITULO XXI \\ GESTÃO: O REMÉDIO QUE A SAÚDE NECESSITA
}

DOI: 10.51859/AMPLLA.PAE1993-21

\author{
Brenda Cardoso Arruda Ferreira ${ }^{1}$ \\ Thaís Araújo Vianna ${ }^{2}$ \\ Mariana Keller Campos Lima ${ }^{3}$ \\ Yasmim Souza Rodrigues ${ }^{4}$ \\ Wanda de Albuquerque Nogueira ${ }^{5}$ \\ Sandra Conceição Ribeiro Chícharo ${ }^{6}$ \\ Alex Coelho da Silva Duarte ${ }^{7}$
}

\begin{abstract}
Graduando do curso de Enfermagem. Universidade Castelo Branco/Ucb - Brasil ${ }^{2}$ Graduando do curso de Enfermagem. Universidade Castelo Branco/Ucb - Brasil

${ }^{3}$ Enfermeira, Pós graduada em Saúde da Família pela Universidade Estácio de Sá; Docente do curso técnico de enfermagem do CAP Paulo Gissoni da UCB. Rio de Janeiro, RJ - Brasil

${ }^{4}$ Graduando do curso de Enfermagem. Universidade Castelo Branco/Ucb - Brasil

5 Enfermeira, Graduada pela Universidade do Grande Rio; Pós Graduanda em Estomatoterapia e Controle de Infecção Hospitalar pela Faculdade Venda Nova do Imigrante; Cursando MBA Executivo em Saúde pela Faculdade Unyleya - Brasil

${ }^{6}$ Enfermeira, doutoranda em ciências do cuidado a saúde, mestre em ensino na Saúde pela UFF, especialista em terapia intensiva e docência do ensino superior

${ }^{7}$ Graduação em Enfermagem pelo Centro Universitário Universus Veritas - (UNIVERITAS)
\end{abstract}

\section{RESUMO}

Objetivo: desse estudo é apresentar desafios colocados para a gestão, no contexto de luta pela construção do SUS implica a constituição de novas tecnologias de governo, mobilidade das relações estratégicas, que reconheçam e afirmem a dimensão política com a produção da realidade social. Metodologia: Trata-se de uma pesquisa qualitativa, no qual buscou discutir estudos no campo da enfermagem que contemplassem a temática voltada para Gestão em saúde. Resultados: ao se abordar os pontos relacionados à qualidade em saúde e o cuidado da gestão em saúde pública aos usuários se ressalta o desafio na avaliação no âmbito da gestão do sistema único de saúde tendo como base a construção de uma agenda estratégica e organizada a partir das ações do gestor que tem como base o pacto pela saúde. Conclusão: Destaca a criação de mecanismos que articulem a decisão político-institucional, a criação de incentivos financeiros, o desenvolvimento de estratégias organizacionais de qualificação das equipes de gestores; nas suas diferentes esferas e tendo como base um amplo processo de cooperação.

Palavras-chave: Gestão em saúde, Sistema Único de Saúde, Gestão de Qualidade. 


\section{INTRODUÇÃO}

O tema gestão mobiliza estudiosos, analistas, executivos de todas as áreas da sociedade. É um assunto polêmico que apresenta diversas opiniões, quer sejam na discussão de modelos, instrumentos, técnicas e práticas, ou no próprio perfil dos gestores e profissionais da área. O nosso modelo de gestão é, na verdade, fazer essas escolhas. Escolhas sobre como vamos coordenar nossas atividades, escolhas sobre as nossas metas, como priorizá-las e escolhas sobre como motivar a nós mesmos e aos outros indivíduos envolvidos no processo.

Trazendo este conceito para o nível das organizações, destacam que o modelo de gestão é produto do subsistema institucional e que representa as principais determinações, vontades e expectativas do gestor, de como as coisas devem acontecer na empresa. Sendo assim, o modelo de gestão é o instrumento de gestão mais significativo seria o conjunto de normas e princípios que orientam os gestores na escolha das melhores alternativas para levar a empresa a cumprir sua missão com eficácia (TAMADA et al., 2013).

Saúde pública no Brasil é coisa séria, que merece respeito e mais informações sobre como tudo funciona. A leitura do "Manual do(a) Gestor(a) Municipal do SUS" é dever de casa para os bons gestores, mas serve também como guia para quem deseja conhecer o sistema. Ser gestor(a) do SUS é manter diálogo permanente com o profissional de saúde, ator principal na consolidação das práticas de saúde do município. Uma boa gestão tem relação direta com a qualidade do atendimento. O SUS é muito complexo, exige conhecimentos específicos. Muitos gestores são profissionais de saúde sem nenhuma experiência ou formação em gestão. Entender toda essa complexidade e lidar com a rotina dos problemas diários, de olho nas melhores soluções, são os desafios dos que querem e devem ser os bons gestores da saúde (PINHEIRO et al., 2016).

\section{METODOLOGIA}

Trata-se de uma pesquisa qualitativa, no qual buscou discutir estudos no campo da enfermagem que contemplassem a temática voltada para Gestão em saúde. Inicialmente foi realizada uma revisão de literatura através da busca de artigos utilizando os seguintes descritores: "Gestão em saúde", "Sistema Único de Saúde", 
"Gestão de Qualidade", indexados nas seguintes bases de dados, Biblioteca Virtual em Saúde (BVS) e Scielo. Onde somente 05 artigos foram incluídos como fundamentadores deste estudo.

O texto foi organizado em duas partes, com abordagem nas temáticas: "Gestão em organizações de saúde", "Novas tendências, responsabilidades e desafios". Após análise observou-se que é preciso esclarecer que para entender a questão, é necessário acabar com alguns mitos: a gestão do sistema de saúde permanece como uma atividade exclusiva e indelegável do Estado. O objetivo é oxigenar as unidades, aproximando-as do conceito privado, de modo que os usuários do SUS (Sistema Único de Saúde) sejam atendidos em centros públicos de saúde equiparáveis aos privados. Essa melhoria na qualidade e redução de custos tem sido experimentada no estado do Rio de Janeiro.

O contrato tem metas quantitativas e qualitativas mensuráveis, que precisam ser cumpridas para que a entidade parceira receba as verbas de custeio a serem aplicadas. O acompanhamento é feito pelas secretarias de Saúde, com base na apresentação mensal de indicadores de produção, analisados por comissões de controle e fiscalização.

Por fim, o modelo tem possibilitado aos estados executar a segunda parte do processo de reforma. Uma etapa endógena, que passa por reformular seu quadro de servidores, pagando-os de acordo com o mercado e mantendo os que contribuam com a redefinição de seu papel. Um estado planejador de políticas públicas eficazes, alinhadas com as necessidades da população, é um fiscalizador de metas e resultado.

\section{RESULTADOS}

Ao se abordar os pontos relacionados à qualidade em saúde e o cuidado da gestão em saúde pública aos usuários se ressalta o desafio na avaliação no âmbito da gestão do sistema único de saúde tendo como base a construção de uma agenda estratégica e organizada a partir das ações do gestor que tem como base o pacto pela saúde.

Os termos gestão e administração referem-se ao ato de governar pessoas, organizações e instituições. Política, portanto, gestão diz respeito à capacidade de dirigir, isto é, confunde-se com o exercício do poder. Em sua origem, na Grécia clássica, o termo 'política' tinha exatamente esse significado. 'Polis' era a cidade, e a política era a capacidade de fazer a gestão democrática das cidades estado (GUALEJAC, 2007). 
Vale a pena ressaltar essa relação entre gestão e política porque a constituição da administração e da gestão, como um campo estruturado e sistemático de conhecimento, pretendeu, exatamente, produzir uma ruptura ou uma descontinuidade entre a política e a gestão (CAMPOS, 2000).

A gestão do Sistema Único de Saúde (SUS) é um processo pelo qual equipes gestoras (sujeitos) tomam decisões na implementação da Política de Saúde. Os bancos de dados e Sistemas de Informação em Saúde (SIS) constituem ferramentas importantes para o planejamento e a avaliação das políticas de saúde, assim como dos serviços, redes e sistemas de saúde (TAMAKI et al.,2012).

O Brasil passa por um momento em que movimentos sociais pedem mais educação, segurança e saúde. São bandeiras legítimas e, sobre a necessidade de melhorias nos setores, não há dissenso. Embora os pleitos sejam importantes, creio que a saúde esteja à frente dos demais.

Organizações de saúde, independente do tamanho, são sempre complexas. Seus processos são padronizados por regras impostas pelo governo, compradoras de serviços e representantes de classe. A sua mão de obra é altamente especializada e qualificada. Diante disso estão presentes profissionais de diferentes áreas no mesmo ambiente de trabalho (médicos, enfermeiros, nutricionistas, farmacêuticos, fisioterapeutas, etc.) o que leva a interesses nem sempre convergentes (TAMADA et al., 2013).

A gestão do sistema de saúde permanece como uma atividade exclusiva e indelegável do Estado. O objetivo é oxigenar as unidades, aproximando-as do conceito privado, de modo que os usuários do SUS sejam atendidos em centros públicos de saúde equiparáveis aos privados.

Gerenciar uma organização de saúde pressupõe o entendimento de toda essa complexidade. Tal situação é conflitante, com a necessidade de inovação contínua dos processos que visa manter a competitividade no mercado. Manter-se competitivo requer inovação, que aumenta a satisfação do cliente e que a torna fiel à organização. Isso por sua vez diminui os custos dos serviços, que acaba viabilizando maiores investimentos em inovação. É o que chama de Ciclo da Inovação Corporativa das Organizações Prestadoras de Serviços. Garantir a competitividade e a inovação contínua é um grande desafio para a gestão das organizações de saúde. Lidar com a diversidade de profissionais, que requerem certa autonomia, só é possível num ambiente que 
possibilite o diálogo e a negociação. Ao mesmo tempo, em que se preocupam com suas carreiras profissionais, esses colaboradores devem ser envolvidos nos objetivos da organização (TAMADA et al., 2013).

O método denominado 'atenção gerenciada' (managed care), que vem sendo proposto para os serviços de saúde, é exemplar dessa tendência. Imagina diminuir custos e aumentar a eficácia do trabalho em saúde, retirando dos profissionais, particularmente dos médicos, a capacidade de decisão sobre o próprio trabalho clínico. Esse poder é passado aos gerentes, que por meio de minuciosos protocolos padronização de condutas diagnósticas e terapêuticas controlam e determinam o que fazer no cotidiano dos trabalhadores (CAMPOS, 2000).

\section{CONCLUSÃO}

Destaca-se a criação do mecanismo que articulem a decisão políticoinstitucional, a criação de incentivos financeiros, o desenvolvimento de estratégias organizacionais de qualificação das equipes de gestores, nas suas diferentes esferas e tendo como base um amplo processo de cooperação.

A gestão em saúde é um desdobramento contemporâneo. Evidente que no lugar da guerra entraram conceitos originários da Ciência Política, da Sociologia e da Teoria Geral da Administração. O Estado foi responsabilizado pelo financiamento e gestão de uma rede de serviços constituída segundo o conceito de integração sanitária. Essa rede pública não executaria apenas ações de caráter preventivo e de relevância coletiva, mas assumiria também a atenção clínica, ou seja, a assistência individual em hospitais e outros serviços (GUALEJAC, 2007).

Considerando a complexidade das organizações de saúde e a relevância dos serviços prestados à sociedade, novos modelos de gestão tornam-se necessários e imprescindíveis para as organizações alcançarem níveis de excelência na prestação de serviços. Nível de eficiência, eficácia e efetividade que o mercado atual exige e cobra. Assim como não há um modelo de gestão ideal, uma receita única para o sucesso de qualquer organização, da mesma forma as organizações de saúde devem levar em conta sua história, missão, visão e valores, assim como a cultura organizacional. Todos esses fatores tornam uma organização única, o que demanda, ações específicas de gestão. Assim são destacados apenas os modelos da Gestão da Qualidade, das Redes de Atenção 
à Saúde (RAS), da Gestão Estratégica e da Gestão Participativa Cogestão, como algumas possibilidades para o enorme desafio nesta área (TAMADA et al., 2013).

- Gestão da Qualidade: É perceptível nos últimos anos a abordagem do tema qualidade e seus métodos para alcançar uma prestação de serviços com qualidade na área da saúde, uma tendência que busca fortalecimento e estratégias interada a um conjunto de intervenção na organização de saúde.

- Redes de Atenção à Saúde (RAS): Redes são sistemas organizacionais capazes de reunir indivíduos e instituições, de forma democrática e participativa, em torno de causas afins. Estruturas flexíveis e estabelecidas horizontalmente, as dinâmicas de trabalho das redes supõem atuações colaborativas e se sustentam pela vontade e afinidade de seus integrantes, caracterizando-se como um significativo recurso organizacional para a estruturação social.

- Gestão Estratégia: O conceito de gestão estratégica é muito mais amplo e abrangente em relação ao planejamento estratégico. Engloba desde as avaliações de diagnósticos e de prontidão, a estruturação do processo de planejamento e formulação de um propósito compartilhado para a organização, a escolha de estratégias, a fixação de metas e desafios, até a atribuição de responsabilidades para o detalhamento dos planos, projetos e a condução e acompanhamento das etapas de sua implantação, processos formais de revisão dos planos para mantê-lo sempre adequados as realidades externas e internas da organização. Sendo assim podemos afirmar que a gestão estratégica é um processo sistemático, planejado, gerenciado, executado e acompanhado sob liderança da alta administração da instituição, envolvendo e comprometendo todos os gerentes, responsáveis e colaboradores da instituição. Quando o processo e a metodologia de trabalho são adequados, consegue-se o envolvimento e o comprometimento de todos aqueles que têm uma contribuição efetiva na elaboração e execução das transformações necessárias, onde as pessoas e os processos deixam de ser parte do problema para tornarem-se parte da solução.

São desse período o desenvolvimento de estudos sobre sistemas locais de saúde, modelos de atenção, gestão de pessoal, atenção primária, planejamento e programação 
em saúde. Observa-se como um fato curioso o pequeno envolvimento da área de Gestão e Planejamento (GUALEJAC, 2007).

Afirma que diversas iniciativas para a avaliação em saúde no Brasil vêm sendo desenvolvidas de forma progressiva, nas últimas três décadas, e ressalta que na presente pode-se afirmar que o interesse pela avaliação não se restringe ao âmbito acadêmico, e que o próprio Ministério da Saúde tem encomendado um conjunto de estudos nessa perspectiva, não só por exigência de financiamento externo, mas devido a uma crescente consciência de responsabilização entre seus técnicos e dirigentes. (VIDOR et al.,2011)

Buscando superar a perspectiva restrita das teorias administrativas têm sido desenvolvidas análises que procuram ampliar e democratizar a gestão. Discute-se a gestão participativa, o controle social dos gestores pela sociedade civil e várias formas de cogestão em saúde (GUALEJAC, 2007).

As transformações tecnológicas da atualidade, aliadas à globalização, exigem mudanças constantes nas organizações. Para garantir sua competitividade, empresas públicas ou privadas, mais do que nunca buscam a satisfação de seus clientes através da prestação de serviços de qualidade. Nas organizações de saúde os avanços tecnológicos, políticas públicas mais efetivas e a preocupação com a realização profissional e pessoal do trabalhador, demandam um novo olhar para esta gestão (TAMADA et al., 2013).

Os novos modelos apresentados mostram-se mais universais, participativos, integrados e focados na excelência da prestação dos serviços à população. São, finalmente, novas ideias que demandam uma nova postura dos gestores, aberta às mudanças necessárias e aos novos e inevitáveis desafios que se apresentam no mundo do século XXI (TAMADA et al., 2013).

\section{REFERÊNCIAS}

TAMADA, Rosane Cristina Piedade; BARRETO, M. F. S.; CUNHA, I. C. K. O. Modelos de gestão em saúde: novas tendências, responsabilidades e desafios. In: Congresso Online-administração. São Paulo: Convibra. 2013.

PINHEIRO, Alba Lúcia Santos et al. GESTÃO DA SAÚDE: O USO DOS SISTEMAS DE INFORMAÇÃO E O COMPARTILHAMENTO DE CONHECIMENTO PARA A TOMADA DE DECISÃO1. Texto \& Contexto-Enfermagem, v. 25, 2016. 
GAULEJAC, Vincent de. Gestão como doença social: ideologia, poder gerencialista e fragmentação social. In: Gestão como doença social: ideologia, poder gerencialista e fragmentação social. 2007. p. 338-338.

CAMPOS, Gastão Wagner de Sousa. Um método para análise e co-gestão de coletivos. In: Um método para análise e co-gestão de coletivos. 2000. p. 236-236.

TAMAKI, Edson Mamoru et al. Metodologia de construção de um painel de indicadores para o monitoramento e a avaliação da gestão do SUS. Ciência \& Saúde Coletiva, v. 17, p. 839-849, 2012.

VIDOR, Ana Cristina; FISHER, Paul Douglas; BORDIN, Ronaldo. Utilização dos sistemas de informação em saúde em municípios gaúchos de pequeno porte. Revista de Saúde Pública, v. 45, p. 24-30, 2011.

Brow GD. Managed Car. ed. Springfiel: Merrian-Webster Inc; 1996.

FERLA, Alcindo Antônio; CECCIM, Ricardo Burg; ALBA, Rafael Dall. Informação, educação e trabalho em saúde: para além de evidências, inteligência coletiva. Revista Eletrônica de Comunicação, Informação e Inovação em Saúde, v. 6, n. 2, 2012.

FERLIE, E; ASBURNER, L; FITZGERALD, L; PETTIGREW, A. A nova Administração pública em ação. Brasília: ENAP, 1999.

HOUAISS, Antônio; VILLAR, Mauro de Salles; FRANCO, Francisco Manoel de Mello. Dicionário Houaiss da língua portuguesa. In: Dicionário Houaiss da língua portuguesa. 2001. p. Ixxiii, 2922-Ixxiii, 2922.

LORENZETTI, Jorge et al. Gestão em saúde no Brasil: diálogo com gestores públicos e privados. Texto \& Contexto-Enfermagem, v. 23, p. 417-425, 2014.

LORENZETTI, Jorge et al. Tecnologia, inovação tecnológica e saúde: uma reflexão necessária. Texto \& Contexto-Enfermagem, v. 21, p. 432-439, 2012.

Lourau R. A Análise Institucional. 2 ed. revisada. Tradução Ferreira M. Petrópolis/RJ: Editora Vozes; 1995.

MORGAN, Gareth; BERGAMINI, Cecília Whitaker; CODA, Roberto. Imagens da organização. São Paulo: Atlas, 1996.

MOTTA, F.C.P.; VASCONCELOS, I.G.V. Teoria Geral da Administração. São Paulo: Cengage Learning, 2006. 
BINOTTO, Erlaine; SIQUEIRA, Elisabete Stradiotto; NAKAYAMA, Marina Keiko. Criação de Conhecimento no Agronegócio: estudo de casos. Revista de Administração da UFSM, v. 2, n. 3, p. 367-384, 2009.

ROCHA, Elyrose Sousa Brito et al. Gestão do conhecimento na saúde: revisão sistemática de literatura. Revista latino-americana de enfermagem, v. 20, p. 392-400, 2012.

SANTOS, Cleide Moreira; DE CARVALHO, Gres Micaeli Moreira. ERGONOMIA: SURGIMENTO DE DOENÇAS NO AMBIENTE PROFISSIONAL E SOLUÇÕES PARA COMBATÊ-LAS. Caleidoscópio, v. 6, n. 1, p. 235-242, 2014.

TESTA, Mario. Decida sobre a saúde: Quem?,Como? e por quê? Saúde coletiva,v. 3, p. 247-257, 2007.

TRAGTENBERG, Maurício. Burocracia e ideologia. Editora Unesp, 2006. 


\title{
CAPITULO XXII
}

\section{REFLETINDO SOBRE POLITICAS PÚBLICAS DE SAÚDE PELA ÓTICA CINEMATOGRÁFICA: UMA ANÁLISE DO DOCUMENTÁRIO 'SICKO: SOS SAÚDE'}

DOI: 10.51859/AMPLLA.PAE1993-22

\author{
Naila Caroline Barbosa de Morais ${ }^{1}$ \\ Jonas Vitor de Araújo Silva ${ }^{1}$ \\ Bárbara Luna Lacerda ${ }^{1}$ \\ Ihago Saraiva de Alencar Silvestre ${ }^{1}$ \\ Gabriel da Silva Brito ${ }^{1}$ \\ João Paulo Xavier Silva ${ }^{2}$
}

\begin{abstract}
${ }^{1}$ Graduando(a) do curso de Enfermagem. Centro Universitário Doutor Leão Sampaio - UNILEÃO
2 Enfermeiro. Doutorando em Cuidados Clínicos em Enfermagem e Saúde pela Universidade Estadual do Ceará-UECE e Docente no Centro Universitário Doutor Leão Sampaio.
\end{abstract}

\section{RESUMO}

A evolução do modelo de saúde do Brasil foi resultado de um conjunto de mobilizações da população. Uma das conquistas alcançadas foi implantação do Sistema Único de Saúde, através de um marco significativo da Reforma Sanitária, a 8a Conferência Nacional de Saúde. Por insciência, parte expressiva da coletividade subestima essa conquista e aprecia países mais ricos. O "Sonho americano", constantemente idealizado por muitos, torna-se questionável diante dos fatos evidenciados pelo documentarista Michael Moore. O cenário caótico de saúde dos Estados Unidos é alarmante, no qual as pessoas têm atendimento assistencial de acordo com o seu nível socioeconômico. Em contrapartida, o modelo de saúde pública adotado no Brasil presta serviços, até de alta complexidade, para todos, independente da sua renda e status social. Refletir sobre essa dessemelhança é de grande relevância, uma vez que desenvolve e fortalece o reconhecimento da riqueza do SUS e evidencia o risco do seu desmonte.

Palavras-chave: Sistema Único de Saúde. Brasil. Plano de Saúde. 


\section{INTRODUÇÃO}

Para admirar, reconhecer e aprimorar o SUS, é preciso conhecer sua história e entender que, verdadeiramente, é fruto de uma luta social. Entretanto, não somente prezar, mas perceber que existem ameaças de retrocesso. É de conhecimento coletivo que a saúde pública no Brasil não era e, até hoje, não é suficientemente o foco de aplicação do capital do país. Todavia, o aperfeiçoamento desse serviço público é incontestável, uma vez que, durante décadas, a assistência à saúde era vinculada a previdência social e atualmente esse modelo não é mais vigente, por ação da seguridade social contemplada no Art. 194 da Constituição Federal (BRASIL, 1988).

Ademais, em consideração a tantos esforços da população durante o Movimento da Reforma Sanitária, o conceito de saúde foi modificado, não era somente a ausência da doença. Saúde, de acordo com o Art. 196 da Constituição Federal, passou a ser um direto social, ou seja, tornou-se desassociado com a situação previdenciária do cidadão (BRASIL, 1988).

Falha no repasse de verbas e na gestão de insumos, longas filas de espera e falta de leitos são alguns dos casos que favorecem para a desvalorização do sistema. Isso incentiva a população a contrapor o Brasil com outros países considerados mais ricos. $O$ documentário SiCKO - SOS Saúde, apresenta criticamente a realidade da assistência à saúde de um país desenvolvido, considerado potência mundial por muitos: os Estados Unidos da América. Mostra que por trás de toda propaganda e glamour há um sistema nacional de saúde sucateado, com o objetivo, não de prestar assistência, mas sim o lucro que cada usuário pode gerar para os planos de saúde. Ter acesso, assistir e compreender o que é exposto na película é primordial para somar ao fortalecimento do Sistema Único de Saúde e lembrar onde não se deve chegar quando se trata de metas de políticas públicas da saúde brasileira.

Nesse viés, estabelecendo um paralelo da sistematização de saúde populacional do Brasil com os EUA, faz-se nítida a necessidade da valorização e defesa do SUS, bem como a necessidade de partilhar conhecimento acerca das políticas públicas de saúde, e o que deve ser oferecido às pessoas por direito. A condição utilizada para comparação apresenta-se como um mecanismo de segregação social, no qual não apenas prioriza, 
mas somente permite que indivíduos possuidores de um capital significativo realizem procedimentos de emergência, prevenção e promoção a saúde.

Fazendo alusão ao estudo de Friederich Engels (1986), no qual apresenta a interferência da condição de vida dos proletários da Inglaterra na produção da saúde, por volta do ano de 1800 . Notoriamente observações nesse âmbito são executadas há bastante tempo, nas quais correlatam assertivamente doença à pobreza. Engels soma às suas evidências, fatores de agravos e mortes, denotando isso como degradação da dignidade humana. (CAMPOS et al., 2006, P. 111)

\section{REVISÃO BIBLIOGRÁFICA}

\subsection{CENAS/ACONTECIMENTOS IMPACTANTES DO DOCUMENTÁRIO S.I.C.K.O. S.O.S. SAÚDE}

Michael Moore, o documentarista crítico que apresenta a realidade da assistência à saúde dos estados unidos, mostra muitas cenas que oscilam entre o espanto e a angústia. Já no início, a história de Rick, o homem que serrou a ponta dos dedos, traz uma inquietação muito grande, quando ele tem que decidir qual dos dedos vai poder salvar, porque para a recuperação deles, cada um tem um valor.

Outra exposição que expressa o modelo de mercantilização da saúde, é a atividade dos planos de saúde. Mais de 50 milhões de americanos não possuem esse benefício e, mesmo os que o tem, pagam por fora taxas que não são cobertas pelo plano, como no caso de Larry e a esposa, que tiveram que vender a casa para pagar a dívida; o senhor de 79 anos que precisa trabalhar pra ter acesso aos remédios e, conformado com a situação, relata: "Meus remédios são de graça, por isso tenho que seguir trabalhando, não há nada de errado nisso".

Ademais, a assistência prestada por esses planos é de imensa repulsa. O fato de existir uma lista de doenças pré-existentes que desaprova uma pessoa a adquirir o plano é vergonhoso; Colaboradores que procuram falhas no histórico médico das pessoas para conseguir negar um tratamento; médicos que ganham bônus por recusar assistência são exemplos de desumanidade.

Como fica a esposa que perdeu o marido por câncer renal? Um transplante de medula poderia ter salvo sua vida, e o plano recusou alegando ser experimental. A mãe 
que perdeu a filha de 18 meses porque o plano não autorizou ser tratada no hospital mais próximo da sua casa, a criança estava com febre, teve convulsão e, depois de horas de espera, uma parada cardíaca. Quem ou o que é responsável pela morte dessas e outras pessoas?

Quando Michael viaja para outros lugares (Canadá, Reino Unido, França e Cuba) e se depara com um SNS (Sistema Nacional de Saúde) do Reino Unido, por exemplo, ele presencia uma assistência universal, gratuita e de qualidade. Os médicos britânicos que, ao contrário dos americanos, recebem bônus se tratarem mais pacientes. O relato do médico que participa do filme expressa um contraste gigante: "Eu fico feliz em trabalhar em um sistema que me dá liberdade de ajudar as pessoas".

Um dos depoimentos que chama atenção é do ex-membro do parlamento do Reino Unido, Tony Benn, em que ele explica como o país chegou naquele modelo de atenção à saúde. Tony diz: "A democracia levou o poder do mercado para a mesa de votação" e soma lendo um panfleto sobre o SNS de 1948 "[...] mas não é caridade, você está pagando por ele como contribuinte e ele o livrará de preocupações com dinheiro na hora da doença.", perceber o governo tomando para si a responsabilidade da saúde da população, é marcante.

\subsection{IMPORTÂNCIA DE UM SISTEMA DE SAÚDE PÚBLICO}

De acordo com o levantamento da FGV social (2021), 12,8\% da polução brasileira passou a viver com menos de $\mathrm{R} \$ 246$ ao mês ( $R \$$ 8,20 por dia). Portanto, é notório que o Brasil há longos anos vem enfrentando problemas com a desigualdade social e, como mostra os dados, hodiernamente à situação se agravou ainda mais. Em consonância disto, essa população passou a sobreviver até mesmo sem as necessidades básicas. Diante destes fatos, fica perceptível a importância de um sistema de saúde público em um país com estas circunstâncias.

Se relembrar a história do Brasil de algumas décadas atrás, é possível identificar o descaso no qual os brasileiros enfrentavam em relação ao acesso a saúde, naquela época somente pessoas com algum vínculo trabalhista tinham direito a assistência médica. Diante da pandemia da Covid-19, no qual já foram vacinadas mais de 300 milhões de pessoas, caso não fosse ofertado um sistema de saúde gratuito, com certeza o número de vítimas seria ainda maior, uma vez que a taxa de desemprego aumentou 
consideravelmente e muitas pessoas precisaram de assistência e medicamentos. No entanto, graças ao SUS, houve um esforço para minimizar os impactos e as consequências não foram maiores. (BRASIL, 2021)

No ano de 2015 , mais de $60 \%$ da população brasileira estava vinculada com a Estratégia de Saúde da Família. Especificamente no Nordeste, essa cobertura ainda é maior, de 76\%. Isto quer dizer que mais da metade do país passou a ser usuário do Sistema Único de Saúde por meio da Atenção Básica, principal porta de entrada para o sistema e, essencialmente, gerador da promoção de saúde. (VIAVACA et al., 2018, P. 8)

A ação da vigilância sanitária, que está dentro das competências do SUS, firma o quanto a fiscalização, controle e regulamentação de produtos e serviços são importantes para a promoção de saúde. Portanto, aos países, principalmente os mais pobres, onde a população está mais vulnerável, é de suma importância à implementação de um serviço público universal e gratuito.

\subsection{DESMONTE DO SUS E SEU IMPACTO NA SAÚDE DO BRASILEIRO}

Adversidades como a demora no atendimento, falta de profissionais, má qualidade na infraestrutura dos serviços públicos, recursos insuficientes, favorecem a introdução de ideias neoliberais e somam forças para que o SUS seja menosprezado. Mesmo que a participação complementar do setor privado esteja amparada pela lei 8080/90, a terceirização demasiada de serviços públicos para setores privados, a concepção de estado mínimo, evidenciam o desmonte do SUS. (PINHEIRO et al., 2020, P. 2)

Mas se, mesmo assim, optando por opções neoliberalistas, o Brasil preferisse por privatizar o sistema de saúde único e universal sob a justificativa de "aumentar a qualidade dos serviços, devido ao aumento da concorrência", quais seriam os efeitos disso sobre a população e a política? Não precisa ir muito longe para saber a resposta. Por exemplo, pode-se analisar a maior inspiração para esse ideal de privatização, característica do desmonte do SUS: os Estados Unidos da América.

Mesmo se tratando de um país de primeiro mundo, as políticas de saúde são das mais retrógradas possíveis. O motivo: a Guerra ao Lucro, travada entre os planos de saúde sob a política de não assistência e os preços exorbitantes sobre procedimentos, medicamentos e internações. Enquanto no Brasil, normas operacionais do SUS 
estimulam internações e o cuidado, inclusive financeiramente; nos EUA a aprovação de uma simples internação é vista como uma perda drástica de dinheiro para hospitais e planos de saúde.

Muito além de não poder ficar doente, o modelo privado exige uma saúde utópica durante toda a vida para poder, ao menos, ter o direito a uma análise de um requerimento de procedimento. Tal modelo é a reprodução do monopólio de poder e de capital e uma lembrança de como o capitalismo pode ser cruel. Tal panorama, se implementado, representa não só a perda de direitos sociais ou um ato inconstitucional, mas também anos de lutas sendo apagados para que uma prática homicida, permeada por corrupção, seja aprovada legalmente.

\subsection{MOVIMENTO PELA DEFESA E VALORIZAÇÃO DO SUS}

Realizando um comparativo da sistematização de saúde do Brasil com os EUA, faz-se nítida a necessidade da valorização e defesa do SUS, pois se não há políticas públicas de saúde sendo aplicadas no país, algo que deveria ser oferecido às pessoas por direito, torna-se um meio de segregação social, no qual não apenas prioriza, mas somente permite que indivíduos possuidores de um capital significativo realizem procedimentos de prevenção e promoção a saúde.

No Brasil, a maior arma foi e continua sendo a democracia. Durante a Reforma Sanitária, várias classes e movimentos sociais contribuíram para a criação do SUS, e é necessário que essa participação social seja constante. Por meio de congressos, conselhos municipais/estaduais/federais de saúde e manifestações, a população tem o poder e o direito de fiscalizar e interferir no direcionamento das políticas públicas, podendo colaborar contra o seu possível desmonte. (PINHEIRO et al., 2020)

A 16a Conferência Nacional de Saúde, que aconteceu no mês de agosto de 2019, teve como tema "Democracia e Saúde", contou com a colaboração de mais de 5 mil pessoas que puderam avaliar a condição de saúde, elaborar propostas a partir das necessidades do país e abordar sobre políticas que objetivavam impedir o retrocesso. Essa conferência foi significativa no que tange ao fortalecimento da defesa do SUS. (GARCIA, 2020)

Destarte, posicionar-se a favor e defender o SUS é participar de um movimento que intenta aspectos positivos ao povo. A luta por melhorias nesse sistema impacta 
diretamente na qualidade e expectativa de vida da população, essa que além de conhecer os seus direitos e deveres, deve manifestar-se de maneira fidedigna ao mínimo sinal de ameaça.

\subsection{POLÍTICAS PÚBLICAS DE SAÚDE: RELAÇÕES COM O DOCUMENTÁRIO S.I.C.K.O. S.O.S. SAÚDE}

Segundo o Ministério da Saúde (2018), políticas públicas de saúde são ações do Governo Federal, Estadual e Municipal que compreende as estratégias e diretrizes adotadas pelo país para organizar a assistência às pessoas com necessidades de tratamento e cuidados em saúde. Essas políticas são executadas através do nosso sistema de saúde universal, que é o sistema único de saúde (SUS), o mesmo foi pensado e planejado na VIII conferência nacional de saúde e foi instituído na constituição federal de 1988. (BRASIL, 2018)

Na constituição de 1988 esse sistema de saúde é colocado no Art. 196 como: “A saúde é direito de todos e dever do Estado" essa é a realidade brasileira, ao contrário dos EUA que a assistência é exclusivamente do setor privado e livre da responsabilidade do governo americano, além disso, a assistência do setor privado dos planos de saúde das grandes empresas como a Cigna, Horizon, e a Blue of California é de difícil acesso e os tratamentos classificados como caros e complexos são rotineiramente rejeitados pelos profissionais que ganham mais para fazer isso. No Brasil, de acordo com o Art. 199 da Carta Magna, o setor privado é colocado como uma assistência complementar ao sistema único de saúde. (BRASIL, 2021)

E se tratando de políticas públicas assistencialista temos a França, onde 0 governo francês proporciona assistência de qualidade a sua população, mas para aqueles que são assalariados pagam uma taxa pelo uso de seus medicamentos presente na rede governamental, o que difere do Brasil que todo medicamento estabelecido na rede SUS é ofertado gratuitamente para qualquer classe social, independentemente da renda do cidadão segundo a lei 8.080/90.

\section{CONSIDERAÇÕES FINAIS}

Este trabalho se propôs, com principal objetivo, elaborar uma reflexão sobre políticas públicas de saúde a fim de que possa contribuir sobre uma nova óptica, a 
importância desse complexo para a sociedade brasileira, a valorização e defesa do Sistema Único de Saúde (SUS), na perspectiva de incidir o leitor a lutar pela permanência dessa ferramenta que é essencial para a sociedade brasileira.

Pode-se afirmar, que o sistema de saúde pública no Brasil está enfrentando uma série de conturbações e consequentemente espelhando aos brasileiros uma visão que o SUS não tem mais condições de ser um órgão público, sendo discutido bastante sua privatização. Levando-se em consideração a situação econômica atual do país, cabe uma reflexão: Será que diante a privatização desse sistema de saúde, a população brasileira terá uma melhor qualidade de vida?

Diante dos fatos evidenciados no estudo, fica claro que um sistema de saúde privado acarreta ainda mais nos problemas sociais, uma vez que de uma simples até uma complexa assistência médica os valores são despropósitos. No entanto, em um país como o Brasil, onde a desigualdade assola a maioria da população, o fim da gratuidade desse programa levaria a uma catástrofe irreparável.

Portanto, informar sobre os benefícios trazidos pelo o SUS ao Brasil, é suma importância, para que desta maneira o paradigma no qual somente a privatização é a melhor saída, seja quebrado, como também fazer com que os brasileiros renovem suas esperanças e possam lutar pela sua permeância e melhoria.

\section{REFERÊNCIAS}

BRASIL ECONÔMICO. Brasil tem taxa de pobreza extrema maior do que no início da década passada. Economia. 2021. Disponível em: https://economia.ig.com.br/2021-01-31/brasil-tem-taxa-de-pobreza-extremamaior-do-que-no-inicio-da-decada-passada.html.amp. Acesso em: 2 nov. 2021.

BRASIL, Ministério da Saúde; Secretaria de Vigilância em Saúde; Secretaria de Atenção à Saúde. Política Nacional de Promoção da Saúde (PNPS). 1ạ ed. Brasília: MS, 2018. $42 \quad$ p. $\quad$ Disponível em: https://bvsms.saude.gov.br/bvs/publicacoes/politica_nacional_pro mocao_saude.pdf. Acesso em: 3 nov. 2021.

BRASIL, Ministério da Saúde. Vacinação: \#PatriaVacinada. gov.br. Brasília, 2021. Disponível em: https://www.gov.br/saude/pt-br/vacinacao. Acesso em: 23 nov. 2021. 
BRASIL. Congresso Nacional. Lei n. 8080, de 18 de setembro de 1990. Diário Oficial da União, ano $1990 . \quad$ Disponível em: http://www.planalto.gov.br/ccivil_03/leis//8080.htm. Acesso em: 9 nov. 2021.

BRASIL. Congresso Nacional. Lei n. 8142, de 27 de dezembro de 1990. Diário Oficial da União, ano $1990 . \quad$ Disponível em: http://www.planalto.gov.br/ccivil_03/leis//8142.

htm. Acesso em: 3 nov. 2021.

BRASIL. Constituição. República Federativa do Brasil de 1988. Brasília, DF. Senado Federal, $1988 . \quad$ Disponível em: http://www.planalto.gov.br/ccivil_03/Constituicao/

ConstituicaoCompilado.htm. Acesso em: 9 out. 2021.

CAMPOS, Gastão Wagner de Sousa et al. Tratado de saúde coletiva. 1a ed. Hucitec e Fiocruz, 2006. 880 p.

GARCIA, Leila Posenato. 16a Conferência Nacional de Saúde: Democracia e Saúde. SciElo. Brasília, 2020. Disponível em: http://scielo.iec.gov.br/scielo.php?script=sci_arttext\&

pid=S1679-49742019000300001\&lng=pt\&nrm=iso. Acesso em: 23 nov. 2021.

PINHEIRO, Fernanda Thayná de Souza et al. Participação universitária em defesa do Sistema Único de Saúde. SciElo. Ceará, 2020. 12 p. Disponível em: https://www.scielosp.org/

article/csc/2018.v23n6/1751-1762. Acesso em: 23 nov. 2021.

S.I.C.K.O. S.O.S. Saúde: Michael Moore completo legendado. Michael Moore. 2007. Documentário(123 min). Disponível em: https://www.youtube.com/watch? v=VoBleMNAwUg. Acesso em: 9 out. 2021.

SILVA, Maria Helena; CAVALCANTE, Marcella Nascimento Tenório; OLIVEIRA, Daniel. SICKO: SOS SAÚDE - UMA BREVE ANÁLISE DO MODELO DE GESTÃO PÚBLICO OU PRIVADO. In: SEMANA DE PESQUISA DA UNIT. 2021, Alagoas, 2021. 3 p. Disponível em: https://eventos.set.edu.br/al_sempesq/article/view/13707/6138. Acesso em: 3 nov. 2021.

VIACAVA, Francisco et al. SUS: oferta, acesso e utilização de serviços de saúde nos últimos 30 anos. SciELO. Rio de Janeiro, 2018. 12 p. Disponível em: https://www.scielosp.org/

article/csc/2018.v23n6/1751-1762. Acesso em: 22 nov. 2021. 


\title{
CAPITULO XXIII
}

\section{A PROTEÇÃO DA PESSOA IDOSA: UMA ANÁLISE DA POLÍTICA PÚBLICA NO MUNICÍPIO DE PALMAS/TO}

DOI: 10.51859/AMPLLA.PAE1993-23

\author{
Luciane Gomes da Costa ${ }^{1}$ \\ Gleiciane Sabino Mateus Andrade ${ }^{2}$ \\ Auricélia Maria da Cruz e Silva Moreira ${ }^{3}$
}

\begin{abstract}
${ }^{1}$ Graduada em Serviço Social. Instituto Tocantinense de Educação Superior e Pesquisa - Faculdade ITOP
${ }^{2}$ Especialista em Docência Universitária. Centro Universitário Araguaia - UNIARAGUAIA.

${ }^{3}$ Mestre em Ciências do Ambiente e Sustentabilidade na Amazônia Legal. Universidade Federal do Amazonas - UFAM. Docente da Faculdade ITOP.
\end{abstract}

\section{RESUMO}

Introdução: O processo de envelhecimento é complexo e trata-se de um aspecto universal, agindo de forma gradual, irreversível e de mudanças envolvendo o sujeito em todos os meios deste inserido, sendo de caráter biológico, essa etapa é seguida por características próprias, constituindo uma fase da vida. Objetivo: Analisar a política pública para pessoa idosa executada no município de Palmas/TO. Métodos: Realizou-se uma pesquisa documental de abordagem qualitativa no site da prefeitura, na categoria "Órgãos" componente no menu do mesmo. Ao tratamento e análise dos dados coletados foi realizada leitura completa de todos os documentos encontrados, dando destaque às ações voltadas à população idosa. Resultado e discussão: Como resultado observou-se os registros das ações realizadas com os idosos com e sem articulação de secretarias e também resultados de projetos das secretarias municipais. Dos trinta e três órgãos de responsabilidade da prefeitura, apenas seis apresentaram projetos e ações voltadas para este segmento populacional, com destaque para a Secretaria Municipal de Saúde. Além disso, viu-se a necessidade de 'menu de pesquisa' mais objetivo, para que seja direcionado a itens de maior relevância sobre o assunto pesquisado. Conclusão: Conclui-se que é necessário a implementação de mais ações para esta população e que seja amplamente divulgada pelo órgão executor, desde o planejamento aos relatórios para que sirva de indicações para as futuras ações e parcerias com outros órgãos com vistas a garantir os direitos das pessoas idosas no município de Palmas.

Palavras-chave: Política Pública. Idoso. Assistência Social para Idoso. 


\section{INTRODUÇÃO}

Com aumento da população idosa brasileira nas últimas décadas, as entidades públicas perceberam a necessidade de implantação de programas sociais e assistenciais para atender às necessidades emergentes desse grupo populacional e a garantia de direitos da população idosa nos aspectos social, econômico, de justiça e saúde (SILVA et al., 2011). Nesse sentido, a Política Nacional do Idoso (PNI) assegura direitos sociais à pessoa idosa ao criar condições para promover sua autonomia, integração e participação efetiva na sociedade (BRASIL, 2010).

As esferas que compõem a vida pública (união, estadual e municipal) implantam políticas públicas na tentativa de responder às crescentes demandas da população que envelhece, preparando para enfrentar as questões da saúde e do bem-estar dos idosos de acordo com a realidade de cada comunidade. Desse modo, a identificação dessas características e condições são fundamentais para o direcionamento das ações e projetos sociais com intuito de proporcionar a qualidade de vida desta parcela da população, onde os diferentes aspectos e realidades influência na mobilização dos setores necessários para a diminuição das vulnerabilidades (SILVA et al., 2011; SANTOS, 2013).

Conseguinte, compreende-se que as políticas são designadas a entender as condições e situações que a população necessita de programas básicos para garantir os direitos de uma determinada comunidade. Por esse motivo, a construção e a constante revisão e fundamentação dos objetivos são realinhados, na tentativa de promover, prevenir e garantir os direitos de todos (FERNANDES; SOARES, 2012).

O Instituto Brasileiro de Geografia e Estatística (IBGE), aponta uma tendência ao crescimento gradual da população idosa brasileira, já percebida desde a década de 70 . Em 2010, quase 11\% da população era igual ou superior a 60 anos, estimativa de um a cada 153 idosos para 100 jovens de até 15 anos. É dado pelo órgão, que a taxa de envelhecimento é "razão entre a população de 65 anos ou mais de idade em relação à população total" (IBGE, 2010).

Visto que as Regiões Brasileiras apresentam mudanças de formas diferentes, pois cada região apresenta características específicas. Segundo os dados do IBGE, a Região Norte possui uma estrutura jovem, com contínuo crescimento do envelhecimento, 
apresentando a "proporção de idosos na população de 3,0\% em 1991, e 3,6\% em 2000, e 4,6\% em 2010". Essas condições no estado do Tocantins, especificamente, se destacam com o aumento gradativo de 1991, 2000 e 2010. A taxa de envelhecimento passou de $4,83 \%$, para $5,83 \%$ e para $7,36 \%$, respectivamente. O crescimento da população idosa resulta em desafios de ordem social, econômica, e especialmente em saúde (IBGE, 2010).

Das atribuições destinadas a esfera estadual de acordo com a Política Nacional do Idoso, o Conselho Estadual dos direitos da pessoa idosa (CEDI/TO), dado pela lei no 2.087, de 6 de julho de 2009, assegura sobre o controle e fiscalização das ações a respeito à proteção, defesa e garantia dos direitos dos idosos. A missão da política estadual de atendimento é a articulação com os demais setores para que sejam executadas ações abrangendo todas as perspectivas da vida do idoso, com atribuições na educação pelo Ministério da Educação (MEC), bem como, pelo Ministério da Saúde, da Infraestrutura e outros. Dá-se a responsabilidade ao estado de implementar conselhos eficientes e ao menos $20 \%$ de municípios também possuir essas instalações (BRASIL, 2009).

A lei municipal em destaque aos direitos dos idosos é a Lei no 1.190 de 27 de maio de 2003. Esta tem por responsabilidade a implementação da PNI, tendo como princípios, envolver a pessoa idosa como responsável também pelo desenvolvimento social, econômico, cultural e político. Frente ao paradigma de que a idade não é um fator limitante de realizações próprias, e por isso, a família, sociedade e o estado têm o dever de garantir a cidadania a esta população (BRASIL, 2003).

Esta assegura, no âmbito municipal, aos idosos o direito à ocupação e trabalho, a participação na família e na comunidade, à educação, à cultura, ao esporte e ao lazer; à justiça, ao exercício da sexualidade, a saúde, aos serviços públicos, à moradia e a participação na formulação das políticas para o Idoso, a informação sobre os serviços à sua disposição (BRASIL, 2003).

Por esses e outros direitos, surgiu o questionamento quanto aos direitos dados à pessoa idosa, em relação aos direitos fundamentais à dignidade humana, buscou-se o entendimento se as políticas públicas direcionadas a esses públicos é efetivo no município de Palmas/TO? Como está ocorrendo a divulgação dessas ações? São de fácil acesso a população geral? O objetivo desta pesquisa é analisar a política pública para 
pessoa idosa desenvolvida pelo município de Palmas/TO, com a identificação das ações e a descrição das ações elaboradas para esse público e apontar sugestões/recomendações a fim de aprimorar as ações na esfera municipal.

O motivo da realização da pesquisa é conhecer a respeito do acesso à informação a pessoa idosa, que o conhecimento dos seus direitos deve-se expandir de forma simples, como pela publicação nos sites dos órgãos públicos, incluindo uma linguagem de fácil compreensão, em que o público referente possa compreendê-las. A importância de verificar e analisar esses arquivos é de tornar-se conhecimento se há informação suficiente disponível à comunidade, e como essas informações são publicadas, identificando as ações, saberes e esforços conjuntas (intersetorialidade) no município de Palmas/TO a um mesmo público. Assim, o objetivo da pesquisa é analisar a política pública para pessoa idosa executada no município de Palmas/TO.

\section{MATERIAIS E MÉTODOS}

Esta é uma pesquisa de cunho documental e bibliográfica de abordagem qualitativa, ou seja, fundamenta-se na análise e compreensão ampla e minuciosa de materiais diversos, e documentos, buscando interpretações ou informações complementares, bem como a observação de elementos informativos de um documento primário para a construção de um documento secundário (KRIPKA; SCHELLER; BONOTTO, 2015; CECHINEL et al., 2016).

O foco da pesquisa foi a publicação da política pública voltada aos idosos, identificando as ações criadas pela Prefeitura do município de Palmas/TO e divulgadas no seu respectivo site. Os dados foram de origem primária e secundária. Os primários foram coletados no site da Prefeitura do município de Palmas/TO. Enquanto os dados secundários, foram de pesquisas disponíveis nos bancos de dados do Scientific Electronic Library Online (Scielo) e Biblioteca Digital Brasileira de Teses e Dissertações (BDTD), de caráter complementar no processo de discussão sobre o problema de pesquisa proposto. $\mathrm{O}$ instrumento de coleta de dados foi o site, ou seja, via internet, da Prefeitura do município de Palmas/TO (https://www.palmas.to.gov.br/).

A busca foi realizada no site do Prefeitura de Palmas/TO, na categoria "Órgãos" componente no menu do mesmo site. Com critérios de inclusão: publicações que relatam e mencionam a políticas e/ou ações voltadas à pessoa idosa. Foram analisados 
todos os arquivos disponíveis. E, os estudos incluídos foram todos os arquivos desta categoria para leitura prévia. Como critério de exclusão: foram desconsiderados todos os arquivos que não estiverem relacionados à pessoa idosa de forma direta, apresentando políticas ou ações. Quanto ao tratamento e análise dos dados coletados, para todos os arquivos foi realizada leitura completa e analisada de forma minuciosa, na busca da identificação das ações sociais e descrição dos objetivos da política pública direcionadas ao idoso. A apresentação dos dados foi em forma de tabela e figura demonstrando de forma organizada e ilustrativa.

A limitação da pesquisa deu-se pela eventual retirada de arquivos do site, ou ainda, por problemas nos servidores de internet da prefeitura, impossibilitando o acesso aos arquivos necessários, além de alguns links apresentando erros ou mesmo com o direcionamento a 'arquivo não encontrado'.

\section{RESULTADOS E DISCUSSÃO}

Por meio da busca no site da Prefeitura de Palmas/TO, foi identificado 33 órgãos que possuíam documentos anexados, incluindo, leis, portarias, relatórios, editais, projetos, programas e registro de ações realizadas. No entanto, a respeito da pessoa idosa, apenas 6 desses órgãos, tiveram documentos anexados com ações e projetos (Figura 1).

Figura 1 - Total de órgãos municipais no site do Município de Palmas/TO aos que possuem documentos envolvendo a pessoa idosa.

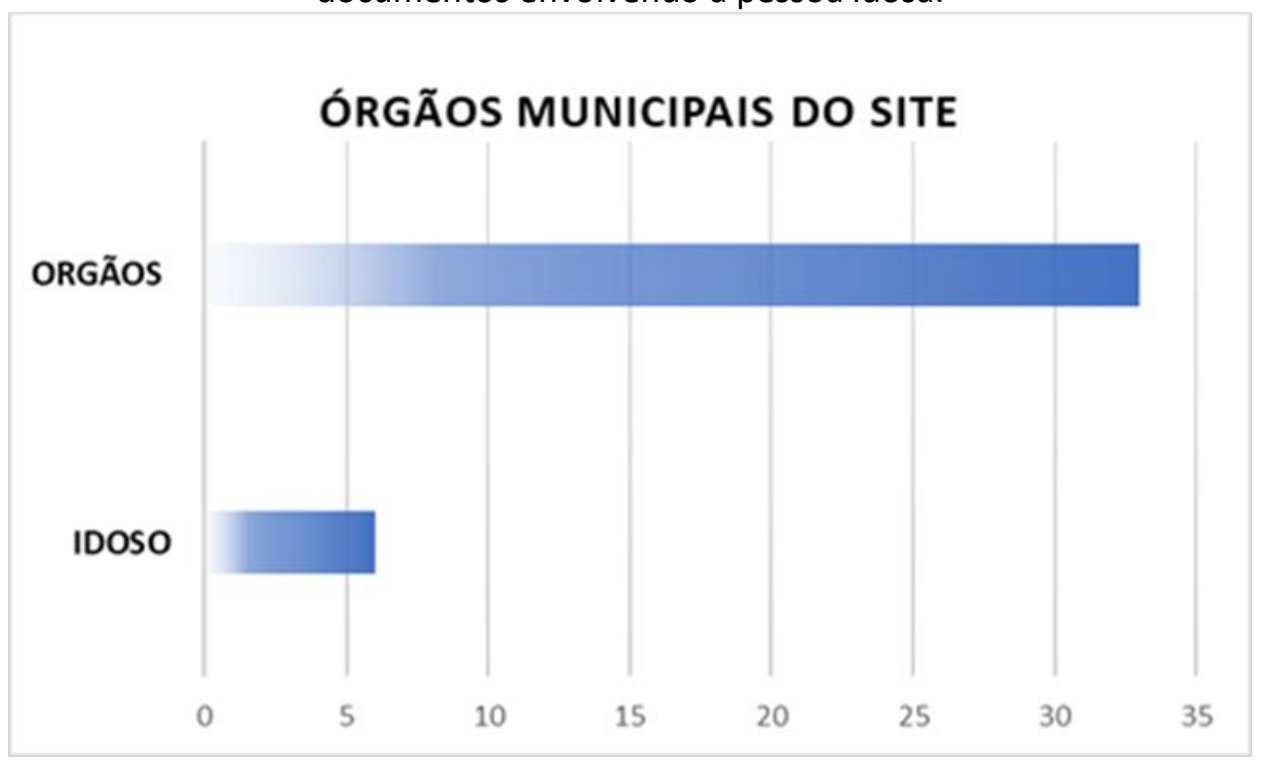

Fonte: Autores, 2020. 
Os seis órgãos municipais são: Secretaria de Transparência e Controle Interno, Secretaria de Educação, Secretaria de Governo e Relações Institucionais, Secretaria de Finanças, Secretaria de Saúde, PREVIPALMAS - Secretaria Municipal de Desenvolvimento Social.

A tabela 1, apresenta inicialmente o nome do documento, seguido pelo órgão (negrito) de onde estava anexado, e posteriormente a descrição da ação ou projeto desenvolvido pela secretaria para a população idosa. Os documentos foram organizados por ano de publicação.

$\mathrm{Na}$ tabela com o destaque cinza, representa os documentos que não são relatórios, os quais possuem descrições das atividades realizadas com a população idosa de Palmas. Já as informações com destaque branco consistem nos relatórios, que são apenas da Secretaria Municipal de Saúde (SMS). Viu-se que a maioria dos documentos foram da SMS, divididos em ações individuais da própria secretaria e outras articuladas com os demais órgãos.

O primeiro documento, a Lei orgânica do Município de 1990, relata sobre a necessidade da inserção da pessoa idosa na comunidade, dito que é responsabilidade da administração do município, envolvendo o amparo de quaisquer espécies, bem como, a criação do conselho do idoso, para que seus direitos sejam garantidos. De modo igual, Andrade et al., (2013) afirma que a participação da pessoa idosa na comunidade, como pessoa capaz de realizar atividades tanto no âmbito pessoal quanto profissional é o meio de integrar essa população às atividades que oferece a eles gratificação e sentimento de realização, bem como, é muito relevante o Estado compreender as necessidades dessa população, e ir além, ou seja, ser atuante com a elaboração de projetos integrativos e possíveis de serem implantados.

Nesta perspectiva, no Código Tributário de 2013, o segundo documento da tabela, dentro das limitações legais, relata sobre o direito do idoso quanto a isenção de alguns impostos - os tributos municipais, auxiliando-os com o cumprimento de deveres como cidadãos e minimização das preocupações quanto suas moradias em regiões urbanas como: de propriedade predial e territorial urbano, transmissão de bens, taxas de razão do poder de polícia, de serviços públicos e contribuições de melhoria, custeios de serviço de iluminação pública e serviços de outras naturezas. Para o processo de isenção, criam-se projetos e protocolos avaliativos e comprobatórios. 
Mediante as diversas ações necessárias a serem realizadas pelas secretarias municipais, por responsabilidade pública, para Reis e Torres (2011) ainda há "a necessidade de incentivo governamental, tanto em forma de verbas e isenção de impostos", assim poderá ofertar ao idoso a possibilidade de encontra-se mais apto a conviver com a família e suprir outros custos melhorando a qualidade de vida.

Tabela 1 - Nome do documento, secretaria responsável pela publicação, e programas e atividades direcionadas à pessoa idosa.

\section{№ DOCUMENTO / \\ SECRETARIA \\ MUNICIPAL DIVULGAÇÃO.}

RESPONSÁVELPELA PROGRAMAS E/OU AÇÕES DIRECIONADAS AS PESSOAS IDOSAS

01 Lei Orgânica do município de Palmas-

TO. 05 de

maio de 1990.

Secretaria de

Transparência e

Controle Interno.

Art. 186 - É dever da Administração Municipal em conjunto com a sociedade, amparar as pessoas idosas, assegurando sua participação na comunidade, defendendo sua dignidade e bem-estar.

$\S 1$ - O amparo ao idoso será, quando possível, exercido no próprio lar.

§ 20 - Para assegurar a integração do idoso na comunidade e na família, serão criados centros diurnos de lazer e de amparo à velhice.

$\S 5^{\circ}$ - Fica criado o Conselho Municipal do Idoso, que terá a incumbência dentre outras estabelecidas por lei, o de zelar e reivindicar as garantias constitucionais expressas nos artigos 203, V e 230, da Constituição Federal, e artigos 121 e 122 da Constituição do Estado do Tocantins.

$\S 6^{\circ}$ - A lei disporá sobre o Conselho Municipal do Idoso.

02 Código Tributário do

Município de

Art. 20. São isentos do imposto:

Palmas/TO. Lei

Complementar № 285,

de 31 de

outubro de 2013.

Secretaria de

Transparência e

Controle Interno.

03 Programa Brasil Alfabetizado/Palmas para Alfabetização 2013;2014.

Secretaria de Educação. a) idosos, com idade superior a 65 (sessenta e cinco) anos. 
04 Edital de Convocação - A Comissão Eleitoral, indicada pelo Conselho Municipal dos Direitos da Comissão Eleitoral, Pessoa Idosa - em reunião ordinária de 27 de março de 2013, no uso de suas indicada pelo COMDIPI atribuições legais, convoca, em cumprimento ao que prevê oartigo 50 da Lei Secretaria de Governo no 842, de 8 de outubro de 2008, as Entidades com atuação no campo da e RelaçõesInstitucionais promoção e defesa dos direitos da pessoa idosa no Município de Palmas, para participarem da eleição dos membros da sociedade civil para formação do Conselho Municipal dos Direitos da Pessoa Idosa - COMDIPI, Gestão 2013-2015, na forma deste edital.

05 Manual Técnico de Orçamento (MTO):2014;2016. Secretaria de Finanças. própria manutenção ou de tê-la provida por sua família, conforme dispuser a lei."
06 Plano Municipal de Saúde - 2014;2017. 2a Revisão. Secretaria de Saúde
Atualmente há 16 Grupos de Idosos implantados pelas equipes de Saúde da Família. Principais atividades desenvolvidas:

- Realização de ações de prevenção de quedas;

- Incentivo e apoio, nas USFs, da realização de ações depromoção e prevenção voltadas para as comorbidades acometidas nas pessoas idosas, por meio de palestras, orientações nas consultas, visitas domiciliares, distribuição de materiais educativos;

- $\quad$ Distribuição e acompanhamento da caderneta da pessoa idosa;

- $\quad$ Participação mensal das reuniões do conselho do Idoso.

07 Lei № 2.299, de 30 de Art. 37. Compete à Secretaria Municipal de Desenvolvimento Social: XIV março de 2017. Reorganização Oportunizar, à pessoa idosa, o convívio social e o aprimoramento pessoal por meio de atividades sócio educativas, culturais, artísticas e de lazer; administrativa do PoderXX - Articular a implementação, no âmbito da saúde pública, de políticas de Executivo do município atenção à saúde da mulher, do negro, do idoso e do deficiente; XXXII de Palmas.

PREVIPALMAS apoiar instrumentos que gerem oportunidades de trabalho para jovens, mulheres, idosos e pessoas com necessidades especiais;

SecretariaMunicipal de XLV - adotar medidas para a mobilidade de pedestres, ciclistas, passageiros DesenvolvimentoSocial. de transporte coletivo, pessoas com necessidades especiais e idosos, no uso do espaço urbano de circulação.

08 ChamamentoPúblico Desenvolvimento de ações em instituições educativas (escolas, faculdades, №001/2020. Conselho cursos etc.), nos diversos níveis de educação, capazes de oportunizar a Municipal dos Direitos pessoa idosa: a transmissão de cultura e valores a outras gerações, o da Pessoa Idosa de Palmas (COMDIPI). aproveitamento do seu potencial e conhecimento, a ressignificação do seu papel na sociedade.

\section{Secretaria de DesenvolvimentoSocial.}


Relatório de Gestão 1ㅇ Atividades

09 Quadrimestre 2015. Secretaria da Saúde

- Implementação de grupos de idosos junto às Unidades de Saúde da Família;

- $\quad$ Ações de prevenção de quedas;

- Incentivar e apoiar, nas USFs, a realização de ações de promoção e prevenção voltadas para as comorbidades

acometidas nas pessoas idosas, por meio de palestras, orientações nas consultas, visitas domiciliares, distribuição de materiais educativos;

- Distribuição e acompanhamento da caderneta da pessoa idosa;

- Participação mensal das reuniões do conselho do Idoso.

05 Grupos realizados com 2.100 atendimentos.

10 Relatório Detalhado doPrincipais atividades desenvolvidas no período:

2ㅇ Quadrimestre de• Implementação de grupos de idosos junto às Unidades de Saúde da 2015. Família;

Secretaria da Saúde $\quad$ - $\quad 29$ Grupos de Idosos desenvolvidos pelas equipes de saúde da família;

- Ações de prevenção de quedas;

- Incentivar e apoiar, nas USFs, a realização de ações de promoção e prevenção voltadas para as comorbidades acometidas nas pessoas idosas, por meio de palestras, orientações nas consultas, visitas domiciliares, distribuição de materiais educativos;

- Distribuição e acompanhamento da caderneta da pessoa idosa;

- Participação mensal das reuniões do conselho do Idoso.

11 Relatório Detalhado doPrincipais atividades desenvolvidas no 3ㅇ quadrimestre/2015:

3을 Quadrimestre RDQA• Implementação de grupos de idosos junto às Unidades de Saúde da -3 은 Família;

Quadrimestre de 2015. • Ações de prevenção de quedas;

Secretaria de Saúde - Incentivar e apoiar, nas USFs, a realização de ações de promoção e prevenção voltadas para as comorbidades acometidas nas pessoas idosas, por meio de palestras, orientações nas consultas, visitas domiciliares, distribuição de materiais educativos.

- Distribuição e acompanhamento da caderneta da pessoa idosa;

- $\quad$ Participação mensal das reuniões do conselho do Idoso.

12 Relatório Detalhado doPrincipais atividades desenvolvidas no 10 quadrimestre/2016:

10 Quadrimestre RDQA• Implementação de grupos de idosos junto às Unidades de Saúde da - 1 o de 2016. Família;

Secretaria de Saúde - Ações de prevenção de quedas;

- Incentivar e apoiar, nas USFs, a realização de ações de promoção e prevenção voltadas para as comorbidades acometidas nas pessoas idosas, por meio de palestras, orientações nas consultas, visitas domiciliares, distribuição de materiais educativos;

- Distribuição e acompanhamento da caderneta da pessoa idosa;

- $\quad$ Participação mensal das reuniões do Conselho do Idoso;

- $\quad$ Articulação com o Ministério da Saúde para realização de Curso de Implementação da Caderneta de Saúde da Pessoa Idosa;

- Participação em Oficinas sobre Envelhecimento e Saúde da Pessoa Idosa e Enfrentamento da demência em Idoso.

- Destacamos como desafio a implementar da nova Caderneta do Idoso em $100 \%$ das unidades de saúde. 
13 Relatório Detalhado do Atividades:

Quadrimestre Anterior - Implantação da Caderneta no Grupo de Idoso no Parque Vida Ativa e - RDQA 2은 avaliação de idosos utilizando o instrumento;

Quadrimestre de 2016. - Abertura das atividades do Parque Vida Ativa com presença da SEMUS, Secretaria de Saúde. SEDES, Universidade da Melhor Idade - UMA, Conselho Municipal do Idoso, Liga de Geriatria da UFT, Clube da Melhor Idade e Núcleo de Arte Terapia e Educação Popular - NUPOPS;

- Elaboração do Fluxo de atendimento do Idoso na rede municipal de saúde.

14 Relatório Detalhado do Atividades realizadas:

Quadrimestre Anterior • Grupo de Idosos, com palestras sobre comorbidades da Hipertensão (RDQA) - 2o Arterial e do Diabetes Mellitus;

Quadrimestre de 2017. • Quadrilha da Melhor Idade, para os idosos da área de abrangência, Secretaria de Saúde. com palestras sobre a Caderneta do Idoso e momentos de confraternização;

- Atendimento na Zona Rural, para moradores idosos com dores, com prática de alongamento para melhorar as dores no corpo, realizado pela fisioterapeuta do NASF.

- Capacitações como: sobre a Caderneta do Idoso; com o Ministério da Saúde sobre Incapacidade - Hanseníase, sobre a Prevenção da incapacidade em Hanseníase;

- Roda de conversa Prevenção de Quedas no Idoso.

15 Relatório Detalhado do Atividades:

Quadrimestre Anterior • Dia Mundial do Enfrentamento à Violência contra a Pessoa Idosa/Ação (RDQA) 2은 realizada no parque do idoso/Stand com exposição e divulgação de material, Quadrimestre de 2018. bem como orientações acerca do Enfrentamento da Violência contra a Secretaria de Saúde. pessoa Idosa e também orientação e quanto a existência da rede de proteção.

- $\quad$ Reunião do Conselho Municipal dos Direitos da Pessoa Idosa.

16 Relatório Detalhado do Quadrimestre Anterior 30 Quadrimestre - 2018. Secretaria de Saúde.

\section{Atividades:}

- Participação em conselhos, comitês e outros espaços de representação social que realizam reuniões periódicas: Conselho Municipal dos Direitos da Pessoa Idosa, Conselho Municipal Direito da Pessoa com Deficiência, Conselho Municipal Segurança Alimentar e Nutricional, Conselho Municipal de Assistência Social, Coordenação Intersetorial do Programa Bolsa Família e Comitê Intersetorial Selo UNICEF.

- Participação na 4a Conferência Municipal dos Direitos da Pessoa Idosa de Palmas, "O Desafio de Envelhecer no século XXI e o papel das Políticas Públicas". 

que é destinado aos idoso e aos deficientes; em que um salário mínimo é destinado a quem comprovem não possuir meios de prover a própria manutenção, desse modo é possível garantir o básico para a sobrevivência daqueles que não possuem meios para tal.

A observação realizada por Paulo e seus colaboradores (2013), consideram que a renda dos idosos é uma preocupação não somente dos familiares, mas também do Estado, uma vez que há tendência de situações de elevada pobreza, afetando outros sistemas, como o de saúde por exemplo. Então, neste caso, a realização de programas como esse, é dado por meio de perspectivas para melhoria em diversas áreas da vida do idoso e dos familiares.

Quanto a Secretaria Municipal de Saúde de Palmas, o destaque está nos planos municipais voltados a diminuir as ocorrências das situações de agravamento da saúde dos idosos, realizando atividades como o incentivo a formação de grupos, para que possam socializar e manter a coletividade, bem como, executar ações voltadas a prevenção de queda (uma das principais incidências em idosos envolvendo a área da saúde), os incentivos e apoios aos atendimentos da rede primária, projetos envolvendo palestras, visitas a domicílio e distribuição de material educativo.

Ainda é reforçado, sobre o chamamento para participação do conselho municipal de saúde e do idoso. As ações que compõem várias dimensões da vida dos idosos são a respeito da educação em saúde, onde é estimulado a manutenção da independência e autonomia, que devem sem dúvidas, ser ampliadas, podendo assegurar a qualidade de vida.

Dá-se ênfase, como meio mais eficaz para a continuidade de uma condição dada como boa de saúde, provinda da promoção da saúde e prevenção de doenças, inclusive pode ser analisado as ações de atenção ao idoso de forma articulada entre as secretarias do município, onde observa-se que as políticas de desenvolvimento social e educação, bem como a de saúde interagem entre si em busca de benefícios aos idosos, ações das quais possam garantir o convívio social, integração ativa na sociedade, direitos educativos, culturais e de lazer (ZEN et al., 2018).

De todas as secretarias municipais de Palmas, a secretaria da saúde tem destaque quanto à variação de atividades concretizadas e registradas no site. Os relatórios são mais esclarecedores e destacam as ações e a eficácia de cada uma delas, 
mostrando os resultados mesmo que não satisfatórios. Assim, como é posto no relatório do quadrimestre anterior 20 de 2019, em que neste caso a meta não foi alcançada, tendo como justificativa a mudança de perspectiva das ações - invés de realizar atividades diretas com os idosos, foram desenvolvidas etapas de planejamento e diagnóstico situacional, com o objetivo de realizar o levantamento sobre o perfil dos idosos, além das caraterísticas sobre a morbimortalidade do município, o que dificultou no cumprimento das atividades presenciais com os idosos. Para mais, com a realização de reuniões, foi possível iniciar discussões sobre a criação e implementação de ações a este público para os próximos semestres, pois apesar das metas não serem cumpridas (ao que foi planejado inicialmente), verificou-se a preocupação do secretário de saúde municipal em colaborar com a preparação da equipe de primeiro contato e sobre a necessidade de entender o perfil de cada região do município.

Um aspecto muito importante, é sobre a preparação da equipe, como é destacado na pesquisa de Witt et al., (2014) sobre as diversas competências que devem ser aprimoradas e avaliadas para garantir a efetividade da atenção integral ao idoso, entre elas estão: o pensamento crítico, comunicação efetiva, avaliação das dificuldades, trabalhar respeitando a promoção da saúde, redução de risco, e a prevenção das enfermidades, manejo de doenças, ética, provisão de cuidado e planejamento e coordenação do cuidado.

Constatou-se que a saúde foi o assunto de maior prioridade quando a temática é a pessoa idosa. Isso porque, as situações de saúde são de características amplas, envolvendo aspectos crônicos, mas também de caráter agudo - influenciadas pelas mudanças naturais do envelhecer. A atenção não deve ocorrer somente no âmbito físico, mas cognitivo e emocional, que podem desencadear sofrimento psíquico e psicossomático.

Neste contexto, a Secretaria Municipal de Saúde de Palmas, além da atenção da equipe multidisciplinar nas unidades básicas de saúde, realiza atividades conjuntas como articulação com a Liga de geriatria da Universidade Federal do Tocantins, e Clube da Melhor Idade e Núcleo de Arte Terapia e Educação Popular (NUPOPS); o estímulo à memória e ao enfrentamento das 'dores' psicológicas é uma das variáveis de estimular a saúde mental, oferecendo melhor qualidade de vida aos idosos (ZEN et al., 2018; WITT et al., 2014). 
Outra pauta importante, é a questão da violência à pessoa idosa. Em repercussão a essa temática foram efetuadas atividades com pautas de conscientização para o "Dia Mundial do Enfrentamento à Violência contra a Pessoa Idosa/Ação realizada no parque do idoso/Stand" com exposição e divulgação de material, bem como orientações acerca do Enfrentamento em situações de violência contra o idoso e o levantamento da discussão sobre a existência da rede de proteção.

Autores como Castro et al., (2013), Souza e Minayo (2010) esclarecem que o atendimento aos idosos, que infelizmente são vítimas de violência, é discutida nos três níveis de atenção à saúde, pois depende da gravidade dos traumas. Reforçando a respeito das estratégias assistenciais e a importância para a construção de políticas e utilização correta dos recursos para dar conta dos desafios a esse fenômeno.

É necessário também distinguir a tipologia das principais violências vivenciadas pelos idosos que são: a violência física, a violência psicológica, a sexual, a financeira e econômica. É dado também como violência a negligência e autonegligência, e o abandono. O impacto dessas violências no sistema de saúde é digno de análise e investigação, visto que a maioria são ocorrências de origem familiar ou no ambiente doméstico, pronunciando-se como falha no sistema público, pois o mapeamento da origem das ocorrências ainda não é investigado de forma apropriada (Castro et al., 2013).

\section{CONCLUSÃO}

Diante do aumento da população idosa, em todo o território brasileiro, surgiu a necessidade de investigar as políticas públicas no município de Palmas/TO por meio do site da prefeitura. Desse modo, no site da Prefeitura de Palmas/TO foram identificados registros das ações e resultados de projetos das secretarias municipais, observando-se que não possui nenhuma política específica à população em estudo, no entanto há registro de várias ações realizadas com os idosos com e sem articulação de secretarias (como mostrado na tabela 1). O destaque, foi para a Secretaria municipal de Saúde, portanto ver-se que há preocupação com a qualidade de vida dos idosos e principalmente com os fatores extrínsecos e intrínsecos à saúde.

Ademais, sabe-se que os resultados estão longe de ser satisfatórios, uma vez que a assistência a população idosa ainda é muito precária, como ressaltado nos relatórios 
e metas vários projetos não foram cumpridos, bem como notou-se a carência de ações intersetoriais. Não somente aos fatores que envolvem a saúde, mas a educação, lazer, cultura e principalmente a segurança da pessoa idosa. Pode-se sugerir primeiramente a intenção de registrar as políticas e posteriormente os projetos derivados dessa e por último as ações, para que ao acessar o site da prefeitura, possa existir uma relação do que foi proposto, ao que foi de fato realizado e cumprido.

Além disso, viu-se a necessidade de 'menu de pesquisa' mais objetivo, para que seja direcionado a itens de maior relevância sobre o assunto pesquisado. Um destaque importante, dado como limitação da pesquisa, é a respeito de links indisponíveis, que ao serem pesquisados, apresentaram "erro" ou "documento não encontrado", consequentemente surgindo a sensação de perda de dados importantes para a pesquisa.

Todos os autores declararam não haver qualquer potencial conflito de interesses referente a este artigo.

\section{REFERÊNCIAS}

SILVA, H. O.; CARVALHO, M. J. A. D.; LIMA, F. E. L.; RODRIGUES, L. V. Perfil epidemiológico de idosos frequentadores de grupos de convivência no município de Iguatu, Ceará. Revista Brasileira de Geriatria e Gerontologia, Rio de Janeiro, v.14, n.1, p.123-133, 2011.

BRASIL. Política Nacional do Idoso. Lei no 8.842, de janeiro de 1994. 1ำed. Brasília-DF; 2010. Disponível em < http://www.mds.gov.br/webarquivos/publicacao/assistencia_social/Normativa s/politic a_idoso.pdf>; Acesso em: 16 de ago. 2020.

SANTOS, J. S. Atendimento preferencial no estatuto e na voz do idoso: uma análise discursiva. Linguagem em (Dis)curso, Tubarão, SC, v. 13, n. 2, p. 243-271, maio/ago 2013.

FERNANDES, M. T. O.; SOARES, S. M. O desenvolvimento de políticas públicas de atenção ao idoso no Brasil. Revista da Escola de Enfermagem da USP. v. 46, n. 6, p.14941502, 2012.

IBGE. Instituto Brasileiro e Geografia de Estatística (IBGE). Atlas do censo demográfico. 2010. Disponível em < https://biblioteca.ibge.gov.br/visualizacao/livros/liv49230.pdf>; Acesso em: 15 de ago. 2020. 
BRASIL. Estado do Tocantins. Lei no 2.087, de 6 de julho de 2009. Dispõe sobre o Conselho Estadual dos Direitos da Pessoa Idosa - CEDI/TO e adota outras providências. Palmas/TO. Disponível em: < https://www.al.to.leg.br/arquivos/21969.pdf > Acesso em: 11 de set. 2020.

BRASIL. Câmara Municipal de Palmas. Lei no 1.190, de 27 de maio de 2003. Institui o Estatuto do Idoso no município de Palmas e dá outras providências. Palmas/TO. Disponível em: < https://leismunicipais.com.br/a/to/p/palmas/leiordinaria/2003/119/1190/lei-ordinaria-n-1190-2003-institui-o-estatuto-doidoso-no- municipio-de-palmas-e-da-outras-providencias > Acesso em: 11 de set. 2020.

KRIPKA, R. M. L.; SCHELLER, M.; BONOTTO, D. L. Pesquisa Documental: considerações sobre conceitos e características na Pesquisa Qualitativa. Atlas - Investigação Qualitativa em Educação. v. 2, p. 243-247; 2015.

CEChINel, A.; FOnTANA, S. A. P.; GIUStinA, K. P. D.; PEREIRA, A. S.; PRADO, S. S. do. Estudo/Análise Documental: uma Revisão Teórica e Metodológica. Criar educação - UNESC, Criciúma, v. 5, n. 1, 2016.

ANDRADE, L. M.; SENA, E. L. S.; PINHEIRO, G. M. L.; MEIRA, E. M.; LIRA, L. S. S.P. Políticas públicas para pessoas idosas no Brasil: uma revisão integrativa. Ciência \& Saúde Coletiva, v. 8, n. 12, p.3543-3552, 2013.

REIS, L. A.; TORRES, G. V. Influência da dor crônica na capacidade funcional de idosos institucionalizados. Pesquisa - Revista Brasileira de Enfermagem; v.64, n. 2, $2011 . \quad$ Disponível em: https://www.scielo.br/j/reben/a/Y3qCnJMkqdsDJjwwjX84MTh/?format=pdf\&la $\mathrm{ng}=\mathrm{pt}$

LAFFIN, M. H. L. F. Alfabetização de idosos e adultos ou leitura e escrita? Revista Portuguesa de Educação, v.25, n.2, p. 141-165, 2012.

FERNANDES, J. S. G.; ANDRADE, M. S. Conselhos Municipais do Idoso e Representações Sociais de seus Conselheiros. Psicologia: Ciência e Profissão, v. 39, p.1-14, 2019.

PAULO, M. A.; WAJNMAN, S.; OLIVEIRA, A.M.C.H. de. A relação entre renda e composição domiciliar dos idosos no Brasil: um estudo sobre o impacto do recebimento do Benefício de Prestação Continuada. Revista Brasileira de Estudos de População, Rio de Janeiro, v. 30, Sup., p. S25-S43, 2013.

ZEN, D.; LEITE, M. T.; HILDEBRANDT, L. M.; SILVA, L. A. A.; SAND, I. C. P. V. der. Políticas de atenção a idosos na voz de gestores municipais de saúde. Revista Gaúcha de Enfermagem. v. 39, p. 1-9, 2018.

WITT, R. R.; ROOS, M. O.; CARVALHO, N. M.; SILVA, A. M.; RODRIGUES, C. D. S.; SANTOS, M.T. dos. Competências profissionais para o atendimento de idosos em Atenção 
Primária à Saúde. Revista da Escola de Enfermagem da USP. v.48, n.6, p.1020-5, 2014.

CASTRO, A. P. de; GUILAM, M. C. R.; SOUSA, E. S. S.; MARCONDES, W. B. Violência na velhice: abordagens em periódicos nacionais indexados. Ciência \& Saúde Coletiva, v.18, n. 5, p.:1283-1292, 2013.

SOUZA, E. R. de; MINAYO, M. C. S. Inserção do tema violência contra a pessoa idosa nas políticas públicas de atenção à saúde no Brasil. Ciência \& Saúde Coletiva, v.15, n.6, p.:2659-2668, 2010. 


\title{
CAPITULO XXIV
}

\section{AÇÕES DA ATENÇÃO PRIMÁRIA À SAÚDE NO COMBATE À TUBERCULOSE: REVISÃO INTEGRATIVA}

DOI: 10.51859/AMPLLA.PAE1993-24

\author{
Cássia Valéria Ferreira Vianna Gomes ${ }^{1}$ \\ Juliana Cristina Martins de Souza ${ }^{2}$ \\ Shirley Aparecida da Silveira ${ }^{3}$ \\ Fabiola maria dos Santos 4 \\ Marília Dutra Teixeira ${ }^{5}$ \\ João Vitor Andrade ${ }^{2}$
}

\footnotetext{
1 Enfermeira. Especialista em Saúde da Família pela Faculdade Única (GRUPO PROMINAS).

${ }^{2}$ Enfermeira(o). Especialista em Enfermagem em Saúde Mental e Psiquiátrica. Universidade de São Paulo (USP).

${ }^{3}$ Enfermeira. Mestranda em Ciências Biológicas pela Universidade Federal de Juiz de Fora (UFJF).

${ }^{4}$ Discente de Farmácia. Universidade Federal de Alfenas (UNIFAL).

${ }^{5}$ Discente de Enfermagem. Centro Universitário de Viçosa (UNIVIÇOSA).
}

\section{RESUMO}

Objetivo: identificar, através da literatura disponível, ações da atenção primária à saúde no combate à tuberculose. Método: trata-se de uma revisão integrativa de literatura realizada nas bases de dados LILACS, PubMed, e SciELO a partir dos descritores: "Primary Health Care", "Tuberculosis" e "Family Health", cruzados com o operador booleano And. Resultados: após a aplicação dos critérios de inclusão e exclusão, foram selecionados 11 artigos que permitiram a elaboração de duas categorias a serem discutidas: "Ações direcionadas aos usuários" e "Ações direcionadas aos profissionais". Conclusão: os dados obtidos neste estudo apontam para a importância das ações implementadas pela APS no combate à tuberculose, sobretudo pela potência desta instância na saúde das populações. Enfatiza-se que a proximidade que a APS estabelece com os usuários, torna o processo de cuidar mais fácil, assim, pontuasse a respeito da necessidade de fortalecimento e ampliação da APS, isso a nível global, bem como da divulgação das ações realizadas por esta.

Palavras-chave: Atenção Primaria à Saúde. Tuberculose. Saúde da Família. 


\section{INTRODUÇÃO}

A nível mundial a tuberculose caracteriza-se como uma das mais importantes causas de morbimortalidade na contemporaneidade (DEUTSCH-FELDMAN et al., 2021). Tem como principal agente etiológico a Mycobacterium tuberculosis, e embora seja negligenciada nos países em desenvolvimento, dados estatístico expressam que já infectou cerca de 2 bilhões de pessoas em todo o mundo (BARBERIS et al., 2017).

Ratifica-se que a tuberculose é uma doença infecciosa grave, transmissível e curável, sua transmissão ocorre através das vias aéreas, por inalação contendo bacilos, por tosse, fala ou espirro pelo portador da doença ativa (pulmonar ou laríngea), podendo atingir outros órgãos ou ocorrer de forma disseminada (BARBERIS et al., 2017; FURIN, COX, PAI, 2019). Pontua-se que um terço da população mundial carrega o bacilo da tuberculose e tem o risco de desenvolver a doença de maneira ativa (BARBERIS et al., 2017).

Bem como as demais doenças negligenciadas, está associada à vulnerabilidade econômica, como viver em condições precárias habitação, baixo nível educacional, uso de álcool e outras drogas (ORLANDI, et al., 2019). No intuito de enfrentar a doença de maneira efetiva, em 2014 a Organização Mundial da Saúde (OMS) criou a "Estratégia End Tuberculosis", que estabelece metas para reduzir as mortes em $90 \%$ e a incidência de 80\% até 2030 e erradicar a tuberculose em 2035 (OPAS, 2018; SILVA et al., 2018).

Esta Estratégia é composta por três pilares: cuidados de tuberculose integrados e centrados no paciente e prevenção; políticas ousadas e informações integradas sistemas, incluindo proteção social e universal política de cobertura de saúde; pesquisa intensificada e inovação e incorporação de novos tecnologias (MACIEL, 2016). Acompanhando essa necessidade de combater mais a tuberculose intensamente, 0 Ministério da Saúde do Brasil emitiu, em 2017, um documento estruturando um plano para tuberculose eliminação (Plano Nacional para o Fim do Tuberculose como um problema de saúde pública) que foi projetado para reduzir, até 2035 , a incidência de tuberculose para menos de 10 casos / 100.000 habitantes e a mortalidade por tuberculose para menos de 1 morte em 100.000 habitantes (SILVA et al., 2018).

Pontua-se ainda que o Brasil ocupa o $16^{\circ}$ lugar em número de casos absolutos entre os 22 países responsáveis por $80 \%$ do total de casos de tuberculose no mundo, 
estando na 108a posição quanto à carga de incidência (BRASIL, 2013, 2014). Este dado gera grande preocupação social, visto que, uma grande parcela dos aproximadamente 214 milhões de brasileiros (IBGE, 2020), vive em situação de vulnerabilidade (BARATA et al., 2015).

Nesse contexto, é reconhecida a importância da Atenção Primária à Saúde (APS), dado seus atributos essenciais e derivados que abrangem desde atenção ao primeiro contato à orientação familiar e comunitária. A APS por meio de seus atributos (acessibilidade, longitudinalidade, integralidade e coordenação) (BARATIERI; MARCON, 2011), visa à promoção, proteção, prevenção, recuperação e reabilitação em saúde, intervindo em fatores que colocam a saúde da população em risco (BRASIL, 2017).

Ratifica-se que a APS juntamente com os demais serviços relacionados à atenção primária, visam resolver até $80 \%$ dos problemas de saúde da população (BRASIL, 2017). A APS constitui-se na porta de entrada do Sistema Único de Saúde (SUS), sendo imprescindível destacar que a proximidade alcançada pela equipe de saúde da APS com o usuário permite que se conheça a pessoa, a família e a vizinhança (BRASIL, 2017). Essa proximidade garante uma maior adesão do usuário aos tratamentos e às intervenções propostas pela equipe de saúde (BRASIL, 2017).

Frente à articulação que a APS possui com a comunidade em seu território, a mesma constitui-se em um importante instrumento para o combate à tuberculose, e concomitantemente para fortalecimento da rede de atenção à saúde, o que converge para a proposta de assistência pautada nos princípios do Sistema Único de Saúde (SUS) (BRASIL, 2017). Neste ínterim, o presente trabalho visa realizar uma inquirição bibliográfica concernente às ações da APS no tocante ao combate à tuberculose.

\section{MÉTODO}

O presente estudo trata-se de uma Revisão Integrativa de Literatura. Este método de pesquisa objetiva à análise de trabalhos científicos e permite a sistematização de conhecimento sobre um determinado tema (MENDES, SILVEIRA; GALVÃO, 2019). A Revisão Integrativa caracteriza-se em um método que possibilita a síntese de evidências de diversos estudos sobre um determinado tema por meio de um processo fragmentado em etapas, sendo estas, definição da questão norteadora, busca e seleção de estudos, observação dos dados principais, avaliação destes estudos, síntese 
dos resultados e apresentação do corpus pós analise (MENDES, SILVEIRA; GALVÃO, 2019).

A questão norteadora deste estudo foi: "Quais as ações da APS no combate à tuberculose?" O levantamento bibliográfico foi realizado online nos meses de agosto e setembro de 2021, por meio das bases de dados LILACS (Literatura Latino-Americana e do Caribe em Ciências da Saúde), PubMED (U.S. National Library of Medicine National Institute of Health), SciELO (Scientific Electronic Library Online).

Utilizou-se a estratégia PICOT para delimitar a revisão integrativa (MENDES; SILVEIRA; GALVÃO, 2019). Sendo a mesma um acrônimo, representando no presente estudo: P) População (pacientes atendidos na APS); I) Intervenção (quais as ações realizadas pela equipe da APS no combate à tuberculose?); C) Comparação (trazem benefício para as pessoas?); O) Desfecho ou resultados (existe consenso ou protocolos?) e T) Tempo (estudos publicados nos últimos cinco anos 2017/2021).

A busca foi realizada de maneira interdependente por dois pesquisadores, por meio dos descritores controlados disponíveis nos Descritores em Ciência da Saúde (DeCS) e seus correspondentes em espanhol e português da Biblioteca Virtual em Saúde: "Primary Health Care", "Tuberculosis" e "Family Health", utilizou-se para o cruzamento dos descritores o operador booleano "AND".

Os estudos foram selecionados pela leitura criteriosa dos títulos, resumos e posteriormente dos artigos na íntegra. Os critérios de inclusão definidos foram artigos científicos similares com a temática deste estudo, produções disponíveis na íntegra, nos idiomas português, inglês e espanhol e que detalhassem e versassem o assunto: ações da APS no combate à tuberculose, independentemente do método de pesquisa utilizado, publicado no quinquênio 2017/2021. Artigos que se encontravam repetidos nas bases de dados foram incluídos apenas uma vez e os que não abarcavam a temática principal foram excluídos na análise.

Para a caracterização dos estudos selecionados utilizou-se um instrumento de fichamento de dados adaptado [incluindo-se os itens autor, ano, título do artigo, país de realização da pesquisa, objetivos do estudo, método, ação desenvolvida pela APS, nível de evidência, conclusão e amostra], visando a sistematização e organização (GALVÃO, 2006). A análise dos dados deu-se através da leitura dos artigos, sendo as informações utilizadas para elaborar um quadro no Microsoft Word ${ }^{\circledR} 2016$. 


\section{RESULTADOS}

Na busca realizada nas bases de dados, identificaram-se 226 publicações potencialmente elegíveis: LILACS (35), PubMed (161), SciELO (30).

Em uma análise inicial por título, foram excluídos 29 artigos por estarem duplicados e 138 por não se relacionarem com o objetivo da presente análise. Procedeu-se então com a leitura dos resumos, e após esta, 41 publicações foram excluídas por não se tratarem da temática em estudo. Por fim, realizou-se a leitura na integra de 18 trabalhos, dos quais 11 foram selecionados para compor a amostra da presente revisão. Assim, a amostra da revisão integrativa foi composta de 11 estudos primários, conforme Figura 1.

Figura 1 - Fluxograma da estratégia realizada para busca e inclusão dos artigos, segundo modelo PRISMA (MOHER et al., 2009).

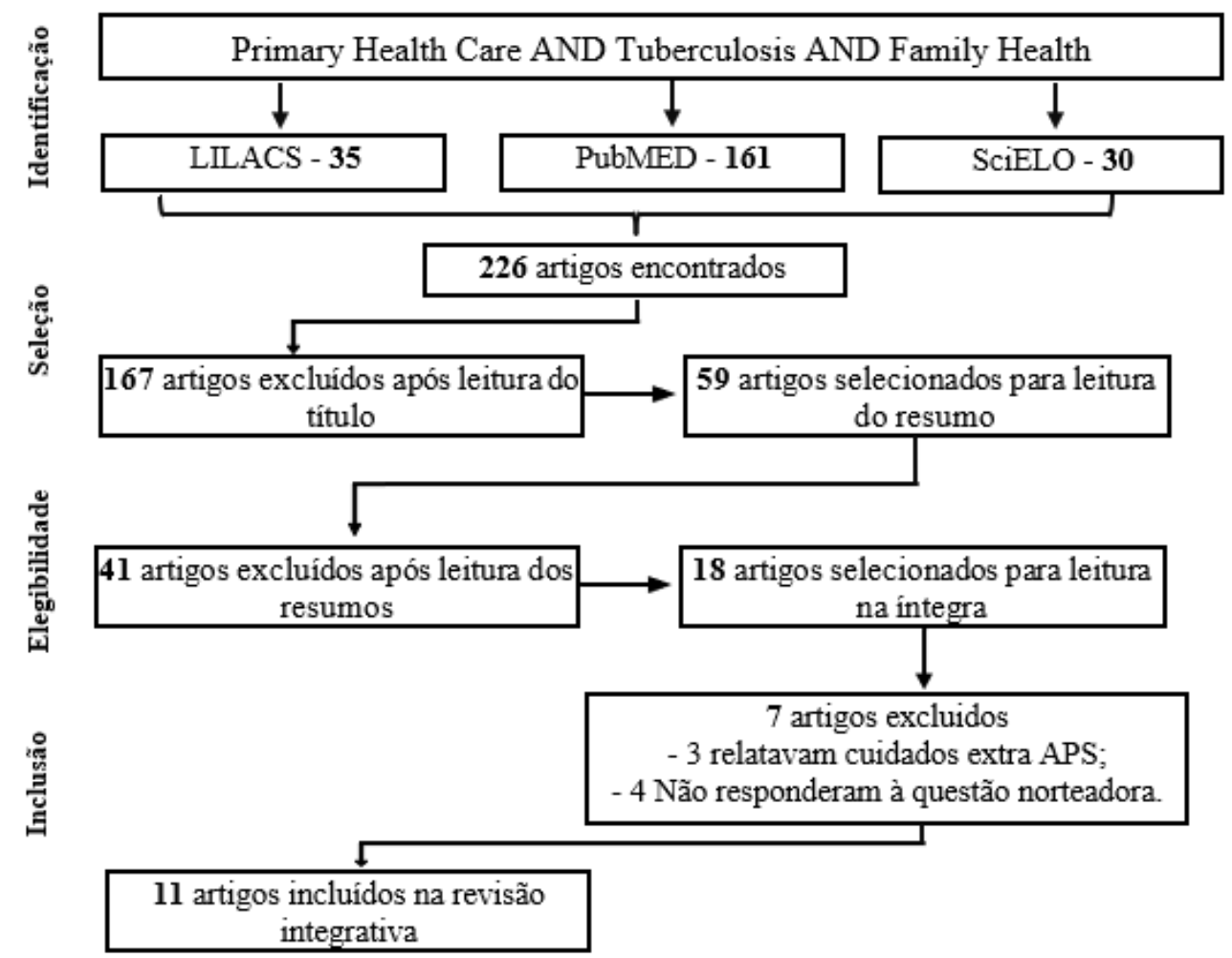

Fonte: Autoria própria.

O período de publicação dos artigos compreende os anos de 2017 (9,09\%), 2018 (45,45\%), 2019 (9,09\%), 2020 (18,18\%) e 2021 (9,09\%). Os estudos são provenientes dos seguintes países: Brasil (45,45\%), África do Sul (18,18\%), Argentina (9,09\%), Turquia $(9,09 \%)$ e Cuba (9,09\%), outros detalhes e dados dos estudos estão no Quadro 1. 
Quadro 1: Dados de identificação dos artigos incluídos na presente revisão, 2021.

\begin{tabular}{|c|c|c|c|}
\hline $\begin{array}{l}\text { Autor } \\
\text { [Ano] }\end{array}$ & $\begin{array}{l}\text { Título } \\
\text { [País] }\end{array}$ & Ação da APS & Conclusão \\
\hline $\begin{array}{l}\text { SIQUEIRA et al. } \\
\text { [2020] }\end{array}$ & $\begin{array}{l}\text { Percepção de enfermeiros: } \\
\text { enfoque na família e } \\
\text { orientação para a } \\
\text { comunidade nas ações de } \\
\text { tuberculose } \\
\text { [Brasil] }\end{array}$ & $\begin{array}{lr}\text { Realização } & \text { de } \\
\text { propagandas, } & \\
\text { campanhas } & \text { e } \\
\text { trabalhos } & \\
\text { educativos } & \text { para } \\
\text { informar } r & \text { a } \\
\text { comunidade } & \text { sobre } \\
\text { a tuberculose. } & \end{array}$ & $\begin{array}{l}\text { É essencial a sensibilização } \\
\text { dos profissionais em relação a } \\
\text { esses aspectos, já que, por } \\
\text { meio dessas dimensões, } \\
\text { pode-se contribuir com o } \\
\text { controle da doença enquanto } \\
\text { problema de saúde pública. }\end{array}$ \\
\hline $\begin{array}{l}\text { BENETTI et al. } \\
\text { [2018] }\end{array}$ & $\begin{array}{l}\text { Desempenho dos serviços } \\
\text { de saúde na atenção à } \\
\text { tuberculose na estratégia de } \\
\text { saúde da família } \\
\text { [Brasil] }\end{array}$ & $\begin{array}{l}\text { Acolhimento, } \\
\text { orientação }\end{array}$ & $\begin{array}{l}\text { O desempenho dos serviços } \\
\text { de saúde apresenta } \\
\text { fragilidades e atende } \\
\text { parcialmente a clientela. }\end{array}$ \\
\hline $\begin{array}{c}\text { SANTANA et } \\
\text { al. } \\
\text { [2018] }\end{array}$ & $\begin{array}{l}\text { Avaliação do desempenho } \\
\text { das ações e serviços de } \\
\text { controle da tuberculose pela } \\
\text { estratégia saúde da família } \\
\text { [Brasil] }\end{array}$ & $\begin{array}{l}\text { Supervisão da } \\
\text { tomada da } \\
\text { medicação; } \\
\text { atividade/grupos de } \\
\text { educação em saúde. }\end{array}$ & $\begin{array}{l}\text { Houve fragilidades no } \\
\text { desempenho das ações e } \\
\text { serviços pela estratégia saúde } \\
\text { da família no munícipio de } \\
\text { Salgueiro, com prejuízos ao } \\
\text { controle e ao tratamento, } \\
\text { sendo necessário } \\
\text { fortalecimento das ações e } \\
\text { serviços no combate à } \\
\text { doença. }\end{array}$ \\
\hline $\begin{array}{l}\text { LÓPEZ et al. } \\
\text { [2020] }\end{array}$ & $\begin{array}{l}\text { Programa de intervención } \\
\text { comunitaria dirigido a } \\
\text { pacientes con riesgo de } \\
\text { tuberculosis pulmonar } \\
\text { [Cuba] }\end{array}$ & $\begin{array}{l}\text { Realização de } \\
\text { atividades } \\
\text { educacionais; } \\
\text { discussão em grupo. }\end{array}$ & $\begin{array}{l}\text { O programa de intervenção } \\
\text { comunitária voltado para } \\
\text { pacientes com risco de } \\
\text { tuberculose pulmonar, } \\
\text { avaliado por especialistas, é } \\
\text { relevante e viável. Encontra- } \\
\text { se em fase de aplicação na } \\
\text { área da saúde onde foi } \\
\text { realizada a investigação. }\end{array}$ \\
\hline $\begin{array}{l}\text { KESSLER et al. } \\
\text { [2018] }\end{array}$ & $\begin{array}{l}\text { Ações educativas e de } \\
\text { promoção da saúde em } \\
\text { equipes do Programa } \\
\text { Nacional de Melhoria do } \\
\text { Acesso e da Qualidade da } \\
\text { Atenção Básica, Rio Grande } \\
\text { do Sul, Brasil } \\
\text { [Brasil] }\end{array}$ & $\begin{array}{l}\text { Ações educativas e } \\
\text { de promoção da } \\
\text { saúde. }\end{array}$ & $\begin{array}{l}\text { Ações voltadas ao período } \\
\text { reprodutivo e a morbidades } \\
\text { crônicas eram o foco da APS. } \\
\text { A implementação da } \\
\text { estratégia de saúde da família } \\
\text { fortalece a promoção da } \\
\text { saúde. }\end{array}$ \\
\hline $\begin{array}{l}\text { OKEYO; } \\
\text { DOWSE } \\
\text { [2018] }\end{array}$ & $\begin{array}{l}\text { An illustrated booklet for } \\
\text { reinforcing community } \\
\text { health worker knowledge of } \\
\text { tuberculosis and facilitating } \\
\text { patient counselling } \\
\text { [África do Sul] }\end{array}$ & $\begin{array}{l}\text { Construção de } \\
\text { cartilha; palestras } \\
\text { sobre educação e } \\
\text { saúde; } \\
\text { aconselhamento. }\end{array}$ & $\begin{array}{l}\text { Um livreto sobre tuberculose } \\
\text { simples e fácil de usar } \\
\text { contendo pictogramas } \\
\text { melhorou o conhecimento do } \\
\text { agente comunitário de saúde } \\
\text { e atuou como uma } \\
\text { ferramenta valiosa na } \\
\text { comunicação e educação do } \\
\text { paciente. }\end{array}$ \\
\hline
\end{tabular}




\begin{tabular}{|c|c|c|c|}
\hline $\begin{array}{l}\text { Autor } \\
\text { [Ano] }\end{array}$ & $\begin{array}{l}\text { Título } \\
\text { [País] }\end{array}$ & Ação da APS & Conclusão \\
\hline PELTZER & $\begin{array}{l}\begin{array}{l}\text { Tuberculosis } \\
\text { communicable } \\
\text { comorbidity } \\
\text { multimorbidity in public } \\
\text { and }\end{array} \\
\text { primary care patients in } \\
\text { South Africa } \\
\text { [África do Sul] }\end{array}$ & $\begin{array}{l}\text { Ações educativas e } \\
\text { de promoção da } \\
\text { saúde. }\end{array}$ & $\begin{array}{l}\text { Alta comorbidade e } \\
\text { multimorbidade de doenças } \\
\text { crônicas não transmissíveis } \\
\text { foram encontradas entre } \\
\text { pacientes com tuberculose, } \\
\text { previstas pela disparidade } \\
\text { socioeconômica. }\end{array}$ \\
\hline $\begin{array}{c}\text { MEDEIROS et } \\
\text { al. } \\
\text { [2017] }\end{array}$ & $\begin{array}{l}\text { Sistemas de informação } \\
\text { clínica para o manejo da } \\
\text { tuberculose na atenção } \\
\text { primária à saúde } \\
\text { [Brasil] }\end{array}$ & $\begin{array}{lr}\text { Capacitação } & \text { dos } \\
\text { profissionais } & \mathrm{e} \\
\text { disponibilização } & \text { de } \\
\text { materiais } & \\
\text { informativos } & \text { de } \\
\text { qualidade. } & \end{array}$ & $\begin{array}{l}\text { Os sistemas de informação } \\
\text { clínica estão presentes no } \\
\text { município, principalmente em } \\
\text { prontuários e dados sobre os } \\
\text { pacientes, e possuem a } \\
\text { contribuição de profissionais } \\
\text { com vínculo para com os } \\
\text { portadores de tuberculose. }\end{array}$ \\
\hline $\begin{array}{l}\text { BERALDO et al. } \\
\text { [2017] }\end{array}$ & $\begin{array}{l}\text { Adesão ao tratamento da } \\
\text { tuberculose na Atenção } \\
\text { Básica: percepção de } \\
\text { doentes e profissionais em } \\
\text { município de grande porte } \\
\text { [Brasil] }\end{array}$ & $\begin{array}{l}\text { Orientação sobre } \\
\text { tuberculose; } \\
\text { entrega de } \\
\text { informações } \\
\text { escritas sobre o } \\
\text { tratamento; } \\
\begin{array}{l}\text { oferecimento de } \\
\text { grupo. }\end{array}\end{array}$ & $\begin{array}{l}\text { A identificação de lacunas na } \\
\text { oferta de ações para a adesão } \\
\text { ao tratamento da tuberculose } \\
\text { pode ajudar os serviços de } \\
\text { saúde a modificar e melhorar } \\
\text { a prática e o cenário } \\
\text { epidemiológico da doença. }\end{array}$ \\
\hline $\begin{array}{l}\text { MARIANI et al. } \\
\text { [2021] }\end{array}$ & $\begin{array}{l}\text { Evaluation of the first level } \\
\text { of care for tuberculosis } \\
\text { control in Buenos Aires, } \\
\text { Argentina } \\
\text { [Argentina] }\end{array}$ & $\begin{array}{l}\text { Cuidado centrado } \\
\text { na família e } \\
\text { orientação para a } \\
\text { comunidade. }\end{array}$ & $\begin{array}{l}\text { Na percepção dos } \\
\text { participantes com e sem } \\
\text { tuberculose, as funções da } \\
\text { APS não são satisfatórias, seja } \\
\text { nas favelas ou fora delas. }\end{array}$ \\
\hline $\begin{array}{c}\text { TÜRKKANI et } \\
\text { al. }\end{array}$ & $\begin{array}{l}\text { National Control of } \\
\text { Tuberculosis: Does Primary } \\
\text { Health Care System Play a } \\
\text { Crucial Role in the Fight } \\
\text { Against Tuberculosis? } \\
\text { [Turquia] }\end{array}$ & $\begin{array}{l}\text { Educação em saúde; } \\
\text { educação } \\
\text { permanente e } \\
\text { conscientização dos } \\
\text { profissionais de } \\
\text { saúde. }\end{array}$ & $\begin{array}{l}\text { O controle da tuberculose na } \\
\text { APS é parcialmente bem- } \\
\text { sucedido e insuficiente. A taxa } \\
\text { geral de exame microscópico, } \\
\text { cultura de escarro e testes de } \\
\text { sensibilidade a medicamentos } \\
\text { realizados em pacientes no } \\
\text { sistema de APS é baixa e deve } \\
\text { ser melhorada } \\
\text { imediatamente. }\end{array}$ \\
\hline
\end{tabular}

Fonte: Autoria própria.

Os achados foram agrupados em duas categorias denominadas "Ações direcionadas aos usuários" e "Ações direcionadas aos profissionais". 


\section{DISCUSSÃO}

\subsection{AÇÕES DIRECIONADAS AOS USUÁRIOS}

Em um estudo brasileiro realizado recentemente, onde se investigou as ações da APS no enfrentamento da COVID-19, os autores pontuam que "a APS tradicionalmente é o loco onde se tem a efetivação do cuidado integral, com possibilidade do olhar singular para cada para "caso/família" especificamente" (ANDRADE et al., 2021). Neste interim sinaliza-se convergência entre as ações encontradas na presente revisão e as funções/características da APS.

As ações direcionadas aos usuários foram: realização de propagandas, campanhas para informar a comunidade sobre a tuberculose (SIQUEIRA et al., 2020); acolhimento, orientação (BERALDO et al., 2017; BENETTI et al., 2018; MARIANI et al., 2021); aconselhamento (OKEYO; DOWSE, 2018); supervisão da tomada da medicação (SANTANA et al., 2018); cuidado centrado na família (MARIANI et al., 2021); ações educativas e de promoção da saúde (KESSLER et al., 2018; OKEYO; DOWSE, 2018; SANTANA et al., 2018; PELTZER, 2018; TÜRKKANI et al., 2019; SIQUEIRA et al., 2020); discussão em grupo (BERALDO et al., 2017; LÓPEZ et al., 2020);construção de cartilha (OKEYO; DOWSE, 2018); disponibilização de materiais informativos de qualidade (MEDEIROS et al., 2017; BERALDO et al., 2017).

Em relação a realização de propagandas, campanhas, estas estão atreladas a função primordial da APS, de promoção e prevenção em saúde (BRASIL, 2017), tendo em vista que ao se investir em ações como as supra referidas, tem-se maior cuidado por parte das pessoas e por conseguinte redução na transmissão e no número de casos de adoecimento. Ratifica-se, portanto, as ações de base comunitária e que sejam condizentes à realidade da população, para que então faça sentindo e desencadeia a sensibilização (ROSSETTO, M. et al., 2017).

$\mathrm{O}$ ato de acolher, orientar, aconselhar e supervisão na tomada de medicação, demonstram a potência da APS na comunidade, e desvela a proximidade que esta possui com a comunidade, haja visto que é a instancia de saúde mais próxima do usuário (ALVES et al., 2017). Assim, vale destacar a importância da tecnologias leves no cuidado em saúde, sobretudo na criação/fortalecimento do vínculo na díade usuário-profissional (FERREIRA; SANTOS; ORFÃO, 2019). Pontua-se também que o vínculo é imprescindível 
para um cuidado adequado e efetivo (FERREIRA; SANTOS; ORFÃO, 2019). Os achados do presente estudo, são consoantes ao da literatura, e pontua-se que, acolher, orientar, aconselhar e supervisionar a tomada de medicação só é possível com proximidade e vinculo, ratificando-se, portanto, os achados supra referidos.

Outra ação descrita foi o cuidado centrado na família, de acordo com Lino et al. (2020), a articulação entre a equipe de saúde e a família possibilita ações de cuidado na perspectiva da integralidade, e ao se priorizar as necessidades na perspectiva do usuário, tem-se o reconhecimento e a valorização de sua autonomia, sentimentos e necessidades, que se tornam elementos centrais para a consolidação do cuidado em saúde e consequentemente da APS. Andrade e colaboradores (2021), corroboram esses achados e argumentam que a APS é fundamental no cuidado tanto de problemas crônicos, quanto agudos, sendo capaz de resolver até $80 \%$ da demanda da população.

Outras ações da APS no combate à tuberculose, dizem respeito a ações educativas e de promoção da saúde, envolvendo a discussão em grupo, construção de cartilha e disponibilização de materiais informativos de qualidade. Tais ações se relacionam com a experiência de pesquisadoras da Universidade Federal do Rio de Janeiro, que perceberam a escassez de informações adequadas e de qualidade direcionada ao público com tuberculose e então, construíram um material informativo com base em informações de um revisão de literatura (ROCHA et al., 2020). As autoras também pontuam sobre a importância da terapia medicamentosa e do diálogo com a equipe de saúde responsável pelo tratamento, visando a estruturação de metas adaptadas ao tratamento, que é singular, envolvendo a realidade de cada indivíduo (LINO et al., 2020; ROCHA et al., 2020).

Destaca-se que cada um a seu modo, os cinco países relacionados nesta revisão (Brasil, África do Sul, Argentina, Turquia e Cuba), possuem ações de educação em saúde, voltadas à população. Logo, enfatiza-se a importância das ações encontradas na primeira categoria, pontua-se que estas se referem a diferentes realidades e contextos, sendo necessário divulgação e replicação destas para possível replicação em outras realidades, no intuito de se obter sucesso na prevenção e tratamento da tuberculose. 


\subsection{AÇÕES DIRECIONADAS AOS PROFISSIONAIS}

Desde sua gênese a APS possui um forte envolvimento com a educação permanente (BRASIL, 2017), e esta, foi relata em alguns dos estudos que compõem a presente análise (MEDEIROS et al., 2017), sendo promotora da conscientização dos profissionais de saúde (TÜRKKANI et al., 2019), da realização de atividades educacionais (LÓPEZ et al., 2020), e consequentemente na capacitação dos profissionais (TÜRKKANI et al., 2019).

No tocante a educação permanente, ela é imprescindível para a compreensão dos processos vivenciais por parte dos profissionais. Neste aspecto, um estudo brasileiro, apontou que a educação permanente se constitui em um nó crítico do processo de trabalho na APS (AMARAL, et al., 2021). Os autores pontuam ainda, que a educação permanente possibilita aos profissionais a compreensão e consequentemente o desenvolvimento de suas funções, além de ampliar o conhecimento necessário para atuarem no cenário da APS (AMARAL, et al., 2021). A argumentação acima, vai ao encontro do que foi encontrado no presente estudo, sendo, portanto, imprescindível investir em ações de educação permanente, como as encontradas, um vez que estas, possibilitam a sensibilização (SIQUEIRA et al., 2020) e capacitação dos profissionais (MEDEIROS et al., 2017; TÜRKKANI et al., 2019; LÓPEZ et al., 2020), culminando na maior oferta de cuidado e melhoria dos serviços.

Sinaliza-se que em relação a tuberculose, ao responsabilizar apenas os pacientes pelo seu estado de saúde, a equipe acaba restringindo o significado de "saúde ampliada" e para além disso, acaba sendo negligente em relação as necessidades que os usuários possuem (FABRINI, et al., 2018). Porém, ao se colocar como corresponsável pelo processo de saúde-adoecimento-doença, a equipe da APS, possibilita um cuidado ampliado e fortalece o vínculo entre serviço-comunidade, conseguindo desempenhar seu papel adequadamente, com efetividade e excelência (FABRINI, et al., 2018). E todo esse processo de mudança de atitude, está diretamente relacionada a educação permanente, sendo, portanto, extremamente importante tal ação tanto para o cuidado de pessoas com tuberculose, quanto para outras necessidades dos usuários e comunidade (FABRINI, et al., 2018; AMARAL, et al., 2021). 
Por fim, demarca-se que diferentemente das ações direcionadas a população, as ações direcionadas a profissionais, foram relatadas somente em três estudo, e estes eram originados do Brasil (MEDEIROS et al., 2017), Cuba (LÓPEZ et al., 2020) e Turquia (TÜRKKANI et al., 2019). Logo, é imprescindível disseminar tais experiências, que relacionam a educação permanente ao combate à tuberculose e para além disso, faz-se urgente o fortalecimento da educação permanente na APS.

\section{CONCLUSÃO}

Os dados obtidos neste estudo apontam para a importância das ações implementadas pela APS no combate à tuberculose, sobretudo pela potência desta instância na saúde das populações. Enfatiza-se que a proximidade que a APS estabelece com os usuários, torna o processo de cuidar mais fácil, assim, pontuasse a respeito da importância das ações implementadas pela APS, bem como da necessidade de divulgálas.

Demarca-se que cinco nacionalidades diferentes (Brasil, África do Sul, Argentina, Turquia e Cuba), estão debruçadas sobre a presente temática, evidenciando diversas ações de enfrentamento à tuberculose, tanto de impacto a população como: realização de propagandas, campanhas para informar a comunidade sobre a tuberculose; acolhimento, orientação; aconselhamento; supervisão da tomada da medicação; cuidado centrado na família; ações educativas e de promoção da saúde; discussão em grupo; construção de cartilha; disponibilização de materiais informativos de qualidade. E algumas ações de impacto profissional, envolvendo: conscientização dos profissionais de saúde; realização de atividades educacionais; capacitação dos profissionais e educação permanente.

Por fim, pontua-se que o quão é urgente a necessidade de fortalecimento e ampliação da APS, isso a nível global. Ademais este trabalho evidencia a escassez de pesquisas sobre as ações da APS ante à tuberculose. Portanto, novos estudos são necessários para melhor compreensão da temática e mensuração das ações desempenhadas pela APS no enfrentamento à tuberculose. 


\section{REFERÊNCIAS}

ALVES, S. R. P. et al. Gestão da tuberculose na atenção primária à saúde: uma revisão integrativa. Revista de Pesquisa: Cuidado é Fundamental, v. 10, n. 2, p. 183-186, 2018.

AMARAL, V. S. et al. Os nós críticos do processo de trabalho na Atenção Primária à Saúde: uma pesquisa-ação. Physis: Revista de Saúde Coletiva, v. 31, p. e310106, 2021.

ANDRADE, J. V. et al. Ações da Atenção Primária à Saúde no Combate à COVID-19: Revisão Integrativa. In: João Vitor Andrade. (Org.). Introdução às Ciências da Saúde. 1ed.Belo Horizonte: AFORISMO, 2021, p. 9-28.

BARATA, R. B. et al. Desigualdade social em saúde na população em situação de rua na cidade de São Paulo. Saúde e Sociedade, v. 24, n. 1, p. 219-232, 2015.

BARATIERI, T.; MARCON, S. S. Longitudinalidade do cuidado: compreensão dos enfermeiros que atuam na estratégia saúde da família. Escola Anna Nery, v. 15, n. 4, p. 802-810, 2011.

BARBERIS, I. et al. The history of tuberculosis: from the first historical records to the isolation of Koch's bacillus. Journal of preventive medicine and hygiene, v. 58, n. 1, p. e9, 2017.

BENETTI, K. V. et al. Desempenho dos serviços de saúde na atenção à tuberculose na estratégia de saúde da família. Revista Enfermagem UERJ, v. 26, p. e31643, 2018.

BERALDO, A. A. et al. Adesão ao tratamento da tuberculose na Atenção Básica: percepção de doentes e profissionais em município de grande porte. Escola Anna Nery, v. 21, 2017.

BRASIL. Ministério da Saúde. Política Nacional de Atenção Básica. Brasília: Ministério da Saúde, 2017.

BRASIL. Ministério da Saúde. Secretaria de Vigilância em Saúde. Departamento de Vigilância Epidemiológica. Tuberculose: alinhada com o social, afinada com a tecnologia. Boletim Epidemiológico, n. 44, v. 2, p. 1-6, 2013.

BRASIL. Ministério da Saúde. Secretaria de Vigilância em Saúde. Departamento de Vigilância das Doenças Transmissíveis. Panorama da tuberculose no Brasil: indicadores epidemiológicos e operacionais. Brasília: MS, 2014.

DEUTSCH-FELDMAN, Molly et al. Tuberculosis-United States, 2020. Morbidity and Mortality Weekly Report, v. 70, n. 12, p. 409, 2021. 
FABRINI, V. C. N. et al. Cuidado a pessoas com tuberculose privadas de liberdade e a educação permanente em saúde. Trabalho, Educação e Saúde, v. 16, p. 10571077, 2018.

FERREIRA, M. R. L.; SANTOS, A. A.; ORFÃO, N. H. O vínculo no tratamento da tuberculose na atenção primária à saúde: uma revisão integrativa. Revista Brasileira em Promoção da Saúde, v. 32, 2019.

FURIN, J.; COX, H.; PAI, M. Tuberculosis. Lancet, v. 393, n. 10181, p. 1642-1656, 2019.

GALVAO, C. M. Níveis de evidência. Acta Paulista de Enfermagem, v. 19, n. 2, p. 5, 2006.

IBGE - Instituto Brasileiro de Geografia e Estatística. Projeção da população do Brasil e das Unidades da Federação. Brasil: IBGE; 2020. Disponível em: http://www.ibge.gov.br/apps/populacao/projecao

KESSLER, M. et al. Ações educativas e de promoção da saúde em equipes do Programa Nacional de Melhoria do Acesso e da Qualidade da Atenção Básica, Rio Grande do Sul, Brasil. Epidemiologia e Serviços de Saúde, v. 27, p. e2017389, 2018.

LINO, I. G. T. et al. Desafios para o cuidado às famílias de crianças com deficiência na atenção primária à saúde. Revista Mineira de Enfermagem, v. 24, p. 1-8, 2020.

LÓPEZ, M. J. G. et al. Programa de intervención comunitaria dirigido a pacientes con riesgo de tuberculosis pulmonar. Revista Cubana de Salud Pública, v. 45, p. e1522, 2020.

MACIEL, E. L. N. Estratégias da agenda pós-2015 para o controle da tuberculose no Brasil: desafios e oportunidades. Epidemiologia e Serviços de Saúde, v. 25, p. 423-426, 2016.

MARIANI, J. et al. Evaluation of the first level of care for tuberculosis control in Buenos Aires, Argentina. Revista Panamericana de Salud Pública, v. 45, 2021.

MEDEIROS, E. R. et al. Sistemas de informação clínica para o manejo da tuberculose na atenção primária à saúde. Revista Latino-Americana de Enfermagem, v. 25, p. e2964, 2017.

MENDES, K. D. S.; SILVEIRA, R. C. C. P.; GALVÃO, C. M. Uso de gerenciador de referências bibliográficas na seleção dos estudos primários em revisão integrativa. Texto \& Contexto-Enfermagem, v. 28, 2019.

OKEYO, I. L. A.; DOWSE, R. An illustrated booklet for reinforcing community health worker knowledge of tuberculosis and facilitating patient counselling. African Journal of Primary Health Care \& Family Medicine, v. 10, n. 1, p. 1-7, 2018. 
OPAS - Organização Pan-Americana da Saúde. Tuberculosis in the Americas, 2018. Washington, D.C.: PAHO, 2018. Available from: https://iris.paho.org/bitstream/handle/10665.2/49510/PAHOCDE18036_eng?s equence $=1$ \&isAllowed $=y$

ORLANDI, G. M. et al. Incentivos sociais na adesão ao tratamento da tuberculose. Revista Brasileira de Enfermagem, v. 72, p. 1182-1188, 2019.

PELTZER, K. Tuberculosis non-communicable disease comorbidity and multimorbidity in public primary care patients in South Africa. African Journal of Primary Health Care \& Family Medicine, v. 10, n. 1, p. 1-6, 2018.

ROCHA, N. L. et al. Material educativo para pacientes com tuberculose pulmonar frente a pandemia de COVID-19. Revista de Saúde Coletiva da UEFS, v. 10, n. 1, p. 18$22,2020$.

ROSSETTO, M. et al. Comunicação para promoção da saúde: as campanhas publicitárias sobre tuberculose no Brasil. Revista de Enfermagem da UFSM. v. 7, n. 1, p. 1828, 2017.

SANTANA, F. M. et al. Avaliação do desempenho das ações e serviços de controle da Tuberculose pela estratégia saúde da família. Journal of Human Growth and Development, v. 28, n. 3, p. 337-347, 2018.

SILVA, D. R., et al. Série tuberculose. Jornal Brasileiro de Pneumologia, v. 44, n. 2, p. 7172, 2018.

SIQUEIRA, T. C. et al. Percepção de enfermeiros: enfoque na família e orientação para a comunidade nas ações de tuberculose. Ciência, cuidado e saúde, v. 19, p. e50175, 2020.

TÜRKKANI, M. H. et al. National Control of Tuberculosis: Does Primary Health Care System Play a Crucial Role in the Fight Against Tuberculosis? Turkish thoracic journal, v. 20, n. 4, p. 230-235, 2019. 


\section{ESTEATOSE HEPÁTICA: UM RELATO DE CASO}

DOI: 10.51859/AMPLLA.PAE1993-25

Karine Aparecida de Lima $^{1}$

${ }^{1}$ Nutricionista. Mestranda no Programa de Pós-Graduação Interdisciplinar em Desenvolvimento Comunitário PPGDC.

\section{RESUMO}

Paciente D.D., 67 anos, sexo masculino, de 67 anos, possui esteatose hepática com hepatomegalia leve, refere desconfortos abdominais e dor nos membros inferiores (perda da força), incluindo fraqueza. O paciente também relatou episódios frequentes de êmese, o que estava ocasionando uma perda grave de peso, agravando seu estado nutricional. Foi realizada uma avaliação nutricional, a partir da qual obteve-se dados subjetivos e objetivos. De acordo com a avaliação antropométrica o paciente apresentava-se abaixo do seu peso ideal para a idade e altura, com ingestão alimentar abaixo da demanda energética recomendada. Com o objetivo de melhorar o prognóstico do paciente, foi proposta uma dieta via oral de consistência normal, com prescrição energética normocalórica, hipolipídica, normoglicídica, hiperproteica, com fracionamento de 6 vezes ao dia.

Palavras-Chave: Esteatose Hepática. Desnutrição. Fígado. Nutrição. 


\section{INTRODUÇ̃̃o}

O fígado é a maior glândula do corpo humano, sua funcionalidade morfológica requer que esteja atuando de forma íntegra no organismo para seu melhor desempenho (KUNTZ, 2006). Dentre as funções realizadas pelo fígado destaca-se as fisiológicas, as homeostáticas, o metabolismo de nutrientes e micronutrientes, a produção e secreção de bile, a síntese de protrombina e de fatores de coagulação (ARIAS et al., 2020). Além disso o fígado participa de funções relacionadas ao armazenamento de glicogênio, degradação e excreção de hormônios, biotransformação de compostos e auxílio de resposta imune do organismo (SCHINONI,2008).

Por ser um órgão propenso a insultos metabólicos, tóxicos, microbianos, circulatórios e neoplásicos, o fígado é suscetível desenvolver doenças de formas primárias, que podem ter diagnósticos tais como hepatite viral, doença hepática alcoólica, doença hepática gordurosa não alcoólica (DHGNA), também denominada esteatose hepática e o carcinoma hepatocelular (STEFAN et al., 2019). E de forma secundária podem desenvolver-se descompensação cardíaca, câncer disseminado e infecções extra-hepáticas (ABBAS et al., 2008).

A esteatose hepática ou Doença Hepática Gordurosa Não Alcoólica (DHGNA) pode ser definida acúmulo de gordura nos hepatócitos e causar estresse oxidativo hepático, causando lesão hepatocelular (FARZANEGl et al., 2019). Além de modificações histopatológicas no fígado a esteatose hepática pode ocasionar alterações das funções e das enzimas hepáticas. Nesse caso o prejuízo decorrente pode ser perda da função do fígado, o qual vai apresentar dificuldade na metabolização dos nutrientes, na produção da bile, ocasionando falência do órgão (CHAVES et al., 2012). As causas de esteatose incluem sedentarismo, alimentação desequilibrada, excesso de toxinas, desnutrição proteica, diabetes mellitus e obesidade (ABBAS et al., 2008).

O acúmulo de gorduras nos hepatócitos, é formada através dos ácidos graxos livres ou do tecido adiposo. A gordura é transportada para os hepatócitos onde são esterificados em forma de triglicerídeos e convertidos em colesterol, fosfolipídios ou corpos cetônicos. O acúmulo de gordura nos hepatócitos pode aumentar o órgão, o que pode gerar a hepatomegalia, torná-lo palpável e devido a quantidade de gordura tornase amarelo (ROBBINS; COTRAN, 2007). 
O diabetes mellitus pode levar o fígado a desenvolver esteatose hepática, que pode resultar da resistência à insulina e da sua deficiência. A resistência à insulina ocorre quando há uma menor captação de glicose por tecido muscular e hepático em reposta à ação da insulina. Essas alterações metabólicas no corpo inibem a lipólise que é mediada através da enzima lipase hormônio-sensível (LHS), sendo assim sem a quebra de moléculas de gordura (lipólise) o quadro vai evoluindo para esteatose hepática (FONSECA-ALANIZ et al., 2016).

O tratamento consiste no controle de problemas associados, como no caso deste paciente inicialmente controlar episódios de êmese interrupção de drogas potencialmente hepatóxicas que possam piorar a esteatose, impedindo a evolução do dano hepático. No entanto, considera-se também essencial além do tratamento medicamentoso, o tratamento nutricional visando a melhora do estado nutricional e da qualidade de vida do paciente (CUPPARI, 2005). Portanto, o objetivo deste estudo de caso é verificar as condições atuais de saúde do paciente e conduzir alternativas para a recuperação do fígado, referente ao quadro da esteatose hepática e consequentemente a melhora do estado nutricional.

\section{METODOLOGIA}

Paciente D.D, do sexo masculino, com idade de 67 anos, foi internado na clínica médica de um hospital no estado do Paraná. O paciente havia sido diagnosticado com esteatose hepática há 9 meses e há 1 mês e meio vem apresentando piora no quadro. Apresentava abdômen distendido (hepatomegalia), desconfortos abdominais com episódios frequentes de êmese, e nos últimos 10 dias anterior à avaliação havia perdido $10 \mathrm{~kg}$.

O paciente referiu que aos 42 anos teve diabetes tipo 2 , realizou o tratamento e tomou medicamentos por dois anos e após esse período o nível de glicemia manteve-se controlado e sem alterações. Relatou ser tabagista, sem histórico de etilismo.

Foram executados alguns exames para melhor estudar o caso, além de avaliação antropométrica, foi realizado o exame físico, o qual possui objetivo é detectar deficiências nutricionais. No exame físico são observados sob olhar clínico fatores como tipo físico, mobilidade do paciente e os sinais de depleção nutricional, sinais de perda de massa muscular e perda de peso tanto dos membros superiores quanto inferiores 
(AZEVEDO et al., 2016). É observada também a pigmentação da pele, a presença ou ausência de edema, turgor, lesões e presença de úlceras. Deve-se avaliar também através do exame físico a conjuntiva ocular, as gengivas, a cor da língua, os cabelos e as unhas (ACUÑA; CRUZ, 2004).

A Mini Avaliação Nutricional (MAN) é um método com o objetivo de avaliar de uma forma rápida o estado nutricional de pacientes idosos e verificar o possível risco de desnutrição, com perguntas relacionadas ao estilo de vida, medicação e morbidade. A MAN verifica informações referentes ao consumo dietético do paciente, com perguntas relativas ao número de refeições, ingestão alimentar e avaliação subjetiva avaliando percepção da saúde e nutrição, por isso foi essencial incluí-la para avaliação do paciente (LOZOYA et al., 2017). A escala de classificação da MAN determina paciente com pontuação menor de 17 como um indivíduo desnutrido, entre 17 a 23,5 pontos sob risco de desnutrição e 24 a 30 pontos estado nutricional saudável ou normal (VELLAS, B et al., 2006).

A avaliação Subjetiva global (ASG) é um questionário de fácil aplicação e com métodos não-invasivos, sem necessidade de aparelhos ou exames complementares, realizável à beira do leito, com sensibilidade e especificidade apropriadas e com resultado imediato (YAMAUTI et al., 2007). O principal objetivo da ASG é determinar com maior sensibilidade casos de desnutrição e investigar mudanças de peso em curto espaço de tempo, o que permite a verificação da necessidade de intervenções nutricionais pertinentes (LIM et al., 2016; VASCONCELOS et al., 2020). A Classificação é composta por uma pontuação de 0 a 9 pontos, sendo considerada a pontuação de 0 a 1: Sem necessidade de intervenção no momento. A pontuação de 2 a 3: Necessidade de acompanhamento com um profissional nutricionista para fornecer instruções de educação nutricional que devem ser adotadas pelo paciente e seus familiares a fim de melhora da qualidade de vida. Pontuação entre 4 a 8: Necessita intervenção por nutricionista, juntamente com profissionais da enfermagem e médico, como indicado pelo inquérito dos sintomas. E a pontuação $\geq 9$ : Indica necessidade crítica de melhora no manuseio dos sintomas e/ou opções de intervenção nutricional, incluindo equipe multidisciplinar para atuar junto no tratamento (GONZALEZ et al., 2010).

A avaliação antropométrica é fundamental para análise do estado nutricional dos pacientes, com o objetivo de manutenção, prevenção ou até mesmo tratamento de 
patologias quando é o caso (BHATTACHARYA et al., 2019). No ambiente hospitalar, a avaliação antropométrica deve ser rotineiramente realizada, para seu diagnóstico é importante um conjunto de procedimentos a fim de que torne mais precisa a determinação do estado nutricional. A avaliação antropométrica realizada periodicamente em hospitais promove melhor acompanhamento nutricional de cada paciente e apuração de dados para intervenções, uma vez que a desnutrição pode ocorrer durante o período de internação (DUCHINI et al., 2010; SOUSA et al., 2018).

\section{RESULTADOS}

Ao realizar o exame físico, o paciente D.D apresentou conjuntiva hipocorada, perda da musculatura temporal, perda da bola gordurosa de Bichart, membros superiores e inferiores com perda de massa muscular, ausência de edema e demais itens do exame físico sem alterações.

Ao realizar a MAN, o paciente D.D pode ser classificado como desnutrido, ao considerar que sua pontuação foi de 16 pontos neste instrumento. Na avaliação da ASG, o paciente apresentou mudança de peso nos últimos seis meses e continua perdendo peso atualmente, dieta diminuída, com mudança persistente, presença de vômitos. Além disso, foi verificada capacidade funcional física abaixo do normal, estresse moderado e perda de gordura subcutânea em membros inferiores e superiores. 0 somatório da ASG foi de 10 pontos, sendo assim o paciente D.D foi classificado com desnutrição leve.

Na tabela 1, estão apresentados os dados dos parâmetros antropométricos que foram avaliados no paciente D.D e seus respectivos valores.

Tabela 1 - Dados do paciente referente à avaliação antropométrica

\begin{tabular}{|l|c|}
\hline Avaliação Antropométrica & Valor \\
\hline Peso atual & $57,2 \mathrm{~kg}$ \\
\hline Peso usual & $78 \mathrm{~kg}$ \\
\hline Peso ideal & $80,5 \mathrm{~kg}$ \\
\hline Semi-envergadura & $82,5 \mathrm{~cm}$ \\
\hline Altura estimada & $1,65 \mathrm{~m}$ \\
\hline Índice de Massa Corporal (IMC) & $21,0 \mathrm{~kg} / \mathrm{m}^{2}$ \\
\hline Circunferência do Braço (CB) & $27,5 \mathrm{~cm}$ \\
\hline Circunferência Muscular do Braço (CMB) & $24,3 \mathrm{~cm}$ \\
\hline Circunferência do Punho (CPunho) & $15,8 \mathrm{~cm}$ \\
\hline Circunferência da Panturrilha (CP) & $27,6 \mathrm{~cm}$ \\
\hline Prega Cutânea Bicipital (PCB) & $7 \mathrm{~mm}$ \\
\hline Prega Cutânea TricipitaL (PCT) & $10 \mathrm{~mm}$ \\
\hline
\end{tabular}




\begin{tabular}{|l|c|}
\hline Avaliação Antropométrica & Valor \\
\hline Prega Cutânea Subescapular (PCSE) & $13 \mathrm{~mm}$ \\
\hline Músculo Adutor do Polegar (MAP) & $6 \mathrm{~mm}$ \\
\hline Altura do Joelho (AJ) & $46,1 \mathrm{~cm}$ \\
\hline \%Perda de Peso/tempo & $26,6 \%(20,8 \mathrm{~kg}$ em 3 meses $)$ \\
\hline
\end{tabular}

Fonte: Autoria própria.

Para a aferição do peso $(\mathrm{kg})$ foi utilizada balança digital portátil (Elite Imports ${ }^{\circledR}$, EL2005D, Brasil) com capacidade de $180 \mathrm{~kg}$ (precisão de $100 \mathrm{~g}$ ). A altura (m) foi estimada através do método de semi-envergadura, com o auxílio de uma fita (Cescorf ${ }^{\oplus}$, Brasil) inelástica, em aço $(2 \mathrm{~m}$, com precisão de $0,1 \mathrm{~cm})$. Além disso, para realizar as pregas cutâneas e o Músculo Adutor do Polegar (MAP) foi utilizado um adipômetro clínico tradicional (Cescorf ${ }^{\oplus}$, Brasil). Ao aferir peso e altura, é possível realizar o diagnóstico de Índice de Massa Corporal (IMC) (WHO, 1995; 1998), o qual apresentou baixo peso considerando que é um indivíduo idoso. Sua perda de peso foi de 26,6\% em 3 meses, uma perda grave de peso, agravando seu estado nutricional. Outros dados, como Circunferência do Braço (CB), Circunferência da Panturrilha (CP) e a espessura do MAP, confirmam o estado de desnutrição do paciente, com perda de massa muscular e tecido adiposo, observados também no exame físico.

Como diagnóstico nutricional do paciente, determina-se que este encontrava-se desnutrido, devido a perda grave de peso associados à perda de massa muscular e de tecido adiposo confirmados na avaliação antropométrica e no exame físico, assim como nos instrumentos MAN e ASG.

O paciente estava recebendo apenas dois medicamentos que eram dipirona e metoclopramida durante o período de internamento, visto que administrava outros medicamentos em sua residência, os quais no momento estavam interrompidos para não sobrecarregar o fígado.

O paciente alimenta-se via oral, referiu baixa aceitação da dieta hospitalar, relata que nos últimos dias não estava conseguindo alimentar-se, constatou que no lar sua ingestão energética é melhor. Refere ingestão hídrica de aproximadamente 500 a 750 $\mathrm{ml}$ por dia, valor bem abaixo do ideal, sendo que a recomendação seria pelo menos 2 litros de água por dia (BRASIL, 2008). Dessa forma recomenda-se dieta via oral, com indicação energética normocalórica, normoglicídica, hiperproteica e hipolipídica. 0 fracionamento deve ser de pelo menos 6 refeições por dia, evitando longos períodos de jejum. A dieta via oral é sugerida considerando que o paciente não apresenta nenhuma 
dificuldade na mastigação e deglutição, e a indicação de normocalórica e hipolipídica é recorrente à esteatose hepática, visando uma melhora do estado nutricional do paciente (CUPPARI, 2005).

A alimentação deve ser composta por frutas, hortaliças, carnes, ovos, leite desnatado e alimentos integrais, considerando que são alimentos qualitativamente mais saudáveis, pois são fontes de vitaminas, minerais, fibras e proteínas principalmente (GOMES, 2014). Alimentos integrais, além de promover mais saciedade, podem auxiliar na melhor do estado nutricional, com redução de gordura corporal (GOMES, 2014), nesse caso especialmente visando a redução da gordura do localizada no fígado. 0 consumo de alimentos integrais, contribui no aumento de massa magra, para ganho de peso saudável (CUPPARI, 2005), sendo uma estratégia dietética que beneficiará o paciente o qual encontra-se com desnutrição.

\section{DISCUSSÃO}

A substituição de grãos refinados por cereais integrais é uma estratégia para a redução da possiblidade de ocorrer resistência insulínica, já as fibras solúveis contribuem para a redução dos níveis de colesterol sérico e LDL (SILVA; MURA, 2007).

Considera-se ideal apenas a perda da gordura abdominal, mais precisamente do fígado, uma vez que a perda de peso nesse paciente não é recomendada nesse caso, pois pode levar a fibrose e inflamação portal. A fibrose na esteatose hepática pode ocorrer devido à perda de peso, e nesse caso relaciona-se com a diminuição de parte das funções das células do fígado, o que leva a redução da síntese de lipoproteínas, como consequência diminui a liberação de lipídios para o fígado, afetando a secreção de VLDS e beta-oxidação, contribuindo para a perda de peso (HASHIMOTO et al., 2015; MINCIS; MINCIS, 2011).

Referente aos micronutrientes, uma alimentação saudável e equilibrada promove um aporte adequado de vitaminas ( $A$ e E), as quais são consideradas antioxidantes, pois são capazes de combater radicais livres (SAEED et al., 2018; NAGASHIMADA; OTA, 2019). Em geral o consumo frutas e hortaliças fornecem vitaminas e minerais, alimentos fontes de antioxidantes que auxiliam no tratamento do fígado gorduroso, no entanto o baixo consumo desses micronutrientes podem interferir no 
agravamento da esteatose hepática (PICKETT-BLAKELY et al., 2018; NAGASHIMADA; OTA, 2019).

As necessidades basais de um idoso estão em média diminuídas e têm associação com menor atividade física. No entanto, como paciente está desnutrido, mas com esteatose hepática, para a manutenção de gastos calóricos em atividade regular recomenda-se cerca de 35-40 kcal/kg/dia (normoglicídica e normocalórica) (O'BRIEN; WILLIAMS, 2008). Sugere-se que no máximo $23 \%$ da energia total ingerida seja de gordura (hipolipídica) (CUPPARI, 2005). A ingestão recomendada de proteína é entre 1.2 a $1.5 \mathrm{~g} / \mathrm{kg} /$ dia (hiperproteíca), visando recuperação de massa magra, para melhora do estado nutricional (O'BRIEN; WILLIAMS, 2008). De maneira análoga à energia, situações clínicas como o trauma e doenças, em geral, podem estar associadas a uma maior necessidade protéica (MARCHINI, 1998).

\section{CONCLUSÃO}

O paciente diagnosticado com esteatose hepática encontra-se em desnutrição, recomenda-se que a alimentação seja via oral, normocalórica, normoglicídica, hiperproteica e hipolipídica devido ao elevado percentual de gordura localizada no fígado. Além disso, a hidratação deve ser recomendada é de pelo menos 2 litros de água por dia. Essas recomendações nutricionais visam a melhora do estado nutricional e da qualidade de vida do indivíduo.

\section{REFERÊNCIAS}

ABBAS, Abul K. et al. Robbins Patologia Básica. Elsevier Brasil, 2008.

ACUÑA, Kátia; CRUZ, Thomaz. Avaliação do estado nutricional de adultos e idosos e situação nutricional da população brasileira. Arquivos Brasileiros de Endocrinologia \& Metabologia, v.48, n.1, p.345-361, 2004.

AZEVEDO, Arúquia Souza; OLIVEIRA, Dayane Cardoso; SOARES, Priscilla Kálisy. Perfil Nutricional de Pacientes Adultos e Idosos Hospitalizados. Revista Saúde e Pesquisa, v.9, n.1, p.25-29, 2016.

ARIAS, Irwin M. et al. The Liver: Biology and Pathobiology. 1Ed. John Wiley \& Sons, 2020. 
BHATTACHARYA, Ankita et al. Assessment of nutritional status using anthropometric variables by multivariate analysis. BMC Public Health, v.19, n.1, p.1-9, 2019

Brasil. Ministério da Saúde. Secretaria de Atenção à Saúde. Guia alimentar para a população brasileira: promovendo a alimentação saudável. Brasília: Ministério da Saúde, 2008. Disponível em: <https://bvsms.saude.gov.br/bvs/publicacoes/guia_alimentar_populacao_brasi leira_2008.pdf $>$. Acesso em: 08 de Set de 2021.

CHAVES, Gabriela Villaça et al. Associação entre doença hepática gordurosa não alcoólica e marcadores de lesão/função hepática com componentes da síndrome metabólica em indivíduos obesos classe III. Revista da Associação Médica Brasileira, v.58, n.3, p.288-293, 2012.

CUPPARI, Lilian. Guia de Nutrição: Nutrição clínica no adulto. 2. ed. Manole: Barueri, 2005.

DUCHINI, Lya et al. Avaliação e monitoramento do estado nutricional de pacientes hospitalizados: uma proposta apoiada na opinião da comunidade científica. Revista de Nutrição, v.23, n.1, p.513-522, 2010.

FARZANEGI, Parvin et al. Mechanisms of beneficial effects of exercise training on nonalcoholic fatty liver disease (NAFLD): roles of oxidative stress and inflammation. European Journal of Sport Science, v.19, n.7, p.994-1003, 2019.

FONSECA-ALANIZ, Miriam $\mathrm{H}$. et al. O tecido adiposo como centro regulador do metabolismo. Arquivos Brasileiros de Endocrinologia \& Metabologia, v.50, n.1, p.216-229, 2006.

GOMES, Clarissa Emília Trigueiro. Nutrição e dietética. Saraiva Educação SA, 2014.

GONZALEZ, M. Cristina et al. Validação da versão em português da avaliação subjetiva global produzida pelo paciente. Rev Bras Nutr Clin, v.25, n.2, p.102-8, 2010.

HASHIMOTO, Etsuko; TOKUSHIGE, Katsutoshi; LUDWIG, Jurgen. Diagnosis and classification of non-alcoholic fatty liver disease and non-alcoholic steatohepatitis: Current concepts and remaining challenges. Hepatology Research, v.45, n.1, p.20-28, 2015.

KUNTZ, Erwin. Biochemistry and functions of the liver. In: Hepatology Principles and Practice, 2006. 
LIM, S. L.; LIN, X. H.; DANIELS, L. Seven-Point Subjective Global Assessment Is More Time Sensitive Than Conventional Subjective Global Assessment in Detecting Nutrition Changes. JPEN J Parenter Enteral Nutr. v.40, n.7, p.966-972, 2016.

LOZOYA, Raimunda Montejano et al. Predictive ability of the Mini Nutritional Assessment Short Form (MNA-SF) in a free-living elderly population: a crosssectional study. Peer-Reviewed Journal, v.5, n.1, p.3345-3361, 2017.

MARCHINI, Júlio Sérgio; FERRIOLLI, Eduardo; MORIGUTI, Julio Cesar. Suporte nutricional no paciente idoso: definição, diagnóstico, avaliação e intervenção. Medicina (Ribeirão Preto), v.31, n.1, p.54-61, 1998.

MINCIS, Moysés; MINCIS, Ricardo. Álcool e o Fígado. GED - Gastroenterologia Endoscopia Digestiva, v.30, n.4, p.152-162, 2011.

NAGASHIMADA, Mayumi; OTA, Tsuguhito. Role of vitamin E in nonalcoholic fatty liver disease. IUBMB life, v.71, n.4, p.516-522, 2019.

O'BRIEN, Alastair; WILLIAMS, Roger. Nutrition in end-stage liver disease: principles and practice. Gastroenterology, v.134, n.6, p.1729-1740, 2008.

PICKETT-BLAKELY, Octavia; YOUNG, Kimberly; CARR, Rotonya M. Micronutrients in nonalcoholic fatty liver disease pathogenesis. Cellular and Molecular Gastroenterology and Hepatology, v.6, n.4, p.451-462, 2018.

ROBBINS, Stanley; COTRAN, Ramzi S. Patologia: Bases patológicas das doenças. In: Patologia Bases patológicas das Doenças. 8a Edição. Rio de Janeiro: Elsevier, 2007.

SCHINONI, Maria Isabel. Fisiologia hepática. Gazeta Médica da Bahia, v.76, n.2, p.5-9, 2008.

SAEED, Ali et al. Disturbed vitamin A metabolism in non-alcoholic fatty liver disease (NAFLD). Nutrients, v.10, n.1, p.29-53, 2018.

SILVA, Sandra Maria Chemin Seabra da; MURA, Joana D. Tratado de alimentação, nutrição e dietoterapia. In: Tratado de Alimentação, Nutrição e Dietoterapia. 2007.

SOUSA, Juliany Caroline Silva de et al. Evaluation of the nutritional status of hospitalized patients: use of conventional and non-conventional methods. Demetra: Food, Nutrition \& Health/Alimentação, Nutrição \& Saúde, v.13, n.1, p.195-208, 2018.

STEFAN, Norbert; HÄRING, Hans-Ulrich; CUSI, Kenneth. Non-alcoholic fatty liver disease: causes, diagnosis, cardiometabolic consequences, and treatment strategies. The Lancet Diabetes \& Endocrinology, v.7, n.4, p.313-324, 2019. 
VASCONCELOS, Fábio Costa de; MOIA, Lizomar de Jesus Maués Pereira; MARTENS, Irland Barroncas Gonzaga. Competências e habilidades para aplicar a avaliação subjetiva global para fins de diagnóstico nutricional. Revista Sustinere, v.8, n.2, p.338-356, 2020.

VELLAS, B et al. Overview of the $\mathrm{MNA}^{\circledR}$ - Its history and challenges. Journal of Nutrition Health and Aging, v.10, n.6, p.456-465, 2006.

WORLD HEALTH ORGANIZATION (WHO). Physical status: the use and interpretation of anthropometry. Geneva: WHO, $1995 . \quad$ Disponível em: <https://apps.who.int/iris/handle/10665/37003>. Acesso em: 30 de Set de 2021.

WORLD HEALTH ORGANIZATION (WHO). Obesity: preventing and managing the global epidemic. Report of a WHO consultation. Geneva: WHO, 1998. Disponível em: < https://apps.who.int/iris/handle/10665/63854>. Acesso em: 30 de Set de 2021.

YAMAUTI, Aurea Kaoru et al. Avaliação nutricional subjetiva global em pacientes cardiopatas. Arquivos Brasileiros de Cardiologia, v.87, n.6, p.772-777, 2006. 


\title{
CAPITULO XXVI
}

\section{AÇÕES INVESTIGATIVAS E EXTENSIONISTAS EM SAÚDE MENTAL PARA INCLUSÃO DE MULHERES, NEGROS E IDOSOS FRENTE AO ESTIGMA SOCIAL VIVENCIADO}

\author{
DOI: $10.51859 / A M P L L A . P A E 1993-26$
}

\author{
Jaqueline Rocha Borges dos Santos ${ }^{1}$ \\ Janaína Pereira de Oliveira ${ }^{2}$ \\ Matheus de Lima Rodrigues ${ }^{2}$ \\ Larrysa de Morais Alves da Cruz ${ }^{2}$ \\ Bruna Souza Ramos Larrubia da Silva ${ }^{2}$
}

\begin{abstract}
1 Professora Adjunta do Departamento de Ciências Farmacêuticas. Universidade Federal Rural do Rio de Janeiro UFRRJ.

${ }^{2}$ Graduando/a do curso de Farmácia. Universidade Federal Rural do Rio de Janeiro - UFRRJ.
\end{abstract}

\section{RESUMO}

A sociedade brasileira é moldada pelo racismo estrutural desde o período colonial escravocrata e até hoje esses princípios são disseminados. O objetivo geral deste trabalho foi promover reflexões educativas com o propósito de modificar atitudes e comportamentos relacionados ao estigma social em saúde mental. Devido ao cenário de pandemia, não foi possível a realização integral das atividades de maneira presencial. A partir de março de 2020, as ações do projeto aconteceram de forma remota. Por meio do instagram, como mídia social, atingimos 5064 pessoas. Espera-se que ao final do projeto no ano 2, a população conheça a situação de um paciente em saúde mental, compreendendo que o estigma social está atrelado a outros fatores biopsicossociais, além de promover inclusão, desmistificação sobre enfermidades e ampliação do conhecimento.

Palavras-chave: Direitos humanos. Saúde mental. Estigma social. Interprofissionalidade. 


\section{INTRODUÇÃO}

A saúde mental é considerada uma área da saúde que envolve as circunstâncias e enfermidades que acometem o sistema nervoso central (SNC) (STAHL, 2014). Todavia, somado a isto, está um universo de questões biopsicossociais, que somatizam e buscam explicar com a relação subjetividade/objetividade, os acontecimentos e as manifestações de atitudes e comportamentos dos usuários. Diferente de outras enfermidades, questões de saúde mental são tratadas com um olhar preconceituoso, evidenciando o estigma social existente para este tema (AMARANTO, 2007; WHO, 2018). De maneira mais profunda, mulheres, negros (as) e idosos (as) sofrem os impactos do estigma social, por serem excluídos direta ou indiretamente do convívio social.

O modelo psiquiátrico passou por mudanças no cenário nacional e mundial. Atualmente, dispomos de uma rede associada à saúde mental, que buscou desospitalizar os usuários (BRASIL, 2001), para garantir inclusão social. Ainda assim, vale destacar que o antigo modelo permeia as atitudes e comportamentos de profissionais da saúde, em processo contínuo de transição à atuação profissional nesta área de saber. A criação dos Centros de Atenção Psicossocial (CAPS) (BRASIL, 2002) trouxe uma luz ao retrógrado e punitivo modelo de isolamento psiquiátrico hospitalar, aos usuários. No entanto, a cultura de atuação em saúde mental, continua alicerçada em medicalização, aliada às iniciativas de acolhimento. Assim, este projeto tem como propósito inserir mulheres, negros (as) e idosos (as) usuários de saúde mental, no contexto social; bem como promover conhecimento acerca do tema, como estratégia para modificação de comportamentos e atitudes que culminam com o estigma social.

\section{OBJETIVO}

Esse trabalho teve como objetivo promover discussões com o propósito de modificar atitudes e comportamentos relacionados ao estigma social em saúde mental, principalmente relacionados às mulheres, aos (às) negros (as) e aos (às) idosos (as) acometidos (as) por enfermidade de natureza psíquica. Devido ao cenário de pandemia, a partir do mês de março de 2020 o objetivo foi cumprido de maneira remota. 


\section{MÉTODO}

A partir de agosto de 2019, iniciamos o planejamento de atividades com propósito educativo e informativo. As estratégias de comunicação foram pautadas na ampliação de canais de comunicação com a comunidade acadêmica e a população de Seropédica. Para tanto, em dezembro de 2019 foi criado um canal no instagram (@dhsauderural) e, posteriormente, iniciamos o canal com a divulgação de vídeos elaborados por alguns integrantes do projeto, no mês de janeiro de 2021, com abordagem para reflexões sobre a vida e os anseios que permeiam o cotidiano, bem como foi colocado o propósito do projeto.

O projeto proposto foi submetido ao Comitê de Ética de Pesquisa em Humanos da UFRRJ, e, somente a partir de aprovação, iniciamos a etapa de aplicação de instrumentos relacionados com saúde mental. O processo de sensibilização consistiu em elaboração de materiais educativos visuais e didáticos, que foram divulgados em redes sociais.

Em virtude da suspensão das atividades acadêmicas devido à pandemia do novo coronavírus, alterações foram feitas no cronograma de atividades que passaram a ser integralmente remotas através das mídias sociais, com destaque à publicação intensificada no instagram administrado pelos discentes bolsistas, não bolsistas e pela coordenadora do projeto. Os materiais elaborados foram revisados e analisados quanto à facilidade de leitura, formato, cores, tamanho de letra e, principalmente, quanto à utilização de referências consistentes para as temáticas abordadas.

As atividades realizadas estão descritas, mês e mês, conforme seguem:

Setembro de 2019 a Janeiro de 2020 - (1) participação na organização do Setembro Amarelo na UFRRJ; (2) organização de roda de conversa no Setembro Amarelo; (3) início do planejamento e criação de materiais psicoeducativos; (3) realização de seleção para participação de estudantes voluntários dos cursos de Farmácia, Psicologia e Serviço Social;

Fevereiro e Março de 2020 - (1) apresentação do cronograma às parcerias e definição de dias e horários destinados às atividades do projeto; (3) elaboração de materiais educativos iniciais; (4) divulgação de material educativo sobre saúde mental e estigma social em mulheres; (5) submissão do projeto ao Comitê de Ética da UFRRJ; 
Abril de 2020 - (1) divulgação de materiais educativos nas redes sociais; (2) sensibilização intensificada com materiais educativos no dia mundial da saúde mental;

Maio de 2020 - (1) discussão sobre o perfil de pacientes da UFRRJ e do CAPS; (2) discussão para definir estratégia de atuação junto aos canais de comunicação disponíveis e a necessidade de atender à demanda relacionada com o cenário de pandemia;

Junho de 2020 - (1) elaboração divulgação constante de materiais educativos nas redes sociais; (2) aplicação de instrumento proposto no projeto, a partir da aprovação do protocolo durante este mês; (3) avaliação das ações desenvolvidas em 2019; (4) início de avaliação das respostas aos instrumentos aplicados;

Julho de 2020 - (1) divulgação contínua de materiais educativos em atenção à saúde mental no cenário de pandemia; (2) realização de palestra com inscrição pela plataforma CED, intitulada: "Drogas de abuso e uso compassivo de cannabis medicinal"; (3) aplicação do segundo instrumento de opinião pública;

Agosto de 2020 - (1) continuidade na elaboração de materiais educativos; (2) criação de novos canais de comunicação (facebook, twitter e youtube); (3) revisão e finalização do relatório final.

\section{RESULTADOS E DISCUSSÃO}

Nos meses compreendidos entre agosto de 2019 e janeiro de 2020, participamos da organização e oferecemos roda de conversa no III Setembro Amarelo da UFRRJ, conforme proposto no plano de trabalho inicial. Neste período alguns materiais psicoeducativos foram elaborados, assim como o planejamento das atividades aos meses seguintes foi realizado. Nestes meses, estudantes dos cursos de Farmácia, Psicologia e Serviço Social foram selecionados para participação voluntária no projeto. Para tanto, realizamos reuniões e discussões entre os integrantes do projeto.

No mês de janeiro de 2020 iniciamos a divulgação, em nosso perfil no instagram (https://instagram.com/dhsauderural?igshid=2ezvt1u9rwzp), da campanha Janeiro Branco que é dedicado a discussão e reflexão sobre temas da saúde mental e emocional em máxima evidência com o propósito de conscientizar à importância da prevenção ao adoecimento emocional da humanidade. 
No mês de fevereiro foi divulgado uma série de posts referentes à saúde mental dos idosos e como a atividade física pode interferir de forma positiva na qualidade de vida desse grupo. Segundo Pacheco (2002) normalmente doenças crônicas, sentimento de abandono, perdas de entes queridos ao longo da vida, isolamento social, entre outros, são os fatores que geralmente contribuem para o desenvolvimento de depressão em idosos. A prática de atividade física pode minimizar ou até mesmo retardar a perda da capacidade física e mental, inclusive associado às pessoas que já apresentam declínios na capacidade, em um ambiente de apoio e estímulo, podem permitir que o quadro não piore, assim elas podem viver de forma digna (OMS, 2015).

No mês de março iniciamos e continuamos no mês de abril com abordagem sobre: "Saúde mental em tempos de coronavírus". A pandemia do novo coronavírus (Severe Acute Respiratory Syndrome Coronavirus 2 - Sars-Cov-2) é a maior crise sanitária que a população mundial enfrenta em décadas e traz a necessidade de promover ações além do cuidado quanto saúde física, levando em consideração o sofrimento psicológico que pode ser experenciado pela população no geral (SCHMIDT, 2020). De modo geral, na urgência de combater o agente infecioso patogênico, a saúde física do paciente acaba sendo o foco primordial dos profissionais da área da saúde enquanto as questões sobre a saúde mental tendem a ser negligenciadas.

Em maio realizamos uma série que abordou o tema maternidade $\mathrm{e}$ desenvolvemos ao longo do mês materiais informativos sobre diferentes ramificações desse assunto, como: maternidade durante a pandemia associada à COVID-19, maternidade compulsória e ansiedade na gestação.

Aliado a isto, elaboramos materiais informativos sobre o Dia Nacional da Luta Antimanicomial que é comemorado no dia 18 de maio. As Políticas de Saúde Mental (SM) e Atenção Psicossocial (AP) no SUS têm relação direta com a ideia-propostaprojeto-movimento-processo da reforma sanitária e com a conjuntura da transição democrática e, consequentemente, com a construção do próprio estado democrático (AMARANTE; NUNES, 2018).

Com o lema "por uma sociedade sem manicômios" diversos profissionais, instituições acadêmicas e outros segmentos da sociedade questionam o modelo de assistência centralizado em hospitais psiquiátricos, denunciam graves violações aos direitos das pessoas com transtornos mentais e propõem a reorganização deste modelo 
buscando a garantia da cidadania de usuários e familiares; historicamente discriminados e excluídos da sociedade (BRASIL, 2017).

Em junho abordamos o impacto do racismo na saúde mental da população negra que segundo o IBGE 2019 corresponde a 56,10\% da população brasileira. Vários veículos de pesquisa apontam as condições de pobreza em que esse grupo populacional está inserido, oriundo de uma extensa política de exclusão que retrata as condições desiguais entre a população branca e a população negra do país. Assim, ao tratarmos das grandes desigualdades enfrentadas pela população, o mapa da exclusão retrata que entre os $10 \%$ da população mais pobre do país, 76\% são negros (SILVA; RIBEIRO; SOUZA, 2018). Este cenário acaba por impactar negativamente a saúde mental deste grupo, visto que ao longo de sua vida enfrentarão dificuldades maiores devido à falta de assistência, oportunidades e ao racismo institucional que está enraizado em todas as estruturas da nossa sociedade. Hoje os jovens negros são os que mais apresentam quadro de transtornos mentais, vistos que nessa fase da vida começam a projetar seu futuro e acabam por encontrar as primeiras faces do racismo estrutural, as dificuldades de ingresso ao ensino superior, a violência policial, as dificuldades de inserção ao mercado de trabalho, dentre outros. Considerando que habitualmente são parte da parcela mais vulnerável da sociedade brasileira, o acesso escolar é através das redes públicas que infelizmente até hoje não proporcionam a esse jovem meios de competir igualmente com o jovem que pertence à parcela da sociedade representada pelas classes média e alta. Todos esses padrões e outros mais contribuem e explicam a prevalência para que esta população se torne mais propensa a desenvolver transtornos mentais.

Ainda no mês de junho, após a aprovação do protocolo de pesquisa no Comitê de Ética na Pesquisa com Seres Humanos da UFRRJ, analisamos os resultados do instrumento aplicado e disponibilizado nas redes sociais durante duas semanas.

O nosso primeiro instrumento foi divulgado e teve o objetivo de coletar informações, de forma voluntária e anônima, de alunos, técnicos administrativos, terceirizados e professores dos Campi da UFRRJ, a fim de analisar os dados sobre a saúde mental no contexto acadêmico. Obtivemos 264 respostas, com tempo de coleta durante duas semanas. Considerando as perguntas colocadas no instrumento a respeito de enfermidades que acometem o sistema nervoso central (SNC), os resultados estão demonstrados figura 1. 
No instrumento constavam perguntas sobre algumas enfermidades de natureza psíquica, para avaliar como elas aparecem no cenário acadêmico. A literatura sinaliza que a população universitária está vulnerável ao desenvolvimento de alguns transtornos mentais, como por exemplo, a depressão, a ansiedade e o estresse (ARIÑO, 2018).

Figura 1 - Demonstra o percentual de relatos voluntários sobre enfermidades mentais, obtido a partir de instrumento para conhecer o perfil de saúde mental na comunidade acadêmica.

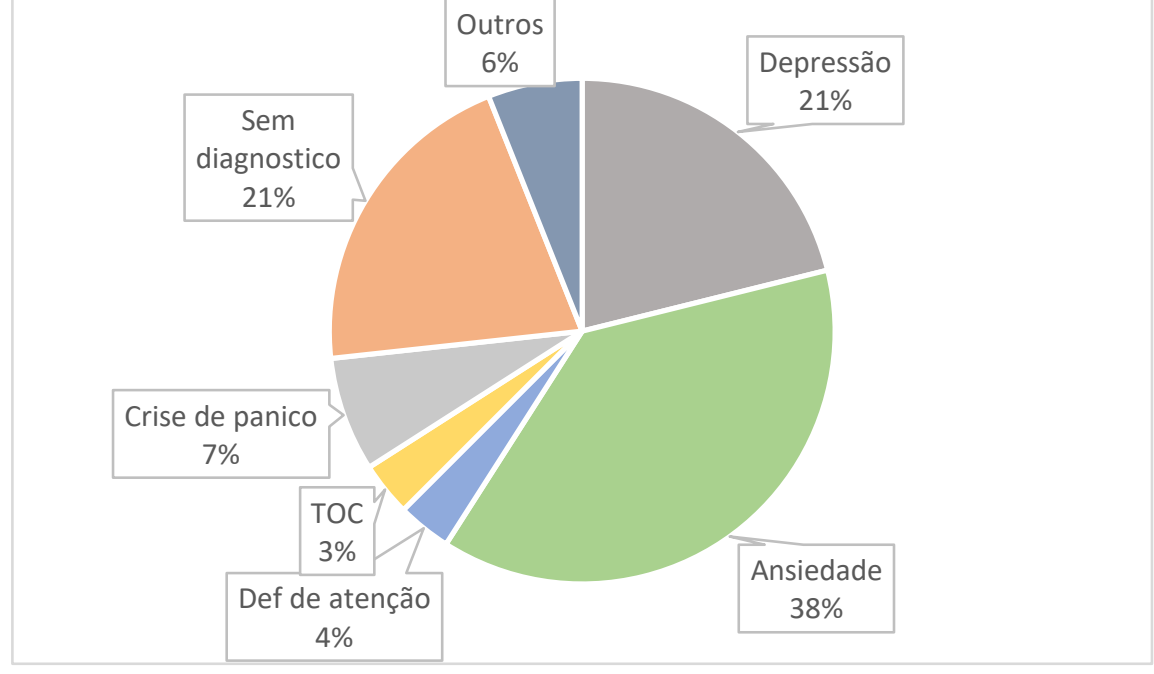

Fonte: Autoria própria.

Estudos apontam uma prevalência elevada destes transtornos dentre universitários, sendo previsto que cerca de 15 a 25\% dos universitários irão apresentar algum transtorno mental durante a vida acadêmica (VASCONCELOS et al., 2015).

Alguns estudos epidemiológicos indicam, inclusive, que a presença de transtornos mentais não psicóticos neste público é significativamente maior que na população geral e em adultos jovens não universitários (IBRAHIM et al., 2013; EISENBERG et al., 2017; ARIÑO \& BARDAGI, 2018).

Com esses dados, a hipótese é de que o modo de vida acadêmico, que inclui as cobranças de cumprimento ao conteúdo programático, bem como prazos e carga horária excessiva, contribuem para o desenvolvimento de transtornos mentais nesta população e podem explicar, mesmo que parcialmente, o porquê de tantos casos no meio acadêmico.

Com relação à pandemia fizemos uma análise de como as pessoas estavam se sentindo nesse período e novamente pudemos observar que na maioria dos participantes o quadro de ansiedade prevalece, conforme colocado na Figura 2 - Esses 
dados podem estar atrelados ao fator estressor do contexto de uma pandemia, que diante de um cenário até então desconhecido gera medo e sensação de falta de controle que por consequência pode piorar os quadros clínicos de transtornos mentais.

Figura 2 - Demonstra a manifestação de enfermidades mentais durante a pandemia associada ao novo coronavírus, a partir de pergunta sobre o estado de saúde e manifestações sintomáticas.

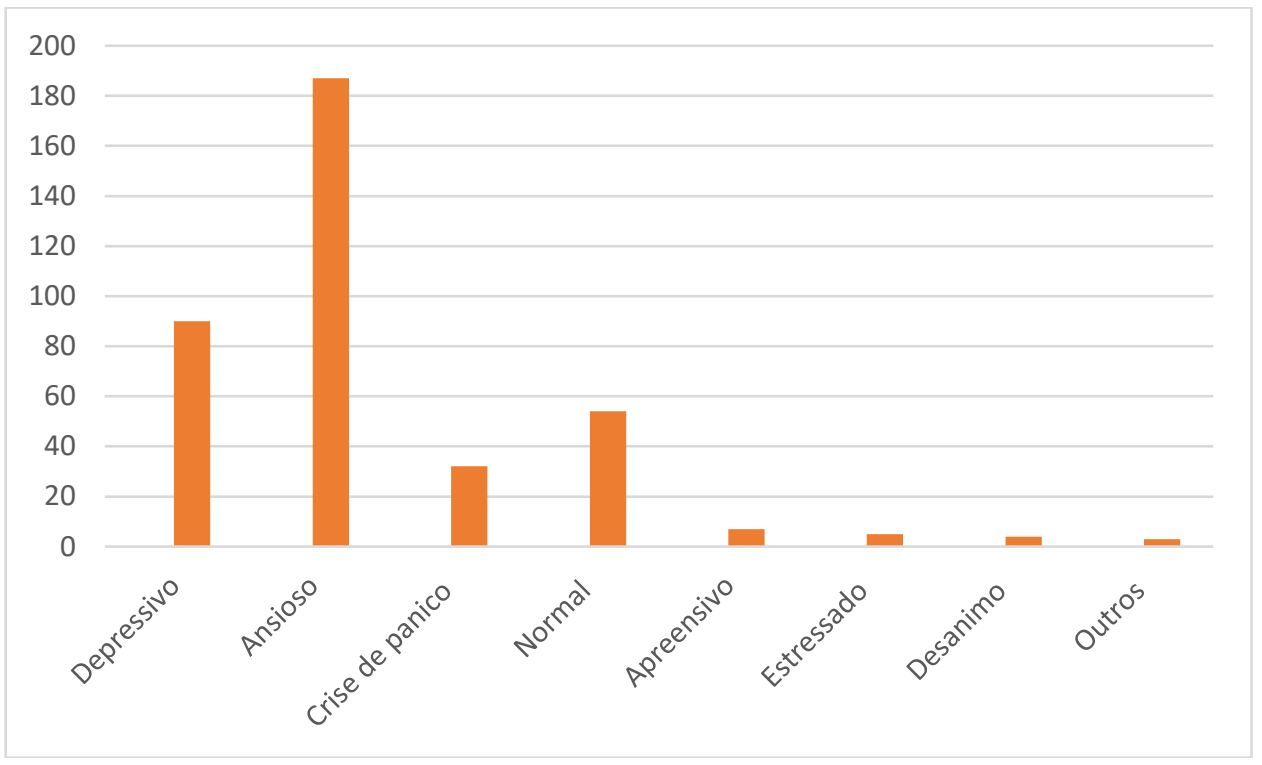

Fonte: Autoria própria.

Entre as análises os sintomas de insônia, dificuldade de concentração e desânimo persistente foram frequentemente relatados sendo $23 \%$, $24 \%$ e $26 \%$ respectivamente. Em $58 \%$ dos casos os participantes alegam que esses sintomas pioram em determinados momentos, como à noite, quando discutem assuntos relacionados à pandemia ou quando estão sozinhos, conforme sinaliza a Figura 3 - 
Figura 3 - Demonstra o resultado de acordo com o relato dos participantes acerca de sintomas ao longo do dia, durante a pandemia associada ao novo coronavírus.

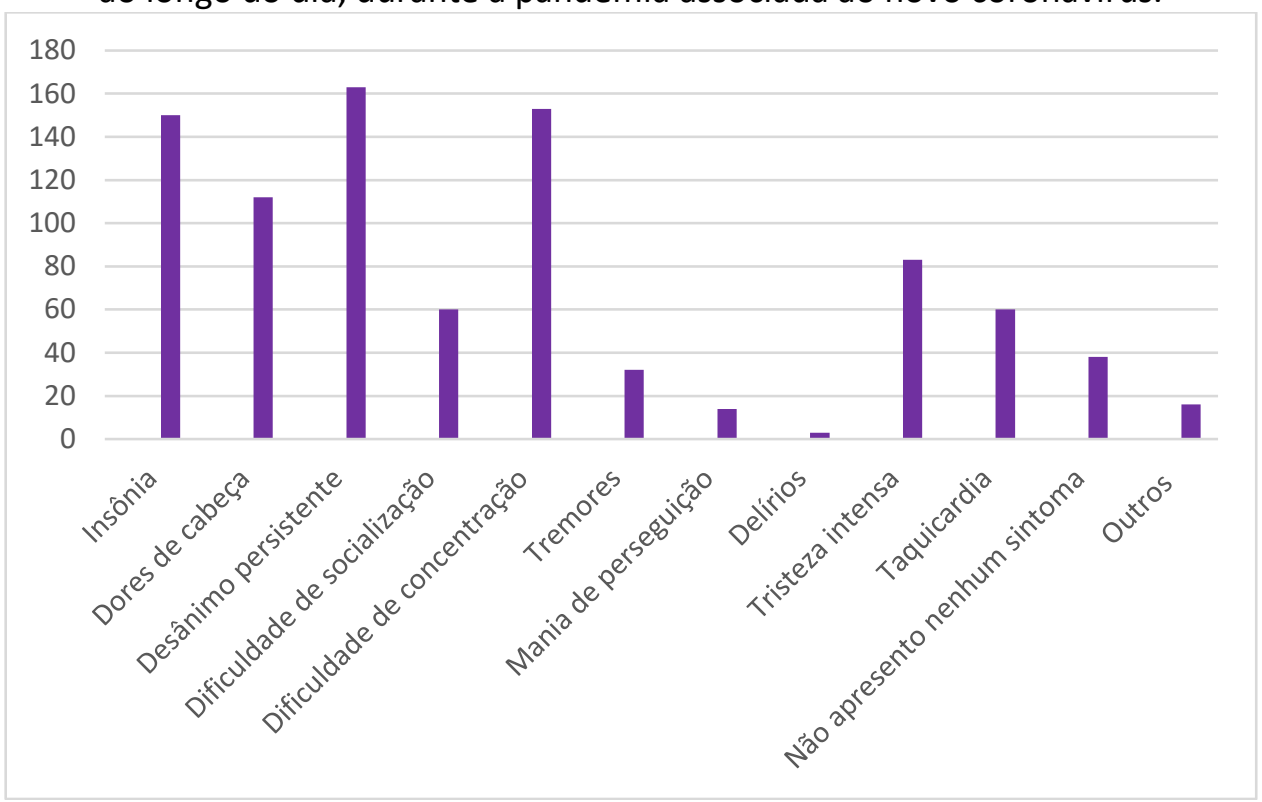

Fonte: Autoria própria.

O terceiro bloco de perguntas do instrumento disponibilizado para preenchimento voluntário tinha o objetivo de analisar a frequência de uso de medicamentos controlados ou não, drogas de abuso, e ainda, conhecer a opinião em relação à necessidade de orientação promovida por profissional farmacêutico. De acordo com os resultados, $71 \%$ dos analisados não fazia uso de medicamentos; $29 \%$ sim e dentre eles destacam-se os fármacos: ansiolíticos, os antidepressivos de vários grupos farmacológicos e os antipsicóticos. Esses números confirmam os dados iniciais que mostraram relatos de depressão e ansiedade.

Somado a isto, foi analisado como as pessoas observam a importância do profissional farmacêutico quando precisam de alguma orientação medicamentosa. Conforme sinalizado na figura 4, 37\% dos casos julgou não ser necessário a orientação deste profissional, $26 \%$ não buscaram esse tipo de orientação pois nunca tiveram acesso e/ou oportunidade, $13 \%$ não sabem o que isso significa e $11 \%$ sempre buscam orientação deste profissional. 
Figura 4 - Demonstra a opinião dos participantes sobre a necessidade de orientação realizada por profissional farmacêutico quando necessitam de informações relacionadas com o uso racional de medicamentos.

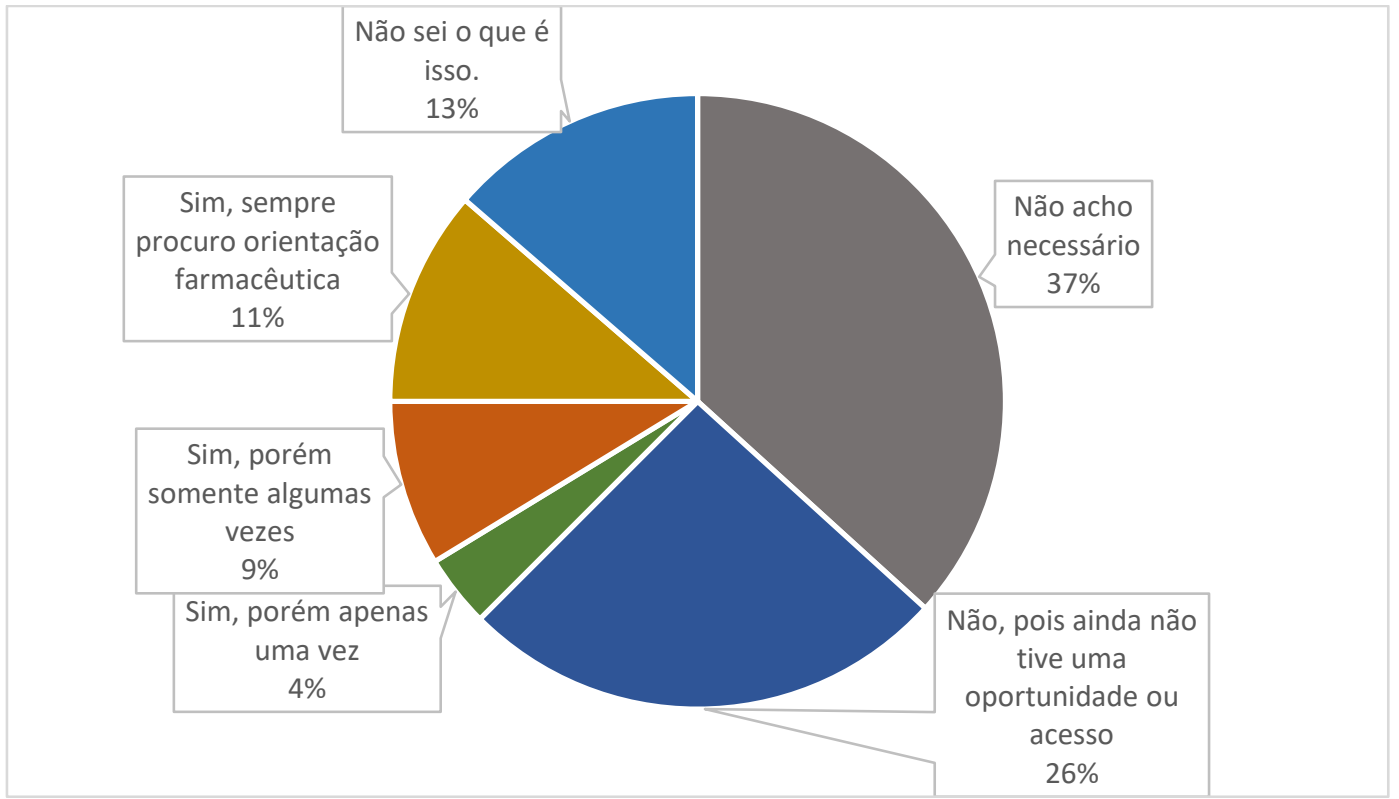

Fonte: Autoria própria.

No último bloco de perguntas direcionamos para o uso de substâncias lícitas com potencial abusivo, como álcool e cigarro (nicotina), assim como outras substâncias ilícitas com potencial abusivo. Conforme demonstrado na figura 5, 42\% dos analisados já fez uso de etanol, cannnabis $21 \%$, nicotina $16 \%$, LSD $4 \%$, ecstasy $3 \%$ e cocaína $2 \%$. Em sua maioria a utilização dessas substâncias ocorre somente em festas.

Figura 5 - Apresenta as respostas voluntárias para o uso de substâncias com potencial abusivo, lícitas e ilícitas.

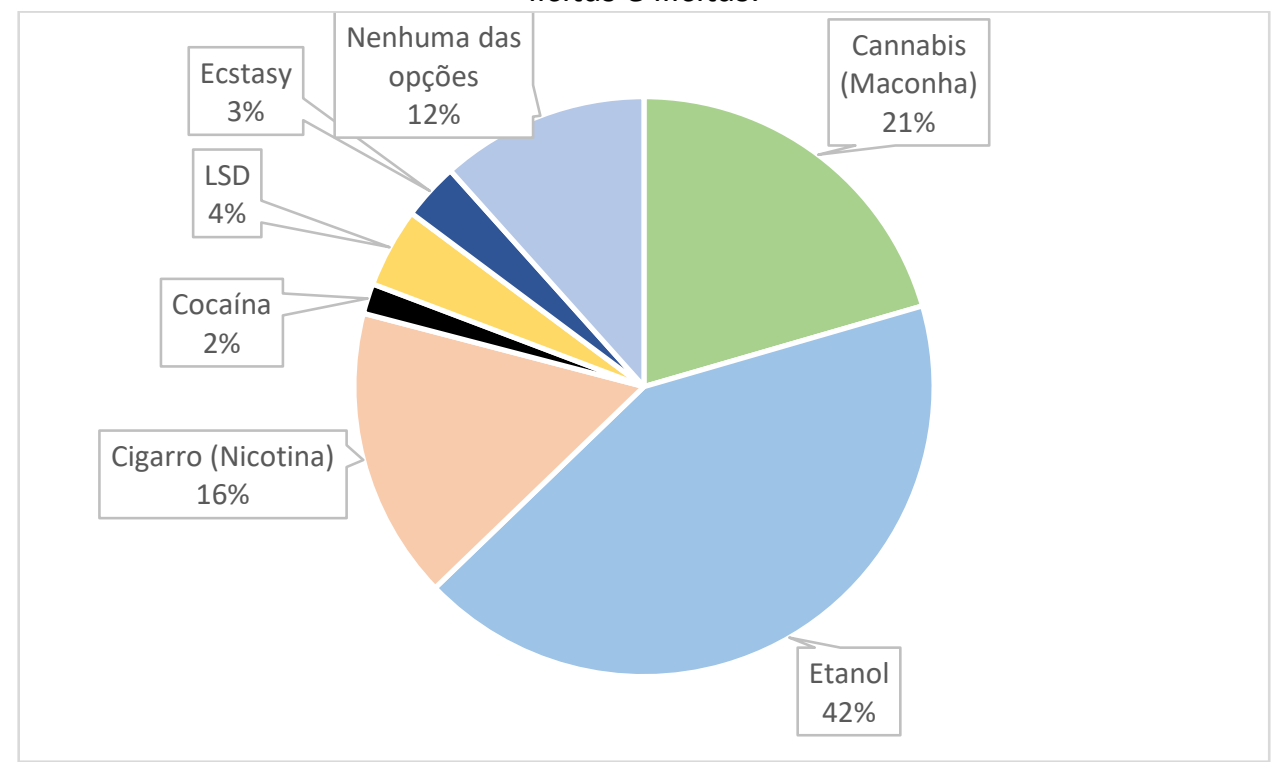

Fonte: Autoria própria. 
No mês de julho realizamos a palestra remota na plataforma RNP e cadastro na Central de Dados Extensionista (CED) da UFRRJ, com o tema: "Drogas de abuso e uso compassivo de cannabis medicinal". Para esta palestra foram disponibilizadas 200 (duzentas) vagas e todas foram preenchidas em curto espaço de tempo. No dia da palestra, a transmissão foi revisada, para garantia de participação acima de 75 (setenta e cinco) participantes pela plataforma RNP. Todavia, ao realizar os comandos orientados pela referida plataforma, não obtivemos êxito para autorização à participação com mais de 75 pessoas. Assim, a palestra foi ministrada para estes participantes e, o ano 2 do projeto, será disponibilizado aos demais vídeo gravado com a palestra, para que todos (as) tenham acesso ao tema abordado. Na referida palestra, foi abordado o histórico que contextualiza o uso de substâncias com potencial abusivo, assim como foi explicado como atuam no SNC, como as mesmas produzem dependência e tolerância. Aliado a isto, foi destacado o uso compassivo de cannabis medicinal e a relação com os benefícios do ponto de vista terapêutico produzido pelo canabidiol. Ainda durante o mês de julho, começamos a construir o relatório final e aplicamos um segundo instrumento de opinião pública, que segue em análise para que seja inserido no relatório do ano 2 . O diagnóstico situacional acerca da saúde mental na UFRRJ, foi norteadora para a construção de materiais aplicados à demanda, e seguirão de maneira crescente a serem elaborados na continuidade deste projeto. No mês de agosto criamos novos perfis de canais de comunicação (facebook, twitter e canal no youtube), para ampliar a divulgação de materiais educativos, considerando que estamos em período de quarentena; ao mesmo tempo que almejamos promover mudanças na maneira de agir diante do estigma social em saúde mental. No final do mês de agosto de 2020, atingimos 5064 pessoas por meio de materiais divulgados no instagram. Por fim, uma programação ao mês de setembro de 2020 foi cumprida ao IV Setembro Amarelo, pensando na valorização à vida, unido à crescente necessidade de acolher as pessoas em todos os espaços virtuais.

\section{CONSIDERAÇÕES FINAIS}

Diante da exposição que vivemos da fragilidade humana e do acentuar em desigualdades que permeiam o universo da saúde mental, em especial com as populações mais vulneráveis, entende-se a precípua necessidade de educar em saúde com a garantia de informações referenciadas; para promover mudanças em atitudes 
pautadas por estigma social acerca de temáticas que envolvem sofrimento psíquico. A amplitude de acessos aos materiais divulgados, aponta que há interesse dos usuários em redes sociais sobre temáticas em saúde mental. Dentre os dados obtidos com a aplicação do instrumento à comunidade acadêmica, nota-se um aumento de ansiedade, associada majoritariamente à insônia, ao desânimo persistente e à dificuldade de concentração. Estes dados reforçam a continuidade das ações, com materiais psicoeducativos esclarecedores e acolhedores. Logo, as mudanças de atitudes e comportamentos diante do estigma social acontecerão de maneira gradativa e à medida que as pessoas se tornam multiplicadoras e disseminadores de informações referenciadas em saúde mental.

\section{REFERÊNCIAS}

AMARANTE, P. Saúde mental e a atenção psicossocial. Rio de Janeiro: Fiocruz; 2007. 120 p. ISBN: 978-85-7541-135-3.

AMARANTE, P; NUNES, M.O. A reforma psiquiátrica no SUS e a luta por uma sociedade sem manicômios. Ciênc. Saúde Coletiva [online], v. 23, n. 6, p. 2067-2074, 2018. Disponível em: SciELO - Brasil - A reforma psiquiátrica no SUS e a luta por uma sociedade sem manicômios A reforma psiquiátrica no SUS e a luta por uma sociedade sem manicômios. Acesso em: 20 jan. 2021.

ARIÑO, D. O.; BARDAGI, M. P. Relação entre fatores acadêmicos e a saúde mental de estudantes universitários. Revista Psicologia em Pesquisa, v. 12, n. 3, p. 44 -52, 2018. Disponível em: https://doi.org/10.24879/2018001200300544. Acesso em: 21 jan. 2021.

BRASIL, Lei federal $n^{\circ} 10216$ de 6 de abril de 2001. Política Nacional de Saúde Mental. Dispõe sobre a proteção e os direitos das pessoas portadoras de transtornos mentais e redireciona o modelo assistencial em saúde mental. Disponível em: L10216 (planalto.gov.br). Acesso em: 10 jan. 2021.

BRASIL, Portaria/GM n 336 de 19 de fevereiro de 2002. Estabelece CAPS I, CAPS II, CAPS III, CAPS i II e CAPS ad II. Disponível em: Ministério da Saúde (saude.gov.br). Acesso em: 10 jan. 2021.

BRASIL. Ministério da Saúde (MS). Blog da saúde, 2017. Publicado 18 Maio, 2017. Disponível em: http://www.blog.saude.gov.br/index.php/promocao-dasaude/52612-18-de-maio-dia-nacional-da-luta-antimanicomial. Acesso em: 21 set. 2020. 
EISENBERG, Daniel; GOLLUST, Sara E.; GOLBERTEIN, Ezra; HEFNER, Jennifer. Prevalence and Correlates of Depression, Anxiety and Suicidality Among University Students. American Journal of Orthopsychiatry, v 77, p. 532-534, 2007. Disponível em: prevalence -- AJO 2007.pdf (umich.edu). Acesso em: 22 set. 2020.

IBRAHIM, Ahmed K.; KELLY, Shona J.; ADAMS, Clive E.; GLAZEBROOK, Cris. A systematic review of studies of depression prevalence in university students. Journal of Psychiatric Research, v 47, p. 391-400. 2013. Disponível em: 1SystematicReview.pdf. Acesso em: 23 set. 2020.

ORGANIZAÇÃO MUNDIAL DA SAÚDE (OMS). Relatório mundial de envelhecimento e saúde. $2015 . \quad$ Disponível em: WHO_FWC_ALC_15.01_por.pdf;jsessionid=C7EBDD79EDF91FCAA2014AD861ED D454. Acesso em: 10 out. 2020.

PACHECO, Jaime Lisandro. Educação, Trabalho e Envelhecimento: Estudo das histórias de vida de trabalhadores assalariados e suas relações com a escola, com o trabalho e com os sintomas depressivos, após a aposentadoria. Tese (Doutorado em Educação / Gerontologia) UNICAMP, Campinas, São Paulo. 2002. Disponível em: Microsoft Word - Pacheco, J. L_V.I .doc (unicamp.br). Acesso em: 11 out. 2020.

SILVA, G. A.; RIBEIRO, F. N. L.; SOUZA, F. L. Negro drama: a trama do racismo e os desafios para a política de saúde mental na contemporaneidade. VI Seminário CETROS. Brasil, 2018. Disponível em: 425-51388-18072018-095144.pdf (uece.br). Acesso em: 14 out. 2020.

SCHMIDT, B.; CREPALDI, M.A.; BOLZE, S.D.A.; NEIVA-SILVA, L.; DEMENECH, L.A. Saúde mental e intervenções psicológicas diante da pandemia do novo coronavírus (COVID-19). Estud. Psicol. (Campinas), Campinas, v. 37, e200063, 2020. Disponível em: SciELO - Brasil - Saúde mental e intervenções psicológicas diante da pandemia do novo coronavírus (COVID-19) Saúde mental e intervenções psicológicas diante da pandemia do novo coronavírus (COVID-19). Acesso em: 22 agos. 2020.

STAHL, S.M. Psicofarmacologia. Bases neurocientíficas e aplicações práticas. $4^{\text {a }}$ ed. Rio de Janeiro: Guanabara Koogan, 2014. 568 p. ISBN-13: 9788527725866.

VASCONCELOS, T. C.; DIAS, B.R.T.; ANDRADE, L.R.; MELO, G.F.; BARBOSA, L.; SOUZA, E. Prevalência de sintomas de ansiedade e depressão em estudantes de medicina. Revista Brasileira de Educação Médica., Rio de Janeiro, v. 39, n. 1, p. 135-142, 2015. Disponível em: SciELO - Brasil - Prevalência de Sintomas de Ansiedade e Depressão em Estudantes de Medicina Prevalência de Sintomas de Ansiedade e Depressão em Estudantes de Medicina. Acesso em 22 set. 2020. 
VICTORIA, M. S. et al. Níveis de ansiedade e depressão em graduandos da Universidade do Estado do Rio de Janeiro (UERJ). Encontro Revista de Psicologia, v. 16, n. 25, p 163-165, 2013. Disponível em: 2345.pdf. Acesso em: 20 set. 2020.

WORLD HEALTH ORGANIZATION (WHO). Mental Health Atlas 2017. Geneva: World Health Organization, 2018. 68 p. Disponível em: Mental Health ATLAS 2017 (who.int). Acesso em: 21 set. 2020. 


\title{
CAPITULO XXVII
}

\section{SIMULAÇÃO REALÍSTICA EM SAÚDE MENTAL: RELATO DE EXPERIÊNCIA}

DOI: 10.51859/AMPLLA.PAE1993-27

\author{
Anne Manuelle dos Santos ${ }^{1}$ \\ Letícia de Jesus Alves ${ }^{2}$ \\ Jessica dos Santos Costa ${ }^{3}$ \\ Glebson Moura da Silva ${ }^{4}$ \\ Andreia Freire de Menezes ${ }^{5}$
}

\footnotetext{
' Mestranda em Enfermagem. Programa de Pós-Graduação em Enfermagem- UFS

${ }^{2}$ Graduada em Enfermagem. Universidade Federal de Sergipe-UFS

${ }^{3}$ Residente em Saúde da Família. Universidade Federal de Sergipe- UFS

${ }^{4}$ Professor do departamento de Enfermagem da Universidade Federal de Sergipe - UFS

${ }^{5}$ Professora do departamento de Enfermagem da Universidade Federal de Sergipe - UFS
}

\section{RESUMO}

A simulação realística é um elemento importante para o processo de aprendizagem e é incorporada como estratégia de ensino. É uma estratégia de alta fidelidade de capacitação, produção, desenvolvimento do conhecimento e habilidades psicomotoras. Com relação à atenção em saúde mental, que a formação dos profissionais nesse contexto merece ser contínua e aliada à rotina dos serviços, visto que, para o manejo adequado, há a necessidade de conhecimentos adquiridos na prática. Diante disso, entende-se a necessidade da utilização com maior frequência das simulações realísticas no âmbito educacional em saúde mental.

Palavras-chave: Simulação. Saúde Mental. Estudantes. Saúde. 


\section{INTRODUÇÃO}

O ensino superior no Brasil, mesmo em expansão, enfrenta desafios em busca de melhor qualidade (NASCIMENTO; MAGRO, 2018). No ensino em saúde, uma série de alterações, inclusões e novas tendências em relação ao ensino-aprendizagem apontam para a adoção de métodos inovadores, exigindo que o docente repense, reavalie e reconstrua sua prática pedagógica, buscando novas estratégias de ensino capazes de melhorar os resultados de aprendizagem (FERREIRA et al., 2018). A tendência atual de muitos programas curriculares de educação encontra-se direcionada para os métodos ativos, fundamentada na necessidade de alcançar tanto autoconfiança como satisfação pessoal do aprendiz (NASCIMENTO; MAGRO, 2018).

Atualmente a simulação realística é um elemento importante para o processo de aprendizagem e é incorporada como estratégia de ensino pelas instituições de graduação e pós-graduação (PACHECO et al., 2021). A simulação realística permite que o estudante aprenda o conteúdo de forma aproximada do ambiente real e com perfil ético e seguro. É uma estratégia de alta fidelidade de capacitação, produção, desenvolvimento do conhecimento e habilidades psicomotoras (DOMINGUES et al., 2021). Assim, a simulação é apresentada como um processo dinâmico que envolve a criação de uma oportunidade hipotética que incorpora uma representação autêntica da realidade. Além disso, facilita o acoplamento do estudante ativo, e integra as complexidades da aprendizagem prática e teórica com a oportunidade de repetição, feedback, avaliação e reflexão (COSTA et al., 2017).

O preparo do método da simulação realística é caracterizado pela elaboração de conteúdo e planejamento estratégico para abordagem temática, que pode ser aplicada por meio de diversos recursos caracterizando a baixa, média ou alta complexidade (DOMINGUES et al., 2021). A simulação favorece não somente o desenvolvimento de competências relacionadas aos processos clínicos, mas técnicos e tecnológicos da prática profissional, e ainda estimula o desenvolvimento da capacidade de análise, síntese e tomada de decisão (NASCIMENTO; MAGRO, 2018).

No campo da assistência em saúde mental o SUS adota o modelo da Reforma Psiquiátrica através da Lei no 10.216, de 06 de abril de 2001, que reorganizou o modelo assistencial em saúde mental, substituindo de forma progressiva os hospitais 
psiquiátricos por uma rede fundamentada no território e de caráter aberto (JUNIOR; SILVA, 2021). Com relação à atenção em saúde mental, que a formação dos profissionais nesse contexto merece ser contínua e aliada à rotina dos serviços, visto que, para o manejo adequado, há a necessidade de conhecimentos adquiridos na prática (FERNANDES et al., 2018). Seus princípios envolvem: a internação como último recurso a ser indicado à pessoa com transtorno mental; a assistência humanizada e integral em serviços comunitários que contem com equipe interdisciplinar e uma diversidade de recursos terapêuticos (JUNIOR; SILVA, 2021).

Diante disso, por entender que existe uma real necessidade de utilização com maior frequência de simulações realísticas no âmbito educacional em saúde mental, objetivamos expor um relato de experiência em colhimento de enfermagem ao usuário em sofrimento psíquico com implementação do Projeto Terapêutico Singular (PTS).

\section{METODOLOGIA}

Trata-se de um estudo descritivo, do tipo relato de experiência, vivenciado através da aplicação de um modelo de cenário de simulação realística, que foi elaborado para o estágio em docência de mestrado do Programa de Pós-Graduação em Enfermagem (PPGEN) e reproduzido durante uma aula remota de alunos de graduação do curso de enfermagem na disciplina de Saúde do Adulto e do Idoso I da Universidade Federal de Sergipe (UFS) através da plataforma Google Meet, durante a pandemia.

O cenário teve como tema: Acolhimento de enfermagem ao usuário em sofrimento psíquico com implementação do Projeto Terapêutico Singular (PTS). Com o intuito de reforçar a prática assistencial do atendimento do enfermeiro frente a uma consulta em saúde mental, assim como a elaboração e desenvolvimento do Projeto Terapêutico Singular (PTS).

A simulação realística é dividida em sessões como briefing, desenvolvimento da cena e debriefing. Também foi disponibilizado aos facilitadores/atores do cenário as informações necessárias para o desenvolvimento da cena. O educador deve delinear à atividade de simulação considerando a especificidade, mensurabilidade e abrangência da ação, com foco nos resultados a serem atingidos pela atividade e nos elementos requeridos pela atividade (YAMANE et al., 2019). 


\section{RESULTADOS E DISCUSSÃO}

A elaboração do cenário e criação da cena ocorreu após disponibilização pela instituição dos materiais e estrutura para nortear a montagem do caso clínico que seria encenado.

No dia da simulação realística, para auxiliar na atuação, foram convidadas duas enfermeiras que assumiram os papeis de paciente e familiar, ajudando a conduzir a cena de maneira educativa e norteando os alunos que foram convidados para encenar o papel de enfermeiro do Centro de Atenção Psicossocial (CAPS). Devido a gama de ferramentas que podem ser aplicadas, como o uso de atores no presente relato, as simulações exercem alto impacto tanto na vida acadêmica quanto na atualização profissional, sendo que independente da ferramenta escolhida, permite para ambos a atualização das técnicas do cuidado e reflexão sobre o saber fazer e como está fazendo (SANTOS, et al. 2020).

Devido ao tamanho da turma, os alunos foram divididos em dois grupos, e em cada um deles foi realizado um sorteio para ver qual discente seria o ator, enquanto os demais fariam o papel de observador da cena, função importante para o debriefing.

Para a realização da simulação realística é necessário que os alunos conheçam como funciona esse processo de ensino-aprendizagem. Portanto antes de iniciar a cena, foi realizado uma aula expositiva-dialogada onde eles puderam conhecer a metodologia que seria aplicada e os passos de uma simulação, além da demonstração de como preencher um projeto terapêutico singular (PTS) que foi o que norteou o aluno na condução da cena.

A simulação foi realizada seguindo os seguintes passos: Informações disponíveis para os atores e condutores da cena, briefing, desenvolvimento da cena e debriefing. Todas as informações do caso (Tabela 1), como história clínica e pregressa, medicamentos utilizados e algumas falas para auxiliar as enfermeiras que ficaram com os papéis de paciente e familiar. 
Tabela 1- Informações para facilitador/ator da simulação

\begin{tabular}{|l|l|}
\hline PERFIL DO PACIENTE & $\begin{array}{l}\text { Idade: 26 anos } \\
\text { DN: 04/08/1995 }\end{array}$ \\
\hline Nome: Aurora Paz & $\begin{array}{l}\text { Peso: 67 Kg Altura:1.67 } \\
\mathrm{m}\end{array}$ \\
\hline Sexo: feminino &
\end{tabular}

Apresentação: Paciente vestido adequadamente e higienizado. Mostra-se um pouco inquieto durante o atendimento, mexendo braços e pernas, mas mantendo-se sentado. Não apresenta agressividade, mas apresenta discurso ilógicos e sinais de alucinação.

Solteira, sem filhos e teve um aborto espontâneo há 03 anos. Orfã de mãe e pai, possui apenas uma irmã mais velha com quem reside e que está como acompanhante.

Mãe faleceu devido a infarto agudo do miocárdio e Pai abandonou a família quando ela tinha 16 anos. Segundo grau completo, caixa de supermercado até recentemente, atualmente desempregada. Alcoolista há 10 anos e tabagista há 6 anos. Faz uso de drogas ilícitas (maconha e Lsd). Tentativa de suicídio há 3 anos, 3 meses após o aborto espontâneo.

Apresenta diminuição dos relacionamentos sociais, ataques de pânico em ambientes aglomerados e alucinações frequentes e discursos ilógicos há cerca de 6 meses.

História Médica Pregressa: paciente diabética e hipertensa, realizou cirurgia de hérnia umbilical há 1 ano.

História familiar: Mãe com histórico de depressão e pai histórico de diabetes. Não conhece outro histórico familiar de transtorno mental.

Primeira vez da usuária no serviço do CAPS.

Medicamentos que utiliza: Metfomina, furosemida e anlodipino. Faz uso inadequado.

Programação da Cena

Simulador: (especificar qual simulador)

Paciente Padronizado:

Acompanhante: (especificar)

A usuária entra na sala de acolhimento do CAPS, acompanhada da irmã. A familiar solicita uma vaga de acolhimento no turno para sua irmã. A paciente retruca e refere que "não precisa daquilo, que ela era uma rainha, e que vinha dos céus a força o poder e o pudor, em seguida a paciente silencia e a irmã volta a falar que não aguenta mais tanta coisa que passa, que elas haviam perdido a mãe há alguns anos e tinha que cuidar dela. A familiar apresenta choro fácil.

\begin{tabular}{|l|l|l|l|}
\hline Componentes & Etapa 1 & Etapa 2 & Etapa 3 \\
\hline Acolhimento ao choro da irmã & $\mathrm{X}$ & & \\
\hline Levantamento do histórico social e familiar & $\mathrm{X}$ & & \\
\hline Identificação dos sinais e sintomas & $\mathrm{X}$ & & \\
\hline Elementos de psicoeducação & & $\mathrm{x}$ & \\
\hline Elementos de educação em saúde & & $\mathrm{x}$ & \\
\hline Aconselhamento & & & $\mathrm{x}$ \\
\hline Conduta e Planejamento do PTS & & & $\mathrm{x}$ \\
\hline
\end{tabular}

Falas direcionadas e/ou paciente padronizado (paciente e irmã):

-Paciente: Vocês vão me obrigar a ficar nesse lugar?.

- Paciente: Eu sou um anjo, eu preciso voar.

- Paciente: Aqui tem duas forças do mal, dois anjos obscuros.

- Paciente: Eu vou morrer, todos vamos morrer um dia. 
- Paciente: Aqui é o inferno ou céu, tenho certeza que é o purgatório!

- Irmã: Todo mundo da família pode ter essa doença? Eu posso ter essa doença?

- Irmã: Isso pode ser um encosto?

- Irmã: Tem cura?

- Irmã: ela precisa é de uma igreja;

- Irmã: Quando ela for para casa tem que ficar dentro de casa não é?

- Irmã: Ela vai passar muito tempo aqui né?

- Irmã: Os outros doidos não vão machucar ela não?

- Irmã: Muito obrigada pelos seus esclarecimentos.

- Paciente: tem pessoas boas aqui?

Fonte: Autoria própria.

No momento do briefing foi explicado aos estudantes sobre o desenvolvimento

e todo o preparo da cena de forma sucinta. O briefing significa orientar alguém para uma tarefa ou experiência antes de sua execução. "Inclui instruções sobre objetivos, procedimentos e regras para participar e atingir os objetivos pretendidos e os resultados de aprendizagem" (CHERENI; SLIUZAS; FLACKE, 2020). Foi disponibilizado um roteiro para todo o grupo como mostrado na tabela 2, e segundo esse roteiro a turma poderia acompanhar o desenvolvimento dos alunos sorteados como atores, para posteriormente fazer o feedback.

Tabela 2 - Briefing

\begin{tabular}{|c|c|}
\hline \multicolumn{2}{|r|}{ Briefing } \\
\hline Introdução & $\begin{array}{l}\text { Conhecimentos prévios do discente sobre acolhimento na saúde mental e } \\
\text { PTS. }\end{array}$ \\
\hline $\begin{array}{l}\text { Conteúdo } \\
\text { Prévio }\end{array}$ & $\begin{array}{l}\text { Aula expositiva, material prévio para leitura; instrumento contendo toda a } \\
\text { estrutura do Projeto Terapêutico Singular. }\end{array}$ \\
\hline $\begin{array}{l}\text { Objetivos de } \\
\text { Aprendizagem }\end{array}$ & $\begin{array}{l}\text { Treinar as habilidades necessárias para o atendimento ao paciente em } \\
\text { sofrimento psíquico mantendo uma comunicação terapêutica; } \\
\text { Sensibilizar os profissionais de saúde na abordagem do familiar; } \\
\text { Demonstrar como deve ser realizado o acolhimento na saúde mental; } \\
\text { Implementar o projeto terapêutico singular. }\end{array}$ \\
\hline \multicolumn{2}{|r|}{ Preparo do cenário } \\
\hline Tema & $\begin{array}{l}\text { Atendimento de enfermagem à paciente em sofrimento psíquico para } \\
\text { construção de PTS. }\end{array}$ \\
\hline Ambientação & Sala de acolhimento do CAPS III \\
\hline $\begin{array}{l}\text { Complexidade } \\
\text { do cenário }\end{array}$ & $\begin{array}{l}\text { Média (Espera-se o Desenvolvimento adequado do atendimento de } \\
\text { enfermagem à paciente em sofrimento psíquico) }\end{array}$ \\
\hline $\begin{array}{l}\text { Habilidades } \\
\text { prévias }\end{array}$ & $\begin{array}{l}\text { Comunicação e interação com o cliente, anamnese, análise dos dados } \\
\text { fornecidos pelo paciente e família. }\end{array}$ \\
\hline \multicolumn{2}{|r|}{ Desenvolvimento do cenário } \\
\hline Participantes & $\begin{array}{l}3 \text { participantes: enfermeiro, acompanhante do paciente (familiar), paciente } \\
\text { (ator padronizado). }\end{array}$ \\
\hline $\begin{array}{l}\text { Caracterização } \\
\text { do ator }\end{array}$ & $\begin{array}{l}\text { Paciente com cabelo desarrumado, aspecto de cansaço, sem maquiagem e } \\
\text { comportamento ansioso. }\end{array}$ \\
\hline Vinheta & $\begin{array}{l}\text { Aurora Paz, } 26 \text { anos, chega ao CAPS III, através de encaminhamento da UBS, } \\
\text { acompanhada de familiar. Apresentando diminuição dos relacionamentos } \\
\text { sociais, ataques de pânico em ambientes aglomerados, alucinações } \\
\text { frequentes e discursos ilógicos, segundo relato da irmã. }\end{array}$ \\
\hline
\end{tabular}


No desenvolvimento da cena, os alunos que atuaram como enfermeiros do CAPS entraram em ação junto com as enfermeiras que estavam atuando como paciente e familiar. A autoconfiança é considerada um indicador de proatividade suficiente para intervir em situações desconhecidas. O profissional de saúde deve sentir-se confiante quanto a capacidade de atuar de forma adequada (MESQUITA; SANTANA; MAGRO, 2019). Foi perceptível que ao longo do atendimento e desenvolvimento da cena, que os estudantes adquiriam confiança e melhoravam o desempenho durante a simulação e conseguiam extrair o máximo de informações para o preenchimento do projeto terapêutico singular (PTS) e para tornar o atendimento mais humanizado.

O feedback dessa cena ocorreu através do Debriefing (Tabela 3), parte fundamental da simulação realística, onde todos os alunos podem discutir pontos fortes e frágeis que foram encontrados durante a simulação e a atuação dos atores. Debriefing é uma reflexão deliberada, por um indivíduo ou grupo, para discutir e trabalhar as ideias, questões, sentimentos ou preocupações que são gerados pela experiência individual ou grupal durante a execução de uma tarefa (CHERENI; SLIUZAS; FLACKE, 2020). Os alunos são motivados a analisar se durante a cena os objetivos de aprendizagem foram alcançados: "Treinar as habilidades necessárias para o atendimento ao paciente em sofrimento psíquico mantendo uma comunicação terapêutica; sensibilizar os profissionais de saúde na abordagem do familiar; demonstrar como deve ser realizado o acolhimento na saúde mental; implementar o projeto terapêutico singular". Possibilitando a interação de toda a turma na análise da cena e da forma que ela foi conduzida, sem a intenção de apontar erros mas direcionar para que o próximo atendimento seja realizado da melhor forma possível. 
Tabela 3- Debriefing

\begin{tabular}{|l|l|l|}
\hline \multicolumn{3}{|c|}{ Debriefing } \\
\hline Estágio & Objetivo & Ações \\
\hline Reunir & $\begin{array}{l}\text { O objetivo da } \\
\text { simulação } \\
\text { alcançado? }\end{array}$ & $\begin{array}{l}\text { - Como você descreve o caso clínico trabalhado no cenário? } \\
\text { - Qual situação obteve maior atenção durante a realização do } \\
\text { cenário e por quê? } \\
\text { - Como vocês avaliam a conduta do enfermeiro diante do caso } \\
\text { clínico? } \\
\text { - O que vocês elencam que poderia ter sido feito diferente ou ser } \\
\text { melhorado? } \\
\text { - Como vocês se sentiram atuando no cenário? }\end{array}$ \\
\hline \multicolumn{3}{|c|}{ Pontos norteadores do debriefing } \\
\hline $\begin{array}{l}\text { Objetivos do cenário: } \\
\text { Treinar as habilidades necessárias para o acolhimento ao paciente em sofrimento psíquico mantendo } \\
\text { uma comunicação terapêutica; } \\
\text { Sensibilizar os profissionais de saúde na abordagem do familiar; } \\
\text { Demonstrar como deve ser realizado o acolhimento na saúde mental; } \\
\text { Implementar o projeto terapêutico singular. }\end{array}$
\end{tabular}

Fonte: Autoria própria.

A imersão de profissionais em cenários clínicos permite familiarização com o processo de atendimento ao paciente, o que favorece o desenvolvimento cognitivo, da autoconfiança na tomada de decisão, do pensamento crítico, do trabalho em equipe e de habilidades psicomotora, afetiva e perceptiva (MESQUITA; SANTANA; MAGRO, 2019). Dessa forma, a simulação realística compõe uma prática com bons resultados para o aprendizado do aluno, com destaque para o desenvolvimento de conhecimentos, habilidades e atitudes necessárias no atendimento ao paciente (FERNANDES; ALVES, 2019).

Na simulação realística, a fidelidade consta em criar um cenário com maior aproximação possível da realidade de acordo com a proposta. ${ }^{12}$ Neste intuito, a resolução dos problemas, durante a simulação, acontece de acordo com o aprendizado do estudante e conforme o conteúdo fornecido previamente, de modo que ele possa se sentir capaz de resolvê-los (MAGNAGO et al., 2020).

\section{CONSIDERAÇÕES FINAIS}

É possível observar a necessidade da estimulação na realização de práticas de simulação realística no cotidiano acadêmico dos estudantes. A importância da aplicação 
de estratégias amparadas nas metodologias ativas de ensino, como a simulação realística, durante o estágio em docência permite a melhoria da formação do mestrando, com técnicas que aperfeiçoem o processo de ensino-aprendizagem e, como consequência, o desenvolvimento dos processos avaliativos, onde o aluno se sustente como autor do próprio conhecimento.

A vantagem de trabalhar com esta abordagem metodológica é que a simulação realística constitui em método didático efetivo e inovador, auxiliando no processo ensino-aprendizagem por possibilitar ao aluno praticar procedimentos clínicos em um espaço pedagógico seguro, controlado e muito próximo do real, sem o risco da exposição do paciente.

Além de treinar as habilidades técnicas dos alunos, ela também possibilita, no âmbito da saúde mental, a comunicação e interação com o cliente, a realização de anamnese, análise dos dados fornecidos pelo paciente e família, além da prática do preenchimento de um projeto terapêutico singular.

\section{REFERÊNCIAS}

NASCIMENTO, M. S.; MAGRO, M. C. S. Realistic simulation: method of improving knowledge and self-confidence of nursing students in the administration of medication. Reme Revista Mineira de Enfermagem, v. 22, p. 1-5, 2018.

FERREIRA, R. P. N. et. al. Simulação Realística como Estratégia de Ensino no Aprendizado de Estudantes da Área da Saúde. Revista de Enfermagem do Centro-Oeste Mineiro. V.8, p. 2508, 2018.

PACHECO, G. G. et al. Simulação médica no período da pandemia da COVID-19: um relato de experiência. Revista Eletrônica Acervo Saúde, v. 13, n. 5, p. 7301, 2021.

DOMINGUES, I. et al. Contribuições da simulação realística no ensino-aprendizagem da enfermagem: revisão integrativa. Research, Society and Development. v. 10, n. 2, p. 55710212841, 2021.

COSTA, R. R. O. et al. Percepção de estudantes da graduação em enfermagem sobre a simulação realística. Revista CUIDARTE, v. 8, n. 3, p. 1799-1808, 2017.

JUNIOR, M. M. F. R.; SILVA, J. A. C. Capacitação em metodologia ativa para ensino e aprendizagem em saúde mental : conhecimento de médicos egressos que atuam na atenção básica de saúde. Brazilian Journal of Development, p. 48089-48110, 2021. 
FERNANDES, M. A. et al. Metodologias ativas como instrumento para a capacitação em saúde mental. Revista de Enfermagem UFPE on line, v. 12, n. 12, p. 3172, 2018.

YAMANE, M. T. et al. Simulação realística como ferramenta de ensino na saúde: uma revisão integrativa. Espaço para a Saúde - Revista de Saúde Pública do Paraná, v. 20, n. 1, p. 87-107, 2019.

SANTOS, L. C. et al. Características e repercussões da simulação como estratégia para o ensino-aprendizagem em enfermagem: revisão integrativa. Arquivos de Ciências da Saúde, v. 27, n. 1, p. 70, 2020.

CHERENI, S.; SLIUZAS, R. V.; FLACKE, J. An extended briefing and debriefing technique to enhance data quality in cross-national/language mixed-method research. International Journal of Social Research Methodology, v. 23, n. 6, p. 661-675, 2020.

MESQUITA, H. C. T.; SANTANA, B. DE S.; MAGRO, M. C. DA S. Effect of realistic simulation combined to theory on self-confidence and satisfaction of nursing professionals. Escola Anna Nery, v. 23, n. 1, p. 1-6, 2019.

FERNANDES, M. T. C.; ALVES, C. N. Simulação como metodologia na formação de discentes em enfermagem no estágio final da graduação. Atas de Ciências da Saúde, v. 7, p. 115-125, 2019.

MAGNAGO, T. et al. Simulação realística no ensino de segurança do paciente: relato de experiência. Revista de Enfermagem da UFSM, v. 10, p. e13, 2020. 


\section{CAPITULO XXVIII}

\section{ALTERAÇÕES MORFOFISIOLÓGICAS CARDIOVASCULARES DECORRENTES DO PROCESSO DE SENESCÊNCIA}

DOI: 10.51859/AMPLLA.PAE1993-28

Bárbara Queiroz de Figueiredo ${ }^{1}$

Ana Clara Viana Soares Brito ${ }^{2}$

Bianca Reis Carvalho Miranda ${ }^{3}$

Lunalva Gabrielli Veras Sousa ${ }^{2}$

\footnotetext{
'Graduanda do curso de Medicina. Centro Universitário de Patos de Minas.

${ }^{2}$ Graduanda do curso de Medicina. Centro Universitário Uninovafapi.

${ }^{3}$ Graduanda do curso de Medicina. Centro Universitário Barão de Mauá.
}

\section{RESUMO}

As doenças cardiovasculares (DCV) assumiram uma dimensão global e não se apresentam mais restritas às sociedades ocidentais. Durante o envelhecimento, desenvolvem-se várias modificações no sistema cardiovascular, como o enrijecimento das grandes artérias, decorrente de deposição aumentada de colágeno associada a alterações qualitativas nas fibras de elastina. Além disso, nos idosos, também é observada menor resposta à estimulação $\beta$-adrenérgica e, portanto, há diminuição da frequência cardíaca máxima alcançada em ritmo sinusal, quase de modo linear. Também há declínio no mecanismo de vasodilatação dependente do endotélio. Durante o repouso, as alterações no sistema cardiovascular decorrentes da senescência produzem modestos efeitos clínicos na hemodinâmica cardíaca e no rendimento cardíaco, ou seja, mesmo nos muito idosos, durante o repouso, estão preservados a frequência cardíaca, a fração e o volume de ejeção do ventrículo esquerdo e o débito cardíaco. Entretanto, progressivamente, com o avançar da idade, declina a capacidade do sistema cardiovascular em responder ao aumento das demandas associadas ao exercício ou às doenças (cardíacas ou não). Embora não exista um tratamento específico para o envelhecimento cardíaco, os recentes avanços na compreensão de seus mecanismos nos têm proporcionado boas perspectivas para o desenvolvimento de novas intervenções que possibilitem sua atenuação ou reversão.

Palavras-chave: Senescência; Aterosclerose; Cardiovascular. 


\section{INTRODUÇÃO}

As doenças cardiovasculares (DCV) assumiram uma dimensão global e não se apresentam mais restritas às sociedades ocidentais. Atualmente são responsáveis por mais de $30 \%$ de todas as mortes no mundo, e provavelmente, no ano de 2025 , superarão as doenças infecciosas como a principal causa de mortalidade e incapacidade. De acordo com a Organização Mundial da Saúde, As DCV foram responsáveis por 15 milhões de mortes anuais no mundo, das quais 9 milhões nos países em desenvolvimento e 2 milhões nas economias em transição. Homens e mulheres sadios apresentam, aos 40 anos, uma probabilidade de acometimento por DCV de $50 \%$, hipertensão arterial de $85 \%$, e insuficiência cardíaca de $20 \%$. Aos 70 anos o risco de acometimento da DCV em indivíduos sadios é virtualmente o mesmo que aos 40 anos, sugerindo uma possibilidade extremamente elevada de apresentá-la durante a vida (OLIVEIRA et al., 2003).

O envelhecimento, atualmente, pode ser considerado um processo heterogêneo em razão de diferenças genéticas ou morte celular programada, bem como de fatores externos, como doenças, dieta, exercício e estilo de vida ou a combinação de todos esses fatores. A impossibilidade da distinção da importância desses fatores no sistema cardiovascular dificulta afirmar se essas alterações são próprias do envelhecimento ou resultantes de tais fatores. Apesar de vários estudos epidemiológicos terem demonstrado que fatores genéticos, dislipidemias, diabetes e vida sedentária são os principais fatores de risco para doença coronária, hipertensão arterial, insuficiência cardíaca e acidente vascular encefálico (AVE), consideradas as doenças cardiovasculares mais prevalentes, a idade se configura como o principal fator de risco cardiovascular. Assim, várias explicações têm surgido, mostrando o efeito da idade na prevalência dessas doenças (CAETANO et al., 2008).

Os fatores de risco para as doenças cardiovasculares são mais prevalentes e mais graves com o aumento da idade, ocorrendo também maior tempo de exposição a esses fatores. Apesar de muitos idosos não apresentarem doenças evidentes, frequentemente apresentam comorbidades, doenças subclínicas, alterações funcionais e anatômicas que agem modificando a estrutura cardiovascular, facilitando a atuação dos mecanismos fisiopatológicos das doenças. Como a população idosa vem se tornando progressivamente mais idosa em muitos países, principalmente naqueles em 
desenvolvimento, as implicações clínicas e econômicas desta mudança demográfica tornam-se extremamente relevantes. Desse modo, com a senescência, observam-se alterações cardiovasculares nos idosos, sejam elas morfológicas ou fisiológicas (MARAFON et al., 2003). Por isso, o objetivo deste estudo foi evidenciar essas principais alterações cardiovasculares decorrentes do processo de envelhecimento.

\section{METODOLOGIA}

Trata-se de uma pesquisa descritiva do tipo revisão narrativa da literatura, que buscou evidenciar, por meio de análises empíricas e atuais, as principais alterações morfofisiológicas cardiovasculares decorrentes do processo de senescência. A pesquisa foi realizada através do acesso online nas bases de dados National Library of Medicine (PubMed MEDLINE), Scientific Electronic Library Online (Scielo), Cochrane Database of Systematic Reviews (CDSR), Google Scholar, Biblioteca Virtual em Saúde (BVS) e EBSCO Information Services, no mês de novembro 2021. Para a busca das obras foram utilizadas as palavras-chaves presentes nos descritores em Ciências da Saúde (DeCS): em inglês: "elderly", "atherosclerosis", "cardiovascular diseases", "physiology", "senescence" e em português: "idosos", "aterosclerose", "doenças cardiovasculares", "fisiologia", "senescência".

Como critérios de inclusão, foram considerados artigos originais, que abordassem o tema pesquisado e permitissem acesso integral ao conteúdo do estudo, publicados no período de 2002 a 2021, em inglês e português. O critério de exclusão foi imposto naqueles trabalhos que não estavam em inglês ou português, que não tinham passado por processo de Peer-View e que não abordassem o tema da pesquisa. A estratégia de seleção dos artigos seguiu as seguintes etapas: busca nas bases de dados selecionadas; leitura dos títulos de todos os artigos encontrados e exclusão daqueles que não abordavam o assunto; leitura crítica dos resumos dos artigos e leitura na íntegra dos artigos selecionados nas etapas anteriores. Assim, totalizaram-se 17 artigos científicos para a revisão narrativa da literatura, com os descritores apresentados acima. 


\section{REVISÃO BIBLIOGRÁFICA}

As teorias do envelhecimento podem ser agrupadas em teoria do genoma, fisiológica e orgânica, e os estudos têm mostrado que, em relação ao sistema cardiovascular, as duas últimas seriam as mais aceitas. As teorias fisiológicas parecem ser as mais esclarecedoras e claramente mais atrativas para explicar as alterações cardiovasculares ligadas à teoria do cruzamento, mostrando a importância das alterações da matriz proteica extracelular relacionadas com o tempo, principalmente do colágeno e da substância fundamental, e essas alterações são a base para explicação do aumento da rigidez pericárdica, valvular e talvez miocárdica e dos tecidos vasculares associado à idade (AFFIUNE, 2002).

Já as teorias orgânicas são simples e de fácil compreensão e demonstração, sendo, deste grupo, duas as mais importantes: imunológica e neuroendócrina. A teoria imunológica oferece pouca explicação para as alterações de seleção específica no sistema cardiovascular, explicando as características de duração da sobrevivência da espécie em termos de disfunção imunológica programada. Já a teoria neuroendócrina, em combinação com a teoria ligada ao cruzamento, forneceria explicações para muitas alterações cardíacas próprias do envelhecimento (WAJNGARTEN, 2010).

O sistema cardiovascular sofre significativa redução de sua capacidade funcional com o envelhecimento. Em repouso, contudo, o idoso não apresenta redução importante do débito cardíaco, mas em situações de maior demanda, tanto fisiológicas (esforço físico) como patológicas (doença arterial coronariana), os mecanismos para a sua manutenção podem falhar, resultando em processos isquêmicos. As mudanças cardiovasculares eram consideradas tão características ao processo do envelhecimento que algumas pessoas as consideravam a causa deste processo. Com base em seu trabalho de dissecação em seres humanos, Leonardo da Vinci disse que a causa do envelhecimento são "veias que, devido ao espessamento das túnicas, que ocorre nos idosos, limitam a passagem do sangue e, como resultado dessa falta de nutrição destrói a vida dos idosos sem provocar febre e os idosos enfraquecem pouco a pouco em uma morte lenta" (FERREIRA et al., 2017).

Com o avanço da idade, o coração e os vasos sanguíneos apresentam alterações morfológicas e teciduais, mesmo na ausência de qualquer doença, sendo que, ao 
conjunto dessas alterações, convencionou-se chamar coração senil ou presbicárdia. Ocorre uma evolução diferente de indivíduo para indivíduo, ocasionando alterações hemodinâmicas que se caracterizam por redução da reserva funcional, que é demonstrada pela diminuição da resposta cardiovascular ao esforço observada nos idosos (FREITAS et al., 2017).

\subsection{ALTERAÇÕES MORFOLÓGICAS}

Devido à elevada incidência de doenças cardíacas e vasculares no idoso, há dificuldade de reconhecimento das alterações decorrentes especificamente do processo de senescência. Na maioria das vezes, as alterações do pericárdio são discretas, em geral decorrentes do desgaste progressivo, sob a forma de espessamento difuso, particularmente nas cavidades esquerdas do coração, sendo comum o aumento dataxa de gordura epicárdica, não havendo alterações degenerativas ligadas diretamente à idade (MENDES et al., 2014).

Já as alterações encontradas no endocárdio são o espessamento e a opacidade, em especial no coração esquerdo, com proliferação das fibras colágenas e elásticas, fragmentação e desorganização destas com perda da disposição uniforme habitual, devido à hiperplasia irritativa resultante da longa turbulência sanguínea (FREITAS et al., 2009). Estudo de Fechine et al. (2012), em corações de vários grupos etários, evidenciaram que áreas de espessamento com aspecto focal, já presentes em jovens, acentuam-se e tornam-se difusas na sexta e na sétima década da vida. Após os 60 anos, há focos de infiltração lipídica particularmente no átrio esquerdo, e na oitava década, as alterações escleróticas são observadas de modo difuso em todas as câmaras, sendo que em qualquer idade o átrio esquerdo é o mais profundamente afetado.

As mudanças na matriz extracelular do miocárdio são comparáveis àquelas na vasculatura, com colágeno aumentado, diâmetro fibroso aumentado e cruzamento de ligações de colágeno, com aumento na proporção de colágenodos tipos I e III, diminuição de elastina e fibronectina aumentada, podendo ocorrer aumento na produção de matriz extracelular. Ademais, a proliferação de fibroblastos é induzida por fatores de crescimento, em particular angiotensinas, fator alfa de necrose tumoral e fator de crescimento derivado de plaquetas, e essas mudanças são acompanhadas de perda celular e alterações nas funções celulares (AFIUNE, 2002). 
Alterações do miocárdio são as mais expressivas, embora em determinadas necropsias, mesmo de indivíduos idosos, não se destaquem por sua intensidade. No miocárdio há acúmulo de gordura principalmente nos átrios e no septointerventricular, mas pode também ocupar as paredes dos ventrículos. Na maioria dos casos, não apresenta expressão clínica, sendo que em algumas situações parece favorecer o aparecimento de arritmias atriais (CARDOSO, 2009).

Observa-se também uma moderada degeneração muscular com substituição das células miocárdicas por tecido fibroso, sem correlação com lesões de artérias coronárias. Portanto, essas alterações podem ser indistinguíveis das resultantes de isquemia crônica.Depósitos intracelulares de lipofuscina, chamada de pigmento senil, têm sido admitidos como real manifestação biológica do envelhecimento, sendo encontrados na velhice precoce e descritos como um estado chamado de atrofia fosca ou parda, caracterizado por atrofia miocárdica associada a grande acúmulo de lipofuscina, comum em idosos queapresentam doenças consumptivas (SOUZA, 2002).

Ademais, o aumento da resistência vascular periférica pode ocasionar moderada hipertrofia miocárdica concêntrica, principalmente de câmara ventricular esquerda. A massa do ventrículo esquerdo (VE) está associada a múltiplos fatores de risco sociodemográficos e cardiovasculares, incluindo idade, sexo, massa corpórea, história de tabagismo, atividade física e hipertensão. Outrossim, o envelhecimento do VE responde de forma diferente em termos de massa e volume entre homens e mulheres (MACEDO, 2006).

Com o passar da idade, pode-se encontrar depósitos de substância amiloide que, com frequência, constitui a chamada amiloidose senil, e sua prevalência aumenta de forma rápida após os 70 anos, podendo atingir 50 a $80 \%$ dos indivíduos. A presença de depósitos amiloides está relacionada frequentemente à maior incidência de insuficiência cardíaca, independentemente de outra causa. As consequências da amiloidose senil são variáveis, dependendo da intensidade e eventualmente da localização do processo. O depósito amiloide pode ocupar áreas do nódulo sinoatrial e/ou do nódulo de Tawara, podendo acarretar complicações de natureza funcional, como arritmias atriais, disfunção atrial e até bloqueio atrioventricular (ZASLAVSKY et al., 2002). 
Estudos evidenciaram que as valvas permaneciam delgadas, flexíveis e delicadas, mesmo em indivíduos idosos, sendo essas alterações observadas em corações normais ou quase normais. O tecido valvar, composto predominantemente por colágeno, está sujeito a grandes pressões. Com o envelhecimento, observam-se degeneração e espessamento dessas estruturas, sendo que, histologicamente, as valvas de quase todos os indivíduos idosos apresentam algum grau dessas alterações, mas somente uma pequena proporção irá desenvolver anormalidades em grau suficiente para desencadear manifestações clínicas (CAETANO et al., 2008).

As manifestações acontecem particularmente em cúspides do coração esquerdo, sendo raras em valvas pulmonares e tricúspide. Nas fases iniciais, podemos ter alterações metabólicas com redução do conteúdo de mucopolissacarídios e aumento da taxa de lipídios; com o aumento da idade, poderemos ter processos moderados de espessamento, de esclerose discreta, de fragmentação colágena com pequenos nódulos na borda de fechamento das cúspides, que se acentuam com a idade (AMADO et al., 2004).

\subsubsection{ALTERACÕES DA VALVA MITRAL}

Calcificação e degeneração mucoide são relativamente frequentes, acometendo principalmente as valvas mitral e aórtica. A calcificação da valva mitral é uma das alterações mais importantes e mais comuns do envelhecimento cardíaco, ocorrendo em $10 \%$ das necropsias de indivíduos com mais de 50 anos. Em $50 \%$ dos nonagenários, as alterações da valva mitral iniciam-se geralmente na parte média do folheto posterior e estendem-se para a base de implantação, podendo levar a deformação ou deslocamentos da cúspide, sendo caracterizadas por espessamento, depósito de lipídios, calcificação e degeneração mucoide (MARAFON et al., 2003).

Na maioria das vezes, a calcificação mitral não provoca manifestações clínicas importantes, mas em alguns casos observa-se um sopro sistólico nítido em área mitral apresentando: disfunção valvar sob a forma de insuficiência e/ou estenose, alterações na condução do estímulo, pela vizinhança do tecido específico, endocardite infecciosa, condições que levam à formação de insuficiência cardíaca (DINIZ et al., 2013).

A degeneração mucoide ou mixomatosa torna o tecido valvar frouxo e, com isso, poderemos ter prolapso e insuficiência mitral. A literatura descreve casos de 
insuficiência cardíaca e morte súbita provocadas por rupturas das cordoalhas com valvas muito redundantes. A frequência de endocardite infecciosa sem doença cardíaca aparente geralmente aumenta com a idade, devido às alterações degenerativas do envelhecimento cardíaco, levando alguns autores a indicar a profilaxia medicamentosa antes de procedimentos de risco em idosos portadores de calcificação e degeneração mixomatosa (AFFIUNE, 2002).

\subsubsection{ALTERAÇÕES DA VALVA AÓRTICA}

À semelhança do que ocorre na valva mitral, o processo mais importante na valva aórtica é a calcificação, comalterações pouco significativas sob a forma de acúmulo de lipídios, de fibrose e de degeneração colágena, que podem estender-se ao feixe de His, com a presença de áreas fibróticas nas bordas das cúspides, constituindo as chamadas "excrescências de Lambia". A calcificação é mais frequente em indivíduos do sexo masculino, sendo já relatada, em estudos antigos, a ocorrência de esclerose primária de Monkberg. Aliado a isso, as experiências demonstram que há habitual relação entre calcificações da valva mitral e aórtica e, em muitos casos, concomitantes calcificações de artérias coronárias (MACEDO, 2006).

Na maioria dos casos, as alterações estruturais não acarretam manifestações clínicas, observando-se sopro sistólico em área aórtica, não sendo, geralmente, encontrada estenose valvar sem comprometimento da abertura das cúspides. 0 diagnóstico diferencial entre os estados de calcificação, com e sem estenose valvar, é importante para a conduta clínica. A estenose aórtica foi durante muito tempo considerada uma condição degenerativa associada à idade em que o "desgaste" resultava na formação progressiva de cálcio dentro da válvula (CAETANO et al., 2008).

De acordo com Esquenazi et al. (2014), a mesma pode ser dividida em 2 fases distintas: uma fase inicial precoce dominada por deposição valvar de lipídios, lesão e inflamação apresentando muita semelhança com a aterosclerose e uma fase de evolução tardia, em que os fatores pró-calcificantes e pró-osteogênicos em última análise causam a progressão da doença. A ligação aparente entre lipídios, inflamação e calcificação nas fases iniciais da estenose aórtica e as semelhanças patológicas com aterosclerose levaram à premissa de que as estatinas podem ser benéficas em pacientes com estenose aórtica. Essa hipótese foi apoiada por dados encorajadores de estudos 
não randomizados em humanos e em modelos de animais hipercolesterolêmicos, demonstrando que a deposição de lipídios e o estresse oxidativo precedem a conversão de células intersticiais valvulares para um fenótipo osteoblástico e que este processo é inibido pela atorvastatina.

No entanto, quando as estatinas foram formalmente testadas em três ensaios independentes, randomizados e controlados de pacientes com estenose aórtica, cada um demonstrou uma ineficiência desta terapêutica para interromper ou retardar a progressão da estenose aórtica, apesar de reduzir as concentrações de colesterol LDL no soro pela metade. Esse fato levou os pesquisadores a reexaminarem a fisiopatologia da estenose aórtica e perceberemque embora a inflamação e a deposição de lípidíos possam ser importantes no estabelecimento da doença (fase inicial), as fases posteriores são caracterizadas por um ciclo aparentemente de autoperpetuação na formação de cálcio e lesão valvular (fase de propagação). Uma vez que esta fase de propagação foi estabelecida, a progressão da doença não é ditada por inflamação ou pela deposição de lipídios, mas sim pelo acúmulo implacável de cálcio nos folhetos da válvula. Isto pode explicar a falha das estatinas em modificar a progressão da doença na estenose aórtica, que comumente se apresenta para além da fase de iniciação (OLIVEIRA et al., 2003).

\subsubsection{ALTERACÕ̃ES DAS ARTÉRIAS CORONÁRIAS}

As alterações das artérias coronárias não são, em geral, expressivas quando não é considerada a arteriosclerose vascular, podendo ser encontradas, como condição habitual de envelhecimento, perdas de tecido elástico e aumento do colágeno acumulando-se em trechos proximais das artérias. Eventualmente, ocorre depósito de lipídios com espessamento da túnica média. É comum a presença de vasos epicárdicos tortuosos, ocorrendo mesmo quando não há diminuição dos ventrículos. No coração, a coronária esquerda altera-se antes da direita. Essas alterações são diferentes da arteriosclerose; outra situação discutida seria a de artérias coronárias dilatadas, que não encontrou apoio em verificações de necropsia antigas. Outra alteração significativa é a calcificação das artérias coronárias epicárdicas, observada com frequência em indivíduos muito idosos e muito comuns nessa população, podendo atingir o tronco coronário e as três grandes artérias, ocupando geralmente o terço proximal desses vasos (AMADO et al., 2004). 
A calcificação da artéria coronária (CAC) resulta em redução na complacência vascular, respostas vasomotoras anormais e perfusão miocárdica diminuída. Adicionalmente, o sistema renina-angiotensina pode desempenhar um papel na calcificação da média, porque bloqueadores dos receptores da angiotensina II tipo 1 abolem o desenvolvimento da CAC em modelo pré-clínico. O ativador do receptor do fator nuclear-kappaB (osteoprotegerina) surgiu como uma potencial interface entre osteoporose e CAC. Dados epidemiológicos em humanos sugerem que os níveis mais elevados de osteoprotegerina estão associados com CAC e eventos cardiovasculares (MARAFONI et al., 2003).

\subsection{ALTERAÇÕES DO SISTEMA DE CONDUÇÃO OU ESPECÍFICO}

Processos degenerativos e/ou depósitos de substâncias podem ocorrer desde o nódulo sinusal aos ramos do feixe de His. O envelhecimento é acompanhado de acentuada redução das células do nó sinusal, podendo comprometer o nó atrioventricular e o feixe de His. A infiltração gordurosa separando o nó sinusal da musculatura subjacente contribui para o aparecimento de arritmia sinusal, sendo a mais frequente nessa faixa etária a fibrilação atrial. Essas alterações se instalam de forma lenta e gradual após os 60 anos e não estão, geralmente, relacionadas com a doença coronariana, sendo que os distúrbios do ritmo relacionados com esse processo variam de arritmias benignas até bloqueios de ramos que evoluem para bloqueios atrioventriculares, podendo levar até a crises de Stokes-Adams (SOUZA, 2002).

As principais alterações da aorta que ocorrem, sem considerar a arteriosclerose, seria a alteração na textura do tecidoelástico e o aumento do colágeno. Os processos ocorrem na camada média, sob a forma de atrofia, de descontinuidade e de desorganização das fibras elásticas, aumento de fibras colágenas e eventual deposição de cálcio. A formação de fibras colágenas não distensíveis predomina sobre as responsáveis pela elasticidade intrínseca que caracteriza a aorta jovem, resultando, portanto, em redução da elasticidade, maior rigidez da parede e aumento do calibre. A dilatação da raiz da aorta é cerca de $6 \%$ em média entre a quarta e a oitava década (CARDOSO, 2009).

Normalmente, as implicações clínicas das modificações da parede e do diâmetro da aorta são pouco acentuadase observa-se, ocasionalmente, aumento da pressão 
sistólica e da pressão de pulso, com moderadas repercussões sobre otrabalho cardíaco. Em alguns casos podemos ter dilatação da artéria e aumento do anel valvar com certo grau de insuficiência dascúspides, a chamada insuficiência aórtica isolada, quase sempre assintomática, com sopro diastólico curto audível em área de base ou ápice do coração, sem os sinais periféricos da insuficiência aórtica significativa. Outra alteração estrutural metabólica importante é a amiloidose senil da aorta que se desenvolve independentemente da arteriosclerose, e ainda poderemos ter a calcificação da parede aórtica com graus diversos de intensidade e incidência (MARAFON et al., 2003).

O aumento da rigidez arterial provoca aumento da pós-carga diretamente pela diminuição da complacência arterial e, indiretamente, acelera a velocidade de propagação da onda de pulso pelo sistema vascular, promovendo um retorno precoce ainda no período sistólico na parede da raiz da aorta, ocorrendo, como consequência, um pico tardio dapressão sistólica com aumento desta, bem como aumento da pressão de pulso e aumento da pós-carga. Como resultado do envelhecimento, além do aumento da pressão sistólica e da pressão de pulso, há diminuiçãoda pressão diastólica. A elevação crônica da pressão de pulso transmitida ao cérebro e ao rim causa dano ao fluxo arterial destes órgãos, levando a encefalopatia vascular e insuficiência renal crônica (AFFIUNE, 2002).

Embora estas alterações que acompanham o avanço da idade tenham sido sempre consideradas como envelhecimento arterial "fisiológico", estas mudanças estão longe de serem assim entendidas e são mais apropriadamente caracterizadas como fisiopatológicas. Há uma lacuna substancial em nosso conhecimento entre o queestá acontecendo na estrutura da parede arterial, no que diz respeito à microscopia e o que acontece in vivo. Caracteristicamente, há fragmentação e calcificação das fibras elásticas, aumento da deposição de colágeno, deposição amiloide na camada média e migração e proliferação de células vasculares do músculo liso. Os processos que conduzem a mudanças estruturais e funcionais da matriz celular, associadas à idade na paredearterial, são movidos por um microambiente pró-inflamatório, mediado por fatores mecânicos e humorais (ZASLAVSKY et al., 2002).

A resposta inicial de nosso organismo ao estresse é moderada por aumento na sinalização adrenérgica. O receptor de sinalização em cascata a jusante resulta em maior ativação do sistema renina-angiotensina-aldosterona e sinalização da endotelina, 
mecanismos utilizados para responder ao estresse crônico. É importante ressaltar que células vasculares endoteliais e células vasculares do músculo liso mudam seus fenótipos para produzir citocinas inflamatórias. Outros fatores que também desempenham um papel-chave na inflamação arterial são AGTRAP e SIRT1, reguladores negativos da sinalização dos receptores de angiotensina, que levam a pró-inflamação e, consequentemente, remodelação associada à idade (CAETANO et al., 2008).

\subsection{SISTEMA NERVOSO AUTÔNOMO}

Há uma grande influência do sistema nervoso autônomo sobre o desempenho cardiovascular. Vários estudos demonstraram que a eficácia da modulação betaadrenérgica sobre o coração e os vasos diminui com o envelhecimento, mesmo que os níveis de catecolaminas estejam aumentados, principalmente durante o esforço. Os mecanismos bioquímicos responsáveis por essas alterações ainda não estão bem estabelecidos. Acredita-se que haja uma falha nos receptores beta-adrenérgicos, ocasionada pelo aumento dos níveis de catecolaminas, principalmente a norepinefrina, que frequentemente está aumentada nos idosos (AFFIUNE, 2002).

A magnitude da deficiência beta-adrenérgica associada ao envelhecimento pode ser tão intensa quanto na insuficiência cardíaca. As consequências funcionais da diminuição da influência simpática sobre o coração e vasos do idoso são observadas principalmente durante o exercício; portanto, à medida que o idoso envelhece, o aumento do débito cardíaco durante o esforço se obtém com o maior uso da lei de Frank-Starling com dilatação cardíaca, aumentando o volume sistólico para compensar a resposta atenuada da frequência cardíaca. O efeito vasodilatador dos agonistas betaadrenérgicos sobre a aorta e os grandes vasos também diminui com a idade, bem como a resposta inotrópica do miocárdio às catecolaminas e a capacidade de resposta dos barorreceptores às mudanças de posição (CARDOSO, 2009).

\subsection{FUNÇÃO CARDIOVASCULAR}

O envelhecimento determina modificações estruturais que levam à diminuição da reserva funcional, limitando o desempenho durante a atividade física, bem como reduzindo a capacidade de tolerância em várias situações de grande demanda, principalmente nas doenças cardiovasculares. O débito cardíaco pode diminuir em 
repouso, principalmente durante o esforço, tendo influência importante do envelhecimento por meio de vários determinantes: diminuição da resposta de elevação da frequência cardíaca ao esforço ou outro estímulo; diminuição da complacência do ventrículo esquerdo mesmo na ausência de hipertrofia miocárdica, com retardo no relaxamento do ventrículo, com elevação da pressão diastólica desta cavidade, levando à disfunção diastólica do idoso, muito comum, e que se deve principalmente à dependência da contração atrial para manter o enchimento ventricular e o débito cardíaco (ESQUENAZI et al., 2014).

Além disso, há diminuição da complacência arterial, com aumento da resistência periférica e consequente aumento da pressão sistólica, com aumento da pós-carga dificultando a ejeção ventricular devido às alterações estruturais na vasculatura; diminuição da resposta cronotrópica e inotrópica às catecolaminas, mesmo com a função contrátil do ventrículo esquerdo preservada; diminuição do consumo máximo de oxigênio pela redução da massa ventricular encontrada no envelhecimento; diminuição da resposta vascular ao reflexo barorreceptor, com maior suscetibilidade do idoso à hipotensão (AFFIUNE, 2002).

Outrossim, ocorre diminuição da atividade da renina plasmática, sendo que nos hipertensos poderemos encontrar níveis de aldosterona plasmática normais, com diminuição da resposta ao peptídio natriurético atrial, embora a sua concentração plasmática esteja aumentada; no idoso teremos maior prevalência de hipertensão sistólica isolada, mais frequente do que a sistodiastólica acima dos 70 anos, estando associada a maior risco de doenças cárdio e cerebrovasculares. Com o envelhecimento, o débito cardíaco poderá estar normal ou diminuído, sendo que o coração idoso é competente em repouso, com resposta ao esforço alterada, podendo facilmente entrar em falência quando submetido a maior demanda, como na presença de doenças cardíacas ou mesmo sistêmicas (SOUZA, 2002; MACEDO, 2006).

\section{CONSIDERACÕES FINAIS}

A necessidade da compreensão das alterações estruturais e funcionais cardíacas durante o envelhecimento possibilita intervenções preventivas, aumentando a expectativa de vida, além de retardar mortes relacionadas à doença cardiovascular. Embora não exista um tratamento específico para o envelhecimento cardíaco, os 
recentes avanços na compreensão de seus mecanismos nos têm proporcionado boas perspectivas para o desenvolvimento de novas intervenções que possibilitem sua atenuação ou reversão.

\section{REFERÊNCIAS}

AFFIUNE, A. Envelhecimento cardiovascular. Tratado de Geriatria e Gerontologia. Rio de Janeiro: Guanabara Koogan, p. 28-32, 2002.

ALVES, C. B., et al. Pressão arterial de idosos que praticam atividades físicas em um grupo de envelhecimento saudável. Arquivos de Ciências do Esporte, v. 1, n. 11, p. 7580, 2012.

AMADO, T. C. F., et al. Hipertensão arterial no idoso e fatores de risco associados. Rev Bras Nutr Clin., v. 19, n. 2, p. 94-99, 2004.

CAETANO, J. A., et al. Descrição dos fatores de risco para alterações cardiovasculares em um grupo de idosos. Texto \& Contexto Enfermagem, v. 17, n. 2, p. 67-74, 2008.

CARDOSO, A. F. Particularidades dos idosos: uma revisão sobre a fisiologia do envelhecimento. EF Deportes, v. 13, n. 130, p. 1-6, 2009.

DINIZ, M. A., et al. Fatores de risco para doenças cardiovasculares em idosos de um município do interior de Minas Gerais. Texto \& Contexto Enfermagem, v. 22, n. 4, p. 1-11, 2013.

ESQUENAZI, D., et al. Aspectos fisiopatológicos do envelhecimento humano e quedas em idosos. Revista HUPE, v. 13, n. 2, p. 12-22, 2014.

FECHINE, B. R. A., et al. O processo de envelhecimento: as principais alterações que acontecem com o idoso com o passar dos anos. Revista Científica Internacional, v. 20, n. 7, p. 106-194, 2012.

FERREIRA, J. D. F., et al. Fatores de risco para doenças cardiovasculares em idosos. Revista de Enfermagem da UFPE, v. 11, n. 12, p. 4895-4898, 2017.

FREITAS, E. V., et al. Importância da HDL-c para a Ocorrência de Doença Cardiovascular no Idoso. Arq Bras Cardiol., v. 93, n. 3, p. 231-238, 2009.

MACEDO, M. P. Envelhecimento e parâmetros hematológicos. Tratado de Geriatria e Gerontologia. 2. ed. Rio de Janeiro: Guanabara Koogan, p. 1040-1048, 2006.

MARAFON, L. P., et al. Preditores cardiovasculares da mortalidade em idosos longevos. Cadernos de Saúde Pública, v. 19, n. 3, p. 799-808, 2003. 
MENDES, G. S., et al. Prevalência de hipertensão arterial sistêmica em idosos no Brasil entre 2006 e 2010. Rev. Bras. Med. Família e Comunidade, v. 9, n. 32, p. 273278, 2014.

OLIVEIRA, T. C., et al. Avaliação de fatores de risco para alterações cardiovasculares e de alterações oculares em um grupo de idosos. Nursing, v. 6, n. 56, p. 15-21, 2003.

SOUZA, R. S. Anatomia do envelhecimento. Geriatria: Fundamentos, Clínica e Terapêutica. 2. ed. São Paulo: Atheneu, p. 35-42, 2002.

WAJNGARTEN, M. O coração no idoso. Jornal Diagnósticos em Cardiologia, v. 13, n. 43, p. 1-9, 2010.

ZASLAVSKY, C., et al. Idoso: Doença Cardíaca e Comorbidades. Arq Bras Cardiol., v. 79, n. 6, p. 1-17, 2002. 


\title{
CAPITULO XXIX
}

\section{ANÁLISE EPIDEMIOLÓGICA DA HANSENÍASE NO ESTADO DO PIAUI ENTRE OS ANOS DE 2015 A 2020}

DOI: 10.51859/AMPLLA.PAE1993-29

\author{
Lucas Rafael Uchôa ${ }^{1}$ \\ Lanielle de Sousa Brito Oliveira ${ }^{2}$
}

\begin{abstract}
${ }^{1}$ Mestrando pelo Programa de Pós-graduação em Biodiversidade, Meio Ambiente e Saúde pela Universidade Estadual do Maranhão - UEMA

${ }^{2}$ Graduada em Licenciatura em Ciências Biológicas pelo Instituto Federal de Educação, Ciência e Tecnologia do Piauí - IFPI
\end{abstract}

\section{RESUMO}

A hanseníase continua a ser um grande problema de saúde no Brasil. O diagnóstico tardio da hanseníase, associado geralmente a áreas endêmicas com alta vulnerabilidade, contribui para maiores complicações, desse modo, o conhecimento da epidemiologia local é importante para aumentar a detecção precoce de casos novos. Este estudo visou analisar os casos de hanseníase no estado do Piauí de 2015 até 2020. Estudo epidemiológico descritivo, realizado por meio da utilização de dados do Sistema de Informação sobre Agravos de Notificação e do Departamento de Informática do Sistema Único de Saúde. A partir dos dados analisados sobre hanseníase, observou-se que dos estados do nordeste, o Piauí apresenta a quinta maior frequência de casos diagnosticados e os casos no estado vêm mantendo uma constância desde 2012, com a capital Teresina possuindo o maior número de casos (37.6\%). A maioria dos casos foram registrados no intervalo da faixa etária de 40 a 59 anos. Levando em consideração as formas clínicas, a dimorfa (multibacilar) representa $44.5 \%$ dos casos confirmados. Com os resultados obtidos a partir deste estudo, observa-se que os casos de hanseníase no estado do Piauí vêm mantendo uma constância nos últimos anos, mas o grupo de indivíduos com faixa etária entre 40-59 anos, despertando uma maior atenção em relação a saúde e qualidade de vida. A maioria dos indivíduos acometidos evoluíram para a cura, mas diante da importância clínica da hanseníase ressalta-se a importância da divulgação da prevenção e tratamento no estado, enfatizando suas formas de transmissão e agravos.

Palavras-chave: Hanseníase. Áreas endêmicas. Lesões. 


\section{INTRODUÇÃO}

A hanseníase é uma doença crônica, infectocontagiosa, cujo agente etiológico é o Mycobacterium leprae, que se infiltra através do trato respiratório e se manifesta por meio de sinais e sintomas dermatoneurológicos (BRASIL, 2017; SANTOS, 2019). A hanseníase é uma incapacidade evitável (BRITTON; LOCKWOOD, 2004), se não tratada na forma inicial a doença geralmente evolui, torna-se transmissível e pode atingir pessoas de qualquer idade, ocasionando incapacidades físicas (BRASIL, 2017).

A pele e os nervos periféricos são os principais afetados pela hanseníase, graves deficiências físicas e deformidades podem ser geradas se a doença não for diagnosticada e tratada adequadamente em seus estágios iniciais (BARRETO, 2014). Conforme a resposta imunológica individual, a hanseníase pode permanecer leve, sem alterações físicas aparentes, ou pode progredir e a proliferação do bacilo $M$. leprae no corpo causa danos aos nervos periféricos, alterando a aparência física e a mobilidade física da pessoa acometida (WHITE; FRANCO-PAREDES, 2015).

A hanseníase continua a ser um grande problema de saúde em muitos países, dentre eles o Brasil (MATOS et al., 2016). A doença possui notificação compulsória no Brasil (BARRETO, 2014), o país possui o segundo maior número de novos casos da doença no mundo, perdendo apenas para a Índia (ALBERTS et al., 2011). Dos altos percentuais de hanseníase registrados até 2013, o Brasil foi um dos países das Américas que mais teve notificações de novos casos da doença (MONTEIRO et al., 2017). A distribuição da doença no Brasil é heterogênea e as regiões Norte, Centro-Oeste e Nordeste são as mais afetadas (BARRETO, 2014).

O diagnóstico tardio da hanseníase, associado geralmente a áreas endêmicas com alta vulnerabilidade, contribui para maiores complicações como diversos sintomas clínicos, que podem resultar em desfiguração permanente e incapacidade (HAMBRIDGE, 2021). Para que o ciclo de transmissão seja interrompido e o número de novos casos com deformidade física diminua, é fundamental diagnosticar e tratar os pacientes precocemente, antes do surgimento das lesões (CRUZAR, 2007).

O diagnóstico precoce e o tratamento adequado minimizam os danos causados ao indivíduo e reduzem a transmissão da doença em territórios e comunidades com 
maior risco e vulnerabilidade (SOUZA, 2018), desse modo, o conhecimento da epidemiologia local é importante para aumentar a detecção precoce de casos novos.

Diante da importância da hanseníase no contexto de saúde em áreas endêmicas da doença no Brasil e da necessidade de conhecer a epidemiologia local para o diagnóstico precoce e tratamento adequado, este estudo visou analisar os casos de hanseníase no estado do Piauí nos últimos anos (2015 a 2020).

\section{REVISÃO BIBLIOGRÁFICA}

A hanseníase é considerada uma Doença Tropical Negligenciada (DTN) com ocorrência desigual, especialmente em populações socioeconomicamente desfavorecidas e marginalizadas em países tropicais (HOLT, 2012). Geralmente, a transmissão da hanseníase ocorre no ambiente familiar, devido ao contato próximo e prolongado de uma pessoa suscetível com uma pessoa doente e que não está em tratamento (BRASIL, 2017).

A M. leprae é transmitida pelas vias respiratórias, e não pelos objetos utilizados pelo paciente, a maior parte das pessoas que entrarem em contato com o bacilo não adoecerão, estima-se que a maioria da população possui imunidade contra a bactéria (BRASIL, 2017) A M. leprae multiplica-se lentamente e o período médio de incubação da doença dura entre três a cinco anos, mas os sintomas podem demorar até 30 anos para se manifestarem (BARRETO, 2014).

O diagnóstico da Hanseníase requer conhecimento clínico e epidemiológico adequado consistindo em correta análise das pessoas acometidas, além de realizar exames adequados para identificar tipos de lesões na pele ou sensibilidades alteradas nos nervos e tipos de bacilos (VELÔSO, 2018). Os principais sintomas observados em indivíduos com hanseníase são manchas esbranquiçadas, acastanhadas ou avermelhadas com alterações de sensibilidade, formigamentos, choques e câimbras nos braços e pernas, que evoluem para dormência, pápulas, infiltrações, tubérculos e nódulos, diminuição ou queda de pelos e ausência de sudorese no local (BRASIL, 2017).

Por meio da introdução de medidas de controle como vacinação com Bacillus Calmette-Guérin (BCG), estabelecimento de registros nacionais, rastreamento de contatos, diversos países apresentaram diminuição na incidência de casos de hanseníase (HAMBRIDGE, 2021). Tratamentos com poliquimioterapia (PQT) e o uso de 
terapias antiinflamatórias, contribuem para melhorias nos resultados de saúde em longo prazo para indivíduos com hanseníase (WHITE; FRANCO-PAREDES, 2015).

Visando reduzir os casos de hanseníase, a Organização Mundial da Saúde (OMS) criou a Estratégia Global para Hanseníase 2016-2020, cujo propósito é a deteç̧ão precoce da hanseníase e o tratamento imediato para evitar a incapacidade dos indivíduos acometidos e reduzir a transmissão da infecção na comunidade (OMS, 2016). No Brasil, apesar dos avanços na redução de casos, a meta sugerida pela OMS de eliminação da doença como problema de saúde pública com registro de menos de um caso para cada 10.000 habitantes ainda não havia sido alcançada no ano de 2018 (SILVA et al., 2018).

\section{METODOLOGIA}

O presente trabalho trata-se de um estudo epidemiológico descritivo, documental e retrospectivo de abordagem quantitativa e qualitativa, realizado por meio e análise de dados secundários, visto que na visão de Gil (2002) o estudo exploratório e documental visa buscar informações como, por exemplo, dados brutos colhidos de um relatório a fim de levantar informações acerca de um dado assunto pertinente ao objetivo do estudo.

Os dados foram obtidos através da utilização das ocorrências registradas no do Sistema de Informação sobre Agravos de Notificação (SINAN) e do Departamento de Informática do Sistema Único de Saúde (DATASUS), do Ministério da Saúde. Os dados pesquisados foram referentes informações sobre casos de hanseníase no estado do Piauí.

Posteriormente as informações obtidas foram submetidas à análise estatística descritiva, sendo realizada a tabulação de dados primários através do sistema Microsoft Office Excel, que, posteriormente, foram dispostos através de tabelas e gráficos para melhor compreensão das informações agrupadas com base nos dados obtidos considerando o período de notificações de 2015 até 2020 e englobam critérios como coeficientes de deteç̧ão geral, faixa etária, porcentagem de cura e grau de incapacidade. 


\section{RESULTADOS E DISCUSSÃO}

A partir dos dados analisados sobre hanseníase, observou-se que dos estados do nordeste, o Piauí apresenta a quinta maior frequência de casos diagnosticados e os casos no estado vêm mantendo uma constância desde 2012, variando em um pouco mais de 100 casos nos últimos anos, com a capital Teresina possuindo o maior número de casos (37.6\%).

A doença exibe distribuição heterogênea, com registro de casos novos em todas as Unidades Federadas, porém, um dos fatores que contribui para a manutenção do indicador de prevalência no país é o padrão de alta endemicidade das regiões Norte, Nordeste e Centro Oeste (SILVA et al., 2018). E os administradores de saúde precisam conhecer o quadro epidemiológico de sua região e elencarem ações de acordo com as prioridades de sua população (OPROMOLLA; DALBEN; CARDIM, 2006).

Figura 1 - Frequência dos números de casos de hanseníase no estado do Piauí entre 2015 a 2020.

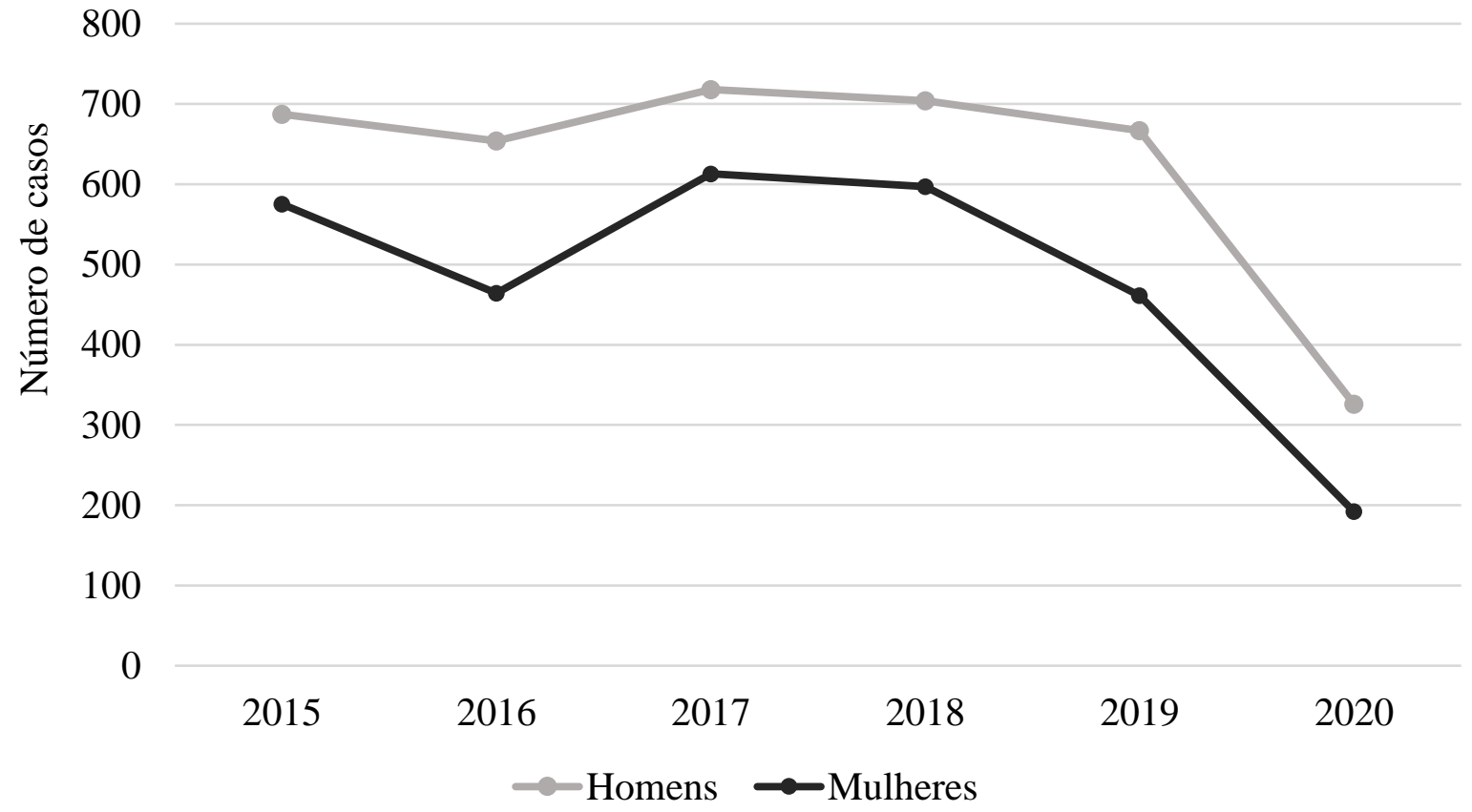

Fonte: Ministério da Saúde/SVS - Sistema de Informação de Agravos de Notificação - Sinan Net.

A maioria dos casos foram registrados no intervalo da faixa etária de 40 a 59 anos, correspondendo a $37 \%$ dos casos corroborando com resultados anteriores de relatórios da Vigilância Epidemiológica (WORLD HEALTH ORGANIZATION, 2012). 
Figura 2 - Frequência dos casos de hanseníase pela forma clínica notificada.

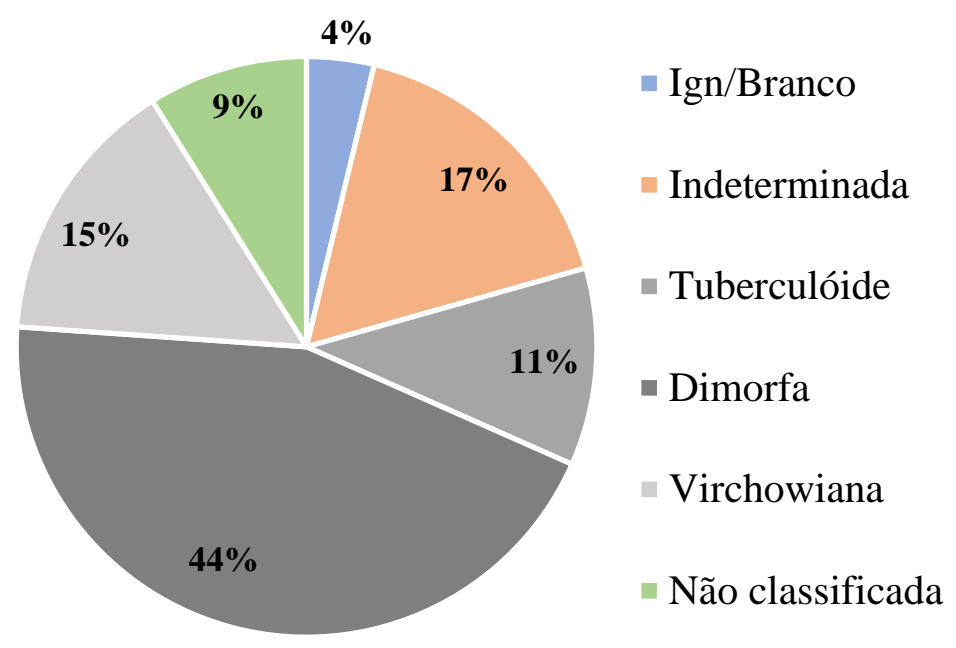

Fonte: Ministério da Saúde/SVS - Sistema de Informação de Agravos de Notificação - Sinan Net.

Levando em consideração as formas clínicas, a dimorfa (multibacilar) representa 44.5\% dos casos confirmados.

Figura 3 - Frequência dos casos de hanseníase pelo número de lesões cutâneas.

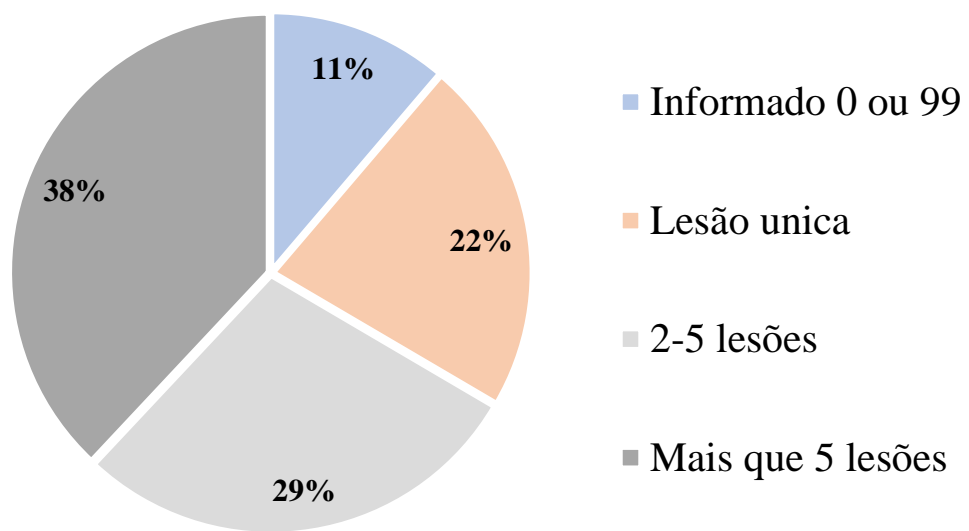

Fonte: Ministério da Saúde/SVS - Sistema de Informação de Agravos de Notificação - Sinan Net.

As lesões cutâneas consistiram em 38\% dos casos sendo caracterizadas pela presença de mais de cinco lesões. 
Figura 4 - Progressão dos números de casos de hanseníase por faixa etária

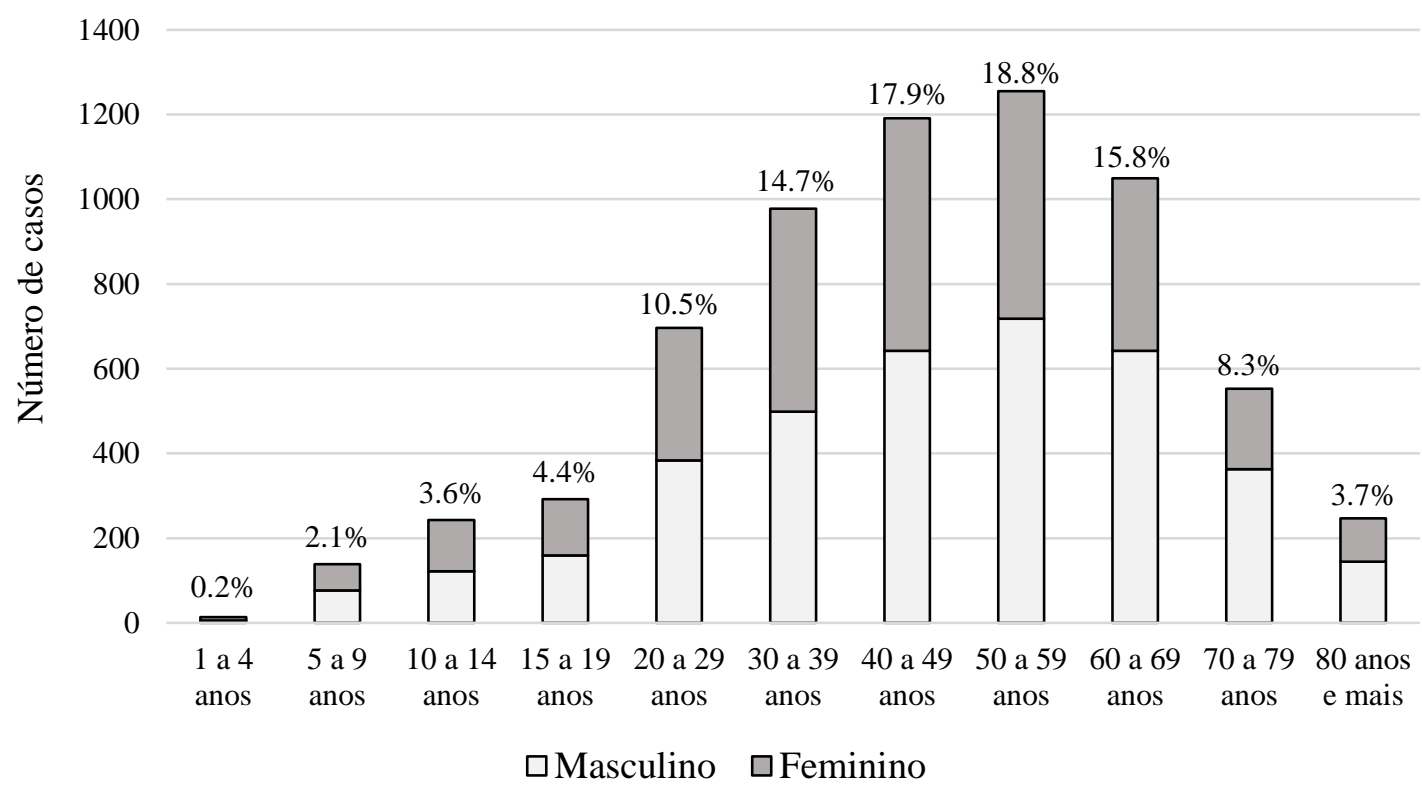

Fonte: Ministério da Saúde/SVS - Sistema de Informação de Agravos de Notificação - Sinan Net.

Quanto ao tipo de saída, 68\% evoluíram para a cura. A maioria dos casos (63\%) tiveram grau de incapacidade 0 . O grau zero foi o que prevaleceu em todas as faixas etárias, assim como é descrito em outros trabalhos (GOMES et al., 2005; MIRANZI; PEREIRA; NUNES, 2010)

Vale ressaltar que o estigma associado à hanseníase e a discriminação de pessoas afetadas pela doença continuam a desafiar a detecção precoce e a conclusão bemsucedida do tratamento. Muitos pacientes continuam a sofrer exclusão social, depressão e perda renda. Com frequência, as famílias também sofrem devido ao estigma (WORLD HEALTH ORGANIZATION, 2019).

\section{CONSIDERAÇÕES FINAIS}

Com os resultados obtidos a partir deste estudo, observa-se que os casos de hanseníase no estado do Piauí vêm mantendo uma constância nos últimos anos, mas o grupo de indivíduos com faixa etária entre 40-59 anos desperta atenção em relação a saúde e qualidade de vida desses pelo fato de serem o grupo mais acometido pela doença. A maioria dos indivíduos acometidos evoluíram para a cura, mas diante da importância clínica da hanseníase ressalta-se a importância da divulgação da prevenção e tratamento no estado, enfatizando suas formas de transmissão e agravos. 


\section{REFERÊNCIAS}

ALBERTS, C. J.; SMITH, W. C. S.; MEIMA, A.; WANG, L.; RICHARDUS, J. H. Efeito potencial da estratégia global de hanseníase 2011-2015 da Organização Mundial da Saúde sobre a prevalência de grau 2 de deficiência: uma análise de tendência. Boletim da Organização Mundial da Saúde, v. 89, p. 487-495, 2011.

BARRETO, J. G. et al. Análise espacial destacando a transmissão da hanseníase na primeira infância em um município hiperendêmico da Amazônia brasileira." PLoS neglected tropical disease,v. 8,2, e2665, 2014.

BRASIL. Ministério da Saúde. Secretaria de Vigilância em Saúde. Departamento de Vigilância das Doenças Transmissíveis. Guia prático sobre a hanseníase [recurso eletrônico] / Ministério da Saúde, Secretaria de Vigilância em Saúde, Departamento de Vigilância das Doenças Transmissíveis. - Brasília: M. Saúde, 2017. 68 p.

BRITTON, W. J.; LOCKWOOD, D. N. Leprosy. Lanceta. v. 363, p. 1209-19, 2004.

CRUZAR, H. A prevenção da deficiência para as pessoas afetadas pela hanseníase: quem precisa mudar a atitude?. LEPR Rev, v. 78, p. 321-329, 2007.

GIL, A. C. Como elaborar projetos de pesquisa. 4 ed. São Paulo: Atlas S. A, 2002.

GOMES, C. C. D.; PONTES, M. A. A.; GONÇALVES, H. S.; PENNA, G. O. Perfil clínicoepidemiológico dos pacientes diagnosticados com hanseníase em um centro de referência na região nordeste do Brasil. Anais Brasileiros de Dermatologia, v. 8, p. 283-288, 2005.

HAMBRIDGE, T. et al. Mycobacterium leprae transmission characteristics during the declining stages of leprosy incidence: A systematic review. PLoS neglected tropical diseases, v. 15,5, e0009436, 2021.

HOLT, F.; GILLAM, S. J.; NGONDI, J. M. Melhorando o acesso a medicamentos para doenças tropicais negligenciadas em países em desenvolvimento: lições de três economias emergentes. PLoS negligenciou doenças tropicais, v. 6, n. 2, e1390, 2012.

MATOS, H. J. et al. Tendências de detecção de novos casos de hanseníase e o efeito futuro de intervenções preventivas no estado do Pará, Brasil: um estudo de modelagem. PLoS neglected tropical disease, v. 10,3, e0004507, 2016.

MIRANZI, S. S. C.; PEREIRA, L. H. M.; NUNES, A. A. Perfil epidemiológico da hanseníase em um município brasileiro, no período de 2000 a 2006. Revista da Sociedade Brasileira de Medicina Tropical, v. 43, p. 62-67, 2010. 
MONTEIRO, L. D.; MOTA, R.; MARTINS-MELO, F. R., ALENCAR, C. H., HEUKELBACH, J. Determinantes sociais da hanseníase em um estado hiperendêmico do Norte do Brasil. Revista de saúde pública, v. 51, p. 70, 2017.

OPROMOLLA, P. A.; DALBEN, I.; CARDIM, M. Análise geoestatística de casos de hanseníase no Estado de São Paulo, 1991-2002. Revista de Saúde Pública, v. 40, p. 907-913, 2006.

SANTOS, K. C. B. D.; CORRÊA, R. D. G. C. F.; ROLIM, I. L. T. P.; PASCOAL, L. M.; FERREIRA, A. G. N. Estratégias de controle e vigilância de contatos de hanseníase: revisão integrativa. Saúde em Debate, v. 43, p. 576-591, 2019.

SILVA, G. H. D.; SAAVEDRA, I. P.; NASCIMENTO, J. R. T.; VELHO, J. A. D. S.; GRIMES, N. C.; NAHAS, T. P. Abordagem da hanseníase na atenção básica. 2018. Disponível em: https://moodle.unasus.gov.br/vitrine29/course/view.php?id=252. Acessado em 05 de Set de 2021.

SOUZA, E. A. D.; BOIGNY, R. N.; FERREIRA, A. F.; ALENCAR, C. H.; OLIVEIRA, M. L. W.; RAMOS, A. N. Vulnerabilidade programática no controle da hanseníase: padrões na perspectiva de gênero no Estado da Bahia, Brasil. Cadernos de Saúde Pública, v. 34, n. 1, e00196216, 2018.

VELÔSO, D. S.; MELO, C. B. D.; SÁ, T. L. B. D.; SANTOS, J. P. D.; NASCIMENTO, E. F. D.; COSTA, F. A. C. Perfil Clínico Epidemiológico da Hanseníase: Uma Revisão Integrativa. REAS, Revista Eletrônica Acervo Saúde, v. 10, n. 1, p. 1429-1437, 2018.

WHITE, C.; FRANCO-PAREDES, C. Hanseníase no século 21. Revisões de microbiologia clínica, v. 28, n. 1, p. 80-94, 2015.

WORLD HEALTH ORGANIZATION. Global leprosy situation Weekly Epidemiological Record, v. 87, n. 34, p. 317-328, 2012.

WORLD HEALTH ORGANIZATION. Global Leprosy Strategy 2016-2020 Accelerating towards a leprosy-free world. WHO Library, Cataloguing-in-Publication data. 2019. 


\section{CAPITULO XXX}

\section{VITAMINA D EM INFECÇÃO VIRAL POR SARS-COV-2: PERSPECTIVA TERAPÊUTICA NA COVID-19}

DOI: 10.51859/AMPLLA.PAE1993-30

Ana Beatriz Bessa de Albuquerque ${ }^{1}$ Bruna Zavarize Reis ${ }^{2}$ Alan Lins Fernandes ${ }^{3}$

\footnotetext{
${ }^{1}$ Graduada em Nutrição. Departamento de Nutrição da Universidade Federal do Rio Grande do Norte UFRN, Natal, RN-Brasil.

${ }^{2}$ Doutora em Ciências (FCF-USP). Professora Doutora no Departamento de Nutrição e no Programa de Pós-Graduação em Nutrição (PPGNut). Centro de Ciências da Saúde. Universidade Federal do Rio Grande do Norte - UFRN, Natal, RN-Brasil.

${ }^{3}$ Doutor em Ciências (EEFE-USP). Pós-Doutorando no Laboratório de Metabolismo Ósseo. Departamento de Reumatologia. Faculdade de Medicina da Universidade de São Paulo - FMUSP, São Paulo, SP-Brasil.
}

\section{RESUMO}

Em alusão ao seu papel modulador no sistema imune, a vitamina D tem sido cogitada como um eventual recurso terapêutico na prevenção e/ou tratamento da COVID-19. Dada a relevância do tema, os estudos têm crescido em número e qualidade visando responder a esta pertinente questão. A vitamina D é amplamente conhecida por diversas funções extra esqueléticas no organismo, em que pese um relevante papel no sistema imunológico. Em face da necessidade por maiores esclarecimentos da relação vitamina D e COVID-19, foi realizado um levantamento da literatura científica no tocante aos papéis fisiológicos e imunológicos da vitamina $D$, bem como os mecanismos de ação nas infecções respiratórias, sobretudo, relacionadas à COVID-19. Este capítulo elencou diferentes desfechos no que se refere a associação da concentração sérica de 25hidroxivitamina D [25(OH)D] e o quadro clínico da COVID-19: mortalidade, inflamação, gravidade da doença, uso de ventilação mecânica e/ou admissão em unidade de terapia intensiva (UTI). Portanto, apesar do emergente avanço na temática, ainda faz-se necessário estudos bem delineados, particularmente ensaios clínicos randomizados, que fomentem diferentes estratégias de manipulação da vitamina $D$ no amplo espectro de manifestações da COVID-19, avaliando de forma objetiva o seu papel na prevenção e/ou tratamento da COVID-19.

Palavras-chave: Vitamina D. Vitamina D3. 25OHD. COVID-19. SARS-CoV-2. 


\section{INTRODUÇÃO}

A doença do coronavírus 2019 (COVID-19) compreende a manifestação clínica decorrente da infecção promovida pelo vírus da síndrome respiratória aguda grave 2, SARS-CoV-2, agente etiológico da síndrome respiratória aguda grave (do inglês severe acute respiratory syndrome, SARS) (HARRISON; LIN; WANG, 2020). Dada as características de alta transmissibilidade, morbidade e letalidade (HARRISON; LIN; WANG, 2020), o SARS-CoV-2 foi responsável por uma das mais expressivas propagações da história, com elevadas taxas de mortalidade, no qual recebeu o atributo de agente pandêmico pela Organização Mundial de Saúde (OMS) em fevereiro de 2020 (GAO et al., 2021). Obviamente, a COVID-19 passou a ser considerada um problema de saúde pública global (WANG et al., 2021), e graças as semelhanças do SARS-CoV-2 com outros vírus pré-existentes, a codificação de seu material genético pode ocorrer de forma rápida, permitindo notórios avanços científicos a fim de encontrar recursos terapêuticos eficazes que minimizem os impactos da COVID-19 (JIN et al., 2020; LING et al., 2020).

Neste sentido, a vitamina D emerge como um potencial agente capaz de atuar em outros papéis para além da manutenção da saúde óssea, em que pese um possível campo de ação fora dos sítios esqueléticos (BIKLE, 2016). Dentre as evidências disponíveis, destaca-se a função imunomoduladora da vitamina $D$, responsável por ativar respostas imunes inatas e adaptativas mediadas por citocinas (BILEZIKIAN et al., 2020; KAUFMAN et al., 2020). Alguns estudos têm sugerido funções da vitamina D associadas à prevenção ou tratamento de infecções agudas do sistema respiratório, dando ênfase também a uma possível associação entre o status da vitamina $D$ e o risco de infecções virais pelo SARS-CoV-2 (SABETTA et al., 2010; BRENNER; HOLLECZEK; SCHÖTTKER, 2020; MELTZER et al., 2020; RIBEIRO et al., 2021).

O estudo observacional multicêntrico de Ling et al., (2020) sugere que a vitamina D estaria associada à redução do risco de mortalidade em pacientes com COVID-19, assim, é possível conjecturar que a vitamina D potencialmente seria uma proposta eficiente em prevenir e tratar a COVID-19, embora, os mecanismos pelos quais a vitamina D atuaria na doença (REIS et al., 2021), ou minimizaria os riscos de infecções do trato respiratório (KAUFMAN et al., 2020) ainda permanecem obscuros. Portanto, torna-se imprescindível investigar os diferentes papéis terapêuticos da vitamina $D$ no 
tocante a incidência ou agravo da COVID-19. Assim, ante o exposto, o presente capítulo teve por objetivo revisar o corpo de evidências da literatura no que tange as supostas atribuições e perspectivas da vitamina D em pacientes diagnosticados com COVID-19.

\section{BREVE REVISÃO BIBLIOGRÁFICA}

\subsection{COVID-19}

SARS-CoV-2 é de origem zoonótica, um novo tipo de Beta-coronavírus que acomete humanos e possui alta transmissibilidade, cujas evidências apontam sua origem no Mercado Atacadista de Frutos do Mar de Huanan, localizado em Wuhan na China (HARRISON; LIN; WANG, 2020). Os primeiros relatos de caso datam de dezembro de 2019, em que os pacientes hospitalizados eram diagnosticados com "pneumonia de etiologia desconhecida" (LI et al., 2020). Entretanto, somente em fevereiro de 2020, a Organização Mundial da Saúde (OMS) reconheceu a doença e a nomeou como COVID19 (GAO et al., 2021).

Este vírus assemelha-se a outros vírus pré-existentes, a exemplo do SARS-CoV e do vírus da síndrome respiratória do oriente médio, 2012, MERS-CoV. Contudo, apesar das semelhanças biológicas, algumas características são divergentes, a saber: as formas de transmissão, o processo das respostas imunes frente à infecção e o rápido agravamento dos quadros clínicos (HARRISON; LIN; WANG, 2020).

A forma de contaminação pelo SARS-CoV-2 ocorre através do aparelho respiratório, principalmente nos casos de contato direto com gotículas respiratórias de pacientes já infectados. Uma vez contaminado, o SARS-CoV-2 liga-se ao receptor da enzima conversora de angiotensina-2 (ECA-2), conhecida por ser a principal porta de entrada do vírus e, em seguida, à transmembrana serina protease 2 (TMPRSS2), enzima responsável por endocitar o vírus e promover os meios de replicação, causando a COVID-19 e contribuindo para a sua transmissibilidade (KAUR et al., 2020).

O receptor da ECA-2 está presente em diversos tecidos e órgãos do corpo, dentre os quais destacam-se os pulmões, brônquios, coração, rins, estômago e íleo. Possivelmente, a presença destes receptores em diversas estruturas seria uma das principais hipóteses que justificaria os efeitos sistêmicos tão rápidos e letais da COVID19 (KAUR et al., 2020). Embora existam casos assintomáticos (cerca de 20\%) (IZDA; 
JEFFRIES; SAWALHA, 2020), há um predomínio de manifestações sintomáticas, as quais têm como sintomas mais comuns a febre, tosse, mialgia, fadiga, dispneia e anosmia (perda do olfato), que pode estar ou não acompanhada de ageusia (perda do sentido do paladar). Ainda, em proporções menores, existem pacientes que podem manifestar quadros de diarreia e cefaleia. Contudo, cumpre destacar que os indivíduos infectados, ainda que assintomáticos, podem atuar como agentes transmissores, elevando, portanto, os índices de disseminação (GAO et al., 2020).

Para identificar a gravidade dos quadros de COVID-19 destacam-se os achados radiográficos (radiografia de tórax ou tomografia computadorizada), pelos quais é possível visualizar o comprometimento pulmonar. Existem ainda os parâmetros laboratoriais comumente observados em pacientes com COVID-19, como leucopenia, linfopenia e hipoalbuminemia. Além disso, alguns pacientes apresentam também aumento de alguns marcadores inflamatórios, destacando-se a proteína C-reativa e o dímero-D. Tais achados podem indicar que existe a possibilidade do paciente desenvolver a síndrome respiratória aguda grave (em inglês, SARS) ou mesmo o aumento nos índices de mortalidade. Já em pacientes no estado grave da doença, observa-se frequentemente o aumento dos leucócitos e da razão entre neutrófilos e linfócitos (NLR), indicando alta probabilidade para cuidados mais intensivos, a exemplo da ventilação mecânica (IZDA; JEFFRIES; SAWALHA, 2020).

A COVID-19 apresenta diferentes parâmetros de gravidade que podem estar relacionados tanto com a carga viral em que o indivíduo foi exposto quanto à capacidade responsiva do hospedeiro, influenciando, portanto, o curso da doença (WIERSINGA et al., 2020). O aspecto multifatorial da COVID-19 relaciona-se com alguns fatores de risco importantes, como a idade avançada, tabagismo, obesidade, doenças crônicas (ex.: diabetes mellitus e hipertensão) e sexo, sendo mais comum em homens (ZHOU et al., 2020; GARIBALDI et al., 2021). Dentre os fatores citados anteriormente, a idade parece ser o mais relevante, haja visto o pior prognóstico da doença em pacientes mais velhos (CHEN et al., 2020).

Desde o aparecimento da COVID-19, a comunidade médica e científica vem buscando soluções terapêuticas e preventivas que sejam eficazes contra a COVID-19, minimizando a disseminação do vírus e, consequentemente, os índices de mortalidade. Algumas vacinas já foram desenvolvidas e vêm sendo amplamente utilizadas (IZDA; 
JEFFRIES; SAWALHA, 2020). Quanto aos medicamentos, muitas abordagens estão sendo testadas na intenção de ampliar as possibilidades de êxito contra a COVID-19.

\subsection{VITAMINA D}

A vitamina D é um composto lipossolúvel com função hormonal. Este nutriente pode ser adquirido pela ingestão dietética de alimentos de origem animal e vegetal, nas formas de colecalciferol ou vitamina $D_{3}$ e ergocalciferol ou vitamina $D_{2}$, respectivamente. Entretanto, a principal forma de aquisição da vitamina $\mathrm{D}$ no organismo dá-se a partir da síntese cutânea (cerca de 90\%), em que através da exposição solar aos raios ultravioleta-B (UVB) ocorrem reações fotolíticas formando a pré-vitamina $D_{3}$ (CHANG e LEE, 2019).

O metabolismo e conversão da vitamina $D$ inicia na epiderme, por meio da conversão do 7-deidrocolesterol a pré-vitamina $\mathrm{D}_{3}$. Este composto possui características termoinstavéis e sofre um processo de isomerização induzida pelo calor, produzindo a vitamina $\mathrm{D}_{3}$ (colecalciferol). Tanto o colecalciferol (endógeno ou dietético) quanto $\mathrm{o}$ ergocalciferol (dietético) são transportados na corrente sanguínea pela proteína ligadora da vitamina D (DBP). No fígado, ambas as isoformas sofrem uma hidroxilação no carbono 25 , dando origem à 25 -hidroxivitamina $D[25(\mathrm{OH}) \mathrm{D}]$ ou calcidiol (CHANG e LEE, 2019; GRUBER-BZURA, 2018).

Desse modo, a 25(OH)D, novamente acoplada à DBP no sangue, é transportada para vários órgãos. Diversos tecidos possuem em suas células a 1-alfa-hidroxilase (CYP27B1), enzima responsável por proporcionar uma segunda hidroxilação, agora na posição do carbono 1 , formando o metabólito ativo da vitamina $D$, conhecido por 1,25 di-hidroxivitamina $D\left[1,25(\mathrm{OH})_{2} \mathrm{D}\right]$ ou calcitriol. Contudo, a enzima CYP27B1 encontra-se em maiores quantidades nos rins, local, este, que concentra a maior parte da síntese do calcitriol (CHANG e LEE, 2019; GRUBER-BZURA, 2018).

A avaliação do estado nutricional em relação à vitamina $D$ é realizada no soro por meio da dosagem do metabólito 25(OH)D (calcidiol), pela razão de possuir uma maior meia-vida ( 2 a 3 semanas) e uma concentração mil vezes maior que a forma ativa de calcitriol. Embora a maior parte dessa vitamina seja sintetizada endogenamente, a deficiência de vitamina $D$ (hipovitaminose $D$ ) é um problema recorrente na população, e possui alguns fatores de risco principais, a saber: idade, obesidade, cor da pele, 
utilização de protetor solar, roupas agasalhadas, exposição solar diminuída, uso de medicamentos específicos, pessoas que possuem doenças renais e hepáticas (MOREIRA et al., 2020).

A hipervitaminose $D$ é um quadro menos recorrente e se dá pelo excesso de vitamina D presente no soro, é responsável por desencadear um aumento na absorção intestinal de cálcio e por propiciar uma reabsorção tubular renal de cálcio, o que pode vir a ocasionar tanto quadros de hipercalcemia quanto outros sintomas como: vômitos, náuseas, fraqueza, desidratação e até insuficiência renal aguda (SHARMA et al., 2017).

A vitamina $D$ é amplamente conhecida por desempenhar funções essenciais no organismo, dentre as quais destaca-se a atuação na saúde óssea e manutenção de sua homeostase. Neste sentido, a vitamina D age aumentando a absorção de cálcio e fósforo no intestino, o que propicia adequados processos de mineralização óssea (BEARD; BEARDEN; STRIKER, 2011), desempenhando um papel importante na prevenção e no tratamento de doenças ósseas, a exemplo da osteoporose, do raquitismo e da osteomalácia (BIKLE, 2016).

A vitamina D possui outras funções ou ações extra esqueléticas, graças à presença do receptor de vitamina D (VDR) em diferentes órgãos e sistemas corporais, possibilitando múltiplas ações fisiológicas (BIKLE, 2016; GRUBER-BZURA, 2018). Dentre essas funções, destaca-se o papel na ativação das respostas imunes inata e adaptativa, mediando processos funcionais do sistema imunológico (BIKLE, 2016).

As recomendações nutricionais diárias de vitamina D propostas pelo Institute Of Medicine (IOM, 2011) através das Dietary Reference Intakes (DRI), recomendam uma necessidade média estimada (EAR) de $10 \mu \mathrm{g} / \mathrm{d}$, o que equivale a $400 \mathrm{UI}$ para todas as faixas etárias. Já a ingestão diária recomendada (RDA) para indivíduos adultos até 70 anos de idade é de $15 \mu \mathrm{g} / \mathrm{d}$, equivalente a $600 \mathrm{UI}$; para pessoas idosas com idade superior a 70 anos, é recomendado uma ingestão de $20 \mu \mathrm{g} / \mathrm{d}$, equivalente a $800 \mathrm{UI}$. Por fim, o nível de ingestão superior tolerável (UL) de vitamina D baseia-se em $100 \mu \mathrm{g} / \mathrm{d}$, o que equivale a $4.000 \mathrm{UI}$.

A Sociedade Brasileira de Endocrinologia e Metabolismo (SBEM, 2020) e a Sociedade Brasileira de Patologia Clínica (SBPC, 2020), recomendam que o diagnóstico do status de vitamina $D$ seja realizado por meio dos valores de concentração de 25(OH)D no soro, que são divididos por faixas etárias. O valor de referência para o diagnóstico de 
deficiência é $25(\mathrm{OH}) \mathrm{D}<20 \mathrm{ng} / \mathrm{mL}$. Os valores considerados ideais para a população estão situados entre 30 e $60 \mathrm{ng} / \mathrm{mL}$ e o risco de intoxicação é observado com valores > $100 \mathrm{ng} / \mathrm{mL}$.

\subsection{VITAMINA D EM PACIENTES COM COVID-19}

A vitamina D desempenha papéis importantes no sistema imunológico, possuindo a propriedade de ativação da resposta imune inata e adaptativa. No entanto, a deficiência de vitamina $D$ implica em prejuízos na síntese de $1,25(\mathrm{OH})_{2} \mathrm{D}$ e, consequentemente, pode interferir no funcionamento do sistema imune (BILEZIKIAN et al., 2020).

Em situações de infecção orgânica, a primeira reação de combate é a ativação do sistema imunológico por meio de uma resposta inata, identificando o invasor com auxílio dos receptores do tipo toll (TLR). Em seguida, peptídeos antimicrobianos recrutam monócitos, macrófagos e neutrófilos, visando destruir o patógeno e ativar a resposta imune adaptativa. Esta segunda resposta imunológica é mais específica e atua restringindo células dendríticas, ocasionando mudanças no perfil de diferenciação de linfócitos T auxiliares 1 (T helper 1, Th1) e 2 (Th2). Estes processos podem ser mediados de acordo com as concentrações do metabólito ativo da vitamina D (calcitriol) (BILEZIKIAN et al., 2020). Assim, sugere-se que a deficiência de vitamina D poderia estar relacionada com maiores riscos de desenvolvimento de infecções respiratórias, dentre elas a COVID-19 (QUESADA-GOMEZ; ENTRENAS-CASTILLO; BOUILLON, 2020; RIBEIRO et al., 2021).

Existem muitos parâmetros laboratoriais de 25(OH)D que definem o diagnóstico do status de vitamina D. Todavia, de acordo com a Endocrine Society as concentrações de $25(\mathrm{OH})$ D são estratificadas em quatro categorias principais, dentre elas: Deficiência grave (< $10 \mathrm{ng} / \mathrm{mL}$ ); Deficiência (10 a $20 \mathrm{ng} / \mathrm{mL}$ ); Insuficiência (20 a $30 \mathrm{ng} / \mathrm{mL}$ ) e Suficiência (> $30 \mathrm{ng} / \mathrm{mL}$ ) (LIPS et al., 2019). Os estudos que avaliam pacientes com COVID-19 utilizam diferentes pontos de corte na avaliação do status de vitamina D, dificultando a comparação entre eles.

No início de 2020 foi realizado um estudo do tipo retrospectivo em que 212 indivíduos com COVID-19 foram investigados, fazendo uso de um banco de dados de três hospitais localizados no sul da Ásia (ALIPIO, 2020). Neste estudo foi analisada a 
possível associação entre o status de vitamina $D$ e os desfechos clínicos de pacientes com COVID-19. Os autores observaram uma correlação positiva significativa, em que a elevação dos níveis de 25(OH)D influenciou em um melhor desfecho clínico na COVID19 (ALIPIO, 2020).

Uma revisão sistemática com meta-análise objetivou investigar se a deficiência de vitamina $D$ implicaria em algum prejuízo no quadro clínico de pacientes com COVID19 (PEREIRA et al., 2020). Observou-se que havia uma alta prevalência de deficiência de vitamina $D$ nestes pacientes, principalmente em pessoas idosas, contribuindo significativamente para o agravo dos sintomas da doença (PEREIRA et al., 2020).

Outro estudo, realizado por Maghbooli et al., (2020) com 235 pacientes diagnosticados com COVID-19 no Irã, observou uma associação significativa entre as concentrações de $25(\mathrm{OH}) \mathrm{D}$ e os marcadores de gravidade da doença (MAGHBOOLI et al., 2020). Este trabalho demonstrou que concentrações séricas adequadas de 25(OH)D ( $\geq 30 \mathrm{ng} / \mathrm{mL}$ ), além de indicarem menores índices de mortalidade, correlacionou-se também com níveis de PCR diminuídos e linfócitos aumentados, permitindo aos autores concluir que o status de vitamina D poderia desempenhar melhores repostas imunológicas. Todavia, os autores ressaltaram a importância de realizar outros estudos que melhor avaliem a relação da vitamina D com a COVID-19 (MAGHBOOLI et al., 2020).

Um estudo de coorte prospectivo multicêntrico realizado em dois hospitais de São Paulo, Brasil, avaliou 220 pacientes diagnosticados com COVID-19 moderado a grave. $O$ estudo foi elaborado para investigar se a concentração sérica de 25(OH)D no início da hospitalização possuía associação com o tempo de internação e com o prognóstico dos pacientes. Os resultados mostraram que pacientes com deficiência grave de $25(\mathrm{OH}) \mathrm{D}(<10 \mathrm{ng} / \mathrm{mL})$ apresentaram uma tendência ao maior tempo de internação em comparação com pacientes os que possuíam altas concentrações de 25(OH)D (REIS et al., 2021).

Recentemente, foi realizado um ensaio clínico randomizado, no qual participaram da pesquisa 240 pacientes hospitalizados com COVID-19 moderada a grave. O estudo tinha como objetivo avaliar o efeito da suplementação de uma dose única de vitamina $\mathrm{D}_{3}(200.000 \mathrm{UI})$ ou placebo no tempo de internação destes pacientes. Os resultados não demonstraram redução significativa no tempo de internação ou outros desfechos clínicos (mortalidade, admissão em unidade de terapia intensiva ou 
necessidade de ventilação mecânica) em favor da estratégia de suplementação com vitamina $D_{3}$ (MURAl et al., 2021a).

Este mesmo grupo realizou uma análise post hoc considerando apenas a amostra de pacientes hospitalizados que apresentaram níveis séricos de 25(OH)D $<10 \mathrm{ng} / \mathrm{mL}$, considerado como pacientes em deficiência grave, e que possuíam diagnóstico de COVID-19 ( $n=32)$ O objetivo foi investigar o efeito de uma dose única com alta concentração de vitamina $\mathrm{D}_{3}$ (200.000 UI) no tempo de internação hospitalar. De acordo com os achados, não foi observada redução significativa no tempo de internação por COVID-19 destes pacientes com deficiência grave de 25(OH)D (MURAl et al., 2021b). Assim, apesar do potencial efeito imunomodulador da vitamina $D$, ainda não há evidências que comprovem a eficácia do seu uso como uma estratégia terapêutica para casos moderados ou graves de COVID-19, fazendo-se necessário novos estudos que avaliem diferentes estratégias de suplementação.

\section{CONSIDERAÇÕES FINAIS}

Embora muitos estudos apresentem uma possível associação entre as concentrações séricas de 25(OH)D e o quadro clínico da COVID-19 como a melhora do prognóstico, redução da mortalidade, redução da gravidade da doença, diminuição da inflamação sistêmica e local, necessidade de ventilação mecânica e admissão em UTI, tais estudos apresentam delineamentos experimentais distintos que tendem a que comprometer uma análise comparativa, mitigando a capacidade de inferência dos dados individuais ou agrupados. Dessa forma, faz-se necessário que mais estudos sejam realizados, sobretudo ensaios clínicos randomizados, a fim de avaliar diferentes estratégias de administração/utilização da vitamina D nas múltiplas manifestações da COVID-19 e, portanto, ratificar as eventuais associações da vitamina $D$ na terapêutica da COVID-19.

\section{REFERÊNCIAS}

ALIPIO, Mark. Vitamin D supplementation could possibly improve clinical outcomes of patients infected with Coronavirus-2019 (COVID-2019). SSRN Journal. Available at SSRN: https://ssrn. com/abstract, 3571484, 2020. 
BEARD, Jeremy A.; BEARDEN, Allison.; STRIKER, Rob. Vitamin D and the antiviral state. Journal of Clinical Virology, vol. 50, n. 3, p. 194-200, 2011.

BIKLE, Daniel D. Extraskeletal actions of vitamin D. Annals of the New York academy of sciences, v. 1376, n. 1, p. 29, 2016.

BILEZIKIAN, John P. et al. Mechanisms in endocrinology: vitamin D and COVID19. European journal of endocrinology, v. 183, n. 5, p. R133-R147, 2020.

BRENNER, Hermann.; HOLLECZEK, Bernd.; SCHÖTTKER, Ben. Vitamin D insufficiency and deficiency and mortality from respiratory diseases in a cohort of older adults: potential for limiting the death toll during and beyond the COVID-19 pandemic?. Nutrients, v. 12, n. 8, p. 2488, 2020.

CHANG, Szu-Wen.; LEE, Hung-Chang. Vitamin D and health-The missing vitamin in humans. Pediatrics \& Neonatology, v. 60, n. 3, p. 237-244, 2019.

CHEN, Yiyin. et al. Aging in COVID-19: Vulnerability, immunity and intervention. Reviews of research on aging, p. 101205, 2020.

GAO, Zhiru. et al. A systematic review of asymptomatic infections with COVID19. Journal of Microbiology, Immunology and Infection , v. 54, n. 1, pág. 12-16, 2021.

GARIBALDI, Brian T. et al. Patient trajectories among people hospitalized by COVID-19: a cohort study. Annals of internal medicine, v. 174, n. 1, p. 33-41, 2021.

GRUBER-BZURA, Beata M. Vitamin D and influenza - prevention or therapy?. International Journal of Molecular Sciences, Vol. 19, n. 8, p. 2419, 2018.

HARRISON, Andrew G.; LIN, Tao.; WANG, Penghua. Transmission mechanisms and pathogenesis of SARS-CoV-2. Trends in immunology, 2020.

Institute of Medicine (US). (2011). Dietary reference intakes for calcium and vitamin D. National Academies Press.

IZDA, Vladislav.; JEFFRIES, Matlock A.; SAWALHA, Amr H. COVID-19: A review of therapeutic strategies and vaccine candidates. Clinical Immunology, p. 108634, 2020.

JIN, Yuefei. et al. Virology, epidemiology, pathogenesis, and control of COVID19. Viruses, v. 12, n. 4, p. 372, 2020.

KAUFMAN, Harvey W. et al. Positivity rates for SARS-CoV-2 associated with circulating levels of 25-hydroxyvitamin D. PLoS One, v. 15, n. 9, p. e0239252, 2020. 
KAUR, Supreet. et al. The impending storm: blood and cytokines in COVID-19. Blood reviews, p. 100743, 2020.

LI, Qun. et al. Early transmission dynamics in Wuhan, China, of novel coronavirusinfected pneumonia. New England journal of medicine, 2020.

LING, S. F. et al. High-dose cholecalciferol booster therapy is associated with a reduced risk of mortality in patients with COVID-19: A cross-sectional multi-centre observational study. Nutrients 12 (12), 3799. 2020.

LIPS, Paul. et al. Current vitamin D status in European and Middle East countries and strategies to prevent vitamin D deficiency: a position statement of the European Calcified Tissue Society. European journal of endocrinology, v. 180, n. 4, p. P23P54, 2019.

MAGHBOOLI, Zhila. et al. Sufficiency of vitamin D, serum 25-hydroxyvitamin D of at least $30 \mathrm{ng} / \mathrm{mL}$ reduced the risk of adverse clinical outcomes in patients with COVID19 infection. PloS one, v. 15, n. 9, p. e0239799, 2020.

MELTZER, David O. et al. Association of vitamin D status and other clinical characteristics with COVID-19 test results. JAMA network open, v. 3, n. 9, p. e2019722e2019722, 2020.

MOREIRA, Carolina Aguiar. et al. Reference values of 25 -hydroxyvitamin D revisited: a position statement from the Brazilian Society of Endocrinology and Metabolism (SBEM) and the Brazilian Society of Clinical Pathology/Laboratory Medicine (SBPC). Archives of Endocrinology and Metabolism, n. AHEAD, v. 64, p. 462-478, 2020.

MURAl, Igor $\mathrm{H}$. et al. Effect of a single high dose of vitamin D3 on hospital length of stay in patients with moderate to severe COVID-19: a randomized clinical trial. JAMA, v. 325 , n. 11, p. 1053-1060, 2021 .

MURAI, Igor $\mathrm{H}$. et al. Effect of a single dose of vitamin D3 on the length of hospital stay of patients with severe 25-hydroxyvitamin D deficiency with COVID-19. Clinics, v. 76, 2021b.

PEREIRA, Marcos. et al. Vitamin D deficiency aggravates COVID-19: systematic review and meta-analysis. Critical reviews in food science and nutrition, p. 1-9, 2020.

QUESADA-GOMEZ, José Manuel.; ENTRENAS-CASTILLO, Marta.; BOUILLON, Roger. Stimulation of the vitamin $D$ receptor to reduce acute respiratory distress syndrome (ARDS) in patients with SARS-CoV-2 coronavirus infections: Revised Ms. SBMB 2020_166. The Journal of steroid biochemistry and molecular biology, v. 202, p. 105719, 2020. 
REIS, Bruna Z. et al. Influence of vitamin D status on hospital length of stay and prognosis in hospitalized patients with moderate to severe COVID-19: a multicenter prospective cohort study. The American journal of clinical nutrition, 2021.

RIBEIRO, Heriks Gomes. et al. Previous vitamin D status and total cholesterol are associated with SARS-CoV-2 infection. Clinica Chimica Acta, v. 522, p. 8-13, 2021.

SABETTA, James $R$. et al. Serum 25-hydroxyvitamin $d$ and the incidence of acute viral respiratory tract infections in healthy adults. PloS one, v. 5, n. 6, p. e11088, 2010.

SHARMA, Lokesh Kumar. et al. The growing problem of subclinical and evident hypervitaminosis D in India: an experience and institutional review. Nutrition, v.34, p. 76-81, 2017.

WANG, Rui. et al. The Vitamin D Trial for COVID-19 (VIVID): A pragmatic randomized cluster design. Contemporary clinical trials, v. 100, p. 106176, 2021.

WIERSINGA, W. Joost. et al. Pathophysiology, transmission, diagnosis, and treatment of coronavirus disease 2019 (COVID-19): a review. JAMA, v. 324, n. 8, p. 782-793, 2020.

ZHOU, Fei. et al. Clinical course and risk factors for mortality of adult patients hospitalized with COVID-19 in Wuhan, China: a retrospective cohort study. The Lancet, v. 395, n. 10229, p. 1054-1062, 2020. 


\title{
CAPITULO $X \times X \mathbf{X}$ \\ AS CONTRIBUIÇÕES DO MANEJO RACIONAL DE CORTICOSTEROIDES SOB A COVID-19
}

DOI: 10.51859/AMPLLA.PAE1993-31

\author{
Bárbara Queiroz de Figueiredo ${ }^{1}$ \\ Ana Paula Herrera de França ${ }^{2}$ \\ Francisca Rafaela Pereira de Amorim Castro Rosa ${ }^{3}$ \\ Jeniffer Botelho Comelli ${ }^{4}$
}

\footnotetext{
${ }^{1}$ Graduanda do curso de Medicina. Centro Universitário de Patos de Minas.

${ }^{2}$ Graduanda do curso de Medicina. Universidade Positivo.

${ }^{3}$ Graduanda do curso de Medicina. Instituto Master de Ensino Presidente Antônio Carlos.

${ }^{4}$ Graduanda do curso de Medicina. Universidade da Região de Joinville.
}

\section{RESUMO}

O uso adequado de corticosteroides foi associado a uma redução de mortalidade e da internação de pacientes infectados pelo SARS-CoV2, sendo preferível a utilização em um curto prazo, para assim, diminuir a necessidade de oxigenoterapia. Em contrapartida, a introdução precoce do fármaco, implica na inibição da cascata inflamatória que pode ocasionar à insuficiência respiratória e consequentemente, ao aumento das evoluções para o suporte ventilatório. Tais medicamentos, não são recomendados corriqueiramente para Covid-19 sem indicação de alternativa. Com isso, não devem ser administrados em indivíduos que não requerem suplementação de oxigênio. Os corticosteroides, portanto, precisam ser usados com cautela, considerando a relação risco-benefício, como uma abordagem terapêutica de curto prazo, para apresentarem evidências de sobrevida. No entanto, o uso prolongado de esteroides pode ser prejudicial, assim como, não obtêm indícios de que o manejo a longo prazo aos infectados por Covid-19 previnem o paciente de não evoluir para complicações.

Palavras-chave: Corticosteroides. Covid-19. Uso Terapêutico. 


\section{INTRODUÇÃO}

Os glicocorticoides são medicamentos amplamente utilizados por várias especialidades médicas no tratamento de doenças inflamatórias e imunológicas. Fisiologicamente, são produzidos pela glândula suprarrenal, que anatomicamente é dividida em córtex e medula. A medula secreta epinefrina, ao passo que o córtex, secreta dois tipos de corticosteroides (glicocorticoides e mineralocorticoides). A regulação da síntese e, consequentemente, dos níveis circulantes de corticosteroides é feita por meio do eixo Hipotálamo-Pituitária-Adrenal (HPA) e em condições fisiológicas, os níveis hormonais variam ao longo do dia, com altos níveis durante os períodos de maior atividade diária, tendo o seu pico correspondente ao início do período de atividades (WHALEN et al., 2016).

A ação anti-inflamatória dos corticosteroides está relacionada ao aumento da produção de citocinas anti-inflamatórias e diminuição das citocinas pró-inflamatórias, redução da inflamação ao inibir a produção de prostaglandinas e leucotrienos, aumento da contagem de neutrófilos, plaquetas e hemácias, entre outros efeitos. Essa ação é explorada pelo uso de análogos sintéticos de glicocorticoides, como a prednisona, no tratamento de doenças inflamatórias crônicas, de forma relevante no tratamento de doenças respiratórias (MOLINA, 2021).

Os corticosteroides são drogas imunomoduladoras potentes que podem, por meio de efeitos genômicos e não genômicos, ajudar a prevenir ou atenuar o estado de hiperinflamação que caracterizou infecções graves por SARS-CoV-2. No início da pandemia da doença coronavírus em 2019 (Covid-19), as orientações sobre corticosteroides eram variadas. Embora os primeiros dados de observação da China sugerissem um benefício potencial de mortalidade desses pacientes, estudos anteriores de corticosteroides em outras pneumonias virais, especialmente a síndrome respiratória aguda grave (SARS) e a síndrome respiratória do Oriente Médio (MERS), encontraram uma associação com atraso eliminação viral e preocupações reforçadas de que os corticosteroides podem prejudicar a resposta do hospedeiro ao SARS-CoV-2. (PRESCOTT et al., 2020).

Nesse contexto, em função dos efeitos anti-inflamatórios, os corticosteroides se mostram medicamentos importantes e muitas vezes essenciais, para um tratamento 
adequado nas doenças pulmonares, sendo frequentemente utilizados e testados em diferentes cenários patológicos (TONGYOO et al., 2016). Sendo assim, haja vista a complexidade farmacológica e clínica dos corticosteroides, o presente estudo tem como objetivo, por meio de Revisão de Literatura, investigar as evidências atuais sobre seu uso para tratamento contra a Covid-19.

\section{METODOLOGIA}

Trata-se de uma pesquisa descritiva do tipo revisão integrativa da literatura, que buscou responder quais as evidências sobre o uso de corticosteroides no tratamento para Covid-19. A pesquisa foi realizada através do acesso online nas bases de dados National Library of Medicine (PubMed MEDLINE), Scientific Electronic Library Online (Scielo), Cochrane Database of Systematic Reviews (CDSR), Google Scholar, Biblioteca Virtual em Saúde (BVS) e EBSCO Information Services, nos meses de abril a junho de 2021.

Para a busca das obras foram utilizadas as palavras-chaves presentes nos descritores em Ciências da Saúde (DeCS): em inglês: "corticosteroids", "Covid-19", "Acute respiratory distress syndrome (ARDS)", "Coronavírus", e em português: "Corticosteroides", "Síndrome do desconforto respiratório agudo (SDRA)", "Covid-19", "Coronavirus", "Sars-Cov-2".

Como critérios de inclusão, foram considerados artigos originais, que abordassem o tema pesquisado e permitissem acesso integral ao conteúdo do estudo, publicados no período de 2020 a 2021, em inglês e português. O critério de exclusão foi imposto naqueles trabalhos que não estavam em inglês ou português, que não tinham passado por processo de Peer-View e que não relacionassem a utilização de corticosteroides para o tratamento contra a Covid-19. A estratégia de seleção dos artigos seguiu as seguintes etapas: busca nas bases de dados selecionadas; leitura dos títulos de todos os artigos encontrados e exclusão daqueles que não abordavam o assunto; leitura crítica dos resumos dos artigos e leitura na íntegra dos artigos selecionados nas etapas anteriores. Assim, totalizaram-se 25 artigos científicos para a revisão integrativa da literatura, com os descritores apresentados acima. 


\section{REVISÃO BIBLIOGRÁFICA}

Segundo Matthay et al. (2020), embora os corticosteroides amorteçam o sistema imunológico desregulado e às vezes são prescritos como um tratamento adjuvante para pneumonia, sua eficácia no tratamento da Covid-19 permanece controversa. Sendo assim, é necessário que os riscos e benefícios potenciais sejam cuidadosamente ponderados em cada situação, e recomenda-se que os corticosteroides não sejam utilizados na lesão pulmonar induzido por SARS-CoV-2 fora de um ensaio clínico sendo que a Organização Mundial da Saúde (OMS) sugere que, dada a falta de eficácia e os possíveis danos, os corticoides de rotina devem ser evitados, a menos que sejam indicados por outro motivo como exacerbação da asma ou DPOC, choque séptico devendo ser analisado risco e benefício para pacientes de forma individual (COLPANI et al., 2020).

De acordo com Russell et al. (2020), não existem dados clínicos suficientes para indicar que o benefício líquido é derivado de corticosteroides no tratamento de infecção respiratória devido ao SARS-CoV, sendo que, assim, corticosteroides não são recomendados rotineiramente em pacientes com COVID-19 sem indicação alternativa ou presença de SDRA, sendo o uso de corticosteroides em doenças respiratórias virais anteriores demonstrativos de atraso na depuração viral e aumento da mortalidade. Ademais, segundo revisão literária de Veronese et al. (2020), dois estudos relataram resultados negativos em relação ao uso de corticosteroides em pacientes com Covid-19, ou seja, os corticosteroides tiveram um impacto prejudicial nos desfechos clínicos. Um estudo não relatou associação significativa entre o uso de corticosteroides e desfechos clínicos. Por outro lado, um estudo concluiu que a metilprednisolona estava associada a uma redução significativa da mortalidade em pacientes com pneumonia por Covid-19 que desenvolveram síndrome respiratória. Ademais, um estudo prospectivo, randomizado, duplo-cego e controlado por placebo comparou o tratamento precoce com hidrocortisona (antes do sétimo dia da doença) com um placebo e descobriu que a terapia precoce com hidrocortisona estava associada a uma carga viral plasmática subsequente mais elevada.

Ainda sobre a metilprednisolona, de acordo com estudo de Andrade et al. (2020), em quatro coortes retrospectivas analisadas, o tempo para melhora dos sintomas foi 
menor no grupo que recebeu metilprednisolona do que no grupo que não recebeu o tratamento, bem como mostrou uma taxa de mortalidade maior para pacientes com Covid-19 que receberam corticosteroides do que no grupo de pacientes que não receberam. Em pacientes com MERS-CoV, a taxa de mortalidade e a necessidade de ventilação mecânica invasiva foram maiores no grupo que recebeu corticosteroides do que no grupo controle, já pacientes com SARS-CoV que receberam corticosteroides tiveram uma chance 20,7 vezes maior de serem admitidos.

De acordo com hipótese de Fadel et al. (2020), os corticosteroides precoces iriam combater a cascata inflamatória que levaria à insuficiência respiratória, ao aumento do atendimento na UTI e de ventilação mecânica. Sendo assim, notou-se que um curto curso precoce de metilprednisolona em pacientes com Covid-19 moderado a grave reduziu o aumento do atendimento e melhorou os resultados clínicos. Além disso, os pacientes hospitalizados com Covid-19 moderado a grave que receberam um curso curto precoce de metilprednisolona tiveram uma taxa reduzida do desfecho primário composto de morte, transferência de UTI e ventilação mecânica, com um número necessário para tratar 8 para evitar a transferência de 1 paciente para ventilação mecânica.

As evidências existentes são inconclusivas e mesmo revisões sistemáticas e metanálises sobre este tópico chegam a conclusões diferentes. De acordo com o consenso de dos especialistas citados no estudo, os princípios a seguir devem ser seguidos ao decidir a terapia por corticosteroides: os benefícios e os danos devem ser cuidadosamente pesados antes de usar corticoesteroides; corticoesteroides devem ser usados com prudência em pacientes gravemente enfermos com 2019-nCoV pneumonia; para pacientes com hipoxemia devido a doenças subjacentes ou que usam corticosteroides regularmente para doenças crônicas, o uso posterior dos corticosteroides devem ser cautelosos; e a dosagem deve ser baixa a moderado ( $\leq 0 \cdot 5-$ $1 \mathrm{mg} / \mathrm{kg}$ por dia metilprednisolona ou equivalente) e a duração deve ser curta ( $\leq 7$ dias). O uso adequado de corticosteroides foi associado a uma redução de mortalidade e encurtamento do período de internação de pacientes criticamente enfermos com SARSCov-2, sem causar danos secundários, infecções e outras complicações (SHANG et al., 2020). 
Tomazini et al. (2020), descrevem que a fase inicial da síndrome respiratória (SDRA) provavelmente coincide com uma fase tardia no processo patológico, o que poderia reduzir o risco de aumento da replicação viral induzido pelos corticosteroides. Alguns estudos demonstraram que, para formas graves de Covid-19, desde que os corticosteroides sistêmicos sejam utilizados na fase aguda da doença e durante um curto período de tempo, diminuem a necessidade de oxigenoterapia, melhoram os achados radiológicos e diminuem a mortalidade, outros indicam que os corticosteroides inalados aumentam o número de infeções do trato superior (CARVALHO et al., 2020). Apesar da baixa qualidade das evidências encontradas, os autores concluem que os corticoides no tratamento da Covid-19 não são indicados para pacientes com sintomas leves, e doses moderadas podem ser utilizadas em pacientes com condições severas para suprimir a resposta imune e reduzir os sintomas (SIQUEIRA et al., 2020).

$\mathrm{O}$ uso de corticosteroides em pacientes infectados por SARS-CoV-2, SARS-CoV e MERS-CoV, embora não melhore a sobrevivência, não reduza a permanência hospital, a necessidade de internação em UTI ou uso de ventilação mecânica invasiva, pode trazer benefícios aos pacientes graves e com SDRA (RODRIGUEZ et al., 2020). Em estudo clínico de Liu et al., (2020), pacientes tratados com corticosteroides tiveram uma mortalidade significativamente maior em 28 dias do que aqueles sem tratamento com corticosteroides, sendo seu uso apontado como um fator de risco independente para mortalidade em uma análise de regressão logística multivariada e um modelo de regressão de Cox estendido. Além disso, os corticosteroides também atrasaram a depuração do RNA do SARS-CoV-2, e a maioria dos pacientes não apresentou SDRA na admissão.

Em contraste, o estudo de Horby et al. (2021), relatou um benefício significativo na mortalidade da corticoterapia com $6 \mathrm{mg}$ de dexametasona por dia (150 mg equivalente de hidrocortisona) por até 10 dias em pacientes que estavam recebendo oxigenoterapia ou ventilação mecânica, com o maior benefício em pacientes ventilados mecanicamente. Houve, no entanto, uma forte tendência de maior mortalidade em pacientes que receberam dexametasona e que não estavam necessitando de oxigenoterapia. Já estudo de François et al. (2020) demonstrou que a hidrocortisona, em comparação com o placebo, não reduziu significativamente a taxa de falha do tratamento, definida como morte ou dependência persistente de ventilação mecânica 
ou oxigenoterapia de alto fluxo, no dia 21 entre pacientes criticamente enfermos com Covid-19.

O uso de corticosteroides foi associado a uma resolução mais rápida do choque e ventilação mecânica no choque séptico e possível mortalidade mais baixa tanto no choque séptico quanto na SDRA. No entanto, devido a achados inconsistentes em estudos individuais e preocupação persistente de que efeitos adversos importantes, como infecção secundária e delirium, possam ser submedidos e subnotificados nesses ensaios clínicos, muitos médicos permaneceram hesitantes em prescrever corticosteroides para essas condições (PRESCOTT et al., 2020). Assim, Annane (2021) conclui que corticosteroides não devem ser administrados a pacientes que não requerem suplementação de oxigênio. Se requererem ventilação mecânica, devem ser administrados por via intravenosa ou oral, dependendo da gravidade clínica da doença, como dexametasona, hidrocortisona ou metilprednisolona, em dose equivalente a 6 mg de dexametasona e por 5 a 10 dias.

As reações adversas aos corticosteroides no grupo de início precoce não foram maiores do que no grupo de controle, e os dados sobre reações adversas no estudo apoiam ainda mais a estratégia do uso precoce de corticosteroides em doses baixas a moderadas em pacientes de alto risco. Ou seja, os corticosteroides podem atrasar a eliminação do vírus em pacientes com Covid-19, o que se torna outra grande preocupação com a aplicação de corticosteroides enquanto os dados relevantes ainda são limitados. (YANG et al., 2020).

Entre os pacientes com Covid-19 grave, o tratamento com um curso de dose fixa de 7 dias de hidrocortisona ou dosagem dependente de choque de hidrocortisona, em comparação com nenhuma hidrocortisona, resultou em $93 \%$ e $80 \%$ de probabilidades de superioridade em relação ao chances de melhora nos dias sem suporte de órgão em 21 dias. No entanto, o estudo foi interrompido precocemente e nenhuma estratégia de tratamento atendeu aos critérios pré-especificados de superioridade estatística, impedindo conclusões definitivas. (DEREK et al., 2020)

Para pacientes que têm Covid-19 grave, mas não estão gravemente enfermos, as evidências diretas de estudos observacionais forneceram evidências de qualidade muito baixa de um aumento na mortalidade com corticosteroides. Em SARS e MERS, as evidências de estudos observacionais levantam a possibilidade de uma redução 
modesta da mortalidade com corticosteroides, mas também de um atraso na eliminação viral. Outrossim, as evidências de RCT também aumentam a possibilidade de redução da mortalidade com corticosteroides e outros benefícios, incluindo redução no tempo de internação hospitalar e na UTI, e necessidade e duração da ventilação mecânica (ZHIKANG et al., 2020)

Estudo de Cheng et al. (2020) indicou que a corticoterapia esteve associada à recuperação clínica e à redução significativa do tempo de internação na UTI, mas não afetou a mortalidade, a utilização de ventilação mecânica e o tempo de eliminação do vírus em pacientes com Covid-19. No entanto, o tratamento com corticosteroides nesses pacientes com pode causar resultados adversos leves. Os achados em nosso estudo não demonstram uma forte eficácia da corticoterapia, mas parece melhorar o prognóstico e promover a recuperação clínica em pacientes com Covid-19 grave.

Segundo Haytham et al. (2020), haja vista que a replicação viral do SARS-CoV2 começa a diminuir após a primeira semana de infeç̧ão com o pico dos níveis de interferon, os pacientes que mais se beneficiaram com a CST são aqueles que iniciaram a CST há mais de 7 dias do início dos sintomas, que podem estar correlacionados com o início do sistema imunológico desregulado. Ou seja, o momento da CST no estágio da doença provavelmente desempenha um papel vital na modulação da resposta imunológica e do resultado.

Segundo Kumar et al. (2020), a corticoterapia para pacientes asmáticos que contraíram Covid-19 deve ser balanceada com as evidências sobre a redução de sintomas de asma e risco de recaída, particularmente aqueles pacientes com inflamação aumentada do tipo 2, onde o uso de corticosteroides pode restaurar a imunidade antiviral e conferir benefícios. Aliado a isso, Hasan et al. (2020) alegam que, em relação a pacientes asmáticos ou com DPOC que estejam infectados por Covid-19 ou em pacientes com doença grave, especialmente aqueles com choque séptico ou síndrome respiratória, onde a tempestade de citocinas está sendo cada vez mais reconhecida, a corticoterapia pode desempenhar um papel importante, porém, os corticoides inalatórios e soluções nebulizadoras devem ser evitados, haja vista o risco infeccioso significativo por gotículas virais.

Assim, segundo Falavigna et al. (2020), sugere-se evitar utilizar glicocorticoesteroides de rotina em pacientes com Covid-19. Porém, seu uso pode ser 
considerado em casos selecionados, como síndrome de angústia respiratória do adulto (SARA) moderada a grave, sem suspeita de infecção bacteriana não controlada, após 10 a 14 dias do início dos sintomas da Covid-19. Além disso, pacientes com outras indicações para o uso de corticosteroides, como pacientes com asma a DPOC exacerbadas, devem utilizá-las de acordo com a indicação clínica, avaliando os demais riscos e benefícios, diante da infeção pela Covid-19.

Os corticosteroides, portanto, parecem ser uma faca de dois gumes na luta contra Covid-19 e precisam ser usados com cautela, considerando a relação riscobenefício, como um agente terapêutico de curto (por exemplo, até 10 dias) em um grupo selecionado de pacientes com Covid-19 para os quais foi relatado benefício de sobrevida. Não há evidências que apoiem o uso a longo prazo de esteroides em pacientes com Covid-19 para prevenir sequelas adversas potenciais, como fibrose pulmonar. Pelo contrário, um curso prolongado de esteroides pode ser prejudicial, inclusive pode desencadear um desequilíbrio na produção natural de cortisol no organismo e pode, inclusive, corroborar a gênese de diabetes mellitus tipo 2 (GYANSHANKAR et al., 2020).

\section{CONSIDERAÇÕES FINAIS}

Com o surgimento da Covid-19, vários estudos vêm testando a eficácia do uso de corticosteroides como coadjuvante no tratamento dessa infecção. Neste trabalho, fora estabelecido uma revisão sistemática a respeito dos dados na literatura atual sobre a eficácia do uso dessa classe medicamentosa no tratamento da enfermidade. Embora alguns estudos observacionais relatam uma diminuição das hospitalizações, bem como da mortalidade dos pacientes com Covid-19 que utilizaram glicocorticoides no tratamento, vários ensaios clínicos não demonstraram tais benefícios, sendo que, relacionaram o uso indiscriminado à uma piora dos sintomas e ao aumento da mortalidade. Há divergências também quanto ao tempo de uso, uma vez que alguns estudos evidenciaram melhora clínica no uso de corticoides em pacientes graves, já outros, referem que o uso prolongado, desde os sintomas iniciais da doença, está relacionado a um menor índice de hospitalização.

Portanto, o presente estudo concluiu que o uso de corticosteroides em pacientes Covid-19 deve ser individualizado e utilizado em uma abordagem terapêutica cautelosa, 
relacionando ao risco-benefício ao paciente, bem como às comorbidades associadas que fazem jus a tal medicação. Os dados disponíveis na literatura atual a respeito dessa abordagem são controversos e vários estudos são limitados, sendo alguns meramente observacionais e outros com espaço amostral reduzido. Logo, faz-se necessário o desenvolvimento de maiores ensaios clínicos randomizados e controlados para analisar eficácia do uso glicocorticoides na propedêutica do Covid-19.

\section{REFERÊNCIAS}

ANDRADE, K. R. C. et al. Terapia medicamentosa para infecções por coronavírus wm humanos: revisão sistemática rápida. Ciência \& Saúde Coletiva, v. 25, n. 9, p. 3517-3553, 2020.

ANNANE, D. Corticosteroids for COVID-19. Journal of Intensive Medicine, v. 9, n. 6, 12 p., 2021.

CARVALHO, J. C. et al. Asma e COVID-19: atualização. Revista Portuguesa de Imunoalergologia, v. 28, n. 2, p. 97-109, 2020.

CHENG, W. et al. Efficacy and Safety of Corticosteroid Treatment in Patients With COVID19: a systematic review and meta-analysis. Frontiers in Pharmacology, v. 11, n. 1, 14 p., 2020.

COLPANI, V. et al. Corticoides para infecção por Sarvs-CoV-2 (Covid-19). Hospital Moinhos do Vento, 83 p., 2020.

DEREK, C. A. et al. Effect of hydrocortisone on mortality and organ support in patients with severe COVID-19. JAMA, v. 324, n. 13, p. 1317-1329, 2020.

FADEL. R. et al. Early Short-Course Corticosteroids in Hospitalized Patients With COVID19. Clinical Infectious Diseases, v. 71, n. 1, 7 p., 2020.

FALAVIGNA, M. et al. Diretrizes para o tratamento farmacológico da COVID-19: Consenso da Associação de Medicina Intensiva Brasileira, da Sociedade Brasileira de Infectologia e da Sociedade Brasileira de Pneumologia e Tisiologia. Rev Bras Rev Intensiva, v. 32, n. 2, p. 166-196, 2020.

FRANÇOIS, D. P. et al. Effect of Hydrocortisone on 21-Day Mortality or Respiratory Support Among Critically III Patients With COVID-19. JAMA, v. 324, n. 13, p. 12981306, 2020.

GYANSHANKAR, P, M. et al. Corticosteroids for COVID-19: the search for an optimum duration of therapy. The Lancet, v. 9, n. 1, p. 8, 2020. 
HASAN, S. S. et al. Use of corticosteroids in asthma and COPD patients with or without COVID-19. Respiratory Medicine, v. 170, n. 1, 5 p, 2020.

HAYTHAM, T. et al. Association of corticosteroids use and outcomes in COVID-19 patients: a systematic review and meta-analysis. Journal of Infection and Public Health, v. 13, n, 1, p. 1652-1663, 2020.

HORBY, P. et al. Dexamethasone in Hospitalized Patients with Covid-19. The New England Journal of Medicine, v. 384, n. 8, p. 693-704, 2021.

KUMAR, K. et al. Treatment of COVID-19 exacerbated asthma: should systematic corticosteroids be used? Am J Physiol Lung Cell Mol Physiol, v. 318, n. 1, p,1244$1247,2020$.

LIU, J. et al. Corticosteroid treatment in severe COVID-19 patients with acute respiratory distress syndrome. The Journal of Clinical Investigation, v. 130, n. 12, p. 6417$6428,2020$.

MATTHAY, M. A. et al. Corticosteroids, COVID-19 pneumonia, and acute respiratory distresss syndrome. The Journal of Clinical Investigation, v. 120, n. 12, p. 62186221, 2020.

MOLINA, P. Fisiologia Endócrina. McGraw Hill Brasil, 2021.

PRESCOTT, H. C. et al. Corticosteroids in COVID-19 ARDS. JAMA, v. 2, n. 1, 4 p. 2020.

RODRIGUEZ, E. D. M. et al. Effect of Parenteral Corticosteroids in Mortality from Severe Cvodi-19. Rev Cuerpo Méd, v. 13, n. 4, p. 386-394, 2020.

RUSSELL, C. D. et al. Clinical evidence does not support corticosteroid treatment for 2019 n-CoV lung injury, The Lancet, v. 395, n.1, 4 p, 2020.

SHANG, L. et al. On the use of corticosteroids for 2019-nCoV pneumonia. The Lancet, v. 395, n. 1, 3 p, 2020.

SIQUEIRA, L. O. et al. Fármacos com potencial terapêutico para tratamento da COVID19. Brazilian Journal of Health Review, v. 3, n. 6, p. 17324-17343, 2020.

TOMAZINI, B. M. et al. Síndrome do desconforto respiratório agudo associada à COVID19 tratada com dexametasona (CoDEX): delineamento e justificativa de um estudo randomizado. Rev Bras Ter Intensiva, v. 32, n. 3, p. 354-362, 2020.

TONGYOO, S. et al. Hydrocortisone treatment in early sepsis-associated acute respiratory distress syndrome: results of a randomized controlled trial. Critical Care, v. 20, n. 1, p. 1-11, 2016. 
VERONESE, N. et al. Use of corticosteroids in Coronavirus Disease 2019 Pneumonia: a systematic review of the literature. Frontiers in Medicine, v. 7, n. 170, 6 p, 2020.

WHALEN, K. et al. Farmacologia Ilustrada-6ạ Edição. Artmed Editora, 2016.

YANG, L. et al. Corticosteroid prevents COVID-19 progression within is theurapeutic window: a multicentrem proof-of-concept, observational study. Emerging Microbes \& Infections, v. 9, n. 1, p. 1869-1877, 2020.

ZHIKANG, Y. et al. Efficacy and safety of corticosteroids in COVID-19 based on evidence for COVID-19, other coronavirus infections, influenza, community-acquired pneumonia and acute respiratory distress syndrome: a systematic review and meta-analysis. CMAJ, v. 192, n. 1, p. 756-767, 2020. 


\title{
CAPITULO XXXII
}

\section{AS MÍDIAS SOCIAIS NA PROMOÇÃO DE SAÚDE E PREVENÇÃO DAS VIOLÊNCIAS CONTRA IDOSOS DURANTE A PANDEMIA DA COVID-19: RELATO DA EXPERIÊNCIA}

DOI: 10.51859/AMPLLA.PAE1993-32

\author{
Danielly Farias Santos de Lima ${ }^{1}$ \\ Jennifer Alves dos Santos ${ }^{2}$ \\ Susanne Pinheiro Costa e Silva ${ }^{3}$ \\ Emília Carolina Félix Rosas de Vasconcelos ${ }^{4}$ \\ Kelaine Pereira Aprígio Silva 5 \\ Izabelly Ohana de Morais Inácio ${ }^{6}$
}

\begin{abstract}
'Graduanda do curso de Enfermagem Licenciatura e Bacharelado. Universidade Federal da Paraíba - UFPB.
${ }^{2}$ Graduanda do curso de Enfermagem Licenciatura e Bacharelado. Universidade Federal da Paraíba - UFPB.

${ }^{3}$ Professora Associada do Departamento de Enfermagem em Saúde Coletiva. Universidade Federal da Paraíba - UFPB.

4 Graduanda do curso de Enfermagem Licenciatura e Bacharelado. Universidade Federal da Paraíba - UFPB.

5 Graduanda do curso de Enfermagem Licenciatura e Bacharelado. Universidade Federal da Paraíba - UFPB.

6 Graduanda do curso Letras - Inglês. Universidade Federal da Paraíba - UFPB.
\end{abstract}

\section{RESUMO}

A pandemia da Covid-19 trouxe diversos impactos no que diz respeito à saúde da população idosa, envolvendo seus aspectos físicos e psicológicos. A violência contra idosos configurou-se como um aspecto relevante devido ao isolamento social, exacerbando situações já presentes nas comunidades. Desse modo, o presente trabalho teve como objetivo descrever a experiência de atividades extensionistas realizadas através de mídias sociais no que concerne às ações de promoção, prevenção e educação em saúde, evidenciando seus impactos na formação profissional em enfermagem e outras áreas. O projeto, através de abordagem visual e interativa, produziu e divulgou materiais informativos sobre os diversos temas que envolvem tal problema. Observouse a tecnologia digital como recurso fundamental que permitiu conciliar o momento do distanciamento social com a continuidade das atividades extensionistas. As ações do projeto consistem no uso das redes sociais como ferramentas que promovem o compartilhamento de informações, comunicação e educação em saúde. Os resultados das atividades foram favoráveis e o EnvelheSendo mostrou-se promissor, estimulando um envelhecimento ativo e saudável, além do engajamento expressivo do público participante.

Palavras-chave: Violência. Idoso. Mídias Sociais. Covid-19. Extensão universitária. 


\section{INTRODUÇ̃̃o}

O envelhecimento pode ser caracterizado como um processo intrínseco, ativo e progressivo, acompanhado de alterações fisiológicas, físicas e psicológicas, que necessitam de um olhar atencioso e capaz de oferecer um conjunto de políticas públicas e programas baseados nos direitos, necessidades, preferências e habilidades das pessoas mais velhas. Visando o bem-estar desse grupo social, tem-se o envelhecimento ativo como um processo de otimização das oportunidades de saúde, participação e segurança, com intervenções adequadas para recuperar ou manter sua autonomia e independência (CABRAL et al., 2015).

A Política Nacional de Saúde da Pessoa Idosa (PNSPI) foi regulamentada em 2006, com o objetivo de desenvolver um conjunto de ações de saúde, no âmbito individual e coletivo, garantindo os direitos da pessoa idosa. Além disso, tal política busca a integralidade da atenção em saúde com foco em um dos principais problemas que acometem os idosos: a incapacidade funcional para a realização de atividades básicas e instrumentais da vida diária - o que visa promover maior qualidade de vida na terceira idade, tendo em visto a inversão da pirâmide etária nacional (SANTOS et al., 2018).

A proposta de promoção à saúde, voltada para educação em saúde, configurase como um processo de intervenção pedagógica bem sucedida, tendo como eixo principal a dimensão do desenvolvimento de capacidades individuais e coletivas, visando à melhoria da qualidade de vida e saúde da comunidade assistida pelos serviços. Diante disso, tem-se as oficinas de educação em saúde com idosos que favorecem o desenvolvimento de um pensar crítico e reflexivo e troca de saberes, de modo a reconhecer as potencialidades e o valor das pessoas idosas (CABRAL et al., 2015).

Nesse interim, a pandemia da COVID-19 atingiu e produziu mudanças em várias esferas da sociedade. Um dos grupos mais afetados foram os idosos, o que ocasionou grandes desafios frente às necessidades e vulnerabilidades em relação ao direito à saúde, bem como a fragilidade do sistema de saúde para apoiar as pessoas mais velhas e considerar suas necessidades específicas (ARAÚJO et al., 2021). Como consequência, impossibilitou a continuidade de ações presenciais com idosos, grupo bastante afetado até o início da vacinação contra a doença, demandando que outras atividades pudessem ser pensadas e organizadas para manter a promoção da saúde nesse público. 
Desse modo, sabe-se que durante os primeiros meses da pandemia ocasionada pelo novo coronavírus (SARS-coV-2), houve expressivo aumento das denúncias de violências por todo o mundo e em todas as faixas etárias. Esse fato gerou preocupação acerca da violência contra a pessoa idosa (VCPI), que cresceu exponencialmente, já que a crise sanitária da Covid-19 é fator de grande influência sobre as vulnerabilidades vivenciadas por este público (MORAES et al., 2020).

A VCPI é definida como qualquer tipo de ato que gere prejuízo na esfera biopsicossocial e financeira, bem como omissão de ações que atendam as demandas do idoso, ocorrendo de forma continuada ou não. As violências sofridas pelos idosos desencadeiam fatores responsáveis por danos na capacidade cognitiva e funcional, tentativas de interromper a vida e diminuição da qualidade de vida. Além disso, ferem os direitos humanos, elevando a morbidade, mortalidade e institucionalização (CASTLE; FERGUSON; TERESINE, 2015; YON et al., 2017).

O isolamento social no Brasil - como prática preventiva da disseminação do SARScoV-2 e da contaminação em massa da população (MORAES et al., 2020), demandou também das instituições de ensino superior brasileiras a necessidade de adaptação à uma nova realidade, que foi marcada pelo ensino remoto, aprovado pelo Ministério da Educação e da Cultura (MEC) e executado nas instituições de ensino superior, como a Universidade Federal da Paraíba (UFPB).

Nesse sentido, em 2020 foi criado o projeto "EnvelheSendo: Promoção da Saúde e Prevenção da Violência contra idosos através de mídias sociais" com o objetivo principal de tratar de temas transversais à saúde pública, em veículos de mídia da internet, sendo o público-alvo idosos, familiares, trabalhadores e toda a comunidade usuária dos serviços de saúde. O que se busca com tal ação de extensão é promover conhecimento e mudanças nos hábitos, ao ampliar e facilitar o aprendizado, além de melhorar e estimular a qualidade de vida de pessoas mais velhas, suas famílias e sociedade em geral.

As mídias sociais possuem grande importância na veiculação de informações relevantes para a comunidade. Além disso, há possibilidade de debater assuntos concomitantemente pertinentes e delicados, como a violência, de forma interativa, para diferentes públicos, incluindo os idosos (MARCHI; ROSSETTI; COTONHOTO, 2020). 
Nesse cenário, objetiva-se com esse trabalho descrever a experiência de atividades extensionistas realizadas através de mídias sociais no que concerne às ações de promoção, prevenção e educação em saúde, evidenciando seus impactos na formação profissional em enfermagem e outras áreas.

\section{MATERIAIS E MÉTODOS}

Trata-se de um estudo descritivo, do tipo relato de experiência, vivenciado durante as atividades do projeto de extensão "EnvelheSendo: Promoção da Saúde e Prevenção da Violência contra idosos através de mídias sociais", que visa discutir mediante os meios de comunicação, informações básicas sobre a promoção da saúde e prevenção de doenças na terceira idade, além de viabilizar a discussão acerca da violência contra idosos, elencando ações para que tais conhecimentos difundidos sejam eficazes no seu combate.

Criou-se um perfil no Instagram de codinome "EnvelheSendo UFPB", nome escolhido com o intuito de transmitir a ideia de que ao envelhecer, o sujeito continua a ser alguém que tem vez e voz.

O projeto iniciou em 2020, sendo renovado para a vigência 2021-2022. Os encontros aconteceram semanalmente, de maneira on-line por meio do aplicativo Google Meet, para promover reuniões da equipe e discussão de temas relacionados ao projeto, com a participação de discentes da graduação de Enfermagem e Letras e docentes do Departamento de Enfermagem em Saúde Coletiva da UFPB.

As atividades iniciaram através de reuniões semanais entre as integrantes da extensão, com o intuito de prover às estudantes embasamento teórico e metodológico que pudessem facilitar o trabalho da equipe e o modo de articular soluções para os possíveis problemas encontrados. Nessas reuniões, foram escolhidos os temas das publicações, dinâmicas e formas de apresentação.

Todo o processo de readequação das extensões universitárias para o contexto pandêmico exigiu da equipe do EnvelheSendo UFPB certo preparo para o uso das mídias digitais, visto que, inicialmente, o projeto deveria ser executado através de atividades presenciais com grupos de idosos em Unidades Básicas de Saúde de João Pessoa-PB.

Para viabilização das atividades programadas, utilizou-se da plataforma Instagram, pela qual foi possível repassar informações sobre a saúde de uma maneira 
interativa, esclarecendo dúvidas existentes acerca de assuntos no âmbito do envelhecimento. Sendo assim, as postagens neste aplicativo foram realizadas intensamente através dos seus segmentos: stories, feed, lives, reels e direct, por meio de imagens, vídeos, textos, cordéis, dentre outros, os quais estimularam a promoção da saúde e a prevenção de doenças e violências em/contra idosos. O conteúdo gerado foi produzido utilizando as ferramentas canva, tiktok, inshot, capcut, powerpoint, buscando estratégias para facilitar e dinamizar a compreensão dos assuntos abordados.

Através desta mídia, diversas publicações foram realizadas para tratar desde os tipos de violência contra idosos, curiosidades sobre o processo de envelhecimento discriminação, isolamento social, atividade física, autoestima, sexualidade, câncer, assim como outros tópicos considerados pertinentes, diminuindo os aspectos negativos deste período e contribuindo para a qualidade de vida.

A princípio, foi elaborado um calendário para o desenvolvimento das ações a serem realizadas no decorrer do projeto, de tal forma que as temáticas fossem previamente agendadas para auxiliar na organização e desenvolvimento das postagens nas redes sociais (Figura 1 ).

Figura 1 - Publicações de cunho educativo do projeto
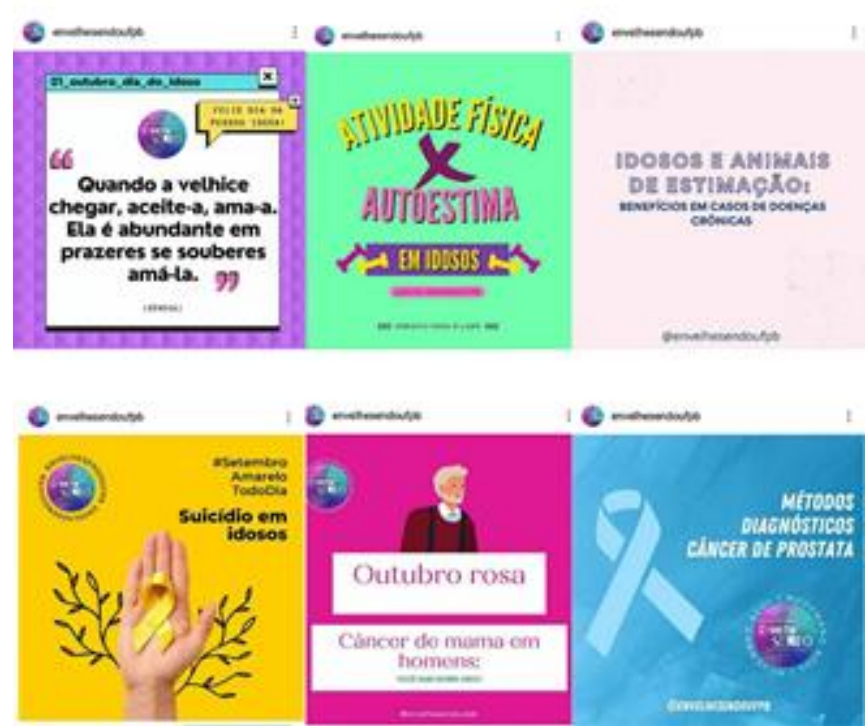

Fonte: Autoria própria. Projeto EnvelheSendo, 2021.

As temáticas desenvolvidas permearam o universo do bem-estar e qualidade de vida dos idosos, compreendendo a preparação de conteúdos de cunho educativo, abordando diversos assuntos relacionados a pessoa idosa como: discriminação, 
isolamento social, atividade física, autoestima, sexualidade, câncer, tipos de violência contra idosos, e sinais de alerta para situações de violência, curiosidades sobre o processo de envelhecimento, assim como a respeito de assuntos que envolvem a saúde mental da pessoa idosa, contemplando dicas de atividades diárias e demais tópicos considerados pertinentes à publicação.

O uso de metodologias diversas, através das plataformas web e mídias digitais, está sendo cada vez mais utilizado para a disseminação de educação e trabalho em saúde, uma vez que esses instrumentos fazem parte do cotidiano de vida da sociedade. Os métodos digitais contam com uma grande diversidade de conteúdos visuais e textuais que possibilitam a transmissão de determinada informação de uma forma mais dinâmica e divertida, tornando-a de fácil compreensão e permitindo a troca de conhecimentos e experiências constantes pelos usuários das redes (FRANÇA; RABELLO; MAGNAGO, 2019).

A cada reunião, avaliações acerca do impacto das postagens são realizadas, entendendo que a extensão é dinâmica e carece de um processo avaliativo contínuo para dirimir possíveis entraves encontrados na comunicação. A partir disso, as estratégias eram traçadas e novas ideias possibilitaram que o projeto alcançasse um número considerável de seguidores, com interação e reconhecimento.

\section{RESULTADOS E DISCUSSÃO}

O Projeto EnvelheSendo UFPB, seguindo as recomendações e decretos do poder público e de saúde do país, deu continuidade às atividades remotas abordando temáticas interligadas ao envelhecimento saudável e seus parâmetros, assim como publicou conteúdo visando o fortalecimento de campanhas já em curso do calendário da Agenda de Saúde do Sistema Único de Saúde (SUS). Assim, realizar intervenções educativas nas mídias sociais merece destaque enquanto instrumento de promoção da saúde capaz de estimular atitudes para o autocuidado de pessoas idosas e seus familiares. Deste modo, compreende-se a educação em saúde como intermediadora do processo de ensino-aprendizagem de profissionais e estudantes da saúde, assim como da comunidade como um todo (CARVALHOKM et al., 2018).

Mesmo que as modificações no formato de se estabelecer relações sociais, consequentes da pandemia da Covid-19, tenham impactado nos modelos preexistentes 
de extensão universitária brasileiros, algumas alternativas foram pensadas para sanar tais dificuldades. Com isso, as intervenções de saúde pelo meio digital se tornaram mais frequentes e, também, eficazes (MARQUES, 2020).

O Ministério da Educação, em 2018, já havia previsto que as extensões universitárias seriam em 2021, no mínimo 10\% da carga horária curricular dos cursos de ensino superior no país, o que demonstra a importância do fazer científico, que se aglutina à pesquisa e ao ensino (MEC, 2018).

A atividade de extensão universitária é uma ferramenta de democratização do acesso ao conhecimento e de reestruturação da função social. Sendo uma via de "mão dupla", contribui tanto para o conhecimento acadêmico quanto para o popular, voltando-se para os interesses e necessidades da comunidade, utilizando metodologias ativas com o intuito de ser um agente de desenvolvimento e transformação social. Ademais, a extensão possibilita a formação do profissional cidadão, implicando em relações multi, interdisciplinares e interprofissionais (GADOTTI, 2017).

Desse modo, os conteúdos produzidos pelo EnvelheSendo fomentaram interações com o público, das quais originaram-se comentários valorativos feitos pela comunidade sobre o perfil do projeto e suas publicações. Em pouco tempo, profissionais da saúde em atuação contactaram a equipe para propor articulações com a mesma através de atividades como lives, a serem exibidas no próprio Instagram da extensão, dialogando com os participantes sobre assuntos como o isolamento social e seus impactos na saúde dos idosos.

Usar as mídias sociais para divulgação e discussão de temas científicos é algo novo perante os recursos digitais. No entanto, ainda são debatidos os efeitos positivos e negativos destes no que tange a promoção da saúde. Além disso, trata-se de um campo de atuação que extrapola os saberes da enfermagem por requisitar o uso da tecnologia.

Sendo assim, constatou-se a dificuldade de manuseio e preparação de conteúdo para as redes sociais enquanto fator limitante do trabalho extensionista. Entretanto, estas adversidades foram superadas recorrendo-se a capacitações para o trabalho virtual, bem como utilizando-se dos atributos criticidade, cuidado e criatividade, habilidades importantes para exercer a enfermagem em qualquer contexto, permitindo aos membros da extensão gerenciar com coerência o aparato tecnológico. 
O Instagram, enquanto plataforma de rede de relacionamentos, atingiu em 2018 a marca de 57 milhões de usuários brasileiros ativos na mídia, tornando-se a 4o rede social mais usada no país, bem como a de maior engajamento no ambiente virtual, caracterizando-se como a preferida nacionalmente (COSTA, 2019). Não obstante, tornou-se campo de trabalho para extensionistas do Brasil inteiro durante o isolamento social, prática que perdura até o presente momento de flexibilização dos espaços físicos para socialização. Tal rede permanece em destaque e exerce função de ponte comunicacional entre as extensões universitárias e a comunidade (BORGES JÚNIOR et al., 2019).

Para lançar conteúdos visuais, utilizou-se várias ferramentas (Inshot, Instagram e TikTok) além do Canva. Este, por sua vez, é uma ferramenta online lançada em 2013 que tem por missão garantir o acesso de qualquer pessoa no mundo à criação de designs próprios de publicação e utilização livre (CANVA, 2021). Através desta mídia, diversas publicações foram produzidas para tratar dos temas escolhidos, contemplando também dicas de atividades diárias. Tais materiais assumiram cores, formatos e padrões entendidos como propícios para ampliar o alcance dos mesmos nas redes sociais.

A readequação dos conhecimentos específicos da enfermagem na promoção da saúde para os formatos consumíveis nos veículos de mídias digitais é processual; dá-se de forma paulatina e investigativa, pois considera os algoritmos em constante atualização das redes sociais. Contudo, é importante para a extensão comunitária que haja campo de trabalho no segmento virtual também, visto a premissa em que se fundamenta as suas ações que é a devolutiva do conhecimento para a sociedade. Assim, utilizar-se das redes é atributo necessário para a difusão do conhecimento.

A experiência extensionista é potencializada quando alicerçada em pilares de ensino e pesquisa, corroborando com tal afirmativa, as integrantes do projeto participaram de eventos científicos realizados de forma remota, espaços em que se discutiu a respeito da educação e formação profissional em saúde, pelos quais as extensionistas puderam arguir sob a ótica da graduação de enfermagem em tempos de pandemia.

Os temas abordados ao decorrer da atual vigência, tal qual os formatos escolhidos para cada conteúdo - se imagens, lives, vídeos ou textos -, colocaram a ação de extensão em posição de destaque referente ao quantitativo de seguidores e suas 
devolutivas para o projeto, demonstrando o alcance e impacto das informações apresentadas ao grande público.

Os temas abordados ao decorrer da vigência do projeto e os formatos escolhidos para cada conteúdo colocaram a ação de extensão em posição de destaque no que tange ao quantitativo de seguidores e suas devolutivas para o projeto, demonstrando o alcance e impacto das informações apresentadas ao grande público. O perfil do Instagram ${ }^{\circledast}$ superou a marca de mil seguidores, um grande público em potencial para ações educativas, com 46,5\% deste pertencendo à cidade de João Pessoa-PB, tendo também alcance em outros locais do mundo. A faixa etária é bastante variada, sendo $28,1 \%$ pertencente ao intervalo entre 35 a 44 anos e $77,6 \%$ de consumidores do sexo feminino. A página possui picos de visualização durante toda a semana, em especial nos horários de 12, 15 e 18 horas.

Tal marco pode ser compreendido como um engajamento expressivo, já que a variedade de perfis encontrados nesta rede torna difícil o acompanhamento valorativo dos conteúdos postados, funcionando, assim, como um sensor quanti-qualitativo do desempenho da extensão.

Ao incorporarmos à equipe uma estudante de Letras - Inglês. Com foco na amplificação do alcance das publicações, a tradução das legendas e hashtags para a língua inglesa foi incorporada ao projeto. A adição da descrição da publicação em inglês agregou novos seguidores de países diversos, permitindo que mais pessoas pudessem consumir o conteúdo sem precisar da tradução automática do aplicativo, o qual não traduz o texto fielmente, tornando a comunicação mais orgânica. Outrossim, a inclusão das hashtags traduzidas auxiliou no alcance dessas publicações por usuários que ativamente pesquisam publicações a partir delas, contribuindo para a difusão da mensagem expressa nas postagens por todos os continentes.

O inglês é uma língua franca, indispensável para a comunidade internacional, permitindo o diálogo entre todos os países e pessoas do mundo. A língua franca é a escolhida por falantes não nativos para a comunicação corriqueira entre povos diferentes. Ela possibilita que dados, estudos e pesquisas sejam facilmente compartilhados em suas respectivas áreas, sem barreiras de linguagem. $\mathrm{O}$ idioma mais utilizado na Internet é o inglês, sendo este também empregado nas relações internacionais e no próprio mundo acadêmico, tornando-o indispensável para o 
currículo profissional de quem deseja expandir sua carreira (RIBEIRO; OLIVEIRA; FURTADO, 2019).

A fusão do trabalho extensionistas das graduandas de Enfermagem e Letras Inglês trouxe perspectivas e finalidades diferentes para ambos os campos de atuação. Dentre as vantagens para a graduação em Letras Inglês destaca-se um maior conhecimento do vocabulário, com terminologias da área da saúde, somado ao exercício da capacidade de tradução textual. À enfermagem, a adesão do inglês nas postagens viabiliza o consumo do conteúdo produzido a nível internacional, expandindo as intervenções de educação em saúde para uma quantidade maior de pessoas no mundo todo.

Ao longo dos anos de 2020 e 2021, a equipe EnvelheSendo UFPB recebeu mensagens positivas sobre sua atuação, que foi o combustível para continuar construindo o trabalho, mesmo diante das dificuldades encontradas no percurso. Contudo, pesquisar sobre a saúde do idoso e sua transversalidade possibilitou às integrantes da extensão construir novos alicerces para suas formações pessoais e profissionais, articulando este pilar com a pesquisa científica e o ensino da graduação.

A readequação dos conhecimentos específicos da enfermagem na promoção da saúde para os formatos consumíveis nos veículos de mídia digitais é processual, dar-se de forma paulatina e investigativa, pois considera os algoritmos em constante atualização das redes sociais. Por isso, é importante para a extensão comunitária que haja campo de trabalho extensionista no segmento virtual, visto as premissas em que se fundamentam as ações de extensão, que incluem a devolutiva do conhecimento à sociedade. Assim, utilizar-se das redes é atributo necessário, pois as mídias constituem um novo formato de comunidade relacional (Figura 2). 
Figura 2 - Perfil do instagram @envelhesendoufpb

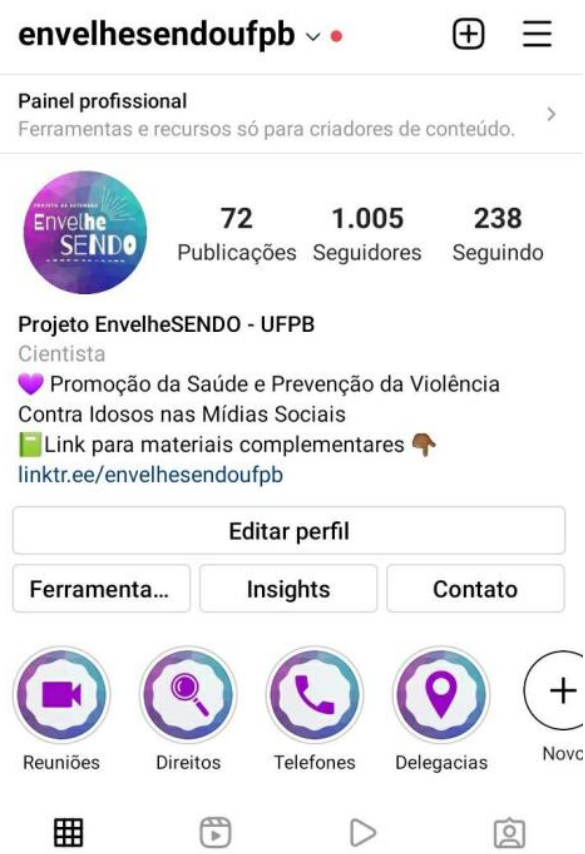

Fonte: Autoria própria. Projeto EnvelheSendo, 2021.

\section{CONSIDERAÇÕES FINAIS}

Diante de tal panorama, conclui-se que as redes sociais podem viabilizar significativamente o processo de promoção da saúde do idoso, de sua família e sociedade, tornando-se um artifício indispensável de implementação no cotidiano para além da pandemia da Covid-19, contemplando os requisitos de socialização da educação em saúde exigidos pela era digital.

Além disso, para o grupo extensionista, foi de extrema relevância perceber que os resultados poderão ser colhidos a longo prazo, com a transformação da realidade comunitária no que tange à violência contra o idoso, promovendo também ações de saúde e prevenindo os problemas que decorrem da idade, fortalecendo a extensão universitária como estratégia indispensável para o enfrentamento de questões sociais.

Por fim, o projeto possibilitou agregar conhecimento e auxiliar na trajetória acadêmica das extensionistas, aprimorando suas habilidades e competências, com destaque para o trabalho em equipe e busca de estratégias que promovam a autonomia do idoso, além de oportunidades contínuas de saúde, participação social e segurança. Desse modo, conclui-se que as ações de extensão podem ir muito além daquilo que se aprende na teoria, potencializando o agir prático, fortalecendo o processo de ensino- 
aprendizagem e gerando benefícios diretos para os futuros profissionais, independente da área do conhecimento, ao contribuir para o exercício profissional e cidadão.

\section{AGRADECIMENTOS}

À Universidade Federal da Paraíba, pela bolsa concedida através do Programa de Bolsas de Extensão (PROBEX).

\section{REFERÊNCIAS}

ARAÚJO, G. B.; APOLINÁRIO, J. M. S. S.; AFONSO, T. O. Impacto da pandemia de Covid19 na saúde do idoso: um estudo a partir de artigos originais da Brazilian Journal of Geriatrics and Gerontology. RECIMA21 - Revista Científica Multidisciplinar, 2(9), e29780, 2021.

BORGES JÚNIOR, A. N.; SANTOS, A. S.; SILVA, E. C. N.; AZEVEDO, T. F. V. B; PIMENTEL, M. R. R. Gestão do instagram da clínica médica Popclin saúde: uma análise semiótica sobre identidade e presença digital. Anais da 22a Semana de Mobilização Científica- SEMOC. 2019.

BRASIL. Ministério da Educação. Resolução no 7, de 18 de dezembro de 2018. Estabelece as diretrizes para a extensão da Educação Superior Brasileira e regimenta o disposto na Meta 12.7 da Lei no 13.005/2014, que aprova o Plano Nacional de Educação-PNE 2014-2024 e dá outrasprovidências.

CABRAL, J. R. et al. Oficinas de educação em saúde com idosos: uma estratégia de promoção da qualidade de vida. Revista Enfermagem Digital Cuidado e Promoção da Saúde, 1(2): 71-75, 2015.

CARVALHO, K. M. et al. Intervenções educativas para promoção da saúde do idoso: revisão integrativa. Acta Paul Enferm., 31(4): 446-54, 2018.

CASTLE, N.; FERGUSON-ROME, J. C.; TERESI, J. A. Elder Abuse in Residential Long-Term Care: an update to the 2003 National Research Council Report. Journal of Applied Gerontology, 34(4):407-43, 2015.

COSTA, T. Quais são as rede sociais mais usadas no Brasil?, São Paulo: Rock Content, 2019.

FRANÇA, T.; RABELLO, E. T.; MAGNAGO, C. As mídias e as plataformas digitais no campo da Educação Permanente em Saúde: debates e propostas. Saúde em Debate, v. 43, p. 106-115, 2019.

MARCHI, B. F.; ROSSETTI, C. B.; COTONHOTO, L. A. Idoso e redes digitais um estudo exploratório. Revista Envelhecer, 25(1): 21-40, 2020. 
MASSI, G. et al. Envelhecimento ativo: um relato de pesquisa-intervenção. Revista Cefac, v. 20, p. 5-12, 2018.

SANTOS, M. S. et al. Práticas integrativas e complementares: avanços e desafios para a promoção da saúde de idosos. Revista Mineira de Enfermagem, v.22, p. 1-5, 2018.

YON, Y. et al. Elder abuse prevalence in community settings: a systematic review and meta-analysis. Lancet Glob Health, 5(2): 157-156, 2017. 


\title{
CAPITULO XXXIII
}

\section{ASSISTÊNCIA DE ENFERMAGEM NO DOMICÍLIO A HIPERTENSOS E DIABÉTICOS ACOMPANHADOS PELA ESTRATÉGIA SAÚDE DA FAMÍLIA}

DOI: 10.51859/AMPLLA.PAE1993-33

\author{
Sonia Pantoja Nascimento Lima ${ }^{1}$ \\ Beatriz Aguiar da Silva ${ }^{2}$ \\ Maria das Dores Medeiros de Almeida Santos ${ }^{3}$ \\ Maria Alzenira Loura do Carmo Albuquerque ${ }^{4}$ \\ Marília Rosendo Rodrigues Soares ${ }^{5}$ \\ Edileny de Sousa Maciel Silva ${ }^{6}$
}

\footnotetext{
Graduada em Enfermagem. Centro Universitário de Ciências e Tecnologia do Maranhão/UNIFACEMA

2 Residente em Saúde da Família. Programa de Residência Multiprofissional em Saúde da Família. Universidade

Estadual do Maranhão - UEMA

${ }^{3}$ Graduada em Enfermagem. Centro Universitário de Ciências e Tecnologia do Maranhão/ UNIFACEMA

${ }^{4}$ Graduada em Enfermagem. Centro Universitário de Ciências e Tecnologia do Maranhão/ UNIFACEMA

${ }^{5}$ Graduada em Enfermagem. Faculdade Integral Diferencial - FACID

${ }^{6}$ Graduada em Enfermagem. Universidade Estadual do Piauí - UESPI
}

\section{RESUMO}

A assistência de enfermagem no domicílio compreende o fornecimento de atividades que promovem o bem-estar e conforto do ser humano como um todo, seja no seio familiar ou no meio social, ou seja, o enfermeiro é o profissional que está diretamente ligado ao cliente e família, o mesmo é habilitado e capacitado para atuar como gestor do cuidado, desempenhando tarefas que auxiliam na programação e estruturação do funcionamento do trabalho. Assim a presente pesquisa tem como objetivo mostrar que a assistência de enfermagem no domicílio permite a caracterização real dos problemas e dificuldades vivenciadas por hipertensos e diabéticos. É indispensável a assistência de enfermagem na comunicação constante e regular ao paciente hipertenso e diabético, as visitas domiciliares devem ser planejadas pois possibilita o desenvolvimento de ações de promoção, prevenção e manuseio das dificuldades, na intensão de proporcionar uma vida saudável. Com o acompanhamento através da visita domiciliar, o cuidado e monitoramento de enfermagem tem como resultado a prevenção do agravamento e complicações das patologias mais comuns na comunidade, bem como HAS, DM, obesidade, doenças cardiovasculares dentre outras. Com essa abordagem é possível promover ações que impactam na modificação da qualidade de vida e na mudança de hábitos e costumes.

Palavras-chave: Enfermagem domiciliar. Visita domiciliar. Hipertensão. Diabetes. Estratégia Saúde da Família. 


\section{INTRODUÇÃO}

A partir de períodos bem antigo há relatos do atendimento domiciliar, este é um recurso voltado para o cuidado a saúde do indivíduo no lar, no Brasil esse método manteve-se associado ao âmbito do bem-estar comunitário dirigido apenas ao manejo de patologias infecciosas, com o passar do tempo essa estratégia se estendeu ao cuidado de pacientes acometido por doenças crônicas, com incapacidade de locomoção por alguma deficiência ou em cuidados paliativos (OLIVEIRA et al., 2017)

De acordo com a RDC no 11/2016 da Anvisa (Agência Nacional de Vigilância Sanitária), assistência domiciliar é o agrupamento de funções que presta cuidados ambulatorial, agendados e de forma constante executados no domicilio, ou seja, o cuidado no domicílio é destinado a pacientes em qualquer fase da vida, seja no lar ou em outra localidade não organizacional favorecendo a prevenção, cura e recuperação nos diferentes níveis de complexidade que a circunstância possa requerer (BUENO, 2011).

Acrescenta-se que, o desenvolvimento de estratégias de saúde como a extensão do cuidado de enfermagem no domicílio, permite que leitos hospitalares fiquem vazios por mais tempo, redução de custos com internação e minimização do risco de infecções hospitalares, visto que a atenção primária em saúde engloba um agrupamento de intervenções que beneficiem a comunidade como um todo, dentre elas a promoção da saúde, prevenção de agravos, tratamento e reabilitação (BRASIL, 2012; BUENO 2011).

Assim a assistência de enfermagem no domicílio compreende o fornecimento de atividades que promovem o bem-estar e conforto do ser humano como um todo, seja no seio familiar ou no meio social, ou seja, o enfermeiro é o profissional que está diretamente ligado ao cliente e família, o mesmo é habilitado e capacitado para atuar como gestor do cuidado, desempenhando tarefas que auxiliam na programação e estruturação do funcionamento do trabalho (VALARISTINO et al., 2019).

Deste modo o desenvolvimento de atividades de planejamento e acompanhamento através da visita domiciliar, direcionados a grupos de risco como Hipertensos e Diabéticos, oferece uma visão real do que pode estar influenciando no desenvolvimento do problema do paciente, o que geralmente não é perceptível na consulta de enfermagem na Unidade Básica de Saúde (UBS). 
A saber, muitos detalhes ficam omissos e passam despercebidos, como por exemplo, não é possível saber as condições de higiene do domicílio, se o domicílio é um local aberto e arejado ou fechado e úmido, não é possível identificar as condições de humor dos familiares que estão em convívio com o paciente dentre outros que fazem o diferencial no momento da tomada de decisão e planejamento.

Os motivos que levaram ao desenvolvimento do tema estão relacionados as ações de busca ativa e visita domiciliar de Hipertensos e Diabéticos em acompanhamento pela Estratégia Saúde da Família. Através das visitas é possível identificar problemas como: hipertensos e diabéticos que não fazem acompanhamento de rotina, descompensados com risco elevado para doença cardiovascular, dificuldade de locomoção, abandono de tratamento etc.

A relevância do estudo se dá em favor da identificação das vulnerabilidades e das características do ambiente sociofamiliar dos grupos de risco supracitado, bem como enfatizar a importância do planejamento da assistência de enfermagem no domicílio, levando em consideração que essa prática permite mudança de comportamento pelo paciente, através de ações de educação em saúde baseada em evidências vivenciadas na prática profissional.

A pesquisa tem como objetivo mostrar que a assistência de enfermagem no domicílio permite a caracterização real dos problemas e dificuldades vivenciadas por hipertensos e diabéticos, possibilitando mudança no prognóstico do paciente e na tomada de decisão pelo profissional de enfermagem.

\section{METODOLOGIA}

O estudo atual foi elaborado através de levantamento bibliográfico do tipo revisão integrativa, acerca das ações de enfermagem relacionadas ao acompanhamento domiciliar de pacientes portadores de Hipertensão Arterial Sistêmica e Diabetes Mellitus a partir de uma análise de artigos científicos, a pesquisa bibliográfica segue uma sequência de etapas fazendo com que o leitor realize uma investigação minuciosa, identificando e explorando o conteúdo a ser trabalhado, com a finalidade de mostrar os resultados de acordo com o objetivo proposto baseado em evidencias cientificas (PEREIRA et al., 2018). 
A revisão integrativa é um processo que permite fazer um levantamento abrangente da literatura, mas com aspectos inerentes ao objetivo indicado, possibilitando interpretação vasta de um dado em particular, a partir de então é possível a formulação de novos conceitos e percepções de acordo com análise de resultados e conclusões apresentados na literatura em pesquisa (BOTELHO; CUNHA; MACEDO, 2004).

Para o desenvolvimento desta revisão, foram percorridas as seguintes etapas: definição do tema e formulação da questão norteadora, estabelecimento dos critérios de inclusão e exclusão, definição dos descritores, pré-seleção dos artigos, avaliação dos estudos (interpretação dos resultados) e apresentação da revisão. A pergunta norteadora utilizada para investigação foi: "Qual a importância da assistência de enfermagem no domicílio para Hipertensos e Diabéticos acompanhados pela Estratégia Saúde da Família?".

A realização das buscas ocorreu entre junho a setembro de 2021, utilizando as bases de dados Biblioteca Virtual em Saúde (BVS), National Library of Medicine (PUBMED) e Scientific Electronic Library Online (Scielo), com o recorte temporal de 2016 a 2021. Houve uma seleção criteriosa no que diz respeito às obras utilizadas para o desenvolvimento desta revisão.

Os descritores utilizados foram: "Enfermagem domiciliar, visita domiciliar, Hipertensão, Diabetes, Estratégia Saúde da Família", em inglês, espanhol e português, indexados no Descritores em Ciências da Saúde (DeCS). Como critérios de exclusão foram utilizados: trabalhos não disponíveis na integra, incompatível com o objetivo do estudo e com mais de 5 anos de publicação.

\section{RESULTADOS}

Dentro das buscas, foram encontrados 1315 artigos, porém, após a exclusão de achados duplicados e incompletos, restringiu-se a 303 obras, estas foram analisadas quanto a sua relação com o tema e ao final foram limitadas a 8 artigos, dos quais foram lidos e avaliados individualmente, levando em consideração os quais possuíam os descritores inclusos no tema e/ou resumo e foram incluídos porque melhor se enquadravam no objetivo proposto. 
A seguir estão listados os artigos finais selecionados para o estudo, com base no seu título, autores e seu ano de publicação, plataformas de busca e nas revistas (Quadro 1).

Quadro 1 - Descrição dos artigos selecionados segundo nome do artigo, autor e ano, plataforma e periódico

\begin{tabular}{|c|c|c|c|c|}
\hline № & Titulo & Autor e ano & Plataforma & Periódico \\
\hline 01 & $\begin{array}{l}\text { Conhecimento e Atitude: } \\
\text { perfil de pessoas com } \\
\text { diabetes em diálise }\end{array}$ & $\begin{array}{l}\text { Capellari e Figueiredo } \\
\qquad(2020)\end{array}$ & BVS & $\begin{array}{c}\text { Revista de } \\
\text { Enfermagem } \\
\text { UERJ }\end{array}$ \\
\hline 02 & $\begin{array}{l}\text { Educação em saúde no } \\
\text { domicílio de idosos } \\
\text { hipertensos e diabéticos }\end{array}$ & $\begin{array}{l}\text { Moreira, Ferreira, } \\
\text { Felício, Lima, Gomes } \\
\text { e Oliveira (2020) }\end{array}$ & BVS & $\begin{array}{c}\text { Revista de } \\
\text { Enfermagem } \\
\text { UFPE on line }\end{array}$ \\
\hline 03 & $\begin{array}{c}\text { Assistência de } \\
\text { enfermagem no } \\
\text { programa hiperdia: relato } \\
\text { de experiência em estágio } \\
\text { supervisionado }\end{array}$ & $\begin{array}{l}\text { Nascimento, Almeida, } \\
\text { Sandra Cosson e } \\
\text { Santos (2017) }\end{array}$ & BVS & $\begin{array}{l}\text { CuidArte, } \\
\text { Enferm }\end{array}$ \\
\hline 04 & $\begin{array}{l}\text { Perinatal Nurse Home } \\
\text { Visiting Referral Patterns } \\
\text { Among Women With } \\
\text { Diabetes and } \\
\text { Hypertension in } \\
\text { Philadelphia }\end{array}$ & $\begin{array}{c}\text { Bloch, Zupan, } \\
\text { McKeever e Barkin } \\
\text { (2016) }\end{array}$ & BVS & $\begin{array}{c}\text { Journal of } \\
\text { Obstetric, } \\
\text { Gynecologic, \& } \\
\text { Neonatal } \\
\text { Nursing } \\
\text { (JOGNN) }\end{array}$ \\
\hline 05 & $\begin{array}{c}\text { Avaliação do } \\
\text { acompanhamento de } \\
\text { pacientes adultos com } \\
\text { hipertensão arterial e/ou } \\
\text { diabetes melito pela } \\
\text { Estratégia Saúde da } \\
\text { Família e identificação de } \\
\text { fatores associados, } \\
\text { Cambé-PR, Brasil, } 2012\end{array}$ & $\begin{array}{l}\text { Radigonda, Souza, } \\
\text { Junior e Silva (2016) }\end{array}$ & SCIELO & $\begin{array}{l}\text { Epidemiologia } \\
\text { e Serviços de } \\
\text { Saúde }\end{array}$ \\
\hline 06 & $\begin{array}{c}\text { Nursing care practices for } \\
\text { people with Chronic } \\
\text { Noncommunicable } \\
\text { Diseases }\end{array}$ & $\begin{array}{c}\text { Becker, Heidemannl, } \\
\text { Meirelles, Costal, } \\
\text { Antonini e Durand } \\
\text { (2018) }\end{array}$ & SCIELO & $\begin{array}{c}\text { Revista } \\
\text { Brasileira de } \\
\text { Enfermagem }\end{array}$ \\
\hline
\end{tabular}




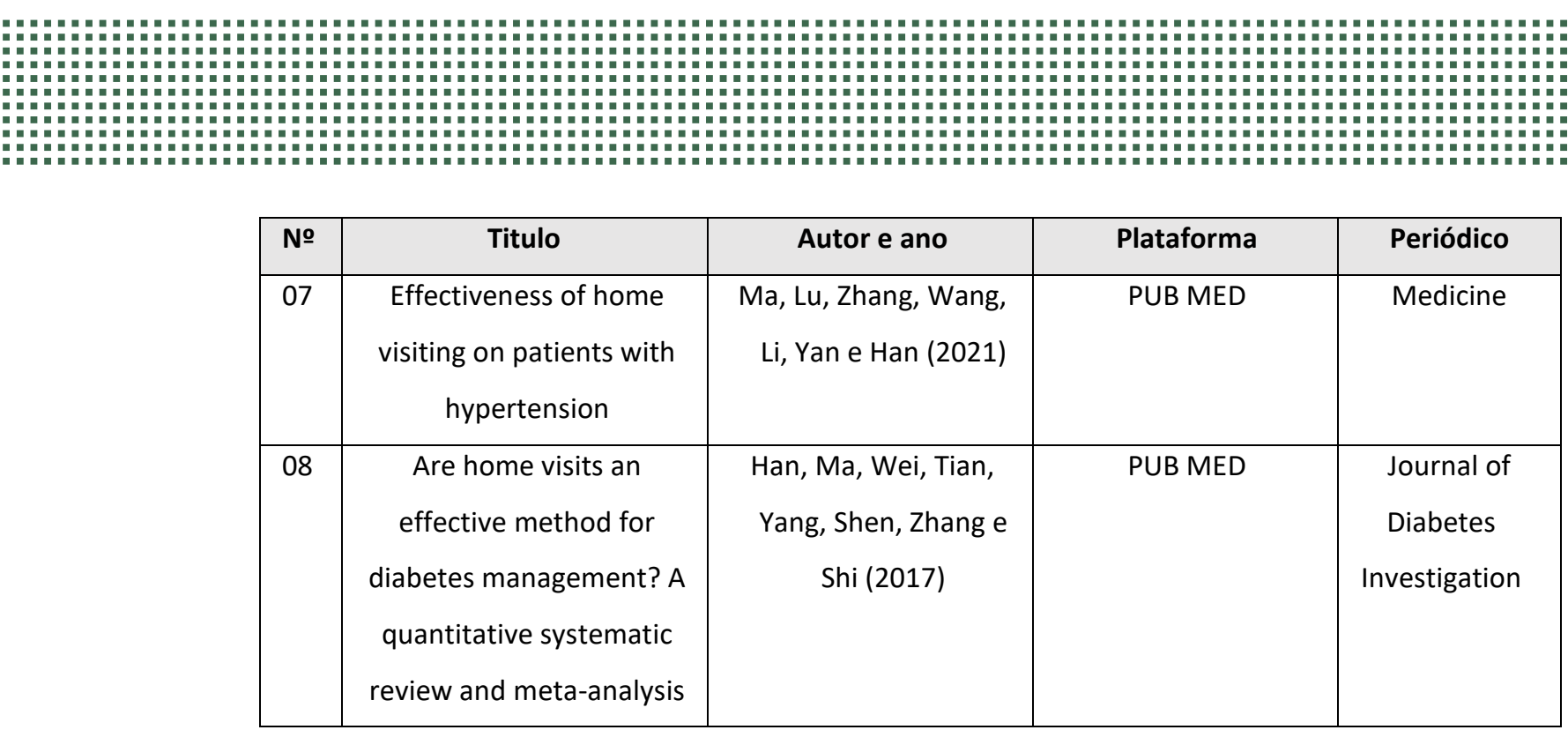

Fonte: Lima et al., 2021.

A seguir estão listados todos os artigos finais selecionados para o estudo, com tipo de estudo, objetivo e conclusão (Quadro 2).

Quadro 2: Descrição dos artigos por tipo de estudo, objetivo e conclusão

\begin{tabular}{|c|c|c|c|}
\hline № & Tipo de estudo & Objetivo & Conclusão \\
\hline 01 & Transversal & $\begin{array}{l}\text { Identificar o conhecimento e o } \\
\text { enfrentamento do diabetes } \\
\text { junto a pessoas com diabetes } \\
\text { em diálise. }\end{array}$ & $\begin{array}{l}\text { Pessoas com diabetes, em diálise, } \\
\text { apresentam } \\
\text { conhecimento deficiente em relação } \\
\text { ao diabetes, assim como baixo } \\
\text { enfrentamento da doença }\end{array}$ \\
\hline 02 & Descritivo & $\begin{array}{l}\text { Relatar a experiência de } \\
\text { sessões educacionais sobre } \\
\text { saúde cardiovascular no } \\
\text { domicílio de idosos com } \\
\text { hipertensão arterial e/ou } \\
\text { diabetes mellitus }\end{array}$ & $\begin{array}{l}\text { A visita domiciliar é uma estratégia } \\
\text { para se desenvolver sessões educativas } \\
\text { sobre saúde } \\
\text { cardiovascular de idosos hipertensos } \\
\text { e/ou diabéticos, principalmente os do } \\
\text { sexo masculino e com risco } \\
\text { cardiovascular } \\
\text { aumentado }\end{array}$ \\
\hline 03 & $\begin{array}{l}\text { Relato de } \\
\text { experiência }\end{array}$ & $\begin{array}{l}\text { Relatar a experiência de } \\
\text { Estágio Supervisionado na } \\
\text { Atenção Básica em } \\
\text { Saúde e traçar um paralelo } \\
\text { entre as ações assistenciais } \\
\text { realizadas e as preconizadas } \\
\text { pelo Ministério da Saúde, } \\
\text { quanto ao programa } \\
\text { Hiperdia }\end{array}$ & $\begin{array}{c}\text { Perceberam-se falhas na comunicação } \\
\text { do enfermeiro com o cliente e a } \\
\text { família, não contribuindo para } \\
\text { acompanhamento integral } \\
\text { e longitudinal dos pacientes com } \\
\text { fatores de risco e, consequentemente, } \\
\text { para a emancipação do usuário do } \\
\text { sistema. }\end{array}$ \\
\hline 04 & $\begin{array}{c}\text { Análise } \\
\text { documental }\end{array}$ & $\begin{array}{l}\text { Examinar o acesso a serviços } \\
\text { de visita domiciliar de } \\
\text { enfermeiras perinatais para } \\
\text { gestantes de alto risco que têm } \\
\text { diabetes ou hipertensão. }\end{array}$ & $\begin{array}{l}\text { A visita domiciliar da enfermeira } \\
\text { perinatal oferece uma oportunidade } \\
\text { para que as enfermeiras avaliem e } \\
\text { gerenciem as mulheres grávidas em } \\
\text { suas próprias casas, do ponto de vista } \\
\text { da saúde da população, programas de } \\
\text { visitas domiciliares de enfermeiras } \\
\text { perinatais para mulheres grávidas com } \\
\text { diabetes e hipertensão são } \\
\text { necessárias. }\end{array}$ \\
\hline 05 & $\begin{array}{c}\text { Pesquisa avaliativa } \\
\text { de análise } \\
\text { documental }\end{array}$ & $\begin{array}{l}\text { Avaliar o acompanhamento de } \\
\text { adultos com hipertensão } \\
\text { arterial e/ou diabetes pelas }\end{array}$ & $\begin{array}{l}\text { O acompanhamento pelas equipes não } \\
\text { atende ao padrão assistencial }\end{array}$ \\
\hline
\end{tabular}




\begin{tabular}{|c|c|c|c|}
\hline № & Tipo de estudo & Objetivo & Conclusão \\
\hline & & $\begin{array}{c}\text { equipes de Saúde da Família e } \\
\text { identificar fatores associados, } \\
\text { na cidade de Cambé-PR, Brasil, } \\
\text { em } 2012 .\end{array}$ & $\begin{array}{l}\text { estabelecido para os grupos } \\
\text { programáticos analisados. }\end{array}$ \\
\hline 06 & Estudo qualitativo & $\begin{array}{l}\text { Compreender as práticas de } \\
\text { cuidado às pessoas com } \\
\text { Doenças Crônicas Não } \\
\text { Transmissíveis, desenvolvidas } \\
\text { por enfermeiras da Atenção } \\
\text { Básica à Saúde de um } \\
\text { município do sul do Brasil. }\end{array}$ & $\begin{array}{l}\text { O enfermeiro atua de forma } \\
\text { diversificada neste campo, estando } \\
\text { presente na vida de pessoas com } \\
\text { doenças crônicas. No entanto, é } \\
\text { necessário avançar, principalmente na } \\
\text { busca pelo desenvolvimento constante } \\
\text { e contínuo de uma prática assistencial } \\
\text { ampliada e acolhedora }\end{array}$ \\
\hline 07 & $\begin{array}{l}\text { Revisão } \\
\text { sistemática e } \\
\text { meta-análise }\end{array}$ & $\begin{array}{l}\text { Avaliar a eficácia de programas } \\
\text { de visita domiciliar em } \\
\text { pacientes hipertensos }\end{array}$ & $\begin{array}{l}\text { Os programas de visita domiciliar } \\
\text { foram associados a um melhor } \\
\text { controle da pressão arterial e à } \\
\text { redução da pressão arterial, o que } \\
\text { indica que pode ser um método eficaz } \\
\text { para o controle da hipertensão. }\end{array}$ \\
\hline 08 & $\begin{array}{c}\text { Revisão } \\
\text { sistemática } \\
\text { quantitativa e } \\
\text { meta-análise }\end{array}$ & $\begin{array}{c}\text { Avaliar os efeitos das } \\
\text { intervenções de visita } \\
\text { domiciliar entre pacientes com } \\
\text { diabetes. }\end{array}$ & $\begin{array}{c}\text { As visitas domiciliares foram } \\
\text { associadas a um melhor controle } \\
\text { glicêmico e redução dos fatores de } \\
\text { risco cardiovascular, o que mostra que } \\
\text { é um método eficaz para o controle do } \\
\text { diabetes. }\end{array}$ \\
\hline
\end{tabular}

Fonte: Lima et al., 2021.

\section{DISCUSSÃO}

Os princípios que regulam a Atenção Primária em Saúde (APS) estabelece a Estratégia Saúde da Família como base das Redes de Atenção à Saúde (RAS) visando reformular um padrão de intervenção válido, a mesma é definida como porta de entrada para o acesso aos serviços básicos de saúde prestados pela APS, tendo a equipe multiprofissional, atuante nas ações mais pertinentes ao acompanhamento da comunidade, a saber as Visitas domiciliares (VD), a qual pode ser feita a partir do levantamento das necessidades apresentadas pela mesma (MARTINS; BERTELLI; BORGES, 2019).

\subsection{EDUCAÇÃO EM SAÚDE NO DOMICÍLIO}

A educação em saúde tem por finalidade estimular a prevenção de doenças, o engajamento e a participação da comunidade em ações relacionadas a saúde e a qualidade de vida, cabendo ao profissional de saúde desenvolver métodos e estratégias que induzam a aceitação e a continuidade do tratamento, é importante que o 
profissional conheça o contexto social e familiar do paciente para que suas estratégias sejam eficazes (CAPELLARI; FIGUEIREDO, 2020).

Sob o mesmo ponto de vista Souza et al. (2018), enfatiza que a prática da visita domiciliar pelo profissional de enfermagem, colabora para que a educação em saúde seja posta em ação possibilitando o desenvolvimento de parâmetros, que auxiliem na descoberta das vulnerabilidades presentes no meio familiar, indo para além das atribuições assistenciais restritas a Unidade Básica de Saúde (UBS).

Na pesquisa realizada por Moreira et al. (2020), afirmam que o desempenho de ações educativas no convívio domiciliar, contribuem de forma significativa para a diminuição das complicações de doenças crônicas não transmissíveis, pois a mesma possibilita a aproximação entre profissional e paciente permitindo a identificação de dificuldades que influenciam na autonomia e no autocuidado.

Assim também Tan et al. (2020) evidenciam em sua pesquisa que as atividades de enfermagem no domicílio colaboram para o aperfeiçoamento de resultados positivos no controle da hipertensão e diabetes, a saber, metas de pressão arterial e controle glicêmico respectivamente alcançadas, e que as estratégias de conhecimento das condições ambientais, socioeconômicas e sociofamiliar auxiliam de forma considerável o aperfeiçoamento da assistência de enfermagem.

Portanto é essencial a construção de uma relação afetiva entre enfermeiro e paciente, tornando o seu acompanhamento assíduo, a assistência de enfermagem no domicílio induz ao progresso do bem-estar não apenas do usuário, mas de todo meio sociofamiliar. A educação em saúde é uma ferramenta indispensável na prática assistencial voltada para família e comunidade pois é a base na formação dos serviços de saúde (NASCIMENTO et al., 2017)

\subsection{A ASSISTÊNCIA DE ENFERMAGEM NO DOMICÍLIO A HIPERTENSOS E DIABÉTICOS}

A Hipertensão Arterial Sistêmica (HAS) é definida por um estado de múltiplos fatores que determinam padrões elevados e firmados da pressão arterial (PA), constantemente está ligada as mudanças na atividade ou na estrutura dos principais órgãos elevando o risco cardiovascular. O "diabetes mellitus" (DM) é determinado pelo 
aumento de glicose no sangue e desordem no metabolismo de carboidratos, proteínas e gorduras, ocasionando falha na eliminação e/ou execução da insulina (BRASIL, 2013).

Acrescenta-se que a assistência de enfermagem ao hipertenso e diabético estão para além da identificação prévia e da terapêutica medicamentosa, é indispensável a comunicação constante e regular, as visitas domiciliares devem ser planejadas pois possibilita o desenvolvimento de ações de promoção, prevenção e manuseio das dificuldades, na intensão de proporcionar uma vida saudável (BUENO; SILVEIRA; REZENDE, 2019).

Assim os autores Bloch et al. (2016), em um estudo que avaliou o acompanhamento de enfermagem no domicílio a gestantes na condição de hipertensa e diabética, pode concluir que essa estratégia tem influência relevante na melhoria da qualidade de vida materno infantil, e importante diminuição das taxas de morbidade e mortalidade materna.

Ainda conforme os autores supracitados, a visita domiciliar no período gestacional, oportuniza ao profissional de enfermagem qualificar e gerir as gestantes durante o pré-natal em seu próprio domicílio, favorecendo melhor perspectiva populacional.

Embora a assistência de enfermagem no domicílio seja um método que traga benefícios para o acompanhamento, de acordo com Radigonda et al. (2016) em seu estudo realizado em Cambé-SP, observou-se baixa cobertura nas ações de enfermagem no que tange as consultas e visitas realizadas pela mesma a hipertensos e diabéticos, com o argumento de ter muitas atribuições agregadas e deficiência no desenvolvimento de tais atividades, afetando a cobertura do seguimento populacional.

Em um outro estudo feito com enfermeiros da Estratégia Saúde da Família em uma região do Sul do Brasil, observou-se que as rotinas das ações de enfermagem voltadas a população com comorbidades crônicas, são desenvolvidas pela visita domiciliar, acolhimento individual e coletivo, estas, ocasionalmente com aspecto estendido, priorizando as práticas de educação em saúde e o autocuidado, porém ainda é necessário prosseguir com mecanismos de atenção ampliada e convidativa de forma permanente e regular (BECKER et al., 2018)

A busca no domicílio contém potencialidade para ampliar e caracterizar o método aprimorado do cuidar, e proporcionar ao profissional investigar as deficiências 
do paciente e as possíveis chances de interferência, nas quais divergem conforme os aspectos sociais, ambientais, sociodemográficos e familiar (BARRA et al., 2021)

Ma et al. (2021) evidenciam em sua pesquisa a efetividade do programa de visita domiciliar no processo de estabilização da pressão arterial, e o auxílio no cuidado com doenças cardiovasculares, os autores concluem que a aplicação da visita domiciliar está

ligada ao avanço no manejo e diminuição da PA, incentivo a promoção do estilo de vida o que leva a manter os níveis pressóricos abaixo da meta, sugerindo que seja um critério adequado para o tratamento da hipertensão.

Corroborando com os autores Bueno, Silveira e Rezende (2019), é fundamental a construção de um planejamento de mudanças dos fatores de risco que estão associados a HAS e DM, como o incentivo a atividade física, a diminuição do peso corporal quando elevado, o abandono do tabagismo e alcoolismo, de forma coletiva e individual, o acompanhamento domiciliar fortifica o elo entre equipe-usurário-família, oportunizando a identificação de problemas que influenciam o desenvolvimento ou agravamento de doenças crônicas.

Sob o mesmo ponto de vista, a pesquisa de Han et al. (2017), avaliou a ligação entre os programas de visita domiciliar e o controle do diabetes, teve como resultado impacto benéfico no manejo glicêmico como o decrescimento nos níveis de HbA1c, lipidograma, níveis pressóricos da PA adequados, visto que o controle glicêmico é um relevante precursor das disfunções crônicas do diabetes.

\section{CONSIDERAÇÕES FINAIS}

Avaliar a pessoa, família e comunidade, realizar investigação das necessidades, problemas, preocupações e reações fazem parte do processo de enfermagem, estes quando aplicados ao processo de acompanhamento domiciliar gera benefícios que vão além de um tratamento medicamentoso, essa estratégia tem fins de prevenção e promoção da saúde com foco na melhoria da qualidade de vida e mudança de fatores de risco influenciáveis na vida saudável.

Em razão disso faz-se necessário a adoção de medidas estratégicas para conhecimento das condições ambientais, socioeconômicas, sociofamiliar e as vulnerabilidades apresentadas pelo paciente hipertenso e diabético. A visita domiciliar intensificada, favorece a identificação de problemas, concebe e promove processos 
construtivos, que visem a melhoria da qualidade de vida do cliente, família e/ou grupo social.

O estabelecimento de atividades educativas como palestras, orientações, rodas de conversa juntamente com a equipe multiprofissional, otimizam meios educativos que objetivam o aperfeiçoamento da assistência de enfermagem no domicilio.

Com o acompanhamento através da visita domiciliar, o cuidado e monitoramento de enfermagem tem como resultado a prevenção do agravamento e complicações das patologias mais comuns na comunidade bem como HAS, DM, obesidade, doenças cardiovasculares dentre outras.

Com essa abordagem é possível promover ações que impactam na modificação da qualidade de vida e na mudança de hábitos e costumes, reduzindo o risco de morbimortalidade cardiovascular, limitando ou retardando o desenvolvimento de patologias preveníveis.

Os resultados desse estudo promoverão um olhar diferente contribuindo para o diagnostico situacional elaborado a partir da observação do convívio do paciente, este servirá de base para o planejamento da assistência de enfermagem, a aproximação tornará mais forte o vínculo entre profissional e comunidade o que favorece maior confiança e segurança no processo de trabalho da Atenção Primária em Saúde.

\section{REFERÊNCIAS}

BLOCH, J. R. et al. Perinatal Nurse Home Visiting Referral Patterns Among Women With Diabetes and Hypertension in Philadelphia. Journal of Obstetric, Gynecologic, \& Neonatal Nursing (JOGNN). Philadelphia. Volume 46, 2016. Disponível em: https://doi.org/10.1016/j.jogn.2016.08.009. Acesso em: 12 set. 2021.

BECKER, R. M. et al. Nursing care practices for people with Chronic Non communicable Diseases. Rev Bras Enferm [Internet]. 2018; 71(Suppl 6): 2643-9. Disponível em: https://www.scielo.br/j/reben/a/zgFQT3LpQDWXrFwxZRmD7jF/?lang=en. Acesso em: 13 set. 2021.

BOTELHO, L. L. R.; CUNHA, C. C. A.; MACEDO, M. O método da revisão integrativa nos estudos organizacionais. Gestão e sociedade - Belo Horizonte. v. 5. (11) ·p.121136. maio/agosto.2011. ISSN 1980-5756. Disponível em: https://www.gestaoesociedade.org/gestaoesociedade/article/view/1220/906. Acesso em 10 ago. 2021.

BRASIL. Ministério da Saúde. Secretaria de Atenção à Saúde. Departamento de Atenção Básica. Estratégias para o cuidado da pessoa com doença crônica: hipertensão 
arterial sistêmica. Brasília. 2013. 128 p. (Cadernos de Atenção Básica, n. 37) ISBN 978-85-334-2058-8

BRASIL. Ministério da Saúde. Política Nacional de Atenção Básica. Brasília, 2012. 110 p. Disponível em: http://189.28.128.100/dab/docs/publicacoes/geral/pnab.pdf. Acesso em 10 de ago. 2021.

BUENO, P. D. R.; Home care: o que o profissional de enfermagem precisa saber sobre assistência domiciliar. 1 ed., São Paulo, Rideel, 2011.

BUENO, M. C. G.; SILVEIRA, M. B.; REZENDE, H. H. A. Ações da enfermagem no enfrentamento às doenças crônicas: hipertensão e diabetes. Revista Saúde Multidisciplinar. 2019. v. 2. 6a Ed. Disponível em: http://revistas.famp.edu.br/revistasaudemultidisciplinar/article/view/84/8. Acesso em 10 set. 2021.

BARRA, D. C. C. et al. Validação de diagnósticos de enfermagem para consulta de enfermagem na visita domiciliar ao adulto. Rev. Bras. Enferm. 74 (2) • 2021. Disponível em: https://www.scielo.br/j/reben/a/wLftTP59qFv9VwkPY48Kqm/?lang=pt. Acesso em: 13 set. 2021.

CAPELLARI, C.; FIGUEIREDO, A. E. P. L.; Conhecimento e Atitude: perfil de pessoas com diabetes em diálise. Revista de Enfermagem UERJ. Rio de Janeiro, 2020; 28: e 45261. Disponível em: http://dx.doi.org/10.12957/reuerj.2020.45261. Acesso em: 27 ago. 2021

HAN, L. et al. Are home visits an effective method for diabetes management? A quantitative systematic review and meta-analysis. J Diabetes Investig. 2017 Sep;8(5):701-708. doi: 10.1111/jdi.12630. 2017 Mar 11. Disponível em: https://doi.org/10.1111/jdi.12630. Acesso em: 27 ago. 2021.

MOREIRA, R. P. et al. Educação em saúde no domicílio de idosos hipertensos e diabéticos. Rev enferm UFPE on line. 2020;14: e245034. Disponível em: https://doi.org/10.5205/1981-8963.2020.245034. Acesso em: 28 ago. 2021.

MA, Y. et al. Effectiveness of home visiting on patients with hypertension: A systematic review and meta-analysis. Medicine (Baltimore). 2021 Mar 12;100(10): e24072. Disponível em: https://doi.org/10.1097/MD.0000000000024072. Acesso em: 28 ago. 2021.

MARTINS, B. R.; BERTELLI, C.; BORGES, A. M.; Visita domiciliar: atuação do enfermeiro às pessoas com doenças crônicas não transmissíveis. Cad. Saúde Colet. Rio Grande do Sul. 2019. Disponível em: https://publicacoeseventos.unijui.edu.br. Acesso em: 02 set. 2021.

NASCIMENTO, M. A. et al. Á.; Assistência de enfermagem no programa hiperdia: relato de experiência em estágio supervisionado. CuidArte, Enferm. Acre, 11(2): 231238. 2017. Disponível

em: 
https://pesquisa.bvsalud.org/portal/resource/pt/biblio-1027757. Acesso em: 02 set. 2021.

OLIVEIRA, A. L. S. et al. Assistência de enfermagem em atenção domiciliar no nível primário de atenção à saúde. Cadernos de graduação, ciências biológicas e da saúde. Aracaju, v. 4, n. 1, p. 11-22. 2017. Disponível em: https://periodicos.set.edu.br/fitsbiosaude/article/view/3403/2266. Acesso em 26 ago. 2021.

PEREIRA, A. S. et al. Metodologia da pesquisa científica. [e-Book]. Santa Maria. ed. 1. UAB / NTE / UFSM. 2018. Disponível em: https://repositorio.ufsm.br/bitstream/handle/1/15824/Lic_Computacao_Meto dologia-Pesquisa-Cientifica.pdf?sequence=1. Acesso em 26 ago. 2021.

RADIGONDA, B. et al. Avaliação do acompanhamento de pacientes adultos com hipertensão arterial e ou diabetes melito pela Estratégia Saúde da Família e identificação de fatores associados, Cambé-PR, Brasil, 2012. Epidemiologia e Serviços de Saúde. Paraná. v. 25 (1). 2016. Disponível em: https://doi.org/10.5123/S1679-49742016000100012. Acesso em: 02 set. 2021.

SOUZA, E. et al. Educação em saúde a portadores de hipertensão e diabetes na atenção primaria. Revista Nursing. 2018. v. 21. (240). 218-2183. Rio Grande do Sul. Disponível em: http://www.revistanursing.com.br/revistas/240Maio2018/hipertensao_diabetes.pdf. Acesso em: 28 ago. 2021

TAN, S. M. et al. A systematic review of community nursing interventions focusing on improving outcomes for individuals exhibiting risk factors of cardiovascular disease. Journal of Advanced Nursing. v. 76 , ed. 1, Janeiro de 2020. Pag. 47-61. DOI https://doi.org/10.1111/jan.14218. Disponível em: https://pesquisa.bvsalud.org/portal/resource/pt/mdl-31588578. Acesso em: 08 ago. 2021.

VALARISTINO, J. M. et al. Atuação do enfermeiro na atenção domiciliar: revisão narrativa. Artigos.Com. ISSN 2596-0253, vol. 12, 2019. Disponível em: https://www.acervomais.com.br/index.php/artigos/article/view/2567/1094. Acesso em 26 ago. 2021. 


\title{
CAPITULO XXXIV
}

\section{AVALIAÇÃO DAS PRESCRICÕES E DISPENSAÇÕES DE ANTIBIÓTICOS NA FARMÁCIA COMUNITÁRIA NO BAIRRO DA CIDADE OPERÁRIA EM SÃo LUÍS - mA}

DOI: 10.51859/AMPLLA.PAE1993-34

\author{
Sammya Tairine de Oliveira Telemberg ${ }^{1}$ \\ Alamgir Khan ${ }^{2}$ \\ Raquel Maria Trindade Fernandes ${ }^{3}$
}

\begin{abstract}
1 Graduanda Farmácia do Instituto Florence de Ensino Superior - IFES
2 Professor Adjunto do Departamento de Química. Universidade Estadual do Maranhão - UEMA

${ }^{3}$ Professora Adjunta do Departamento de Química. Universidade Estadual do Maranhão - UEMA
\end{abstract}

\section{RESUMO}

Este trabalho avaliou as prescrições e dispensações de antibióticos nas farmácias comunitárias de São Luís - Maranhão, assim como identificou os tipos de prescritores e também quais os antibióticos que tem mais saída num estudo transversal utilizando questionário com 12 perguntas fechadas e abertas. Foram avaliados 1.501 receituários, onde $388(\approx 26 \%)$ receitas foram prescritas por Clínico Geral, e só $315(\approx 21 \%)$ receituários por Pediatras, estas apresentaram um índice elevado de prescrições de antibióticos e observou-se que prescrições com médicos sem especialidades foi de 284 ( $\approx 19 \%)$ receituários. Quanto aos antibióticos que tiveram mais prescrições, a Amoxicilina associada a Clavulonato de Potássio foi a que teve mais saída com $365(\approx 24$ \%) prescrições, Amoxicilina 258 ( $\approx 17 \%$ ) prescrições, Azitromicina 140 ( $\approx$ \%) prescrições, foram observados também em relação às receitas que melhorou a prescrição de medicamentos Genéricos, e que $689(\approx 46 \%)$ receitas não continham o nome do paciente e 1.048 ( $\approx 70 \%)$ não continham a idade e nem sexo do paciente. Através dos dados obtidos, pode-se concluir que os antibióticos são a primeira escolha dos médicos e que a reinfecção ocorre com frequência, podemos também analisar que os medicamentos mais prescritos foram as Amoxicilinas por serem de amplo aspecto, geralmente indicadas para infecção simples como a de garganta e como um pósoperatório.

Palavras-chave: Antibióticos. Dispensação de antimicrobianos. Prescrições de medicamentos Antimicrobianos. 


\section{INTRODUÇ̃̃o}

Antes da existência dos antibióticos, muitas mortes eram causadas por doenças infecciosas, mas com a evolução da ciência, medicamentos capazes de combater o crescimento e em muitos casos erradicar a doença foram desenvolvidos (ALMEIDA, 2011; ANVISA, 2016). Os medicamentos são substancias ou medidas que nus fornecem capacidade de curar, prevenir ou diagnosticar certos tipos de enfermidades, o seu uso adequado é extremamente importante para que os resultados pretendidos sejam alcançados (SILVA, et. al., 2012).

Uso dos antibióticos de forma desordenada pode gerar resistência bacteriana, desta forma desencadeando uma série de complicações como reações alérgicas, havendo uma regressão do estímulo a formação de anticorpos. Assim, os antimicrobianos são os medicamentos mais prescritos pelos hospitais e cerca de $50 \%$ dos casos apontam que este uso seja inapropriado, uma vez que este grupo de medicamentos causam muitas Reações Adversas a Medicamentos (SILVA, 2012a; OLIVEIRA \& DESTEFANI, 2011).

Neste sentido, é certo que todo medicamento seja obtido com a prescrição médica, tal medida é fundamental para que não ocorra possíveis complicações futuras ao estado de saúde do paciente (SILVA, 2012b). As farmácias são os principais locais destinados a dispensação de medicamento, onde o profissional farmacêutico é responsável pela liberação do medicamento, agindo o mesmo com devida segurança na hora de repassar as corretas informações ao paciente, sobre o seu uso, observando o que está prescrito pelo médico (ARRAIS, et. al., 2007).

Respaldados pela publicação, em 5 de maio de 2011, a Anvisa publicou a RDC no 20, com intuito de racionalizar a população que esta classe medicamentosa poderia não só causar danos à saúde se utilizado de forma errada, como também, fortalecer a bactéria a ser tratada. Segundo a resolução, o medicamento antibiótico deveria ser prescrito em receituário de duas vias, sendo uma delas retidas no estabelecimento comercial farmacêutico. Assim contendo dados relativos ao comprador, este receituário possibilita um rastreamento e controle de medicamento dispensado, que deve ser aquele indicado pelo prescrito ou o seu equivalente genérico na quantidade, posologia e duração do tratamento (ANVISA, 2011). 
A Organização Mundial de Saúde (OMS) conceitua os antimicrobianos como, medicamentos apropriados, em doses, período adequado e pelo menor custo para si e para a sociedade (SILVA, 2012a).

A não observância do que está previsto no receituário é a consequente liberação da medicação incorreta, daquele identificado no receituário, implica no erro de dispensação, onde o mesmo poderá gerar graves problemas ao paciente. Geralmente tais erros, são cometidos por um profissional farmacêutico, devendo este proceder com integra responsabilidade e segurança ao dispensar qualquer tipo de medicamento, contribuindo assim, portanto, com a diminuição dos erros provenientes destes profissionais (ANACLETO, et. al., 2006; CONSENDEY, et. al., 2000).

O aperfeiçoamento das prescrições com a informatização é uma forma legível de dispensação consciente, de uma forma que tanto o prescrito entenda a receita com o paciente e o dispensador, para não ocorrer na dispensação, principalmente nos antimicrobianos de acordo com o tempo, e a posologia adequada para não criar casos de cepas resistentes. Devido a intercambia idade do medicamento estes só podem ser substituídos pelo de referência para o genérico e vice-versa, e o similar pelo similar, e isto só poderá acontecer se no receituário de forma legível o médico não prescreva: "os medicamentos prescritos não devem ser trocados na farmácia" (FREIRE, 2004; SILVA, 2012a).

É importante ressaltar a descrição que Anacleto produziu a respeito do tema trabalhado neste projeto: "falha na dispensação significam o rompimento de um dos últimos elos na segurança do uso dos medicamentos. Mesmo considerando que grande parte não cause danos ao paciente, os erros de dispensações demonstram fragilidade no processo de trabalho e indicam uma relação direta com risco maior de ocorrências de acidentes graves" (BRASIL, 2001; GRISOTO \& SILVA, 2006).

Assim, o objetivo deste trabalho foi avaliar as prescrições e dispensação de antibióticos na farmácia comunitária no bairro da Cidade Operaria em São Luís do Maranhão, identificando os antibióticos mais prescritos, qual a especialidade do profissional que prescreveu, se nesses receituários continham idade, sexo e nome dos pacientes. 


\section{METODOLOGIA}

O presente trabalho tratou-se de um estudo descritivo de natureza quantitativa, no qual foi realizada uma coleta de dados dos seguintes itens : nome do paciente, idade e sexo do paciente, durante um período de 4 anos sobre o antibióticos na farmácia comunitária da Cidade Operária em São Luís -MA, nos anos de janeiro de 2012 à dezembro de 2015 . Foram coletadas 1,502 receitas, em busca dos medicamentos mais prescritos e com os dados do paciente.

\section{RESULTADOS E DISCUSSÕES}

Nos meses de janeiro de 2012 a dezembro 2015 foram aplicados questionários com as seguintes questões: Posologia, nome do medicamento, se é Genérico, Similar ou Referência, e quais os mais dispensados.

Na Tabela 1 observa-se as especialidades médicas responsáveis pela prescrição de medicamentos antibióticos observados nos receituários atendidos na farmácia comunitária da Cidade Operária em São Luís -MA. Nota-se que um conjunto de outras especialidades como dentistas, veterinários e outros, caracterizaram um índice de 388 prescrições (cerca de $26 \%$ ) contendo antibióticos.

Tabela 1 - Especialidades médicas responsáveis pela prescrição de medicamentos antibióticos observados nos receituários atendidos na farmácia comunitária da Cidade Operária em São

\begin{tabular}{ccc} 
& Luís -MA & \\
\hline Especialidade Médica & $\mathrm{n}$ & $\%$ \\
\hline Clínico Geral & 284 & 18,9 \\
Dermatologia & 114 & 7,6 \\
Ginecologia & 206 & 13,7 \\
Neurocirurgia & 34 & 2,3 \\
Pediatria & 315 & 21,0 \\
Pneumologia & 105 & 7,0 \\
Urologia & 55 & 3,7 \\
Outras especialidades & 388 & 25,8
\end{tabular}

Fonte: Autoria própria.

As Tabela 2 e 3 apresentam o tempo de terapêutica em quantidade de dias e a posologia, respectivamente em que os pacientes fizeram uso dos medicamentos. Observa-se que há um elevado índice, tanto no período de tratamento que é o de $0-7$ 
dias ( $\approx 15 \%$ ) e da posologia de $4 x$ ao dia ( $\approx 42 \%)$. De acordo com Oliveira e Destefani, a duração do tratamento, quando ausente na prescrição, pode levar à utilização do medicamento por um período de tempo além ou aquém do necessário, podendo acarretar gastos desnecessários, desconforto para o usuário, intoxicação medicamentosa ou mesmo a não obtenção dos efeitos terapêuticos desejados (OLIVEIRA \& DESTEFANI, 2011).

Tabela 2 - Tempo de terapêutica de medicamentos antibióticos observados nos receituários atendidos na farmácia comunitária da Cidade Operária em São Luís -MA

\begin{tabular}{ccc}
\hline Tempo de Terapêutica (dias) & $\mathbf{n}$ & $\%$ \\
\hline $0-3$ & 219 & 14,6 \\
$3-7$ & 280 & 18,7 \\
$7-14$ & 450 & 30,0 \\
$14-21$ & 365 & 24,3 \\
+21 dias & 187 & 12,4 \\
\hline
\end{tabular}

Fonte: Autoria própria.

Tabela 3 - Posologia dos medicamentos antibióticos observados nos receituários atendidos na farmácia comunitária da Cidade Operária em São Luís -MA

\begin{tabular}{ccc}
\hline Posologia (intervalo entre doses) & $\mathbf{n}$ & $\%$ \\
\hline $1 \times(24 / 24 \mathrm{~h})$ & 165 & 11,0 \\
$2 \times(12 / 12 \mathrm{~h})$ & 264 & 17,6 \\
$3 \times(8 / 8 \mathrm{~h})$ & 438 & 29,2 \\
$4 \times(6 / 6 \mathrm{~h})$ & 634 & 42,2 \\
\hline
\end{tabular}

Fonte: Autoria própria.

A Tabela 4 apresenta os medicamentos mais prescritos. Observou-se um número elevado de prescrições dos medicamentos antibióticos Amoxicilina associada a Clavulonato de Potássio e Amoxicilina, talvez por terem amplo espectro de ação em relação as infecções bacterianas. De acordo com Freitas et. al. e Lucena et. al., os medicamentos mais prescritos no âmbito da farmácia comunitária é o Ciprofloxacino, seguido pela cefalexina e as amoxicilinas, de acordo com o enfoque dos dispensários farmacêuticos analisados, uma vez que estes medicamentos são mais utilizados no tratamento de infecções do trato geniturinário (FREITAS, et. al., 2016; LUCENA, et. al., 2016). 
Tabela 4 - Medicamentos antibióticos observados nos receituários atendidos na farmácia comunitária da Cidade Operária em São Luís -MA

\begin{tabular}{ccc}
\hline Medicamento & $\mathbf{n}$ & $\%$ \\
\hline Amoxicilina & 258 & 17,2 \\
Amoxicilina + Clavulonato de Potássio & 365 & 24,3 \\
Azitromicina & 140 & 9,3 \\
Cefadroxila & 116 & 7,7 \\
Cefalexina & 128 & 8,5 \\
Levofloxacino & 36 & 2,4 \\
Morfloxacino & 79 & 5,3 \\
Norfloxacino & 136 & 9,1 \\
Rifamicina & 23 & 1,5 \\
Outras especialidades & 220 & 14,7 \\
\hline
\end{tabular}

Fonte: Autoria própria.

A Tabela 5 apresenta a forma nominal como os medicamentos antibióticos são prescritos, onde observa-se que 665 ( $\approx 44 \%$ ) prescrições continham o nome da substância a ser tomada, ou seja, o nome Genérico. Este resultado está em desacordo com os estudos de Silva et. al., onde foi relatado que mais de $70 \%$ das prescrições estudadas apresentaram o nome Genérico, $25 \%$ apresentam nome comercial e $5 \%$ com o nome similar. Porém, ainda é a forma de designação mais significativa encontrada nos receituários analisados (SILVA, et. al., 2012).

Tabela 5 - Forma nominal dos medicamentos antibióticos observados nos receituários atendidos na farmácia comunitária da Cidade Operária em São Luís -MA

\begin{tabular}{ccc}
\hline Forma nominal & $\mathbf{n}$ & $\%$ \\
\hline Genérico & 655 & 43,6 \\
Referência & 464 & 30,9 \\
Similar & 382 & 25,5 \\
\hline
\end{tabular}

Fonte: Autoria própria.

Quanto à presença do nome do paciente e a idade e sexo do paciente, foram analisadas 1.501 receituários e dentre eles 689 ( $\approx 46 \%)$ receituários não continham o nome do paciente e $1.048(\approx 70 \%)$ receituários não continham nem o sexo e nem a idade do paciente, colocando em questão que estes dados são de suma importância e relevância para o cadastro destas receitas junto ao controle do Sistema Nacional de 
Gerenciamento de Produtos Controlados - SNGPC, site no qual são lançados os dados do paciente e de seu prescritor para um controle dos medicamentos em questão.

O estudo mostrou que há um grande índice de antibióticos dispensados nas farmácias e que quase sempre estes vêm só na receita, e os mais dispensados são as Amoxicilinas, e muitos dos prescritores não se atentam para preencher a receita de forma correta com nome, idade e sexo do paciente, que é exigido por lei (RDC 20 DE 2011 ANVISA), e que esta mesma tem brechas para que o dispensador colete estes dados.

Em estudos passados mostrou-se que havia uma resistência dos médicos quanto a prescrição dos medicamentos Genéricos, mais podemos observar que isto está mudando pois conforme observamos na Tabela 5, a forma de prescrição com o nome do medicamento Genérico foi a mais proeminente. Foi observado o tempo do tratamento e a posologia, que alterada quanto as outras apresentações de antibióticos como a Azitromicina, e que muitos dos prescritores são Clínicos Gerais e Pediatras, na maioria das vezes estes escolhem os medicamentos sem exames prévios antes das prescrições, e que embora seja errado, estes pacientes podem retornar ao médico com o mesmo tipo de infecção e acabar utilizando medicamento em excesso, além de possibilitar resistência bacteriana.

Esses médicos que não tem especialidades definidas como Clínico Geral, prescrevem com muita frequência antibióticos, devido ao fato dos mesmos atuarem em emergências, onde há um fluxo exacerbado de pacientes e onde muita da vezes não há uma avaliação criteriosa quanto a fisiologia e patologia do paciente, acarretando em sérios danos para o paciente e para a infecção deste.

Observou-se que especialidades como Ginecologia e a Dermatologia avaliam o paciente mais criteriosamente, o que reflete numa menor frequência de prescrição de antibióticos, evitando assim o retorno do paciente e a resistência bacteriana.

\section{CONSIDERAÇÕES FINAIS}

O presente trabalho permitiu identificar alguns erros nos receituários médicos. Os antibióticos são a primeira escolha de médicos e a reinfecção ocorre com frequência, podemos também analisar que os medicamentos mais prescritos foram as amoxicilinas por terem amplo espectro de ação em relação as infecções, tanto simples como graves. 
Com um número elevado de prescrições feitas por Pediatras deixou claro que há um número grande de crianças usando antibióticos. A maioria desses profissionais prescrevem medicamentos e não colocam os dados pessoais dos pacientes, e a posologia do medicamento muita das vezes fica duvidosa, prescrevem medicamentos com miligramas que se quer existem, e muitos dos casos não colocam a duração do tratamento que em relação aos antimicrobianos que é muito importante.

Neste sentido, há necessidade desses prescritores colocarem os dados pessoais dos pacientes, colocar com clareza a posologia , o período do tratamento, compreender como profissional da saúde o que o paciente tem, para não sair prescrevendo antibióticos em grande escala, porque estes causam também grandes riscos a seus usuários, pela resistência que essas bactérias pode ter, assim concluir-se que os tratamentos com antibióticos, tem que ser de acordo com o grau de infecção, e devem ser avaliados com todo o critério e para que não haja uma reinfecção.

\section{REFERÊNCIAS}

ALMEIDA, E.S.B. de. Uso profilático e terapêutico de antimicrobianos em pacientes pediátricos. Universidade Estadual da Paraíba, 2011.

ANACLETO, T.A; PERINI, E; ROSA, M.B. Prevenindo erros de dispensacões em farmácias hospitalares. Inframa.Brasilia.2006; 18(7-8).

ANVISA. Agência Nacional de Vigilância Sanitária. Disponível em: <http://portal.anvisa.gov.br/antibioticos> Acesso em 18/07/2021.

ARRAIS, P.S.D; BARRETO, M.L; COELHO, H.L.L; Aspectos dos processos de prescrições e dispensações de medicamentos na percepção do paciente: estudo de base populacional em Fortaleza, Ceará, Brasil. Cad. Saúde Pública. Rio de Janeiro. 2007 Abr; 23(4):927-37.

BRASIL. Conselho Federal de Farmácia (CFF). Resolução no 357, 20 abr. 2001. Aprova o regulamento técnico das Boas Práticas de Farmácia. [Acessado em 17 de abr. 2016]. Disponível em: <http://www.cff.org.br/legis/legis.html> Acesso em $18 / 07 / 2021$.

COSENDEY, M.A.E; BERMUSEZ, J.A.Z; REIS, A.L.A; SILVA, H.F; OLIVEIRA, M.A; LUIZA, V.L. Assistência farmacêutica na atenção básica de saúde: a experiência de três estados brasileiros. Cad Saúde Pública. Rio de Janeiro.2000 Jan-Mar; 16(1): 17182.

FREIRE, C.C. et.al. Análise de Prescrições Informatizada em duas Clínicas de um Hospital Universitário. Medicina, Ribeirão Preto, 37: 91 - 96. Jan/Jun. 2004. 
FREITAS, A. V; OLIVEIRA C. G. A; FUMIAN, L. Avaliação das prescrições de antibióticos entre os diferentes dispensários farmacêuticos no município de natividade, RJ. Acta Biomédica Brasiliensia / Volume 6/ no 2/ Dezembro de 2015.

GRISOTO, E; SILVA, P.V. A prescrição de medicamento em um município do norte do Paraná. Rev Bras Epidemiol.2006; 9(2): 226-34.

LUCENA, N. P; ARAÚJO, V. R; ARAÚJO, L.L.N. Levantamento das prescrições de antimicrobianos dispensadas na farmácia básica, no município de niquelândiaGO. $2016 . \quad$ Disponível em www.fasem.edu.br/revista/index.php/fasemciencias/article/download/80/ 120. Acesso em 18/07/2021.

OLIVEIRA, K. R. Destefani, S.R.A. Perfil da prescrição e dispensação de antibióticos para crianças em uma Unidade Básica de Saúde (USB) no município de ljuí- RS. Rev. Cienc. Farm. Apl., 2011; 32(3): $395-401$.

SILVA ,E. R.B; BANDEIRA, V. A. C; OLIVEIRA , K. R. Avaliação das prescrições dispensadas em uma farmácia comunitária no município de São Luiz Gonzaga - RS. Rev Ciênc Farm Básica Apl., 2012;33(2):275-281.

SILVA, E.R.M.; Análise do perfil das prescrições de antimicrobianos na clínica médica de um hospital público do Pará. Rev. Bras. Farm. Hosp. Serv. Saúde. São Paulo. v.3 n.2 15 - 19 abr./ jun. 2012.

SILVA, S.M. Avaliação das prescrições em farmácia comunitária universitária [Tese de Mestrado]. Araraquara, SP: Universidade Estadual Paulista ;2012. 


\title{
CAPITULO XXXV
}

\section{CARACTERIZAÇÃO EPIDEMIOLÓGICA DOS CASOS DE DENGUE NO ESTADO DO MARANHÃO ENTRE OS ANOS DE 2015 A 2020}

\author{
DOI: $10.51859 /$ AMPLLA.PAE1993-35
}

Lanielle de Sousa Brito Oliveira ${ }^{1}$
Lucas Rafael Uchôa $^{2}$

\begin{abstract}
1 Graduada em Licenciatura em Ciências Biológicas pelo Instituto Federal de Educação, Ciência e Tecnologia do Piauí - IFPI

${ }^{2}$ Mestrando pelo Programa de Pós-graduação em Biodiversidade, Meio Ambiente e Saúde pela Universidade Estadual do Maranhão - UEMA
\end{abstract}

\section{RESUMO}

Nos últimos anos, o Brasil apresentou aumento no número de casos notificados de dengue. Os fatores demográficos, sociais, ambientais e ecológicos estão diretamente associados à incidência ou surtos de dengue. O aumento no índice de desmatamento, falta de saneamento e mudanças climáticas estão relacionados ao aumento nos números de casos. O presente estudo objetivou analisar os casos de dengue no estado do Maranhão entre os anos de 2015 a 2020. Estudo epidemiológico do tipo ecológico realizado por meio da utilização de dados do Sistema de Informação sobre Agravos de Notificação do Ministério da Saúde, entre os anos de 2015 a 2020. As variáveis estudadas incluíram aspectos sociodemográficos e variáveis clínicas. Com base nos dados coletados, foram notificados 49.747 casos de dengue no estado do Maranhão, confirmados principalmente através dos critérios clínico-epidemiológicos (55\%) do total de casos, não sendo especificada a classificação do sorotipo na maioria das notificações. Quando se trata dos percentuais relacionados ao gênero, a maior parte dos casos notificados foram por pessoas do sexo feminino (56\%), quanto à faixa etária houve prevalência de pessoas de 20 a 39 anos (37\%). Os demais dados foram expostos através de mapas, tabelas e gráficos. Com os resultados obtidos, observou-se elevado número de casos de dengue no estado e número considerável de óbitos, tal resultado desperta atenção e faz-se relevante no que concerne ao acompanhamento epidemiológico e estratégias de controle da doença no Maranhão.

Palavras-chave: Epidemiologia. Dengue. Maranhão. 


\section{INTRODUÇÃO}

A dengue é uma das doenças causadas por mosquitos mais difundidas mundialmente (KHETARPAL; KHANNA, 2016). A infecção por dengue pode resultar em uma síndrome semelhante à gripe leve, conhecida como dengue, até a síndrome do choque da dengue com risco de vida ao indivíduo acometido (HARAPAN et al., 2020).

A dengue pode ser causada por quatro sorotipos DENV (DENV1-4), transmitidos pelos mosquitos Aedes aegypti (KATZELNICK; COLOMA; HARRIS, 2017). Ao ser infectado pela primeira vez, o indivíduo pode desenvolver febre alta com erupção cutânea ou dor de cabeça e dores nos olhos, articulações, músculos ou ossos, porém, em caso de nova infecção por outro sorotipo o risco de desenvolver dengue grave aumenta, podendo haver complicações fatais (MACIEL-DE-FREITAS; VALLE, 2014).

Por ser uma infecção sistêmica e dinâmica com manifestações clínicas graves e não graves, a dengue tem sido bastante estudada (SALLES et al., 2018). Vários estudos foram realizados para determinar os fatores associados à alta incidência de dengue em determinadas regiões e aspectos demográficos, ambientais, sociais e ecológicos estão associados à incidência ou surtos de dengue (HARAPAN et al., 2020).

O aumento no índice de desmatamento, falta de saneamento e mudanças climáticas estão relacionados ao aumento nos números de casos (MACIEL-DE- FREITAS; VALLE, 2014). No Brasil, três em cada quatro municípios estão fortemente infestados pelo mosquito Ae. aegypti (SALLES et al., 2018). Grandes surtos de dengue costumam ser observados após períodos chuvosos e quentes, principalmente em áreas urbanas (TEIXEIRA et al., 2009).

Devido à ausência de prevenção e tratamento adequado da dengue no Brasil, o número de casos notificados da doença no país aumentou nos últimos anos (SALLES et al., 2018). A identificação precoce dos casos de dengue é imprescindível para a tomada de decisões e implantação de medidas, visando principalmente evitar a ocorrência de óbitos (BRASIL, 2013).

Diante da importância da dengue, sua incidência associada aos fatores mencionados e de sua ampla ocorrência nos diversos municípios brasileiros, o presente estudo objetivou analisar os casos de dengue no estado do Maranhão nos últimos anos, especificamente entre os anos de 2015 a 2020. 


\section{REVISÃO BIBLIOGRÁFICA}

A dengue é causada por quatro sorotipos DENV (DENV1-4), transmitidos pelos mosquitos Aedes aegypti, que picam durante o dia e Aedes Albopictus (KATZELNICK; COLOMA; HARRIS, 2017). Os sorotipos da dengue são transmitidos em áreas urbanas (ciclo de transmissão humana) e florestais (ciclo de transmissão silvestre); os principais vetores da transmissão humana são Ae. aegypti e Ae. albopictus (KHETARPAL; KHANNA, 2016). A distribuição de Ae. aegypti e Ae. albopictus é comum em todo o Brasil, com Ae. aegypti ocorrendo amplamente em ambientes urbanos e reproduzindo-se em recipientes artificiais, o Ae. albopictus é mais encontrado em ambientes rurais e periurbanos (KRAEMER et al., 2015).

As manifestações clínicas da dengue podem variar de assintomática a uma ampla gama de síndromes com manifestações clínicas graves (KHETARPAL; KHANNA, 2016). Além disso, a infecção pode evoluir em fases: uma fase crítica febril com sintomas de febre hemorrágica, conhecida como febre hemorrágica da dengue, e síndrome do choque da dengue (SALLES et al, 2018). Os sintomas debilitantes da dengue incluem febre alta, artralgia, mialgia, anorexia, petéquias/erupção cutânea e dor retro-orbitária (KATZELNICK; COLOMA; HARRIS, 2017).

Devido a remissão ou agravamento dos sintomas no que concerne a manifestação da dengue, a reavaliação e observação dos casos de dengue são importantes para que as intervenções sejam oportunas e para que não ocorram óbitos (BRASIL, 2016). O diagnóstico laboratorial junto com a perspicácia clínica é fundamental para a redução de casos de óbitos pela doença (KATZELNICK; COLOMA; HARRIS, 2017). Os casos graves, geralmente, ocorrem pelo extravasamento plasmático, portanto, a observação cuidadosa e o uso racional de líquidos intravenosos são essenciais; outras manifestações clínicas indicam gravidade, tais como hemorragias graves e comprometimento grave de órgãos (BRASIL, 2016).

No Brasil, as esferas de governo federal, estadual e municipal compartilham a responsabilidade pelo controle da dengue (MACIEL-DE-FREITAS; VALLE, 2014), que se centra principalmente na conscientização acerca combate a criadouros de mosquitos e disseminação de informações sobre os sinais e sintomas da doença para facilitar a 
chegada mais rápida aos serviços de saúde para diagnóstico precoce e tratamento das formas graves da doença (SALLES et al., 2018).

\section{MÉTODO}

O presente trabalho trata-se de um estudo epidemiológico do tipo ecológico, de abordagem quantitativa e qualitativa, realizado por meio e análise de dados secundários, visto que na visão de Gil (2002) o estudo exploratório e documental visa buscar informações como, por exemplo, dados brutos colhidos de um relatório a fim de levantar informações acerca de um dado assunto pertinente ao objetivo do estudo.

Os dados foram obtidos através da utilização das ocorrências registradas no Sistema de Informação sobre Agravos de Notificação (SINAN) do Ministério da Saúde. Os dados pesquisados foram referentes informações sobre casos de dengue no estado do Maranhão.

Posteriormente as informações obtidas foram submetidas à análise estatística descritiva, sendo realizada a tabulação de dados primários através do sistema Microsoft Office Excel, que, posteriormente, foram dispostos através de tabelas e gráficos para melhor compreensão das informações agrupadas com base nos dados obtidos sobre a progressão dos casos de dengue considerando o período de notificações de 2015 até 2020. As variáveis estudadas incluíram aspectos sociodemográficos como sexo, faixa etária, raça, zona de residência e variáveis clínicas como mês de notificação, classificação, casos autóctones, forma grave e óbitos.

\section{RESULTADOS E DISCUSSÃO}

Com base nos dados coletados, foram notificados 49.747 casos de dengue para o estado do Maranhão, com picos principalmente nos meses de fevereiro, março e abril (Fig. 1). Caracterizado como um período com mudanças de temperatura e regime de chuvas, o que contribui para uma maior abundância e disseminação de vetores patogênicos, no caso a dengue (CONFALONIERI; MARINHO, 2007), uma vez que o mosquito transmissor da dengue não consegue sobreviver a regiões frias (COSTA, 2001). Mas as ocorrências não se restringem a alguns meses, uma vez que características 
climáticas do país apresentam condições para a proliferação do mosquito durante todo o ano (BRASIL, 2002).

Figura 1 - Progressão do número de casos por mês.

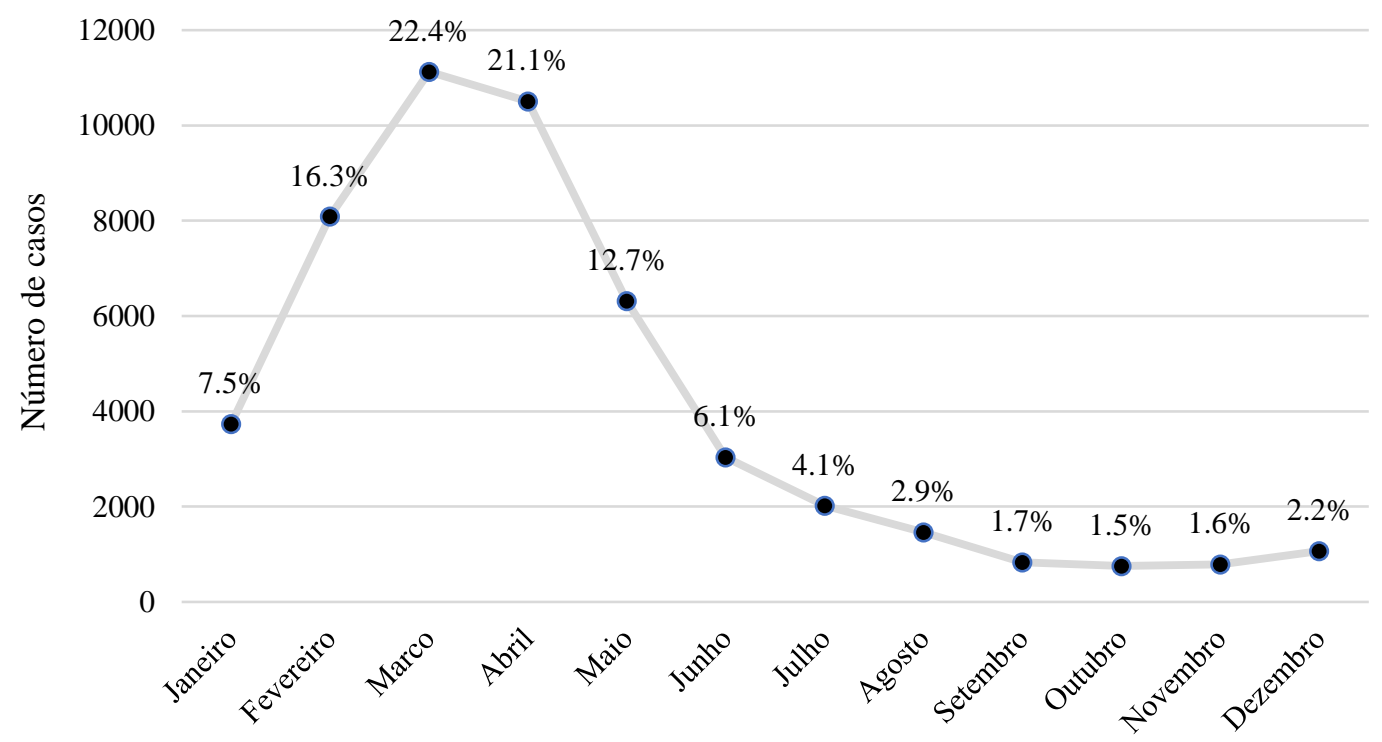

Fonte: Ministério da Saúde/SVS - Sistema de Informação de Agravos de Notificação - Sinan Net.

No estado em 2016, foram notificados 23.938 casos prováveis de dengue, um aumento de 197 \% em comparação a 2015 com 8.062 notificações registradas. Já em 2017 foram notificados 7.229 casos, observando assim, um maior controle da doença, com redução de 231,1 \% de casos prováveis em relação a 2016.

Os casos foram confirmados principalmente através dos critérios clínicoepidemiológicos (55\%), não sendo especificada a classificação do sorotipo na maioria das notificações (Fig. 2). Divergindo do sugerido por Oliveira e Oliveira (2019) pois na maioria dos casos, os sintomas da dengue podem ser parecidos com outras doenças como gripe, influenza, outras infecções, por isso, para a confirmação do diagnóstico, devem ser feitos exames laboratoriais específicos. 
Figura 2 - Metodologias utilizadas para diagnosticar os casos registrados de dengue.

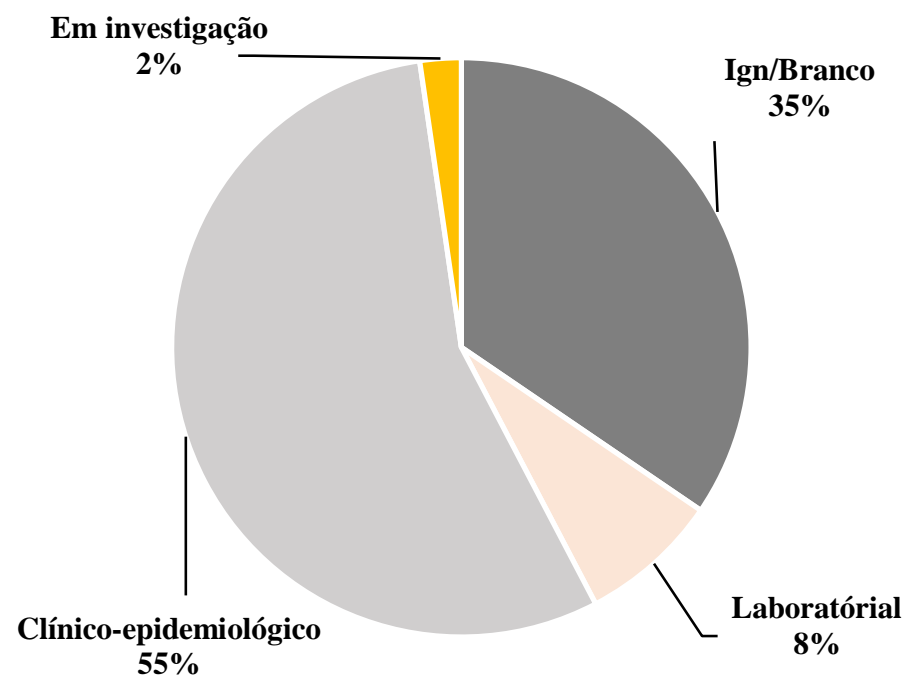

Fonte: Ministério da Saúde/SVS - Sistema de Informação de Agravos de Notificação - Sinan Net.

Nos percentuais relacionados ao gênero, a maior parte dos casos notificados foram por pessoas do sexo feminino (56\%). Quanto à faixa etária houve prevalência de pessoas de 20 a 39 anos (37\%), seguida da faixa etária de 40 a 59 anos (19\%) (Fig. 3), corroborando com (e. g. FANTINATI et al., 2013; ASSUNÇÃO; AGUILAR, 2014), no entanto Santos et al. (2009) destaca que a dengue não possui um comportamento preferencial para ocorrência por idade.

Figura 3 - Total de casos confirmados de dengue por faixa etária e sexo.

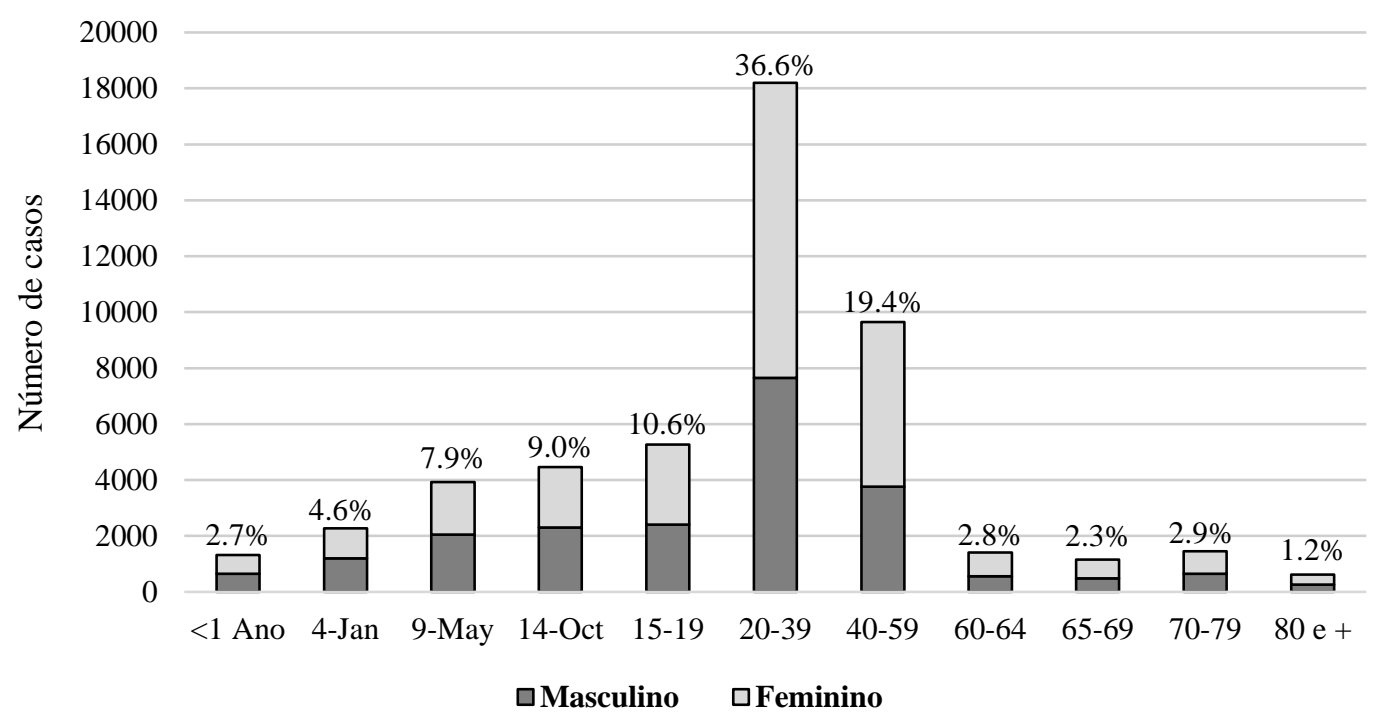

Fonte: Ministério da Saúde/SVS - Sistema de Informação de Agravos de Notificação - Sinan Net. 
Na evolução, a maioria dos casos chegaram à cura (61\%), seguida do não preenchimento (39\%) e cerca de $11 \%$ dos casos precisaram de hospitalização e, por fim, foram registrados 42 óbitos pelo agravo (Tab. 1). Segundo Furtado et al., (2019), não existe tratamento específico contra o vírus da dengue, contudo é indicado uma forma de tratar baseada em hidratação e medicação sintomática. Porém em alguns casos fazse necessária a internação para hidratação endovenosa, tratamento na UTI nos casos graves.

Tabela 1 - Evolução dos casos de dengue entre 2015 a 2020 no Estado do Maranhão.

\begin{tabular}{ccccccc}
\hline $\begin{array}{c}\text { Ano } \\
\text { notificação }\end{array}$ & $\begin{array}{c}\text { Ign/ } \\
\text { Branco }\end{array}$ & Cura & $\begin{array}{c}\text { Óbito pelo agravo } \\
\text { notificado }\end{array}$ & $\begin{array}{c}\text { Óbito por } \\
\text { outra causa }\end{array}$ & $\begin{array}{c}\text { Óbito em } \\
\text { investigação }\end{array}$ & Total \\
\hline 2015 & 3.003 & 5.039 & 14 & 3 & 3 & 8.062 \\
2016 & 11.442 & 12.480 & 11 & - & 5 & 23.938 \\
2017 & 1.701 & 5.520 & 4 & 3 & 1 & 7.229 \\
2018 & 526 & 1.648 & 3 & 1 & 7 & 2.185 \\
2019 & 1.734 & 3.989 & 5 & 1 & - & 5.729 \\
2020 & 924 & 1.675 & 5 & - & - & 2.604 \\
Total & 19.330 & 30.351 & 42 & 8 & 16 & 49.747 \\
\hline
\end{tabular}

Fonte: Ministério da Saúde/SVS - Sistema de Informação de Agravos de Notificação - Sinan Net.

A falta de condição sanitária favorece o surgimento de potencial criadouro do Ae. aegypti. A necessidade da utilização da água para higiene corporal, domiciliar e até mesmo manipulação de alimentos leva a população ao armazenamento de água em recipientes desfavoráveis ou inapropriados, tipo tonel, que por não conseguir a total vedação facilita a reprodução do vetor (TAUIL, 2002; BARCELLOS et al., 2005; CAPRARA et al., 2009).

Apesar das ações de prevenção, os esforços de controle, notadamente, não conseguiram travar a crescente incidência de epidemias de dengue e a expansão da distribuição geográfica de transmissão endêmica (BHATT et al., 2013). Fatores como níveis elevados de precipitação, temperatura, proximidades de periferias urbanas e baixa renda estão associados a um maior risco de dengue (BHATT et al., 2013). 


\section{CONSIDERAÇ̃̃ES FINAIS}

Com os resultados obtidos, observou-se elevado número de casos de dengue no estado e número considerável de óbitos, tal resultado desperta atenção e faz-se relevante no que concerne ao acompanhamento epidemiológico e estratégias de controle da doença no Maranhão. Tais evidências reforçam a importância da adoção das práticas de prevenção da dengue, especialmente no período chuvoso no qual há mais incidência da doença e, desse modo, evitá-la bem como outras doenças causadas por mosquitos.

\section{REFERÊNCIAS}

ASSUNÇÃO, M. L.; AGUIAR, A. M. M. Perfil clínico-epidemiológico da dengueno Município de Juscimeira-MT. Revista de Epidemiologia e Controle de Infecção, v. 4, n. 4, p. 249-253, 2014.

BARCELLOS, C.; PUSTAI, A. K.; WEBER, M. A.; BRITO, M. R. V. Identificação

de locais com potencial de transmissão de dengue em Porto Alegre através de técnicas de geoprocessamento. Revista da Sociedade Brasileira de MedicinaTropical, v. 38, p. 246-250, 2005.

BHATT, S.; GETHING, P. W.; BRADY, O. J.; MESSINA, J. P.; FARLOW, A. W.;

MOYES, C. L.;...; HAY, S. I. The global distribution and burden of dengue. Nature,v. 496, n. 7446, p. 504-507, 2013.

BRASIL. Ministério da Saúde (2002). Dengue: aspectos epidemiológicos, diagnóstico e tratamento. Fundação Nacional de Saúde. Brasília, 2002.

. Ministério da Saúde (2013). Secretaria de Vigilância em Saúde. DiretoriaTécnica de Gestão. Dengue: diagnóstico e manejo clínico: adulto e criança / Ministério da Saúde, Secretaria de Vigilância em Saúde, Diretoria Técnica de Gestão. 4. ed. Brasília: Ministério da Saúde, 2013. 80 p.

Ministério da Saúde (2016). Secretaria de Vigilância em Saúde. Departamento de Vigilância das Doenças Transmissíveis. Dengue: diagnóstico e manejo clínico: adulto e criança [recurso eletrônico] / Ministério da Saúde, Secretariade Vigilância em Saúde, Departamento de Vigilância das Doenças Transmissíveis. - 5. ed. - Brasília: Ministério da Saúde, 2016. 58 p.

CAPRARA, A.; LIMA, J. W. O; MARINHO, A. C. P.; CALVASINA, P. G.; LANDIM, L. P.; SOMMERFELD, J. Irregular water supply, household usage and dengue: a bio-social study in the Brazilian Northeast. Cadernos de saude publica, v.25, p. S125-S136, 2009. 
CONFALONIERI, U. E. C.; MARINHO, D. P. Mudança climática global e saúde:perspectivas para o Brasil. Revista Multiciência, v. 8, p. 48-64, 2007.

COSTA, M. A. R. A ocorrência do Aedes aegypti na Região Noroeste do Paraná:Um estudo sobre a epidemia da dengue em Paranavaí-1999, na perspectiva da Geografia Médica. 2001. Dissertação (Mestrado em Área de Concentração Desenvolvimento Regional e Planejamento Ambiental). Conselho de Pós-Graduaçãoem Geografia da Universidade Estadual Paulista, 2001.

FANTINATI, A. M. M.; SANTOS, A. C. A. S.; INUMARU, S. S.; VALÉRIO, V. T. D.; FANTINATI, M. S. Perfil epidemiológico e demográfico dos casos de dengue na região central de Goiânia-Goiás: de 2008 a março de 2013. Tempus Actas de SaúdeColetiva, v. 7, n. 2, p. 107-119, 2013.

FURTADO, A. N. R., LIMA, A. S. F., OLIVEIRA, A. S. de., TEXEIRA, A. B., FERREIRA, D. S., OLIVEIRA, E. C., CAVALCANTI, G. B., SOUSA, W. A.; LIMA, W. M. Dengue e seus avanços. Rev. bras. anal. clin, p. 196-201, 2019.

GIL, A. C. Como elaborar projetos de pesquisa. 4 ed. São Paulo: Atlas S. A, 2002.HARAPAN, H.; MICHIE, A.; SASMONO, R. T.; IMRIE, A. Dengue: A Minireview. Viruses, v. 12, n. 8, p. 829, 2020.

KATZELNICK, L C.; COLOMA, J.; HARRIS, E. Dengue: knowledge gaps, unmetneeds, and research priorities. The Lancet Infectious Diseases, v. 17, n. 3, p. e88- e100, 2017.

KHETARPAL, N.; KHANNA, I. Febre da dengue: causas, complicações eestratégias de vacinas. Journal of immunology research, 6803098, 2016.

KRAEMER, M. U. G.; SINKA, M. E.; DUDA, K. A.; MYLNE, A. Q. N.; SHEARER, F.M.; BARKER, C. M.; ...; HAY, S. I. A distribuição global dos vetoresarbovírus Aedes aegypti e Ae. albopictus. elife. v.4, e11285, 2015.

MACIEL-DE-FREITAS, R., VALLE, D. Desafios encontrados usando medidas decontrole de vetores padrão para dengue em Boa Vista, Brasil. Bull World Health Organ. 2014; v. 92, n. 9, p. 685-689.

OLIVEIRA, R. M.; OLIVEIRA, L. R. M. Epidemiologia da Dengue: análise em diversas regiões do Brasil. EsSEX: Revista Científica, v. 2, n. 2, p. 32-44, 2019.

SALLES, T. S.; ENCARNAÇÃO SÁ-GUIMARÃES, T.; DE ALVARENGA, E.; GUIMARÃES-RIBEIRO, V.; DE MENESES, M.; DE CASTRO-SALLES, P. F.;...; MOREIRA, M. F. History, epidemiology and diagnostics of dengue in the Americanand Brazilian contexts: a review. Parasites \& vectors, v. 11, n. 1, p. 1-12, 2018.

TAUIL, P. L. Aspectos críticos do controle do dengue no Brasil. Cadernos deSaúde Pública, v. 18, p. 867-871, 2002.

TEIXEIRA, M. G.; COSTA, M. C. N.; BARRETO, F.; BARRETO, M. L. Dengue: vinte e cinco anos da reemergência no Brasil. Cad Saude Publica, v. 25, n. Sup 1, p.S7-18, 2009. 


\section{CAPITULO XXXVI}

\section{COVID-19 E OS IMPACTOS NA SAÚDE MENTAL DA POPULAÇÃO}

DOI: 10.51859/AMPLLA.PAE1993-36

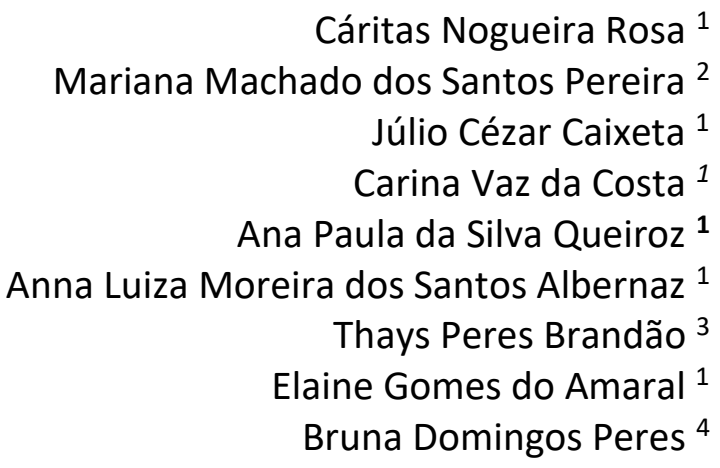

1 Universidade Federal de Uberlândia - UFU- Uberlândia - MG.

2 Proadi/ SUS Hospital Albert Einstein - Uberlândia - MG

3 Professora Mestre em Saúde Ambiental e Saúde do Trabalhador

${ }^{4}$ Prefeitura Municipal de Uberlândia, Uberlândia - MG

\section{RESUMO}

A Covid-19, ocasionada pela disseminação do novo coronavírus trouxe muitos impactos, e a extensão deles ainda não está clara. Desde sua instalação, em 2020, surge a preocupação com as repercussões psicológicas e psiquiátricas dessa pandemia. Existem estudos que demonstram que durante as epidemias, a quantidade de vítimas afetadas mentalmente é maior que a infectada pelos vírus. Assim o objetivo do presente estudo é reunir conhecimentos sobre implicações na saúde mental e intervenções psicológicas em virtude da pandemia. Com isso, no referencial teórico, emergiram-se as categorias Complicações Psicológicas da Covid-19 e Medidas de otimização da saúde mental durante a Covid-19. Portanto, percebeu-se que uma pandemia, dessa estirpe, pode provocar consequências na saúde mental da população. Por isso a importância de um olhar cuidadoso, por parte dos órgãos públicos, de forma a facilitar e incentivar, fornecendo orientações em saúde, para atender às necessidades da população, especialmente os com maior risco de desenvolver algum transtorno mental é fundamental.

Palavras-chave: saúde mental; covid-19; repercussões psicológicas. 


\section{INTRODUÇÃO}

A pandemia ocasionada pela disseminação do novo coronavírus trouxe muitos impactos e a extensão deles ainda não está clara. E, embora já tenha havido epidemias no passado, nenhuma se difundiu num cenário tão extenso quanto essa, fazendo dela então uma realidade inédita (LI et al., 2020).

Ademais, seu alto potencial de contágio fez com que sua incidência aumentasse exponencialmente. Fazendo com que sua transmissão generalizada fosse reconhecida pela Organização Mundial da Saúde (OMS) como uma pandemia e a situação foi exacerbada devido ao desconhecimento do vírus, dos métodos de combate, da dificuldade de acesso a exames que o detectavam e a extensão dos danos causados ao ser humano (ORNELL et al., 2020).

Desde então, além dos problemas causados diretamente pelo vírus, uma outra preocupação acometia a população, os danos colaterais, quais seriam as repercussões psicológicas e psiquiátricas dessa pandemia?

Um impacto psicológico imediato, já vem sendo observado em um crescimento de sintomas de ansiedade e de depressão (WANG et al., 2020). Além disso, tanto a ameaça em si quanto a adoção de medidas de enfrentamento trouxeram à tona uma mudança importante nas rotinas dos indivíduos, principalmente se tratando das rupturas nas relações sociais (LOSADA et al., 2020).

É sabido que em uma pandemia os níveis de ansiedade e estresse em indivíduos saudáveis são consideravelmente aumentados pelo medo e intensificados de forma substancial naqueles que já possuem transtornos psiquiátricos pré existentes (SHIGEMURA et al., 2019).

Inclusive, existem estudos que demonstram que durante as epidemias, a quantidade de vítimas afetadas mentalmente é maior que a infectada pelos vírus (REARDON, 2015). E, fato ainda mais preocupante é que os danos causados à saúde mental da população duraram mais tempo que a própria epidemia (SHIGEMURA et al., 2019).

Por isso, sabe-se que o fornecimento de primeiros socorros e atendimento sequencial psicológicos é uma modalidade de assistência fundamental para populações vítimas de emergências e desastres (DIELTJENS, 2014). Contudo, neste contexto, ainda 
não foi criado normas ou protocolos universais direcionando às práticas de apoio psicossocial.

Nessa esteira, fica evidente que as medidas de prevenção e cuidado com a saúde mental devem ser amplamente divulgadas, inclusive, devem ser alvo de intervenções no intuito de mitigar os impactos negativos a curto e a longo prazo. Segundo a OMS, quanto mais rápido esse suporte é oferecido, menor é a probabilidade de as pessoas desenvolverem algum transtorno mental (WHO, 2020)

Diante do exposto, o objetivo do presente estudo é reunir conhecimentos sobre implicações na saúde mental e intervenções psicológicas em virtude da pandemia. Pretende-se, ainda, apresentar uma noção de emergência do cuidado que tem sido tomado para preservar a saúde mental.

\section{REVISÃO BIBLIOGRÁFICA}

\subsection{COMPLICAÇÕES PSICOLÓGICAS DA COVID-19}

Em virtude da inexistência de medicação e falta de conhecimento acerca do vírus, as medidas iniciais de saúde, determinadas pelo sistema público foram decisivas no controle da pandemia. A OMS preconizou a adoção de intervenções não farmacológicas, como o distanciamento social, e uso de máscaras e álcool em gel com intuito de reduzir o contato físico entre pessoas e dirimir a transmissão da COVID-19. Obviamente, o distanciamento foi uma das medidas mais difíceis (SMITH; FREEDMAN, 2020).

Outrossim, a sua rápida disseminação, as incertezas acerca do vírus, sobretudo a imprevisibilidade do tempo de duração da pandemia e dos seus desdobramentos, se mostram como potenciais fatores de risco à saúde mental da população em geral (ZANDIFAR; BADRFAM, 2020). Esse cenário foi agravado também pela alta propagação de mitos e informações equivocadas sobre o vírus no geral, assim como pela dificuldade da população em compreender as orientações das autoridades sanitárias, que por um bom tempo se contradisseram.

Nessa esteira Holmes e outros autores (2020) também citam que o isolamento social desencadeou tédio, solidão e raiva, bem como um estresse acentuado, somado ao medo da instabilidade financeira, desencadeada pelo desemprego. 
Ademais, um dos principais gatilhos para o surgimento do estresse durante a pandemia é o sentimento de perda do direito de ir e vir, a incerteza e os limites impostos pelas medidas preventivas de isolamento, a alteração substancial dos planejamentos e a separação brusca do ambiente social ou familiar, tornam-se catalisadores constantes para o surgimento de sintomas de ansiedade e até mesmo de depressão (LU et al., 2020)

Percebeu-se também que pessoas com suspeita de infeç̧ão ou infectadas tendiam a desenvolver sintomas obsessivos compulsivos, como a verificação repetida da temperatura corporal (LI et al., 2020), e interpretação equivocada de sensações corporais causadas pela ansiedade, ocasionando pânico e desespero (ASMUNDSON; TAYLOR, 2020).

Infelizmente também se notou maior risco de violência contra mulheres nesse período, o isolamento junto de seus agressores aumentou o fato de as vítimas não conseguirem denunciar as agressões sofridas, fato que consequentemente contribuiu para transtornos psíquicos (SCHMIDT et al., 2020).

Na pesquisa realizada por Barros e outros autores (2020) ficou claro que, durante o período da pandemia estudado, de 45.161 participantes, 40,4\% dos adultos brasileiros sentiram-se tristes ou deprimidos, e 52,6\% declararam estar ansiosos ou nervosos. Mais de $40 \%$ passaram a ter problemas com o sono e quase $50 \%$ dos que já possuíam tiveram o problema agravado. Os sentimentos de tristeza e de ansiedade e os problemas do sono revelaram prevalências mais elevadas em adultos jovens, mulheres e pessoas com diagnóstico prévio de depressão.

Assim, essa catástrofe biológica, se reveste de um acontecimento extremamente traumático que pode aumentar consideravelmente os níveis de estresse, depressão, pânico e suicídio (QUE et al.2020)

\subsection{MEDIDAS DE OTIMIZAÇÃO DA SAÚDE MENTAL DURANTE A COVID-19}

Conforme bem coloca Conejero e outros autores (2021) as sociedades sociais são essenciais na eficácia coletiva, tendo em vista que, elas geram esperança, e oportunidades de partilhar altruísmo, emoções positivas, clemência e gratidão.

Por isso, esse momento pós-pandêmico deve ser encarado como uma fase de reconstrução social. À medida que se percebe o declínio de novos casos e a redução de transmissão, as regras de distanciamento social vão sendo reduzidas e as pessoas 
começam a retomar as atividades habituais. Em pesquisa realizada na crise da COVID19, por Wang e outros autores (2020) verificou-se que, dentre 1.210 participantes, $53,0 \%$ apresentaram sequelas psicológicas moderadas ou severas, incluindo sintomas depressivos $(16,5 \%)$, ansiedade $(28,8 \%)$ e estresse de moderado a grave $(8,1 \%)$. Os maiores impactos foram verificados no sexo feminino, estudantes e pessoas com algum sintoma relacionado à COVID-19, bem como naqueles que julgavam sua saúde como ruim.

Em virtude disso, autoridades sanitárias e organizações ligadas à saúde e cientistas, em diferentes países, têm divulgado orientações e práticas direcionadas às demandas desse cenário (WHO, 2020). Inclusive, no Brasil, em março de 2020, foi publicada a Resolução do Conselho Federal de Psicologia no 4/2020, na qual, autoriza a prestação de serviços psicológicos por meios de tecnologia da informação e da comunicação, iniciativa muito importante em um momento que o isolamento é primordial (CFP, 2020).

Nessa esteira, demais intervenções foram implantadas, voltadas à população geral como por exemplo, propostas psicoeducativas, como, cartilhas e outros materiais informativos (WEIDE et al., 2020); disponibilização de canais para escuta psicológica, ou atendimento em plataformas online, 24 horas por dia e sete dias por semana (JIANG et al., 2020); atendimentos psicológicos por meio de cartas (XIAO, 2020).

Outra iniciativa são os levantamentos através de pesquisas online, que também têm sido realizados para melhor entender o estado de saúde mental da população diante da COVID-19, com o objetivo de ofertar intervenções psicológicas rapidamente para casos identificados como sendo de maior risco (ZHOU, 2020).

E sobre o aumento de casos de violência doméstica, baseado na experiência de outros países, o Centro de Tecnologia da informação e Comunicação do estado do Rio Grande do Sul (2020) e o serviço de rádio da secretaria executiva de comunicação (2020) retratam que algumas instituições no Brasil estão buscando ampliar os canais de denúncia durante o período de pandemia, disponibilizando comunicação online (por aplicativos de mensagens ou até mesmo sites), além de fornecer contato telefônico ou presencial nos órgãos da rede de enfrentamento a esse tipo de violência.

Essas medidas visam a fortalecer as relações afetivas com rodas de conversas virtuais ou acolhida virtual. Portanto, faz-se necessário reforçar também os serviços de 
saúde para a demanda desses atendimentos no período pós-pandêmico, por meio de medidas que possibilitem ao indivíduo ter esperança no contexto futuro de saúde, reduzindo consideravelmente as consequências do isolamento social na saúde mental.

\section{CONSIDERAÇÕES FINAIS}

Os resultados do presente estudo, evidenciaram o quão uma pandemia, dessa estirpe, pode provocar consequências na saúde mental da população. Por isso a importância de um olhar cuidadoso por parte dos órgãos públicos, de forma a facilitar e incentivar, fornecendo orientações em saúde, para atender às necessidades da população, especialmente os com maior risco de desenvolver algum transtorno mental é fundamental.

E ainda, com base na ideia de que uma epidemia pode se tornar uma catástrofe em saúde mental, esforços imediatos devem ser empregados, em todos os níveis e áreas de conhecimento, a fim de minimizar resultados ainda mais negativos na saúde mental da população.

\section{REFERÊNCIAS}

ASMUNDSON, G. J. G.; TAYLOR, S. Coronafobia: o medo e o surto de nCoV em 2019. Jornal de transtornos de ansiedade, [s.;l.], v. 70, p. 102196, 2020.

BARROS, M. B. A. et al. Relato de tristeza / depressão, nervosismo / ansiedade e problemas de sono na população adulta brasileira durante uma pandemia de COVID-19. Epidemiologia e Serviços de Saúde, [s.;.]. v. 29, p. e2020427, 2020.

CENTRO DE TECNOLOGIA DA INFORMAÇÃO e Comunicação do Estado do Rio Grande do Sul. Delegacia Online amplia possibilidades de registro de ocorrência. 2020. [Online]. Disponível em: https://www.procergs.rs.gov.br/delegacia-onlineampliapossibilidades-de-registro-de-ocorrencia. Acesso em: 02 out. 2021.

CFP. Conselho Federal de Psicologia. Resolução do exercício profissional no4, de $\mathbf{2 6}$ de março de 2020. Dispõe sobre regulamentação de serviços psicológico prestados por meio de Tecnologia da Informação e da Comunicação durante a pandemia do COVID19. Brasília: Conselho Federal de Psicologia, 2020. Disponível em: https://atosoficiais.com.br/cfp/resolucao-do-exercicio-profissional-n-4-2020dispoe-sobre-regulamentacao-de-servicos-psicologicos-prestados-por-meio-detecnologia-da-informacao-e-dacomunicacao-durante-a-pandemia-docovid19?origin=instituicao. Acesso em: 02 out. 2021. 
CONEJERO, I. et al. How Does COVID-19 Affect the Neurobiology of Suicide?. Curr Psychiatry Rep., [s.;l.], v. 23, n. 4, 2021. Doi:10.1007/s11920-021-01227-x

DIELTJENS, T. et al. Uma busca sistemática da literatura sobre primeiros socorros psicológicos: falta de evidências para desenvolver diretrizes. PloS one, [s.;l.], v. 9, n. 12, pág. e114714, 2014.

HOLMES, E. A. et al. Prioridades de pesquisa multidisciplinar para a pandemia COVID19: um chamado para ação para as ciências da saúde mental. The Lancet Psychiatry, [s.;l.], v. 7, n. 6, p. 547-560, 2020.

JIANG, X. et al. Intervenção em crise psicológica durante o período de surto de nova pneumonia por coronavírus com base na experiência em Xangai. Pesquisa em psiquiatria, [s.;l.], v. 286, p. 112903, 2020.

LI, S. et al. O impacto da declaração de epidemia COVID-19 nas consequências psicológicas: um estudo em usuários ativos do Weibo. Jornal internacional de pesquisa ambiental e saúde pública, [s.;l.], v. 17, n. 6, 2020.

LOSADA, A. B. et al. Diferencias en función de la edad y la autopercepción del envejecimiento en ansiedad, tristeza, soledad y sintomatología comórbida ansioso-depresiva durante el confinamiento por la COVID-19. Revista espanola de geriatria y gerontologia, [s.;/.], v. 55, n. 5, p. 272-278, 2020.

LU, P. et al. Os estados psicológicos das pessoas depois de Wuhan amenizaram o bloqueio. Plos One, [s.;.], v. 15, n. 11, p. e0241173, 2020.

OMS. Saúde mental e considerações psicossociais durante o surto de COVID-19, 18 de março de 2020. Genebra: Organização Mundial da Saúde, 2020.

ORNELL, F. et al. Pandemia de medo e COVID-19: impacto na saúde mental e possíveis estratégicas. Revista debates in psychiatry, [s.;.].], 2020.

QUE, J. et al. Aumentando a conscientização sobre a prevenção do suicídio durante a pandemia COVID - 19. Relatórios de neuropsicofarmacologia, [s.;.], v. 40, n. 4, p. 392-395, 2020.

REARDON, S. As feridas de saúde mental do ebola persistem na África. Nature News, [s.,Il.], v. 519, n. 7541, p. 13, 2015.

PODCAST. Coronavírus em SC: Polícia Civil intensifica proteção e canais de denúncia contra violência contra mulheres. Serviço de rádio da secretaria Executiva de Comunicação. [Locução de]: Fabiana de Liz. Santa Catarina, 2020. Disponível em: https://www.sc.gov.br/noticias/radio/coronavirus-em-sc-policia-civilintensifica-protecao-e-canais-de-denuncia-contraviolencia-contra-mulheres. Acesso em: 03 out. 2021. 
SHIGEMURA, J. et al. Public responses to the new coronavirus 2019 (2019-nCoV) in Japan: consequences for mental health and target populations. Psychiatry Clin Neurosci, [s.;l.], v. 74, n. 4, p. 281-282, 2020.

SCHMIDT, B. et al. Saúde mental e intervenções psicológicas diante da pandemia do novo coronavírus (COVID-19). Estudos de Psicologia, Campinas, v. 37, 2020.

SMITH, A. W.; FREEDMAN, D. O. Isolamento, quarentena, distanciamento social e contenção da comunidade: papel central para medidas de saúde pública de estilo antigo no novo surto de coronavírus (2019-nCoV). Journal of travel medicine, [s.;l.], 2020.

XIAO, C. Uma nova abordagem de consulta sobre novos problemas psicológicos e mentais relacionados ao coronavírus (COVID-19) em 2019: terapia com cartas estruturadas. Investigação psiquiátrica, [s.;/.], v. 17, n. 2, p. 175, 2020.

WANG, C. et al. Respostas psicológicas imediatas e fatores associados durante o estágio inicial da epidemia de doença coronavírus de 2019 (COVID-19) entre a população em geral na China. Jornal internacional de pesquisa ambiental e saúde pública, [s.;l.], v. 17, n. 5, p. 1729, 2020.

WEIDE, J. N. et al. Cartilha para enfrentamento do estresse em tempos de pandemia. Porto Alegre: PUCRS/Campinas, 2020.

WHO. Mental health and psychosocial considerations during the COVID-19 outbreak. Genebra: World Health Organization, 2020. Disponível em: https://www.who.int/docs/default-source/coronaviruse/mental-healthconsiderations.pdf. Acesso em: 03 out. 2021.

ZANDIFAR, A.; BADRFAM, R. Saúde mental iraniana durante a epidemia de COVID-19. Jornal asiático de psiquiatria, [s.;l.], v. 51, 2020.

ZHOU, X. Intervenções de crise psicológica na província de Sichuan durante o novo surto de coronavírus de 2019. Psychiatry Research, [s.;l.], v. 286, p. 112895, 2020. 


\title{
CAPITULO XXXVII
}

\section{ENTRE DESAFIOS E POTENCIALIDADES: O COTIDIANO DE TRABALHO NA VIGILÂNCIA DE ÓBITOS}

\author{
DOI: 10.51859/AMPLLA.PAE1993-37
}

\author{
Laylla Veridiana Castória Silva ${ }^{1}$ \\ Beatriz Santana Caçador ${ }^{2}$ \\ Gian Batista Carmo ${ }^{3}$ \\ Amanda Nogueira de Paula 4 \\ Thalyta Cassia de Freitas Martins ${ }^{5}$ \\ Larissa Bruna Bhering Silva ${ }^{6}$
}

\footnotetext{
${ }^{1}$ Enfermeira. Mestranda em Doenças Infecciosas pela Universidade Federal do Espírito Santo- UFES.

2 Enfermeira. Professora Adjunta do Departamento de Medicina e Enfermagem da Universidade Federal de ViçosaUFV

${ }^{3}$ Enfermeiro. Mestre em Ciências da Saúde- UFV.

${ }^{4}$ Estudante de Enfermagem na Universidade Federal de Viçosa- UFV.

${ }^{5}$ Enfermeira. Doutoranda do Programa de Saúde Pública na Fundação Oswaldo Cruz - FioCruz.

${ }^{6}$ Enfermeira. Residente em Enfermagem de Saúde da Família pela Universidade Federal de São João del-Rei - UFSJ.
}

\section{RESUMO}

Objetivo: Compreender os desafios e as potencialidades enfrentados pelos profissionais que atuam na Vigilância do Óbito em uma região de saúde no interior de Minas Gerais. Método: Estudo qualitativo, realizado em uma região de saúde no interior de Minas Gerais. Participaram 8 profissionais referências técnicas de vigilância do óbito materno, fetal e infantil. A coleta de dados ocorreu por meio de entrevista orientada por roteiro semiestruturado, no primeiro semestre de 2016. Realizou-se Análise de Conteúdo de Bardin. Os aspectos éticos da pesquisa com seres humanos foram respeitados. Resultados: Emergiram duas categorias, sendo: 1) Desafios da vigilância do óbito e 2) Potencialidades da vigilância do óbito: Comitê de Prevenção da Mortalidade Materna, Fetal e Infantil. A primeira categoria refere a falta de treinamentos, fragilidades na realização de referência e contra referência e a grande sobrecarga de trabalho. A segunda categoria apreende questões como a importância do Comitê de Prevenção da Mortalidade Materna, Infantil e Fetal para formulação de políticas que visam reduzir a mortalidade materna, fetal e infantil e para busca de uma atenção à saúde efetivamente cuidadora, de qualidade e integral. Conclusão: Compreender os desafios vivenciados pelos profissionais facilita a adequação de práticas de trabalho que viabilizem a qualidade laboral do trabalhador. Além disso, conhecer as potencialidades, dentre os quais destaca-se a efetivação e consolidação dos objetivos do Comitê, abre horizontes para formulação de políticas públicas pautadas no cuidado de qualidade.

Palavras-chave: Vigilância em Saúde. Comitês de Profissionais. 


\section{INTRODUÇÃO}

Após a criação do Sistema Único de Saúde em 1990, a fim de realizar uma atuação sistemática da coleta, análise e disseminação de dados referentes à saúde no Brasil, a Vigilância em Saúde (VS) surge com intuito de implementar ações de políticas públicas para promoção, prevenção e recuperação da saúde da população (BRASIL, 2013).

A criação da Vigilância em Saúde foi motivada pela decisão do Conselho Nacional de Saúde (CNS), com o objetivo central de "propor diretrizes para a formulação da Política Nacional de Vigilância em Saúde e o fortalecimento de ações de promoção e proteção da saúde". Dessa forma, propõe-se a compreender a situação de saúde da população em cada território transcendendo os espaços institucionalizados do sistema de serviços de saúde (NETTO et al., 2017).

Uma vez que o modelo de Vigilância da Saúde compreende aspectos de organização de serviços e transita entre as dimensões técnica e política, seu escopo passa a englobar recursos metodológicos para o monitoramento de condições de vida e saúde por meio da Epidemiologia, a reorientar os serviços de saúde na superação das desigualdades de cobertura, acesso e qualidade do serviço, por meio da Estratégia Saúde da Família (GUIMARÃES et al., 2017).

Desse modo, por compreender vários níveis de prevenção e de organização da atenção à saúde, a Vigilância em Saúde apresenta divisões, a fim de organizar e sistematizar o trabalho em saúde, sendo: vigilância sanitária, ambiental, epidemiológica, nutricional e do trabalhador (GUIMARÃES et al., 2017).

Neste sentido, destaca-se a Vigilância Epidemiológica, entendida segundo a Lei no 8080 de 1990 como um "conjunto de ações que proporcionam o conhecimento, a detecção ou prevenção de qualquer mudança nos fatores determinantes e condicionantes de saúde individual ou coletiva, com a finalidade de recomendar e adotar as medidas de prevenção e controle das doenças ou agravos" (BRASIL, 1990). Assim, torna-se atribuição do componente municipal do Sistema Nacional de Vigilância em Saúde a vigilância epidemiológica e o monitoramento da mortalidade infantil e materna e, dos Estados, complementar a atuação dos municípios (BRASIL, 2009). 
Cabe destacar que no Brasil a operacionalização da vigilância dos óbitos materno e infantil ganhou espaço específico com a criação dos Comitês de Prevenção Materno, Fetal e Infantil (CPMFI). Tais instâncias constituem-se como verdadeiros espaços de controle social e apoio à gestão e são, hoje, entendidos como imprescindíveis para a redução dos óbitos através do conhecimento de sua magnitude, determinantes e proposição de ações para a qualificação da atenção à saúde (MELO et al., 2016).

A partir disso, questiona-se quais os desafios enfrentados pelos profissionais que atuam na vigilância do óbito e quais as contribuições dos Comitês de Prevenção da Mortalidade Materna, Infantil e Fetal. Neste sentido, o objetivo do estudo é compreender os desafios e as potencialidades enfrentados pelos profissionais que atuam na vigilância do óbito em uma região de saúde no interior de Minas Gerais.

\section{MÉTODOS}

Trata-se de estudo de natureza qualitativa. Os estudos qualitativos aplicam-se ao estudo da história, relações, percepções e opiniões, produtos das interpretações que os sujeitos sociais fazem a respeito de como vivem, constroem seus artefatos, sentem e pensam (MINAYO, 2007).

O estudo foi realizado com 8 profissionais que são referências técnicas de vigilância do óbito materno, fetal e infantil de uma região de saúde do Estado de Minas Gerais. A coleta dos dados ocorreu no primeiro semestre de 2016. As entrevistas foram previamente agendadas, ocorreram em local privativo, com a presença de duas entrevistadoras, previamente treinadas. Não houve gravação das entrevistas, pois as mesmas foram transcritas no momento das entrevistas, compostas por um questionário semiestruturado de questões discursivas. A fim de garantir sigilo os depoimentos foram identificados de E1 a E8.

Os dados obtidos foram tratados mediante a técnica de análise de conteúdo proposta por Bardin (BARDIN, 2011). A organização dessa análise requer a aplicação de três etapas: pré-análise, exploração do material, e, tratamento dos resultados, inferência e a interpretação. A fase de pré-análise envolveu a leitura flutuante e exaustiva do material. A exploração do material deu-se através do tratamento descritivo, codificação e categorização das informações contidas nos depoimentos, na qual os dados brutos foram transformados em dados com significados. Na fase de 
tratamento dos resultados, inferência e interpretação, foram extraídos e agrupados os temas identificados e confrontados à luz da literatura (BARDIN, 2011).

As normas do Conselho Nacional de Saúde para pesquisa envolvendo seres humanos conforme a Resolução 466/2012 do Conselho Nacional de foram observadas e aplicadas em todas as fases. Os participantes assinaram o Termo de Consentimento Livre e Esclarecido (TCLE) após serem informados sobre a garantia de anonimato, privacidade e utilização dos resultados somente para fins científicos.

\section{RESULTADOS E DISCUSSÃO}

\subsection{OS DESAFIOS DA VIGILÂNCIA DO ÓBITO}

O Ministério da Saúde (MS), sob a portaria 72 de 2010, estabelece a obrigatoriedade da vigilância do óbito infantil e fetal em todo território brasileiro, a fim de atuar como uma estratégia na diminuição da subnotificação dos óbitos e a subinformação, visto que estes ocultam a real extensão da mortalidade infantil e fetal, que ainda constituem um problema no país (BRASIL, 2010).

A vigilância do óbito, desta maneira, é reconhecida como uma importante ferramenta de gestão, por ser capaz de proporcionar informações às Estratégias de Saúde da Família (ESF) sobre o cuidado ofertado no pré-natal e puericultura, além de favorecer o aprimoramento dos sistemas de informação. Além disso, possibilita o planejamento de intervenções direcionadas aos principais problemas e às barreiras assistenciais do sistema de saúde contribuindo para redução de mortes evitáveis e das iniquidades (BRASIL, 2009).

Desta forma, a vigilância do óbito consiste em estratégia de prevenção de novas mortes por envolver uma sequência de etapas que permite detectar correções nas informações dos registros vitais, analisar a cadeia de determinantes, avaliar a rede assistencial envolvida nas ocorrências com o enfoque na evitabilidade e propor medidas preventivas e corretivas. Para isso, as informações precisam, ainda, dispor de boa qualidade, com dados representativos, corretos e totalmente disponíveis (OLIVEIRA et al., 2017).

Entretanto, nota-se entraves para a realização da vigilância do óbito infantil e fetal, pois os profissionais referenciados à este trabalho, muitas vezes desconhecem 
suas atribuições, não recebem treinamento, capacitações e cursos. Muitos profissionais são desviados de suas funções para suprirem a demanda da falta de recursos humanos na equipe, o que dificulta o serviço e causa lentidão no processo investigativo (DUTRA et al., 2015).

Evidencia-se tais entraves nos depoimentos a seguir, em que os profissionais constatam a falta de treinamento para realização do serviço de vigilância do óbito. Além disso, salientam que somente foram informados do cargo, sem cursos prévios e reuniões.

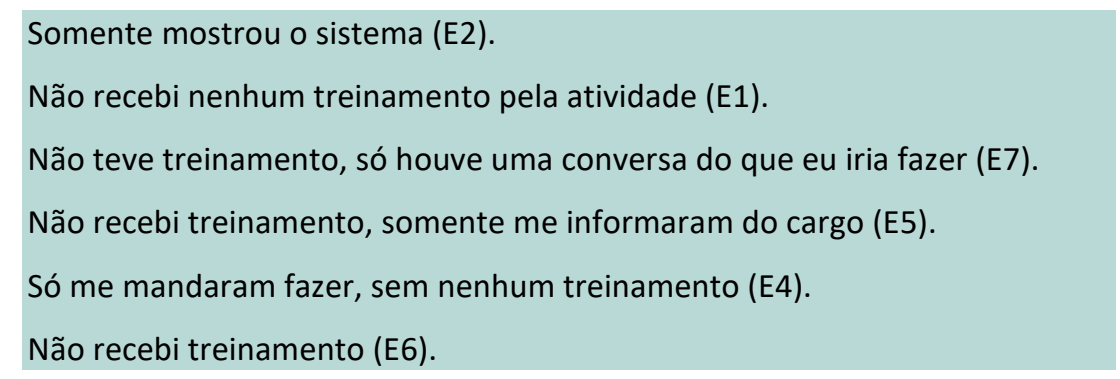

Neste sentido, apreende-se que o Ministério da Saúde estabelece que os responsáveis pela vigilância do óbito e pela investigação devem receber capacitação adequada em investigação de óbitos, principalmente no tocante aos instrumentos de vigilância, às fichas de investigação e planilha municipal. Segundo Dutra et al (2015), uma capacitação correta e no tempo certo auxilia à realização adequada da investigação, contribuindo para queda da taxa de mortalidade (DUTRA et al., 2015).

Além disso, evidencia-se, ainda, que cabe à gestão municipal o favorecimento e a cobrança da prática de investigação, oferecendo cursos de capacitação dos profissionais atuantes na investigação dos óbitos, melhor estruturação e profissionais específicos para a realização do serviço (DUTRA et al., 2015).

Destaca-se, também, que a falta de comprometimento de alguns profissionais que preenchem as fichas de notificação, tanto em hospitais, quanto na Atenção Básica, prejudicam a investigação e a alimentação dos dados nos sistemas de informação. Além disso, a falta de referência e contra referência entre os serviços de saúde e a vigilância, também, constituem-se como entraves para um bom andamento do serviço, conforme evidenciado a seguir.

Falta de comprometimento com os profissionais para o adequado preenchimento dos prontuários e auxílio nas investigações, falta de referência e contra referência da atenção primária com os demais níveis de atenção (E1). 
Dessa forma, destaca-se que muitos profissionais que atuam em redes hospitalares e realizam o preenchimento das fichas de notificação, tanto de nascimento quanto de óbito, não preenchem de maneira correta e completa, por isso, dados como endereço, contato do responsável e relativos ao processo de cuidado e óbito, quando constam indisponíveis ou errôneos dificultam as investigações. Também, a falta de referência e contra referência entre a ESF, hospital e vigilância do óbito, no município ou em outras localidades, contribui para o enfraquecimento das ações de prevenção dos óbitos (SANTA MARIA; ARAÚJO, 2017).

Segundo Dutra et al (2015), o trabalho de investigação do óbito está concentrado principalmente no enfermeiro, que além de suas funções na Atenção Básica, como assistência e cuidado, ainda, por falta de recursos humanos, atua na investigação do óbito. Tais dados encontram-se em consonância com as falas relatadas pelos entrevistados, pois mediante o acumulo de atividades diárias de trabalho, burocracias e afazeres e, consequente pela falta de tempo, a investigação do óbito torna-se constantemente um desafio.

O principal desafio é o tempo, pois tenho de fazer vários serviços no PSF, e
ainda fazer as investigações do óbito (E3).
Falta de valorização pela burocracia (E7).

Neste sentido, ocorrem, também, obstáculos quanto a realização da entrevista domiciliar por recusa familiar, mudança ou inexistência do endereço ou sentimento de luto pela família que não deseja relatar sobre o ocorrido (SANTA MARIA; ARAÚJO, 2017).

Observa-se tais questões, pois o prazo para a conclusão do levantamento dos dados que compõem a investigação, discussão, análise e a conclusão do caso ser de, no máximo, 120 dias a contar da data da ocorrência do óbito. Neste período, as famílias encontram-se em processo de enfrentamento da nova realidade, muitas não desejam relembrar o ocorrido, não se lembram com clareza ou apresentam-se em luto profundo (SANTA MARIA; ARAÚJO, 2017). Dessa forma, os profissionais tendem a lidar com dificuldades de entrevistas, abordagens e de investigação do óbito, conforme os depoimentos abaixo.

\footnotetext{
A abordagem da família que está em luto (E5).

Fazer entrevista, muitas vezes perco tempo indo na residência e não acho ninguém, ou então tenho de fazer muitas perguntas e a pessoa não quer responder, não me sinto bem, ela está de luto (E6).
} 
Ademais, são inúmeros os desafios enfrentados pelos profissionais que atuam na referência da vigilância dos óbitos. Alguns, como treinamentos, reuniões e cursos, direcionamento de profissionais exclusivos para a investigação do óbito, diminuindo a sobrecarga de burocracias e outras atividades, além de cursos para os profissionais que realizam o preenchimento das notificações poderiam ser resolvidos pela própria gestão.

\subsection{POTENCIALIDADES DA VIGILÂNCIA DO ÓBITO: COMITÊ DE PREVENÇÃO DA MORTALIDADE MATERNA, FETAL E INFANTIL}

Em 2004, o Ministério da Saúde elaborou o Manual dos Comitês de Prevenção da Mortalidade Materna, Infantil e Fetal, que sistematizou as experiências de vigilância ao óbito infantil e fetal, com o objetivo de ampliar a mobilização e o comprometimento dos gestores e profissionais de saúde do país para a organização de um sistema de acompanhamento de óbitos com maior potencial de prevenção (BRASIL, 2009).

Observa-se como objetivos do Comitê de Prevenção da Mortalidade Materna, Infantil e Fetal, a investigação dos óbitos infantis e fetais pelas equipes de saúde, segundo critérios definidos, resguardando os aspectos éticos e o sigilo das informações; identificação e avaliação dos problemas relacionados à assistência à saúde prestada à gestante, parturiente e criança; elaboração de medidas de intervenção necessárias para a prevenção de óbitos evitáveis, de forma a motivar estratégias de redução da e efetivação das medidas de intervenção realizadas para tal (BRASIL, 2009).

Pautado nesses objetivos o trabalho na vigilância dos óbitos passou a compreender a identificação, investigação e, posteriormente, discussão dos dados apreendidos no Comitê, a fim de gerar propostas de promoção e atenção à saúde. Dessa forma, a investigação do óbito passou a permitir por meio dos registros em prontuários e entrevistas com a família e profissionais envolvidos na atenção materno-infantil, a avaliação do óbito, para desvendar as circunstâncias em que o evento ocorreu e identificar falhas na cadeia de ações do cuidado oferecido (OLIVEIRA et al., 2017).

Neste sentido, a vigilância do óbito em conjunto com o Comitê de Prevenção da Mortalidade Materna, Infantil e Fetal propicia informações para as equipes locais de saúde, favorece a construção da consciência crítica, auxilia na geração de dados em saúde do município e, consequentemente, contribui para a redução da mortalidade infantil, materna e fetal (OLIVEIRA et al., 2017). 
Dessa forma, salienta-se, através dos depoimentos, que o comitê atua como um aliado na conclusão dos casos, esperança de diminuição dos casos de óbitos nos municípios, apoio na discussão dos casos, geração de dados fundamentais aos municípios e uma forma de redução da mortalidade, conforme evidenciado a seguir.

O Comitê ajuda muito, sem ajuda do comitê é impossível concluir sozinha as
investigações (E1).
Através do Comitê há mudança da forma de atendimento a sociedade e a
geração de dados importantes ao município (E8).
Esperança de um dia melhorar e a taxa de mortalidade que vem caindo (E7).

Além disso, os depoimentos dos entrevistados relatam que o Comitê de Prevenção da Mortalidade Materna, Infantil e Fetal agrega valor às investigações de óbito, pois em geral, adquirem aprendizado, opiniões e experiências, mediante evidenciado abaixo.

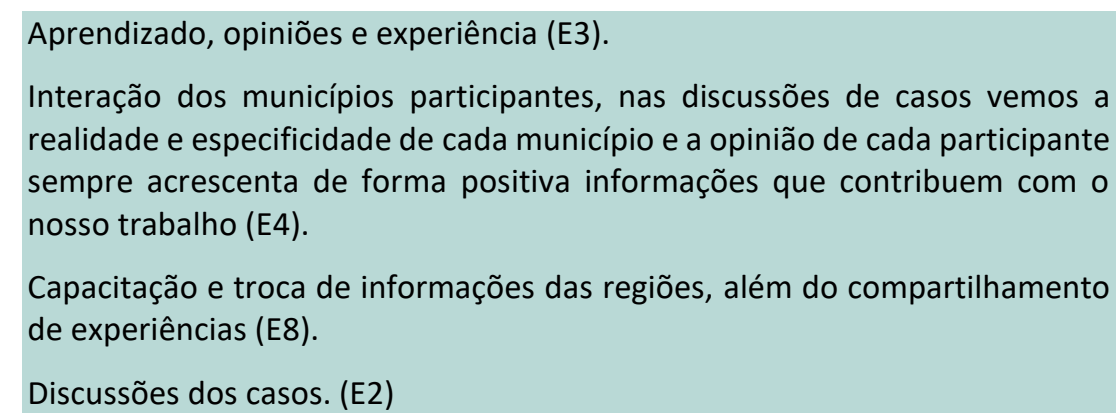

Ademais, apesar dos desafios enfrentados pelos profissionais da vigilância do óbito, o Comitê de Prevenção da Mortalidade Materna, Infantil e Fetal, surge como uma potencialidade do serviço, por contribuir para resolução do serviço, formação de dados para alimentação dos sistemas de informação, formulação de políticas que visam reduzir a mortalidade materna, fetal e infantil e para busca de uma atenção cuidadora de qualidade e integral.

O estudo apresenta como limitação a utilização de apenas um questionário como fonte de coleta de dados. O uso em conjunto de impressos e outros dados oferecidos por cada município no que se refere à individualidade de cada processo investigativo poderia agregar valor ao estudo. Contudo, isso deu-se devido ao expressivo número de municípios a serem visitados, à distância geográfica entre eles e ao curto prazo para a coleta de dados. 


\section{CONSIDERAÇ̃̃ES FINAIS}

Constata-se que são inúmeros os desafios dos profissionais que atuam na vigilância do óbito, entretanto há, também potencialidades de trabalho. Compreender esses desafios vivenciados facilita a adequação de práticas de trabalho que viabilizem a qualidade laboral do trabalhador. Além disso, estabelecer o Comitê de Prevenção da Mortalidade Materna, Infantil e Fetal, como uma potencialidade do serviço de vigilância do óbito, abre horizontes para formulação de políticas públicas pautadas no cuidado de qualidade.

\section{AGRADECIMENTOS}

À FAPEMIG, ao CNPq, ao PROEXT/SESu e ao Programa de Educação pelo Trabalho - PET Saúde/Vigilância em Saúde (Ministério da Saúde/Ministério da Educação), pelo apoio financeiro à pesquisa e concessão de bolsas de estudos.

\section{REFERÊNCIAS}

ARAÚJO, T.M.; PALMA, T.F.; ARAÚJO, N.C. Work-related Mental Health Surveillance in Brazil: characteristics, difficulties, and challenges. Ciência \& Saúde Coletiva, 22(10):3235-3246, 2017. DOI: 10.1590/1413-812320172210.17552017

BARDIN, L. Análise de conteúdo. São Paulo: Edições 70, pp. 229, 2016.

BRASIL. Ministério da Saúde. Manual de vigilância do óbito infantil e fetal e do comitê de prevenção do óbito infantil e fetal. Brasília (DF): Ministério da Saúde; 2009

BRASIL. Ministério da Saúde. Portaria GM no 72 de 11 de janeiro de 2010. Estabelece que a vigilância do óbito infantil e fetal é obrigatória nos serviços de saúde (públicos e privados) que integram o SUS. Brasília (DF):MS; 2010.

BRASIL. Ministério da Saúde (MS). Secretaria de Vigilância à Saúde. Secretaria de Atenção à Saúde. Diretrizes Nacionais da Vigilância em Saúde. Brasília: MS; 2010.

BRASIL. Ministério da Saúde, Secretaria de Vigilância à Saúde. Portaria no 72, de 11 de janeiro de 2010. Dispõe sobre a regulamentação da Vigilância de Óbitos Infantis e Fetais. Diário Oficial da União. 2010

DUTRA, I.R.; ANDRADE, G.N.; REZENDE, E.M.; GAZZINELLI, A. Investigação dos óbitos infantil e fetal no vale do Jequitinhonha, Minas Gerais, Brasil. Rev Min Enferm. 2015 jul/set; 19(3): 597-604. DOI: 10.5935/1415-2762.20150046 
GUIMARÃES, R.M, et al. Challenges for the formulation, implantation and implementation of a National Health Surveillance Policy in Brazil. Ciência \& Saúde Coletiva, 22(5):1407-1416, 2017. DOI: 10.1590/141381232017225.33202016

MELO, C.M.; AQUINO, T.I.S.; SOARES, M.Q.; BEVILACQUA, P.D. Vigilância do óbito como indicador da qualidade da atenção à saúde da mulher e da criança. Ciência \& Saúde Coletiva, 22(10):3457-3465, 2017. DOI: 10.1590/1413812320172210.19652017

MINAYO, M.C.S. O desafio do conhecimento: pesquisa qualitativa em saúde. 8ª ed. São Paulo: Hucitec; 2004

NETTO, G.F, et al. Brazilian Health Surveillance: reflections and contribution to the debate of the First National Conference on Health Surveillance. Ciência \& Saúde Coletiva, 22(10):3137-3148, 2017 . DOI: 10.1590/1413-812320172210.18092017

OLIVEIRA, C.M.; BONFIM, C.V.; MEDEIROS, Z.M. Mortalidade infantil e sua investigação: reflexões sobre alguns aspectos das ações da vigilância do óbito. Rev enferm UFPE on line., Recife, 11(Supl. 2):1078-85, fev., 2017 . DOI: 10.5205/reuol.1026391568-1-RV.1102sup201725

SANTA MARIA, L.F.B.; ARAÚJO, T.V.B. Um olhar sobre a vigilância dos óbitos fetais do Jaboatão dos Guararapes, Pernambuco, Brasil, em 2014. Ciência \& Saúde Coletiva, 22(10):3415-3428, 2017. DOI: 10.1590/1413-812320172210.17572017 


\title{
CAPITULO XXXVIII
}

\section{EXERCÍCIOS FÍSICOS REGULARES COMO PROMOÇÃO DE SAÚDE PARA INDIVÍDUOS IDOSOS}

DOI: $10.51859 /$ AMPLLA.PAE1993-38

Kethllyn Oliveira Santos ${ }^{1}$

Nilcélia Barbosa Gaspar ${ }^{2}$

Regiane Caris dos Santos ${ }^{3}$

\begin{abstract}
${ }^{1}$ Graduada no curso de Licenciatura em Educação Física. Centro Universitário São Lucas de Ji-Paraná/RO- UniSL
${ }^{2}$ Graduada no curso de Licenciatura em Educação Física. Centro Universitário São Lucas de Ji-Paraná/RO- UniSL

3 Professora do Centro Universitário São Lucas de Ji-Paraná.RO. Mestra em Educação Escolar. Universidade Federal do Estado de Rondônia- UNIR.
\end{abstract}

\section{RESUMO}

Nos últimos anos a população idosa vem aumentando significativamente, e sendo esse um período onde ocorrem diversas mudanças fisiológicas no corpo humano, como o surgimento de doenças e limitações, torna-se necessário a prática de exercício físico como forma de prevenção e tratamento. O objetivo do presente estudo consiste em analisar os benefícios da prática dos exercícios físicos para a qualidade de vida dos idosos. A metodologia utilizada foi a pesquisa exploratória de cunho bibliográfico. Os resultados apontam que a prática de exercício físico regular pode proporcionar a diminuição e tratamento de doenças crônicas, transtornos psicológicos, além de melhorar a força, equilíbrio, flexibilidade e relacionamento social, entre outros. Através dos resultados apresentados, ficou evidente que a prática de exercícios físicos contribui de forma significativa para uma melhor qualidade de vida dos idosos. Mesmo diante de todos os benefícios apresentados se torna necessário à realização de novos estudos, onde seja explorado a fundo os benefícios dos diversos tipos de exercícios físicos e a influência que exercem na qualidade de vida do idoso e no processo de envelhecimento.

Palavras-chave: Promoção de saúde. Exercício físico. Envelhecimento. Educação física. 


\section{INTRODUÇÃO}

O número de idosos no Brasil vem aumentando de forma acelerada, de acordo com o Instituto Brasileiro de Geografia e Estatística (IBGE, 2018) o percentual dos indivíduos com mais de 65 anos chegará a 25,5\% em 2060, representando um quarto da população. Essa predominância no número de idosos tem acontecido em virtude da grande diminuição na taxa de fertilidade no decorrer dos anos (ALMEIDA et al., 2020).

Nesse sentido, é preciso entender como acontece o processo natural do envelhecimento humano, que segundo Nahas (2017) ocorre de forma gradual, universal e irreversível, provocando progressivamente perdas funcionais no organismo.

Diante do envelhecimento o corpo humano sofre diversas modificações que interferem na saúde, dentre elas estão à diminuição no peso corporal, estatura e massa muscular (ALMEIDA et al., 2020). Além disso, durante este período surgem inúmeras alterações fisiológicas nos sistemas digestório, renal, neuromuscular, cardiorrespiratório e endócrino-metabólico (SILVA; SOUZA; CREPALDI-ALVES, 2015).

Essas alterações acontecem de maneira natural, ocorrendo o aparecimento de doenças como as vestibulopatias que causa tonturas, zumbidos e desequilíbrio corporal que consequentemente resulta em quedas, provocando fraturas leves ou graves, podendo levar o indivíduo a óbito, além disso, também é capaz de provocar inseguranças e diminuições nos afazeres gerais, prejudicando a sua interação social (VIEIRA et al., 2014).

Devido às perdas que advém do envelhecimento humano podemos destacar que elas podem ser retardadas através do estilo de vida que levamos, por exemplo, com a prática regular de exercícios físicos. É importante que as pessoas mantenham um estilo de vida saudável para que seja minimizado ou adiado o surgimento de doenças, a perda de nutrientes nos ossos e a fraqueza muscular, trazendo assim melhor mobilidade, equilíbrio e flexibilidade (ALLENDORF et al., 2016).

A ausência de exercício físico pode gerar malefícios que torna o idoso mais exposto à ocorrência de acidentes, proporcionando no decorrer do tempo dificuldades motoras, ausência de equilíbrio, força e resistência, que são os fatores capazes de permitir ao idoso a independência de atividades do dia a dia (SILVA; SOUZA; CREPALDIALVES, 2015). 
Nesse sentido, Bárrios e Fernandes (2014) afirmam a necessidade do desenvolvimento de iniciativas integradoras que abrangem todas as idades e que inclua o público idoso, como os programas de ação social, ambientais, habitacionais, socioculturais e educacionais e os programas de saúde, onde está incluso um estilo de vida ativo.

É possível salientar que desde a antiguidade houve interesse nos possíveis benefícios do exercício físico durante o envelhecimento, e no final do século XIX iniciou as pesquisas científicas onde já se via ligações entre inatividade física com mortes prematuras, com isso, no decorrer do tempo pode-se comprovar grande associação do exercício físico ao bem-estar, saúde e qualidade de vida das pessoas (NAHAS, 2017).

A qualidade de vida está associada ao bem-estar pessoal e da autoestima, em que através dela os indivíduos se sentem bem emocionalmente e fisicamente, possibilitando a satisfação nos ambientes sociais, com isso, os idosos praticantes de exercícios físicos apresentam maior nível de qualidade de vida se comparado aos sedentários (COSTA et al., 2015).

Diante disso, estudos afirmam que o exercício físico praticado de forma regular auxilia os idosos no alcance de uma vida independente, proporcionando um envelhecimento saudável e contribuindo para a qualidade de vida desses indivíduos, visto que a redução da capacidade funcional é causada em parte pela necessidade de um estilo de vida ativo (CINEL; ALVES; GOMES, 2016).

Visto as dimensões de benefícios que são proporcionados pelo exercício físico, houve um aumento de sua procura, na qual inúmeros órgãos públicos têm investido nesta área, pois acreditam que as buscas por medicamentos são reduzidas, uma vez que o praticante diário de exercícios irá obter melhora em sua saúde, prevenindo diversas doenças não transmissíveis e reduzindo também a procura por médicos (CIVINSKI; MONTIBELLER; BRAZ, 2011).

Em síntese, é de grande importância que todos saibam sobre os aspectos positivos ligados à prática de exercício físico durante o envelhecimento, visto que estudos demonstram que sua prática provoca a melhora dos aspectos cognitivos, sociais e corporais do idoso. Portanto, o objetivo desta pesquisa é analisar como a prática regular de exercício físico atua na promoção de saúde dos idosos. 


\section{METODOLOGIA}

A presente pesquisa é caracterizada como exploratória de cunho bibliográfico, que segundo Gil (2008, p. 27) "tem como principal finalidade desenvolver, esclarecer e modificar conceitos e idéias, tendo em vista a formulação de problemas mais precisos ou hipóteses pesquisáveis para estudos posteriores".

Os autores Munaretto, Corrêa e Cunha (2013) também afirmam que esse tipo de pesquisa é um método que tem o objetivo de conhecer e de aprofundar no tema abordado, com o propósito de deixá-lo mais claro, sendo assim essa é uma pesquisa voltada para descobertas.

A pesquisa abordou publicações entre os anos de 2010 a 2021, onde foram realizadas análises do tema em artigos com os descritores: promoção de saúde, exercício físico, envelhecimento e educação física, em bases de dados eletrônicos como ScienceDirect, Scielo, Portal de periódicos CAPES, biblioteca virtual do Centro Universitário São Lucas e Google acadêmico.

Para analisar os dados optamos por categorizar em exercícios de força, aquáticos, aeróbicos e de flexibilidade, abordando seus benefícios e influência que exercem na qualidade de vida dos idosos, bem como no processo de envelhecimento.

Na seleção dos artigos, foram analisados os resumos descartando os que não tinham relevância com o tema e considerando os que efetivamente correspondiam aos objetivos traçados. Através da leitura dos artigos foram elaborados resumos e fichamentos dos assuntos. Após a análise, foi dado seguimento na organização do artigo.

\section{RESULTADO E DISCUSSÃO}

Diante do aumento gradativo da população idosa, torna-se necessário a interferência de uma programação diária de exercícios adequados e indicados pelo profissional de Educação Física, na qual pode proporcionar a esse público desfrutar-se de diversos benefícios físicos, sociais e mentais, permitindo que essa fase seja mais saudável, propiciando a realização de atividades diárias, gerando autonomia e também qualidade de vida (CINEL; ALVES; GOMES, 2016).

Deste modo, sabe-se que manter um estilo de vida ativo é primordial para alcançar um envelhecimento saudável, portanto, diante do objetivo geral desta 
pesquisa serão apontados os benefícios da prática regular do exercício físico para a terceira idade, e no intuito de facilitar a compreensão foi realizado o método de categorização. Para a primeira categoria serão analisados os exercícios de força e como eles podem contribuir de forma significativa para a promoção da saúde dos idosos.

O treinamento de força é definido como um exercício físico que geralmente é realizado com aparelhos, na qual a musculatura do corpo deverá aplicar e/ou tentar executar movimentos contra a força oposta, tendo como exemplo o supino, agachamento, abdominal, movimentos funcionais com a perna, como subida de escada, onde se é trabalhado grandes grupos musculares (FLECK, KRAEMER, 2017).

Estudo realizado por Pereira et al. (2020), mostrou que o exercício de força é eficaz na aquisição da qualidade de vida, ocorrendo melhoras na força, no estado cognitivo, aumento da massa muscular e também da capacidade funcional, possibilitando a realização das atividades diárias, ocasionando o menor risco de quedas para o idoso.

Foi evidenciado no estudo de Fonseca et al. (2018) com 12 idosos acima de 60 anos de ambos os sexos, que o treinamento intervalado de musculação aumenta o índice de aptidão física e de composição corporal, possibilitando melhora da autonomia e independência deste público. Em concordância com os estudos discorridos, é comprovado que além dos benefícios já citados, pode-se apontar o ganho de força, aptidão cardiorrespiratória, retardamento e reversão de diminuição de massa magra e peso ósseo (MENDONÇA, MOURA, LOPES, 2018).

O exercício de força é um importante aliado no combate à sarcopenia, doença que surge devido ao estilo de vida inadequado durante o envelhecimento, trazendo limitações na vida do idoso e aumentando o risco de quedas, por sua vez o treinamento de força age proporcionando efeitos positivos, como a diminuição das perdas musculares e motoras (MARTINEZ; CAMELIER; CAMELIER, 2014).

$\mathrm{Na}$ segunda categoria pode-se citar os exercícios aquáticos, mencionando a hidroginástica como sendo uma atividade que interfere positivamente na qualidade de vida do indivíduo. Deste modo, o estudo realizado por Hilário et al. (2018) aponta que seus benefícios ocasionam grandes mudanças funcionais devido à força atingida na água, propiciando o fortalecimento muscular e o combate à sarcopenia, assegurando a manutenção do nível de massa magra e preservando a funcionalidade vital desses 
indivíduos, além disso, é possível observar que os idosos praticantes dessa atividade obtiveram progresso no peso corporal, apresentaram melhoras na coordenação motora, equilíbrio, mobilidade articular, flexibilidade e força muscular, desenvolvendo maior disposição e desempenho na realização de atividades diárias.

Através dos resultados obtidos do estudo de Teixeira et al. (2018), realizado com 60 indivíduos a partir de 60 anos e de ambos os sexos, averiguou-se que $56,7 \%$ são encaminhados ao serviço de hidroginástica através de prescrição médica, e em concordância com Hilário et al. (2018) pode-se verificar também que os praticantes desta atividade apresentam melhor desenvolvimento nas suas atividades do dia a dia, além de contribuir para a socialização, tornando-se uma atividade motivacional, visto que se trata de uma prática realizada em grupo.

Os exercícios de hidroginástica apresentam menor impacto e baixo risco de quedas, além de promover a diminuição em torno de $80 \%$ do peso corporal total, com isso essa modalidade proporciona redução dos níveis pressóricos na mesma intensidade das atividades aeróbicas, como caminhadas, corridas, entre outras, sendo assim uma prática recomendada ao público idoso (LEHNEN et al., 2019).

Notou-se ainda que a hidroginástica e a técnica de hidroterapia auxiliam na melhoria da capacidade funcional, equilíbrio postural, capacidade aeróbia e flexibilidade, além de proporcionarem alívio de dores e rigidez, reduzindo o impacto articular, devido a temperatura da água, sendo assim de grande eficácia no tratamento da osteoartrite de joelho, doença que causa desgaste articular (LEÃO et al., 2019).

Além disso, pode-se citar a natação como um exercício completo que também proporciona diversos benefícios aos idosos, por meio de fatores biológicos e funcionais, ocorrendo melhoras na força muscular, resistência, elasticidade e nos ligamentos, propiciando assim maior expectativa de vida (ALVES; MACIEL, 2018).

Na pesquisa realizada por Silva, Bocato e Isler (2018) com 10 idosos praticantes de hidroginástica e 10 de natação, na cidade de Rio Claro, foram expostas melhorias na segurança, independência e locomoção, além da diminuição de dores musculares e articulares, melhores noites de sono e aumento da autoestima.

$\mathrm{Na}$ terceira categoria serão exemplificados os exercícios aeróbicos, começando pela caminhada, por ser uma atividade que também colabora para a melhoria da condição física, cognitiva e social do idoso. Na pesquisa realizada por Torres et al. (2013), 
com a participação de 10 idosos praticantes de caminhada em grupo, encontram-se relatos dos benefícios trazidos deste exercício, onde os participantes do estudo relataram melhoras no controle de doenças crônicas degenerativas, redução de massa corpórea, alívio nos quadros álgicos, favorecendo a saúde mental, social e mobilidade física.

Ademais é possível mencionar no estudo de Melo (2012) constituído por 50 idosos com idades de 59 a 91 anos, onde os mesmos citaram diversos benefícios adquiridos através da prática da caminhada, como a diminuição das dores, melhoras no quadro de hipertensão, artrite, artrose e aptidão física, além das mudanças benéficas psicológicas e sociais, devido a interação e socialização que essa prática proporciona.

Foi verificado que além dos benefícios já discorridos, a caminhada apesar da baixa intensidade é uma excelente opção para os idosos, pois com 30 minutos de sua prática diária ocorre a liberação do hormônio endorfina, capaz de propiciar alívio do estresse do ambiente social, lutando com os transtornos psicológicos como a depressão e contribuindo para a satisfação da saúde mental, além disso, o exercício citado tem efeitos positivos em nível sistêmico, proporcionando melhoras no equilíbrio, força muscular, flexibilidade, auxiliando no tratamento e prevenção de doenças crônicas assim como problemas emocionais, visto que promove a socialização e autoconfiança, trazendo para esse público satisfação e bem-estar (SANTOS; ARAUJO; PACHÚ, 2019).

Através de análises, classifica-se a dança como um exercício aeróbico que contribui de maneira contínua para a melhora da saúde corpórea e cognitiva do idoso, beneficiando a mobilidade física, por meio do equilíbrio e da coordenação, além de estimular o sistema cognitivo e neuromuscular, prevenir as quedas e preservar o equilíbrio, a fim de possibilitar um envelhecimento saudável, melhor funcionalidade e qualidade de vida (SIQUEIRA; DANIN; FREITAS, 2020).

Similarmente, é afirmado que a dança contribui na melhoria do cotidiano e bemestar desses indivíduos, por ser uma atividade que visa a socialização e integração, tirando os idosos do isolamento e os colocando de volta ao convívio social, onde eles resgatam a autoestima, disposição e vontade de viver, além de propiciar a melhora de suas patologias, derivadas do envelhecimento (CASTRO; WLHLIG; SÁ, 2019).

$\mathrm{Na}$ quarta categoria apresentam-se os exercícios de flexibilidade, sendo uma alternativa para o idoso a prática de alongamento, que segundo André et al. (2013) a 
falta da mesma pode ocasionar má postura, quedas, dores e problemas articulares, comprometendo a qualidade de vida e independência desses indivíduos, diante disso, o autor afirma que esse exercício proporciona diversos benefícios, como o ganho de força, amplitude de movimento, melhora da circulação sanguínea, postura, respiração, auto estima e do desempenho em exercícios, possibilitando autonomia para o idoso.

O alongamento exerce grande influência na produção de maior nível de flexibilidade e manutenção da mesma, visto que os idosos acabam perdendo essa capacidade física durante o processo de envelhecimento, sobretudo se forem indivíduos sedentários, sendo assim, a prática desse exercício acarreta em melhorias na amplitude do movimento corporal e da execução de atividades do dia a dia, diminuindo o risco de lesões e proporcionando qualidade de vida (ROSA, 2012).

Assim como o alongamento, o método de pilates proporciona melhoria na flexibilidade, uma vez que esse exercício sempre busca a amplitude de movimento, além de trabalhar a força em todos os grupos musculares, acarretando em melhoras no equilíbrio e postura corporal (DEON; SILVA, 2012). Este método é eficaz para os indivíduos que buscam preservar e melhorar a saúde, visto que previne doenças que estão associadas ao processo de envelhecimento, possibilitando melhora na agilidade, equilíbrio dinâmico, resistência aeróbia, tempo de reação, aptidão física e qualidade de vida (MELLO et al., 2018).

Notou-se ainda que o pilates contém diversos efeitos positivos na saúde e bemestar de idosos patológicos e saudáveis, tais como a melhora da marcha, postura, força, desempenho funcional, resistência muscular, habilidades motoras, aumento da autonomia e redução de dores e quedas (VEIGA et al., 2019).

Diante disso, a prática de exercício físico proporciona mudanças significativas na qualidade de vida do idoso, em aspectos sociais, emocionais, físicos e funcionais, sugerindo que a vida ativa promove o equilíbrio e a força muscular, ocasionando a diminuição de quedas, depressão, melhorando o convívio social e a independência (COSTA et al., 2015).

Pode-se concluir através dos estudos analisados, que os processos advindos do envelhecimento como as doenças crônicas não transmissíveis, as perdas das capacidades funcionais, transtornos psicológicos e necessidades sociais, podem ser diminuídos com o exercício físico regular, juntamente com a instrução de um 
profissional especializado. E neste estudo foram citados alguns métodos específicos que colaboram para o bem-estar do idoso, sendo eles os exercícios de força, aquáticos, aeróbicos e de flexibilidade.

\section{CONSIDERAÇÕES FINAIS}

Através dos resultados apresentados, ficou evidente que a prática de exercícios físicos contribui de forma significativa para a promoção de saúde dos idosos. Podemos afirmar que os exercícios de força propiciam o aumento da aptidão física e da composição corporal, além de combater a sarcopenia, possibilitando autonomia para esse público. Similarmente, os exercícios aquáticos proporcionam menores riscos de lesões, aumento do fortalecimento muscular, melhoras na coordenação motora, equilíbrio, flexibilidade, entre outros.

Podemos citar também que os exercícios aeróbicos acarretam em melhoras no equilíbrio, força muscular, flexibilidade, sendo de grande importância no tratamento e prevenção de doenças crônicas e problemas emocionais. Além disso, têm-se os exercícios de flexibilidade, que promovem o ganho de força, amplitude de movimento, melhora da circulação sanguínea, postura, respiração, autoestima e no desempenho de exercícios, trazendo independência para o idoso.

Com isso, ao considerar o aumento gradual do número de idosos, é imprescindível o monitoramento e indicação do exercício físico pelo profissional de Educação Física, onde o mesmo irá auxiliar de maneira adequada, considerando a individualidade biológica de cada indivíduo, prevenindo lesões e garantindo que este público possa desfrutar dos benefícios.

É necessário a realização de novos estudos, onde sejam explorados a fundo os benefícios dos diversos tipos de exercícios físicos e a influência que exercem na qualidade de vida do idoso e no processo de envelhecimento. Sendo assim, é indispensável pesquisas de campo futuras para uma análise aprofundada desses e demais exercícios, bem como os seus benefícios. 


\section{REFERÊNCIAS}

ALLENDORF, D. B. et al. Idosos praticantes de treinamento resistido apresentam melhor mobilidade do que idosos fisicamente ativos não praticantes. Revista brasileira de ciência e movimento, v. 24, n. 1, p. 134-144, 2016.

Almeida, B. L. et al. Qualidade de vida de idosos que praticam atividade física. Revista Fun Care Oline, v. 12, p. 432-436, 2020.

ALVES, R. A. de S.; MACIEL, R. M. Benefícios da prática da natação na terceira idade. Disponível em: <http://psicodebate.dpgpsifpm.com.br/index.php/periodico/article/view/399>. Acesso em: 12 de maio de 2021.

ANDRÉ, F. B. et al. A importância do alongamento no idoso. Disponível em: <http://www.afrid.faefi.ufu.br/sites/afrid.faefi.ufu.br/files/Importancai_Alonga mento_em_idosos.pdf>. Acesso em: 23 de abril de 2021.

BÁRRIOS, M. J.; FERNANDES, A. A. A promoção do envelhecimento ativo ao nível local: análise de programas de intervenção autárquica. Revista Portuguesa de Saúde Pública, v. 32, p. 188-196, 2014.

CALDAS, L. R. D. R. et al. Dezesseis semanas de treinamento físico multicomponente melhoram uma resistência muscular, agilidade e equilíbrio dinâmico em idosas. Revista Brasileira de Ciências do Esporte, v. 41, n. 2, p. 150-156, 2019.

CASSIANO, A. D. N. et al. Efeitos do exercício físico sobre o risco cardiovascular e qualidade de vida em idosos hipertensos. Ciência \& Saúde Coletiva, v. 25, n. 6, p. 2203-2212, 2020.

CASTRO, G. I. D.; WLHLIG, F. L. R.; SÁ, F. G. D. S. D. A dança como meio de integração social para a terceira idade. Revista Cosmos Acadêmico, vol. 1, n. 7, p. 73-84, 2019.

CINEL, A. L. G. B.; ALVES, J. R.; GOMES, L. P. R. A importância do exercício físico na terceira idade para a manutenção das atividades de vida diária. Revista Científica do Unisalesiano, v. 15, n. 7, p. 378-389, 2016.

CIVINSKI, C.; MONTIBELLER, A.; BRAZ, A. L. D. O. A importância do exercício físico no envelhecimento. Revista da Unifeb (Online), v. 1, n. 9, p. 163-175, 2011.

COSTA, L. D. S. V. D. et al. Análise comparativa da qualidade de vida, equilíbrio e força muscular em idosos praticantes de exercício físico e sedentários. Revista Faculdade Montes Belos (FMB), v. 8, n. 3, p. 61-179, 2015.

DEON, L. S.; SILVA, E. R. D. Benefícios da prática do Método Pilates sobre a aptidão física de idosos. Geriatria \& Gerontologia, v. 6, n. 4, p. 412-421, 2012. 
FLECK, S. J.; KRAEMER, W. J. Fundamentos do treinamento de força muscular.4ํ edição, Santana: Artmed editorial LTDA, 2017.

FONSECA, A. I. S. et al. Efeito de um programa de treinamento de força na aptidão funcional e composição corporal de idosos praticantes de musculação. Revista Brasileira de Prescrição e Fisiologia do Exercício, v.12, n.76, p. 556-563, 2018.

GIL, A. C. Métodos e técnicas de pesquisa social. 6 ed., São Paulo: Atlas, 2008.

HILÁRIO, B. C. P. D. C. et al. As vantagens de uma prática sistemática de hidroginástica no cotidiano do idoso. Revista Universo, n. 5, p. 1-17, 2018.

IBGE - INSTITUTO BRASILEIRO DE GEOGRAFIA E ESTATÍSTICA. Projeções da população: Brasil e unidades da Federação. 2. ed. Rio de Janeiro: IBGE, 2018. Disponível em: <https://goo.gl/y1UwJc>. Acesso em: 06 de abril de 2021.

LEÃO, L. A. et al. Benefícios das atividades aquáticas para idosos. Revista Atenção Saúde, v. 17, n. 61, p. 127-134, 2019.

LEHNEN, A. M.; FAGUNDES, D. S.; JUNIOR, L. L. D. O.; ROMÃO, M. F. Exercício físico para populações especiais. Disponível em: $<$ https://integrada.minhabiblioteca.com.br/\#/books/9788595029798/>. Acesso em: 22 de abril de 2021.

MARTINEZ, B. P.; CAMELIER, F. W. R.; CAMELIER, A. A. Sarcopenia em idosos: um estudo de revisão. Revista Pesquisa em Fisioterapia, v. 4, n. 1, p. 62-70, 2014.

MELO, D. G. D. Benefícios da prática da caminhada para os idosos do grupo "terceira idade" de Cavalcante GO. Orientador: Thiago Santos da Silva. 2012. p. 1-55. Trabalho de conclusão de curso II (Licenciatura em educação física) - Programa UAB da Universidade de Brasília - Pólo de Alto Paraíso - GO, 2012.

MELLO, N. F. et al. Método pilates contemporâneo na aptidão física, cognição e promoção da qualidade de vida em idosos. Revista brasileira de geriatria e gerontologia, v. 21, n. 5, p. 1-8, 2018.

MENDONÇA, C. D. S.; MOURA, S. K. M. S. F.; LOPES, D. T. Benefícios do treinamento de força para idosos: revisão bibliográfica. Revista Campo do Saber, v. 4, n. 1, p. 7487, 2018.

MUNARETTO, L. F.; CORRÊA, H. L.; CUNHA, J. A. C. D. Um estudo sobre as características do método Delphi e de grupo focal, como técnicas na obtenção de dados em pesquisas exploratórias. Revista de Administração da Ufsm, v. 6, n. 1, p. 9-24, 2013. 
NAHAS, M. V. Atividade física, saúde e qualidade de vida: Conceitos e sugestões para um estilo de vida ativo. 7ạ edição, Florianópolis, 2017.

PEREIRA, C. C. B. et al. Treinamento de força para idosos: uma revisão integrativa. Medicus, v. 2, n. 2, p. 6-17, 2020.

ROSA, A. L. A flexibilidade em indivíduos idosos. Revista de Educação do Ideau, v. 7, n. 14, p. 1-15, 2012.

SANTOS, A. G.; ARAUJO, K. R. B.; PACHÚ, C. O. Qualidade de vida do idoso: prática de caminhada ao ar livre. Disponível em: <http://www.editorarealize.com.br/editora/anais/cieh/2019/TRABALHO_EV12 5_MD1_SA4_ID1059_04062019110833.pdf>. Acesso em: 26 de abril de 2021.

SILVA, V. R.; SOUZA, G. R.; CREPALDI-ALVES, S. C. Benefícios do exercício físico sobre as alterações fisiológicas, aspectos sociais, cognitivos e emocionais no envelhecimento. Revista CPAQV: Centro de Pesquisas Avançadas em Qualidade de Vida, v. 7, n. 3, p. 1-9, 2015.

SILVA, J. P. D.; BOCATO, M.; ISLER, G. L. A percepção de saúde e a qualidade de vida do idoso praticante de atividades aquáticas. Medicina e Saúde, v. 1, n. 1, p. 21-34, 2018.

SIQUEIRA, A. O.; DANIN, N. F.; FREITAS, W. M. T. D. M. A interferência da dança na mobilidade de idosos: revisão sistemática. FisiSenectus, v. 8, p. 67-79, 2020.

TEIXEIRA, R. V. et al. Fatores que levam os idosos a prática da hidroginástica. Motricidade, vol. 14, n. 1, p. 175-178, 2018.

TORRES, A. G. et al. Efeitos da prática de caminhada de idosos em grupo: um olhar do protagonista. J Manag Prim Health Care, v.4, n.1, p. 19-26, 2013.

VEIGA, A. M. et al. Benefícios do método pilates na terceira idade. Brazilian Journal of Health Review, v. 2, n.4, p. 2657-2661, 2019.

VIEIRA, A. A. U.; APRILE, M. R.; PAULINO, C. A. Exercício físico, envelhecimento e quedas em idosos: revisão narrativa. Equilíbrio Corporal e Saúde, v. 6, n. 1, p. 23-31, 2014. 


\title{
CAPITULO $X X X I X$
}

\section{LISTA DE ESPERA PARA RESIDIR EM INSTITUIÇÃO DE LONGA PERMANÊNCIA PARA IDOSOS}

DOI: 10.51859/AMPLLA.PAE1993-39

\author{
Jaklinne Romão Lopes ${ }^{1}$ \\ Anna Ruthe da Silva Chissolucombe ${ }^{2}$ \\ Fernanda Maria Chianca da Silva ${ }^{3}$ \\ Andrea Mendes da Silva ${ }^{4}$
}

\begin{abstract}
${ }^{1}$ Estudante do Curso Técnico em Cuidados de Idosos, da Escola Técnica de Saúde da UFPB, bolsista PIBIC TEC.
${ }^{2}$ Estudante do Curso Técnico em Enfermagem, da Escola Técnica de Saúde da UFPB, bolsista PIBIC EM.

${ }^{3}$ Enfermeira, professora da Escola Técnica de Saúde da UFPB, Doutora em Gerontologia Biomédica.
\end{abstract}

\section{RESUMO}

Lista de espera para residir em Instituições de Longa Permanência, em algumas regiões do Brasil, é realidade vivenciada por pessoas idosas e familiares ao optar pelo serviço. Neste sentido, o presente estudo objetivou realizar revisão da literatura sobre lista de espera para residir em Instituição de Longa Permanência para idosos. Os dados foram coletados em publicações nacionais, como recurso para pesquisa foi utilizado o Google Scholar;Scientific Electronic Library On-line, Literatura Latino-Americana e do Caribe em Ciências da Saúde, Revista Kairós: gerontologia e Biblioteca Virtual do Sistema Integrado de Gestão de Atividades Acadêmicas. Após a coleta de dados e leitura crítica do material foi realizada uma síntese coerente da literatura pesquisada. Lista de espera reflete fragilidades na assistência a pessoa idosa. $O$ solicitante da vaga em instituição de longa permanência, em sua maioria, é familiar do idoso, motivado por não possuir suportes necessário para prestar assistência em domicílio. A insuficiência familiar, a não efetividade de políticas públicas de atenção as demandas do envelhecimento corroboram para o panorama descrito no presente estudo. Recomenda-se mais estudos sobre a temática.

Palavras-chave: Pessoa Idosa. Habitação. Assistência. ILPI. 


\section{INTRODUÇÃO}

O aumento na expectativa de vida da população brasileira é reflexo da implementação de políticas públicas, entre elas, a de saúde, que ampliou alternativas de tratamento e controle para diversas doenças, levando ao declínio os níveis de mortalidade em todas as faixas etárias. Segundo Flores (2015) as mudanças na dinâmica populacional requerem reflexões e ações para atender demandas oriundas do processo, no tocante a assistência a pessoa idosa, espera-se que a família seja o suporte principal para atender as necessidades, porém, essa também sofre importantes mudanças, o que compromete a assistência familiar. Neste contexto, as Instituições de Longa Permanência para Idosos (ILPI), preenchem um espaço fundamental na assistência a pessoa idosa, sobretudo àquelas que não possui suporte familiar.

Segundo Araújo et al (2016) índices crescentes de pessoas idosas impõem situações desafiadoras ao poder público, sociedade, família e indivíduos, no que se refere à elaboração de estratégias que favoreçam uma longevidade com preservação da autonomia e independência, alicerçada na promoção de uma vida ativa e saudável.

$\mathrm{Na}$ literatura registra-se aumento progressivo da procura por ILPI, em algumas regiões do país existem idosos aguardando vaga em lista de espera para residir em ILPI, (ARAÚJO et al, 2016; CAMARGOS, 2013; POLLO, 2008). Ao analisar a demanda ascendente de solicitações de vaga, se faz referência aos insustentáveis encargos sociais, financeiros e subjetivos para a família quand o a velhice está associada com incapacidade funcional e limitações financeiras (POLLO, 2008).

A pesquisa realizada por Araújo et al (2016), intitulada "Diferenças no perfil de pessoas idosas institucionalizadas, em lista de espera e que não desejam institucionalização, realizada na cidade de João Pessoa/PB", referiu a existência de 690 pessoas idosas em lista de espera para residir em ILP, a pesquisa relata ainda uma subnotificação no registro das solicitações de vaga.

Diante da necessidade de conhecer melhor o fenômeno apresentado, o presente trabalho objetivou realizar revisão da literatura sobre lista de espera para residir em Instituição de Longa Permanência para Idosos. Contribuindo assim, com informações sobre a temática que irão possibilitar ao meio acadêmico, sociedade e profissionais da 
área da gerontologia conhecer essa população, discutir sobre a temática e formular novos conceitos sobre a institucionalização da pessoa idosa.

\section{METODOLOGIA}

Trata-se de uma revisão da literatura, para sua realização foram adotadas etapas, entre elas:

Seleção de descritores: importante estratégia para fazer a pesquisa nas bases de dados e nos demais meios de busca, para tanto, foram utilizados os descritores: Instituição de Longa Permanência para Idosos; ILPI; Idosos e Pessoas idosas. No tocante a lista de espera, optamos por utilizar expressões como: lista de espera para residir em ILPI; necessidade de vaga para ILPI; Lista de espera para Instituição de Longa Permanência para Idosos; Lista de espera para ILPI; Idosos em lista de espera. Como estratégia para otimização da busca, foram utilizados os operadores booleanos AND e OR, neste sentido, o AND foi utilizado para localizar mais de um termo na mesma referência e OR para localizar um dos termos, sendo assim, utilizou-se os descritores e expressões preestabelecidos relacionando-os com os operadores booleanos (lista de espera para residir em ILPI and vagas; Lista de espera and ILPI; Lista de espera para ILPI OR necessidade de vaga para ILPI). Na tentativa de obter artigos com expressões exatas, foram utilizadas as aspas ("') nas expressões "Lista de espera para residir em ILPI"; "Lista de espera para Instituição de Longa Permanência de Idosos"; "Lista de espera para ILPI"; "Idosos em lista de espera".

Coleta de dados: os dados foram coletados por meio Google Scholar, SCIELO (Scientific Electronic Library On-line), LILACS (Literatura Latino-Americana e do Caribe em Ciências da Saúde), Revista Kairós: gerontologia e Biblioteca Virtual do Sistema Integrado de Gestão de Atividades Acadêmicas - SIGAA, da Universidade Federal da Paraíba.

Leitura crítica e redação do material coletado: após a coleta de dados fez-se leitura crítica do material, sendo selecionadas as informações pertinentes a temática, bem como os pontos comuns entre os vários autores, para então escrever uma síntese coerente da literatura.

Por se tratar de uma revisão da literatura não foi necessário submeter ao comité de ética e pesquisa. 


\section{REVISÃO DA LITERATURA}

O aumento na expectativa de vida é resultante de políticas públicas empregadas ao longo das últimas décadas. Esse importante período de avanços demográficos é simultâneo as transformações ocorridas nas famílias, na atualidade são menores e apresentam novos arranjos familiares. Diante das transformações, cuidar de parentes no seio familiar, para alguns tornou-se inviável. Essa situação gera para o Estado e a sociedade o aumento de demandas por serviços e atendimentos voltados à pessoa idosa, de modo exclusivo ou associado aos cuidados familiares (OLIVEIRA et al, 2016). No Brasil, até o momento não existe política pública direcionada a auxílio financeiro para contratação de cuidador formal para prestar existência ao idoso em seu domicílio.

O aumento da população idosa acarreta muitos desafios, entre eles, atender necessidades de assistência a moradia e cuidados com a saúde. Miranda et al (2016) refere que o Estado deverá fomentar políticas específicas, dando suporte e atenção integral com impactos positivos na qualidade de vida desses indivíduos (MIRANDA et al, 2016). O Artigo $3^{\circ}$ do Estatuto do Idoso afirma que é obrigação da família, da comunidade, da sociedade e do Poder Público assegurar ao idoso, com absoluta prioridade, a efetivação do direito à vida, à saúde, à alimentação, à educação, à cultura, ao esporte, ao lazer, ao trabalho, à cidadania, à liberdade, à dignidade, ao respeito e à convivência familiar e comunitária (BRASIL, 2003).

A assistência à moradia e saúde estão previstas na Política Nacional do Idoso (BRASIL, 1994), também faz referência a "priorização do atendimento ao idoso através de suas próprias famílias, em detrimento do atendimento asilar, à exceção dos idosos que não possuam condições que garantam sua própria sobrevivência" (p.1), O Estatuto do Idoso discorre sobre a assistência integral na modalidade de instituições de longa permanência, sendo opção na inexistência de outras alternativas. O referido documento aponta regras de fiscalização e penalidades, citadas nos capítulos VII e IX, Assistência social e habitação respectivamente (BRASIL, 2003).

Fagundes (2017), faz referência a adaptação à nova realidade, mudanças ocorridas ao longo do tempo entre elas, inserção da mulher no mercado de trabalho (retirou dos lares a cuidadora familiar), a redução de fecundidade, e transformações dos arranjos familiares, são importantes motivadores para a procura por instituições para 
idosos morarem. Para Souza et al, (2015), as Instituições de Longa Permanência para Idosos (ILPI) surgem como alternativa, considerando que não existem, no Brasil, muitas opções para o cuidado não familiar.

Segundo Fagundes et al (2017), a finalidade de uma instituição de longa permanência é garantir ao idoso segurança e seu bem-estar, pois é uma residência coletiva, que atende pessoas com limitação ou não em situação de carência de renda e/ou de família quanto aqueles com dificuldades para o desempenho das atividades diárias, que necessitem de cuidados prolongados.

Segundo Camarano e Barbosa (2016,)

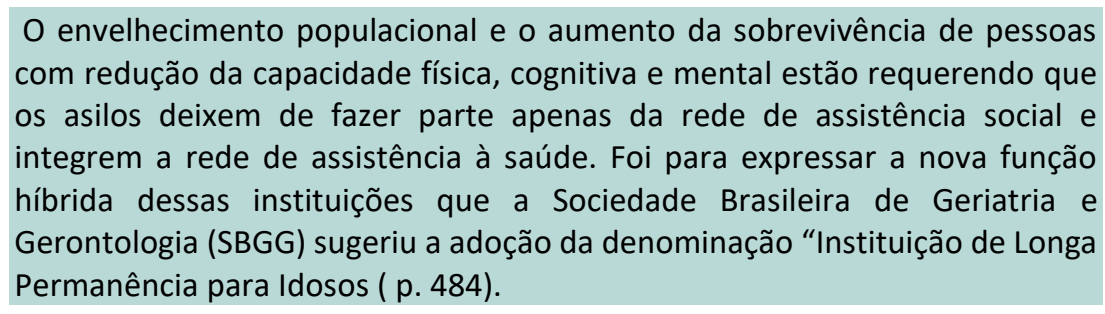

Existência de Instituições de Longa Permanência para Idosos, na atualidade é fundamental para o amparo da população idosa, elas podem ser de natureza pública ou privadas com fins lucrativos ou sem fins lucrativos. São definidas como estabelecimentos de caráter residencial para atendimento integral às pessoas de 60 anos ou mais, defendendo a sua dignidade os seus direitos (ANVISA, 2005).

A cada dia cresce a procurar por Instituições de Longa Permanência para Idosos (ILPIs), aumentando a necessidade destes serviços (CAMARANO; BARBOSA, 2016). De acordo com pesquisa, existe um perfil para os idosos institucionalizados, geralmente necessitam de auxílio para desenvolver as atividades vida diária (AVDs) e, em sua grande maioria, não disponibilizam de cuidador ou suporte familiar, cita-se como motivos para a institucionalização: comprometimento funcional, idade avançada, sexo feminino, solteiros, analfabetos, sem escolaridade formal, sem companheiro, restrição financeira (LINI et al, 2016).

Instituições de Longa Permanência para Idosos têm o dever e a responsabilidade de proporcionar atenção integral com qualidade (ORSI; 2018). Autores discorrem sobre a importância das instituições de Longa Permanência promoverem espaço qualificado, conforto e acolhimento, uma atenção planejada que estimule a autonomia e 
independência do idoso, valorizando e estimulando a sua autoestima (SOARES et al, 2018).

Faz parte do contexto nacional pessoas idosas em lista de espera para residir em ILPI, estudos em algumas regiões do país mostram a lamentável realidade daqueles que necessitam de atenção a moradia e cuidados com a saúde, sendo as ILPIs uma das poucas opções existentes, e para estas, longas filas de espera (ARAÚJO, 2021).

Segundo dados apresentados pelo Censo Demográfico de 2000, no Brasil, existem 3.548 instituições espalhadas pelo país, acolhendo em torno de 83,870 pessoas com mais de 60 anos (IBGE, 2000). No Estado da Paraíba foram registradas 19 ILPI, 06 destas na capital João Pessoa e as demais espalhadas pelo Estado (IPEA/SEDH 2008). O número de instituições é insuficiente para acolher a demanda de idosos que necessitam desse tipo de assistência, uma evidência dessa ocorrência é a existência de pessoas idosas aguardando vaga em lista de espera para residir em ILPI na Cidade de João Pessoa/PB (ARAÚJO et al 2016), realidade também apresentada em outras regiões do país como Belo Horizonte, $73,1 \%$ das ILPIs filantrópicas tem registro de lista de espera (CAMARGOS, 2013).

O exposto reflete possivelmente a fragilidade na atenção às necessidades da pessoa idosa, despreparo para acolher as demandas oriundas do aumento significativo da população idosa nas últimas décadas, incertezas de cuidadores, mudança nos arranjos familiares impulsionando a busca por vaga em ILPI (CAMARANO, 2016).

O acesso a serviços públicos nem sempre é rápido, em algumas situações se faz necessário espera prolongada, no Brasil, fazer parte de lista de espera para assistência as necessidades, vêm se configurando uma prática em muitas áreas, em especial na área da saúde. (CAMARGO, 2013). Uma ocorrência frequente também para o público de 60 anos ou mais, que acaba se deparando com filas extensas e falta de estrutura. A lista de espera vai para além de procedimentos clínicos ou cirúrgicos, pesquisas revelam idosos aguardando vaga em lista de espera para residir em Instituição de Longa Permanência para Idosos em alguns Estados do Brasil, a citar: Belo Horizonte (MG) - com relatos de longas listas de espera nas instituições, em uma delas mais de 100 pessoas a espera de uma única vaga (CAMARGOS,2013); João Pessoa (PB) - pesquisa realizada nos anos de 2010 a 2012, registrou 690 pessoa idosas em lista de espera aguardando vaga para residir em ILPI (ARAUJO et al, 2016). Segundo Camargos (2013) o aumento da população 
idosa só agrava a situação das longas filas por vaga em ILPI, deixando evidente a necessidade de mais instituições.

A literatura registra vários motivos que levam o idoso a residir em ILPI, entre eles, conflito e falta de tempo para o cuidar por parte dos familiares, carências de cuidados dentro e fora do âmbito familiar, seguidos por falta de moradia e restritos recursos econômicos. (BORN; BOECHAT,2011). O motivo mais citado na pesquisa realizada pelos autores ARAÚJO; BÓS (2021), com a população em lista de espera foi falta de cuidador, corroborando com estudo anteriormente citado, a maioria dos solicitantes de vaga em ILPIs são familiares que não possuem suportes necessário para prestar assistência aos seus idosos.

Ao optar pelos cuidados em instituição de longa permanência, a pessoa idosa e seu familiar podem enfrentar fila de espera para obter a vaga. Em outubro de 2018 foi veiculada, em jornal local (JORNAL DA PARAÍBA, 2018), informação da existência de 1.138 pessoas em lista de espera para residir em instituições da cidade de João Pessoa, os dados mostram um importante crescimento no número de idosos que aguardam vaga em lista de espera, considerando os critérios para obter uma vaga em ILPI, considerando ainda o número reduzido de instituições e a falta de dispositivos na sociedade que atendam as demandas apresentadas pela pessoa em lista de espera, provavelmente, muitos dos idosos não irão obter a requerida vaga. Os autores (ARAÚJO; BÓs, 2021) referiram que $23 \%$ dos 690 idosos que aguardavam vaga para residir em ILPI no município de João Pessoa, foram a óbito antes de alcançar a tão sonhada vaga.

\section{CONSIDERAÇÕES FINAIS}

A revisão da literatura evidenciou uma problemática que vem se configurando no cenário nacional, pessoas idosas em lista de espera para residir em instituições de longa permanência. Pode-se observar nas referências estudadas, que a pessoa idosa opta pela instituição para obter atenção a moradia e cuidados com a saúde, e as instituições são insuficientes para acolher a demanda crescente.

Lista de espera para residir em ILPI evidencia ineficiência de ações para assistir as necessidades do longeviver. A legislação aponta serviços diurnos de atenção ao idoso que poderiam minimizar a procura pela atenção de longa duração, muitas famílias não conseguem conciliar o cuidado do idoso com as exigências sociais, e, em algumas 
situações, falta conhecimento para o cuidado domiciliar, portanto, como única opção tem-se a institucionalização do idoso. A insuficiência familiar, a não efetividade de políticas públicas de atenção as demandas do envelhecimento corroboram para o panorama descrito no presente estudo.

Recomenda-se mais estudos sobre a população idosa que aguarda vaga em lista de espera para residir em ILPI. É necessário repensar práticas e mudar estratégias para assegurar um envelhecimento com qualidade.

\section{REFERÊNCIAS}

ANVISA, Agência Nacional de Vigilância Sanitária. RDC no 283/05. Regulamento técnico para o funcionamento das instituições de longa permanência para idosos. Brasília, 2005.

ARAÚJO, A.M.; BÓS, A.J.G. Características das pessoas idosas em lista de espera para institucionalização. Atena, 2021 p. 1-388-416.

ARAÚJO, A.M et al. Diferenças no perfil de pessoas idosas institucionalizadas, em lista de espera e que não desejam institucionalização. Revista Brasileira de Geriatria e Gerontologia, v. 19, n. 1, p. 105-118, 2016.

BRASIL. Lei no 8.842, de 4 de janeiro de 1994. Dispõe sobre a Política Nacional do Idoso, cria o Conselho Nacional do Idoso e dá outras providências. Diário Oficial União 6 jan. 1994; Seção 1.

BRASIL. Estatuto do idoso. Brasília (DF): Senado Federal, 2003.

BORN, T.; BOECHAT, N.S. A qualidade dos cuidados ao idoso institucionalizado. In: Freitas Ev, Py L(org)Tratado de geriatria e gerontologia. 3. ed. Rio de Janeiro: Guanabara Koogan; 2011. p.1132-41.

CAMARANO, A. A.; BARBOSA P. Instituições de Longa Permanência para Idosos no Brasil: do que se está falando? In: Alcântara A et al (orgs). Política nacional do idoso: velhas e novas questões. Rio de Janeiro: IPEA, 2016. p. 479-514.

CAMARGOS, M.C.S. Instituições de longa permanência para idosos: um estudo sobre a necessidade de vagas. Revista Brasileira de Estudos de População, v. 31, p. 211217, 2013.

INSTITUTO BRASILEIRO DE GEOGRAFIA E ESTATÍstICAS. IBGE. Sinopse do Censo Demográfico 2000. Rio de Janeiro, IBGE, 2000.

JORNAL DA PARAÍBA. A paraíba tem mais de mil idosos em fila de espera para viver em asilos. 2018

Disponível em: 
http://www.jornaldaparaiba.com.br/vida_urbana/paraiba-tem-mais-milidosos-em-fila-de-espera-para-viver-em-asilos.html. Acesso em 20/04/2020.

FAGUNDES, K. V. D. L., et al. Instituições de longa permanência como alternativa no acolhimento das pessoas idosas. Revista de Salud Pública, v. 19, p. 210-214, 2017.

FLORES, L.P.O. O envelhecimento da população brasileira. Revista Eletrônica do Departamento de Ciências Contábeis \& Departamento de Atuária e Métodos Quantitativos (REDECA), v. 2, n. 1, p. 86-100, 2015.

LINI, E.V et al. Fatores associados à institucionalização de idosos: estudo caso-controle. Revista Brasileira de Geriatria e Gerontologia, v.19, n.6, p. 1004-1014, 2016.

MIRANDA, G.M.D et al. O envelhecimento populacional brasileiro: desafios e consequências sociais atuais e futuras. Revista brasileira de geriatria $e$ gerontologia, v. 19, p. 507-519, 2016.

OLIVEIRA, B.C et al. A enfermagem dá o tom no atendimento humanizado aos idosos institucionalizados. Revista Kairós Gerontologia, v. 19, n. 1, p. 239-254, 2016.

ORSI, M. Percepções do cuidado da equipe multiprofissional aos idosos em uma instituição de longa permanência. TCC, 2018. 79 p.

POLLO, S.H.L.; ASSIS, M. Instituições de longa permanência para idosos-ILPIS: desafios e alternativas no município do Rio de Janeiro. Revista Brasileira de Geriatria e Gerontologia, v. 11, n. 1, p. 29-44, 2008.

SOARES, N.V et al. Sentimentos, expectativas e adaptação de idosos internados em instituição de longa permanência. Revista Mineira de Enfermagem, v. 22, p. 1-7, 2018.

SOUZA, A et al. Conceito de insuficiência familiar na pessoa idosa: análise crítica da literatura. Revista Brasileira de Enfermagem, v. 68, p. 1176-1185, 2015. 


\title{
CAPITULO XL
}

\section{ImPORTÂNCIA DA EDUCAÇÃO NA PREVENÇÃO E CONTROLE DA ESQUISTOSSOMOSE MANSÔNICA}

DOI: 10.51859/AMPLLA.PAE1993-40

Tânia da Silva Santos ${ }^{1}$

Fred da Silva Julião ${ }^{2}$

\begin{abstract}
${ }^{1}$ Graduanda do curso de Licenciatura em Ciências Biológicas. Instituto Federal Baiano Campus Santa Inês - IF Baiano Campus Santa Inês

${ }^{2}$ Docente no Instituto Federal de Educação Baiano Campus Santa Inês Santa Inês - IF Baiano Campus Santa Inês
\end{abstract}

\section{RESUMO}

A esquistossomose mansônica é uma doença parasitária endêmica encontrada em diferentes áreas do território brasileiro, constituindo um grave problema de saúde pública. Objetivou-se evidenciar a influência da educação na prevenção e controle da esquistossomose mansônica. Este foi um estudo de relato de caso de uma forma grave de esquistossomose, Mielorradiculopatia Esquistossomotica, que ocorreu no município de Mutuípe-BA. Foi realizada entrevista com a paciente, pontuando os fatores de risco, forma clínica, nível de conhecimento e ações educativas foram conhecidas. O caso ocorreu entre o fim do ano de 2017 e início do ano 2018, apresentando dores nas pernas e na lombar, o que mesmo depois de alguns exames, não associou a esquistossomose. O diagnóstico, veio com o exame de líquor. A paciente relatou que não tinha histórico de infecção por Schistosoma. Com o diagnóstico foi tratada e começou a apresentar uma melhora progressiva, até plena recuperação, foram mais de sete meses de tratamento. A esquistossomose é uma doença inicialmente assintomática, podendo evoluir para formas clínicas graves e óbito. As sintomatologias graves são pouco conhecidas, sendo importante ações educativas no controle da esquistossomose buscando intervenções na área social e ambiental, a fim de aumentar a conscientização da população na adoção de atitudes que diminuam a infecção.

Palavras-Chave: Mielorradiculopatia. Schistosoma. Relato de caso. 


\section{INTRODUÇÃO}

A esquistossomose é uma doença parasitária provocada por vermes trematódeos do gênero Schistosoma. São conhecidas seis espécies (S. mansoni, S. hematobium, S. japonicum, S. intercalatum, S. mekongi e S. melayensis), que podem provocar a doença no ser humano, sendo que no continente americano existe apenas o S. mansoni. É conhecida no Brasil como xistosa, mal do caramujo, barriga d'água, esquistossomose mansônica ou bilharziose (REY, 1992).

A transmissão da esquistossomose ocorre quando o ser humano infectado elimina os ovos do verme por meio das fezes. Em contato com a água, os ovos eclodem e liberam miracídios que infectam os caramujos gênero Biomphalaria, hospedeiros intermediários que vivem nas águas doces. Após quatro semanas, as cercárias abandonam o caramujo e ficam livres nas águas. O ser humano adquire a infecção pelo contato com essas águas. Alguns hábitos como nadar, tomar banho ou simplesmente lavar roupas e objetos na água contaminada favorecem a transmissão. Qualquer pessoa, independente de sexo, cor, raça e idade são susceptíveis a contaminação pelo verme (KATZ ALMEIDA, 2003; MINISTÉRIO DA SAÚDE, 2006).

A introdução da esquistossomose no Brasil se deu por meio do tráfico de escravos originários da costa ocidental da África, que ingressaram no país, principalmente pelos portos de Recife-PE e Salvador-BA, para trabalharem nas lavouras de cana-de-açúcar (KATZ ALMEIDA, 2003).

Com o crescimento do fluxo migratório, devido ao desenvolvimento de novas atividades econômicas e a consolidação da produção industrial, associados ao fortalecimento do processo de urbanização, possibilitou a disseminação da esquistossomose para todo o território brasileiro. A doença ocorre em localidades sem saneamento ou com saneamento básico deficitário, sendo adquirida através da pele e mucosas. A prevenção da esquistossomose consiste em evitar o contato com águas onde existam os caramujos, hospedeiros intermediários, infectados (CARVALHO, 2005; MINISTÉRIO DA SAÚDE, 2006; 2008).

A maioria dos portadores são assintomáticos, no entanto, na fase aguda, o paciente pode apresentar febre, dor na cabeça, calafrios, sudorese, fraqueza, falta de apetite, dor muscular, tosse e diarreia. Em alguns casos o fígado e o baço podem 
inflamar e aumentar de tamanho. Na forma crônica a diarreia se torna mais constante, alternando-se com prisão de ventre, e pode aparecer sangue nas fezes. Além disso, o paciente pode sentir tonturas, dor na cabeça, sensação de plenitude gástrica, prurido anal, palpitações, emagrecimento. Nos casos mais graves, o estado geral do paciente piora bastante, com emagrecimento, fraqueza acentuada e aumento do volume do abdômen, conhecido popularmente como barriga d'água, podendo chegar a quadros neurológicos, como é o caso da mielorradiculopatia esquistossomotica (MRE) que se deve à presença de ovos do Schistosoma mansoni no sistema nervoso central (KATZ ALMEIDA, 2003; CARVALHO, 2005; COELHO e LENZI, 2008; MINISTÉRIO DA SAÚDE, 2008).

A Organização Mundial de Saúde (OMS) estima que a esquistossomose acometa cerca 200 milhões de pessoas em 74 países. No Brasil mensura-se que exista de seis a oito milhões de indivíduos infectados e 35 milhões de brasileiros sob risco de infecção (KATZ ALMEIDA, 2003).

O diagnóstico da esquistossomose é feito por meio de exames laboratoriais de fezes. É possível detectar, por meio desses exames, os ovos do parasita causador da doença. Os casos graves podem requerer internação hospitalar e até mesmo tratamento cirúrgico, conforme cada situação (MINISTÉRIO DA SAÚDE, 2006; CARVALHO; COELHO e LENZI, 2008).

O trabalho relatou um caso grave de MRE no município de Mutuípe-BA, e ao mesmo tempo, associar a importância da educação em saúde na prevenção da esquistossomose mansônica, relatando à ausência de conhecimento, inclusive da MRE. Nesse sentido, a educação em saúde passa a ser repensada como um processo capaz de desenvolver nas pessoas a consciência crítica.

A MRE é a forma mais grave o diagnóstico baseia-se na presença de sintomas neurológicos decorrentes de lesões da medula espinhal em nível torácico baixo ou lombar alto, na demonstração da infecção esquistossomótica por técnicas microscópicas ou sorológicas e na exclusão de outras causas de mielite transversa. Geralmente, a doença se apresenta com uma tríade clínica prodrômica de dor lombar, alteração de força ou sensibilidade de membros inferiores e distúrbio urinário (caracterizada pela presença de ovos e de granulomas esquistossomóticos no sistema 
nervoso central (KATZ et. al., 2003; MINISTÉRIO DA SAÚDE, 2006; CARVALHO; COELHO; LENZI, 2008).

\section{METODOLOGIA}

Trata-se de um estudo descritivo qualitativo informando, um relato de caso que ocorreu numa paciente que teve MRE associando a influência da educação a esquistossomose mansônica.

Com intuito de associar a importância da educação sobre esquistossomose mansônica, foi reportado um relato de caso que ocorreu no município de Mutuípe que está localizado no Recôncavo Sul da Bahia a 116 Km de Salvador -BA em linha reta, 245 Km por via rodoviária, com uma população de 21.449 habitantes (IBGE, 2017).

O município tem diversas trilhas e cachoeiras, verdadeiros paraísos ecológicos, cenários naturais da região, passando pelo Riacho do Mutum, Rio Jiquiriçá e pelas cachoeiras Alta, Roda D'água e Três Saltos, às serras, cercadas por florestas nativas, grutas, flora e fauna características da região. É um destino muito procurado para quem curte a natureza que são belas atrações para os visitantes.

Foi registrado como o conhecimento sobre esquistossomose mansônica pode interferir na ocorrência dessa doença e oportunamente foi descrito um relato de caso de MRE, presente no município de Mutuípe-BA, com uma paciente do sexo feminino, residente no município:

Foi relatado o histórico evolutivo da doença os fatores de risco, além de exames clínicos para análise e estudo.

A paciente apresentava alguns sintomas, e após alguns exames, foi diagnosticada com a mielorradiculopatia. Trata-se de uma infecção pouco conhecida, por isso, a importância de escrever sobre a MRE, já que é uma região com cachoeiras e diversos pontos turísticos ecológicos, considerando as variáveis que interferem na situação de saúde.

A obtenção dos dados foi dada através de entrevista com questionário norteador onde a paciente informou sobre: diagnóstico, sintomas, e evolução do quadro clínico.

O trabalho foi realizado por uma estudante de final de curso em Licenciatura em Ciências Biológicas, orientada por professor na área de Parasitologia. Vale ressaltar que, 
o relato de caso foi autorizado pela paciente, respeitando todos os fatores éticos, zelando pela legitimidade das informações e anonimato.

\section{RESULTADOS}

Na sequência será apresentado um relato de caso real de esquistossomose ocorrido em uma paciente do município de Mutuípe-BA.

\subsection{RELATO DE CASO}

Será relatado o quadro de esquistossomose mansônica que ocorreu em uma pessoa do sexo feminino, com 34 anos, no Município de Mutuípe-BA entre o fim do ano de 2017 e início do ano 2018.

Os primeiros sintomas referiam queixa de dor nas pernas, um dia posterior tinha trabalhado na organização de evento e associou a dor a isso, ao cansaço físico, não dando muita importância de início. Porém, dois dias depois ela começou a sentir muita dor, na área pélvica e nas pernas, essa dor foi atribuída a região lombar.

A paciente foi ao hospital municipal de Mutuípe-BA onde foi medicada e liberada para casa. Porém as dores aumentaram muito e no dia seguinte a paciente foi para o hospital de maior porte em Santo Antônio de Jesus-BA, onde fez alguns exames com a suspeita de trombose o qual deu negativo e foi liberada para casa. As dores aumentaram e dois dias depois ela retornou a cidade de Santo Antônio ,e fez alguns exames, incluindo a ressonância magnética, mas nada era associada a Schistosoma e sim a duas hérnias de disco nas vertebras lombares. Em seguida foi para casa de praia no intuito de passar o final de semana com a família, certa que era consequência de alteração lombar. As dores pioraram, e cinco dias depois foi a um hospital particular de grande porte na capital em Salvador - Ba, no qual o médico solicitou um exame chamado de eletroneuromiografia.

Com muita dor e perda de sensibilidade nas pernas, começou a tomar injeções, tomou tantas medicações que chegou a ter hepatite medicamentosa e às dores não passavam.

Quando conseguiu fazer a eletroneuromiografia três dias depois, com os resultados em mãos, foi imediatamente transferida para outro hospital de grande porte e avaliada por um ortopedista, que encaminhou o caso para um neurologista que 
diagnosticou lesão medular, pela eletroneuromiografia. Nesta ocasião, a paciente apresentava paraplegia. O médico pediu uma nova ressonância, e os resultados foi de mielite do cone medular até região torácica. Foi colhido o líquor para tentar investigar o que estava acontecendo, os médicos descartavam a possibilidade de ser Schistosoma, porque a lesão nestes casos fica no cone medular. No caso da paciente, a lesão se estendia até a região torácica.

Pensou-se em várias possibilidades, como infecção bacteriana, herpes e a esclerose lateral amiotrófica (ELA). Chegou a fazer seis dias de doses altas de corticoesteróides, evoluindo com regressão das queixas e ausência de sequelas, reduzindo um pouco as dores que permaneciam.

O diagnóstico de esquistossomose, veio com os resultados do exame pelo líquor conhecido também como Líquido Cefalorraqueano, ou popularmente, como líquido da espinha. É um fluído corporal transparente e incolor produzido pelo cérebro. Ele está concentrado em parte da cabeça, e da coluna. Sua análise é fundamental para o diagnóstico de doenças que atuam no Sistema Nervoso Central.

Com o diagnóstico a paciente chegou a tomar praziquantel e repetiu a dose trinta dias depois. Daí começou a apresentar uma melhora progressiva a se recuperar aos poucos e durante esse período chegou a fazer sete meses de tratamento com fisioterapia.

\subsection{OUTRAS CONSIDERAÇÕES}

A paciente, quando foi questionada sobre a forma de infecção por S. mansoni afirma que a infecção ocorre pelo contato com a água de rios ou lagoas contaminados. Soube responder como ocorre a infecção por S. mansoni e o desenvolvimento da esquistossomose e que o município de Mutuípe-BA é uma área endêmica para esquistossomose, mas nunca imaginanaria que poderia acontecer com ela a infecção.

Ela relatou que em momento algum fez exames de fezes e que o contato com a água só teve quando era criança e uma única vez nas cachoeiras do rio Jiquiiriçá depois de adulta. Também relatou que o município de Mutuípe-BA tem casos de pessoas que não conseguem nem andar devido a infecção por esquistossomose. 
Atualmente a paciente está bem, seus hábitos continuam os mesmos, a única coisa após a infecção hoje em dia é um pequeno formigamento nos pés, mas nada limitante.

A paciente ressaltou também, sobre as ações que são feitas pelos agentes de endemias no município de Mutuípe-BA que são fundamentais. Além de promover ações de educação e saúde junto à comunidade e de informar à população sobre os riscos das doenças, também é realizada visitas aos imóveis e outras localidades com o objetivo de prevenir e controlar doenças como dengue, malária, leishmaniose, doença de Chagas, controle de roedores, e principalmente a esquistossomose, já que o município é uma área endêmica, entre outras ações de manejo ambiental para prevenir e controlar doenças.

\section{DISCUSSÃO}

Esquistossomose mansônica é uma doença endêmica onde o agente causador encontrou condições epidemiológicas favoráveis, especialmente nas regiões Nordeste e Sudeste do Brasil constituindo importante problema de saúde pública (CARVALHO; COELHO e LENZI, 2008; MINISTÉRIO DA SAÚDE, 2014). A Bahia é o estado com a segunda maior área endêmica do País. Dos 417 municípios, a esquistossomose está presente em 251. A doença já foi detectada em todas as regiões do estado. As localidades com as prevalências mais elevadas são encontradas em municípios das bacias dos rios Paraguaçu, Jequiriçá, Itapecuru, Contas e Jaguaribe (SVS/MS,2008).

O contato direto com a água contaminada é o principal fator para a infecção por esquistossomose no município de Mutuípe-BA. Parte dos moradores tem contato com a água de alguma forma, seja por lazer, atividades domésticas ou por conta do trabalho. Uma das principais fontes de contato com a água do rio pelos moradores são as cachoeiras no município no rio Jiquiriçá. Observou-se também que há residências no município que ficam próximas ao rio já que o mesmo passa dentro da cidade.

No município de Mutuípe-BA algumas casas lançam seus esgotos diretamente no rio, o que incide diretamente sobre a saúde das pessoas que mantém contato com estes que estão contaminados.

Estudos feitos pela FIOCRUZ em comunidades no município de Ubaíra no ano de 2009 e 2012 mostraram o índice de prevalência e a intensidade de infecção de 45,8\% e 
23,7\%, a intensidade de infecção $60,8 \%$ e 34,2\% respectivamente, os números de moradores participantes foram de 461 e 452 respectivamente (BARBOSA, 2013).

Sem saneamento e tratamentos de esgotos o espaço fica propicio a proliferação de doenças perigosas. O tratamento na rede de esgoto é de extrema importância para diminuir a proliferação da doença, conforme informa ROLLEMBERG (2011). O contato humano com águas que contêm cercárias, devido a atividades domésticas tais como lavagem de roupas e louças, de lazer, banhos em rios e lagoas, e de atividades profissionais é a maneira pela qual o indivíduo adquire a esquistossomose (BRASIL, 2005). A falta de informações no município pode ser considerada um fator relevante sobre o conhecimento e prevenção contra parasitoses e suas consequências, as informações sobre a infecção são necessárias para a população adotar atituldes comportamentais capazes de evitar a infecção pelo S. mansoni, contribuindo significativamente para o seu controle.

$\mathrm{Na}$ entrevista, a paciente relatou que existem pessoas no município que não conseguem andar devido a infecção. Cabe aos municípios realizar regularmente busca ativa e tratamento dos portadores, para manter a prevalência baixa e reduzir o aparecimento das formas graves. Uma das dificuldades para detecção precoce dos portadores do S. mansoni é que a infecção pode evoluir de maneira silenciosa até a instalação das formas graves da doença (CARVALHO,2005; MINISTÉRIO DA SAÚDE, 2006).

Segundo o relato na paciente, alguns moradores do município não acreditam no processo de infecção da doença a partir do contato com a água contaminada, ela mesma nunca imaginava que a infecção aconteceria com ela. A manifestação clínica da doença pode levar anos para se manifestar (KATZ, ALMEIDA, 2003). Esta infecção inicia quando fezes humanas contendo ovos de S. mansoni contaminam os rios, córregos e lagoas e encontram condições que permitam que os ovos eclodam e liberem os miracídios, estes penetraram nos caramujos e sofrem transformações no seu interior, dando origem ao seu estágio infectante ao homem a cercaria (BARBOSA et al.,2008; BRASIL, 2005).

O caso da paciente no município de Mutuípe que teve a forma mais grave dá infecção é um caso atípico da esquistossomose mansônica, um caso de Mielorradiculopatia Esquistossomotica que se dá pela presença de ovos do Schistosoma mansoni no Sistema Nervoso Central. De início a doença é assintomática, porém os 
sintomas se manifestam na fase aguda e crônica. Por apresentar formas clínicas parecidas com outras doenças, o diagnóstico definitivo da esquistossomose é possível por exames de laboratórios, utilizando métodos diretos e indiretos. Os diretos detectam a presença de ovos de S. mansoni e os indiretos identificam evidências indiretas da presença do parasito e dependem de marcadores clínicos, bioquímicos ou imunológicos associados à infecção (NEVES, 2011).

É importante que os moradores do município de Mutuípe-BA façam periodicamente o exame para esquistossomose através de métodos laboratoriais disponível pelo posto de saúde do município, que utiliza a técnica de Kato-Katz. Considerando os riscos e o extenso espectro clínico da esquistossomose mansônica o diagnóstico de certeza só é estabelecido através de exames laboratoriais (LENZI, 2008).

Quando foi questionada sobre as ações educativas no município, a paciente afirmou que é algo importante a ser trabalhado já que é uma área endêmica, sugerindo palestras e uso das redes sociais afim de passar informações relevantes para a população.

Segundo um manual pela Organização Mundial da Saúde (1994), a educação e saúde, é como, um dos aspectos dos cuidados primários de saúde, voltado para a promoção e reforço do comportamento saudável, com participação dos indivíduos e comunidades envolvidas e caracteriza tal processo como voluntário e capaz de encorajar as pessoas a tomarem decisões informadas que permitam manter e melhorar a sua saúde. Estabelece, como objetivo da educação em saúde no controle da esquistossomose, auxiliar as pessoas a compreenderem que o seu próprio comportamento é um fator chave na transmissão da doença.

Com a criação do Programa Especial de Controle da Esquistossomose (PECE), pela Superintendência de Campanhas de Saúde Pública (SUCAM), sendo substituído, posteriormente, pelo Programa de Controle da Esquistossomose (PCE), na década de 1980. Com a descentralização das ações de vigilância e controle de doenças, em 1999, a execução das ações do PCE passou a ser de responsabilidade compartilhada, e os municípios passaram a exercer um papel fundamental à realização de ações voltadas à educação em saúde contribuem para o alcance de melhores resultados, uma vez que o monitoramento detém um maior controle do agente causador da doença, e as atividades de educação em saúde possibilitam uma maior aproximação da população 
com a equipe de saúde, o que é de extrema importância para a doença. A esquistossomose é uma doença endêmica que está intimamente ligada às condições socioambientais e necessita de conscientização sanitária de quem vive nas áreas de transmissão da doença (FAVRE, 2001).

Uma série de ações, visando à realização das atividades do PCE, deve ser realizada nos municípios, como prevenção, tratamento no controle de doenças, medidas de saneamento ambiental, educação em saúde, vigilância epidemiológica (BRASIL, 2004; BRASIL, 2008).

Vale ressaltar também que o Programa Saúde na Escola (PSE) visa à integração e articulação permanente da educação e da saúde, proporcionando melhoria da qualidade de vida da população brasileira. Tendo como objetivo contribuir para a formação integral dos estudantes por meio de ações de promoção, prevenção e atenção à saúde, com vistas ao enfrentamento das vulnerabilidades que comprometem o pleno desenvolvimento de crianças e jovens da rede pública de ensino. O processo de educação em saúde é uma das formas de se promover a saúde por meio do compartilhamento de saberes na busca de soluções dos mais diversos problemas. As atividades de educação em saúde devem ser realizadas independentemente dos níveis de prevalência da doença, e visa não só a envolver as comunidades na execução das ações de controle, como também, ampliar seu nível de conscientização, de modo a trazer o empoderamento necessário para demandar das autoridades competentes as medidas pertinentes para a solução do problema da esquistossomose (FARIAS, 2010).

É importante considerar que o risco de uma reinfecção pode existir se não tomados todos os cuidados necessários (BODSTEIN,2002). As ações educativas no controle da esquistossomose são importantes e devem ser buscadas e valorizadas permanentemente, como intervenções na área social e ambiental, a fim de aumentar a conscientização da população na adoção de atitudes que diminuam a infecção e de melhorar os resultados das intervenções para o controle da endemia. Portanto educação em saúde e controle de caramujos em lagos e rios, devem estar inseridas em todas as ações, de modo a garantir a eficiência e a eficácia das atividades desenvolvidas.

Mediante ações educativas, a população busca melhorar as condições de vida a partir do conhecimento de sua realidade. A participação da comunidade e o desenvolvimento de ações de informação, educação e comunicação produzem 
mudanças de condutas e hábitos da população, melhorando a eficácia das ações de controle.

Por se tratar de uma pessoa do convívio público, esse caso servirá como disseminação do assunto na região. Com a proposta de fazer com que a população que reside numa região de risco possa conhecer o relato de caso, e está ciente que pode acontecer com qualquer uma das pessoas em exposição. E servirá como exemplo para a educação na região, conscientizando assim a população acerca da importância desse tema.

O caso apresentado confirma que a MRE é doença grave, que acomete o indivíduo de forma aguda. O diagnóstico de MRE deve ser rápido para que se tomem imediatamente as medidas anti-inflamatórias específicas que evitam sequelas neurológicas. Sendo assim, esse relato de caso servirá para alertar e ao mesmo tempo conscientizar a população no controle e prevenção da esquistossomose, buscando registrar o relato de caso com a finalidade de servir como base de referência para futuros estudos e fusão do conhecimento. É importante trazer informações sobre a doença, já que a região é uma área endêmica e as pessoas têm conhecimento limitado sobre formas graves da doença.

\section{CONSIDERAÇ̃̃ES FINAIS}

A esquistossomose mansônica pode levar ao quadro de Mielorradiculopatia Esquistossomotica especialmente em áreas endêmicas como no município de MutuípeBA.

Foi possível compreender a importância da educação na prevalência e controle da esquistossomose mansônica. Assim, este relato de caso contribuiu como referência de caso grave de Schistosoma.

As ações educativas no controle da esquistossomose são importantes e devem ser buscadas e valorizadas permanentemente. Devem estar inseridas no contexto escolar, de modo a garantir a eficiência e a eficácia das atividades desenvolvidas.

\section{REFERÊNCIAS}

BRASIL. Ministério da Saúde. Departamento de Vigilância Epidemiológica. 2 ed. Brasília. Editora do Ministério da Saúde. 2005. 
BARBOSA, C.S et al. Epidemiologia e controle da esquistossomose mansoni. In: Carvalho OS, Coelho PMZ, Lenzi HL. Schistosoma mansoni Esquistossomose:uma visão multidisciplinar. Rio de Janeiro: FIOCRUZ, 2008.

BARBOSA, L. M. Avaliação da estrutura populacional do Schistosoma mansoni em duas comunidades rurais e em uma localidade urbana. $115 \mathrm{f}$. il. Tese (Doutorado) Fundação Oswaldo Cruz, Centro de Pesquisas Gonçalo Moniz, Salvador, 2013.

BODSTEIN, R. Atenção básica na agenda da saúde. Ciência \& Saúde Coletiva, São Paulo, v.7 n.3, 2002.

BRASIL. Ministério da Saúde. Secretaria de Vigilância em Saúde. Guia de vigilância epidemiológica e controle da mielorradiculopatia esquistossomótica / Ministério da Saúde, Secretaria de Vigilância em Saúde. - Brasília: Ministério da Saúde, 2006.

BRASIL. Ministério da Saúde. Secretaria de Vigilância em Saúde. Departamento de Vigilância Epidemiológica. Vigilância da Esquistossomose Mansoni: diretrizes técnicas / Ministério da Saúde, Secretaria de Vigilância em Saúde, Departamento de Vigilância das Doenças Transmissíveis. - 4. ed. - Brasília: Ministério da Saúde, 2014.

CARVALHO, et al. Desenvolvimento de um sistema de informações para o estudo, planejamento e controle da esquistossomose no Estado de Minas Gerais. In: XII Simpósio Brasileiro de Sensoriamento Remoto. 2005 Goiânia. GO. Anais. Goiânia, GO: Brasil, INPE, 2005.

Cadernos de Atenção Básica № 21/Secretaria de Atenção à Saúde, Departamento de Atenção Básica - Brasília: Ministério da Saúde, 2008.

FARIAS, G. C. F. Avaliação do grau de implantação do Programa de Controle da Esquistossomose no município de Tracunhaém, Zona da Mata 2010. $92 \mathrm{f}$. Monografia (Gestão de Sistema e Serviço de Saúde) - Centro de Pesquisas Aggeu Magalhães, Fundação Oswaldo Cruz, Recife, 2010.

FAVRE, T. C. Avaliação das ações de controle da esquistossomose implementadas entre 1977 e 1996 na área endêmica de Pernambuco, Brasil. Rev. Soc. Bras. Med. Trop., Uberaba,2001.

Guia de Vigilância e controle da mielorradiculopatia esquistossomótica/Ministério da Saúde, Secretaria de Vigilância em Saúde - Brasília: Ministério da Saúde, 2006

IBGE - Instituto Brasileiro de Geografia e Estatística, v4. 3.16.1, Mutuípe 2017 disponível em: https://cidades.ibge.gov.br/brasil/ba/mutuipe/panorama > 
KATZ, N; ALMEIDA, K. Esquistossomose, xistosa, barriga d'água. Ciência e Cultura, São Paulo, v.55, n.1, 2003.

NEVES, D. P. Parasitologia humana 12ª ed. São Paulo: Editora Atheneu, 2011.

Organização Mundial de Saúde. O controle da esquistossomose: segundo relatório do Comitê de Especialistas da OMS. Rio de Janeiro; Fundação Oswaldo Cruz; 1994.

OMS, Ministério da Saúde. Guia de Vigilância Epidemiológica. Brasília: Ministério da Saúde: Secretaria de Vigilância Epidemiológica, 2008.

REY, L. Parasitologia 2. ed. Rio de Janeiro: Guanabara Koogan. 1992.

Secretaria de Vigilância em Saúde. Guia de vigilância epidemiológica e controle da Mielorradiculopatia Esquistossomótica. Brasília: Ministério da Saúde; 2006.

Secretaria de Vigilância em Saúde - SVS/MS .144 p. il. Título da 3ạ edição: Vigilância e Controle da Esquistossomose: diretrizes técnicas, 2008.

Vigilância e controle de moluscos de importância epidemiológica - Diretrizes Técnicas; Programa de Vigilância e Controle da Esquistossomose - PCE, Secretaria de Vigilância em Saúde, 2ª̣ed. Brasília: Ministério da Saúde, 2008.

Vigilância e controle de moluscos de importância epidemiológica - Diretrizes Técnicas; Programa de Vigilância e Controle da Esquistossomose - PCE, Secretaria de Vigilância em Saúde, 2aed. Brasília: Ministério da Saúde, 2008. 



\section{INTRODUÇÃO}

As parasitoses intestinais são infecções causadas por protozoários e helmintos, que configuram um grave problema de saúde pública, especialmente, em países subdesenvolvidos ou em desenvolvimento, onde costumam ser endêmicas. Nesses locais, as condições sanitárias precárias, relacionadas ao baixo nível socioeconômico e cultural, contribuem para disseminação e para a alta prevalência da doença, pois são fatores que estão diretamente associados à manutenção desses enteropatógenos, facilitando a infecção e/ou reinfecção da população (FREI; JUNCANSEN; PAES, 2008).

Em crianças em idade escolar o problema é ainda mais grave, pois representam um grupo de alto risco para infecção por esses parasitos intestinais (BELLOTO et al., 2011). Dessa maneira, creches e escolas são locais propícios para a disseminação dos enteropatógenos, pois os hábitos inadequados de higiene e a imunidade ainda em desenvolvimento, associada ao alto contato inter-humano favorecem a infecção (KOMAGOME et al., 2008; SILVA et al., 2016). Segundo Andrade et al., (2010), essas parasitoses ainda colaboram para o agravo de quadros de desnutrição, diarreia e anemias, além de comprometer significativamente o aproveitamento escolar das crianças.

Ainda assim, essas infecções podem ser minimizadas pelas autoridades, isto se reflete na carência de investimento em ações preventivas e de promoção a saúde. Em consequência disto uma grande parcela da população desconhece ou não sabe identificar as parasitoses, além de apresentar percepções equivocadas quanto a aspectos relacionados à doença que contribuem para a disseminação dos patógenos (BRAGAGNOLLO et al., 2018).

Desse modo, além das autoridades governamentais investirem em assistência médica, adicionalmente é essencial que haja o investimento em ações profiláticas, através da conscientização da população, com o intuito de diminuir os elevados índices de infecção. Para Bóia et al., (2006) a implementação de práticas educativas que direcionam a comunidade a adquirir conhecimentos a respeito das doenças em geral, tornando-os promotores da saúde, capazes de atuar na prevenção e redução da carga parasitária, configura uma intervenção clara e eficaz para o controle das enteroparasitoses. 
Neste contexto, este artigo relata o processo criativo de conteúdos educativos sob o formato de História em Quadrinhos (HQ) por alunos do ensino superior, cujo o tema abordado tratava-se de uma das principais parasitoses intestinais que acometem os seres humanos, a amebíase. O objetivo da oficina de criação foi o de disponibilizar para o público, de uma maneira democrática e de fácil compreensão, um material didático e instrucional, assim como o de empoderar os discentes, tornando-os responsáveis pelo seu processo de aprendizagem e desenvolvimento, reafirmando seu papel como agentes transformadores do conhecimento.

\section{REVISÃO BIBLIOGRÁFICA}

\subsection{O USO DO LÚDICO PARA O ENSINO DA AMEBíASE}

Amebíase é o nome dado à infecção parasitária causada ao ser humano pelo protozoário Entamoeba histolytica, popularmente conhecido como ameba. Apesar da doença ser majoritariamente assintomática (80-90\%), alguns pacientes podem evoluir para a forma latente que conduz a surtos agudos, ou eventualmente, a complicações mais graves que decorrem de quadros de amebíase extraintestinal. Além disso, apesar da eficiência, os tratamentos disponíveis não são suficientes para reduzir os altos índices de morbidade e mortalidade em locais endêmicos. Em virtude disso, ações que alertem a população a respeito de fatores associados à doença são essenciais para seu controle (SILVA; GOMES, 2015).

Na construção dessas ações de promoção à saúde além do primor pelo rigor científico, é importante que os leitores assimilem os conceitos apresentados. Nesse sentido, as HQs, quando bem construídas, produzem efeito a contento. Para Rama e Vergueiro (2004) “As histórias em quadrinhos são escritas em linguagem de fácil entendimento, com muitas expressões que fazem parte do cotidiano dos leitores facilitando a aprendizagem" (RAMA; VERGUEIRO, 2004, p. 170). Para além da linguagem simples, a combinação dos códigos presentes nas HQs (recurso visual e verbal), cumprem o papel de chamar atenção do público, envolvendo-os na construção de uma aprendizagem significativa (VILLA, 2006).

O uso de HQs como recurso didático foi comentando por Rebolho, Casarotto e João (2009). Para os autores: 


\begin{abstract}
A facilidade com que a história em quadrinhos comunica conhecimentos científicos está relacionada ao fato de que ela transmite informações de forma atrativa, divertida e facilita a memorização de conceitos. [...] A aproximação das histórias em quadrinhos das práticas pedagógicas pode favorecer a comunicação do conhecimento especifico (REBOLHO; CASAROTTO; JOÃO, 2009, p. 49).
\end{abstract}

Para os docentes, essa ferramenta educativa permite a transposição de saberes, de maneira que o saber cientifico é transformado naquele a ser ensinado. No decurso desse processo, o professor desenvolve habilidades que potencializam sua performance, o que se reflete na melhoria do processo de ensino e aprendizagem (KLEIN, 2018). Um exemplo disto, é o desenvolvimento da afetividade entre aluno, professor e conteúdo, a qual possibilita ao educador perceber as necessidades de seus alunos, abrindo espaço para promoção de uma aprendizagem eficiente que valoriza o protagonismo dos estudantes.

Para o ensino da parasitologia, o uso dessa estratégia lúdica serve como instrumento de informação, contribuindo para a mudança de hábitos e consequente inclusão destes no cotidiano de seus leitores. Além disso, a construção de HQs pelos alunos, permite um contato maior com a realidade, de maneira que os estudantes atribuem significado ao tema, o que, por conseguinte, desperta o senso crítico a respeito de fatores sociais e econômicos que contribuem, por exemplo, na forma de transmissão do parasito ao hospedeiro. Portanto, o uso de HQs para o ensino da amebíase parece ser um excelente recurso didático que por meio do lúdico promove educação em saúde, gerando uma rede de retroalimentação na qual toda a coletividade aumenta seus conhecimentos a respeito do tema abordado (BRAVO; PAIXÃO, 2012; FREIRE, 1980).

\title{
2.2. OFICINA DE PROMOÇÃO EM SAÚDE: PRODUÇÃO DE HQ
}

O estudo qualitativo analisou o planejamento e a produção de um recurso didático sob o formato de uma história em quadrinhos que tinha como temática principal uma parasitose intestinal, produzida por alunos da disciplina de parasitologia clínica do curso de Ciências Biológicas. A oficina de promoção em saúde foi segmentada em 3 momentos distintos. Inicialmente, os alunos participaram de uma aula teórica a respeito das parasitoses intestinais, tema que já estava previsto no calendário acadêmico dos discentes, em um segundo encontro foi promovida uma roda de 
conversa e deu-se início a oficina de produção da $\mathrm{HQ}$, por fim, os alunos apresentaram seu o conteúdo.

Diferente do modelo tradicional de ensino, a aula teórica fundamentou-se nos princípios do Dr. R. W. Revans (1970). Nesta aula, primou-se pelo uso de estratégias de ensino baseadas em concepções pedagógicas reflexivas e críticas, onde os alunos puderam interpretar o tema e interagir abertamente, cabendo ao docente apenas o papel de mediador das discussões. Desta maneira, foi apresentado aos alunos um caso fictício, onde se omitia da história apenas os agentes etiológicos, logo, as parasitoses intestinais que acometiam os personagens. Devido à dificuldade dos alunos em identificar a amebíase, assim como, alguns aspectos relacionados à doença, como fatores de risco e profilaxia, esta foi a parasitose intestinal escolhida para compor o tema da HQ. Esse processo de construção permite que os alunos aprendam para ensinar, tornando-os mais seguros em relação ao conteúdo estudado (CARUSO; SILVEIRA, 2009).

No segundo momento, foi promovida uma roda de conversa sobre os elementos que compõe as HQs, proporcionando aos alunos um primeiro contato com ferramentas on-line que permitem a criação desse recurso didático. Neste encontro, os alunos começaram a estabelecer os personagens e a narrativa da história, assim como, deu-se início à produção da $\mathrm{HQ}$, que foi finalizada em grupo de maneira assíncrona. Quando houveram discordâncias a respeito de qualquer ponto que comporia a história, discussões foram promovidas, tendo o docente como mediador, para que se chegasse a uma conclusão que agradasse a todos os membros do grupo. Finalmente, no último encontro os discentes apresentaram a HQ produzida. As características da doença presentes na história foram novamente discutidas, e os pontos que divergiam das conclusões obtidas na primeira discussão, baseada apenas no conhecimento prévio dos estudantes, foram novamente analisados.

\subsection{A HISTÓRIA EM QUADRINHOS PRODUZIDA PELOS DISCENTES}

A HQ elaborada pelos alunos (Figura 1), foi desenvolvida com o auxílio de diversas ferramentas on-line que fornecem diversas ilustrações de maneira gratuita para a construção de história em quadrinho. Em seguida, as tirinhas produzidas foram reunidas em um arquivo do Microsoft PowerPoint e apresentadas em sala de aula. 
Figura 1 - Educação sanitária com a bióloga Milena, HQ produzida pelos discentes
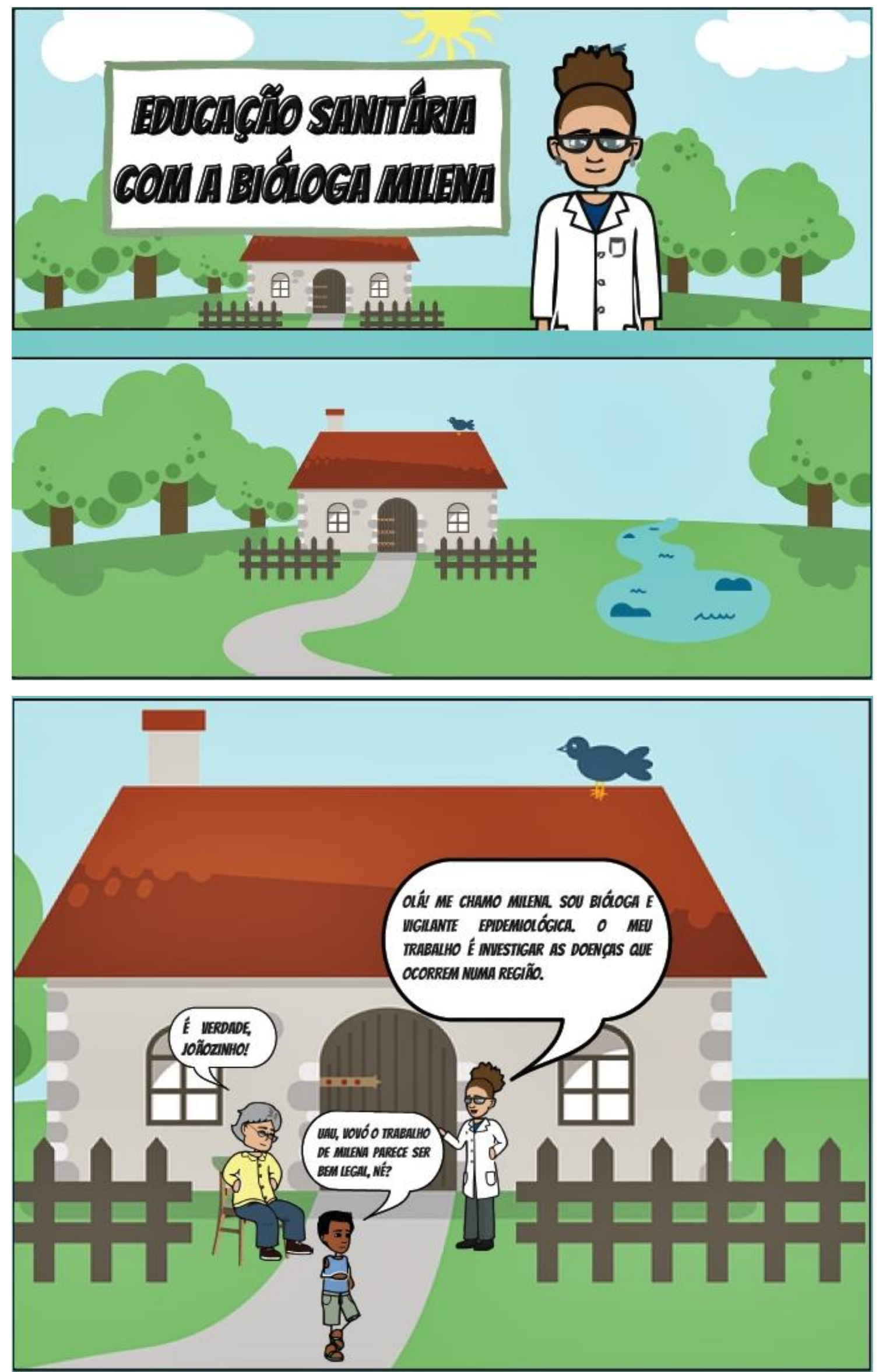

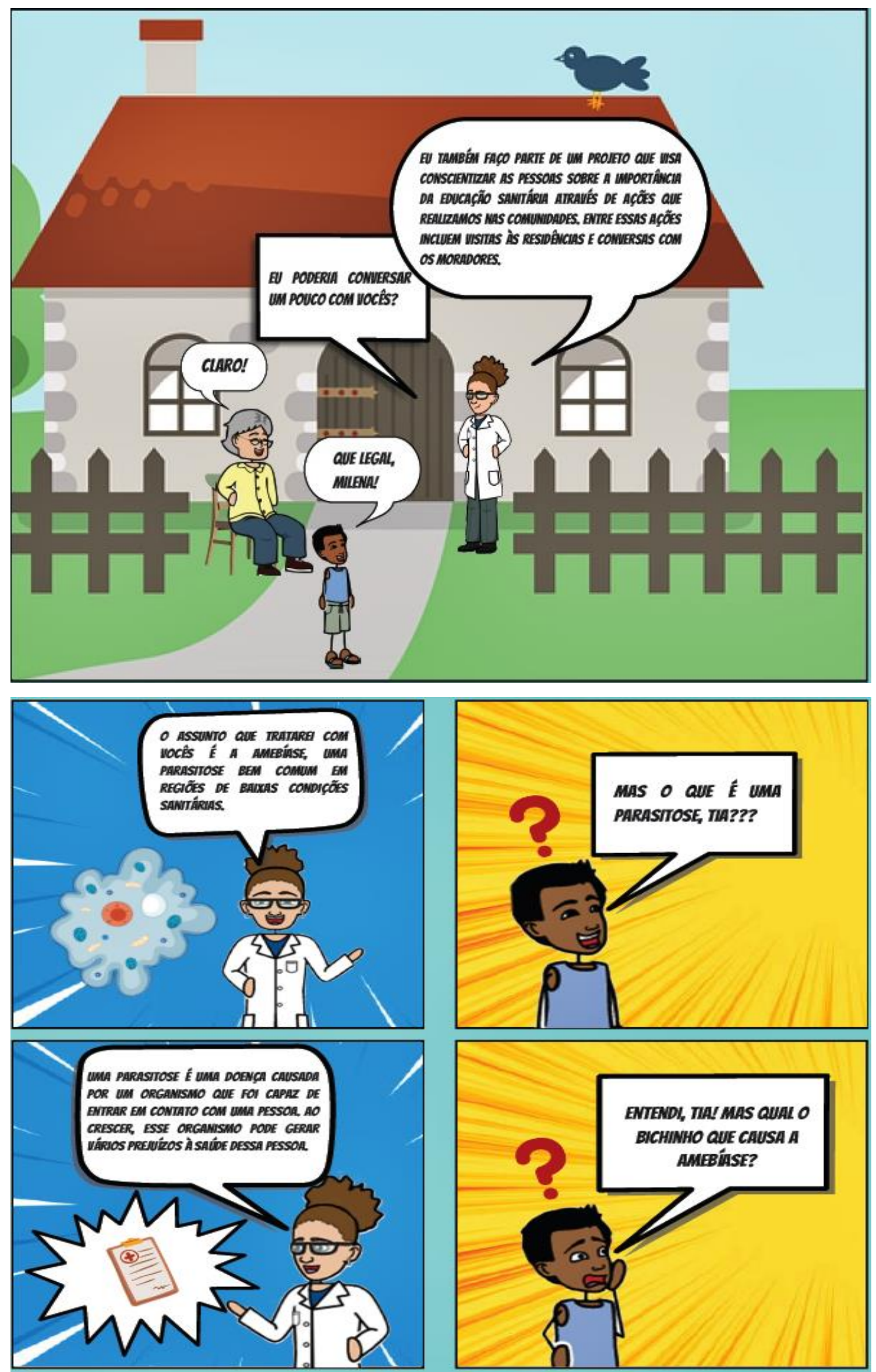

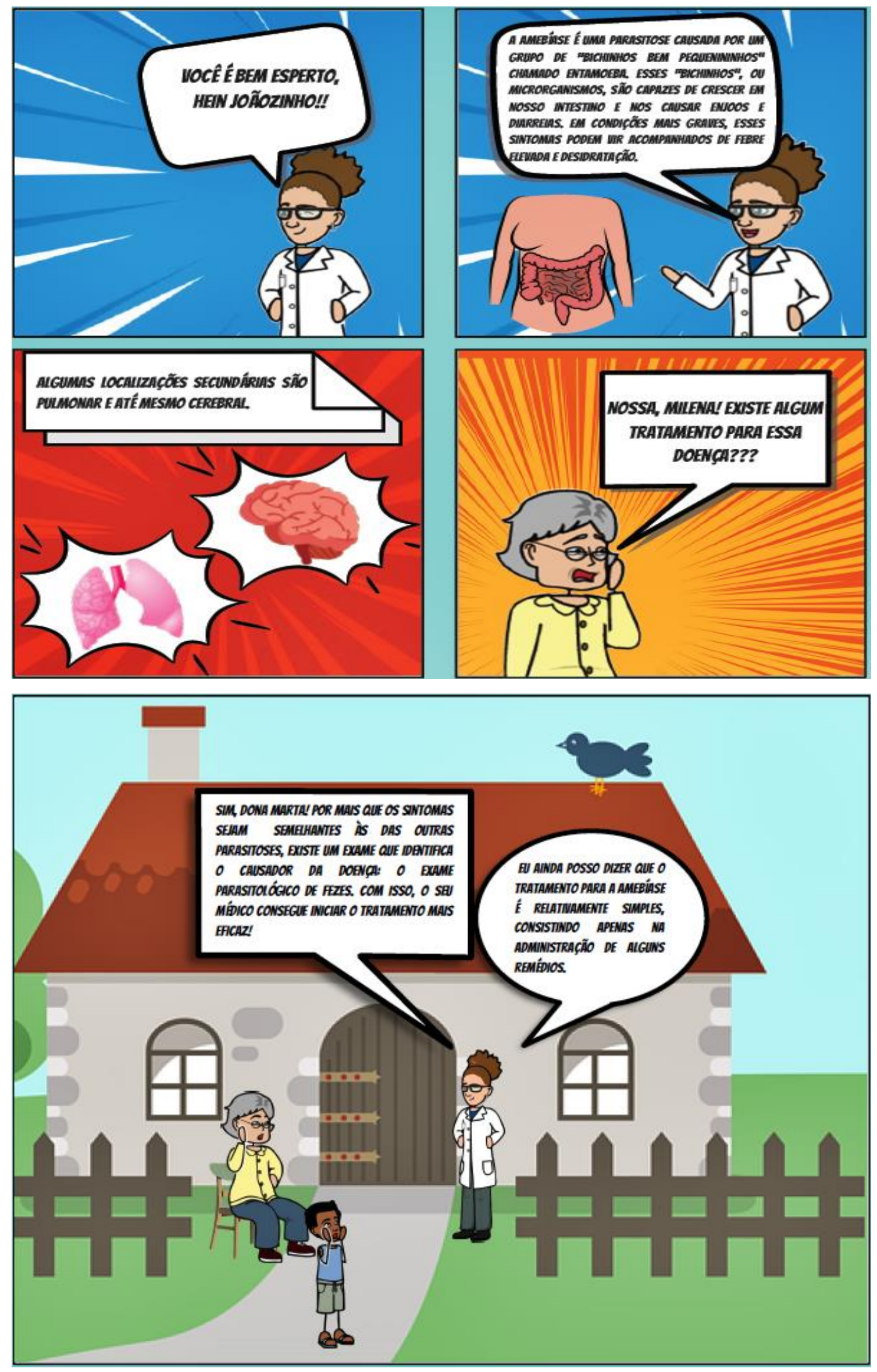

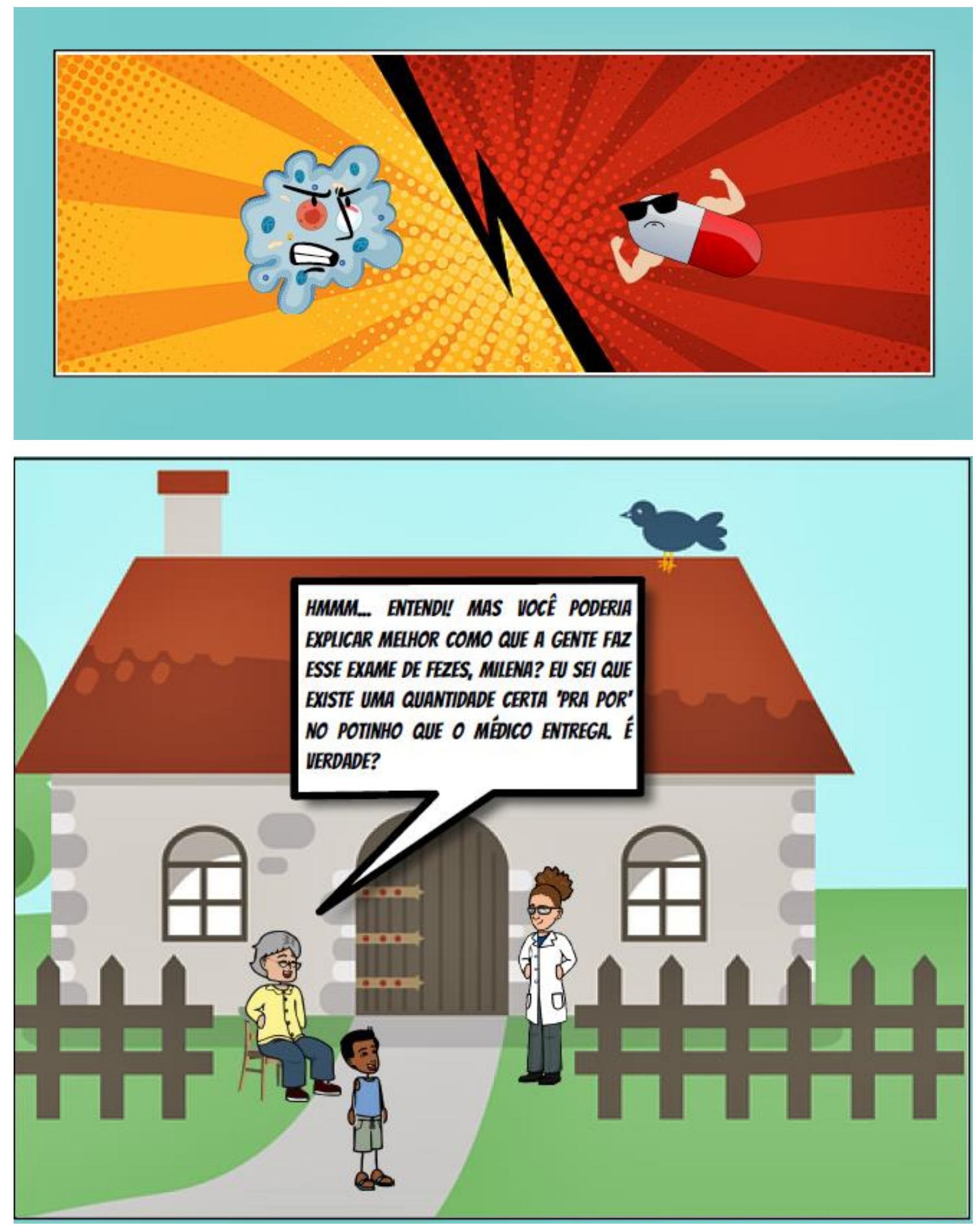

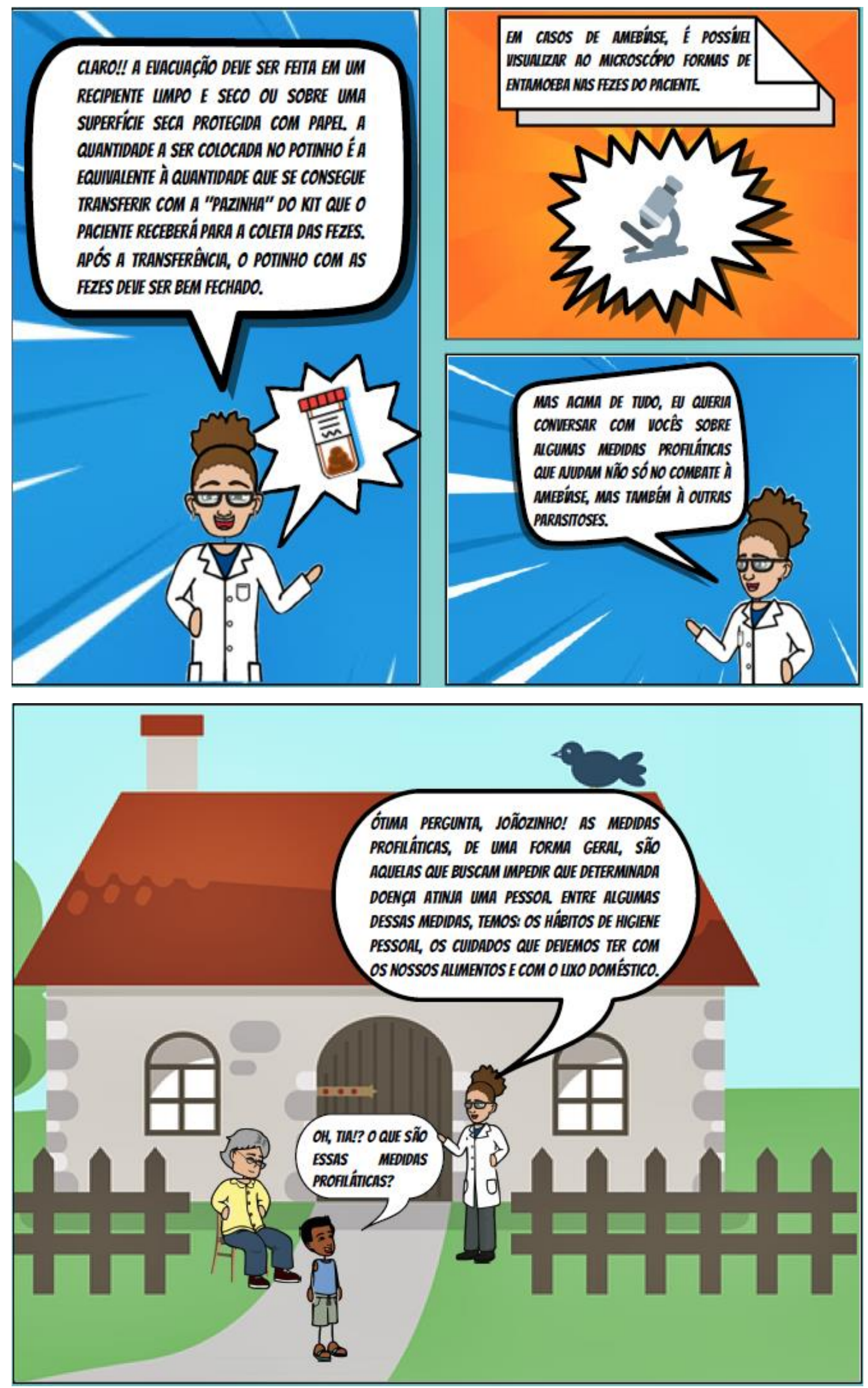

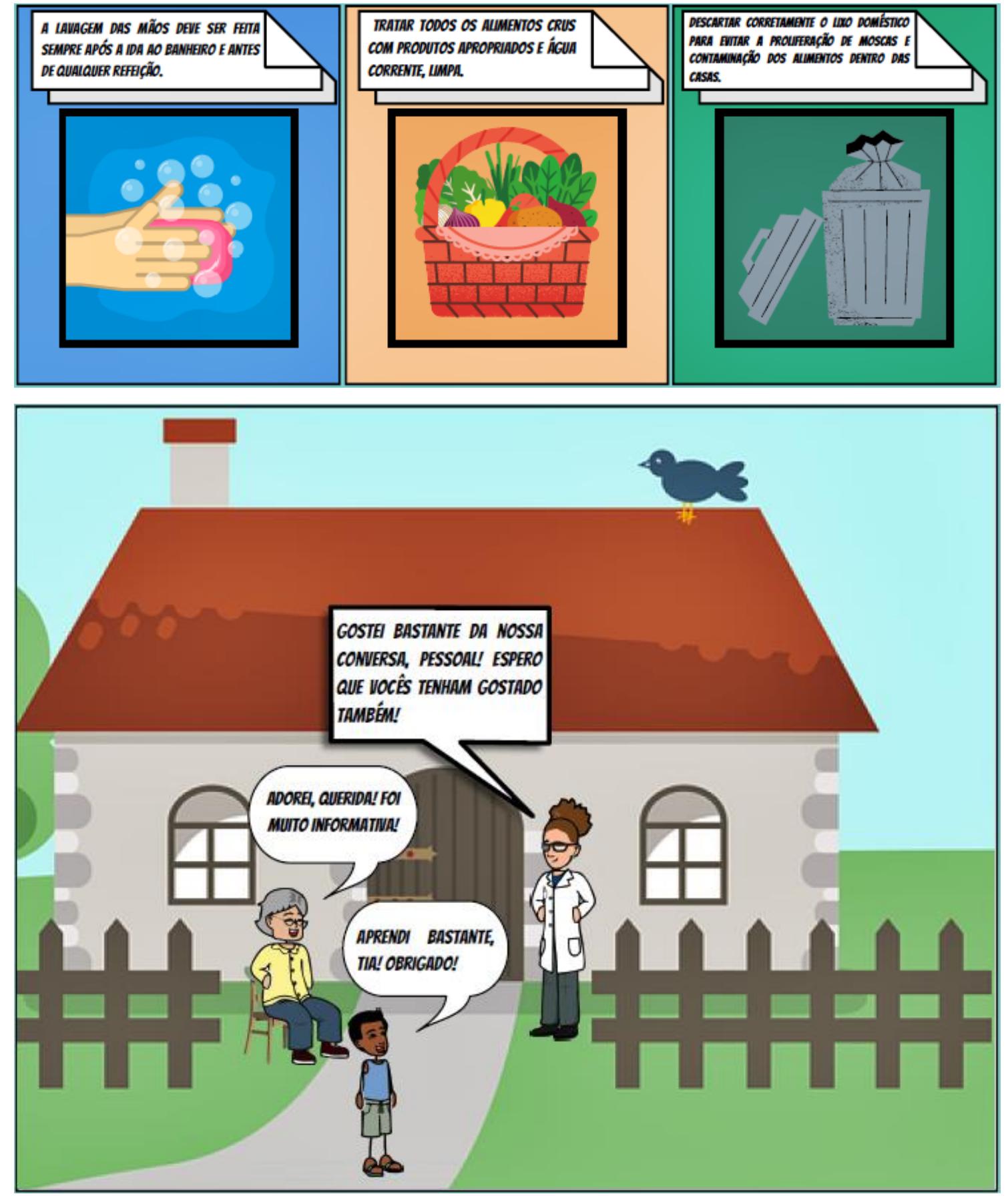

Fonte: Autoria própria.

A história em quadrinhos "Educação sanitária com a bióloga Milena" é uma narrativa visual que apresenta um enredo rápido sobre uma vigilante epidemiológica que orienta uma idosa e seu neto, uma criança, a respeito da amebíase. A bióloga Milena, personagem criada pelos estudantes e inspirada em uma das alunas, explica de uma maneira simples e didática vários aspectos importantes que estão relacionados a manutenção da doença. Para Bravo e Paixão (2012): 


\begin{abstract}
A utilização de personagens criados pelos próprios estudantes denota envolvimento e percepção da realidade, na medida em que lhes permite total liberdade para trabalhar o contexto econômico e social, mostrando-se, também, como um mecanismo versátil de comunicação com o público alvo (BRAVO; PAIXÃO, 2012, p. 161).
\end{abstract}

Além disso, por meio da fala dessa personagem, os alunos retrataram nos quadrinhos as principais características clínicas da doença, pontuando ainda questões como o diagnóstico e tratamento. Um dos assuntos trazidos pelos alunos na HQ estava relacionado aos fatores de risco e à profilaxia para a amebíase. No primeiro encontro, os discentes mostraram certa dificuldade em discutir esses tópicos, especialmente, a respeito do risco que o descarte incorreto do lixo doméstico traz para a saúde humana. No entanto, ao apresentar a HQ os alunos demonstraram mais segurança ao discutir os temas, provando, mais uma vez, que "aprender para ensinar" é um processo formativo valioso para o ensino e aprendizagem.

Nesta perspectiva é importante destacar que ter o domínio dos conteúdos disciplinares não assegura mais uma pratica docente que seja suficiente para construção do conhecimento. Atualmente, é necessário atribuir um novo significado ao conceito de ensinar, assumindo a relevância desses processos formativos para o conhecimento pedagógico, pois segundo (1986):

O conhecimento pedagógico representa uma combinação entre o
conhecimento da matéria e o conhecimento do modo de como ensinar. O
conhecimento pedagógico compreende as formas de representação das
ideias, as analogias, ilustrações, exemplos, explicações e demonstrações, ou
seja, a forma de representar e formular a matéria para torná-la
compreensível para os estudantes (SHULMAN, 1986, p. 9).

Desta maneira, o uso do gênero história em quadrinhos como estratégia de aprendizagem, se mostrou um excelente recurso didático que contribuiu para consolidação e apropriação do conhecimento científico por parte dos discentes. Através das histórias produzidas, os estudantes mostraram-se capaz de comunicar corretamente várias características importantes sobre a amebíase, e que servirão de alerta para a população que terá acesso a HQ produzida.

\title{
3. CONSIDERAÇÕES FINAIS
}

A inclusão do lúdico no processo de ensino e aprendizagem se mostrou uma excelente ferramenta educativa para o ensino da parasitologia. Por meio de seu conteúdo visual e linguagem simples a história em quadrinhos atraiu a atenção dos 
alunos. Aliado a isto, o tema escolhido, proporcionou a conscientização e o desenvolvimento do senso crítico dos discentes. Para além disso, constatou-se que o lúdico, teve um papel fundamental na construção de conhecimento sobre a amebíase, uma vez que por meio das discussões os alunos puderam aliar seus conhecimentos prévios com os adquiridos através da revisão do conteúdo, a qual foi necessária para produção da $\mathrm{HQ}$.

Desta maneira, destacamos que o uso do lúdico como ferramenta pedagógica gerou resultados satisfatórios, pois contribuiu para a aprendizagem e desenvolvimento da criatividade e protagonismo dos estudantes, visto que foram capazes de construir e disseminar o conhecimento científico e tecnológico, assumindo, portanto, o papel de agentes transformadores do conhecimento. Essas constatações reafirmam o potencial que as HQs possuem para o processo formativo de futuros professores, assim como, para a alfabetização científica de seus leitores.

\section{REFERÊNCIAS}

ANDRADE, Elisabeth Campos de et al. Parasitoses intestinais: uma revisão sobre seus aspectos sociais, epidemiológicos, clínicos e terapêuticos. Revista de APS, v. 13, n. 2, 231-240, 2010. Disponível em: https://periodicos.ufjf.br/index.php/aps/article/view/14508. Acesso em: 14 ago. 2021.

BELLOTO, Marcus Vinicius Tereza et al. Enteroparasitoses numa população de escolares da rede pública de ensino do Município de Mirassol, São Paulo, Brasil. Revista Pan-Amazônica de Saúde, v. 2, n. 1, p. 37-43, 2011. Disponível em: https://doi.org/10.5123/S2176-62232011000100004. Acesso em: 01 ago. 2021.

BÓIA, Márcio Neves et al. Mass treatment for intestinal helminthisis control in an Amazonian endemic area in Brazil. Revista do Instituto de Medicina Tropical de São Paulo, v. 48, n. 4, p. 189-195, 2006. Disponível em: https://doi.org/10.1590/S0036-46652006000400003. Acesso em: 01 ago. 2021.

BRAGAGNOLLO, Gabriela Rodrigues et al. Intervenção educacional sobre enteroparasitoses: um estudo quase experimental. Revista Cuidarte, v. 9, n. 1, p. 2030, 2018. Disponível em: https://doi.org/10.15649/cuidarte.v9i1.486. Acesso em: 30 out. 2021.

BRAVO, Lia Guedes; PAIXÃO, Germana Costa. Quadrinhos Como Ferramenta Pedagógica Lúdica. Revista Diálogos Acadêmicos, v. 2, n. 1, p. 158-164, 2012. 
CARUSO, Francisco; SILVEIRA, Cristina. Quadrinhos para a cidadania. História, Ciências, Saúde - Manguinhos, v. 16, n. 1, p. 2017-2236, 2009.

CHRISTINA, Marilia et al. Estratégias para ensino de hábitos posturais em crianças: história em quadrinhos versus experiência prática. Fisioter Pesq, v. 16, n. 1, 2009.

FREI, Fernando; JUNCANSEN, Camila; PAES, João Tadeu Ricardo. Levantamento epidemiológico das parasitoses intestinais: viés analítico decorrente do tratamento profilático. Cadernos de Saúde Pública, v. 24, n. 12, p. 2919-2925, 2008. Disponível em: https://doi.org/10.1590/S0102-311X2008001200021. Acesso em: 15 out. 2021.

FREIRE, P. Conscientização: teoria e prática da libertação: uma introdução ao pensamento de Paulo Freire. 3 ed. São Paulo: Cortez \& Moraes, 1980.

KLEIN, Vanessa. Histórias em quadrinhos: uma alternativa pedagógica para o ensino de química. 2018. Dissertação (Mestrado em Tecnologias Educacionais em Rede) Universidade Federal de Santa Maria, Rio Grande do Sul, 2018.

KOMAGOME, Sandra Hozumi et al. Fatores de risco para infecção parasitária intestinal em crianças e funcionários de creche. Ciência, Cuidado e Saúde, v. 6, n. 0, p. 442447, 2008. Disponível em: https://doi.org/10.4025/cienccuidsaude.v6i0.5354. Acesso em: 15 out. 2021.

RAMA, Angela; VERGUEIRO, Waldomiro. Como usar as Histórias em Quadrinhos em sala de aula. São Paulo: Editora Contexto, 4. ed., p. 175, 2004.

REVANS, Reginald William. Aprendizaje a través de la solución de los problemas, 1970. Disponível em: https://repositorio.sena.edu.co/handle/11404/6506. Acesso em: 15 out. 2021.

SILVA, Edward Félix; GOMES, Maria Aparecida. Amebíase: Entamoeba histolytica/ Entamoeba dispar. In: NEVES, David Pereira. Parasitologia Humana, São Paulo: Editora Atheneu, cap. 15, p. 127-138, 2015.

SILVA, Mariane Roberta da et al. Fatores de riscos relacionados às parasitoses em crianças. ANAIS VIII SIMPAC, v. 8, n. 1, 2017. Disponível em: https://academico.univicosa.com.br/revista/index.php/RevistaSimpac/article/vi ew/677. Acesso em: 13 out. 2021.

SHULMAN, Lee S. Those who understand: Knowledge growth in teaching. Educational Researcher, v. 15, n. 2, p. 4-14, 1986. Disponível em: https://doi.org/10.3102/0013189X015002004. Acesso em: 30 out. 2021.

VILLA, Eliane. Educação em saúde: a prática educativa no cotidiano do trabalho do profissional. In: GAZINELLI, Maria Flávia; REIS, Dener Carlos; MARQUES, Rita Cássia (Org.). Educação em saúde: teoria, método e imaginação, Belo Horizonte: Editora UFMG, p. 166, 2006. 


\title{
CAPITULO XLII
}

\section{O PAPEL DO ENFERMEIRO NA PREVENÇÃO DO CÂNCER DE PELE NA ATENÇÃO PRIMÁRIA EM SAÚDE}

DOI: 10.51859/AMPLLA.PAE1993-42

\author{
Vanessa de Oliveira Bezerra ${ }^{1}$ \\ Aline Maria Afonso Lino ${ }^{2}$ \\ Rafaela Lima de Oliveira ${ }^{3}$ \\ Luciano Godinho Almuinha Ramos ${ }^{4}$
}

${ }^{1}$ Graduanda do curso de enfermagem. Centro Universitário IBMR
2 Graduanda do curso de enfermagem. Centro Universitário IBMR
${ }^{3}$ Graduanda do curso de enfermagem. Centro Universitário IBMR
${ }^{4}$ Mestre em Enfermagem, Professor orientador. Centro Universitário IBMR

\section{RESUMO}

Este estudo versa sobre o papel do enfermeiro na prevenção do câncer de pele na Atenção Primária em Saúde. Objetiva-se destacar a importância do profissional enfermeiro frente a prevenção do câncer de pele, na Atenção Primária. Para isso, foi utilizada a seguinte questão norteadora: Qual a importância do enfermeiro na prevenção do câncer de pele voltada para a Atenção Primaria em Saúde? Como critérios de inclusão foram utilizados artigos científicos entre os anos de 2015 à 2020, nas bases de dados, LILACS, SCIELO, BVS e BVS oncologia, em inglês, francês e espanhol. Como critérios de exclusão foram excluídos artigos de revisão fora do espaço temporal de pesquisa e que não abordavam a temática. Os resultados obtidos através dos 18 artigos científicos selecionados, trouxeram efetivação a elaboração de três categorias temáticas trazendo como principal foco o papel do enfermeiro na prevenção do câncer de pele na Atenção Primária. Conclui-se que a atuação do enfermeiro na atenção primária na conscientização da população sobre o câncer de pele e o estímulo às mudanças de comportamento são de fundamental importância para sua prevenção.

Palavras-chave: Papel do enfermeiro; Câncer de pele; Atenção primária. 


\section{INTRODUÇÃO}

O câncer de pele é o tipo de câncer mais comum no mundo e corresponde a cerca de $30 \%$ de todos os tumores malignos registrados no Brasil, o câncer de pele tem dois subtipos, o melanoma e o não melanoma.

A exposição excessiva ao sol e sem o uso de filtro solar são fatores de risco para desenvolver o câncer de pele. Em um país de clima tropical como o Brasil é preciso ficar a alerta para os sintomas da doença e a importância do diagnóstico precoce. Por isso, estar informado sobre a doença é a melhor maneira de prevenção, diagnóstico e tratamento (MINISTÉRIO DA SAÚDE, 2020).

O câncer de pele do tipo melanoma representa apenas 3\% das neoplasias malignas do órgão, é o tipo mais grave devido à sua alta possibilidade de provocar metástase, ele tem origem nos melanócitos, células produtoras de melanina, substância que determina a cor da pele e é mais corriqueiro em adultos brancos. O melanoma pode aparecer em qualquer parte do corpo, na pele ou mucosas, na forma de manchas, pintas ou sinais, nos indivíduos de pele negra, ele é mais comum nas áreas claras, como palmas das mãos e plantas dos pés.

O câncer de pele não melanoma é o mais frequente no Brasil, apresenta altos percentuais de cura, se for detectado e tratado precocemente (MINISTÉRIO DA SAÚDE, 2021). Entre os tumores de pele este é o mais frequente e de menor mortalidade, porém, se não tratado adequadamente pode deixar mutilações bastante expressivas. Pessoas de pele clara, sensíveis à ação dos raios solares, com história pessoal ou familiar deste câncer ou com doenças cutâneas prévias são as mais atingidas, o câncer de pele não melanoma apresenta tumores de diferentes tipos, sendo os mais costumeiros o carcinoma basocelular e o carcinoma epidermoide (MINISTÉRIO DA SAÚDE, 2018).

Dentre os principais fatores de risco para o desenvolvimento do câncer de pele temos o envelhecimento, exposição prolongada ao sol, possuir pele e olhos claros e muitos nevos (pintas) pelo corpo, câmaras de bronzeamento artificial, onde as mesmas foram reclassificadas pela Organização Mundial de Saúde (OMS) no mesmo patamar do cigarro e do sol, pois a prática de bronzeamento artificial antes dos 35 anos aumenta em 75\% as chances de um desenvolvimento de câncer de pele (OLIVEIRA, et al., 2019). As principais ações para o controle do câncer de pele concentram-se na prevenção e na 
detecção precoce, entre educador e educado com a finalidade não apenas de informar, mas principalmente de trocar experiências e reconhecimento que favoreçam a promoção de hábitos saudáveis de vida (BIBLIOTECA VIRTUAL DE ENFERMAGEM, 2017).

A prevenção deve ser feita principalmente por meio da foto proteção, sendo recomendada a utilização de chapéu e protetor solar diariamente, também se deve evitar a exposição à radiação artificial ultravioleta encontrada no processo de bronzeamento artificial (OLIVEIRA, et al., 2021). Deve-se focar na diminuição de fatores de risco relacionados ao ambiente e à ocupação dos indivíduos, como a exposição a compostos químicos, tais como agrotóxicos, carvão e outros, e exposição prolongada aos raios ultravioletas, nesse sentido, torna-se necessário que o enfermeiro esteja apto a reconhecer e a ensinar à população os principais sinais e sintomas desse tumor, a fim de possibilitar o reconhecimento dessas lesões, além de possibilitar a identificação dos casos suspeitos o mais precocemente possível (PURIM, et al., 2020).

\section{METODOLOGIA}

Uma das principais características do conhecimento científico é a sua estruturação, pois consiste num saber ordenado, o qual é construído a partir de um conjunto de ideias. Outra característica do conhecimento científico é ser verificável, isto é, determinada ideia deve ser verificada e comprovada sob a perspectiva da ciência para que possa fazer parte do conhecimento científico (PEREIRA, et al., 2018).

A revisão integrativa é um método que proporciona a síntese de conhecimento e a incorporação da aplicabilidade de resultados de estudos significativos na prática (SOUZA, et al., 2010).

Para alcançar o objetivo proposto, foi utilizado uma revisão integrativa da literatura e para a seleção dos artigos foram acessadas as seguintes bases de dados: Biblioteca virtual em saúde (BVS), BVS oncologia, Literatura Latino- Americana e do Caribe em Ciências da Saúde (LILACS), Scientific Electronic Library Online (SCIELO) e Instituto Nacional do Câncer Jose Alencar Gomes da Silva (INCA), onde todo o processo de desenvolvimento da pesquisa e seleção dos artigos foi conduzido por três pesquisadores independentes. No processo de montagem, foram encontrados 93 artigos, sendo 32 na BVS, 41 no LILACS e 20 no SCIELO. 
Foi escolhida a seguinte questão norteadora: Qual a importância do enfermeiro na prevenção do câncer de pele, voltada para a Atenção Primaria em Saúde? Com a busca dos estudos selecionados conforme os critérios de inclusão, foi utilizado artigos científicos entre os anos de 2015 a 2021, em inglês, espanhol e francês, artigos em sua versão na íntegra, artigos originais que englobassem os objetivos propostos e abordassem o tema: O papel do enfermeiro na prevenção do câncer de pele na atenção primária em saúde, totalizando 32 artigos.

Conforme os critérios de exclusão, os artigos que não apresentavam a temática, artigos de revisão, artigos que não se relacionavam aos objetivos desta pesquisa, dissertações ou teses, foram descartados. Dessa forma foram excluídos um total de 13 artigos. Sendo que, após a leitura, foram selecionados 18 artigos para a elaboração final do estudo pelos bancos de dados.

A figura a seguir, apresenta como foi realizada a seleção dos artigos que compuseram a amostra final da revisão.

Figura 1 - Fluxograma de busca e seleção dos 18 artigos. Rio de janeiro, RJ, Brasil, 2021

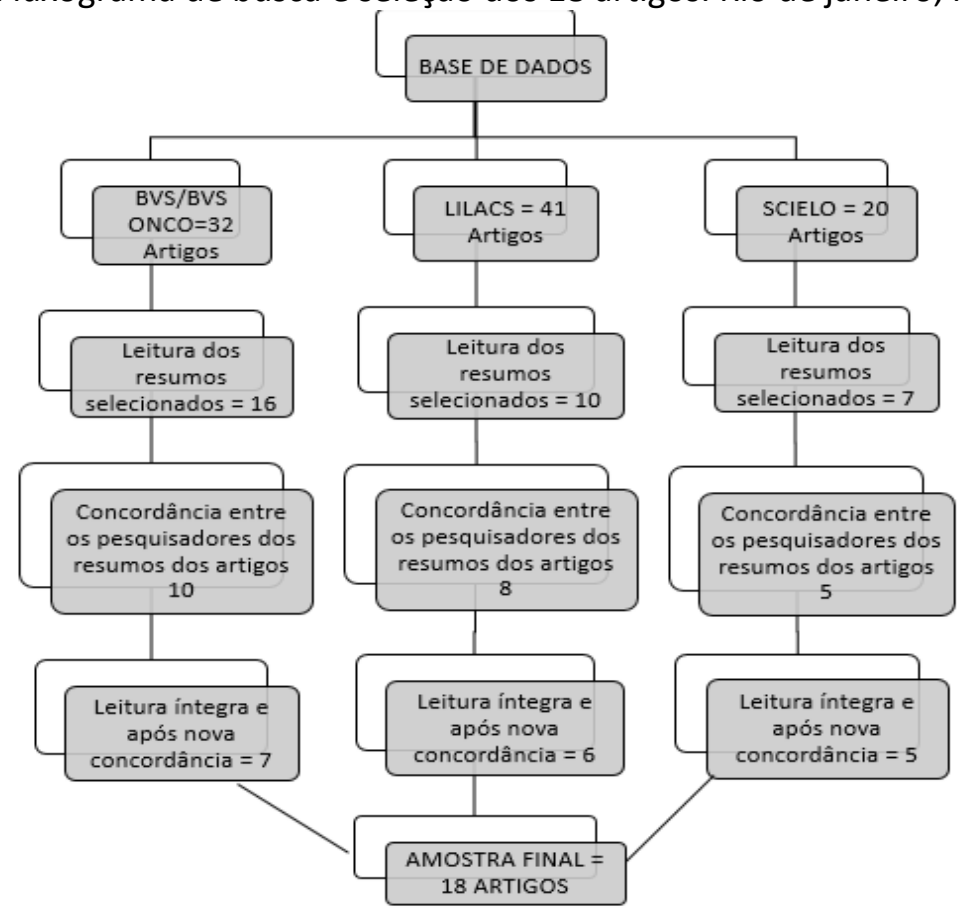

Fonte: Dados da pesquisa.

Analisando o Fluxograma 1, podemos observar os artigos que levaram a elaboração desta revisão, juntamente com a ordem de busca dos mesmos, verificando, banco de dados, seleção, exclusão e escolha para a obtenção da amostra final. 


\section{RESULTADOS E DISCUSSÃO}

Analisando o Quadro 1, podemos observar o esqueleto de organização e estrutura de seleção dos artigos, compondo o desenvolvimento desta revisão integrativa.

A busca dos artigos científicos foi realizada entre março e abril de 2021, e para a apresentação das etapas de seleção dos artigos de acordo com as informações adquiridas, foi elaborado um quadro como metodologia com os principais dados dos artigos científicos escolhidos.

Dos 18 artigos selecionados no campo deste estudo, todos tiveram publicação entre 2015 e 2020, sendo em maior quantidade as apresentações dos artigos de 2017 e 2018.

Tabela 1 - Tabela expositiva dos artigos pesquisados neste estudo. Rio de Janeiro, RJ, Brasil, 2021

\begin{tabular}{|c|c|c|}
\hline AUTOR/ANO & TíTULO & OBJETIVOS \\
\hline $\begin{array}{l}\text { PURIM, et al., } \\
2020\end{array}$ & $\begin{array}{l}\text { Características do melanoma em } \\
\text { idosos. }\end{array}$ & Avaliar características do melanoma em idosos. \\
\hline $\begin{array}{l}\text { CRUZ, et al., } \\
2020\end{array}$ & $\begin{array}{l}\text { Fatores associados ao uso } \\
\text { do protetor solar como } \\
\text { medida de prevenção aos } \\
\text { danos causados pela } \\
\text { exposição solar. }\end{array}$ & $\begin{array}{l}\text { Investigar os fatores associados ao uso do } \\
\text { fotoprotetor solar como na região } \\
\text { metropolitana de Belém. }\end{array}$ \\
\hline $\begin{array}{l}\text { OLIVEIRA et } \\
\text { al., } 2019\end{array}$ & $\begin{array}{l}\text { Educação em saúde do paciente } \\
\text { com diagnóstico de câncer de pele. }\end{array}$ & $\begin{array}{l}\text { Realizar uma análise sobre a educação em } \\
\text { saúde oferecida na atenção primaria a } \\
\text { pacientes diagnosticados com câncer de pele. }\end{array}$ \\
\hline $\begin{array}{l}\text { CARMO, et al., } \\
2019\end{array}$ & $\begin{array}{l}\text { Cuidar em Oncologia: Desafios e } \\
\text { Superações Cotidianas Vivenciados } \\
\text { por Enfermeiros. }\end{array}$ & $\begin{array}{l}\text { Compreender a perspectiva de enfermeiros } \\
\text { acerca do processo de enfrentamento dos } \\
\text { desafios vivenciados no cuidado à pessoa com } \\
\text { câncer. }\end{array}$ \\
\hline $\begin{array}{l}\text { CAUDURO, et } \\
\text { al., } 2018\end{array}$ & $\begin{array}{l}\text { Atuação dos enfermeiros no } \\
\text { cuidado das lesões de pele. }\end{array}$ & $\begin{array}{l}\text { Conhecer a atuação dos enfermeiros no } \\
\text { cuidado aos pacientes com lesões de pele. }\end{array}$ \\
\hline
\end{tabular}




\begin{tabular}{|c|c|c|}
\hline AUTOR/ANO & TÍTULO & OBJETIVOS \\
\hline $\begin{array}{l}\text { FOLONI, et al., } \\
2018\end{array}$ & $\begin{array}{l}\text { Analise de casos de câncer de pele } \\
\text { em um hospital do interior } \\
\text { paulista. }\end{array}$ & $\begin{array}{l}\text { Avaliar as estatísticas dos casos de câncer de } \\
\text { pele em um hospital escola, a fim de contribuir } \\
\text { na programação de ações voltadas à prevenção } \\
\text { e controle da doença. }\end{array}$ \\
\hline $\begin{array}{l}\text { PIRES, et al., } \\
2018\end{array}$ & $\begin{array}{l}\text { Câncer de pele: caracterização do } \\
\text { perfil e avaliação da proteção solar } \\
\text { dos pacientes atendidos em } \\
\text { serviço universitário. }\end{array}$ & $\begin{array}{l}\text { Descrever os casos de câncer de pele, bem } \\
\text { como o hábito de proteção solar na prevenção } \\
\text { de lesões causadas por radiação ultravioleta. }\end{array}$ \\
\hline $\begin{array}{l}\text { SCHMIDT, et } \\
\text { al., } 2018\end{array}$ & $\begin{array}{l}\text { Conhecimento da equipe de } \\
\text { enfermagem sobre cuidados com } \\
\text { pacientes com feridas neoplásicas. }\end{array}$ & $\begin{array}{l}\text { Avaliar o conhecimento da equipe de } \\
\text { enfermagem de um hospital oncológico sobre o } \\
\text { cuidado de pacientes com Feridas Neoplásicas } \\
\text { Malignas (FNM) e analisar fatores } \\
\text { sociodemográficos e educacionais associados. }\end{array}$ \\
\hline $\begin{array}{l}\text { BELTRÃO, et } \\
\text { al., } 2018\end{array}$ & $\begin{array}{l}\text { Acompanhamento de pessoas com } \\
\text { câncer por enfermeiros da atenção } \\
\text { primária }\end{array}$ & $\begin{array}{l}\text { Compreender o processo de acompanhamento } \\
\text { de pessoas com câncer por enfermeiros da } \\
\text { atenção primária. }\end{array}$ \\
\hline $\begin{array}{l}\text { SANTOS, et } \\
\text { al., } 2017\end{array}$ & $\begin{array}{l}\text { Atuação do enfermeiro na } \\
\text { detecção precoce do câncer de } \\
\text { pele. }\end{array}$ & $\begin{array}{l}\text { Analisar a produção científica na } \\
\text { área da enfermagem em relação à detecção } \\
\text { precoce do câncer de pele. }\end{array}$ \\
\hline $\begin{array}{l}\text { ESPOSITO, et } \\
\text { al., } 2017\end{array}$ & $\begin{array}{l}\text { Fatores que levam a negligencia } \\
\text { quanto aos cânceres da pele não } \\
\text { melanoma }\end{array}$ & $\begin{array}{l}\text { Pontuar através de estudos de caso, os fatores } \\
\text { que levam ao negligenciamento do CPNM. }\end{array}$ \\
\hline $\begin{array}{l}\text { SOUZA, et al., } \\
2017\end{array}$ & $\begin{array}{l}\text { Atuação dos enfermeiros da } \\
\text { estratégia saúde da família na } \\
\text { atenção oncológica. }\end{array}$ & $\begin{array}{l}\text { Identificar a qualificação e conhecer a atuação } \\
\text { dos enfermeiros da Estratégia Saúde da Família } \\
\text { na atenção oncológica. }\end{array}$ \\
\hline $\begin{array}{l}\text { WAKIUCHI, et } \\
\text { al., } 2016\end{array}$ & $\begin{array}{l}\text { Atenção a pacientes oncológicos } \\
\text { na Estratégia Saúde da Família: } \\
\text { olhar do usuário }\end{array}$ & $\begin{array}{l}\text { Compreender as experiências de pacientes com } \\
\text { câncer referentes aos cuidados recebidos e a } \\
\text { relação com os profissionais da Estratégia } \\
\text { Saúde da Família. }\end{array}$ \\
\hline $\begin{array}{l}\text { BARATTO, et } \\
\text { al., } 2016\end{array}$ & $\begin{array}{l}\text { Humanização da assistência na } \\
\text { atenção básica às pessoas com } \\
\text { neoplasia: percepção de } \\
\text { profissionais de enfermagem. }\end{array}$ & $\begin{array}{l}\text { Conhecer a percepção de profissionais de } \\
\text { enfermagem atuantes na atenção básica acerca } \\
\text { da humanização da assistência às pessoas com } \\
\text { neoplasias. }\end{array}$ \\
\hline
\end{tabular}




\begin{tabular}{|c|c|c|}
\hline AUTOR/ANO & TÍTULO & OBJETIVOS \\
\hline $\begin{array}{l}\text { WAKIUCHI, et } \\
\text { al., } 2016\end{array}$ & $\begin{array}{l}\text { Atuação da estratégia saúde da } \\
\text { família na perspectiva de usuários } \\
\text { com câncer. }\end{array}$ & $\begin{array}{l}\text { Apreender como usuários com câncer } \\
\text { percebem a atuação das equipes da Estratégia } \\
\text { Saúde da Família. }\end{array}$ \\
\hline $\begin{array}{l}\text { MOREIRA, et } \\
\text { al., } 2015\end{array}$ & $\begin{array}{l}\text { Câncer de pele não melanoma e } \\
\text { risco ocupacional de trabalhadores } \\
\text { ao ar livre. }\end{array}$ & $\begin{array}{l}\text { Analisar a relação do câncer de pele não } \\
\text { melanoma e os riscos ocupacionais dos } \\
\text { trabalhadores expostos ao ar livre. }\end{array}$ \\
\hline $\begin{array}{l}\text { MATHEUS, et } \\
\text { al., } 2015\end{array}$ & $\begin{array}{l}\text { Aspectos epidemiológicos } \\
\text { do melanoma cutâneo. }\end{array}$ & $\begin{array}{l}\text { Analisar aspectos epidemiológicos do } \\
\text { melanoma cutâneo. }\end{array}$ \\
\hline $\begin{array}{l}\text { CEZAR-VAZ, et } \\
\text { al., } 2015\end{array}$ & $\begin{array}{l}\text { Câncer de pele em trabalhadores } \\
\text { rurais: conhecimento } \quad \text { e } \\
\text { intervenção de enfermagem. }\end{array}$ & $\begin{array}{l}\text { Identificar a exposição de trabalhadores rurais } \\
\text { à radiação ultravioleta solar e pesticidas; } \\
\text { identificar casos anteriores de câncer de pele; } \\
\text { implementar clínica e ações comunicativas de } \\
\text { enfermagem entre trabalhadores rurais com } \\
\text { diagnóstico prévio de câncer de pele. }\end{array}$ \\
\hline
\end{tabular}

Fonte: Dados da pesquisa.

Os resultados obtidos através dos 18 artigos científicos selecionados, trouxeram efetivação a elaboração de três categorias temáticas: O papel do enfermeiro frente ao câncer de pele na atenção primária, Melanoma: O enfermeiro em sua identificação e A humanização do atendimento na percepção do enfermeiro na atenção primária.

\subsection{CATEGORIA 1 - O PAPEL DO ENFERMEIRO FRENTE AO CÂNCER DE PELE NA ATENÇÃO PRIMÁRIA}

Ao analisar os 18 artigos selecionados foi possível evidenciar que compete à Atenção Primária, as ações de diagnóstico precoce. Nesse sentido, torna-se necessário que o enfermeiro transmita à população o conhecimento necessário para identificação dos sinais e sintomas de Câncer de pele, possibilitando o reconhecimento dessas lesões e a identificação dos casos suspeitos o mais precocemente possível.

O profissional de enfermagem é essencial na deteç̧ão precoce do câncer de pele (PURIM, et al., 2020). Uma vez que está inserido diretamente na área do cuidado, atuando diretamente na prevenção e na assistência dos usuários nos diversos pontos da atenção primária o profissional de enfermagem mostra a sua importância no gerenciamento (BARATTO, et al., 2016). 
O enfermeiro na Atenção Primaria em Saúde (APS), vêm conquistando espaço social e reconhecimento junto aos integrantes da equipe de saúde e dos usuários que vivenciam com ele o atendimento clínico e identificam nele a referência para o seu cuidado, o que traz muita satisfação e dá sentido ao trabalho.

Observa-se que o profissional de enfermagem é um dos primeiros a ter contato com os pacientes que procuram assistência de uma equipe de cuidados específicos (SCHMIDT, et al., 2020). Esse profissional, ocupa uma posição privilegiada para realizar a avaliação visual da pele e obter a história clínica dos pacientes dentro das unidades de pronto atendimento (CAUDURO, et al., 2018). O profissional de enfermagem possui um campo fértil de atuação para desenvolver ações de educação em prevenção e deteç̧ão precoce do câncer de pele, propício à realização de ações que, junto à equipe de atenção primaria na RAS, busquem controlar a incidência e a mortalidade do câncer no país (CRUZ, et al., 2020).

O autoconhecimento do profissional de saúde é importante para que se estabeleça um relacionamento interpessoal adequado ao processo de cuidar, desenvolvendo consciência de suas limitações, fragilidades e potencialidades (MATHEUS, et al., 2015).

O conhecimento abrangente e profundo dos fatores relacionados e dos problemas que afetam a saúde da população atendida pela instituição, como sua condição socioeconômica, necessidades e carências, crenças e valores culturais, entre outros aspectos, contribui para que os profissionais se tornem mais comprometidos com a população atendida e com a busca de resultados concretos e coerentes com a realidade de vida das pessoas sob seus cuidados.

$\mathrm{Na}$ oncologia, os cuidados técnicos são de extrema importância para o prognóstico da pessoa, entretanto, apenas essa modalidade de cuidado não supre as necessidades psicológicas, emocionais, sociais, culturais e as crenças inerentes a cada ser (MACENA, et al., 2020). Evidencia-se que o conhecimento técnico do enfermeiro e a humanização precisam estar interligados para prover melhor qualidade de vida ao usuário (ARAÚJO, et al., 2016).

A maneira como as relações entre a enfermagem e os usuários dos serviços de saúde ocorrem é fundamental para a produção do cuidado, quando esta relação é realizada no trabalho vivo em ato (SOUZA, et al., 2017). Um estudo diz que a 
enfermagem conta com altos graus de liberdade, podendo exercer melhor a criatividade necessária ao cuidado em saúde e fortalecer os aspectos relacionais do seu trabalho, promovendo abertura para o encontro da produção do cuidado que atenda às reais expectativas dos usuários na unidade de atendimento (BICA, et al., 2020).

Sendo uma profissão fundamental no sistema de saúde, a enfermagem se destaca e diferencia pelo desenvolvimento de práticas interativas e integradoras de cuidado, às quais vêm adquirindo uma repercussão cada vez maior, tanto na educação e promoção da saúde, quanto no fomento de políticas voltadas para o bem-estar social das famílias e comunidades.

A Atenção Primária é responsável, dentre outras demandas, por ações direcionadas ao usuário com câncer e aos seus familiares (GOMIDE, et al., 2018). Devendo se fazer presente em todas as fases da doença, o que demonstra que o enfermeiro tem um papel importante no atendimento, tanto durante a consulta de enfermagem, diagnóstico, quanto ao tratamento do câncer nos pacientes (WAKIUCHI, et al., 2016.)

O plano de cuidados de enfermagem ao usuário da Atenção Primária na prevenção do câncer de pele tem como prioridade o acolhimento (RIBEIRO, et al., 2016).

Com a postura ética, que integre o usuário como protagonista em seu processo terapêutico, considerando sua cultura, seus saberes e sua capacidade de avaliar riscos, respeitando seus medos e fragilidades o planejamento da enfermagem torna-se efetivo (CARMO, et al., 2019). Nesta perspectiva que a equipe de enfermagem é fundamental e a primordial referência na atenção diária, responsável e gestora desse processo (ESPOSITO, et al., 2017).

O acolhimento deve ser entendido como diretriz ética, estética e política constitutiva dos modos de se produzir saúde, além de ferramenta tecnológica de intervenção na qualificação de escuta, construção de vínculo, garantia do acesso com responsabilização e resolutividade nos serviços (CEZAR-VAZ, et al., 2015).

Para que as necessidades básicas apresentadas pelos usuários sejam sanadas, é necessário que haja interação entre o profissional e o usuário, sendo assim, podemos dizer que a criação do vínculo do enfermeiro para com o cliente favorece a construção de confiança e compromisso entre os usuários e a enfermagem, facilitando o acesso ao serviço e as relações interpessoais. 
Atribui-se ao enfermeiro o cuidado ao paciente, esse profissional pode realizar consulta de enfermagem (MOREIRA, et al., 2015). Prescrever e executar curativos, coordenar e supervisionar a equipe de enfermagem na prevenção e cuidados referentes a neoplasias de pele, dentre outras atribuições específicas (PIRES, et al., 2018).

Na Atenção Primária, o enfermeiro é responsável pelo planejamento, organização, execução e avaliação da assistência dispensada aos pacientes visando a um cuidado seguro e de qualidade, unindo e ampliando as estratégias de sistematização do cuidado da pele, avaliação e classificação das lesões, tratamento adequado e recuperação (SILVA, et al., 2017).

A equipe da APS conta com ativa participação do enfermeiro, que realiza, entre outras ações, consulta de enfermagem e atividades de educação (CAVALCANTE, et al., 2015).

O enfermeiro tem autonomia para desenvolver atividades variadas, isso envolve o cargo a que ele está inserido, mas em todos eles ele desenvolve atividades do aperfeiçoamento do pessoal e manutenção das condições para a prestação de um atendimento com excelência.

A importância de conhecer as práticas de atenção à saúde e a maneira como se efetivam no cotidiano do trabalho para a produção do cuidado tanto para a área da gestão quanto da organização dos serviços de saúde, são de relevância para a configuração da integralidade, não somente como princípio do SUS, mas também como boas práticas de saúde para a melhoria do cuidado (VALENTIM, et al.,2020).

As Unidades de Atenção Primária à Saúde, são consideradas porta de entrada do usuário no sistema de saúde, espaço em que o enfermeiro é importante integrante da equipe multiprofissional da Estratégia Saúde da Família (FOLONI, A. R., et al., 2018).

O enfermeiro que está inserido na atenção primária tem o papel de gerente e provedor da assistência à saúde (LOPES, et al., 2020).

A responsabilidade do enfermeiro é de contribuir com a compreensão da realidade em todas as suas dimensões, é parte das atribuições do enfermeiro, realizar assistência integral aos usuários que procuram a unidade de saúde, neste caso, a realização da consulta de enfermagem com atenção voltada a identificação, prevenção, educação em saúde e tratamento das neoplasias de pele (BELTRÃO, et al., 2020). 


\subsection{CATEGORIA 2 - MELANOMA: O PAPEL DO ENFERMEIRO EM SUA IDENTIFICAÇÃO}

Os diferentes tipos de câncer de pele fundam-se a partir das camadas celulares. Estes se dividem Câncer de pele do tipo Não Melanoma (CPNM) e o câncer de pele tipo melanoma (CPM).

O tipo não melanoma se subdivide em carcinoma basocelular representando o tipo de câncer de pele mais comum, apresenta-se principalmente como uma lesão (ferida ou nódulo) com as bordas róseas, translucidas ou peroladas, que não cicatriza, podendo ulcerar e sangrar, já o epidermoide, em geral surge como uma mancha vermelha que descama e sangra formando uma ferida que muitas vezes aparece sobre uma cicatriz, principalmente aquelas recorrentes a queimaduras (MINISTÉRIO DA SAÚDE, 2018).

Então consideramos importante que um conhecimento ou um plano preventivo do câncer na pele seja de suma importância para toda a população, como também aos profissionais de saúde da região, pois os indicadores de saúde demostram um aumento na população pelos fatores genéticos e ambientais, desta forma uma correta educação em saúde para população auxilia ao diagnóstico precoce do câncer de pele, pois $78 \%$ dos canceres de pele, originam-se das células da camada basal da epiderme, onde raramente ocorre metástase, diferentemente dos carcinomas de células escamosas, que equivalem aproximadamente a $20 \%$ de todos os cânceres de pele que possuem tendências para a metástase.

O câncer de pele do tipo melanoma, conhecido também como melanoma maligno é o mais perigoso, surge como uma pinta escura que se deforma ao longo do tempo podendo ser fatal se não for diagnosticado precocemente, pois o mesmo pode se desenvolver rapidamente atingindo outros órgãos (SANTOS, 2017).

A presença de assimetria (A), bordas irregulares e mal definidos (B), alterações de cor (C), diâmetro maior que $6 \mathrm{~mm}$ (D) e evolução/ evolução recente da lesão (E) constituem o $A B C D E$ dos diagnósticos do melanoma que deve ser confirmado por análise histopatológica da lesão.

O melanoma é uma doença perigosa e as pessoas precisam saber identificar quando alguma pinta mudou na sua pele. A pinta suspeita nem sempre vai se 
transformar em um melanoma. Porém, quanto antes iniciar-se um diagnóstico e um tratamento, mais tranquilo será o processo, então cabe a enfermagem saber identificar as lesões, e um conhecimento relacionado ao ABCDE é de suma importância.

O melanoma é classificado em extensivo superficial, nodular, acrolentiginoso e lentigo maligno melanoma, podendo ocorrer outras apresentações e diferente tipo entre as faixas etárias. Com a senescência o sistema imune diminui a resposta contra neoplasias, favorecendo alta mortalidade nessa faixa etária, além disso, idosos apresentam maior índice de Breslow e metástase ao diagnostico inicial (OLIVEIRA, et al., 2021).

O Instituto Nacional do Câncer (INCA) afirma que o câncer de pele não melanoma é o mais incidente no Brasil em ambos os sexos, mesmo considerando que estes índices podem estar subestimados pelo fato de que muitas lesões suspeitas são retiradas sem diagnóstico. Este tipo de câncer apresenta ainda a propriedade de possuir baixa letalidade, sendo esse um tumor relativamente fácil de diagnóstico precocemente, porque está exposto e facilmente visível. Porém em alguns casos podem levar a deformidade física e ulcerações graves, consequentemente, onerando os serviços de saúde (FOLONI, et al., 2018).

\subsection{CATEGORIA 3 - A HUMANIZAÇÃO DO ATENDIMENTO NA PERCEPÇÃO DO ENFERMEIRO NA ATENÇÃO PRIMÁRIA}

A temática humanização tem sido abordada com maior ênfase a partir da implementação pelo Ministério da Saúde em 2003, O Humaniza SUS, essa política tem como princípios norteadores a valorização da dimensão subjetiva e social em todas as práticas de atenção e gestão no Sistema Único de Saúde (MINISTÉRIO DA SAÚDE, 2015).

Como qualquer outro trabalhador da saúde, o enfermeiro precisa estar ciente e sensibilizado quanto à questão da humanização, saber reconhecer o ser humano na sua integridade e singularidade e ter consciência do seu papel frente aqueles que o procuram acometidos por alguma enfermidade, aceitando suas reações psíquicas e a própria atitude frente à doença.

Dentre as inúmeras doenças que acometem a população encontra-se o câncer, que, nas últimas décadas, ganhou maior dimensão, convertendo-se em problemas da saúde pública mundial (BARATTO, et al., 2016). 
Os cuidados prestados pelo enfermeiro são realizados de diferentes formas, no atendimento direto tanto ao paciente quanto a família (MACENA, et al., 2020).

Sendo assim, o enfermeiro traz ao familiar a consciência da necessidade de apoio que essa deve dispensar ao doente com câncer uma vez que o enfrentamento poderá se tornar mais seguro e tranquilo, conduzindo essa pessoa a um tratamento e cuidado com algum conforto ao longo de sua caminhada pós-diagnóstico.

No campo da atenção primária à saúde, muitas práticas tem sido desenvolvidas por meio das Unidades Básicas de Saúde da família, sendo esta uma proposta de reorientação do modelo assistencial de saúde, a partir da Atenção Primária (FOLONI, et al., 2018).

A enfermagem deve atuar junto aos usuários e seus familiares no sentido de apoiar os sentimentos, medos e ansiedade decorrente do adoecimento, realizando planejamento e traçando metas que venham minimizar as consequências a serem enfrentadas pela pessoa com câncer e sua família, promovendo a qualidade de vida e continuidade do cuidado. Desta forma, há a compreensão das estratégias utilizadas pelos enfermeiros da equipe da saúde da família no acompanhamento de pessoas com câncer, bem como das dificuldades para a implementação desse acompanhamento.

O acompanhamento dos pacientes com câncer pela equipe tem o papel não só de estabelecer a construção e o fortalecimento do vínculo entre o usuário, família e unidade de saúde, como também permite que a equipe possa prestar uma assistência de qualidade priorizando a necessidade do indivíduo (BELTRÃO, et al., 2019).

\section{CONSIDERAÇÕES FINAIS}

Os 18 artigos científicos selecionados destacaram que, entre as estratégias utilizadas pelo enfermeiro à atuação do cuidado da pele, a importância de manter-se atualizado estimulando o raciocínio clínico e buscando a melhor terapêutica como investir em educação permanente pode permitir a troca de experiências vivenciadas institucionalmente no cuidado da pele.

É evidente que o acolhimento é como uma ação que por meio de diálogos responsabiliza o usuário no processo da produção da saúde, ressalta-se que o conhecimento básico sobre a doença ajuda em suas possíveis prevenções. Neste caso, é de suma importância o apoio do enfermeiro para que possam fornecer orientações de 
saúde pertinentes às carências de cada indivíduo de acordo com seus conhecimentos básicos.

No cenário da prevenção do câncer de pele, a atuação do enfermeiro na atenção primária revelou-se de importância fundamental, como as ações educativas diversas junto à equipe de saúde e comunidade, como também ações preventivas ao câncer de pele.

Constatou-se que os fatores relacionados ao uso do protetor solar como forma preventiva aos danos gerados pela exposição solar, e o grau de informação do indivíduo para a realização do autocuidado juntamente à questão da renda do paciente, é um aspecto que pode influenciar no cuidado com a pele, uma vez que as pessoas favorecidas financeiramente têm acesso a melhores tipos de prevenção do que as menos favorecidas.

A prevenção representa uma estratégia promissora para enfrentar os múltiplos problemas de saúde que a população enfrenta, relacionando-se com os saberes técnicos e populares, mobilizando os recursos comunitários, públicos e privados, buscando sempre uma construção de propostas com o intuito de proporcionar um conhecimento mais adequado sobre o câncer de pele.

A conscientização da população sobre o câncer e o estímulo às mudanças de comportamento é de fundamental importância para sua prevenção, e neste processo o papel educativo da enfermagem na atenção primária merece destaque.

Tendo em vista os resultados obtidos neste trabalho, são feitas as seguintes sugestões para futuras pesquisas: o reconhecimento dos sinais e sintomas indicativos de câncer de pele, assim como o fácil acesso ao serviço de saúde especializado pelo enfermeiro, um acolhimento mais qualificado, onde deve ser feita, ainda, uma abordagem mais direta e clara em relação a prevenção a exposição aos raios UV, com o uso de protetores, como também a não exposição ao sol em horários específicos, estimulando, orientando e conscientizando a população sobre a prevenção deste tipo de câncer.

\section{AGRADECIMENTOS}

Agradecemos a Deus, a nossa família e aos que nos apoiaram durante o desenvolvimento desta obra. 


\section{REFERÊNCIAS}

ARAÚJO, M. P. S., et al. Relacionamento interpessoal da equipe de enfermagem: fragilidades e fortalezas. Rev enferm UERJ, Rio de Janeiro, 24(5):e7657. http://dx.doi.org/10.12957/reuerj.2016.7657, 2016.

BARATTO, F., et al. (2016). Humanização da assistência na atenção básica às pessoas com neoplasia: percepção de profissionais de enfermagem. Rev enferm UFPE on line., Recife, 10(2):615-22, 2016.

BELTRÃO, T. A., et al. (2019). Acompanhamento de pessoas com câncer por enfermeiros da atenção primária. Revista cubana de enfermeira volumen 35, Número 4, 2019.

BIBLIOTECA VIRTUAL DE ENFERMAGEM, (2017). Fundação do Câncer Dá Dicas de Prevenção ao Câncer de Pele, 2017.

BICA, M. C., et al. Gerenciamento do cuidado em estratégias saúde da família na percepção de enfermeiros. Rev. Enferm. UFSM - REUFSM. Santa Maria, RS, v. 10, e74, p. 1-18, 2020.

BRASIL. Ministério da saúde. Política nacional de humanização- HumanizaSUS, 2015. https://www.gov.br/saude/pt-br/acesso-a-informacao/acoes-eprogramas/humanizasus\#: :text=A\%20Pol\%C3\%ADtica\%20Nacional\%20de\%20 Humaniza\%C3\%A7\%C3\%A3o,entre\%20gestores\%2C\%20trabalhadores\%20e\%20 usu\%C3\%A1rios.

BRASIL. Ministério da Saúde. Instituto Nacional de Câncer (INCA). Tipos de câncer: Câncer de pele não melanoma - versão para Profissionais de Saúde, 2018. https://www.inca.gov.br/tipos-de-cancer/cancer-de-pele-naomelanoma/profissional-de-saude

BRASIL. Ministério da Saúde. Câncer de pele: saiba como prevenir, diagnosticar e tratar- Saúde e vigilância sanitária, 2018. https://www.gov.br/saude/ptbr/assuntos/noticias/cancer-de-pele-saiba-como-prevenir-diagnosticar-e-tratar

BRASIL. Ministério da Saúde. Instituto Nacional de Câncer (INCA). Tipos de câncer: Câncer de pele melanoma - versão para Profissionais de Saúde, 2021. https://www.inca.gov.br/tipos-de-cancer/cancer-de-pelemelanoma/profissional-de-saude

CARMO, R. A. L. O., et al. Cuidar em Oncologia: Desafios e Superações Cotidianas Vivenciados por Enfermeiros. Rev. bras. cancerol ; 65(3), 19/09/2019.

CAUDURO, F.P., et al. Atuação dos enfermeiros no cuidado das lesões de pele. Rev. enferm. UFPE on line ; 12(10): 2628-2634, 2018. 
CAVALCANTE, A. K. C. B., et al. Cuidado seguro ao paciente: contribuições da enfermagem. Revista cubana de enfermeira volumen 31, Número 4, 2015.

CEZAR-VAZ, M. R., et al. Câncer de pele em trabalhadores rurais: conhecimento e intervenção de enfermagem. Rev Esc Enferm USP. 49(4):564-571, 2015.

CRUZ, G. T. A., et al. Fatores associados ao uso do protetor solar como medida de prevenção aos danos causados pela exposição solar. Braz. J. of Develop. Curitiba, v.6, n.12, p.99546-99563, 2020.

ESPOSITO, A. C. C., et al. Fatores que levam à negligência quanto aos cânceres da pele não melanoma. Diagn. tratamento ; 22(2): 63-66, 2017.

FOLONI, A. R., et al. Analise de casos de câncer de pele em um hospital do interior paulista. CuidArte, Enferm ; 12(2): 175-180, 2018.

GOMIDE, M. F. S., et al. A satisfação do usuário com a atenção primária à saúde: uma análise do acesso e acolhimento. Artigos. Interface 22 (65), 2018.

LOPES, O. C. A., et al. Competências dos enfermeiros na estratégia Saúde da Família. Esc Anna Nery 24(2): e20190145, 2020.

MACENA, A.A., et al. Aspectos emocionais da equipe de enfermagem frente aos cuidados em oncologia. Anais do congresso de geriatria e gerontologia do UNIFACIG, capa v. 1, n.1, 2020.

MATHEUS, L. G. M., et al. Aspectos epidemiológicos do melanoma cutâneo. Revista Ciência e Estudos Acadêmicos de Medicina - Número 3. Universidade do Estado de Mato Grosso - UNEMAT (Cáceres). (p. 10-24), 2015.

MOREIRA, A. P. A., et al. Câncer de pele não melanoma e risco ocupacional de trabalhadores ao ar livre. J Nurs UFPE on line., Recife, 9(12):1310-9, 2015.

Oliveira, F. M. A., et al. Uso de medidas preventivas para câncer de pele por mototaxistas. Rev. Pesqui. (Univ. Fed. Estado Rio J., Online) ; 13: 282-287, 2021.

OLIVEIRA, E. F. S., et al. Educação em saúde do paciente com diagnóstico de câncer de pele. Nursing (Säo Paulo) ; 22(251): 2898-2903, 2019.

PEREIRA A. S., et al. Metodologia da pesquisa científica. [free e-book]. Santa Maria/RS. Ed. UAB/NTE/UFSM, 2018.

PIRES, C. A. A., et al. Câncer de pele: caracterização do perfil e avaliação da proteção solar dos pacientes atendidos em serviço universitário. J. Health Biol Sci. 6(1):5459, 2018. 
PURIM, K. S. M., et al. Características do melanoma em idosos. Rev Col Bras Cir 47:e20202441. http// DOI: 10.1590/0100-6991e-20202441, 2020.

RIBEIRO, J. P., et al. Assistência de enfermagem ao paciente oncológico hospitalizado: diagnósticos e intervenções relacionadas às necessidades psicossociais e psicoespirituais. res.: fundam. care. Online, 2016.

SANTOS, R. O. M. D. Atuação do enfermeiro na detecção precoce do câncer de pele. Rev. baiana saúde pública ; 41(1):doi.org/10.22278/2318-2660.2017.v41.n1.a2331, 2017.

SCHMIDT, F. M. Q., et al. Conhecimento da equipe de enfermagem sobre cuidados com pacientes com feridas neoplásicas. Rev. Bras. Enferm. vol.73 no.1 Brasília, 2020.

SILVA, S. S., et al. Enfermeira como protagonista do gerenciamento do cuidado na estratégia saúde da família: diferentes olhares analisadores. Texto Contexto Enferm, 26(3):e1090016, 2017.

SOUZA, G. R. M., et al. (2017) Atuação dos enfermeiros da estratégia saúde da família na atenção oncológica. Esc. Anna Nery vol.21 no.4, doi.org/10.1590/2177-9465ean-2016-0380, 2017.

SOUZA, M. T., et al. Revisão integrativa: o que é e como fazer 1. einstein.; 8(1 Pt 1):1026, 2010.

VALENTIM, L. V., et al. Percepção dos profissionais de enfermagem quanto ao trabalho em equipe. Rev baiana enferm; 34:e37510, 2020.

WAKIUCHI, J., et al. Atenção a pacientes oncológicos na Estratégia Saúde da Família: olhar do usuário. Rev. Gaúcha Enferm. [online]. ISSN 19831447. doi.org/10.1590/1983-1447.2016.01.54088, 2016.

WAKIUCHI, J., et al. Atuação da estratégia saúde da família na perspectiva de usuários com câncer. Rev. Eletr. Enf. [Internet]. doi.org/10.5216/ree.v18.38612, 2016. 


\title{
CAPITULO XLIII
}

\section{PANDEMIA DA COVID-19: IMPACTOS NO COMBATE E TRATAMENTO DA MALÁRIA}

DOI: 10.51859/AMPLLA.PAE1993-43

\author{
Larissa Santos Carneiro Gomes ${ }^{1}$ \\ Davi de Lacerda Coriolano ${ }^{2}$ \\ Elias Vicente Bueno ${ }^{3}$ \\ Athila da Costa Silva 4 \\ Daniel Charles dos Santos Macedo ${ }^{5}$ \\ Jaqueline Barbosa de Souza ${ }^{6}$
}

\begin{abstract}
${ }^{1}$ Acadêmica de Farmácia. Centro Universitário Maurício de Nassau.
${ }^{2}$ Acadêmico de Biomedicina. Universidade Federal de Pernambuco.

${ }^{3}$ Acadêmico de Farmácia. Faculdades de Enfermagem Nova Esperança.

${ }^{4}$ Acadêmico de Biomedicina. Centro Universitário São Miguel.

${ }^{5}$ Farmacêutico. Doutorando pelo Programa de Pós-Graduação em Ciências Farmacêuticas da Universidade Federal de Pernambuco.

${ }^{6}$ Farmacêutica. Mestranda pelo Programa de Pós-Graduação em Inovação Terapêutica da Universidade Federal de Pernambuco.
\end{abstract}

\section{RESUMO}

O atual cenário epidemiológico mundial ocasionado pela pandemia da COVID-19, além de exercer impactos na saúde pública, também atinge o controle de outras doenças, como a malária. A malária é uma doença infecciosa, causada por parasitas do gênero Plasmodium sp., que embora seja endêmica da África Subsaariana, é descrita em países tropicais como o Brasil. Com a implantação dos Programas Nacionais de Controle da Malária, observou-se reduções significativas nos números de mortes, entretanto, muitos desses foram interrompidos em decorrência da realocação de verbas para combater a pandemia da COVID-19, podendo exercer impactos negativos nos índices de morbimortalidade pela malária. Dessa forma, foi realizada uma revisão integrativa da literatura com objetivo de abordar os efeitos da pandemia quanto ao acesso aos serviços de saúde e os impactos no tratamento e prevenção da malária. Portanto, constatou-se que, ao considerar a redução da distribuição de mosquiteiros, bem como a limitação do acesso às terapias que empregam fármacos antimaláricos, prevê-se um aumento de $22 \%$ nos casos de malária e a duplicação das mortes pela mesma doença em um ano. Diante da pandemia da COVID-19, os programas de combate à malária foram substancialmente exauridos, o que favoreceu o aumento dos números de incidência daquela doença. Ressalta-se a importância da continuidade dos programas de combate à malária para a redução da incidência assim como da prevalência desta patologia e evidencia-se, também, a relevância das políticas públicas, especialmente na luta com fim a evitar uma mudança epidemiológica dessa doença e o aumento da mortalidade.

Palavras-chave: COVID-19. Malária. Antimalárico. Pandemia. 


\section{INTRODUÇÃO}

A primeira notificação de pneumonia com causa desconhecida ocorreu na cidade de Wuhan, na China, culminando na descoberta de um novo tipo de coronavírus, nomeado pelo Comitê Internacional de Taxonomia de Vírus como o vírus causador da síndrome respiratória aguda grave de coronavírus 2 (SARS-CoV-2), sendo o responsável pelo desenvolvimento da doença COVID-19, a qual disseminou-se aceleradamente em curto tempo, atingindo proporções pandêmicas (AMIMO et al., 2020; GENNARO et al., 2020; ZHU et al., 2020).

Os impactos causados pela COVID-19 afetam tanto o sistema de saúde, a política e a economia, como também o curso de outras doenças infectocontagiosas, por dificultar o acesso das pessoas aos serviços de saúde e aos tratamentos medicamentosos (PENJOR et al., 2021). Nesse sentido, a malária é uma doença que apresenta uma elevada taxa de morbimortalidade, atingindo países em desenvolvimento, e sendo assim, considerada um dos maiores desafios mundiais de saúde pública, especialmente ao que se refere à sua erradicação (GENNARO et al., 2020).

A malária é uma doença infecciosa causada por parasitas do gênero Plasmodium e transmitida, principalmente, através da picada de mosquitos Anopheles fêmea geralmente entre o crepúsculo e o amanhecer. Tem prevalência em países de baixo desenvolvimento econômico, situando-se entre as dez principais causas de morte, e, representando um dos grandes desafios de saúde pública global. Assim, embora alguns países tenham obtido sucesso na eliminação da malária como o Paraguai e a Argentina, outros como os pertencentes à África Subsaariana, apenas em 2018, foram responsáveis por cerca de 300 milhões de casos de malária e 500 mil mortes pela doença (GENNARO et al., 2020).

Nos últimos 20 anos houve significativos avanços no combate da malária, de forma que, países como Sri Lanka, Uzbequistão, Argélia e a Argentina conseguiram erradicar esta parasitose de seus respectivos territórios (ROGERSON et al., 2020). Vale salientar que a erradicação da malária alcançada pelos países mencionados anteriormente foi possível devido à efetividade dos programas de combate e prevenção implantados, promovendo ações como distribuição de mosquiteiros tratados com 
inseticidas, pulverização domiciliar com inseticidas residuais, diagnóstico precoce e quimioprofilaxia, são exemplos de medidas adotadas (GENNARO et al., 2020).

Tratando-se das abordagens farmacológicas empregadas no tratamento da malária, a cloroquina (CQ) e hidroxicloroquina (HCQ) são os fármacos comumente utilizados (GUASTALEGNAME; VALLONE, 2020). O mecanismo de ação da CQ e seus derivados, como a $\mathrm{HCQ}$, ainda carece de esclarecimentos, contudo a principal teoria demonstra que o mecanismo de ação antimalárico se baseia, principalmente, na inibição da fase assexuada do parasita, ou seja, quando aquele infecta os glóbulos vermelhos e degrada a hemoglobina, sintetizando, por fim a ferriprotoporfirina IX (FPIX) que é tóxica ao Plasmodium. Assim, a CQ inibe a desintoxicação da FPIX e também se acumula no vacúolo alimentar impedindo a sua polimerização, de modo que induz a lise celular do parasita (LEl et al., 2020).

Em especial, o efeito antiviral da CQ e HCQ recebeu muita atenção desde o início da pandemia da COVID-19, acarretando o uso destes fármacos de forma extensiva no tratamento de pacientes acometidos pelo vírus SARS-CoV-2, tendo como único respaldo científico testes in vitro (LEl et al., 2020). Ambos medicamentos já têm histórico de atividade antiviral in vitro, frente aos vírus da hepatite C, dengue 1-4, Zika, entre outros. Nos estudos, eles apresentaram atividade antiviral baseada na inibição da infecção viral por meio de alterações na glicosilação de proteínas, no pós infecção, por agir em interferência no processamento de proteínas e acidificação, além de também pode interromper a liberação de enzimas fundamentais para a replicação e disseminação viral (SOUZA et al., 2020).

Em virtudes das prováveis propriedades antivirais, o uso da CQ e da HCQ foi indicado para o tratamento da COVID-19 por alguns médicos e órgãos públicos, como o Ministério da Saúde Brasileiro, visto que não existiam medicamentos eficazes para o tratamento dessa doença, sendo utilizados devido os resultados satisfatórios apresentados nos ensaios in vitro e da necessidade urgente de terapia antiviral, favorecendo a promoção destes como a possível solução para o tratamento da COVID19 (CAPONI et al., 2021; HUSSEIN et al., 2020).

O redirecionamento errôneo da CQ e HCQ para o uso no tratamento da COVID19 sem evidências concretas acarretou em preocupação nas áreas indígenas endêmicas para malária no território Brasileiro, diante do risco iminente de desabastecimento 
desses medicamentos (JN, 2021; SASSINE, 2021). Consequentemente, este uso irracional dificulta a redução dos números prevalentes da malária, uma vez que não há medicamentos suficientes para realização de um efetivo tratamento (CHIODINI, 2020; PAHAN; PAHAN, 2020; QUASHIE; DUAH-QUASHIE, 2020).

O uso exacerbado de medicamentos antimaláricos e a maneira como ocorre a rápida propagação da COVID-19 no âmbito global configura-se como uma ameaça no controle da malária, por afetar diretamente os programas e o tratamento da mesma (ROGERSON et al., 2020). A partir disso, objetiva-se abordar neste estudo quais os efeitos da pandemia da COVID-19 no casos de incidência, prevalência, acesso aos serviços essenciais de saúde e as suas implicações nos programas de prevenção, diagnóstico e tratamento da malária.

\section{REVISÃO BIBLIOGRÁFICA}

\subsection{MUDANÇAS NO CENÁRIO EPIDEMIOLÓGICO DA MALÁRIA APÓS INSTITUIÇÃO DA PANDEMIA DA COVID-19}

A malária é uma doença infecto-parasitária de grande relevância mundial, sendo endêmica em mais de 85 países. O relatório mundial da malária de 2020, realizado pela Organização Mundial da Saúde (OMS), indicou que houve 229 milhões de novos casos reportados em 2019, assim como 409 mil mortes decorrentes da doença, entre esse alto índice de óbitos, 274 mil (67\%) eram crianças com idade inferior a 5 anos (WHO, 2020).

No Brasil, o Ministério da Saúde divulgou os casos de malária de 2019, através do boletim epidemiológico da malária de 2020. Este boletim mostra que houve 154.454 novos casos de malária, casos esses, concentrados majoritariamente na região amazônica. Também foram registrados 37 óbitos em decorrência de complicações da malária (BRASIL, 2020).

Em março de 2020, o Diretor-Geral da OMS declarou o novo surto de coronavírus uma emergência de saúde pública internacional. Após esse marco, grande parte dos esforços dos sistemas de vigilância epidemiológica e saúde foram voltados à pandemia da COVID-19, afetando a coleta e notificação de casos de outras doenças, como a malária, por exemplo, especialmente em países como Brasil e Índia, que juntos 
apresentam mais de 64\% dos casos de COVID-19 entre os países endêmicos para malária (WHO, 2020; ZAWAWI et al., 2020).

Segundo dados do Sistema de Informação de Agravos de Notificação (SINAN), apenas 296 casos de malária foram notificados e registrados na plataforma no ano de 2020 no Brasil, um número quase 50\% inferior ao ano anterior. Mesmo esses dados não sendo os dados concretos do boletim epidemiológico da malária disponibilizado anualmente pelo Ministério da Saúde, observa-se uma grande redução no número de casos, que pode ser caracterizada por uma subnotificação ainda maior durante a pandemia (SINAN, 2021).

Entre janeiro e junho de 2020, a situação da malária nas Américas foi caracterizada por uma redução do número de casos confirmados em relação ao mesmo período do ano de 2019, entretanto essa diminuição também pode estar relacionada a subnotificação, uma vez que as Américas chegaram a ser consideradas o novo epicentro da COVID-19 no mês de maio de 2020, tendo a atenção dos sistemas de saúde e epidemiologia voltados a pandemia (BRASIL, 2020; NEIVA et al., 2020).

No continente africano o fenômeno foi diferente, uma vez que houve surtos de malária registrados no Zimbabué e em Camarões. Os autores relatam que os principais fatores para o elevado número de novos casos foram o diagnóstico falso-positivo para a malária, provocada pela febre ocasionada pelas duas doenças, e especialmente devido aos sintomas iniciais da COVID-19 como mialgia, febre e fadiga, sobretudo em regiões endêmicas, podendo causar confusão em ambientes com testagem limitada, além de escassez de medicamentos contra a malária, uma vez que estavam sendo utilizados erroneamente no tratamento da COVID-19, e a falta de acesso a instalações médicas saturadas pelo quantitativo de pacientes infectados pelo SARS-CoV-2. Além disso, estimativas sugeriam que em 2020 haveria um aumento significativo no índice de mortalidade por malária na região da África subsaariana por causa das interrupções nos esforços de controle da malária pela pandemia da COVID-19 (NGHOCHUZIE et al., 2020; SHERRARD-SMITH et al., 2020; ZAWAWI et al., 2020).

\subsection{DESAFIOS NO CONTROLE DA MALÁRIA EM TEMPOS DE PANDEMIA}

De acordo com relatório da OMS (2020), durante as últimas duas décadas (2000 - 2019), houve uma redução no quantitativo de casos de malária do ano de 2000, cerca 
de 238 milhões de casos comparando-se ao ano de 2019, o qual apresentou cerca de 229 milhões de casos. Ademais, a incidência de casos mostrou-se em declínio, onde diminuiu de 80 em 2000 para 57 em 2015 e, deste ano a 2019, apresentou uma redução menor do que $2 \%$, revelando uma desaceleração na redução dos casos. Nesse período, pode-se destacar a redução da mortalidade, de 736.000 óbitos em 2000 a 409.000 óbitos em 2015 (OMS, 2020).

Apesar da redução de casos, a malária continua sendo uma doença preocupante, sobretudo na região Africana, a qual compreende cerca de $90 \%$ dos casos mundiais. No entanto, para que o cenário de declínio dos casos e consequente eliminação da malária prosperem, faz-se necessário não apenas diagnósticos corretos e pacientes prontamente tratados, mas também a continuidade das intervenções preventivas contra a referida parasitose (AMIMO et al., 2020).

Países como o Sri Lanka tiveram sucesso na erradicação dessa doença, enquanto países como a Turquia e o Turquemenistão estão perto de zerar os casos de malária (ROGERSON et al., 2020).

A efetiva erradicação da malária é provocada pela efetividade e continuidade dos programas de combate e prevenção através da distribuição de mosquiteiros tratados com inseticidas e medicamentos antimaláricos, por exemplo (PENJOR et al., 2021). Porém, com a chegada da COVID-19, os governos mundiais implementaram medidas restritivas visando a redução da propagação do SARS-CoV-2, e dentre tais medidas, estava a necessidade de a população permanecer em casa. Diante disso, o aumento da permanência da população em suas respectivas residências dificultou o acesso aos serviços de combate à malária, como por exemplo o tratamento farmacoterapêutico. (AMIMO et al., 2020; PENJOR et al., 2021). Além disso, com a interrupção de programas de combate e prevenção da malária provocadas por pandemias como a da COVID-19, aumenta o risco de surgimento de novos casos de malária (VAUGHAM, 2020).

Entre os desafios encontrados para o manejo da malária leve (sintomas mais brandos como mialgia, febre e fadiga, sem sinais e sintomas neurológicos), especialmente onde esta é endêmica, destaca-se o diagnóstico diferencial da doença, uma vez que a malária apresenta curso clínico sintomatológico semelhante ao observado em outras infecções, como nos casos da COVID-19, sendo a febre, sobretudo, 
o aspecto clínico relevante, a qual pode confundir o diagnóstico de ambas as doenças (GENNARO et al., 2020; SHERRARD-SMITH et al., 2020 ).

No contexto pandêmico, outros fatores são limitantes para o diagnóstico e tratamento da malária, como os óbitos dos profissionais de saúde, centros de saúde sobrecarregados e o medo da população em voluntariamente buscar o serviço de saúde a fim de se realizar a testagem e, posteriormente, terapêutica, em virtude, principalmente, do medo de contrair a COVID-19 (AMIMO et al., 2020).

Um exemplo dos impactos na restrição dos programas de controle e prevenção da malária pôde ser evidenciada durante a epidemia do ebola no ano de 2013, na África Central e Ocidental, onde um declínio do acesso aos centros de saúde pelos indivíduos infectados pelo Plasmodium sp., redução de medidas profiláticas básicas, somada à redução do tratamento farmacoterapêutico, culminaram na elevação das mortes provocadas pela malária, em populações vulneráveis, como gestantes e crianças (AMIMO et al., 2020; VELAVAN et al., 2021). Assim, de acordo com Gennaro et al. (2020), países como Guiné, Libéria e Serra Leoa, por exemplo, poderiam apresentar incidência de 1 milhão de novos casos se medidas básicas como a distribuição de mosquiteiros tratados com inseticidas não fossem realizadas.

Segundo o Ministério da Saúde (2020), nas Américas, Brasil, Colômbia e Venezuela, respondem por $80 \%$ de todos os casos estimados de malária. Neste aspecto, colapsos econômicos e falha no sistema de saúde são, geralmente, relacionados a causas críticas do aumento de morbimortalidade de doenças infecciosas. A Venezuela, por exemplo, devido à crise econômica apresentada entre os últimos 6 anos, presenciou o aumento de movimentos populares e, consequentemente, das doenças transmitidas por vetores, incluindo do número de casos de malária (ROGERSON et al., 2020).

A situação da malária nas Américas no ano de 2020 marcou o declínio do número de casos confirmados se comparado ao ano anterior, o que foi atribuível, em grande parte, à diminuição dos casos notificados na Venezuela - a qual conseguiu reverter o quadro outrora prejudicial em virtude da crise econômica (Ministério da Saúde, 2020). Assim, diante do cenário pandêmico atual, a COVID-19 já causou grande interrupção na atividade econômica, podendo contribuir para o ressurgimento da malária em países com sucesso quanto ao combate e controle da parasitose (ROGERSON et al., 2020). 
Vale destacar que avaliar os aspectos econômicos e epidemiológicos particulares de cada país é de suma importância uma vez que populações mais vulneráveis, especialmente aquelas do continente Africano, ao qual concentra a maior parte dos casos de malária, podem enfrentar dificuldades para custear as despesas de transporte bem como outros custos médicos indiretos, cenário que pode afetar não apenas o diagnóstico, mas também o tratamento da malária (AMIMO et al., 2020). Desta forma, populações em vulnerabilidade social podem enfrentar dificuldades de acesso aos serviços de saúde, e, além disso, são afetadas negativamente em virtude da interrupção dos programas de combate àquela parasitose (ROGERSON et al., 2020).

Nesse contexto, apesar do impacto epidemiológico provocado pela pandemia do novo Coronavírus, doenças como a malária ainda requerem atenção dos órgãos governamentais e dos poderes estatais, a fim de que sua erradicação ocorra ao redor do mundo. Para isso, o acesso da população endêmica aos programas de tratamento e prevenção da malária é de suma importância no controle e erradicação da parasitose, buscando o controle do vetor, por meio de estratégias que se baseiam na aplicação de inseticidas, além da promoção da educação em saúde, diagnóstico efetivo e fornecimento de medicamentos de qualidade (OMS, 2020).

Logo, deve ser levado em consideração o auxílio para o tratamento e programas de prevenção de doenças como a malária, dado a sua importância epidemiológica e seus impactos econômicos e na saúde pública (SANDS, 2020).

\subsection{PROCESSOS INFECCIOSOS MEDIADOS POR PLASMODIUM SP. E SARS- COV-2}

Um dos aspectos que relacionam o SARS-CoV-2 e o Plasmodium sp., refere-se ao sítio de contato com a célula hospedeira, que se baseia na enzima conversora de angiotensina 2 (ECA2) (PHADKE; SAUNIK, 2020). Nesse sentido, o sistema renina angiotensina trata-se de um componente essencial para a homeostase do organismo, regulando a pressão arterial, o equilíbrio eletrólito-fluido e os processos de inflamação e fibrose. Este é regulado por três importantes enzimas, a saber: a renina, a ECA e a ECA2 (PILLAT et al., 2020).

Em ambas as infecções, deleções genéticas e polimorfismos, têm sido associados a uma reduzida expressão da ECA2, de modo que altera a concentração da ECA 1 e dos 
alelos D. Assim, polimorfismos no alelo $D$ têm sido relacionados, embora ainda não demonstrado, a variações geográficas relevantes quanto à prevalência da infecção por COVID-19 mundialmente. Do mesmo modo, nos casos de malária cerebral, é sugerido um possível papel protetor em virtude do polimorfismo do alelo ECA 1/D, a estas variações atribui-se a redução das invasões aos eritrócitos por $P$. falciparum, relacionando-se a um efeito "protetor" o qual é capaz de influenciar não apenas o desenvolvimento do parasita, mas também a suscetibilidade do hospedeiro à doença (GENNARO et al., 2020).

O vírus afeta inicialmente os pulmões devido à abundância de receptores ECA2 nas células epiteliais alveolares presentes neste órgão, facilitando a entrada do patógeno, lesionando-as, e afetando gravemente o endotélio vascular, facilitando o acesso do SARS-CoV-2 na circulação sanguínea, alcançando outros órgãos, como rim e fígado (SCIGLIANO; SCIGLIANO, 2021).

Durante o processo infeccioso promovido pelo SARS-CoV-2, há interação da proteína spike (S) presente na superfície viral com a ECA2. Através dessa interação, é possível que o vírus se interiorize, principalmente por meio da endocitose. Em seguida, ocorre a clivagem da proteína S presente na superfície viral, facilitando desta forma a fusão lisossomal (FATIMA et al., 2020; LEl et al., 2020).

Para a malária, é sugerido um papel protetor devido ao polimorfismo ECA I/D do alelo D. Na pesquisa de Gennaro et al. (2020) e Velevan et al. (2021), descrevem que os vários polimorfismos ECA I e ECA 2 são capazes de reduzir a invasão por P.falciparum nos eritrócitos, corroborando para um efeito protetor que influencia tanto no desenvolvimento do parasita como na suscetibilidade do hospedeiro à doença.

\subsection{ANTIMALÁRICOS E COVID-19: EXISTEM POSSIBILIDADES DE APLICAÇ̃̃O TERAPÊUTICA?}

Dentre os fármacos que exibiram inibição in vitro contra cepas do SARS-CoV-2, destacaram-se os antimaláricos: cloroquina e a hidroxicloroquina, considerados como a terapia antiviral para a COVID-19 (PILLAT et al., 2020).

O efeito antiviral desses fármacos é atribuído, principalmente, ao seu mecanismo de ação que exerce alcalinização endossômica, além de atividades frente a citocinas pró-inflamatórias, como a IL-1 e IL-6, desempenhando função no combate à 
inflamação. Ademais, apresentam a capacidade de inibição da glicosilação dos receptores da ECA2, afetando consequentemente a infecção pelo SARS-CoV-2 nas células, em virtude da sua natureza físico-química alcalina, uma vez que este vírus se acumula em organelas ácidas, como os lisossomos (PILLAT et al., 2020; GENNARO et al., 2020).

Liu et al. (2020) comparou o efeito antiviral tanto da CQ quanto da HCQ contra a infecção por SARS-CoV-2 in vitro. Primeiramente, avaliaram a citotoxicidade nas células Vero E6, resultando em 273,20 e 249,50 $\mu \mathrm{M}$, respectivamente. Em seguida, analisaram a seletividade dos medicamentos em diferentes concentrações e exposição das células ao vírus, onde notou-se que a CQ apresentou maior seletividade que a HCQ. Por fim, todos os dados obtidos no experimento confirmaram que tanto a CQ quanto a $\mathrm{HCQ}$, inibiram efetivamente a etapa de entrada do vírus, como também, causaram alterações perceptíveis na morfologia, tamanho e quantidade de células, caracterizando-os como medicamentos eficazes para combater a COVID-19.

Por outro lado, nos estudos realizados por Hoffmann et al. (2020), constatou-se que a CQ não tem efeito inibitório para infecção por SARS-CoV-2 em células de pulmão humano. Como também, durante o estudo desenvolvido por Maissonasse et al. (2020), a HCQ não demonstrou atividade farmacológica significativa na redução da infecção em modelos de epitélio das vias aéreas humanas.

Apesar da efetividade da CQ e HCQ em estudos in vitro, em 15 julho de 2020, a Food and Drug Administration (FDA) cancelou a autorização de utilização destes fármacos para o uso emergencial no tratamento de pacientes hospitalizados, reafirmando que nenhum destes ativos é eficaz na terapia da COVID-19, sobretudo devido aos seus efeitos adversos cardíacos (FDA, 2020).

Várias estratégias farmacoterapêuticas têm sido testadas para o tratamento da COVID-19, envolvendo antivirais, antibacterianos e glicocorticóides, porém nenhum destes foram efetivamente aprovados com esse propósito, necessitando não apenas de estudos clínicos com resultados promissores, mas também de pesquisas que determinem o verdadeiro impacto da $\mathrm{CQ}$ e $\mathrm{HCQ}$ em diferentes faixas etárias, manifestações clínicas e nos estágios da doença, assim como seus efeitos relacionados à comorbidades, doses e duração terapêutica (FATIMA et al., 2020; ZOU et al., 2020). 
A automedicação durante a pandemia da COVID-19 aumentou excessivamente, principalmente dos medicamentos do "kit-covid" e do "tratamento precoce", onde consistiu em suplementos a base de vitaminas C, D e zinco, bem como dos medicamento $\mathrm{CQ}, \mathrm{HCQ}$, ivermectina e a azitromicina. A carência de informações associadas ao medo e o favorecimento de autoridades governamentais e da mídia em geral, facilitou tal ação pela sociedade. Mesmo sem comprovação clínica de eficácia, segurança e efetividade para a COVID-19, diversas pessoas estimularam tal ação, até mesmo, profissionais da saúde incentivaram e prescreveram, promovendo a prática. Contudo, reações adversas a medicamentos e danos sérios à saúde podem ocorrer, além disso, o uso irracional de medicamentos possivelmente gerará custo para o sistema de saúde, afetando também a economia (MELO et al., 2021).

Diante da pandemia da COVID-19 diversos medicamentos foram reposicionados em busca de uma terapêutica eficiente no combate ao SARS-CoV-2. No entanto, até o momento a infecção continua sem nenhum tratamento seguro e eficaz no combate ao SARS-CoV-2, sendo apenas utilizada a profilaxia por meio da vacinação (PILLAT et al., 2020).

As principais vacinas disponíveis até o momento são a da Pfizer/BioNTech do tipo mRNA com 95\% de eficácia (CDC, 2021a); Moderna também do tipo mRNA apresentando 94.1\% de eficácia (CDC, 2021b); Johnson \& Johnson's Janssen, vacina de vetor viral de dose única com 63,6\% de eficácia (CDC, 2021c); Oxford-AstraZeneca que utiliza da modificação genética viral (vetor viral) e tem eficácia de 70.4\% (KNOLL; WONODI, 2020); Sputnik V que também é de tipo vetor viral e apresenta eficácia acima de 90\% (JONES; ROY, 2021); e a CoronaVac que utiliza a tecnologia do vírus inativo e demonstra eficácia de 50\% no Brasil (INSTITUTO BUTANTAN, 2021).

\subsection{POSSÍVEIS DESAFIOS ENFRENTADOS POR PAÍSES COM ALTA INCIDÊNCIA DE MALÁRIA DURANTE A PANDEMIA PELA COVID-19}

Existe uma grande preocupação acerca dos impactos da pandemia da COVID-19 em países como a África, o qual consiste em uma região endêmica da malária, onde a maioria dos casos registrados mundialmente são referenciados à essa região (GENNARO et al., 2020). Apesar do referido cenário, a preocupação em situações pandêmicas é a negligência, suspensão ou ainda encerramento dos serviços essenciais de prevenção e 
tratamento de saúde, especialmente no que concerne os indivíduos moradores de regiões de risco, uma vez que se configura uma ameaça iminente frente ao combate e a erradicação da malária (ROGERSON et al., 2020).

Assim, vários cenários são possíveis, desde a interrupção da distribuição de mosquiteiros tratados com inseticidas até a redução do acesso a medicamentos antimaláricos (SANDS, 2020). Considerando a redução da distribuição de mosquiteiros juntamente com a limitação do acesso a terapias que empregam fármacos como a cloroquina, hidroxicloroquina e artemisinina, é previsto um aumento de $22 \%$ nos casos de malária e a duplicação das mortes pela mesma doença em um ano (ROGERSON et al., 2020; VAUGHAM, 2020).

Além disso, uma vez que o sistema de saúde tem sua atenção voltada para a redução da propagação da COVID-19, patologias como a malária acabam ficando em segundo plano, e a consequência disso são os atrasos recorrentes no diagnóstico e no tratamento de pacientes infectados pelo Plasmodium sp. Ademais, os impactos podem ser ainda maiores quando crianças são acometidas pela malária, uma vez que nestes casos o desenvolvimento para o estado crônico da patologia ocorre rapidamente, de forma que 10 a $20 \%$ dos casos desenvolvem a forma cerebral da malária, culminando no óbito dos pacientes (GENNARO et al., 2020).

Em consideração as características epidemiológicas da pandemia provocada pela COVID-19 e tomando como exemplo também a epidemia provocada pelo Ebola em 2013, é de suma importância que os países acometido pela malária reflitam sobre o impacto provocado pela interrupção dos programas que tem como objetivo a erradicação desta patologia (ROGERSON et al., 2020). Desta forma, o presente trabalho alerta para importância da manutenção do diagnóstico, do tratamento anti-malária e da distribuição das medidas preventivas como ferramentas que visem a erradicação desta patologia.

\section{CONSIDERAÇÕES FINAIS}

Uma vez que a malária e a COVID-19 são infecções responsáveis por milhões de mortes particularmente em regiões onde a malária é endêmica, destacam-se preocupações quanto ao risco de a população obter acesso limitado ao tratamento 
antimalárico, devido especialmente à diminuição dos diagnósticos e ao medo de visita aos centros de saúde.

Diante disso, uma vez que a população afetada pela malária não possui o devido acompanhamento pelos profissionais de saúde, os pacientes passam a fazer uso dos medicamentos de forma demasiada e/ou em doses subterapêuticas. Este cenário, além de contribuir para um aumento da morbimortalidade de pacientes, contribui também para o surgimento e a disseminação de patógenos resistentes a medicamentos, panorama relevante em virtude da possibilidade da resistência cruzada entre os fármacos antimaláricos.

Assim, a interrupção dos programas de combate e prevenção contra a malária parece provocar um aumento nos casos de mortalidade. Diante disso, o governo deve dar máxima atenção para os programas que visam a realização do diagnóstico, do tratamento antimalárico e da distribuição das medidas preventivas, a fim de que ocorra uma redução da incidência e na prevalência desta patologia.

\section{REFERÊNCIAS}

AMIMO, F; LAMBERT B; MAGIT, A. What does the COVID-19 pandemic mean for HIV, tuberculosis, and malaria control?. Tropical Medicine and Health, v. 48, p. 1-4, 2020.

BRASIL. Ministério da Saúde. Secretaria de Vigilância em Saúde. Boletim Epidemiológico Malária 2020. Brasília, n. especial, 2020.

BRASIL. Ministério da Saúde. Secretaria de Vigilância em Saúde. Programa Nacional de Prevenção e Controle da Malária - PNCM. Brasília - DF, 2003.

CAPONI, S. et al. O uso político da cloroquina: COVID-19, negacionismo e neoliberalismo. Revista Brasileira de Sociologia-RBS, v. 9, n. 21, p. 78-102, 2021.

CDC, Centers for Disease Control and Prevention. Pfizer-BioNTech COVID-19 Vaccine Overview and Safety. EUA, 21. mai. 2021a. Disponível em: <https://www.cdc.gov/coronavirus/2019-ncov/vaccines/differentvaccines/Pfizer-BioNTech.html> Acesso em: 30 de mai. 2021.

CDC, Centers for Disease Control and Prevention. Moderna COVID-19 Vaccine Overview and Safety. EUA, 05. abr. 2021b. Disponível em: <https://www.cdc.gov/coronavirus/2019-ncov/vaccines/differentvaccines/Moderna.html> Acesso em: 30 de mai. 2021. 
CDC, Centers for Disease Control and Prevention. Johnson \& Johnson's Janssen COVID-

19 Vaccine Overview and Safety. EUA, 11. mai. 2021c. Disponível em: <https://www.cdc.gov/coronavirus/2019-ncov/vaccines/differentvaccines/janssen.html> Acesso em: 30 de mai. 2021.

CHIODINI, J. COVID-19 and the impact on malaria. Travel Medicine and Infectious Disease, v. 35, 2020.

SOUZA, J. B. et al. Hidroxicloroquina como alternativa para o tratamento da infecção causada pelo SARS-CoV-2: O que se sabe até agora?. Brazilian Journal of Health Review, v. 3, n. 3, p. 4255-4273, 2020.

FATIMA, U. et al. Impact of Hydroxychloroquine/Chloriquine in Covid-19 Therapy: Two Sides of the Coin. Journal of Interferon \& Cytokine Research, v. 40, n. 10, p. 469-471, 2020.

FDA. Coronavirus (COVID-19) update: FDA revokes emergency use authorization for chloroquine and hydroxychloroquine. 2020. Disponível em: <https://www.fda.gov/news-events/press-announcements/coronavirus-covid19-update-fda-revokes-emergency-use-authorization-chloroquine-and>. Acesso em 30 de abril, 2021.

GENNARO, F. D. et al. Malaria and COVID-19: Commom an Different Findings. Tropical Medicine and Infectious Disease, v. 5, n. 3, p. 141, 2020.

GUASTALEGNAME, M.; VALLONE, A. Could Chloroquine/Hydroxychloroquine Be Harmful in Coronavirus Disease 2019 (COVID-19) Treatment?. Clinical Infectious Diseases, v. 71, n. 15, p. 888-889, 2020.

HOFFMANN, M. et al. Chloroquine does not inhibit infection of human lung cells with SARS-CoV-2. Nature, v. 585, n. 7826, p. 588-590, 2020.

HUSSEIN, M. I. H. et al. Malaria and COVID-19: unmasking their ties. Malaria Journal. v. 19, n. 1, p. 457, 2020.

INSTITUTO BUTANTAN. Estudos de campo comprovam a eficiência da CoronaVac, diz Dimas Covas ao entregar mais 1 milhão de doses. São Paulo, 07. Abril. 2021. Disponível em:<https://butantan.gov.br/noticias/estudos-de-campocomprovam-eficiencia-da-coronavac-diz-dimas-covas-ao-entregar-mais-1milhao-de-doses>. Acesso em: 30 de mai. 2021.

JONES, I.; ROY, P. Sputnik V COVID-19 vaccine candidate appears safe and effective. The Lancet, v. 397, n. 10275, p. 642-643, 2021.

KNOLL, M. D.; WONODI, C. Oxford-AstraZeneca COVID-19 vaccine efficacy. The Lancet, v. 397, n. 10269, p. 72-74, 2021. 
LEI, Z. et al. Chloroquine and hydroxychloroquine in the treatment of malaria and repurposing in treating COVID-19. Pharmacology \& Therapeutics, v. 216, p. 107672, 2020.

LIU, J. et al. Hydroxychloroquine, a less toxic derivative of chloroquine, is effective in inhibiting SARS-CoV-2 infection in vitro. Cell Discovery, v. 6, n. 1, p. 1-4, 2020.

MAISONNASSE, P. et al. Hydroxychloroquine use against SARS-CoV-2 infection in nonhuman primates. Nature, v. 585, n. 7826, p. 584-587, 2020.

MELO, J. R. R. et al. Self-medication and indiscriminate use of medicines during the COVID-19 pandemic. Cadernos de Saúde Pública, v. 37, n. 4, 2021.

Missionários dizem que falta cloroquina na reserva Yanomami para o combate à malária. Jornal Nacional, São Paulo, 10 de mai. 2021. Disponível em: <https://g1.globo.com/jornal-nacional/noticia/2021/05/10/missionariosdizem-que-falta-cloroquina-na-reserva-yanomami-para-o-combate-amalaria.ghtml> Acesso em: 28 de mai. 2021.

NEIVA, M. B. et al. Brazil: the emerging epicenter of COVID-19 pandemic. Revista da Sociedade Brasileira de Medicina Tropical, v. 53, p. 1-8, 2020.

NGHOCHUZIE, N. N. et al. Pausing the Fight Against Malaria to Combat the COVID-19 Pandemic in Africa: Is the Future of Malaria Bleak?. Frontiers in Microbiology, v. 11, p. 1476, 2020.

PAHAN, P; PAHAN, K. Smooth or risky revisit of an old malaria drug for COVID-19?. Journal Neuroimmune Pharmacol. v. 15, v. 1, p. 174-180. 2020.

PENJOR, K. et al. Has COVID-19 derailed Bhutan's national malaria elimination goal? A commentary. Malaria Journal, v. 20, n. 1, p. 1-3, 2021.

PILLAT, M. M. et al. Insights in chloroquine action: perspectives and implications in Malaria and COVID-19. Cytometry, v. 97, n. 9, p. 872-881, 2020.

PHADKE, M.; SAUNIK, S. COVID-19 treatment by repurposing drugs until the vaccine is in sight. Drug Development Research, v. 81, n. 5, p. 541-543, 2020.

PONTICELLI, C.; MORONI, G. Hydroxychloroquine in systemic lupus erythematosus (SLE). Expert Opinion on Drug Safety, v. 16, n. 3, p. 411-419, 2016.

QUASHIE, N.; QUASHIE, N. O. D. Treatment of COVID-19 with Chloroquine: Implication for Malaria Chemoterapy Using ACTs in Disease Endemic Countries. Journal of Tropical Pediatrics, v. 67, n. 1, p. 1-6, 2020.

ROGERSON, S. J. et al. Identifying and combating the impacts of COVID-19 on malaria. BMC Medicine, v. 18, n. 1, p. 1-7, 2020.

SANDS, P. HIV, tuberculosis, and malaria: how can the impact of COVID-19 be minimised?. The Lancet Global Health, v. 8, n. 9, p. e1102-e1103, 2020. 
SASSINE, V. Saúde desviou 2 milhões de comprimidos de cloroquina para Covid, e programa de malária ficou sem estoque. Folha de São Paulo, São Paulo, 2 de mar. $2021 . \quad$ Disponível em: <https://www1.folha.uol.com.br/equilibrioesaude/2021/03/saude-desviou-2milhoes-de-comprimidos-de-cloroquina-para-covid-e-programa-de-malariaficou-sem-estoque.shtml> Acesso em: 28 de mai. 2021.

SCIGLIANO, Giulio; SCIGLIANO, Giuseppe Augusto. Methylene blue in covid-19. Medical Hypotheses, v. 146, p. 110455, 2021.

SHERRARD-SMITH, E. et al. The potential public health consequences of COVID-19 on malaria in Africa. Nature Medicine, v. 26, n. 9, p. 1411-1416, 2020.

SISTEMA DE INFORMAÇÃO DE AGRAVOS DE NOTIFICAÇÃO - SINAN. Malária Notificações Registradas: Banco de dados. Disponível em: <http://tabnet.datasus.gov.br/cgi/tabcgi.exe?sinannet/cnv/malabr.def> Acesso em: 28 de mai. 2021.

SMITH, E. S. et al. The potential public health consequences of COVID-19 on malaria in Africa. Nature Medicine, v. 26, n. 9, p. 1411-1416, 2020.

VAGHAN, A. Covid-19 could have disastrous impacts on HIV, TB and malaria. New Scientist, v. 247, n. 3291, p. 8, 2020.

VELAVAN, T. et al. COVID-19 and syndemic challenges in 'Battling the Big Three': HIV, TB and malaria. International Journal of Infectious Diseases, v. 106, p. 29-32, 2021.

World Health Organization. World malaria report 2020: 20 years of global progress and challenges. Geneva: World Health Organization, 2020. Licence: CC BY-NC-SA 3.0 IGO

ZAWAWI, A. et al. The impact of COVID-19 pandemic on malaria elimination. Parasite Epidemiology and Control, v. 11, p. e00187, 2020.

ZHU, N. et al. China Novel Coronavirus Investigating and Research Team. A novel coronavirus from patients with pneumonia in China, 2019. New England Journal of Medicine, v. 382, n. 8, p. 727-733, 2020.

ZOU, L. et al. Hydroxychloroquine and chloroquine: a potential and controversial treatment for COVID-19. Archives of pharmacal research, v. 43, p. 765-772, 2020. 


\title{
CAPITULO XLIV
}

\section{RASTREIO DA DOENÇA RENAL CRÔNICA EM FUNCIONÁRIOS HIPERTENSOS E DIABÉTICOS DE UMA ESCOLA PÚBLICA}

DOI: 10.51859/AMPLLA.PAE1993-44

\author{
Samira Mislane da Silva Santos ${ }^{1}$ \\ Maria Lucrécia da Silva Santos ${ }^{2}$ \\ Angélica de Godoy Torres Lima ${ }^{3}$ \\ Jaciele Cristina da Silva Belone ${ }^{4}$ \\ Judicléia da Silva Marinho ${ }^{5}$ \\ Juliana de Castro Nunes Pereira ${ }^{6}$ \\ Sônia Maria da Silva Garcia ${ }^{7}$
}

\footnotetext{
Discente do Curso Técnico em Enfermagem. Instituto Federal de Educação, Ciência e Tecnologia de Pernambuco - IFPE campus Belo Jardim. 2 Discente do Curso Técnico em Enfermagem. Instituto Federal de Educação, Ciência e Tecnologia de Pernambuco - IFPE campus Belo Jardim. ${ }^{3}$ Doutoranda em Enfermagem - UPE/UEPB. Docente do Instituto Federal de Educação, Ciência e Tecnologia de Pernambuco - IFPE campus Belo Jardim.

${ }^{4}$ Doutoranda em Economia da Saúde - UFPE. Docente do Instituto Federal de Educação, Ciência e Tecnologia de Pernambuco - IFPE campus Belo Jardim.

${ }^{5}$ Mestre em Gestão e Economia da Saúde - UFPE. Docente do Instituto Federal de Educação, Ciência e Tecnologia de Pernambuco - IFPE campus Belo Jardim.

${ }^{6}$ Doutoranda em Saúde Integral - IMIP. Docente do Instituto Federal de Educação, Ciência e Tecnologia de Pernambuco - IFPE campus Belo Jardim.
}

7 Doutora em Ciências Materiais - UFPE. do Instituto Federal de Educação, Ciência e Tecnologia de Pernambuco - IFPE campus Belo Jardim.

\section{RESUMO}

Introdução: a doença renal crônica é uma síndrome clínica que se caracteriza por alterações irreversíveis na função e/ou estrutura dos rins. A mesma é uma patologia que tem evolução lenta, silenciosa e progressiva. Método: trata-se de estudo descritivo, observacional, transversal utilizando abordagem quantitativa. Essa pesquisa foi realizada com funcionários diabéticos e hipertensos de uma Instituição pública de ensino no interior de Pernambuco. Inicialmente parte da coleta de dados foi realizada presencialmente na campanha do dia mundial do rim em março de 2020, sendo coletadas algumas informações de saúde. O presente estudo foi finalizado através de formulário eletrônico devido a dificuldades de coleta por causa da pandemia do novo coronavírus. Resultados: a pesquisa obteve um total de 17 participantes, dos quais 52,9\% (9) era do sexo feminino e 47,1\% (8) do masculino, não havendo predominância de sexo, com faixa etária variando de 30 até mais de 60 anos, sendo mais prevalente indivíduos com idade entre 41 a 50 anos $(35,3 \%, 6)$, isso corrobora com outros estudos no que diz respeito a idade, em que $90 \%$ dos indivíduos hipertensos e diabéticos se encontram na faixa etária entre 40 e 50 anos. Conclusão: a realização de atividades de educação para a saúde com esse grupo é uma medida simples, factível e de baixo custo que pode ser realizada por profissionais de saúde a fim de contribuir na prevenção de complicações da HAS e DM, como a DRC.

Palavras-chave: Insuficiência Renal Crônica. Hipertensão. Diabetes Mellitus. Prevenção Secundária 


\section{INTRODUÇÃO}

A doença renal crônica (DRC) é um problema de saúde pública no Brasil e no mundo. A mesma "afeta $8 \%$ a $16 \%$ da população mundial e é uma das principais causas de morte". (CHEN; KNICELY; GRAMS, 2019). A doença renal crônica é uma síndrome clínica que se caracteriza por alterações irreversíveis na função e/ou estrutura dos rins. A mesma é uma patologia que tem evolução lenta, silenciosa e progressiva. Os pacientes portadores de DRC, só descobrem a doença e apresentam complicações em estágios mais avançados (AMMIRATI, 2020).

A DRC consiste em uma complicação comum do diabetes mellitus e da hipertensão arterial sistêmica, os quais consistem nos principais fatores de risco para o seu desenvolvimento e está associada com elevadas taxas de morbidade e mortalidade (PORTO, et al., 2015; SILVA, et al., 2020). Os indivíduos com risco para desenvolver a DRC são pessoas com diabetes mellitus- quer seja do tipo 1 ou do tipo 2 -, hipertensas, com histórico de DRC na família, idade avançada, portadores de obesidade, doenças cardiovasculares, tabagismo e em uso de agentes nefrotóxicos (BRASIL, 2014).

Segundo Lo et al. (2019) diabetes é a causa mais comum de doença renal crônica (DRC), ambas as condições comumente coexistem. Na atualidade os números de DRC são bastante elevados, no entanto ainda existe uma escassez de conhecimento da população sobre essa enfermidade. É de grande importância a implementação de políticas de controle da progressão da doença que precisam ser acrescentadas às práticas dos serviços de saúde, com ênfase na atenção básica (SILVA JÚNIOR, et al., 2018).

O controle dos níveis glicêmicos e pressóricos podem minimizar a progressão da DRC, do mesmo modo, pode também até impedir o seu aparecimento quando os sintomas são detectados precocemente, prevenindo sua manifestação em indivíduos do grupo de risco. Essa patologia reduz consideravelmente o funcionamento físico e profissional, causando um impacto negativo sobre a saúde do indivíduo, que está além daqueles causados pelos sintomas, mas também pelo tratamento dessa doença (ROCHA, et al., 2015).

O diagnóstico precoce da DRC pode dar-se por meio de marcadores laboratoriais de lesão do parênquima renal, como por meio da proteinúria. A avaliação deste 
marcador pode ser realizada em amostra de urina coletada durante 24 horas ou em amostra de urina isolada normalizada pela creatinina urinária. Esta normalização tem como finalidade corrigir possíveis erros decorrentes da diluição ou concentração da amostra de urina isolada (PORTO, et al., 2015).

Desenvolver ações como acompanhamento frequente de doentes renais e seus familiares, realizar rastreamento, triagem anual com creatinina sérica, razão albumina / creatinina urinária e urinálise para pacientes com fatores de risco, em especial diabetes mellitus, para diagnóstico precoce de novos casos, ajudam na implementação de tratamento em estágios iniciais da doença que tem como consequência um melhor prognóstico e preservação da função renal (DAVID, et al., 2017; SILVA JÚNIOR, et al., 2018).

A partir disso, o presente estudo teve como objetivos analisar o perfil sócio epidemiológico e clínico de funcionários diabéticos e hipertensos de uma instituição pública de ensino no interior de Pernambuco e realizar o rastreio da DRC através de um instrumento validado pela literatura nesse público.

\section{METODOLOGIA}

Trata-se de estudo descritivo, observacional, transversal utilizando abordagem quantitativa. No estudo observacional, o investigador age como espectador de fenômenos ou fatos, sem realizar qualquer intervenção que possa interferir no desfecho dos mesmos, embora possa realizar medições, análises e outros procedimentos para coleta de dados (CUMMINGS; BROWNER; HULLEY, 2003).

Essa pesquisa foi realizada em uma Instituição pública de ensino no interior de Pernambuco. A população foi composta por funcionários diabéticos e hipertensos atuantes nessa Instituição Educacional. Os seguintes critérios de inclusão foram adotados: ser diabético ou hipertenso e ser maior de 18 anos. Foram critérios de exclusão: vigência de tratamento psiquiátrico e pessoas acometidas por DRC.

Inicialmente realizamos parte da coleta de dados durante a campanha do dia mundial do rim no dia 10 de março de 2020, presencialmente, através da qual foi possível coletar algumas informações de saúde, tais como pressão arterial, glicemia de jejum, urina para avaliação de proteinúria por meio de fita reagente, circunferência da cintura, peso e altura, de forma padronizada pelas pesquisadoras. 
O presente estudo foi finalizado através de formulário eletrônico devido a dificuldades de coleta por causa da pandemia do novo coronavírus. A partir de uma lista de funcionários obtida a partir do setor de gestão de pessoas, foram enviados por e-mail ou via aplicativos de mensagens um formulário eletrônico do Google forms com o convite para participar da pesquisa. Na parte inicial do formulário tem o Termo de Consentimento Livre Esclarecido (TCLE) e um link com a disponibilização de uma cópia deste termo, que após a opção de aceite em participar da pesquisa, a seção do formulário com um questionário de coleta de dados é liberada. Este foi confeccionado pelas pesquisadoras com base em dados na literatura e utilizando-se de instrumento validado, no qual havia perguntas sobre dados sociodemográficos, informações de saúde e o instrumento SCORED (Screening For Occult Renal Disease) para rastreio da DRC na comunidade.

Após a coleta de dados, os mesmos foram digitados em uma planilha do Excel $^{\circledR}$ da Microsoft Office, e digitado em dupla entrada, para conferência de erros de digitação sendo utilizado o programa EPI-INFO versão 3.5.4, em seguida, os dados transferidos para o programa Statistical Package for the Social Sciences ${ }^{\circledR}$-SPSS versão 21.0 para serem analisados. Realizou-se uma análise descritiva dos dados sociodemográficos, das informações de saúde e nutricionais e do rastreio de risco para a DRC. Os dados estão organizados em formato de tabelas, nas quais estão apresentadas as frequências absolutas e relativas para variáveis qualitativas e para as variáveis quantitativas, são expostas a média ou mediana e suas respectivas medidas de dispersão conforme teste de normalidade de Shapiro-Wilk.

O estudo respeitou os aspectos éticos de pesquisa envolvendo seres humanos pela Resolução $n^{\circ}$ 466/2012 do Conselho Nacional de Saúde (BRASIL, 2012) e foi aprovado pelo Comitê de Ética em Pesquisa sob número de parecer 3.461.955. Aos participantes da pesquisa foram explicadas todas as informações sobre os objetivos do estudo que constam no Termo de Consentimento Livre e Esclarecido (TCLE), e após aceitação, assinaram o mesmo, em que ficou uma via com os entrevistados e outra com os pesquisadores através de formulário online. 


\section{RESULTADOS E DISCUSSÃO}

A pesquisa obteve um total de 17 participantes, dos quais 52,9\% (9) era do sexo feminino e 47,1\% (8) do masculino, não havendo predominância de sexo, com faixa etária variando de 30 até mais de 60 anos, sendo mais prevalente indivíduos com idade entre 41 a 50 anos $(35,3 \%, 6)$, isso corrobora com o estudo realizado por Souza et al. (2019) no que diz respeito a idade onde destacou na sua pesquisa que $90 \%$ dos indivíduos hipertensos e diabéticos se encontram na faixa etária entre 40 e 50 anos (Tabela 1).

Observa-se que no presente estudo que negros e pardos configuram a maior população de hipertensos e diabéticos, assemelhando-se à pesquisa de Francisco et al. (2018), onde a prevalência de diabéticos e hipertensos em seu estudo foi de $48,0 \%$ e $55,0 \%$ para indivíduos de cor de pele parda e preta, respectivamente. Quanto ao nível de escolaridade, a maioria possui pós-graduação $(58,8 \%, 10)$ e possui renda salarial acima de 4 salários mínimos (70,6\%). Em Oliveira et al. (2019), destaca-se que a educação associada ao alto nível socioeconômico é um fator muito importante que contribui para melhores indicadores de saúde (Tabela 1).

Tabela 1 - Dados sociodemográficos de funcionários hipertensos e diabéticos de uma Instituição de Ensino pública no interior de Pernambuco

\begin{tabular}{lcc}
\hline VARIÁVEL & $\mathbf{n}$ & $\%$ \\
\hline Sexo & & \\
$\quad$ Feminino & 9 & 52,9 \\
$\quad$ Masculino & 8 & 47,1 \\
Faixa etária & 5 & 29,4 \\
$\quad$ Entre 30 e 40 anos & 6 & 35,3 \\
$\quad$ Entre 41 e 50 anos & 4 & 23,5 \\
$\quad$ Entre 51 e 60 anos & 2 & 11,8 \\
$\quad$ Mais de 60 anos & & \\
Escolaridade & 1 & 5,9 \\
$\quad$ Ensino fundamental & 1 & 5,9 \\
$\quad$ Ensino médio & 5 & 29,4 \\
$\quad$ Ensino superior & 10 & 58,8 \\
$\quad$ Pós-graduação & & \\
Raça & 6 & 35,3 \\
$\quad$ Branco & 7 & 41,2 \\
$\quad$ Pardo & 4 & 23,5 \\
$\quad$ Negro & & \\
Estado Civil & 3 & 17,6 \\
$\quad$ Solteiro & 14 & 82,4 \\
$\quad$ Casado & & \\
Função & & 52,9 \\
$\quad$ Docente & 9 & 29,4 \\
$\quad$ Técnico-Administrativo & 5 & 17,6
\end{tabular}




\begin{tabular}{lcc}
\hline VARIÁVEL & $\mathbf{n}$ & $\mathbf{\%}$ \\
\hline Renda & 1 & \\
Até 1 salário mínimo & 2 & 5,9 \\
Entre 2 e 4 salários mínimos & 2 & 11,8 \\
Entre 3 e 4 salários mínimos & 12 & 11,8 \\
Mais de 4 salários mínimos & 70,6 \\
\hline
\end{tabular}

Fonte: Autoria própria.

Ademais, foram coletadas informações quanto ao histórico e hábitos de vida desse público. Sobre as comorbidades, encontrou-se: 76,5\% (13) hipertensos, 11,8\% (2) diabéticos, e 11,8\% (2) que tem as duas doenças (hipertensão e diabetes), e sendo notável que a morbidade de maior prevalência nessa população é a hipertensão. $A$ prevalência da hipertensão está associada conforme idade, sendo maior prevalência na faixa etária de 30 a 59 anos, do sexo feminino e idosos entre 60 e 74 anos (FIÓRIO, et al., 2020).

Esses dados fazem relação com o estudo de Felipetti et al. (2016) no qual 26.450 pacientes da sua pesquisa que são cadastrados no Sistema HiperDia, do total de pacientes cadastrados, 871 (3,3\%) são diabéticos e 20.238 (76,5\%) são hipertensos, que concorda com o estudo de Tortorella et al. (2017) onde mostra que a prevalência de HAS tem um aumento mais considerável do que o DM no decorrer dos anos Também analisou-se que $70 \%$ dos indivíduos dessa pesquisa não têm histórico de DRC na família, e $60 \%$ refere consumo de bebida alcoólica.

Tabela 2 - Informações com histórico e hábitos de saúde de funcionários hipertensos e diabéticos de uma Instituição de Ensino pública no interior de Pernambuco

\begin{tabular}{lcc}
\hline VARIÁVEL & $\mathbf{n}$ & $\%$ \\
\hline Comorbidade & 13 & 76,5 \\
$\quad$ Hipertensão & 2 & 11,8 \\
Diabetes & 2 & 11,8 \\
$\quad$ Hipertensão e diabetes & & \\
Histórico Familiar de DRC & 5 & 29,4 \\
$\quad$ Sim & 12 & 70,6 \\
Não & & \\
DRC do familiar & 2 & 40,0 \\
DRC em tratamento conservador & 1 & 20,0 \\
DRC em TRS & 2 & 40,0 \\
$\quad$ Litíase renal & & \\
Consumia bebida alcóolica & 10 & 58,8 \\
Sim & 7 & 41,2 \\
Não & & \\
Tabagismo & 0 & 0 \\
Sim & 17 & 100 \\
Não & & 47,1 \\
Pratica atividade física & 8 & 52,9 \\
Sim & 9 &
\end{tabular}




\begin{tabular}{lll}
\hline VARIÁVEL & $\mathbf{n}$ & $\%$ \\
\hline Tipo de atividade física & 3 & \\
Caminhada & 37,5 \\
Outras (ciclismo/pilates) & 5 & 62,5 \\
\hline
\end{tabular}

Fonte: Autoria própria.

Observa-se que quase a metade dos participantes possuem o hábito de fazer alguma atividade física regularmente $(47,1 \%, 8)$, isso pode estar atrelado à maior escolaridade e melhores condições de vida (CHEHUEN NETO, et al., 2019).

Dentre os tipos de exercícios praticados, $37,5 \%$ (3) das pessoas que fazem caminhada e $62,5 \%$ (5) optam por outras atividades, como ciclismo ou pilares. Ainda houve 3 relatos de que cessaram as atividades físicas após o advento da pandemia. Pois, mesmo as atividades físicas sendo de extrema importância para a uma vida saudável, o advento da pandemia ocasionou dificuldade para realização das mesmas, tendo em vista o isolamento social (OSÓRIO, et al., 2020).

Todos os participantes da pesquisa relataram que não são tabagistas, destes 2 participantes relataram não ter mais o hábito de fumar por no mínimo sete anos. Assim, evitam possíveis complicações da doença, visto que o tabagismo tem efeitos vasoconstritores, tromboembólicos e diretos no endotélio vascular, tornando-se um fator de risco para a DRC, justamente por ser um forte preditor no aumento dos níveis séricos de creatinina. Além disso, o risco de pacientes com diabetes tipo 2 que pararem de fumar reduz em 30\% (BASTOS; KIRSZTAJN, 2011).

Na tabela 3 estão descritos dados dos participantes que participaram da avaliação de saúde presencial, antes da pandemia e a pontuação do instrumento SCORED realizada por todos os participantes. Observa-se que todos os participantes estão com sobrepeso ou obesos, além de uma parte apresentar a circunferência da cintura com valores acima dos recomendados, aumentando significativamente o risco para doenças cardiovasculares e a DRC (SILVA JUNIOR, et al., 2017).

A hipertensão arterial é, portanto, definida como uma pressão arterial sistólica (PAS) maior ou igual a $140 \mathrm{mmHg}$ e uma pressão arterial diastólica (PAD) maior ou igual a $90 \mathrm{mmHg}$, em indivíduos que não estão fazendo uso de medicação anti-hipertensiva. Admite-se como pressão arterial ideal, condição em que o indivíduo apresenta o menor risco cardiovascular, PAS $<120 \mathrm{mmHg}$ e PAD $<80 \mathrm{mmHg}$. Níveis de PAS entre 130 e 139 mmHg e de PAD entre 85 e 89 mmHg são considerados limítrofes. Já os níveis de glicemia 
de jejum são tidos como alterados quando passam de 100 a 126 mg/dl (MINISTÉRIO DA SAÚDE, 2011; GOVERNO DO DISTRITO FEDERAL, 2018). Sobre isso, foi identificado que a população do estudo apresenta níveis pressóricos controlados e que uma parte apresenta níveis glicêmicos alterados (tabela 3).

Tabela 3 - Dados da avaliação de saúde de funcionários hipertensos e diabéticos de uma Instituição de Ensino pública no interior de Pernambuco*

\begin{tabular}{|c|c|c|c|}
\hline VARIÁVEL & & $n$ & $\%$ \\
\hline \multicolumn{4}{|l|}{ IMC } \\
\hline Peso normal & & 0 & 0 \\
\hline Sobrepeso & & 6 & 60,0 \\
\hline Obesidade & & 4 & 40,0 \\
\hline \multicolumn{4}{|l|}{ Circunferência da cintura\# } \\
\hline Sem risco cardiovascular & & 6 & 60,0 \\
\hline Com risco cardiovascular & & 4 & 40,0 \\
\hline \multicolumn{4}{|l|}{ Pressão arterial sistólica } \\
\hline Média \pm Desvio Padrão & $120 \pm 10$ & & \\
\hline (mínimo - máximo) & $(110-130)$ & & \\
\hline \multicolumn{4}{|l|}{ Pressão arterial diastólica } \\
\hline $\begin{array}{l}\text { Média } \pm \text { Desvio Padrão } \\
\text { (mínimo - máximo) }\end{array}$ & $\begin{array}{c}86,67 \pm 15,27 \\
(70-100)\end{array}$ & & \\
\hline \multicolumn{4}{|l|}{ Glicemia capilar de jejum $\$$} \\
\hline Normal & & 1 & 11,1 \\
\hline Hiperglicemia & & 8 & 88,9 \\
\hline \multicolumn{4}{|l|}{ Pontuação SCORED } \\
\hline Com risco para DRC & & 12 & 70,6 \\
\hline Sem risco para DRC & & 5 & 29,4 \\
\hline
\end{tabular}

Fonte: Autoria própria.

*Apenas 10 indivíduos participaram da avaliação de saúde junto aos pesquisadores, devido as dificuldades de coleta presencial durante a pandemia. "Foram considerados como risco cardiovascular a circunferência de cintura $\geq 88 \mathrm{~cm}$ para mulheres e $\geq 102 \mathrm{~cm}$ para homens. sForam considerados normais valores até $99 \mathrm{mg} / \mathrm{dl}$.

Contudo, após a avaliação do risco para DRC através do SCORED realizada com todos os indivíduos da amostra, gerou uma preocupação, visto que a maioria apresentou uma pontuação de risco para DRC conforme pode ser visto na Tabela 3 -

O SCORED traz a perspectiva do uso de métodos preditores de DRC baseado no efeito cumulativo de múltiplos fatores, em um contexto em que o enfoque é "doenças de risco" - como hipertensão e diabetes (SANTOS; NETO MONTE, 2016).

A presente pesquisa demonstra o quanto importante pode ser a contribuição do SCORED em alertar para o risco de DRC e estimular a realização de exames da função renal em grupos de risco, reduzindo a parcela de pessoas com DRC que não é avaliada laboratorialmente. Estabelecendo-o como uma ferramenta na estratégia de diminuir os casos de diagnóstico tardio da DRC em grupos de risco, sendo viável utilizá-lo em 
espaços para a promoção da saúde (SANTOS; NETO MONTE, 2016; VANELLI, et al., 2018; SIDRIM, et al., 2017).

Portanto, o problema de saúde pública do diagnóstico tardio da DRC deve ser enfrentado com o envolvimento do maior número de pessoas da comunidade, além dos profissionais da área de saúde. Nesse contexto, são muito importantes questionários simples validados para alertar as pessoas sobre uma probabilidade aumentada da presença de DRC, sem dependência de exame laboratorial, que possam ser auto aplicados ou aplicados por leigos (pessoas fora da área de saúde), em vários cenários: empresas, instituições, salas de espera de consultório médico, comunidades, campanhas educativas (SANTOS; NETO MONTE, 2016; VANELLI, et al., 2018).

Quanto a proteinúria, dos seis indivíduos que coletaram a amostra de urina para análise, dois apresentaram alterações, sendo um com traços de proteinúria e outro com 1+ de proteinúria, o que corresponde a uma alteração que necessita de melhor avaliação de profissional médico com exames mais precisos para confirmar se esta alteração pode ser algo preditor para a doença renal nesses indivíduos posteriormente, caso não investigado e realizadas as intervenções necessárias. Nenhum dos participantes apresentou hematúria.

A melhor forma de redução dos danos causados pela DRC é o diagnóstico precoce que, por sua vez, não pode depender de sintomas, pois na maioria dos casos, a sintomatologia é discreta, inexistente ou tardia. Portanto, a pesquisa de proteinúria ou albuminúria notabiliza-se como instrumento para diagnóstico precoce e consequente prevenção secundária (KIRSZTAJN, 2010).

Considerando sua importância diagnóstica e prognóstica para estratificação da DRC, Vanelli et al. (2018) sugerem que a proteinúria tem sido subutilizada na atenção primária à saúde como forma de rastreio, visto que este foi referido verbalmente por um pequeno número de indivíduos em seu estudo.

A identificação dos fatores de risco dá acesso a uma melhor estratégia de prevenção para a DRC. Se descoberta em seus estágios iniciais, evita-se o maior comprometimento das estruturas renais e se reduz o número de pacientes em tratamento dialítico. Por isso, é importante que medidas de detecção precoce e controle de fatores de risco sejam tomados e intensificados desde a atenção primária. Isto 
melhoraria a qualidade de vida e diminuiria os gastos do sistema de saúde (BRAVOZÚÑIGA, et al., 2019; SILVA JÚNIOR, et al., 2018).

\section{CONSIDERAÇÕES FINAIS}

O presente estudo descreveu o perfil da população do estudo e dos indivíduos com risco para desenvolver a DRC através do instrumento SCORED, os quais estão com sobrepeso ou obesidade, apresentam como principal comorbidade a hipertensão, a qual apresenta-se controlada nessa população, a maioria é de não fumantes e quase metade desses indivíduos realizam atividade física. Existe também predominância de idade abaixo de 60 anos, predomínio de escolaridade de graduação e pós-graduação, maioria casados e com renda acima de quatro salários mínimos. Além de possuir história de HAS e DM e realizar alguma atividade física.

Vale destacar que tanto a HAS como a DM são enfermidades que são capazes de ser controladas com hábitos de vida saudáveis tais como alimentação adequada, exercícios físicos, ausência de tabagismo e consumo de bebida alcoólica. Portanto, é necessário orientar e explicar a esses indivíduos que manter o autocuidado em relação a realização de medidas não farmacológicas, tais como: atividade física regular e acompanhamento dietético para controle de peso são fundamentais para evitar complicações como a DRC.

A principal limitação desta pesquisa foi o baixo número de participantes hipertensos e diabéticos na instituição, o que restringiu a possibilidade de realizar um estudo com estatística inferencial, a fim de realizar associações entre os achados.

A realização de atividades de educação para a saúde com esse grupo é uma medida simples, factível e de baixo custo que pode ser realizada por profissionais de saúde a fim de contribuir na prevenção de complicações da HAS e DM, como a DRC.

\section{REFERÊNCIAS}

AMMIRATI, A. L. Doença Renal Crônica. Rev. Assoc. Med. Bras, v. 66, n. 1, p. s03-s09, 2020. 01300003\&lng=en\&nrm=iso. 
BASTOS, M. G.; KIRSZTAJN, G. M. Doença renal crônica: importância do diagnóstico precoce, encaminhamento imediato e abordagem interdisciplinar estruturada para melhora do desfecho em pacientes ainda não submetidos à diálise. Braz J Nephrol, v. 33, n.1, 2011. Disponível em: https://www.scielo.br/scielo.php?script=sci_arttext\&pid=S0101-280020110001 00013. Acesso em: 24 fev. 2021.

BRASIL. Ministério da Saúde. Diretrizes clínicas para o cuidado ao paciente com doença renal crônica - DRC no sistema único de saúde. Brasília, 2014. Disponível em: https://bvsms.saude.gov.br/bvs/publicacoes/diretrizes_clinicas_cuidado_pacie nte_renal.pdf Acesso em: 04 jan. 2021.

BRASIL. Ministério da Saúde. Conselho Nacional de Saúde. Resolução CNS 466/2012. Normas para Pesquisa envolvendo Seres Humanos. 2012.

BRAVO-ZÚÑIGA, J. et al. Detecção precoce de doença renal crônica: trabalho coordenado entre atenção primária e especializada em uma rede peruana de atenção renal ambulatorial. Braz. J. Nephrol., v. 41, n. 2, p. 176-184, 2019. Disponível em: https://www.scielo.br/j/jbn/a/MNW smssygjM8pT6mYZVqwCp/abstract/?lang=pt. Acesso em: 08 jul. 2021.

CHEN, T. K.; KNICELY, D. H.; GRAMS, M. E. Chronic Kidney Disease Diagnosis and Management: A Review. JAMA., v. 322, n. 13, p. 1294-1304, 2019. Available from: 10.1001/jama.2019.14745. Access in: 24 fev. 2021.

CHEHUEN NETO, J. A. et al. Functional Health Literacy in chronic cardiovascular patients. Ciênc. saúde coletiva, v. 24, n. 3, p. 1121-1132, 2019. Available from: http://www.scielo.br/scielo.php?script=sci_arttext\&pid=S141381232019000301121\&lng=en\&nr m=iso. Acesso em: 6 nov. 2021

CUMMINGS, S. R.; BROWNER, W. S.; HULLEY, S. B. Elaborando a questão de pesquisa. In: HULLEY, S. B.; CUMMINGS, S. R.; BROWNER, W. S. et al. Delineando a pesquisa clínica: uma aordagem epidemiológica. 2a Ed. Porto Alegre: Artmed, 2003. p: 3541.

DAVID, Y. G. et al. Chronic Kidney Disease: Detection and Evaluation. Am Fam Physician, v.96, n.12, p.776-783, 2017. Disponível em: https://www.aafp.org/afp/2017/1215/p776.html?utm_medium =email\&utm_source=transaction

FIÓRIO, C. E. et al. Prevalência de hipertensão arterial em adultos no município de São Paulo e fatores associados. Revista Brasileira de Epidemiologia. 2020. Disponível em: https://doi.org/10.1590/1980-549720200052. Acesso em: 29 mai. 2021.

FELIPETTI, F. et al. Prevalência de hipertensos e diabéticos cadastrados e acompanhados pelas unidades de saúde do município de Cascavel - Paraná. Rev. APS, v.19, n.1, 
p.77-84,

2016.

Disponível

em:

https://pesquisa.bvsalud.org/portal/resource/pt/biblio-2698.

FRANCISCO, P. el al. Prevalência simultânea de hipertensão e diabetes em idosos brasileiros: desigualdades individuais e contextuais. Ciênc. saúde coletiva, v.23, n.11, $2018 . \quad$ Disponível em: https://www.scielo.br/scielo.php?script=sci_arttext\&pid=S1413-

81232018001103829.

GOVERNO DO DISTRITO FEDERAL. Secretaria de Estado de Saúde. Protocolo de Atenção à Saúde: Manejo da Hipertensão Arterial Sistêmica e Diabetes Mellitus na Atenção Primária à Saúde. Portaria SES-DF № 161 de 21 de fevereiro de 2018, publicada no DODF № 37 de 23.02.2018. Brasília-DF, 2018. Disponível em: http://www.saude.df.gov.br/wp-conteudo/uploads/ 2018/04/ hipertencao-ediabetes-Manejo_da_HAS_e_DM_na_APS.pdf. Acesso em: 25 fev. 2021.

KIRSZTAJN, G. M. Proteinúria: muito mais que uma simples dosagem. J Bras Patol Med Lab., v. 46, n. 3, p. 1-2, 2010. Disponível em: https://www.scielo.br/j/jbpml/a/66FsXxG7x8SHCC

cSHcKmNrz/?lang=pt\&format=pdf Acesso em: 25 mai. 2021.

LO, C. et al. Insulin and glucose-lowering agents for treating people with diabetes and chronic kidney disease. The Cochrane database of systematic reviews. v. 9, n. 9, p. CD011798, 2018. Available from: 10.1002/14651858.CD011798.pub2

OSÓRIO, N. B. et al. O impacto da educação física na saúde de idosos em isolamento social em tempos de pandemia: Relato de experiência. Revista observatório. v. 6, n. 2, Abr-Jun. 2020. Disponível em: https://redib.org/Record/oai_articulo2895921-o-impacto-da-educa\%C3 \%A7\%C3\%A3o-fisica-na-sa\%C3\%BAde-de-idosos-em-isolamento-social-emtempos-de-pandemia-relato-de-experi\%C3\%AAncia Acesso em: 29 mai. 2021.

OLIVEIRA, J. S., et al. Influência da renda e do nível educacional sobre a condição de saúde percebida e autorreferida de pessoas idosas. J. Health Biol Sci. Fortaleza. 2019.

Disponível

em: https://periodicos.unichristus.edu.br/jhbs/article/view/2343/1014. Acesso em: 24 fev. 2021.

PORTO, J. R., et al. Avaliação da função renal na doença renal crônica. Revista Brasileira de Análises Clínicas. Minas Gerais. 2015. Disponível em: http://www.rbac.org.br/artigos/ avaliacao-da-funcao-renal-na-doenca-renalcronica/. Acesso em: 05 jan. 2021.

ROCHA, C. C. T., et al. Hipertensos e diabéticos com insuficiência renal crônica no Brasil cadastrados no SIS/HIPERDIA. Rev. Bras. Hipertens. v. 22, n. 1, p. 27-32, 2015. Disponível

em: 
https://docs.bvsalud.org/biblioref/2018/03/881290/rbh_v22n1_27-32.pdf.

Acesso em: 04 jan. 2021.

SANTOS, P. R.; NETO MONTE, V. L. Aplicação do questionário SCORED para rastreamento da doença renal crônica entre pacientes hipertensos e diabéticos. Cad. Saúde Colet. Rio de Janeiro.2016. Disponível em: https://www.scielo.br/pdf/cadsc/v24n4/1414-462X-cadsc- 24-4428.pdf. Acesso em: 25 fev. 2021.

SIDRIM, L. B. et al. Avaliação do questionário SCORED no rastreamento da doença renal crônica em população de hipertensos e/ou diabéticos. Rev. Soc. Bras. Clín. Méd., v. 15, n. 3, p. 171-177, 2017. Disponível em: http://www.sbcm.org.br/revistas/RBCM/RBCM-2017-03.pdf\#page=28. Acesso em: 14 jan. 2021.

SILVA, P. A. B. et al. Política pública brasileira na prevenção da doença renal crônica: desafios e perspectivas. Revista de Saúde Pública. São Paulo, 2020. Disponível em: $\quad$ https://www.scielo.br/scielo.php?script=sci_arttext\&pid=S0034$89102020000100608 \&$ Ing=pt \&nrm=iso\&tlng=pt. Acesso em: 14 jan. 2021.

SILVA JUNIOR, G. B. et al. Obesidade e doença renal. J Bras Nefrol., v. 39, n. 1, p. 65-69, 2017. Disponível em: https://www.scielo.br/pdf/jbn/v39n1/pt_0101-2800-jbn39-01-0065.pdf. Acesso em: 6 nov. 2021.

SILVA JUNIOR, G. B. et al. Global costs attributed to chronic kidney disease: a systematic review. Rev. Assoc. Med. Bras, v. 64, n. 12, p. 1108-1116, 2018. Disponível em: $\quad<$ http://www.scielo.br/scielo.php?script=sci_arttext\&pid=S0104$42302018001201108 \& \operatorname{lng}=e n \& n r m=i s o>$.

SOUZA, N. el al. Fatores de risco e complicações em diabéticos/hipertensos cadastrados no HiperDia. SANARE, v.18, n.01, p.31-39, 2019. Disponível em: https://sanare.emnuvens.com.br/sanare/article/view/1303

TORTORELLA, C. et al. Tendência temporal da prevalência de hipertensão arterial sistêmica e diabetes mellitus entre adultos cadastrados no Sistema Único de Saúde em Florianópolis, Santa Catarina, 2004-2011. Epidemiol. Serv. Saúde [online], v.26, n.3, p.469-480, 2017. Disponível em: https://www.scielo.br/scielo.php?pid=S2237-

96222017000300469\&script=sci_abstract\&tIng=pt\#: :text=no\%20per\%C3\%AD odo\%202004\%2D2011\%2C\%20aumentaram,idosos\%2C\%20menos\%20escolariz ados\%20e\%20residentes.

VANELLI, C. P. et al. Chronic kidney disease: susceptibility in a representative populationbased sample. Revista de Saúde Pública [online], v. 52, n. 68, 2018. Disponível em: https://doi.org/10.11606/S1518-8787.2018052017410. Acesso em: 3 ago. 2021. 


\title{
CAPITULO XLV
}

\section{REVISÃO INTEGRATIVA DA LITERATURA SOBRE O TRATAMENTO E CONTROLE DE DIABETES MELLITUS COM PLANTAS MEDICINAIS}

\author{
DOI: 10.51859/AMPLLA.PAE1993-45
}

\author{
Gleicy Kelly China Quemel ${ }^{1}$ \\ Cintia Cristina Gomes de Lima ${ }^{3}$ \\ Laís Paiva da Assunção ${ }^{3}$ \\ Brena Mykaella Pereira da Silva ${ }^{3}$ \\ Regianne Maciel dos Santos Correa ${ }^{2}$ \\ Milene Pereira Gomes 4 \\ Marcos Alexandre dos Santos Farias ${ }^{3}$ \\ Elda Mary Soares ${ }^{3}$
}

\footnotetext{
${ }^{1}$ Mestre em Ciências Ambientais e Docente da Escola Superior da Amazônia (ESAMAZ), Curso de Farmácia, Belém PA, Brasil.

2 Doutora em Neurociências e Biologia Celular e Docente da Escola Superior da Amazônia (ESAMAZ), Curso de Farmácia, Belém PA, Brasil.

${ }^{3}$ Graduandas do Curso de Bacharelado em Farmácia da Escola Superior da Amazônia (ESAMAZ), Belém PA, Brasil

${ }^{4}$ Farmacêutica da rede Farma Norte, Belém PA, Brasil
}

\section{RESUMO}

As plantas medicinais são aquelas que possuem princípios bioativos com propriedades profiláticas ou terapêuticas. Com base nessa informação, o presente estudo objetivou avaliar, com base na literatura, as farmacoterapias alternativas com plantas medicinais no tratamento e controle da Diabetes Mellitus. Foi realizada uma revisão integrativa da literatura com apoio da análise de conteúdo de Bardin. Os descritores, de acordo com o DECS, foram [Diabetes Mellitus], [Tratamento/ Treatment], [Plantas medicinais/ Medicinal plants] e [Medicamentos fitoterápicos/ Phytotherapeutic Drugs]. As literaturas utilizadas foram retiradas das bases de dados MEDLINE e LILACS, e da biblioteca do SCIELO. Os critérios de inclusão definidos para a seleção dos artigos foram: literaturas completas, disponíveis nos idiomas português, inglês e espanhol, e publicadas nos últimos dez anos (2011 à 04/2021), e exclusas literaturas duplicadas e com acesso restrito mediante à pagamento. Foram selecionadas 24 literaturas, sendo que as plantas mais citadas foram: Bauhinia forficata, Mormodica charantia, Baccharis trimera, Eugenia jambolana e Olea europea. De acordo com os estudos analisados há segurança na utilização, revelando eficácia no tratamento da hiperglicemia com risco tóxico nulo ou muito baixo. Dessa forma, ainda são necessários mais estudos para fomentar a utilização dessas plantas, a fim estimular cada vez mais os profissionais de saúde na sua prescrição consciente e segura bem como oferecer mais uma alternativa complementar ao tratamento da diabetes mellitus.

Palavras-Chaves: fitoterápicos, plantas medicinais, tratamento, diabetes mellitus. 


\section{INTRODUÇÃO}

O diabetes mellitus (DM) integra um grupo de doenças metabólicas caracterizadas por níveis elevados de glicose no sangue (hiperglicemia) decorrente de defeitos na secreção e/ou na ação da insulina no metabolismo dos alimentos (BARBOSA е CAMBOIM, 2016).

A insulina é produzida pelo pâncreas e é responsável pela manutenção do metabolismo da glicose e a falta desse hormônio provoca déficit na metabolização da glicose e consequentemente, diabetes. Caracteriza-se por altas taxas de açúcar no sangue de forma permanente (BRASIL, 2009).

A adesão ao tratamento da DM inclui a manutenção contínua pelos indivíduos do tratamento medicamentoso prescrito e a mudança do estilo de vida a partir da obediência às condutas orientadas aos hábitos de dieta e atividade física. (SILVA et al, 2018).

Os medicamentos mais utilizados e disponíveis são das classes biguanidas e derivados da ureia sulfonamidas que são: cloridrato de metformina 500mg, 850mg, glibemclamida $5 \mathrm{mg}$, gliclazida $30 \mathrm{mg}, 60 \mathrm{mg}, 80 \mathrm{mg}$ todos com apresentação em comprimidos. (BRASIL, 2012).

Neste contexto, reduzir o impacto do DM significa, sobretudo, reduzir a incidência da doença, antecipando-se ao seu aparecimento com medidas preventivas, principalmente em indivíduos de alto risco, como os portadores de tolerância diminuída à glicose (TDG) e de glicemia de jejum alterada (GJA). Intervenções comportamentais e farmacológicas têm sido estudadas e implementadas com esse objetivo. Modificações no estilo de vida, controle dietoterápico e prática sistemática de exercícios físicos, bem como o uso de alguns agentes orais, como fitoterápicos e plantas medicinais são medidas essenciais para o controle do DM (LYRA et al, 2006).

Apesar de haver medicamentos que ajudam no controle do DM no mercado, ainda são necessárias outras alternativas para controle e tratamento. Pensando nisso, busca-se outras alternativas, como as plantas medicinais. Desse modo, a pergunta que norteou o trabalho foi: Quais plantas medicinais podem ser utilizadas no tratamento e controle do Diabetes? O trabalho teve como objetivo avaliar em bases literárias farmacoterapias alternativas com plantas medicinais no tratamento e controle do DM, 
assim como apresentar ativos hipoglicemiantes que atuam de forma eficaz no tratamento do diabete e citar posologia e possíveis efeitos adversos das plantas citados.

\section{METODOLOGIA}

Foi realizada uma revisão integrativa de literatura (RIL), pois é um método que tem como finalidade sintetizar resultados obtidos em pesquisas sobre um tema ou questão, de maneira sistemática, ordenada e abrangente (SOUZA; SILVA; CARVALHO, 2010).

Para o levantamento das literaturas, realizou-se uma busca nas bases de dados Literatura Latino-Americana e do Caribe em Ciências da Saúde (LILACS), Medical Literature Analysis and Retrieval Sistem on-line (MEDLINE) e na biblioteca do Scientific Electronic Library Online (SCIELO)

Foram utilizados, para busca dos artigos, os seguintes descritores, contidos nos escritores em ciências da saúde (DeCS): [Diabetes Mellitus], [Tratamento/ Treatment], [Plantas medicinais/ Medicinal plants] e [Medicamentos fitoterápicos/ Phytotherapeutic Drugs], combinadas ou não com o operador booleano "And".

Os critérios de inclusão definidos para a seleção dos estudos foram: literaturas completas, disponíveis nos idiomas português, inglês e espanhol, e publicadas nos últimos dez anos (2011 a 04/2021). E os critérios de exclusão foram: literaturas duplicadas e com acesso restrito mediante à pagamento.

A análise crítica dos estudos foi realizada segundo Bardin (2011) que pode ser dividida em três etapas: na primeira etapa, a pré-análise, foram utilizadas cincos filtros referentes ao critério de inclusão e exclusão; na segunda etapa, a exploração do material, foram definidas as unidades de registro e a elaboração das categorias de análises ou eixos temáticos (Quadro 1); e na terceira etapa, o tratamento e interpretação dos dados, consistiu nos seguintes passos: apresentação dos estudos selecionados e explanação dos eixos temáticos.

Quadro 1: Categorização em eixos temáticos

\begin{tabular}{|l|l|}
\hline \multicolumn{1}{|c|}{ Unidade de Registro } & \multicolumn{1}{|c|}{ Eixos Temáticos } \\
\hline $\begin{array}{l}\text { - Utilização de fitoterápicos na atenção básica a } \\
\text { saúde } \\
\text { - Fitoterápicos e RENAME }\end{array}$ & $\begin{array}{l}\text { As principais plantas medicinais utilizadas no } \\
\text { tratamento da diabetes mellitus. }\end{array}$ \\
\hline
\end{tabular}




\begin{tabular}{|l|l|}
\hline \multicolumn{1}{|c|}{ Unidade de Registro } & \multicolumn{1}{|c|}{ Eixos Temáticos } \\
\hline $\begin{array}{l}\text { - Uso racional de fitoterápicos no tratamento da } \\
\text { DM fitoterápicos } \\
\text {-Mecanismos de ação dos } \\
\text { hipoglicemiantes } \\
\begin{array}{l}\text { Biodisponibilidade dos fitoterápicos no } \\
\text { tratamento da DM }\end{array}\end{array}$ & $\begin{array}{l}\text { Ativos hipoglicemiantes que atuam de forma eficaz } \\
\text { no tratamento do diabetes. }\end{array}$ \\
\hline $\begin{array}{l}\text {-Papel do farmacêutico na dispensação e } \\
\text { orientação no uso de fitoterápicos }\end{array}$ & $\begin{array}{l}\text { A possível toxicidade de plantas medicinais e } \\
\text { fitoterápicos no tratamento de diabetes; } \\
\text { Interações medicamentosas com plantas e } \\
\text { fitoterápicos. }\end{array}$ \\
\hline
\end{tabular}

Fonte: Autores (2021).

\section{RESULTADOS E DISCUSSÃO}

Foram selecionadas 24 literaturas para o desenvolvimento do trabalho, em que $20,83 \%$ (5) são em português, $70,83 \%$ (17) em inglês e 8,33\% artigos (2) em espanhol. A busca das literaturas resultou em 79,17\% (19) da base de dados MEDLINE, 16,67\% (4) da base de dados do LILACS e 4,16\% (1) da biblioteca do SCIELO.

Os estudos selecionados abordam temas variados, sendo $4,16 \%$ (1) sobre Hiperglicemia e glicocorticoides; 20,8\% (5) a respeito de estudos de pesquisas da utilização de plantas medicinais no tratamento da DM; $29,16 \%$ (7) a respeito do estudo sobre mecanismos e efeitos hipoglicemiantes de fitofármacos contidos em planta medicinais; 4,16\% (1) sobre o efeito hipoglicemiante da Bauhinia forficata,; 8,33\% (2) sobre o efeito hipoglicemiante da carqueja; $12,5 \%$ (3) relacionados como efeito hipoglicemiante da Mormodica charantia; $8,33 \%$ (2) sobre o efeito hipoglicemiante da Eugenia jambolana; 12,5 \% (3) a respeito do efeito hipoglicemiante da Olea Europea.

No quadro 2 estão dispostas as literaturas selecionadas para pesquisa, informando autor/título/ano, base/banco/repositório, objetivo, abordagem metodológica e conclusão

Quadro 2: Características dos estudos incluídos na revisão integrativa

\begin{tabular}{|c|c|c|c|}
\hline No & AUTOR/TíTULO/ANO & OBJETIVO & CONCLUSÃO \\
\hline 01 & $\begin{array}{c}\text { Utilização das Plantas } \\
\text { Medicinais por } \\
\text { Diabéticos do Município } \\
\text { de Goioerê-PR. }\end{array}$ & $\begin{array}{c}\text { Abordar o conhecimento } \\
\text { popular que a comunidade } \\
\text { diabética tem sobre as plantas } \\
\text { com possíveis propriedades } \\
\text { medicinais. }\end{array}$ & $\begin{array}{c}\text { A população diabética do } \\
\text { népio de Goioerê entrevistada } \\
\text { nesta pesquisa, utiliza as plantas } \\
\text { medicinais e tem bons resultados no } \\
\text { controle glicêmico e nas } \\
\text { complicações causadas por essa } \\
\text { síndrome metabólica }\end{array}$ \\
\hline
\end{tabular}




\begin{tabular}{|c|c|c|c|}
\hline № & AUTOR/TÍTULO/ANO & OBJETIVO & CONCLUSÃO \\
\hline 7 & $\begin{array}{l}\text { Traditional Indian } \\
\text { Medicines Used for the } \\
\text { Management of Diabetes } \\
\text { Mellitus } \\
\text { RIZVI e MISHRA, } 2013\end{array}$ & $\begin{array}{l}\text { Fornecer informações } \\
\text { detalhadas sobre o potencial } \\
\text { antidiabético e compostos } \\
\text { bioativos presentes em Ficus } \\
\text { religiosa, Pterocarpus } \\
\text { marsupium, Gymnema } \\
\text { sylvestre, Allium sativum, } \\
\text { Eugenia jambolana, } \\
\text { Momordica charantia e } \\
\text { Trigonella foenum-graecum. }\end{array}$ & $\begin{array}{l}\text { Os estudos mostraram vários } \\
\text { graus de atividade hipoglicêmica. } \\
\text { Também foi relatado que essas } \\
\text { plantas contribuem no controle } \\
\text { de complicações do diabetes. }\end{array}$ \\
\hline 8 & $\begin{array}{l}\text { Efeito hipoglicemiante de } \\
\text { um fitofármaco (DIAMET) } \\
\text { MARTINEZ et al., } 2014\end{array}$ & $\begin{array}{c}\text { Comprovar o efeito } \\
\text { hipoglicemiante de um } \\
\text { fitofármaco (DIAMET) que } \\
\text { contém as seguintes plantas } \\
\text { medicinais: Cudeamor } \\
\text { (Mormódia charantia), Pata de } \\
\text { vaca (Bauhinia forficata link), } \\
\text { Eucalipto (Eucalyptus globulus } \\
\text { Labil) e Achiote (Bixa orellana } \\
\text { L.) em células sanguíneas }\end{array}$ & $\begin{array}{l}\text { Observou-se uma diminuição } \\
\text { progressiva nas concentrações de } \\
\text { glicose no sangue }\end{array}$ \\
\hline 9 & $\begin{array}{l}\text { Utilização das Plantas } \\
\text { Medicinais por Diabéticos } \\
\text { do Município de Colorado } \\
\text { - PR } \\
\text { DEFINI e OLIVEIRA, } 2015\end{array}$ & $\begin{array}{l}\text { Averiguar quais e se as plantas } \\
\text { utilizadas no combate ao } \\
\text { diabetes realmente têm } \\
\text { fundamentação científica para } \\
\text { o fim utilizado }\end{array}$ & $\begin{array}{l}\text { Concluiu-se que a maioria da } \\
\text { população diabética do município } \\
\text { de Colorado (PR), entrevistada } \\
\text { neste trabalho, não é adepta ao } \\
\text { uso de plantas medicinais }\end{array}$ \\
\hline 10 & $\begin{array}{c}\text { Hancornia } \\
\text { Speciosa Gomes } \\
\text { (Apocynacea) as a } \\
\text { potential anti-diabetic } \\
\text { drug. } \\
\text { PEREIRA et al, } 2015\end{array}$ & $\begin{array}{l}\text { Avaliar o potencial efeito } \\
\text { antidiabético } \\
\text { do extrato de Hancornia } \\
\text { speciosa e suas frações } \\
\text { derivadas }\end{array}$ & $\begin{array}{l}\text { O trabalho demonstra que } \\
\text { Hancornia speciosa reduz a } \\
\text { concentração de glicose no } \\
\text { sangue por meio da inibição da } \alpha \text { - } \\
\text { glicosidase intestinal e } \\
\text { estimulação da captação de } \\
\text { glicose pelos dipócitos. Esses } \\
\text { resultados sugerem o uso } \\
\text { potencial dessa planta para o } \\
\text { tratamento do diabetes mellitus. }\end{array}$ \\
\hline 11 & $\begin{array}{l}\text { Abordagem e tratamento } \\
\text { da Hiperglicemia } \\
\text { induzida por } \\
\text { glicocorticóides. } \\
\text { PAREDES e ALVES, } 2016\end{array}$ & $\begin{array}{l}\text { Avaliar o uso de } \\
\text { glicocorticóides no tratamento } \\
\text { da hipoglicemia }\end{array}$ & $\begin{array}{l}\text { Estudos clínicos são necessários } \\
\text { para avaliar o real impacto da HIG } \\
\text { em seu uso temporário ou } \\
\text { permanente }\end{array}$ \\
\hline 12 & $\begin{array}{l}\text { Recent Advances in } \\
\text { Momordica charantia: } \\
\text { Functional Components } \\
\text { and Biological Activities. } \\
\qquad \text { JIA et al., } 2017\end{array}$ & $\begin{array}{c}\text { Abordar os constituintes } \\
\text { químicos de } M \text {. charantia e } \\
\text { discute suas atividades } \\
\text { farmacológicas, bem como } \\
\text { seus efeitos adversos, com o } \\
\text { objetivo de fornecer uma visão } \\
\text { abrangente da fitoquímica e } \\
\text { atividades biológicas de } M \text {. } \\
\text { charantia }\end{array}$ & $\begin{array}{c}\text { Até agora, a pesquisa sobre as } \\
\text { bioatividades de } M \text {. charantia } \\
\text { desenvolveu-se rapidamente. A } \\
\text { separação e identificação dos } \\
\text { componentes bioativos da planta } \\
\text { têm atraído mais atenção, e ainda } \\
\text { mantêm uma tendência } \\
\text { ascendente }\end{array}$ \\
\hline 13 & $\begin{array}{l}\text { In vivo assessment of } \\
\text { antidiabetic and } \\
\text { antioxidative activity of } \\
\text { natural phytochemical }\end{array}$ & $\begin{array}{c}\text { Investigar o efeito } \\
\text { antidiabético e antioxidante de } \\
\text { um composto ativo (FIIC) }\end{array}$ & $\begin{array}{c}\text { Os resultados demonstram que o } \\
\text { Fllc possui atividade antidiabética } \\
\text { e antioxidante significativa. }\end{array}$ \\
\hline
\end{tabular}




\begin{tabular}{|c|c|c|c|}
\hline № & AUTOR/TÍTULO/ANO & OBJETIVO & CONCLUSÃO \\
\hline & $\begin{array}{c}\text { isolated from fruit-pulp } \\
\text { of Eugenia jambolana in } \\
\text { streptozotocin-induced } \\
\text { diabetic rats. } \\
\text { TANWAR, SHARMA e } \\
\text { PRABHU, } 2017\end{array}$ & $\begin{array}{l}\text { isolado da polpa do fruto de } E \text {. } \\
\text { jambolana }\end{array}$ & \\
\hline 14 & $\begin{array}{c}\text { Utilização de plantas } \\
\text { medicinais por pacientes } \\
\text { diabéticos e hipertensos: } \\
\text { estudo transversal no } \\
\text { nordeste Brasileiro } \\
\text { CASTRO et al., } 2018\end{array}$ & $\begin{array}{l}\text { Descrever a utilização de } \\
\text { plantas medicinais por } \\
\text { pacientes diabéticos e/ou } \\
\text { hipertensos em unidades de } \\
\text { atenção primária a saúde }\end{array}$ & $\begin{array}{l}\text { A população pesquisada faz uso } \\
\text { de plantas medicinais e a elevada } \\
\text { prevalência nessa utilização } \\
\text { requer mais estudos }\end{array}$ \\
\hline 15 & $\begin{array}{c}\text { Momordica charantia } \\
\text { Administration Improves } \\
\text { Insulin Secretion in Type } \\
2 \text { Diabetes Mellitus } \\
\text { CORTEZ-NAVARRETE et } \\
\text { al, } 2018\end{array}$ & $\begin{array}{l}\text { Avaliar o efeito da } \\
\text { administração de } M \text {. charantia } \\
\text { na secreção e sensibilidade à } \\
\text { insulina }\end{array}$ & $\begin{array}{l}\text { Estudo demonstrou que a } \\
\text { administração de } M \text {. charantia } \\
\text { pode modificar a secreção de } \\
\text { insulina, aumentando a AUC da } \\
\text { insulina e a secreção de insulina } \\
\text { de primeira fase e total }\end{array}$ \\
\hline 16 & $\begin{array}{c}\text { Baccharis trimera } \\
\text { (Carqueja) Improves } \\
\text { Metabolic and Redox } \\
\text { Status in an Experimental } \\
\text { Model of Type } 1 \text { Diabetes } \\
\text { DO NASCIMENTO KAUT } \\
\text { et al., } 2018\end{array}$ & $\begin{array}{c}\text { Explorar o potencial de } \\
\text { aplicação da } B \text {. trimera.extrato } \\
\text { hidroetanólico na prevenção } \\
\text { do estresse redox induzido } \\
\text { pelo diabetes e suas } \\
\text { propriedades hipoglicêmicas }\end{array}$ & $\begin{array}{l}\text { Embora a carqueja não atue } \\
\text { sobre as enzimas antioxidantes, } \\
\text { ela modula sua expressão e } \\
\text { diminui o dano oxidativo } \\
\text { promovido pelo diabetes. Em } \\
\text { conclusão, esses resultados } \\
\text { sugerem que o perfil metabólico } \\
\text { e o status redox melhoram em } \\
\text { animais diabéticos tratados com } \\
\text { B. trimera }\end{array}$ \\
\hline 17 & $\begin{array}{l}\text { Phenolic acid profiling } \\
\text { and antiglycation studies } \\
\text { of leaf and fruit extracts } \\
\text { of tyrosine primed } \\
\text { Momordica charantia } \\
\text { seeds for possible } \\
\text { treatment of diabetes } \\
\text { mellitus. } \\
\text { FARAH et al, } 2018\end{array}$ & $\begin{array}{l}\text { Investigar antiglicação } \\
\text { atividade de Momordica } \\
\text { charantia por semente } \\
\text { priming com tirosina solução } \\
\text { Tirosina (4-hidroxifenilalanina) } \\
\text { é um de os } 20 \text { padrão } \\
\text { aminoácidos, tem é role em } \\
\text { proteína síntese, fotossíntese, } \\
\text { processos de transdução de sin }\end{array}$ & $\begin{array}{l}\text { O extrato de frutos de sementes } \\
\text { preparados com tirosina poderia } \\
\text { ser efetivamente testado em } \\
\text { estudos pré-clínicos e clínicos } \\
\text { para controlar a doença do } \\
\text { diabetes mellitus. }\end{array}$ \\
\hline 18 & $\begin{array}{l}\text { Eugenia jambolana } \\
\text { extract reduces the } \\
\text { systemic exposure of } \\
\text { Sitagliptin and improves } \\
\text { conditions associated } \\
\text { with diabetes: A } \\
\text { pharmacokinetic and a } \\
\text { pharmacodynamic herb- } \\
\text { drug interaction study. } \\
\text { ZAC- VARGHESE e } \\
\text { WINOCOUR, } 2018\end{array}$ & $\begin{array}{l}\text { Avaliar o risco da utilização de } \\
\text { extratos de Eugenia jambolana } \\
\text { com medicamentos } \\
\text { hipoglicêmicos orais juntos }\end{array}$ & $\begin{array}{l}\text { A combinação SITA + EJ não } \\
\text { mostrou nenhuma interação } \\
\text { medicamentosa adversa com } \\
\text { ervas e é segura para ser } \\
\text { explorada em um ambiente } \\
\text { clínico }\end{array}$ \\
\hline
\end{tabular}




\begin{tabular}{|c|c|c|c|}
\hline № & AUTOR/TÍTULO/ANO & OBJETIVO & CONCLUSÃO \\
\hline 19 & $\begin{array}{c}\text { Proteomic } \\
\text { characterization of } \\
\text { medicinal plants used in } \\
\text { the treatment of } \\
\text { diabetes } \\
\text { HAUSER-DAVIS, PEDRETE } \\
\text { e MOREIRA, } 2019\end{array}$ & $\begin{array}{c}\text { Caracterizar proteínas vegetais } \\
\text { utilizadas na medicina popular } \\
\text { como agentes } \\
\text { hipoglicemiantes para o } \\
\text { tratamento da diabetes, } \\
\text { nomeadamente "abajerú" } \\
\text { (Chrysobalanus icaco) e "pata } \\
\text { de vaca" (Bauhinia forficata e } \\
\text { Bauhinia variegata) } \\
\end{array}$ & $\begin{array}{l}\text { Os resultados são valiosos na } \\
\text { caracterização proteômica de } \\
\text { plantas fitoterápicas, podendo } \\
\text { servir de linha de base para as } \\
\text { espécies avaliadas no Brasil, onde } \\
\text { se observa um desconhecimento } \\
\text { a esse respeito. }\end{array}$ \\
\hline 20 & $\begin{array}{l}\text { Estudio etnobotánico de } \\
\text { plantas medicinales } \\
\text { utilizadas para el } \\
\text { tratamiento de la } \\
\text { diabetes mellitus en la } \\
\text { región de Sidi Bel Abbes } \\
\text { (noroeste da Argelia). } \\
\text { LAKHDARI et al. } 2019\end{array}$ & $\begin{array}{l}\text { Identificar plantas medicinais } \\
\text { utilizadas para ao tratamento } \\
\text { da DM na região de Sidi Bel } \\
\text { Abbes (noroeste da Argélia) }\end{array}$ & $\begin{array}{c}\text { Em locais com baixo } \\
\text { desenvolvimento econômico, } \\
\text { onde o gasto com saúde pública é } \\
\text { um problema social, faz-se } \\
\text { necessário a identificação, } \\
\text { utilização e conservação de } \\
\text { plantas com atividades } \\
\text { antidiabéticas }\end{array}$ \\
\hline 21 & $\begin{array}{c}\text { Water-soluble } \\
\text { polyphenol-rich clove } \\
\text { extract lowers pre- and } \\
\text { post-prandial blood } \\
\text { glucose levels in healthy } \\
\text { and prediabetic } \\
\text { volunteers: an open label } \\
\text { pilot study. } \\
\text { MOHAN et al. } 2019\end{array}$ & $\begin{array}{l}\text { Testar se este extrato } \\
\text { polifenólico de cravo-da-índia } \\
\text { (PCE) poderia influenciar o } \\
\text { metabolismo da glicose. }\end{array}$ & $\begin{array}{l}\text { Esses achados ressaltam a } \\
\text { utilidade terapêutica do PCE para } \\
\text { manter o metabolismo da glicose } \\
\text { saudável e justificam outros } \\
\text { ensaios clínicos em larga escala. }\end{array}$ \\
\hline 22 & $\begin{array}{c}\text { Olive Leaf (Olea } \\
\text { europaea L. folium): } \\
\text { Potential Effects on } \\
\text { Glycemia and Lipidemia. } \\
\text { ACAR-TEK e } \\
\text { AĞAGÜNDÜZ, } 2020\end{array}$ & $\begin{array}{l}\text { Definir a relação entre folha de } \\
\text { oliveira (Olea europaea } L . \\
\text { folium) polifenóis e vários } \\
\text { problemas de saúde }\end{array}$ & $\begin{array}{l}\text { Os efeitos potenciais do consumo } \\
\text { de pó ou de folhas secas de } \\
\text { oliveira sobre a saúde devem ser } \\
\text { levados em consideração em } \\
\text { estudos futuros. }\end{array}$ \\
\hline 23 & $\begin{array}{l}\text { Antidiabetic potential of } \\
\text { bauhinia forficata Link } \\
\text { leaves: a non-cytotoxic } \\
\text { source of lipase and } \\
\text { glycoside hydrolases } \\
\text { inhibitors and molecules } \\
\text { with antioxidant and } \\
\text { antiglycation, } \\
\text { FRANCO et al., } 2020\end{array}$ & $\begin{array}{c}\text { Sugerir a constituição } \\
\text { fitoquímica das frações do } \\
\text { extrato etanólico das folhas de } \\
\text { B. forficata e avaliar suas } \\
\text { atividades em ensaios } \\
\text { enzimáticos }\end{array}$ & $\begin{array}{c}\text { Este estudo apresentou novos } \\
\text { achados e reforçou o potencial } \\
\text { biológico e farmacológico da B. } \\
\text { forficata }\end{array}$ \\
\hline 24 & $\begin{array}{l}\text { Phytochemical profile, } \\
\text { cytotoxic, antioxidant, } \\
\text { and allelopathic } \\
\text { potentials of aqueous } \\
\text { leaf extracts of Olea } \\
\text { europaea } \\
\text { ZAïR et al.. } 2020\end{array}$ & $\begin{array}{l}\text { Investigar e comparar } \\
\text { composição fitoquímica, a } \\
\text { atividade antioxidante, o } \\
\text { potencial citotóxico e o } \\
\text { potencial alelopático de } \\
\text { extratos aquosos de folhas de } \\
\text { duas variedades de Olea } \\
\text { europaea }\end{array}$ & $\begin{array}{c}\text { Mais experimentos são } \\
\text { necessários para purificar, } \\
\text { explorar os mecanismos de ação } \\
\text { envolvidos e elucidar a estrutura } \\
\text { dos compostos ativos para o } \\
\text { desenvolvimento de uma nova } \\
\text { classe de metabólitos biológicos. }\end{array}$ \\
\hline
\end{tabular}

Fonte: Autoras (2021). 
Dentre os 24 estudos habilitados para análise, as plantas medicinais mais citadas com ação hipoglicemiante foram: Bauhinia forficata, Mormodica charantia, Baccharis trimera, Eugenia jambolana e Olea europea (Figura 1):

Figura 1 - Plantas mais citadas dentre os estudos selecionados

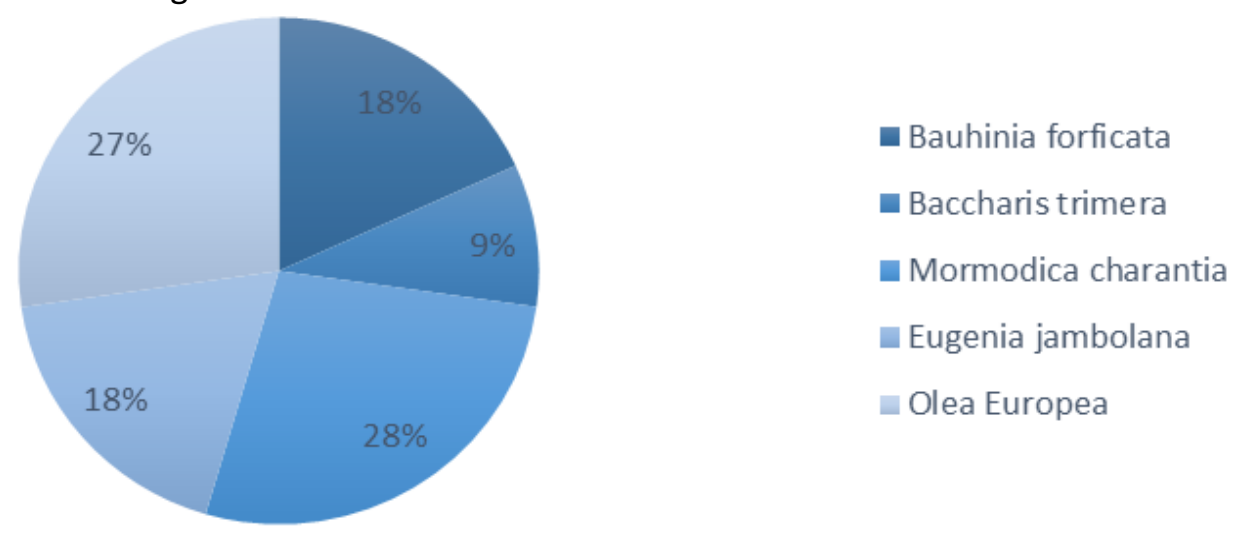

Fonte: Autoras (2021)

Os mecanismos de ação antidiabéticas das plantas podem ser atribuídos aos seguintes fatores: aumento da liberação de insulina através da estimulação das células beta pancreáticas, resistência aos hormônios que aumentam a taxa de glicose, aumento do número e da sensibilidade do sítio receptor de insulina, diminuição da perda de glicogênio, aumento de consumo de glicose nos tecidos e órgãos, eliminação de radicais livres, resistência a peróxidação de lipídeos, correção da desordem metabólica causada por lipídeos e proteínas e estímulo ao aumento da micro circulação do sangue no organismo (VOLPATO et al, 2002).

Das plantas selecionadas existem algumas espécies que apresentam potencial efeito na Diabetes Mellitus, uma delas é a Baccharis trimera, conhecida popularmente como carqueja, da família Asteraceae, tem potencial tóxico importante o que inspira mais estudos, pois nota-se a escassez de dados mais precisos sobre sua toxicidade. Seu efeito hipoglicêmicos é devido à presença de flavonoides e ácidos cloro gênicos (DO NASCIMENTO KAUT et al., 2018). Neste mesmo estudo, o autor sugeriu que o tratamento com B. trimera em ratos diabéticos, alterou a transcrição do RNAm, atuando como modulador e regulador dos níveis de RNAm, especialmente contendo danos mitocondriais. A B. trimera foi incluída na Relação Nacional de Plantas Medicinais de Interesse ao SUS (RENISUS), como parte da Política Nacional de Plantas Medicinais e 
Fitoterápicos do Ministério da Saúde e sua monografia consta na Farmacopéia Brasileira 5a edição (BRASIL, 2010).

Karam et al (2013), indica em seu estudo químico que a planta demonstrou a presença de flavonóides (como quercetina, luteolina, nepetina, apigenina, rutina, kaempferol e hispidulina), taninos, saponinas, lactonas diterpênicas, além de óleo essencial com $\alpha$-pineno, $\beta$-pineno, carquejol, acetato de carquejila, canfeno e limoneno, ou seja, uma planta medicinal rica em metabolitos secundários, indicando um potencial efeito farmacológico.

Já Bauhinia forficata ou "pata de vaca" é uma planta nativa do serrado Brasileiro, pertencente à família Fabaceae, potencialmente eficaz no tratamento a hiperglicemia e controle no estresse oxidativo das células, provocado em pacientes diabéticos, devido a oxidação da glicose e a glicação proteica, que podem aumentar a formação de radicais livres (PEPATO, et al., 2002). Suas partes são utilizadas puras ou em preparos, infusões e extratos. O extrato etanólico das folhas de B. forficata confere ação antidiabética devido à fração de $n$-butanol por apresentar o flavonoide insulinomimético denominado kaempferol, cujo mecanismo de ação ainda está sendo estudado (FRANCO et al, 2020). Quanto as interações medicamentosas, pode potenciar o efeito de hipoglicemiantes orais e da insulina, sendo necessário controle ou monitorização os níveis de glicemia. Desta forma, o uso da planta B. forficata está contra-indicada em indivíduos com hipotensão (SILVA e CECHINEL FILHO, 2002).

Outra planta utilizada no tratamento e controle do DM citada em artigos selecionados é a Mormodica charantia (MC). Pertencente à família Cucurbitaceae, também chamada de "melão de são Caetano", tem origem Africana e foi trazida para o Brasil por escravos. O efeito hipoglicemiante da MC pode ser explicado por vários mecanismos de ação designadamente o aumento a utilização da glucose pelo fígado, diminuição da gliconeogénese através da inibição das enzimas glicose-6-fosfatase e a frutose-1,6- bisfosfatase, optimização da oxidação da glicose através da ativação da glicose-6- fosfato desidrogenase, aumento da absorção celular de glicose, promoção da libertação de insulina e potenciação do seu efeito. Há ainda, aumento do número de células- $\beta$ no pâncreas de animais diabéticos (ANÔNIMO, 2007).

Eugenia jambolana, pertencente à família das Myrtaceae e é vulgarmente conhecida por ameixa preta ou jambolão. As sementes são a parte mais estudada, 
utilizada em preparações como chás e infusões e que possui maior potencial antidiabético. São constituídas por glicosídeo jambosina, ácido gálico, ácido elágico, 3,6hexahidroxi difenilglucose, 4,6-hexahidroxi difenilglucose, 1- galloylglucose, 3galloylglucose, quercetina, $\beta$-sitoterol. Sua atividade hipoglicêmica ocorre devido à redução da glicose sanguínea por aumento da secreção de insulina pelo pâncreas ou por inibição da degradação de insulina. (TELES, 2013)

A Olea europaea (OE) popularmente conhecida como oliveira é uma das frutíferas mais antigas cultivadas pelo homem, produz grande quantidade de folhas que são descartadas durante o ciclo de produção. As folhas contêm quantidades apreciáveis de compostos fenólicos, dentre os quais se destaca a oleuropeína, à qual são atribuídas atividades antioxidante, antimicrobiana, hipoglicemiante, anti-inflamatória, dentre outras. Sabe-se que a OE possui grande potencial hipoglicêmico e no controle do estresse oxidativo causado pelo DM, porém sua forma de ação ainda está sendo estuda. A ingestão de extratos aquosos de folhas de oliveira resultou em melhoras no perfil lipídico e na lipoperoxidação dos órgãos de ratos Wistar, demonstrando o potencial na atividade biológica das mesmas. Sugerem-se mais pesquisas para elucidar concentrações mínimas do extrato, e se o efeito hipolipidêmico das folhas de oliveira se deve a um único componente ou a interações entre seus constituintes (ANTUNES, 2018)

Com relação à segurança e eficácia das plantas medicinais estudadas, verificouse a comprovação de seus efeitos hipoglicemiantes por diversos estudos experimentais (in vivo, in vitro), em estudos de suas partes (folhas, raízes, frutos, sementes) ou em suas partes utilizadas em extratos e soluções, bem como a todas se confere ações além das antidiabéticas, também como antitumorais, protetores cardíacos e antioxidante. (ZACVARGHESE e WINOCOUR, 2018). Porém, mais estudos se fazem necessários no que diz respeito à toxicidade e efeitos adversos por interação medicamentosa.

A toxicidade dos fitoterápicos pode variar de acordo com as partes da planta utilizadas em seu preparos e extratos. Por vezes, esses mesmos efeitos tóxicos serão os responsáveis pela ação hipoglicemiante de um determinado fitoterápico, A alergenicidade, fotossensibilização, hepatotoxicidade, bloqueio adrenérgico, hipoglicemia, são outros aspectos de toxicidade, os quais não são revelados nos testes de toxicidade aguda e que ainda representam riscos significativos (BRITO, 2015). 
A posologia é indispensável para a eficácia em qualquer tratamento, sendo um dos melhores indicativos entre efeito terapêutico e toxicidade de um ativo, seja em infusões, chás ou em outras preparações (MARTINEZ et al ,2014) O quadro 3 apresenta as principais plantas citadas, seus princípios ativos hipoglicemiantes mais importantes e a dose diária sugerida como ideal na apresentação de chá.

Quadro 3: Principais plantas citadas e suas características terapêuticas

\begin{tabular}{|c|c|c|c|c|c|}
\hline Planta & $\begin{array}{l}\text { Princípio ativo } \\
\text { hipoglicemiante }\end{array}$ & $\begin{array}{l}\text { Parte } \\
\text { mais } \\
\text { utilizada }\end{array}$ & $\begin{array}{l}\text { Forma de } \\
\text { utilização }\end{array}$ & Posologia & Efeitos adversos \\
\hline $\begin{array}{c}\text { Baccharis } \\
\text { trimera }\end{array}$ & $\begin{array}{l}\text { Flavonoides e } \\
\text { ácidos cloro } \\
\text { gênicos }\end{array}$ & $\begin{array}{l}\text { Partes } \\
\text { aéreas }\end{array}$ & $\begin{array}{l}\text { Extratos } \\
\text { aquosos, } \\
\text { chás, } \\
\text { decocção }\end{array}$ & $\begin{array}{c}\text { Chá/1 a 3x } \\
\text { ao dia }\end{array}$ & $\begin{array}{l}\text { concomitantemente a } \\
\text { inibidores da síntese de } \\
\text { proteína, tratamento } \\
\text { com anti-hipertensivos } \\
\text { pode ocorrer } \\
\text { sinergismo } \\
\end{array}$ \\
\hline $\begin{array}{l}\text { Bauhinia. } \\
\text { forficata }\end{array}$ & $\begin{array}{l}\text { Flavonóides, } \\
\text { cumarinas }\end{array}$ & $\begin{array}{l}\text { Folhas, } \\
\text { casacas e } \\
\text { flores }\end{array}$ & $\begin{array}{l}\text { Chás, } \\
\text { extratos, } \\
\text { infusões }\end{array}$ & $\begin{array}{l}\text { Chá/4x por } \\
\text { semana }\end{array}$ & $\begin{array}{c}\text { pode potencializar o } \\
\text { efeito de anti- } \\
\text { hiperglicemiantes orais } \\
\text { e da } \\
\text { insulina, }\end{array}$ \\
\hline $\begin{array}{l}\text { Mormodica } \\
\text { charantia }\end{array}$ & $\begin{array}{c}\text { ácido } \\
\text { clorogénico e } \\
\text { ácido cafeico }\end{array}$ & $\begin{array}{l}\text { fruto, } \\
\text { sementes, } \\
\text { raízes } \\
\text { partes } \\
\text { aéreas }\end{array}$ & $\begin{array}{l}\text { Extratos } \\
\text { aquosos, } \\
\text { chás, } \\
\text { decocção }\end{array}$ & $\begin{array}{c}\text { Chá/2x ao } \\
\text { dia }\end{array}$ & $\begin{array}{l}\text { gastrointestinais, } \\
\text { desconforto ou dor } \\
\text { abdominal e diarreia }\end{array}$ \\
\hline $\begin{array}{c}\text { Eugenia } \\
\text { jambolana }\end{array}$ & $\begin{array}{l}\text { ácido málico, } \\
\text { glicosídeo } \\
\text { jambosina, } \\
\text { ácido gálico }\end{array}$ & $\begin{array}{l}\text { Sementes, } \\
\text { frutos e } \\
\text { casca do } \\
\text { caule }\end{array}$ & $\begin{array}{l}\text { Infusões, } \\
\text { chás }\end{array}$ & $\begin{array}{c}\text { Chá/2 a } 3 x \\
\text { ao dia }\end{array}$ & Não possui \\
\hline $\begin{array}{c}\text { Olea } \\
\text { europaea }\end{array}$ & $\begin{array}{l}\text { Compostos } \\
\text { fenólicos, } \\
\text { oleuropeína }\end{array}$ & Folhas & $\begin{array}{l}\text { Extratos } \\
\text { aquosos, } \\
\text { chás }\end{array}$ & $\begin{array}{c}\text { Chá/2x ao } \\
\text { dia }\end{array}$ & Não possui \\
\hline
\end{tabular}

Fonte: Adaptado de Do Nascimento Kaut et al (2018); Franco et al (2020); Farah et al(2018); Tanwar, Sharma e Prabhu (2017); ZAï̈ et al (2020).

O uso de plantas medicinais vem sendo estimulada também pelo SUS como uma alternativa segura e com menos efeitos tóxicos e adversos no tratamento de diversas doenças. Isso faz com que cada vez mais estudos sejam feitos no intuito de aumentar a oferta de plantas que possam ser utilizadas no combate ao DM. Esta política foi aprovada por meio do Decreto 5.813 de 22 de junho de 2006. Este estabelece dentre outras coisas, as diretrizes para as ações voltadas à garantia do acesso seguro e uso racional de plantas medicinais e fitoterápicos em nosso país (BRASIL, 2006), tornandose um legal e histórico para às áreas das plantas medicinais e dos fitoterápicos no Brasil. 


\section{CONCLUSÃO}

A presente revisão bibliográfica possibilitou elencar algumas das plantas medicinais mais mencionadas na literatura, discernindo suas principais características e reafirmado suas propriedades anti-diabéticas, como: Baccharis trimera, Bauhinia forficata, Mormodica charantia, Eugenia jambolana e Olea europaea. A utilização das plantas mostrou-se segura e eficaz no tratamento e controle do DM, sendo utilizadas de forma majoritária de maneira complementar ao tratamento convencional, por vezes sem controle de quantidade e/ou qualidade desse produto. Em média têm-se conhecimento de 800 plantas com propriedades antidiabéticas, entretanto ainda faltam mais estudos sobre a maioria delas acerca dos efeitos tóxicos e adversos dos fitoterápicos, bem como das plantas e seus ativos hipoglicemiantes e suas possíveis interações com os medicamentos já utilizados pelo indivíduo com DM, os quais são essenciais para assegurar a utilização desses ativos no tratamento do DM, a fim de oferecer ao paciente um tratamento seguro, eficaz e acessível.

\section{REFERÊNCIAS}

ACAR-TEK, N, AĞAGÜNDÜZ, D Olive Leaf (Olea europaea L. folium): Potential Effects on Glycemia and Lipidemia. Ann Nutr Metab, 76(1), 10-15, 2020

ANÔNIMO. Momordica charantia (Bitter melon). Alternative Medicine Review , 12(4), 360-363, 2007

ANTUNES, B. F. Folhas de Oliveira (Olea europaea L): Composição em Bioativos, Atividades Antioxidante e Biológica. 2018. 90f. Dissertação (Mestrado em Nutrição e Alimentos) - Pós-Graduação em Nutrição e Alimentos da Faculdade de Nutrição -Universidade Federal de Pelotas. 2018

ANVISA. Agencia Nacional de Vigilância Sanitária. Farmacopeia Brasileira, volume 1. 5 a Ed. Brasilia,2010b.

BARBOSA, S.A; CAMBOIM, F.E.F. Diabetes mellitus: cuidados de enfermagem para controle e prevenção de complicações. Temas de Saúde. 16(3), 404-417, 2016

BRASIL. Ministério da Saúde. Secretaria de Ciência, Tecnologia e Insumos Estratégicos. Departamento de Assistência Farmacêutica e Insumos Estratégicos. Política Nacional de Plantas Medicinais e Fitoterápicos. Brasília: Ministério da Saúde, 2006. 136 p.: il. - (Série C. Projetos, Programas e Relatórios, 1a edição). 
BRASIL. Ministério da Saúde. Secretaria de Ciência, Tecnologia e Insumos Estratégicos. Departamento de Assistência Farmacêutica e Insumos Estratégicos. Programa Nacional de Plantas Medicinais e Fitoterápicos - Brasília; Ministério da Saúde, 2009.

BRASIL. Ministério da Saúde. Secretaria de Ciência, Tecnologia e Insumos Estratégicos. Departamento de Assistência Farmacêutica e Insumos Estratégicos. Relação Nacional de Medicamentos Essenciais: Rename. 8Ş ed. Brasília: Ministério da Saúde; 2012. (Série B. Textos Básicos de Saúde).

BRITO, N. C. B862p Perfil de utilização e fatores associados ao uso de plantas medicinais em pessoas com diabetes mellitus em Minas Gerais, Brasil. 2015. 100 f. Dissertação (mestrado) - Programa de Pós-Graduação em Medicamentos e Assistência Farmacêutica, Faculdade de Farmácia, Universidade Federal de Minas Gerais, Belo Horizonte, 2015

BARDIN, L.. Análise de conteúdo. Traduzido por Luís Antero Reto, Augusto Pinheiro. São Paulo: Edições 70, 2011. Tradução de: L'Analyse de Contenu.

CASTRO, K. S.;VIRGÍNIO, T. B.; LIMA, A. L. A.; ROCHA, J. V.; BONFIM, I. M.;CAMPOS, A. R. Utilização de plantas medicinais por pacientes hipertensos e diabéticos: estudo transversal no nordeste brasileiro. Rev Bras Promoç Saúde, 31(4), 1-10, 2018

CORTEZ-NAVARRETE, M.; MARTÍNEZ-ABUNDIS, E.; PÉREZ-RUBIO, K.G.; GONZÁLEZORTIZ, M.; MÉNDEZ-DEL VILLAR, M. Momordica charantia Administration Improves Insulin Secretion in Type 2 Diabetes Mellitus. J Med Food,21(7),672677,2018

DE BOCK, M., DERRAIK, J.G., BRENNAN, C.M.; BIGGS, J.B.;MORGAN, P.E.; HODGKINSON,S.C.; HOFMAN, P.L.; CUTFIELD, W.S. Olive (Olea europaea L.) leaf polyphenols improve insulin sensitivity in middle-aged overweight men: a randomized, placebo-controlled, crossover trial. PLoS One., 8(3), e57622, 2013

DEFANI, M. A.; BARBOSA, T. K.; ROSSI, S. L.; NASCIMENTO, R. C. Utilização das Plantas Medicinais por Diabéticos do Município de Goioerê - PR. Revista Saúde e Pesquisa, 4(2), 223-231,2011

DEFINI, M. A.; OLIVEIRA, L. E. N.. Utilização das Plantas Medicinais por Diabéticos do Município de Colorado - PR. Revista Saúde e Pesquisa, 8(3), 413-421, 2015

DO NASCIMENTO KAUT, N.N.;RABELO, A.C.S; ARAUJO, G.R.; TAYLOR, J.G.; SILVA, M.E.; PEDROSA, M.L.; CHAVES, M.M.; ROSSONI JUNIOR, J.V.; COSTA, D.C. Baccharis trimera (Carqueja) Improves Metabolic and Redox Status in an Experimental Model of Type 1 Diabetes. Evid Based Complement Alternat Med. 2018

FARAH, N.; BUKHARI, S.A.; ALI, M.; NAQVI, S.A.; MAHMOOD, S. Phenolic acid profiling and antiglycation studies of leaf and fruit extracts of tyrosine primed Momordica 
charantia seeds for possible treatment of diabetes mellitus. Pak J Pharm Sci. 31(6 (Supplementary),2667-2672, 2018

FEIJÓ, A.M.I; BUENO, M.E.N.I; CEOLIN, T.I; LINCK, C.L.I; SCHWARTZ, E.I; LANGE, C.I; MEINCKE, S.M.K.I; HECK, R.M.I; BARBIERI, R.L.II; HEIDEN, G. Plantas medicinais utilizadas por idosos com diagnóstico de Diabetes mellitus no tratamento dos sintomas da doença. Rev. Bras. PI. Med., 14(1), 50-56, 2012

FRANCO, R.R.; MOTA, V.H.A.;RIBEIRO, L.F.R; JUSTINO,A.B.; MARTINS, M.M.; SARAIVA, A.L.; GOULART, L.R.; ESPINDOLA, F.S. Antidiabetic potential of Bauhinia forficata Link leaves: a non-cytotoxic source of lipase and glycoside hydrolases inhibitors and molecules with antioxidant and antiglycation properties. Biomed Pharmacother. 123 (2020), 109798-109809,2020

HAUSER-DAVIS, R. A.; PEDRETE, T. A..; MOREIRA, J. C.. Proteomic characterization of medicinal plants used in the treatment of diabetes. Int J Biol Macromol. 140(1), 294-302. 2019

JIA, S. ; SHEN, M.; ZHANG, F.; XIE, J. Recent Advances in Momordica charantia: Functional Components and Biological Activities. Int J Mol Sci.18(12),2555,2017

KHAN, V.; NAJMI, A.K.; AKHTAR, M.; AQIL, M.; MUJEEB, M., PILLAI, K.K. A pharmacological appraisal of medicinal plants with antidiabetic potential. J Pharm Bioallied Sci. 4(1).27-42. 2012

KARAM, T.K.; DALPOSSO, L.M.; CASA, D.M.; DE FREITAS, G.B.L. Carqueja (Baccharis trimera): utilização terapêutica e biossíntese. Rev. Bras. PI. Med., 15(2), 280-286, 2013.

LAKHDARI,A.;MERAZ, Z.; HANITET, N. E. H.;DRIR, F.Z. Ethnobotanical study of medicinal plants used for the treatment of Diabetes mellitus in Sidi Bel Abbes region (North-west Algeria). Boletín latinoamericano y del Caribe de plantas medicinales y aromáticas 18 (4): $392-410,2019$.

LYRA, R.; OLIVEIRA, M.; LINS, M.; CAVALCANTI, N. Prevenção do diabetes mellitus tipo 2. Arq Bras Endocrinol Metab 50 (2), 1-11, 2006.

MARTINEZ, N.; AMARAL, G.; LEYDISABEL, C.; RODRIGUES, L.; FELIX, R.; ESPINO, C.; REQUENA, D. Efecto hipoglicemiante de un fitofármaco (DIAMET). Comunidad y Salud. 12 (2), 18-22, 2014.

MOHAN, R.; JOSE, S.; MULAKKAL J, KARPINSKY-SEMPER D, SWICK AG, KRISHNAKUMAR IM. Water-soluble polyphenol-rich clove extract lowers pre- and post-prandial blood glucose levels in healthy and prediabetic volunteers: an open label pilot study. BMC Complement Altern Med. 19(1), 99-107, 2019

PAREDES, S.; ALVES, M. Abordagem e Tratamento da Hiperglicemia Induzida por Glicocorticóides. Acta. Med.Port. 29(9), 556-563, 2016 
PEPATO, M.T;KELLER, E.H.; BAVIERA, A.M.; KETTELHUT, I.C.;VENDRAMINI, R.C.; BRUNETTI, I.L. Anti-diabetic activity of Bauhinia forficata decoction in streptozotocin-diabetic rats. J Ethnopharmacol. 81(2):191-197. 2002.

PEREIRA, A.C.; PEREIRA, A.B.D; MOREIRA, C.C.L; BOTION, L.M.; LEMOS, V.L.; BRAGA, F.C.; CORTES, S.F. Hancornia speciosa Gomes (Apocynaceae) as a potential antidiabetic drug. Journal of Ethnopharmacology, 161(23), 30-35,2015

RIZVI, S.; MISHRA N. Traditional Indian medicines used for the management of diabetes mellitus. J Diabetes Res, 2013, 1-11, 2013

SILVA, K.L; CECHINEL FILHO, V. Plantas do gênero Bauhinia: composição química e potencial farmacológico. Quim. Nova, 25(3), 449- 454. 2002

SILVA, P. F; RAMALHO, S. M.; VILLARINHO, L. P. M.; LUCIA, V. L.; RODRIGUES, M. C. Uso de serviços de saúde e de medicamentos por portadores de Hipertensão e Diabetes no Município do Rio de Janeiro, Ciênc. saúde colet. 23 (7), 2383-2392, 2018.

SOUZA, M.T.; SILVA, M.D.;CARVALHO, R. Revisão integrativa: o que é e como fazer. Einstein, 8 (1), 102- 106. 2010

TANWAR, R.S; SHARMA, S.B; PRABHU, K.M. Avaliação in vivo da atividade antidiabética e antioxidante de fitoquímicos naturais isolados da polpa do fruto de Eugenia jambolana em ratos diabéticos induzidos por estreptozotocina. Redox Rep .22(6), 301-307. 2017

TELES, D. I. C. A. Fitoterapia como tratamento complementar na Diabetes mellitus. 2013. 54f. Tese (Mestrado em Ciências Farmacêuticas) Universidade Fernando Pessoa, Porto, 2013.

TROJAN-RODRIGUES M, ALVES TL, SOARES GL, RITTER MR. Plants used as antidiabetics in popular medicine in Rio Grande do Sul, southern Brazil. J Ethnopharmacol. 139(1), 155-163, 2012

VOLPATO, G. T.; DAMASCENO, D. C.; CALDERON, I. M. P.; RUDGE, M. V. C. Revisão de plantas brasileiras com comprovado efeito hipoglicemiante no controle do Diabetes mellitus. Rev. Bras. PI. Med., 4,35-45, 2002.

ZAC-VARGHESE, V.;WINOCOUR, P. Gerenciando doença renal diabética.British Medical Bulletin, 125(1), 55-66, 2018

ZAÏR, I A.; NOUIR, S.; ZARROUK, A.; HADDAD, H.; KHÉLIFA, A.; ACHOUR, L. Phytochemical profile, cytotoxic, antioxidant, and allelopathic potentials of aqueous leaf extracts of Olea europaea. Food Sci Nutr. 8(9), 4805-4813. 2020 


\title{
CAPITULO XLVI
}

\section{SÍNDROME DE BURNOUTEM PROFISSIONAIS DA SAÚDE: IMPORTÂNCIA DO CONHECER PARA PREVENIR}

\author{
DOI: 10.51859/AMPLLA.PAE1993-46
}

\author{
Bruna Sampaio Lopes Costa ${ }^{1}$ \\ lara Oliveira Costa ${ }^{2}$ \\ Jordana Dutra da Silva ${ }^{3}$ \\ Maria Heloísa Bezerra Vilhena ${ }^{1}$ \\ Bárbara Vilhena Montenegro ${ }^{1}$ \\ Michelle Sales Barros de Aguiar ${ }^{4}$
}

${ }^{1}$ Graduanda do curso de Medicina. Centro Universitário de João Pessoa - UNIPÊ

${ }^{2}$ Graduanda do curso de Medicina. Centro Universitário Christus - UNICHRISTUS

${ }^{3}$ Graduanda do curso de Medicina. Universidade Estadual de Roraima - UERR

${ }^{4}$ Doutora em Biotecnologia e Inovação em Saúde. Universidade Anhanguera de São Paulo - UNIAN/SP

\section{RESUMO}

Situações que desencadeiam estresse e ansiedade no ambiente de trabalho podem levar ao desenvolvimento da Síndrome de Burnout. Essa patologia atinge, sobretudo, profissionais de saúde que são expostos diariamente a essas situações e sua incidência aumentou com a pandemia da COVID-19. O objetivo deste estudo é revisar a importância de conhecer a respeito da Síndrome de Burnout em profissionais da saúde para prevenir o desenvolvimento deste transtorno. Realizou-se uma revisão de literatura nas plataformas PubMed e Biblioteca Virtual em Saúde, utilizando os descritores "Esgotamento profissional", "Esgotamento psicológico", "Educação em saúde" e "Estratégias de enfrentamento" e seus correspondentes em inglês combinados entre si pelos operadores booleanos " $A N D$ " e "OR" dos anos de 2016 a 2021, encontrando 16 estudos. Estudos epidemiológicos mostram que profissionais nos primeiros anos de trabalho, os que trabalham em centros de terapia intensiva, os do sexo feminino e solteiros são mais propensos a desenvolver a síndrome. Estudos demonstram que é uma patologia crônica relacionada ao trabalho que se assemelha a transtornos depressivos e ansiosos e tem etiologia multifatorial. As estratégias de enfrentamento incluem desde de terapias não farmacológicas, como a psicoterapia ao uso de medicações psiquiátricas no tratamento dos sintomas ansiosos e depressivos. Por ser uma patologia crônica e comum em profissionais de saúde, mais estudos são necessários para diminuir os seus índices.

Palavras-chave: Esgotamento profissional. Esgotamento psicológico. Prevenção primária. Educação em saúde. Estratégias de enfrentamento. 


\section{INTRODUÇÃO}

Profissionais de saúde se deparam diariamente com situações desencadeantes de estresse e ansiedade. Quando há uma exposição prolongada a esses fatores, podese desenvolver a Síndrome de Burnout, caracterizada pela exaustão emocional, despersonalização e sentimentos de reduzida realização profissional (PAIVA et al., 2019).

As pesquisas relacionam a etiologia dessa síndrome ao eixo HipotálamoHipófise-Adrenal, já que é uma doença diretamente relacionada ao estresse, tendo influência do metabolismo do cortisol, do ACTH e de desidroepiandrosterona (DHEA) (JONSDDTTIR; DAHLMAN, 2018).

Além do sofrimento psíquico, que se assemelha aos quadros de ansiedade e de depressão, essas alterações metabólicas levam a distúrbios posteriores, decorrentes do aumento da glicose, obesidade, elevação da pressão arterial (KAUTZY et al., 2021).

Nesse contexto, os profissionais de saúde representam uma população de risco importante com relação à Síndrome de Burnout, pois, geralmente, encontraram-se em ambientes estressantes, além de possuírem cargas horárias de trabalho excessivas, má alimentação, sono prejudicado, e por serem tipicamente um grupo que possui baixa taxa de busca por ajuda médica, favorecendo o adoecimento e agravamento de condições patológicas (FIOL-DEROQUE et al., 2021).

Estudos mostram que as mulheres são as mais acometidas. Intensivistas, em particular, são um grupo com altos índices de Burnout, destacam-se enfermeiros e principalmente profissionais que trabalharam na pandemia de COVID-19 (TIRONI et al., 2016; SAKAE et al., 2017; WANG et al., 2021).

Desde que essa patologia começou a ser estudada, métodos para lidar com ela e para preveni-la são igualmente pesquisados. Psicólogos falam da resiliência como fator importante para diminuir os riscos do Burnout e, para isso, fatores como a personalidade do indivíduo, a existência e a força de seus laços familiares e a presença de sistemas de apoio são fundamentais (AFSHARI et al., 2021).

Além disso, para uma pessoa em Burnout, a psicoterapia se mostra essencial, especialmente a abordagem pela terapia cognitivo comportamental (TCC) (GOMÉZ et al., 2021) . Pode ainda ser necessário o auxílio de uma terapia farmacológica, a depender 
do grau de desgaste pela doença com o uso de medicamentos que podem ser os benzodiazepínicos, para auxiliar nos episódios agudos de ansiedade, e/ou antidepressivos (LATORRACA et al., 2019).

O objetivo deste estudo é revisar a importância de conhecer a respeito da Síndrome de Burnout em profissionais da saúde para prevenir o desenvolvimento deste transtorno.

\section{METODOLOGIA}

Trata-se de uma revisão de literatura, de caráter descritivo e qualitativo. Adotouse como estratégia de busca a aplicação dos Descritores em Ciências da Saúde (DeCS/MeSH) "Esgotamento profissional", "Esgotamento psicológico", "Educação em saúde" e "Estratégias de enfrentamento" e seus correspondentes em inglês combinados entre si pelos operadores booleanos " $A N D$ " e "OR". Utilizaram-se dados e informações extraídos das bases de dados eletrônicas PubMed e Biblioteca Virtual em Saúde (BVS).

Os critérios de inclusão consistiram em: artigos e cartilhas disponíveis na íntegra e textos escritos no idioma inglês ou português dos anos de 2016 a 2021. Os critérios de exclusão, por sua vez, foram: duplicatas; estudos com resultados inconclusivos e pesquisas que não respondessem ao nosso objetivo.

Após a avaliação dos trabalhos segundo os critérios de inclusão e exclusão, foram utilizados para compor a discussão da nossa pesquisa 16 estudos. A busca e interpretação das fontes bibliográficas ocorreu nos meses de setembro e outubro de 2021.

\section{REVISÃO BIBLIOGRÁFICA}

\subsection{EPIDEMIOLOGIA DA SÍNDROME DE BURNOUT EM PROFISSIONAIS DA SAÚDE}

Estudos epidemiológicos que abordam a Síndrome de Burnout em profissionais da saúde apontam que as mulheres são as mais acometidas (TIRONI et al., 2016; SAKAE et al., 2017; WANG et al., 2021). Tal sobreposição feminina pode se dever à extensa jornada de trabalho, que leva em conta o exercício profissional associado às atribuições familiares (SAKAE et al., 2017). 
Entretanto, um estudo (SAKAE et al., 2017) que abordou 218 profissionais do Programa de Saúde da Família da cidade de Tubarão - Santa Catarina apontou que o sexo masculino representou fator de risco para a síndrome. Ao todo, 179 profissionais $(82,1 \%)$ apresentaram diagnóstico de Burnout nesta pesquisa.

Também se observou uma menor prevalência da Síndrome de Burnout em profissionais com parceiro estável (WANG et al., 2021; SAKAE et al., 2017).

Os médicos intensivistas contabilizam $53 \%$ dos casos de Burnout dentre as especialidades médicas (WANG et al., 2021). Na China, os intensivistas foram responsáveis por $82,1 \%$ dos casos clássicos da síndrome e $38,8 \%$ dos casos mais severos (WANG et al., 2021).

A prevalência de Burnout no estudo de Sakae et al. (2017) chegou a 63,8\% para intensivistas atuantes em Unidade de Terapia Intensiva (UTI) adulto, e 56,6\% para intensivistas atuantes em UTI pediátrica e neonatal.

O número de médicos pós-graduandos com diagnóstico de Burnout foi de 51,2\% na América do Norte; 39,6\% na América do Sul; 30,8\% na Europa; 67,8\% no Oriente Médio; $69,5 \%$ na África; 48,8\% na Ásia; 43\% na Austrália e Nova Zelândia (NAJl et al., 2021).

Os primeiros anos da atuação profissional podem predispor à síndrome (SAKAE et al., 2017), o que pode justificar em parte tais percentagens apresentadas no trabalho de Naji et al. (2021).

O histórico educacional, segundo Wang et al. (2021), não mostrou qualquer associação com a prevalência de Burnout ( $P=0.675 ; P=0.063)$.

Enfermeiros possuem maiores níveis de exaustão emocional quando comparados a técnicos e auxiliares, sendo tal exaustão emocional inversamente proporcional ao tempo de experiência profissional (SAKAE et al., 2017).

Profissionais diretamente envolvidos no combate da pandemia de COVID-19, principalmente enfermeiros e médicos, apresentaram maiores níveis de estresse emocional relacionado ao trabalho, sintomas psicossomáticos e Burnout (SHARIFI; ASADI-POOYA; MOUSAVI-ROKNABADI, 2020).

Apesar dos altos números de profissionais da saúde acometidos pelo Burnout, as políticas voltadas para o bem-estar psicológico ainda não surtiram efeito significativo na redução da prevalência desta síndrome na população estudada (NAJl et al., 2021). 
Além disso, a prevalência de Burnout sofre mudanças de acordo com a região, o que pode ser devido a políticas sociais voltadas ao equilíbrio da vida pessoal e profissional, tais como férias remuneradas e ajustamento da carga horária de trabalho (NAJl et al., 2021).

\subsection{FATORES ASSOCIADOS À SÍNDROME DE BURNOUT}

O Burnout é um transtorno crônico que tem como principal característica o esgotamento devido ao estresse emocional de forma prolongada, por diversos motivos, como trabalho que envolve interpessoalidade ou proximidade com alguém doente crônico ou terminal. Apesar da semelhança, há evidências de diferenças de outras doenças como a depressão e ansiedade, mas por não ser enquadrada como doença "verdadeira", muitas vezes o tratamento é equivocado ou mesmo não é realizado (KAKIASHIVIII et al., 2013).

Assim como a dor, a resposta ao estresse possui causa multifatorial, sendo válido ressaltar a cultura, a compreensão e sentido que o indivíduo emprega sobre. Muitos esforços têm sido realizados na busca de diferenciar o Burnout de outras doenças semelhantes e encontrar biomarcadores para descrever sua fisiopatologia e servir de diagnóstico. (JONSDDTTIR; DAHLMAN, 2018).

As pesquisas sobre o assunto estão concentradas no eixo Hipotálamo-PituitáriaAdrenal (HPA), afinal, como é uma doença relacionada ao estresse, este sistema de fornecimento de estímulos e energia para o organismo, se torna de grande interesse (JONSDDTTIR; DAHLMAN, 2018).

Encontra-se no HPA diversos aspectos imunológicos e endócrinos, que explicariam o Burnout. Observou-se que indivíduos com Burnout graves apresentam menor aumento da resposta ao despertar do cortisol (CAR), elevados níveis de desidroepiandrosterona (DHEA) e seu metabólito, que como o cortisol são respostas ao ACTH, secretados pelo córtex adrenal. (JONSDDTTIR; DAHLMAN, 2018).

A DHEA tem propriedade neuroprotetora, anti-inflamatória e antiglicocorticoide, mas nos indivíduos Burnout a razão cortisol\DHEAS é baixa e há uma maior supressão desse precursor andrógeno quando se faz o teste de supressão de dexamestasona (DST). Portanto, ocorre que o estresse estimula o HPA, levando à resistência à insulina, que proporciona aumento da cortisol e este estimula mais liberação de ACTH, aumentando 
a energia para esse indivíduo para situações de estresse, configurando a Síndrome de Burnout (ARIAS et al., 2020).

Qualquer alteração no metabolismo, principalmente do eixo HPA, afeta a produção e o transporte de hormônios para todo o organismo. Um fator corriqueiro que afeta esse eixo é o estresse, a partir desse raciocínio consegue-se interrelacionar questões como níveis de glicose, obesidade, frequência cardíaca e mesmo o gênero ao Burnout, sendo as mulheres muito mais propensas ao desenvolvimento de doenças psiquiátricas (KAUTZY et al., 2021). Apesar de já ser constatado que a testosterona também pode influenciar no desenvolvimento mais forte e mais precoce no sexo masculino de profissionais submetidos a alto estresse, como os bombeiros (VINNIKOV et al.,2021).

A compulsão por alimentos doces, gordurosos, geralmente presente ou causada por medicamentos psiquiátricos podem retroalimentar os transtornos mentais, doenças metabólicas e cardiovasculares, piorando o Burnout (KAUTZKY et al., 2021). Como dito, não há como quantificar a flexibilidade de cada indivíduo para as situações de estresse, mas pode-se estimar, devido a esses conhecimentos, somando-se à situação social do indivíduo, criação, traumas, questões financeiras, a sua vulnerabilidade (JONSDDTTIR; DAHLMAN, 2018).

Os profissionais de saúde fazem parte de um grupo que possuem baixa taxa de busca por ajuda médica, se alimentam mal, possuem baixa qualidade de vida, distúrbios do sono, e carregam uma alta sobrecarga estressora devido a responsabilidade de salvar vidas (FIOL-DEROQUE et al., 2021).

Com a pandemia da COVID-19, esses profissionais têm apresentado diversos transtornos mentais, a exaustão, principalmente devido aos desafios impostos pelo Sars-coV-2, com alta demanda e o contato diário com a morte, levando ao sentimento de impotência e frustrações (TORRES et al., 2021). Depressão, estresse agudo, ansiedade são as manifestações mais presentes nesse grupo de trabalhadores. De acordo com pesquisas, cerca de 58,5\% dos profissionais da linha de frente apresentam Burnout (FIOL-DEROQUE et al., 2021).

Ressalta-se que esses estudos ainda são heterogêneos, não possuem metodologia padrão e não levam em consideração as fases de liberação dos hormônios, impedindo a conclusão generalizada dos resultados (JONSDDTTIR; DAHLMAN, 2018). 


\subsection{TÉCNICAS DE PREVENCẼ̃O E COPING PARA A SÍNDROME DE BURNOUT}

A resiliência representa a capacidade individual de lidar com os estressores e integrá-los à vida diária sem danos psicológicos persistentes. Como um possível mecanismo de proteção na prevenção ativa de transtornos mentais, a resiliência abrange comportamentos e pensamentos que podem ser aprendidos e desenvolvidos (LUIBL et al., 2021).

De acordo com psicólogos, fatores como traços individuais e de personalidade, laços familiares e sistemas de apoio reforçam a resiliência (AFSHARI et al., 2021).

Além disso, o sexo feminino, em relação ao masculino, não só parece estar em maior risco de transtornos psiquiátricos, mas também desproporcionalmente carece de recursos de proteção (LUIBL et al., 2021).

A diferença é significativa em termos de resiliência entre os grupos com diferentes níveis de experiência de trabalho, idade e escolaridade, onde um aumento em cada um dos três fatores levaria ao aumento do nível desse fator (AFSHARI et al., 2020).

Existe uma grande proporção no grupo de estudantes de medicina que apresentam valores de resiliência baixos a moderados, esta circunstância se correlaciona com um aumento da vulnerabilidade às doenças mentais, como a Síndrome de Burnout (LUIBL et al., 2021).

A rápida disseminação do COVID-19 em diferentes países impôs alta pressão sobre a população, em especial aos profissionais de saúde, de tal forma que esse estresse afetou seu grau de resiliência. A carga de trabalho excessiva, o grande número de pacientes e a falta de equipamento, associados a falta de conhecimento sobre a doença e as preocupações com a família e os filhos são problemas que têm gerado medo, ansiedade e esgotamento (AFSHARI et al., 2020).

A esse respeito, os resultados de um estudo realizado por Zhu et al. sobre o impacto psicológico imediato da pandemia de COVID-19 na equipe médica também mostrou que viver com a família e se preocupar consigo mesmo e com a família em se infectar com a doença estão entre os fatores que contribuem para a ansiedade e o estresse na equipe médica (AFSHARI et al., 2021). 
As técnicas de relaxamento e mente-corpo são opções viáveis e promissoras para contribuir na resiliência. Uma sólida ancoragem curricular de ensino e treinamento dessas técnicas poderia ser alcançada através da implementação de exercícios recorrentes e, em última instância, autoaplicáveis no currículo. Essas medidas podem resultar em uma maior sensibilidade para a tolerância ao estresse dos futuros médicos e o hábito de manutenção da saúde mental auto-administrada (LUIBL et al., 2021).

As estratégias psicoterapêuticas que proporcionam os melhores resultados são as terapias cognitivo-comportamentais, que consistem em ferramentas terapêuticas mais utilizadas pelos terapeutas que lidam com a Síndrome de Burnout. Por sua vez, observa-se um impacto favorável na redução dos sintomas relacionados ao estresse, e outros problemas, no ambiente social e familiar do paciente (GÓMEZ et al., 2021).

Apesar da ampla intervenção terapêutica de abordagens na Síndrome de Burnout, como as psicodinâmicas e interpessoais, essas não são suficientemente investigadas, apenas a terapia cognitivo- comportamental (TCC) descrita anteriormente (LATORRACA et al., 2019)

A importância da relação terapeuta-paciente na abordagem do tratamento da Síndrome de Burnout, visto que funciona como uma interação fundamental na transversalidade do processo terapêutico, o que permite atingir os objetivos. Por isso, é preciso levar em conta não só a visão individual do paciente, mas também focar em uma posição multicausal, partindo da dinâmica de trabalho. Além disso, a psicoterapia envolve ética e responsabilidade, bem como a capacidade e o treinamento adquiridos na experiência clínica (GÓMEZ et al., 2021).

Por isso, o papel do psicoterapeuta, no processo, permite adquirir uma aprendizagem de: teoria, prática e técnicas, a partir de uma preparação contínua e permanente da vida profissional. Isso ajuda você a obter novos conhecimentos e usar (ou desenvolver) ferramentas para ajudá-lo a aumentar sua eficiência e eficácia no tratamento (GÓMEZ et al., 2021).

As formas terapêuticas não-farmacológicas, além do que já foi descrito, consistem na modificação da atividade de rotina, evitando monotonia, reduzindo o excesso de longas jornadas de trabalho, buscando melhorar a qualidade das relações sociais, das condições físicas no trabalho e investindo no aperfeiçoamento profissional e pessoal dos trabalhadores (LATORRACA et al., 2019). 
A terapia farmacológica vai ser indicada dependendo do grau de desgaste causado pela doença. Os benzodiazepínicos consistem em boas opções nesse tratamento, são ansiolíticos capazes de estimular mecanismos que normalmente equilibram os estados de tensão e ansiedade, resultando em diminuição desses sintomas, indução do sono, relaxamento muscular e redução do estado de alerta (LATORRACA et al., 2019).

Os antidepressivos são drogas que atuam no sistema noradrenérgico e serotoninérgico, aumentam o tônus psíquico, melhorando o humor e a psicomotricidade de maneira global. Essas medicações são divididas em 3 grupos: Antidepressivos Tricíclicos (ADT); Inibidores Seletivos de Recaptação da Serotonina; Antidepressivos Atípicos e Inibidores da Monoaminaoxidase (IMAO) (LATORRACA et al., 2019).

\section{CONSIDERAÇÕES FINAIS}

A Síndrome de Burnout é uma patologia que tem uma gênese multifatorial e que atinge, sobretudo, os profissionais de saúde, que são expostos a várias estressores diariamente. As estratégias de enfrentamento incluem desde de terapias não farmacológicas, como a psicoterapia ao uso de medicações psiquiátricas no tratamento dos sintomas ansiosos e depressivos. Estudos são necessários para melhorar a assistência dos profissionais acometidos por essa síndrome.

\section{REFERÊNCIAS}

AFSHARI, D. et al. Demographic predictors of resilience among nurses during the COVID19 pandemic. Work, v. 68, n. 2, p. 297-303, fev 2021. Disponível em: https://content.iospress.com/articles/work/wor203376. Acesso em: 07 out 2021.

ARIAS, Y. M. et al. Síndrome de Burnout em estomatologistas. Revista Cubana de Estomatologia, v. 57, n. 4, e3109, dez 2020. Disponível em http://scielo.sld.cu/scielo.php?script=sci_arttext\&pid=S0034$75072020000400002 \&$ Ing=es\&nrm=iso. Acesso em: 07 out 2021.

FIOL-DEROQUE, M. A. et al. A Mobile Phone-Based Intervention to Reduce Mental Health Problems in Health Care Workers During the COVID-19 Pandemic (PsyCovidApp): Randomized Controlled Trial. Jmir Mhealth e Uhealth, v. 9, n. 5, e27039, maio 2021.

Disponível em: 
https://www.ncbi.nlm.nih.gov/pmc/articles/PMC8133164/. Acesso em: 07 out 2021.

GÓMEZ, M. et al. La psicoterapia como una alternativa para el Síndrome de Burnout. Universidad Internacional SEK, p. 145, mar 2021. Disponível em: https://repositorio.uisek.edu.ec/bitstream/123456789/4199/1/Mónica\%20del \%20Consuelo\%20Cerón\%20Gómez.pdf. Acesso em: 07 out 2021.

JONSDOTTIR, I. H.; DAHLMAN, A. S. Mechanisms in Endocrinology - Endocrine and immunological aspects of burnout: a narrative review. European Journal of Endocrinology, v. 180, n.3, p. R147-R158,dez 2018. Disponível em: https://www.ncbi.nlm.nih.gov/pmc/articles/PMC6365671/. Acesso em: 05 out 2021.

KAUTZY, A. et al. Biological and Psychological Stress Correlates Are Linked to Glucose Metabolism, Obesity, and Gender Roles in Women. Neuroendocrinology, jan 2021. Disponível em: https://www.karger.com/Article/Abstract/514484. Acesso: 05 out 2021.

LATORRACA, C. A. C. et al. O que as revisões sistemáticas Cochrane dizem sobre prevenção e tratamento da síndrome de burnout e estresse no trabalho. Diagn Tratamento, v. 24, n. 3, p. 119-25, jul 2019. Disponível em: http://associacaopaulistamedicina.org.br/assets/uploads/revista_rdt/9a57d80c 82543cd780b8b45596accd5a.pdf\#page=41. Acesso: 05 out 2021.

LUIBL, L. et al. Resilience and sense of coherence in first year medical students - a crosssectional study. BMC Medical Education 21, p. 142, mar 2021. Disponível em: https://bmcmededuc.biomedcentral.com/articles/10.1186/s12909-021-025715. Acesso em: 07 de outubro de 2021.

NAJI, L. et al. Global prevalence of burnout among postgraduate medical trainees: a systematic review and meta-regression. Cmaj Open, v. 9, n. 1, p. 189-200, jan 2021. Disponível em: https://www.cmajopen.ca/content/9/1/E189. Acesso: 05 out 2021.

PAIVA, J. D. M. et al. Fatores desencadeantes da Síndrome de Burnout em enfermeiros. Revista de enfermagem: UFPE Online, Recife, v. 13, n. 1, p. 483-490, jan 2019. Disponível em: https://pesquisa.bvsalud.org/portal/resource/pt/biblio1010352. Acesso em: 05 out 2021.

SAKAE, T. M. et al. Prevalência da Síndrome de Burnout em funcionários da estratégia da Saúde da família em um município no sul do Brasil. Arquivos Catarinenses de Medicina, v. 1, n. 46, p. 43-54, jan 2017. Disponível em: http://acm.org.br/acm/seer/index.php/arquivos/article/view/252. Acesso: 05 out 2021.

SHARIFI, M.; ASADI-POOYA, A. A.; MOUSAVI-ROKNABADI, R. S. Burnout among Healthcare Providers of COVID-19; a Systematic Review of Epidemiology and Recommendations: burnout in healthcare providers. Archives of Academic 
Emergency Medicine, v. 9, n. 1, p. 1-17, dez 2020. SBMU Journals. Disponível em: https://journals.sbmu.ac.ir/aaem/index.php/AAEM/article/view/1004. Acesso: 05 out 2021.

TIRONI, M. O. S. et al. Prevalence of burnout syndrome in intensivist doctors in five Brazilian capitals. Revista Brasileira de Terapia Intensiva, v. 28, n. 3, p. 270-277, set $2016 . \quad$ Disponível em: https://www.scielo.br/j/rbti/a/CB8XsX7JTMb37W4b3j3BLmR/?lang=en\&format $=$ html. Acesso: 05 out 2021.

TORRES, L. A. P. et al. Comparison of the Effectiveness of an Abbreviated Program versus a Standard Program in Mindfulness, Self-Compassion and Self-Perceived Empathy in Tutors and Resident Intern Specialists of Family and Community Medicine and Nursing in Spain. International Journal of Environmental Research and Public Health, v. 18, n. 8, p. 4340, abr 2021.Disponível em: https://www.ncbi.nlm.nih.gov/pmc/articles/PMC8073262/. Acesso em: 05 out 2021.

VINIKKOV, D. et al. Testosterone and occupational burnout in professional male firefighters. BMC Public Health, v. 21, n. 1, p. 1-7, fev 2021. Disponível em: https://www.ncbi.nlm.nih.gov/pmc/articles/PMC7903594/. Acesso em: 05 out 2021.

WANG, J. et al. Prevalence of burnout among intensivists in mainland China: a nationwide cross-sectional survey. Critical Care, v. 25, n. 1, p. 1-10, jan 2021. Disponível em: https://ccforum.biomedcentral.com/articles/10.1186/s13054020-03439-8. Acesso em: 05 out 2021. 


\section{CAPITULO XLVII}

\section{SÍNDROME DE WOLFF-PARKINSON- WHITE COM VIA ANÔMALA PARA- HISSIANA: UM RELATO DE CASO}

DOI: 10.51859/AMPLLA.PAE1993-47

Paulo da Silva Campos Filho ${ }^{1}$ Lucas Carvalho Mendes ${ }^{2}$ Alberto Rodolpho Huning ${ }^{3}$ Bruno Gabriel Gonçalves Batista Teixeira ${ }^{4}$ Vanessa Cristina Guedes Silveira ${ }^{5}$

\footnotetext{
1 Discente do curso de Medicina. Universidade Federal do Tocantins - UFT

${ }^{2}$ Discente do curso de Medicina. Universidade Federal do Tocantins - UFT

${ }^{3}$ Médico residente de Cardiologia. Santa Casa de Misericórdia de Porto Alegre

${ }^{4}$ Discente do curso de Medicina. Universidade Federal do Tocantins - UFT

${ }^{5}$ Discente do curso de Medicina. Universidade Federal do Tocantins - UFT
}

\section{RESUMO}

A Síndrome de Wolff-Parkinson-White (SWPW) é uma patologia que se caracteriza pela presença de ao menos uma via acessória de excitação do coração, muito associada à taquiarritmias. Esse defeito congênito acomete certa parcela da população e, mesmo que na maioria dos casos haja um bom prognóstico a longo prazo, deve-se atentar para o risco de desenvolvimento de arritmias e até mesmo morte súbita. O relato descreve o atendimento de uma paciente com queixa de palpitações esporádicas com duração de até 5 minutos, com história pregressa da síndrome e com evolução de 3 anos sem tratamento definitivo ou melhora clínica. Importante salientar a utilização, no caso, dos métodos diagnósticos como o estudo eletrofisiológico do coração e as escolhas terapêuticas abordadas aqui materializadas pela ablação por radiofrequência da via acessória e a crioablação.

Palavras-chave: Síndrome de Wolff-Parkinson-White. Criocirurgia. Ablação por Radiofrequência. Relatos de Casos. 


\section{INTRODUÇÃO}

Em 1930, Louis Wolff, John Parkinson e Paul Dudley White publicaram uma série de casos de pacientes com paroxismos de taquicardia cujo ECG basal mostrava um intervalo PR curto e um padrão de bloqueio de ramo (ZIPES, 2018).

A síndrome de Wolff-Parkinson-White (SWPW) caracteriza-se pela presença de uma ou mais vias acessórias, resultando na chamada pré-excitação ventricular, associada à taquiarritmias recorrentes, como, por exemplo, a taquicardia paroxística supraventricular (MARAZZATO et al., 2019). Vias acessórias ocorrem entre, aproximadamente, $0,05 \%$ e 0,06\% da população. Quando há um impulso do nó sinusal por via anômala anterógrada, ou seja, do átrio para o ventrículo, com tempo de condução menor que o do nó atrioventricular para o feixe de His, há uma pré-excitação ventricular durante o ritmo sinusal, acarretando num intervalo $P R$ curto $(<0,12 s)$, alargamento na porção inicial do complexo QRS (Onda delta) e prolongamento do QRS no eletrocardiograma (ECG), além de uma possível configuração de bloqueio de ramo esquerdo em V1 em alguns casos. (BRUGADA et al., 2019).

A localização anatômica da via acessória em pacientes com síndrome de WPW é variável, podendo estar presente na parede direita, parede esquerda ou septo interventricular, local onde fica parte significativa do feixe de condução normal do coração. Um estudo com 91 pacientes mostrou que 46,2\% das vias acessórias presentes estão em parede lateral esquerda, 9,9\% em parede lateral direita, 30,8\% em parede póstero-septal (Direita e esquerda), 12,1\% em parede médio-septal e apenas 1,1\% em parede ântero-septal. (KASPER, 2020). Em outro estudo que avaliou 79 pacientes submetidos a ablação por cateter de radiofreqüência, notou-se que a localização das vias é mais frequente à esquerda, no anel mitral, conectando átrio e ventrículo esquerdos $(56,1 \%)$, localização em parede livre de anel tricúspide em 9,9\% dos casos e região inferior do septo em até $20 \%$ dos casos. Apenas $12 \%$ encontra-se na região média ou anterior do septo e, alguns desses, apresentou feixe acessório próximo ao feixe de condução normal (Feixe de Hiss). (TOSCANI et al., 2014). É estimado que 10\% das vias anômalas estejam posicionadas em região ântero-septal próxima ao feixe de His (ANDALAFT et al., 2015). 
Para fins diagnósticos, o ECG se mostra como método não invasivo, amplamente disponível, de baixo custo e que ainda pode ajudar a determinar a possível localização da via acessória. Já o estudo eletrofisiológico é um meio invasivo para diagnóstico, que pode, também, ser útil no processo de estratificação de risco das taquicardias e está associado à perspectiva de ablação da via acessória por cateter de radiofrequência, mecanismo que é resolutivo na grande maioria dos casos de via acessória na síndrome de Wolff-Parkinson-White. (KASPER, 2020).

O tratamento de escolha é a ablação por radiofreqüência, que apresenta uma taxa de sucesso em torno de $95 \%$ e mortalidade menor que 0,08\%. Ablação com cateter de radiofrequência é um método seguro e eficaz, sendo eficaz para o tratamento das duas formas mais comuns de taquicardia supraventricular. (YILDIRIM et al., 2013).

Figura 1 - ECG de 12 derivações de paciente com síndrome de WPW revelando intervalo PR curto, ondas delta e alargamento do complexo QRS.
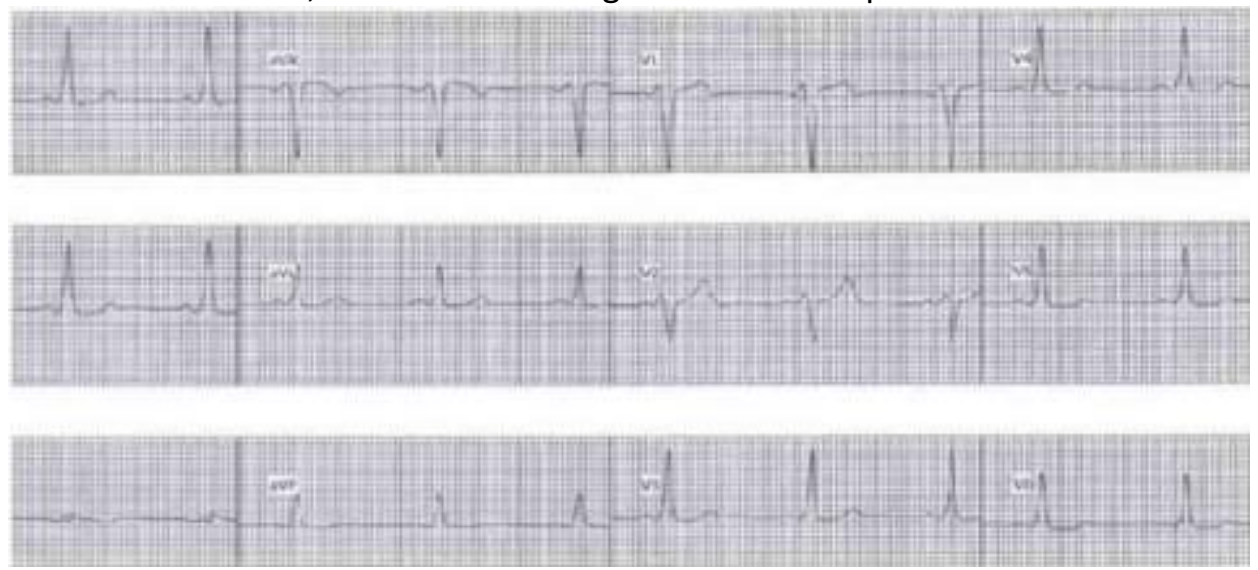

Fonte: KASPER, 2020.

Figura 2 - Representação eletrocardiográfica ilustrativa de uma onda delta encontrada em pacientes portadores da síndrome de WPW.

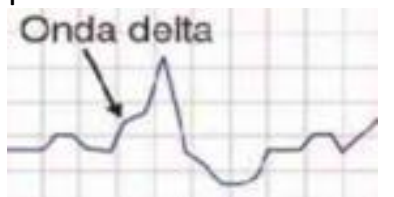

Fonte: KASPER, 2020.

\section{DESCRIÇÃO DO CASO}

Paciente A. M., 38 anos de idade, sexo feminino, deu entrada no ambulatório de arritmologia do Hospital São Francisco da Santa Casa de Misericórdia de Porto Alegre com queixa de palpitações esporádicas com duração de até 5 minutos. Relata ansiedade. Nega comorbidades, precordialgia, dispneia, tonturas, síncopes, sudorese ou náuseas. 
Em uso contínuo de Propafenona 300 mg, meio comprimido, de doze em doze horas e Selozok (Succinato de metoprolol) $25 \mathrm{mg}$ uma vez ao dia. Apresenta história pregressa de Síndrome de Wolff-Parkinson-White com via acessória para-hissiana. Relata que passou por duas tentativas de estudo eletrofisiológico (EEF) e ablação por cateter de radiofrequência, em novembro de 2018 e junho de 2021, porém ambas sem sucesso terapêutico. A paciente segue com queixas de palpitações de início e término súbitos, sendo que o último episódio foi há, aproximadamente, um mês.

No exame físico, a paciente apresentou bom estado geral, lúcida e orientada no tempo e no espaço, corada, hidratada, anictérica, acianótica, afebril, eupneica em ar ambiente, murmúrio vesicular pulmonar preservado, bulhas cardíacas normofonéticas, regulares, em dois tempos e sem sopros, extremidades aquecidas e perfundidas, pressão arterial de $130 \times 93 \mathrm{mmHg}$ e frequência cardíaca igual a 78 batimentos por minuto.

No dia 05 de novembro de 2018, a paciente foi submetida ao primeiro estudo eletrofisiológico e tentativa de ablação por radiofrequência. Através de punções nas veias femoral e jugular, foram introduzidos os cateteres. O estudo eletrofisiológico mostrou um ritmo de base sinusal com pré-excitação ventricular. Durante manipulação do cateter em átrio direito, ocorreu indução de taquicardia supraventricular ortodrômica, mediada por via acessória para-hissiana. Além disso, também sobreveio uma taquicardia antidrômica pela mesma via acessória. Iniciado mapeamento anterógrado da via acessória com sinal AV fusionado em região do feixe de His. Durante a manipulação do cateter nesta região havia interrupção traumática da condução pela via acessória, com recorrência após alguns minutos ou, em algumas ocasiões, após extra-estímulos no átrio. Havia interrupção anterógrada e retrógrada da condução pela via acessória na manipulação do cateter. Em região médio-septal, ligeiramente abaixo do feixe de His, com precocidade ventricular em relação ao início do QRS pré-excitado, foi realizada aplicação de radiofrequência, 40W e 50C, sem interrupção da via acessória. Após desaparecimento da pré-excitação por trauma da manipulação do cateter, sem retorno da pré-excitação após 10 minutos. Diante da localização parahissiana da via acessória e do risco de comprometimento da condução atrioventricular normal durante a ablação, optou-se por finalizar o procedimento. 
Em novembro de 2019, a paciente realizou um ecocardiograma transtorácico, o qual apresentou uma fração de ejeção do ventrículo esquerdo igual a $68 \%$ e demais fluxos cardíacos dentro dos limites normais.

Em junho de 2021, foi realizado um novo estudo eletrofisiológico e houve uma nova tentativa de ablação por cateter de radiofrequência da via acessória de localização para-hissiana indutora de taquicardia supraventricular ortodrômica e antidrômica. Novamente, a tentativa de ablação por cateter de radiofrequência foi suspensa devido ao risco de lesionar o feixe de condução atrioventricular normal, o feixe de His.

Foi sugerido para a paciente a realização de crioablação como alternativa para tratamento definitivo.

\section{DISCUSSÃO}

Na síndrome de Wolff-Parkinson-White, há a presença de um ou mais feixes anômalos que podem conduzir estímulos elétricos extras no coração, promovendo, geralmente, um descompasso no batimento cardíaco normal. A síndrome pode evoluir com taquicardias paroxísticas supraventriculares, taquicardias supraventriculares sustentadas e até síncope. Pode ainda haver evolução para fibrilação atrial, fibrilação ventricular e até morte súbita. (BRUGADA et al., 2019). Portanto, deve-se buscar um tratamento que permita resolução definitiva para essa condição e que, concomitantemente, seja seguro para o paciente, preservando as demais estruturas anatômicas do coração, como o feixe de His.

A ablação por radiofrequência é o tratamento de escolha na maioria dos casos de vias anômalas relacionadas à síndrome de Wolff-Parkinson-White, sendo resolutiva na grande maioria dos pacientes, com eficácia maior que 90\% (ANDALAFT et al., 2015). Contudo, tratando-se de uma via acessória para-hissiana e neste caso relatado, especificamente, uma via paralela muito próxima ao feixe de His, ou seja, a via acessória localizada juntamente a uma importante via de condução normal do sistema elétrico cardíaco, deve-se buscar outras medidas terapêuticas. Pois, há um grande risco de lesionar o feixe de condução normal do coração, o que pode acarretar uma série de repercussões clínicas, como um bloqueio atrioventricular total (BAVT), por exemplo. A ablação da região para-hissiana é um desafio devido ao risco de lesão no feixe de His, pois a localização para-hissiana está relacionada em grandes séries a risco de até $20 \%$ 
de desenvolvimento de bloqueio atrioventricular total durante a liberação do pulso de radiofrequência. (CHENG et al., 2000).

Logo, nesse caso, foi necessário indicar outra medida terapêutica para resolução do feixe anômalo. Foi sugerido a crioablação como tratamento definitivo, pois a mesma apresenta maior segurança em relação à terapia convencional por cateter de radiofrequência, pois permite com que haja a possibilidade de preservar o tecido de condução do feixe de His. Antes de produzir uma lesão irreversível, existe a possibilidade de realizar um criomapeamento, que consiste em resfriar o tecido até $-30 \circ \mathrm{C}$ por até 60 segundos, criando uma lesão totalmente reversível e, só após a confirmação do tecido no qual será destruído pelo cateter é que se reduz a temperatura para -70 ำ , lesando o tecido definitivamente. A crioablação se tornou opção de escolha em ablação em pacientes com alvo terapêutico próximo a estruturas que não devem ser lesionadas, como o feixe de His. (TOSCANI et al., 2014).

A ablação por cateter de radiofrequência de vias acessórias para-hissianas é um procedimento potencialmente prejudicial devido à sua localização, por outro lado, a crioablação de vias para-hissianas é um processo altamente seguro e eficaz (ZELKO; YUE, 2015). 
Fluxograma: Após a queixa de palpitações, deve-se identificar se o início e fim ocorrem subitamente ou gradativamente. Se for subitamente, deve-se solicitar um ECG para avaliação de uma possível taquiarritmia. A síndrome de Wolff-Parkinson-White pode manifestar-se com onda delta, intervalo PR curto, QRS alargado e alterações de repolarização. Posteriormente, deve-se realizar um estudo eletrofisiológico para determinar a localização dos feixes acessórios. Mais de $90 \%$ dos feixes anômalos permitem resolução através de ablação por radiofrequência, contudo uma minoria só pode ser tratada através de crioablação por proporcionar mais segurança do tecido de condução normal, o feixe de His.

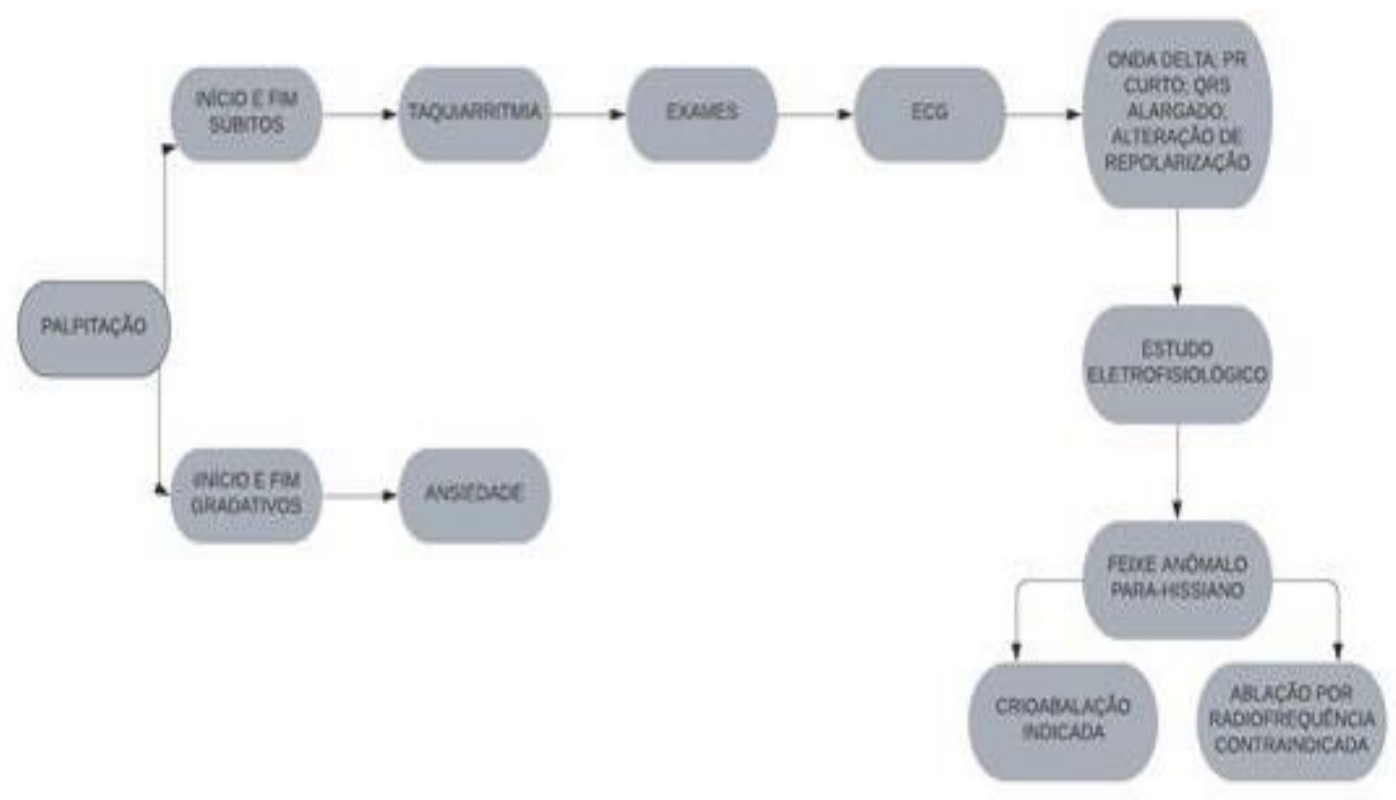

Fonte: Autoria própria.

\section{CONCLUSÃO}

A síndrome de Wolff-Parkinson-White é uma condição na qual pode cursar com taquiarritmias, como, por exemplo, fibrilação atrial e fibrilação ventricular, o que pode levar a um mal súbito. A mesma se caracteriza pela presença de vias acessórias que podem ser distribuídas em diversas partes do coração, contudo há alguns casos nos quais o feixe anômalo localiza-se paralelamente ao feixe de His, o chamado feixe acessório para-hissiano. Tal localização do feixe anômalo impossibilita a realização da ablação convencional por cateter de radiofrequência, que por sua vez, é resolutivo em quase todos os casos de feixes anômalos na síndrome de Wolff-Parkinson-White. Contudo, o uso da técnica com cateter de crioabalação permite uma alternativa para resolução definitiva destes casos com maior margem de segurança e eficácia devido ao 
criomapeamento com rebaixamento da temperatura a -30 ํ C e crioablação resolutiva a

-70 으, destruindo apenas o feixe anômalo e preservando o feixe de His.

\section{AGRADECIMENTOS}

Gostaríamos de agradecer, com imenso prazer, ao Dr. Alberto Rodolpho Huning, residente de cardiologia, e a todos tutores e colaboradores do Hospital São Francisco da Santa Casa de Misericórdia de Porto Alegre, por todo apoio técnico, acadêmico e científico prestados durante o período de estágio teórico e prático na instituição.

\section{REFERÊNCIAS}

ANDALAFT, Rogerio B. et al. Crioablação em atleta com via acessória anterosseptal parahissiana. Uma nova esperança para pacientes com WPW e vias acessórias de alto risco. Revista do DERC, p. 106-109, 2015.

BRUGADA, J. et al. 2019 ESC Guidelines for themanagement of patients with supraventricular tachycardia. European Heart Journal, v. 41, n. 5, p. 655-720, 2020.

CAY, Serkan et al. Various routes and techniques for ablation of parahisian bypass tracts. International journal of cardiology, v. 223, p. 217, 2016.

CHENG, Carol HF et al. Cost-effectiveness of radiofrequency ablation for supraventricular tachycardia. Annals of internal medicine, v. 133, n. 11, p. 864876, 2000.

KASPER, Dennis L. Medicina interna de Harrison. 20 ed. Porto Alegre. AMGH Editora, 2020.

MARAZZATO, Jacopo et al. Efficacy and safety of cryoablation of para-Hisian and midseptal accessory pathways using a specific protocol: single-center experience in consecutive patients. Journal of Interventional Cardiac Electrophysiology, v. 55, n. 1, p. 47-54, 2019.

TOSCANI, Bruno et al. Via acessória médio-septal: papel do eletrocardiograma como preditor da localização no estudo eletrofisiológico. Journal of Cardiac Arrhythmias, v. 27, n. 2, p. 77-84, 2014.

YILDIRIM, Işil et al. Efficacy and safety of cryoablation of parahissian accessory pathways in children: a single institution study. Pacing and Clinical Electrophysiology, v. 36, n. 12, p. 1495-1502, 2013.

ZELKO, Hrvojka Marija; YUE, Arthur. Catheter inversion technique for ablation of parahisian accessory pathway. Europace, v. 17, n. 11, p. 1707-1707, 2015.

ZIPES, Douglas P. Braunwald's heart disease: a textbook of cardiovascular medicine. BMH Medical Journal-ISSN 2348-392X, 2018. 


\title{
CAPITULO XLVIII
}

USO INDISCRIMINADO DE ANTIINFLAMATÓRIOS NÃO ESTEROIDAIS (AINES) OBSERVADOS EM UMA DROGARIA DE SÃO LUIS - MA

\author{
DOI: $10.51859 /$ AMPLLA.PAE1993-48
}

Luciane Feitosa dos Santos ${ }^{1}$

Alamgir Khan ${ }^{2}$

Raquel Maria Trindade Fernandes ${ }^{3}$

\footnotetext{
Graduando do curso de Farmácia. Instituto Florence de Ensino Superior - IFES

2 Professor Adjunto do Departamento de Química. Universidade Estadual do Maranhão - UEMA

${ }^{3}$ Professora Adjunta do Departamento de Química. Universidade Estadual do Maranhão - UEMA
}

\section{RESUMO}

Os anti-inflamatórios não esteroidais (AINES), possuem propriedades analgésica, antitérmica, anti-inflamatória e antitrombótica. Estão entre os agentes terapêuticos mais utilizados no controle de dores e inflamações crônicas e agudas. Com características farmacocinéticas e farmacodinâmicas individuais e eficácia clinica diferente, existem no mercado mais de 50 tipos de medicamentos, sendo os compostos farmacológicos mais utilizados em todo o mundo. O presente trabalho tem como objetivo analisar o consumo de AINE prescritos e não prescritos, identificando os medicamentos mais consumidos, em uma drogaria de São Luis - MA. Para realização do mesmo, utilizou-se pesquisa do tipo descritiva de natureza quantitativa, foi elaborado um questionário contendo perguntas abertas e fechadas sobre o medicamento utilizado. Foram colhidos 42 questionários sendo que $55 \%$ foram do sexo feminino e 45 $\%$ do sexo masculino. A nimesulida foi o medicamento mais citado, seguido do diclofenaco. Dos entrevistados, 60 \% consomem AINES sem prescrição e $40 \% \mathrm{com}$ prescrição. Inflamação de garganta e dores musculares foram os principais motivos de uso relatado. Após a análise dos dados pode- se concluir que as pessoas utilizam a classe farmacológica estudada de forma indiscriminada, apontando para a necessidade de orientação do profissional farmacêutico nas drogarias visando intervenção dessa prática.

Palavras-chave: Medicamentos. Consumo. Inflamação. Dor. 


\section{INTRODUÇÃO}

A Agência Nacional de Vigilância Sanitária (ANVISA) define automedicação como sendo o uso de medicamento sem a prescrição, orientação ou acompanhamento do médico ou dentista. E já automedicação responsável é definida como sendo a prática pela qual os indivíduos tratam doenças, sinais e sintomas utilizando medicamentos aprovados para venda sem prescrição médica, sendo estes de eficácia e segurança comprovadas quando utilizados racionalmente (BRASIL, 2001).

Entre os medicamentos mais utilizados na prática da automedicação, os analgésicos, antitérmicos e os anti-inflamatórios não esteroidais estão entre os grupos farmacológicos com maiores índices de automedicação, provavelmente por serem utilizados para tratamento de dores músculo-esqueléticas e constantemente administrados para dores menores, sem prescrição ou orientação de um profissional habilitado (BEZERRA, 2006).

De acordo com o Sistema Nacional de Informações Tóxico-Farmacológicas (SINITOX) no ano de 2016, 33 \% dos casos intoxicações registradas, estão relacionadas ao uso de medicamentos, principalmente pela classe de anti-inflamatórios não esteroidais que é bastante utilizada pela população (BEZERRA, 2006; SINITOX, 2016).

Segundo a RDC 138/03 da Agência Nacional de Vigilância Sanitária (ANVISA), alguns medicamentos da classe dos AINES estão disponíveis entre os Medicamentos Isentos de Prescrição (MIPS), o que torna mais fácil o acesso a estes, favorecendo o uso irracional de medicamentos e a prática da automedicação (SILVA et. al., 2014).

Os anti-inflamatórios não esteroidais (AINES) são medicamentos que possuem propriedades analgésica, antitérmica, anti-inflamatória e antitrombótica, e estão entre os agentes terapêuticos mais utilizados no controle da dor e inflamação crônica e aguda. Existem no mercado mais de 50 tipos de medicamentos AINES, sendo um dos compostos farmacológicos mais utilizados em todo o mundo. Podemos citar como exemplo diclofenaco, nimesulida, ácido acetilsalićlico, naproxeno, ibuprofeno e cetoprofeno (SCHALLEMBERGER \& PLESTSCH, 2014).

Estes medicamentos possuem características farmacocinéticas e farmacodinâmicas individuais e eficácia clínica diferente, sendo que o mecanismo de ação destes medicamentos se dá pela inibição das sínteses de prostaglandinas, que é 
uma substância presente no processo inflamatório, inativando a enzima cicloxigenase constitutiva (COX1) e a cicloxigenase indutiva (COX2), sendo que a primeira tem a função de proteger os tecidos e ajuda no funcionamento fisiológico do organismo, como por exemplo, na mucosa gástrica, intestino e nos sítios renais, já a segunda é estimulada em inflamações. A inibição farmacológica desta última enzima, $\operatorname{COX} 2$, pode causar redução aos sintomas da dor e da inflamação (VILETTI \& SANCHES, 2009).

Com inibição da cicloxigenase (COX1), os AINES podem provocar inúmeras reações adversas, como: diarreia, úlcera péptica, falência renal, dispepsia, hemorragia gastrointestinal, inibição da agregação plaquetária, e interações com outras drogas. Existe uma alta prevalência do uso de AINES no mundo e alto índice de morbimortalidade relacionada com o uso desses fármacos. Prescrições dessa classe de medicamentos devem ser criteriosas, em pacientes com alto risco de desenvolver lesões renais como hipertensos idosos e diabéticos (PINHEIRO \& WANNMACHER, 2010; MELGAÇO et. al., 2010).

Nos Estados Unidos ocorrem mais de 70 milhões de prescrições de AINES e mais de 30 milhões de comprimidos destes medicamentos de venda livre comercializados anualmente. No Brasil o consumo elevado é atribuído a vários fatores, sendo que o principal é o cultural, o hábito da pessoa se automedicar. A população acredita que se o medicamento foi bom para um vai ser bom para todos (SIOMARA, 2006; ABRAÃO et. al., 2010).

Faz- se indispensável a presença do profissional farmacêutico, exercendo suas competências e responsabilidades na assistência farmacoterapêutica do paciente, aconselhando e buscando o meio mais adequado para que o paciente sinta- se melhor e mais empenhado com o tratamento exigido. Conhecimentos de reações adversas, interações, indicações e contraindicação são de suma importância para o bom tratamento e acompanhamento junto ao paciente (AGONESI \& SEVALHO, 2010).

Esses fármacos trazem um grande impacto para a população. Estudá-los e orientar a sociedade sobre uso e riscos é de grande relevância para a saúde e bem-estar de todos. O consumo de AINES vem crescendo largamente. Assim o presente trabalho teve como objetivo analisar o consumo de anti-inflamatórios não esteroidais prescritos e não prescritos, identificando os medicamentos mais consumidos, em uma drogaria de São Luís - MA. 


\section{METODOLOGIA}

Trata-se de um estudo descritivo de natureza quantitativa, no qual foram realizadas entrevistas através de um questionário semiestruturado contendo questões abertas e fechadas, durante a compra de anti-inflamatórios não esteroidais em uma drogaria localizada em São Luís - MA, no mês de outubro de 2016. Foram entrevistadas pessoas com faixa etária acima de 18 anos, que buscavam anti-inflamatórios não esteroidais, com ou sem prescrição médica ou odontológica.

Os entrevistados foram informados do conteúdo do questionário, dos requisitos necessários e, voluntariamente responderam as perguntas sobre variáveis demográficas (idade e sexo) e aquelas relacionadas ao medicamento. Os consumidores foram convidados a preencher o questionário em uma área reservada da drogaria. Para os que apresentaram dificuldade de leitura e compreensão, foi feita a leitura do mesmo e as explicações necessárias sem intervenção ou direcionamento das respostas. Após a coleta, os dados obtidos foram analisados e organizados por meio do programa Microsoft Excel versão 2010, gerando as tabelas.

\section{RESULTADOS E DISCUSSÃO}

Foram entrevistadas aleatoriamente 42 pessoas que buscaram a drogaria no mês de outubro de 2016 e compraram AINES com ou sem prescrição do profissional habilitado. A Tabela 1 apresenta a distribuição dos entrevistados de acordo com o sexo.

Tabela 1 - Distribuição dos entrevistados de acordo com o sexo.

\begin{tabular}{ccc}
\hline Variável & $\mathbf{n}$ & \% \\
\hline Masculino & 19 & 45 \\
Feminino & 23 & 55 \\
\hline
\end{tabular}

(n) = n. ㅇ de entrevistados. (\%) frequência percentual.

Fonte: Autoria própria.

Diante de tal levantamento, observou-se que $55 \%$ das pessoas entrevistadas eram do sexo feminino e $45 \%$ do sexo masculino. Segundo Kreling et. al. (2006), o conceito de dor para homens e mulheres, pode ser influenciado por normas sociais e culturais que permitem à mulher expressar ou manifestar a dor, enquanto encorajam os homens a desconsiderá-la. Para Duarte \& Junior (2015), 60 \% das mulheres praticam 
automedicação, justificando que estas possuem maior preocupação com manutenção da saúde.

Lira \& Maria (2013), afirma que as mulheres por se encontrarem mais expostas do que os homens a determinadas situações, como dismenorreia e parto, não só apresentam níveis de dor mais severo, como também episódios dolorosos mais frequentes e duráveis.

Observou-se que quem mais faz uso de AINES está entre 32 e 53 anos de idade (39 \%) e quem menos faz uso é a faixa etária de 19 a 25 anos (8\%). Viletti \& Sanches (2009), afirmam que a idade avançada, fatores econômicos e culturais, sexo feminino, e depressão são fatores precursores para automedicação.

O difícil acesso a um atendimento na unidade de saúde também são fatores que contribuem com essa prática que cresce a cada dia, a procura por medicamentos em drogarias de dispensação, a fim de amenizar as dores da sociedade (VILETTI \& SANCHES, 2009).

Quando questionados quanto a finalidade do uso medicamento obteve-se como resposta diversos tipos de queixas como dor muscular, dor de dente, inflamação na garganta, hemorroidas, dor no ouvido, dor na coluna, dores pós-cirurgias, dores reumáticas, dentre outras. Os mais citados podem ser observados na Tabela 2.

Tabela 2 - Principais sintomas que levaram os entrevistados a utilização AINES.

\begin{tabular}{|c|c|c|}
\hline Sintomas & $\mathbf{n}$ & $\%$ \\
\hline Inflamação de garganta & 12 & 29 \\
\hline Dores musculares & 10 & 24 \\
\hline Dor na coluna & 8 & 20 \\
\hline Dor no dente & 6 & 12 \\
\hline Dores pós-cirurgias & 4 & 10 \\
\hline Outros & 2 & 5 \\
\hline
\end{tabular}

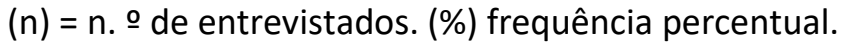

Fonte: Autoria própria.

Na Tabela 2 podemos ver que o sintoma que mais levou uma pessoa a utilizar AINES foi inflamação na garganta com 29 \%, seguido de dor muscular com 24 \% e dor na coluna com $20 \%$. Também foram citados dor de dente com $12 \%$ e pós-cirurgia com 10 \% e outros com menor frequência somando $5 \%$. 
Gabossa (2008) e Silva et. al. (2014), relataram dor de garganta como um dos principais motivos da utilização de anti-inflamatórios não esteroidais.

Viletti \& Sanches (2009) relataram dor de garganta, dor muscular e dores póscirúrgicas como sintomas mais citados por seus entrevistados. Sallum et. al. (2012), dizem que a presença constante da dor, pode causar alterações em atividades físicas, no sono, na atividade sexual, modificação no humor, e alterar relações familiares, trabalho e lazer; mas o uso de medicamentos sem orientação de um profissional habilitado pode mascarar doenças e até mesmo causar danos à saúde da população.

Outra informação avaliada foi em relação aos AINES mais utilizados pelos entrevistados. Estas informações estão dispostas na Tabela 3 descritas pelo nome do princípio ativo do medicamento. Conforme a Denominação Comum Brasileira (DCB).

Tabela 3 - AINES mais utilizados pelos entrevistados.

\begin{tabular}{lll}
\hline Medicamentos & $\mathbf{n}$ & $\%$ \\
\hline Nimesulida & 17 & 40 \\
Diclofenaco & 13 & 31 \\
Naproxeno & 4 & 9 \\
Aceclofenaco & 3 & 7 \\
Piroxicam & 2 & 5 \\
Meloxicam & 2 & 5 \\
Outros & 1 & 3 \\
\hline
\end{tabular}

(n) = n. @ de entrevistados. (\%) frequência percentual.

Fonte: Autoria própria.

Na Tabela 3 podemos observar que entre os AINES mais utilizados pelos entrevistados na pesquisa, destaca-se nimesulida como anti-inflamatório de escolha com 40 \%; seguido de diclofenaco com $31 \%$; naproxeno $9 \%$; aceclofenaco $7 \%$; piroxicam e meloxicam 5 \% cada e outros com menor frequência somando $3 \%$.

Ao avaliar o uso de AINES de acordo com a fonte de indicação, observou-se que a nimesulida, seguido do diclofenaco, como fármacos de escolha para inflamação na garganta, dores musculares e coluna. Esses medicamentos, apesar de não serem de venda livre, são muito utilizados pela população. Lima et. al. (2010), afirmam que esses medicamentos possuem efeitos anti-inflamatório, analgésico e antipirético e sua ampla utilização para dor aguda é a possível resposta para o uso desses AINES (LIMA et. al., 
2010). Silva Filho (2013), em seu estudo, relata nimesulida como 58 \% das dispensações, em concordância com os resultados deste trabalho (SILVA FILHO, 2013).

Segundo Geller et. al. (2012), há uma vasta experiência com evidências clínicas sobre a utilização do diclofenaco em diversas condições dolorosas, no tratamento da dor lombar, diclofenaco e outros AINES estão entre os medicamentos mais utilizados no mundo. Os autores também verificaram que o uso do diclofenaco é semelhante ao da nimesulida na redução da intensidade da dor, ambos são utilizados pela população para controle de sintomas análogos.

Schallemberger \& Plestsch (2014), em estudo sobre uso indiscriminado de antiinflamatórios não esteroidais verificaram o uso do diclofenaco e nimesulida para dores e inflamações. O uso do naproxeno, meloxicam e piroxicam também se destacam nesse estudo.

Outro dado de grande relevância questionado no presente trabalho foi quanto a relação do uso prescrito e não prescrito na utilização de AINES, e quando usado de forma indiscriminada, por quem eram orientados. Os resultados estão dispostos na Tabela 4.

Tabela 4 - Orientação do uso de anti-inflamatórios não esteroidais pelos entrevistados, e uso com ou sem prescrição.

\begin{tabular}{lll}
\hline Indicação & $\mathbf{n}$ & $\%$ \\
\hline Própria & 13 & 31 \\
Pais & 3 & 7 \\
Médicos & 17 & 40 \\
Amigos & 4 & 9 \\
Balconistas & 2 & 5 \\
Farmacêuticos & 2 & 5 \\
Outros & 1 & 3 \\
& & \\
Com prescrição & 17 & 40 \\
Sem prescrição & 25 & 60 \\
\hline
\end{tabular}

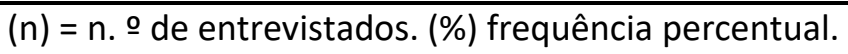
Fonte: Autoria própria.

Entre os entrevistados, 17 pessoas (40 \%) vieram com prescrição em mãos, 25 pessoas (60 \%) estavam realizando uso do medicamento por indicação própria (31 \%), amigos (9 \%), pais (7\%), balconista de farmácia (5\%), farmacêutico (5 \%) e outros somaram (3\%). Os $40 \%$ por indicação médica estão relacionados aos AINES com 
prescrição. Sendo que o farmacêutico foi um dos menos procurado. Segundo Silva et. al. (2014), esses dados mostram que a população ainda não aprendeu a usar os serviços farmacêuticos, dando pouco valor ao seu conhecimento (SILVA et. al., 2014). Nessa pesquisa o uso próprio exerceu forte influência sobre a automedicação, diferente de resultados obtidos em outros estudos, como o de Duarte \& Junior (2015), no qual os balconistas de farmácia tiveram maior influência com 30 \% (18) das orientações.

Viletti \& Sanches (2009), Arruda et. al. (2011), e Silva et. al. (2016) em estudos realizados sobre automedicação de anti-inflamatórios, apontam a utilização dessa classe de medicamentos como os mais utilizados sem prescrição ou orientação de um profissional habilitado. A orientação por terceiros já citados no presente trabalho, encontra-se em concordância com esses autores.

Bezerra (2006), em trabalho realizado na região nordeste, sobre automedicação, afirma que o número de pessoas que utilizam essa prática é bem relevante, sendo que os analgésicos e anti-inflamatórios estão entre os mais citados pelos entrevistados. OS autores ressaltam também que a automedicação se dá principalmente devido a falta de uma política pública de saúde que atenda às necessidades básicas das pessoas, principalmente as de baixa renda.

De acordo com a Associação Brasileira de Indústrias Farmacêuticas (Abifarma), cerca de 80 milhões de brasileiros seriam adeptos a automedicação. Vitor et. al. (2008) destacam que a automedicação constitui uma prática universal presente nas mais diversas sociedades e culturas, independente do grau de desenvolvimento socioeconômico (VITOR et. al.,2008).

Quanto às pessoas que seguem ou não orientação da bula também foi questionado no presente trabalho, os dados estão descritos na Tabela 5.

Tabela 5 - Distribuição do seguimento das instruções da bula de medicamentos.

\begin{tabular}{lll}
\hline Seguem instruções da bula & $\mathbf{n}$ & $\%$ \\
\hline Sim & 13 & 31 \\
Não & 29 & 69 \\
\hline
\end{tabular}

(n) = n. ㅇ de entrevistados. (\%) frequência percentual. Fonte: Autoria própria.

Como podemos observar na Tabela 5, 69 \% responderam que não seguem orientação da bula, 31 \% disseram que sim. A bula é o nome que se dá ao papel que acompanha o medicamento, onde apresenta uma série de informações obrigatórias, 
dirigidas aos usuários e profissionais da saúde. As pessoas não possuem o hábito de lê bulas, provavelmente porque por muito tempo elas apresentavam letras muito pequenas e um leque de informações que dificultavam o entendimento (RIGOTTO et. al., 2016). A RDC 47/09, estabelece regras para elaboração, harmonização, atualização, publicação e disponibilização de bulas de medicamentos (BRASIL, 2009).

Na Tabela 6 podemos observar as principais doenças crônicas relatadas pelos entrevistados, sendo que a maioria respondeu que não possui nenhuma doença crônica.

Tabela 6 - Principais doenças crônicas relatadas pelos entrevistados.

\begin{tabular}{|c|c|c|}
\hline Doenças & $n$ & $\%$ \\
\hline Diabetes & 7 & 17 \\
\hline Colesterol alto (LDL) & 5 & 12 \\
\hline Hipertensão & 4 & 10 \\
\hline Gastrite & 4 & 9 \\
\hline Não possui & 21 & 50 \\
\hline Outros & 1 & 2 \\
\hline
\end{tabular}

(n) = n. o de entrevistados. (\%) frequência percentual.

Fonte: Autoria própria.

Malta et. al. (2014) destacam que doenças crônicas não transmissíveis (DCNT) constituem o maior problema global de saúde e tem gerado grande número de mortes prematuras, perda da qualidade de vida, além de impactos econômicos para família, comunidades e sociedade geral. A existência de outras patologias em indivíduos que fazem uso de AINES, também foi objeto do presente trabalho, obtendo como respostas: diabetes (17\%), colesterol (LDL) elevado (12\%), pressão alta (10\%), gastrite (9\%), outros (2\%). Sendo que 50 \% responderam que não possuem doenças crônicas. Silva et. al. (2016), afirmam que anti-inflamatórios não esteroidais são potenciais agravantes ou causadores de problemas gástricos e intestinais como ulcerações (SILVA et. al., 2016).

Para Sousa et. al. (2016), a adição de um AINE ao esquema terapêutico de paciente em uso de diurético para controle de doença cardiovascular e hipertensão associada à retenção sódio e água aumenta a probabilidade de insuficiência cardíaca. Em seu estudo envolvendo cerca de 10.000 indivíduos com 55 anos ou mais, essa combinação aumentou duas vezes mais a taxa de hospitalização por insuficiência cardíaca. Destacam também que tanto os AINES tradicionais quantos os coxibes 
aumentam a pressão arterial, devido a alterações do equilíbrio hidroeletrolítico e na reatividade vascular.

Araújo (2012) destaca que a hepatotoxicidade relacionada ao uso de antiinflamatórios embora seja rara, pode se manifestar de maneira severa, o que fez com que alguns fármacos dessa categoria fossem retirados do mercado. Balbino (2011) afirma que os AINES podem mascarar a evolução de doenças graves, onde num estudo norte americano destaca que uso dessa classe de medicamentos contendo salicilatos e ibuprofeno podem reduzir os níveis de Antígeno Prostático Específico (PSA) no sangue, e dificultar a detecção do câncer de próstata.

\section{CONSIDERAÇÕES FINAIS}

O uso indiscriminado de medicamentos de maneira geral pode ser preocupante e com os AINES essa preocupação fica evidente, pois entre os entrevistados muitos utilizam esses fármacos para as mais diversas finalidades. $O$ ato de se medicar para solucionar problemas simples, não pode ser de certa forma condenada, pois o atual sistema de saúde não suporta a demanda. Logo, existe a necessidade de um acompanhamento profissional para orientar e conscientizar as pessoas sobre os riscos da automedicação. AINES e os demais medicamentos devem ser utilizados com cautela, pois as consequências podem ser irreversíveis.

Diante dos dados obtidos fica claro o uso indiscriminado dessa classe de medicamentos, pois os resultados apresentados demostram que a maioria das pessoas que buscam anti-inflamatórios não tem prescrição, correspondendo a $60 \%$ dos entrevistados. O medicamento mais consumido foi nimesulida com $17 \%$, seguido de diclofenaco com $13 \%$. O estudo também mostrou que o sexo feminino é quem mais faz uso de AINES com 55 \%. A maioria utiliza por conta própria, sem nenhuma orientação de um profissional da área, colocando em risco a sua saúde.

\section{REFERÊNCIAS}

ABRAÃO, L. M.; SIMAS, J. M. M.; MIGUEL, T. L. B. Incidência da automedicação e uso indiscriminado de medicamentos entre jovens universitários. II Encontro Científico e II Simpósio de Educação, 02, Lins, Brasil, 2009. 
ANGONESI, D.; SEVALHO, G. Atenção Farmacêutica: fundamentação conceitual e crítica para um modelo brasileiro. Ciência \& Saúde Coletiva 15 (2010): 3603-3614.

ARAÚJO, M. A. R. Hepatotoxicidade associada à nimesulida: uma revisão da literatura. Universidade- UNICEUMA. São Luís - MA. Rev. Bras. Farm. 93(3): 283-289, 2012.

ARRUDA, L. E.; ARRUDA, R. L.; SOUSA, L. T.; MARIANO, W. S. Automedicação verificação em estudantes universitários da Universidade Federal do Tocantins - UFT Araguaína. Ensaios e Ciência: Ciências Agrárias, Biológicas e da Saúde, Vol. 15, №. 6 , Ano 201, p. 21-30.

BALBIDO, C. A. Anti-inflamatórios: uma compreensão total. [ENTREVISTA cedida a] Pelo jornalista Aloísio Brandão, Revista Pharmacia Brasileira no 81 - Abril/Maio 2011. Disponível:

https://www.cff.org.br/sistemas/geral/revista/pdf/131/030a045_entrevista_dr _balbino.pdf. Acessado em 10/08/2021.

BEZERRA, J. L. Automedicação por usuários de uma farmácia comercial no bairro Pirajá na cidade de Juazeiro do Norte-Ce. 2006. 69p. Curso de Especialização em Assistência Farmacêutica. Escola de Saúde Pública do Ceará, 2006.

BRASIL. Agência Nacional de Vigilância Sanitária-ANVISA. Consulta Público no 95, de 19 de novembro de 2001.2 Disponível em: http://www4.anvisa.gov.br/base/visadoc/CP/CP\%5B2735-1-0\%5D.PDF Acessado em 03/08/2021.

BRASIL. Agência Nacional de Vigilância Sanitária - ANVISA. Resolução-RDC no 47, de 8 de setembro de 2009. Estabelece regras para elaboração, harmonização, atualização, publicação e disponibilização de bulas de medicamentos. Disponível em https://mooc.campusvirtual.fiocruz.br/rea/medicamentos-dabiodiversidade/RDC_47 09.pdf Acessado em 19/08/2021.

DUARTE, D’A; MALTA JÚNIOR, A. Perfil da automedicação em um a farmácia de dispensação em Barbalha - CE. Revista e-ciência, 2015, Volume 3, n² 2, p.66-73.

FILHO, C. C. V.; SILVA, D. A. Avaliação da dispensação de fármacos parcialmente seletivos para COX-2. Acta Biomédica Brasiliensia, ISSN 2236-0867, Volume 4, no 2, julho de 2013. p. 1-11.

GARBOSSA, A. F.; FRANCIELI P.; GIACOMELLI, G. M.; NADAL, J.; PRISCILA T.; FURMANN, P; THIESEN, P. C. T. Automedicação com analgésicos e anti-inflamatórios na cidade de Quedas do Iguaçu - PR. Revista de Biologia e Saúde da UNISEP. 2007, Volume 1, no 1, p. 9-15.

GELLER, M.; KRINCHANTOWSKI, A. V.; STEIN, M. Utilização do diclofenaco na prática clínica: revisão das evidências terapêuticas e ações farmacológicas. Rev. Bras. Clín. Med., São Paulo, 2012 jan-fev; Volume 10, no 1, p. 29-38. 
KRELING, M. C.G.D.; CRUZ, D. A. L. M.; PIMENTA, C. A. M. Prevalência de dor crônica em adultos. Revista Pesquisa Brasileira de Enfermagem Rev. Bras. Enferm. Ago. 2006 Volume 59, no4. Doi. https://doi.org/10.1590/S0034-71672006000400007.

LIMA, A. L. Z.; MOTA, P. M.; COELHO, E.; PAULA, E. M. X. Estudo sobre a utilização de anti-inflamatórios não esteroidais prescritos em receitas para idosos da Região Noroeste. Rev Ciênc. Farm. Básica Apl., 2010, Volume 31, no 2, p. 157-163.

LIRA, M. O. S. C.; MARIA, F. A. G. C. Dor Aguda e Relação de Gênero: Diferentes Percepções em Homens e Mulheres. Rev. Rene. 2013, Volume 14n no 1, p. 7181.

MALTA D. C.; MOURA, L.; PRADO, R. R.; ESCALANTE, J. C.; SCHMIDT, M. I.; DUNCAN, B. B. Mortalidade por doenças crônicas não transmissíveis no Brasil e suas regiões, 2000 a 2011. Epidemiol. Serv. Saúde, Brasília, out-dez 2014, Volume 23, no 4, p. 599-608. Doi: 10.5123/S1679-49742014000400002

MELGAÇO, S. S. C.; SARAIVA, M. I. R.; LIMA, T. T. C.; JUNIOR G. B. S.; DAHER, E. F. Nefrotoxidade dos anti-inflamatórios não esteroidais, Medicina (Ribeirão Preto), 2010. Volume 43, $\mathrm{n}^{\circ} 04$. Doi. https://doi.org/10.11606/issn.21767262.v43i4p382-390.

PINHEIRO M. R, WANNMACHER L. Uso racional de anti-inflamatórios não esteroides. In: MINISTÉRIO DA SAÚDE. Uso Racional de Medicamentos Temas relacionados. Brasília: Editora MS, 2012. Cap. 5, p. 41-50, ISBN 978-85-33.4-1897-4

RIGOTTO, G. C.; LIMA, R. R. O.; GERON, L. R. M.; SOUSA, J. M.; JUNIOR, A. T. T. A bula de medicamentos: A Importância da Leitura de Bulas. Revista Cientifica da Faculdade de Educação e Meio Ambiente jan. - jun.; 2016, Volume 7, no 1. P. 1626. Doi. https://doi.org/10.31072/rcf.v7i1.355

SALLUM, A. M. C.; GARCIA, D. M.; SANCHES, M. Dor aguda e crônica: Revisão narrativa da literatura. Acta paul. enferm., 2012, Volume 25, especial 1. Doi. https://doi.org/10.1590/S0103-21002012000800023

SCHALLEMBERGER, J. B.; PLESTSCH, U. M. Risco do uso indiscriminado de antiinflamatórios não esteroides. Relatório técnico-cientifico, evento: XXII seminário de iniciação cientifica, Modalidade do trabalho: Relatório técnico-científico, Campus ljuí Santa Rosa, Panambi e Três Passos 2014.

SILVA, F. A.; DUARTE, H. K. O.; RAIMUNDO, R. J. S. Estudo sobre automedicação no uso de anti-inflamatórios não esteroides na cidade de Valparaíso de Goiás. Revista Saúde e Desenvolvimento. jan. - jun. - 2016, Volume 9, no5. P. 142-153.

SILVA, J. M.; MENDONÇA, P. P.; PARTATA, A. K. Anti-inflamatórios não esteroidais e suas propriedades gerais. Revista Cientifica ITPAC, Araguaína- TO, out 2014, Volume 7, no 4, p. ISSN 1983-6708 
SIOMARA R. H. Avaliação Farmacoepidemiologia de anti-inflamatório não esteroidais em hospital geral do interior do RS. Tese (Pós Graduação em Medicina: Ciências Medicas), Faculdade de Medicina/UFRGS, Porto Alegre 2006.

SINITOX. Sistema Nacional de Informações Tóxico Farmacológica. Tabela 3 - Casos, Óbitos e Letalidade de Intoxicação Humana por Agente e por Região. Brasil, 2016. Disponivel em: https://sinitox.icict.fiocruz.br/sites/sinitox.icict.fiocruz.br/files//Brasil3_9.pdf. Acessado em 19/08/2021

SOUSA, J. M.; NETO, M. F. R.; PARTATA, A. K. Ação Anti-inflamatória da Nimesulida e seu Grau de Hepatotoxidade. Revista Científica do ITPAC, Araguaína, fev. 2016, Volume 9, no 1. ISSN 1983-6708.

VILETTI, F.; SANCHES, A. C. C. Uso indiscriminado ou irracional de anti-inflamatórios não esteroidais (AINES) observados em uma farmácia de dispensação. Visão Acadêmica, Curitiba, Jan 2009, Volume 10, $\mathrm{n}^{\circ} 1$, p. 69-76. Doi. http://dx.doi.org/10.5380/acd.v10i1.21321

VITOR, R. S.; LOPES, C. P.; MENEZES, H. S.; KERKHOFF, C. E. Padrão de consumo de medicamentos sem prescrição médica na cidade de Porto Alegre, RS. Ciênc. Saúde Coletiva, ISSN 1413-8123 (On-line version) 2008, Volume 13 (suppl), p. 737-743. Doi. https://doi.org/10.1590/S1413-81232008000700024 


\title{
CAPITULO XLIX
}

\section{VIGILÂNCIA EM SAÚDE NO CONTEXTO BRASILEIRO: UMA REVISÃO INTEGRATIVA}

DOI: 10.51859/AMPLLA.PAE1993-49

\author{
Ana Francesca Vommaro Leite ${ }^{1}$ \\ André Ribeiro Alexandre ${ }^{1}$ \\ José Renato Martins Cisconi ${ }^{1}$ \\ Otavio Dias Ferreira ${ }^{1}$ \\ Pedro Lucas Magalhães dos Reis ${ }^{1}$ \\ Policardo Gonçalves da Silva ${ }^{2}$
}

\begin{abstract}
${ }^{1}$ Graduando(a) do curso de graduação em Medicina na Universidade do Estado de Minas Gerais (UEMG) - Unidade Passos-MG.

2 Docente no curso de graduação em Medicina da Universidade do Estado de Minas Gerais (UEMG) - Unidade PassosMG. Doutorando no Programa de Pós-Graduação em Enfermagem Fundamental da Escola de Enfermagem de Ribeirão Preto/Universidade de São Paulo - EERP/USP.
\end{abstract}

\section{RESUMO}

A Vigilância é hoje um componente inequívoco da Saúde Pública brasileira, e tem como princípio a descentralização, sendo dividida em quatro campos principais e amparada por órgãos de diferentes níveis de competência. Tais órgãos recentemente foram atualizados com a Resolução 588/2018 do Conselho Nacional de Saúde, estruturadora da Polícia Nacional de Vigilância em Saúde de 2018. A perspectiva atual de Vigilância em Saúde no Brasil se fundamenta no modelo gerado a partir do movimento de Reforma Sanitária de 1986, e consolidado pela criação do Sistema Único de Saúde, sendo esse instituído pela Constituição de 1988 e pela Lei Orgânica de Saúde de 1990. Hoje, o modelo se distancia da centralização institucional e do foco nas campanhas sanitárias de outrora, e se estabelece como um conceito mais amplo de vigilância em saúde, que engloba a prevenção aos fatores de risco pertinentes não só à epidemiologia, mas também à saúde do trabalhador e à segurança ambiental. $O$ modelo descentralizado de vigilância, centrado no município, apresenta, no entanto, também um número de desafios conectados às desigualdades regionais, intrínsecas a um país de dimensões continentais e provedor de um sistema universal de saúde

Palavras-chave: Vigilância em Saúde, Saúde pública, Sistema Único de Saúde. 


\section{INTRODUÇÃO}

Descrita pela Política Nacional de Vigilância em Saúde (PNVS), o conceito de Vigilância em Saúde é definido como

"processo contínuo e sistemático de coleta, consolidação, análise de dados e
disseminação de informações sobre eventos relacionados à saúde, visando o
planejamento e a implementação de medidas de saúde
pública, incluindo a regulação, intervenção e atuação em condicionantes
e determinantes da saúde, para a proteção e promoção da saúde da
população, prevenção e controle de riscos, agravos e doenças" (BRASIL,
2018).

São áreas de sua atuação a vigilância, prevenção e o controle de doenças transmissíveis, de fatores de risco para o surgimento de doenças crônicas não transmissíveis, de saúde ambiental, e de saúde do trabalhador, além da análise situacional da saúde brasileira. Com a finalidade de atender a essas áreas, a Vigilância em Saúde se subdivide em Vigilância Epidemiológica, Vigilância Ambiental, Vigilância Sanitária e Vigilância em Saúde do Trabalhador (BRASIL, 2018).

No Brasil, os primeiros relatos de ações sistemáticas nas áreas de vigilância, prevenção e controle de doenças remontam ao século $X X$, com programas verticais, estruturados em forma de campanhas, que eram formulados, coordenados e executados pelo Governo Federal (NETTO et al, 2017).

Com a criação do Sistema Único de Saúde (SUS), ocorreram várias mudanças nas instituições de saúde, como a organização do Centro Nacional de Epidemiologia (CENEPI), a criação da Agência Nacional de Vigilância Sanitária (Anvisa), e, em 2003, a criação da Secretaria de Vigilância em Saúde (SVS). Mais recentemente, nos dias 27 de fevereiro a 2 de março de 2018, foi realizada a 1ạ Conferência Nacional de Vigilância em Saúde, a qual foi um marco na criação da PNVS, um passo de suma importância no desenvolvimento desta área em nosso país (GARCIA, 2018).

\section{MÉTODOS}

O presente artigo científico consiste em uma revisão integrativa da literatura, de abordagem qualitativa e caráter descritivo, sobre a Vigilância em Saúde no Brasil. Ressalta-se que o objetivo deste foi de fazer uma análise crítica acerca das publicações nacionais a respeito da temática e fomentar reflexões. 
Estudos metodológicos de caráter qualitativo na área da saúde adequam-se em tal categoria devido ao fato de formularem uma opinião na equipe pesquisadora, após a interpretação e análise dos dados coletados no estudo. Já a revisão integrativa caracteriza-se como uma busca pelo conhecimento disponível gerando um compilado sistematizado das informações coletadas (PEREIRA et al, 2018).

A pesquisa de artigos ocorreu no período de setembro de 2021, sendo realizada pela Biblioteca Científica Eletrônica Online SciELO, e buscou-se pelo descritor "Vigilância em Saúde". Como critério de inclusão valeu-se de artigos publicados nos últimos 5 anos e artigos que abordavam os temas: Vigilância em Saúde, Vigilância Sanitária, Vigilância Epidemiológica, Vigilância do Trabalhador e Vigilância Ambiental. Considerou-se como critério de exclusão artigos que não apresentavam os temas supracitados; não estavam inclusos na plataforma no período de busca; e apresentaram-se duplicados na base de dados.

Dessa forma, foram obtidos 216 resultados, sendo que os primeiros 100 trabalhos foram selecionados para leitura de títulos e resumos. Nesse momento, retomando o uso dos critérios de inclusão e exclusão, a equipe executora identificou 31 artigos para serem lidos na íntegra. Após realizar tal avaliação, 26 estudos foram considerados pertinentes pelos autores para compor tal revisão.

\section{RESULTADOS}

Os 26 artigos incluídos na presente revisão são apresentados no quadro 01.

Quadro 01: Resultados da revisão

\begin{tabular}{|c|c|c|c|}
\hline Autores & Título & $\begin{array}{c}\text { Ano de } \\
\text { Publica } \\
\text { ção }\end{array}$ & Revista \\
\hline $\begin{array}{c}\text { Albuquerq } \\
\text { ue, AC; } \\
\text { Cesse, } \\
\text { EAP; } \\
\begin{array}{c}\text { Felisberto, } \\
\text { E; Samico, } \\
\text { IC; Frias, } \\
\text { PG; }\end{array}\end{array} \quad \begin{array}{c}\text { Avaliação de desempenho da regionalização da vigilância } \\
\text { em saúde em seis Regiões de Saúde brasileiras }\end{array}$ & 2019 & $\begin{array}{c}\text { Cadernos de Saúde } \\
\text { Pública }\end{array}$ \\
\hline $\begin{array}{c}\text { Bezerra, } \\
\text { ACV }\end{array}$ & $\begin{array}{c}\text { Vigilância em saúde ambiental no brasil: Heranças e } \\
\text { desafios }\end{array}$ & 2017 & Saúde e Sociedade \\
\hline $\begin{array}{c}\text { Bezerra, } \\
\text { ACV; }\end{array}$ & $\begin{array}{c}\text { Metodologia participativa como instrumento para a } \\
\text { territorialização das ações da vigilância em saúde } \\
\text { Bitoun, J; }\end{array}$ & 2017 & Ciência e Saúde \\
ambiental
\end{tabular}




\begin{tabular}{|c|c|c|c|}
\hline Autores & Título & $\begin{array}{l}\text { Ano de } \\
\text { Publica } \\
\text { ção }\end{array}$ & Revista \\
\hline $\begin{array}{c}\text { Cazarin, G; } \\
\text { Reis, YAC; } \\
\text { Costa, } \\
\text { JMBS; } \\
\text { Duarte, } \\
\text { MS; } \\
\text { Bezerra, } \\
\text { LCA; }\end{array}$ & $\begin{array}{l}\text { Monitoramento do Desempenho da Gestão da Vigilância } \\
\text { em Saúde: análise dos usos e da influência }\end{array}$ & 2020 & Saúde em Debate \\
\hline $\begin{array}{c}\text { Croda, } \\
\text { JHR; } \\
\text { Garcia, LP; }\end{array}$ & $\begin{array}{l}\text { Resposta imediata da Vigilância em Saúde à epidemia da } \\
\text { COVID-19 }\end{array}$ & 2020 & $\begin{array}{l}\text { Epidemiologia e } \\
\text { Serviços de Saúde }\end{array}$ \\
\hline $\begin{array}{c}\text { Da Silva, } \\
\text { JAA; Costa, } \\
\text { EA; } \\
\text { Lucchese, } \\
\text { G; }\end{array}$ & Unified health system 30th birthday: Health surveillance & 2018 & $\begin{array}{l}\text { Ciência e Saúde } \\
\text { Coletiva }\end{array}$ \\
\hline $\begin{array}{c}\text { de Seta, } \\
\text { MH; } \\
\text { Oliveira, } \\
\text { CVS: Pepe, } \\
\text { VLE; }\end{array}$ & $\begin{array}{l}\text { Proteção à saúde no Brasil: O sistema nacional de } \\
\text { vigilância sanitária }\end{array}$ & 2017 & $\begin{array}{l}\text { Ciência e Saúde } \\
\text { Coletiva }\end{array}$ \\
\hline $\begin{array}{c}\text { Franco, } \\
\text { NG; } \\
\text { Villardi, } \\
\text { JWR; } \\
\text { Machado, } \\
\text { JMH; De } \\
\text { Souza, MS; } \\
\text { Brito, IF; } \\
\text { Santorum, } \\
\text { JA; Ocké- } \\
\text { Reis, CO; } \\
\text { Fenner, } \\
\text { ALD; }\end{array}$ & $\begin{array}{c}\text { Vigilância em saúde brasileira: Reflexões e contribuição } \\
\text { ao debate da 1a conferência nacional de vigilância em } \\
\text { saúde }\end{array}$ & 2017 & $\begin{array}{l}\text { Ciência e Saúde } \\
\text { Coletiva }\end{array}$ \\
\hline $\begin{array}{l}\text { Garcia, } \\
\text { LPDE; }\end{array}$ & $\begin{array}{l}\text { 1a Conferência Nacional de Vigilância em Saúde: marco } \\
\text { para a construção da Política Nacional de Vigilância em } \\
\text { Saúde }\end{array}$ & 2018 & $\begin{array}{l}\text { Epidemiologia e } \\
\text { Serviços de Saúde }\end{array}$ \\
\hline $\begin{array}{l}\text { Gondim, } \\
\text { GMM; }\end{array}$ & $\begin{array}{l}\text { Decifra-me ou te devoro: enigmas da Vigilância em Saúde } \\
\text { na pandemia Covid-19 }\end{array}$ & 2020 & $\begin{array}{l}\text { Trabalho, Educação } \\
\text { e Saúde }\end{array}$ \\
\hline $\begin{array}{c}\text { Guimarães } \\
\text {, RM; } \\
\text { Meira, KC; } \\
\text { Paz, EPA; } \\
\text { Dutra, } \\
\text { VGP; } \\
\text { Campos, } \\
\text { CEA; }\end{array}$ & $\begin{array}{l}\text { Os desafios para a formulação, implantação e } \\
\text { implementação da política nacional de vigilância em } \\
\text { saúde }\end{array}$ & 2017 & $\begin{array}{l}\text { Ciência e Saúde } \\
\text { Coletiva }\end{array}$ \\
\hline $\begin{array}{c}\text { Limongi, JE; } \\
\text { Caldeira,BFA } \\
\text {; Gonçalves, } \\
\text { LA; Félix, CG; } \\
\text { Bonito, RF; } \\
\text { Silva, VP; }\end{array}$ & $\begin{array}{l}\text { Estrutura e processos da Vigilância em Saúde em } \\
\text { municípios mineiros: uma análise qualiquantitativa }\end{array}$ & 2017 & $\begin{array}{l}\text { Cadernos de Saúde } \\
\text { Coletiva }\end{array}$ \\
\hline
\end{tabular}




\begin{tabular}{|c|c|c|c|}
\hline Autores & Título & $\begin{array}{l}\text { Ano de } \\
\text { Publica } \\
\text { ção }\end{array}$ & Revista \\
\hline $\begin{array}{c}\text { Neta, ISS; } \\
\text { Medeiros, } \\
\text { MS; } \\
\text { Gonçalves, } \\
\text { MJF; }\end{array}$ & $\begin{array}{l}\text { Vigilância da saúde orientada às condições de vida da } \\
\text { população: uma revisão integrativa da literatura }\end{array}$ & 2018 & Saúde em Debate \\
\hline $\begin{array}{c}\text { Okumoto, } \\
\text { O; Brito, } \\
\text { SMF; } \\
\text { Garcia, LP; }\end{array}$ & A Política Nacional de Vigilância em Saúde & 2018 & $\begin{array}{l}\text { Epidemiologia e } \\
\text { Serviços de Saúde }\end{array}$ \\
\hline $\begin{array}{l}\text { Pintor, } \\
\text { EAS; } \\
\text { Garbin, } \\
\text { AC; }\end{array}$ & $\begin{array}{c}\text { Notificações de violência relacionadas ao trabalho e } \\
\text { vigilância em saúde do trabalhador: rompendo a } \\
\text { invisibilidade }\end{array}$ & 2019 & $\begin{array}{l}\text { Revista Brasileira de } \\
\text { Saúde Ocupacional }\end{array}$ \\
\hline $\begin{array}{l}\text { Porto, } \\
\text { MFS; }\end{array}$ & $\begin{array}{c}\text { Pode a vigilância em saúde ser emancipatória? Um } \\
\text { pensamento alternativo de alternativas em tempos de } \\
\text { crise }\end{array}$ & 2017 & $\begin{array}{l}\text { Ciência e Saúde } \\
\text { Coletiva }\end{array}$ \\
\hline $\begin{array}{c}\text { Recktenwa } \\
\text { Idt, M; } \\
\text { Junges, JR; }\end{array}$ & $\begin{array}{l}\text { A organização e a prática da Vigilância em Saúde } \\
\text { em municípios de pequeno porte }\end{array}$ & 2017 & Saúde e sociedade \\
\hline $\begin{array}{c}\text { Ribeiro, IG; } \\
\text { Sanchez, } \\
\text { MN; }\end{array}$ & $\begin{array}{l}\text { Avaliação do sistema de vigilância da síndrome } \\
\text { respiratória aguda grave (SRAG) com ênfase em influenza, } \\
\text { no Brasil, 2014 a } 2016\end{array}$ & 2020 & $\begin{array}{l}\text { Epidemiologia e } \\
\text { Serviços de Saúde }\end{array}$ \\
\hline $\begin{array}{c}\text { Sales, } \\
\text { CMM; } \\
\text { Silva, Al; } \\
\text { Maciel, } \\
\text { ELN; }\end{array}$ & $\begin{array}{c}\text { Vigilância em saúde da COVID-19 no Brasil: investigação } \\
\text { de contatos pela atenção primária em saúde como } \\
\text { estratégia de proteção comunitária }\end{array}$ & 2020 & $\begin{array}{l}\text { Epidemiologia e } \\
\text { serviços de saúde }\end{array}$ \\
\hline Sevalho, G; & $\begin{array}{l}\text { Apontamentos críticos para o: Desenvolvimento da } \\
\text { vigilância civil da saúde }\end{array}$ & 2016 & $\begin{array}{l}\text { Physis: Revista de } \\
\text { Saúde Coletiva }\end{array}$ \\
\hline $\begin{array}{l}\text { Silveira, M; } \\
\text { Fenner, } \\
\text { ALD; }\end{array}$ & $\begin{array}{l}\text { Avaliação de impactos à saúde (AIS): Análises e desafios } \\
\text { para a vigilância em saúde do Brasil }\end{array}$ & 2017 & $\begin{array}{l}\text { Ciência e Saúde } \\
\text { Coletiva }\end{array}$ \\
\hline $\begin{array}{l}\text { Simões, } \\
\text { AFS; } \\
\text { Souza, } \\
\text { LEPF; }\end{array}$ & $\begin{array}{l}\text { As ações judiciais contra a Vigilância Sanitária: pode-se } \\
\text { falar de 'judicialização'? }\end{array}$ & 2018 & Saúde em Debate \\
\hline $\begin{array}{c}\text { Teixeira, } \\
\text { MG; Costa, } \\
\text { MCN; } \\
\text { Carmo, EH; } \\
\text { De } \\
\text { Oliveira, } \\
\text { WK; } \\
\text { Penna, } \\
\text { GO; }\end{array}$ & $\begin{array}{l}\text { Health surveillance at the SUS: Development, effects and } \\
\text { perspectives }\end{array}$ & 2018 & $\begin{array}{l}\text { Ciência e Saúde } \\
\text { Coletiva }\end{array}$ \\
\hline $\begin{array}{c}\text { Vianna, } \\
\text { LCR; } \\
\text { Ferreira, } \\
\text { AP; } \\
\text { Vasconcell } \\
\text { os, LCF; } \\
\text { Bonfatti, } \\
\text { RJ; Oliveira, } \\
\text { MHB; } \\
\end{array}$ & $\begin{array}{l}\text { Vigilância em Saúde do Trabalhador: um estudo à luz da } \\
\text { Portaria no } 3.120 / 98\end{array}$ & 2017 & Saúde em Debate \\
\hline
\end{tabular}




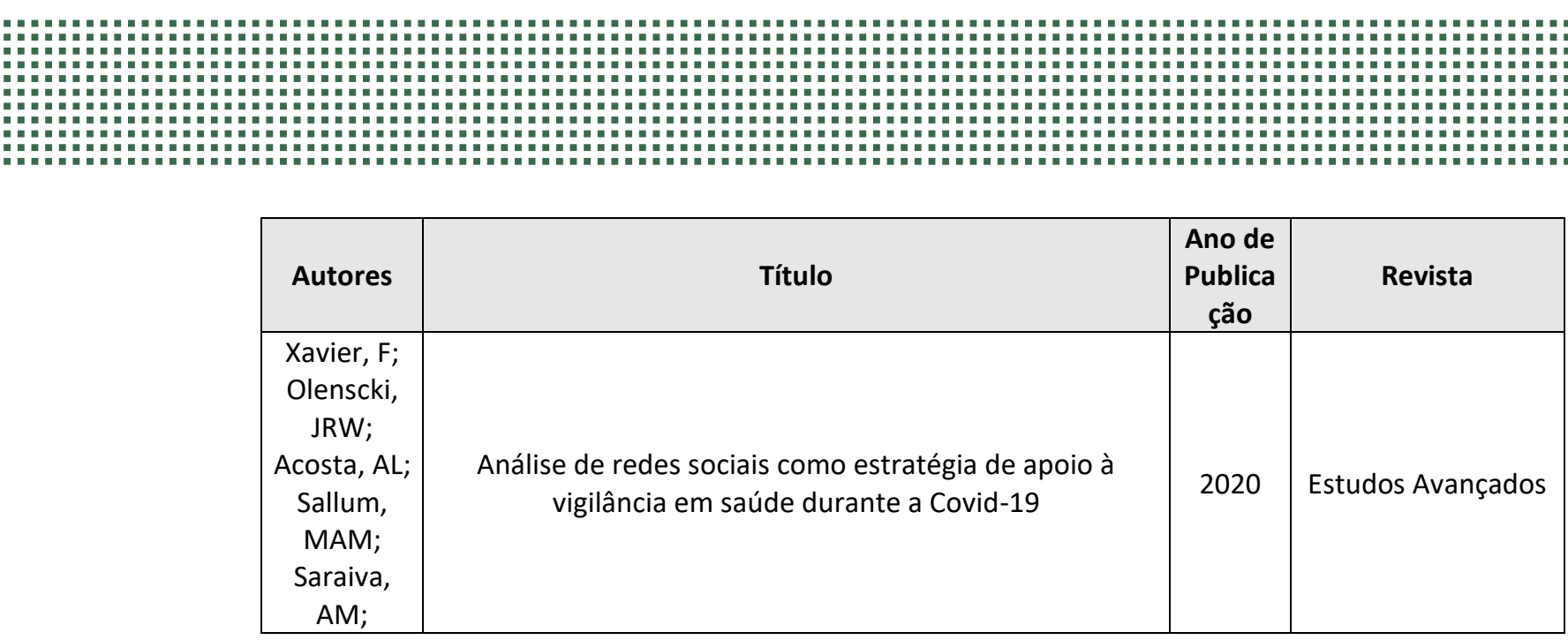

Fonte: autoria própria

\section{DISCUSSÃO}

No Brasil, o traçado histórico que tange o desenvolvimento da vigilância na saúde, está presente desde antes mesmo da criação de uma legislação que a preconiza. Embora presente, essa vigilância se fazia de forma incompleta e se concentrava nas regiões que moviam a economia brasileira, não apresentando uma organização efetiva em todas as esferas de poder.

Ao final do período do Governo Constitucional de Getúlio Vargas, foi instituída, pela Lei n. 378, de 13/01/1937, a Conferência Nacional de Saúde (CNS) como um mecanismo do governo federal para articular e conhecer ações desenvolvidas pelos estados na área da saúde (BRASIL, 2009).

A 1a CNS tinha como objetivos:

[...]ocupar-se dos diferentes problemas da saúde e da assistência, mas de modo especial dos seguintes: a) Organização sanitária estadual e municipal; b) ampliação e sistematização das campanhas nacionais contra a lepra e a tuberculose; c) determinação das medidas para desenvolvimento dos serviços básicos de saneamento e d) plano de desenvolvimento da obra nacional de proteção à maternidade, à infância e à adolescência." Um temário nitidamente relativo à gestão e administração dos serviços de saúde, no âmbito de um Estado que se constituía [...](BRASIL, 1941).

Apesar da determinação legal de que deveria ocorrer a cada dois anos, a 1a CNS ocorreu apenas no ano de 1941, durante o Estado Novo, a 2a CNS em 1950 e a 3a em 1963. A implementação das CNS foi um avanço, embora a passos curtos, da vigilância em saúde no Brasil. No período de sua criação, o atual Ministério da Saúde e o Ministério da Educação eram fundidos em um Ministério da Educação e Saúde, que viera a ser separado apenas no ano de 1953. Essa separação não possuía como objetivo a resolução 
dos problemas sanitários do país, tratava-se apenas de uma iniciativa para a separação dos dois setores (GUIMARÃES et al, 2017).

Podia notar-se, naquele momento, que a centralização das ações governamentais de saúde em um país de dimensões continentais, população majoritariamente rural e que passava por um intenso processo de transição demográfica8, não se fazia infimamente suficiente para atender as demandas populacionais. Com isso, na 3a CNS houve articulações por parte dos integrantes com propostas de descentralização e de redefinição dos papéis das esferas de governo, além de proposição de um plano nacional de saúde. Muito embora essa ideia fosse promissora e necessária, foi mantida no papel até o final da ditadura militar (BRASIL, 2009).

Com a aproximação do período de redemocratização brasileiro, pressões populares de movimentos sociais se fizeram presentes, incluindo movimentos acadêmicos que criticavam o modelo médico assistencial privatista. A necessidade de um programa de saúde coletiva, aliada à articulação realizada pela academia detentora de conhecimento do período, constituiu a formação do Movimento da Reforma Sanitária Brasileira (BRITO, 2007). É indubitável a participação do Movimento na proposta de teses apresentadas na $8^{a}$ CNS, realizada em 1986, que deu luz à possibilidade de se definir um conceito ampliado de saúde (GUIMARAES et al, 2017), que viria a ser materializado na Constituição Federal de 1988 e na criação de um Sistema Único de Saúde com a aprovação da Lei nำ8080, de 19 de setembro de 1990.

De fato, com a Reforma Sanitária de 1986, o movimento sanitário conseguiu encampar grande parte de suas propostas à Constituição de 1988, principalmente após a promulgação da Lei Orgânica de Saúde (lei n.8080/1990). Os propósitos da vigilância epidemiológica, foram assim ampliados, não mais abarcando somente o monitoramento das epidemias de zoonoses, mas "qualquer mudança nos fatores determinantes e condicionantes de saúde individual ou coletiva" (CUNHA E CARNUT, 2015).

Reunindo diversas funções em órgãos específicos e criando órgãos, como o Centro Nacional de Epidemiologia (Cenepi), o Ministério da Saúde norteou a Vigilância Epidemiológica no sentido da descentralização, trazendo o conhecimento epidemiológico como uma ferramenta estratégica para a definição de políticas e 
planejamento de ações (CUNHA E CARNUT, 2015). As competências do sistema foram então divididas entre as três esferas administrativas: a Secretaria de Vigilância em Saúde do Ministério da Saúde (SVS/MS), as Secretarias Estaduais de Saúde (SES) e as Secretarias Municipais de Saúde (SMS). A Secretaria de Vigilância em Saúde (SVS), criada em 2003, substituiu o Cenepi, buscando reafirmar o compromisso da esfera federal em coordenar ações de controle, prevenção e proteção à saúde (CUNHA E CARNUT, 2015).

No dia 12 de julho de 2018, com a Resolução no 588/2018 do Conselho Nacional de Saúde (CNS) foi instituída a PNVS, na qual está definido o conceito de vigilância no parágrafo 1 do artigo primeiro, onde está escrito que:

\footnotetext{
“entende-se por Vigilância em Saúde o processo contínuo e sistemático de coleta, consolidação, análise de dados e disseminação de informações sobre eventos relacionados à saúde, visando o planejamento e a implementação de medidas de saúde pública, incluindo a regulação, intervenção e atuação em condicionantes e determinantes da saúde, para a proteção e promoção da saúde da população, prevenção e controle de riscos, agravos e doenças" (BRASIL, 2018).
}

Para o cumprimento desse processo contínuo e sistemático, a vigilância em saúde se organiza com base na articulação efetiva entre as vigilâncias, na integração com os diversos pontos de atenção das redes de atenção à saúde, nos Sistemas de Informação integrados, na gestão do serviço, na educação permanente, nos estudos científicos e no controle social (ALBUQUERQUE et al, 2019).

Na mesma Resolução, fica definido que são áreas de atuação da Vigilância em Saúde: prevenção, vigilância e controle de doenças transmissíveis, de fatores de risco para o surgimento de doenças crônicas não transmissíveis, de saúde ambiental, e de saúde do trabalhador, além da análise situacional da saúde brasileira. Para isso, a Vigilância em Saúde se subdivide em Vigilância Sanitária, Vigilância Ambiental, Vigilância em Saúde do Trabalhador e Vigilância Epidemiológica (BRASIL, 2018).

A Vigilância em Saúde, assim como o SUS, segue um modelo de descentralização e regionalização dos serviços (ALBUQUERQUE et al, 2019). Partindo desse conhecimento, sabendo das disparidades socioeconômicas e político-culturais do Brasil, e valendo-se do conceito de determinantes sociais de saúde, compreende-se a necessidade de análises locais da qualidade dos serviços para que novas políticas assistenciais e administrativas sejam geradas. 
Um estudo que avaliou o desempenho da regionalização da Vigilância em Saúde em seis Regiões de Saúde brasileiras, concluiu que, em geral, os melhores desempenhos nesse quesito foram registrados em regiões com os maiores níveis de desenvolvimento socioeconômico e oferta de serviços. Ainda assim, a maioria dos resultados obtidos foram considerados intermediários ou insatisfatórios (ALBUQUERQUE et al, 2019), revelando que ainda há muito a se melhorar.

Outro estudo, avaliando a qualidade da Vigilância em Saúde em municípios de pequeno porte, os quais correspondem à maioria dos municípios brasileiros, concluiu que o repasse financeiro é insuficiente; o modelo de trabalho ainda é muito curativo, isto é, responde ao urgente pois não há tempo e planejamento para ações preventivas e educativas; a desvalorização das vigilâncias é facilmente observada; e as equipes de vigilância são pouco articuladas entre si e com outros serviços de saúde (RECKTENWALDT e JUNGES, 2017).

A Vigilância Sanitária, um componente de essencial papel no Sistema Único de Saúde (SUS), gerenciada pela Anvisa, é definida como um conjunto de práticas sanitárias e conhecimentos que têm como objetivos eliminar, diminuir ou prevenir riscos à saúde associados ao processo de produção, circulação e consumo de bens e serviços que se relacionam com a saúde, direta ou indiretamente, denotando, assim, sua abrangência e sua natureza essencialmente preventiva e regulatória ao atuar no controle desses riscos (SIMÕES e SOUZA, 2018).

O controle de qualidade dos serviços de saúde e a cultura de segurança do paciente são conceitos importantes no que tange a redução de riscos de danos desnecessários associados ao cuidado em saúde (SILVA, COSTA e LUCCHESE, 2018). Nesse sentido, a Vigilância Sanitária mostra-se imperiosa no cumprimento do princípio bioético da não maleficência.

Além dessa importante área de atuação, a Vigilância Sanitária, no Brasil, fiscaliza:

"alimentos; medicamentos; produtos biológicos - vacinas, hemoderivados,
órgãos e tecidos para transplantes; produtos médico-hospitalares,
odontológicos e laboratoriais, órteses e próteses; saneantes; produtos de
higiene, perfumes e cosméticos; serviços de saúde e relacionados à saúde;
controle sanitário de portos, aeroportos e fronteiras" (SILVA, COSTA e
LUCCHESE, 2018).

Na prática, a atuação da Vigilância Sanitária se dá por meio da expedição de licenças sanitárias para produção e comércio de bens e serviços, e de certificados de 
boas práticas de produção; fiscalização do cumprimento das normas sanitárias; e notificação e prevenção dos eventos adversos relacionados a esses bens (SILVA, COSTA e LUCCHESE, 2018).

Alguns episódios nacionais ocorridos na década de 90 acentuaram a importância da criação, regulamentação e efetivação da Vigilância Sanitária enquanto órgão essencial às boas práticas em saúde. Entre esses eventos, destacam-se a tragédia radioativa de Goiânia (GO), ocorrida após o descarte inadequado de césio-137 por um serviço de radioterapia, e a tragédia do soro Ringer Lactato em Recife (PE), na qual os pacientes infundidos com o soro contaminado por uma endotoxina bacteriana foram a óbito ou tiveram graves sequelas (SILVA, COSTA e LUCCHESE, 2018).

Não obstante, mesmo com o fortalecimento do Serviço Nacional de Vigilância Sanitária após a criação da Anvisa, análises de efetividade e propostas de melhorias são sempre necessárias para a superação das deficiências dos programas. Ainda assim, é inegável que a Vigilância Sanitária no Brasil, ao longo dos pouco mais de 30 anos do SUS, atingiu melhorias significativas (SILVA, COSTA e LUCCHESE, 2018).

A Vigilância em Saúde do Trabalhador é um outro componente SUS que possui como objetivos a promoção da saúde e a redução da morbidade e mortalidade dos trabalhadores do país. Atua por meio de ações integradas de intervenção nos agravos, bem como em seus determinantes, decorrentes dos modelos de desenvolvimento e dos processos de produção. Tal dimensão prevencionista cabe, principalmente, à Rede Nacional de Atenção Integral à Saúde do Trabalhador (RENAST), que conta com os Centros de Referência em Saúde do Trabalhador (CEREST), os seus núcleos executivos de ação efetiva. Tais instituições têm como objetivo fornecer auxílio técnico para o SUS, nas ações de promoção, prevenção, vigilância, diagnóstico, tratamento e reabilitação em saúde dos trabalhadores urbanos e rurais (VIANNA et al, 2017).

A principal estratégia de reconhecimento, combate e prevenção da violência contra o trabalhador, adotada pelo Ministério da Saúde, foi o sistema de notificação compulsória. Sabe-se que o rompimento da invisibilidade dessa forma de agressão contribui para a prevenção da violência de repetição e fortalece a rede de proteção e garantia de direitos dos trabalhadores, além de subsidiar ações de prevenção e promoção à saúde do trabalhador (VIANNA et al, 2017). 
A Vigilância Epidemiológica, por sua vez, recebeu atenção especial em toda América Latina em 1973, com a realização de um seminário no Rio de Janeiro, em que o conceito ganha uma dimensão menos abrangente, com a priorização da vigilância de doenças tropicais e zoonoses. Isso deve-se ao contexto sociopolítico da década de 1970, em que existia urgente necessidade de se maximizar a eficácia e a eficiência de programas de controle de doenças (CUNHA E CARNUT, 2015).

Em 1975, seguindo essa linha, foi instituído o Sistema Nacional de Vigilância Epidemiológica (SNVE), com a promulgação da lei n.6259/75. Juntamente com o sistema, foi divulgada a Lista Nacional de Doenças de Notificação Compulsória (portaria n.314/BSB, 1976), atualizada desde então (CUNHA E CARNUT, 2015).

Por fim, as discussões acerca da saúde ambiental possuem início incerto, embora alguns autores arrisquem estabelecer um período decisivo para o tema (CUNHA E CARNUT, 2015). A era microbiana ou bacteriológica, por exemplo, foi a fase responsável por banir a teoria miasmática, trazendo assim atenção para a tríade hospedeiroparasita-ambiente. Posteriormente, com a metodologia multicausal, adotada pela epidemiologia e pela saúde coletiva, o entendimento dos riscos ambientais, vulnerabilidades e doenças tornou-se mais determinante no processo saúde-doença (CZERESNIA e RIBEIRO, 2000).

No que tange o Brasil, a maior influência para o surgimento da Vigilância Ambiental advém das campanhas de saúde pública que aconteceram em meados do século XX, mostrando avanços e retrocessos ao longo do tempo. Tendo o principal objetivo de aproximar as abordagens dos diferentes tipos de riscos, assim como promover avanço na inter-relação entre as demais instâncias da vigilância em saúde, a vigilância em saúde ambiental embasa-se na interpretação do território em seu aspecto biológico-cultural-social, então como um espaço propício para análises e ações.

Visando o combate a vetores de doenças presentes no ambiente, as campanhas de saúde trouxeram à tona a percepção de que o espaço geográfico requer fiscalização, ao passo que pode ser fator causal e de agravamento de um número relevante de doenças. Nesse quesito, a vigilância em saúde ambiental emerge, nas últimas décadas do século XX, expondo a discussão dos riscos não biológicos como fatores de relevância no campo da saúde. Todavia, essa área de estudo, segue construindo sua identidade 
própria, uma vez que ainda existem divergências a serem superadas, como as distintas lógicas de planejamento dependentes da esfera federal e municipal.

\section{CONCLUSÃO}

Portanto, a partir das leituras elencadas, percebe-se bem que a origem do campo da Vigilância em Saúde, tal como ela apresenta-se nos dias de hoje, está mais definida pelas reformas iniciadas na saúde pública brasileira na década de 80 , consolidadas através da Constituição Cidadã de 1988, e através da Lei orgânica do SUS, de 1990. Assim, inicialmente, observa-se um modelo pautado pela centralização, fundado na lógica curativa, como visto com as políticas de saúde no período da Ditadura Militar (1964-1985) (principalmente durante a década de 1970, com a emergência de epidemias zoonóticas em um país em franca urbanização), mas também de caráter campanhístico, através de episódios focais que remontam ao início do século XX. Posteriormente, há a construção de um modelo descentralizado, focado na esfera municipal, e amparado em pontos distribuídos através da rede de atenção contida no SUS. Essa conformação deu-se apesar do histórico já exposto, ocorrendo tanto em segmentos dotados de órgãos precursores (como a vigilância epidemiológica) quanto em segmentos que ganham importância e abrem novos campos de estudo nas últimas décadas (como a Vigilância Ambiental).

É de extrema importância estabelecer que, apesar da inflexão observada a partir da Reforma Sanitária, devemos pontuar que a importância de novas políticas de saúde está longe de diminuir, uma vez que importantes distorções são visualizadas ao longo do tecido social brasileiro. A descentralização do sistema parece abrir margem para a expressão de desigualdades regionais na forma da oferta dos serviços de vigilância em saúde, um aspecto presente em um cenário cuja ausência de novos programas que fortaleçam a saúde pública brasileira, hoje alvo de um virulento projeto de sucateamento, acentuado nos últimos anos. Nesse cenário, encontramos grandes desafios concernentes à efetivação das políticas de saúde referentes à vigilância da festão previstas, desafios que incluem as reminiscências de modelos passados, o subfinanciamento e a desarticulação. 


\section{REFERÊNCIAS}

BRASIL. Conselho Nacional de Saúde. Resolução No 588, de 12 de julho de 2918. 2018. Disponível em: http://conselho.saude.gov.br/resolucoes/2018/Reso588.pdf

NETTO GF, VILLARDI JWR, MACHADO JMH, DE SOUZA MDS, BRITO IF, SANTORUM JA, ET AL. Vigilância em saúde brasileira: Reflexões e contribuição ao debate da 1a conferência nacional de vigilância em saúde. Cienc e Saude Coletiva 2017;22(10):3137-48.

GARCIA, Leila Posenato; DUARTE, Elisete. 1a Conferência Nacional de Vigilância em Saúde: marco para a construção da Política Nacional de Vigilância em Saúde. Epidemiol. Serv. Saúde, Brasília , v. 27, n. 2, e20180002, jun. 2018 Disponível em <http://scielo.iec.gov.br/scielo.php?script=sci_arttext\&pid=S167949742018000200001\&lng=pt\&nrm=iso>. acessos em 09 nov. 2021. Epub 10Ago-2018. http://dx.doi.org/10.5123/s1679-49742018000200020.

PEREIRA, A. S. et al. Metodologia da pesquisa científica.[e-book]. Santa Maria. Ed. UAB/NTE/UFSM. Disponível em: https://repositorio. ufsm. br/bitstream/handle/1/15824/Lic_Computacao_Metodologia-PesquisaCientifica. pdf, 2018.

BRASIL. Conselho Nacional de Secretários de Saúde. (Conass). As Conferências Nacionais de Saúde: Evolução e perspectivas. Cons Nac Secretários Saúde 2009.

BRASIL. M da E e. 1a Conferência Nacional de Educação e 1a Conferência Nacional de Saúde. Brasília Ministério da Educ e Saúde 1941;

GUIMARÃES RM, MEIRA KC, PAZ EPA, DUTRA VGP, CAMPOS CEA. Os desafios para a formulação, implantação e implementação da política nacional de vigilância em saúde. Cienc e Saude Coletiva 2017;22(5):1407-16.

FAUSTO BRITO. A Transição Demográfica No Brasil: As Possibilidades e os Desafios Para a Economia e a Sociedade. CEDEPLAR/FACE/UFMG 2007;вы12y(235):245.

ESCOREL S. Reviravolta na saúde origem e articulação do movimento sanitário. Editora FIOCRUZ; 1999.

BRASIL. LEI No 8.080, DE 19 DE SETEMBRO DE 1990. [Internet]. Brasília: 1990 [cited 2021 May 13]. Available from: http://www.planalto.gov.br/ccivil_03/leis/l8080.htm

CUNHA CLF, CARNUT L. Políticas e Sistemas de Saúde no Brasil. Cad Saude Publica [Internet] 2013 [cited 2021 May 13];29(7):1478-9. Available from: http://www.scielo.br/scielo.php?script=sci_arttext\&pid=S0102$311 X 2013000700022 \& \operatorname{lng}=e n \& n r m=i s o \& t \operatorname{lng}=p t$ 
ALBUQUERQUE AC DE, CESSE EÂP, FELISBERTO E, SAMICO IC, FRIAS PG DE. Avaliação de desempenho da regionalização da vigilância em saúde em seis Regiões de Saúde brasileiras. Cad Saude Publica 2019;35Suppl 2(Suppl 2):e00065218.

RECKTENWALDT M, JUNGES JR. A organização e a prática da Vigilância em Saúde em municípios de pequeno porte. Saude e Soc 2017;26(2):367-81.

SIMÕES AF DE S, SOUZA LEPF DE. As ações judiciais contra a Vigilância Sanitária: podese falar de "judicialização"? Saúde em Debate 2018;42(spe2):61-75.

DA SILVA JAA, COSTA EA, LUCCHESE G. Unified health system 30th birthday: Health surveillance. Cienc e Saude Coletiva 2018;23(6):1953-62.

VIANNA LCR, FERREIRA AP, VASCONCELLOS LCF DE, BONFATTI RJ, OLIVEIRA MHB DE. Vigilância em Saúde do Trabalhador: um estudo à luz da Portaria no 3.120/98. Saúde em Debate [Internet] 2017 [cited 2021 May 13];41(114):786-800. Available from: http://www.scielo.br/scielo.php?script=sci_arttext\&pid=S0103$11042017000300786 \& \operatorname{lng}=e n \& n r m=i s o \&$ tlng=pt

PINTOR EA DA S, GARBIN ADC. Notificações de violência relacionadas ao trabalho e vigilância em saúde do trabalhador: rompendo a invisibilidade. Rev Bras Saúde Ocup [Internet] 2019 [cited 2021 May 13];44. Available from: http://dx.doi.org/10.1590/2317-6369000006918

CZERESNIA D, RIBEIRO AM. The concept of space in epidemiology: a historical and epistemological interpretation [Internet]. Cad. saúde pública / Ministério da Saúde, Fundação Oswaldo Cruz, Esc. Nac. Saúde Pública 2000 [cited 2021 May 13];16(3):595-617. 


\title{
CAPITULO L
}

\section{VIOLÊNCIA SEXUAL INFANTIL: ATUAÇÃO DOS CIRURGIÕES DENTISTAS NA IDENTIFICAÇÃO}

DOI: 10.51859/AMPLLA.PAE1993-50

\author{
Livian Isabel de Medeiros Carvalho ${ }^{1}$ \\ Cecília Pacheco Calado ${ }^{1}$ \\ Myllenna Nayara de França Alves ${ }^{1}$ \\ Geovana de Brito Costa ${ }^{1}$ \\ Carlson Batista Leal ${ }^{2}$ \\ Danilo de Moraes Castanha ${ }^{2}$ \\ Herrison Felix Valeriano da Silva ${ }^{3}$
}

\begin{abstract}
${ }^{1}$ Graduando em Odontologia - Faculdades Nova Esperança - FACENE
${ }^{2}$ Residente em Cirurgia e Traumatologia Bucomaxilo Facial - Universidade Federal da Paraíba - UFPB

${ }^{3}$ Mestrando em Ciências Odontológicas - Universidade Federal da Paraíba - UFPB
\end{abstract}

\section{RESUMO}

A violência sexual infantil pode trazer danos à vítima, considerando desde as sequelas psicológicas até a morte. Com isto, além dos familiares, os profissionais da área da saúde, bem como os cirurgiões-dentistas, devem estar preparados e sensíveis pra identificar os sinais de violência. Com isto, o principal objetivo desse estudo é apresentar os principais sinais de violência sexual infantil e discutir como identificá-los durante o atendimento odontológico, as implicações éticas-legais relevantes ao assunto, bem como as atitudes que devem ser tomadas perante tal situação, incluindo os meios e formas de denúncias. A busca foi realizada nas bases de dados PubMed, Google Acadêmico e Scielo, sendo selecionados a busca sem data limite de publicação, baseando-se em artigos em linguagem inglesa e portuguesa. Logo, é de extrema importância disseminar a informação sobre a violência sexual infantil, sendo imprescindível para que a identificação ocorra de forma precoce, principalmente por parte dos profissionais da saúde, nas quais devem estar capacitados e atentos aos sinais que possam identificar as possíveis violências, tomando as medidas legais necessárias.

Palavras-chave:Abuso Sexual na Infância. Violência Sexual. Assistência Odontológica para Crianças. 


\section{INTRODUÇ̃̃o}

O termo violência pode ser definido, segundo a Organização Mundial da Saúde (OMS), como o uso intencional das condições físicas ou de poder, seja através de ameaças ou efetivação prática do ato violento, contra si próprio ou contra outros indivíduos. As consequências que resultam ou podem resultar os atos de violência incluemsofrimento, dano psicológico, morte, prejuízos de desenvolvimento ou privação (KRUG et al., 2002).

A violência, quando cometida contra crianças, elucida o conceito de violência infantil. Segundo a OMS, um dos tipos de violência praticada contra crianças é o abuso sexual (WHO, 2006). No brasil, os direitos das crianças e adolescentes vítimas ou testemunhas de violência são assegurados por lei (BRASIL, 2017). Na legislação nacional, quanto à tipificação das formas de violência contra crianças e adolescentes, o inciso III, alíneas a), b) e c)do Art. 4ㅇ da Lei № 13.431 de 4 de abril de 2017, esclarece que:

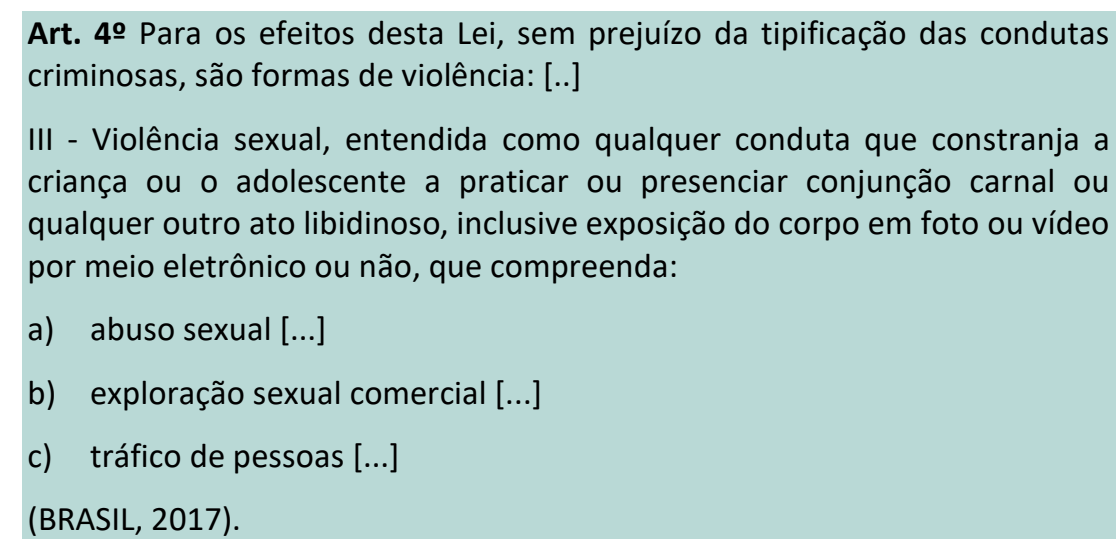

A respeito da definição etária, a Lei № 8.069/1990, que dispõe sobre o Estatuto da Criança e do Adolescente (ECA), estabelece, no Art. 2으, a classificação e os limites cronológicos de idade de crianças e adolescentes. Segundo a lei, é considerada criança a pessoa de até os 12 anos de idade incompletos e adolescente aquele que estiver entre 12 e 18 anos de idade. Entretanto, a lei ainda esclarece que, em situações excepcionais expressas em lei, o ECA pode ser aplicado as pessoas com idade entre 18 e 21 anos (BRASIL, 1990). Entretanto, segundo a OMS, a adolescência estende-se dos 10 aos 19 anos de idade (WHO, 1986).

Em relação aos aspectos epidemiológicos da violência, sabe-se que em 2018, através do Sistema de Informações de Agravos de Notificação (SINAN), foram 
computados por meio do Departamento de Informática do Sistema Único de Saúde do Brasil (DATASUS), 350.354 registros no Brasil de violência doméstica, sexual e outras violências. Entre esses casos, cerca de 140.373 (40,1\%) das vítimas eram de indivíduos da faixa etária entre 0 a 19 , dentre esses, mais de um terço $(36,4 \%)$ eram de crianças até nove anos (BARCELLOS, 2021).

A violência representa um problema social e de saúde pública, com maior exacerbação quando acontece na infância, provocando uma catastrófica repercussão no comportamento e desenvolvimento pessoal da vítima (NUNES; SALES, 2016). A violência sexual infantil, infelizmente, é um problema frequente e que acomete várias localidades, independentemente de classe social, etnia e cultura ou nível educacional (ALVES, 2016).

Caso não sejam tomadas medidas que visem prevenir os casos de abuso sexual infantil, a situação de violência pode causar danos biopsicossociais à criança e provocar consequências durante a vida adulta (ROCHA et al., 2021). Além disso, o aumento significativo no número de casos de violência infantil, de acordo com os dados epidemiológicos tanto nacionais como mundiais, evidencia o quão necessário e urgente é a implementação de ações para controle nos diversos âmbitos, sociais e profissionais (NUNES; SALES, 2016).

O profissional da área de saúde deve estar apto e atento para identificar os sinais de violência contra a criança (MARIN et al., 2015). Na Odontologia, entende-se que o atendimento odontológico é capaz de contribuir para o reconhecimento dos indícios de violência contra a criança (MATHUR; COPRAL, 2013; COSTACURTA et al., 2015). Diante de situações suspeitas de violência infantil, o cirurgião-dentista (CD) tem obrigação legal e ética de notificar e denunciar esses casos (MATHUR; COPRAL, 2013; RAYMAN; DINCER; ALMAS, 2013).

Assim sendo, considerando os números alarmantes de casos de violência sexual infantil e o papel do CD diante dessas situações, é essencial que este profissional esteja capacitado para identificar os sinais de violência contra criança. Além disso, é fundamental que o CD compreenda as normativas legais de notificação dos casos e entenda como proceder perante aos casos de violência sexual infantil.

Deste modo, o objetivo deste estudo foi apresentar os principais sinais de violência sexual infantil e como identificá-los durante o atendimento odontológico. De forma similar, também foi discutido quais atitudes devem ser tomadas perante as 
situações de violência sexual infantil, bem como dos meios e formas de denúncias.

Ademais, serão discutidas as implicações éticas-legais relevantes ao assunto.

\section{REVISÃO BIBLIOGRÁFICA}

Os movimentos sociais em defesa de menores vítimas da inescrupulosa violência sexual, obteve respaldo do Congresso Nacional em agosto de 2009 quando aprovada a Lei 12.015 que promoveu significativas alterações do Código Penal Brasileiro no que se referia aos crimes sexuais (GOUVÊA, 2021).

Assim, de acordo com a Lei $n \cong 12.015 / 2009$, que dispõe sobre crimes hediondos e inclui nessa categoria os crimes sexuais contra vulnerável, no Capítulo I dos crimes contra a liberdade sexual, o Art. 213 assegura:

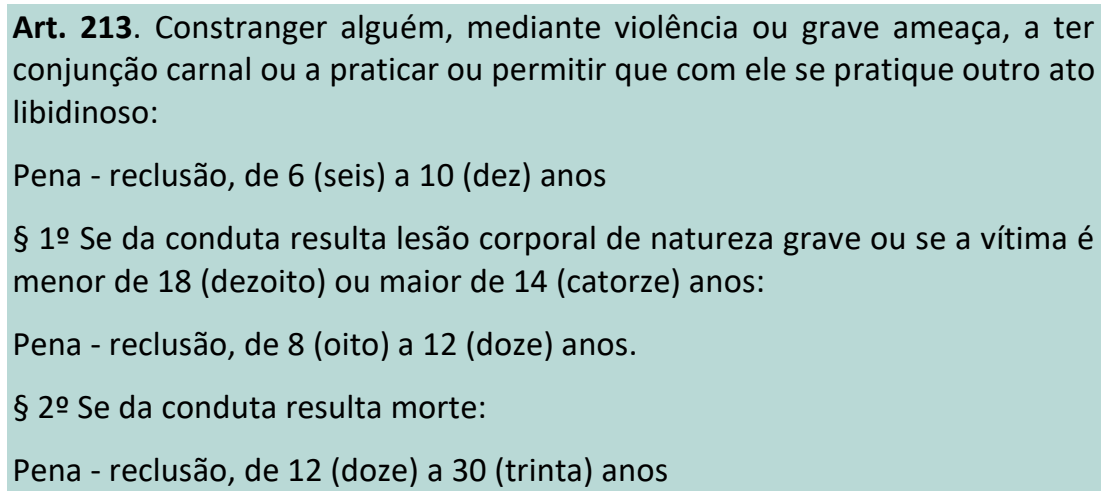

O sistema judiciário brasileiro reconhece crianças e adolescentes menores de 14 anos como um grupo que demanda legítima proteção penal contra todo e qualquer tipo de abuso sexual a que sejam submetidos por um adulto, sendo determinado no Art.217-A do Código Penal como:

\footnotetext{
Estupro de vulnerável

Art. 217-A. Ter conjunção carnal ou praticar outro ato libidinoso com menor de 14 (catorze) anos:

Pena - reclusão, de 8 (oito) a 15 (quinze) anos.

$\S 1$ Incorre na mesma pena quem pratica as ações descritas no caput com alguém que, por enfermidade ou deficiência mental, não tem o necessário discernimento para a prática do ato, ou que, por qualquer outra causa, não pode oferecer resistência.

$\S 2$ (Vetado)

$\S 3$ 으 Se da conduta resulta lesão corporal de natureza grave:

Pena - reclusão, de 10 (dez) a 20 (vinte) anos.

$\S 4$ 은 da conduta resulta morte:

Pena - reclusão, de 12 (doze) a 30 (trinta) anos
} 
No que diz respeito à proteção da criança e adolescente, o Código Penal, a partir das alterações realizadas pela Lei 12.015 , comina ainda penas para outras condutas tipificadas como crimes que são: a satisfação de lascívia mediante presença de criança ou adolescente e o favorecimento da prostituição ou de outra forma de exploração sexual de menor e vulnerável. Os artigos 218-A e 218-B do Código Penal, asseguram:

\section{"Satisfação de lascívia mediante presença de criança ou adolescente}

Art. 218-A. Praticar, na presença de alguém menor de 14 (catorze) anos, ou induzi-lo a presenciar, conjunção carnal ou outro ato libidinoso, a fim de satisfazer lascívia própria ou de outrem:

Pena - reclusão, de 2 (dois) a 4 (quatro) anos."

\section{"Favorecimento da prostituição ou outra forma de exploração sexual de} vulnerável

Art. 218-B. Submeter, induzir ou atrair à prostituição ou outra forma de exploração sexual alguém menor de 18 (dezoito) anos ou que, por enfermidade ou deficiência mental, não tem o necessário discernimento para a prática do ato, facilitá-la, impedir ou dificultar que a abandone:

Pena - reclusão, de 4 (quatro) a 10 (dez) anos.

$\S 1^{\circ}$ Se o crime é praticado com o fim de obter vantagem econômica, aplicase também multa.

$\S 2^{\circ}$ Incorre nas mesmas penas:

I - Quem pratica conjunção carnal ou outro ato libidinoso com alguém menor de 18 (dezoito) e maior de 14 (catorze) anos na situação descrita no caput deste artigo;

II - o proprietário, o gerente ou o responsável pelo local em que se verifiquem as práticas referidas no caput deste artigo.

$\S 3^{\circ} \mathrm{Na}$ hipótese do inciso II do $\S 2^{\circ}$, constitui efeito obrigatório da condenação a cassação da licença de localização e de funcionamento do estabelecimento."

\subsection{INDICADORES COMPORTAMENTAIS}

A violência sexual infantil ocasiona danos irreparáveis ao crescimento e desenvolvimento psicossocial da vítima (MIRANDA, 2020). Em decorrência da violência sexual, efeitos nocivos sobre a saúde mental, assim como, dificuldades nas interrelações pessoais são observadas, além disso, o comportamento autodestrutivo, distúrbios sexuais, episódios depressivos, pensamentos automáticos e disfuncionais, e problemas de processamento cognitivo são outras consequências lastimáveis analisadas (LIMA, 2021). 
Geralmente, a vítima de violência sexual infantil se comporta de maneira diferente de uma vítima de abuso sexual na idade adulta, pois, o fato iminente da vítima ser intimidada por um superior a ela, faz com que essa vítima não denuncie o abuso imediatamente (ROSENSTOCK, 2019). Os danos ocasionados são claros e podem persistir na idade adulta como quadros de depressão, transtorno obsessivo compulsivo, comportamento suicida, falta de ajuste social, falta de confiança e relações inseguras com os pais (MIRANDA, 2020).

Observa-se infelizmente, que a vítima infantil de violência sexual apresenta uma baixa autoestima, isto é, a criança vítima do abuso sexual prolongado usualmente desenvolve uma perda violenta da autoestima (RAMÍREZ, QUESADA, 2021). O suicídio, a ansiedade e a depressão são frequentes como consequências do sentimento de desmoralização e inutilidade pessoal devido à baixa autoestima que foi forjada, sendo isso afetado pelo início, duração e gravidade do abuso (ROSENSTOCK, 2019).

Mais da metade das meninas abusadas são diagnosticadas com Borderline, transtorno de personalidade marcado por uma acentuada instabilidade na autoimagem e nas relações interpessoais e episódios de psicoses, estando vinculado a autolesões e tentativas de suicídios, sendo essas também implicações do abuso sexual sofrido na infância (CRUZ, 2021). Assim, existe uma relação entre problemas de comportamento e doenças psiquiátricas em adultos e história de abuso sexual na infância (ROSENSTOCK, 2019).

Sabe-se que a vergonha relativa à vivência do abuso impacta na relação interpessoal da vítima, que pode assumir comportamentos cada vez mais retraídos. 0 comportamento retraído pode ainda predispor esses indivíduos a serem revitimizados, isso porque tendem a criar a introspecção como um mecanismo de defesa dificultando a revelação do agravo e, por conseguinte, possibilitando a ocorrência de outros abusos (CRUZ, 2021).

Além disso, os menores expostos a situações abusivas podem apresentar sérias alterações comportamentais, entre as quais é constatada a conduta hipersexualizada, esse comportamento sexual inadequado para a idade que se refere a experiências sexuais precoces é uma alteração frequente em meninas menores abusadas sexualmente, sendo um comportamento indicativo do abuso sexual confirmado em laudos periciais (LIRA, 2017). 
Foi constatado que em vítimas de abuso sexual na infância as alucinações auditivas são mais presentes, quando essas alucinações auditivas se tornam duradouras pode ser sinal de alerta para o abuso sexual (CRUZ, 2021). O entendimento do funcionamento psicológico pode ser de grande importância por fornecer as informações necessárias para compreender as características de personalidade, dinâmica emocional e comportamental dos menores que foram submetidos à violência sexual (LIMA, 2021).

\subsection{INDICADORES CLÍNIICOS}

O abuso sexual integra o grupo de agravos da categoria "Síndrome de Maus Tratos", elencado pela Classificação Internacional de Doenças, em sua10 Revisão (CID -10) (WHO, 2019).O conceito de abuso sexual na infância pode ser definido como o envolvimento da criança em alguma prática sexual, onde está não reconhece a situação e não é capaz de consentir com o ato. O abuso sexual é cometidocom o intuito de satisfazer os desejos e vontades sexuais de um adulto ou criança mais velhav(WHO, 1999).

No estudo conduzido por Enydy; Tkisouras e Csorba (2018), foram relatadas as características médicas e legais do abuso sexual em vítimas menores de 18 anos. Foi observado que $51,4 \%$ dos casos envolviam penetração vaginal, $41,8 \%$ perversão sexual (contato e toque genital) e 3,3\% penetração anal. Nota-se que a maior parte dos casos envolve algum tipo de contato íntimo entre o abusador e a vítima. Entretanto, ainda segundo o mesmo estudo, os sinais de lesão foram observadosem apenas 3,5\% dos casos.

Ainda é difícil diagnosticar com precisão os casos de violência sexual infantil, tendo em vista, que não há um padrão de sinais clínicos e psicossociais inerente às vítimas de abuso(VROLIK-BOSSCHAARTet al., 2018).Além disso, a maior parte das crianças vítimas de abuso podenão apresentar sinais físicos claros de violência sexual. Por isso, é necessário manter-se atento aos indícios sugestivos de abuso sexual (ESSABAR; KHALQALLAH; DAKHAMA, 2015; ADAMS; FAROT; KELLOG, 2018).

À vista disso, o profissional de saúde deve estar atento aos seguintes indicadores clínicos:

- Lesões em região genital (HOBBS; OSMAN, 2007); 
- Verrugas anogenitais induzidas pelo Papilomavírus Humano (HPV) (UNGER et al., 2011);

- Lesões em região anorretal(KARABAĞet al., 2018);

- Presença deinfecções sexualmente transmissíveis (IST) (BETCHEL, 2010);

- Gravidez (VROLIK-BOSSCHAART et al., 2018).

$\mathrm{O}$ atendimento médico das vítimas de abuso sexual infantil deve ser realizado de forma cautelosa (PFEIFFER, SALVAGNI, 2005). A avaliação do caso deve ser feita por profissionais de saúde experientes em uma equipe multidisciplinar. Além das queixas físicas, é importante que o profissional considere todo o contexto da situação, atentando-se ao comportamento da vítima durante o atendimento (VROLIKBOSSCHAART et al., 2018).Todos achados clínicos relevantes, encontrados no decurso do exame clínico, devem ser documentados através de fotografiase relatórios. Dessa forma, é possível fornecer as evidências necessárias para os processos jurídicos (LAHOTI et al., 2001; VROLIK-BOSSCHAARTet al., 2018; ENYEDY; TSIKOURAS; CSORBA, 2018).

\subsubsection{INDICADORES CLIÍNICOS NA ODONTOLOGIA}

O cirurgião-dentista pode desempenhar um papel significativo na identificação, notificação e prevenção dos casos de abusosexual infantil (COSTACURTA et al., 2015). Desse modo, é imprescindível que o profissional seja capaz de reconhecer e interpretar os sinais sugestivos de abuso sexual em crianças (CRESPO et al., 2011). Por isso, é importantesalientar algumas condições orofaciais que podem estar relacionadas ao abuso sexual infantil.

A criança vítima de abuso sexual pode apresentarmanifestações orais de infeções sexualmente transmissíveis (IST) (MENOLI et al., 2008). De acordo com o estudo de Fernández-Lopez e Morales-Ângulo (2019) a prática de sexo oral entre adultos pode ocasionar doenças infecciosas e traumas em região orofaríngea. Nesse mesmo estudo, é mencionado que nos casos onde uma criança, após o período neonatal, manifeste agravos como condiloma acuminado,sífilis (Figura 1), gonorreia (Figura 2) ouequimoses palatinas, deve-se suspeitar de abuso sexual.

A presença do papiloma escamosooral em crianças, pode ser um indício de abuso sexual, tendo em vista, que o vírus precursor da lesão, o Papiloma Humano (HPV), pode ser transmitido por via sexual (CANGUSSU et al., 2020). Nessas situações, em que uma 
criança apresenta sinais de IST, recomenda-se a investigação de abuso sexual (BETCHEL, 2010). Em razão disso, o cirurgião-dentista deve estar atento aosaspectos clínicos característicos do papiloma escamoso em cavidade oral (Figura 3 e 4).

O contato entre o pênis e a cavidade oral, durante a felação (sexo oral), pode ocasionar pequenos hematomas na região palatina (Figura 5 e 6). O trauma é causado pela pressão negativa criada pela sucção do pênis durante o ato sexual. As lesões decorrentes são, geralmente, assintomáticas e apresentam-se como petéquias e púrpuras localizadas na região posterior do palato mole (COHEN; MILLER, 2013). Segundo o estudo de Hauet- Wiedemannet al. (2018), osexo oral foi relatado em 14,6\% dos casos de abuso infantil. Assim sendo, lesões induzidas por sexo oral forçado podem ser observadas em crianças vítimas de abuso (COSTACURTA et al., 2015).

$\mathrm{Na}$ cavidade oral, a presença de lesões eritematosas, ulcerativas e vesiculares com drenagem purulenta ou psdeumembranosa também podem ser indícios relevantes de abuso sexual infantil (COSTACURTA et al., 2015). Em face do exposto, entende-seque o cirurgião-dentista deve desempenhar o papel de agente ativo no processo de diagnóstico e notificação dos casos de abuso sexual infantil.

Figura 1 - Aspecto clínico da sífilis em cavidade oral.

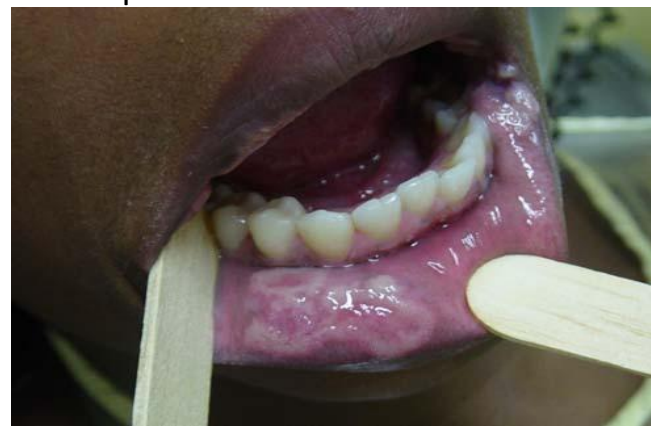

Fonte: NORONHA et al. 2006.

Figura 2 - Aspecto clínico da gonorreia em cavidade oral.

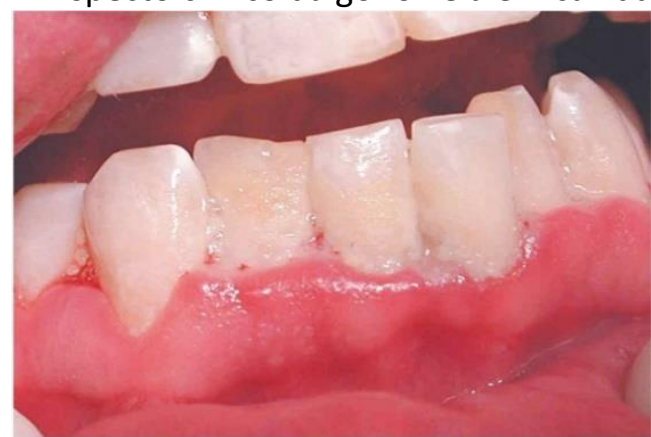

Fonte: NEVILLE; DAMM; ALLEN; CHI, 2016. 


\subsection{PERFIL DOS AGRESSORES SEXUAIS}

Em cerca de $90 \%$ dos casos, o autor do abuso sexual é usualmente conhecido, na maioria dos casos sendo pessoas ligadas às vítimas, sobre as quais exercem poder ou dependência, sendo ainda, verificado que o abuso sexual crônico acontece predominantemente na residência das vítimas, dentro do ambiente familiar, por pais e padrastos, e associado a outros tipos de maus-tratos que impedem o crime de ser descoberto (LUGÃO, 2012).

Ainda, estudos têm indicado que o perfil mais comum do autor de violência sexual contra crianças e adolescentes, geralmente é um agressor homem, com idade entre 30 e 40 anos, esse homem responde criminalmente geralmente apenas a processos sexuais, não possui histórico de reincidência criminal, é próximo de sua vítima (pai, padrasto, tio ou vizinho), e, geralmente, escolhe como local do abuso a residência da vítima ou a sua própria (TEIXEIRA, 2021).

Na maioria dos casos, como já analisado, o agressor é um parente ou alguém conhecido da família, que planeja suas ações, enganar a vítima, convence-a, manipula e suborna. O pedófilo sempre tem características peculiares, como ser muito cortês, e através disso ele tenta conquistar o carinho da criança por meio de elogios e presentes, observando como a vítima responde até aos poucos atingir seu objetivo (RAMIREZ, QUESADA, 2021).

Autores referem algumas características frequentes de pessoas que cometem abuso como a personalidade antissocial, paranoia, impulsividade, baixa tolerância à frustração, sentimentos de insuficiência. Já outros autores afirmam que não é possível formar um perfil único do agressor, já que são indivíduos que geralmente mantêm convívio social como quaisquer outros, sendo a incapacidade de cuidado e percepção das necessidades do menor o que se destaca no perpetrador do abuso (ARPINI, 2017).

De acordo com o perfil de personalidade, alguns autores classificam os autores de violência contra crianças e adolescentes em quatro categorias: pedófilos, psicóticos ou com retardo mental, agressor situacional, psicopatas ou antissociais. Os abusadores geralmente são mais sutis e discretos, além de serem indivíduos imaturos e com poucas habilidades sociais que comumente, envolvem-se com material pornográfico infantil (TEIXEIRA, 2021). 
Caracterizar o agressor sexual de crianças e adolescentes requer estudos em diversas áreas, pois envolve uma dimensão ampla, com um elevado grau de complexidade. A figura do agressor sexual tem sido pouco explorada em pesquisas realizadas no Brasil, por isso, pouco se sabe acerca das diversidades regionais que norteiam o fenômeno, dos aspectos societários e das questões de gênero que tangenciam a investigação do perfil do abusador (REIS, 2015).

Ainda no contexto nacional, outros estudos também observaram a ausência de informações sobre os agressores nos prontuários pesquisados, o que se constitui em um indicativo de que não está ocorrendo a caracterização apropriada desta população específica. Além disso, os casos que envolvem as mulheres como agressoras sexuais, os fatores tanto psicológicos, como sociais e culturais poderão contribuir para que essa violência sexual não seja considerada como abuso pelas próprias vítimas ou pelo meio social (BAÍA, 2013).

\title{
2.4. NOTIFICAÇ̃̃O E DENÚNCIA DOS CASOS DE VIOLÊNCIA INFANTIL
}

Segundo o Ministério da Saúde (2002), o conceito denotificação dos casos de violência infantil pode ser definido como:

\begin{abstract}
'Uma informação emitida pelo Setor Saúde ou por qualquer outro órgão ou pessoa, para o Conselho Tutelar, com a finalidade de promover cuidados sócios sanitários voltados para a proteção da criança e do adolescente, vítimas de maus-tratos. $O$ ato de notificar inicia um processo que visa a interromper as atitudes e comportamentos violentos no âmbito da família e por parte de qualquer agressor. A definição citada e o objetivo proposto significam, portanto, que notificação não é e nem vale como denúncia policial. O profissional de saúde ou qualquer outra pessoa que informa uma situação de maus-tratos está dizendo ao Conselho Tutelar: "esta criança ou este adolescente e sua família precisam de ajuda!" Ao registrar que houve maus-tratos, esse profissional atua em dois sentidos: reconhece as demandas especiais e urgentes da vítima; e chama o poder público à sua responsabilidade.
\end{abstract}

(BRASIL, 2002).

O profissional de saúde que não notificar os casos ou situações suspeitas de violência sexual infantil, poderá incorrer em crime de infração administrativa conforme expresso no Art. 245 da Lei 8.069/1999 do Estatuto da Criança e do Adolescente:

\footnotetext{
Art. 245. Deixar o médico, professor ou responsável por estabelecimento de atenção à saúde e de ensino fundamental, pré-escola ou creche, de comunicar à autoridade competente os casos de que tenha conhecimento, envolvendo suspeita ou confirmação de maus-tratos contra criança ou adolescente:
} 


Pena - multa de três a vinte salários de referência, aplicando-se dobro em
caso de reincidência.
(BRASIL, 1999).

Dessa forma, à vista da lei, trata-se de uma obrigação legal do cirurgião-dentista realizar a notificação dos casos de violência contra crianças e adolescentes. Sob o ponto de vista ético-profissional, o Código de Ética Odontológica expõe as seguintes providências: "Art. 5. Constituem deveres fundamentais dos profissionais e entidades de Odontologia: V - zelar pela saúde e pela dignidade do paciente" (CFO, 2003). No entanto, o Código de Ética em Odontologia ainda não é claro em relação à obrigatoriedade de denúncia dos casos de violência infantil (ALMEIDA et al., 2012).

O profissional de saúde tem o dever de notificar os casos e de prestar assistência à vítima de violência infantil (BRASIL, 2002).O Ministério da Saúde, por meio da Portaria № 1.968 de 25 de outubro de 2001, tornou obrigatório a notificação ao Conselho Tutelar, dos casos suspeitos e confirmados de maus tratos contra crianças e adolescentes atendidos pelo Sistema Único de Saúde. Para a notificação, deve-se preencher um formulário em duas vias, sendo uma delas anexada ao prontuário de atendimento e a outra encaminhada ao Conselho Tutelar (BRASIL, 2001). Relativo à denúncia, esta pode ser realizada de várias formas, neste capítulo, relatamos duas formas de denúncia que podem ser utilizados pelos profissionais nessas situações.

\subsubsection{CONSELHO TUTELAR}

O Conselho Tutelar é um órgão municipal criado com o intuito de zelar e garantir o cumprimento dos direitos das crianças e adolescentes (BRASIL, 1999). As denúncias de casos ou situações suspeitas de violência infantil podem ser feitas, de forma anônima, no Conselho Tutelar da região. A partir da notificação, o Conselho Tutelar poderá tomar as providências cabíveis conforme a gravidade de cada situação (BRASIL, 2002).

\subsubsection{DISQUE DIREITOS HUMANOS}

O Disque Direitos Humanos ou Disque 100 é um serviço 24 horas voltado para as denúncias de violação dos direitos humanos de diversos seguimentos sociais.As denúncias realizadas são recebidas pelo Ministério a Mulher, da Família e dos Direitos Humanos, analisadas e posteriormente encaminhadas aos órgãos de proteção competentes. Além do telefone disponível (100), as denúncias também podem ser realizadas via Whatsapp, pelo telefone (61) 99656-5008. De forma presencial, as 
denúncias podem ser feitas diretamente na Ouvidoria dos Direitos Humanos, localizada na Esplanada dos Ministérios em Brasília - DF.

\section{CONSIDERAÇÕES FINAIS}

Logo, é de extrema importância disseminar a informação sobre a violência sexual infantil, sendo imprescindível para que a identificação ocorra de forma precoce, principalmente por parte dos profissionais da saúde, nas quais devem estar capacitados e atentos aos sinais que possam identificar as possíveis violências, tomando as medidas legais necessárias.

\section{REFERÊNCIAS}

ALMEIDA, A. et al. A responsabilidade dos profissionais de saúde na notificação dos casos de violência contra crianças e adolescentes de acordo com seus códigos de ética. Arq. Odontol., v. 48, n. 2, 2012.

ALVES, $M$ et al. Importância do cirurgião-dentista no diagnóstico de abuso sexual infantil-revisão de literatura. Revista Brasileira de Odontologia Legal, v. 3, n. 2, 2016.

ARPINI, D.; SAVEGNAGO, S.; DOS SANTOS, C. O ponto de vista de adolescentes em situação de vulnerabilidade social sobre o agressor sexual. Revista Pesquisas e Práticas Psicossociais, v. 12, n. 2, p. 247-262, 2017.

BAÍA, P. et al. Caracterização da revelação do abuso sexual de crianças e adolescentes: negação, retratação e fatores associados. Temas em Psicologia, v. 21, n. 1, p. 193-202, 2013.

BARCELLOS, T. et al. Violência contra crianças: descrição dos casos em município da baixada litorânea do Rio de Janeiro. Escola Anna Nery, v. 25, 2021.

BECHTEL, K. Sexual abuse and sexually transmitted infections in children and adolescentes. Currentopinion in pediatrics, v. 22, n. 1 , p. 94-9, 2010.

BRASIL. Lei Federal n. 12.015, de 7 de agosto de 2009. Altera o Título VI da Parte Especial do Decreto-Lei no 2.848, de 7 de dezembro de 1940 - Código Penal, e o art. 10 da Lei no 8.072, de 25 de julho de 1990, que dispõe sobre os crimes hediondos, nos termos do inciso XLIII do art. 50 da Constituição Federal e revoga a Lei no 2.252, de 10 de julho de 1954, que trata de corrupção de menores. Brasília, 2009.

BRASIL. Lei № 13.431, de 4 de abril de 2017. Estabelece o sistema de garantia de direitos da criança e do adolescente vítima ou testemunha de violência e altera a Lei № 8.069, de 13 de julho de 1990 (Estatuto da Criança e do Adolescente). 
BRASIL. Lei № 8.069, de 13 de julho de 1990. Dispõe sobre o Estatuto da Criança e Adolescente e dá outras providências.

BRASIL. Notificação de maus-tratos contra crianças e adolescentes: um passo a mais na cidadania em saúde. 2ª ed. Brasília; 2002.

BRASIL. Portaria № 1. 968, de 25 de outubro de 2001. Dispõe sobre a notificação, às autoridades-competentes, de casos de suspeita ou de confirmação de-maustratos contra-crianças e adolescentes atendidos nas entidades do Sistema Unido de Saúde. Brasil, 2001.

CANGUSSU, A. et al. Papiloma oral escamoso em criança de 4 anos - relato de caso. Revista Científica do ITPAC, v.13, n.2, 2020.

CID-10. Classificação Estatística Internacional de Doenças e Problemas Relacionados à Saúde 10ạ Revisão (CID-10) - Versão da OMS para; 2019-covid-expandido.

COHEN ROSENSTOCK, S; COB GUILLÉN, E. Abuso sexual no paciente pediátrico. Medicina Legal da Costa Rica , v. 36, n. 1 p. 54-61, 2019.

COHEN, P.; VIRGINIA, M. Fellatio-associated petechiae of the palate: report of purpuric palatal lesions developing after oral sex. Dermatology online jornal, v. 19, n. 7, 2013.

COSTACURTA, M. et al. Oral and dental signs of child abuse and neglet. Oral Implatol., v. 8, n. 2-3, p. 68-63, 2015.

CRESPO, M. et al. O papel do medico dentista no diagnóstico e sinalização de abuso de crianças. Acta Med Port, v. 24, p. 939-948, 2011.

DA CRUZ, M. et al. Repercussões do abuso sexual vivenciado na infância e adolescência: revisão integrativa. Ciência \& Saúde Coletiva, v. 26, p. 1369-1380, 2021.

DE DEUS, N. et al. Papiloma Verrucoso em criança: Relato de caso. In: Jornada Odontológica de Anápolis (JOA) - Universidade Evangélica de Goiás, Anápolis GO. Anais da Jornada Odontológica de Anápolis (JOA), 2019.

DE SOUZA, J.; RESENDE, A; PERISSINOTTO, R. Psicopatia e Autores de Violência Sexual contra Crianças e Adolescentes. Avaliação Psicológica, v. 20, n. 1, 2021.

EIDT, G.; MAAS, J.; NETO, L. Criocirurgia como tratamento de papiloma escamoso em odontopediatria: relato de caso. RFO UPF, v.18, n.2, 2013.

ENYEDY, A. et al. Medical and Legal Aspects of Child Sexual Abuse: A Population-Based Study in a Hungarian County. International journal of environmental research and public health, v. 15, n. 4, p. 701, 2018.

ESSABAR, L. et al. Child sexual abuse: report of 311 cases with review of literature. The Pan African medical jornal, v. 20, n. 47, 2015. 
FERNÁNDEZ-LÓPEZ, C.; MORALES-ÂNGULO, C.. Otorhinolaryngology manifestations secondary to oral sex. Lesiones otorrinolaringológicas secundarias al sexo oral. Acta OtorrinolaringolEsp (Engl Ed), v. 68, n. 3, p. 169-180, 2017.

GOUVÊA, M.; CARVALHO, L.; SILVA, I. Movimentos sociais, participação infantil e direitos da criança no Brasil. Educação e Pesquisa, v. 47, 2021.

HAUET-WIEDEMANN, M. et al. Child sexual abuse: Description of a French population having consulted in a forensic medical service between 2011 and 2015. Archives de pediatrie :organeofficiel de La Societefrancaise de pediatrie, v. 25, n. 4, p. 247-250, 2018.

HOBBS, C. Physical evidence of child sexual abuse. European journal of pediatrics, v. 171, n. 5, p. 751-5, 2012.

KARABAĞ, G. et al. The importance of clinical approach in aggravated sexual abuse: Case report. TJTES, v. 24, n. 6, p. 597-600, 2018.

KRUG, E. G. et al. World report on violence and health Geneva: World Health Organization, 2002.

LAHOTI, S. et al. Evaluating the child for sexual abuse. American family physician, v. 63, n. 5, p. 883-92, 2011.

LIMA, E.; SCORTEGAGNA, S.; DE MARCHI, A. Aplicação Zulliger R-Optimized em Crianças Vítimas de Violência Sexual e Câncer. Paidéia, v. 31, 2021.

LIRA, M. et al. Abuso sexual na infância e suas repercussões na vida adulta. Texto \& Contexto-Enfermagem, v. 26, 2017.

LUGÃO, K. et al. Abuso sexual crônico: estudo de uma série de casos ocorridos na infância e na adolescência. DST-J bras Doenças Sex Transm, v. 24, n. 3, p. 179182, 2012.

MARIN, F. et al. O papel do profissional de saúde frente à violência e maus tratos na infância. Colloquium Vitae, v. 7, n. Especial, p. 96-103, 2015.

MATHUR, S.; CHOPRA, R. Combating child abuse: the role of a dentist. Oral Health Prev Dent., v. 11, n.3, p. 243-50, 2013.

MENOLI, A. et al. Manifestações bucais de maus-tratos físicos e sexuais em crianças Conduta do Cirurgião-dentista. Revista Varia Scientia, v. 7, n. 14, p. 11-22, 2009.

MENDEZ, L.; MARTINEZ, R.; RUBIO, M. Fellatio-associated erythema of the soft palate: an incidental finding during a routine dental evaluation. BMJ case reports, v. 2018, 2018.

MIRANDA, M. et al. Violência sexual contra crianças e adolescentes: uma análise da prevalência e fatores associados. Revista da Escola de Enfermagem da USP, v. 54, 2020. 
NEVILLE, B. et al. Patologia Oral e Maxilofacial. 4. ed. Rio de Janeiro: Elsevier, 2016. 912 p.

NORONHA, A. et al. Sífilis secundária: Diagnóstico a partir das lesões orais. DST -J BRAS DOENÇAS SEX TRANSM., v. 18, n. 3, p. 190-193, 2006.

NUNES, A.; SALES, M. Violência contra crianças no cenário brasileiro. Ciência \& Saúde coletiva, v. 21, p. 871-880, 2016.

PFEIFFER, L.; SALVAGNI, E. Current view of sexual abuse in childhood and adolescence. Jornal de pediatria, v. 81, n. 5, 2005.

RAMIRÉZ, M.; QUESADA, L. El abuso sexual enlainfancia y sus secuelas. MEDISAN vol.25 no.4 Santiago de Cuba julho-agosto. 2021 Epub 23 de agosto de 2021

RAYMAN, S.; DINCER, E.; ALMAS, K. Child abuse: concerns for oral health practitioners. NY State Dent J, v. 79, n. 4, p. 30-34, 2013.

REIS, D.; BARROS, A.; CAVALCANTE, L. Agressor sexual de crianças e adolescentes: uma discussão sobre o gênero dos participantes na literatura. Psicologia em Revista, v. 21, n. 2, p. 252-272, 2015.

SILVA, A.; TRINDADE, R.; OLIVEIRA, L. Presunção do abuso sexual em crianças e adolescentes: vulnerabilidade da gravidez antes dos 14 anos. Revista Brasileira de Enfermagem , v. 73, 2020.

UNGER, E. et al. Anogenital human papillomavirus in sexually abused and nonabused children: a multicenter study. Pediatrics, v. 128, n. 3, p. 658-65, 2011.

VROLIK-BOSSCHAART, T. et al. Clinical practice: recognizing child sexual abuse-what makes it so difficult?. European journal of pediatrics, v.177, n. 9, p. 1343-1350, 2018.

WHO, World Health Organization . Report of the consultation on child abuse prevention(WHO/HSC/PVI/99.1) World Health Organization; Geneva: 1999.

WHO, World Health Organization. ICD-10 for mortality and morbidity statistics. Version: 2019 April. Geneva: WHO, 2019.

WHO, World Health Organization. Preventing child maltreatment: a guide to taking action and generating evidence. Geneva: WHO, 2006.

WHO, World Health Organization. Young People's Health - a Challenge for Society. Report of a WHO Study Group on Young People and Health for All. TechnicalReport Series 731. Geneva: WHO, 1986. 


\title{
CAPITULO LI
}

\section{ARTEFATOS PRODUZIDOS POR MATERIAIS ODONTOLÓGICOS METÁLICOS RESTAURADORES EM IMAGENS DE RESSONÂNCIA MAGNÉTICA: UMA REVISÃO SISTEMÁTICA}

\author{
DOI: 10.51859/AMPLLA.PAE1993-51
}

\author{
Maille Ferreira Nunes Rocha ${ }^{1}$ \\ Ana Carolina Dias Viana de Andrade ${ }^{2}$ \\ Dauro Douglas Oliveira ${ }^{3}$ \\ Lucianne Cople Maia ${ }^{4}$ \\ Matheus Melo Pithon ${ }^{5}$
}

\begin{abstract}
Graduada em Odontologia pela Universidade Estadual do Sudoeste da Bahia- UESB e Mestre em Patologia pela Universidade de São Paulo - USP;

${ }^{2}$ Mestre em Biociência pela Universidade Federal da Bahia- UFBA, Doutoranda em Clínica Odontológica pela Pontifícia Universidade Católica de Minas Gerais - PUCMG e Professora do Curso de Medicina da Universidade Estadual do Sudoeste da Bahia - UESB.

${ }^{3}$ Doutor em Odontologia pela Universidade Federal do Rio de Janeiro -UFRJ e Professor Adjunto IV da Pontifícia Universidade Católica de Minas Gerais - PUCMG.

${ }^{4}$ Professora permanente do programa de pós-graduação em Odontopediatria e Ortodontia da Universidade Federal do Rio de Janeiro - UFRJ.

${ }^{5}$ Doutor em Odontologia pela Universidade Federal do Rio de Janeiro -UFRJ e Professor do curso de Odontologia da Universidade Estadual do Sudoeste da Bahia - UESB e Professor permanente do programa de pós-graduação em Odontopediatria e Ortodontia da Universidade Federal do Rio de Janeiro - UFRJ.
\end{abstract}

\section{RESUMO}

Objetivos: esclarecer questões relacionadas à produção de artefatos causados por materiais odontológicos metálicos restauradores nas imagens obtidas por ressonância magnética. Métodos: buscas realizadas por artigos na língua inglesa nas bases de dados Pubmed, Scopus, Web of Science, Clinical Trials, Cochrane e Grey Literature (OpenGrey), sem limite de ano. Para que fossem selecionados os artigos deveriam ser estudos in vitro, que analisassem materiais odontológicos metálicos submetidos ao procedimento de ressonância magnética para obtenção de imagens. Artigos com estudos in vivo e que avaliassem apenas materiais metálicos ortodônticos foram excluídos. Após a leitura dos títulos e resumos, os artigos potencialmente elegíveis foram lidos na íntegra. Os artigos selecionados foram avaliados, quanto à qualidade metodológica e ao risco de viés, de acordo com as características do estudo, as medidas utilizadas, a análise estatística e a significância clínica. Resultados: foram encontrados 2443 artigos, dos quais, 22 estavam de acordo com os critérios de inclusão e foram incluídos. Destes, 16 estudos utilizaram ligas dentárias para exposição à ressonância magnética, 8 avaliaram o amálgama, 9 estudos analisaram implantes dentários, enquanto 4 utilizaram materiais endodônticos e 6 usaram resinas compostas; 5 avaliaram o aço inoxidável. Conclusão: metais ferromagnéticos, como o aço inoxidável, geram artefatos extensos, podendo induzir uma interpretação imprecisa das imagens, assim como os implantes dentários, sendo considerados não compatíveis com a RM. Ligas de metais preciosos e amálgama não reduzem a qualidade da imagem de RM.

Palavras-chave: Imagem de ressonância magnática. materiais dentais. artefatos. 


\section{INTRODUÇÃO}

Uma das ferramentas mais eficazes de diagnóstico em radiologia e ciências de diagnóstico é a ressonância magnética (RM). O fornecimento de imagens da anatomia em qualquer plano e sua excelente resolução de contraste de tecidos moles são algumas de suas vantagens(SHAFIEI, HONDA et al., 2003). O número crescente de pacientes com dispositivos metálicos presentes na região orofacial, como coroas dentárias, pontes fixas, talas e implantes, dispositivos elétricos cirúrgicos e clipes, ocasionou a progressiva indicação de ressonância magnética das regiões de cabeça e pescoço (STARCUKOVA, STARCUK et al., 2008).

As propriedades físicas particulares do metal no campo magnético são importantes, uma vez que a RM é baseada na influência mútua entre a matéria investigada e o campo magnético (EGGERS, RIEKER et al., 2005). De acordo com a sua susceptibilidade magnética, todas as matérias, quando colocadas num campo magnético, são magnetizadas em vários graus (KLINKE, DABOUL et al., 2012). No entanto, muitos materiais utilizados na odontologia, sobretudo aqueles constituídos por vários componentes, ainda não possuem informações disponíveis dessa susceptibilidade (TYMOFIYEVA, VAEGLER et al., 2013).

Desta forma, distorções do campo magnético e a perda de sinal, que irão provocar um artefato na imagem, ocorrem devido às variações na intensidade do campo magnético que acontecem na interface entre o material dentário e os tecidos adjacentes (KLINKE, DABOUL et al., 2012), implicando em uma imagem de qualidade degradada, podendo comprometer a sua avaliação e, em alguns casos, torná-la impossível (COSTA, APPENZELLER et al., 2009).

A partir da necessidade de obter informações a respeito da qualidade da imagem produzida pela RM de pacientes que possuem materiais metálicos odontológicos na cavidade oral, esta revisão sistemática pretende elucidar questões sobre a produção de artefatos causados por materiais odontológicos metálicos restauradores nas imagens obtidas por ressonância magnética. 


\section{MATERIAIS E MÉTODOS}

\subsection{QUESTÃO NORTEADORA}

Esta revisão sistemática pretende responder a seguinte questão norteadora: Existem evidências científicas que comprovem a interferência de materiais odontológicos metálicos não ortodônticos na qualidade das imagens obtidas pelo procedimento de ressonância magnética?

\subsection{ESTRATÉGIA DE BUSCA}

Com a finalidade de selecionar artigos relevantes, buscas foram realizadas por artigos na língua inglesa sem limite de ano de publicação nas bases de dados eletrônicas: Pubmed, Scopus, Web of Science, Clinical Trials, Cochrane e Grey Literature (OpenGrey).

Buscas manuais também foram realizadas nas listas de referências dos estudos selecionados para averiguar se algum estudo não foi encontrado pelas pesquisas anteriores nos bancos de dados.

A estratégia de busca foi ajustada para cada base de dados e os seguintes descritores/Mesh foram utilizados: dental amalgam, dental implants, dental prosthesis, dental pins, crowns, dental materials, magnetic resonance imaging, artifacts, magnetic susceptibility, como demonstrado na Tabela 1.

Tabela 1 - Base de dados e método de pesquisa

\begin{tabular}{|c|c|c|}
\hline $\begin{array}{c}\text { Base de } \\
\text { dados }\end{array}$ & Estratégia de busca & Total \\
\hline Pubmed & $\begin{array}{l}\text { ((()("dental amalgam"[MeSH Terms] OR } \text { "dental } \\
\text { implants"[MeSH Terms]) OR "dental prosthesis"[MeSH Terms]) } \\
\text { OR "internal fixators"[MeSH Terms]) OR "dental pins"[MeSH } \\
\text { Terms]) OR "dental materials"[MeSH } \text { Terms]) OR } \\
\text { "crowns"[MeSH Terms]) AND (("magnetic resonance } \\
\text { imaging"[MeSH Terms] OR "artifacts"[MeSH Terms]) OR } \\
\text { magnetic susceptibility[Title/Abstract]) } \\
\end{array}$ & 1403 \\
\hline $\begin{array}{c}\text { Web of } \\
\text { Knowledge }\end{array}$ & $\begin{array}{l}\text { TS= (dental amalgam OR dental implants OR crowns OR dental } \\
\text { materials) AND (magnetic resonance imaging OR artifacts) }\end{array}$ & 1014 \\
\hline Scopus & $\begin{array}{l}\text { TITLE-ABS-KEY(dental amalgam OR dental implants OR dental } \\
\text { prosthesis OR internal fixators OR crowns) AND (magnetic } \\
\text { resonance imaging OR artifacts OR magnetic susceptibility) }\end{array}$ & 4 \\
\hline Cochrane & $\begin{array}{l}\text { dental amalgam OR dental implants OR dental prosthesis OR } \\
\text { internal fixators OR dental pins OR crowns OR dental materials } \\
\text { in Title, Abstract, Keywords and "magnetic resonance imaging" }\end{array}$ & 21 \\
\hline
\end{tabular}




\begin{tabular}{|c|l|c|}
\hline $\begin{array}{c}\text { Base de } \\
\text { dados }\end{array}$ & \multicolumn{1}{|c|}{ Estratégia de busca } & Total \\
\hline & $\begin{array}{l}\text { OR artifacts OR magnetic susceptibility in Title, Abstract, } \\
\text { Keywords }\end{array}$ & 1 \\
\hline $\begin{array}{c}\text { Clinical } \\
\text { Trials }\end{array}$ & $\begin{array}{l}\text { (dental amalgam OR dental materials) AND (magnetic } \\
\text { resonance imaging) }\end{array}$ & 0 \\
\hline $\begin{array}{c}\text { Grey } \\
\text { Literature }\end{array}$ & $\begin{array}{l}\text { ((dental amalgam OR dental materials) AND (magnetic } \\
\text { resonance imaging)) }\end{array}$ & 0 \\
\hline
\end{tabular}

Fonte: Autoria própria.

\subsection{CRITÉRIOS DE ELEGIBILIDADE DOS ARTIGOS}

Para que os artigos fossem selecionados, eles deveriam seguir os seguintes critérios de inclusão: ser um estudo in vitro que analisasse materiais odontológicos metálicos $(P)$ submetidos ao procedimento de ressonância magnética ( $E$ ) para obtenção de imagens (0). Anais de congresso, relatos de caso, duplicatas, estudos in vivo, revisões, estudos in vitro que avaliassem apenas materiais metálicos ortodônticos e artigos com descrição de técnica foram excluídos.

A seleção inicial foi realizada a partir da leitura dos títulos e resumos dos artigos encontrados. Quando o título e resumo não tinham informações suficientes ou se o resumo não estava disponível, os artigos eram baixados e lidos na íntegra para avaliação de sua elegibilidade. Os artigos encontrados em mais de uma base de dados foram considerados apenas uma vez.

Os estudos foram selecionados pelo pesquisador (M.F.N.R.) e, em caso de dúvidas com relação à inclusão ou exclusão de algum artigo, um segundo avaliador (M.M.P.) foi consultado até que houvesse um consenso.

\subsection{AVALIAÇÃO DA QUALIDADE E RISCO DE VIÉS}

Para a avaliação da qualidade metodológica dos estudos incluídos nesta revisão sistemática, utilizou-se um escore metodológico aplicado no estudo de Ehsani et al(Ehsani, Mandich et al., 2009) (Tabela 2). 
Tabela 2 - Pontuação Metodológica

I. Study Design ( $4 \checkmark$ )

A. Objective: objective clearly formulated $(\checkmark)$

B. Sample size: considered adequate and estimated before collection of data $(\checkmark)$

C. Baseline characteristics: similar baseline characteristics $(\checkmark)$

D. Co-interventions $(\checkmark)$

II. Study Measurements $(5 \checkmark)$

E. Measurement method: appropriate to the objective $(\checkmark)$

F. Blind measurement: blinding (examiner $\checkmark$, statistician $\checkmark$ )

G. Reliability: described $(\checkmark)$, adequate level of agreement $(\checkmark)$

III. Statistical Analysis ( $5 \checkmark$ )

H. Statistical analysis: appropriate for data $(\checkmark)$; combined subgroup analysis $(\checkmark)$

I. Confounders (co-interventions): confounders included in analysis $(\checkmark)$

J. Statistical significance level: P value stated $(\checkmark)$; confidence intervals $(\checkmark)$

IV. Others $(1 \checkmark)$

K. Clinical significance $(\checkmark)$

*Maximum number of $\checkmark \mathrm{s}=15$.

Fonte: Autoria própria.

Os artigos selecionados foram então avaliados de acordo com as características do estudo, as medidas utilizadas, a análise estatística e a significância clínica. Quando as informações solicitadas em cada item da lista de avaliação metodológica estavam presentes nos estudos de forma completa, a pontuação máxima era dada (ü); se as informações oferecidas estivessem incompletas, uma pontuação média era oferecida (/); e, se a informação solicitada não estivesse presente, o estudo não recebia nenhuma pontuação $(x)$.

\section{RESULTADOS}

\subsection{BUSCA}

As buscas nas bases de dados eletrônicas encontraram 2443 artigos, dos quais, após a leitura dos títulos e resumos, 111 artigos foram considerados elegíveis. Os que estavam de acordo com os critérios de inclusão juntamente com os encontrados nas listas de referência totalizaram 22 artigos incluídos nesta revisão, conforme apresentado no flowchart (Figura 1). 


\subsection{AVALIAÇÃO DA QUALIDADE}

A Tabela 3 ilustra a pontuação recebida pelos artigos após a avaliação metodológica e algumas falhas puderam ser observadas: no que se refere à descrição clara do objetivo, apenas 1 estudo (LISSAC, COUDERT et al., 1992) não foi pontuado neste quesito; 3 (FACHE, PRICE et al., 1987; LISSAC, COUDERT et al., 1992; FIALA, PAIGE et al., 1994) não pontuaram quanto à padronização das amostras; no que concerne ao método de medida, somente 7 estudos (LISSAC, METROP et al., 1991; LISSAC, COUDERT et al., 1992; VIKHOFF, RIBBELIN et al., 1995; HUBALKOVA, HORA et al., 2002; STARČUK, BARTUŠEK et al., 2006; TANIYAMA, SOHMURA et al., 2010; TYMOFIYEVA, VAEGLER et al., 2013) não pontuaram neste quesito; apenas 1 estudo (ABBASZADEH, HEFFEZ et al., 2000) relatou o desconhecimento do examinador sobre o material medido e 4 artigos (VIKHOFF, RIBBELIN et al., 1995; BEHR, FELLNER et al., 1996; SHAFIEI, HONDA et al., 2003; CHEN, WU et al., 2010) receberam pontuação máxima para um dos itens avaliados sobre confiabilidade. Somente 5 estudos (BEUF, LISSAC et al., 1994; SHAFIEI, HONDA et al., 2003; DESTINE, MIZUTANI et al., 2008; CHEN, WU et al., 2010; DUTTENHOEFER, MERTENS et al., 2015) foram pontuados em todos os itens quanto à análise estatística; quanto ao quesito nível de significância estatística, apenas 2 estudos (SHAFIEI, HONDA et al., 2003; CHEN, WU et al., 2010) relataram o valor de $p$ e o intervalo de confiança, recebendo pontuações máximas nesse quesito. 
Figura 1 - Fluxograma.

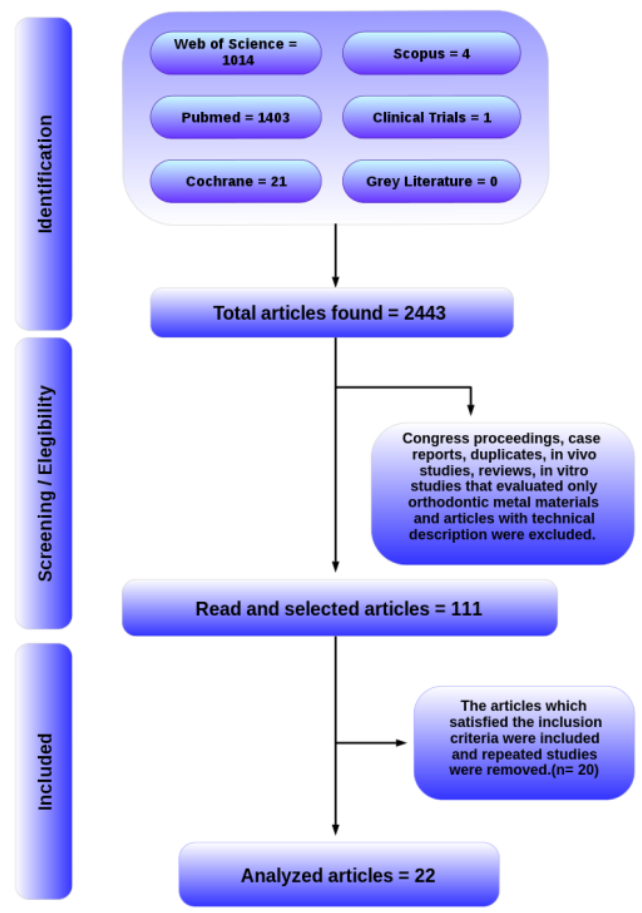

Fonte: Autoria própria.

Tabela 3 - Protocol for qualitative scoring of methodology of articles analyzed.

\begin{tabular}{|c|c|c|c|c|c|c|c|c|c|c|c|c|}
\hline AUTOR & A & B & C & D & $E$ & $\mathbf{F}$ & $\mathbf{G}$ & $\mathrm{H}$ & I & J & $\mathrm{K}$ & Total \\
\hline $\begin{array}{l}\text { Abbaszadeh, } \\
\text { Heffez and } \\
\text { Mafee (2000) }\end{array}$ & $\checkmark$ & $\checkmark$ & / & $\checkmark$ & $\checkmark$ & $\sqrt{x}$ & $x x$ & $x x$ & $\checkmark$ & $x x$ & $\checkmark$ & 7,5 \\
\hline $\begin{array}{l}\text { Behr et al. } \\
(1996)\end{array}$ & $\checkmark$ & $\checkmark$ & $\checkmark$ & $\checkmark$ & $\checkmark$ & $x x$ & $\sqrt{x}$ & $x x$ & $\checkmark$ & $x x$ & $\checkmark$ & 8 \\
\hline $\begin{array}{l}\text { Beuf et al. } \\
(1994)\end{array}$ & / & $\checkmark$ & $\checkmark$ & $\checkmark$ & $\checkmark$ & $x X$ & $x X$ & $\checkmark \checkmark$ & $\checkmark$ & $\sqrt{x}$ & $\checkmark$ & 9,5 \\
\hline $\begin{array}{lr}\text { Chen, } \begin{array}{r}\text { Wu } \\
\text { and Wang } \\
(2010)\end{array} \\
\end{array}$ & $\checkmark$ & $\checkmark$ & $\checkmark$ & $\checkmark$ & / & $x x$ & $\sqrt{x}$ & $\sqrt{ } \sqrt{ }$ & $\checkmark$ & $\sqrt{ } \sqrt{ }$ & $\checkmark$ & 11,5 \\
\hline $\begin{array}{l}\text { Destine, } \\
\text { Mizutani and } \\
\text { Igarashi } \\
(2008) \\
\end{array}$ & $\checkmark$ & $\checkmark$ & $\checkmark$ & $\checkmark$ & $\checkmark$ & $x X$ & $x X$ & $\sqrt{ } \checkmark$ & $\checkmark$ & $\sqrt{x}$ & $\checkmark$ & 10 \\
\hline $\begin{array}{l}\text { Duttenhoefer } \\
\text { et al. (2014) }\end{array}$ & $\checkmark$ & $\checkmark$ & $\checkmark$ & $\checkmark$ & $\checkmark$ & $x x$ & $x x$ & $\checkmark \checkmark$ & $\sqrt{ }$ & $\sqrt{x}$ & $\checkmark$ & 10 \\
\hline $\begin{array}{l}\text { Eggers et al. } \\
(2005)\end{array}$ & $\checkmark$ & $\checkmark$ & $\checkmark$ & $\checkmark$ & $\checkmark$ & $x x$ & $x x$ & $x^{\sqrt{ }}$ & $\checkmark$ & $x x$ & $\checkmark$ & 8 \\
\hline $\begin{array}{ll}\text { Fache } & \text { et } \\
\text { al.(1987) } & \\
\end{array}$ & $\checkmark$ & $\checkmark$ & $\mathrm{x}$ & $\checkmark$ & $\checkmark$ & $x X$ & $x x$ & $X X$ & $\checkmark$ & $X X$ & $\checkmark$ & 6 \\
\hline $\begin{array}{l}\text { Fiala et al. } \\
(1994)\end{array}$ & $\checkmark$ & $\checkmark$ & $x$ & $\checkmark$ & $\checkmark$ & $x x$ & $x x$ & $x x$ & $\checkmark$ & $x x$ & $\checkmark$ & 6 \\
\hline $\begin{array}{l}\text { Grosse et al. } \\
(2013)\end{array}$ & / & $\checkmark$ & $\checkmark$ & $\checkmark$ & $\checkmark$ & $x x$ & $x x$ & $x x$ & $\checkmark$ & $x x$ & $\checkmark$ & 6,5 \\
\hline $\begin{array}{l}\text { Hubálkóva et } \\
\text { al. (2002) }\end{array}$ & $\checkmark$ & $\checkmark$ & $\checkmark$ & $\checkmark$ & $x$ & $x X$ & $x x$ & $x x$ & $\checkmark$ & $x x$ & $\checkmark$ & 6 \\
\hline limuro (1994) & 1 & $\checkmark$ & $\checkmark$ & $\checkmark$ & $\checkmark$ & $x x$ & $x x$ & $x x$ & $\checkmark$ & $x x$ & $\checkmark$ & 6,5 \\
\hline
\end{tabular}




\begin{tabular}{|l|c|c|c|c|c|c|c|c|c|c|c|c|}
\hline \multicolumn{1}{|c|}{ AUTOR A } & B & C & D & E & F & G & H & I & J & K & Total \\
\hline $\begin{array}{l}\text { Klinke et al. } \\
\text { (2012) }\end{array}$ & $\checkmark$ & $\checkmark$ & $\checkmark$ & $\checkmark$ & $\checkmark$ & xx & xx & xx & $\checkmark$ & xx & & 7 \\
\hline $\begin{array}{l}\text { Lissac et al. } \\
\text { (1991) }\end{array}$ & $\checkmark$ & $\checkmark$ & $\checkmark$ & $\checkmark$ & x & xx & xx & xx & $\checkmark$ & xx & $\checkmark$ & 6 \\
\hline $\begin{array}{l}\text { Lissac et al. } \\
\text { (1992) }\end{array}$ & x & $\checkmark$ & x & $\checkmark$ & x & xx & xx & xx & $\checkmark$ & xx & $\checkmark$ & 4 \\
\hline $\begin{array}{l}\text { Shafiei et al. } \\
\text { (2003) }\end{array}$ & $\checkmark$ & $\checkmark$ & $\checkmark$ & $\checkmark$ & $/$ & xx & $\checkmark x$ & $\checkmark \checkmark$ & $\checkmark$ & $\checkmark \checkmark$ & $\checkmark$ & 11,5 \\
\hline $\begin{array}{l}\text { Starčuk et al. } \\
\text { (2006) }\end{array}$ & $\checkmark$ & $\checkmark$ & $\checkmark$ & $\checkmark$ & $\mathrm{x}$ & $\mathrm{xx}$ & $\mathrm{xx}$ & $\mathrm{xx}$ & $\checkmark$ & $\mathrm{xx}$ & $\checkmark$ & 6 \\
\hline $\begin{array}{l}\text { Starcuková et } \\
\text { al. (2008) }\end{array}$ & $\checkmark$ & $\checkmark$ & $\checkmark$ & $\checkmark$ & $\checkmark$ & $\mathrm{xx}$ & $\mathrm{xx}$ & $\mathrm{x} \checkmark$ & $\checkmark$ & $\mathrm{x} \checkmark$ & $\checkmark$ & 9 \\
\hline $\begin{array}{l}\text { Taniyama et } \\
\text { al. (2010) }\end{array}$ & $/$ & $\checkmark$ & $\checkmark$ & $\checkmark$ & $\mathrm{x}$ & $\mathrm{xx}$ & $\mathrm{xx}$ & $\mathrm{xx}$ & $\checkmark$ & $\mathrm{xx}$ & $\checkmark$ & 5,5 \\
\hline $\begin{array}{l}\text { Timofiyeva et } \\
\text { al. (2013) }\end{array}$ & $\checkmark$ & $\checkmark$ & $\checkmark$ & $\checkmark$ & $\mathrm{x}$ & $\mathrm{xx}$ & $\mathrm{xx}$ & $\mathrm{xx}$ & $\checkmark$ & $\mathrm{xx}$ & $\checkmark$ & 6 \\
\hline $\begin{array}{l}\text { Vikhoff et al. } \\
\text { (1995) }\end{array}$ & $\checkmark$ & $\checkmark$ & $\checkmark$ & $\checkmark$ & $\mathrm{x}$ & $\mathrm{xx}$ & $\checkmark \mathrm{x}$ & $\mathrm{xx}$ & $\checkmark$ & $\mathrm{xx}$ & $\checkmark$ & 7 \\
\hline $\begin{array}{l}\text { Zho et al. } \\
\text { (2013) }\end{array}$ & $/$ & $\checkmark$ & $/$ & $\checkmark$ & $\checkmark$ & $\mathrm{xx}$ & $\mathrm{xx}$ & $\mathrm{xx}$ & $\checkmark$ & $\mathrm{xx}$ & $\checkmark$ & 6 \\
\hline
\end{tabular}

Fonte: Autoria própria.

\subsection{DESCRIÇÃO DA AMOSTRA}

Com relação às amostras, 16 estudos (LISSAC, METROP et al., 1991; LISSAC, COUDERT et al., 1992; BEUF, LISSAC et al., 1994; BEHR, FELLNER et al., 1996; ABBASZADEH, HEFFEZ et al., 2000; HUBALKOVA, HORA et al., 2002; SHAFIEI, HONDA et al., 2003; EGGERS, RIEKER et al., 2005; STARČUK, BARTUŠEK et al., 2006; DESTINE, MIZUTANI et al., 2008; STARCUKOVA, STARCUK et al., 2008; CHEN, WU et al., 2010; TANIYAMA, SOHMURA et al., 2010; KLINKE, DABOUL et al., 2012; TYMOFIYEVA, VAEGLER et al., 2013; ZHO, KIM et al., 2013) utilizaram ligas dentárias para exposição à ressonância magnética; referindo-se à amálgama, esta amostra foi utilizada por 8 estudos (LISSAC, METROP et al., 1991; LISSAC, COUDERT et al., 1992; VIKHOFF, RIBBELIN et al., 1995; ABBASZADEH, HEFFEZ et al., 2000; EGGERS, RIEKER et al., 2005; STARČUK, BARTUŠEK et al., 2006; STARCUKOVA, STARCUK et al., 2008; ZHO, KIM et al., 2013); implantes dentários estavam presentes na amostra de 9 estudos (LISSAC, METROP et al., 1991; BEHR, FELLNER et al., 1996; ABBASZADEH, HEFFEZ et al., 2000; HUBALKOVA, HORA et al., 2002; SHAFIEI, HONDA et al., 2003; EGGERS, RIEKER et al., 2005; TYMOFIYEVA, VAEGLER et al., 2013; ZHO, KIM et al., 2013; DUTTENHOEFER, MERTENS et al., 2015). 
Somente 4 (FACHE, PRICE et al., 1987; VIKHOFF, RIBBELIN et al., 1995; GROSSE, SYHA et al., 2013; TYMOFIYEVA, VAEGLER et al., 2013) estudos incluíram em sua amostra materiais endodônticos e 6 (FACHE, PRICE et al., 1987; LISSAC, COUDERT et al., 1992; VIKHOFF, RIBBELIN et al., 1995; KLINKE, DABOUL et al., 2012; GROSSE, SYHA et al., 2013; TYMOFIYEVA, VAEGLER et al., 2013) avaliaram resinas compostas. O aço inoxidável também foi analisado por alguns estudos (FACHE, PRICE et al., 1987; FIALA, PAIGE et al., 1994; IIMURO, 1994; ABBASZADEH, HEFFEZ et al., 2000; HUBALKOVA, HORA et al., 2002). A comparação com o grupo controle foi realizada em apenas 6 estudos (IIMURO, 1994; ABBASZADEH, HEFFEZ et al., 2000; SHAFIEI, HONDA et al., 2003; DESTINE, MIZUTANI et al., 2008; CHEN, WU et al., 2010; KLINKE, DABOUL et al., 2012).

\subsection{CARACTERÍSTICAS DOS ESTUDOS}

No que concerne ao método de medida, 8 artigos (FACHE, PRICE et al., 1987; FIALA, PAIGE et al., 1994; BEHR, FELLNER et al., 1996; DESTINE, MIZUTANI et al., 2008; GROSSE, SYHA et al., 2013; TYMOFIYEVA, VAEGLER et al., 2013; ZHO, KIM et al., 2013; DUTTENHOEFER, MERTENS et al., 2015) mediram os artefatos a partir da distância entre a borda do material até a borda da imagem resultante, 6 (BEUF, LISSAC et al., 1994; ABBASZADEH, HEFFEZ et al., 2000; SHAFIEI, HONDA et al., 2003; STARCUKOVA, STARCUK et al., 2008; CHEN, WU et al., 2010; KLINKE, DABOUL et al., 2012) utilizaram programas específicos, apenas 2 estudos (IIMURO, 1994; EGGERS, RIEKER et al., 2005) compararam as imagem com a presença e ausência do material, e 6 (LISSAC, METROP et al., 1991; LISSAC, COUDERT et al., 1992; VIKHOFF, RIBBELIN et al., 1995; HUBALKOVA, HORA et al., 2002; STARČUK, BARTUŠEK et al., 2006; TANIYAMA, SOHMURA et al., 2010) não mencionaram o método de medida escolhido.

Alguns estudos (HUBALKOVA, HORA et al., 2002; DESTINE, MIZUTANI et al., 2008; TYMOFIYEVA, VAEGLER et al., 2013) relataram que ligas de metais preciosos podem causar grandes artefatos, outros afirmaram que ligas de metais preciosos, como o ouro, podem gerar artefatos mínimos (BEUF, LISSAC et al., 1994; KLINKE, DABOUL et al., 2012) ou não produzem distorções (FACHE, PRICE et al., 1987; LISSAC, METROP et al., 1991; LISSAC, COUDERT et al., 1992). Artefatos de graus variados são determinados por implantes dentários (LISSAC, METROP et al., 1991; LISSAC, COUDERT et al., 1992; HUBALKOVA, HORA et al., 2002; EGGERS, RIEKER et al., 2005; DUTTENHOEFER, 
MERTENS et al., 2015). Alguns autores (LISSAC, METROP et al., 1991; LISSAC, COUDERT et al., 1992; EGGERS, RIEKER et al., 2005) observaram que o amálgama não gera artefatos, enquanto que outros autores descreveram a extensão mínima de distorções causadas por este material (ABBASZADEH, HEFFEZ et al., 2000; STARCUKOVA, STARCUK et al., 2008; DUTTENHOEFER, MERTENS et al., 2015). HUBÁLKOVÁ et al encontraram artefatos com $55 \mathrm{~mm}$ de diâmetro relacionados a splints cirúrgicos constituídos por aço inoxidável; além disso, foi exposto que o aço inoxidável gera uma perda de sinal bem definida (LISSAC, METROP et al., 1991; LISSAC, COUDERT et al., 1992; FIALA, PAIGE et al., 1994; IIMURO, 1994; ABBASZADEH, HEFFEZ et al., 2000).

Um resumo sobre a descrição dos estudos incluídos, explanando sobre algumas características - amostras, tipo de técnica utilizada na exposição, método de medida dos artefatos - está presente na Tabela 4.

Tabela 4 - Descrição dos estudos.

\begin{tabular}{|c|c|c|c|c|c|c|}
\hline Autor & $\begin{array}{l}\text { Grupo } \\
\text { teste }\end{array}$ & $\begin{array}{c}\text { Grupo } \\
\text { controle/Espé } \\
\text { cime }\end{array}$ & Exposição & $\begin{array}{l}\text { Método } \\
\text { de } \\
\text { medida }\end{array}$ & Resultados & Conclusão \\
\hline $\begin{array}{l}\text { Abbaszad } \\
\text { eh, Heffez } \\
\text { and } \\
\text { Mafee } \\
(2000)\end{array}$ & $\begin{array}{l}\text { - Type III } \\
\text { dental } \\
\text { gold } \\
-\quad \text { Dental } \\
\text { lathe-cut } \\
\text { amalgam } \\
\text { - Stainless } \\
\text { steel } \\
\text { crown } \\
\text { - Titanium } \\
\text { endosseo } \\
\text { us } \\
\text { implant } \\
-\quad \text { Silver- } \\
\text { palladium } \\
\text { crown } \\
\text { substruct } \\
\text { ure } \\
\text { - } \\
\text { Vitallium } \\
\text { bone } \\
\text { screw }\end{array}$ & $\begin{array}{l}\text { Vitamin } \\
\text { capsule } \\
\text { Bovine muscle } \\
\text { tissue }\end{array}$ & $\begin{array}{l}\text { Tl-weighted } \\
\text { images } \\
(\mathrm{TR} / \mathrm{TE} \\
500 / 14 \mathrm{~ms})\end{array}$ & $\begin{array}{l}\text { Boley } \\
\text { gauge, } \\
\text { accurate to } \\
\text { the nearest } \\
\text { millimeter. }\end{array}$ & $\begin{array}{l}\text { Gold produced } \\
\text { the greatest } \\
\text { artifact. } \\
\text { Amalgam and } \\
\text { titanium } \\
\text { implant } \\
\text { produced the } \\
\text { least artifact. } \\
\text { The artifacts } \\
\text { produced by } \\
\text { other materials } \\
\text { were } \\
\text { intermediate. } \\
\text { The vitamin E } \\
\text { capsule did not } \\
\text { create an } \\
\text { artifact. }\end{array}$ & $\begin{array}{l}\text { All metals used } \\
\text { in this study } \\
\text { produced } \\
\text { artifacts to } \\
\text { varying } \\
\text { degrees. } \\
\text { The clinician } \\
\text { should inform } \\
\text { the artifacts so } \\
\text { that the } \\
\text { technician can } \\
\text { use preventive } \\
\text { measures to } \\
\text { minimize the } \\
\text { negative effect } \\
\text { of such } \\
\text { artifacts in the } \\
\text { interpretation } \\
\text { of MR images. }\end{array}$ \\
\hline $\begin{array}{l}\text { Behr et al. } \\
1996\end{array}$ & $\begin{array}{l}\text {-Dental } \\
\text { alloys } \\
\text {-Dental } \\
\text { implants }\end{array}$ & $\begin{array}{l}\text { Not mentioned } \\
\text { Simplified TMJ- } \\
\text { model }\end{array}$ & $\begin{array}{l}\text { SE technique } \\
\mathrm{TR}=450 \mathrm{~ms}, \mathrm{TE}= \\
15 \mathrm{~ms} . \\
\mathrm{GE} \text { technique } \\
\mathrm{T} 1-\text { weighted: } \\
\mathrm{TR}=280 \mathrm{~ms} \text {, } \\
\mathrm{TE}=10 \quad \mathrm{~ms} \text {, } \\
\alpha=20 \text {. } \\
\mathrm{T} 2 \text {-weighted: } \\
\mathrm{TR}=450 \mathrm{~ms} \text {, }\end{array}$ & $\begin{array}{l}\text { Artefacts } \\
\text { were } \\
\text { graded on a } \\
\text { scale from } \\
0 \text { to 5. 0: no } \\
\text { artefacts at } \\
\text { all, 1: slight } \\
\text { artefacts, } \\
\text { 2: minimal, } \\
\text { 3: } \\
\text { moderate, }\end{array}$ & $\begin{array}{l}\text { Category A: Ag, } \\
\mathrm{Cu}, \mathrm{Cr}, \mathrm{Ga}, \mathrm{In}, \\
\mathrm{Sn}, \mathrm{Ti}, \mathrm{Zn}, \mathrm{y} \text {-two } \\
\text { free amalgam, } \\
\text { Herador H, } \\
\text { Maingold SG, } \\
\text { Mainbond A, } \\
\text { Heraloy G and } \\
\text { Pors on. } \\
\text { Category B: Pt, } \\
\text { Pd, Wiron 99. }\end{array}$ & $\begin{array}{l}\text { Precious alloys } \\
\text { are } \\
\text { diamagnetic. } \\
\text { They do not } \\
\text { cause metallic } \\
\text { artefacts. } \\
\text { Artefacts } \\
\text { appears as } \\
\text { distortions } \\
\text { with SE } \\
\text { technique and }\end{array}$ \\
\hline
\end{tabular}




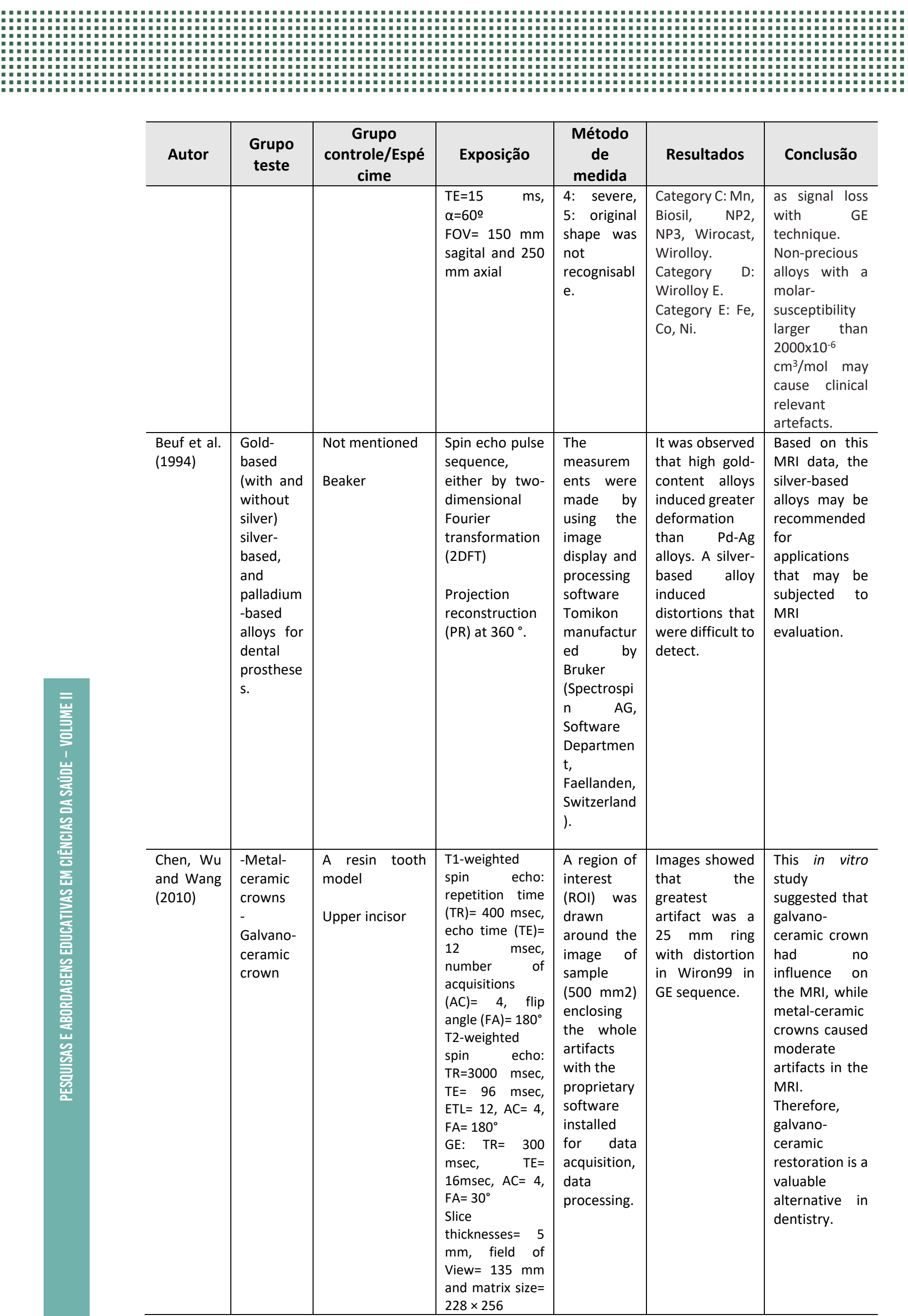




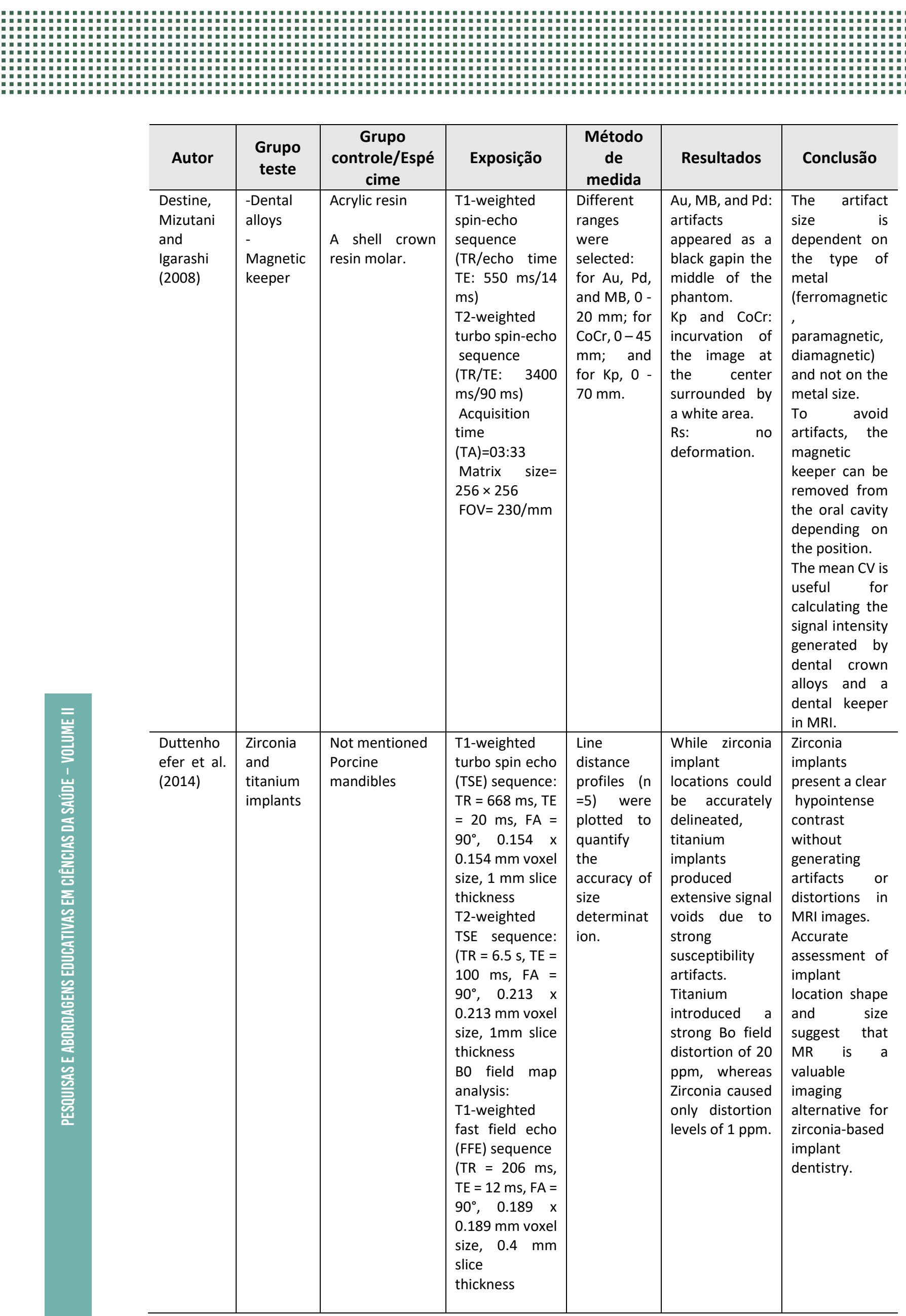




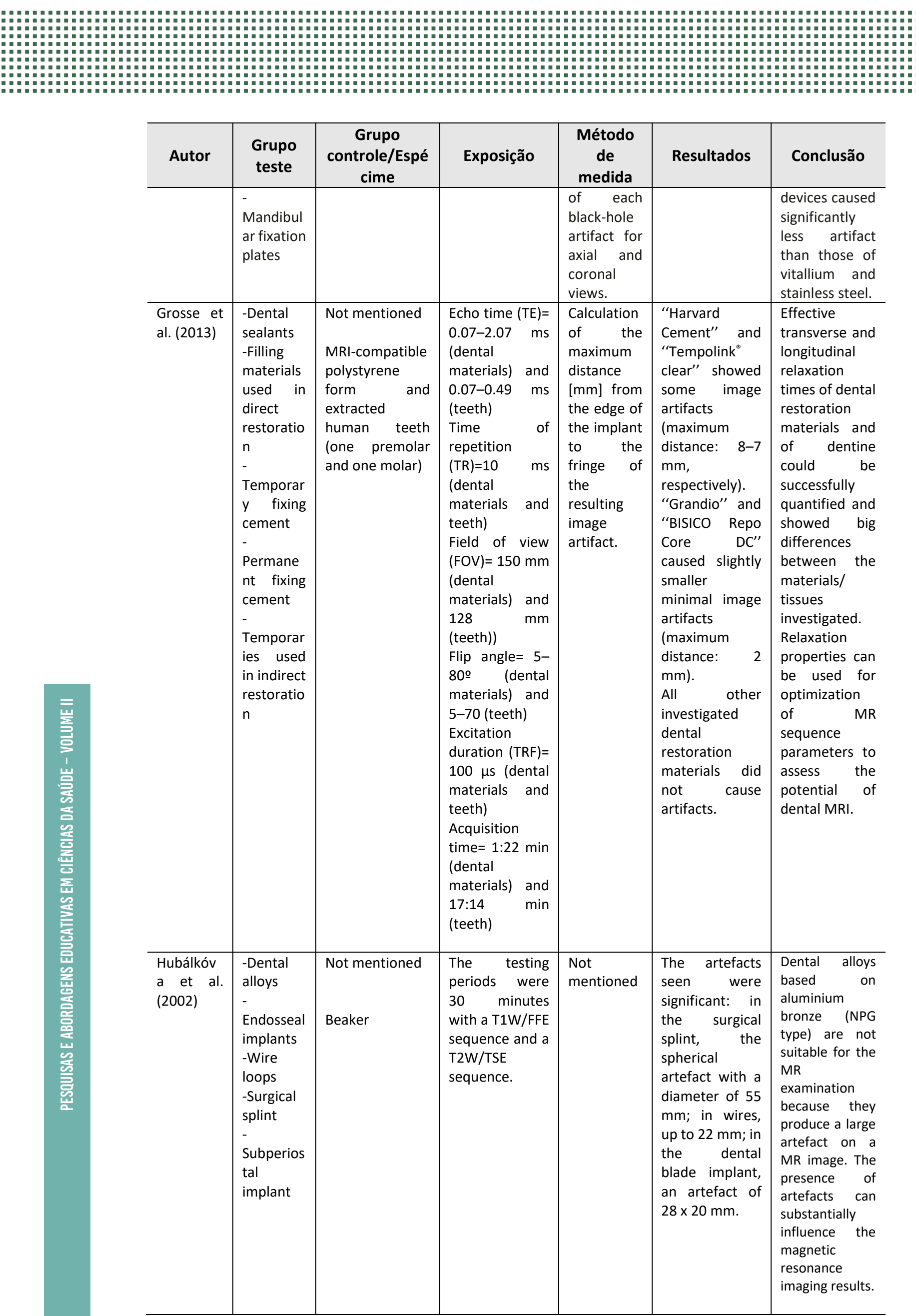




\begin{tabular}{|c|c|c|c|c|c|c|}
\hline Autor & $\begin{array}{l}\text { Grupo } \\
\text { teste }\end{array}$ & $\begin{array}{c}\text { Grupo } \\
\text { controle/Espé } \\
\text { cime }\end{array}$ & Exposição & $\begin{array}{l}\text { Método } \\
\text { de } \\
\text { medida }\end{array}$ & Resultados & Conclusão \\
\hline $\begin{array}{l}\text { Lissac et } \\
\text { al. (1991) }\end{array}$ & $\begin{array}{l}\text {-Precious } \\
\text { alloys } \\
- \\
\text { Nonpreci } \\
\text { ous alloys } \\
\text {-Dental } \\
\text { porcelain } \\
\text { s or } \\
\text { ceramics } \\
\text {-Dental } \\
\text { amalgam } \\
\text { s } \\
\text { - } \\
\text { Composit } \\
\text { es } \\
\text {-Titanium } \\
\text { alloys }\end{array}$ & $\begin{array}{l}\text { Not mentioned } \\
\text { Polypropylene } \\
\text { receptacle }\end{array}$ & $\begin{array}{lr}\text { Matrix } & \text { size= } \\
256 \times 256 & \\
\text { Gradiente } & \\
\text { echo: } & \text { (GE } \\
80 / 12 / 30 & - \\
\text { NEX=2) } & \\
& \\
\text { Spin } & \text { echo: } \\
\text { T2W }= & \text { SE } \\
1500 / 30 / 60 & \\
\text { and T1W= } & \text { SE } \\
300 / 21 & \end{array}$ & $\begin{array}{l}\text { Not } \\
\text { mentioned }\end{array}$ & $\begin{array}{l}\text { Nonprecious } \\
\text { alloys produce } \\
\text { large image } \\
\text { deformations, } \\
\text { whereas } \\
\text { precious alloys } \\
\text { had no effect } \\
\text { on MRI images. }\end{array}$ & $\begin{array}{l}\text { It is advisable } \\
\text { to carry out } \\
\text { careful } \\
\text { examination of } \\
\text { a patient's oral } \\
\text { cavity to } \\
\text { ensure that } \\
\text { there are no } \\
\text { fixed } \\
\text { prostheses } \\
\text { before } \\
\text { performing } \\
\text { MRI } \\
\text { examination of } \\
\text { the face and } \\
\text { cranium. } \\
\text { Considering } \\
\text { the increasing } \\
\text { recourse to } \\
\text { MRI } \\
\text { examination in } \\
\text { medical } \\
\text { practice, it } \\
\text { would appear } \\
\text { necessary for } \\
\text { the dental } \\
\text { profession to } \\
\text { refrain from } \\
\text { using alloys } \\
\text { containing Ni, } \\
\text { Co, or Fe in } \\
\text { fixed } \\
\text { prostheses. }\end{array}$ \\
\hline $\begin{array}{l}\text { Lissac et } \\
\text { al. (1992) }\end{array}$ & $\begin{array}{l}\text {-Precious } \\
\text { metals } \\
- \\
\text { Ceramics } \\
\text {-Resins } \\
\text { used in } \\
\text { aesthetic } \\
\text { prosthese } \\
\mathrm{s} \\
- \\
\text { Amalgam } \\
\mathrm{s}\end{array}$ & $\begin{array}{l}\text { Not mentioned } \\
\text { Not mentioned }\end{array}$ & Not mentioned & $\begin{array}{l}\text { Not } \\
\text { mentioned }\end{array}$ & $\begin{array}{l}\text { Titanium alloys } \\
\text { did however } \\
\text { cause some } \\
\text { slight } \\
\text { disturbance. } \\
\text { Considerable } \\
\text { disturbances } \\
\text { were } \\
\text { encountered } \\
\text { when cobalt } \\
\text { chrome alloys, } \\
\text { nickel chrome } \\
\text { alloys and } \\
\text { stainless steel } \\
\text { alloys were } \\
\text { used. }\end{array}$ & $\begin{array}{l}\text { It would thus } \\
\text { seem quite } \\
\text { clear that } \\
\text { dental } \\
\text { profession will } \\
\text { have to act to } \\
\text { ban materials } \\
\text { which perturb } \\
\text { magnetic } \\
\text { fields, if the } \\
\text { profession is, } \\
\text { along with } \\
\text { other medical } \\
\text { professions, to } \\
\text { continue using } \\
\text { MRI } \\
\text { technology. }\end{array}$ \\
\hline $\begin{array}{l}\text { Shafiei et } \\
\text { al. (2003) }\end{array}$ & $\begin{array}{l}\text {-Implant } \\
\text { materials } \\
\text {-Dental } \\
\text { casting } \\
\text { alloys }\end{array}$ & $\begin{array}{l}\begin{array}{l}\text { Acrylic resin } \\
\text { plate }\end{array} \\
\text { Inlay wax cube }\end{array}$ & $\begin{array}{l}\text { T1 fast-spin } \\
\text { echo (FSE): TR= } \\
500 \mathrm{msec}, \mathrm{TE}= \\
12 \mathrm{msec}, \mathrm{ETL}= \\
3, \mathrm{AC}=6 \text { and } \\
\mathrm{FA}=180^{\circ} \\
\mathrm{T} 2 \mathrm{FSE}: \mathrm{TR}= \\
3000 \mathrm{msec}, \mathrm{TE}= \\
96 \mathrm{msec}, \mathrm{ETL}=\end{array}$ & $\begin{array}{l}\text { A region of } \\
\text { interest } \\
\text { (ROI) was } \\
\text { drawn } \\
\text { around the } \\
\text { image of } \\
\text { sample } \\
\text { with the } \\
\text { proprietary }\end{array}$ & $\begin{array}{l}\text { Both the } \\
\text { commercially } \\
\text { pure titanium } \\
\text { (Titan A) and } \\
\text { titanium alloys } \\
\text { show artifacts } \\
\text { in all } 3 \\
\text { sequences. }\end{array}$ & $\begin{array}{l}\text { We concluded } \\
\text { that selection } \\
\text { of specific } \\
\text { dental casting } \\
\text { alloys } \\
\text { according to } \\
\text { their } \\
\text { elemental } \\
\text { compositions }\end{array}$ \\
\hline
\end{tabular}




\begin{tabular}{|c|c|c|c|c|c|c|}
\hline Autor & $\begin{array}{l}\text { Grupo } \\
\text { teste }\end{array}$ & $\begin{array}{c}\text { Grupo } \\
\text { controle/Espé } \\
\text { cime }\end{array}$ & Exposição & $\begin{array}{c}\text { Método } \\
\text { de } \\
\text { medida }\end{array}$ & Resultados & Conclusão \\
\hline & & & $\begin{array}{l}7, \quad A C=2 \text { and } \\
F A=180^{\circ} \\
\text { Gradient echo } \\
\text { (GE): TR= } 500 \\
\mathrm{msec}, \quad T E=18 \\
\mathrm{msec}, \quad E T L=2 \text {, } \\
\mathrm{AC}=2 \text { and } \mathrm{FA}= \\
18 \\
\text { Slice } \\
\text { thicknesses }=5 \\
\mathrm{~mm} \\
\text { Field of View= } \\
135 \mathrm{~mm} \\
\text { Matrix size= } \\
228 \times 256\end{array}$ & $\begin{array}{l}\text { software } \\
\text { installed } \\
\text { for data } \\
\text { acquisition, } \\
\text { data } \\
\text { processing, } \\
\text { and image } \\
\text { viewing in } \\
\text { the MRI } \\
\text { system. }\end{array}$ & \begin{tabular}{l}
\multicolumn{2}{l}{ Different } \\
magnitudes of \\
artifacts were \\
observed for \\
individual \\
dental casting \\
alloys or \\
implant \\
materials, \\
depending on \\
pulse \\
sequences.
\end{tabular} & $\begin{array}{l}\text { could minimize } \\
\text { the metal } \\
\text { artifacts in } \\
\text { MRI; however, } \\
\text { titanium alloys } \\
\text { currently pose } \\
\text { a problem with } \\
\text { respect to } \\
\text { causing MRI } \\
\text { artifacts. }\end{array}$ \\
\hline $\begin{array}{l}\text { Starčuk et } \\
\text { al. (2006) }\end{array}$ & $\begin{array}{l}\text {-Alloys of } \\
\text { precious } \\
\text { metals } \\
(\mathrm{Au}, \mathrm{Pt}, \\
\mathrm{Ag}, \mathrm{Ir}, \mathrm{Pd}) \\
\text { - Alloys of } \\
\text { non- } \\
\text { precious } \\
\text { metals } \\
\text { (Co-Cr, } \\
\mathrm{Ni}-\mathrm{Cr}) \\
- \\
\text { Amalgam } \\
\mathrm{S} \mathrm{(Hg+Ag-} \\
\mathrm{Sn}-\mathrm{Cu})\end{array}$ & $\begin{array}{l}\text { Not mentioned } \\
\text { Not mentioned }\end{array}$ & $\begin{array}{lr}2 D & \text { gradient- } \\
\text { echo } & \text { (TE= } \\
4.36 \mathrm{~ms}) & \end{array}$ & $\begin{array}{l}\text { Not } \\
\text { mentioned }\end{array}$ & $\begin{array}{l}\text { Precious-metal } \\
\text { alloys and } \\
\text { amalgams are } \\
\text { slightly } \\
\text { diamagnetic } \\
\text { and do not } \\
\text { influence the } \\
\text { homogeneity } \\
\text { significantly. } \\
\text { The highest } \\
\text { conductivities } \\
\text { were found in } \\
\text { the group of } \\
\text { precious-metal } \\
\text { alloys, while } \\
\text { the of } \\
\text { conductivity of } \\
\text { amalgams was } \\
\text { marginally } \\
\text { lower. These } \\
\text { properties } \\
\text { make these } \\
\text { materials prone } \\
\text { to cause } \\
\text { artifacts. }\end{array}$ & $\begin{array}{l}\text { With highly } \\
\text { paramagnetic } \\
\text { materials, loss } \\
\text { of signal due to } \\
\text { intrapixel/intr } \\
\text { aslice } \\
\text { dephasing } \\
\text { occurs around } \\
\text { the metallic } \\
\text { objects in GE } \\
\text { images, } \\
\text { complex } \\
\text { artifacts } \\
\text { (including } \\
\text { bright spots, } \\
\text { stripes and } \\
\text { black holes) } \\
\text { arise in SE } \\
\text { images, for } \\
\text { which slice } \\
\text { selection and } \\
\text { position } \\
\text { encoding } \\
\text { distortions are } \\
\text { responsible. }\end{array}$ \\
\hline $\begin{array}{l}\text { Starcukov } \\
\text { á et al. } \\
(2008)\end{array}$ & $\begin{array}{l}\text { - } \\
\text { Amalgam } \\
\mathrm{S} \\
\text {-Dental } \\
\text { alloys }\end{array}$ & $\begin{array}{l}\text { Not mentioned } \\
\text { PMMA holder }\end{array}$ & $\begin{array}{l}\text { Field of View= } \\
120 \mathrm{~mm} \times 120 \mathrm{~m} \\
\mathrm{~m} \text { Matrix size= } \\
256 \times 256 \\
\text { Slice } \\
\text { thickness= } \\
3 \mathrm{~mm} \\
\text { Spin echo (SE) } \\
\text { sequences: TR = } \\
3000 \text { ms, TE = } \\
15 \mathrm{~ms} \text { and Flip } \\
\text { angle }=180 \text { o } \\
\text { Gradient echo } \\
\text { (GE) } \\
\text { sequences: TR = } \\
200 \text { ms, TE = } \\
10 \mathrm{~ms} \text { and Flip } \\
\text { angle }=35 \text { o }\end{array}$ & $\begin{array}{l}\text { Marevisi } \\
\text { (software } \\
\text { for MRI and } \\
\text { MRSI data } \\
\text { visualizatio } \\
n \text { and } \\
\text { processing } \\
\text { by Institute } \\
\text { for } \\
\text { Biodiagnos } \\
\text { tics, NRC, } \\
\text { Canada). }\end{array}$ & 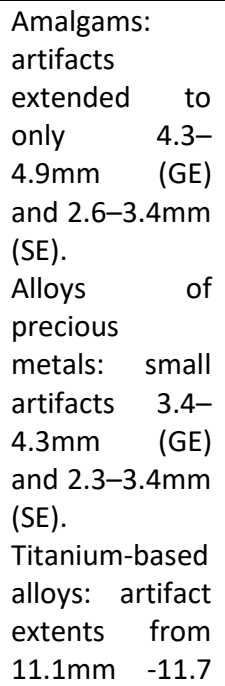 & $\begin{array}{l}\text { MR imaging is } \\
\text { possible even } \\
\text { close to dental } \\
\text { devices if they } \\
\text { are made of } \\
\text { dental } \\
\text { materials with } \\
\text { low magnetic } \\
\text { susceptibility. }\end{array}$ \\
\hline
\end{tabular}




\begin{tabular}{|c|c|c|c|c|c|c|}
\hline Autor & $\begin{array}{l}\text { Grupo } \\
\text { teste }\end{array}$ & $\begin{array}{c}\text { Grupo } \\
\text { controle/Espé } \\
\text { cime }\end{array}$ & Exposição & $\begin{array}{l}\text { Método } \\
\text { de } \\
\text { medida }\end{array}$ & Resultados & Conclusão \\
\hline $\begin{array}{l}\text { Vikhoff et } \\
\text { al. (1995) }\end{array}$ & $\begin{array}{l}\text { - } \\
\text {-Ketac } \\
\text { Silver } \\
\text { glass } \\
\text { cerment } \\
\text {-Occlusin } \\
\text {-Dental } \\
\text { composit } \\
\text { e }\end{array}$ & $\begin{array}{l}\text { Not mentioned } \\
\text { Extracted teeth }\end{array}$ & 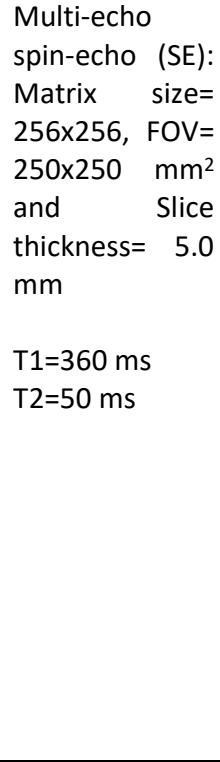 & $\begin{array}{l}\text { Not } \\
\text { mentioned }\end{array}$ & $\begin{array}{l}\text { None or only } \\
\text { minor artefacts } \\
\text { were seen in } \\
\text { the images with } \\
\text { but one } \\
\text { exception. } \\
\text { Heliomolar (30) } \\
\text { radiopaque } \\
\text { (teeth } 4 \text { and 5) } \\
\text { was found to } \\
\text { create more } \\
\text { pronounced } \\
\text { local artefacts } \\
\text { than the other } \\
\text { materials. }\end{array}$ & $\begin{array}{l}\text { The } \\
\text { investigation } \\
\text { showed that } \\
\text { only one of the } \\
\text { materials } \\
\text { caused } \\
\text { significant } \\
\text { artefacts. The } \\
\text { gel phantom } \\
\text { was found to } \\
\text { be a valuable } \\
\text { means for } \\
\text { examination of } \\
\text { artefacts from } \\
\text { small samples, } \\
\text { and can be } \\
\text { recommended } \\
\text { as a standard } \\
\text { technique for } \\
\text { this purpose. }\end{array}$ \\
\hline $\begin{array}{l}\text { Zho et al. } \\
(2013)\end{array}$ & $\begin{array}{l}\text { - } \\
\text { Amalgam } \\
\text {-Titanium } \\
\text { implant } \\
\text {-Gold } \\
\text { crown } \\
\text {-Ni-Cr } \\
\text { crown } \\
\text {-Ni-Ti } \\
\text { wire } \\
\text { (019x025) } \\
\text {-S-Sc wire }\end{array}$ & $\begin{array}{l}\text { Not mentioned } \\
\text { Phantom }\end{array}$ & $\begin{array}{l}\text { Resolution= } \\
0.5 \times 0.5 \times 0.5 \\
\mathrm{~mm}^{3} ; \text { field-of- } \\
\text { view } \quad \text { (FOV)= } \\
100 \times 100 \times 100 \\
\mathrm{~mm}^{3} ; \quad \text { matrix } \\
\text { size= } \\
200 \times 200 \times 200 \\
\mathrm{RF} \text { bandwidth= } \\
1.6 \mathrm{kHz}(2.5 \mathrm{~ms} \\
\text { duration, time- } \\
\text { bandwidth } \\
\text { product four) } \\
\text { for phantom } \\
\text { and } 1.0 \text { kHz (4.0 } \\
\text { ms duration, } \\
\text { time- } \\
\text { bandwidth } \\
\text { product four) } \\
\text { for in vivo } \\
\text { experiments. }\end{array}$ & $\begin{array}{l}\text { In plane } \\
\text { distortion } \\
\text { was } \\
\text { measured } \\
\text { using the } \\
\text { maximum } \\
\text { distance } \\
\text { from the } \\
\text { object edge } \\
\text { to signal } \\
\text { pile- } \\
\text { up/void } \\
\text { region } \\
\text { along the } \\
\text { readout (x) } \\
\text { and phase- } \\
\text { encoding } \\
\text { (y) } \\
\text { direction. } \\
\text { The } \\
\text { through- } \\
\text { plane } \\
\text { distortion } \\
\text { was } \\
\text { quantified } \\
\text { by counting } \\
\text { the number } \\
\text { of slices } \\
\text { that show } \\
\text { signal pile- } \\
\text { up/void. }\end{array}$ & $\begin{array}{l}\text { Compared with } \\
\text { conventional SE } \\
\text { imaging in } \\
\text { phantom } \\
\text { studies, in- } \\
\text { plane artifacts } \\
\text { were reduced } \\
\text { by up to 43\% in } \\
\text { the VAT SE } \\
\text { images and } \\
80 \% \text { in the } \\
\text { SEMAC images. } \\
\text { Through-plane } \\
\text { artifacts were } \\
\text { reduced by up } \\
\text { to } 65 \% \text { in } \\
\text { SEMAC images. } \\
\text { In vivo SEMAC } \\
\text { images also } \\
\text { showed } \\
\text { reduced } \\
\text { artifacts. }\end{array}$ & $\begin{array}{l}\text { The reduction } \\
\text { of artifacts } \\
\text { were above } \\
50 \% \text { in SEMAC } \\
\text { images in case } \\
\text { of Ni-Cr crown } \\
\text { and stainless } \\
\text { steel wire, and } \\
\text { slight } \\
\text { reduction } \\
\text { were observed } \\
\text { in other } \\
\text { materials } \\
\text { having lower } \\
\text { susceptibility. } \\
\text { The reduction } \\
\text { of artifact due } \\
\text { to metallic } \\
\text { dental } \\
\text { materials is } \\
\text { possible using } \\
\text { VAT and } \\
\text { SEMAC } \\
\text { techniques at } \\
3 T \text {. }\end{array}$ \\
\hline
\end{tabular}

Fonte: Autoria própria. 


\section{DISCUSSÃO}

A ressonância magnética (RM), ao avaliar certas doenças da cabeça e pescoço, demonstrou ser um método valioso de diagnóstico para essa região anatômica (HINSHAW, HOLSHOUSER et al., 1988). A RM vem assumindo um papel de grande importância por diversas razões, entre as quais se destacam o alto contraste e precisão dos tecidos, além de ser um exame altamente sensível e específico (HUBALKOVA, LA SERNA et al., 2006). No entanto, a presença de objetos metálicos insere para o campo magnético heterogeneidades locais, que podem resultar em distorções de imagem relacionadas à susceptibilidade magnética dos objetos, podendo levar a áreas de anomalias intensas (BEUF, LISSAC et al., 1994).

De acordo com a sua susceptibilidade magnética, os materiais podem ser classificados como ferromagnéticos, paramagnéticos ou diamagnéticos. Aqueles que possuem grande susceptibilidade magnética e, por isso, causam grandes distorções do campo magnético e perda de sinal, são considerados ferromagnéticos. Os materiais paramagnéticos têm forte suscetibilidade magnética e os diamagnéticos, na grande maioria das vezes, possuem um mínimo efeito sobre a intensidade do sinal da RM (ABBASZADEH, HEFFEZ et al., 2000). Sendo assim, quanto maior for a susceptibilidade magnética do material, maior será o grau de distorção do campo magnético dentro do scanner de RM, gerando artefatos mais proeminentes na imagem resultante (FIALA, PAIGE et al., 1994).

A intensidade, a ausência de homogeneidade do campo magnético e a susceptibilidade magnética dos componentes que constituem os objetos metálicos expostos à ressonância magnética são alguns fatores que determinam o tamanho dos artefatos na RM (STARCUKOVA, STARCUK et al., 2008). Além disso, qualquer alteração do campo magnético, seja por razões intrínsecas ou extrínsecas, pode causar distorção espacial da imagem (FACHE, PRICE et al., 1987). Outros fatores que estão relacionados com o tamanho e a forma dos artefatos são as propriedades magnéticas do objeto de metal avaliado, o seu tamanho e forma, além da homogeneidade da liga que compõe o metal (HUBALKOVA, HORA et al., 2002).

Algumas ligas dentárias atuam como componentes dos materiais dentários metálicos, e podem ser consideradas como ligas de metais preciosos ( $\mathrm{Au}, \mathrm{Pt}, \mathrm{Ag}, \mathrm{Ir}, \mathrm{Pd}$ ) 
ou ligas de metais não preciosos (Co-Cr, Ni-Cr) (STARČUK, BARTUŠEK et al., 2006). Para Destine, Mizutani e Igarashi (DESTINE, MIZUTANI et al., 2008), a liga de cobalto-cromo mostrou maior intensidade de sinal comparado ao grupo controle, enquanto que a intensidade de sinal de ouro-prata-paládio e de fundição de liga de ouro tipo III não foram significativamente diferentes do controle. Grandes artefatos são causados por ligas de Co-Cr, Co-Ni e aço inoxidável, podendo disfarçar a área examinada ou criar um risco de perda de imagem ou de interpretação duvidosa dos resultados de RM (HUBALKOVA, LA SERNA et al., 2006).

Materiais diamagnéticos, como o ouro, são utilizados extensivamente em restaurações orais e não tendem a criar artefatos em imagens de RM (LISSAC, METROP et al., 1991; LISSAC, COUDERT et al., 1992; KLINKE, DABOUL et al., 2012). Restaurações extensas de ouro presentes em um voluntário e uma peça de ouro estudada in vitro, que foram expostas à ressonância magnética, não apresentaram quaisquer distorções (FACHE, PRICE et al., 1987). No entanto, BEUF, LISSAC et al., 1994 e KLINKE, DABOUL et al., 2012, indicaram que ligas com alto teor de ouro geram maiores artefatos e distorções quando comparadas as ligas de paládio, enquanto que a liga à base de prata produz distorções difíceis de serem detectadas. Isso ocorre porque as ligas com alto teor de ouro continham sinais de metais ferromagnéticos, como o ferro. (KLINKE, DABOUL et al., 2012)

TYMOFIYEVA, VAEGLER et al., 2013, relataram que ligas não preciosas, como Co$\mathrm{Cr}$, geram artefatos e distorções, sendo classificadas como não-compatíveis, à medida que os materiais produzem distorções fortes mesmo quando estão localizados longe da região da imagem. Além disso, ligas de ouro e titânio produzem distorções perceptíveis, mas que não prejudicam a avaliação da imagem, sendo consideradas compatíveis. Outro estudo (LISSAC, METROP et al., 1991) concordou com esses achados, afirmando que somente materiais contendo $\mathrm{Ni}$, Co e Fe produzem artefatos consideráveis.

Com relação aos implantes dentários, constituídos em sua maioria por titânio (HUBALKOVA, LA SERNA et al., 2006), (EGGERS, RIEKER et al., 2005) afirmaram que esses materiais geram artefatos pequenos, mas detectáveis, por apresentar vestígios de ferro ferromagnético. No entanto, asseguram ainda que em uma região investigada, mesmo pequenas quantidades de materiais ferromagnéticos, podem gerar uma extensa distorção da imagem. 
Implantes constituídos por titânio com impurezas causam artefatos com tamanho médio de $28 \mathrm{~mm} \times 20 \mathrm{~mm}$, sendo que a extensão do artefato é muito maior do que o tamanho real dos objetos. Desta forma, a interpretação dos resultados da imagem de RM pode ser prejudicada, uma vez que o tamanho excessivo do artefato pode mascarar a área examinada. (HUBALKOVA, HORA et al., 2002) Do mesmo modo, para COSTA, APPENZELLER et al., 2009, os implantes de titânio causam graves artefatos, interferindo em $18 \%$ das imagens obtidas, gerando problemas ao uso de imagens de RM na prática clínica.

Além disso, implantes de titânio produzem extensos vazios de sinais devido aos intensos artefatos de suscetibilidade, enquanto que os implantes de zircônia não implantados podem ser delineados com precisão (DUTTENHOEFER, MERTENS et al., 2015). Sendo assim, a zircônia pode ser classificada como material compatível com a ressonância magnética, não interferindo no procedimento ao estar presente na boca do paciente no momento da exposição, à medida que implantes de titânio não são apropriados para a RM (TYMOFIYEVA, VAEGLER et al., 2013; DUTTENHOEFER, MERTENS et al., 2015).

Amálgama e ouro são os materiais mais utilizados na odontologia (COSTA, APPENZELLER et al., 2009), uma vez que o ouro está presente em coroas e pontes, e o amálgama ainda é bastante utilizado em restaurações dentárias (EGGERS, RIEKER et al., 2005). Diante da importância destes materiais constatou-se que o amálgama não é considerado uma fonte de artefato (LISSAC, METROP et al., 1991; LISSAC, COUDERT et al., 1992; EGGERS, RIEKER et al., 2005; COSTA, APPENZELLER et al., 2009). A ausência de artefatos nesses estudos pode ser explicada pela falta de metais ferromagnéticos nas ligas que compõem o amálgama (EGGERS, RIEKER et al., 2005), ou pela presença de metais não ferromagnéticos (COSTA, APPENZELLER et al., 2009).

Por outro lado, ABBASZADEH, HEFFEZ et al., 2000 relataram, em seu estudo, que o amálgama gerou artefato, mesmo sendo o de menor dimensão dentre todos os materiais metálicos avaliados. Na literatura, outro estudo também concorda com a produção de artefatos pelo amálgama, sendo que, a depender do tipo de sequência de pulso utilizado na ressonância magnética, podiam variar entre 4,3 - 4,9 mm para gradiente eco e 2,6 - 3,4 mm para spin eco (STARCUKOVA, STARCUK et al., 2008). 
ZHO, KIM et al., 2013, ao proporem um processo de redução do artefato de susceptibilidade produzidos por materiais dentários metálicos, afirmaram não ser necessário utilizar este processo de redução de artefatos para o amálgama, uma vez que as distorções decorrentes deste material são relativamente pequenas. Desta forma, a presença de restaurações com amálgama não reduz a qualidade da imagem de RM (EGGERS, RIEKER et al., 2005), o que permite a utilização desse método de diagnóstico quando neste paciente quando necessário.

Materiais utilizados em cirurgias bucomaxilofaciais, como splint cirúrgico, têm em sua composição o aço inoxidável, que é considerado um metal ferromagnético. Por conseguinte, um imenso grau de distorção está associado a este metal (LISSAC, METROP et al., 1991; LISSAC, COUDERT et al., 1992; FIALA, PAIGE et al., 1994; ABBASZADEH, HEFFEZ et al., 2000). Assim como foi demonstrado no estudo de IIMURO, 1994 onde os artefatos gerados pelo aço inoxidável se apresentaram como uma perda de sinal muito bem definida. HUBALKÓVÁ et al (HUBALKOVA, HORA et al., 2002) utilizaram em seu estudo um splint cirúrgico e fios cirúrgicos e constataram que esses materiais causam grandes artefatos, com o splint cirúrgico gerando um de $55 \times 22$ × 260mm de extensão.

Ao se estudar placas de fixação mandibular constituídas por titânio e por vitallium comparadas ao aço inoxidável, observou-se que, ao realizar o exame de ressonância magnética, uma placa de titânio com a espessura necessária para corresponder a uma placa de vitallium causou muito menos perturbação no campo magnético. Desta forma, os artefatos produzidos foram mínimos para placas de titânio, intermediários para placas de vitallium e o aço inoxidável gerou o maior artefato. Isto acontece devido à susceptibilidade magnética do titânio que é cerca de quatro ordens de grandeza menor do que a do vitallium ou aço inoxidável.

O tamanho do material influencia o grau de distorção da imagem. Neste caso, dependendo do tamanho e volume do metal presente na cavidade oral ou na cabeça, a região de interesse pode não ser comprometida pelo artefato ou, ao contrário, pode tornar a imagiologia por ressonância magnética inviável (IIMURO, 1994).

A ressonância magnética é utilizada como meio de diagnóstico por imagem; uma vez que materiais dentários metálicos podem interferir na qualidade dessas imagens, é importante que seja realizada uma anamnese detalhada com um intuito de advertir os profissionais que atuam na área, no momento da exposição, impedindo algum tipo de 
dano ao paciente e obtendo um bom exame que permita um diagnóstico correto e de qualidade.

\section{CONCLUSÃO}

- Metais com propriedades ferromagnéticas tendem a gerar artefatos extensos, enquanto que ligas de metais preciosos não causam artefatos tão graves.

- O titânio pode causar distorções maiores quando comparados com os implantes de zircônia sendo considerado não compatível com a ressonância magnética.

- O amálgama não reduz a qualidade da imagem de RM, pois quando geram artefatos, estes são de extensões mínimas.

- O aço inoxidável, geralmente presente em materiais utilizados em cirurgia bucomaxilofacial, é um metal ferromagnético e por isso, gera perdas de sinais bem definidas nas imagens de RM.

\section{REFERÊNCIAS}

ABBASZADEH, K.; HEFFEZ, L. B.; MAFEE, M. F. Effect of interference of metallic objects on interpretation of T1-weighted magnetic resonance images in the maxillofacial region. Oral Surg Oral Med Oral Pathol Oral Radiol Endod, v. 89, n. 6, p. 759-65, Jun 2000. ISSN 1079-2104 (Print) 1079-2104 (Linking). Disponível em: < http://www.ncbi.nlm.nih.gov/pubmed/10846134 >.

BEHR, M. et al. MR-imaging of the TMJ: artefacts caused by dental alloys. Eur J Prosthodont Restor Dent, v. 4, n. 3, p. 111-5, Sep 1996. ISSN 0965-7452 (Print)

0965-7452 (Linking). Disponível em: < http://www.ncbi.nlm.nih.gov/pubmed/9171016 $>$.

BEUF, O. et al. Correlation between magnetic resonance imaging disturbances and the magnetic susceptibility of dental materials. Dent Mater, v. 10, n. 4, p. 265-8, Jul 1994. ISSN 0109-5641 (Print)0109-5641 (Linking). Disponível em: < http://www.ncbi.nlm.nih.gov/pubmed/7664995 >.

CHEN, D. P.; WU, G. Y.; WANG, Y. N. Influence of galvano-ceramic and metal-ceramic crowns on magnetic resonance imaging. Chin Med J (Engl), v. 123, n. 2, p. 20811, Jan 20 2010. ISSN 0366-6999 (Print)0366-6999 (Linking). Disponível em: < http://www.ncbi.nlm.nih.gov/pubmed/20137372 >.

COSTA, A. L. et al. Artifacts in brain magnetic resonance imaging due to metallic dental objects. Med Oral Patol Oral Cir Bucal, v. 14, n. 6, p. E278-82, Jun 2009. ISSN 
1698-6946 (Electronic)1698-4447 (Linking). Disponível em: < http://www.ncbi.nlm.nih.gov/pubmed/19300375 >.

DESTINE, D.; MIZUTANI, H.; IGARASHI, Y. Metallic artifacts in MRI caused by dental alloys and magnetic keeper. Nihon Hotetsu Shika Gakkai Zasshi, v. 52, n. 2, p. 205-10, Apr 2008. ISSN 0389-5386 (Print)0389-5386 (Linking). Disponível em: < http://www.ncbi.nlm.nih.gov/pubmed/18467793 >.

DUTTENHOEFER, F. et al. Magnetic resonance imaging in zirconia-based dental implantology. Clin Oral Implants Res, v. 26, n. 10, p. 1195-202, Oct 2015. ISSN 1600-0501 (Electronic) 0905-7161 (Linking). Disponível em: < http://www.ncbi.nlm.nih.gov/pubmed/24893967 >.

EGGERS, G. et al. Artefacts in magnetic resonance imaging caused by dental material. MAGMA, v. 18, n. 2, p. 103-11, May 2005. ISSN 0968-5243 (Print)0968-5243 (Linking). Disponível em: < http://www.ncbi.nlm.nih.gov/pubmed/15785943 >.

EHSANI, S. et al. Frictional resistance in self-ligating orthodontic brackets and conventionally ligated brackets. A systematic review. Angle Orthod, v. 79, n. 3, p. 592-601, May 2009. ISSN 0003-3219 (Print)0003-3219 (Linking). Disponível em: < http://www.ncbi.nlm.nih.gov/pubmed/19413397 >.

FACHE, J. S. et al. MR imaging artifacts produced by dental materials. AJNR Am J Neuroradiol, v. 8, n. 5, p. 837-40, Sep-Oct 1987. ISSN 0195-6108 (Print)01956108 (Linking). Disponível em: < http://www.ncbi.nlm.nih.gov/pubmed/3118677 >.

FIALA, T. G. et al. Comparison of artifact from craniomaxillofacial internal fixation devices: magnetic resonance imaging. Plast Reconstr Surg, v. 93, n. 4, p. 725-31, Apr 1994. ISSN 0032-1052 (Print)0032-1052 (Linking). Disponível em: < http://www.ncbi.nlm.nih.gov/pubmed/8134430 >.

GROSSE, U. et al. Magnetic resonance imaging of solid dental restoration materials using 3D UTE sequences: visualization and relaxometry of various compounds. MAGMA, v. 26, n. 6, p. 555-64, Dec 2013. ISSN 1352-8661 (Electronic)0968-5243 (Linking). Disponível em: < http://www.ncbi.nlm.nih.gov/pubmed/23525675 >.

HINSHAW, D. B., JR. et al. Dental material artifacts on MR images. Radiology, v. 166, n. 3, p. 777-9, Mar 1988. ISSN 0033-8419 (Print)0033-8419 (Linking). Disponível em: < http://www.ncbi.nlm.nih.gov/pubmed/3340777 >.

HUBALKOVA, $\mathrm{H}$. et al. Dental materials and magnetic resonance imaging. Eur J Prosthodont Restor Dent, v. 10, n. 3, p. 125-30, Sep 2002. ISSN 0965-7452 (Print)0965-7452 (Linking). Disponível em: < http://www.ncbi.nlm.nih.gov/pubmed/12382608 >.

HUBALKOVA, H. et al. Dental alloys and magnetic resonance imaging. Int Dent J, v. 56, n. 3, p. 135-41, Jun 2006. ISSN 0020-6539 (Print)020-6539 (Linking). Disponível em: < http://www.ncbi.nlm.nih.gov/pubmed/16826879 >. 
IIMURO, F. T. Magnetic resonance imaging artifacts and the magnetic attachment system. Dent Mater J, v. 13, n. 1, p. 76-88, Jun 1994. ISSN 0287-4547 (Print)02874547 (Linking). Disponível em: < http://www.ncbi.nlm.nih.gov/pubmed/7842644 >.

KLINKE, T. et al. Artifacts in magnetic resonance imaging and computed tomography caused by dental materials. PLoS One, v. 7, n. 2, p. e31766, 2012. ISSN 19326203 (Electronic)1932-6203 (Linking). Disponível em: < http://www.ncbi.nlm.nih.gov/pubmed/22384071 >.

LISSAC, M. et al. Disturbances caused by dental materials in magnetic resonance imaging. Int Dent J, v. 42, n. 4, p. 229-33, Aug 1992. ISSN 0020-6539 (Print)00206539 (Linking). Disponível em: < http://www.ncbi.nlm.nih.gov/pubmed/1399040 >.

LISSAC, M. et al. Dental materials and magnetic resonance imaging. Invest Radiol, v. 26, n. 1, p. 40-5, Jan 1991. ISSN 0020-9996 (Print)0020-9996 (Linking). Disponível em: < http://www.ncbi.nlm.nih.gov/pubmed/2022452 >.

SHAFIEI, F. et al. Artifacts from dental casting alloys in magnetic resonance imaging. J Dent Res, v. 82, n. 8, p. 602-6, Aug 2003. ISSN 0022-0345 (Print)0022-0345 (Linking). Disponível em: < http://www.ncbi.nlm.nih.gov/pubmed/12885843 >.

STARČUK, Z. et al. Evaluation of MRI artifacts caused by metallic dental implants and classification of the dental materials in use. Measurement Science Review, v. 6, p. 24-27, 2006.

STARCUKOVA, J. et al. Magnetic susceptibility and electrical conductivity of metallic dental materials and their impact on MR imaging artifacts. Dent Mater, v. 24, n. 6, p. 715-23, Jun 2008. ISSN 0109-5641 (Print)0109-5641 (Linking). Disponível em: < http://www.ncbi.nlm.nih.gov/pubmed/17884157 >.

TANIYAMA, T. et al. Metal artifacts in MRI from non-magnetic dental alloy and its FEM analysis. Dent Mater J, v. 29, n. 3, p. 297-302, May 2010. ISSN 0287-4547 (Print)0287-4547 (Linking). Disponível em: < http://www.ncbi.nlm.nih.gov/pubmed/20448408 >.

TYMOFIYEVA, O. et al. Influence of dental materials on dental MRI. Dentomaxillofac Radiol, v. 42, n. 6, p. 20120271, 2013. ISSN 0250-832X (Print)0250-832X (Linking). Disponível em: < http://www.ncbi.nlm.nih.gov/pubmed/23610088 >.

VIKHOFF, B. et al. Artefacts caused by dental filling materials in MR imaging. Acta Radiol, v. 36, n. 3, p. 323-5, May 1995. ISSN 0284-1851 (Print)0284-1851 (Linking). Disponível em: < http://www.ncbi.nlm.nih.gov/pubmed/7742131 >.

ZHO, S. Y. et al. Artifact reduction from metallic dental materials in T1-weighted spinecho imaging at 3.0 tesla. J Magn Reson Imaging, v. 37, n. 2, p. 471-8, Feb 2013. ISSN 1522-2586 (Electronic)1053-1807 (Linking). Disponível em: < http://www.ncbi.nlm.nih.gov/pubmed/22941956 >. 


\title{
CAPITULO LII
}

\section{TEORIA DO ELO ENTRE VIOLÊNCIA DOMÉSTICA E MAUS-TRATOS CONTRA ANIMAIS: ABORDAGEM E PERSPECTIVA MULTIDISCIPLINAR}

\author{
DOI: 10.51859/AMPLLA.PAE1993-52
}

\author{
Marilia Cristina Pinto ${ }^{1}$ \\ Thamires Aparecida Bojko ${ }^{2}$ \\ Diogo de Andrade Ursulino Dias ${ }^{3}$ \\ Douglas Luís Vieira ${ }^{4}$
}

\begin{abstract}
1 Programa de Residência em Saúde Coletiva da Prefeitura Municipal de Ponta Grossa - Ponta Grossa, PR
${ }^{2}$ Mestranda no Programa de Pós-graduação Interdisciplinar em Desenvolvimento Comunitário na Universidade Estadual do Centro Oeste - UNICENTRO

${ }^{3}$ Curso de Especialização em Direito Constitucional da Academia Brasileira de Direito Constitucional - ABDConst

${ }^{4}$ Doutorando no Programa de Pós-graduação em Ciências Veterinárias na Universidade Federal do Paraná - UFPR
\end{abstract}

\section{RESUMO}

A relação entre os animais e os seres humanos se modificou desde a domesticação destes. Muitas pessoas, atualmente, consideram os pets como parte da família. Por esse motivo estão sujeitos aos mesmo tipos de violência que os familiares humanos. Estudos realizados nas últimas décadas mostram que há uma ligação entre a crueldade animal e a violência interpessoal, tendo esta como alvos os grupos vulneráveis, como pessoas idosas, crianças, pessoas com deficiência e também as mulheres. Pessoas em situação de vulnerabilidade social, financeira, educacional, ambiental, que vivenciaram violência em seus lares, estão expostas a diversos estímulos negativos que podem levar a expressões negativas, tais como a violência e alienação. Locais de vulnerabilidade são mais propensos a proliferação de problemas sociais, perpetuando ciclos de violência, exclusão social, vulnerabilidade. Atualmente contamos com várias leis que garantem a proteção dos grupos de vulneráveis, como os Estatutos da Criança e do Adolescente e o do Idoso, e as vítimas dos casos de violência, sejam elas animais ou humanos, como a Lei Maria da Penha e a Lei de Crimes Ambientais. Os médicos veterinários são os profissionais mais qualificados para atuar no diagnóstico de maus tratos contra os animais e correlacionar a violência interpessoal no ambiente em que estes estão inseridos. Porém a violência é um problema de saúde pública, que deve ser enfrentado de maneira multiprofissional, sendo necessário o conhecimento e participação de profissionais como forças de segurança, outros profissionais de saúde, de assistência e de apoio legal aos envolvidos.

Palavras-chave: Teoria do elo. Violência doméstica. Crueldade animal. Violência Interpessoal. Lei de Crimes Ambientais 


\section{INTRODUÇÃO}

A domesticação dos animais não possui um consenso quanto ao seu início, variando entre 10 e 100 mil anos. É um processo que pode ser definido como a relação entre seres humanos e animais - na qual o ser humano domesticou estes para alimentação, transporte, vestuário e proteção - além da aproximação de animais em comunidades humanas em busca também de alimento e outros benefícios, havendo assim uma troca de conveniências entre as espécies (Zeder, 2012; UFJF, 2020). Ao longo dos séculos a relação entre seres humanos e animais se modificou e hoje animais domesticados, são em sua maioria (especialmente cães e gatos) considerados parte da família. Em uma pesquisa realizada em 2019 pela Proteção Animal Mundial, 94\% dos brasileiros consideravam seus pets como membros da família, constituindo desse modo uma família multiespécie (Proteção Animal Mundial, 2019).

Apesar da maioria das relações interespécie entre seres humanos e animais serem positivas, os animais estão sujeitos às mesmas vulnerabilidades da família na qual estão inseridos. Nas últimas décadas, inúmeros estudos em todo o mundo demonstraram a correlação entre a violência contra os animais e a violência interpessoal, esta ligação passou a ser conhecida como Teoria do Elo (Ascione e Arkow, 1999). A violência que envolve esta teoria é resultado de todas as vivências familiares desde a infância, que podem levar a dessensibilização do indivíduo e que pode começar a se manifestar de forma deletéria desde a infância até a vida adulta, além de outras experiências traumatizantes e de fatores relacionados ao meio em que o indivíduo está inserido, como os referentes à educação, econômicos e socioculturais (Gomes, 2021).

Estudos mostram que pessoas com histórico de abuso infantil, provenientes de lares com violência doméstica e negligência possuem maior chance de realizar alguma forma de maus-tratos aos animais (Beck, 1981). Um estudo realizado em por Levitt et al. (2016) o qual mostrou que $96 \%$ de agressores de animais também haviam sido acusados por outros crimes como violência interpessoal. Outro estudo acerca do tema, realizado por McEwen et al. (2014) identificou que 27,1\% das pessoas com histórico de abuso infantil e de lares com violência doméstica também cometiam maus tratos aos animais. Bright et al. (2018) mostraram que os jovens que vivenciavam doença mental 
de algum parente, negligência física, abusos físico ou sexual e violência tinham 4,82 vezes mais chances de realizar alguma forma de crueldade animal.

Segundo Baquero et al. (2018), da perspectiva de saúde pública e médicoveterinária existe uma ligação entre o número de animais e a existência de violência, ou seja, quanto maior o número de animais em um determinado local, maior será a ocorrência de violência, assim como a frequência da violência está ligada ao grau de vulnerabilidade social da população. Isso pode ocorrer pela falta de recursos, estrutura familiar e exposição a fatores estressantes no dia-a-dia.

O Conselho Federal de Medicina Veterinária (CFMV) na resolução 1.236 de 26 de outubro de 2018, definiu maus-tratos aos animais como: "qualquer ato, direto ou indireto, comissivo ou omissivo, que intencionalmente ou por negligência, imperícia ou imprudência provoque dor ou sofrimento desnecessários aos animais". Assim como na violência doméstica, nos maus-tratos aos animais também há relação de poder e controle sobre a vítima. Pessoas que agridem animais têm maior probabilidade de fazer o mesmo com seus semelhantes, especialmente pessoas pertencentes ao grupo de vulneráveis (crianças, idosos, mulheres, pessoas com deficiência). Por esse motivo, os maus-tratos contra animais podem ser considerados um indicativo de outras formas de violência no ambiente familiar (Rocha, 2020).

Devido a estreita relação entre os seres humanos e os animais (principalmente cães e gatos), estes podem ser usados como instrumentos de violência psicológica, ameaça e manipulação da vítima humana. Com isso a vítima acaba sendo intimidada e mantida presa no ciclo de violência pois teme que seu animal de estimação sofra caso denuncie seu agressor (Monsalve et al., 2017). Tendo em vista a importância do tema Teoria do Elo entre violência doméstica e maus-tratos contra animais, o presente capítulo tem por objetivo abordar de forma multidisciplinar conceitos relevantes, como violência interpessoal e interespécie, violência doméstica e as representações sociais, além da legislação de proteção a vítima.

\section{VIOLÊNCIA INTERPESSOAL E INTERESPÉCIE}

No Brasil, a negligência é a forma mais comum de maus-tratos. A ocorrência desse tipo de violência está associada a fatores como número de animais em casa, dificuldades financeiras, nível educacional dos tutores, presença de pessoas com alguma 
deficiência na casa (Gomes, 2021). Em nosso cotidiano, percebemos que muitas famílias moram em comunidades vulneráveis, esses locais são caracterizados pela carência de inúmeros recursos públicos e privados, sejam de ordem econômica, social ou ambiental. Muitos indivíduos também presenciam a falta de informações objetivas e verdadeiras, isso pode levar a uma abundância de estímulos negativos, reforçando inúmeras expressões da questão social, como: violência, exclusão social, dominação ou alienação, perpetuando o ciclo de empobrecimento e vulnerabilidade social. Por vezes isso pode se tornar um desafio de complexa resolução, perpetuados por padrões culturais excludentes, como o machismo.

Nesse cenário cheio de contradições em que estamos vivendo, as mais afetadas são as comunidades socialmente vulneráveis pois possuem uma carência de informação, oportunidades e direitos. Nesse espaço elas se tornam um dos terrenos mais férteis à proliferação do problema da violência como outros problemas sociais, como os da área da saúde, economia, falta de direitos, entre outros.

A violência pode ser compreendida como um problema de saúde pública, sendo definida como qualquer ação intencional realizada por uma pessoa, grupo, instituição, classe ou até nação, voltados a outros indivíduos, e são ações que causam prejuízos, danos físicos, sociais, psicológicos e/ou espirituais (Minayo e Souza 1998).

A tipologia proposta por Krung e Lozano (2002) com base nos preceitos da Organização Mundial da Saúde, indica três grandes categorias de violência, que correspondem às características por parte de quem comete o ato violento. Podemos citar:

1. Violência coletiva: que inclui os atos violentos que acontecem nos âmbitos macrossociais, políticos e econômicos e caracterizam a dominação de grupos e do Estado. Nessa categoria estão os crimes cometidos por grupos organizados, os atos terroristas, os crimes de multidões, as guerras e os processos de aniquilamento de determinados povos e nações;

2. Violência autoinfligida, subdividida em comportamentos suicidas, e os autoabusos. No primeiro caso a tipologia contempla suicídio, ideação suicida e tentativas de suicídio. $O$ conceito de autoabuso nomeia as agressões a si próprio e as lesões autoinfligidas; 
3. Violência interpessoal, subdividida em violência comunitária e violência familiar, que inclui a violência infligida pelo parceiro íntimo, o abuso infantil, abuso contra os idosos e pessoas com deficiência (PCD). Na violência comunitária incluem-se a violência juvenil, os atos aleatórios de violência, o estupro e o ataque sexual por estranhos, bem como a violência em grupos institucionais, como escolas, local de trabalho, prisões e asilos.

Complementando as definições supracitadas, Minayo (2006) acrescenta a "violência estrutural", que passa a ser os processos sociais, políticos e econômicos que reproduzem a fome, a miséria e as desigualdades sociais, de gênero e etnia no nosso cotidiano. Essa violência ocorre de maneira alienada por parte dos indivíduos, e passa a ser naturalizada e banalizada. Indo de encontro, Coelho et al. (2014) dizem que a maioria dos tipos de violência tem sua base na violência estrutural, pois as violências ocorrem dentro das estruturas organizadas e institucionalizadas, como a família. Esses espaços possuem ligações com os "sistemas econômicos, culturais e políticos que conduzem à opressão de grupos, classes, nações e indivíduos, aos quais são negadas conquistas da sociedade, tornando-os mais vulneráveis ao sofrimento e até a morte" (Coelho et al., 2014).

\section{VIOLÊNCIA DOMÉSTICA E AS REPRESENTAÇÕES SOCIAIS}

A violência pode ser caracterizada como um produto das políticas socioeconômicas, porém o foco principal ainda é a sua identificação e a sua prevenção. Devemos compreender esse fenômeno, em especial as suas formas e implicações na vida das pessoas. Atualmente a violência é vista como um caráter complexo, polissêmico, subjetivo e controverso, caracterizando-a como um problema multifacetado e multidimensional, assim como um fenômeno socialmente construído (Saraiva e Coutinho, 2012).

Considera-se violência doméstica "qualquer ato, conduta ou omissão que sirva para infligir, reiteradamente e com intensidade, sofrimentos físicos, sexuais, mentais ou econômicos, de modo direto ou indireto (por meio de ameaças, enganos, coação ou qualquer outro meio) a qualquer pessoa que habite no mesmo agregado doméstico privado (pessoas - crianças, jovens, mulheres adultas, homens adultos ou idosos - a viver em alojamento comum) ou que, não habitando no mesmo agregado doméstico 
privado que o agente da violência, seja cônjuge ou companheiro marital ou ex-cônjuge ou ex-companheiro marital" (Machado e Gonçalves, 2003).

$\mathrm{Na}$ atualidade presenciamos tanto pessoalmente como através da mídia, um grande número de indivíduos vítimas de abuso, violência, negligência, maus-tratos e discriminação, tendo seus direitos e sua cidadania cruelmente desrespeitados. Com grande frequência a violência é evidenciada nos diferentes espaços de convivência social e privada, onde acaba afetando o bem-estar das vítimas por se tratar de uma questão que afeta os direitos humanos e que compromete a qualidade de vida em sociedade.

Não é possível combater a violência sem trazer a discussão a respeito das representações sociais, pois elas se referem a um conjunto de conceitos, afirmações e explicações que se originam no dia-a-dia, e com isso podemos procurar compreender o mundo. Vendo que o social possui grande importância na construção de uma compreensão da vida em sociedade e entendendo os processos existentes na convivência interpessoal e interespécie (Saraiva e Coutinho, 2012).

As representações sociais são construídas a partir das relações compartilhadas, socializadas e representadas no cotidiano das pessoas. Que podem ser identificadas nas atividades simples e complexas do nosso dia-a-dia. Segundo Moscovici (2009), as representações sociais devem ser vistas "como uma maneira específica de compreender e comunicar o que já sabemos [...] tem como objetivo abstrair o sentido do mundo e introduzir nele ordem e percepções que reproduzam o mundo de forma significativa". Quando se olha mais profundamente para o problema social da violência e maus-tratos aos grupos mais vulnerabilizados, encontramos uma dimensão fundamentada no imaginário popular ou no senso comum. Por muitas vezes, diversas expressões da violência são tratadas como uma forma de agir "normal" e "naturalizada", ficando ocultas nos usos, nas ideias, nas crenças, nos costumes e nas relações entre as pessoas (Minayo e Souza, 2005).

\section{LEGISLAÇÃO DE PROTEÇ̃̃O A VÍTIMA}

No Brasil temos um reconhecido arcabouço legal de proteção às vítimas de violência doméstica, que visa além de punir os agressores criar mecanismos de proteção às vítimas, de educação da comunidade, visando criar meios e prevenção desses crimes. A Constituição da República Federativa do Brasil de 1988, trouxe diversos avanços no 
que tange à proteção de grupos vulneráveis e principalmente no que se refere à proteção dos animais aos maus-tratos. Os constituintes ao tornarem a dignidade da pessoa humana um dos fundamentos da República Federativa do Brasil, conforme se depreende do artigo 10 , III, do texto constitucional, de certa forma deram um recado à sociedade e aos legisladores que viriam após a promulgação da constituição, que a partir desse momento, com o fim do Regime Militar, o país deveria se voltar para a proteção do ser humano visando o bem de todos sem preconceito de origem, raça, sexo, cor, idade ou qualquer forma de discriminação, conforme expresso no artigo 3ำ, IV.

No entanto, a Constituição de 1988 trouxe um maior avanço na proteção à fauna e à flora. Ao trazer em seu artigo 225, que todos tem direito ao meio ambiente ecologicamente equilibrado, e que este é um bem de uso comum do povo, essencial à sadia qualidade de vida, impondo-se ao Poder Público e à coletividade o dever de defende-lo e preservá-lo para as presentes e futuras gerações, observando o disposto no referido artigo tem-se que o ser humano tem o direito e o dever de preservar o meio ambiente, no qual se encontram os animais. Além disso, a Constituição ainda traz os animais como seres juridicamente incapazes devendo ser representados pelo Ministério Público, nos termos do artigo 127.

A partir destas e de outras normas constitucionais decorrem as normas infraconstitucionais que protegem especificamente os grupos vulneráveis que serão analisados no presente capítulo e que veremos abaixo.

\subsection{LEGISLAÇÃO DE PROTEÇÃO A MULHER}

Em relação às mulheres vítimas de violência doméstica, a Lei Maria da Penha (Lei no 11.340/2006) é uma das principais normas legais que visam criar mecanismos para coibir a violência doméstica e familiar contra a mulher. A lei recebe este nome em virtude da denúncia de Maria da Penha Maia Fernandes à Comissão Interamericana de Direitos Humanos da Organização dos Estados Americanos, que acarretou na condenação do Brasil por negligência e omissão em relação à violência doméstica, fato este que levou à uma revisão das políticas públicas de combate à violência contra a mulher, ato contínuo surge a Lei 11.340/2006.

Conforme descrito acima, a Constituição dá amparo para que sejam criadas leis de proteção especial à grupos vulneráveis, no caso da proteção da mulher contra 
violência doméstica o esteio constitucional encontra-se em diversas normas. No artigo 5 o, I, encontra-se a norma que garantiu a igualdade de direitos e obrigações entre homens e mulheres, no artigo $226, \S 5^{\circ}$, temos a igualdade no exercício dos direitos e deveres referentes à sociedade conjugal e no artigo 226 , § 8, a criação de mecanismos para coibir a violência no âmbito familiar.

Para que o fato possa ser englobado pela Lei Maria da Penha, se faz necessário que sejam cumpridos os requisitos dispostos no artigo 5o da referida lei, ou seja, para que se configure a violência doméstica e familiar contra a mulher tem de existir uma ação ou omissão baseada no gênero que the cause morte, lesão, sofrimento físico, sexual ou psicológico no âmbito da unidade doméstica, no âmbito da família ou em qualquer relação íntima de afeto, independente de coabitação. Ainda, a Lei 11.340/2006 traz em seu artigo 8으, de que forma se darão as medidas que visem coibir a violência doméstica e familiar contra a mulher como a promoção de estudos e pesquisas com perspectiva de gênero, implementação de atendimento policial especializado para as mulheres, promoção de campanhas educativas, entre outras.

\subsection{LEGISLAÇÃO DE PROTEÇÃO À CRIANÇA E AO ADOLESCENTE}

As crianças e os adolescentes são protegidos pelo Estatuto da Criança e do adolescente (Lei 8.069/1990). Tal diploma legal é internacionalmente reconhecido como um dos mais avançados dentre os dedicados à garantia dos direitos das crianças e adolescentes. A lei 8.069/1990 (Estatuto da Criança e do adolescente - ECA), dispõe sobre a proteção integral à criança e ao adolescente, conforme aponta seu artigo 10. Ainda, já no seu artigo 2oㅡ. aponta que para efeitos dessa lei, a pessoa de até 12 anos de idade incompletos é considerada criança, e entre doze e dezoito anos de idade é considerada adolescente, porém, faz uma ressalva aos casos expressos em lei, onde será possível aplicar o ECA às pessoas entre 18 e 21 anos de idade.

Os principais avanços do Estatuto da criança e do adolescente foram a proteção destes contra qualquer violência física, psicológica e sexual, bem como a proibição de práticas de castigos físicos, tratamentos degradantes e maus-tratos, bem como o trabalho infantil, e ainda trouxe a obrigatoriedade da criação dos conselhos tutelares. 0 artigo 130, do ECA traz uma proteção as crianças e adolescentes contra os abusos sexuais dentro de casa, possibilitando o afastamento do agressor e definindo 
penalidades para os autores destes crimes. O artigo 241, protege as crianças e adolescentes contra a venda ou exposição de conteúdo pornográfico que envolva sua imagem, ainda, o artigo 241-D, reconhece a violência sexual contra crianças e adolescentes cometidas na internet e nas mídias digitais.

É importante ressaltar que o Estatuto da Criança e do Adolescente assevera em seu artigo 4으, que é dever da família, da comunidade, da sociedade em geral e do poder público assegurar, com absoluta prioridade, a efetivação dos direitos das crianças e dos adolescentes, deixando claro que incumbe a todos os membros da sociedade a proteção desse grupo vulnerável.

\subsection{LEGISLAÇÃO DE PROTEÇÃO AO IDOSO}

Os idosos também são detentores de legislação específica que ajuda a formar o grupo de normas protetoras de seus direitos, o estatuto do idoso (Lei 10.741/2003). Tal lei surge da interpretação e da necessidade de dar forma ao contido no artigo 230 da Constituição que dispõe que a família, a sociedade e os Estado têm o dever de amparar as pessoas idosas, assegurando sua participação na comunidade, defendendo a sua dignidade e bem-estar, garantindo-Ihes o direito à vida. Neste sentido, foi criado o estatuto do idoso, que em seu artigo 1 ㅇ determina que são idosos às pessoas com idade igual ou superior a 60 anos.

No que se refere a violência contra o idoso, dispõe a Lei 10.741/2003 em seu artigo 4ำ que nenhum idoso será objeto de qualquer tipo de negligência, discriminação, violência, crueldade ou opressão, e todo atentado aos seus direitos, serão punidos na forma da lei. Ainda, neste seguimento, o próprio estatuto do idoso em seu artigo 99, dispõe que aquele que expor a perigo a integridade e a saúde, física ou psíquica, do idoso, submetendo-o a condições desumanas ou degradantes ou privando-o de alimento e cuidados indispensáveis, poderá ser sentenciado de 2 meses a 1 ano de detenção e multa, se do ato decorrer lesão corporal grave a pena pode ser de 1 a 4 anos, e, ainda, se do fato decorrer a morte do idoso a pena poderá ser de 4 a 12 anos.

\subsection{LEGISLAÇÃO AS PESSOAS COM DEFICIÊNCIA (PCD)}

O diploma legal que protege as pessoas com deficiência é a Lei 13.146/2015, tal lei é destinada a assegurar e a promover, em condições de igualdade, o exercício dos 
direitos e das liberdades fundamentais para pessoas com deficiência. Conforme o artigo 20 do estatuto, se consideram pessoas com deficiência as que tem impedimento de longo prazo de natureza física, mental, intelectual ou sensorial, o qual, em interação com uma ou mais barreiras, pode obstruir sua participação efetiva na sociedade em igualdade de condições com as demais pessoas.

A Lei 13.146/2015 não trouxe muitas novidades à proteção das pessoas com deficiência, pois, na verdade, se trata de mera internalização da ratificação da convenção da ONU sobre os Direitos da Pessoa com Deficiência, onde o Brasil se comprometeu a implementar medidas para dar efetividade aos direitos lá garantidos. No artigo 40 a lei traz em seu texto que toda pessoa com deficiência tem direito à igualdade de oportunidades com as demais pessoas e não sofrerá nenhuma espécie de discriminação. Considerando-se discriminação em razão da deficiência toda forma de distinção, restrição ou exclusão, que tenha o propósito ou efeito de prejudicar o reconhecimento ou exercício dos direitos e liberdades de pessoa com deficiência.

No que se refere a violência contra esse grupo, a lei traz em seu artigo 5o que a pessoa com deficiência será protegida de toda forma de negligência, discriminação, exploração, violência, tortura, crueldade, opressão, tratamento desumano ou degradante. Traz ainda, em seus artigo 88 ao 91 um rol de crimes contra as pessoas com deficiência como a prática, indução ou incitação de discriminação de pessoa em razão de sua deficiência; apropriar-se de ou desviar bens, proventos, pensão, benefícios, remuneração ou qualquer outro rendimento; abandonar pessoa com deficiência em hospitais, casas de saúde, entidades de abrigamento ou congêneres e reter ou utilizar cartão magnético, qualquer meio eletrônico ou documento de pessoa com deficiência destinados ao recebimento de benefícios, proventos, pensões ou remuneração ou à realização de operações financeiras, com o fim de obter vantagem indevida para si ou para outrem. Sendo assim, o Estatuto da pessoa com deficiência trouxe uma série de dispositivos que visam a proteção desse grupo de todos as maneiras de violência.

\subsection{LEGISLAÇÃO DE PROTEÇÃO AOS ANIMAIS}

Como dito anteriormente, no tópico introdutório, a Constituição brasileira de 1988 trouxe grande evolução no que se refere a proteção dos animais contra os maus tratos e a violência. No artigo 225 , § 1으, inciso VII, da Constituição de 1988, o constituinte 
trouxe expressamente a vedação de práticas que coloquem em risco sua função ecológica, provoquem a extinção de espécies ou submetam os animais a crueldade, deixando clara a opção do constituinte em dar uma especial proteção aos animais.

A norma infraconstitucional que dá proteção aos animais é a Lei de Crimes Ambientais (Lei no 9.605/98), que traz em seu artigo 32 que constitui crime praticar ato de abuso, maus-tratos, ferir ou mutilar animais silvestres, domésticos ou domesticados, nativos ou exóticos, indicando à época de sua feitura a pena de detenção de 3 meses a 1 ano, e multa. Porém, em 2019 com o projeto de Lei 1.095/2019 que posteriormente se tornou a Lei 14.064/2020, houve uma alteração na Lei de Crimes Ambientais aumentando as penas lá previstas, em especial quando se tratar de cães e gatos, para que passem a ser de 2 a 5 anos, multa e proibição de guarda. A legislação abrange animais silvestres, domésticos ou domesticados, nativos ou exóticos, incluindo a partir da Lei $14.064 / 2020$ penas maiores para crimes contra cães e gatos, pois estes acabam por ser as principais vítimas desse tipo de crime. A lei ainda prevê punição aos estabelecimentos comerciais e rurais que facilitem o crime contra animais.

\section{CONSIDERAÇÕES FINAIS}

Os médicos veterinários são profissionais indispensáveis na abordagem de Saúde Única, sendo os mais qualificados para identificar animais em situação de maus tratos e correlacionar com violência interpessoal no ambiente em que estão inseridos. Porém a violência é um problema de saúde pública, que deve ser enfrentado de maneira multiprofissional, sendo necessário o conhecimento e participação de profissionais como forças de segurança, outros profissionais de saúde, de assistência e de apoio legal aos envolvidos.

Em relação às mulheres vítimas de violência, a Lei Maria da Penha (Lei no 11.340/2006) é responsável em garantir mecanismos para coibir a violência doméstica e familiar contra a mulher. Já as crianças e adolescentes são protegidas pelo Estatuto da Criança e Adolescente (Lei 8.060/1990), assim como os idosos que possuem a Lei $n$ 으 10.741/2003 para garantir seus direitos. Em 2015 foi sancionada a lei $n=13.146 / 2015$ de proteção à pessoa com deficiência, onde através deste Estatuto é garantido a igualdade e a não discriminação. Sabemos que esses grupos citados acima são mais suscetíveis a 
violência, por isso foram listadas as legislações que garantem proteção a esses públicos vulneráveis.

A melhor maneira de contribuir para diminuição do ciclo de violência doméstica, é não fechar os olhos quando presenciamos ou até quando vivenciamos uma situação de violência, devemos procurar os mecanismos e redes de apoio, como Polícia Militar, Guarda municipal, Delegacias especializadas (Mulher, Idoso, Criança, Ambiental), Conselhos Municipais, Juizados e os próprios CREAS (Centro de Referência Especializado em Assistência Social), além de Secretarias de Meio Ambiente, Centro de Zoonoses e órgãos municipais de proteção animal. Esses equipamentos possuem profissionais qualificados para receber de forma adequada a vítima, prezando pelo sigilo e segurança.

Quando se tem a dificuldade de mobilidade a esses equipamentos, no Brasil também possuímos o "Disque 100", serviço de atendimento para graves situações de violação aos Direitos Humanos, onde é possível acionar os órgãos competentes, o que possibilita ações para a resolução de situações de violência.

\section{REFERÊNCIAS}

ASCIONE, Frank R..; ARKOW, Phill. Child Abuse, Domestic Violence and Animal Abuse. EUA: Purdue Research Foundation, 1999.

BAQUERO, Oswaldo Santos et al. Bayesian spatial models of the association between interpersonal violence, animal abuse and social vulnerability in São Paulo, Brazil. Preventive veterinary medicine, v. 152, p. 48-55, 2018.

BECK, Alan. Guidelines for planning for pets in urban areas. In: FOGLE, B. Interrelations between people and pets. Springfield: Charles C. Thomas Publisher, p. 232, 1981.

BRASIL. Constituição (1988). Constituição da República Federativa do Brasil. Brasília, DF: Senado Federal: Centro Gráfico, 1988.

CÂMARA DOS DEPUTADOS. Projeto de Lei no 1.095, de 25 de fevereiro de 2019. Altera a Lei $\mathrm{n} 09.605$, de 12 de fevereiro de 1998, para aumentar as penas cominadas ao crime de maus-tratos aos animais quando se tratar de cão ou gato. Comissão Especial, $13 \mathrm{fev}$ 1998. Disponível em: https://www.camara.leg.br/proposicoesWeb/fichadetramitacao?idProposicao= 2192978. Acesso em: 13 nov. 2021.

BRASIL. Lei no 14.064, de 29 de setembro de 2020. Altera a Lei no 9.605, de 12 de fevereiro de 1998, para aumentar as penas cominadas ao crime de maus-tratos aos animais quando se tratar de cão ou gato. Diário Oficial da União, 30 set. 2020. 
Disponível em: http://www.planalto.gov.br/ccivil_03/_ato20192022/2020/lei/L14064.htm. Acesso em: 13 nov. 2021.

BRASIL. Lei no 11.340, de 7 de agosto de 2006. Lei Maria da Penha: Cria mecanismos para coibir a violência doméstica e familiar contra a mulher. Diário Oficial da União, 8 ago. 2006.2 Disponível em: http://www.planalto.gov.br/ccivil_03/_ato2004-2006/2006/lei/l11340.htm.

Acesso em: 11 nov. 2021.

BRASIL. Lei no 10.741, de 1 de outubro de 2003. Dispõe sobre o Estatuto do Idoso e dá outras providências. Diário Oficial da União, 3 out. 2003. Disponível em: http://www.planalto.gov.br/ccivil_03/leis/2003/I10.741.htm. Acesso em: 13 nov. 2021.

BRASIL. Lei no 13.146, de 6 de julho de 2015. Institui a Lei Brasileira de Inclusão da Pessoa com Deficiência (Estatuto da Pessoa com Deficiência). Diário Oficial da União, 7 jul. $72015 . \quad$ Disponível em: http://www.planalto.gov.br/ccivil_03/_ato2015-2018/2015/lei/l13146.htm.

Acesso em: 13 nov. 2021.

BRASIL. Lei no 8.069, de 13 de julho de 1990. Dispõe sobre o Estatuto da Criança e do Adolescente e dá outras providências. Diário Oficial da União, 16 jul. 1990. Disponível em: http://www.planalto.gov.br/ccivil_03/leis/l8069.htm. Acesso em: 13 nov. 2021.

BRASIL. Lei no 9.605, de 12 de fevereiro de 1998. Dispõe sobre as sanções penais e administrativas derivadas de condutas e atividades lesivas ao meio ambiente, e dá outras providências. Diário Oficial da União, 13 fev. 1998. Disponível em: http://www.planalto.gov.br/ccivil_03/leis/19605.htm. Acesso em: 13 nov. 2021.

BRIGHT, Melissa A. et al. Animal cruelty as an indicator of family trauma: Using adverse childhood experiences to look beyond child abuse and domestic violence. Child Abuse \& Neglect, v. 76, p. 287-296, 2018.

COELHO, Elza Berger Salema; SILVA, Anne Carolina Luz Grüdtner; LINDNER, Sheila Rubia. Violência: definições e tipologia. Universidade Federal de Santa Catarina. Florianópolis, 2014.

Conselho Federal de Medicina Veterinária. Resolução $n^{\circ} 1236$, de 26 de outubro de 2018. Define e caracteriza crueldade, abuso e maus-tratos contra animais vertebrados, dispõe sobre a conduta de médicos veterinários e zootecnistas e dá outras providências. Diário Oficial da União: seção 1, Brasília, DF, ed.208, p. 133, 29 de out. 2018

GOMES, Laiza Bonela. A conexão entre as violências: um diagnóstico da relação entre os maus-tratos aos animais e a violência interpessoal. 2021. Tese (Doutorado em Ciência Animal) - Escola de Veterinária, Universidade Federal de Minas Gerais, Belo Horizonte, 2021. 
KRUG, Etienne. G. et al. Relatório mundial sobre violência e saúde. Geneva: World Health Organization, 2002. p. 380. Disponível em: https://portaldeboaspraticas.iff.fiocruz.br/wpcontent/uploads/2019/04/14142032-relatorio-mundial-sobre-violencia-esaude.pdf. Acesso em: 11 nov. 2021.

LEVITT, Lacey; HOFFER, Tia A.; LOPER, Ann B. Criminal histories of a subsample of animal cruelty offenders. Aggression and violent behavior, v. 30, p. 48-58, 2016.

MACHADO, Carla. GONÇALVES, Rui Abrunhosa. Violência e Vítimas de Crimes. Coimbra: Quarteto. 2003

MCEWEN, Fiona S.; MOFFITT, Terrie E.; ARSENEAULT, Louise. Is childhood cruelty to animals a marker for physical maltreatment in a prospective cohort study of children?. Child abuse \& neglect, v. 38, n. 3, p. 533-543, 2014.

MINAYO, Maria Cecília de Souza. Violência e saúde. Rio de Janeiro: Fiocruz, 2006.

MINAYO, Maria Cecília de Souza; SOUZA, Edinilsa Ramos. Violência e saúde como um campo interdisciplinar e de ação coletiva. História, ciência, saúde - Manguinhos, Rio de Janeiro, v. 4, n.3, p. 513-531, nov. 1998

MONSALVE, Stefany; FERREIRA, Fernando; GARCIA, Rita de Cássia Maria. The connection between animal abuse and interpersonal violence: A review from the veterinary perspective. Research in Veterinary Science, v. 114, p. 18-26, 2017.

MOSCOVICl, Serge. Representações Sociais: Investigações em Psicologia Social. Tradução Pedrinho A. Guareschi. 6. ed. Petrópolis: Vozes, 2009. 404 p.

PROTEÇÃO ANIMAL MUNDIAL. 94\% dos brasileiros veem seus cães como membros da família. São Paulo, 16 mai. 2019. Disponível em: https://www.worldanimalprotection.org.br/acabe-com-crueldade-animal. Acesso em: 14 nov. 2021.

ROCHA, Yasmin da Silva Gonçalves da. Maus-tratos aos animais como indicador de violência doméstica. 2020. Dissertação (Mestrado em Ciências Veterinárias) Setor de Ciências Agrárias, Universidade Federal do Paraná, Curitiba, 2020.

SARAIVA, Evelyn Rubia de Albuquerque; COUTINHO, Maria da Penha de Lima A difusão da violência contra idosos: um olhar psicossocial em: https://www.scielo.br/j/psoc/a/69MSpqhvd4FpRpsNBgchyrd/?lang=pt\#. Acesso em: 11 nov. 2021.

UFJF - UNIVERSIDADE FEDERAL DE JUIZ DE FORA. A domesticação dos cães. Coleção Integrante de zoologia. Juiz de Fora, 27 nov. 2020. Disponível em: https://www.ufjf.br/zoologiaitinerante/2020/11/27/entre-lobos-e-caes. Acesso em: 14 nov. 2021. 
ZEDER, Melinda. The Domestication of Animals. Journal of Anthropological Research. Novo México, v.68, n. 2. 


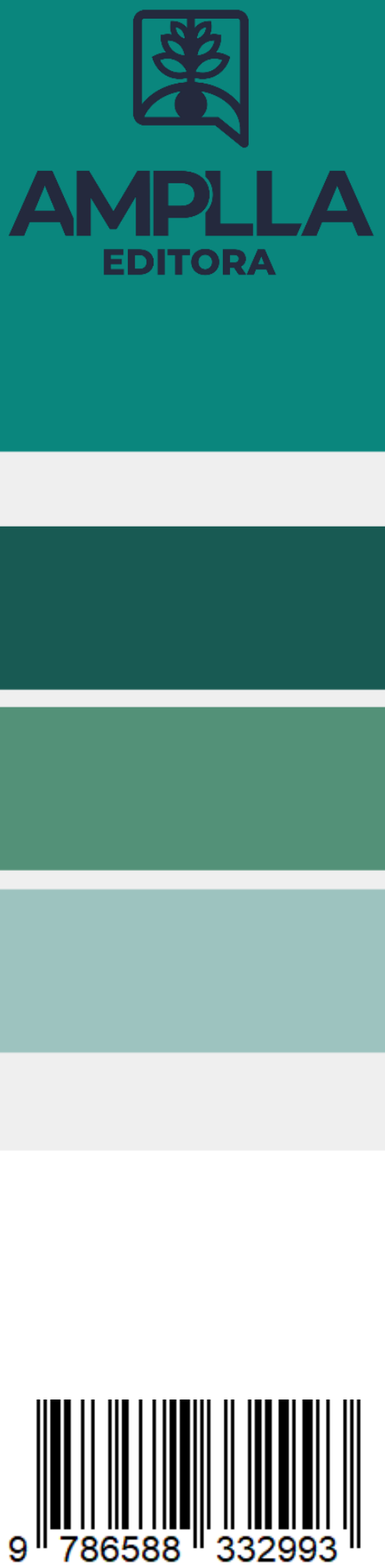